\title{
JÜDISCHE GEMEINDESTATUTEN AUS DEM ASCHKENASISCHEN KULTURRAUM $1650-1850$
}

Herausgegeben von Stefan Litt

ARCHIV JÜDISCHER GESCHICHTE UND KULTUR Band 1 
V\&R 


\section{Archiv jüdischer Geschichte und Kultur}

Band 1

Redaktion

Frauke von Rohden

Stefan Hofmann

Markus Kirchhoff

Ulrike Kramme

Vandenhoeck \& Ruprecht 


\section{Jüdische Gemeindestatuten aus dem aschkenasischen Kulturraum $1650-1850$}

Herausgegeben von Stefan Litt 
Das »Archiv jüdischer Geschichte und Kultur« ist Teil des Forschungsvorhabens »Europäische Traditionen - Enzyklopädie jüdischer Kulturen« der Sächsischen Akademie der Wissenschaften zu Leipzig und wird im Rahmen des Akademienprogramms von der Bundesrepublik Deutschland und dem Freistaat Sachsen gefördert. Das Akademienprogramm wird koordiniert von der Union der deutschen Akademien der Wissenschaften.

Bibliografische Information der Deutschen Nationalbibliothek:

Die Deutsche Nationalbibliothek verzeichnet diese Publikation in der Deutschen Nationalbibliografie; detaillierte bibliografische Daten sind im Internet über https://dnb.de abrufbar.

(C) 2014, Vandenhoeck \& Ruprecht GmbH \& Co. KG, Theaterstraße 13, D-37073 Göttingen

Satz und Layout: Dörlemann Satz, Lemförde

Vandenhoeck \& Ruprecht Verlage | www.vandenhoeck-ruprecht-verlage.com

ISSN 2566-6673

ISBN (Print) 978-3-525-31015-1

ISBN (PDF) 978-3-666-31015-7

https://doi.org/10.13109/9783666310157

Das Werk ist als Open-Access-Publikation im Sinne der Creative-Commons-Lizenz BY-NC-ND International 4.0 (»Namensnennung - Nicht kommerziell - Keine Bearbeitung «) unter dem DOI 10.13109/9783666310157 abzurufen. Um eine Kopie dieser Lizenz zu sehen, besuchen Sie https://creativecommons.org/licenses/by-ncnd/4.0/. Jede Verwertung in anderen als den durch diese Lizenz erlaubten Fällen bedarf der vorherigen schriftlichen Einwilligung des Verlages. 


\section{Inhalt}

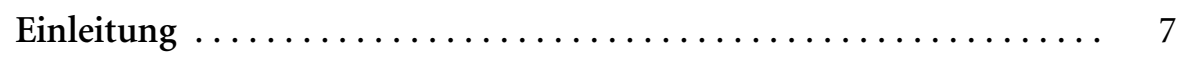

I. Originaltexte hebräischer und jiddischer Gemeindestatuten . . . . 29

1. Heiliges Römisches Reich Deutscher Nation ........... 31

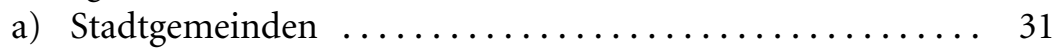

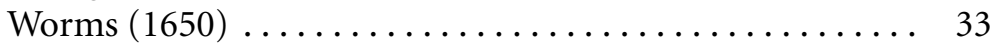

Frankfurt a. M. (1674/75) ................... 49

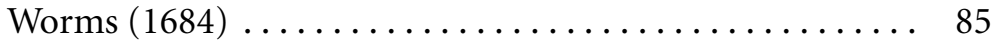

Halberstadt (1741) ........................ 107

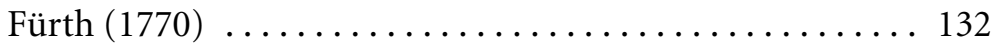

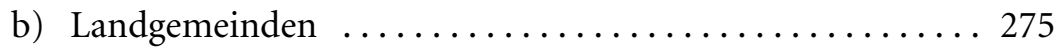

Ühlfeld (ca. 1683-1698) . . . . . . . . . . . . . . . . . 277

Niederwerrn $(1747) \ldots \ldots \ldots \ldots \ldots \ldots \ldots \ldots \ldots \ldots . \ldots . \ldots 285$

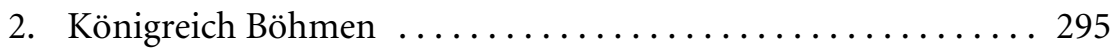

Neuzedlisch $(1755,1789-1849)$................... 297

3. Republik der Vereinigten Provinzen der Niederlande ...... 315

Den Haag $(1701)$. . . . . . . . . . . . . . . . . . . . . . 317

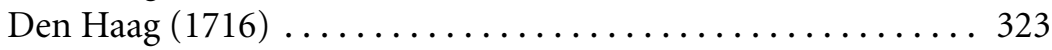

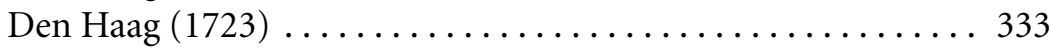

Landesjudenschaft der Meijerij's Hertogenbosch (1764) ..... 345

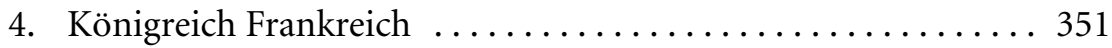

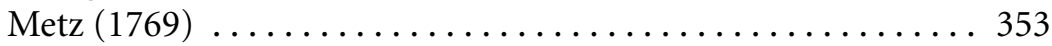

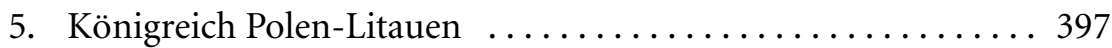

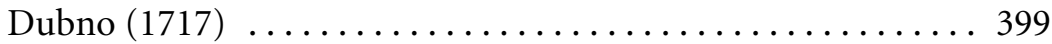

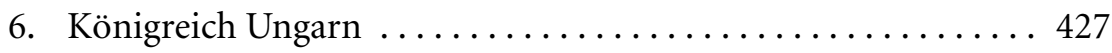

Deutschkreutz (1816) ......................... 429

II. Ausgewählte deutsche Übersetzungen $\ldots \ldots \ldots \ldots \ldots \ldots \ldots . \ldots 445$

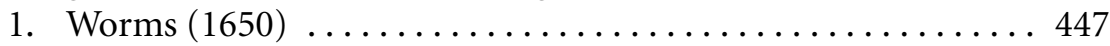

2. Frankfurt a.M. $(1674 / 75) \ldots \ldots \ldots \ldots \ldots \ldots \ldots \ldots \ldots \ldots 64$

3. Ühlfeld (ca. 1683-1698) . . . . . . . . . . . . . . . . . 502

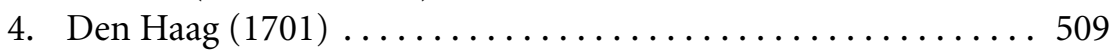

5. Neuzedlisch $(1755,1789-1849) \ldots \ldots \ldots \ldots \ldots \ldots \ldots \ldots \ldots$ 
Anhang: Aschkenasische Statutentexte in anderen Editionen ....... 537

Abkürzungen .................................. 544

Deutsche und englische Abkürzungen ................. 544

Hebräische Abkürzungen und Ligaturen . . . . . . . . . . . 544

Gesamtbibliografie ............................ 549

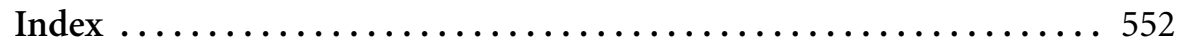




\section{Einleitung}

Aus heutiger Sicht scheint es selbstverständlich, dass eine organisierte Gemeinschaft von Menschen ihr Gruppenleben auf der Grundlage von fixierten Normen und Werten führt. Das Gleiche trifft für Gruppen zu, die innerhalb eines größeren Rahmens durch gleiche Aufgaben oder Interessen gemeinsam handeln. Ein moderner Staat verfügt über eine Verfassung, eine Religionsgemeinschaft oder ein Verein haben ihre Satzungen bzw. Statuten. Diese heutige Selbstverständlichkeit hat jedoch eine lange Vorgeschichte, die ihre Quellen in alten Rechtskodifizierungen und in lokalen bzw. gruppenspezifischen, normativen Regelwerken hat, wie z.B. den mittelalterlichen Stadtstatuten, Zucht- und Policey-Ordnungen, frühen Landesordnungen der Territorialstaaten, den Satzungen mittelalterlicher Gilden oder den Kirchenordnungen seit der Frühen Neuzeit. ${ }^{1}$

Um 1700 war die kurze lateinische Sentenz Ubi societas, ibi ius schon Gemeingut von Rechtsexperten der Zeit geworden. Danach entsprach es dem allgemeinen Verständnis, dass es keine Gesellschaft ohne Ordnung geben könne. Diese Einsicht hatte sich in der christlich-europäischen Welt jedoch erst seit dem 12. Jahrhundert, ausgehend von Italien, langsam durchgesetzt. Die Zeit davor war weitgehend frei von innovativer Gesetzgebung, selbst innerhalb der Kirche blieb sie die Ausnahme. Erst mit dem 12. und 13. Jahrhundert, als sich Rechtsgelehrte auf altes weltliches und kirchliches Recht zurück besannen und es weiter entwickelten, kam ein neues Verständnis für eine Kodifizierung von Gesetz, Ordnung und Regeln zustande, das bis heute andauert. In oberitalienischen Städten entstanden seit dem 12. Jahrhundert lokale Statuten. ${ }^{2}$ Von dort sollte sich das Phänomen mehr und mehr in Europa ausbreiten und viele Schichten der Gesellschaft durchdringen.

Eine religiöse Gruppe mit starkem historischen Selbstverständnis und einer Jahrhunderte alten, weitgehend autonomen Rechtstradition wie die der Juden durchlebte in dieser Hinsicht eine ganz ähnliche Entwicklung. Sie wies einerseits ihre eigenen Wurzeln auf, andererseits war sie aber zu großen

1 Zum Phänomen der Schaffung von normativen Regelwerken in seiner gesamten Breite siehe Gisela Drossbach (Hg.), Von der Ordnung zur Norm. Statuten in Mittelalter und Früher Neuzeit, Paderborn u.a. 2010.

2 Peter Landau, Über die Wiederentdeckung der Gesetzgebung im 12. Jahrhundert, in: Drossbach (Hg.), Von der Ordnung zur Norm, 13-15, passim. 
Teilen eng mit den Gegebenheiten der äußeren Umwelt verflochten. Die eigenen Wurzeln waren die der Halacha, der Gesamtheit des jüdischen Religionsgesetzes, wie es in der in der hebräischen Bibel, der "schriftlichen Tora" sowie deren Auslegung und Diskussion durch jüdische Gelehrte, der »mündlichen Tora « fixiert und anschließend stets aufs Neue interpretiert wurde. Die Erfordernisse gemeinschaftlichen Lebens in der Diaspora schufen eine Notwendigkeit, die Normen des alltäglichen Zusammenlebens den jeweiligen Gegebenheiten anzupassen, unter Wahrung sowohl der halachischen Vorgaben als auch der jeweiligen rechtlichen Rahmenbedingungen, die von der nichtjüdischen Umwelt vorgegeben wurden. Die Ergebnisse der Bemühungen um eine Anpassung der lokalen bzw. auch regionalen Normen für das gemeindliche Leben sind die Statuten, auf Hebräisch takkanot, der jeweiligen jüdischen Gemeinden. Sowohl der Begriff als auch die schriftlich fixierten Rechtsnormen, die damit verbundenen inhaltlichen und juristischen Probleme sind im Judentum seit der Antike präsent. Aus dem mittelalterlichen Aschkenas ist die Existenz solcher Statuten aus den Gemeinden Speyer, Worms und Mainz bekannt. Im Verlauf der Frühen Neuzeit, deren sozioökonomische Dynamik und Modernisierungstendenzen auch das Judentum beeinflussten, erlangten die Gemeindestatuten eine deutlich größere Bedeutung, sodass am Ende der Epoche wohl keine jüdische Gemeinde in Europa ohne mehr oder weniger umfassenden Statuten existierte, die die rechtlichen Grundlagen des innergemeindlichen Lebens regelten.

Inhaltlich befassen sich die Statuten mit einer Reihe von Standardthemen, zu denen Fragen der Mitgliedschaft in der Gemeinde, die Wahl und die Amtstätigkeit der Vorsteher und anderer Funktionsträger, die Besteuerung, die Beschäftigung von Gemeindebeamten, Synagogenangelegenheiten und oftmals auch die Versorgung der Armen gehörten. Es konnten auch weitere, lokalspezifische Themen hinzukommen wie etwa Regelungen für Zeiten der Handelsmessen, Handelsrecht im weiteren Sinne, Buchhandel und Buchdruck und nicht selten auch Regeln zum Umgang mit Christen, insbesondere mit christlichen Geschäftspartnern. Viele der Regeln gründen auf tradierten Konventionen der aschkenasischen (west-, mittel- und osteuropäischen) Juden, andere gehen höchstwahrscheinlich auf konkrete Alltagskonflikte zurück, für deren Wiederholungsfall eine rechtliche Regelung gefunden werden sollte. Noch völlig unerforscht ist der Einfluss durch takkanot anderer Gemeinden, die vor dem Verfassen eigener Statuten konsultiert werden konnten.

Die vorliegende Quellensammlung widmet sich den takkanot aschkenasischer Gemeinden aus dem Zeitraum von 1650 bis 1849. Der Fundus der noch vorhandenen Handschriften aus dieser Quellengattung ist beachtlich und umfasst weit mehr als die hier in Auswahl vorgelegten 15 Texte. Diese 
richtete sich nach folgenden Kriterien: Zunächst sollte möglichst der gesamte aschkenasische Kulturraum berücksichtigt werden, in dem Juden unter unterschiedlichen Existenzbedingungen lebten. Daher kam der gesamte europäische Raum nördlich der Alpen von den Niederlanden und ElsassLothringen im Westen bis nach Polen und der Ukraine im Osten in Frage, in dem hunderte, wenn nicht sogar tausende aschkenasische Gemeinden in der Frühen Neuzeit existiert hatten. Viele Statuten haben jedoch die Wirren der Kriege, Verfolgungen und Zerstörungen insbesondere der letzten 100 Jahre nicht überdauert. Vor allem aus den unzähligen Gemeinden des östlichen Europa haben sich nur verhältnismäßig wenige handschriftliche Zeugnisse der lokalen Gemeindeadministrationen erhalten, weshalb die Wahl hier recht einfach war (Dubno).

Für den mitteleuropäischen Raum ist die Quellenlage trotz großer Verluste günstiger, sodass die Auswahl hier schwerer fiel. Dazu kamen die Kriterien, vornehmlich solche Texte zu berücksichtigen, die noch nie oder nur unvollständig veröffentlicht wurden bzw. deren Veröffentlichung lange zurück liegt und die kaum noch aufzufinden oder von mangelhafter Qualität sind. Auch sollten vor allem takkanot in die Auswahl gelangen, die möglichst früh entstanden und die besonders repräsentativ für die Gemeindegeschichte sind. Schließlich sollten sie auch in einer zeitgenössischen Ausfertigung vorhanden sein, weshalb im Original verschollene Texte, die gleichwohl in Editionen älteren Datums zur Verfügung stehen, nicht in Frage kamen. D.h., dass einerseits Statuten aus bedeutenden und großen Gemeinden berücksichtigt werden sollten (Metz, Frankfurt, Worms, Halberstadt, Fürth), andererseits aber auch von ländlichen Kleingemeinden (Niederwerrn, Neuzedlisch, Ühlfeld) oder gar solche von territorialen Organisationen (Landesjudenschaften: Meijerij's Hertogenbosch). Aber auch Gemeinden mittlerer Größe sollten anhand ihrer takkanot repräsentiert sein (Den Haag, Deutschkreutz, Dubno). Dadurch ergab sich die Verteilung der Gemeinden auf unterschiedliche Staaten: Die vorliegende Edition bietet somit Gemeindestatuten aus den Vereinigten Provinzen der Niederlande, aus dem Königreich Frankreich, dessen aschkenasische Siedlungsregion in der Epoche im Wesentlichen auf Elsass-Lothringen beschränkt war, aus dem Heiligen Römischen Reich deutscher Nation, aus dem Königreich Böhmen, aus dem Königreich Polen-Litauen und schließlich aus dem Königreich Ungarn. Die jeweiligen politischen, konfessionellen und wirtschaftlichen Gegebenheiten wie auch die Existenzbedingungen für die Juden spiegeln sich teils mehr, teils weniger in den Statuten wieder, wie an den einzelnen Beispielen zu sehen ist.

Besonders wichtige Texte aus der vorliegenden Edition wurden ins Deutsche übertragen. Sie stehen exemplarisch für den Gesamtkorpus und sollen Einblicke in die Regelungen innergemeindlichen Lebens auch für des 
Hebräischen und Jiddischen Unkundige ermöglichen. Auch hier wurde darauf geachtet, dass die Übersetzungen ein möglichst breites Spektrum an Gemeinden abdecken, die sich hinsichtlich ihrer Bedeutung, ihrer regionalen Zugehörigkeit und hinsichtlich der Entstehungszeit ihrer Statuten voneinander unterschieden. Daher fiel hier die Wahl auf Worms (1650), Frankfurt a. M. (1674/75), Ühlfeld (1683-1698), Den Haag (1701) und Neuzedlisch $(1755,1789-1849)$.

\section{Antike und mittelalterliche Vorgaben für statuarische Ordnungen}

Eine takkana ist eine Festlegung oder Veränderung einer bestehenden Verhaltensnorm in jüdischen Gemeinden nach den Erfordernissen der Zeit. Sie erlangt ihre Gültigkeit mit Erlass durch eine autoritative Instanz, wie z.B. dem kahal (Vorstand einer Gemeinde) oder einer religionsgesetzlich anerkannten und kompetenten Person (Rabbiner). ${ }^{3}$ Das Wort leitet sich von der hebräischen Wurzel $(t-k-n)$ ab; das Substantiv takkana bedeutet »Korrektur» bzw. »Bereinigung" eines die religionsgesetzlichen oder profanen Normen verletzenden Zustands. Die Pluralform takkanot bezeichnet die Vielzahl solcher Korrekturen oder Festlegungen und wurde im Laufe der Zeit zur internen Bezeichnung für die umfassenden Rechtsstatuten jüdischer Gemeinden. In der aschkenasischen Aussprache wie auch im Jiddischen tritt das Wort in der Form takones auf, wobei hier, je nach Dialekt, die Aussprache variieren konnte.

Nach dem Zerfall des antiken jüdischen Staates im 1. und 2. Jahrhundert gab es keine zentrale Instanz mehr, die dazu berechtigt gewesen wäre, verbindliche Rechtsnormen für Juden zu fixieren, auch wenn dies auf lokaler und zuweilen sogar regionaler Ebene aufgrund sich ändernder Existenzbedingungen sehr wohl notwendig gewesen wäre. Auf der Grundlage von Fixierungen in der antiken Mischna (wörtl. »wiederholte Lehre«) und späteren halachischen Erörterungen wurde im Früh- und Hochmittelalter vor allem die Frage der Teilhabe Einzelner an den finanziellen Aufwendungen für die Gemeinschaft geregelt. Diese Regelungen wurden durch die Ge'onim (Rechtsgelehrte) erlassen, die an den jüdischen Akademien Babyloniens wirkten und die damals das geistige Zentrum des Judentums weltweit darstellten. Die Rechtsentscheidungen der Ge'onim wurden in der Regel auch von den jüdischen Gemeinden in Europa akzeptiert. Einige davon besagten, dass jedes Mitglied einer jüdischen Gemeinde durch eine takkana des Gemeindevorste-

3 Aharon Nachalon, The Kahal and its Enactments in the Geonic Period (hebr.), Jerusalem 2001, 5-9. 
hers gezwungen werden konnte, sich an den Lasten zu beteiligen. Bald darauf wurde den lokalen Gemeindeführern von Seiten der rabbinischen Elite auch die Verabschiedung von takkanot in anderen Bereichen zugestanden. ${ }^{4}$ Seitdem waren diese Führungspersonen die Verfasser von zunächst meist einzelnen Bestimmungen oder kleinen Gruppen von takkanot. Seit dem Mittelalter wurden die gemeindlichen Statuten zunehmend von den lokalen Gemeindeführern geschaffen, jedoch nicht selten unter Konsultierung von Rabbinern, die durch ihre profunde Kenntnis der Religionsgesetze für die Konformität mit Letzteren garantierten.

Im Mittelalter wurden in der jüdischen Welt Europas von Religionsgelehrten immer wieder einzelne Bestimmungen, takkanot, erlassen. Durch Korrespondenz dieser Rabbiner mit babylonischen Ge'onim waren sie zweifellos über die dortigen Auslegungen und ihre Grundprinzipien informiert. Vielfach scheinen diese lokalen oder regionalen Bestimmungen bei Rabbinern durch exegetische Dispute über einen konkreten Fall oder Anlass entstanden zu sein. Dabei tauschten sich angesehene Kenner der Halacha über die Varianten der Auslegung religionsgesetzlich normativer Texte des Judentums (Bibel und ihre Kommentare, Talmud und seine Kommentare) aus und erörterten bestimmte, akut aufgetretene Alltagsprobleme von Juden. Am Ende dieser rechtlichen Abwägungen wurden eine oder mehrere takkanot erlassen, die im Wirkungsraum der rabbinischen Autoritäten und im Idealfall darüber hinaus Gültigkeit besaßen. Tatsächlich scheinen diese Verordnungen vielfach Allgemeingültigkeit besessen zu haben und waren nicht auf einzelne Gemeinden und deren konkrete Situation beschränkt. Zeugnis davon geben die Zitationen derartiger Festlegungen in Rechtsgutachten mittelalterlicher Rabbiner. Es sind jedoch auch zahlreiche einzelne takkanot bekannt, die offenbar von Rabbinern ohne nachweisbare Erörterungen mit anderen Gelehrten erlassen wurden. ${ }^{5}$

Ein Sonderfall sind ohne Zweifel die takkanot der drei benachbarten rheinischen Gemeinden Speyer, Worms und Mainz (auf Hebräisch auch als ShUM-Gemeinden bezeichnet, aus dem Akronym der Anfangsbuchstaben der Städte) ${ }^{6}$ aus der ersten Hälfte des 13. Jahrhunderts. Eine umfangreiche Kompilation mit 28 Paragraphen von allen drei Gemeinden wurde als

4 Ebd., 9-12.

5 Siehe hierzu Louis Finkelstein, Jewish Self-Government in the Middle Ages, New York ${ }^{2}$ 1964, passim.

6 Siehe dazu Rainer Barzen, Jüdische Regionalorganisation am Mittelrhein. Die Kehillot SchUM um 1300, in: Christoph Cluse (Hg.), Europas Juden im Mittelalter. Beiträge des internationalen Symposiums in Speyer vom 20. bis 25. Oktober 2002, Trier 2004, 248-258. 
rechtsverbindlich akzeptiert. Mehrere Überlieferungen dieser takkanot deuten darauf hin, dass ihr Inhalt in Synoden neu bewertet und zum Teil auch revidiert wurde. ${ }^{7}$ Das ist ein eindeutiger Hinweis darauf, dass die rechtlichen Autoritäten die Praktikabilität der Statuten für den Alltag beobachteten und den jeweiligen Erfordernissen anpassten. Thematisch beziehen sich die Paragraphen vor allem auf Fragen der Stellung zur Autorität des rabbinischen Gerichts, auf Steuerleistungen und auf die als problematisch empfundenen nichtjüdischen Einflüsse auf das jüdische Leben. ${ }^{8}$ Auch wenn hinsichtlich Inhalt und Sprachduktus große Unterschiede zwischen den mittelalterlichen und den frühneuzeitlichen Texten bestehen, sind die schon in den ältesten aschkenasischen Statuten bekannten Bereiche immer wieder Teil der späteren und meist viel komplexeren Gemeindestatuten gewesen. Aus den genannten Themen in den takkanot ShUM ist ersichtlich, dass es sich nicht mehr ausschließlich um die Bewahrung der Religionsgesetze in speziellen Situationen handelte, sondern dass auch Angelegenheiten des profanen Alltags darin ihren Platz fanden. Dies ist vor allem der rechtlichen Autonomie gegenüber der nichtjüdischen Mehrheitsgesellschaft geschuldet, aber auch der Komplexität des jüdischen Gemeindelebens in den großen rheinischen Städten.

Es ist fraglich, ob es neben dem außergewöhnlichen Beispiel der rheinländischen Statuten noch ähnliche Texte für andere Gemeinden oder Gemeindeverbände des Mittelalters gegeben hat. Zweifellos ist auch die verhältnismäßig schlechte Quellenlage für viele Regionen und Gemeinden dafür verantwortlich, dass das Wissen darüber fehlt. Es liegt jedoch nahe $\mathrm{zu}$ vermuten, dass die takkanot der überregional bedeutenden Gemeinden Speyer, Worms und Mainz auch von anderen Gemeinden wahrgenommen und teilweise adaptiert wurden. Aufgrund der nachgewiesenen Kontakte, die die Unterzeichner der takkanot ShUM zu anderen Gruppen und Gelehrten unterhielten, lässt sich annehmen, dass diese frühen Statuten auch in anderen jüdischen Niederlassungen Europas Verbreitung gefunden hatten. Auch der Umstand, dass der bedeutendste aschkenasische Rechtsgelehrte des 13. Jahrhunderts, Rabbi Meir von Rothenburg, diese takkanot in seinen Rechtsgutachten immer wieder zitierte, lässt darauf schließen, dass auch er einen Anteil an ihrer Verbreitung hatte. ${ }^{9}$

Bemerkenswert ist jedoch, dass die Erkenntnis der Notwendigkeit zur Schaffung einer statuarischen Ordnung in den drei rheinischen Gemeinden parallel oder nur leicht zeitversetzt zur christlichen Umwelt aufkam, die ge-

7 Finkelstein, Jewish Self-Government, 220.

8 Ebd., 224.

9 Heidemarie Petersen, Judengemeinde und Stadtgemeinde in Polen. Lemberg 13561581, Wiesbaden 2003, 31-36. 
rade, wie eingangs dargelegt, im 13. Jahrhundert verstärkt Rechtsordnungen und normative Texte schuf. Da diese auch für die jüdischen Einwohner der Städte galten, dürften die Juden Kenntnis von dieser Entwicklung genommen haben, die dann in den takkanot der mehr oder weniger autonomen Gemeinden ihren Niederschlag fand.

Bislang konnte immer nur darüber spekuliert werden, inwiefern die mittelalterlichen takkanot ShUM auch den Verfassern frühneuzeitlicher Gemeindestatuten bekannt waren oder vielleicht sogar als Vorbild dienten. So enthält ein Statutentext, der sehr wahrscheinlich aus dem burgenländischen Mattersdorf (heute Mattersburg) des 18. Jahrhunderts stammt, die explizite Erwähnung einer mittelalterlichen Fixierung. Wenn sich die Originalhandschrift des von Max Grunwald edierten Textes ${ }^{10}$ auffinden und sich seine zeitliche Einordnung bestätigen sollte, wäre dies der Beweis für die bemerkenswerte Beständigkeit von Rechtsnormen, die über einen Zeitraum von mehreren Jahrhunderten und eine geographische Ausdehnung von Südwestdeutschland bis ins Burgenland kontinuierliche Gültigkeit behielten. Eine diesbezüglich in die Tiefe gehende Untersuchung unter Berücksichtigung von Themen und ihren sprachlichen Formulierungen steht noch immer aus.

\section{Die Blütezeit der jüdischen Gemeindeordnungen während der Frühen Neuzeit}

Nach den Vertreibungen und Ausweisungen von Juden aus Reichsstädten und Territorien des Alten Reiches, die vom 15. Jahrhundert bis weit ins 16. Jahrhundert hinein stattfanden, erfolgte eine gewisse Konsolidierung jüdischen Lebens in Mitteleuropa. Seitdem war jüdische Lokalgeschichte nicht mehr nur sporadisch, sondern konnte eine Kontinuität entfalten, die oft bis in das 20. Jahrhundert andauerte. Bestehende städtische Gemeinden wuchsen, neue kamen im Verlauf der Epoche hinzu wie etwa Hamburg, Halberstadt, Fürth, Königsberg u.a. Der Schwerpunkt jüdischer Niederlassungen verschob sich mehr und mehr in den Nordosten des Reiches und fand räumlichen Anschluss zu den bereits blühenden Zentren jüdischen Lebens in Polen. Seit dem 17. Jahrhundert setzte ein Zustrom von Juden in die Vereinigten Provinzen der Niederlande ein, der bald darauf mit Amsterdam eines

10 Max Grunwald, Mattersdorf, in: Jahrbuch für Jüdische Volkskunde 26/27 (1924/1925), 402-563, hier: 505-514. In der von Grunwald nicht näher beschriebenen Handschrift findet sich die Erwähnung in $\$ 20$, der sich mit dem Übergang der Gemeindemitgliedschaft durch Eheschließung von einem Mann auf eine ortsfremde Frau befasst. 
der bedeutendsten Zentren jüdischen Lebens in Europa schuf. Trotz vereinzelter, teils sehr schmerzlicher Rückschläge, wie den Kosakenverfolgungen in Polen-Litauen in den Jahren 1648/1649 und die Vertreibung aus Wien und Niederösterreich 1670/1671, stellt die Frühe Neuzeit auch für das Judentum eine Epoche mit neuer Dynamik dar, begleitet von einer erst sehr zögerlichen, ab dem 18. Jahrhundert dann aber machtvoll einsetzenden Säkularisierung.

Die Gemeinden existierten zumeist in einer von den Landesherren zugebilligten Autonomie, die durch besondere Steuern und Abgabenleistungen von den Juden erkauft wurde. Am weitesten ging diese Autonomie in Polen und, mit Abstrichen, in Böhmen und Mähren, wo den Juden in aller Regel sogar ein eigenes Zunftrecht zugestanden wurde. Innerhalb des Reiches war das autonome Gemeindeleben oft mehr reglementiert und von Eingriffen durch die christlichen Behörden geprägt. In den Niederlanden hingegen, wo es de facto keinen Korporationszwang gab, stellten die jüdischen Gemeinden Einrichtungen dar, deren Mitgliedschaft freiwillig war. Allen Gemeinden innerhalb des aschkenasischen Kulturraums war jedoch eigen, dass sie zwar durch eine oligarchische Führung geleitet wurden, es aber dennoch aufgrund der nahezu demokratischen Wahl der Gemeindevorsteher die Möglichkeit der Mitbestimmung für Vollmitglieder (als solche galten die männlichen Haushaltvorstände, hebr. ba'ale batim) gab. Daher verwundert es nicht, dass den Gemeindestatuten einige Bedeutung zukam, denn sie waren »im Bereich der Ordnungsnormen idealtypisch als zwischen den Rechtsgenossen vereinbartes Recht «. ${ }^{11}$ Tatsächlich wurden die takkanot jüdischer Gemeinden oft durch Kommissionen von mehreren Personen aus den unterschiedlichen sozialen Schichten der Gemeinden verfasst, weshalb es in der Tat ein vereinbartes Recht gab, auch wenn es auf der Grundlage der Halacha stand. Die im Folgenden edierten Statuten aus Frankfurt a. M. von 1674/75 legen diesen Prozess in der Einleitung dar:

»[...] Daher kam es zum mehrheitlichen Beschluss, die Namen von 60 Männern in drei Urnen zu tun, 20 Reiche in eine, 20 mit mittlerem Vermögen in eine andere und 20, deren Vermögen weniger als 1000 Gulden beträgt, in eine weitere. Die jeweils 20 aus einer Urne sollen fünf unter ihnen wählen. Diese 15 Männer sollten dann die Statuten zum Besten der Gemeinde verfassen. So geschah es, und sie verfassten die Statuten und durch das Los wurden die ehrwürdigen Männer bestimmt, deren Namen am Rand des Blattes

11 Karl Härter, Statut und Policeyordnung. Entwicklung und Verhältnis des Statuarrechts zur Policeygesetzgebung zwischen spätem Mittelalter und Früher Neuzeit in mitteleuropäischen Reichs- und Landstädten, in: Drossbach (Hg.), Von der Ordnung zur Norm, 127-152, hier 130. 
stehen. So geschah es und sie erließen die Statuten, wie im Folgenden dargelegt, durch die Mehrheit der Gemeinde, nämlich stimmten 192 Hausherren $z u$ und 42 lehnten ab, entsprechend den Stimmzetteln [...].«

Die ebenfalls in dem vorliegenden Band enthaltenen, recht späten Statuten der ungarisch-burgenländischen Gemeinde Deutschkreutz von 1816 beschreiben in der Einleitung diesen Prozess der Rechtsvereinbarung folgendermaßen:

"Ferner haben sich am unten genannten Tag die Befehlshaber des Vorstands, Gott schütze ihn, versammelt und haben eine Zusammenkunft aller Mitglieder der Gemeinde einberufen, damit sie diese Statuten sehen und die guten Dinge vor Augen geführt bekommen und einen unserer Generation gemäßen Zusatz erlassen. Sie haben alles so gesehen und so gehandelt. Alle haben zusammen die alten Bestimmungen zusammengetragen und manchmal haben sie diese ohne Veränderung oder Zusatz akzeptiert. Hin und wieder wurde an einigen Dingen etwas ergänzt, wie auch einige Bestimmungen hinzugefügt wurden, die der Zeit und der Gegenwart entsprechen und nach Sinn und Art der Generation sind."

Daraus lässt sich ableiten, dass vielerorts das gemeinschaftliche Beschließen der Statuten Teil ihrer Legitimation und Anerkennung war. Als Begründungen für den Erlass von takkanot werden oft rechtliche Missstände innerhalb der jüdischen Gemeinde angeführt, wonach sich jedermann nach Belieben verhalte und sich nicht um das Gemeinwohl schere (Frankfurt a. M., Friedberg). In anderen Fällen war es schlichtweg die Entstehung und das weitere Wachstum einer lokalen Gemeinschaft, die den Entwurf einer normativen Ordnung erforderten (Ühlfeld 1683-1698, Den Haag 1701).

Der Prozess der Kodifizierung jüdischer Gemeindestatuten konnte in jeder Gemeinde unterschiedlich verlaufen. Grundsätzlich lassen sich zwei unterschiedliche Formen der Kodifizierung erkennen, die jedoch nicht zwangsläufig voneinander getrennt existierten. Der ältere Brauch war der, dass die Vorsteher der Gemeinde - gegebenenfalls unter Hinzuziehung des Rabbiners bei akutem Bedarf eine oder mehrere takkanot erließen. Diese konnten in den Protokollbüchern (hebr. pinkasim, Sg. pinkas) entsprechend verzeichnet sein und es gibt Hinweise dafür, dass die Vorsteher dazu tendierten, nahezu jeden ihrer Beschlüsse als takkana anzusehen. Diese Art der Fixierung hat eine Parallele in der nichtjüdischen Gesellschaft, wo ebenfalls in sachlicher Begrenzung spezifische Bereiche oder gar Konflikte so geregelt wurden. Mit diesem Instrument konnte schnell auf neue Situationen reagiert werden. ${ }^{12}$

12 Ebd., 134. 
Aus der bedeutenden polnischen Gemeinde Tykocin ist beispielsweise ein umfangreiches Protokollbuch (1719-1806) abschriftlich überliefert, ${ }^{13}$ in dem sich immer wieder vereinzelte Regeln finden, die offenbar aus einem konkreten Anlass heraus formuliert wurden. Bezeichnender Weise ist auch hier der erste Eintrag im Manuskript eine Gruppe von Erlassen, die sich auf so unterschiedliche Themen wie die Öffnung von Läden, Festmahlzeiten, Toralesungen in der Synagoge, sowie Maße und Gewichte beziehen. ${ }^{14}$ Es kann nicht ausgeschlossen werden, dass es daneben, wie auch in anderen Gemeinden besonders im 18. Jahrhundert, auch noch einen umfassenden Statutentext gegeben hat, von dem jedoch im Fall von Tykocin nichts bekannt ist. In Posen war es üblich, dass die Wahlmänner für die Wahlen der Vorsteher neue Regeln erließen, die in der vergangenen Amtszeit notwendig geworden waren. Sie wurden an die älteren Statuten angehängt und so entstand eine stetig wachsende Satzung, die in einem besonderen Protokollbuch seit 1621 niedergeschrieben wurde. ${ }^{15}$

In einigen Gemeinden führte die Entwicklung zur zweiten, schon weiter oben erwähnten Variante, in der man von der bisherigen Form der anlassgebundenen Verfügung von takkanot dazu überging, diese nach einiger Zeit komplett zu sichten und auf ihre Relevanz hin zu überprüfen, zu sammeln und zu ergänzen, um auf diesem Weg ein Gesamtkorpus von umfangreichen Statuten zu schaffen. So geschah es beispielsweise in der alten und bedeutenden jüdischen Gemeinde Friedberg in der Wetterau. Im Jahr 1723 wurden die Statuten von 1664 revidiert, die anscheinend zuvor aus älteren und verstreuten Einzelbestimmungen kompiliert worden waren. ${ }^{16}$ Solch umfassende Satzungen gliedern sich meist in drei Teile: Die Einleitung gibt häufig die Motivation oder die Vorgeschichte der Entstehung der Statuten wieder. Der Hauptteil mit den aufeinander folgenden Paragraphen konnte noch einmal in Unterabschnitte strukturiert sein, die dann durch thematische Überschriften kenntlich gemacht wurden (Worms, Halberstadt, Fürth). Bei kürzeren Texten unterblieb das oft (Den Haag, Ühlfeld, Neuzedlisch). Mancherorts existierten beide Kodifizierungsvarianten über längere Zeit hinweg parallel zueinander.

13 Mordechai Nadav (Hg.), The Minutes Book of the Jewish Community Council of Tykocin. 1621-1806. Decisions and Regulations, 2 Bde, Jerusalem 1996-1999 (hebr.).

14 Ebd., 1, Eintrag Nr. 1 von 1737.

15 Dov Avron (Hg.), Pinkas ha-ksherim shel kehillat Pozna (1621-1835) [Protokollbücher der Gemeinde Poznan] Jerusalem 1966.

16 Stefan Litt (Hg.), Protokollbuch und Statuten der Jüdischen Gemeinde Friedberg (16.-18. Jahrhundert), Friedberg 2003, 393 in der deutschen Übersetzung. 
Die Zahl der Fälle, die in der Vergangenheit Gegenstand von Erörterungen und Auseinandersetzungen gewesen waren, wuchs im Lauf der Zeit und floss ein in ausdifferenzierte, zunehmend profaner werdende Paragraphensammlungen, die für die Zukunft eine Art Präzedenzrecht darstellen sollten. Dies illustrieren die aufeinander folgenden Statutentexte aus Den Haag und aus Worms recht gut, weshalb hier exemplarisch mehrere Texte aus einer Gemeinde wiedergegeben wurden. Ein ähnlicher Kodifizierungsprozess ist auch in Frankfurt a. M. im 17. Jahrhundert und in Fürth im 18. Jahrhundert zu beobachten. ${ }^{17}$ Deshalb lassen umfangreiche und ausführliche Gemeindestatuten meist auf eine längere kontinuierliche jüdische Lokalgeschichte mit einer Vielzahl von Konfliktsituationen schließen, die sich in den takkanot niederschlugen. Die frühesten bekannten Gemeindestatuten aus dem mitteleuropäischen Raum stammen durchweg aus größeren Gemeinden mit einer langen Vorgeschichte und zeichnen sich bereits durch ihre Ausführlichkeit aus: Der älteste, heute bekannte Statutentext einer aschkenasischen Gemeinde ist der aus Krakau von 1595.18 Aus dem Gebiet des Alten Reiches stammen die ältesten frühneuzeitlichen Gemeindestatuten aus den reichsstädtischen Gemeinden Worms (1650), Friedberg (1664) und Frankfurt a. M. (1674/75). In Mähren, wo sich das Verständnis für geordnete Normen offensichtlich bald weitgehend durchgesetzt hatte, sind schon 1650 sehr ausführliche Satzungen für die Landesjudenschaft erlassen worden. Insgesamt scheint es, dass sich im Verlauf des 17. Jahrhunderts in der aschkenasischen Welt der Brauch des Erlasses von Gemeindestatuten durchsetzte. Dies kann jedoch nur aufgrund der bekannten Beispiele vermutet werden; ob eventuell noch frühere Texte, etwa aus dem 16. Jahrhundert, existierten, muss weitgehend der Spekulation anheimfallen.

Grundsätzlich lässt sich feststellen, dass zunehmend solche Fälle und Ereignisse die Statuten anreicherten, die nicht mehr vorrangig mit der Religionsausübung oder Observanz der Halacha zu tun hatten. Vielmehr standen jetzt die sachlichen Erfordernisse der Administration einer autonomen Gemeinschaft im Vordergrund, die rational handeln musste, um innerhalb der rechtlichen und sozialen Rahmenbedingungen ein Existenzoptimum

17 Friedrich Neubürger, Das Sonderrecht der gemeinen Judenschaft zu Fürth und indessen Amt im achtzehnten Jahrhundert, Fürth/Nürnberg 1902, $7 \mathrm{f}$.

18 Majer Bałaban, Die Krakauer Judengemeinde-Ordnung von 1595 und ihre Nachträge, in: Jahrbuch der Jüdisch-Literarischen Gesellschaft 10 (1912), 296-360; 11 (1916), 88-114, 299. Leider ist das Original offensichtlich nicht mehr vorhanden, sodass Bałabans Edition die einzige Quelle für diese Statuten ist. Heidemarie Petersen hat einige Passagen aus dem Jiddischen ins Deutsche übertragen: Petersen, Judengemeinde, 131-137. 
zu schaffen. Da es im Verlauf der Epoche mehr und mehr die Vorsteher der Gemeinden waren, die die Statuten verfassten und erließen, liegt es auf der Hand, dass ihre praktischen Erkenntnisse zunehmend in den Vordergrund traten. Nicht selten ging es dabei um die Festigung der Machtposition der Vorsteher innerhalb der Gemeinde, auch in Hinsicht auf deren Kompetenzen in der Rechtsprechung. So sind die Frankfurter Statuten von 1674/75, wiewohl keinesfalls frei von Anspielungen und Zitaten aus dem traditionellen Kanon des Judentums, ein durchweg profaner Text, der kaum ein Wort über Angelegenheiten der Liturgie oder der Synagogen verliert. Andere Statutensammlungen hingegen, wie etwa die aus Worms (1650), Halberstadt (1741) oder Neuzedlisch $(1755,1789-1849)$ stellen zwar die religiösen Aspekte entweder direkt an den Anfang oder räumen ihnen einen gewissen Platz ein, um dann doch wieder überwiegend die profanen Themen ausführlich zu behandeln.

Mit ihrer zunehmenden Säkularisierung sind die Statuten nicht nur ein Abbild der von den Vorstehern angestrebten Idealzustands in der Gemeinschaft, sondern auch ein Spiegelbild der realen Zustände. Wiederholte Verbote bestimmter Verhaltensweisen und Praktiken deuten darauf hin, dass gerade diese bei den Gemeindemitgliedern sehr beliebt waren und sich nur schwer unterbinden ließen, wie etwa das häufige Spielverbote oder die Ächtung eines aufwändigen Lebensstils. Gerade die umfangreichen takkanot aus Fürth von 1770 sind eine überaus reiche Quelle für sozial- und kulturhistorische Analysen. Regionale Unterschiede zeichnen sich an dieser Stelle sehr klar ab. Vergleicht man beispielsweise die Halberstädter Statuten (1741) mit denen aus Metz (1769), so könnten die Bestimmungen bezüglich der Kleiderordnung kaum unterschiedlicher sein. Blieben die Regelungen aus dem preußischen Halberstadt diesbezüglich eher kurz, und wenig detailliert, so sprudeln die französischen Begriffe aus der Mode des Rokoko in den Metzer Bestimmungen, die zudem gleich am Anfang der takkanot rangieren. Man kann davon ausgehen, dass ein großer Teil der im verfeinerten französischen Metz gerade noch gestatteten Kleider vor den Augen der Halberstädter Sittenwächter keinen Bestand gehabt hätte.

In Aschkenas wurden während des gesamten 18. Jahrhunderts hindurch takkanot erlassen, revidiert oder erneuert. Am Ende des Jahrhunderts veränderte sich die Rechtslage für die Juden in einigen Staaten Europas: In Österreich-Ungarn wurde durch den Erlass der Josephinischen Toleranzedikte zwar der rechtliche Status verbessert, die alte Autonomie aber stark eingeschränkt. In Regionen mit französischer Besatzung (Niederlande - »Batavische Republik«, Königreich Westphalen) in der napoleonischen Zeit wurden häufig sogar vollständige Bürgerrechte gewährt. Trotz dieser Wandlungen wurden weiterhin Statuten erlassen. Jedoch nahmen sie, auch aufgrund neuer Vor- 
gaben der Landesregierungen in Hinsicht auf den Rechtsstatus der Gemeinden, zunehmend den Charakter von Satzungen für Religionsgemeinschaften oder gar Körperschaften des öffentlichen Rechts an. Dieser Umstand wird nicht zuletzt anhand des allmählichen Wechsels zur Landessprache bei der Abfassung der Statuten sichtbar. Obrigkeitliche Eingriffe auf die jüdische Gemeindeautonomie in Form von Policey-Ordnungen waren meist durch eben diese Autonomie beschränkt und finden sich vor allem in der Zeit des 16. und 17. Jahrhunderts in Form der Judenordnungen bzw. der Stättigkeitsverträge, z.B. in Frankfurt a. M., wo als Teil der Einleitung der (auch in den Wormser Statuten zu findende) Zusatz erscheint: "Doch bei alledem geschah der hochlöblichen Obrigkeit nichts Abträgliches und es wurde in nichts eingegriffen, vielmehr bleibt alle Zeit ihr Herrschaftsrecht erhalten. "Meist war es üblich, dass neue Statuten einer Gemeinde vor Inkrafttreten erst noch durch die jeweilige Obrigkeit bestätigt werden mussten. Dafür ließen die Juden häufig selbst Übersetzungen in die Landessprache anfertigen, die sie dann bei den Behörden vorlegten. ${ }^{19}$ Inwiefern sich die massive Bevormundung durch obrigkeitliches Gebotsrecht in Form der preußischen General-Judenreglements auf die statuarischen Ordnungen der jüdischen Gemeinden auswirkte, bleibt ein Desiderat für künftige Untersuchungen.

Von der gewährten Autonomie in Fragen der Statuten weichen zwei der hier edierten Texte deutlich ab, nämlich der älteste aus Den Haag von 1701, und der aus Niederwerrn von 1747. Beide wurden durch obrigkeitlichen Beschluss erlassen, weisen aber klare Anzeichen für eine vorab erfolgte Aushandlung des Inhalts auf. Diese Texte stehen für die Verflechtung von statuarischem Ordnungsrecht und obrigkeitlichem Gebotsrecht auch auf der Ebene der takkanot. ${ }^{20}$

19 Eine solche Übersetzung stellen die Altonaer Statuten von 1726 dar, die von Max Grunwald 1903 ediert wurden; siehe Anhang. Auch die von van Zuiden angeführte niederländische Version der ersten Haager takkanot von 1701 gehört dazu; siehe Desiré S. van Zuiden, De Hoogduitsche Joden in s' Gravenhage van af hunne komst tot op heden [Die Hochdeutschen Juden in s' Gravenhage von ihrer Ankunft bis heute], Den Haag 1913. Dass neue Statuten auch einmal nicht bestätigt wurden, zeigt das Beispiel aus Frankfurt a. M. von 1754; siehe Isidor Kracauer, Geschichte der Juden in Frankfurt a. M. (1150-1824), 2 Bde., Frankfurt a. M. 1925-1927, Bd. 2, 204-211. Härter, Statut, 130. 


\section{Die Handschriften und ihre Überlieferungen}

Die Statuten aus der Frühen Neuzeit finden sich häufig in handschriftlicher Form als Bestandteil von Gemeindeprotokollbüchern (hebr. pinkase kahal), oder bei großen Gemeinden mit ausdifferenzierter Administration auch als einzeln gebundene Manuskripte. Sehr häufig ließen die Gemeindevorsteher die Statuten an den Anfang eines Protokollbuches stellen, so geschehen in Ühlfeld (1683-1698), Den Haag (1723), Neuzedlisch (1755, 1789-1849) und in vielen anderen pinkasim. Dabei stand offenbar nicht nur der Gedanke im Vordergrund, diese Texte an prominenter Stelle zu platzieren und somit leicht auffindbar zu machen, sondern auch allen späteren Einträgen den Rang von Ergänzungen zu den Erlassen der früheren Generationen zu verleihen. Auch erscheint die Verabschiedung von Statuten so als buchstäblich konstitutiver Akt, da mit dem Erlass und der Anlage eines Protokollbuches ein klares Signal für die Institutionalisierung der Gemeinde gegeben wurde.

In anderen Gemeinden erschienen Statuten als Abschrift oder gar als Originalausfertigung in den laufenden Aufzeichnungen der Vorsteher im Protokollbuch, so z.B. in Frankfurt a. M., in Metz und in Deutschkreutz. In diesen Fällen waren sie offenbar nicht Bestandteil grundsätzlicher rechtlicher Neuerungen in den Gemeinden, sondern durchliefen lediglich einen Revisionsprozess. In großen Gemeinschaften gab es häufig ein gesondertes Statutenbuch (pinkas takkanot). Die Führung eines solchen hatte den Vorteil, dass die takkanot damit leichter für Gemeindemitglieder verfügbar waren, für die die Statuten zu ihrer Befolgung immer einsehbar sein mussten. Vielmehr lieBen sich so auch bestimmte Interna der Gemeindeführung leichter vor der Öffentlichkeit verbergen, denn nun waren die Protokolle der Vorsteher nicht gleichzeitig mit der Lektüre der Statuten einsehbar. Das früheste überlieferte Beispiel für umfangreiche frühneuzeitliche Statuten überhaupt, die takkanot von Krakau von 1595, war offenbar schon in einem solchen separaten Band verzeichnet. Auch die Statuten aus Friedberg von 1723 sind in einem gesonderten Band zu finden, ${ }^{21}$ und das umfangreichste Beispiel aus Fürth von 1770 wurde ebenfalls in einem voluminösen Buch niedergeschrieben, hier sicher auch aus Gründen der einfacheren Handhabbarkeit.

Die Handschriften der Statuten werden heute in zahlreichen Archiven, Bibliotheken und auch privaten Sammlungen aufbewahrt. Wegen ihrer Seltenheit und ihres teilweise noch immer verbindlichen religionsgesetzlichen Inhalts und dazugehörigen Auslegungen stellen sie begehrte Sammelobjekte

21 Litt (Hg.), Friedberg. Möglicherweise war auch die frühere Version der Statuten von 1664 , von der nur noch Fragmente erhalten sind, in einem separaten Buch aufgezeichnet worden. 
dar. Viele Statutensammlungen finden sich in den Beständen der Central Archives for the History of the Jewish People in Jerusalem, wie auch in der Handschriftenabteilung der Jerusalemer Nationalbibliothek. Aus den böhmischen und mährischen Gemeinden finden sich pinkasim und takkanot im Archiv des jüdischen Museums Prag, und auch die Sammlungen des Jewish Theological Seminary of America in New York sowie des Hebrew Union College in Cincinnati beherbergen wichtige Statutensammlungen. Zahlreiche Exemplare sind Teil von staatlichen Archiven und Bibliotheken wie beispielsweise in den Niederlanden.

\section{Sprachgebrauch}

Viele der überlieferten takkanot aus dem Alten Reich und den Niederlanden sind auf Jiddisch verfasst worden (Worms, Friedberg, Ühlfeld, Den Haag, Fürth, Deutschkreutz). Jiddisch war die lingua franca des aschkenasisch-europäischen Judentums. Es war die allgemein praktizierte Umgangssprache, mit mehr oder weniger gravierenden regionalen Unterschieden, die in der modernen Forschung zu einer Differenzierung in Ost- und Westjiddisch geführt haben. Innerhalb dieser Sprachräume trat eine gewisse Beeinflussung durch die Umgebungssprache hinzu, die sich in Begriffen oder Phrasen im Jiddischen niederschlagen konnte. Es hat den Anschein, dass gerade aus Gründen der Verständlichkeit die takkanot sehr häufig im von allen Juden verstandenen Jiddisch verfasst wurden, um so die Einhaltung der Regeln durch die Gemeindemitglieder nicht an der Sprachbarriere scheitern zu lassen. Gute Kenntnisse des Hebräischen waren in der Frühen Neuzeit bei weitem nicht mehr bei allen jüdischen Menschen anzutreffen.

Es gibt jedoch auch eine Reihe von Beispielen, die ausschließlich auf Hebräisch überliefert sind. Meist sind dies Texte aus Ostmittel- oder Osteuropa, aber auch in mitteleuropäischen Gemeinden griffen die Verfasser wiederholt auf das Hebräische zurück (Dubno, Altona, Neuzedlisch, Halberstadt). Aus diesem Befund ist die häufig geäußerte Ansicht zu relativieren, wonach das Hebräische bis zur Haskala nur als Sprache der Religion und der traditionellen Gelehrsamkeit benutzt wurde. Statuten und Protokolle finden sich in größeren Mengen in dieser Sprache. Ihr Inhalt bezog sich, wie bereits dargestellt, keinesfalls nur auf Vorschriften für den Bereich des Heiligen oder für das Studium. Es gibt auch Mischformen, in denen beide Sprachen im steten Wechsel gebraucht wurden (Metz, Frankfurt a. M.). Durch die besondere Entstehungsgeschichte der Statuten aus dem fränkischen Niederwerrn, die eigentlich eine Art Judenordnung darstellen, erklärt sich hier der Gebrauch des Deutschen, das lediglich mit dem hebräischen Alphabet transkribiert wurde. 


\section{Editionsgeschichtliches}

Wie aus dem Anhang ersichtlich, übten die takkanot aschkenasischer Gemeinden schon seit langem eine Faszination auf Forscher aus. Sieht man von der ältesten bekannten Edition der Fürther Luxusgesetze durch Andreas Würfel aus dem Jahr 1754 ab, dessen Absichten nebulös blieben und dessen Zuverlässigkeit zumindest fraglich ist, so entwickelten Forscher erst im letzten Viertel des 19. Jahrhunderts ein Interesse für die takkanot. Die Wissenschaftler legten den Schwerpunkt ihrer Textauswahl jedoch zunächst weniger auf die Gemeinden des Alten Reiches, sondern vielmehr auf jene aus Ostmitteleuropa. Der aus Mähren stammende Gerson Wolf gab $1880^{22}$ eine deutsche Übersetzung der mährischen Landesstatuten heraus und eröffnete damit das Feld für die Beschäftigung mit dem Genre, die bis heute anhält. Zugleich blieb Wolfs Edition für die folgenden 72 Jahre die einzige eigenständige Ausgabe von Statuten. Dies blieb auch so bis zur erneuten, diesmal originalsprachlichen Publikation desselben Textes durch Israel Halperin im Jahr 1952. Der Marburger Rabbiner Leo Munk veröffentlichte 1890 in einer wissenschaftlich vorbildlichen Edition die Statuten der Landesjudenschaft von Hessen-Kassel aus dem Jahr 1690 in ihrer originalen Form und blieb damit auf lange Zeit einer der wenigen Forscher aus Deutschland, der sich der Thematik zuwandte. Auch seine Sorgfalt beim Erstellen eines Textapparats blieb für längere Zeit die Ausnahme beim Umgang mit innerjüdischen normativen Texten. Feibel Wetstein, ein aus Polen stammender Forscher, gab 1892 umfangreiche Auszüge aus alten pinkasim der Krakauer Gemeinde heraus; sämtliche Originale sind heute verschollen. Im Jahr 1895 veröffentlichte der Rabbiner von Kremsier, Adolf Frankl-Grün, Teile einer zeitgenössischen deutschen Übersetzung von Statuten seines Dienstortes aus dem Jahr 1708 in den Monatsblättern für Geschichte und Wissenschaft des Judentums, eine damals hoch angesehene wissenschaftliche Fachzeitschrift. Ebenfalls noch im 19. Jahrhundert erfolgte, jetzt wieder unter Wahrung der Originalsprache, die Edition von Teilen des Protokollbuches der bambergischen Landesjudenschaft durch David Kaufmann im Jahr 1896/97, ein Teil dieser Statuten datiert allerdings aus dem Jahr 1682.

Bis 1937 erschienen noch elf weitere Publikationen von Gemeindestatuten. Besondere Erwähnung verdient die Edition der zu den ältesten frühneuzeitlichen Statuten zählenden takkanot aus Krakau von 1595 durch Majer Bałaban, einem der bedeutendsten polnisch-jüdischen Historiker. Ähnlich wie Leo Munk, dessen frühe Edition heute zu Unrecht vergessen ist, ach-

22 Die bibliografischen Angaben aller im Folgenden genannten Textausgaben finden sich in der tabellarischen Zusammenstellung im Anhang. 
tete Bałaban auf ein hohes Niveau seiner originalsprachlichen Ausgabe von 1912/1916, auch wenn er im Umgang mit der ursprünglichen Paragrapheneinteilung etwas frei verfuhr. Im Gegensatz zu Deutschland, Polen, Böhmen und Mähren stand die Beschäftigung mit Quellentexten des Genres in den Niederlanden nie im Vordergrund. Bis zur Mitte des 20. Jahrhunderts wurde nur ein Statutentext ediert. Dabei handelte es sich um die takkanot aus Den Haag (1701), die der Forscher zur dortigen Gemeindegeschichte, Désiré Samuel van Zuiden 1913 in einer zeitgenössischen niederländischen Übersetzung herausgab. Zahlreiche weitere Statutensammlungen befinden sich bis heute meist ungenutzt in niederländischen Archiven und Sammlungen.

Die letzte Edition in Mitteleuropa vor Beginn der Naziherrschaft war die von Bernhard Wachstein zu den landesjudenschaftlichen Statuten der Grafschaft Wied-Runkel (1733-1760) in der Zeitschrift für die Geschichte der Juden in Deutschland. In Wilna erschien 1937 im Rahmen des YIVO (Yidisher Visenshaftlekher Institut) von Yizchok Levitats eine jiddisch kommentierte Ausgabe der Dubnoer Statuten von 1717, allerdings aufgrund einer unvollständigen Abschrift. Alle relevanten Editionen wurden von jüdischen Forschern angefertigt, die allgemeine, nichtjüdische Wissenschaftswelt ignorierte hingegen das Thema weitgehend - ein Schicksal, dass die Statuten mit anderen Bereichen der jüdischen Geschichte und Kultur teilte.

Die Naziherrschaft und der Zweite Weltkrieg bedeuteten eine Zäsur für die jüdische Forschung, denn es wurde während dieser Jahre nicht nur sehr viel Quellenmaterial vernichtet und der Schwerpunkt der Forschung verlagerte sich in den Folgejahren nach Israel. Stand die schon erwähnte Publikation der mährischen Statuten durch Halperin aus dem Jahr 1952 noch etwas allein, so gewann die Arbeit in den 1960er Jahren einige Dynamik. Die Nikolsburger Statuten von 1720-1768 wurden 1961 durch Ernest Roth vorgelegt, 1966 die takkanot der Landesjudenschaft Ansbach durch Daniel J. Cohen, 1967 schließlich der pinkas ha-ksherim (Protokollbuch der Wahlmänner) aus Posen (1621-1835) durch Dov Avron. Die vorläufig letzte Edition von Gemeindestatuten fertigte Simon Schwarzfuchs 1970 an. Er gab ein Fragment der Metzer Satzungen von 1769 heraus und verwendete für seine seit Kriegsende erstmals wieder in Europa angefertigte Publikation nicht mehr Hebräisch, sondern Französisch. In Israel erlahmten die Bemühungen um die Beschäftigung für takkanot für längere Zeit und sollten erst in den 1990er Jahren noch einmal aufleben, jedoch nicht mehr in der gewohnten Intensität. Offenbar war die anfänglich vorhandene ideologische Komponente, nämlich die Erforschung der (profanen) gesetzgebenden Tradition des Judentums als Vorbild für das junge jüdische Staatswesen in Israel, nicht mehr von derselben Brisanz. Im Jahr 2010 legte Elchanan Tal eine Edition der Amsterdamer 
takkanot von 1711 vor - ein für die regional-niederländisch-jüdische wie auch für die gesamtaschkenasische Geschichte bedeutender Schritt. Dabei handelt es sich nicht nur um die erste Publikation eines Statutentextes aus den Niederlanden in der Originalsprache, sondern auch um einen Schlüsseltext für das Genre schlechthin, war doch Amsterdam eines der bedeutendsten Zentren jüdischen Lebens in Aschkenas. Zudem handelt es sich um einen Text, der im Druck verbreitet wurde, was in der Frühen Neuzeit äußerst selten geschah.

Samuel Kerner, ein Kenner der elsässisch-jüdischen Geschichte und in Frankreich lebend, ging 1972 einen Schritt weiter und veröffentlichte erstmals wieder eine Statutensammlung in Übersetzung, nämlich die takkanot aus Metz von 1769. Anders als Simon Schwarzfuchs kurz zuvor publizierte er die Statuten in voller Länge. Mit der wissenschaftlich fundierten Ausgabe aller takkanot aus der Dreigemeinde Altona-Hamburg-Wandsbek widmete sich schließlich nach beinahe 40 Jahren Unterbrechung erstmals wieder ein Forscher aus Deutschland der Thematik. Heinz Mosche Graupe publizierte 1973 mehrere Statuten aus dieser Region, und zwar in der Originalsprache und in deutscher Übersetzung. Er verglich die verschiedenen Statuten miteinander und kommentierte sie auf Deutsch. Nicht nur die Verwendung der deutschen Sprache stellte ein Novum dar, auch die Publikation von Statuten einer deutschen Gemeinde in einer eigenständigen Veröffentlichung war eine Neuerung. Graupe war jedoch eher ein letzter Vertreter der alten europäischjüdischen Forschungstradition denn ein Vorbote neuer Forschungsthemen in einer Gesellschaft, aus der die jüdischen Experten bzw. ihre Erben weitgehend verschwunden waren.

In den folgenden 20 Jahren unterblieben weitere Veröffentlichungen von takkanot oder auch nur die intensive Beschäftigung mit ihnen. Erst zu Beginn der 1990er Jahre lebte das Interesse an den Gemeindestatuten erneut auf. 1992 erschien eine originalsprachliche Gesamtausgabe des Schnaittacher Protokollbuches, herausgegeben durch den israelischen Historiker Meir Hildesheimer, in der sich auch zwei Statutentexte von 1689 und 1710 finden. In seiner ausführlichen Einleitung nimmt Hildesheimer Bezug auf andere Texte des Genres, was bis dahin erstaunlicherweise kaum geschehen war.

In einer Geschichte der burgenländischen Gemeinde Deutschkreutz wurde durch Shmuel Spitzer 1995 eine deutschsprachige Übersetzung der auch hier enthaltenen takkanot von 1816 ediert. Im Jahr 2003 publizierte Simon Schwarzfuchs noch einmal eine Sammlung von Einzelbestimmungen zu mehreren Themengruppen aus Metz vom Ende des 17. Jahrhunderts. Diese Edition und auch Spitzers Werk zeigen, dass es inzwischen auch unter israelischen Wissenschaftlern wieder akzeptabel war, Forschungen und Textausgaben zum Thema in Deutscher Publikationssprache vorzulegen. 
Ein neuer Trend zeichnet sich seit wenigen Jahren in Europa ab, wo erstmals nichtjüdische Forscher sich mit der Herausgabe jüdischer normativer Texte der Frühen Neuzeit beschäftigen. Im Jahr 2003 erschien in Polen eine Sammlung von hebräischen Quellen aus polnisch-jüdischen Gemeinden, in der auch Statuten aus Dubno (1717), Schwersenz (Swarzędz, 1729) und Iwieniec (1759) enthalten sind. Die Herausgeberin, Anna Michałowska, arbeitet intensiv zu den verbliebenen jüdischen literarischen Quellen aus polnischen Gemeinden und legte in ihrer Edition die originalsprachlichen Statuten mit Kommentar und polnischer Übersetzung vor. Auch der Bearbeiter der vorliegenden Edition veröffentlichte eine Ausgabe der Friedberger Statuten von 1664/1723, zusammen mit dem ältesten Protokollbuch der Wetterauer Gemeinde, im Original und mit deutscher Übersetzung. Die vorliegende Edition von 15 Statutensammlungen aus zwölf Gemeinden bzw. gemeindeähnlichen Zusammenschlüssen aus 200 Jahren stellt nun den vorläufigen Schlusspunkt der Arbeit zur Thematik dar.

\section{Editionsrichtlinien}

Jeder der hier edierten Texte wird einzeln in einer kompakten Einleitung vorgestellt. Die Wiedergabe der originalsprachlichen Texte erfolgt getreu den Vorlagen. Ligaturen und Abkürzungen werden daher nicht aufgelöst, sondern exakt beibehalten. Ihre Auflösung ist dem Verzeichnis der hebräischen Abkürzungen und Ligaturen zu entnehmen. Die zeittypische Verkürzung von Wörtern, die in den meisten Fällen durch das Weglassen des letzten Buchstabens geschah, wird ebenfalls nicht im Text aufgelöst, da die Verständlichkeit in der Regel erhalten bleibt. Nur an solchen Stellen, wo die Verkürzung sinnentstellend ist, erfolgt die Auflösung in einer Fußnote. In den Texten enthaltene Wörter der jeweiligen Umgebungssprache werden in Fußnoten in ihrer originalen Schreibweise in lateinischen Buchstaben wiedergegeben und erläutert. Die Interpunktion der Vorlagen folgt zuweilen eigenwilligen Regeln und häufig gibt es keinen Unterschied zwischen Punkt und Komma. Satzzeichen werden hier an der jeweiligen Position im Satz wiedergegeben, jedoch, dem Kontext entsprechend, klar in Punkt und Komma unterschieden. Auf das Hinzufügen oder Weglassen von Satzzeichen wurde verzichtet, lediglich die Paragraphenenden werden jeweils mit einem Punkt gekennzeichnet.

Die Folio- bzw. Seitennummern der Vorlagen werden immer entsprechend der ursprünglichen Zählung in eckigen Klammern wiedergegeben. Vielfach war es üblich, dass spätere Besitzer, Archivare oder Bearbeiter eine neue Foliierung bzw. Paginierung vornahmen, die sich am realen Bestand der 
Handschrift orientierte, nicht jedoch an der ursprünglichen Zählung. Zeilenumbrüche im Text werden immer durch [/] gekennzeichnet. Gelegentliche Anmerkungen zur Schreibweise erscheinen jeweils in eckigen Klammern. Textverluste oder unlesbare Stellen werden im Fall von ganzen Wörtern oder Wortgruppen mit [...] gekennzeichnet, bei Teilen von Wörtern mit [..].

Die oft eingeflochtenen Zitate aus der hebräischen Bibel, der Mischna und dem Talmud werden im Apparat zu den originalsprachlichen Texten angegeben. Sofern die Zitate aus dem Babylonischen Talmud stammen, wird nur die übliche Angabe des Traktatnamens und des Folios gemacht.

Die Übersetzungen ins Deutsche orientieren sich stark an ihren Originalen, weshalb stilistische Abstriche in den deutschen Texten hinzunehmen sind. Wo Textabschnitte schon weitgehend dem deutschen Sprachduktus folgen (z.B. in den takkanot aus Neuzedlisch), wurden solche Teile weitgehend transkribiert und nur bei etwaigem Missverständnis dem heutigen Sprachgebrauch angepasst. Erklärungen zum Text werden im Apparat zur Übersetzung intensiver vorgenommen als in den Fußnoten zum Originaltext, da Lesern mit entsprechenden Sprachkenntnissen der für das Verständnis notwendige kulturgeschichtliche Kontext sicherlich näher ist.

Die Bezeichnungen für Gemeindeämter wurden wegen ihrer Besonderheit meist in ihrer hebräischen Form belassen. Ein parnas ist einer der Gemeindevorsteher, die sich in der Amtsführung meist im Monatsturnus abwechselten. Ein gabbai ist ein bestellter Aufseher oder Pfleger für einen Bereich der Gemeindeadministration. Oft wurden gabba'im mit der Aufsicht über bestimmte Bereiche der Gemeindefinanzen betraut (gabbai zedakaAufseher über die Armenkasse, die oft zugleich die Gemeindekasse war; gabbai erez-Yisra'el - Aufseher über die Spendenkasse für die Gemeinden des Heiligen Landes; pleten-gabbai - Aufseher über die durchreisenden Armen, die einen Zettel (jidd. pleten) zu deren freier Verköstigung erhielten). Shammashim waren in den meisten Fällen die Synagogendiener bzw. Aufseher über die Synagogen und deren ordnungsgemäßen Zustand. In großen Gemeinden finden sich zusätzliche shammashim auch als Gehilfen für andere Amtsträger in den Gemeinden, etwa für die gabba'im. Ein ne'eman war ein vereidigter Angestellter der Gemeinde, der meist die Funktion eines Notars bei der Beglaubigung von Urkunden bzw. Abschriften übernahm. Später waren sie nicht selten auch der jeweiligen Landessprache mächtig und fungierten im amtlichen Schriftverkehr als Schnittstelle zwischen den obrigkeitlichen Kanzleien und den Verwaltungen der jüdischen Gemeinden. 


\section{Danksagung}

Dieses Buch wäre ohne den hilfreichen Beistand vieler Menschen und Institutionen nie zustande gekommen. Zunächst gebührt mein Dank dem Akademieprojekt »Europäische Traditionen - Enzyklopädie jüdischer Kulturen« der Sächsischen Akademie der Wissenschaften zu Leipzig, insbesondere dem Projektleiter Prof. Dan Diner, der mich zur Arbeit an dieser Edition ermunterte und mir die Publikation in der vorliegenden Form ermöglichte. Auch gebührt mein Dank Frau Dr. Frauke von Rohden, die die Erstellung des Manuskripts professionell betreute. Ferner bin ich den Mitarbeitern folgender Archive und Bibliotheken zu Dank verpflichtet: den Central Archives for the History of the Jewish People, dem Manuscript Department der National Library of Israel, beide in Jerusalem, der Bibliotheca Rosenthaliana in Amsterdam, der Bibliothek des Jewish Theological Seminary of America in New York, dem Archiv des Jüdischen Museums in Prag, dem Burgenländischen Landesarchiv in Eisenstadt und der Nederlands Israelietische Gemeente 's Gravenhage.

Für die Klärung von Verständnisfragen danke ich herzlich Dr. Edward Fram von der Ben-Gurion-Universität in Beer Sheva, Frau Prof. Chava Turniansky von der Hebräischen Universität in Jerusalem und Frau Prof. Marion Aptroot von der Heinrich-Heine-Universität in Düsseldorf. Für ihre immerwährende Hilfsbereitschaft bei der Entzifferung und Deutung altjiddischer Wörter und landessprachlicher Begriffe möchte ich meinen Dank aussprechen.

Wie immer denke ich voller Dank auch an die Geduld und das Verständnis meiner Familie, die mir in den letzten Jahren unterstützend zur Seite stand und manche Kuriosa der frühneuzeitlichen takkanot nolens volens über sich ergehen lassen musste. 

I. Originaltexte hebräischer und jiddischer Gemeindestatuten 



\title{
1. Heiliges Römisches Reich Deutscher Nation
}

\author{
a) Stadtgemeinden
}

Worms (1650)

Frankfurt a. M. (1674/75)

Worms (1684)

Halberstadt (1741)

Fürth (1770) 



\section{Statuten aus Worms 1650}

\section{Quelle: Statutentext, CAHJP, Rh/W II, 1}

Die Statuten aus Worms aus dem Jahr 1650 sind nicht nur die ältesten erhaltenen aus dieser bedeutenden reichsstädtischen Gemeinde. Sie scheinen überhaupt die früheste bekannte normative Fixierung größeren Ausmaßes für das Alte Reich zu sein. Der Text hat sich nicht in einer offiziellen Ausfertigung erhalten, sondern wurde zum Zweck einer späteren Revision um 1655/56 abgeschrieben und diente als Grundlage für die Überarbeitung. ${ }^{1}$ Diese Vorlage wurde in sehr sauberer, aber extrem kleiner Form abgeschrieben, die Buchstaben sind meist kaum höher als zwei bis drei Millimeter. Im Text selbst wird Worms als Ursprungsort der takkanot nicht erwähnt, lediglich aus einigen erwähnten Namen und den Parallelen zum späteren Text von 1684 lässt sich die Herkunft erschließen.

Die heute acht Seiten umfassende Handschrift hat sich nicht vollständig erhalten. Die Blätter rissen durch häufiges Falten an den Faltlinien, wodurch auf den Seiten 3 und 4 ein Viertel des Blattes verloren ging, sodass die Paragraphen 61-72 sowie 84-92 nur fragmentarisch erhalten sind. Aus den Fragmenten sind die vollständigen Zusammenhänge zwar nicht immer klar ersichtlich, jedoch lassen sie sich inhaltlich zuordnen, was für die Einschätzung der thematischen Gewichtung bedeutsam ist. Heute sind sämtliche Blätter grundlegend restauriert, jedoch haben sich feine Schichten von neu angegossenem Papier auch über eigentlich intakte Textstellen gelegt, was die Lesbarkeit mancher Passagen beeinträchtigt.

Insgesamt umfasst die Handschrift heute 92 Paragraphen. Darüber hinaus scheint noch ein Blatt mit weiteren Paragraphen verloren gegangen zu sein. Dies wird aus der auf Seite 6 niedergeschriebenen Einleitung zur Revision von 1655/56 ersichtlich, worin auf den Gesamtumfang von 105 Paragraphen verwiesen wird. Aufgrund der Notizen zu dieser Revision lässt sich vermuten, dass sie sich auf Fragen der koscheren Nahrungsmittel und deren Herstellung bzw. dem Handel damit bezogen haben, denn im erhaltenen Textteil werden sie nicht thematisiert. Da diese Einleitung von 1655/56 der

1 Aus einer Marginalie im $₫ 38$ ist jedoch ersichtlich, dass es vorherige, möglicherweise einzelne Bestimmungen gegeben hatte, die in die Version von 1650 einflossen. 
einzig erhaltene Hinweis für die Datierung der Statuten ist, wurde er in dieser Edition mit berücksichtigt.

Bei der Abschrift aus der Mitte des 17. Jahrhunderts wurde auf die Wiedergabe der Einleitung vollständig verzichtet, die möglicherweise Informationen über die Entstehung der Statuten und etwaige Vorgängertexte enthalten haben könnte (der Schlussteil ist offenbar verloren). Dadurch ist nicht aus dem Text selbst zu schließen, dass er tatsächlich aus Worms stammt. Lediglich der Umstand, dass er später von Wormser Juden, unter ihnen Simon Wolf Oppenheimer, dem Vater des späteren kaiserlichen Hoffaktors in Wien, Samuel Oppenheimer, überarbeitet wurde, spricht dafür. Auffällig sind zahlreiche Einschübe und Marginalien, die klar auf den Konzeptcharakter der Handschrift verweisen. Es ist jedoch nicht immer auszumachen, ob sie Teil der originalen Version waren oder Ergebnis der Revision von 1655/56. Der Vollständigkeit halber wurden sie in der vorliegenden Edition gleichwohl berücksichtigt. Auffallend ist das völlige Fehlen einer Interpunktion, die ansonsten bei Texten aus dieser Zeit in der Regel vorhanden ist.

Der sprachliche Gebrauch ist nicht einheitlich. Es gibt Teile auf Hebräisch wie auf Jiddisch, aber auch Artikel mit Vermischungen der Idiome. Insgesamt spielte jedoch Jiddisch eine größere Rolle. Damit ist der Text auch eines der frühesten Beispiele für den Gebrauch des Westjiddischen für normative Texte aus der Frühen Neuzeit. Über den Schreiber lässt sich aus den erhaltenen Textteilen nichts entnehmen, möglicherweise war er Mitglied der Statutenkommission.

Die Paragraphen sind mit hebräischen Buchstaben nummeriert und zu inhaltlichen Abschnitten zusammengefasst, die durch Überschriften kenntlich gemacht wurden. Die Seiten sind in späterer Zeit paginiert worden, vielleicht erst durch Leopold Löwenstein, der zu Beginn des 20. Jahrhunderts bereits an diesem und den späteren Wormser Statutentexten arbeitete.

Inhaltlich gliedern sich die alten Wormser takkanot in sieben eindeutig nachweisbare Abschnitte, angefangen von Fragen des religiösen Studiums und des Betriebs der lokalen Jeschiwa, über Aspekte der Synagoge, des so genannten »Pfenniggelds«, über die Tätigkeit der Steuerschätzer, die Verköstigung der durchreisenden Armen, die Amtsführung der parnasim und schließlich über Hochzeiten und, damit verbunden, die Aufnahme in die Gemeinde. Im offenbar fehlenden letzten Teil könnten vielleicht noch Fragen der koscheren Nahrungsmittel behandelt worden sein, die andernfalls nicht thematisiert werden. Im Teil der Notizen und Entwürfe zur Statutenrevision ist auch ein solcher Abschnitt vorhanden. Auffallend ist die hohe Wertigkeit, die den Aspekten des traditionellen Studiums und Fragen der Liturgie beigemessen werden, da sie prominent an erster Stelle der takkanot rangieren. Darin unterscheiden sich die Wormser Statuten sehr von dem Paralleltext aus 
Frankfurt a. M. von 1674/75. Unterstrichen wird die Wertigkeit noch durch die Existenz des bekannten und äußerst detaillierten Minhag-Texts aus der Feder des Wormser Juspa Schammasch, der das religiöse Brauchtum in der Mitte des 17. Jahrhunderts in Worms ausführlich beschreibt. ${ }^{2}$

Leopold Löwenstein unternahm 1903 eine erste Edition in den von ihm herausgegebenen Blättern für Jüdische Geschichte und Litteratur, verzichtete aber auf die Wiedergabe der fragmentarischen Teile. Auch unterliefen ihm einige Fehllesungen und Auslassungen von Textteilen. Die Zuordnung der Marginalien ${ }^{3}$ erscheint nicht in jedem Fall nachvollziehbar, wiewohl seine Vorlage dieselbe gewesen sein muss. Jedoch hat er schwierige Wörter in ihrer Bedeutung erklärt, weshalb seine Edition nach wie vor bedeutsam ist. Da die Blätter jedoch nur schwer zugänglich sind und Löwenstein den Text nicht vollständig wiedergegeben hat, fanden diese ältesten takkanot aus Worms hier erneut Berücksichtigung, diesmal in ein einer vollständigen Edition. Textteile, die heute im Original nicht mehr eindeutig lesbar sind, wurden aus Löwensteins Edition ergänzt und in eckigen Klammern dargestellt.

2 Benjamin Salomon Hamburger/Eric Zimmer (Hg.), Wormser Minhagbuch des R. Jousep (Juspa) Schammes, 2 Bde., Jerusalem 1988-1992 (hebr.); Shlomo Eidelberg, R. Juspa, Shammash of Warmaisa (Worms). Jewish Life in 17th Century Worms, Jerusalem 1991 (teilw. hebr.). Ein ausführlicher Vergleich der Statuten und der Minhagim steht noch aus.

3 So z.B.im $\$ 57$, zu dem Löwenstein eine Marginalie wiedergibt, die sich jedoch dieser Stelle in der Handschrift nicht finden lässt. 
הסכמנו ראשית חכמה יראת ה'י להחזיק בכל זמן ישיבה של בחורים יננערי] א

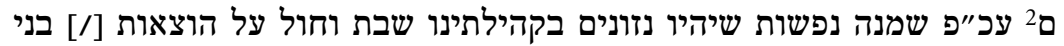

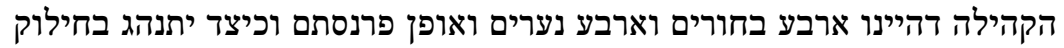

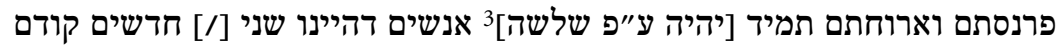

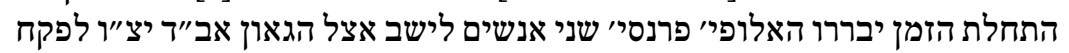
על עניין הנ"ל החמן יברי

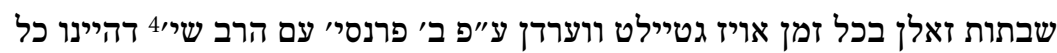

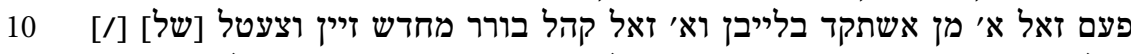

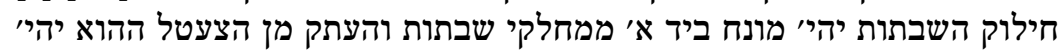
ביד השמש חשילוקות

בן האוכל על שולחן אביו או חמיו זאלן מחלקי שבתות דר קענן עד כמה מחלק

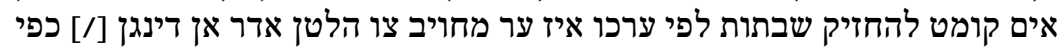

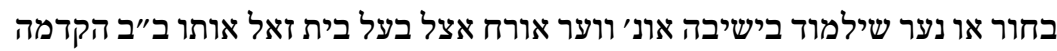

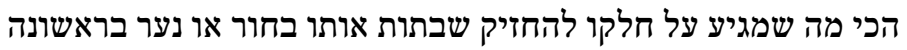

הרב ובני ישיבה יכולין לעשות הסכמה ביניהם איזה מסכת שרוצים ללמוד ואין המלמדים יכולין לעכב יכוליו ליכו

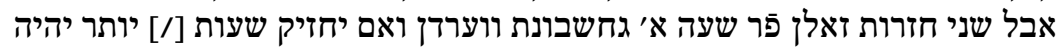

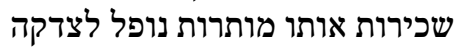

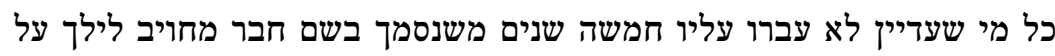
ז

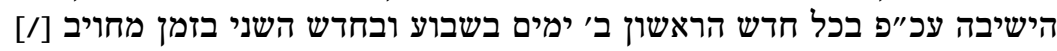
לילך על הישיבה פעם א׳ בכל שבוע בקנס חצי ק"ש על כל פעם שיפרי שיעבור ולא ילך

1 Ps $111,10$.

2 Wort auf einem restaurierten Riss, schwer lesbar. Hier, wie auch bei den folgenden zahlreichen Stellen, die heute nur schwer oder nicht mehr lesbar sind, wird Löwensteins Lesart in eckigen Klammern geliefert.

3 Durch Restaurierung des Textes überdeckter Abschnitt, der jedoch durch Löwensteins Edition rekonstruiert werden konnte.

4 שיחיה. 
ועכ״פ בכל שבוע ראשונה [!] בזמן מחויב כל מי שמכונה בשם חבר לילך שני [פ]]

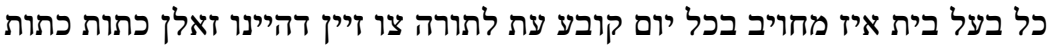
'ט

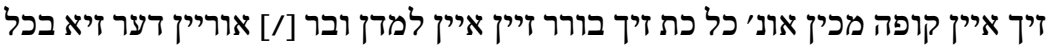

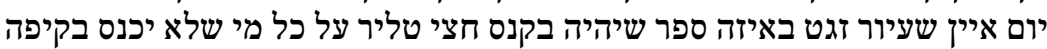

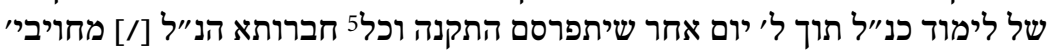

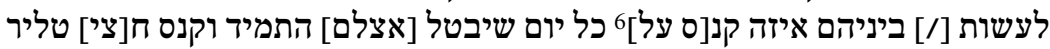

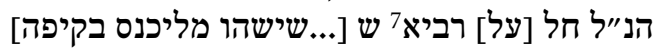

ווען מן מכט איין סיום מסכתא בקהילה זאל גמאכט ווערדן על קהלס שיל שטוב

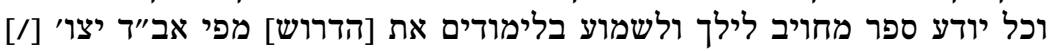

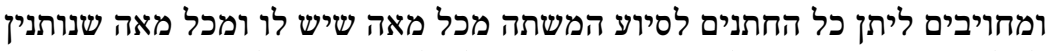

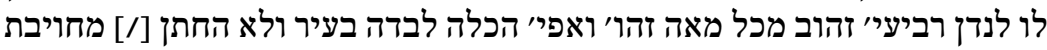

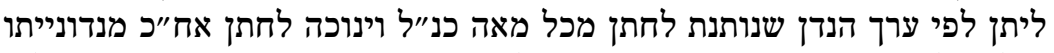

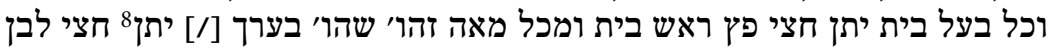

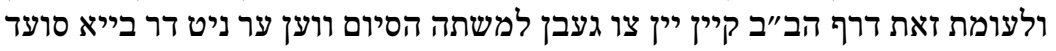

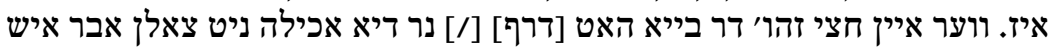

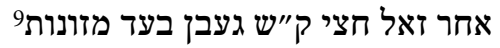

עניני בית הכנסת

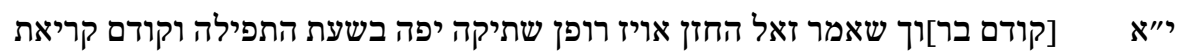

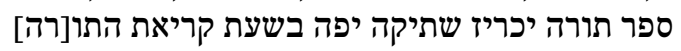

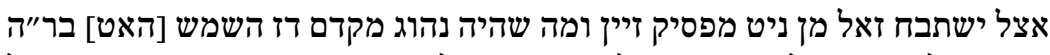
י

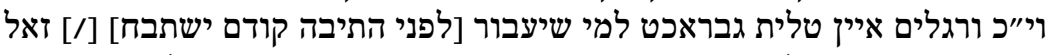

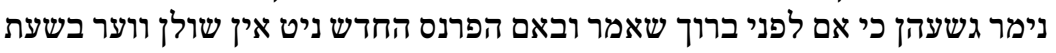

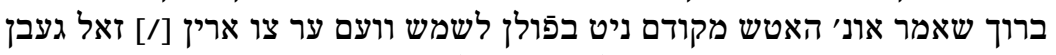

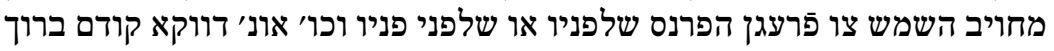

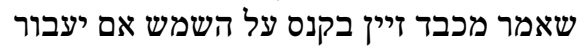

\footnotetext{
5 Ab hier bis zum Ende des Paragraphen als Marginalie hinzugefügt.

6 Textverlust durch beschädigten Blattrand.

7 רביעי?

8 Marginalie am rechten Blattrand in derselben Schrift: ווען ער אבר [/] יא סוער שם איז.

9 Vor Beginn der letzten Zeile des Paragraphen Ergänzungen in anderer Handschrift, לא יתחיל ש״"ץ קדיש לפני מנחה עד שיגמר הדלקת: heute unleserlich. Löwenstein gibt an

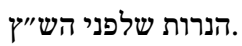




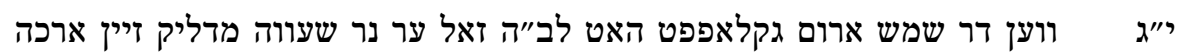

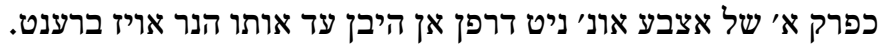

י"ד 5

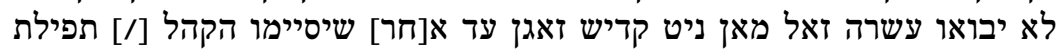

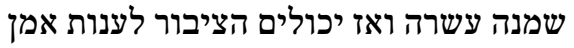

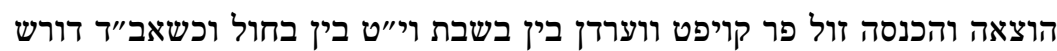

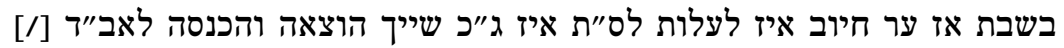
לכבוד הדרשה אר ערה

מי שיש לו הוצאה והכנסה בסוכות שייך לו ג״וכ מצות ההוצאת ס"ת בזמן 10 ההושענות ויכול לכבד בו למי שירצה מסותות שותות

יו"ז

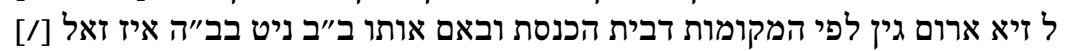

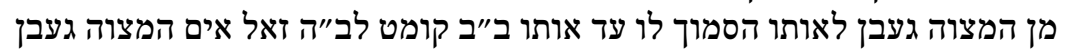

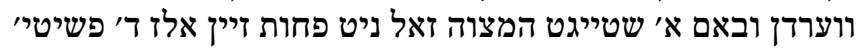

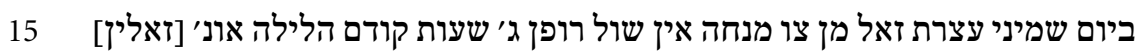

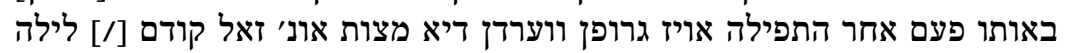

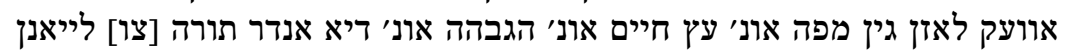
אונ' חיפוש אונ' גלילה ג' חלקים

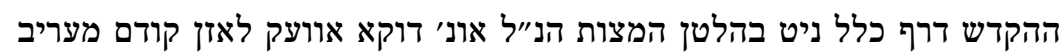
$0^{\prime \prime \prime}$

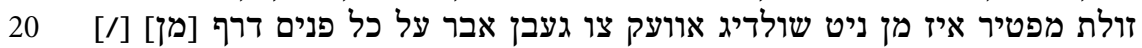

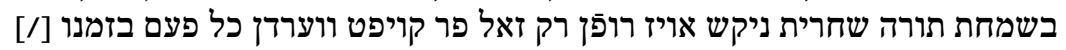

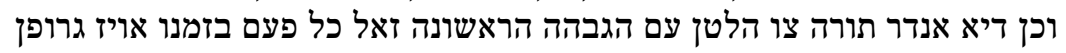
ווערדן ולא בשמיני עצרת

כל השנה דרף מן קיין סגן אוועק געבן אם לא למי שהוא נשוי בקנס ח[צי ליטר]א

שעוה כליה

זאל קיינר דרפן איין קינד אין שול נעמן וואז ניט ריינטלך איז ובאם א׳ מעכ מעט עובר

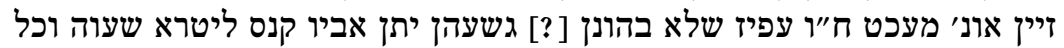

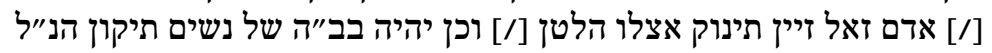

10 Dieser Paragraph wurde statt eines anderen später hinzugefügt. Der ursprüngliche וואן Artikel wurde gestrichen und ist teilweise noch in folgendem Wortlaut lesbar הקהל איש א׳ בשטעלט האט לעלות לתורה זאל מן אותו אדם [?] שמו אויף רופן אונ' ניט פר דן

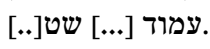


הס"ת תהיה [!] בכל פעם סגורה משעת ברכה אחרונה עד ברכה ראשונה של

אסור להגביה הס״ת עד דער גולל איז על הבימה ולא מקודם בקנס חצי ליטרא

פסוקי דזמרה ימנו הפרנסים ב״ב אחד שיאמר אותם כל השנה בקב[יעו]ת ובקיץ 5

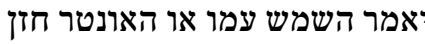

במוצאי שבת מחויב הגבאי לשלוח ע"י ב' וועכטר ליפרי לכל ב״ב נר שעוה באורך אצבע אבל לא יתן נרות לנערים עצמן למיר

כל מי שאין לו נר יום כיפור במשקל ליטרא לא יעמידנו במנורה לפני החזן בקנס חצי ליטרא שעוה לונר יופ

בימים נוראים זאלן שני שלשלאות ברזל אן גלֵיגט ווערדן משני צדדי החזן שלא יכנס א׳ במחיצתו

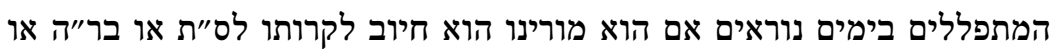

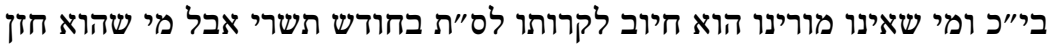

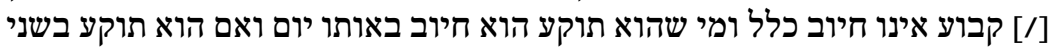
ימים אינו חיוב רק ביום ראשון

באסרו חג דיום כיפורים [יתנ]ו מן הקהל א׳ דוקוטי למשתה חזני ר"ה וי״״

כ"ט

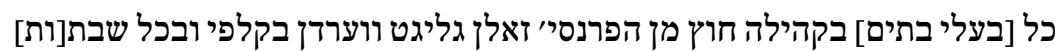
' 20

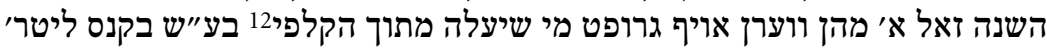

שעוה לצדק[ה]

קיין אורח ואיש נכרי זאל מאן לאזן מתפלל זיין לפני התיבה כי אם ע״פ הסכמתת ל ל רוב הפרנסי' ולא ע"פ פרנס החדש בלבד.

קיין אורח זאל מן צו דרשך געבן אם לא שהוא מברר שהיה ראש ישיבה בקהילה 25 בימנו' ולא בקטנה

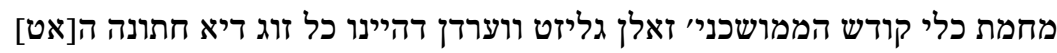
ל ל

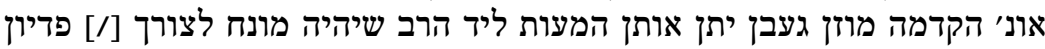

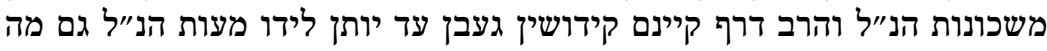

über der Zeile ergänzt, darunter ein gestrichenes Wort.

12 Darüber ergänzt: [?] בתכמש חמשי' למקרא 


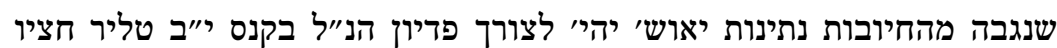

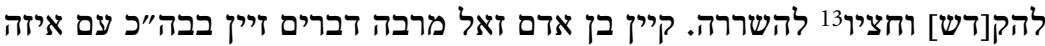

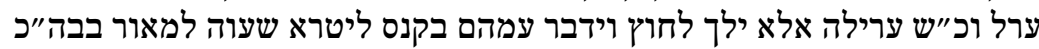

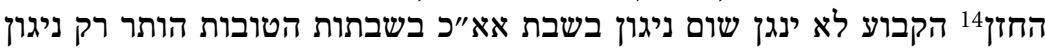

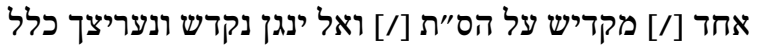

מחמת הקלאמי"ן בב"ה זאל ניט געשהן בלי רשות אב"ד או פרנס החדש בקנס חצי ל ל"ד טליר

שבת אחר פורים או אם חל בשושן פורים שייכים כל המצות להבחורים ל"ה

פפעניג געלט

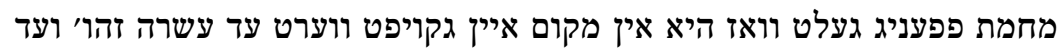
ל פ"ו

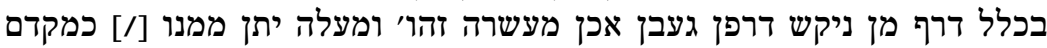

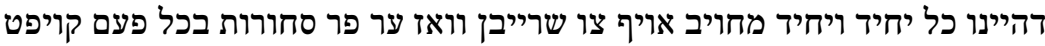

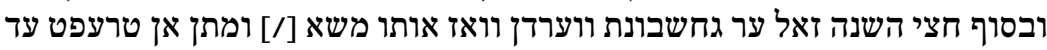

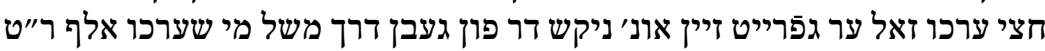

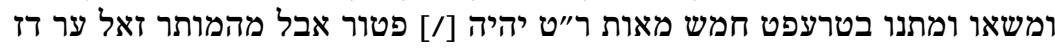

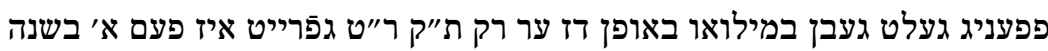

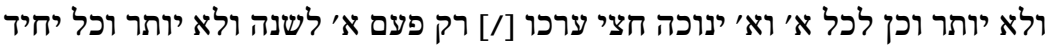

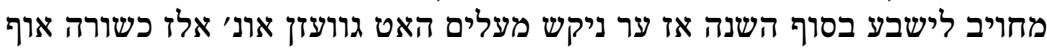

גשריבן.

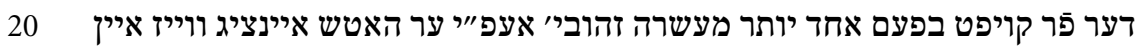

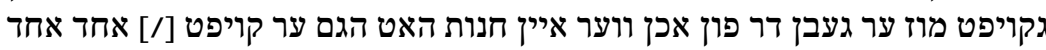

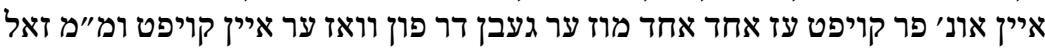

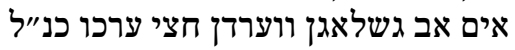

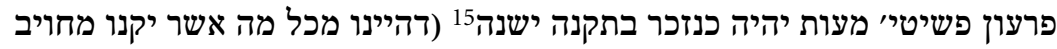
ל ל

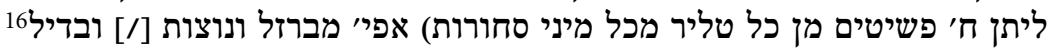

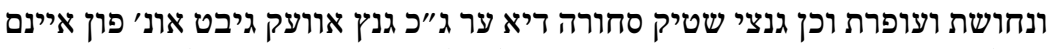

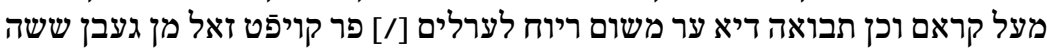

$13 \mathrm{Ab}$ hier gedrängt am linken Blattrand geschrieben.

14 Ab hier spätere Ergänzung in anderer Schrift.

15 Über dem Wort findet sich eine Einfügungsmarke und am linken Blattrand wurde

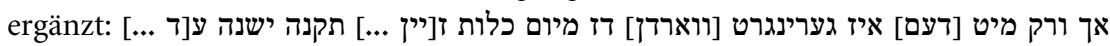
חנוכה תי"א [זול] נאר געבן ד' פשי גיטיטים

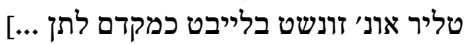

Die Datumsangabe entspricht Mitte Dezember 1650.

16 Am Beginn der Zeile ein Wort gestrichen. 
פשיטיי מכל טליר וכן מן טריפה ליכט וכן פפעניג קרעם ומיין הן כשר או לא איז

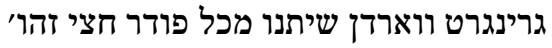

ווען איין יהודי איין אנדרן פר קויפט דרף ער ניקש געבן רק דער איינם ערל פר ל" קויפט איז חייב צו געבן יהודי אנדרן

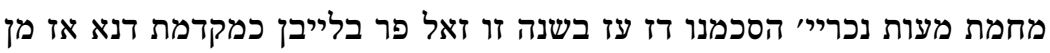
מ' 5

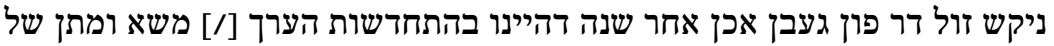

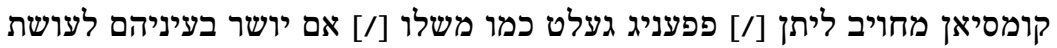
תיקון אודות מעות [..[יי' ויעשו ע״יפ בעלי געלט תקנות משלות

עוד הסכמנו דז קיינר דארף ניט שותפות מכין עם בעל בית שחוץ לקהלה בקנס כפי יצי מואי

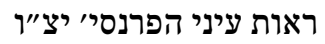

מחמת מעריכים

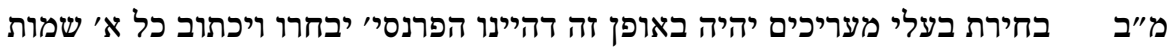

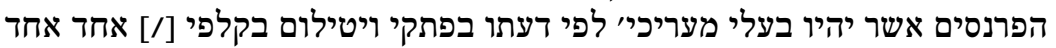

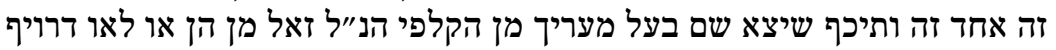

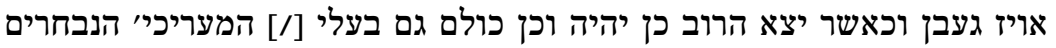

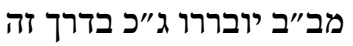

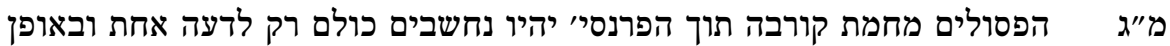

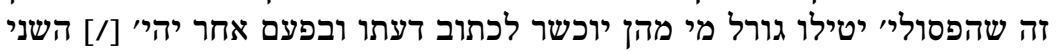

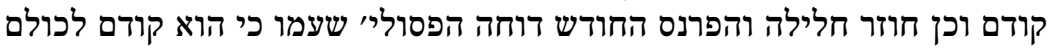

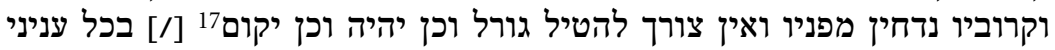

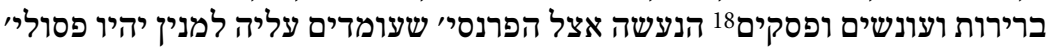

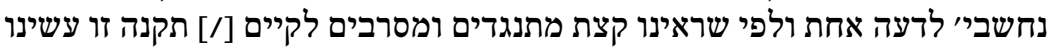

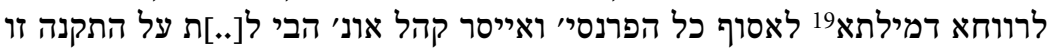

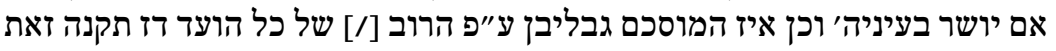

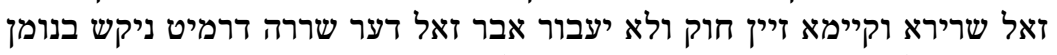

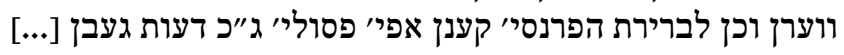

סך הבעלי מעריכים יהיו חמשה שני פרנסי' ושלשה בעלי בתים ולא יהיו ניו נוגעים

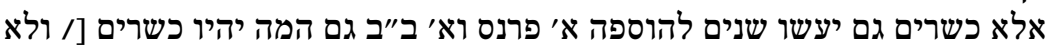
נוגעים בשום קורבה נטים

17 Am linken Blattrand das Wort חרם.

18 Die letzten zwei Wörter über der Zeile ergänzt, darunter ein gestrichenes Wort.

19 לרווחא דמילתא (aram.) = um die Sache zur Vermeidung von Komplikationen auszuweiten. 
בעת בחירת בעלי מעריכים ויסתייעא מילתא דז מן רובן זאל אום איין פרנס מחוי מויב

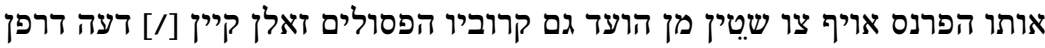

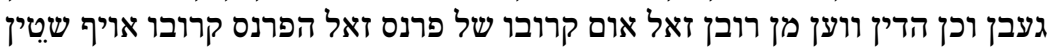

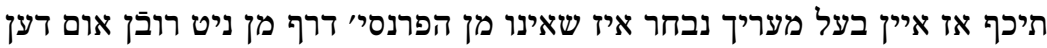
מ"ו

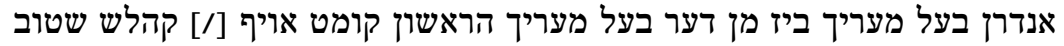

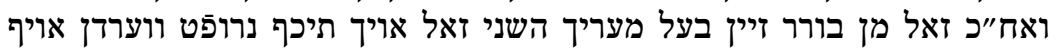

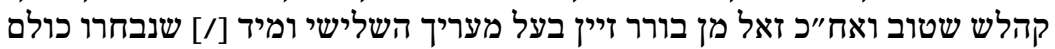

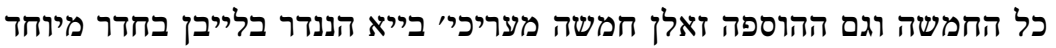

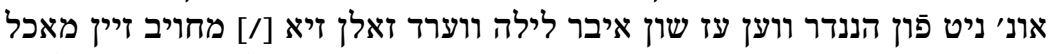

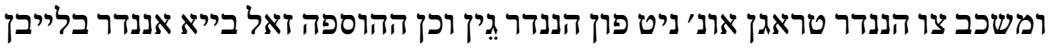

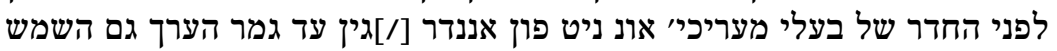

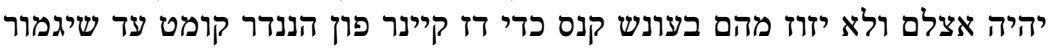

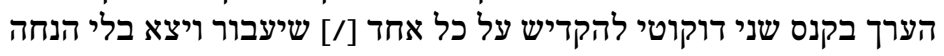

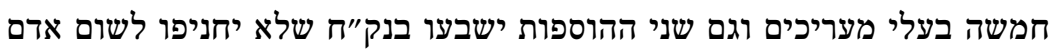
מוז

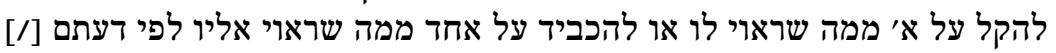
באמת ויושר בלי אהבה ואי ממה לאוי לואה

אם יאמר א׳ על א׳ מבעלי המעריכי' שהוא שונא אותו אין שומעין לו ואינו נאמן מ"ח

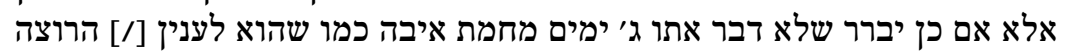

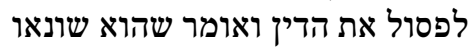

הרוצה לשבע על ערכו מחויב לשבע תוך ה' ימים אחר שיגמר הערך אונ' מוז איין [S. 3]

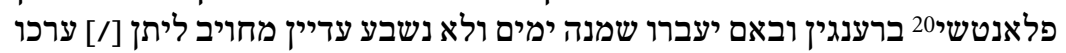
מ"ט

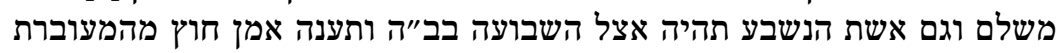
ומ"מ הרשות ביד הקהל להשביע גם הנשע תותה אציה אחר הלידה בריה ותעת

שני בעלי המעריכים והשמש יהיהו אצל שבועת הערך ויטילו גורל בין בעלי ']

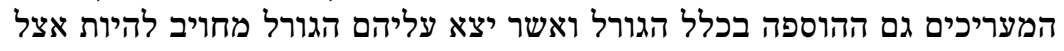

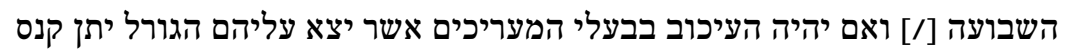
כל אחד חצי טליר

הרוצה להוסיף בשבועתו על ערכו יותר על מה שכתב בפלאנטשי מיראת עונש J"]

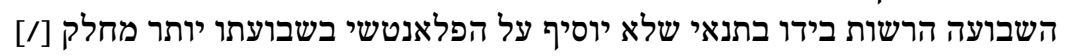

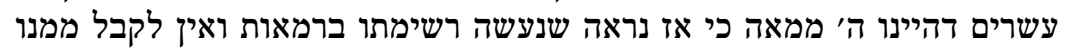

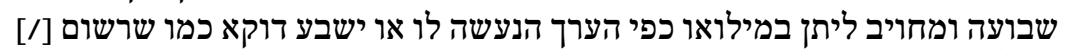

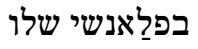

20 plantshe = planche (frz.), Brett, Tafel, hier offenbar in der Bedeutung von Aufstellung. 
חובות וועלכי אין ערך בעלי מעריכים פיר ליגט יתן מהם כמשמעות תקנה הישנה

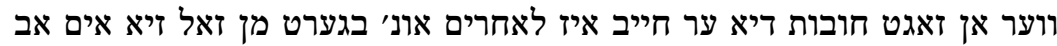
נ"

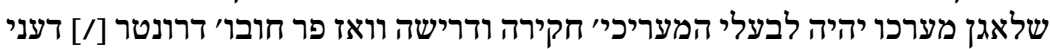

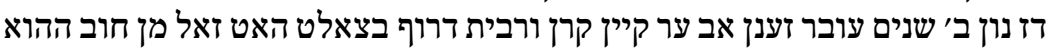

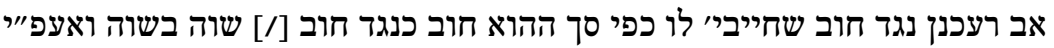

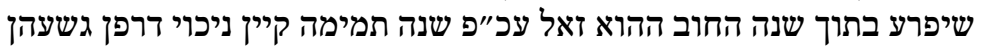

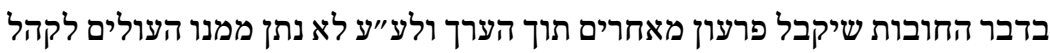

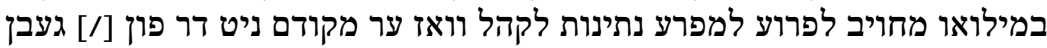

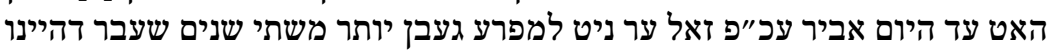

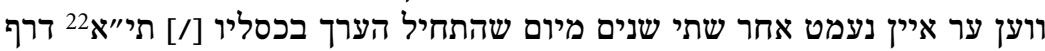

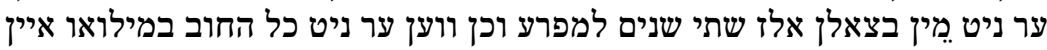

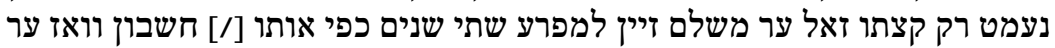

כלי בית כגון בעטליילכר מפות שולחן ומפות הידים ציכן בדיל ונחשת מעסינג מג

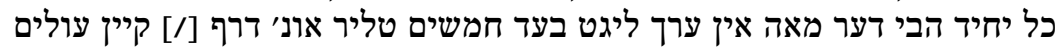

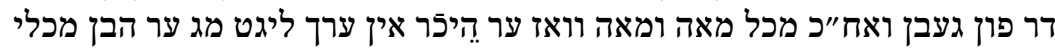

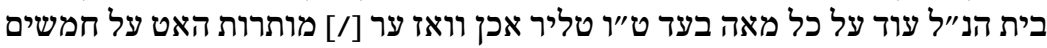

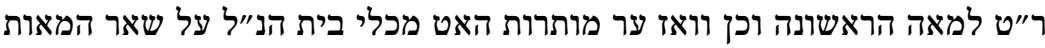

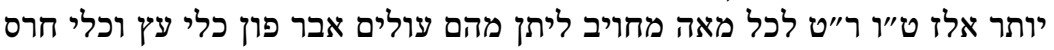

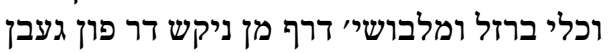

מכסף וזהב מוז מן פון אלים דען ערך פר פול געבן אפיי מה שהוא מחובר במלבושים

תבואה ויין וכן קמח וואז איטלכר בביתו מונח האט מג ער חשבונן ווז ער דרף

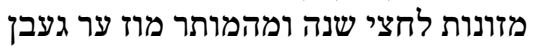

$$
\text { דער ערך זאל פר פַול גמכט ווערדן בלי ניכוי שליש }
$$

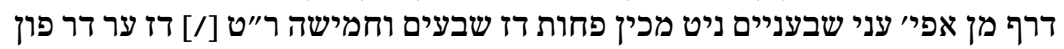

21 Anschließend einige gestrichene Wörter.

$221650 \mathrm{IX} / \mathrm{X}$. 
[ס"א

ניט.... שנים ואז זאל מן הערך מחדש זיין לטובה על שני שנים מכין [?] [/] [...] שנה ב"ס]

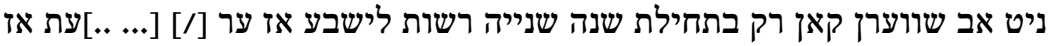

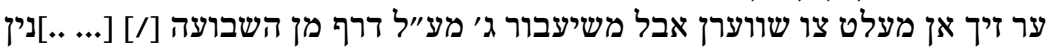

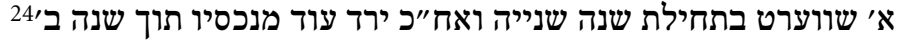

[.... גחשבנת הבי לכל בעל בית למפרע וואז מן געבן האט מר״"ח כסליו העבר [/] $\left.\lambda^{\prime \prime} 0\right]$

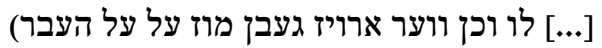

[.... 7"ס]

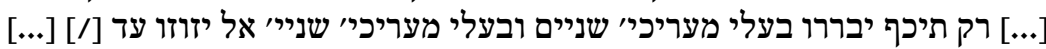
עשיית הערך מה שמגיע עליהם לפי ערך החיכרי משים מבעלי מער

.... או]יף קהלש שטוב גרופָן ווערדן כנ"ל אונ' דרפן ניט פון הננדר גִין עד [/] [...] "ס]

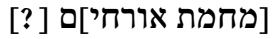
[ס"ו ....] ווען ער25 ביום ה'26 קומט מג ער בלייבן עד יום א׳27 ואותו ב"ב דער [/] [...] [ס"ז

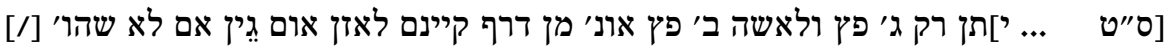

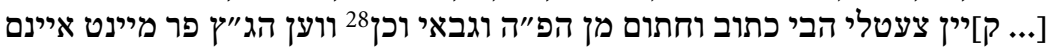

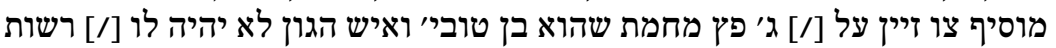

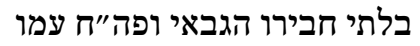

23 Die Paragraphen 61-72 sind nur fragmentarisch erhalten. Daher ist von den folgenden zwölf Artikeln jeweils nur die zweite Zeilenhälfte vorhanden. Die Unterteilung in die einzelnen Paragraphen ist jedoch noch erkennbar, sodass die Nummern rekonstruiert und zugeordnet werden konnten.

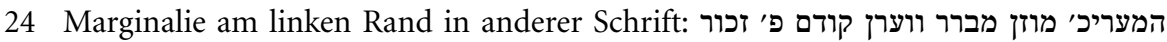

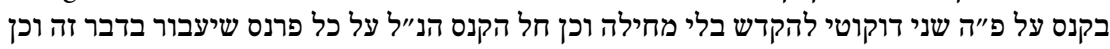

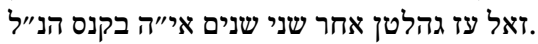

25 Danach ein Wort gestrichen.

über der Zeile ergänzt.

27 Danach gestrichen: ולא עד בכלל

28 Ab hier spätere Ergänzung in anderer Handschrift. 
[מחמת פ]רנסי'

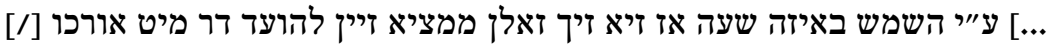

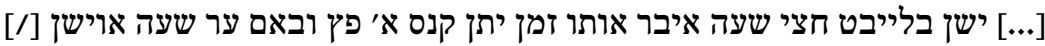

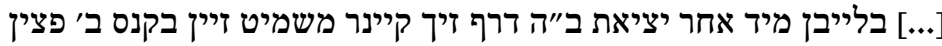

$$
5
$$

[ע"ב .... רידן לבלבל הענין וואז הפ"ה האט פיר גבראכט בקנס א׳ פץ

[S. 4]

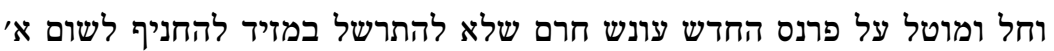
ע"ג

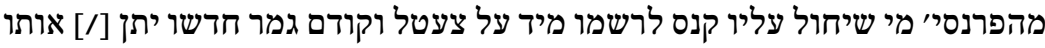

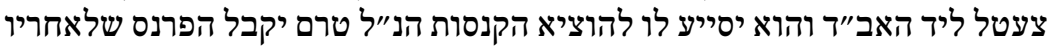

את החודש צעיד

עכ"פ יש כח ויד לפ"ה קנס אן צו ביטן לעת אסיפת הועד כשהדבר נחוץ וכן שלא

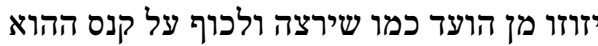

הפ"ה מחויב להשגיח שלא יריבו הפרנסיי יחד ושלא להכות על השלחן ולקנוס על ילי ע"ה

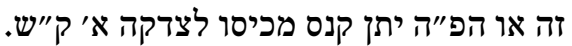

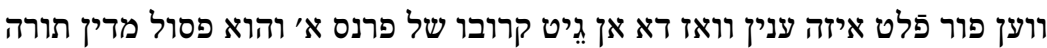

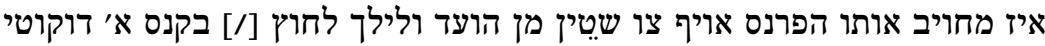

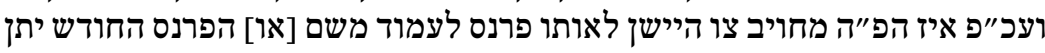

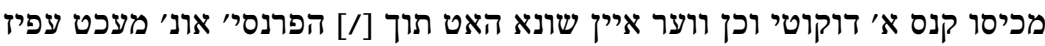

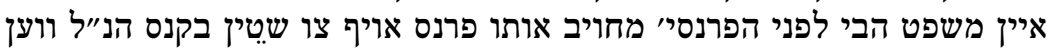

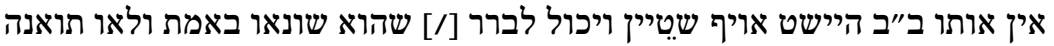

אלר בשייד וואז בייא קהל בלייבט זאל מן שני פעי פעמי' ארום רובכן קודם [דער]

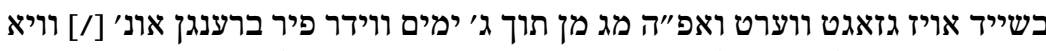

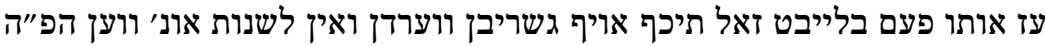

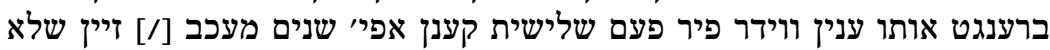
לדבר מאותו ענין

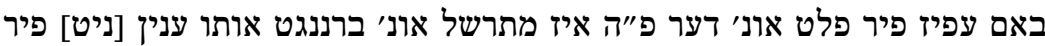

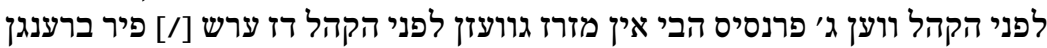

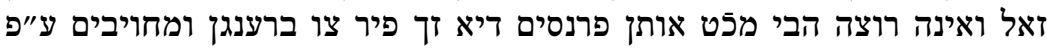




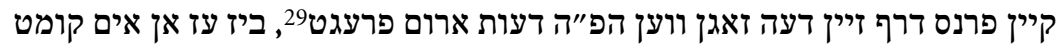
בקנס כמו שירצה הפ"ה והפסולים מחמת קורבה יהיו נחשבי׳ לדעה א׳ כמבואר ע"ט

$$
\text { סיו30 פוגדיג כמו } 31
$$

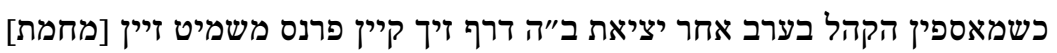

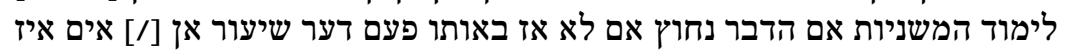

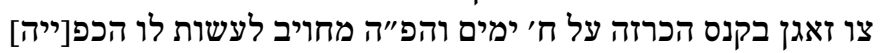

פנקס הקהל זאל אמדארץ32 סגור בתיבה זיין אונ' הפרנס החדש זאל ניט [הבי] פ"א

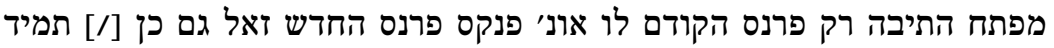

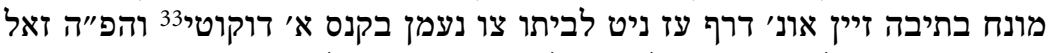

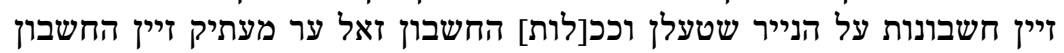

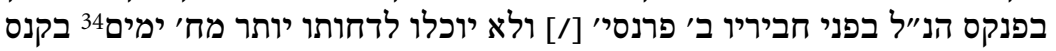

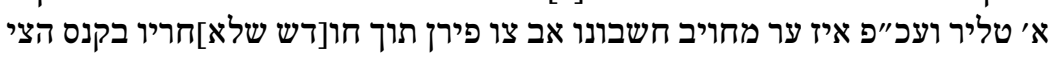

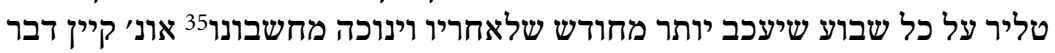

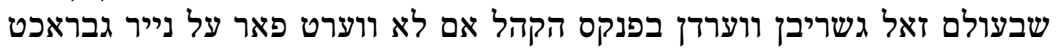

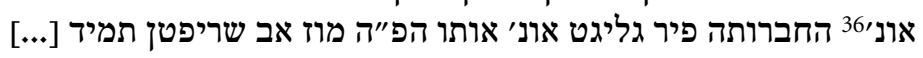

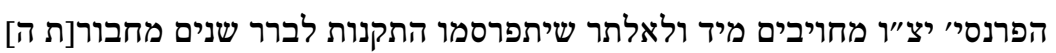
פ"ב37 פ

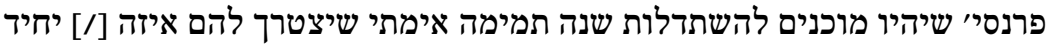
באיזה ענין וסיבה וכן יבררו בכל שנה ושנה להתות שמה תמה

מחמת אייסר קהל יהיי באופן זה כל א׳ מהפרנסי' יוכל לקרות א׳ [מי שי[רצה זולת

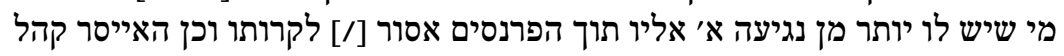

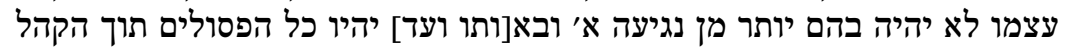

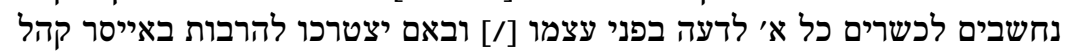

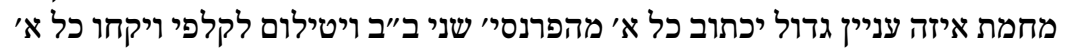

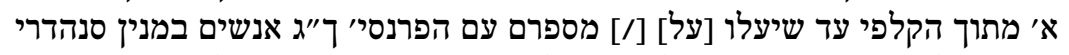

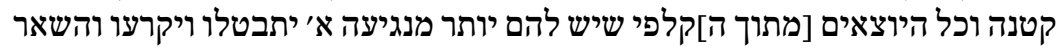

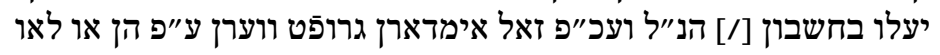

\footnotetext{
29 Die letzten fünf Wörter über der Zeile ergänzt.

30 סימן

31 Am linken Rand ergänzt: לפי [...] ועכ"פ [...] פצין ניט [..]טור [...] או יתן מכיסו

32 Offenbar abgeleitet von »immerdar «.

33 Von אונ' דרף bis hier über der Zeile ergänzt.

34 Die letzten drei Wörter am rechten Blattrand ergänzt.

35 Von בקנס א׳ טליר bis hier über der Zeile ergänzt.

36 Ab hier bis zum Ende des Paragraphen am rechten Blattrand ergänzt.

37 Dieser Paragraph wurde von Löwenstein irrtümlich zwei Mal wiedergegeben.

38 Danach folgt בקנס, jedoch offenbar gestrichen.
} 


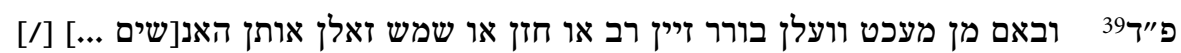

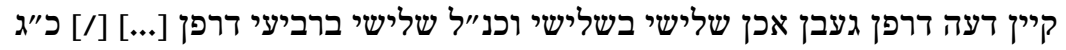
אנשים רק שלשה פסולים מחמת קורבה זיין ולא יותר אפי' שלישי בישי בי......

פּ"ה באם ח"ו יעדר א׳ מהפרנסי' וירצו למנות אחד תחתיו זאל מהיונם ...]

5

פחמת חיתונים בקהילה

מחמת חיתונים זאל אזא גהלטן ווערדן ראשון בראשון דהיינו ווער [...] [/] בני עיריר פ"ז

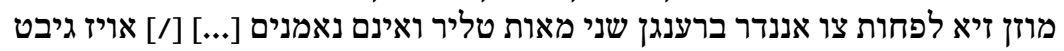

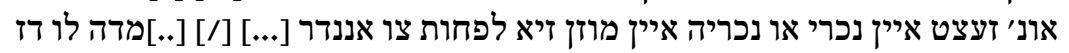
ער קאן איין קומן ווען דז זוג שני מאות טליר האט זיוז זיר

ראשון בשני אם הן שניהן בני עיר מוזן זיא לפחות צו אננדר ברנגן [...] [/] א' מבניי

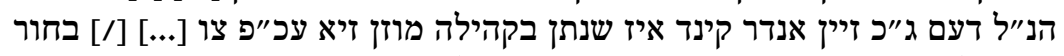

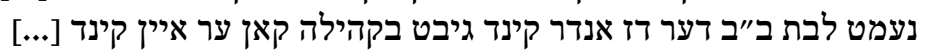

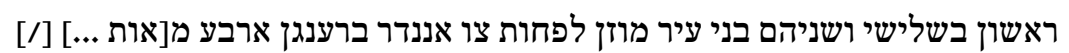
פ"ט

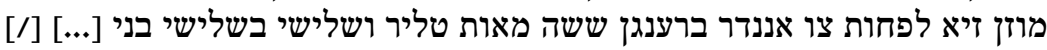

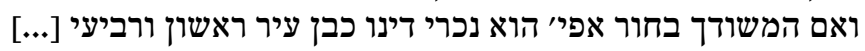

ובכל השידוכי' הנ״ל ווען הבחור בן עיר איז זאל ער גניסן דז ער מג [...]

ועכ"פ איטלכר דער איין חיתון טוט בקהילתינו מוז אותו הזוג הַבין חלק [...]

צ צ

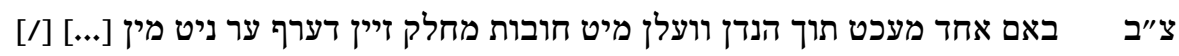

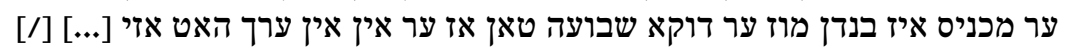

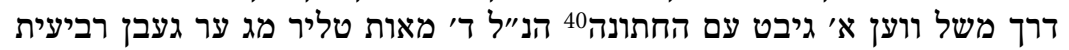

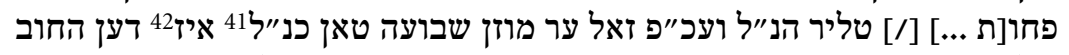

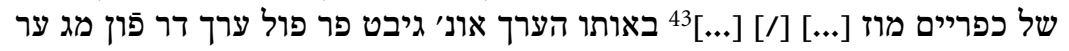

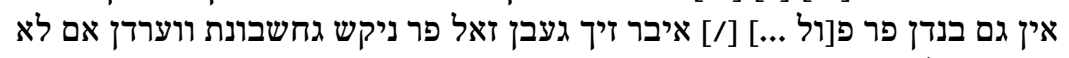
ער גיבט להזוג מש]......

39 Ab diesem Paragraphen bis einschließlich 92 fehlt jeweils die linke Hälfte des Blattes.

40 In der Handschrift: התונה.

41 Darüber ein ב.

42 Darüber ein $\boldsymbol{~}$.

43 Blatt am Zeilenanfang verschmutzt, Wort unleserlich. 
[S. 6] $]^{44}$

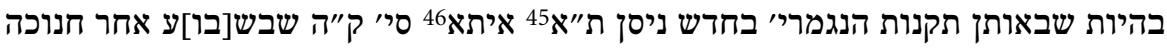

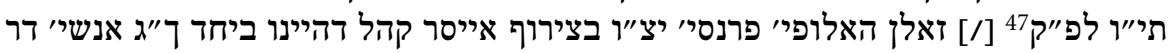

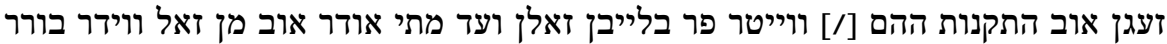

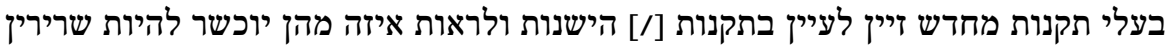

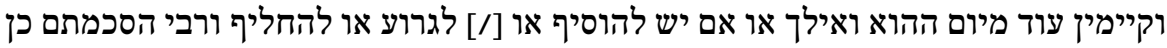

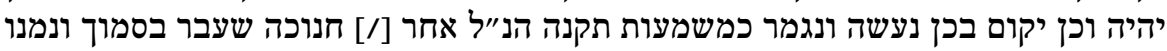

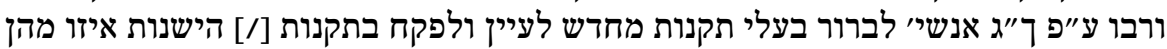

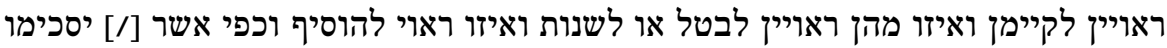

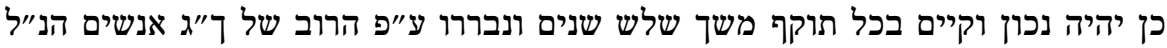

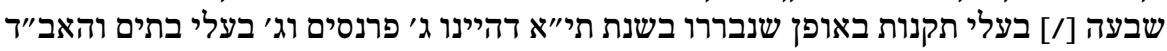

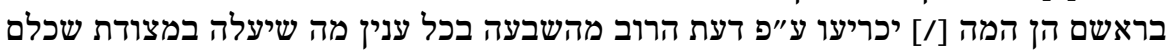

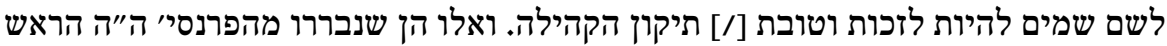

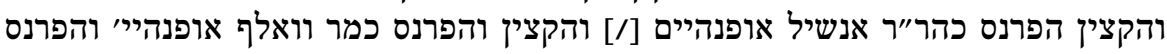

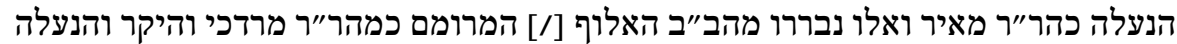

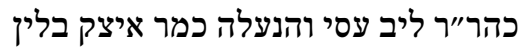

44 Die dazwischen liegende Seite 5 enthält Änderungen der vorhergehenden Paragraphen, ebenso wie der untere Teil von S. 6 sowie S. 7 und 8. Diese Einleitung wurde offenbar für die revidierte Version von 1655 geschrieben, da sie aber die einzige Quelle für die Datierung der vorliegenden Statuten ist, soll sie hier ebenfalls wiedergegeben werden.

$451641 \mathrm{III} / \mathrm{IV}$. Die Stelle ist offenbar korrupt und muss heißen: תיתיא, 1651.

46 איתא (aram.) = gibt es.

471655 XII. Diese Datierung ist jedoch nicht unproblematisch, da für gewöhnlich die Kombination I"י für die Wiedergabe der Zahl 16 umgangen wird. Allerdings ist sie gerade in den Statuten auch für die Nummerierung des 16. Paragraphen verwendet worden, sodass mit תי" ת durchaus auch 416 (der kleinen Zeitrechnung) = 1655/56 gelesen werden kann und nicht nur 400 (=1639/40), was hier keinen Sinn ergäbe. 


\section{Statuten aus Frankfurt a. M. 1674/75}

\section{Quelle: Pinkas Frankfurt a. M., National Library of Israel, MS $4^{\circ} 662$}

Die hier edierten Frankfurter takkanot scheinen die frühesten zu sein, die in dieser Ausführlichkeit von der reichsstädtischen Gemeinde erlassen wurden. Nach dem gegenwärtigen Kenntnisstand gibt es noch einen älteren, jedoch deutlich weniger umfangreichen Text von ca. $1623 .{ }^{1}$ Darüber hinaus erwähnen die hier edierten Statuten frühere Regelungen aus dem Jahr 1657/58 zu den Vorsteherwahlen und zur Heiratsvermittlung. ${ }^{2}$ Die hier erstmals publizierten ${ }^{3}$ takkanot von 1675 entstanden in einer Zeit, als sich die unweit von Frankfurt gelegenen reichsstädtischen Gemeinden Worms (1641) und Friedberg (1664) ebenfalls umfassende Statuten gaben. Es liegt nahe, die Verfassung der Frankfurter Statuten auch im Zusammenhang mit der allgemeinen Entwicklung zu formell stärker strukturierten Großgemeinden in Zentraleuropa zu betrachten.

Die hier vorliegenden Statuten wurden am Ende des Textes auf den 25. Januar 1675 datiert. Der Zeitraum der eigentlichen Entstehung ergibt sich jedoch aus den Paragraphen 85 und 91. Danach scheint der größere Teil (bis $\$ 86)$ innerhalb des jüdischen Jahres 5434 verfasst worden zu sein, während die letzten Paragraphen ab $\$ 87$ offenbar erst später, nämlich nach dem Chanukkafest $5435^{4}$ entstanden. Diese Verzögerung ergibt sich auch aus dem In-

1 National Library of Israel, Heb $4^{\circ} 662$ fol. 81 r-83 v. Da er sich jedoch in seinen Bestimmungen (allesamt unnummeriert) lediglich auf Fragen der Vorsteher, ihrer Wahl und Kompetenzen sowie auf Gerichtsangelegenheiten bezieht und selbst gar nicht als Statuten (takkanot) bezeichnet wird, sondern als Kompromiss (pesher), bleibt er in dieser Edition unberücksichtigt. Siehe dazu auch Kracauer, Geschichte, Bd. 1, $409 \mathrm{f}$.

2 Siehe $\$ \$ 7,49$ und 86.

3 Der ehemalige Direktor der Central Archives for the History of the Jewish People in Jerusalem, Arieh Segall, fertigte vor längerer Zeit eine Transkription des Frankfurter pinkas an, in der er auch die jiddischen Textteile ins Hebräische übertrug. Seine Arbeit enthält Kommentare zu einigen Paragraphen, jedoch ist sie insgesamt nicht fehlerfrei. Das unveröffentlichte Manuskript befindet sich heute in den Beständen der Central Archives (ohne Signatur).

4 Ende November, Anfang Dezember 1674. 
halt der abschließenden Paragraphen, die vielfach frühere Erlasse aufgreifen und bekräftigen.

Die takkanot wurden von einer fünfzehnköpfigen Kommission entworfen und dies zu einer Zeit, als es in Frankfurt offenbar eine Vakanz in der Position des Oberrabbiners gab oder diese in Kürze zu erwarten war, wie aus den Paragraphen 33 und 82 deutlich wird. In der Mitte der 1670er Jahre war Aaron Samuel Kaidanoer Rabbiner der Gemeinde, doch scheint seine Amtszeit gerade in der Entstehungszeit der Statuten ihr Ende gefunden zu haben. ${ }^{5}$ Durch das Verfassen der Statuten während einer Ämtervakanz wurden auch die Konflikte, die sich aus den Kompetenzdiskussionen in Fragen der Rechtsprechung und der Formulierung sowie Bestätigung der takkanot überhaupt ergeben konnten, vollständig umgangen. Paragraph 82 legt lediglich fest, dass der zukünftige Rabbiner die Statuten noch bestätigen und kraft seines Amtes deren Einhaltung überwachen müsse.

Die Statuten wurden auf neun Folioblättern des sehr umfangreichen Frankfurter Protokollbuches niedergeschrieben. Dieser pinkas weist die andernorts unbekannte Laufzeit von 250 Jahren (1552-1802) auf und ist eine unschätzbare und bislang immer noch nicht vollständig gewürdigte Quelle für die jüdische Geschichte von Frankfurt am Main. ${ }^{6}$ Sein offenbar komplett erhaltenes Korpus umfasst auch den Statutenteil von 1674/1675: alle Blätter sind ohne Beschädigungen oder Verluste erhalten, sodass alle 97 Paragraphen einschließlich Einleitung und Schluss überliefert sind.

Im Sprachgebrauch der takkanot überwiegt das Hebräische deutlich vor dem Jiddischen. Viele Paragraphen wurden vollständig auf Hebräisch verfasst; nur wenige Paragraphen wurden ausschließlich in jiddischer Sprache

5 Markus Horovitz, Frankfurter Rabbinen. Ein Beitrag zur Geschichte der israelitischen Gemeinde in Frankfurt a. M., Jerusalem 1969, 89f.; er geht allerdings davon aus, dass Kaidanower noch bis 1676 in Frankfurt gewesen sei, was aber aus dem Statutentext, den Horovitz auch erwähnt, so nicht ersichtlich ist. Auch geht aus dem Text der takkanot hervor, dass der Einfluss eines Rabbiners bei der Abfassung eher gering gewesen sein dürfte. Nach einer anderen Ansicht war er unmittelbar nach der Frankfurter Zeit, und vor 1677 - in diesem Jahr wechselte er nach Krakau - tatsächlich noch in Brest-Litowsk und Groß-Glogau; siehe Paul Arnsberg, Chronik der Rabbiner in Frankfurt am Main, Frankfurt a. M. 22002, 34, jedoch ohne Nennung von Quellen.

6 Der israelische Historiker und Handschriftenforscher Mordechai Nadav legte vor längerer Zeit einen Index für das Protokollbuch vor: Pinkas kahal Frankfurt de-Main [Protokollbuch der Gemeindeleitung Frankfurt am Main], in: Kiryat Sefer 31 (1957), 507-516 (Nachdruck in: Mordechai Nadav, Pinkas patuah. Meḥkarim be-toldot yehude Polin we-Lita [Offenes Protokollbuch. Forschungen zur Geschichte der Juden in Polen und Litauen], Tel Aviv 2003, 257-266. 
niedergeschrieben. Häufig sind Mischformen zu finden, wobei sehr oft der Beginn und die Mitte eines Paragraphen auf Hebräisch verfasst wurden, während der jiddische Teil sich meist auf die jeweils letzten Zeilen beschränkt. In den hebräischen Abschnitten finden sich eine Anzahl von Zitaten aus der Bibel und dem Babylonischen Talmud, was auf ein hohes Bildungsniveau und eine insgesamt hohe Fremdsprachenkompetenz der Statutenkommission schließen lässt. Jiddische Paragraphen behandeln meist Themen des alltäglichen Lebens sowie der Berufspraxis als Krämer oder Kleiderhändler (die Paragraphen 55-79 wurden nahezu vollständig auf Jiddisch verfasst).

Über den Schreiber lässt sich aus dem Text selbst keine Information entnehmen, da er sich nicht eindeutig als solcher zu erkennen gibt. Nicht auszuschließen ist, dass einer der beiden in der Einleitung genannten ne'emanim (Notare), Samuel Ne'eman und Moses Sofer, die Reinschrift in das Protokollbuch übernahmen. ${ }^{7}$

Die Paragraphen wurden alle am jeweils rechten Blattrand mit hebräischen Buchstaben nummeriert. Bei fast allen Artikeln wurde zu Kennzeichnung eines neuen Abschnittbeginns das erste das erste Wort in größerer Kursivschrift geschrieben als der übrige Text. Die Blätter des pinkas wurden in der üblichen Form in hebräischen Lettern in der jeweils linken oberen Blattecke nummeriert. Der Text selbst ist äußerlich sichtbar kaum strukturiert. Lediglich zwei Themenüberschriften wurden eingefügt: vor $\$ 36$ (ha-govim) und vor $\$ 38$ (bet ha-din).

Im ersten Viertel des Textes werden vornehmlich Fragen der Rechtsprechung und der Verfahren geregelt, vor allem in Fällen, die durch die Vorsteher verhandelt wurden. Dies steht sicher in einem gewissen Zusammenhang mit der erwähnten Vakanz des Rabbinats in der Entstehungszeit: Offenbar waren die Vorsteher an der Fixierung ihrer rechtlichen Kompetenzen innerhalb der Gemeinde sehr interessiert, die jedoch in Konkurrenz zu der des rabbinischen Gerichts stand. Auch der letzte $\$ 97$ legt noch einmal die Kompetenz der Rechtsprechung durch die Vorsteher fest, hier vor allem in Bezug auf Klagen wegen Beleidigung oder Handgreiflichkeiten, die vor allem nicht an die nichtjüdischen Instanzen gegeben werden sollten. Im Weiteren wird die Wahl der Gemeindeangestellten geregelt, die wiederum vor allem durch den Vorstand erfolgen sollte. Beachtenswert ist der lange Komplex mit Fragen des Handelsrechts und des Verhaltens durch Krämer und Kleiderhändler, wofür es offensichtlich zur Entstehungszeit einigen Handlungsbedarf gab. Paragraph 83 legt schließlich die Geltungsdauer von neun Jahren fest. Folgerichtig

7 Tatsächlich erscheint in der ersten Gruppe der Unterzeichnenden zweimal ein Moses, jedoch ohne weiteren Zusatz, um auf die Tätigkeit als Schreiber schließen zu können. 
wurden dann 1685 die älteren Statuten noch einmal generell bestätigt, aber auch mit einigen Ergänzungen und Veränderungen versehen. ${ }^{8}$ Bemerkenswert ist, dass es so gut wie keine Bezugnahme auf religiöse oder liturgische Aspekte in den takkanot von 1674/75 gibt. Vielmehr ging es insgesamt um die Regelung solcher Fragen, die man heute unter dem Begriff "Zivilrecht« zusammenfassen würde. Auch deswegen ist dieser Text aus Frankfurt von einiger Bedeutung, zeigt er doch klar Tendenzen einer Säkularisierung der Gemeindeführung auf, die aus anderen Statuten so noch nicht ersichtlich ist.

In der Mitte des 18. Jahrhunderts gab es offenbar erneut intensive Bemühungen um ein erneuertes Gemeindestatut mit 126 Paragraphen, das jedoch beim Rat und Kaiser zur Bestätigung eingereicht werden musste, aber anscheinend nie eine Bestätigung erhielt. ${ }^{9}$

8 Kracauer, Geschichte, Bd. 2, 43.

9 Ebd., 204-211. 
[fol. $138 \mathrm{r}$ ]

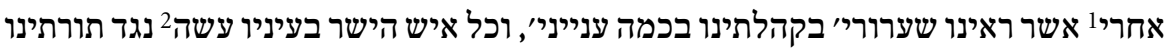

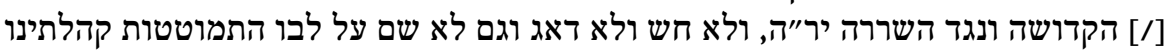

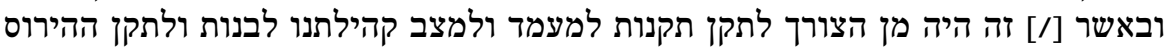

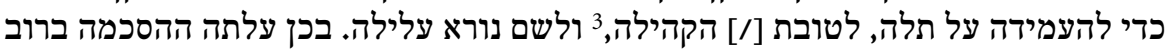

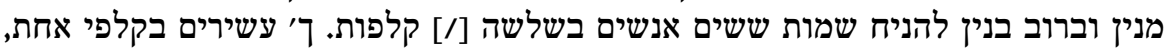

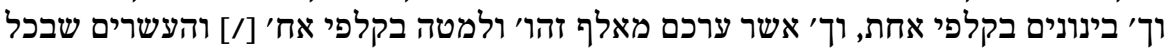

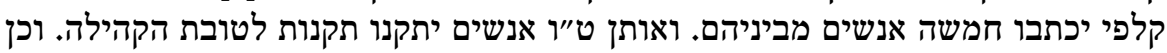

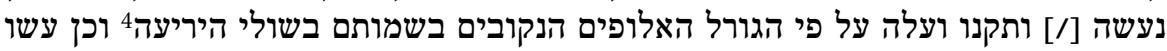

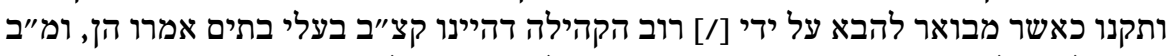

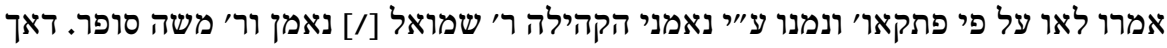

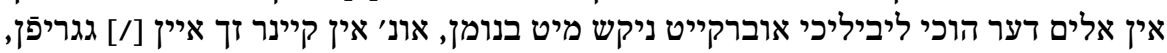

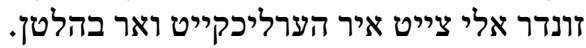

זה יצא ראשונה. התובע את חבירו לפני פרנס החדש לשלם לו כמשמעו' השטר או א

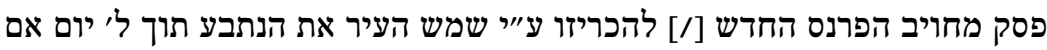

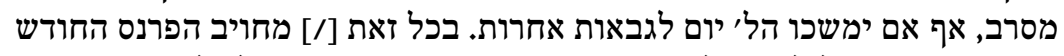

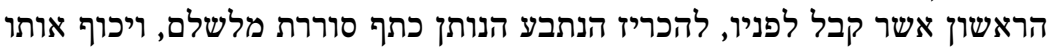

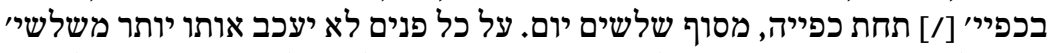

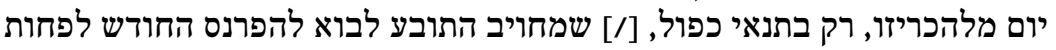

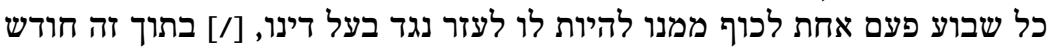

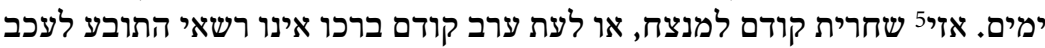

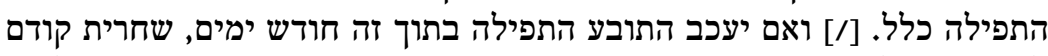

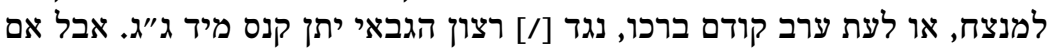

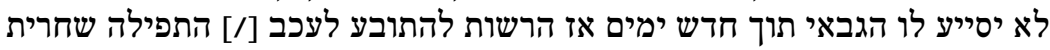

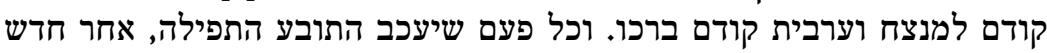

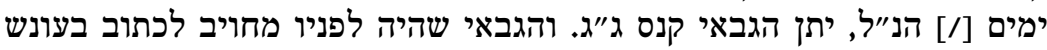

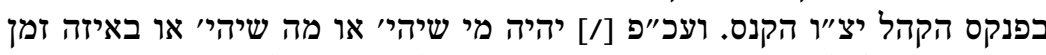

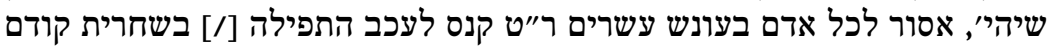

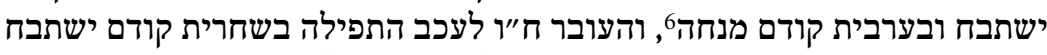
או בערבית [/] קודם מנחה יתן תכף ח"כ להפובר לשמש הקהלה, שיתן מיד אחר יציאת ישתרת

1 Dieses Wort mit größeren Buchstaben geschrieben.

2 Nach Ri 17,6 und Ri 21,25.

3 Pijut von Moses Ibn Esra für den Abschluss des Versöhnungstages aus dem 11./12. Jahrhundert.

4 Sie erscheinen nicht hier, sondern erst am Ende der Statuten.

5 Dieses Wort über der Zeile ergänzt.

6 Das Nachmittagsgebet wurde oft unmittelbar vor das Abendgebet gestellt. Allerdings kann eigentlich keine Unterbrechung vor dem Nachmittagsgebet stattfinden, weshalb hier vielleicht das Abendgebet מעריב gemeint ist. 


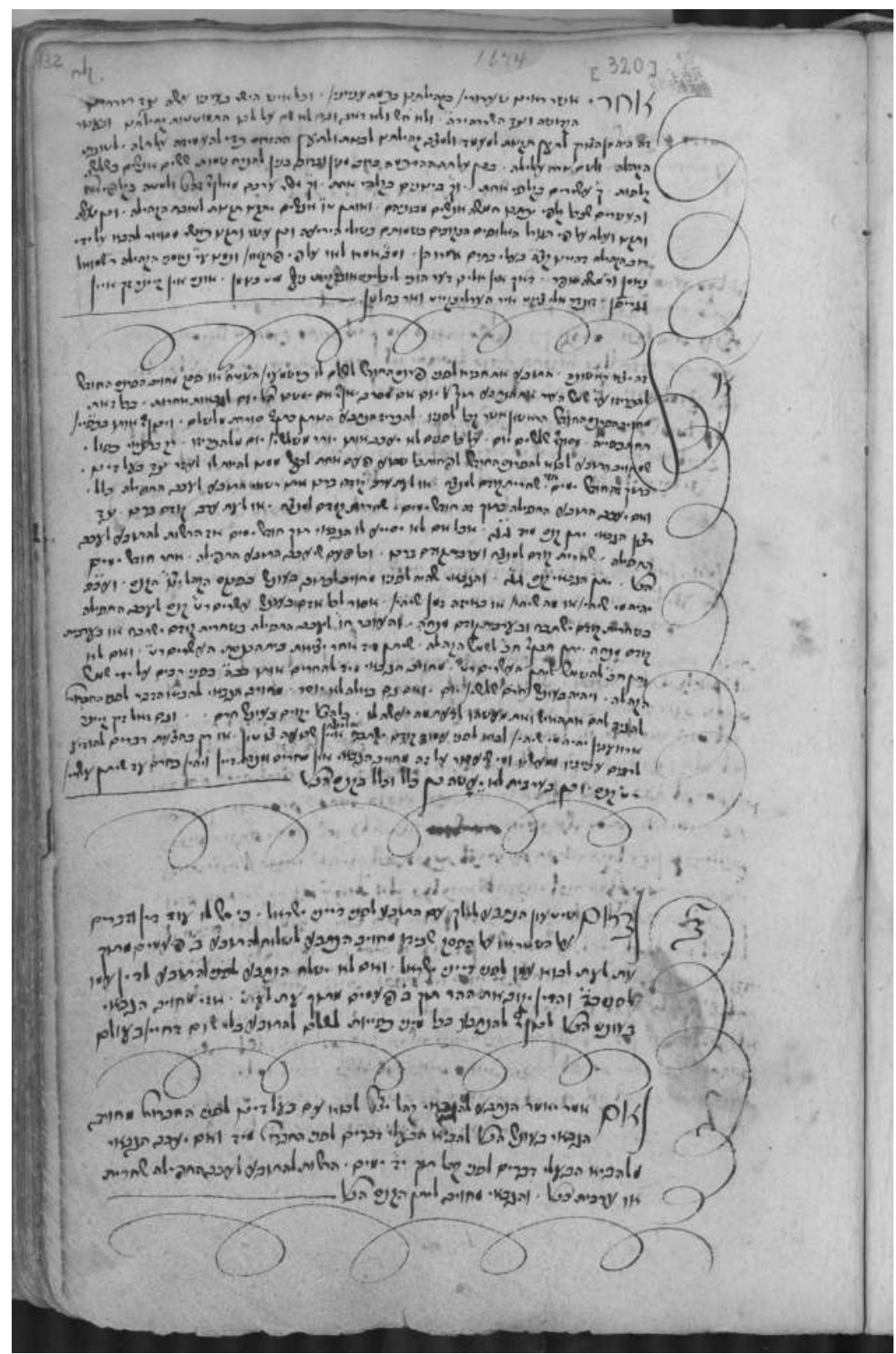

Erste Seite des Statutentextes im Protokollbuch der Frankfurter jüdischen Gemeinde, im Folgenden weitere Abbildungen des Originals. 


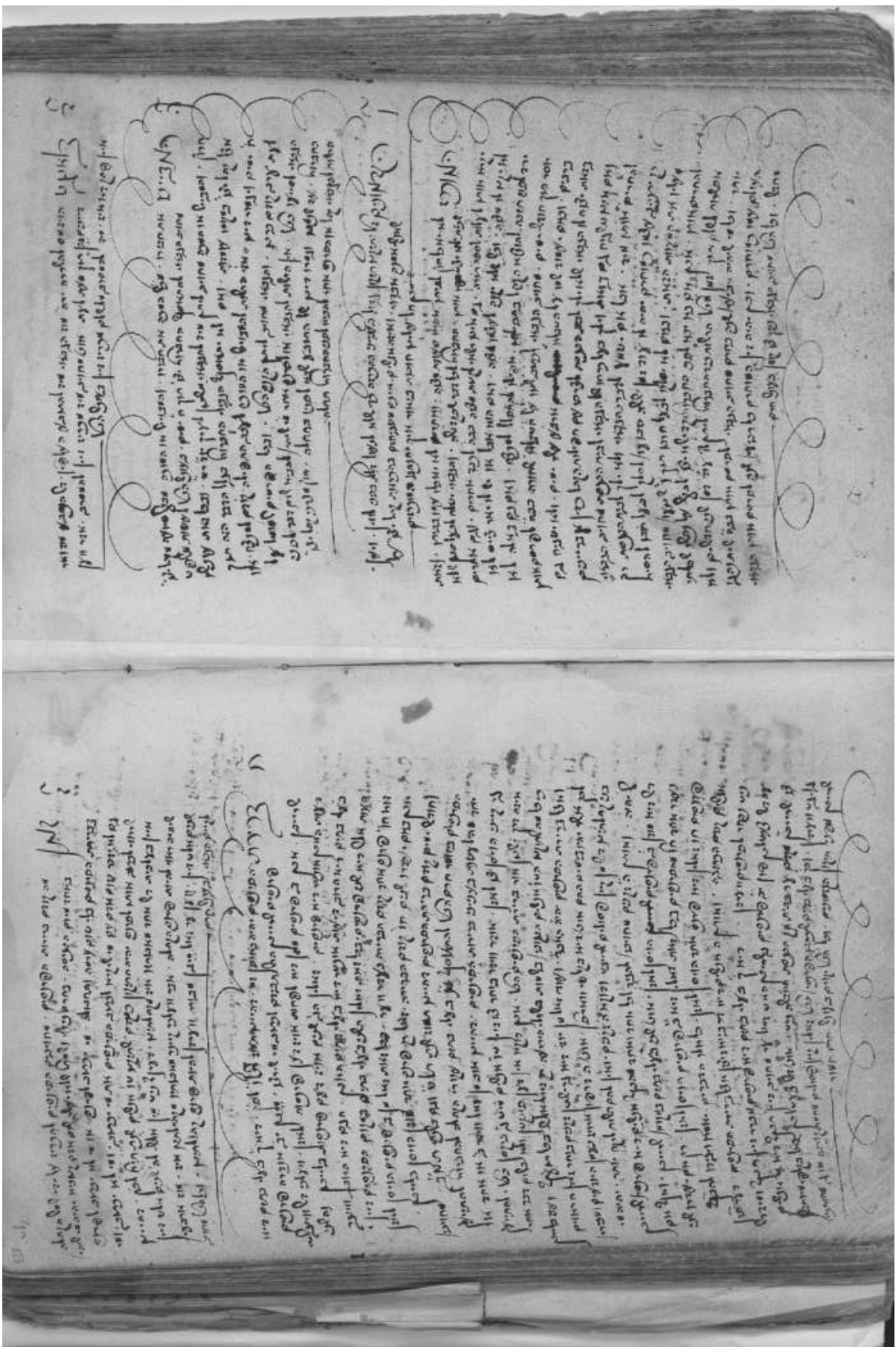




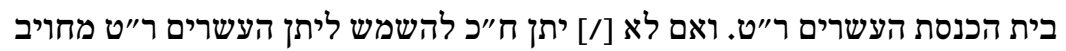

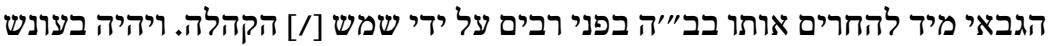

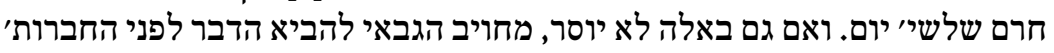

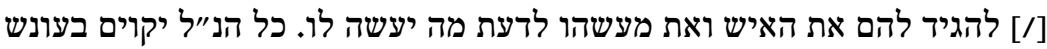

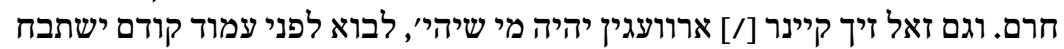

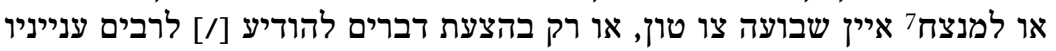

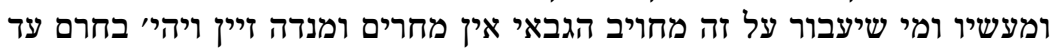

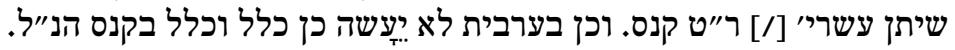
ובאם שיטעון הנתבע לילך עם התובע לפני דייני ישראל, כי יש לו עוד דין ודברים

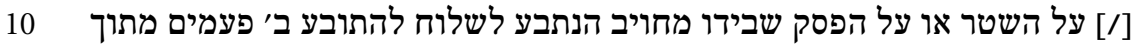

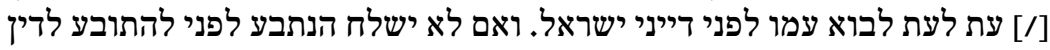

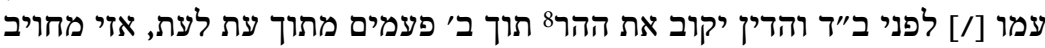

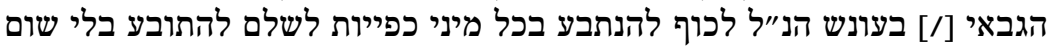

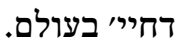

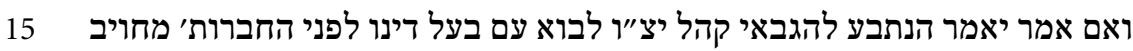

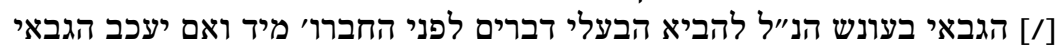

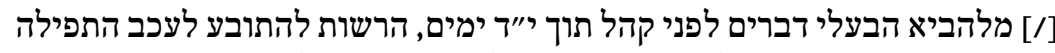

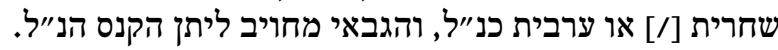

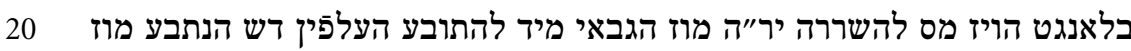
[fol. $138 \mathrm{v}$ ]

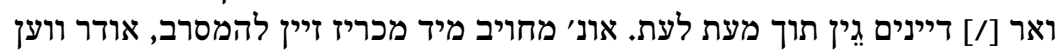

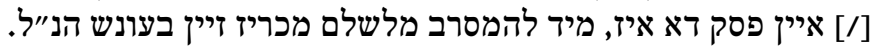

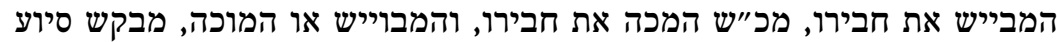

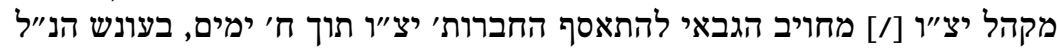

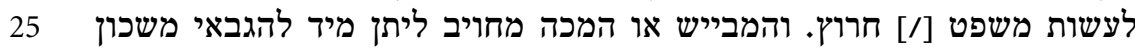

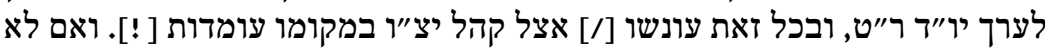

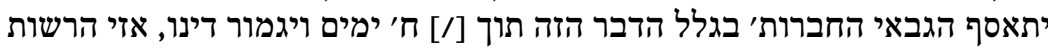

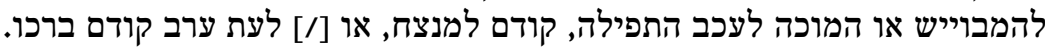

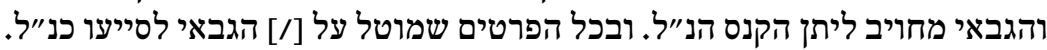

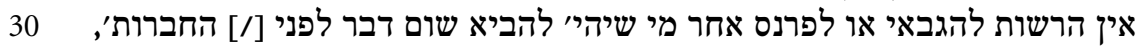

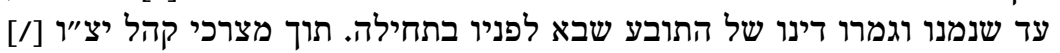

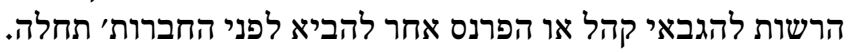

7 Die letzten beiden Wörter über der Zeile ergänzt.

8 Sanhedrin $6 \mathrm{~b}$. 
הקדמונים ז"ל תיקנו תיקוץ גדול בענייני ההכרזה כדי שלא לנעול דלת בפני לוויץ9,

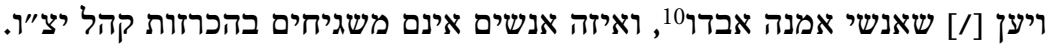

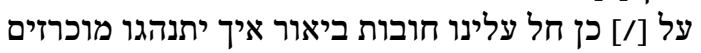

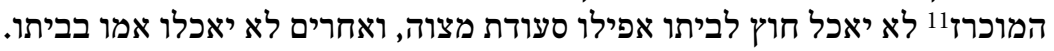

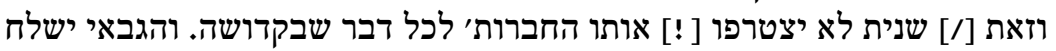

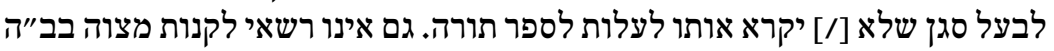

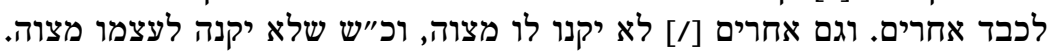

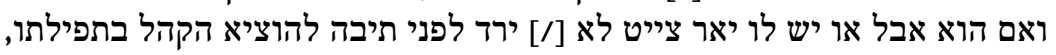

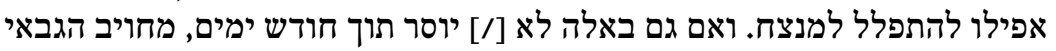

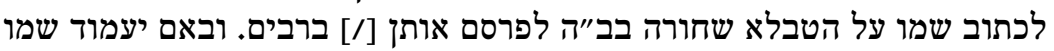

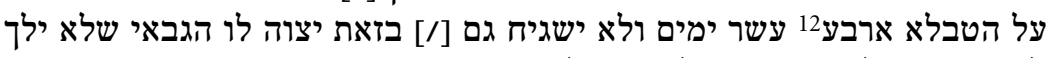

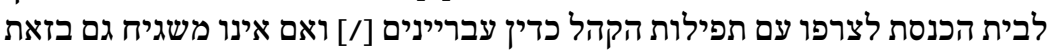

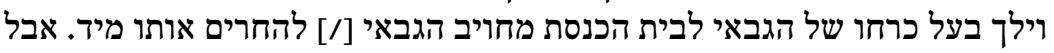

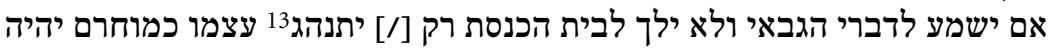

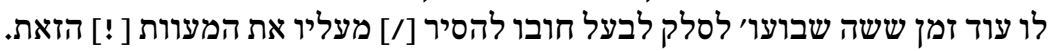

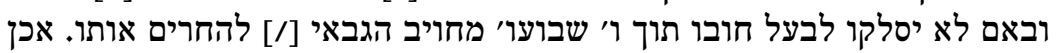

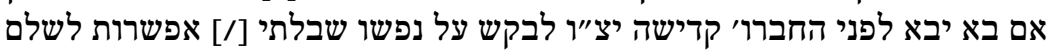

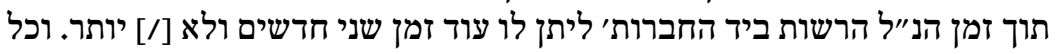

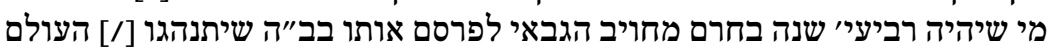

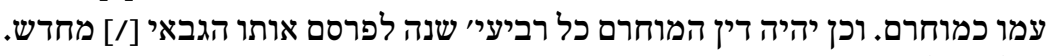

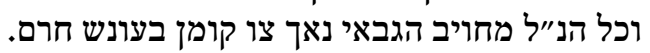

[fol. $139 \mathrm{r}$ ]

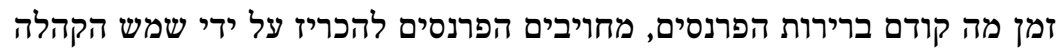

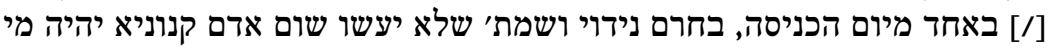

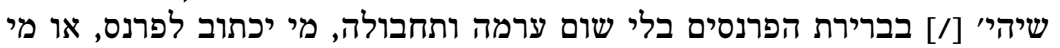

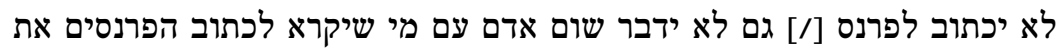

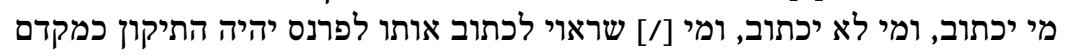

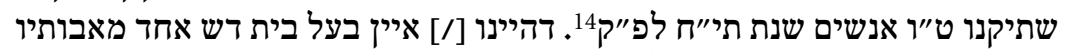

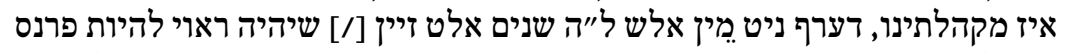

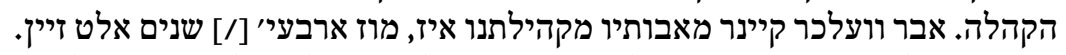

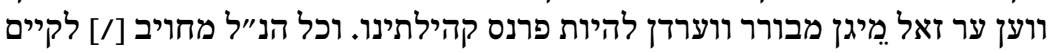
הגבאי בעונש חרם.

\footnotetext{
9 Sanhedrin 3a.

10 Aus einem Gebet zum ersten Selihot-Tag, also am Sonntag vor dem Neujahrsfest.

11 Wort, wie am Beginn eines Paragraphen, großgeschrieben.

12 Davor gestrichen: חודש ימים.

13 Davor, am Anfang der Zeile, ein weiteres קר.

$14 \quad 1657 / 58$.
} 


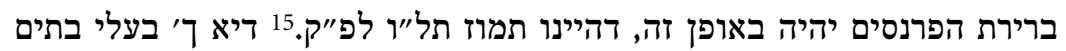

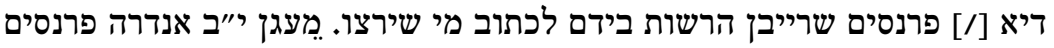

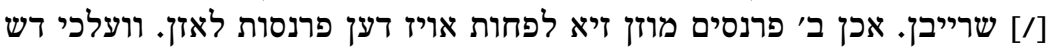

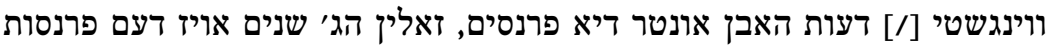

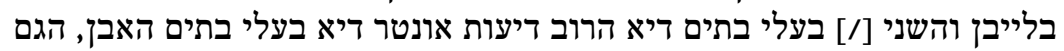

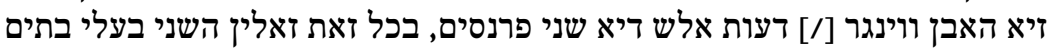

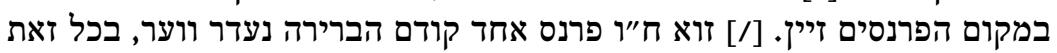

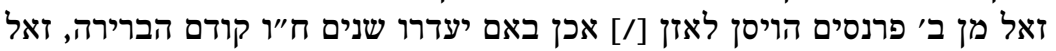

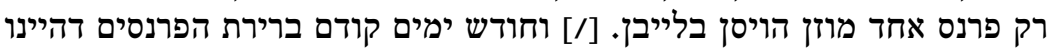

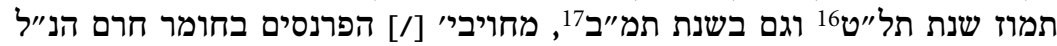

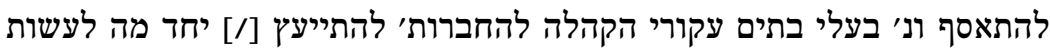

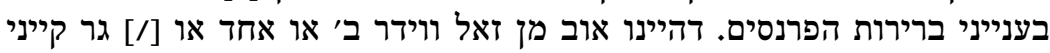

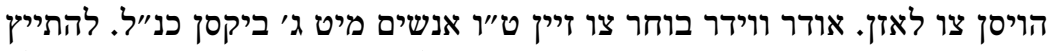

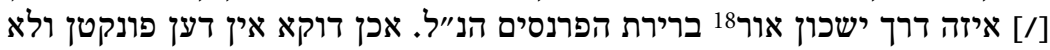

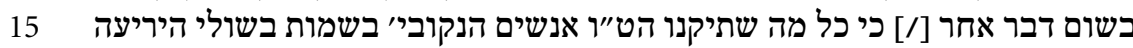

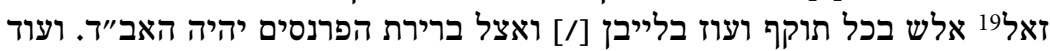

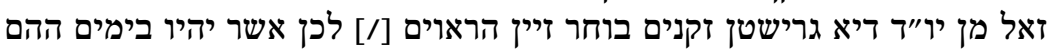

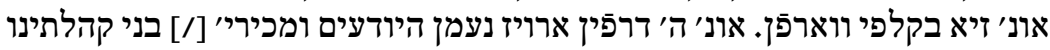

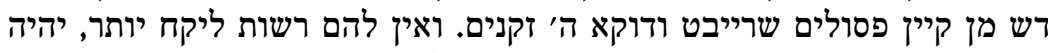

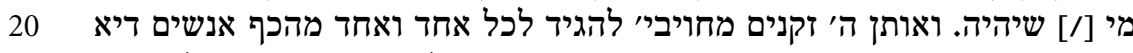

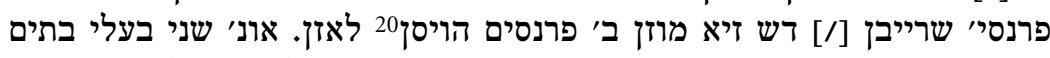

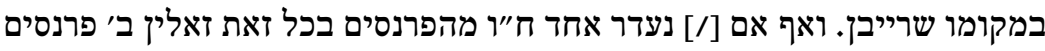

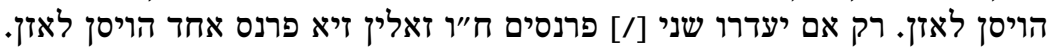

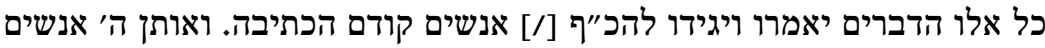

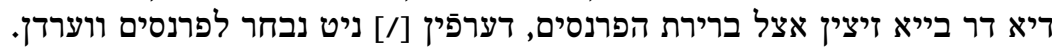

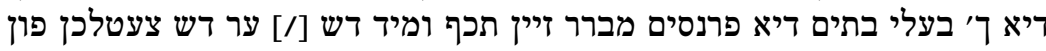

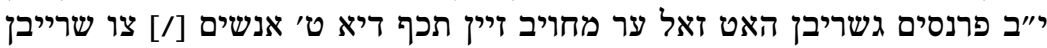

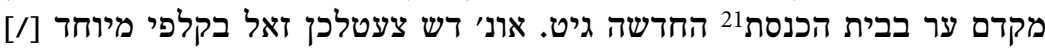

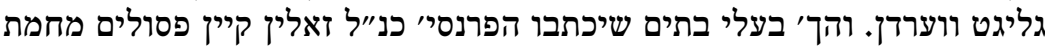

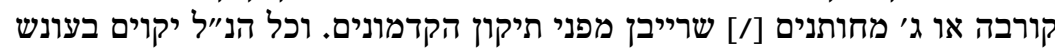

חרם חמור.

\footnotetext{
$15 \quad 1676 \mathrm{VI} / \mathrm{VII}$.

$16 \quad 1679 \mathrm{VI} / \mathrm{VII}$.

$17 \quad 1681 / 82$.

18 Hi 38,19.

19 Davor gestrichen: רק

20 Davor gestrichen: שרייבן.

21 Davor gestrichen:הק.
} 
[fol. $139 \mathrm{v}$ ]

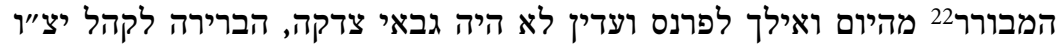
ט

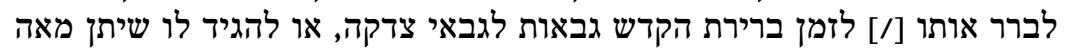

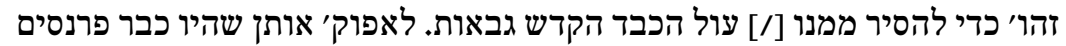

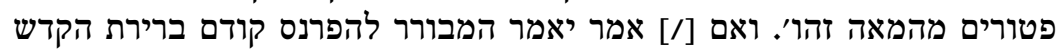

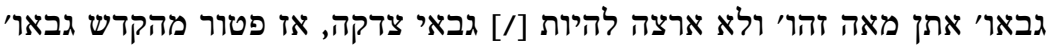

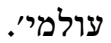

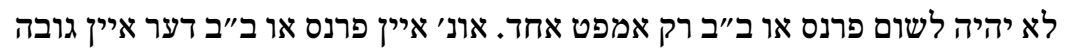

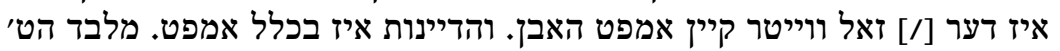

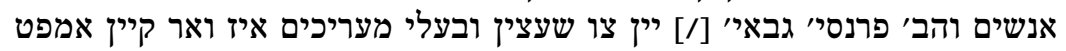

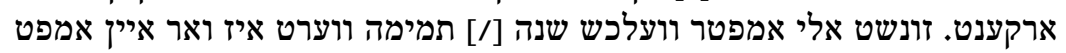
ארקענט. הכל יקוים בעונש חרם.

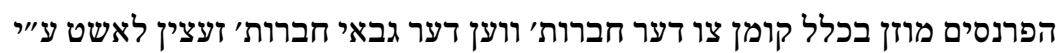

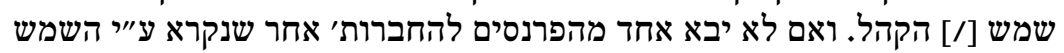

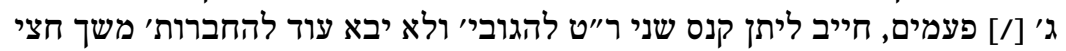

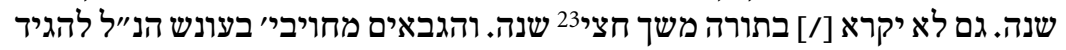

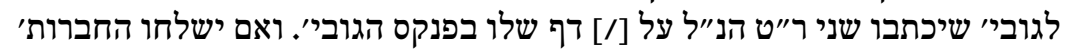

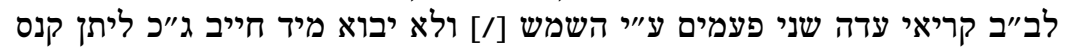

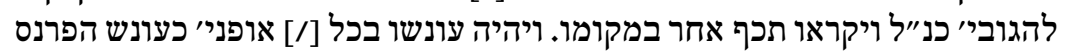

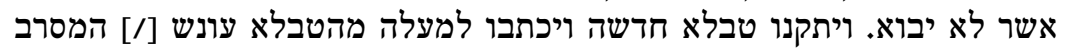

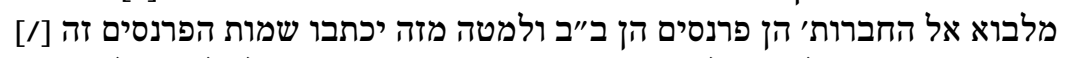

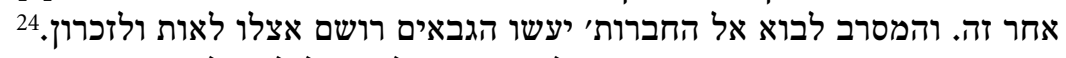

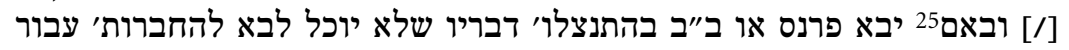

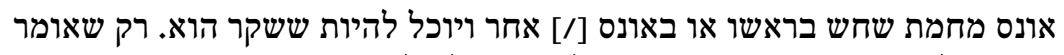

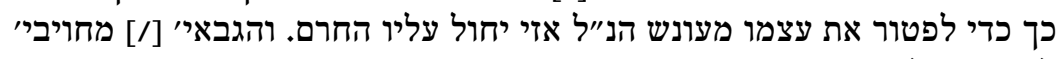

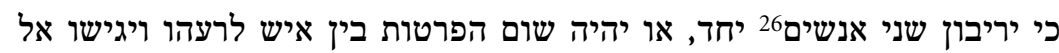

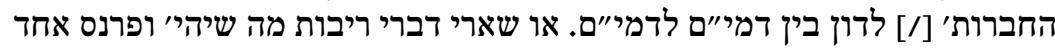

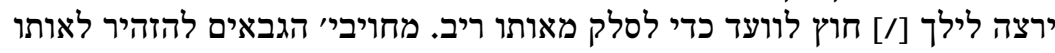

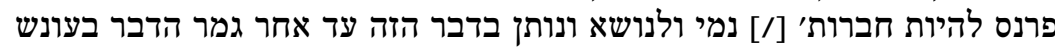

22 In diesem ersten Wort des Paragraphen ist nur die Initiale größer geschrieben.

23 Dieses Wort über der Zeile, ergänzt über einer unleserlichen Streichung.

24 Danach gestrichen: הכל.

25 Ab hier spätere Ergänzung zum Paragraphen in etwas kleinerer Handschrift.

26 Nach Ex 21,18. 


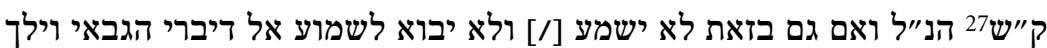

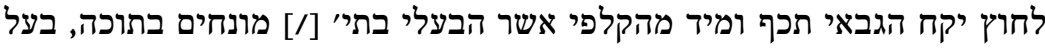

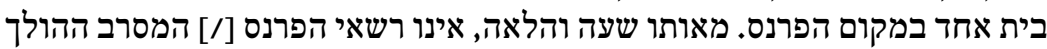

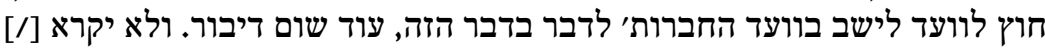

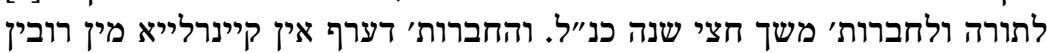

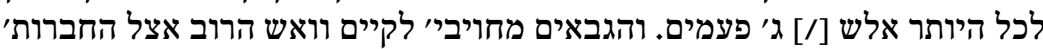

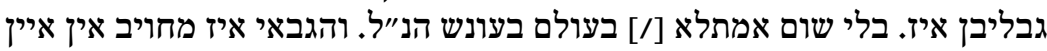

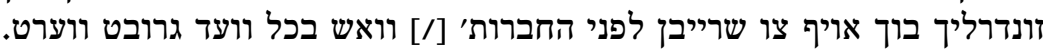

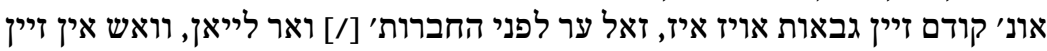

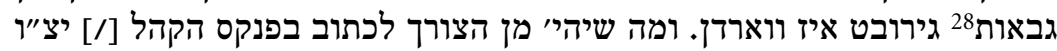

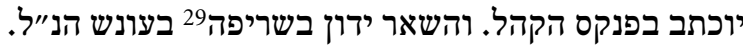

[fol. $140 \mathrm{r}$ ] דארף קיין פרנס ניקש ואר ברענגין אם לא דוקא פרנס החודש אונ' ווש דער פרנס

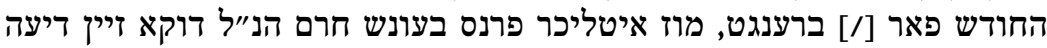

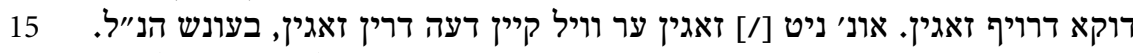

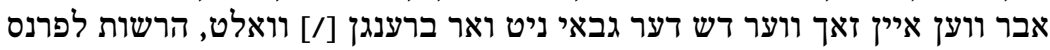

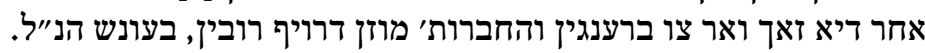

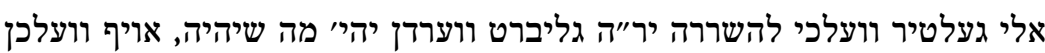

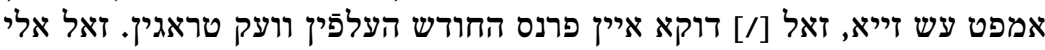

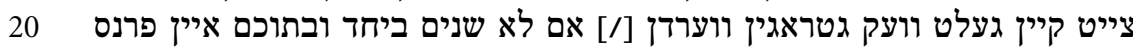

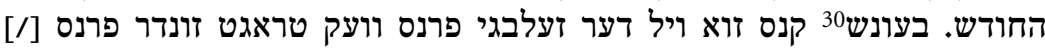

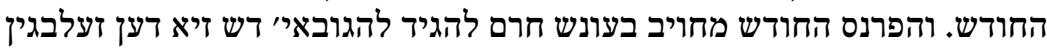
פרנס על דף שלו שרייבן אותו סך.

אם יהיה פרנס בורר בין איש לרעהו ויתגלגל הדבר שיבוא הריב לפני החברות',

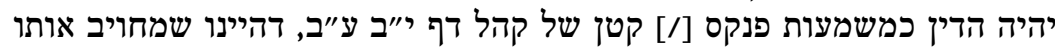

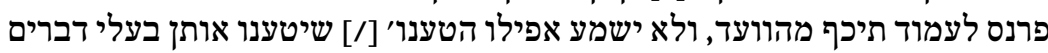

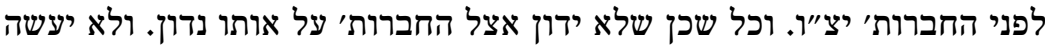

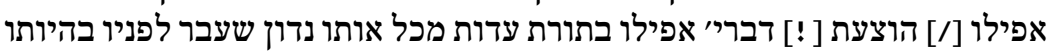

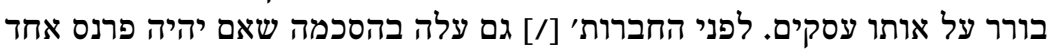

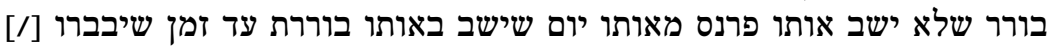

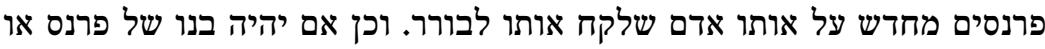

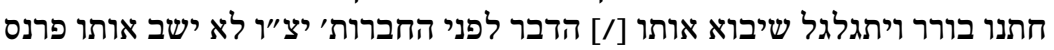

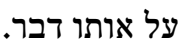

27 Kopfstück, Münze mit dem Herrscherbild, entsprach je nach Region zwischen 15 und 20 Kreuzer.

28 Dieses Wort über der Zeile ergänzt, darunter gestrichen: פרנסות.

29 Kiddushin 32a.

$30 \mathrm{Ab}$ hier offenbar spätere Hinzufügung in kleinerer Schrift. 


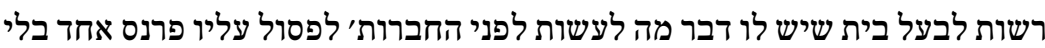

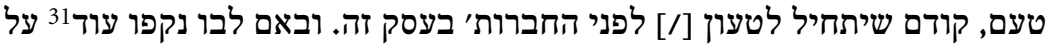

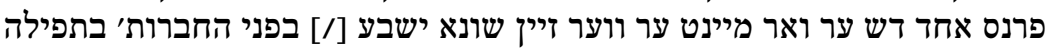

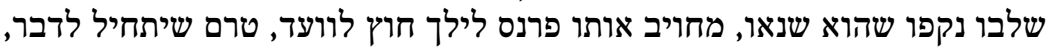

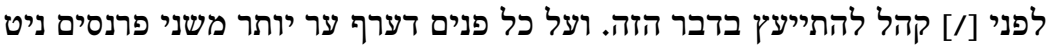

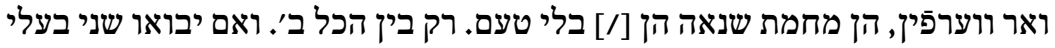

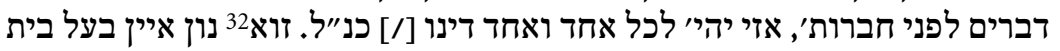

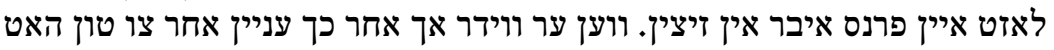

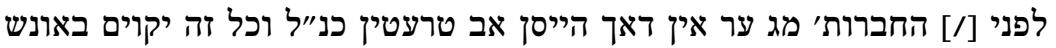

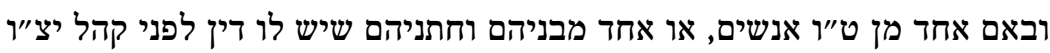

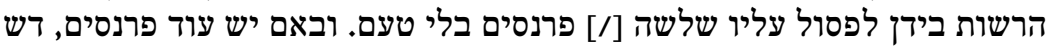

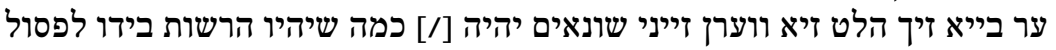

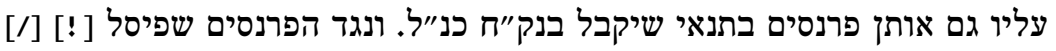

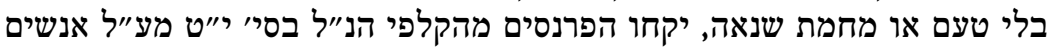

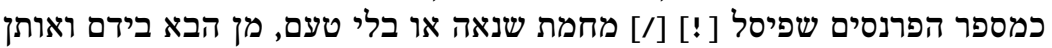

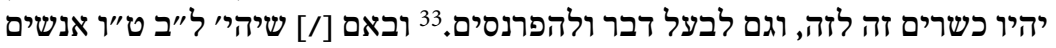

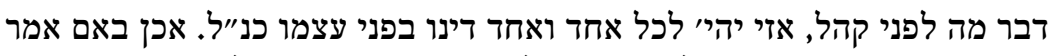

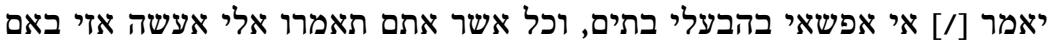

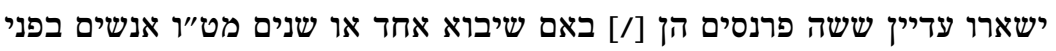

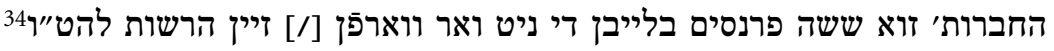

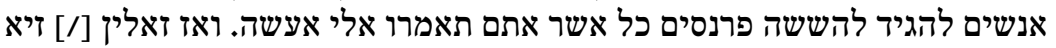

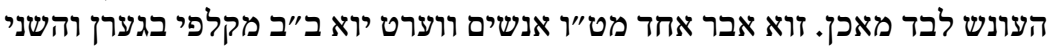

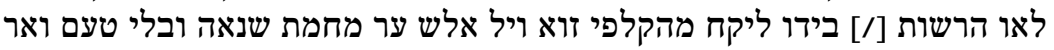

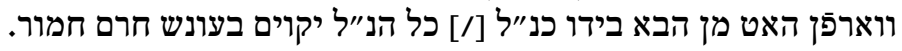

דיא פרנסים דיא איבר ב' שנים דהיינו שנת תל"־35 אויז דעם פרנסות אונ׳ מעכטן י

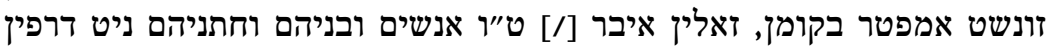

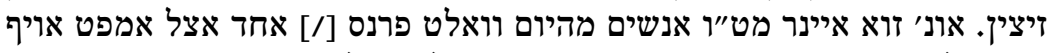

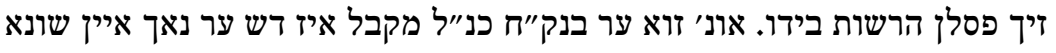

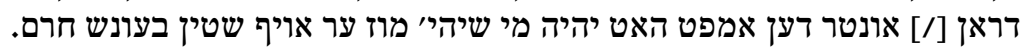

31 Dieses Wort über der Zeile ergänzt.

32 Ab hier spätere Ergänzung in kleinerer Schrift.

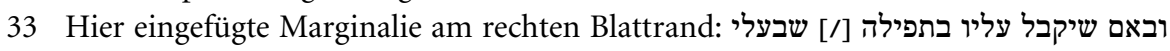

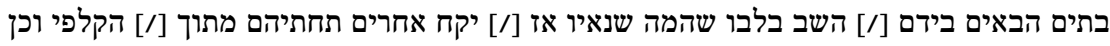

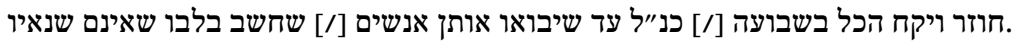

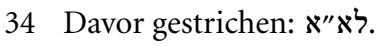

35 Die letzten drei Wörter über der Zeile ergänzt. 
[fol. $140 \mathrm{v}$ ] י"ט

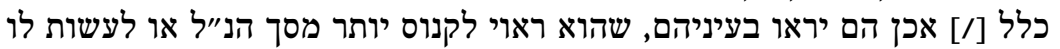

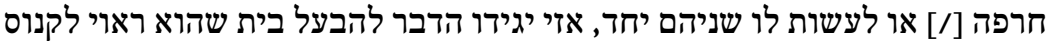

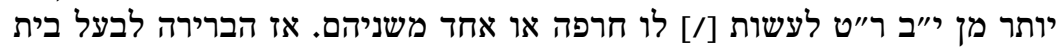

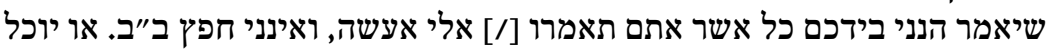

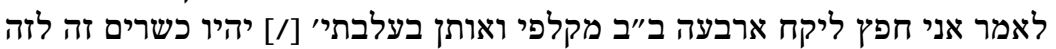

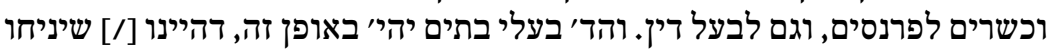

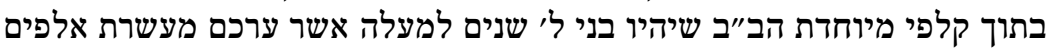

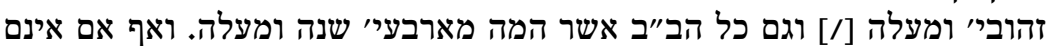

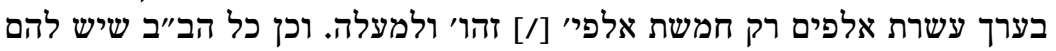

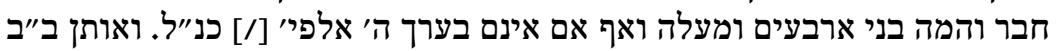

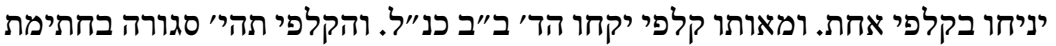

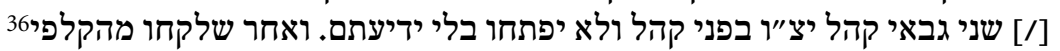
יוחזרו תכף לתוך הקלפי [/] וכן יהי׳ תמיד וכל זה יקוים בעלי יעתם. ואחו חרם.

החברותא אינם רשאי' לעשות לשום ב"ב משפט נעלם, רק לשלוח אחריו ולהוכיחו

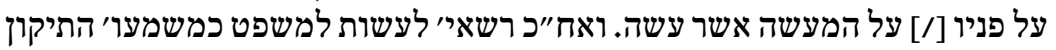
למעלה [/] מזה בסמוך. יקוים בעונש חרם.

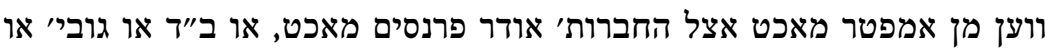
כ" כ

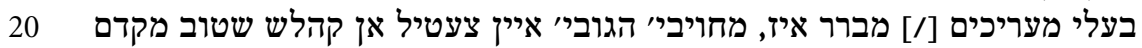

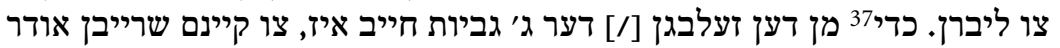

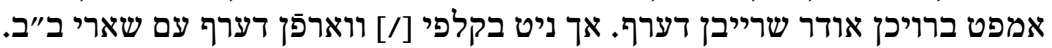

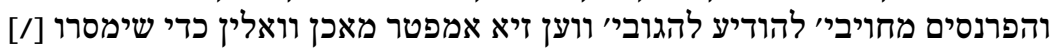
הצעטל כנ״ל וכל זה יקוים גם בעונש חרם.

החברותא מחויבים לברר י״"ט אנשים לתקן ענייני חזקות עירוני' פה והנהגת 25

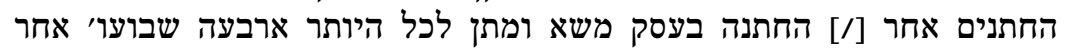

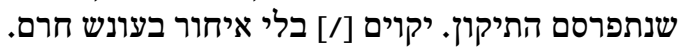

החברות' מחויבים לברר עוד שוחט אחד אצל ר' מענדל ראפ' תוך י"ד ימים אחר שנתפרסם התיקון. [/] יקוים בלי איחור בעונש חרם.

החברות' מחויבי' לברר חזני' ושמשים י"ד ימים אחר שנתפרסם התיקון. והבירור 30

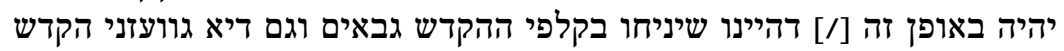


גבאים שהיו משנת תי"״38 עד עתה39 וגם כל הב"ב שהם [/] בני ארבעיי שנה וערכם

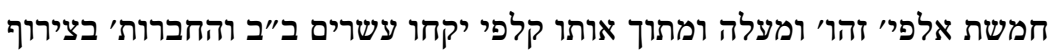

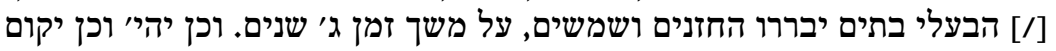

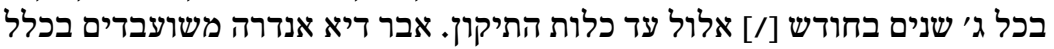

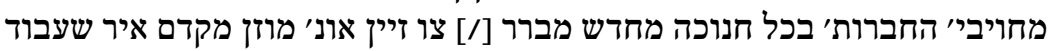

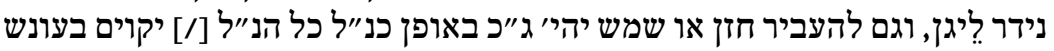

חרם.

אם נכרי אשר לא מבני קהלתנו חייב לבעל בית פה, והב"ב יבקש מגבאי הפי לכוף אות הפותו 10

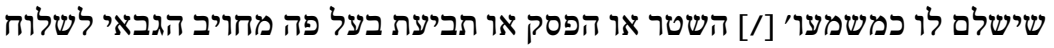

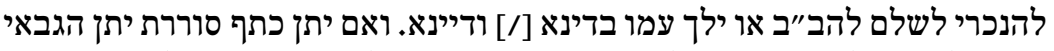

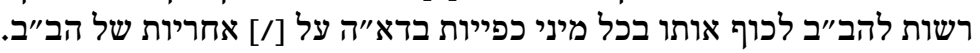

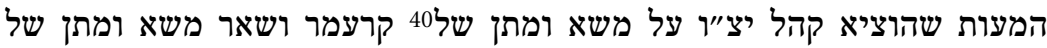

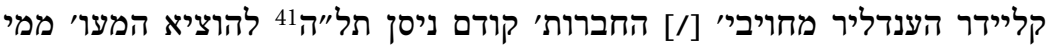

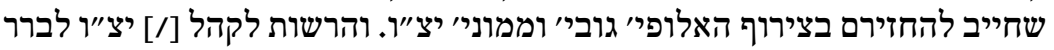

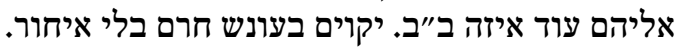

[fol. $141 \mathrm{r}] \quad 20$

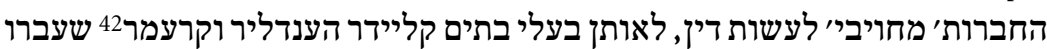

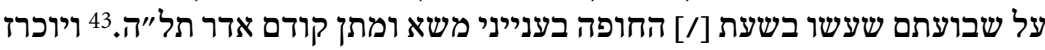

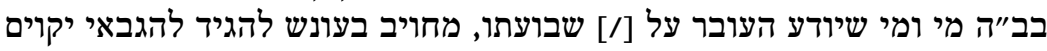

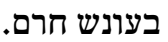

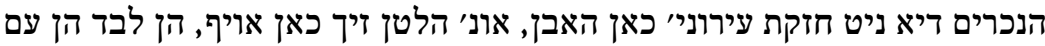

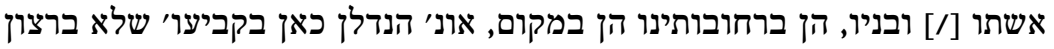

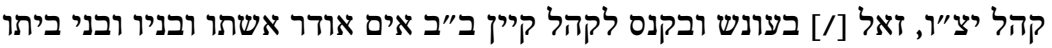

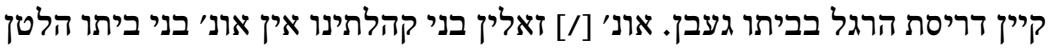

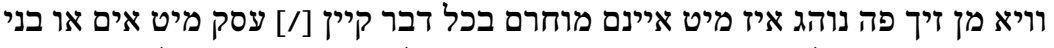

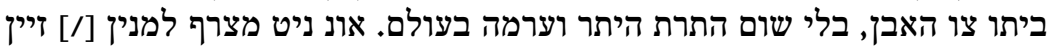

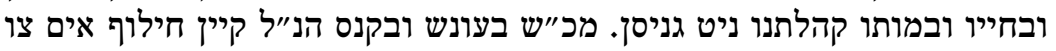

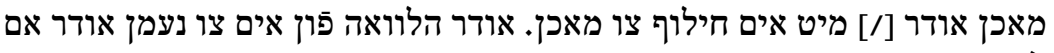

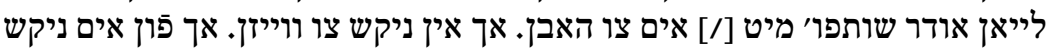
צו ווייזן לאזן בלי ערמה ומרמה [/] וועלכר בעל בית ח"ו עיפ עובר ווער זאל חל עי עליון

\footnotetext{
$38 \quad 1639 / 40$.

39 Die letzten fünf Wörter über der Zeile ergänzt.

40 Davor einige durch Streichung unleserliche Wörter.

411675 III/IV.

42 Dieses Wort über der Zeile ergänzt.

431675 II/III.
} 
זיין עונש חרם הנ"ל. דאך השררה יר"ה איר הערליכקייט [/] ניקש מיט בנומן. והפרנסים מחויבים להתאמץ בדבר הזה בחרם נאך צו צו קומן.

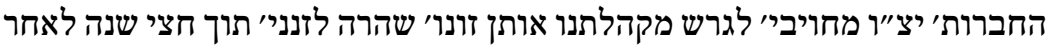
כ"ט

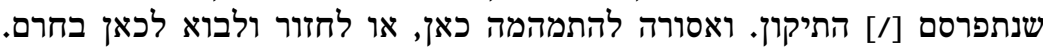

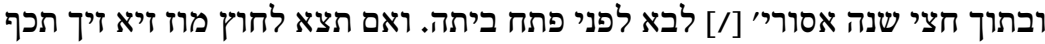

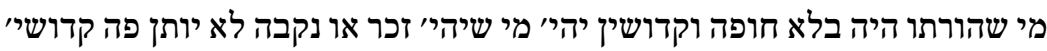
ל

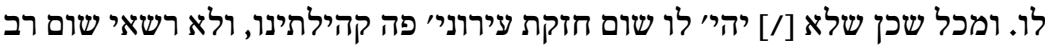

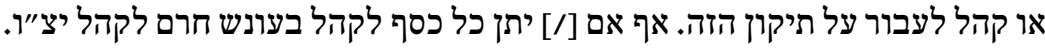

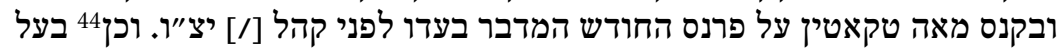

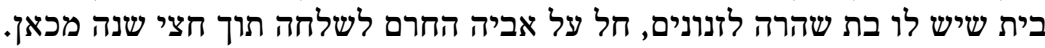

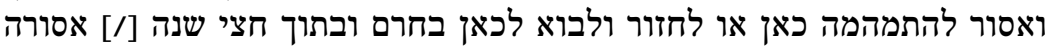

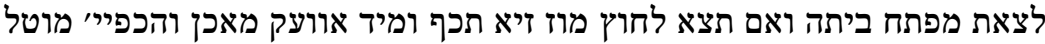

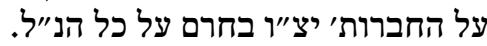

אם פרנס אחד או יותר זאלט עוקר דירה מכאן זיין, אודר קודם ברירת הפרנסיוסים ל

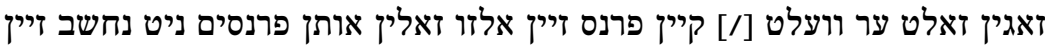

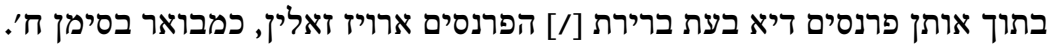
זאלין דאך ב' פרנסים ארת פרנסים ביז בומן ברירת.

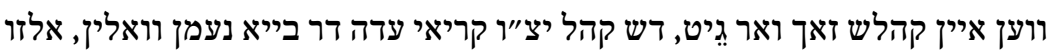
ל"ב

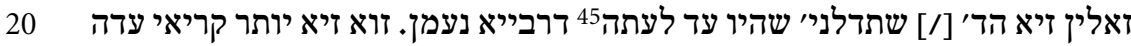

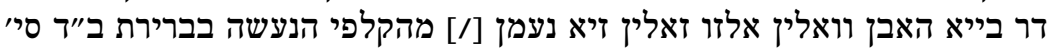

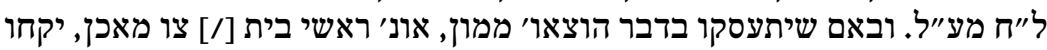

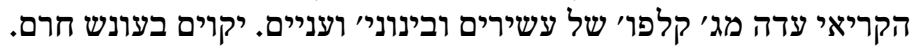

הפרנסים יצ"ו מחויבי' לברר אב"ד תוך שלשה חדשים לאחר שנתפרסם התיקון.

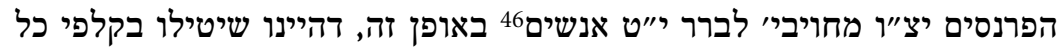
ל

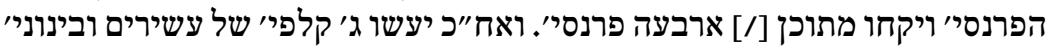

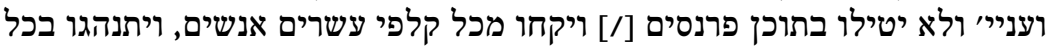

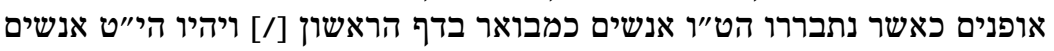

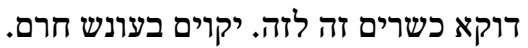

\footnotetext{
44 Ab hier spätere Hinzufügung in kleinerer Schrift.

45 Die letzten drei Wörter über der Zeile ergänzt.

46 Dieses Wort zwei Mal.
} 
[fol. $141 \mathrm{v}$ ]

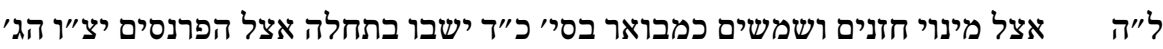

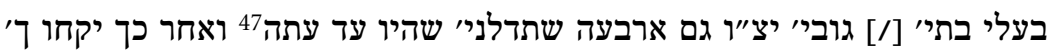
בעלי בתים מתוך הקלפי כמבואר בסי' כ"ד.

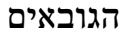
5

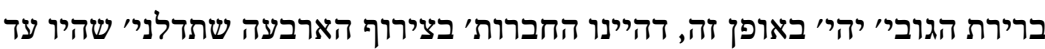
ל רגור

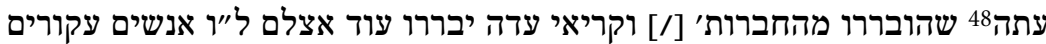

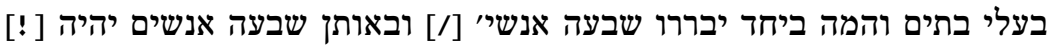

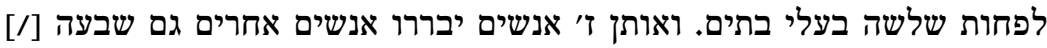

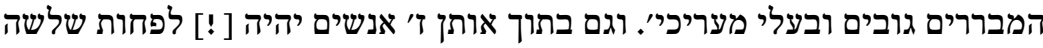

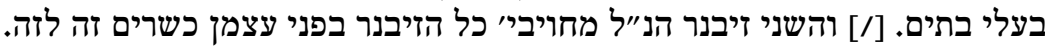

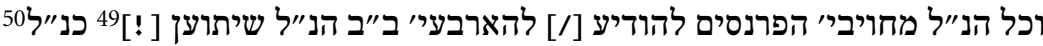

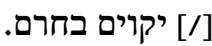

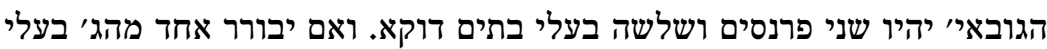
ל

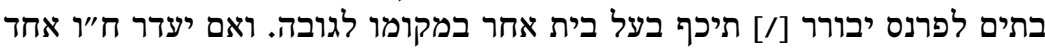
15

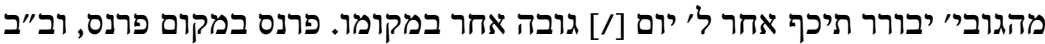

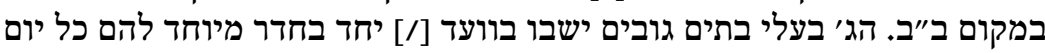

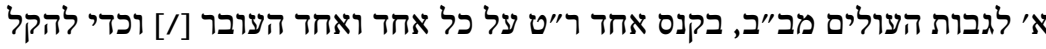

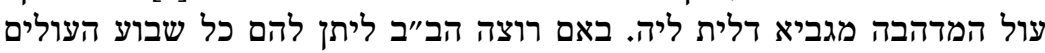

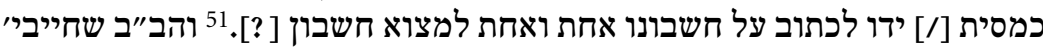

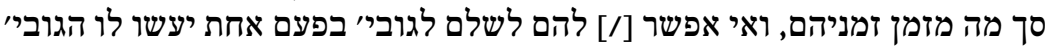

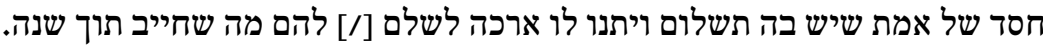

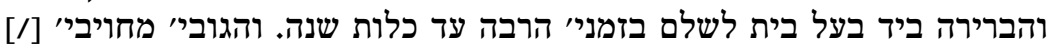

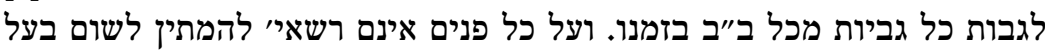

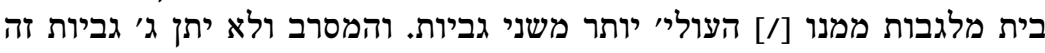

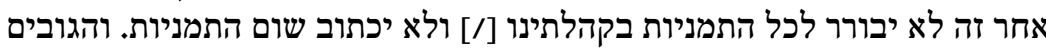

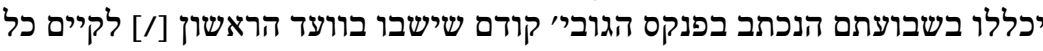

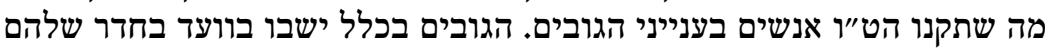

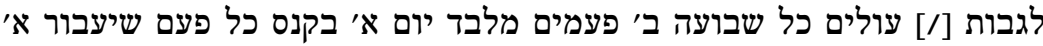

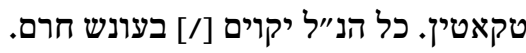

47 Die letzten drei Wörter über der Zeile ergänzt.

48 Die letzten drei Wörter über der Zeile ergänzt.

49 Offenbar ein Schreibfehler, gemeint ist vielleicht: שיתוקן.

50 Fortsetzung unleserlich gestrichen.

51 Das letzte Wort ist schwer zu entziffern. 


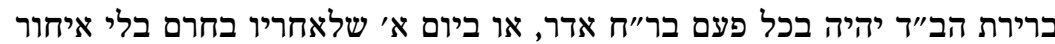
הב"ד ל ל

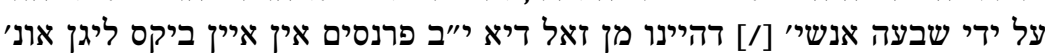

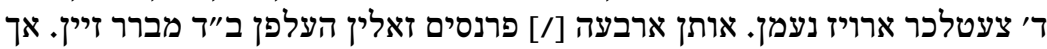

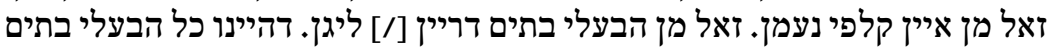

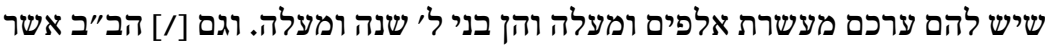

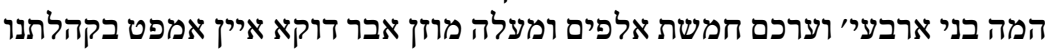

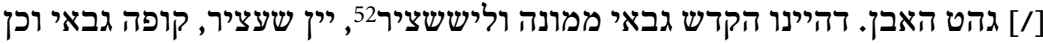

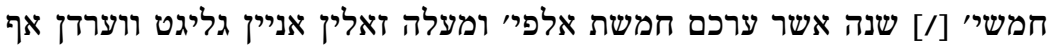

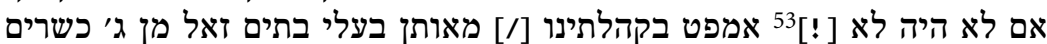

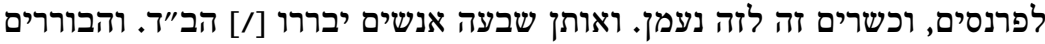

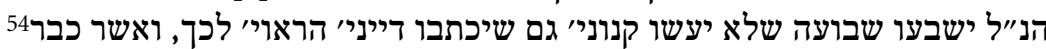

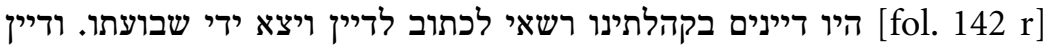

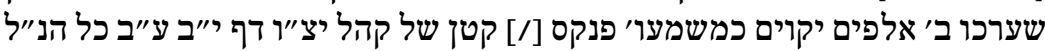
יקוים בעונש חרם.

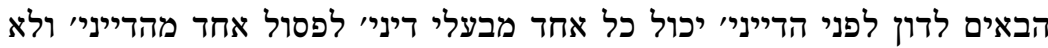

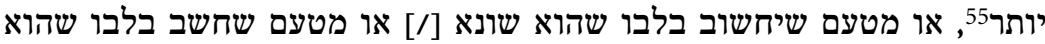

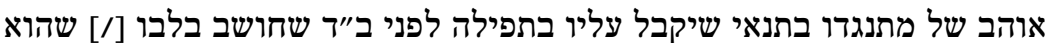

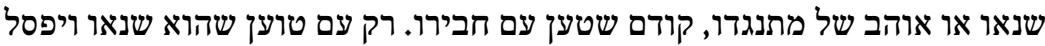

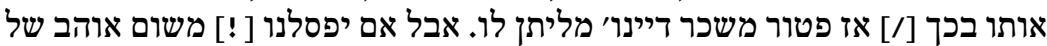

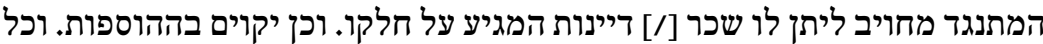

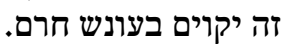

מחמת מטות ליילטיכר ציכן ליינוונט דיא אין דש הקדש קומן פַון ב"מ בילע המיל המות מי

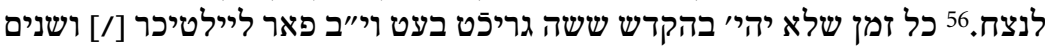

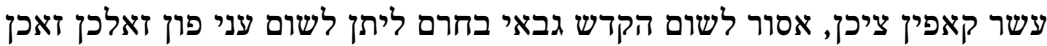
דיא בהקדש [/] ואלין אונ' זיינן.

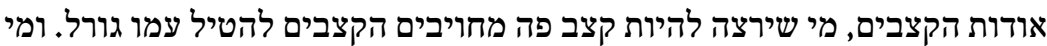
מ"א

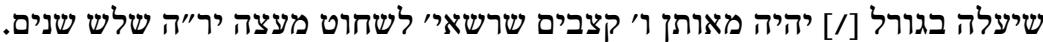

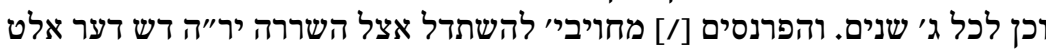
קצב אויז גטאן ווערט, וחדש איין צו שרייבן יקוים בחרם.

52 Fleischschätzer.

53 Gemeint ist wohl: לו

54 Danach die Kustode' היו דייני.

55 Die letzten beiden Wörter über der Zeile ergänzt.

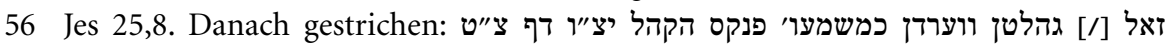

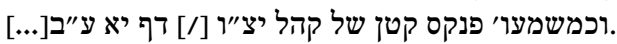




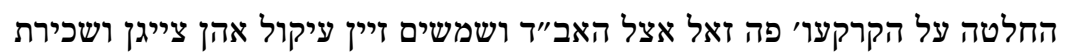
מ"ב

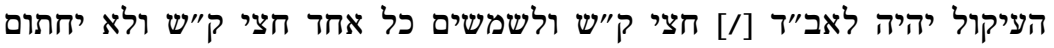
ההחלטה בלי שאלת הגובים והקדש גבאים ולים.

כל דבר אכילה ושתיי' לא ימכר בקהלתנו אם לא זאל עיליי ממונים גשעצט ווערדן

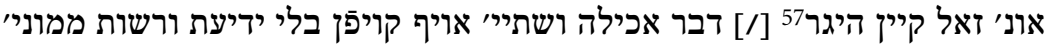
מו"ג

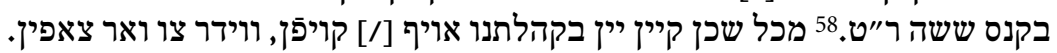

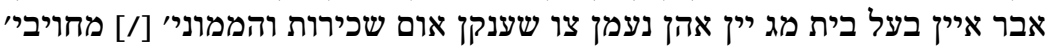
בחרם אויף זאלכש צו הלטן אונ' צו ברירן.

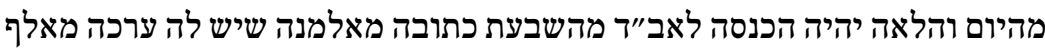

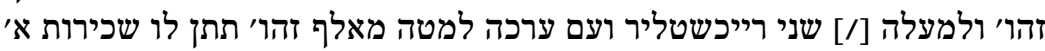

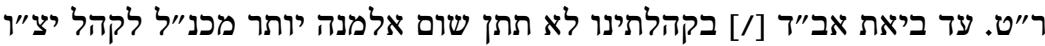
מחמת השבע' כתובה.

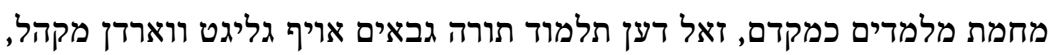

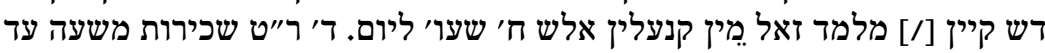

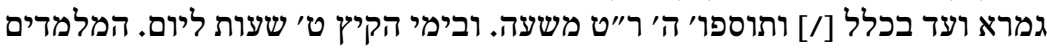

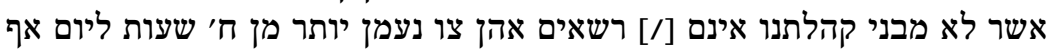

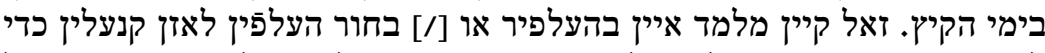

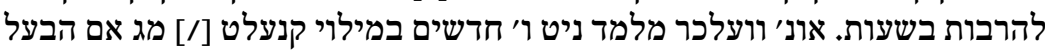

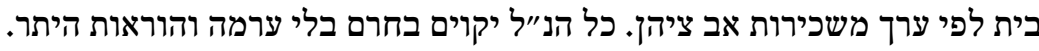

בעולת בעל59 גם זונות אסורים בעונש חרם להיות משרתת אצל שום בעל בית מ"מ 20

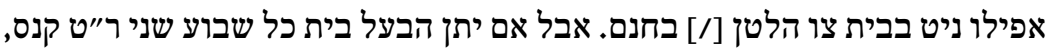
אז פטור מחרם הנ"ל. ואם יעבור [/] זמן אחד ולא ית יתן קודם שבל שבת אזי חל עלית שליו חרם

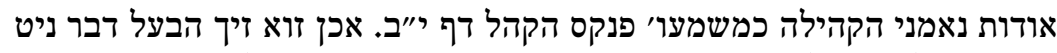
מו"ז

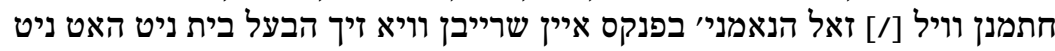

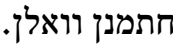

כל מיני שחוק חוץ משאכצייעל, אפילו כלה וחתן אסור בחרם רק בחנוכה ופורים יורים

[fol. $142 \mathrm{v}$ ]

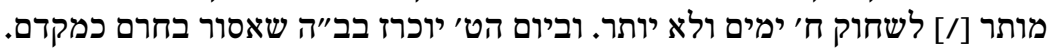

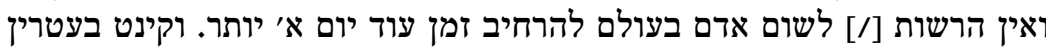

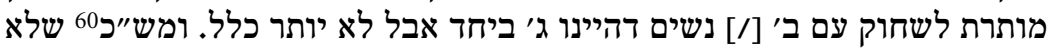

57 היזגר?

58 Die letzten drei Wörter über der Zeile ergänzt.

59 Dtn 22,22.

60 Offenbar falsche Reihenfolge, gemeint ist sicher: מכש"כ. 
תשחק עם איש או בחור, ולא [/] תשחקו [!] שארי נשים כלל, אם לא שהיא עצמה

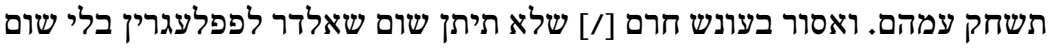

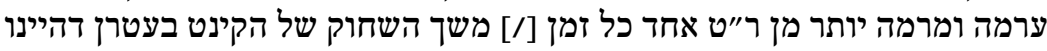

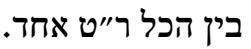

5

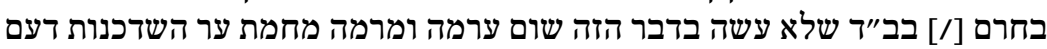
[/] ליבר ואר גינט אלש דעם אנדרן.

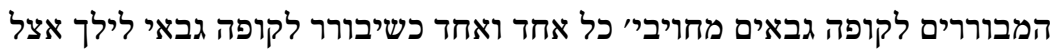

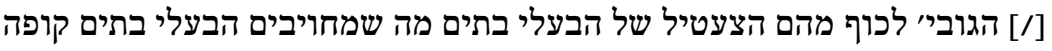

הבעלי מעריכים מחויבים מדי יום ביום צו זיצן נאך מיטאג פפון איין אויאר נינ

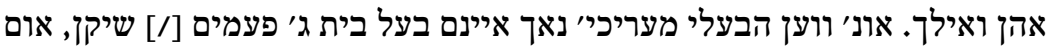

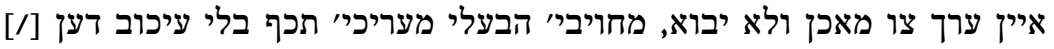

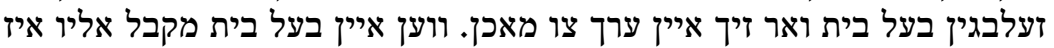

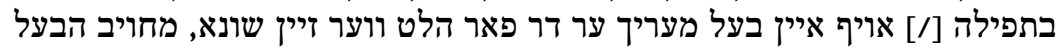

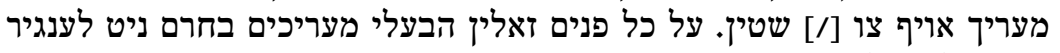
זיצין אלש שלשה שבועו'.

הממונים מחויבי' לישב בוועד כל שבוע ב' פעמים ואם יעברו יתן הממונה שיעבור נ"ב

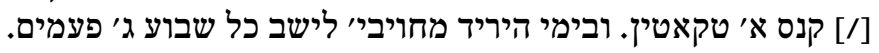

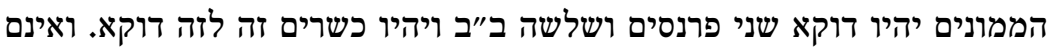

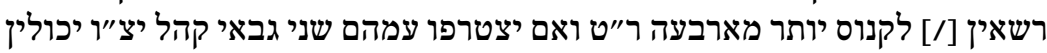
לקנוס [/] עד ששה ר"ט ולא יותר יותר. יקוים בחרם.

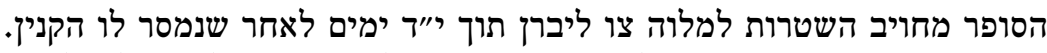

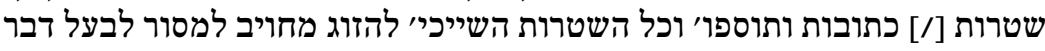

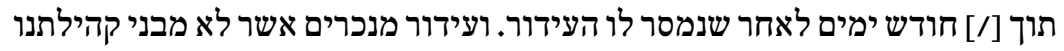

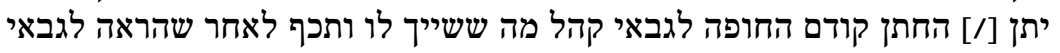

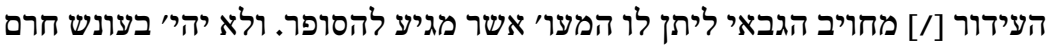

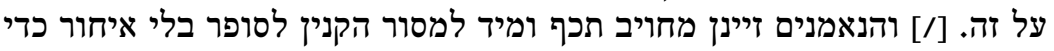

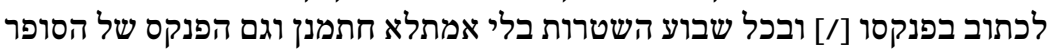

\footnotetext{
$61 \quad 1657 / 58$.

62 Davor gestrichen: איוו.
} 
[fol. $143 \mathrm{r}$ ]

נ"ה

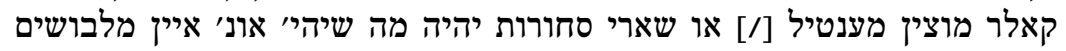

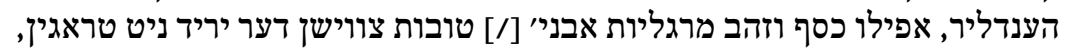

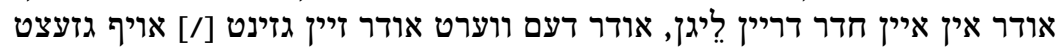

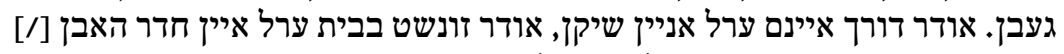

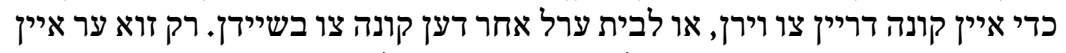

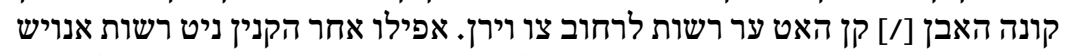

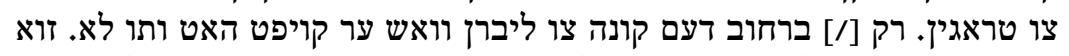

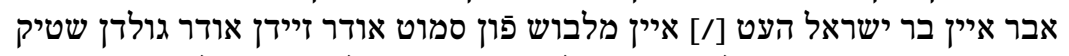

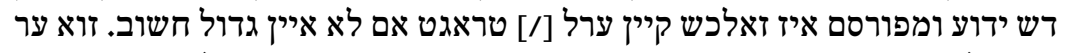

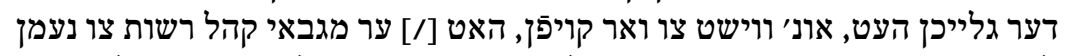

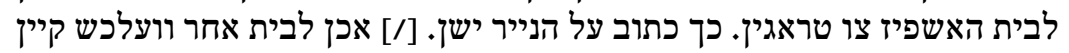

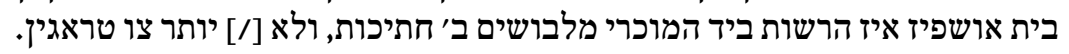

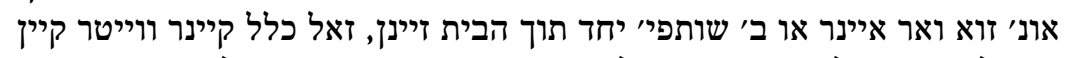

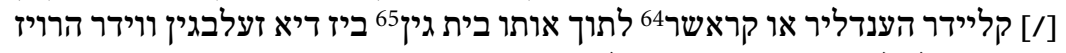
זיינן. אפילו לפני הבית ניט פינדירן לאשרן.

זאל קיין קליידר הענדליר או קראשר שחרית לפני יציאת ב"ה זיר זיך תוך המקום וינדן

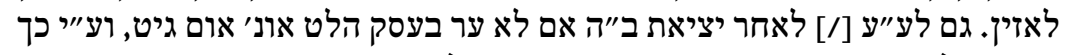

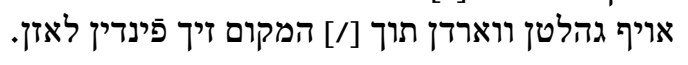

דיא שפיצן הענדליר, מעגין ליינן שפיצן אין ווערצהייזר טראגין אבר זונשט קיין

גם אן דיא מארק שיף זוא זיא אהן קומן ניט וינדין לאזין, ואפילו אצל שער המים ניט צו שֵיטין [/] אויף צו ווארטן ערלי' אהן צו רידן, או צו קראשן.

גם זוא זונשט ערליי קומן, הן אין קוטשן הן על סוסים על הרחוב כלל ניט נאך צו

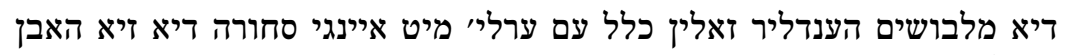

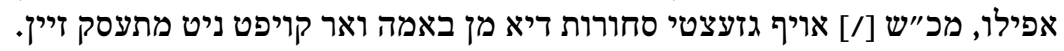

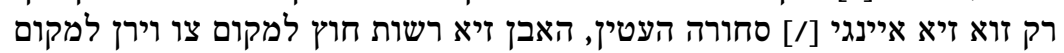

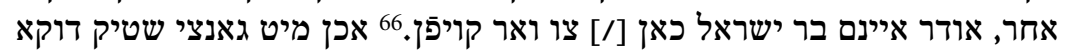

63 Davor gestrichen: הן.

64 Die letzten vier Wörter vor und über dem Zeilenanfang in kleinerer Schrift ergänzt.

65 Dieses Wort über der Zeile ergänzt.

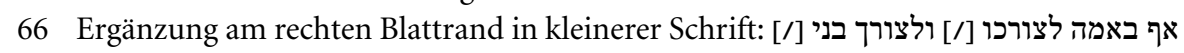
ביתו אכן לא [/] לקנות ולמכור [//][ פה להרוויח בו [/]בחרם על המוכר [/] ועל הקונה. 
האבן זיא רשות למכור. רק המותרות פָון ווילין טוכר [/] וואור פּון זיא מלבושים

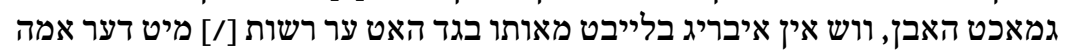

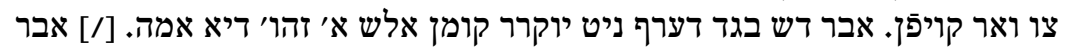

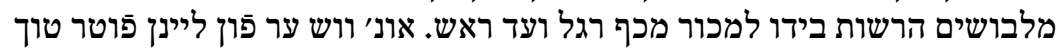

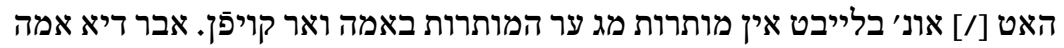

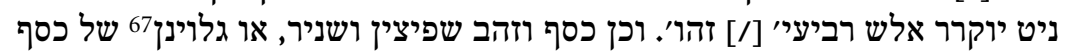

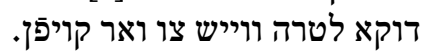

איין קליידר הענדלר זאל68 קיינם אושפיז אודר אנשי ביתו יהיה מי שיהי' צו לייאן ס

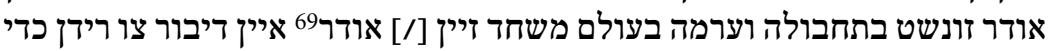

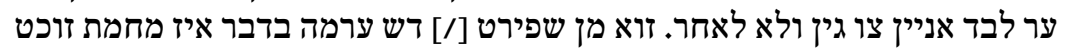

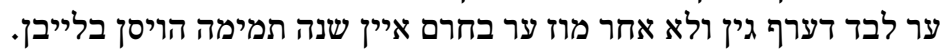

זוא איין מלבושים הענדלער אודר צו ווייזר בייא איינם ערל איז, הן בבית אושפיז ס"ב

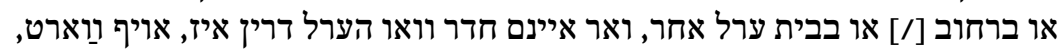

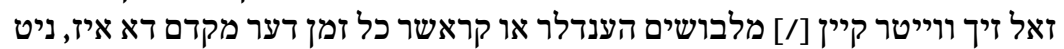

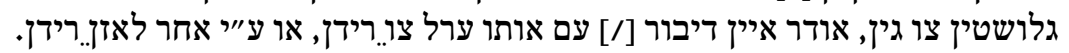

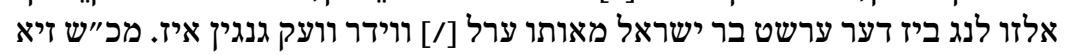

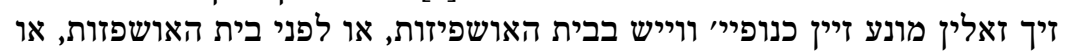

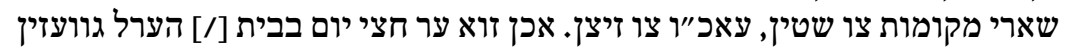

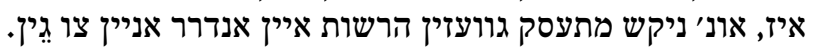

איין70 אויף ווארטר ${ }^{71}$ איזט גאנץ אוני גר ואר באטין בחרם לגמרי קיינן צו שטלין

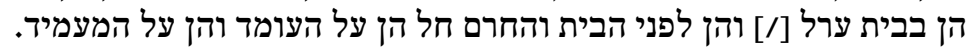

המלבושים הענדליר זאלין איר סחורה יהיה מה שיהי׳ איבר כפל ניט ביטן. דהיינו

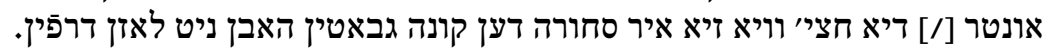

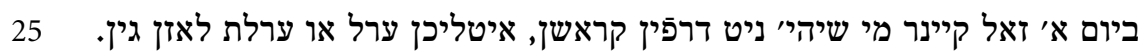

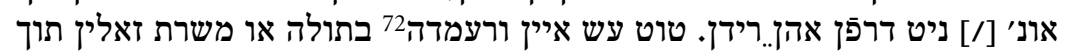

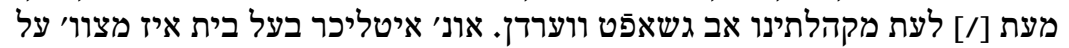

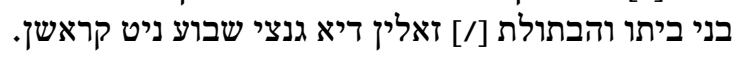

67 galaunen $=$ Galaune, Tresse.

68 Die letzten drei Worte über der Zeile ergänzt.

69 Davor einige Wörter am Zeilenanfang nach Streichung unleserlich.

70 Danach ein Wort nach Streichung unleserlich.

71 Die letzten beiden Wörter über der Streichung ergänzt.

72 Daneben ein gestrichenes פ. 


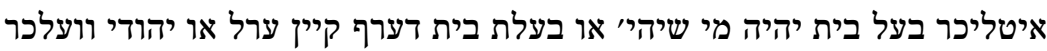
ס"ו

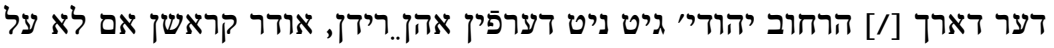

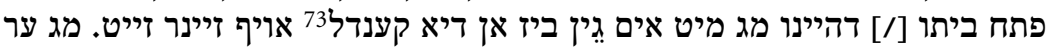

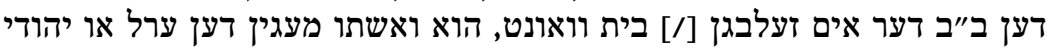

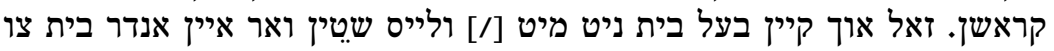

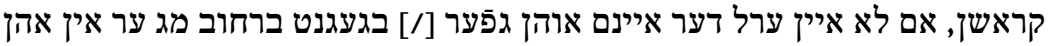

רידן.

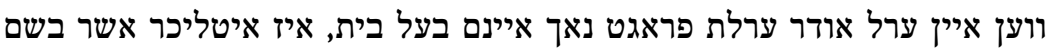
ס ישראל [/] מכונה בחרם גדול אין צו רעכט צו ווייזן אן רעכטין פרין מן בלית בלי שהיי'.

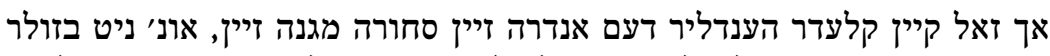
ח 10

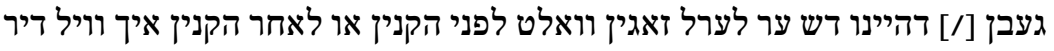

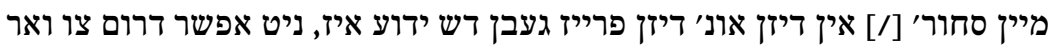

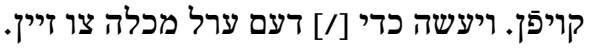

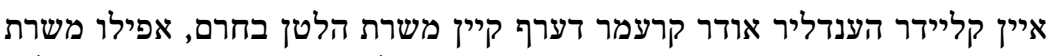

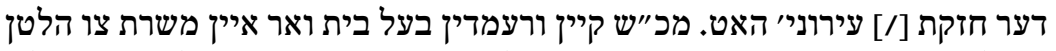
ס"ט

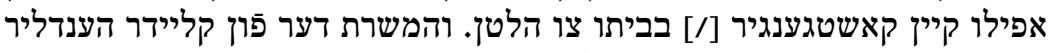

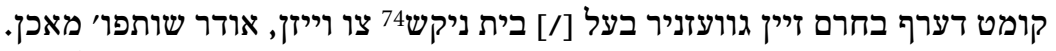

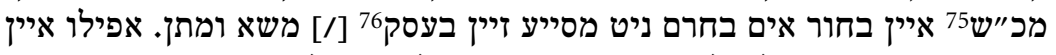

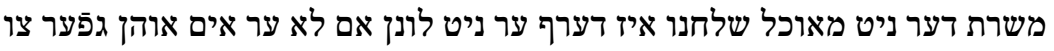

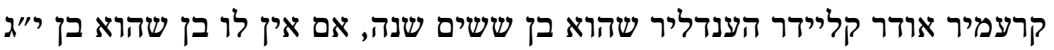

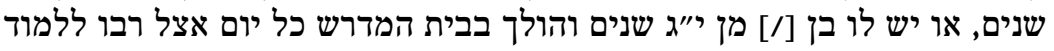

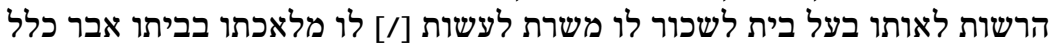

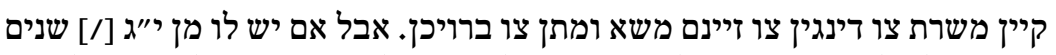

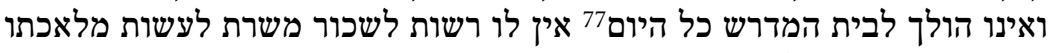

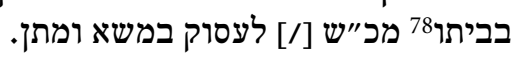

[fol. $144 \mathrm{r}$ ] קרעמר אודר קליידר הענדליר שהוא בן ששים שנה, ולא יכול עוד לצאת ולירוא ולירוא ע"ע

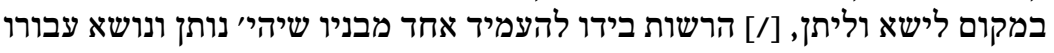

73 kendel = Känel, Synonym für Gosse, den offenen Abwasserkanal in der Straßenmitte.

74 Dieses Wort über der Zeile ergänzt.

75 Ab hier offenbar spätere Ergänzung in kleinerer Schrift.

76 Danach ein Wort durch Streichung unleserlich.

77 Die letzten beiden Wörter über der Zeile ergänzt.

78 Danach ein Wort durch Streichung unleserlich. 


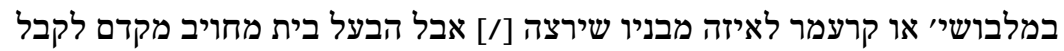

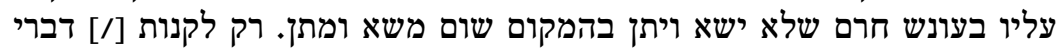

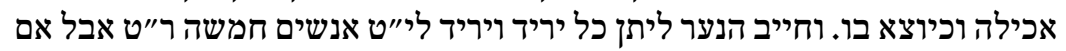

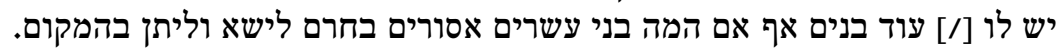

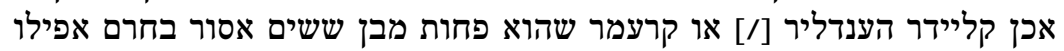

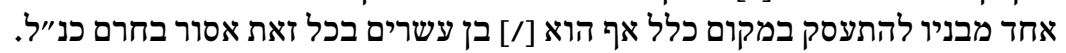

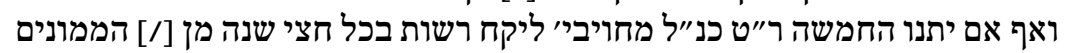
שרשאי' להתעסק. ובלירור רשות חל עליהם החרם לישא וליתן.

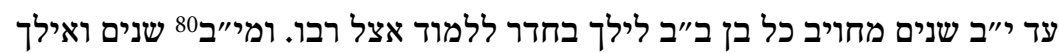

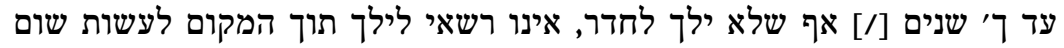

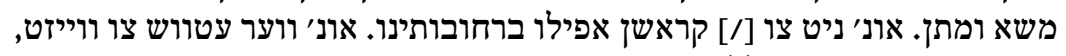

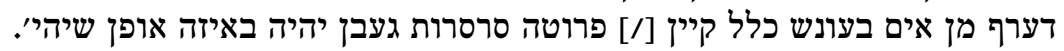

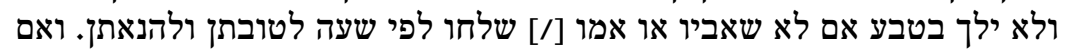

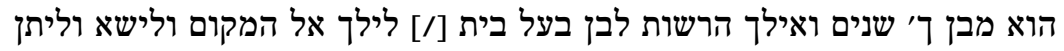

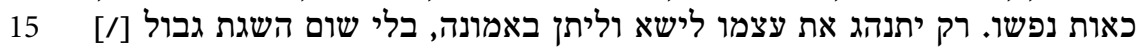

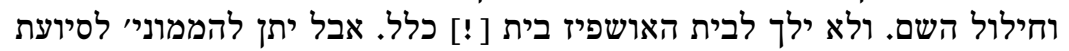

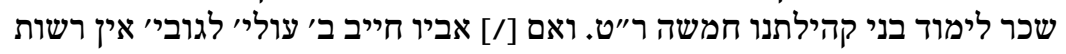

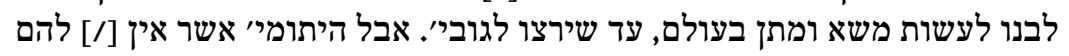

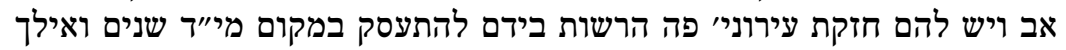

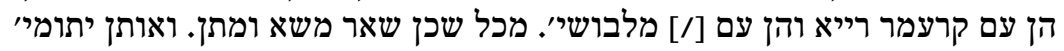

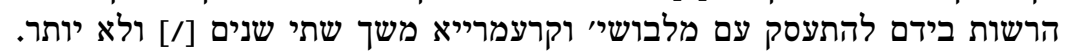

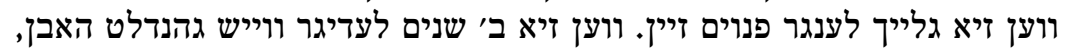

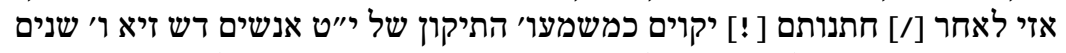

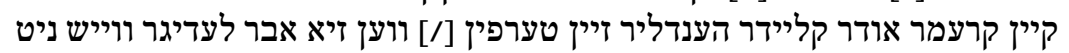

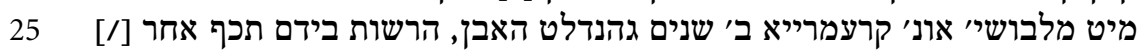

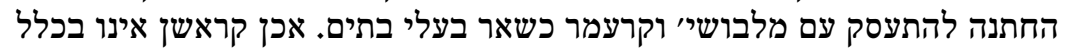

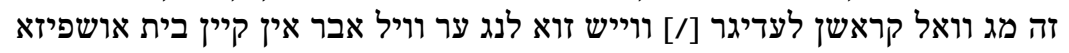
צו קומן.

עש זאל קיין קליידר הענדליר איין חדר דינגין אן דיא ג' שערים ברחובותינו דהיינו ע" ע

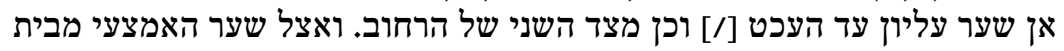

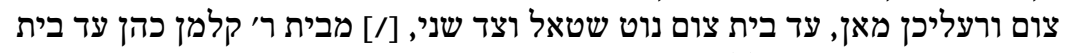
גרשון דארום ועד מאופ ערל בית

איין אלמנה מכ"ש איין בעל בית דערף קיין שותפו' האבן מיט קליידר הענדליר אונ'קרעמר. רק דרף [/] נאר איין משא ומתן האבץ.

\footnotetext{
79 Davor gestrichen: ול

80 Dieses Wort über der Zeile ergänzt, darunter gestrichen: מיג"

81 Dieses Wort zwei Mal.
} 


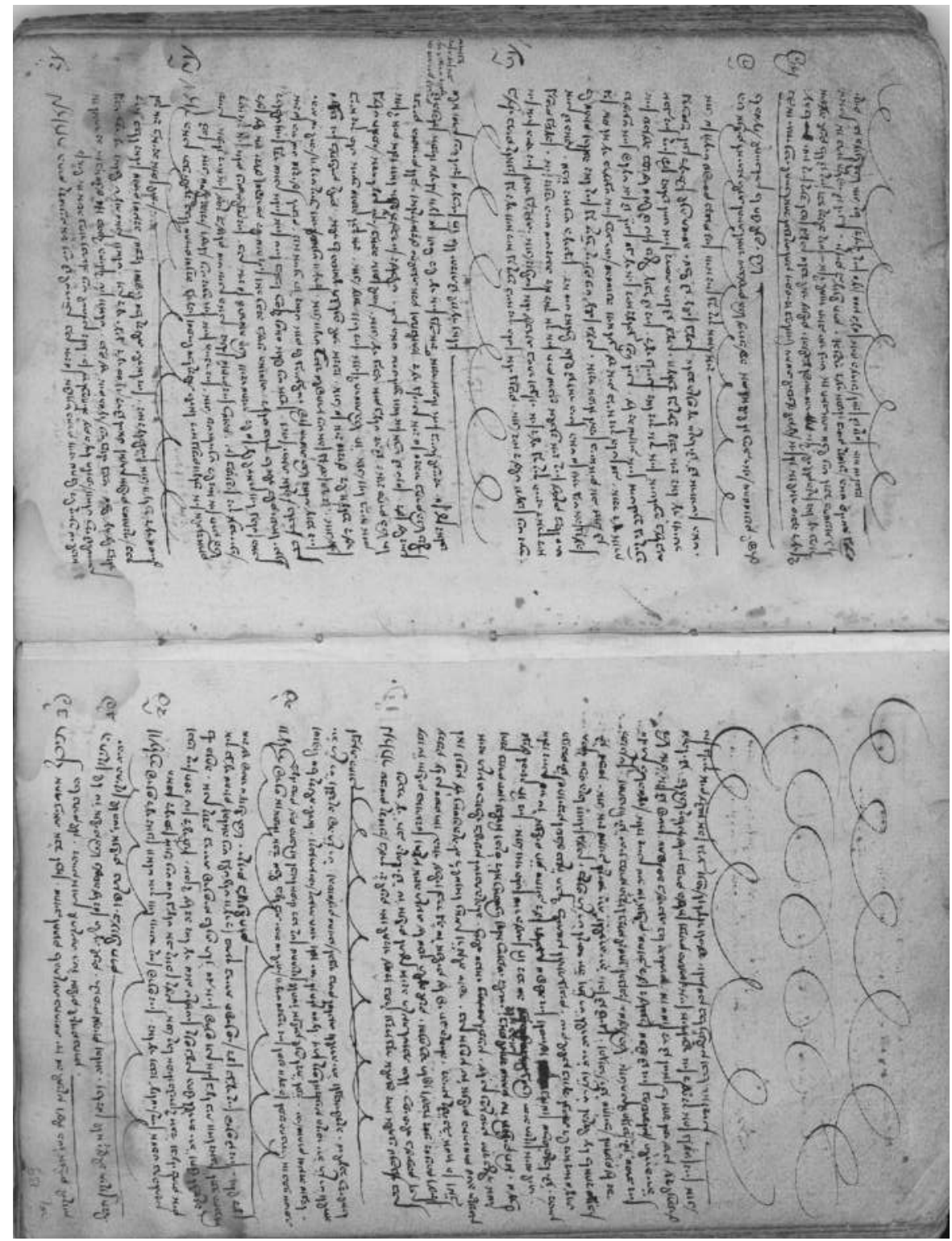




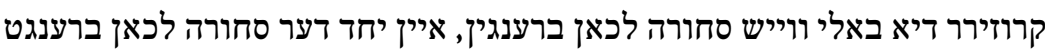

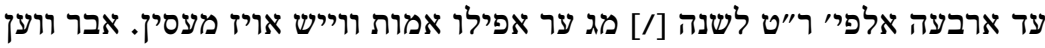

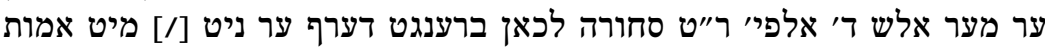

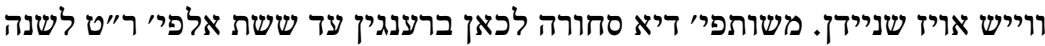

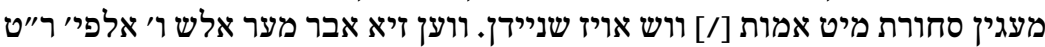

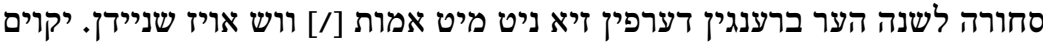

בעונש חרם.82

משרתים אצל בעלי בתים פה סוסים הענדליר, או נכרים סוסים הענדליר זאלין ע"ר

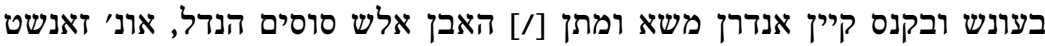

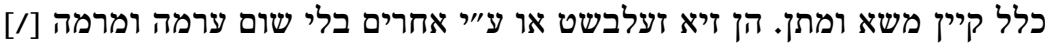

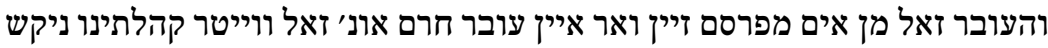

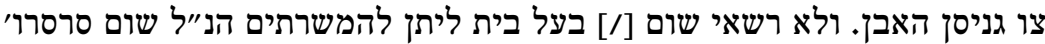

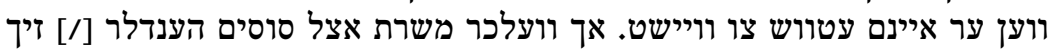

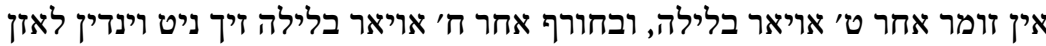

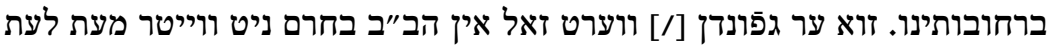

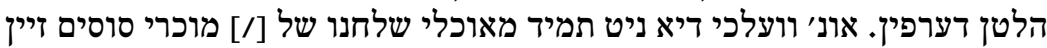

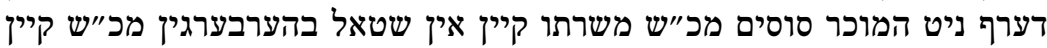

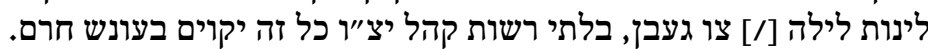

[fol. $144 \mathrm{v}$ ]

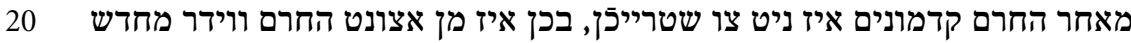

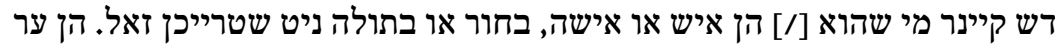

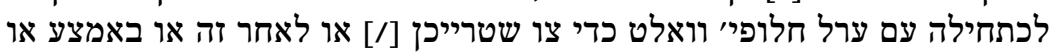

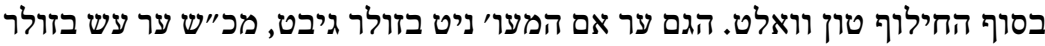

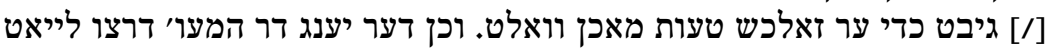

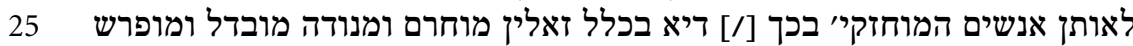

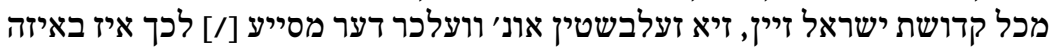

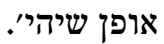

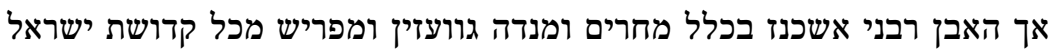

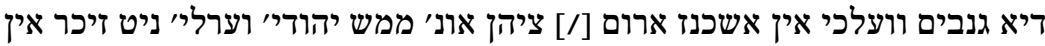

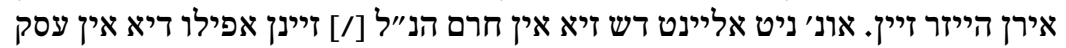

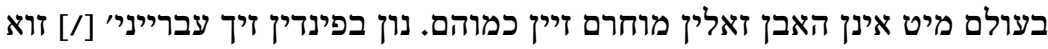

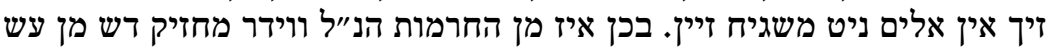

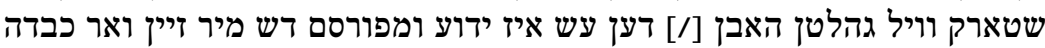

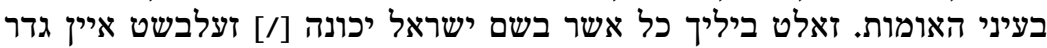
$35 \quad 3$

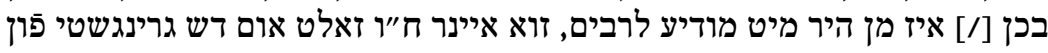

82 Die letzten drei Wörter wurden offenbar später hinzugefügt. 


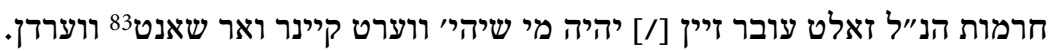

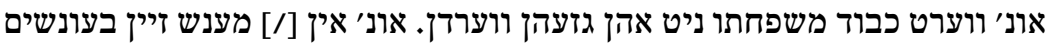

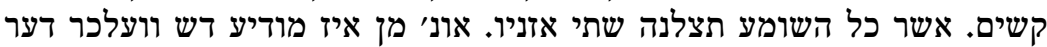

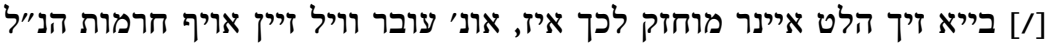

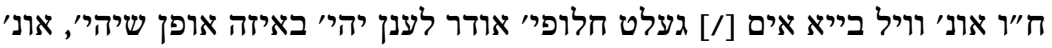

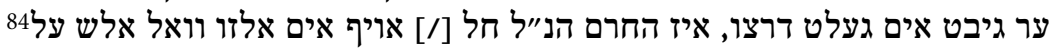

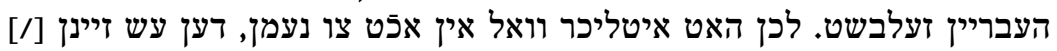

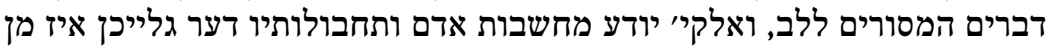

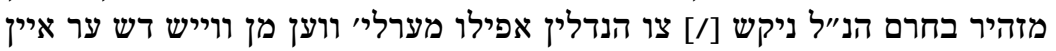

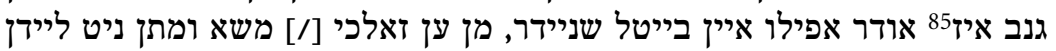
מעכטין ח"ו כלל יהדות צו שווער ואלין.

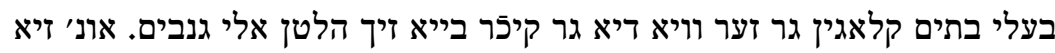
ע"ט

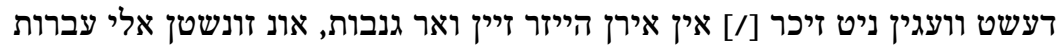

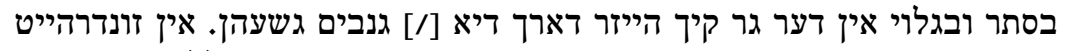

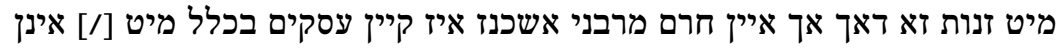

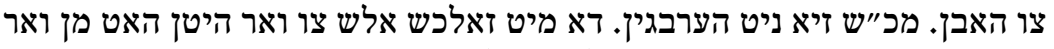

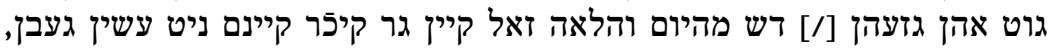

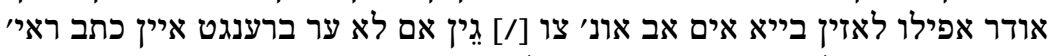

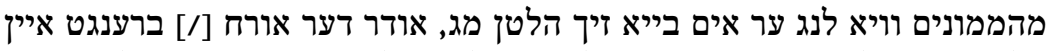

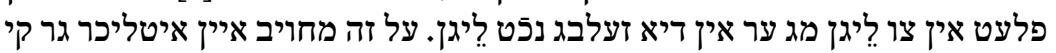

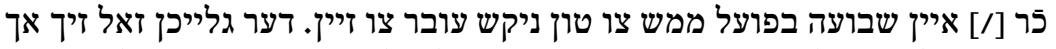

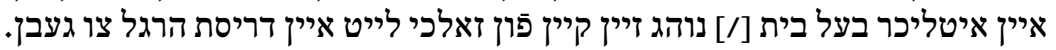

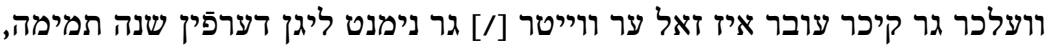

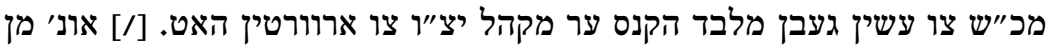

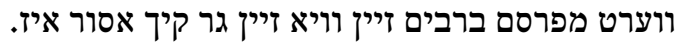

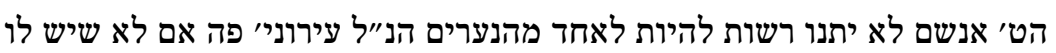

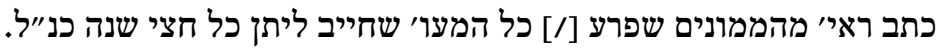

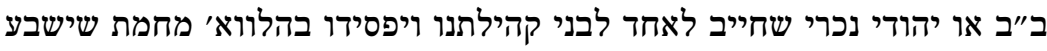
פ"א

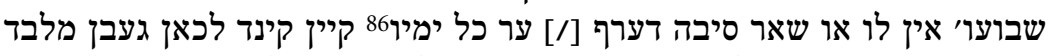

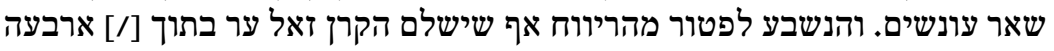
שנים כלל צו קיין דבר קדושה קומן. אף שהוא לפטוא מהיווח איוב יאר צייט הקר זאל ער בתוך חיוב אחר מכ"ש ארבה

83 Das $\boldsymbol{w}$ am Anfang des Wortes wurde erst kursiv geschrieben, dann gestrichen und durch den Buchstaben in Quadratschrift ersetzt.

84 Dieses Wort über der Zeile ergänzt.

85 Ergänzung am rechten Blattrand: או סוחרים עבדים [/] ער שפירט דש ער [/] זיין הערן אב [/].

86 Davor ein Wort nach Streichung unleserlich. 
ניט לדבר התמניות צו [/] מאכן או בתוך הקלפי צו ליגן. יקוים בעונש חרם. והנכרי בעים

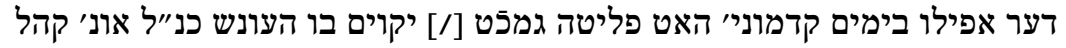

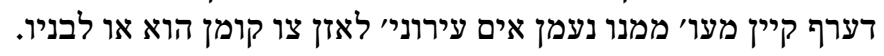

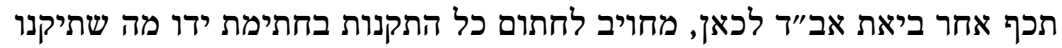
[fol. $145 \mathrm{r}$ ]

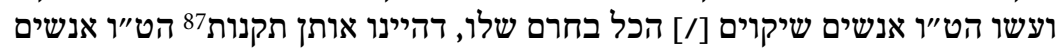
פ"ב שיקוים בחרם.

התיקון של ט"ו אנשים הנ״ל נעשה על זמן תשעה שנים, רצופים מהיום והלאה. פ"פ

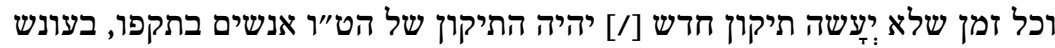

וועלכבר פרנס דער זאגין וואלט איך וויל ווייטר קיין פרנס זיין, זאל ער ובניו עולמיי

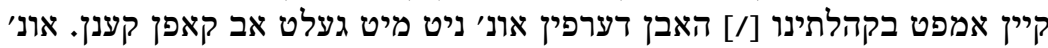

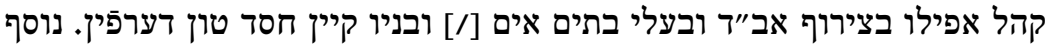

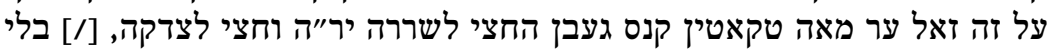

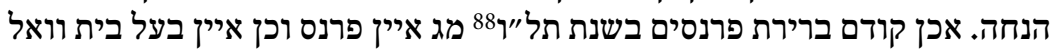

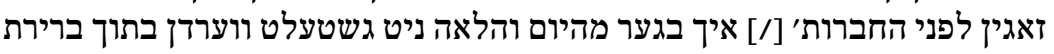

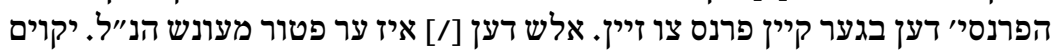

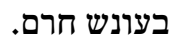

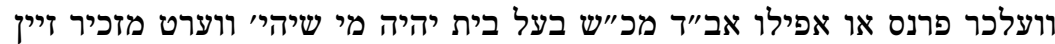

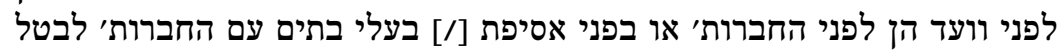

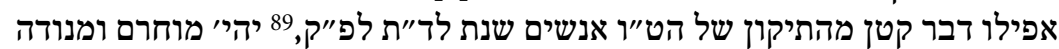

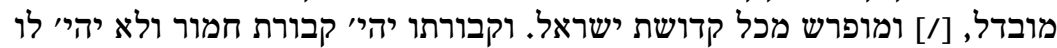

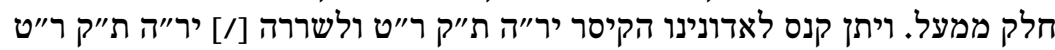

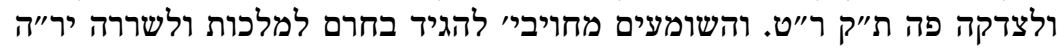

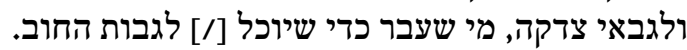

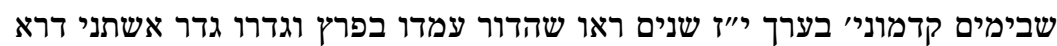

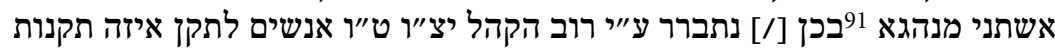

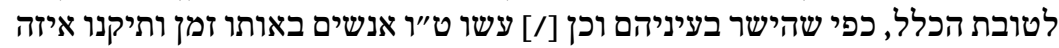

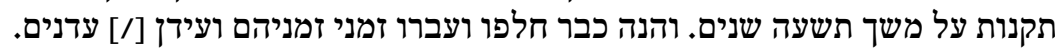

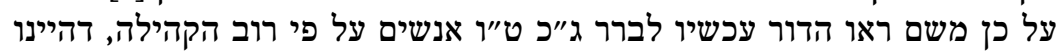

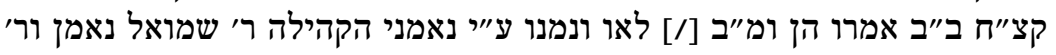

87 Davor ein gestrichenes $ש$.

$88 \quad 1675 / 76$.

$89 \quad 1674 / 75$.

90 Die Nummer anscheinend später in anderer Schrift und Tinte hinzugefügt.

91 Über dem $x$ ein ? geschrieben. 


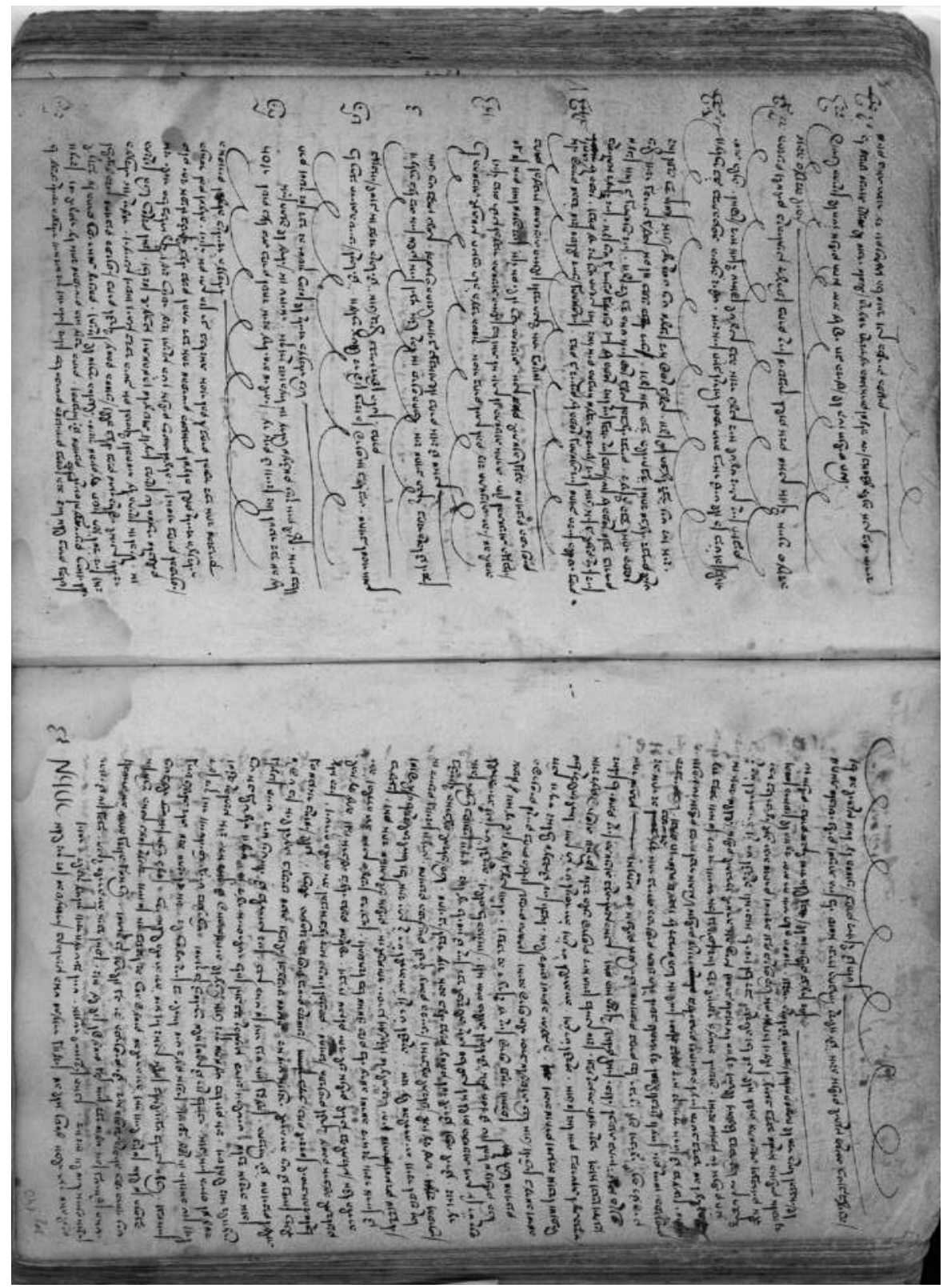




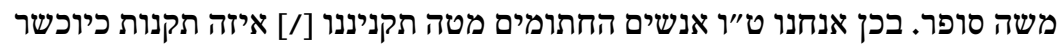

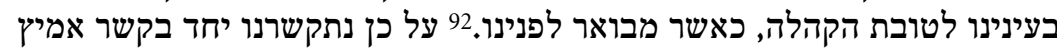

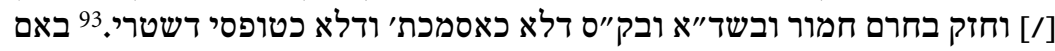

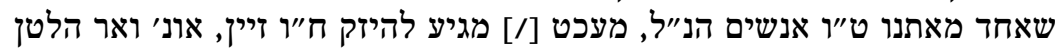

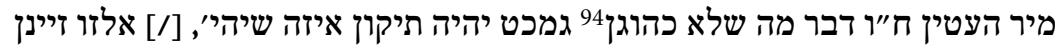

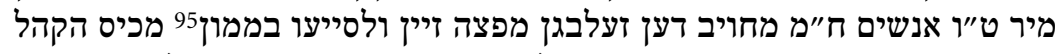

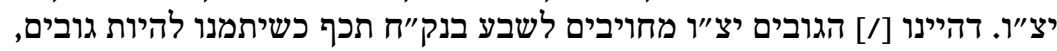

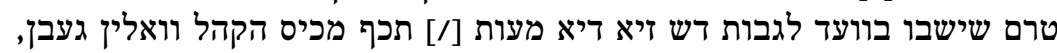

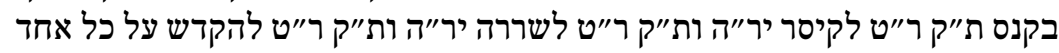

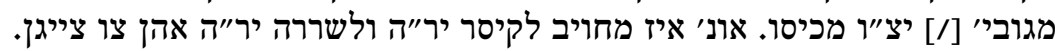

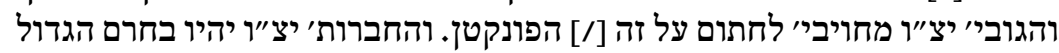

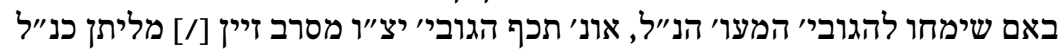

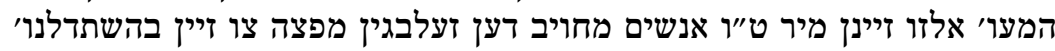

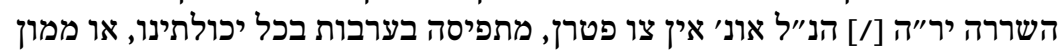

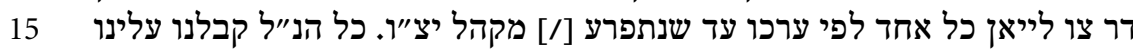

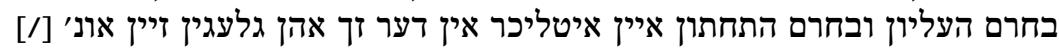

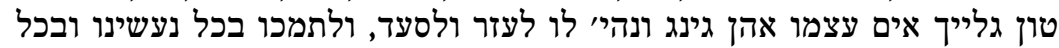

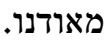

כל ענייני קליידר הענדליר וויא זיא זיך ואר הלטן זאלין בכל הפרטים המבוארים 20 זיטים [fol. $145 \mathrm{v}$ ]

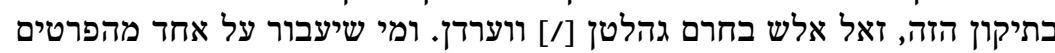

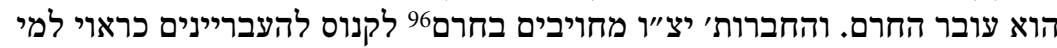

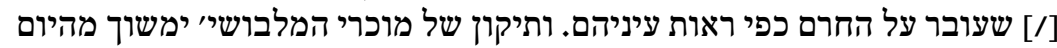

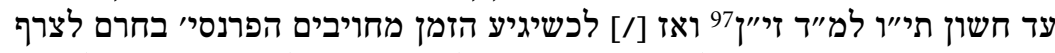

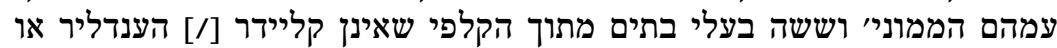

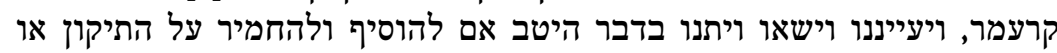

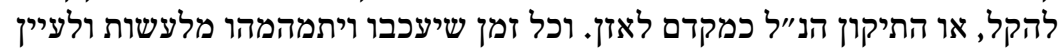

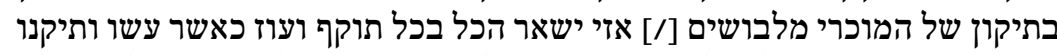

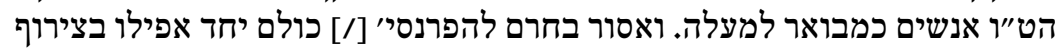

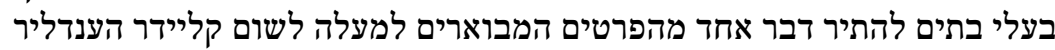

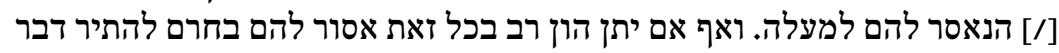

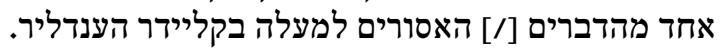

\footnotetext{
92 Davor gestrichen: בחתימת.

93 Baba Batra 44b.

94 Die letzten beiden Wörter über der Zeile ergänzt, darunter einige Wörter nach Streichung unleserlich.

95 Davor ein Wort nach Streichung unleserlich.

96 Dieses Wort über der Zeile.

971676 IX.
} 


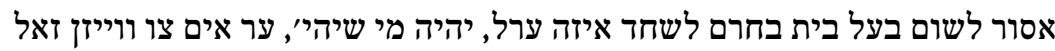
פ"פ

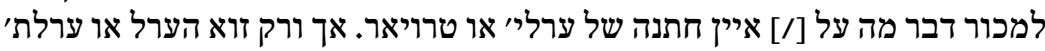

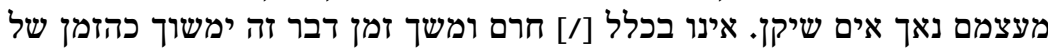
קליידר הענדליר כנ״"ל.

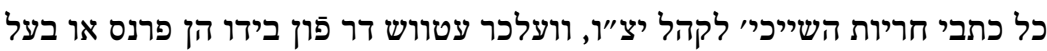

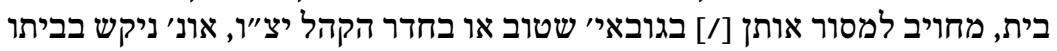

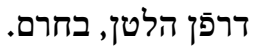

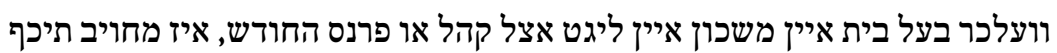

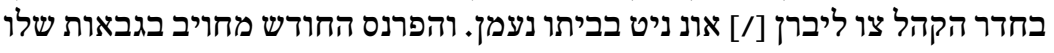
בחרם אויז צו מאכן.

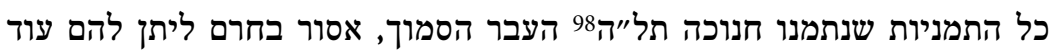
א"צ

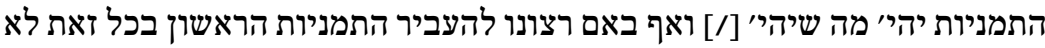

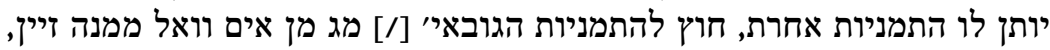

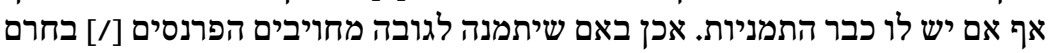

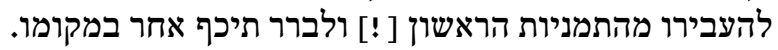

אלי פסקים מהב"ד מוזן משלשה דייניי גחתמנת זיין. באם ב' דיינים על הפסק ובין

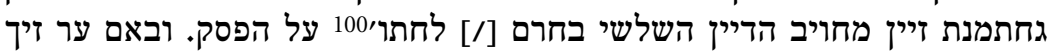

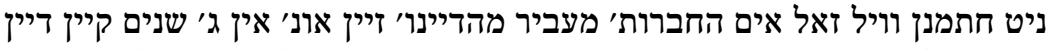

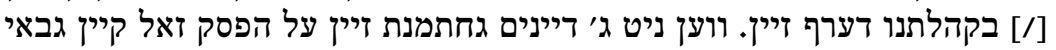

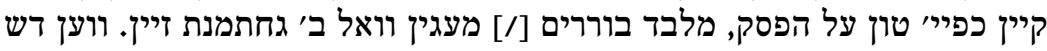

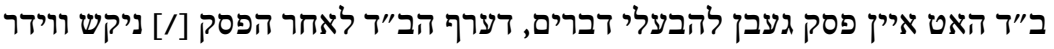

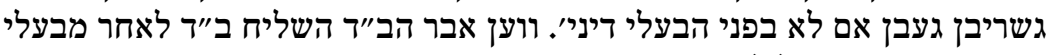

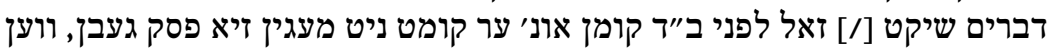
שון הבעל דבר ניט דא איז.

וועלכר ב״ב בבית הכנסת הישנה זיצט, איז איין חיוב לקרותו לספר תורה ביאר

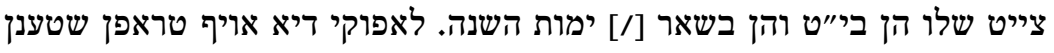
בב"ה אודר נעבן דיא שטאט זיינן קיינר קיין חיובים.

החזנים ושמשים בקהלתינו דערפ̄ן בחרם קיין מי שבירך לשום אדם מאכן אויף

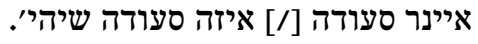

981674 XII 14-21.

99 Das 2 wurde ergänzt, nachdem fälschlicherweise ein $\boldsymbol{x}$ geschrieben wurde. Dasselbe geschah bei allen folgenden Paragraphen bis zum Seitenende.

100 Dieses Wort über der Zeile ergänzt, darunter gestrichen: לפסוק. 
צ"ה פירוש התיקון של הט"ו אנשים הח"מ יהיה על פי רוב הדיעו' של הט"ו אנשים הח"מ.

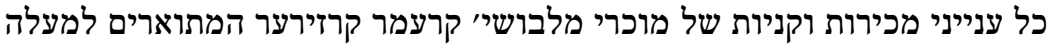
?"צ

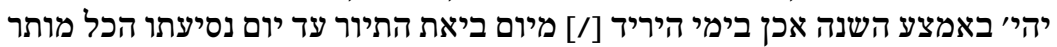

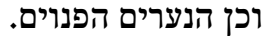

[fol. $146 \mathrm{r}$ ]

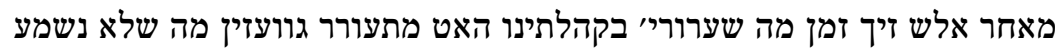

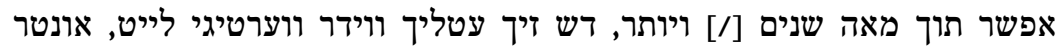

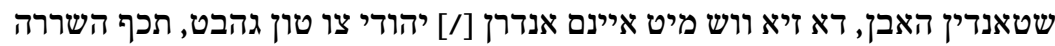

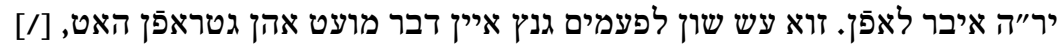

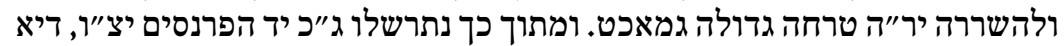

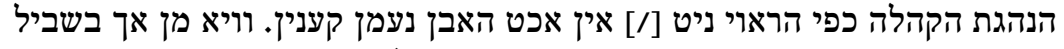

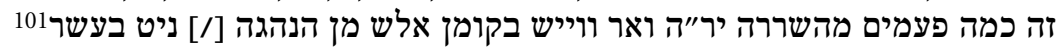

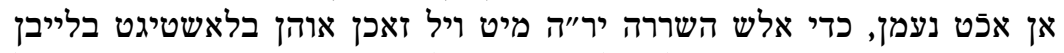

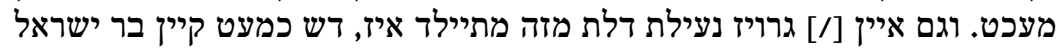

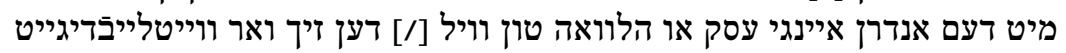

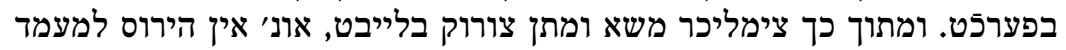

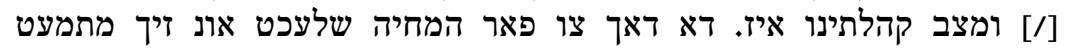

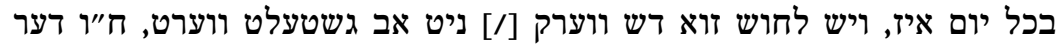

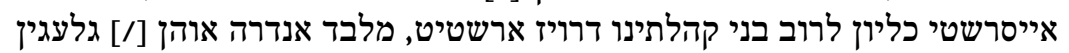

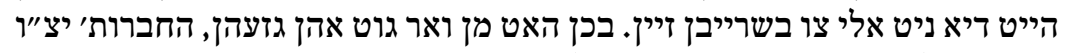

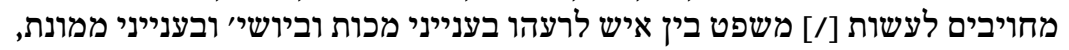

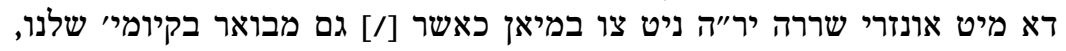

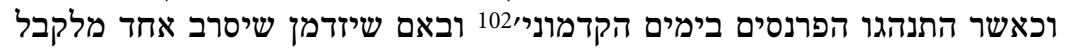

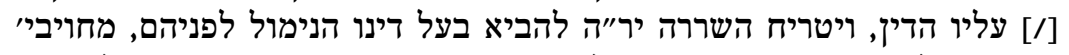

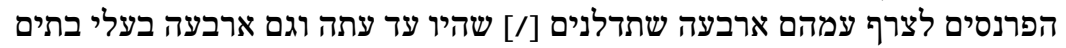

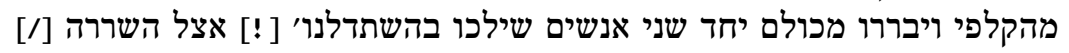

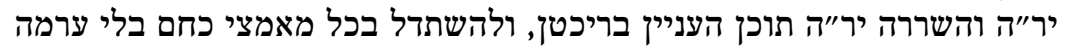

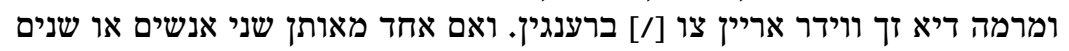

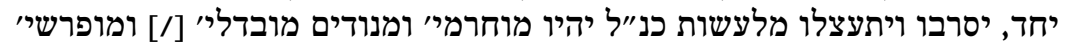

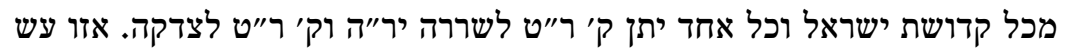

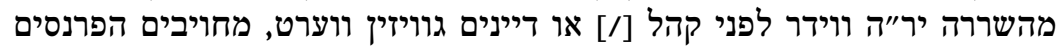

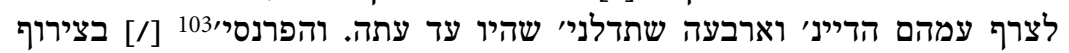

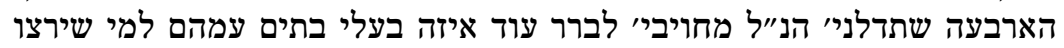

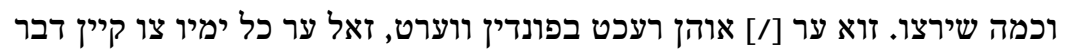

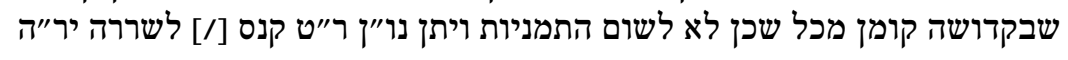

101 Danach gestrichen: ניט.

102 Danach gestrichen: וההולך בערכ.

103 Davor gestrichen: וערכ : 


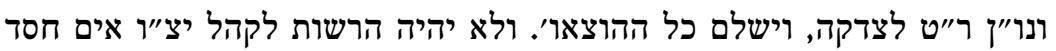

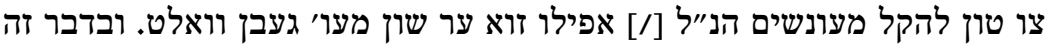

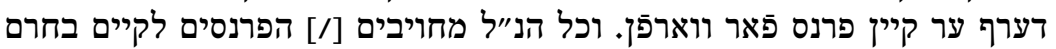

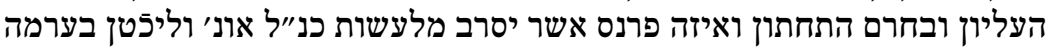

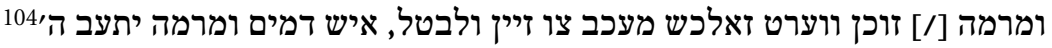

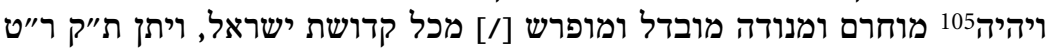

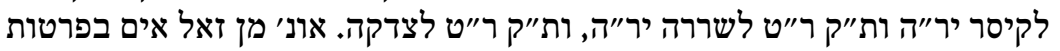

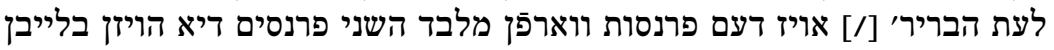

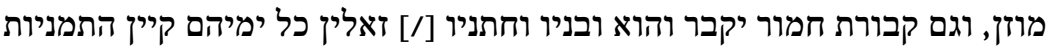

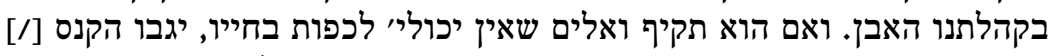

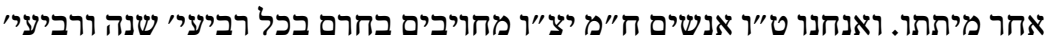

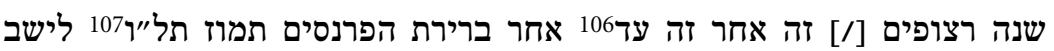

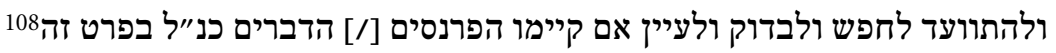

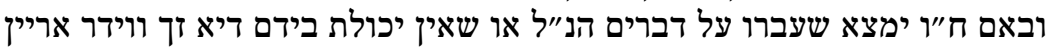

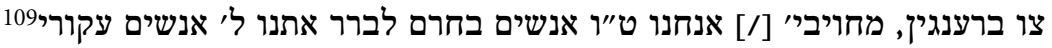

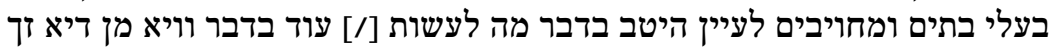

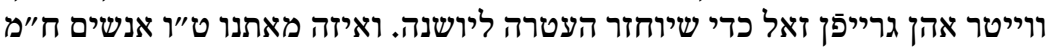

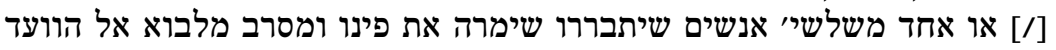

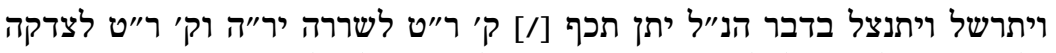

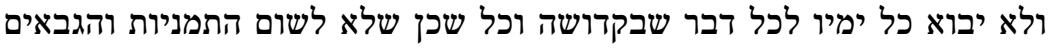

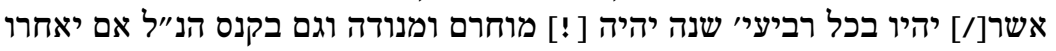

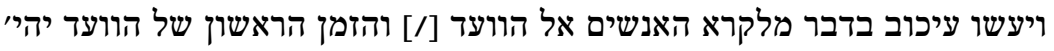

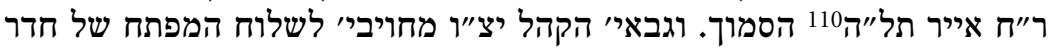

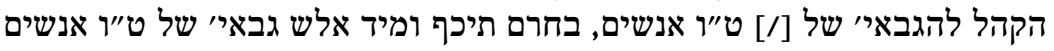

$$
\text { בגערן זיין. }
$$

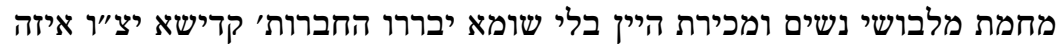

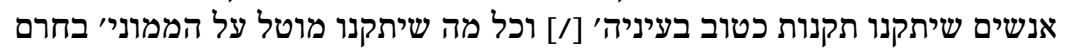
דרויף צו הלטן.

[fol. $146 \mathrm{v}$ ]

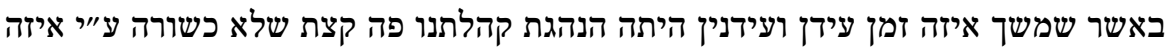

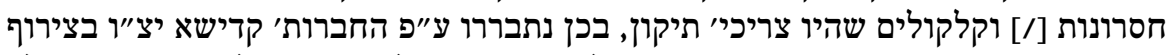

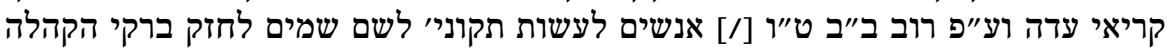
הצריכי' תיקון. ועתה אחר שנגמרו פירו תיקוניהם היתה [/] נפשם בשאלתם לחים לחזק דבריהם

\footnotetext{
104 Ps 5,7.

105 Davor ein Wort nach Streichung unleserlich.

106 Davor gestrichen: לישב.

107 1675 VI/VII.

108 Die letzten beiden Wörter über der Zeile ergänzt.

109 Danach gestrichen: הקהלה.

1101675 IV 17.
} 


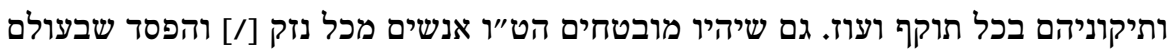

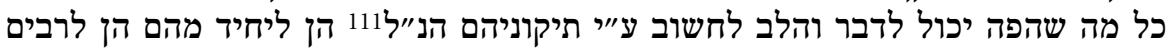

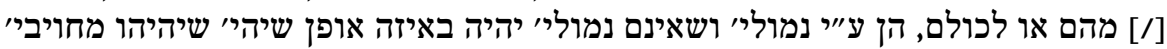

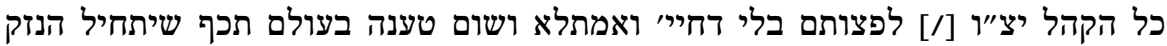

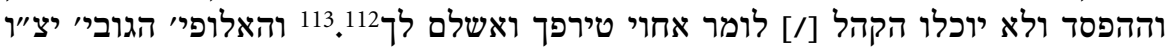

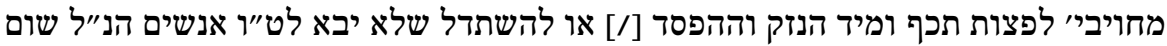

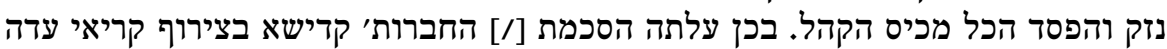

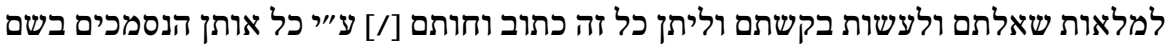

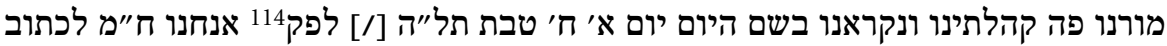

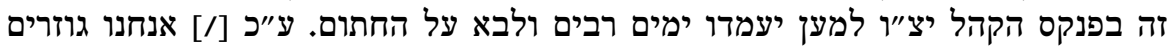

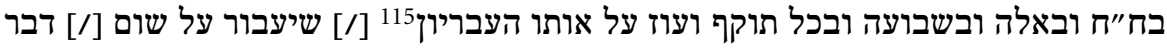

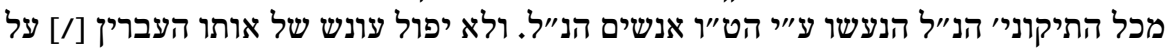

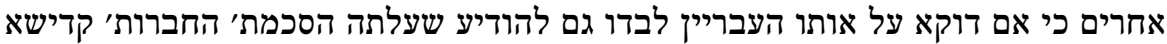

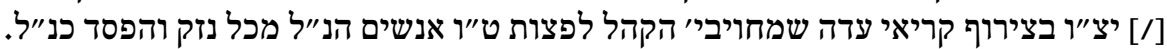

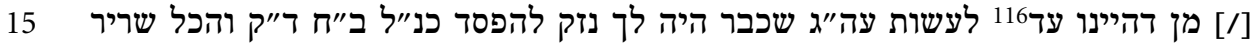

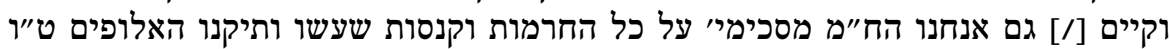

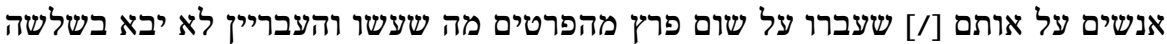

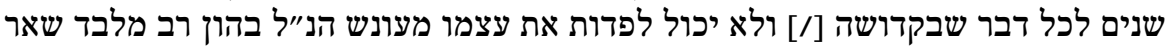

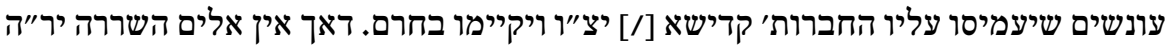

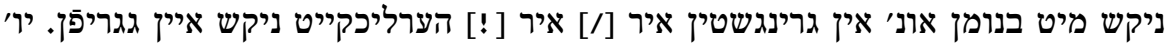
הנ"ל משיק

נא׳ הק' מאיר שט[..] ונאו' הק' הירץ ארוויילר

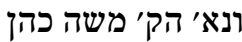
ונאום הק' יוסף כשה כהן117 - (117

ונא׳ משה בן לא"א הריר ארוויר שלמה הלוי זצלה"ה הקטן נתן כהן

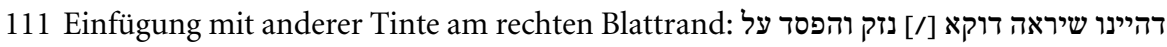
ידי [/] שעשו הט"ו אנשי' הנ"ל איזו תיקונים שלא היו רשאים לעשות

112 Baba Kama 9a.

113 Darüber mit anderer Tinte ergänzt: שכבר היה לך נזק והפסד כנ״ל.

1141675 I 25.

115 Dieses Wort mit anderer Tinte über der Zeile ergänzt. Darunter gestrichen: 'העברייני. 116 Dieses Wort zwei Mal.

117 Daran schließt eine Liste der Streichungen und Änderungen in den einzelnen Paragraphen der Statuten an. Da diese im Text vermerkt sind, wurde auf ihre Wiedergabe hier verzichtet. 


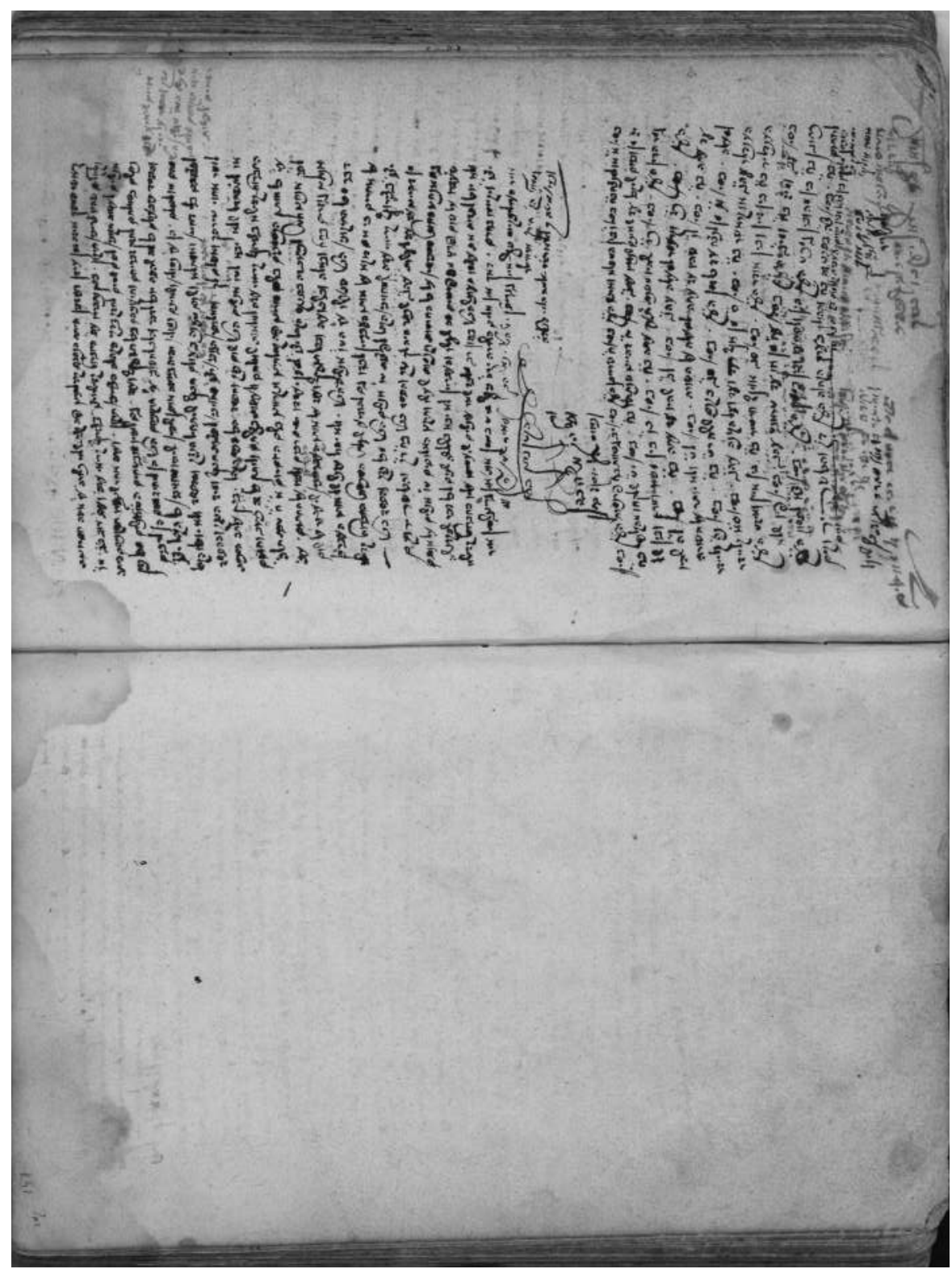




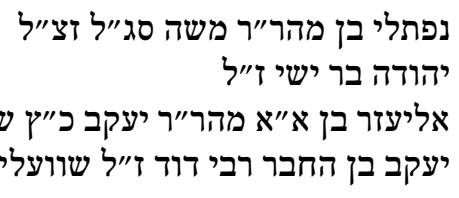

משה וואג בכרך

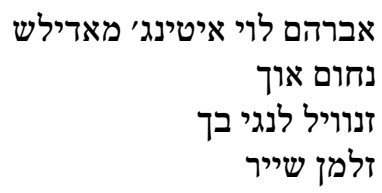

זלמן שייר לנורי

מאיר לוי שנאפיר בכרך
יחיאל כ"ץ אולוף משה אולוף כיץ" כיץ דוטרס אופנהייי דוד רייס שמואל ב"ר ישראל יעקב ז"ל במואל

118 Bei den folgenden 15 eigenhändigen Unterschriften handelt es sich offenbar um die der fünfzehnköpfigen Statutenkommission. 


\section{Statuten aus Worms 1684}

\section{Quelle: Statutentext, CAHJP, Rh/W II/6}

Die takkanot von 1684 sind zwar nicht die ältesten Statuten aus der reichsstädtischen Gemeinde, jedoch sind sie die ältesten, die sich in einer vollständig erhaltenen Originalausfertigung erhalten haben, weshalb sie ein überaus wichtiges Dokument für die Gemeindegeschichte darstellen. Sie entstanden kurz vor der zweiten Zäsur in der jüdischen Lokalgeschichte, als die Stadt und auch die Judengasse im Jahr 1689 durch die französische Belagerung stark beschädigt wurden. Die Existenz der Originalausfertigung zeigt, dass sie durch die Vorsteher vor der Zerstörung gerettet wurde. Eine weitere, spätere Version von takkanot aus dem Jahr 1728 weist erneut inhaltliche Ähnlichkeiten auf, weshalb davon ausgegangen werden kann, dass die Texte des 17. Jahrhunderts nach wie vor in ihren Grundzügen bekannt waren und als Vorbild für die Revision aus der ersten Hälfte des 18. Jahrhunderts dienten.

Wie auch der erhaltene Vorgängertext von 1651 kommen die Statuten von 1684 in ihrer stilistischen Gestaltung nahezu ohne Zitate aus Bibel, Talmud oder anderen traditionellen Texten des Judentums aus. Obwohl beide auf Einzelheiten des Gottesdienstes eingehen, wurden die takkanot offenbar also eher als säkularer Text aufgefasst, der zur Regelung des gemeindlichen Zusammenlebens formuliert worden war. Darin unterscheiden sich dieser und der ältere Wormser Text von den Statuten aus Frankfurt a. M., die zehn Jahre zuvor erlassen wurden, und in denen die säkulare Ausrichtung des Inhalts zwar noch stärker ausgeprägt ist, jedoch durch zahlreiche Bibel- und Talmudzitate die Einbettung der Statuten in die jüdische Tradition deutlich zum Ausdruck gebracht wird.

Die Statutensammlung scheint ein eigenständiges Manuskript gewesen zu sein, da die ursprüngliche Foliierung mit fol. 1 beginnt. Der schlechte Erhaltungszustand der Blätter hat keinen nennenswerten Textverlust verursacht, eine behutsame Restaurierung vor einigen Jahren hat die fehlenden Blattränder wieder ergänzt. Alle sieben Blätter sind erhalten und somit auch alle 138 Paragraphen.

Die Sprache der Statuten ist das aus dem Vorgängertext bekannte Miteinander von längeren Passagen in gut verständlichem Westjiddisch und kürzeren Abschnitten in Hebräisch. Der Schreiber der takkanot wird nicht explizit genannt, jedoch gibt es eine große Ähnlichkeit zwischen der Hand- 
schrift des Schreibers und der des ersten Unterzeichners des Textes, Isaak Warmaisa.

Die Blätter der Handschrift sind original am linken oberen Blattrand mit hebräischen Buchstaben foliiert worden. Später erfolgte eine moderne Foliierung mit arabischen Ziffern unter Einbeziehung einer Seite mit Konzepten, die als Blatt 1 nummeriert wurde. Von unkundiger Hand stammt eine Paginierung mit arabischen Zahlen auf den jeweils unteren, äußeren Ecken der Seiten, die jedoch auf dem Kopf stehen. Dies deutet darauf hin, dass die Person den Text nicht lesen konnte und ihn in der typisch-unkundigen Art auf den Kopf stellte, bevor die Paginierung vorgenommen wurde. Die Paragraphen wurden mit hebräischen Buchstaben in Quadratschrift am rechten Rand nummeriert. Dabei wurden die ersten beiden Zeilen eines jeden Paragraphen eingezogen, sodass die Nummer in den Textblock integriert werden konnte.

Die Statuten von 1684 weisen eine Reihe von parallelen, sogar komplett unveränderten Passagen aus dem bekannten Vorgängertext von 1650 auf. Daraus ist zu schließen, dass sich die grundlegenden Bedürfnisse und Realitäten in der Gemeinde in den dazwischen liegenden Jahren kaum verändert hatten. Allerdings wurde in den Statuten von 1684 auf die thematischen Zwischenüberschriften verzichtet, auch wenn sich eine Reihe von Abschnitten mit inhaltlicher Fokussierung ausmachen lässt. Ähnlich wie der Text von 1650 finden sich an seinem Beginn die Regelungen für die Jeschiwa und die dort lernenden Studenten (Paragraphen 1-7). In den Paragraphen 8-28 folgen die Anweisungen für den synagogalen Gottesdienst, gefolgt vom Prozedere für die Steuerschätzer und die Vermögensschätzung (Paragraphen 29-48). Daran schließen sich die Verordnungen für die Amtsgeschäfte der parnasim an (Paragraphen 49-56), die Regeln für die Aufnahme neuer Mitglieder und die verschiedenen Kategorisierungen der Eheschließungen von Ortsansässigen und Ortsfremden (Paragraphen 57-75) an. In den Paragraphen 76-85 werden Angelegenheiten von Urkunden und Geschäftsrecht geklärt. Die Paragraphen 86-110 sind inhaltlich ungeordnet und stellen ein Konvolut von Erlassen zur Liturgie, zu Abgaben, zum Bann, zu Synagogenplätzen und Krediten, zum Gerichtsprozedere und Handelsrecht und schließlich zu Spielverboten. Die meisten dieser Paragraphen sind aus dem früheren Text unbekannt. Von den Paragraphen 111-119 finden sich, hier wieder im thematischen Zusammenhang, Regeln zur geordneten Abwicklung von Geschäften. Danach folgen wieder Aspekte zur Amtsführung und Besoldung der Gemeindevorsteher und -angestellten. Interessant ist hier die Erwähnung eines Statutenbuchs $(\$ 137)$, das bislang unbekannt war. Ob es sich bei der Textvorlage vielleicht um die ersten Seiten dieses Buches handelt oder seine Anlegung unausgeführt blieb, bleibt unklar. 
[fol. $1 \mathrm{r}$ ]

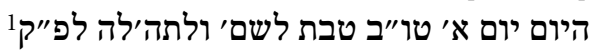

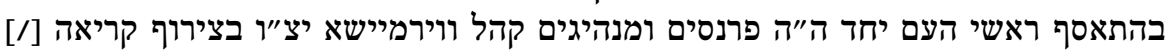

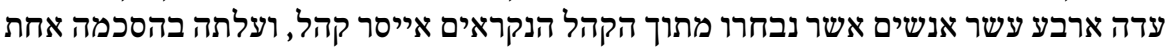

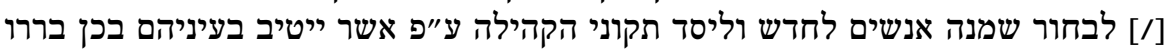

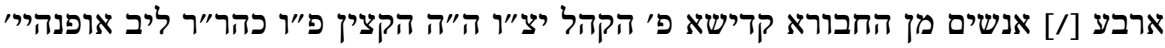

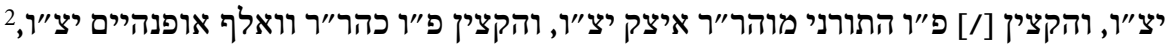

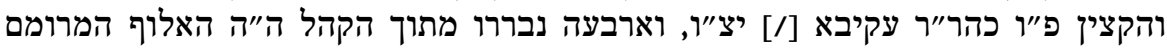

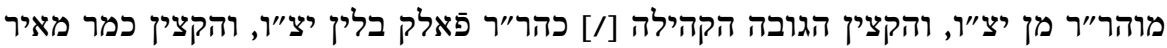

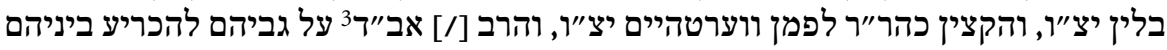

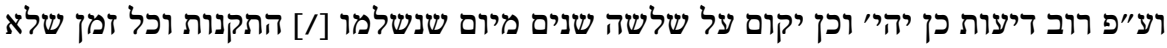
יתחדשו התקנות יהיו התקנות אלו בתוקפן על שיתופ שיתחדשו תקנות חדשות.

בחורים זאלן אן גנומן ווארדן כל זמן ששה בחורים וארבע בהעלפר אונ' הגאון א

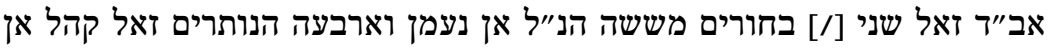
נעמן.

קהל יבררו שני קופה גבאים אחד פרנס ואחד ב״ב ויובררו אצל פ"ו שי' כל שנה ושנה כרצון [/] הקצינים פּוּו.

מחמת יונגי ב״ב דיא מזונות על שלחן אביהם או חמיהם האבן שנה ראשונה נקיים 'ג

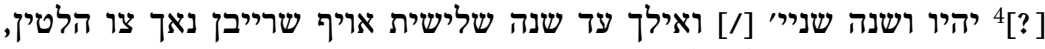

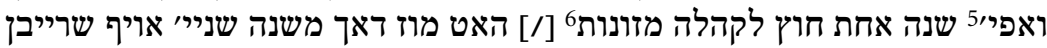
מכאן ואילך הם כשארי ב״בב צו הלטין שבתות המגיע [/] כפי כפי ערכם.

11684 XII 14. Offenbar ist auch das ת aus dem Wort ולתהלה zur Wiedergabe der Jahreszahl mit verwendet worden, obwohl es vom Schreiber nicht gekennzeichnet wurde.

2 Er war bereits an der Revision der Statuten von 1655/56 beteiligt; siehe die Edition der ältesten Wormser Statuten von 1651 in diesem Band.

3 Aaron Teomim (1630-1690), fungierte in Worms als Rabbiner von 1670 bis 1687; siehe Encyclopaedia Judaica, 2. überarbeitete Auflage in 22 Bänden, Detroit 2007, Bd. 19, SP. $642 \mathrm{f}$.

4 An dieser Stelle ein Wasserfleck, Lesung unsicher.

5 ואפילו

6 Danach $\mathrm{n}$ als Zeilenfüller; hier wie in allen folgenden Fällen wurde jeweils der erste Buchstabe der Folgezeile als Zeilenfüller verwendet. 
מחמת מלמדים מתפילת שחרית עד אחר תפילת ערבית זולין המלמדים קייין שיעור

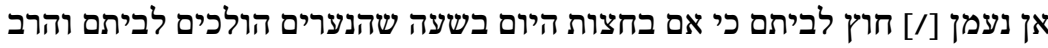

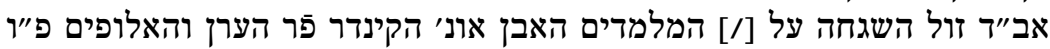

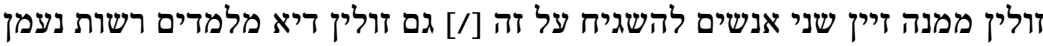
מן שני ממונים ווען זיא חוץ לקהלה גין וואלין.

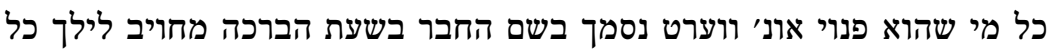
1

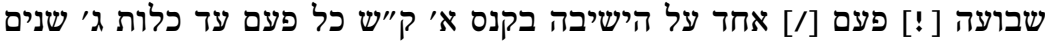

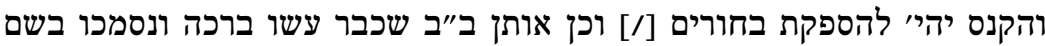

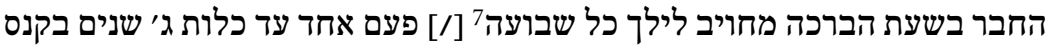

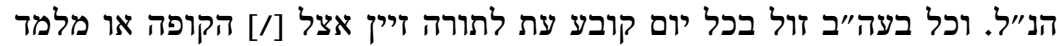
בביתו בקנס שני זהו' כל שנה לת"ת. כלכל יובע

סיום מסכת וואש גמאכט ווירט בקהלה זול גימאכט ווערן בקהלש שטוב דוקא

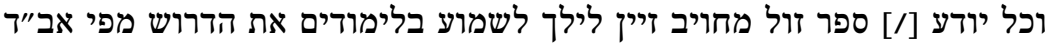

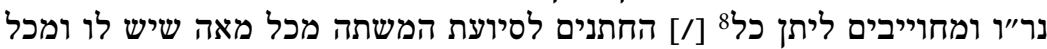

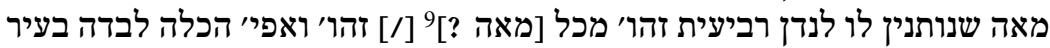

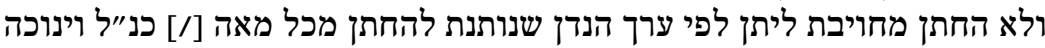

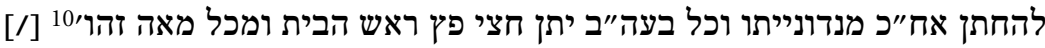

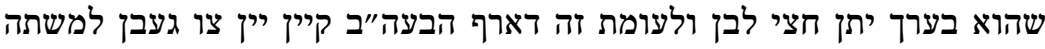

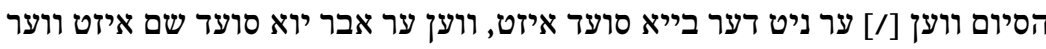

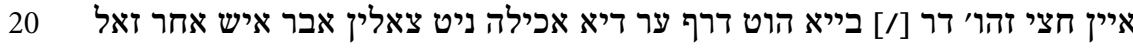
חצי ק"ש געבן בעד מזונות.

קודם ברוך שאמר ושבעת קריאת התורה יקרא החזן שתיקה יפה בשעת הפת התפלה וקודם [/] קריאת ספר התורה יכריז שתיקה יפה בשעת קריאת התורה.

אצל ישתבח זאל מן ניט מפסיק זיין ומה שהיי מקדם מנהג דז השמש האט בריפו"ה ט

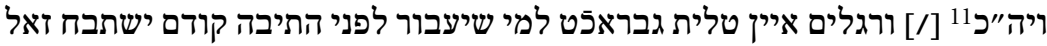

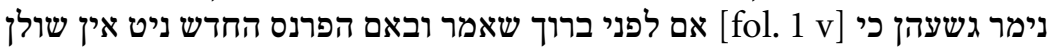

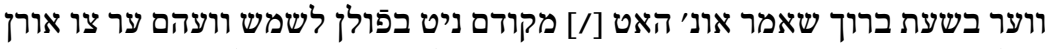

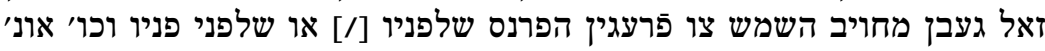
דוקא קודם ברוך שאמר מכבד זיין בקנס על השמש אפוש אם יעבור.

\footnotetext{
7 Danach פ als Zeilenfüller.

8 Danach $\pi$ als Zeilenfüller.

9 Wort verwischt und unleserlich.

10 Danach $\boldsymbol{w}$ als Zeilenfüller.

11 Danach $>$ als Zeilenfüller.
} 
לעת ערב זול לאחר דז השמש ארום גרופן הוט זו בעל הדלקה אחר דז השי השמש אין

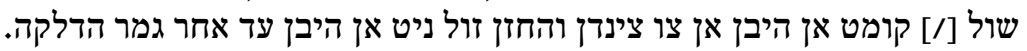

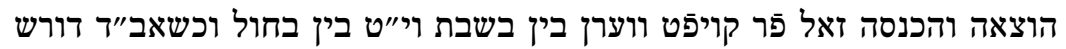

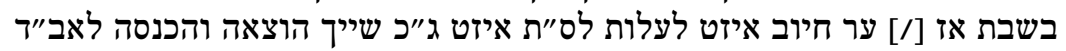

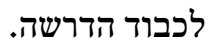

מי שיש לו הוצאה והכנסה בסוכות שייך לו ג״כ מצות הוצאת ס"ת בזמן ההושענות י ][/] ויכול לכבד בו למוצאו שירצה.

כל מצוה זול ניט אויז גרופ̄ן ווערן אונטר איין פצין אונ' ווען זיא בלייבט זאל זיפל זיא

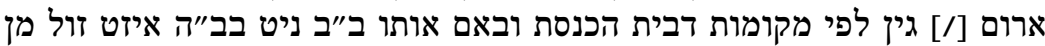

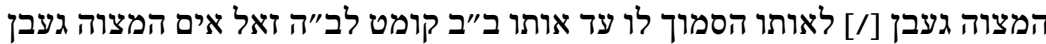
ווערן ובאם אחד שטייגט [/] איין מצוך לוה זול נית ניט פחות זיין אלז ד' פשיטים. בחול זאל מן סגן מיט הוצאה והכנסה צו גלייך אוועק לאזן וכן במנחה בשבת. $7^{\prime \prime \prime}$ אן תענית ציבור זאל מן כלל קיין פנוי לאזין עולה לתורה זיין אפילו למפטיר חוץ ט"ט

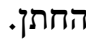
קיין פנוי זאל קיין סגן שטין כי אים אחר בעה"ב במקומו חוץ איין חתן. T"ט 15 וואש מקדם איזט גוועזן הגבאה [!] זול קערן צו דיא אנדר תורה אונ' דיא דריט תורה [/] זול לע"ע בפני עצמו פַר קויפַט ווערן לטובת ההקדש.

זאל קיינר דרפיין איין קינד אין שול נעמן וואז ניט ריינטליך איזט ובאם אחד מעפ מעכט

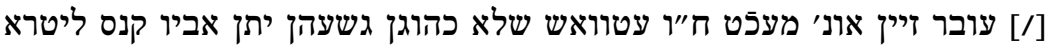

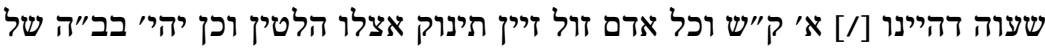

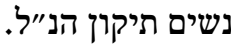

כל מי שיש לו נר פחות ליטרא לא יעמוד אותו לפני החזן ביה״כ.

ט"י

מי שהוא מורינו אם מתפלל בר"ה או ביה"כ הוא חיוב לעלות לתורה באותו יום

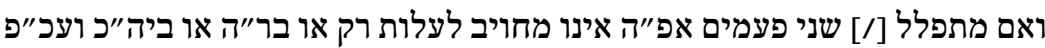

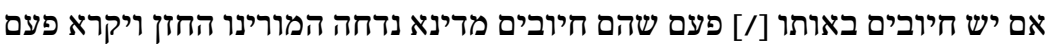

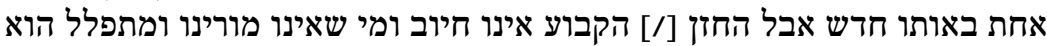
חיוב לקרות באותו חדש.

התוקע חיוב באותו יום ואם הוא תוקע שני ימים אינו חיוב ורק יום הראשון. 
כל בעלי בתים בקהלה חוץ מן הפרנסים זאלן גליגט ווערן בקלפי ובכל שבתות ד

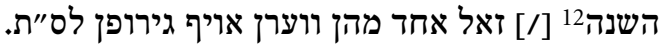

קיין אורח ואיש נכרי זאל מן ניט לאזן מתפלל זיין לפני התיבה בשבת וי"טי בשיפ בשחרית $\left.T^{\prime \prime}\right\rceil$

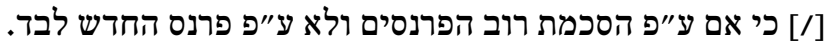

קיין אורח זאל מן צו דרשן געבן אם לא בידוע שהוא ראש ישיבה בקהלה בינוני $R^{\prime \prime}$

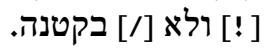

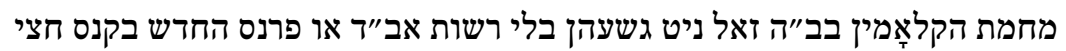
$\left.{ }^{13}\left[7^{\prime \prime}\right\rceil\right]$

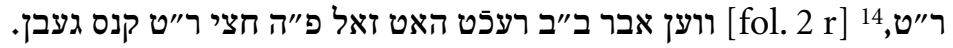

קיין בן אדם זאל מרבה דברים זיין בבה"כ עם עם איזה ליזה ערל או ערלתה אלא ילך ליך T 10

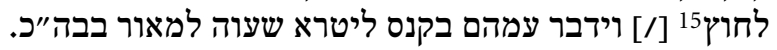

שבת פרשת פרה שייכים כל המצות להבחורים והרשות ביד הקהל. $\left.\pi^{\prime \prime}\right\rceil$ מחמת בעלי מעריכים זולין נברר ווערן מפרנסים עם ך"ג אנשים כנהוג. ๆ" בחירת בעלי מעריכים יהי' באופן זה דהיינו הפרנסים יבחרו ויכתוב כל א׳ שמות16 למ"ד

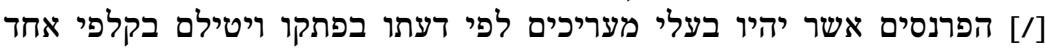

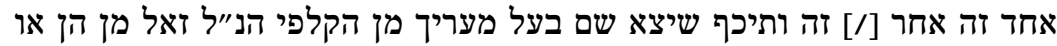

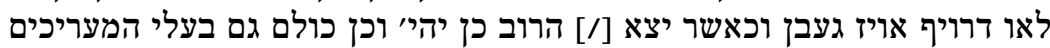

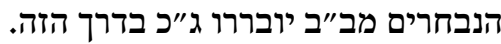

מחמת פסולים אצל פרנסים איזט פּר גוט אן גזיע גועהן ווערן שלשה פסולים ל

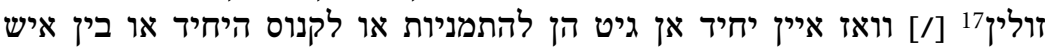

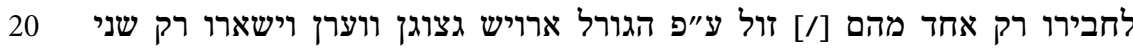

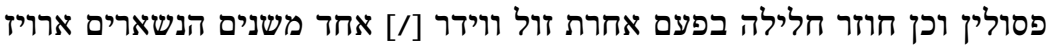
גצוגן ווערן וכן לעולם רק שני פסילה פסולין זיציל זולין בלייבין חוץ חוץ עסקי18 [/] הקהילה

12 Danach ז als Zeilenfüller.

13 Textverlust durch beschädigten Blattrand.

14 Danach die Kustode ווען.

15 Danach $>$ als Zeilenfüller.

16 Danach $ה$ als Zeilenfüller.

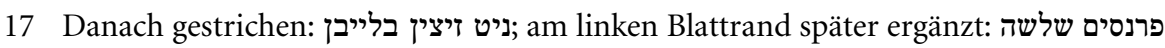

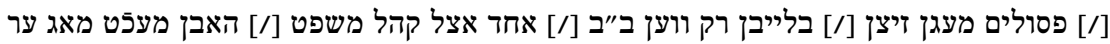

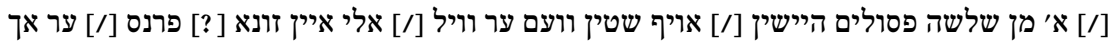
היישן אויף [/] שטין

18 Danach $ה$ als Zeilenfüller. 
מאגין אלי זיצין בלייבין עכ״פ הפרנס החדש מאותן פסולין זול ניט נדחה ווערן.19 ילאין

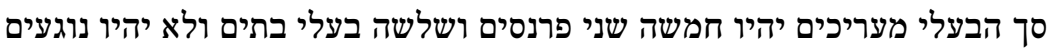
ל"ב

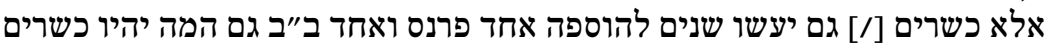
ולא נוגעים בשום קורים נום יעשה.

בעת בחירת בעלי מעריכים ויסתיועא מילתא דז מן רובן זאל אום איין פרנם מחויב $x^{\prime \prime}$

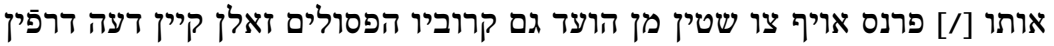

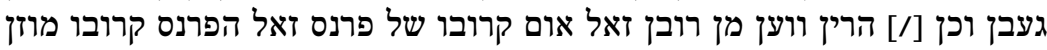
אויף שטין. - מכלן

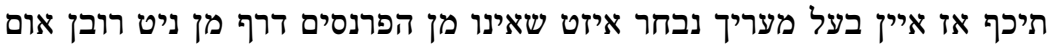
$7^{\prime \prime}$ 10

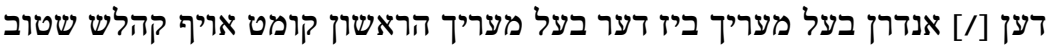

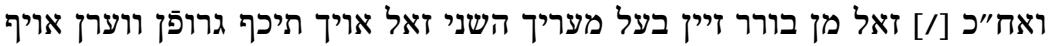

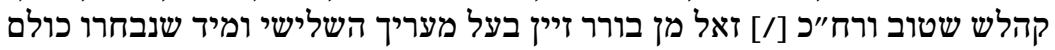

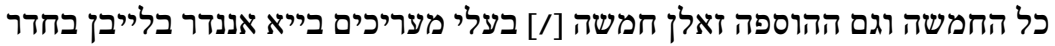

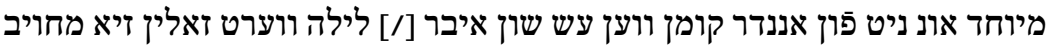

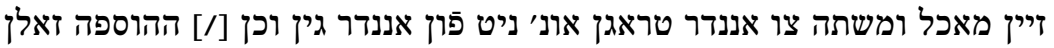

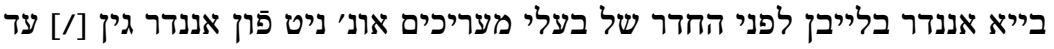

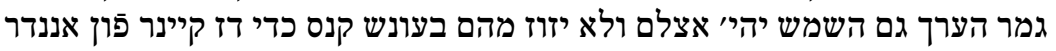

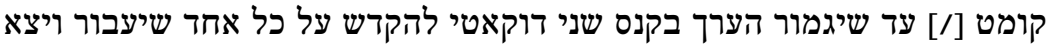
בלי הנחה.

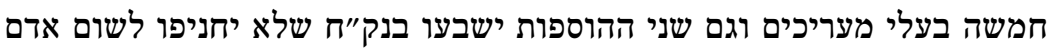
ל

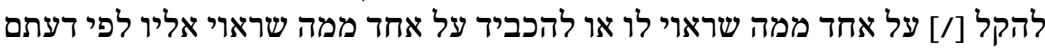
באמת ויושר בלי [/] אהבה אחמה וחיבה והשבועה יהי' על קהלש שטוב.20

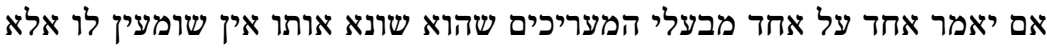
ל יקבל [/] בחרם עליו שהוא שונא שלו ואז יקום אותו בעל מעריך מעיך ולא ישב עליו.

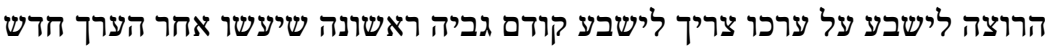
[fol. $2 \mathrm{v}$ ]

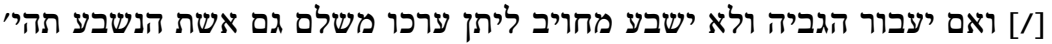

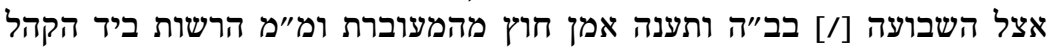
להשביע גם אותה אחר הלידה.

19 Danach gestrichen: וליתר [/] חיזוק עשינו פונקט זה זאל פאר גליגט ווערין אצל פרנסים ואייסר קהל ע"פ הרוב. Dieser Paragraph ist im Vergleich zu der Version von 1651 deutlich verändert; siehe dort $\$ 43$.

20 Die vier letzten Wörter in anderer, stark verblichener Tinte. 


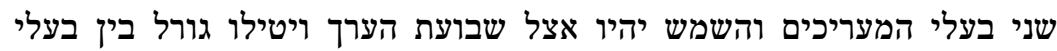

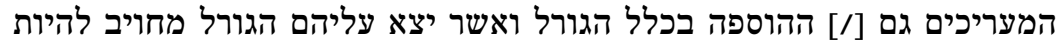

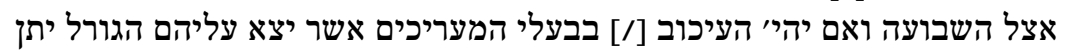
קנס כל אחד חצי טליר.

הרוצא להוסיף בשבועתו על ערכו יותר על מה שכתוב בפלנאנטש21 מיראת 5

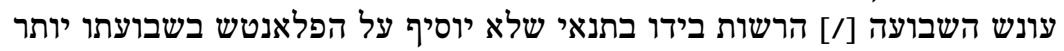

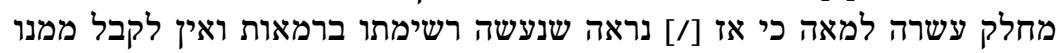

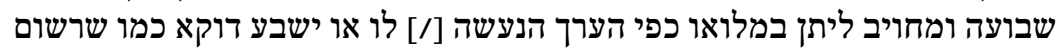

בפלאנטש שלו.

חובות וואש ער בעלי מעריכים פאר ליגט יתן מהם כמו מזומנים אם לא ער ליגט מואי

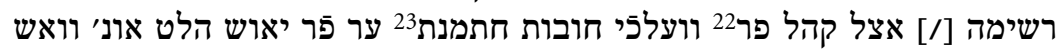

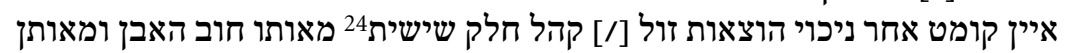

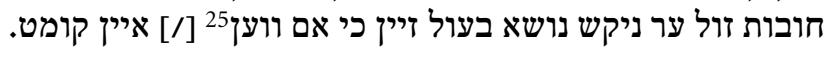

כלי בית כגון בעט ליילדיכר מפות שלחן ומפות הידים ציכן בדיל ונחשת מעסונג

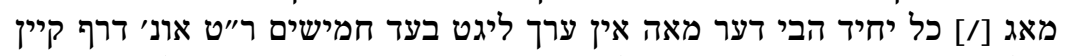

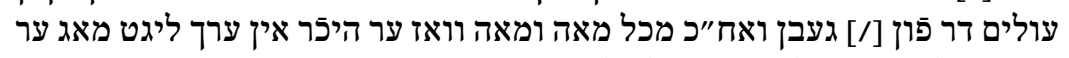

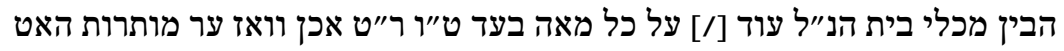

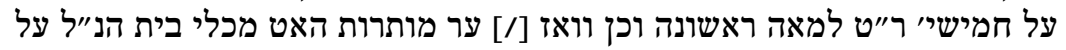

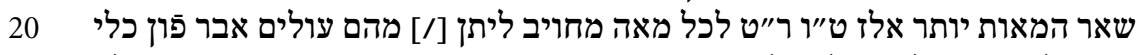

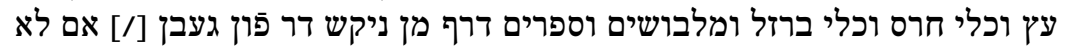

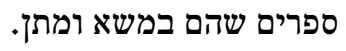

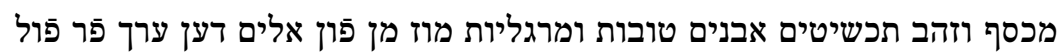
מ"ג געבן [/] אפילו מה שה וזכשיט מחובר במלבושים. לאותו [/] שנה ומהמותר מוז ער ערך טראגן.

21 Von planche (frz.) = Brett, Tafel; hier: Aufstellung.

22 Dieses Wort über der Zeile ergänzt.

23 Dieses Wort über der Zeile ergänzt.

24 Dieses Wort über der Zeile ergänzt, darunter gestrichen: רביעית.

25 Danach $x$ als Zeilenfüller. 


\section{מ"ה אפילו עני שבעניים לא יתן פחות מק"ן ר"ט לערכו.26 מ"ו}

מ"ז

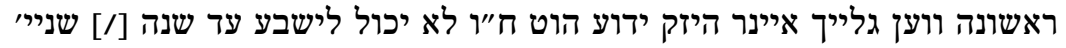
וישבע תוך ג' מעת לעת אז זיך אן גמעלט הוט.

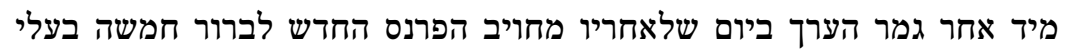
מו"ח

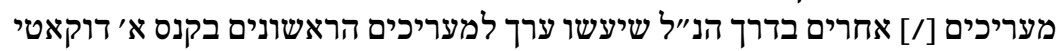

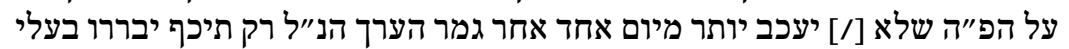

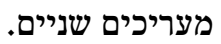

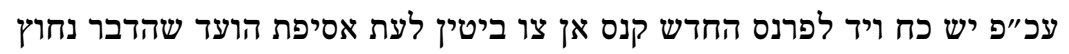
ט"ט] 10 וכן28 [fol. 3 re שלא יזוזו מן היעד כמו שירצה ולכוף על הקנס ההוא.

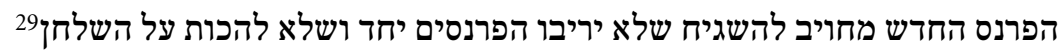
נו"ן

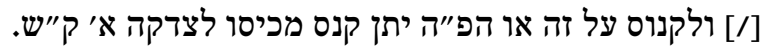

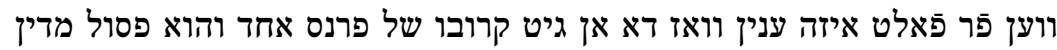
נ

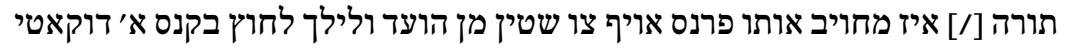

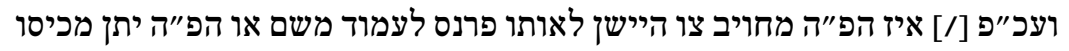

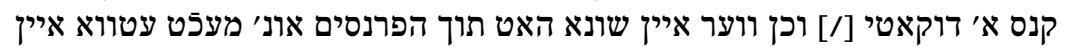

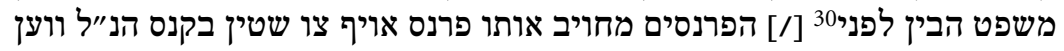

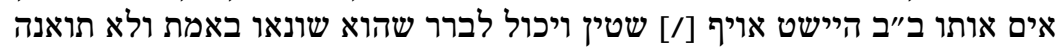

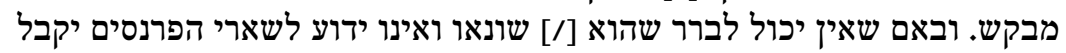

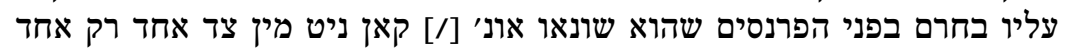
מהפרנסים פَר ווארפין אוני אין קהל זמאך קאן מאן

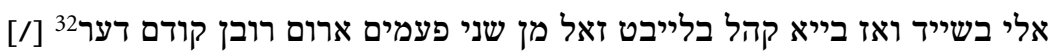

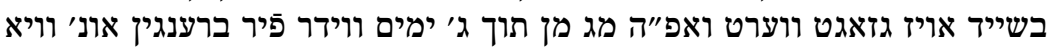

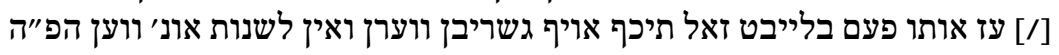

26 Hier wurde der Mindestbetrag für die Vermögensschätzung im Vergleich zu 1651 verdoppelt.

27 Danach eine große Lücke vor der Fortsetzung am Ende der Zeile.

28 Danach, kaum noch sichtbar, die Kustode שלא.

29 Danach 1 als Zeilenfüller.

30 Danach $\boldsymbol{i}$ als Zeilenfüller.

31 Danach $ל$ als Zeilenfüller.

32 Danach $ב$ als Zeilenfüller. 
ברענגט [/] אותו ענין ווידר פיר פעם שלישית קענן אפי' שנים מעכב זייין שלא

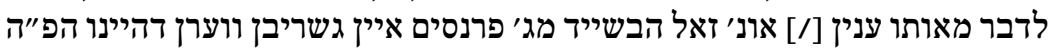

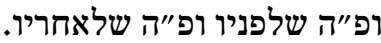

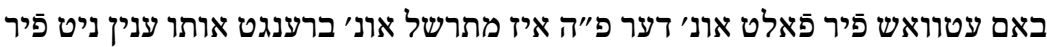
$x^{\prime \prime}$

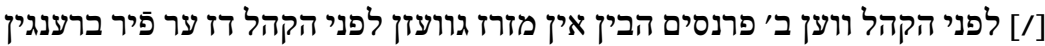

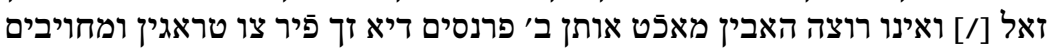
ע"פ דבריהם דרוף [/] צו רובן.

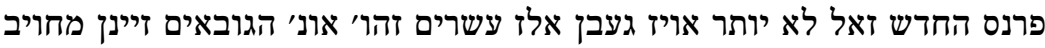

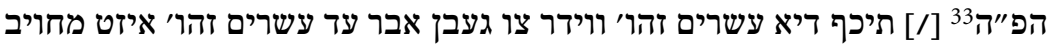

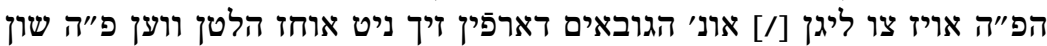

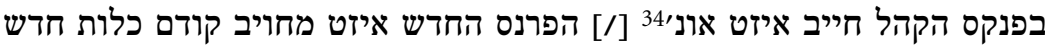
שלאחריו חשבון איין צו שרייבן בקנס על העובר [/] ג' ג' זהובים.

באם יחיד איזה סיבה צו קומט זול הפ"ה ועוד אחד פרנס בייא שטין להשתדלות

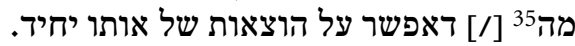

מחמת אייסר קהל יהיי באופן זה זאל קיין ב"ב צו אייסר קהל קומן אם לוּ לו מוז ג'

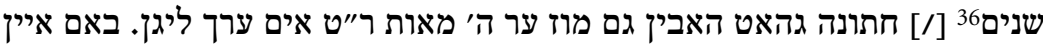

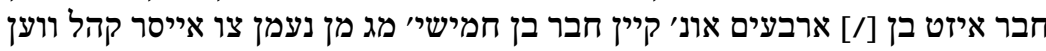

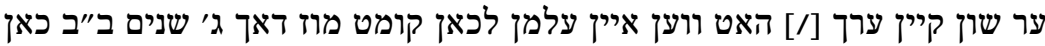

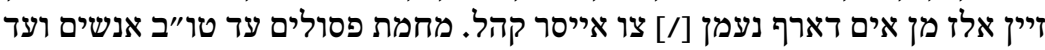

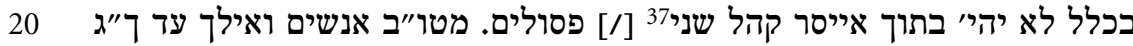

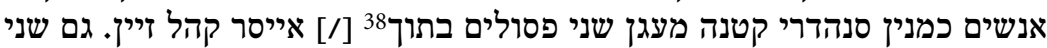

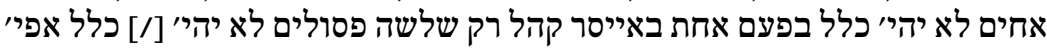

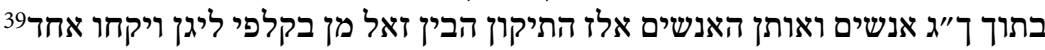

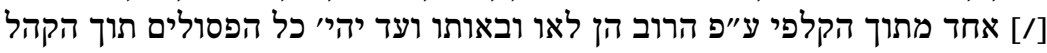

נחשבים לכשרים כל [/] אחד לדעה בפני עצמו הן מאן פוב פרנסי ובאותו ועך יהים או מאייסר קהל.40

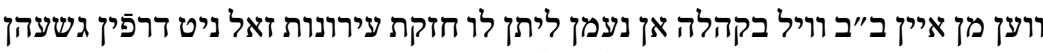

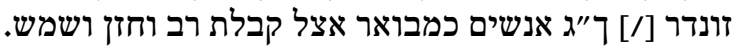

33 Danach ת als Zeilenfüller.

34 Danach $\boldsymbol{B}$ als Zeilenfüller.

35 Danach 7 als Zeilenfüller.

36 Danach $\pi$ als Zeilenfüller.

37 Danach פ als Zeilenfüller.

38 Danach $\boldsymbol{x}$ als Zeilenfüller.

39 Danach $x$ als Zeilenfüller.

40 Danach die Kustode ז"נ. 


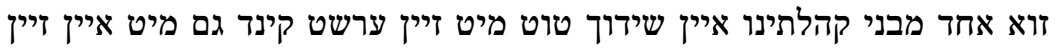

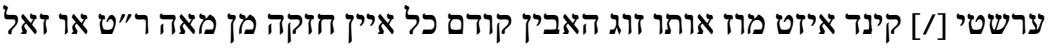

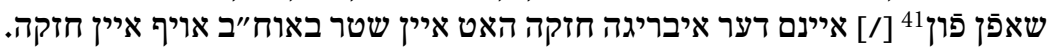

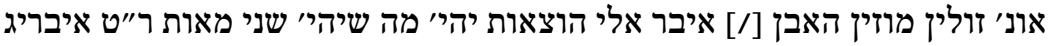

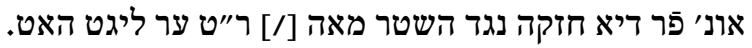

נ"

ווען איינר מפה זיך משדך איזט מיט זיין ערשט קינד מיט איין פרין פרעמדי דער חוץ

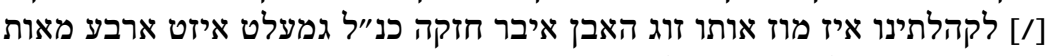

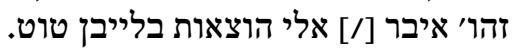

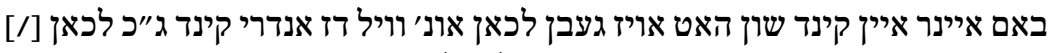

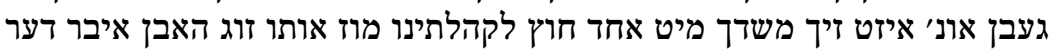

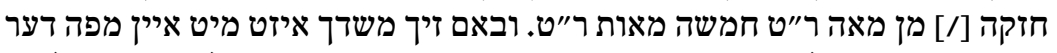

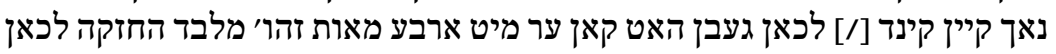

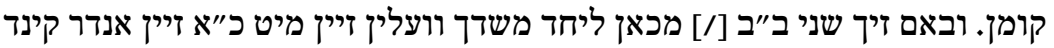

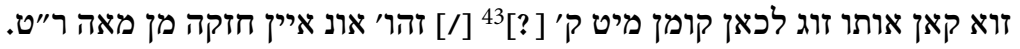

באם איינר מפה מיט דען אנדרן קינד שידוך טוט מיט אחוּ אוד דער חוץ חוץ לקהלתינו 15

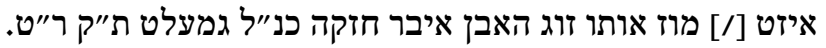

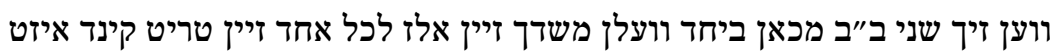

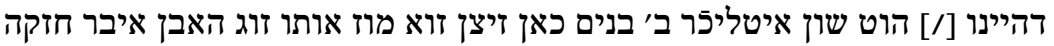
כנ"ל שמנה מאות ר"ט. שוּ.

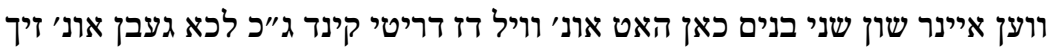
$x^{\prime \prime}$

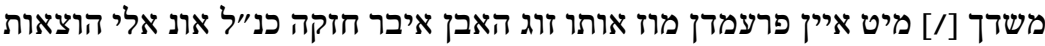

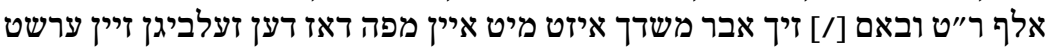

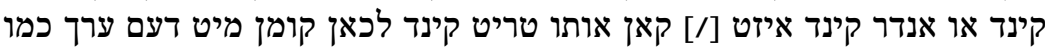

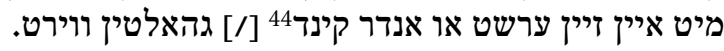

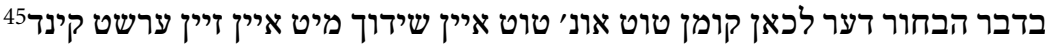

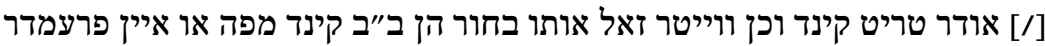

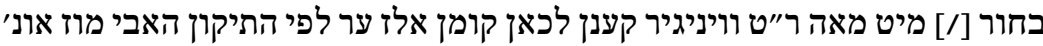

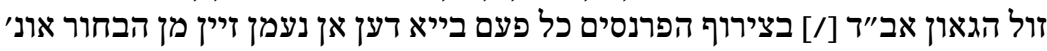

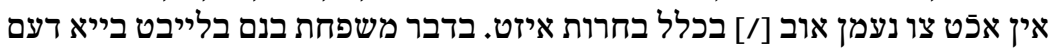

41 Danach $\boldsymbol{x}$ als Zeilenfüller.

42 Danach $ל$ als Zeilenfüller.

43 Beschädigte Stelle, Textverlust.

44 Danach $\lambda$ als Zeilenfüller.

45 Danach $\times$ als Zeilenfüller. 
אלטין תיקון כמאז ומקדם לגמרי [/] ניט בקהלתינו קומן צו לאזן וואו בנם איזט פסולי עדות מיט אותו הזוג.

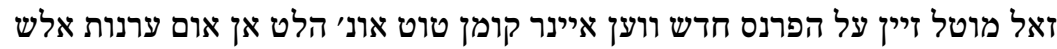

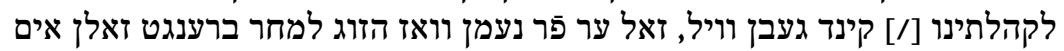

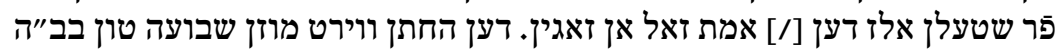

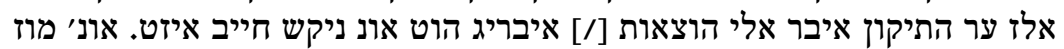
דיא שבועה גשעהן קודם סבלונות ווירט געבן.

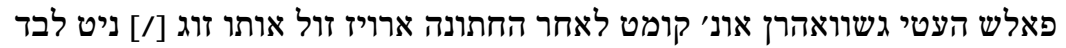

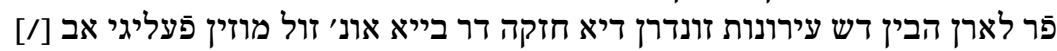

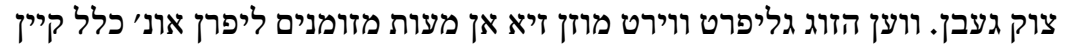

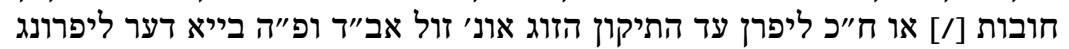

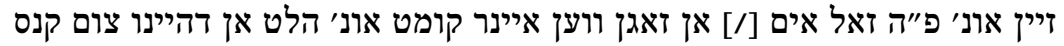

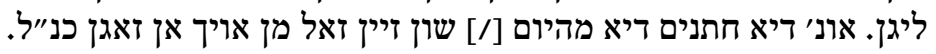

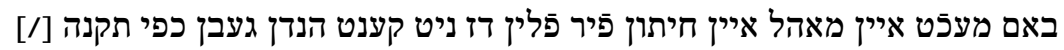

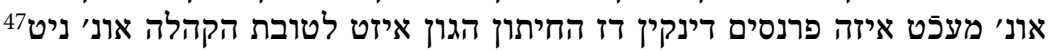

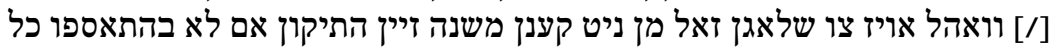

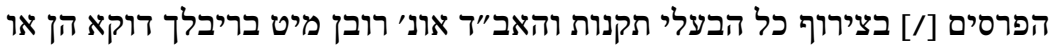

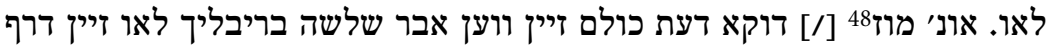

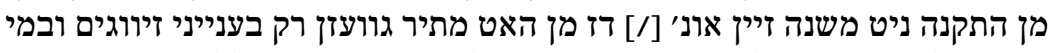

מחמת יתומים עניים דיא זיך בכאן וועלן בזעצין אונ' וועלין עירונות של אביהם

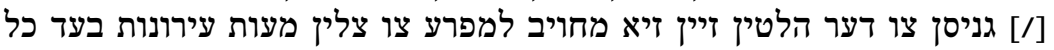

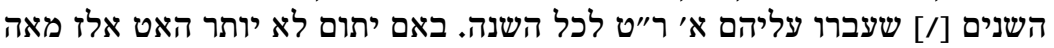

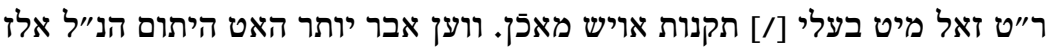

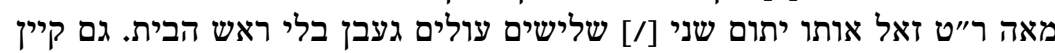

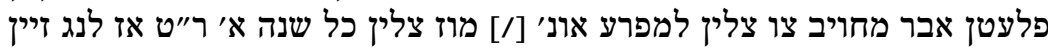
עירונות ניט אויף זאגין טוט צוט.

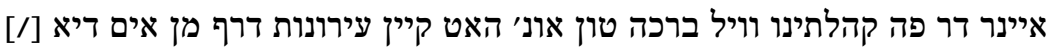
$\pi^{\prime \prime} 0$

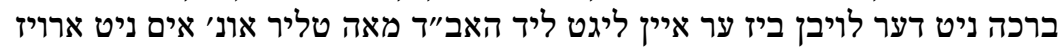

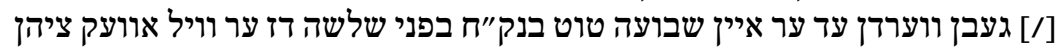

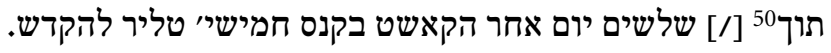

\footnotetext{
46 Danach die Kustode ובא.

47 Danach die Kustode 1.

48 Danach 7 als Zeilenfüller.

49 Danach $\lambda$ als Zeilenfüller.

50 Danach $\boldsymbol{w}$ als Zeilenfüller.
} 


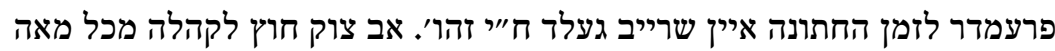
0

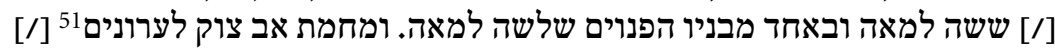

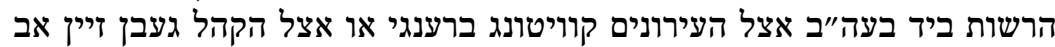
צוק.

כל מי שיעשה חופה מחויב האַמיר צו שטעלן או א׳ זהו' צו געבן לקנות אחד.

קיינים קיין חתונה ערלויבן אונ' זופליציאן צו מאכן אם לא מקדם כל חיוביובת שלו ע

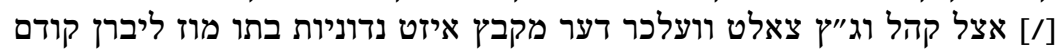

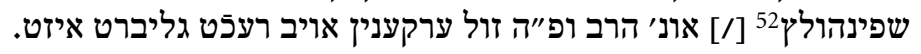

וועלכר דער ניט שפינהולץ מאכט בשבת שלפני החתונה זאל אותו השבועה [!] ע"ב ניט דער [/] לויבט ווערן ברכה צו מכין בשין.

ע"ג קיין חתונה זאל גמאכט ווערן ערב שבת אם לא איין ברייליפט.53 [fol. $4 \mathrm{v}$ ]

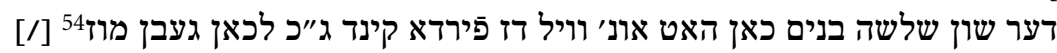
ע"

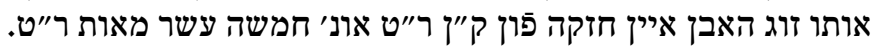

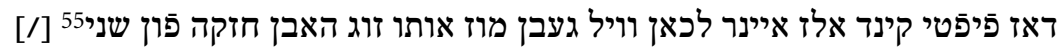
ע"ה 15

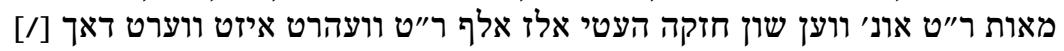

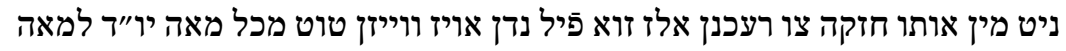
[/] אבר ניט אונדר הסך המעות וואז הבין מוז.

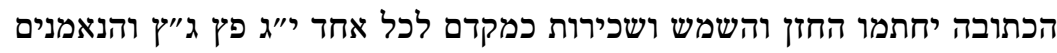
ע"ו

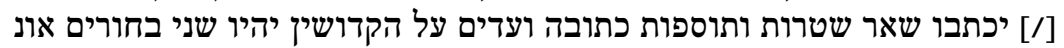
20

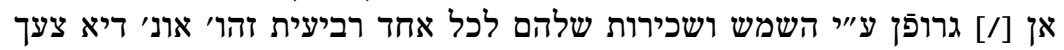

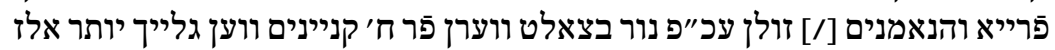

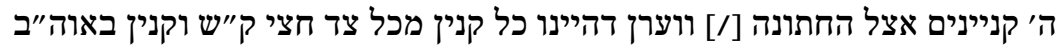

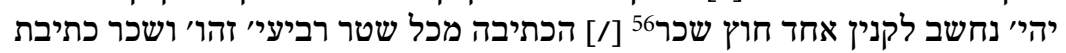
כתובה ישלם החתן חצי זהוב.

51 Danach הרונים Bals Zeilenfüller. Der Begriff ערe üblicherweise die christlichen Bürger, hier sogar den Stadtrat.

52 Feier der Verlobten kurz vor der Hochzeit.

53 Freiluft, d.h. eine Hochzeit im Freien. Danach die Kustode ע"ד.

54 Danach $\times$ als Zeilenfüller.

55 Danach מ als Zeilenfüller.

56 Danach $\mathrm{n}$ als Zeilenfüller. 


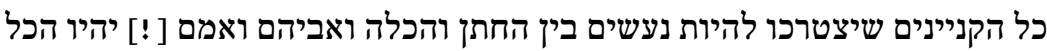

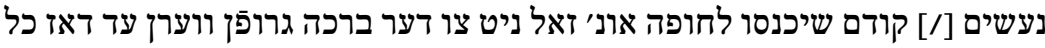

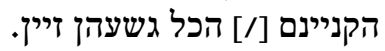

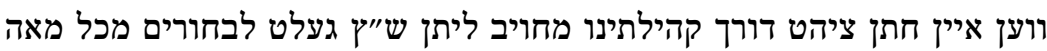
ע"

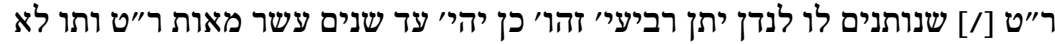

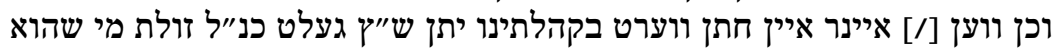
בחור ולומד בקהילה [/] פטור מליתן ש"ץ גיור געלט.

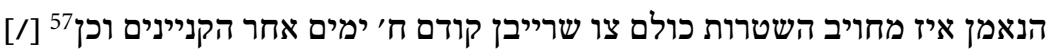

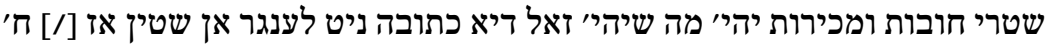

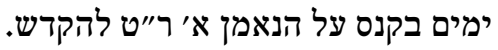

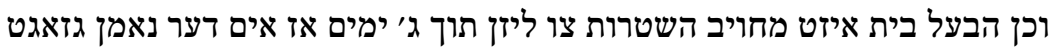

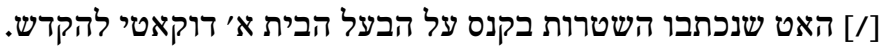

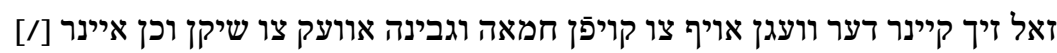

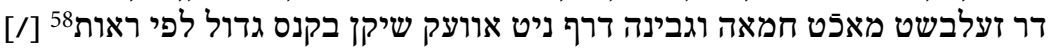

שני אנשים זאלן ממונה זיין על כל מאכל ומשקה בשר חלב וגבינה יין ושכר אונ'

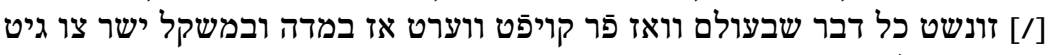

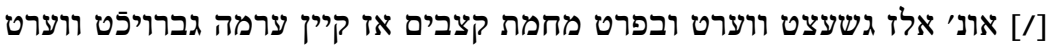
בענין ${ }^{59}[$ שלז שותפות.

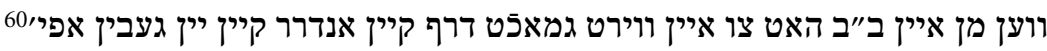
[fol. 5 r]

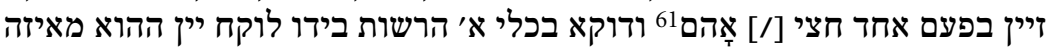

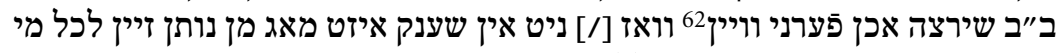
שירצה והחברות זיינן ניט איון כליל.

\footnotetext{
57 Danach $ש$ als Zeilenfüller.

58 Danach ע als Zeilenfüller.

59 Danach $ש$ als Zeilenfüller.

60 Danach die Kustode כששותים.

61 Hohlmaß, ca. 150 Liter.

62 Offenbar Importwein aus anderen Regionen.
} 


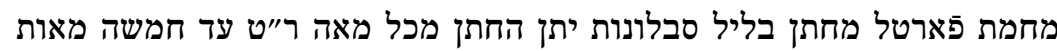
פ"ה

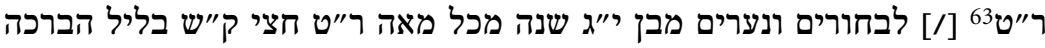

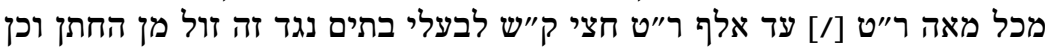

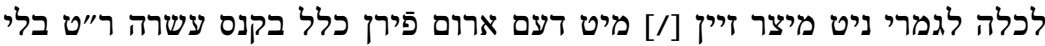

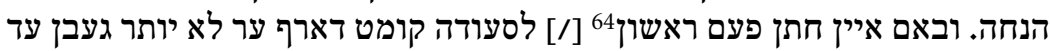

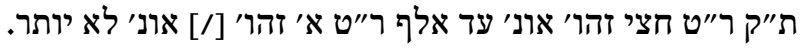

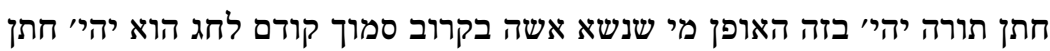

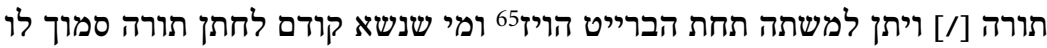

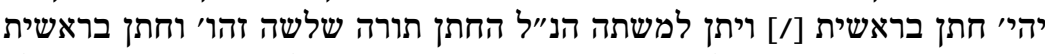

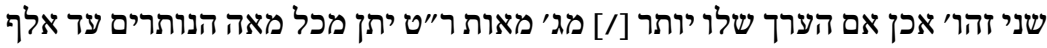

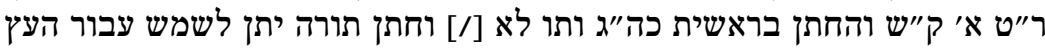

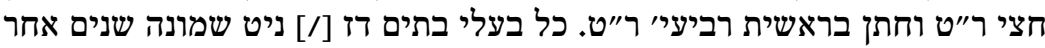

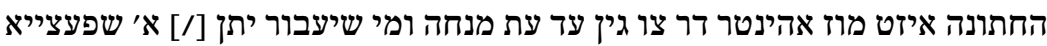

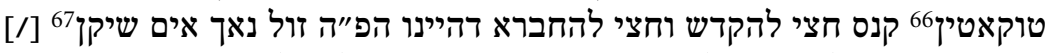

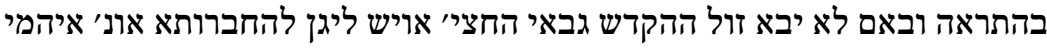

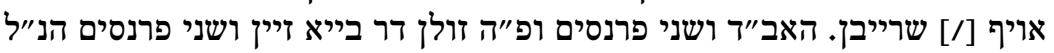

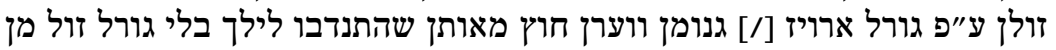

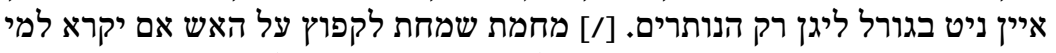

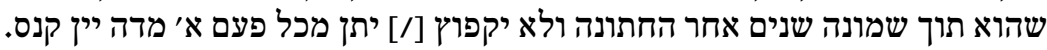

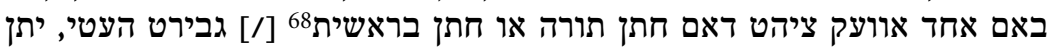

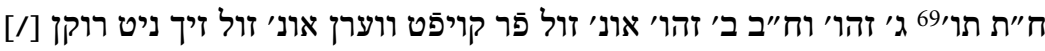

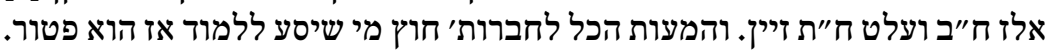

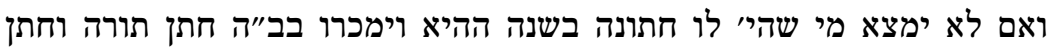

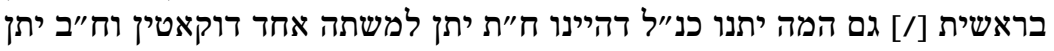

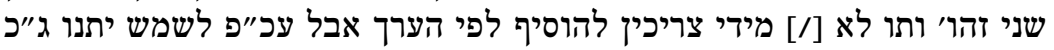

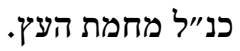

63 Danach ל als Zeilenfüller.

64 Danach $ל$ als Zeilenfüller.

65 Brauthaus? Ein Hausname, der dieser Angabe gleichen würde, ist aus dem 17. Jahrhundert nicht bekannt; siehe Fritz Reuter, Warmaisa. 1000 Jahre Juden in Worms, Worms 1984, $96 \mathrm{f}$.

66 Speziesdukaten. Ein Dukat entsprach im Allgemeinen drei Gulden. Der Zusatz „Spezies« deutet normalerweise auf eine wirklich ausgemünzte Währung hin, in Unterscheidung zu häufig angewandten reinen Rechnungseinheiten (z.B. Gulden).

67 Danach $ב$ als Zeilenfüller.

68 Danach $\lambda$ als Zeilenfüller.

69 תורה, jedoch ist die Abkürzung nicht als solche gekennzeichnet. Durch das vorherige חוst somit eine Doppelung entstanden. 


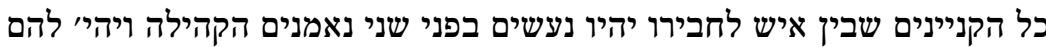
פ"ח

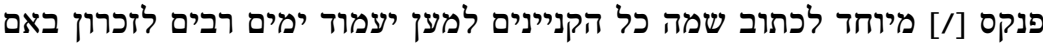

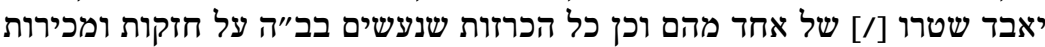

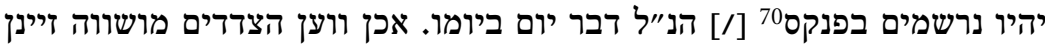

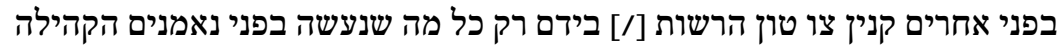

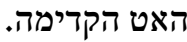

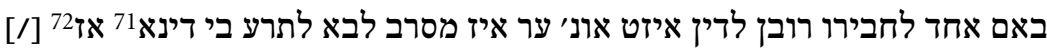
פ"ט

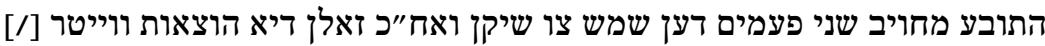

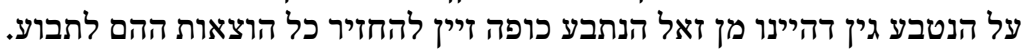

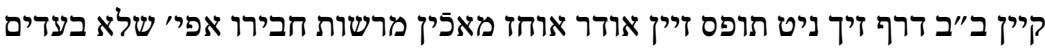

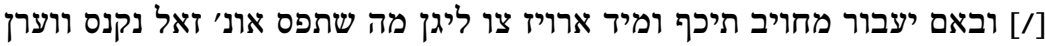

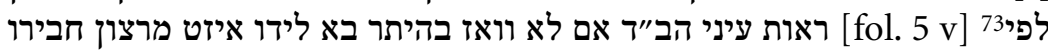
קאן ער תחת ידו ${ }^{74}$ [/] בהלטין על על התביעה שיש לו באותו אדם.

מחמת מעות יתומים ומעות הקדשות מעזבון יחידים זאל בכל שנה חשבון צ'צ

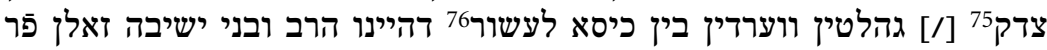

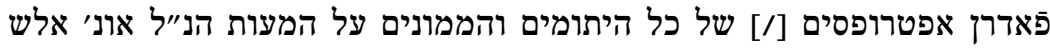

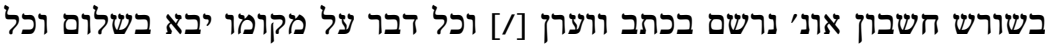

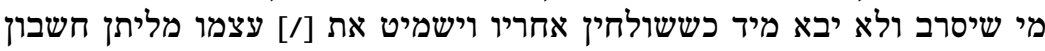

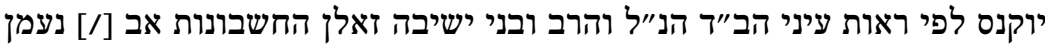

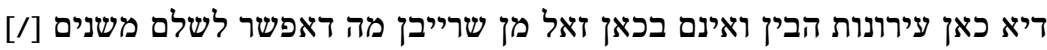

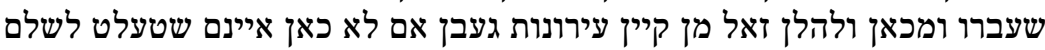

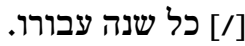

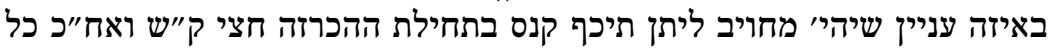
לילה [/] שיעבור עליו יתן א׳ פץ ואים יהי' שני חדשים בהת בהכרזה זילת זול מן אין אויז

70 Danach $ה$ als Zeilenfüller.

71 Jerusalemer Targum (Targum Yerushalmi, auch Targum Jonathan = aramäische Übersetzung des Pentateuch) zu Dtn 22,24. Die Bedeutung ist: »vor das Tor zum Gericht $«$.

72 Danach $ה$ als Zeilenfüller.

73 Danach die Kustode ראות.

74 Danach \& als Zeilenfüller.

75 Danach $\lambda$ als Zeilenfüller.

76 Die Tage zwischen Neujahr und dem Versöhnungstag. 


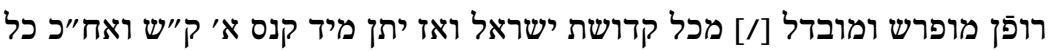

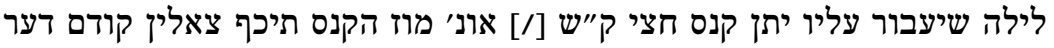

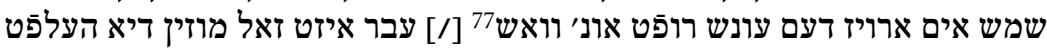

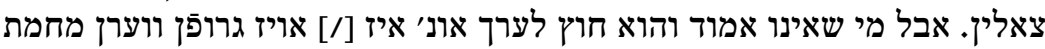

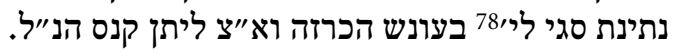

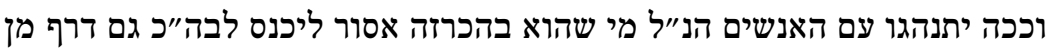
צ"צ

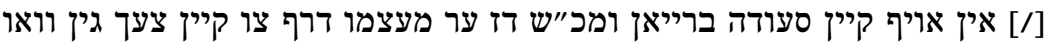
איין [9] [ין סעויף קיודה איזט.

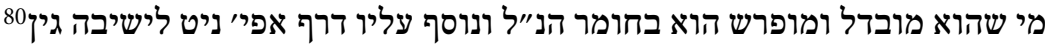

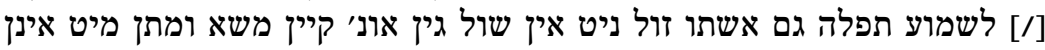

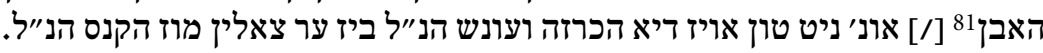

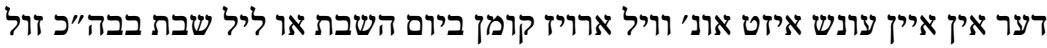

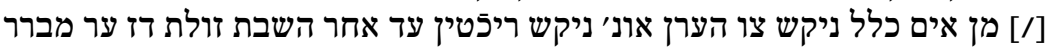

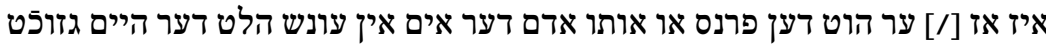
קודם שבת [/] אונ ער ניט בביתו גוועזן מאג מאן אים בשבת פَר נעמן.

זיין מבוררים גמאכט ווארדין זאלן אויז מאכן מחמת שטעט דהיינינו אין ג' חדשים

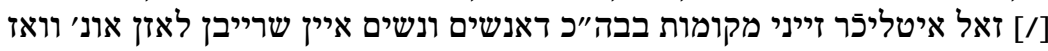

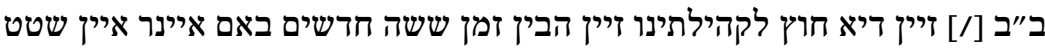

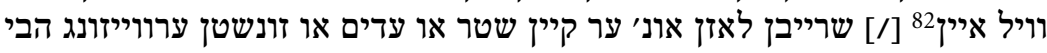
קאן זאל אותו מקום [/] בב"ה דז הקדש דר ווייל פריל פַר לעהנן.

צ"3 10

צ"צ

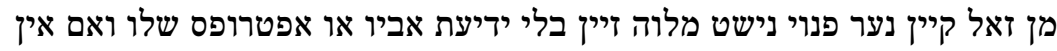

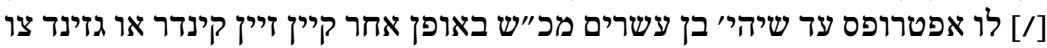

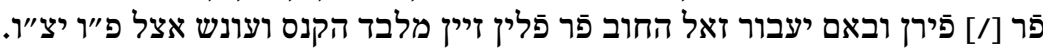

מלי שבירך זאל מן נור מאכין שני מי שבירך מאג כולל זיין מי שירצה חוץ מנשים צ

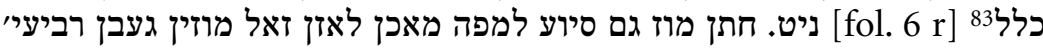

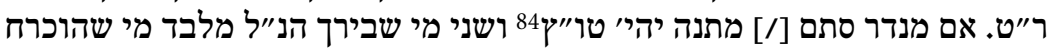

$\pi^{\prime \prime}$

77 Danach ע als Zeilenfüller.

78 סגי ליה (aram.) = es ist genug für ihn.

79 Danach o als Zeilenfüller.

80 Danach ל als Zeilenfüller.

81 Danach $\boldsymbol{\kappa}$ als Zeilenfüller.

82 Danach $ש$ als Zeilenfüller.

83 Danach die Kustode ניט שלמר.

84 ט"ו צעלמר. 
לנדר שעוה למאור ומלבד לחולה [/] אונ' אן שמחת תורה זיינן ח"ת וח"ב ניט אין דען כלל רק מאגין מאכ̄ין לאזין וויא פַיל זיא זיא וועלן.

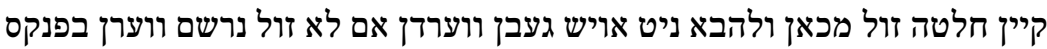

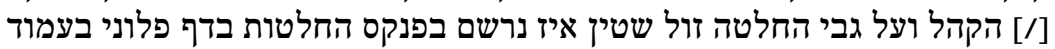

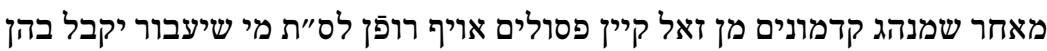
צדק [/] שנעשה לו בבלי דעת. ואם לא יקבל יתן קנס א׳ רייכשטלר.

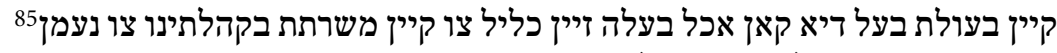
[/] אודר אויף צו הלטין יותר אלז ד' שבועות.

משרת או משרתת וואז ניט אצל בעה"ב שלו בלייבן וויל אודר הבעה"ב נייט הויט הלטין

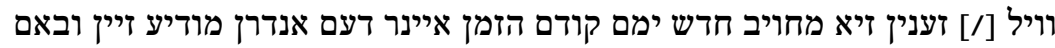

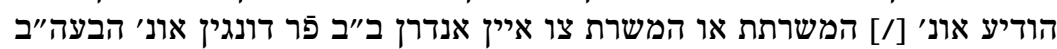

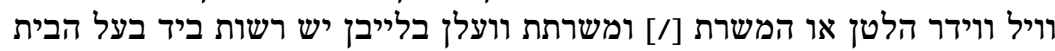

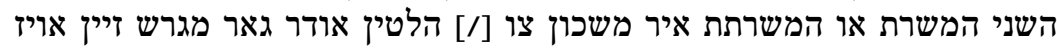

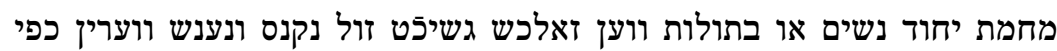
הנראה"86] לאב"ד ופ"ד ופ"ו יצ"ו בעונש גדול או ממונים על התיקון.

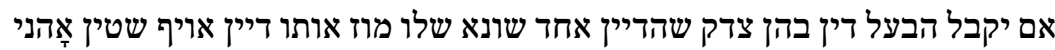

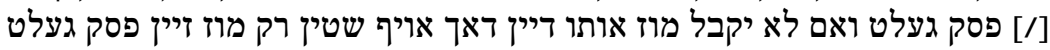

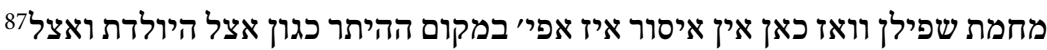

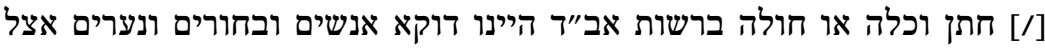

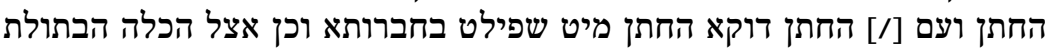

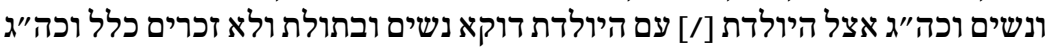

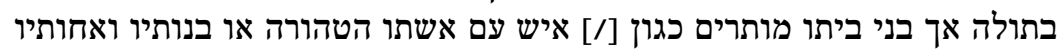

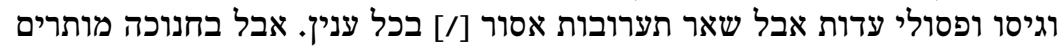
כולם צו שפילן ביחד אנשים אם נשים תים ובתולות ובאות. מחמת שדכנות שלש פרסאות מכאן צריכין ליתן כפל שדכנות.

\footnotetext{
85 Danach $\times$ als Zeilenfüller.

86 Danach ל als Zeilenfüller.

87 Danach $\pi$ als Zeilenfüller.
} 
זוא איינר חתונה טוט או בעה"ב מכאן אוועק ציהט מוז ער איין ערב שטעלן [יל [/]

מחמת זכרון עולמות כל מקום שאפשר אלז מן בצאלט קאן ווער מחרדין מוז מן צאלין. ק ק

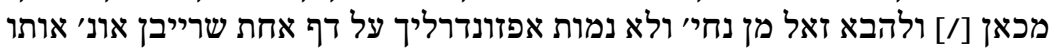

$$
\text { שנה [/] מזכיר זיין. }
$$

באם שני פרנסים זאגין מן זאל אייסר קהל נעמן בעסק יהיי מה שיהי' מוז מן נעמן

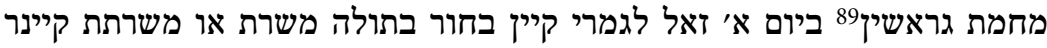

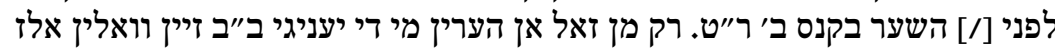

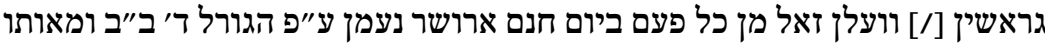

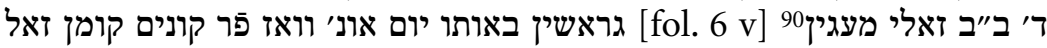
אונדר דיא ד' זיין צו הנדלן וכדי קיין

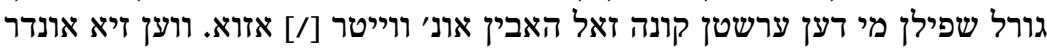

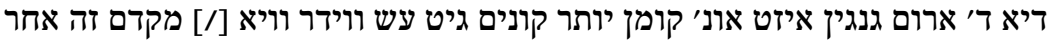

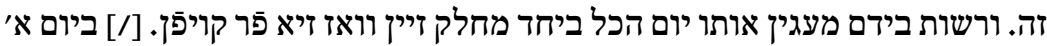

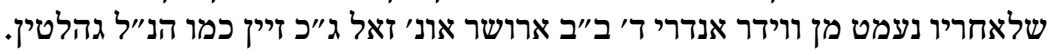
דיא ב"ב אלז דרויזי שטין צו גראשין זאלין ניט ווייטר דארפין גין אלין אלי ביז אן

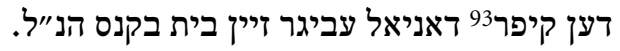

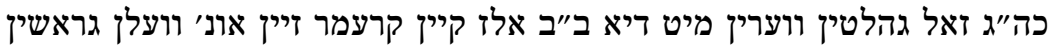

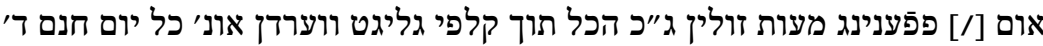

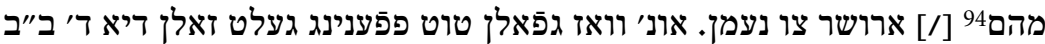

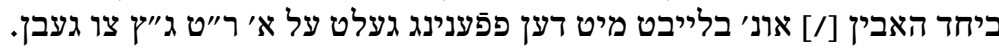

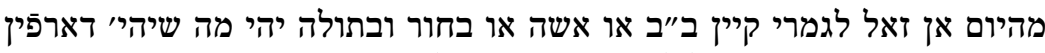
שטין [/] צו גראשין רק זאל לפני פתח בית בית בלי או אשה או בחור ובתיבו

\footnotetext{
88 Danach 7 als Zeilenfüller.

89 Ware ausrufen bzw. anpreisen.

90 Danach die Kustode גראשין.

91 Danach $\pi$ als Zeilenfüller.

92 Danach 7 als Zeilenfüller.

93 Küfer.

94 Danach $\aleph$ als Zeilenfüller.
} 


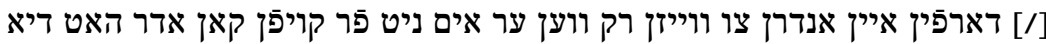

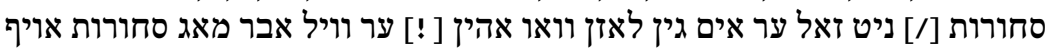

גזעצט נעמן. - (סחורות

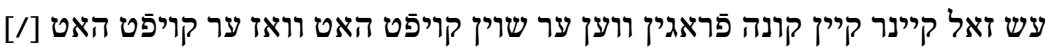
קט"ז

אונ' וויא יוקר ער דיא סחורות קויפט האט ער וועלט אייפטיפ פופיפ בזולר געבן האבי [/]

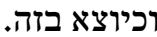

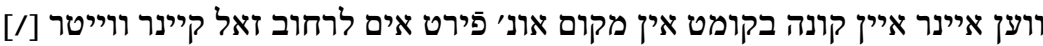

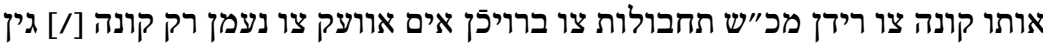

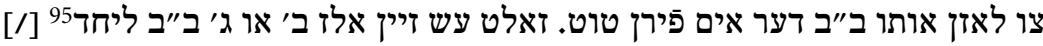

קומן מעכטי הן באושפיז בית'

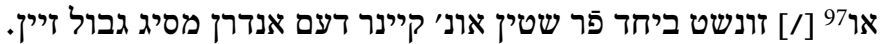

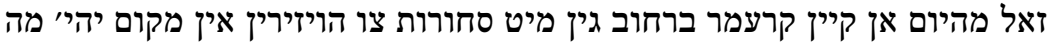

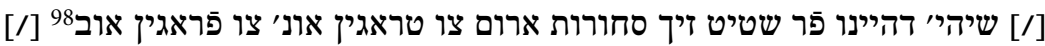

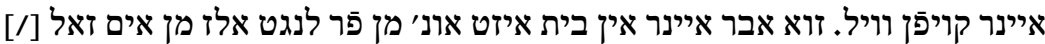

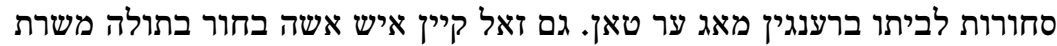

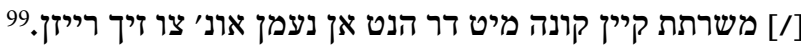

וועץ איין קונה נאך איין שואל איזט זאל ער אים ניט פָראגין וואש ער האבין [/] קי"ט

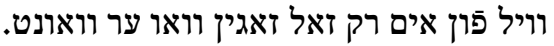

באם אחד כאן חתונה טוט אונ' א' שנה האט אצל אביו או חמיו מזונות זוא [/] עד

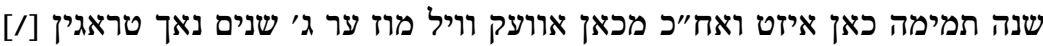

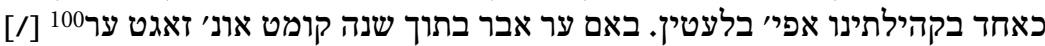

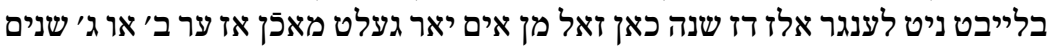

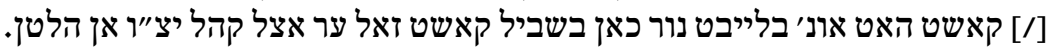

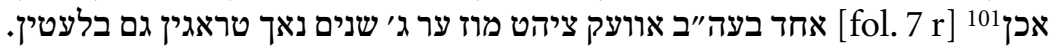

מחמת מלמדים מעגן ב' או ג'ב"ב ביחד הלטין בתנאי זה זאלין מו[ז]ין102 אך ביחד

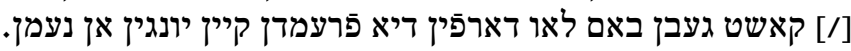

95 Danach $p$ als Zeilenfüller.

96 Herberge.

97 Danach ז als Zeilenfüller.

98 Danach $x$ als Zeilenfüller.

$99 \mathrm{Zu}$ sich ziehen.

100 Danach ב als Zeilenfüller.

101 Danach die Kustode אחד.

102 Textverlust durch schadhaftes Papier. 
אויב מאן מאג מנין מאכין אין בית דער היים איזט גבליבן כלל ניט צו מאכיט מאכן [/] קכ"ב

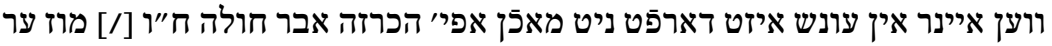

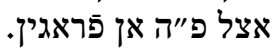

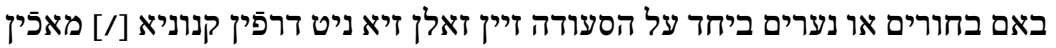

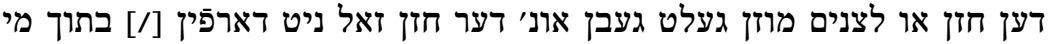
קכ"ג

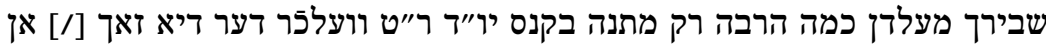
ברענגט זאל א' ר״יט הבין.

באם זאלטי אחד פרנס ניט כאן זיין אויב מן קאן דאך אצל קהל יצ"ו פָארט [/] מאכן

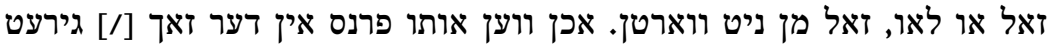

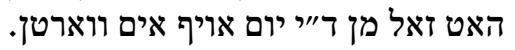

אב"ד זאל מן לא יותר אלז מאה ר״ט הספקה געבן.

קכ"ה חזן זאל לא יותר האבין אלז מאה ר״ט הספקה. קכ"ו אונטר חזן זאל לא יותר האבין אלז ע"ה ר״"ט הספקה. קכ"ז

וועץ ב"ב אחד פסק האט אונ' פ"ה איזט אים ניט מכריז אונ' קומט צו פ"ה דעי דער [/] קכ"ח

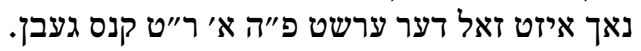

ווער אונטר ד' שנים האט חתונה גיהאט דארף ניט הקדש גבאי זיין. אונ' ווער [/] ניט ח' שנים הט חתונה גהאט דארף ניט האט חתונה גיהט רובה זיין. זאל קיינר קיין גובה ווערץ אם לא מוז פַאר הקדש גבאי זיין. ק"ל

וועץ איינר פרנס ווירט דער ניט הקדש גבאי איזט גוועזן מוז ער פَר דז הקדש [/] קל"א גבאות מאה ר״ט צאלין.

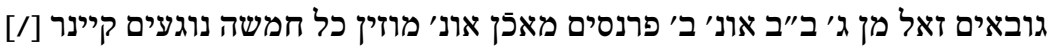
קל"ב

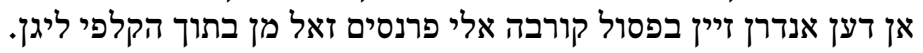
קל"ג גובאים זאל מן מיט טו"ב אנשים מאכין. קל"ד כלי קודש שלא מוקדש זאל מן ניט אן נעמן אין ב"ה.

25 קל"ה 2

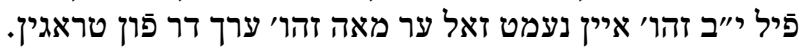


קל"ו איין ב"ב דער שישים אלט איזט זאל מן קורא לתורה זיין פור איין חבר דער נאך

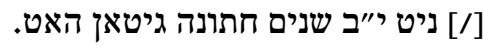

קל"ז

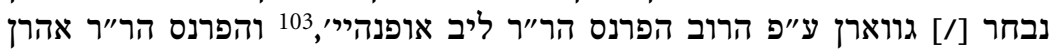

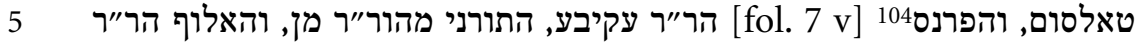

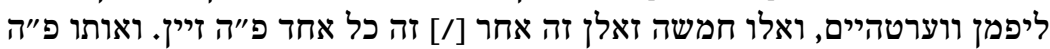

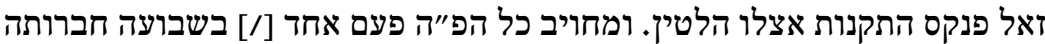

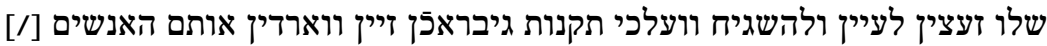

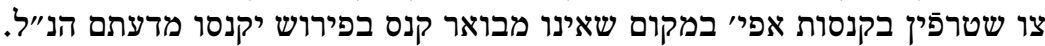

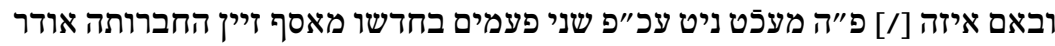

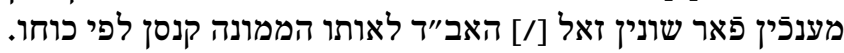

קל"ח באם אחד מן הפרנסים מעכט איין דעה זאגין בשום ענין שיהי' נגד התיקון לסתור

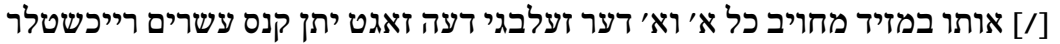

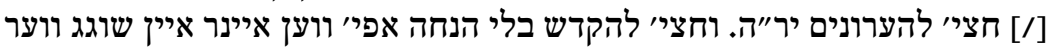

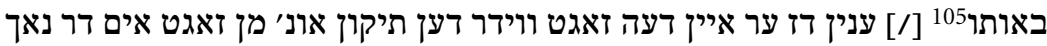

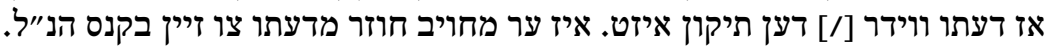

$$
\text { נונ' הקטן הטרוד יצחק ווירמיישאי106 ונאימלך עקיבא וורימשי }
$$

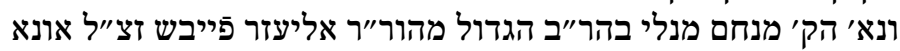

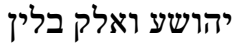

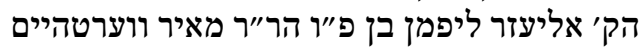

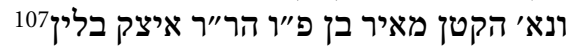

103 Die letzten drei Wörter gestrichen.

104 Danach die Kustode הר.

105 Danach ע als Zeilenfüller.

106 Die Unterschriften stammen von unterschiedlichen Händen.

107 Sein Vater, Itzik Ballin, war an der Revision der Statuten von 1655/56 beteiligt; siehe die Edition der ältesten Wormser Statuten von 1650 in diesem Band. 


\section{Statuten aus Halberstadt (1741)}

\section{Quelle: Statutentext, CAHJP, KGe3/8}

Bei den Statuten aus Halberstadt, einer der ältesten und bedeutendsten jüdischen Gemeinden des Königreiches Preußen, handelt es sich um einen der wenigen erhaltenen und bekannten Texte des Genres aus Großgemeinden dieses Territoriums. ${ }^{1}$ Aus den internen Quellen anderer bedeutender Gemeinden ist jedoch bekannt, dass auch diese Fixierungen ihrer innergemeindlichen Regeln vorgenommen hatten, die sich jedoch entweder nicht erhalten haben oder der Forschung bislang verborgen geblieben sind. Auch deswegen sind die takkanot aus Halberstadt, in denen der hohe Wert der jüdischen Tradition deutlich hervortritt, von großer Bedeutung.

Die Statuten sind in einem kleinen Heft mit mehreren Seiten Papier von mittlerer Qualität im Format $18 \times 21,5 \mathrm{~cm}$ erhalten und bilden einen Teil des Gemeindearchivs. Die Handschrift stellt offenbar eine unvollendete Abschrift der Statuten dar, vielleicht zum Zweck einer späteren Revision, worauf einige teils gestrichene Marginalien hinweisen. Der Charakter einer Abschrift wird aus dem plötzlichen Abbrechen im 14. Abschnitt (Regeln für Steuerschätzer) deutlich, der mit nur einem Paragraphen bei dieser stets kontroversen Thematik deutlich zu kurz bemessen wäre. Nach diesem Paragraphen ist im Heft jedoch noch weiterer Platz vorhanden, sodass hier nicht von einem späteren Verlust von Textteilen ausgegangen werden kann, sondern es sich vielmehr um eine unvollendete Version handeln muss. Zudem fehlen der Schlussteil und die Gültigkeit verschaffenden Unterschriften der Vorsteher bzw. der Statutenkommission. Dennoch sind die erhaltenen 14 Abschnitte auf zwölf Blättern mit insgesamt 138 Paragraphen so umfangreich, dass ihre Wiedergabe gerechtfertigt erscheint. Die Länge der einzelnen Abschnitte variiert stark. Am umfangreichsten sind die Passagen mit den allgemeinen Regeln der Gemeinde (27 Paragraphen), über die tovim (gewählten Gemeinderepräsentanten; 23 Paragraphen) und über die Synagoge (19 Paragraphen). Hin-

1 Ein weiteres Beispiel ist das aus Glogau von 1715, das von Markus Brann vor längerer Zeit publiziert wurde: Marcus Brann, Geschichte der Juden in Schlesien VI, in: Jahres-Bericht des jüdisch-theologischen Seminars Fraenckel'scher Stiftung, für das Jahr 1916, 241-249, Textwiedergabe in der Originalversion dort im Anhang, LXXXIII-XC. 
gegen sind die Kleiderordnung, die Regeln über den gabbai der Erez-IsraelKasse und über die Talmud-Tora-Schule mit jeweils nur drei Paragraphen recht kurz. Teils durch die schlechte Qualität des Papiers, teils durch die sehr kräftige Tinte ist das Lesen des Textes zuweilen kein einfaches Unterfangen, da Textteile von der Rückseite oft in derselben Intensität durch das Papier hindurch scheinen bzw. einzelne Buchstaben stark zerlaufen sind. Abgesehen von dieser Problematik sind die tatsächlich vorhandenen Texte ohne nennenswerte zusätzliche Schäden erhalten.

Die Statuten wurden nahezu vollständig auf Hebräisch verfasst. Nur in einigen Abschnitten, die dies thematisch nahe legen, erfolgte der Rückgriff auf jiddische Wörter oder Satzteile. Dies geschah vor allem in Abschnitten mit vorwiegend profanem Inhalt, wie etwa den allgemeinen Regeln für das innergemeindliche Leben (hanhagot ha-kehilla), der kurzen Kleiderordnung und den Anweisungen für das Betreiben des hekdesh. In diesen Passagen gibt es eine Reihe von Begriffen, für die das damalige Hebräisch noch keine Lösungen anbot.

Obwohl die Handschrift keine abschließende Klausel enthält, die Aufschluss über die Identität des Schreibers geben würde, existiert dennoch ein Hinweis auf ihn. Im Abschnitt über die Regeln des pleten gabbai wurde im Paragraph 8 eine Streichung mit dem Namen des Schreibers vermerkt. Dieser, Meir Cohen, könnte entweder die Vorlage geschrieben haben oder aber die ursprüngliche Ausfertigung, von der dann der Vermerk mit seinem Namen in die Abschrift gelangte. In jedem Fall ist die Schrift im Vermerk identisch mit der des Schreibers der hier edierten Vorlage.

Die Blätter des Hefts sind in der oberen linken Blattecke foliiert. Die Nummerierung der Paragraphen erfolgte in einer eigenwilligen Weise, die sonst bislang nur aus den Glogauer takkanot von 1715 bekannt sind. In jedem der einzelnen Abschnitte setzt die Nummerierung neu ein, sodass die Gesamtzahl der Paragraphen nicht auf einen Blick ersichtlich ist. Auch wurden arabische Zahlen verwendet, was für diese Zeit nicht allgemein üblich war und bei den Statuten von Glogau so noch nicht erfolgte.

Die Halberstädter takkanot sind inhaltlich sehr klar gegliedert. Die Überschriften der 14 Abschnitte bezeichnen den jeweiligen Themenkreis der darin enthaltenen Paragraphen. Neben der anfangs behandelten Regeln für die Synagoge und den Gottesdienstbesuch folgen die Wahlordnung, die Regelung der Kompetenzen der sieben tovim, allgemeine Verhaltensregeln innerhalb der Gemeinde, eine kurze Kleiderordnung, die Festlegung der Kompetenzen und Aufgaben der Steuererheber, der gabba'im, der pleten-gabba'im sowie des gabbai für die Erez-Israel-Kasse. Daran schließen sich Bestimmungen über die Talmud-Tora-Schule in der Gemeinde an, Regeln für die ne'emanim, für das hekdesh, das hier in seiner angestrebten Ausstattung in Paragraph 6 
ausführlich beschrieben wird. Abschließend folgen noch ein Abschnitt über die Kassen-gabba'im und ein unvollendeter Abschnitt über die Aufgaben der Steuerschätzer. Insgesamt sind alle takkanot in gutem Hebräisch verfasst worden, das auch heutigen Lesern kein allzu großes Abstraktionsvermögen abfordert.

Bemerkenswert sind die Festlegungen über einen gabbai in den Zeiten der Leipziger Messe (Paragraph 3 des zweiten Abschnitts - Wahlordnung). Dessen Existenz verweist auf die hohe Bedeutung der Messe in Leipzig für die Halberstädter Juden, die an dieser offenbar regelmäßig teilnahmen. Auch Paragraph 11 der Regelungen über die towim thematisiert erneut die Messe in Leipzig, hier mit einer Bestimmung zu Kosten, die durch einen Messebesuch entstanden. Ein Hinweis auf die Vermarktung jüdischer Bücher und auf die Kontrolle, die die Vorsteher dabei ausübten, ist aus Paragraph 20 der Bestimmungen über die tovim zu entnehmen: Diesen zufolge sollte ein Autor, der sich in die Gemeinde käme, seine Bücher nicht durch Hausieren vertreiben, sondern zunächst dem Vorstand vorlegen, der dann (nach positiver Bewertung des Inhalts) vermögende Hausherren zum Kauf einladen würde. Ähnliche Bestimmungen sind auch aus anderen Gemeinden bekannt, gehörten aber keinesfalls zum Allgemeinbestand von Gemeindestatuten. 
ויהי נועם ד' אלקינו. מעשה ידינו תקנות קהלה נאה² וחסודה [/] לתורה ולתעודה. לפ"ק.

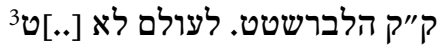

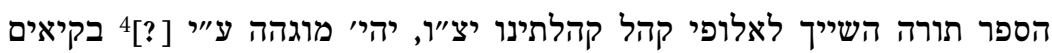

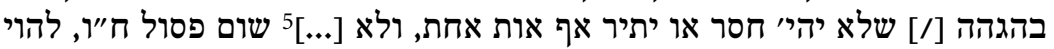

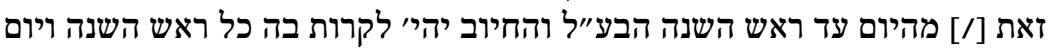

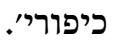

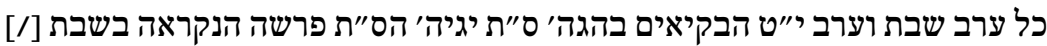

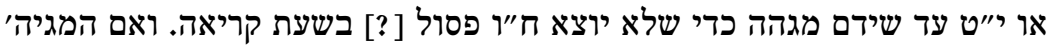

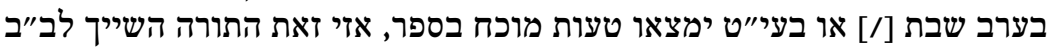

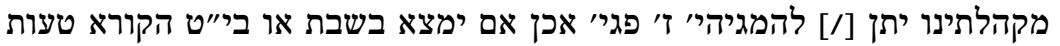
בס"ת, יתנו המגיהי'קנס [//] לצדקה שמנה פגיריי.

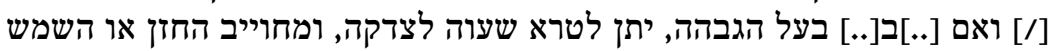
לאמר לבעל [/] הגבהה בקנס.

החיובי' בשבת אפילו כשחל י"ט בשבת יהיי כסדר הזה [...]. הבעלי היולדו',

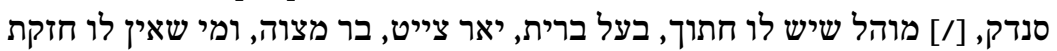

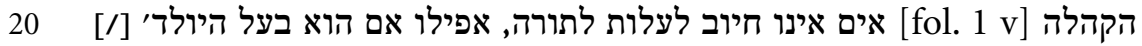

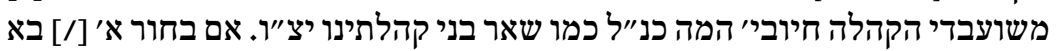

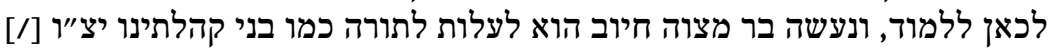

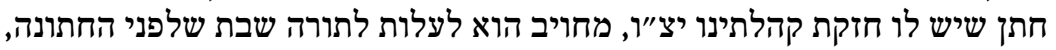

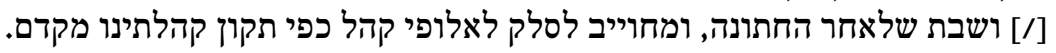

1 Der letzte Buchstabe ist mit einer über das Akronym nach rechts laufenden Mehrfachschleife kalligrafisch ausfiguriert. Das Akronym steht für: שויתי יהוה לנגדי תמיד (Ps 16,8) $=$ Der Herr ist immer vor meinen Augen.

2 Die größer dargestellten Buchstaben im Text markiert, ihr Buchstabenwert ergibt die Zahl 501, was dem christlichen Jahr 1740/41 entspricht.

3 Wort wegen durchscheinender Tinte unleserlich.

4 Stark zerlaufene Buchstaben, Lesung unsicher.

5 Textverlust durch beschädigtes Papier.

6 Blatt an dieser Stelle restauriert und nur schwer lesbar. 
פנוי לא יעלה לתורה בי"ט, והחתן יעלה לתורה כנ"ל בי"ט, חוץ במתנת יד7 ור״"ה

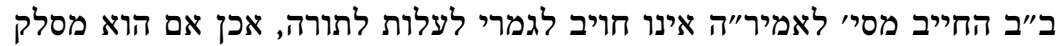

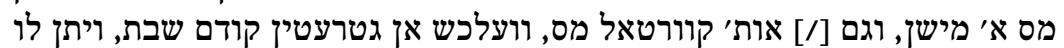

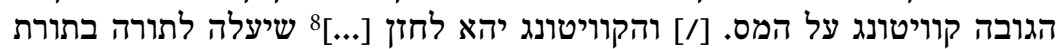

חיוב, ומי שערכו ד' מאות ר"ט, [/] ישלם לפחות שני משוני מסים [..]].

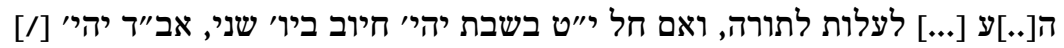

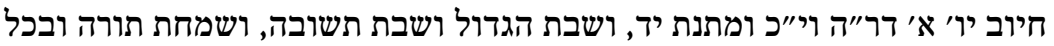
שבת [/] שמברכין החדש.

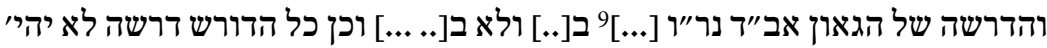

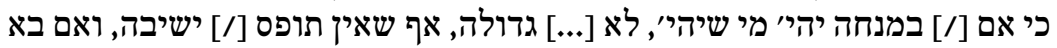

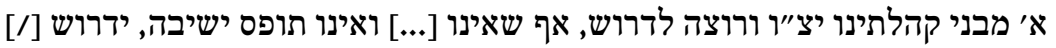
משום כבוד הקהלה.

מי שבירך אינו רשאי לשום א׳ לעשות [...] ולא מן האורחים ובעל סגן בכלל.

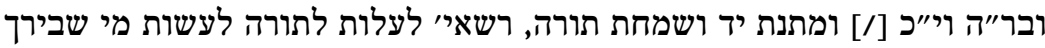

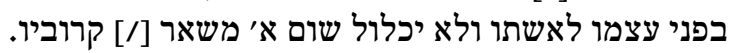

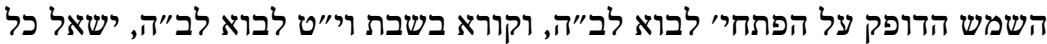

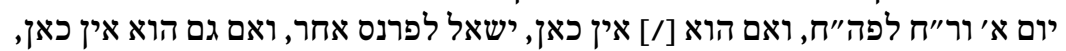

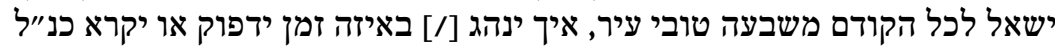

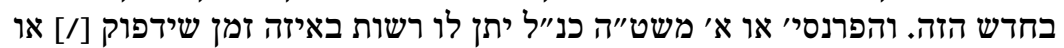

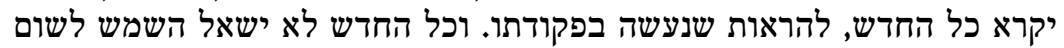

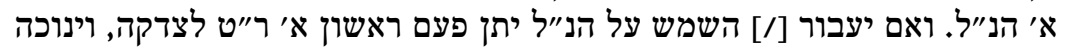

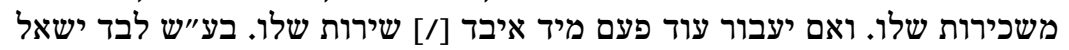
כל פעם להפ"ח באיזה זמן שירור שידפוק.

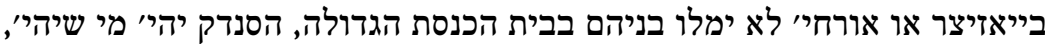

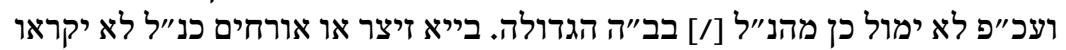
על סעודו' הברית ע"י שמש הקהלה, בקנס על השמש.

7 Spenden für Arme an den letzten Tagen der drei Wallfahrtsfeste Pessach, Wochenfest und Laubhüttenfest.

8 Nach Restaurierung ist diese Stelle unleserlich.

9 Gesamter Paragraph durch Restaurierung nur schwer lesbar, insgesamt unsicher. 


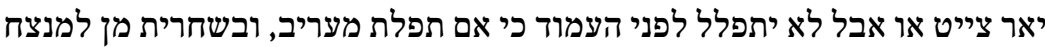
$12^{10}$

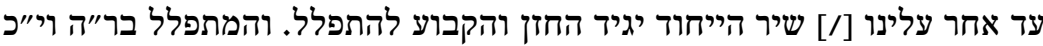
רשאי' להתפלל בשחרית ומננחה כמו חזן קבוע.

השכמה בשבת ובי"ט לא יהיי כי אם בבית הגאון אב"ד, וגם בב"ה. והמנונויים שם

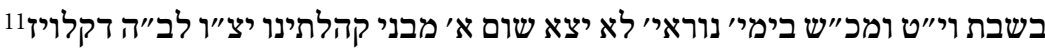

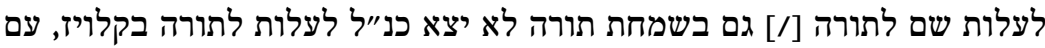

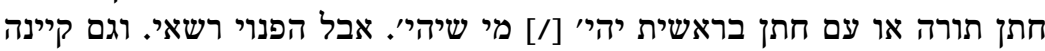
שבעה קרואים ופשיטא קיין מנין צו מאכין, אם לא [/] בביתו אבל בתוך השלשי,

לא ישבו וכן לא יעמדו שנים על מקום א' בעז"א הן המקום ההוא שייך לעצמו, או אם יושיב [/] עלי' בשכירו', חוץ בן אצל אביו עד שנעשה בר מצוה. אין שום אשה רשאי [ !] לגבות מנשים בעז"נ שום דבר מחדש, כי אם שביד' כתב

על האלמער, 12 ולא על הטרעפין, לא ישב ולא יעמוד שום אדם ופשיטא בחור ומר או נער או ילדי', כי [/] אם החזן ומשוררי' והשמשים.

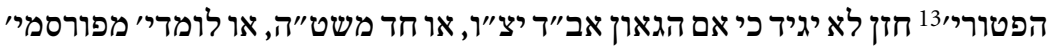

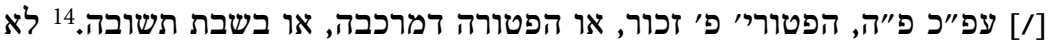
יגיד שום [/] פנוי, בקנס על השמשי פכור.

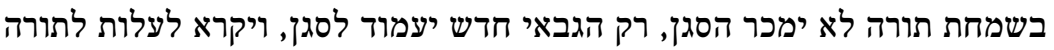

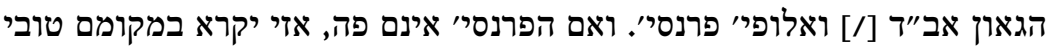
הקהל ועיקרי קהל.

10 Neben der Nummer in derselben Handschrift: [יון ב' או יום ה' [/] חזן דמתא או ר' [לוי משה לוי.

11 Gemeint ist die Klaussynagoge, die vom Halberstädter Hofjuden Berend Lehmann 1698 gestiftet wurde; siehe dazu Lucia Raspe, Individueller Ruhm und kollektiver Nutzen. Berend Lehmann als Mäzen, in: Rotraud Ries/J. Friedrich Battenberg (Hg.), Hofjuden - Ökonomie und Interkulturalität. Die jüdische Wirtschaftselite im 18. Jahrhundert, Hamburg 2002, 191-208, hier: 194-197.

12 Gemeint ist offenbar der Almemor, eine kanzelartige Erhebung mit Treppen, meist in der Synagogenmitte, auf der die zur Toralesung stattfand.

13 הפטרות?

14 Der Schabbat in den zehn Tagen zwischen Neujahr und dem Versöhnungstag. 


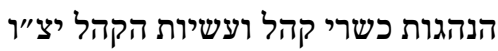

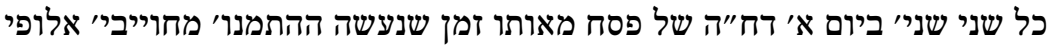

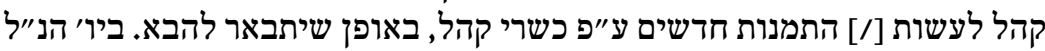

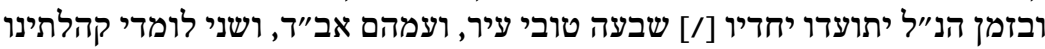

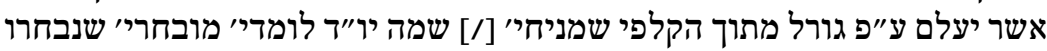

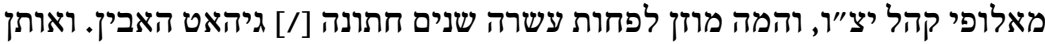

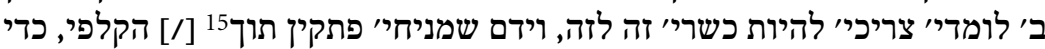

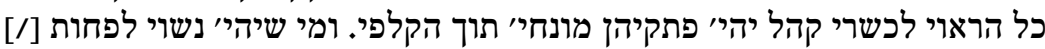

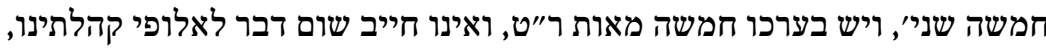

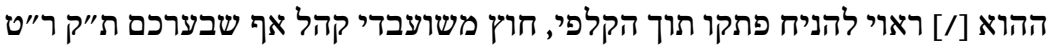
לא יהי' תוך המנויי' בקלפי.

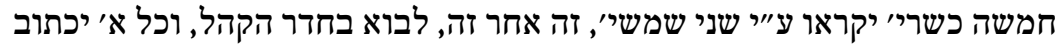
2

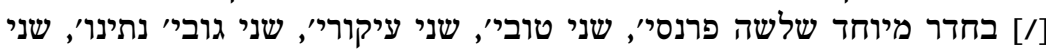

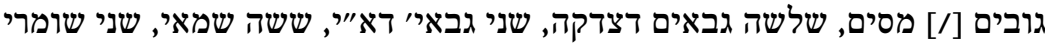

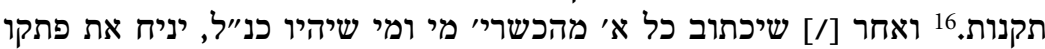

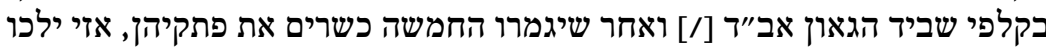

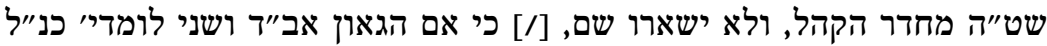

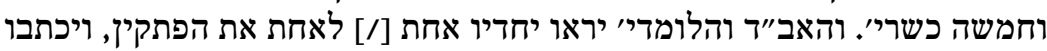

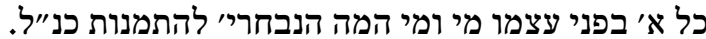

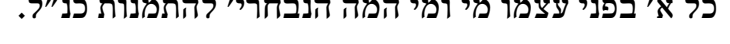

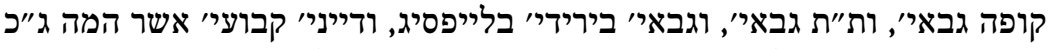

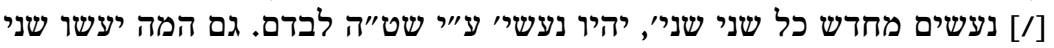

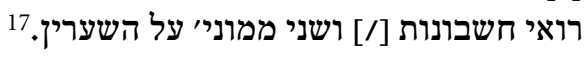

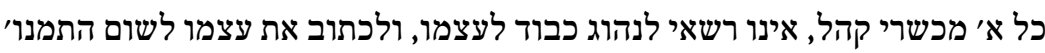

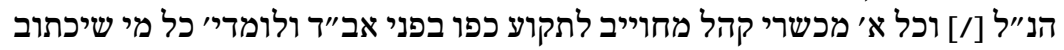

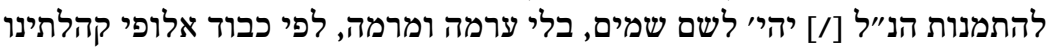

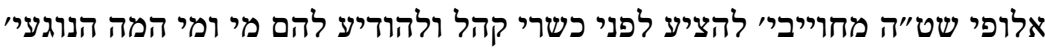

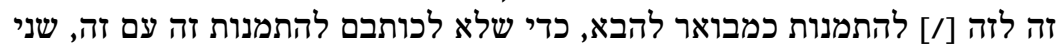

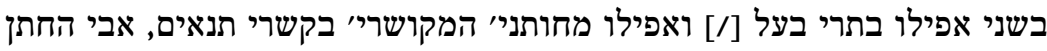

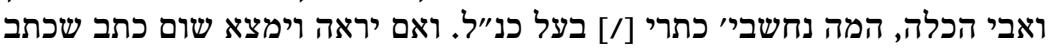

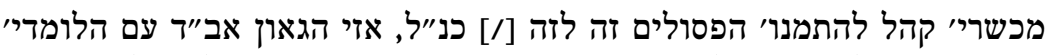

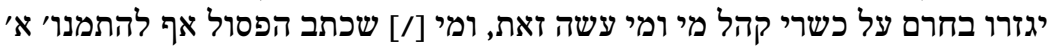

15 Danach $ה$ als Zeilenfüller.

16 Danach ein Doppelkreuz und am rechten Blattrand, gestrichen: ואחד אובר גובה, זוא משואיות משר אבר מן [...] משט"ה זיין מוז

17 Die letzten vier Wörter gestrichen. 


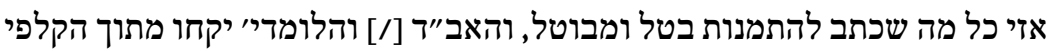

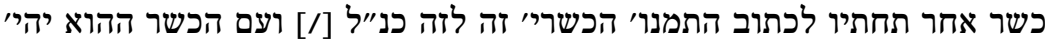

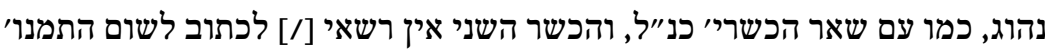
הכשר הראשון שכתב פסולים.

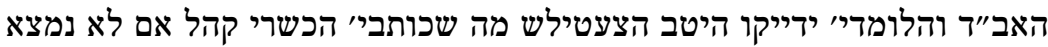

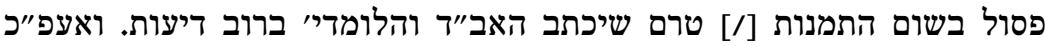

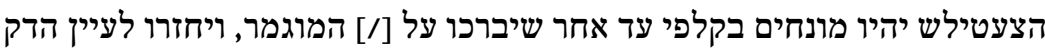
היטב אם ההתמניו' נעשים כראוי.

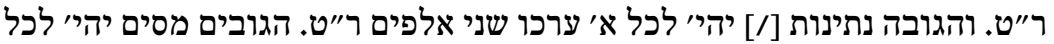

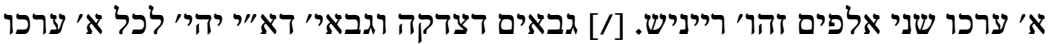

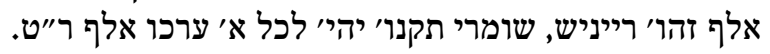

כשרי קהל לא יכתבו פרנסי' כי אם מי שהוא ט"ו שני' אחר נשואין שלו, טובי'

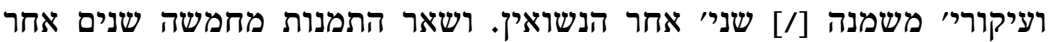

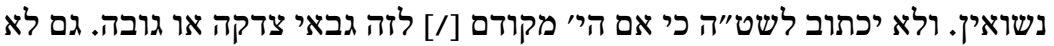

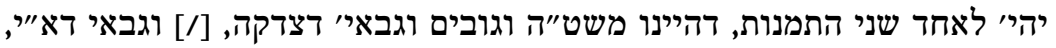
אבל שאר התמנות מותר.

שט"ה אף עיקורים בימים ההם ובזמן הזה לא יהיי נכתבי׳ תוך הקלפי לכשרי קהל, וכמו כן יהיי [/] הנהוג תמיד.

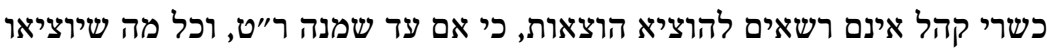

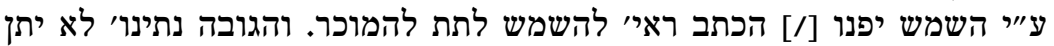

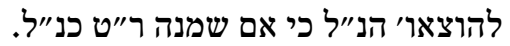

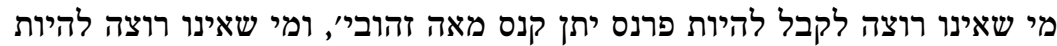

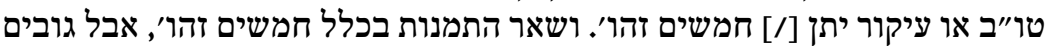

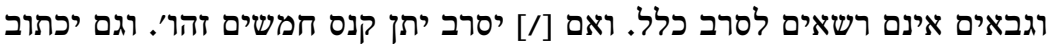

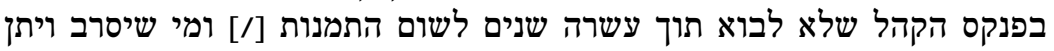
הקנס, אזי יעשו כשרי הקהל אחר במקומו.

הבעל פליטה שאינו משלם כל חובותיו ליחידים עד פ"א, לא יבוא לכשרי קהל ופשיטא [/] לשום התמנות.

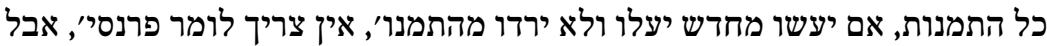

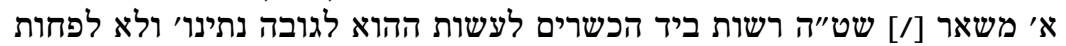


[fol. $4 \mathrm{r}$ ]

הנהגות שבעה טובי עיר

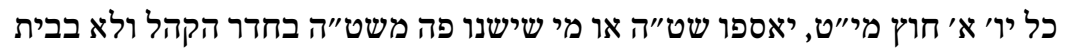

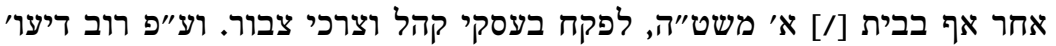

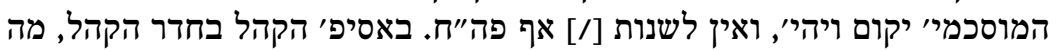

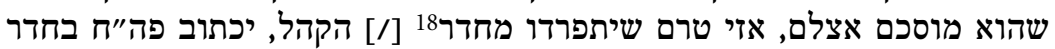

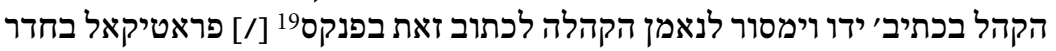

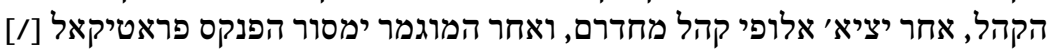

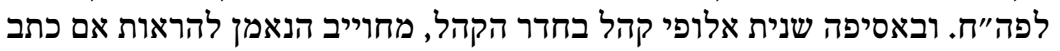

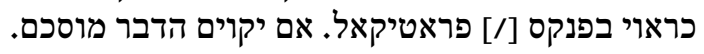

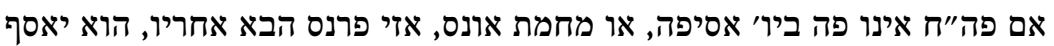

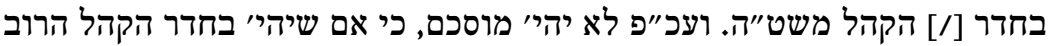

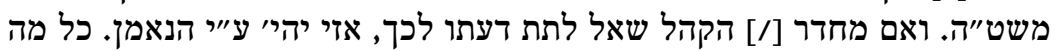
שלא יהי' מוסכם בחדר הקהל דוקא [/] בטל ומבת רומרל.

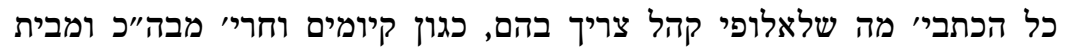

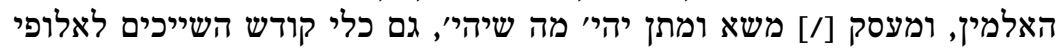

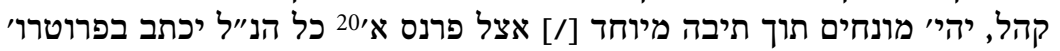

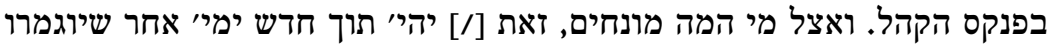

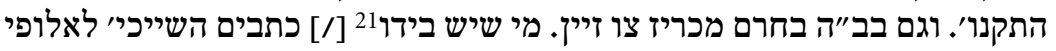

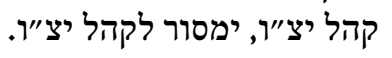

המשועבדיי יהיי מי שיהי' שיש להם שכירות מאלופי קהל קהלתינו יצ"ו, כמו

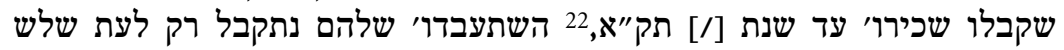

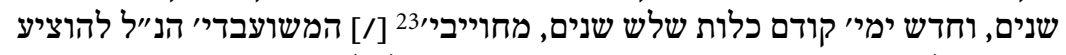
דבריהם לפני שט"ה, אם עדיין עומדים בקיומים מחומי או לסלקם.

המשועבדי' שמתקבלים מחדש יצטרפו שט"ה ט' אנשים כשרי' שיהי' לו נשואין [fol. $4 \mathrm{v}] 25$

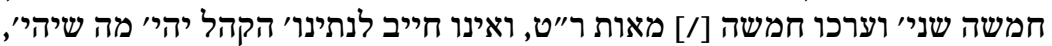

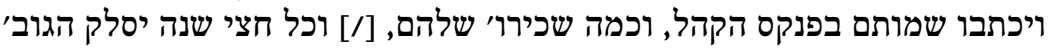

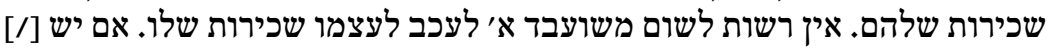

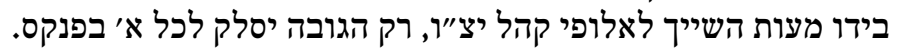

18 Danach $ה$ als Zeilenfüller.

19 Danach פ als Zeilenfüller.

20 Am rechten Blattrand Hinzufügung: או בחדר הקהל.

21 Danach $\supset$ als Zeilenfüller.

22 1740/41.

23 Danach $ה$ als Zeilenfüller. 
דבר שבממון מה שאינו נוגע לנתינו' הקהלה ומסים הקצובי', רק צריך להיון 6

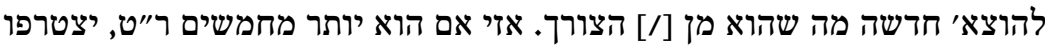

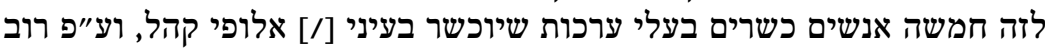

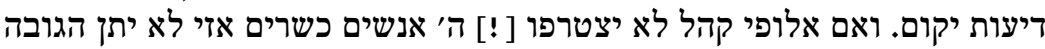

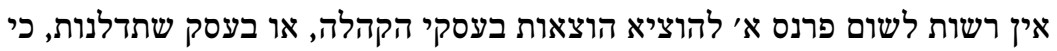

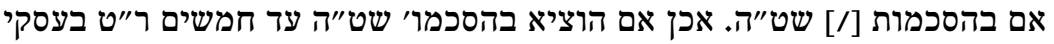

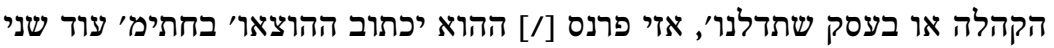

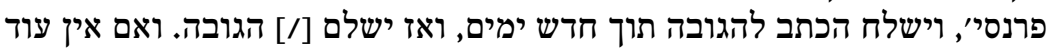

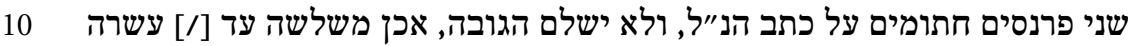

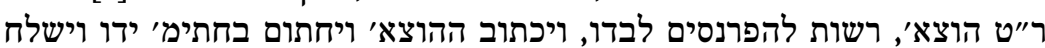

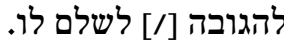

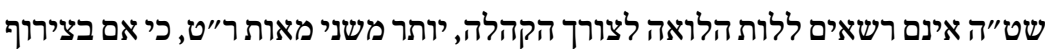

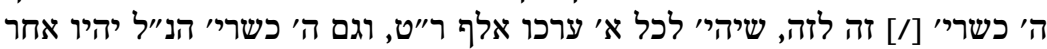

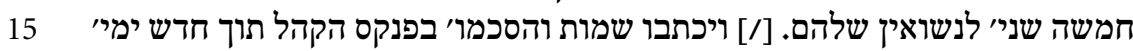

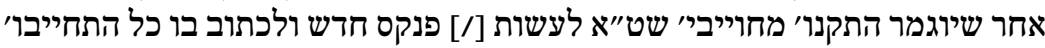

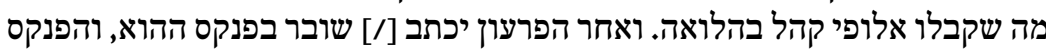

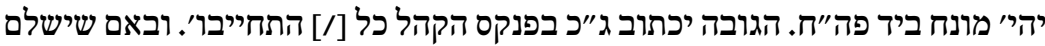

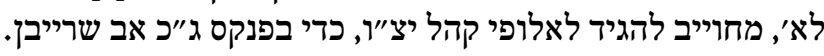

המתנות שנותנים אלופי קהל יצ"ו, בשנה חדשה שלהם להודיע׳ כנהוג, לא יתן

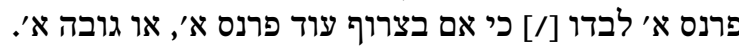

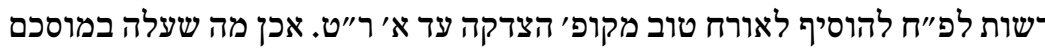
[fol. $5 \mathrm{r}$ ]

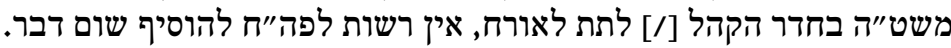

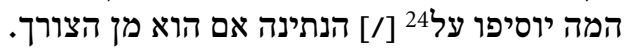

כל הפנקסאו' הישנים, הן מהגובי' או גבאי' ופנקסאו' מברזאן25 יהי' מונחים בחדר

מי שראוי לקנוס, אזי תוך שמונה ימי' יושת עליו הקנס, ולא יקחו מן האיש ההוא

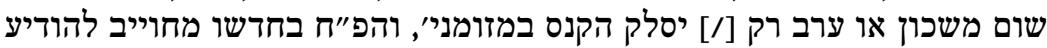

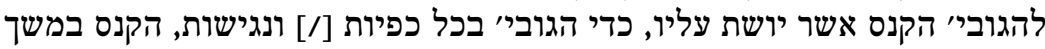

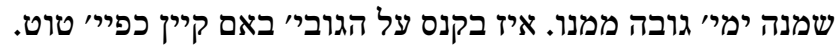

24 Danach $ה$ als Zeilenfüller.

25 Von Personen. 


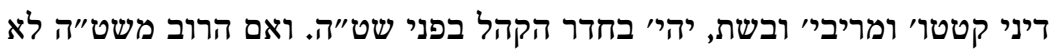

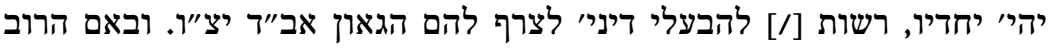

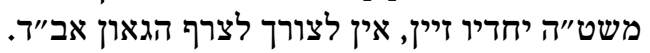

לא ינתן לשום א’ אטעסט על טרויא שיין,26 כי אם אלופי' שט"ה יודעים בבירור

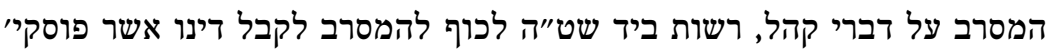

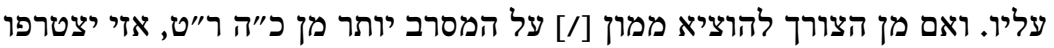

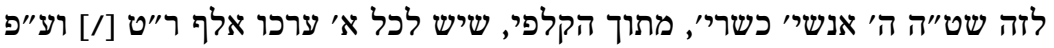

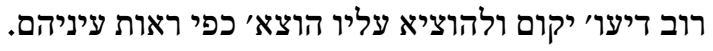

ביו' א' דסליחות יחלקו שט"ה התפלות ותקיעו' שופר, ובצום גדלי' יחלקו תפלות

הקצבה שפוסקיי שט"ה בחדר הקהל לעניי קהלתינו, יהיי בכל עת בחדש ניסיסן,

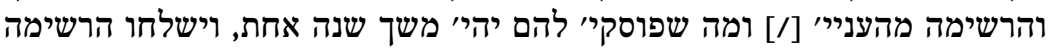

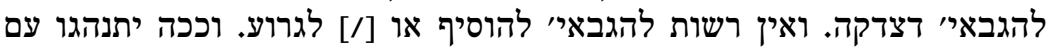

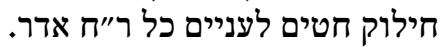

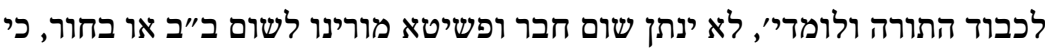
[fol. $5 \mathrm{v}$ ]

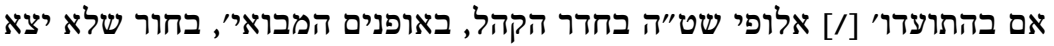

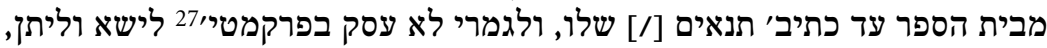

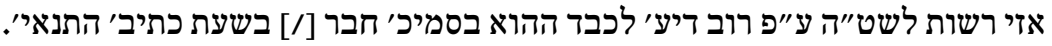

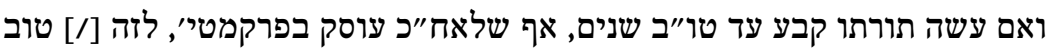

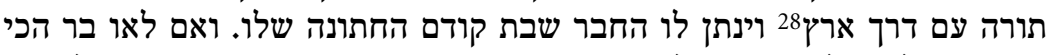

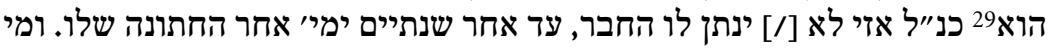

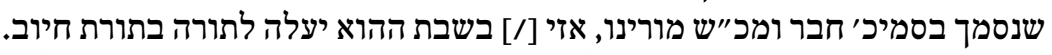

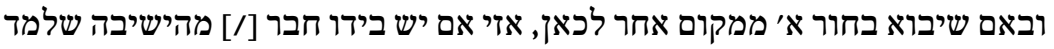

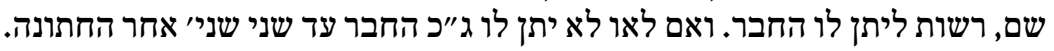

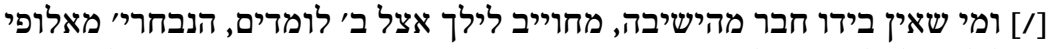

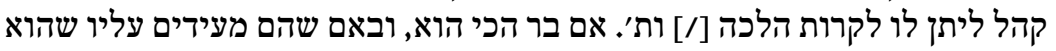
ראוי לכך אזי רשות להנתן לו החבר.

26 Bestätigung der beabsichtigten Aufnahme in die Gemeinde nach dessen Hochzeit, die bei den preußischen Behörden zum Zweck der Zulassung vorgelegt werden musste.

27 Handel.

28 Mischna Avot 2b.

29 Sota $26 a$. 


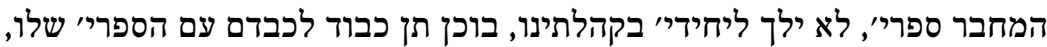
20

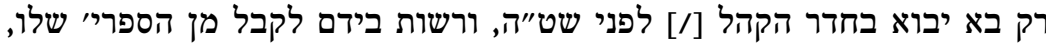
וישלחו ע"י השמש להב"ב שערכם לפח לפחות אלף ר"ה ורטת.

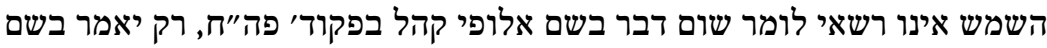

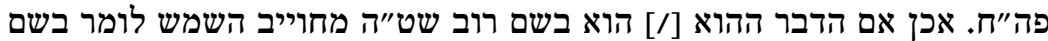

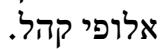

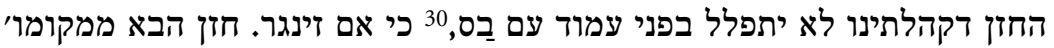

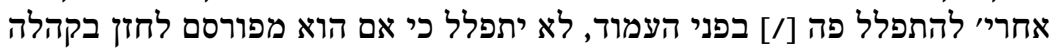

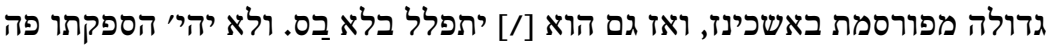

לא יועיל שיעבוד קרקעו' הן על בתים הן על מקומו' בב"ה אם לא נכתב שיר שיעבודו

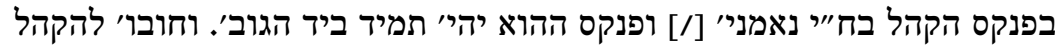

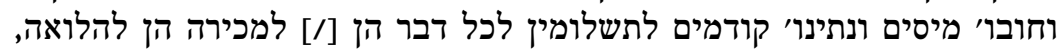

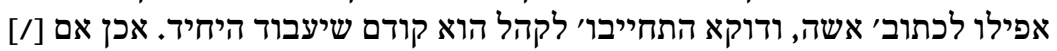

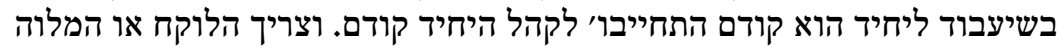

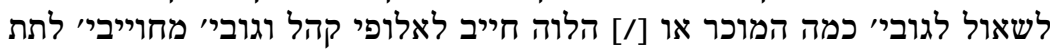

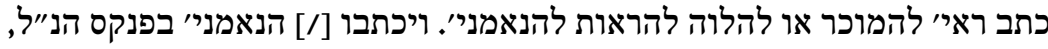

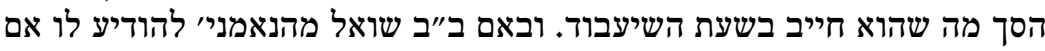

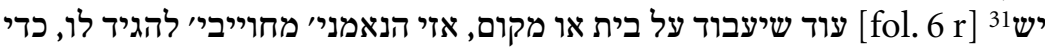

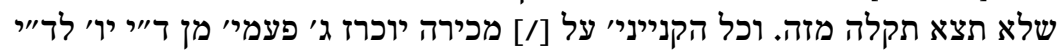

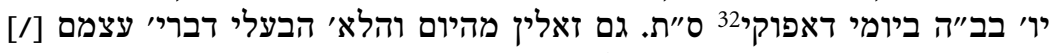

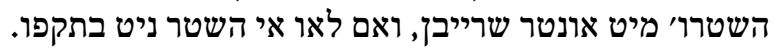

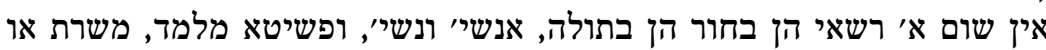
הנהגת הקהלה

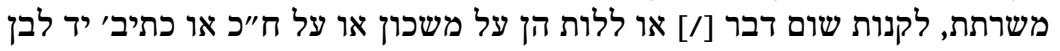

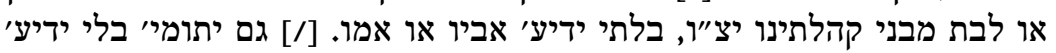

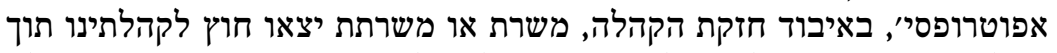

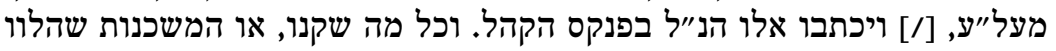

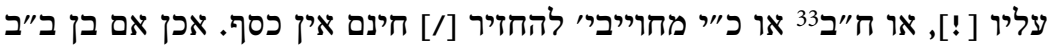

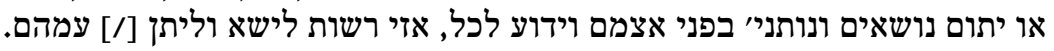

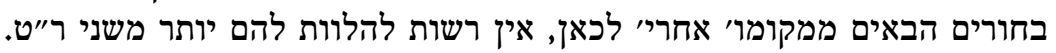
ובאם [/] שהלווה להם יותר, אין לכוף אותי אותם לשלם.

30 Zusätzlicher Sänger zur Begleitung der liturgischen Gesänge.

31 Danach die Kustode עוד.

32 Außer.

33 חובות בריב? 


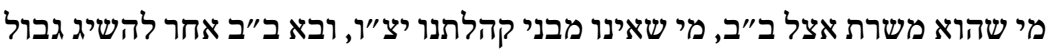

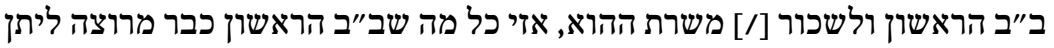

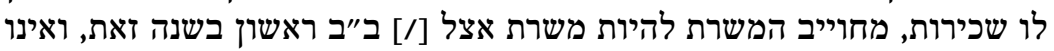

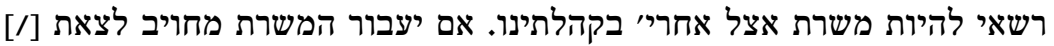

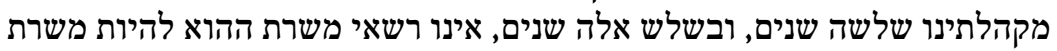
אף בירידי' אשר [/] המה מבני קהלתינינו ובשלת יצ"ו, בקנס על הבעל הבית.

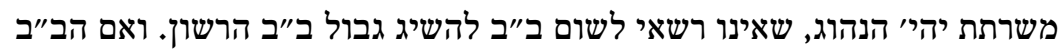

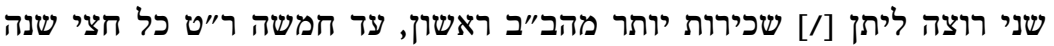

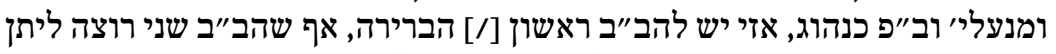

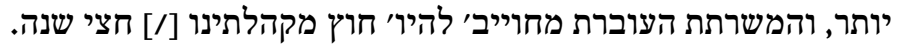

משרתת שברצונם להיות משרתת אצל ב"ב אחר, אזי משרתת ישאל [!" עפ"י

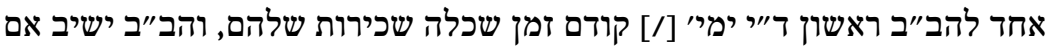

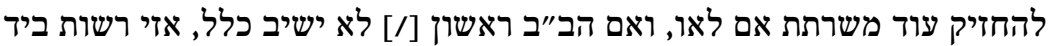

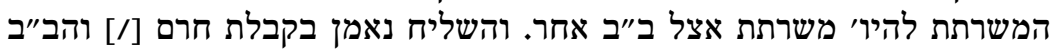

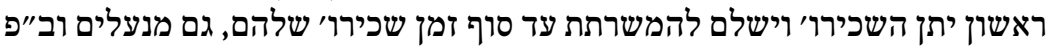
כנהוג [/] בלי עיכוב השכירובי

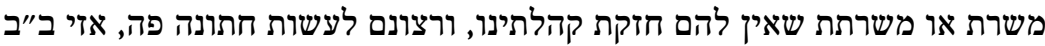

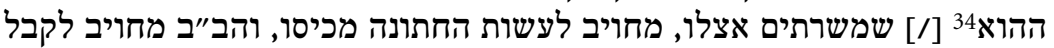
אליו בע"ק [/] שהזוג יצאו חוץ מקהלתים מצלו, מחוב לעשות החתונה ימי' אחר החתונה.

משרתת אצל ב״ב ה' שני' רצופי', ונתקשרת בקשרי תנאי' בימי' ההם, והית' נוהגת

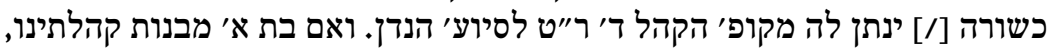

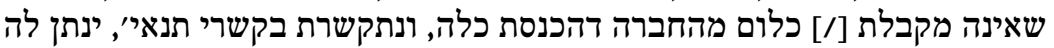

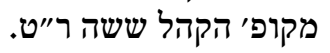

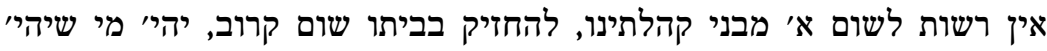

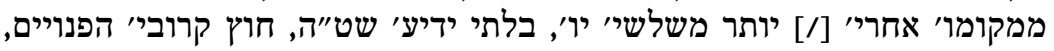

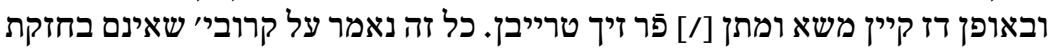
עשירות.

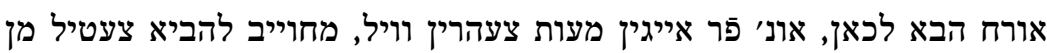

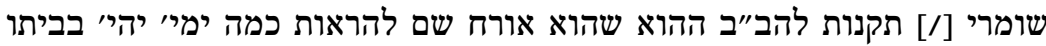
30

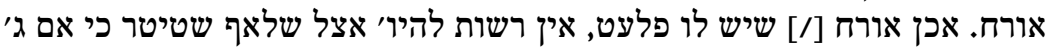

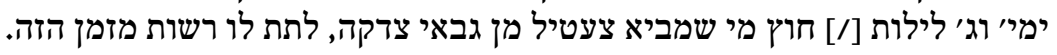

34 Danach $\boldsymbol{w}$ als Zeilenfüller. 


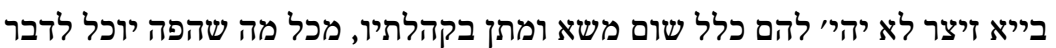

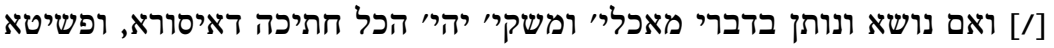

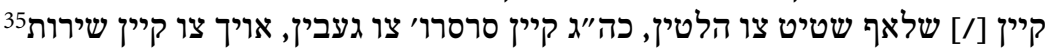
[fol. 7 r]

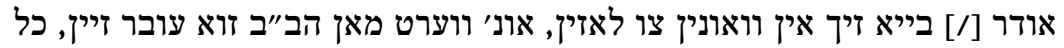

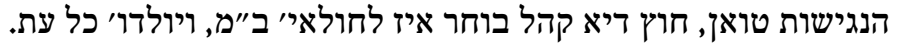

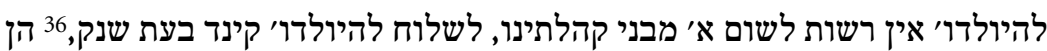

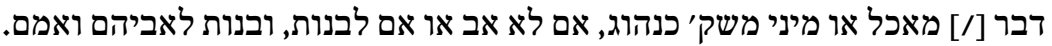

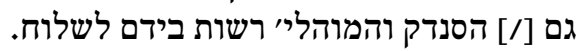

שושבן או מייאן פירר, סנדק, אין רשות בידם וואש צו בעשטין געבין, [/] יהיי מה 10

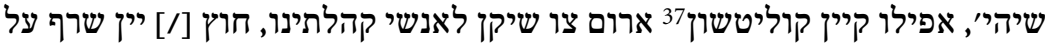

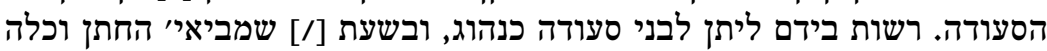

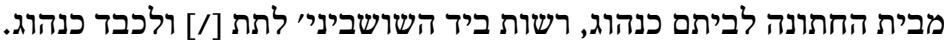

מי שמתקשר בנו או בתו בקשרי תנאי', וכן יולדו', אין רשות בידם לשלוח שום [/]

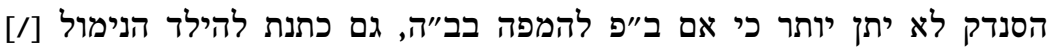

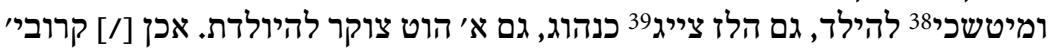

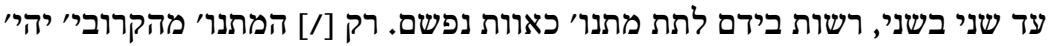

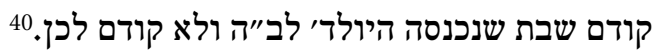

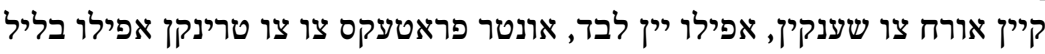

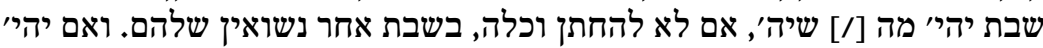

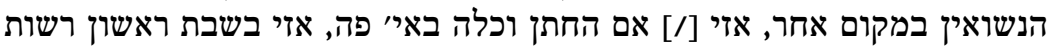
לכל א' זיא צו שענקין כנהוג.

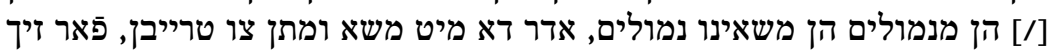

\footnotetext{
35 Danach die Kustode צו.

36 Kindbett-Geschenk.

37 koletson $=$ Kollektion, Sammlung.

38 Mützchen.

39 hals tsayg = Halszeug, Halstuch.

40 Danach die Kustode קיין.
} 


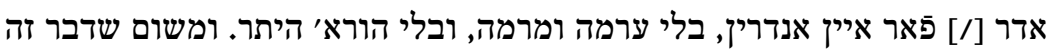

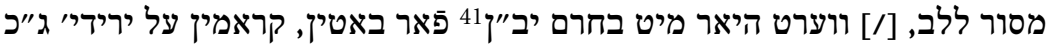

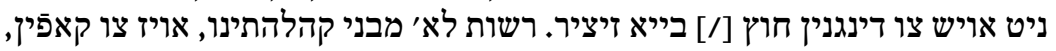

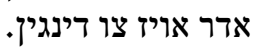

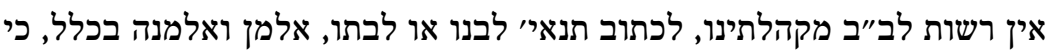
$17 \quad 5$

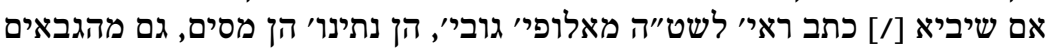

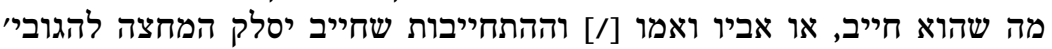

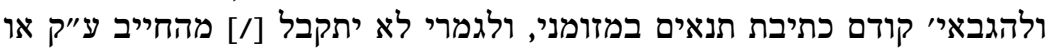

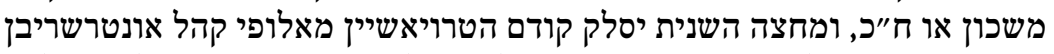

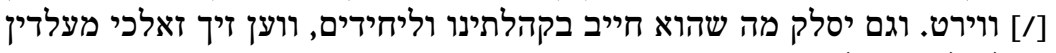

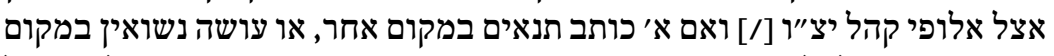

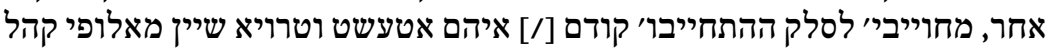
אונטר שריבן ווירט.

מי שנתברר א׳ שגנב או נאף, קלא בישא שהוא מפורסם יכתב בפנקס הקהל שאיבד

מופקרת שילדה, אין רשות לבני קהלתינו יצ״ו, להיות אצלם משרתת אף בחנם, רק

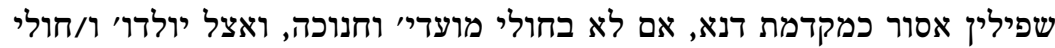

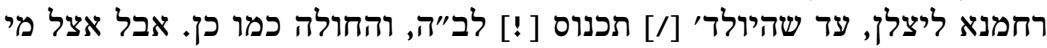

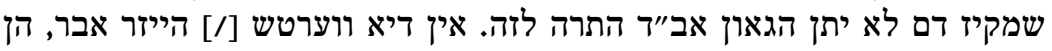

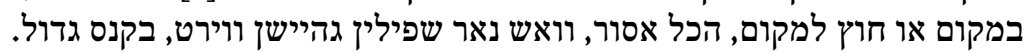

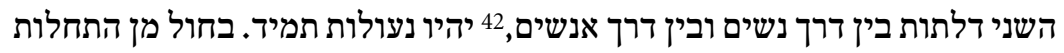

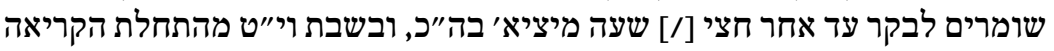

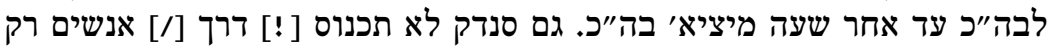

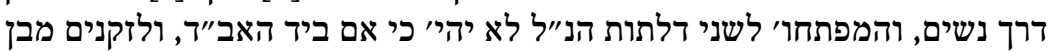

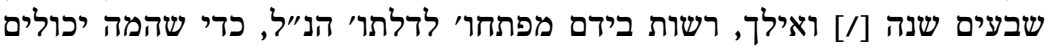

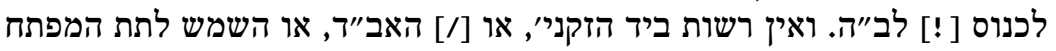

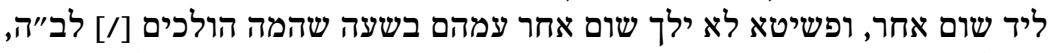

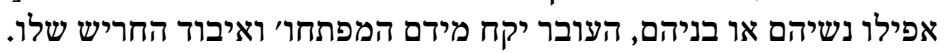


הן ע"י נמולים, הן ע"י אינו [/] נימולים. העובר יהי' דברים כנ"ל אסורי' עד שנה

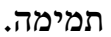

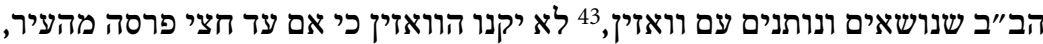

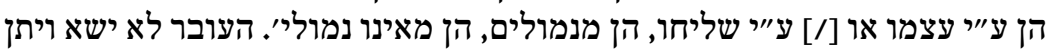

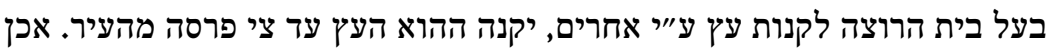

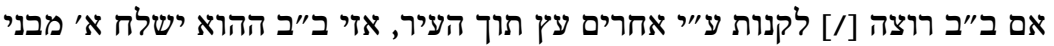

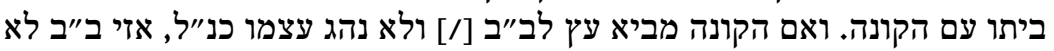

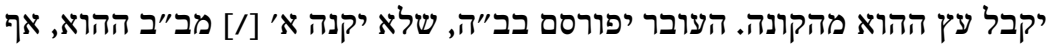

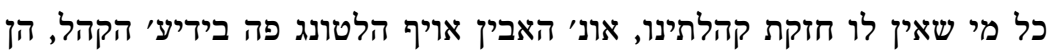

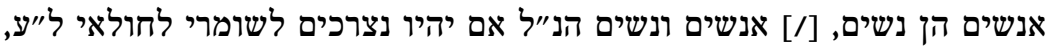

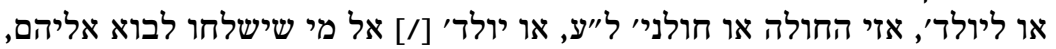

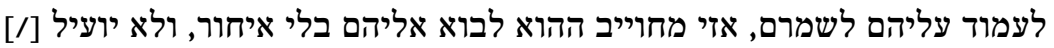

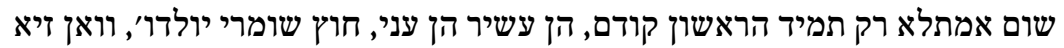

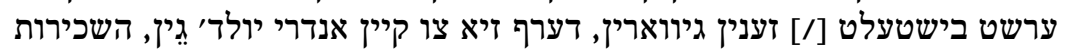

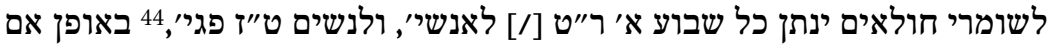

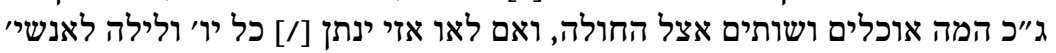

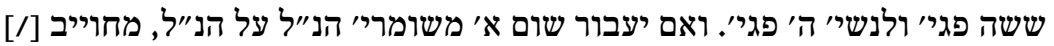
העובר הן איש הן אשה חוץ לקהלתינו תוך יערי שמנה ימים. עבור דין ישראל, יהדרו אלופי קהל יצ"ו, להחזיר עטרה ליושנה,45 להעמיד הד"ת [fol. $8 \mathrm{v}$ ] על תלה במה דאפשר. מאיין פירר, לגמרי קיין מעות בתוך החטי' צו ווארפין, בקנם העובר.

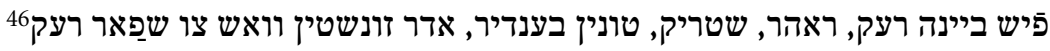

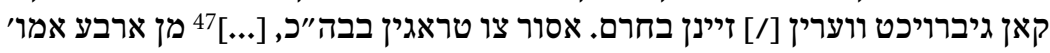

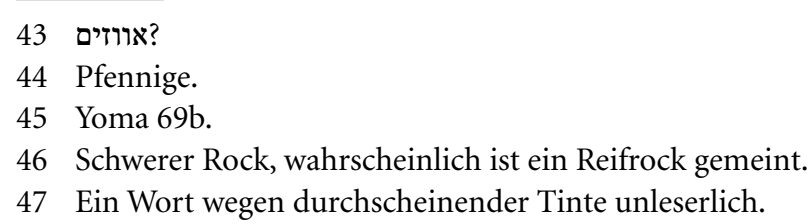


מלבושים של סמוט,48 או מלבושים וואו אין איזט גיווערקט כסיקט כסף או או זהב, או

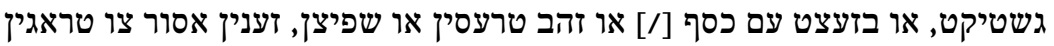

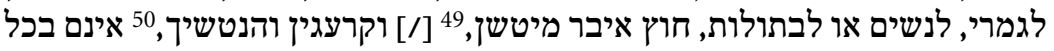
מלבושים הנ"ל. וגם אונטר ברושטיכר זיינינן ג"כ ניט מיט בכלל מלבוש הנ"ל.

מהיום והלאה, לא יתן שום ב״ב הוא או אשתו לבנותם מלבושים לנשואין, יותר

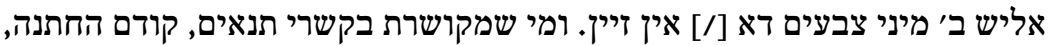

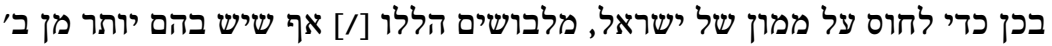

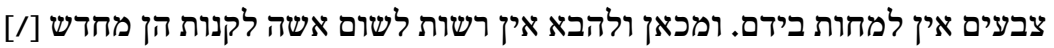

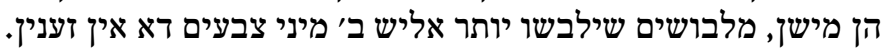

רשות ביד הגובה, בלי ידיע' שט"ה, לעשות כפיי' להחייב נתינו' או מסי', להכריז

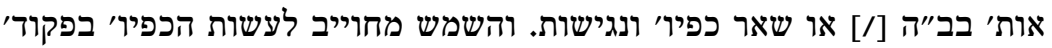

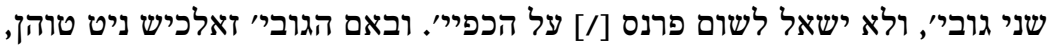

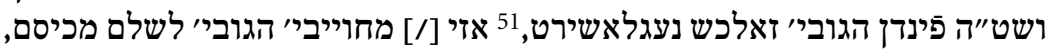

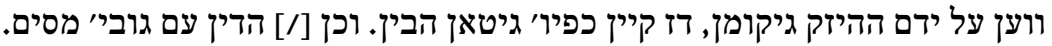

נשים מחוייבו' לפרוע חובו' בעליהן לאלופי קהל, אם הבעל איניו [!! פה חצי

כל נתינו' הקהלה יהיו נגבי', שליש ראש הבית, ושאר לפי ערך, חוץ לצרכי עניים. והמס [/] לאמיר"ה יהקיה יהיו נגבי' שלי כמשמעו' הקיומיי.

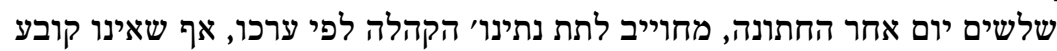
[fol. $9 \mathrm{r}] 20$

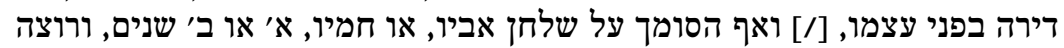

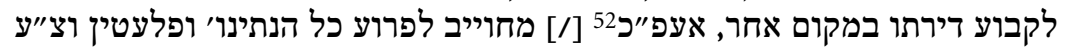

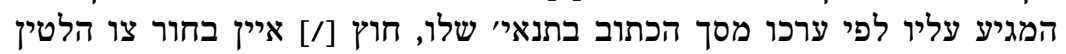
לשבתות, איז שנה ראשונה אחר החתונה בפרי פרייט.

ב״ב הנוסע בישיבה אחרת ללמוד, ההוא יתן מס כחד משאר בני קהלתינו, ולנתינו'

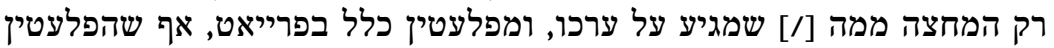

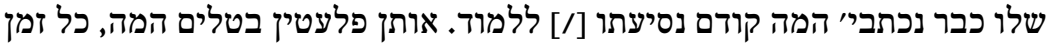

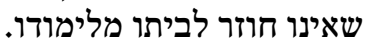

\footnotetext{
48 Samt.

49 Mützen.

50 Handschuhe.

51 negloshirt = negligiert, vernachlässigt.

52 Danach מ als Zeilenfüller.
} 
ג׳' שנים ראשונים [ !] אחר החתונה, מחוייב כל א׳ ליתן ערכו, כמו שכתוב בתנאים, 6

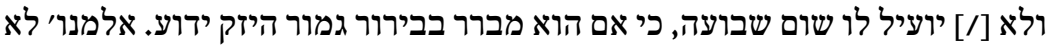

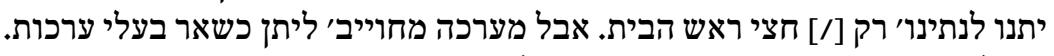

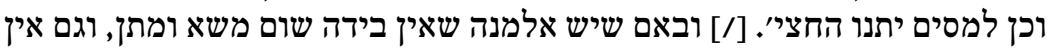

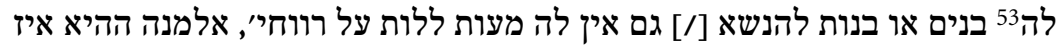

בפרייאט מכל וכל.

בעל בית שנשא בעול עם בני קהלתינו יצ״ו ארבעים שנה, מיום נשואין שלו, וירד

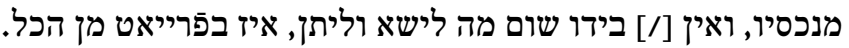

הגובים זאלין קיין פנקס קלאטי54 פיהרין יותר מן שלשים יו', ולאחר שלשים יו'

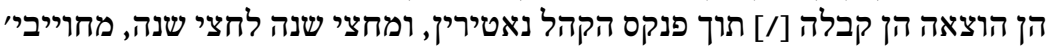

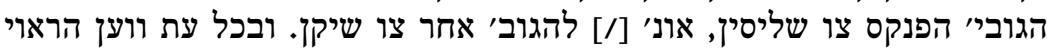

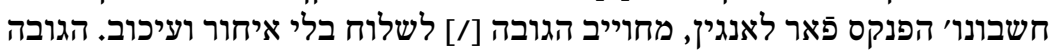

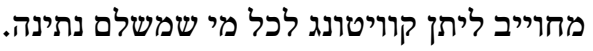

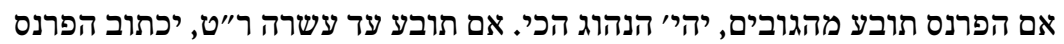

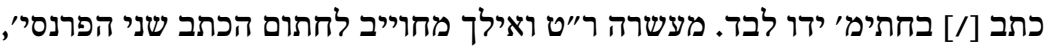

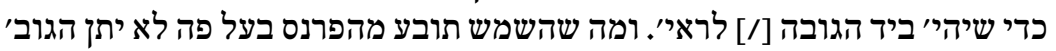

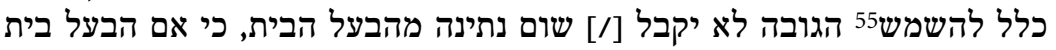

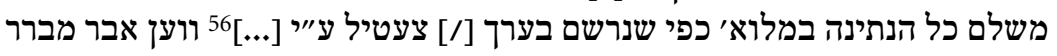

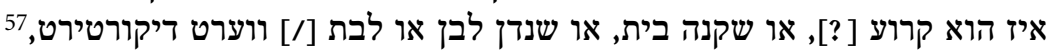

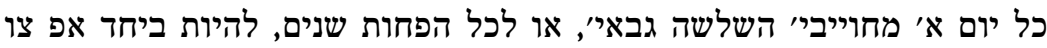

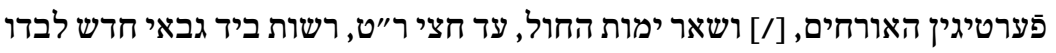

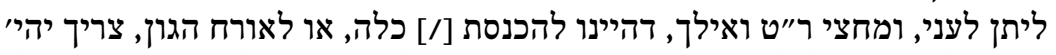

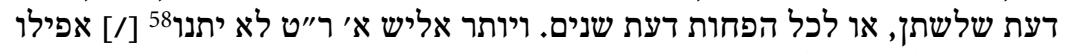

בידיעת שלשתן, בלי ידיעת פה"ח. לפות.

53 Davor gestrichen: לבנים ובנות.

54 Kladde; pinkas klate meint hier ein Notizbuch.

55 Hier eine Marginalie, am rechten Blattrand: No 7 [/"ל בהנהגו' שט"ע.

56 Ein Wort wegen zerflossener Tinte unleserlich.

57 Dekortieren = von der Rechnung abziehen.

58 Danach $\times$ als Zeilenfüller.

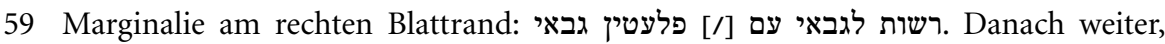
זונשט קענט דער אורח [/] כל ד' שבועו' ווידר קומין [/] ווייל גבאי גבאי ניט קענט :jedoch gestrichen [/]. 
כל המעות מצו', גם מה שמקבלים כשמסבבי' הגבאי' בב"ה, יתנו לקופ' הצדקה

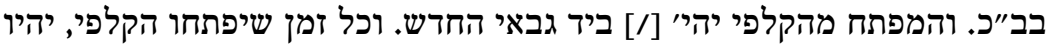

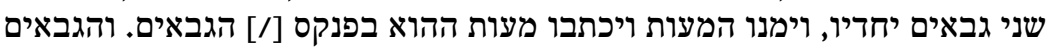

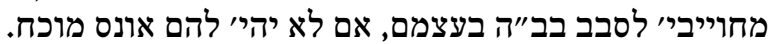

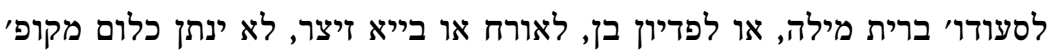

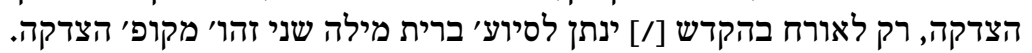

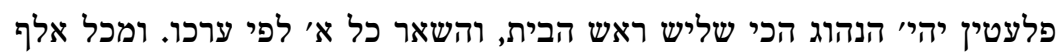

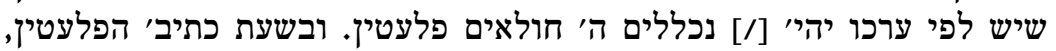

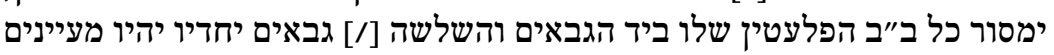

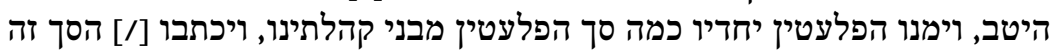

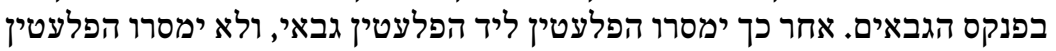

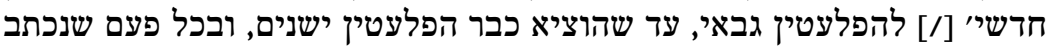

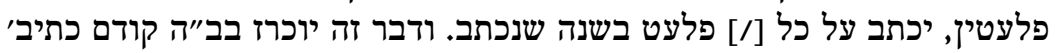
הפלעטין.

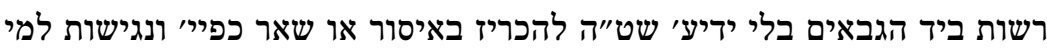

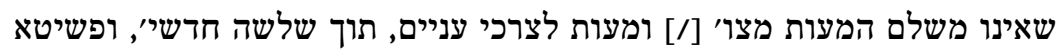

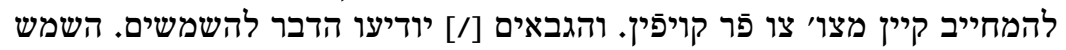

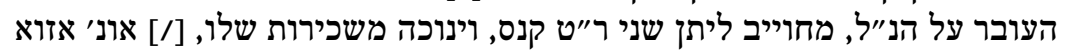

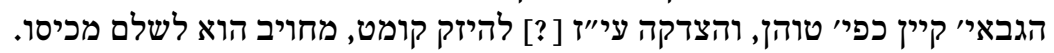

הגבאי' כל שלשה חדשים שמוסר הגבאי לגבאי אחר, לא ימסור גבאי הראשון

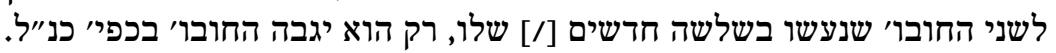

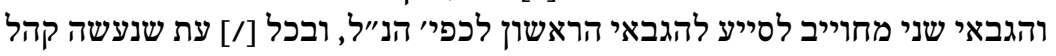

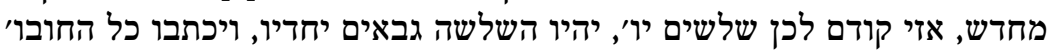
שנעשו עד זמן ההוא [/] בפנקס לכורם הרעשטאנדין.

הגבאי' לא יקבלו מעות לצרכי עניים מהב"ב, עד שישלם כל ב"ב לפי ערכו בערך 7

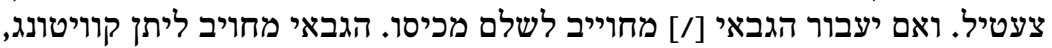

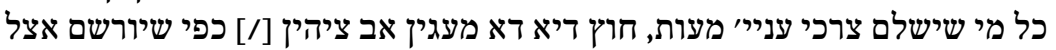

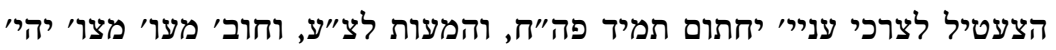
830

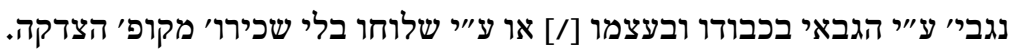
כל זמן שרואי' חשבונו' מבקשים מהגבאי' לשלוח לידם פנקס הגבאים, מחוייבי' לשלוח להם בלי איחור ועיכובי משבובים 
הנהגות פלעטין גבאי

כל זמן שאין פלעטין ישנים נמצאים

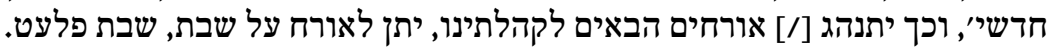

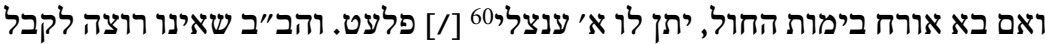

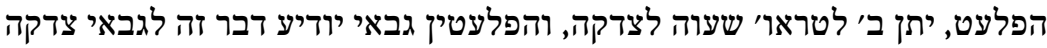

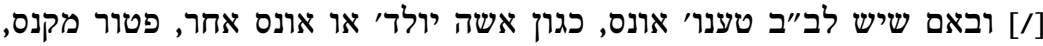

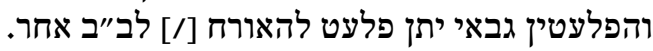

אם אין ב״ב מחוייב' אשתו לקבל הפלעט בקנס הנ״ל, ויש לה ג״כ טענו׳ אונס

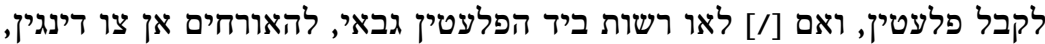
והב"ב בבואו אל ביתו ואם ישלם בלי איחור רשות ביר ועיכוב.

בימים טובי' מחוייב הפלעטין גבאי ליתן קודם י"ט כל הפלעטין שצריך כל אורח

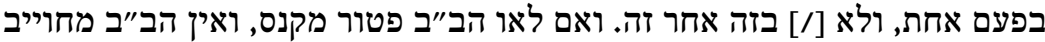
לקבל האורח ההוא.

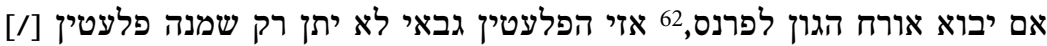

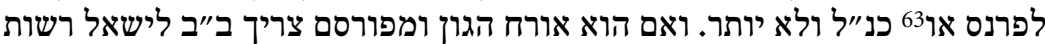

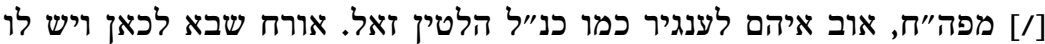

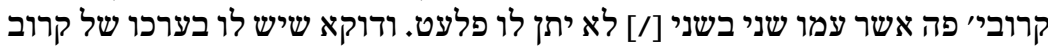

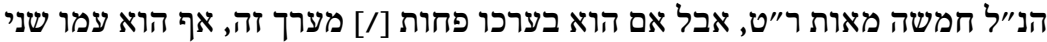
בשני, אעפ"כ יתן לו פלאט. משרת מרל

ואם הקרוב אשר הוא שני בשני עם האורח, וערך הקרוב ה' מאות ר״ּט, ואיני ואינו רוצה

כל פעם שנכתבי' פלעטין חדשי', ונשארו בקלפי אצל הפלעטין גבאי פלעטין

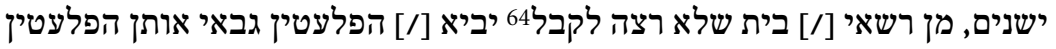

60 Einzelne. Danach פ als Zeilenfüller.

61 חריקא (aram.) = Lücke, die durch die Reise bei der Armenversorgung entsteht.

62 Danach gestrichen: או לאחד מבני קהלתינו יצ"ו

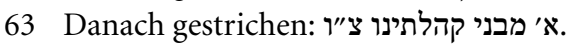

64 Danach gestrichen: האורח בלי פלעט, אזי הפלעטין גבאי זאל אורח ההוא אן דינגינין. 
אצל הגבאי חדש, והוא יכתוב בפנקס הגבאי' בעד כל פלעט כפול [/] ה' פגיי רעשטאנד, המחק ט"ס מאיר הכואי הכהן.65

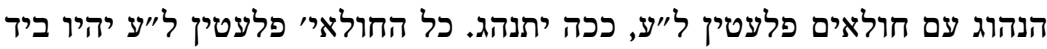

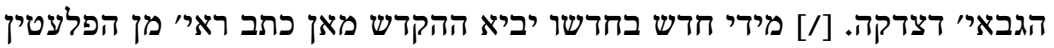

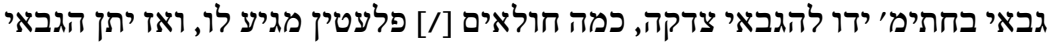

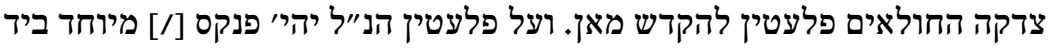

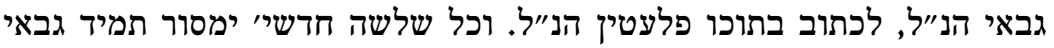
שהחזיק [/] כבר הגבאו' לגבאי שאחריו.

הנהגות גבאי דא"י

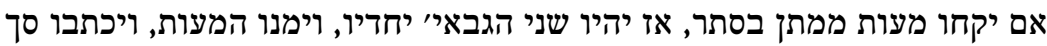
110

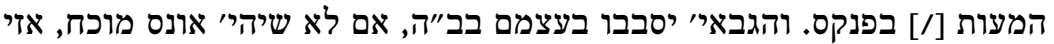
יעמוד אחר בחריקאי'.

בכל עת שנעשה קהל מחדש, אז הגבאיי יתנו המעות מה שאספו תוך השני שנים

ובכל זמן שראוי חשבונו' תובעים מהם הפנקס, מחוייבי׳ למסור להם בלי איחור

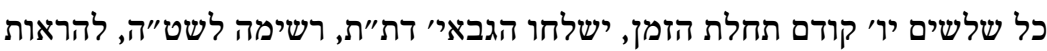

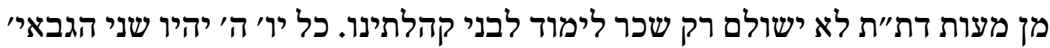

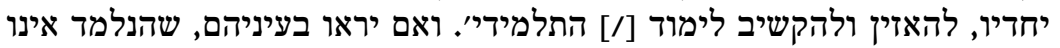

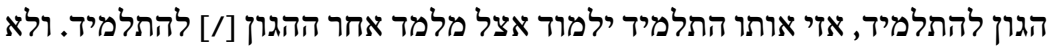

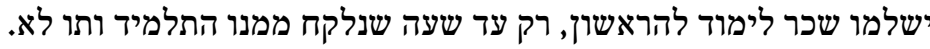

כל חצי שנה ימסור גבאי א׳ לחבירו הגבאו', ובכל עת שנעשה קהלי מחלי מחדש, זאלין

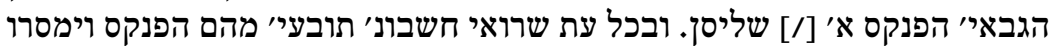
להם בלי איחור ועיכובי

הנהגות הנאמנים

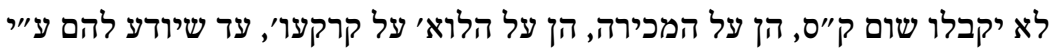

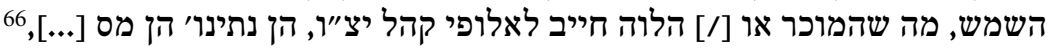

65 Die letzten vier Wörter in derselben Schrift wie der übrige Text, somit war Meir Hacohen offenbar der Schreiber dieser Ausfertigung der takkanot.

66 Kurzes Wort oder Ligatur, wegen durchscheinender Tinte unleserlich. 
לצ"ע. ומי שאלו [?] הנאמניי של [...]67 לקבל הק"ס, ובלאו הכי [/] לא יקבלו הנאמני' כלל ק"ס על שיעי שלות שמני קרקעות.

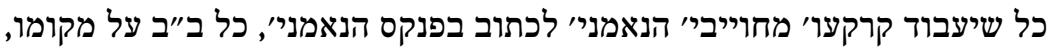

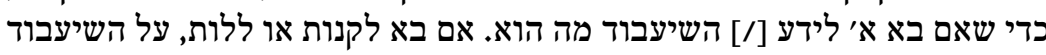

אם הנאמני' פסול א' [..]רם לק"ס, אזי החזן הוא נאמן במקום הפסול להק״ס,

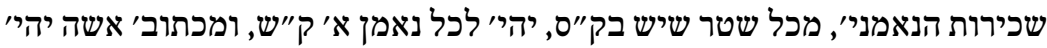

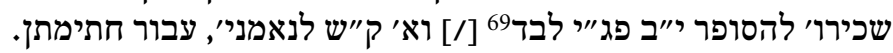

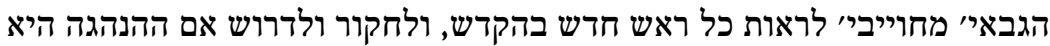

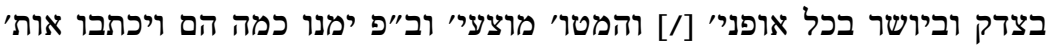

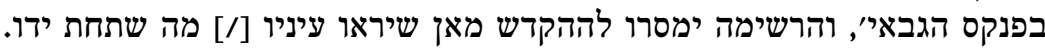

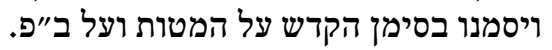

15 [fol. $11 \mathrm{v}$ ]

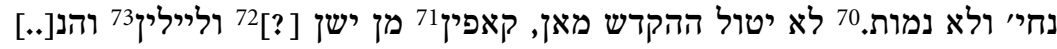

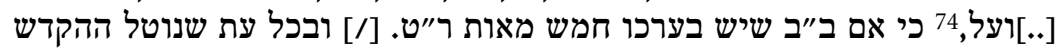
מַאן כַנ"

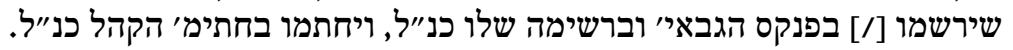

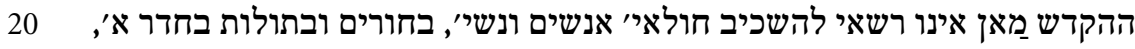

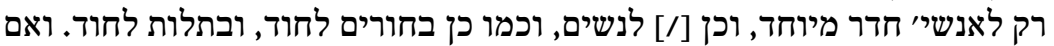

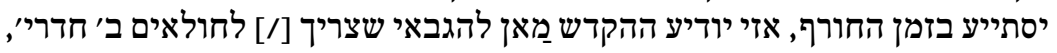

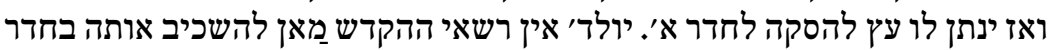

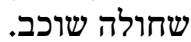

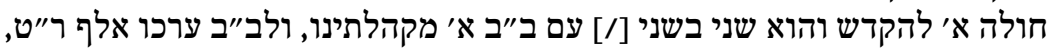

67 Wegen durchscheinender Schrift unleserlich.

68 Daneben, am rechten Blattrand: לא אורחים צו נענין.

69 Darüber ergänzt: 'ג"כ חצי לנאמנין.

70 Gen 42,2; 43,8; 47,19.

71 Kopfbezüge.

72 Lesung sehr unsicher wegen durchscheinender Tinte.

73 Leinentücher.

74 Schwer lesbar wegen durchscheinender Tinte. 
לא יתן הגבאי לחולה ההוא כלל חולה פלעט, עד י"ב שבועו' [/] ושני בשני עמו

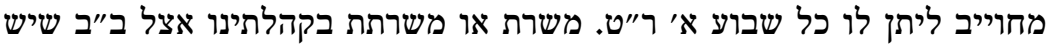

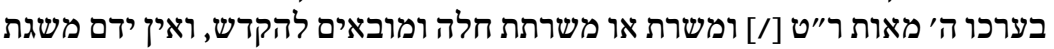

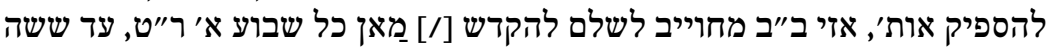

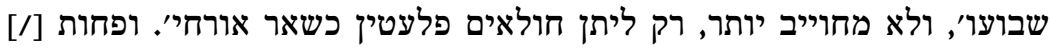

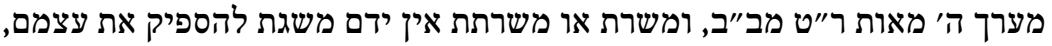

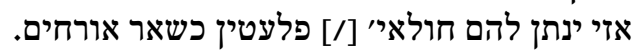

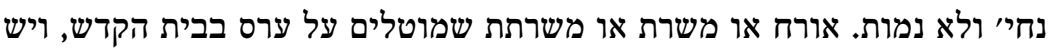

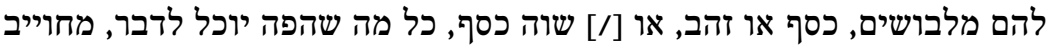

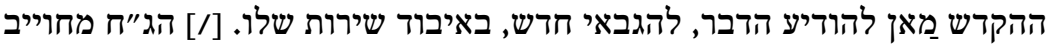

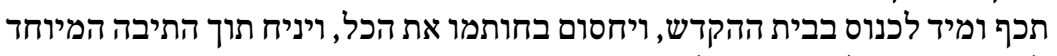
לכך [/] כדי שלא תצא תקלה מזה. בכית.

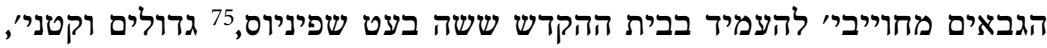

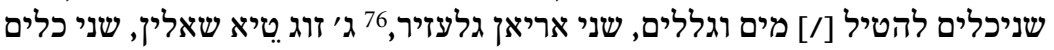
מכוסי' לשתיי, ששה כלי מ[...]

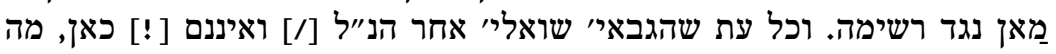

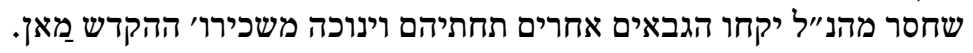

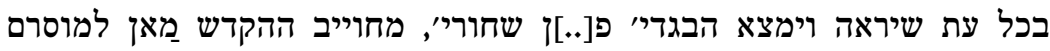

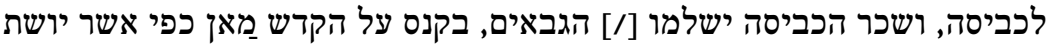

[fol. $12 \mathrm{r}$ ]

יהפי' א' בבית ההקדש, לתת שמירה מעולה, על חולאי' ל"ע, ושכירות יהי'לו לשנה,

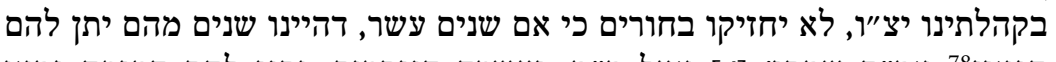

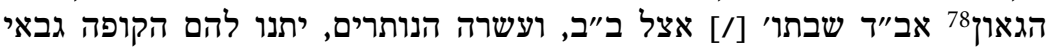

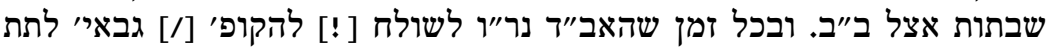

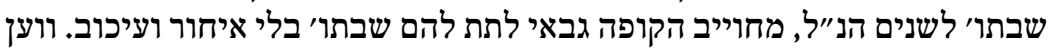
הגבאים [/] פינדין, דז הבחור בכלל הראוי לישיבה לחיבה איזט.

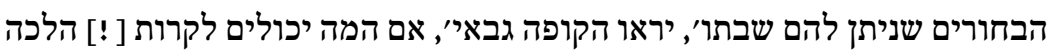

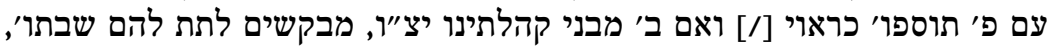

75 Genaues Wort unklar, offenbar Nachtgeschirr.

76 Uhrengläser.

77 Durch Tintenfraß beschädigte Stelle.

78 Dieses Wort zwei Mal. 
ויכולים לקרות הלכה עם פ' תוספו' כנ"ל [/] אזי יהיו מהמנויים תוך עשרה בחורים

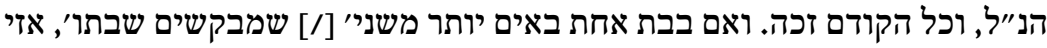

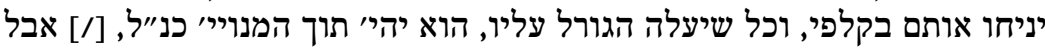

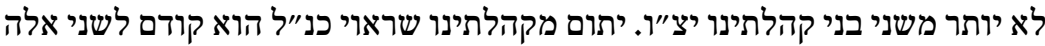
הנ״ל, [/] ויוסיפו עוד א׳ מבני קהלתינותו.

לא ינתן לבחור יהי' מי שיהיי, יותר משלש שנים רצופיי והבחור מחוייב להדריך

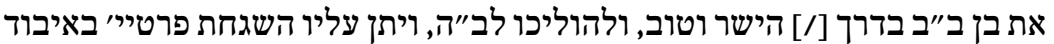

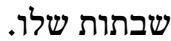

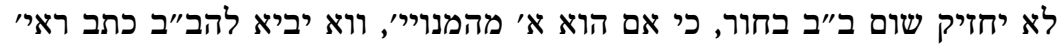

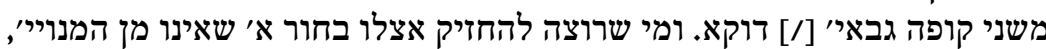

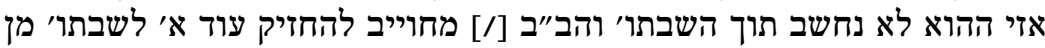
המנוייי.

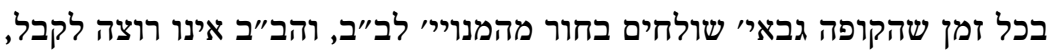

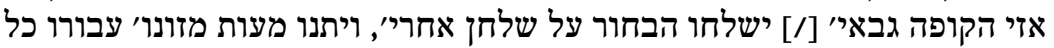

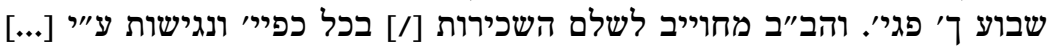

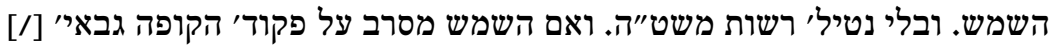
יתן לצדקה ב' ר"ט. וינוכה משכירו' שלות ואפות

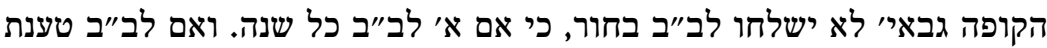

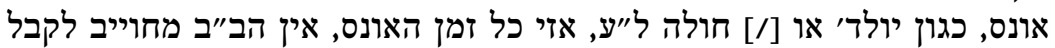
הבחור בשבתו', כי אם לאחר זמן האונס.

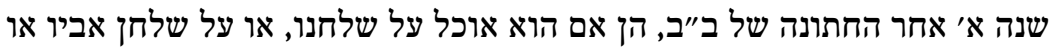
7

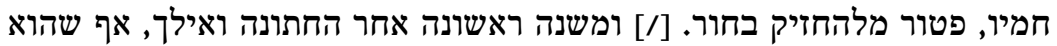

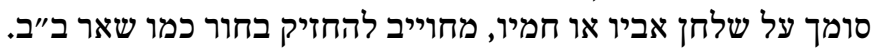

בעלי ערכות עד ה' מאות ר״ט, ולא ה' מאו' ר״"ט בכלל, פטור המה מלהחזיק בחור.

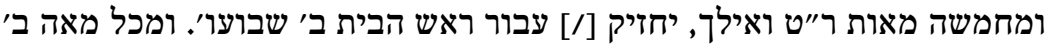
ימיי. אם הקופה גבאים יודעים בבירור, שאב א׳ מבחור יכולת בידו אלפים ר״ט לא יתנו

בחוריי שאינם מנויים, לא יהיו רק שלשה ולא יותר. ואותם שלשה, יתן להם

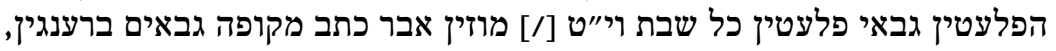
דש להם זאל פלעטין גיגעביו פלין ווירדן. 


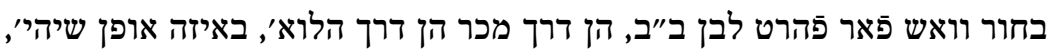

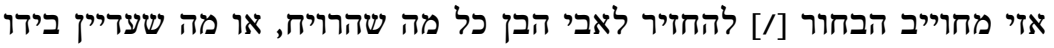

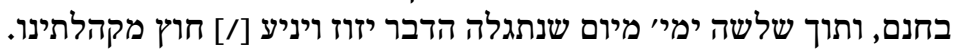

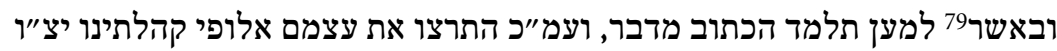

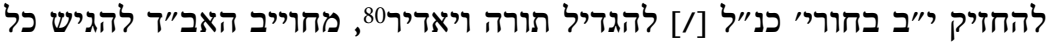

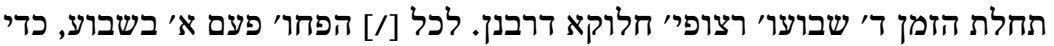

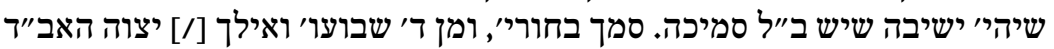

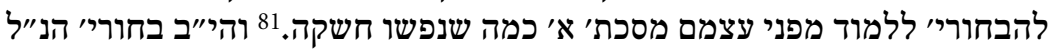

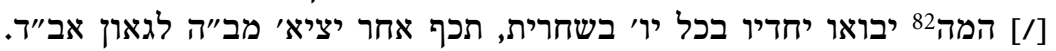

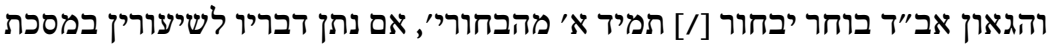
10

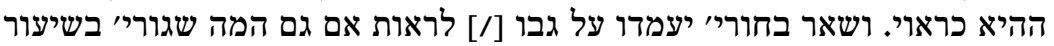

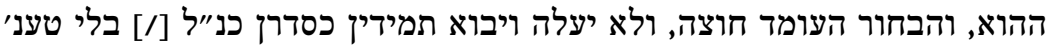

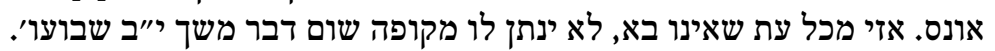

הנהגות השמאים

השמאים מחוייביי תמיד הערך צעטיל צו שליסן קודם חדש מנחם. ומי שאיני שינו 115

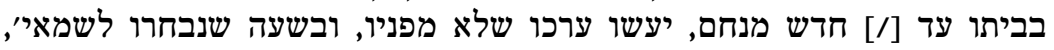

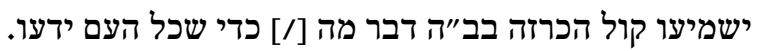

79 Auf dem Text des gesamten Paragraphen zwei senkrechte Striche, was auf eine spätere Aufhebung hindeutet.

80 Jos 42,21.

81 Nach Gen 34,8 .

82 Am rechten Blattrand Marginalie: עד כאן ותו לא מידי. 


\section{Statuten aus Fürth (1770)}

\section{Quelle: Statutenbuch (Kopie), CAHJP, D/Fu1/41}

Die takkanot der bedeutenden fränkischen Gemeinde Fürth stellen ganz offensichtlich den Höhepunkt des Statutenwesens im aschkenasischen Kulturraum dar, zumindest was den Umfang und die Ausführlichkeit anbetrifft. Mit angestrebten 515 Paragraphen (tatsächlich sind es 514, da Nr. 139 versehentlich ausgelassen wurde) sind die Fürther Statuten mit Abstand das umfangreichste Gesetzeswerk, das im frühneuzeitlichen Aschkenas entstand. Die 13 Abschnitte, von denen jeder einzelne in seiner Länge oft den Umfang anderer, kompletter Gemeindestatuten übertrifft, regeln ausführlich viele Bereiche des gemeindlichen Lebens. Bemerkenswert ist, dass liturgische Fragen oder Aspekte des synagogalen Gottesdienstes keine eigenen Abschnitte erhielten, wenngleich sie im Text nicht völlig ausgeklammert bleiben. Aus den abschriftlich wiedergegebenen Namenszügen am Ende des Textes lässt sich auch entnehmen, dass es sich bei dem hier edierten Text wohl um eine Kopie der Originalausfertigung handelt. Diese befindet sich in der Handschriftensammlung des Hebrew Union College in Cincinnati, ${ }^{1}$ jedoch in fragmentarischer Form: Die ersten 28 Paragraphen fehlen, während die Gesamtzahl mit 520 angegeben wird, sodass eine immer noch zu klärende Diskrepanz zwischen Original und vermuteter Kopie vorhanden ist.

Vor rund 100 Jahren existierten im Archiv der Israelitischen Kultusgemeinde Fürth noch die Originalausfertigung, ein älterer Vorgängertext von 1717-1722 mit 238 Paragraphen sowie ein späterer Statutentext von 1786 mit 474 Artikeln. Das Buch mit den takkanot von 1786 befindet sich heute in den Beständen des Hebrew Union College in Cincinnati. ${ }^{2}$ Alle diese Texte wiesen bzw. weisen offenbar große inhaltliche Übereinstimmungen auf. ${ }^{3}$ Dazu muss

1 Acc. 132, Mikrofilm im Institute for Microfilmed Hebrew Manuscripts (IMHM) an der National Library of Israel: F45695. Diese Originalausfertigung wurde nach ihrer Fertigstellung umgebunden, wobei der Index an den Anfang gestellt wurde. Auch die Ränder wurden beschnitten, sodass sich die ursprüngliche Paginierung oft nur fragmentarisch erhalten hat. Dieses Schicksal ist der Kopie, die von derselben Hand stammt, erspart geblieben.

2 Acc. 183, IMHM F49094.

3 Neubürger, Sonderrecht, $7 \mathrm{f}$. 
noch eine gesonderte Ausgabe von Luxusgesetzen erwähnt werden, die angeblich 1728 sogar im Druck erschien. Ein protestantischer Gelehrter dieser Zeit, Andreas Würfel, verstand es - wenn man seiner Schilderung Glauben schenken darf - sich auf Umwegen ein Exemplar des jiddischen Textes zu verschaffen und gab diesen in deutscher Übersetzung im zweiten Teil seines teils überaus polemischen Werkes über die Fürther Juden wieder. ${ }^{4}$ Allerdings ist verwunderlich, dass sich offenbar kein einziges Exemplar des Erstdrucks erhalten hat. Auszüge aus dem Nachfolgertext der hier edierten Satzungen von 1786 wurden von Leopold Löwenstein in einem Beitrag zur Fürther jüdischen Gemeinde 1911 originalsprachlich wiedergegeben.

Die Statuten von 1770 wurden in ein eigenes Buch im Folioformat eingeschrieben. Auf dem vorderen Einbanddeckel ist ein Etikett angebracht, auf dem vermerkt ist: תקנות פיורדא 1771 . Allerdings scheint es, dass dieses Etikett nicht original ist, sondern aus dem 19. Jahrhundert stammt. Der Band ist in gutem Erhaltungszustand und bildet mit einigen Protokollbüchern des 18. Jahrhunderts ${ }^{5}$ den ältesten Teil der innergemeindlichen Überlieferung der Fürther Gemeinde. Das Buch ist vollständig und weist keine nennenswerten Beschädigungen auf. Der eigentliche Text der Statuten nimmt 53 Blatt des Buches ein, was noch einmal den gewaltigen Umfang verdeutlicht. An diesen Hauptteil schließt sich auf fol. $53 \mathrm{v}-64 \mathrm{v}$ eine Art Kurzfassung an, in der für jeden Paragraphen auf einer oder zwei Zeilen der Inhalt zusammengefasst wurde. Offenbar war auch den für die Entstehung Verantwortlichen klar, dass bei Statuten dieser Länge ein Orientierungsmittel notwendig war. Auf die Wiedergabe der Kurzfassung wurde in dieser Edition jedoch verzichtet.

Die Einleitung und der Schlussteil der takkanot wurden auf Hebräisch verfasst, während die Paragraphen hauptsächlich in einem für seine Zeit recht modernen Jiddisch gehalten sind. Dieses zeichnet sich durch die häufige Verwendung von Lehnwörtern aus dem Französischen aus, wie sie im 18. Jahrhundert auch im Deutschen typisch war. Zuweilen wird auch das lateinische »et« (und) verwendet. Im Text finden sich daneben nicht wenige Zitate aus Bibel und Talmud sowie einige Redewendungen aus dem Aramäischen, was auf das hohe traditionelle Bildungsniveau der Verfasser schließen lässt. In Paragraphen, die sich vor allem mit halachischen Aspekten befassen, wurde jedoch wieder auf das für einen entsprechenden Inhalt übliche Hebräisch zurückgegriffen, wie etwa in den Paragraphen 344 und 346. Auffallend ist die häufige Benutzung von textlichen Einschüben in Klammern, das auch

4 Andreas Würfel, Historische Nachricht von der Judengemeinde in dem Hofmarkt Fürth, 2 Teile, Frankfurt/ Prag 1754, hier: Teil 2, 109 f.

5 Diese sind ebenfalls in der Bibliothek des Hebrew Union College in Cincinnati zu finden. 
aus anderen, teils früheren takkanot bekannt ist, jedoch nicht in derselben Intensität. Diese Einschübe werden jedoch nicht durch das heute bekannte (und schon lange übliche) Klammerzeichen gekennzeichnet, sondern durch einen Schrägstrich mit beiderseitigen Punkten, womit das Zeichen sehr dem modernen Prozentsymbol (\%) ähnelt. Es wurde auch als Schlusszeichen am Ende eines jeden Paragraphen verwendet.

Der Schreiber der takkanot, der über eine sehr sorgfältige und leicht lesbare Handschrift verfügte, gibt sich im gesamten Text nicht zu erkennen. Da am Textende keine Unterschriften vorhanden sind, lässt sich nicht rekonstruieren, ob einer der 15 Unterzeichnenden die Niederschrift vorgenommen hat.

Die Blätter des Statutenbuches sind in der oberen linken Ecke mit hebräischen Buchstaben foliiert, jedoch nur bis fol. 53. Die Seiten der nachfolgenden Kurzfassung blieben unnummeriert. Die einzelnen Paragraphen wurden in der üblichen Weise am rechten Blattrand fortlaufen durchnummeriert, wobei der erwähnte Fehler der ausgelassenen Nummer 139 die einzige Unregelmäßigkeit bleibt. Oft wird im Text auf andere, thematisch verwandte Paragraphen verwiesen. Auffallend ist jedoch, dass ab der Mitte der Statuten häufig die Angabe der jeweiligen Paragraphennummer fehlt und der Platz für diese im Text frei blieb.

Die 13 Abschnitte der Statuten besitzen, außer dem ersten, jeweils eigene Überschriften, die die thematische Fixierung andeuten. Der Inhalt der ersten 81 Paragraphen befasst sich ausführlich mit der Wahl und der Amtsführung der Vorsteher der Gemeinde. Der folgende zweite Abschnitt (hanhagot shiddukhim) erörtert in 29 Paragraphen die Konditionen, zu denen Neuaufnahmen in die Gemeinde durch Eheschließungen erfolgen konnten. Paragraph 90 enthält eine tabellarische Übersicht über die jeweilige Höhe des Einzugsgeldes, das die Paare abhängig von ihrer Herkunft vom Platz des Mannes und seiner Ehefrau innerhalb der jeweiligen Geschwisterfolge zahlen musten. In den tikkune govim werden die Aspekte der Steuererhebung und die Amtsführung der Steuererheber dargelegt. Dieser Abschnitt umfasst 30 Paragraphen. Folgerichtig sind im vierten Abschnitt in 23 Paragraphen die hanhagot erekh, also die Regeln für die Vermögensschätzung dargelegt. Daran schließen sich in den tikkune deputirte die Dienstanweisungen für die Deputierten, eine Art Verwaltungsgehilfen, an. In den tikkune beisitzer [sic!] wird die nicht unproblematische Frage der am Ort ansässigen Juden erörtert, die keine Mitgliedschaft in der Gemeinde besaßen. In Fürth wurden sie als Beisitzer, analog zum deutschen Begriff »Beisasse«, bezeichnet. Die 69 Paragraphen des Abschnitts verweisen auf lange und problematische Jahre im Umgang mit dieser Personengruppe, die sicher nicht die vermögenden und angesehenen Juden umfasste. Aus den Bestimmungen wird in drastischer Weise deutlich, dass sie die Unterschicht der Juden in Fürth stellten, die selbst von ihren Glaubens- 
genossen kaum mehr als geduldet wurden. Auch scheint es nicht zufällig, dass sich daran der mit 82 Paragraphen längste Abschnitt über den weiten Bereich der Armenversorgung anschließt ( tikkune $g^{\text {" }} z^{6}$ ), in dem auch ausführlich der Umgang mit ortsfremden Armen beschrieben wird. Auch die Verpflegung und Unterkunft der Jeschiwastudenten in Fürth ist hier ein Thema. In den hanhagot dayyanim ist die Tätigkeit des lokalen jüdischen Gerichts dargelegt und zeichnet sich mit 48 Paragraphen wieder durch große Ausführlichkeit aus. Daran schließen sich die Bestimmungen für den gabbai der TalmudTora-Schule an (29 Paragraphen), gefolgt von den hanhagot memunim, den Bestimmungen der Marktaufseher. Deren Funktion erstreckte sich in Fürth allerdings auf zusätzliche Bereiche wie die soziale Kontrolle der Gemeindemitglieder, wie die Paragraphen 461-464 zeigen, in denen die Eindämmung "moderner « Sitten angestrebt wird. Die Kleiderordnung (hanhagot malbushim) ist mit nur sieben Paragraphen recht knapp, was ein Hinweis darauf sein könnte, dass es tatsächlich eine parallel dazu existierende Luxusgesetzgebung in Fürth gegeben hat, wenngleich zu diesem Themenkreis auch der anschließende Abschnitt mit Bestimmungen über Festmahlzeiten zu rechnen ist (hanhagot se'udot, 13 Paragraphen). Abschließend steht ein Abschnitt vermischten Inhalts (takkanot pratiyot). In dessen Paragraph 500 wird der Einfluss aufklärerischen Gedankenguts deutlich, insofern er jegliche Druckzensur für Fürth, wo sich ein Zentrum des mitteleuropäisch-jüdischen Buchdrucks befand, de facto aufhebt.

Über jeder Seite der Statuten wurde das Kürzel ב"ה geschrieben: Mit Gottes Hilfe.

Im Schlussteil wurde die Gültigkeit der Statuten auf neun Jahre fixiert, worauf allerdings noch eine Verlängerung um weitere 15 Jahre folgte.

6 gabbai zedaka = Armenpfleger. 
[fol. $1 \mathrm{r}$ ]

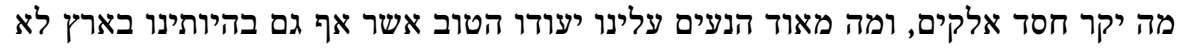

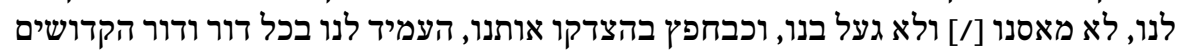

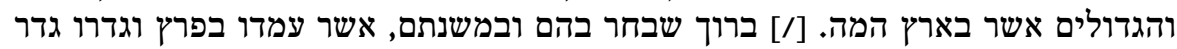

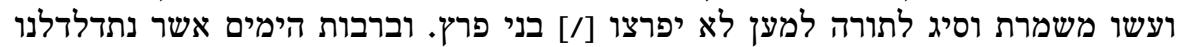

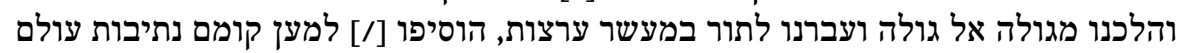

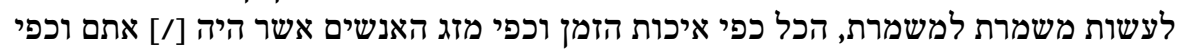

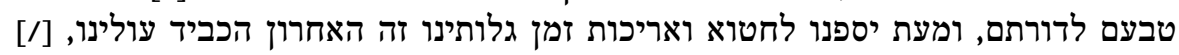

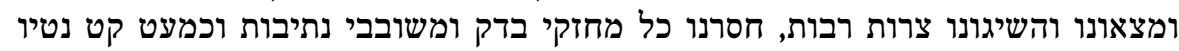

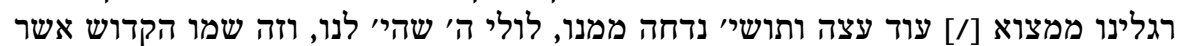

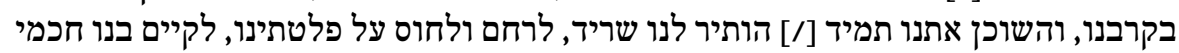

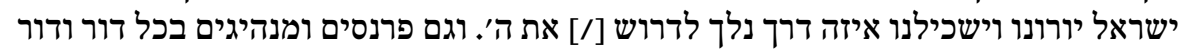

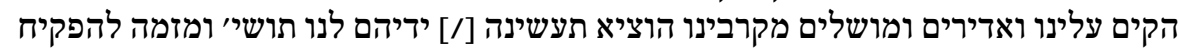

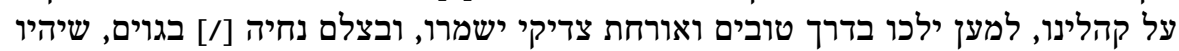

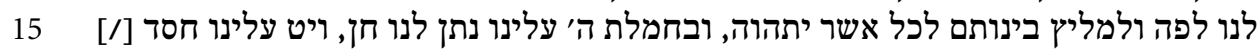

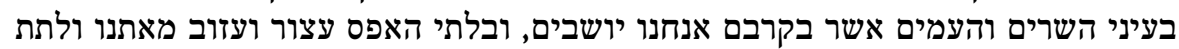

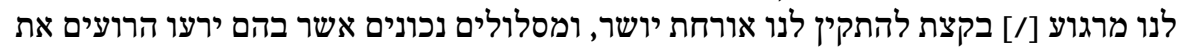

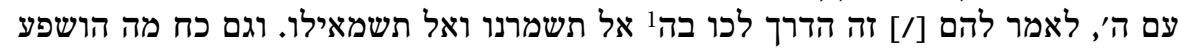

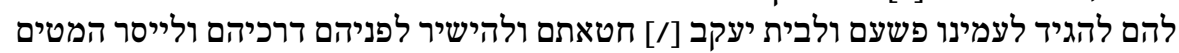

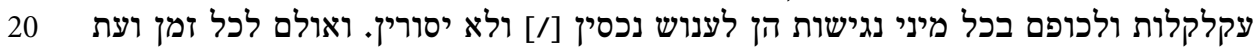

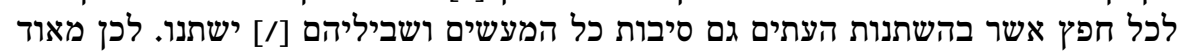

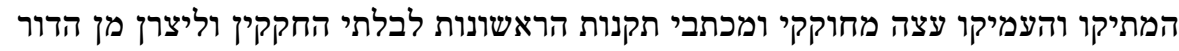

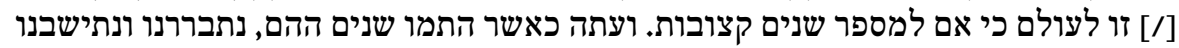

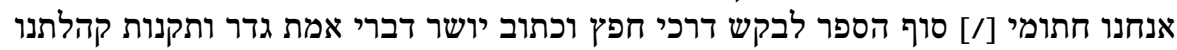

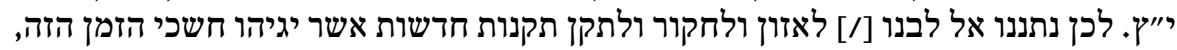

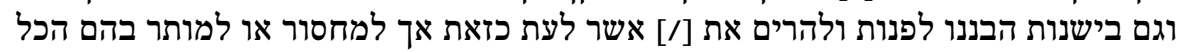

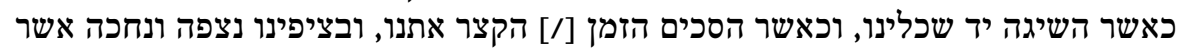

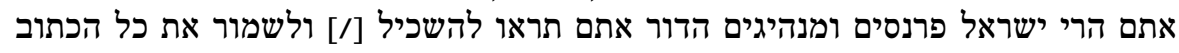

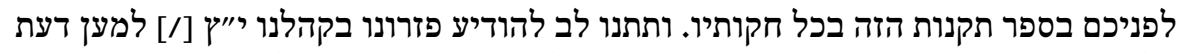

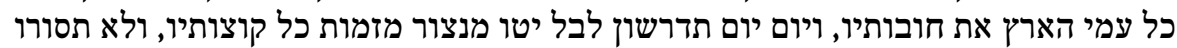

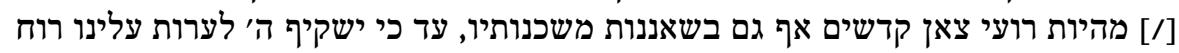

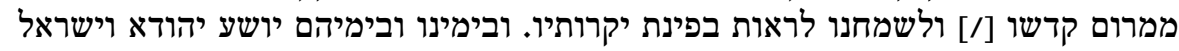

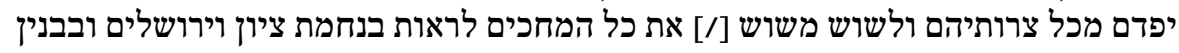

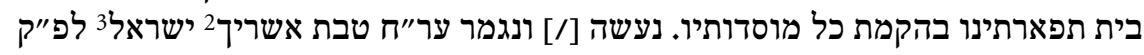

1 Schabbat 153a.

21770 XII 16. Das letzte Wort in großer Quadratschrift zur Verdeutlichung der Jahreszahl.

3 Dtn 33,29. 
[fol. 1 v leer; fol. 2 r]

א׳

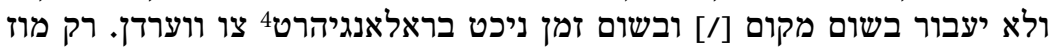

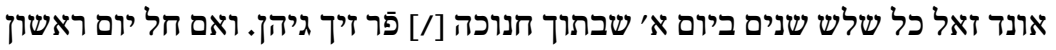

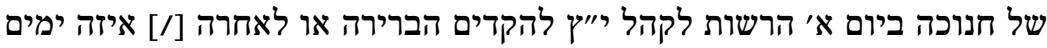

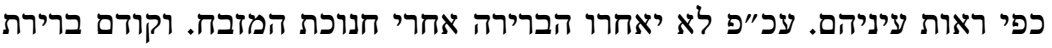

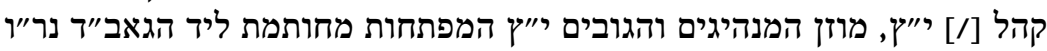

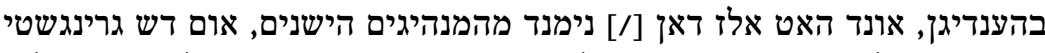

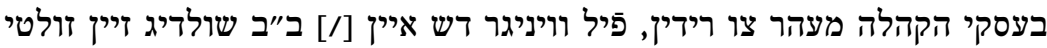

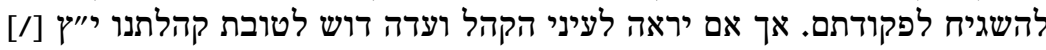

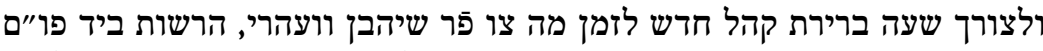

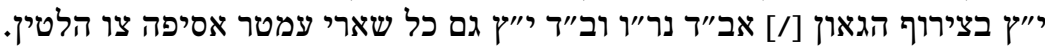

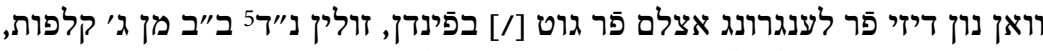

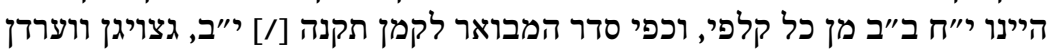

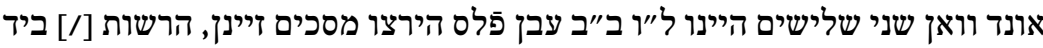

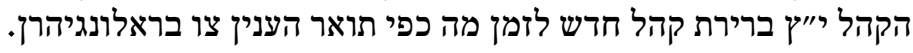

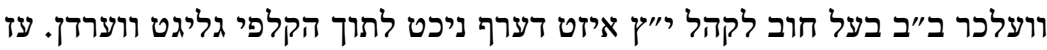

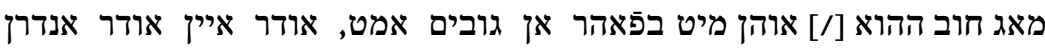

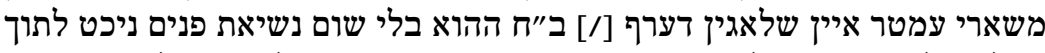

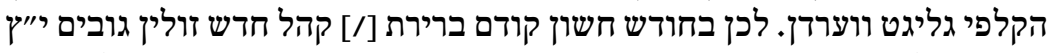

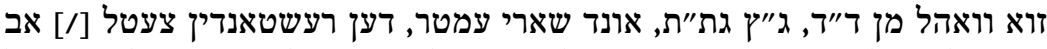

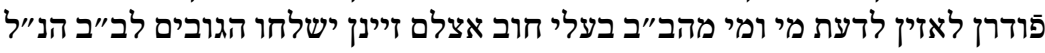

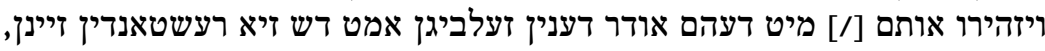

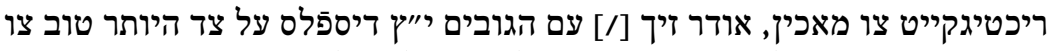

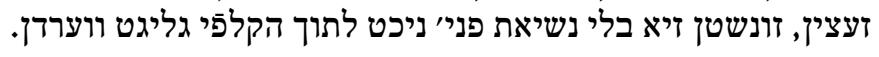

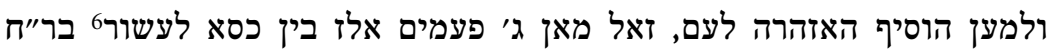

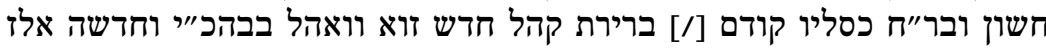

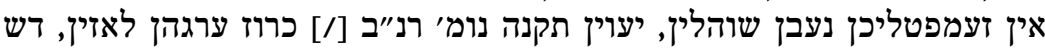

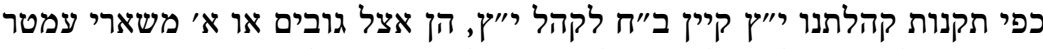

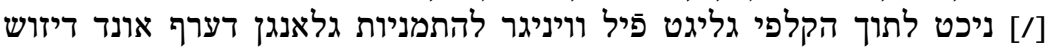

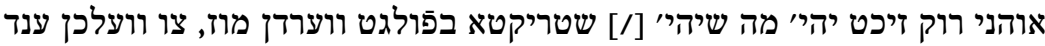

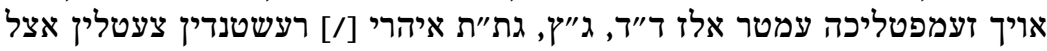

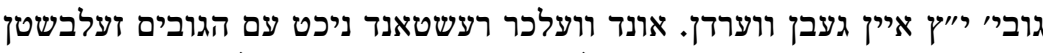

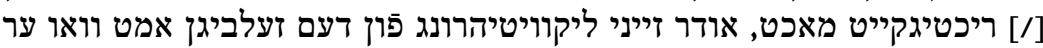

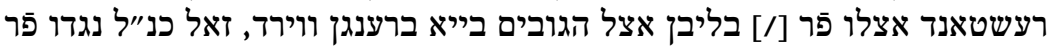

\footnotetext{
4 Prolongieren $=$ verlängern.

5 Bedeutet hier den Zahlenwert von 54.

6 Die Tage zwischen Neujahr und dem Versöhnungsfest.
} 
פَאהרן ווערדן דש ניכט לתוך הקלפי גליגט, [/] אויך על התמניות צעטל גשריבן

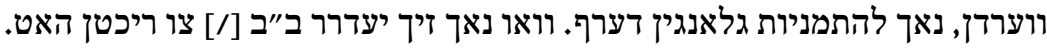

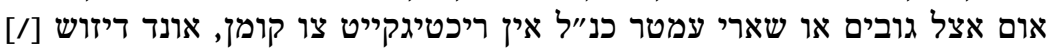

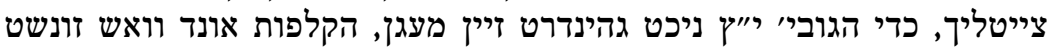

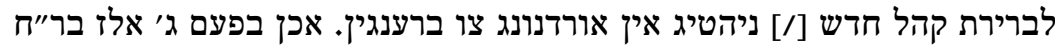

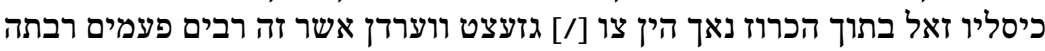

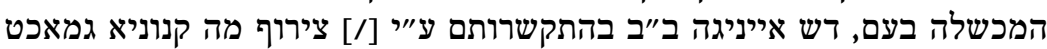

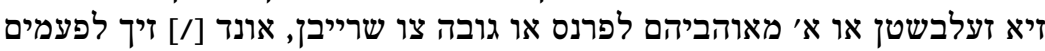

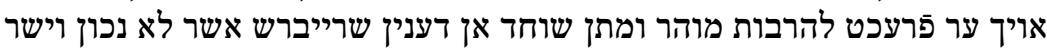

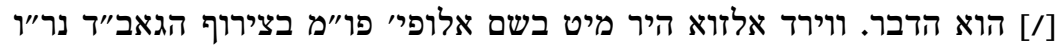

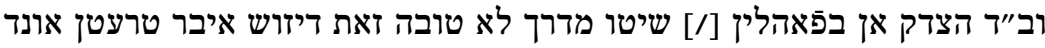

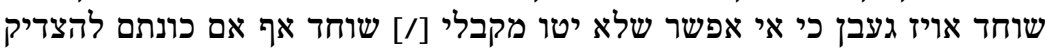

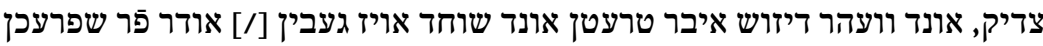

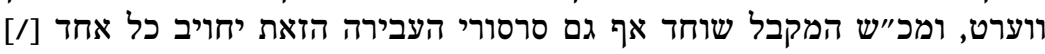

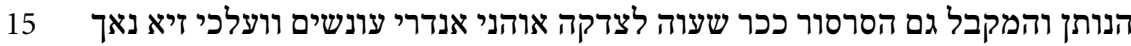

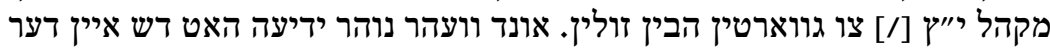

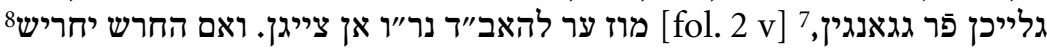

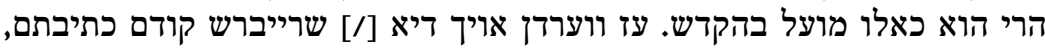

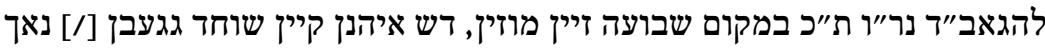

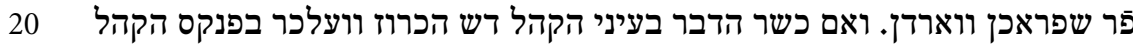

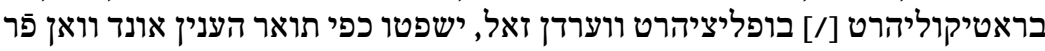

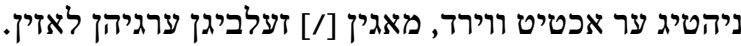

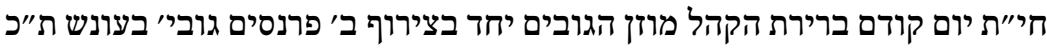

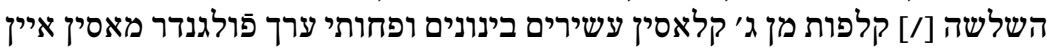

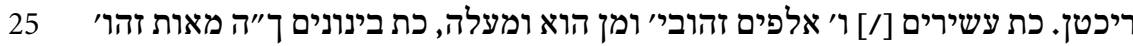

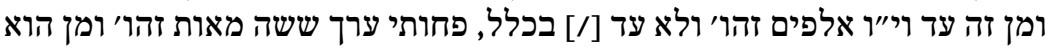

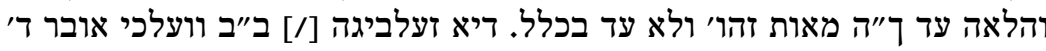

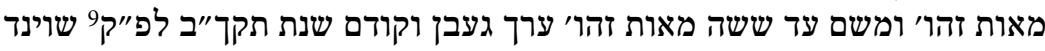

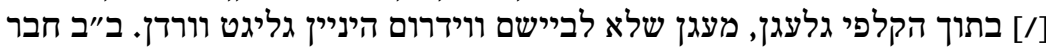

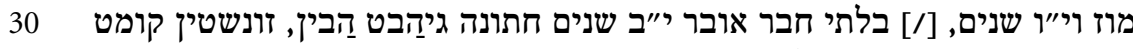

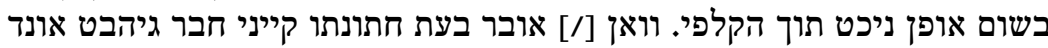

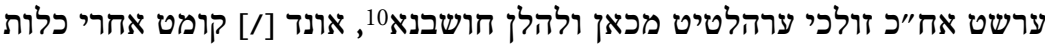

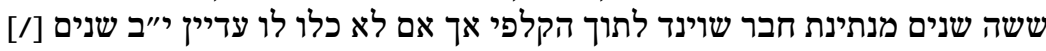

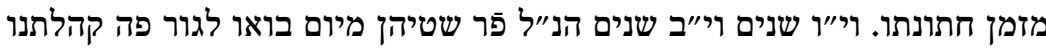

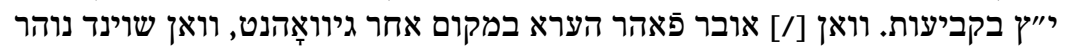

7 Danach die Kustode מוז.

8 Num 30,15.

9 1761/62.

10 Rechnung (aram.). 
אצל אביו או חמיו בחוץ לקהלתנו זיך [/] קאשט בדיהנט האט, לאור לא יבואו שנים

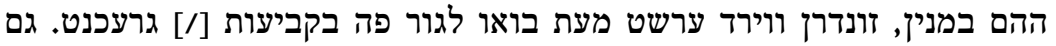

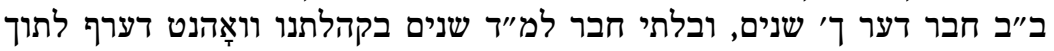

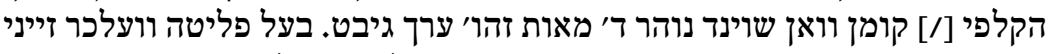

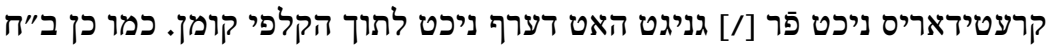

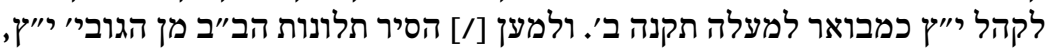

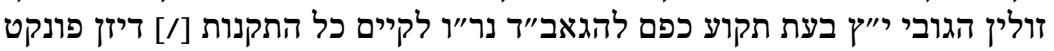

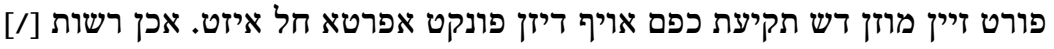

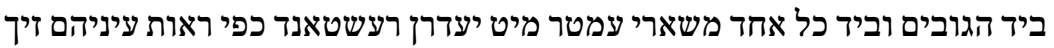

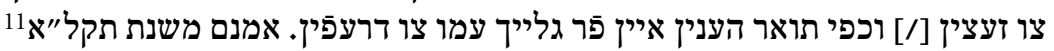

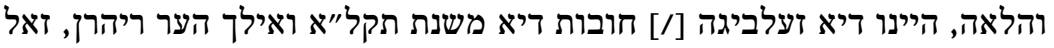

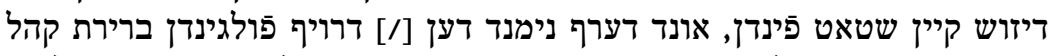

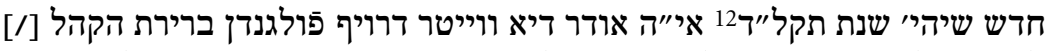

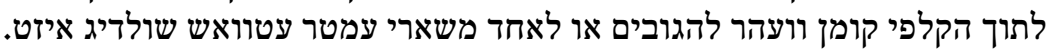

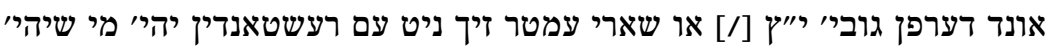
דיזר וועגן פָר גלייכן.

עז זולין אויך הגובים י"ץ התמניות צעטיל פָר פערדיגן לאזין, אשר שם מסיר ירשמו ה'

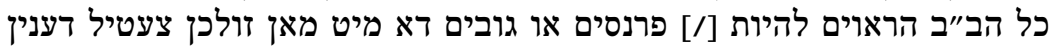

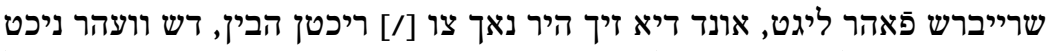

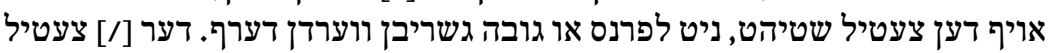

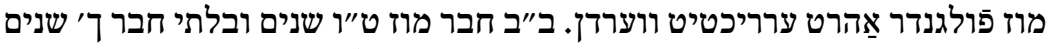

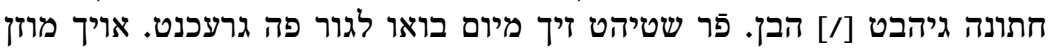

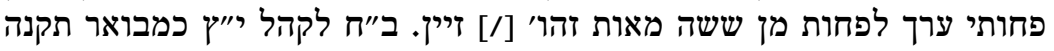

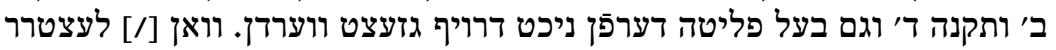

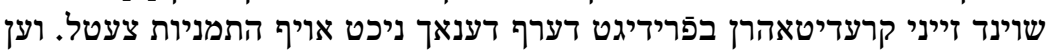

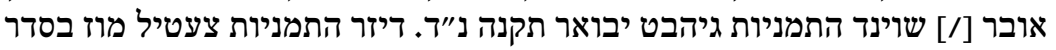

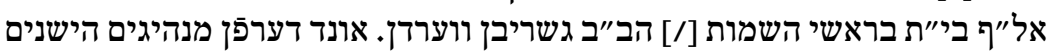

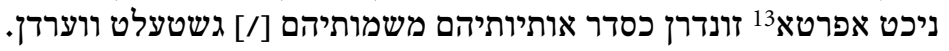

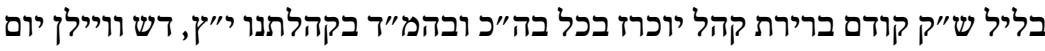
ןייו"ן

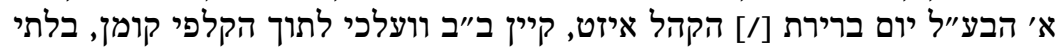

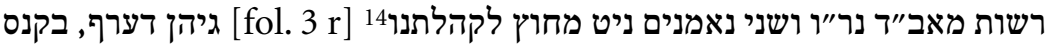

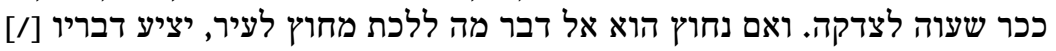

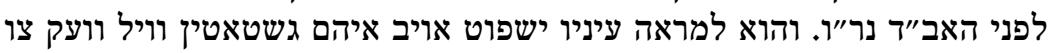

\footnotetext{
$11 \quad 1770 / 71$.

12 1773/74.

13 Getrennt, extra.

14 Danach die Kustode גיהן.
} 


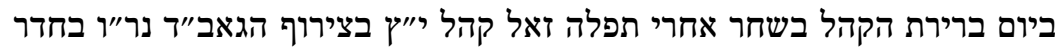

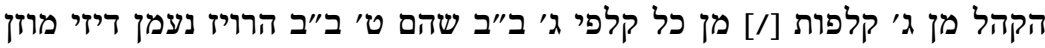

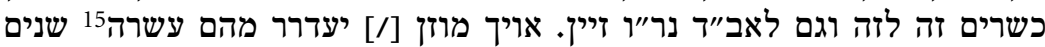

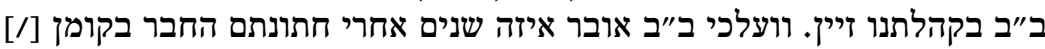

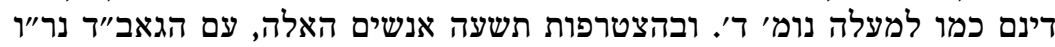

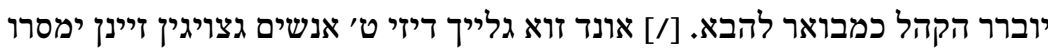

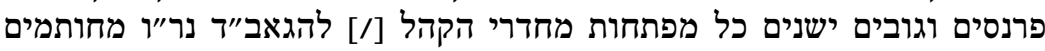
כנזכר לעיל נומרא א' וילכו לביתם לשלום.

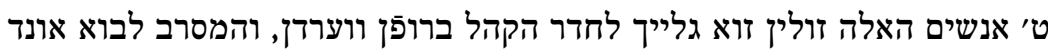

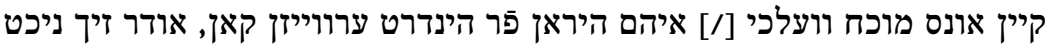

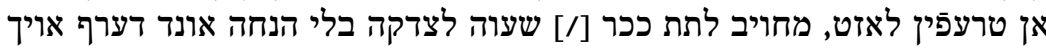

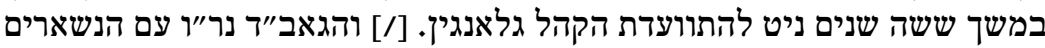

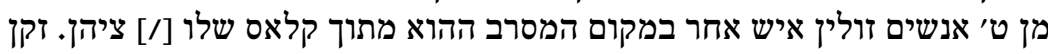
בן שבעים שנה, ומי שאינו יכול לעלות ברגליו פטרור במורים

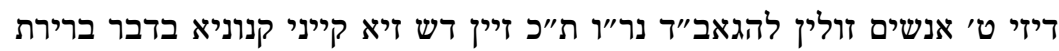

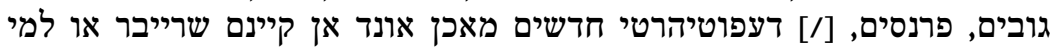

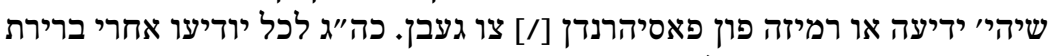

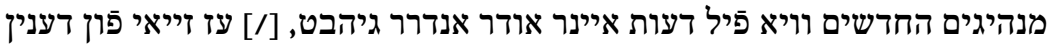

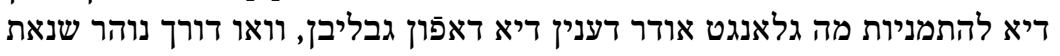

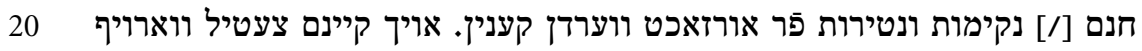

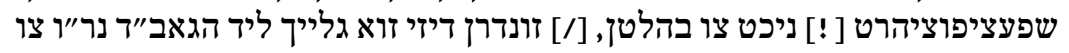

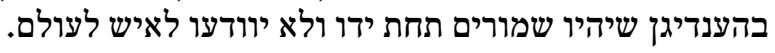

עז זולין שני נאמני הקהלה וגם שלשה חזנים לברירת הקהל בדיהנט ווערדן, היינו

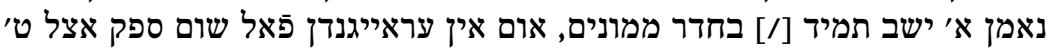

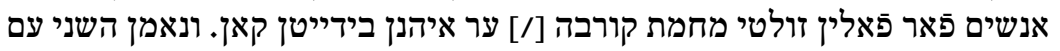

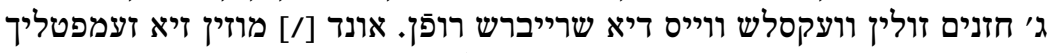

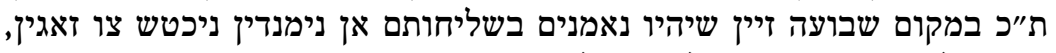

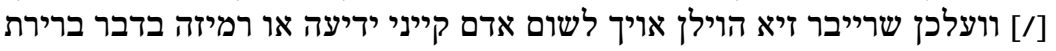

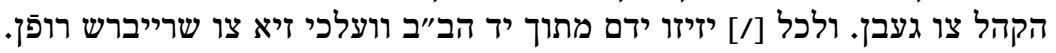

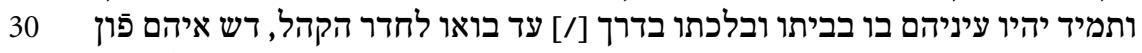

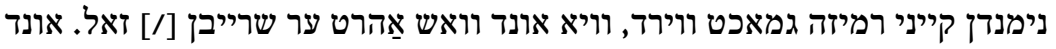

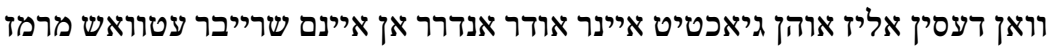

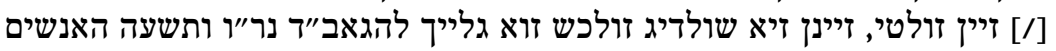

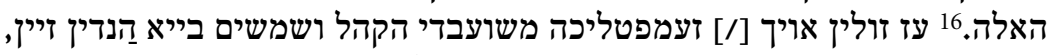

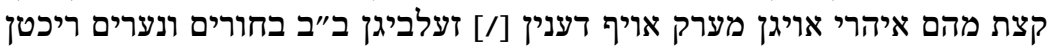

15 Lesung unsicher wegen beschädigtem Papier.

16 Der Satz bleibt unvollendet. Es müsste noch folgen: צו מעלדן. 
זולין בחצר בית הכנסת הין אונד הער גיהן, וישוטטו כמרגלים. [/] זולין השמשים

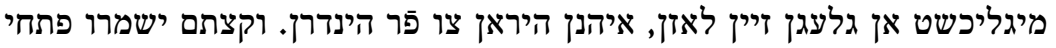

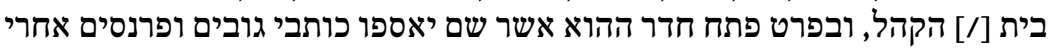

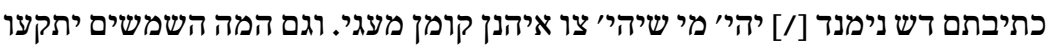

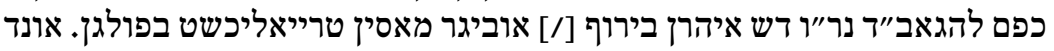

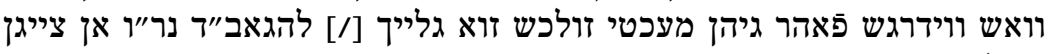
וואלן אונד מוזץ.

עז זאל אובר הקהל חדש בשטיהן ג׳ גובים, י"א פרנסים אשר שנים מהפים מהם יקראו

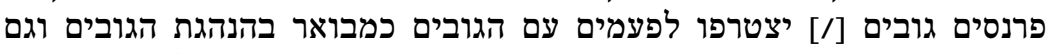

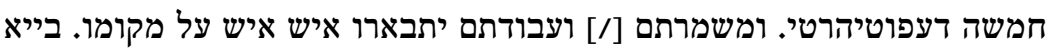

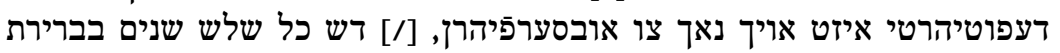

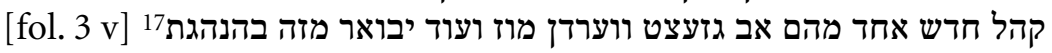

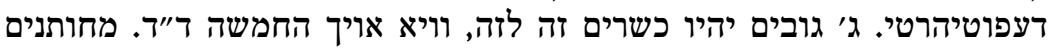

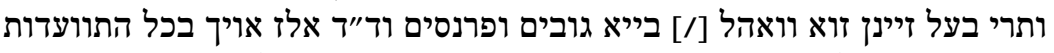

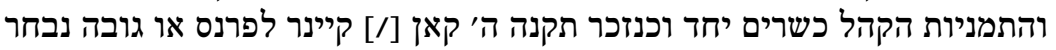

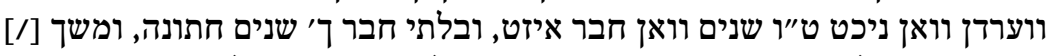

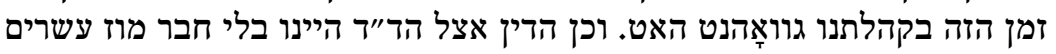

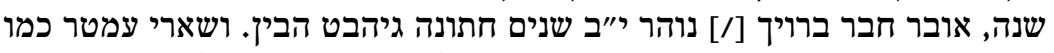

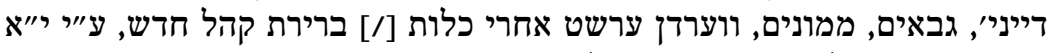

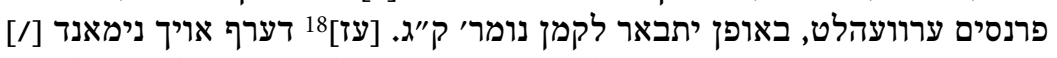

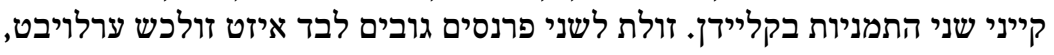

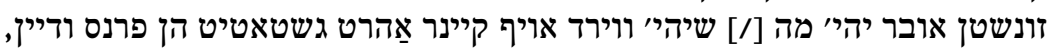

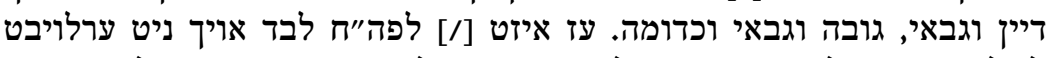
לשלשה הגובי' להתוועדות הקהל צו ברופן אם לא בהסכמת רוב הקהל.

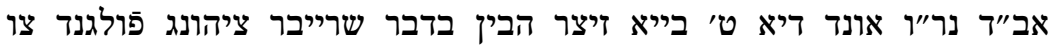
$Z^{\prime \prime}$ 25

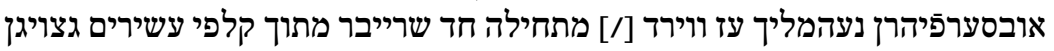

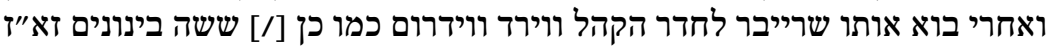

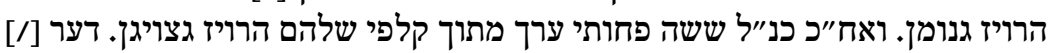

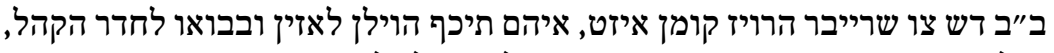

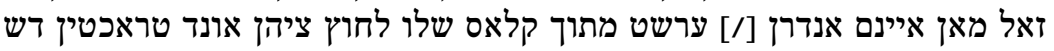

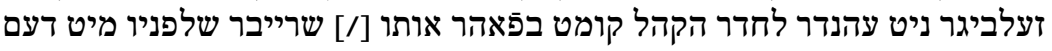

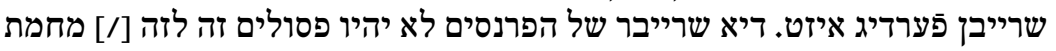

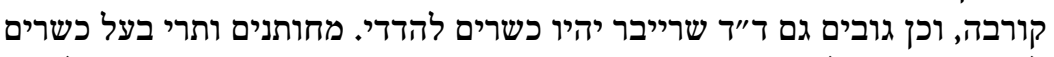

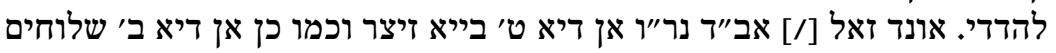

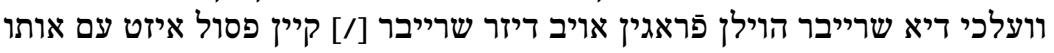
שלפניו ושלפני פניו, ולחקור בדבר זה בקול נמוך דש אותו שריית דייבר בחדר הירו הקהל

$\aleph^{\prime \prime \prime}$

17 Danach die Kustode 7 "ד, auf der folgenden Seite jedoch ausgeschrieben.

18 Beschädigtes Papier. 


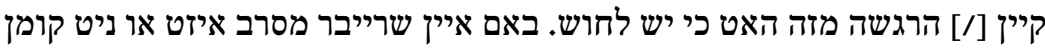

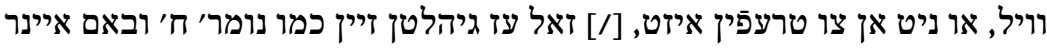

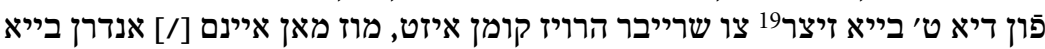

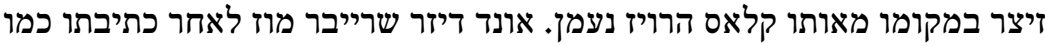

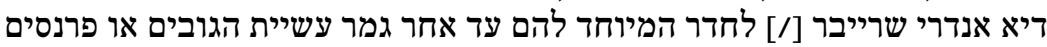

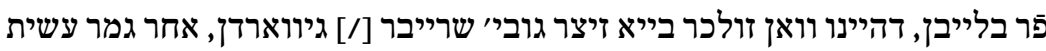

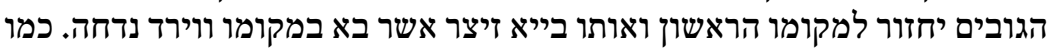

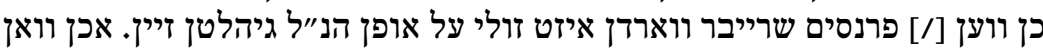

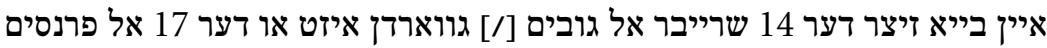

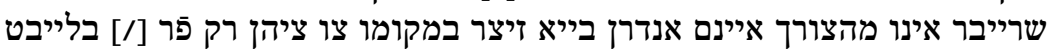

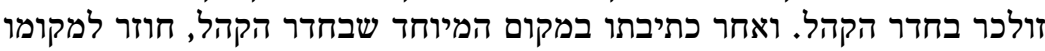

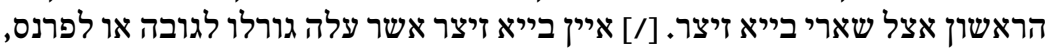

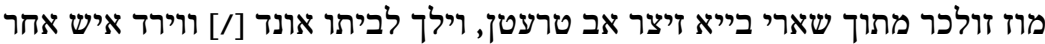

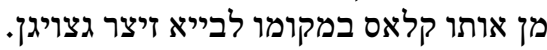

הגאב"ד נר"ו יאיים על כל שרייבר שיכון דעתו לשמים בכותבו, ויענה בפניו י

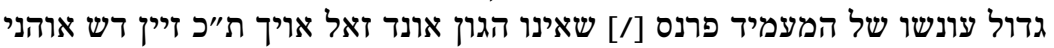

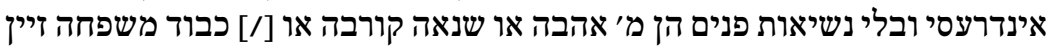

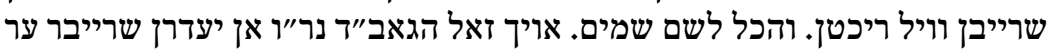

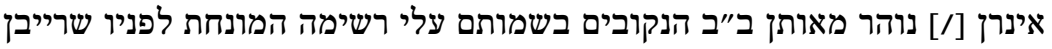

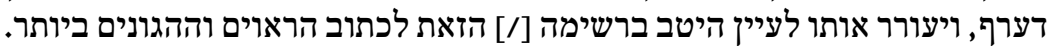

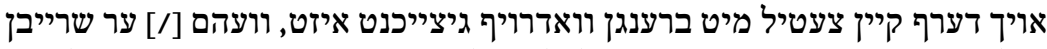

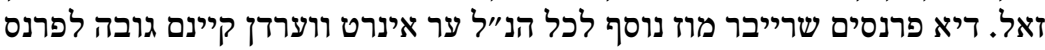

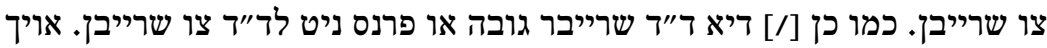

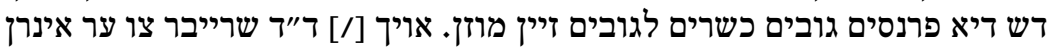

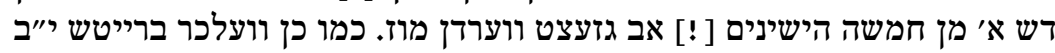
שנים בייא [/] זיינם אמש הישינים גוועזן.

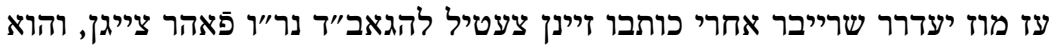
י"ד

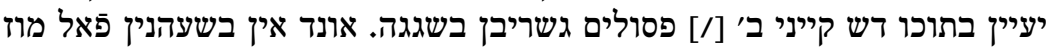

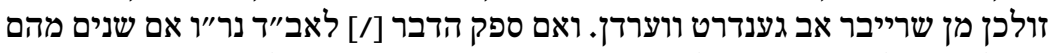

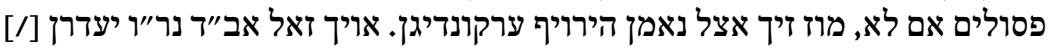

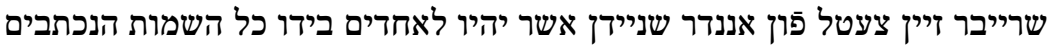

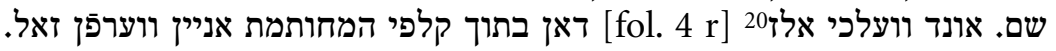

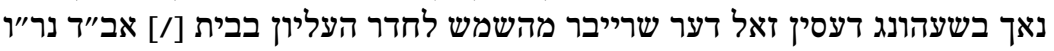

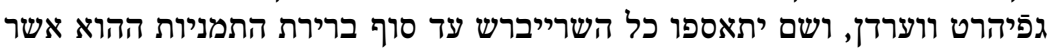

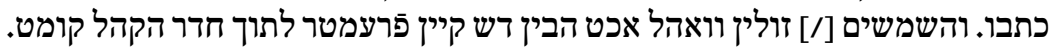

19 Hier bedeutet das Wort tatsächlich »Beisitzer«, während es später als Bezeichnung für »Beisasse« genutzt wird.

20 Danach die Kustode דאן. 


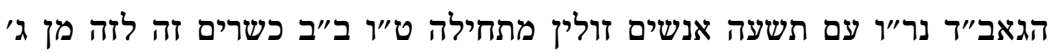
ט"ו

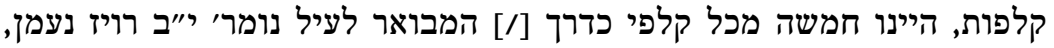

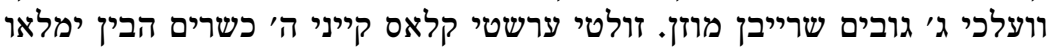

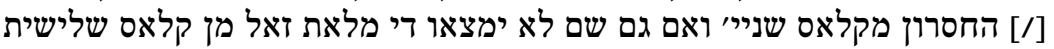

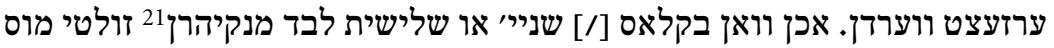

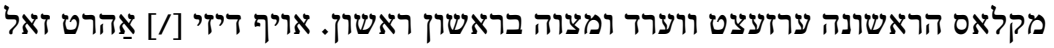
אויך בכל התוועדות גיהלטן זריין.

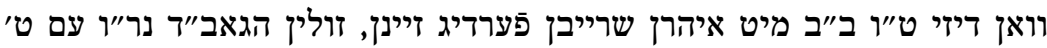

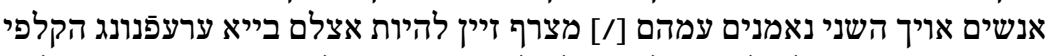

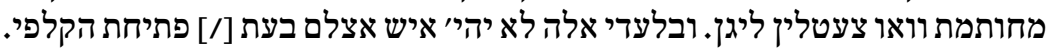

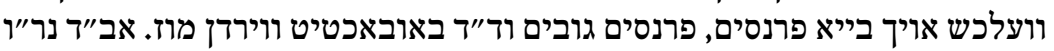

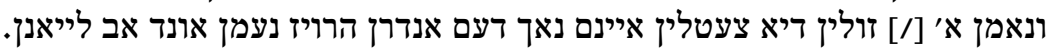

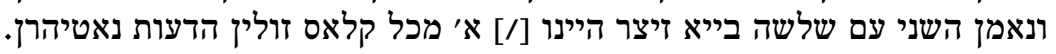

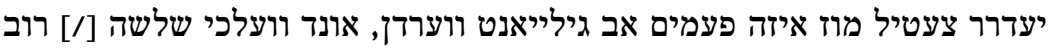

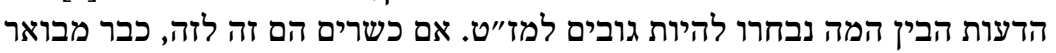

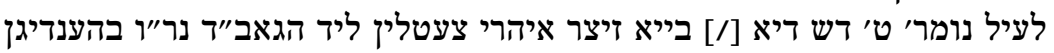

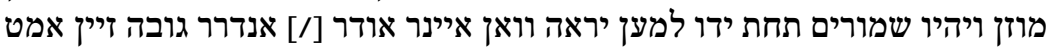

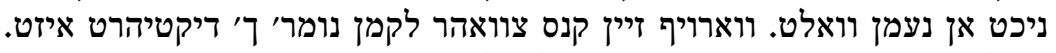

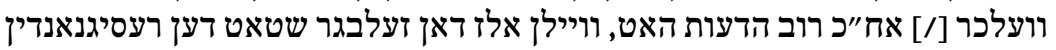

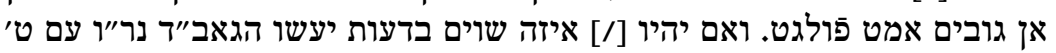

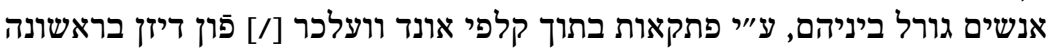

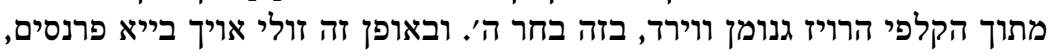

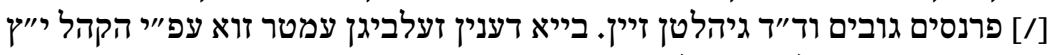

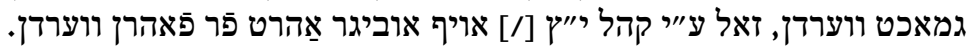

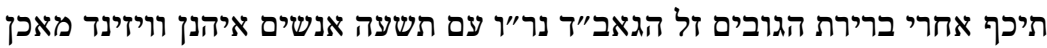

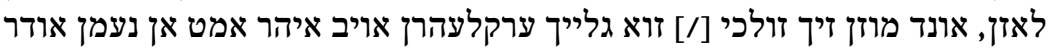

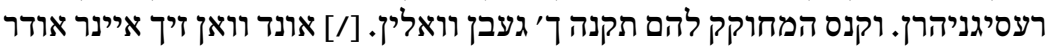

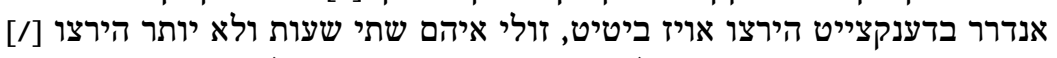

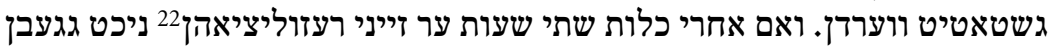

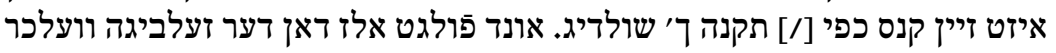
ט"ט

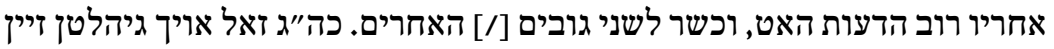

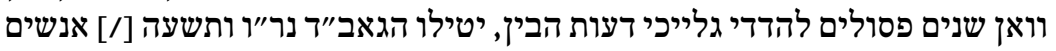

$$
\text { גורל ע"י פתקאות כנ"ל. }
$$

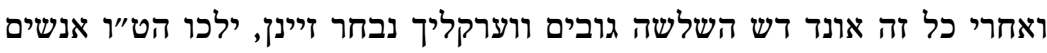
$\Pi^{\prime \prime}$

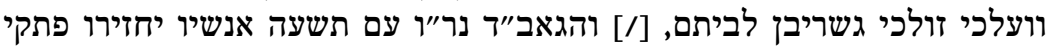

21 mankihrn, abgeleitet von frz. manquer $=$ fehlen.

22 rezolutsyohn $=$ Resolution, Entscheidung. 
השרייברש לתוך קלפותיהם הראוים אונד אלז דאן זולין י"חיח שרייברש [/] באופים יכופן

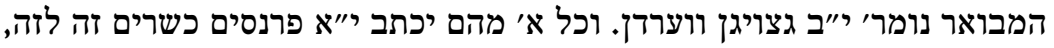

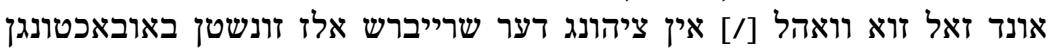

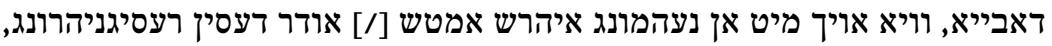

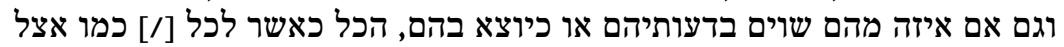

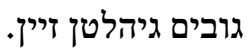

אחרי גמר ברירת הגובים והפרנסים יטילו מתוך הגורל שבעה פרנסים והמים והמה יכתבו

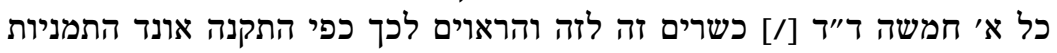

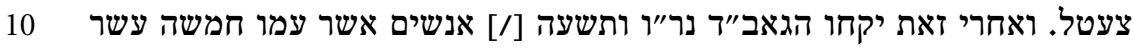

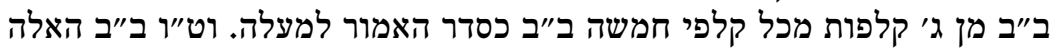

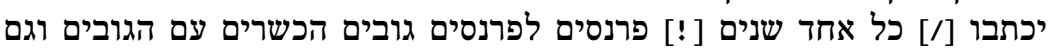

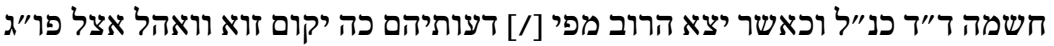

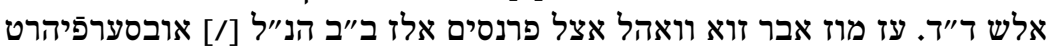

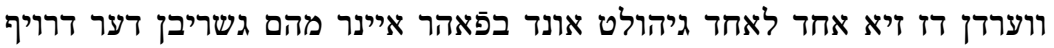

פולגנדי [/] ניכט גהולט ווערד לאחד דערף.23 [fol. $4 \mathrm{v}$ ]

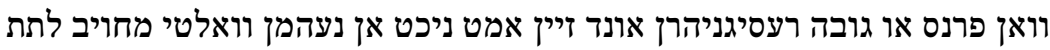

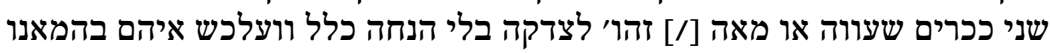

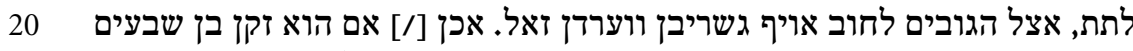

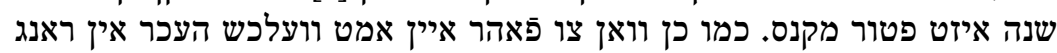

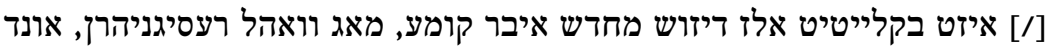

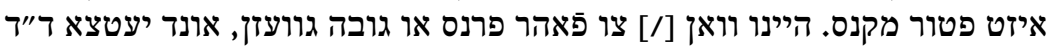

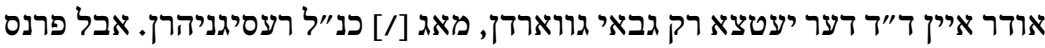

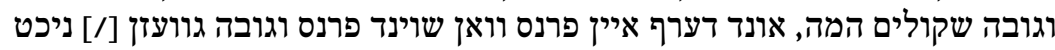

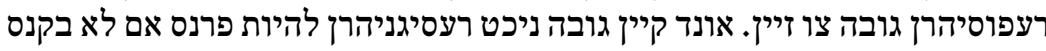

כנ"ל.

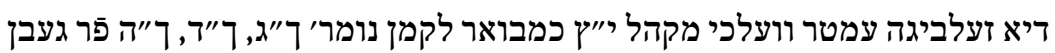

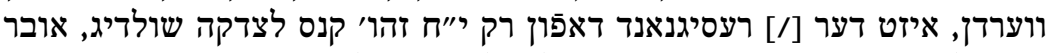

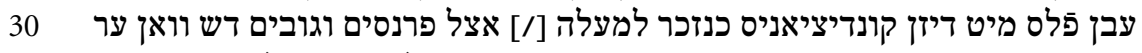

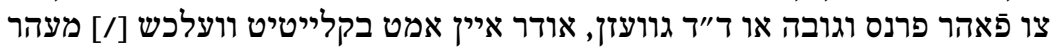

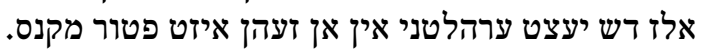

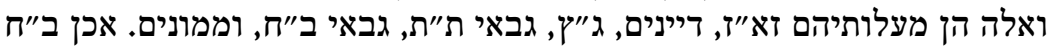

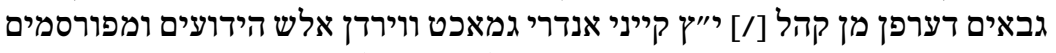

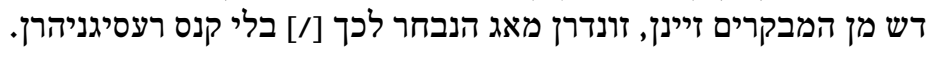

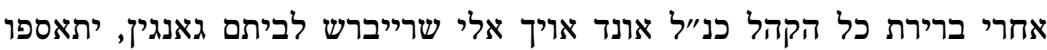

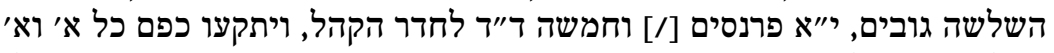

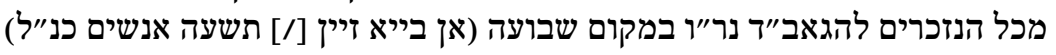

23 Danach die Kustode וואן. 


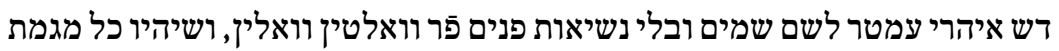

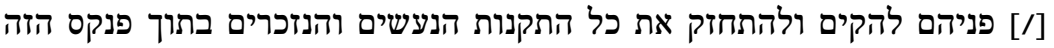

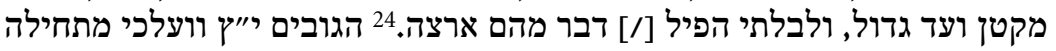

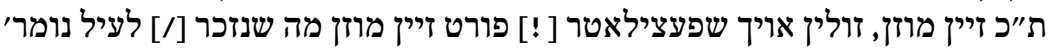

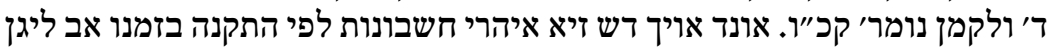

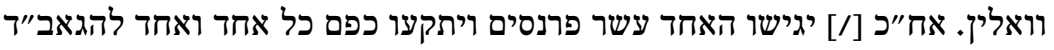

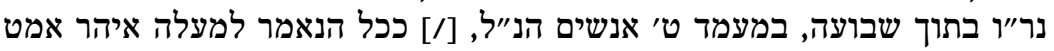

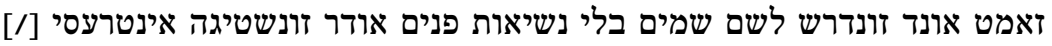

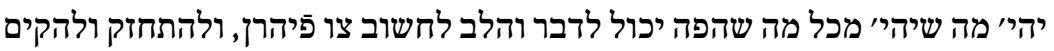

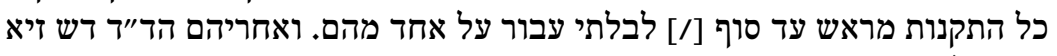

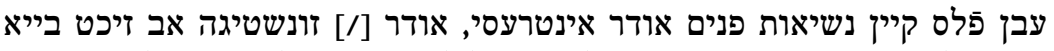

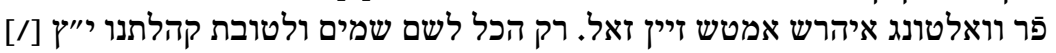

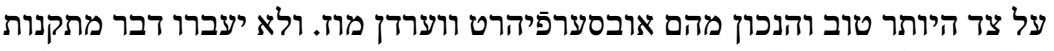

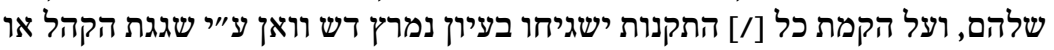

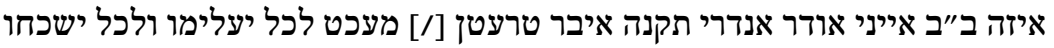

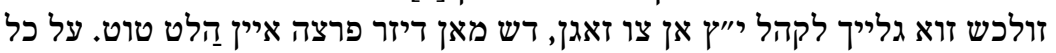

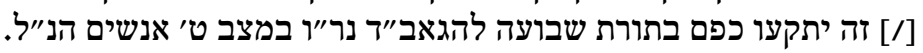

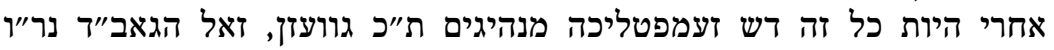

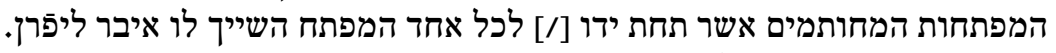

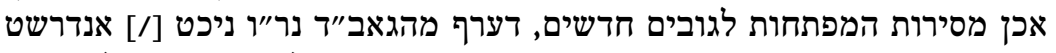

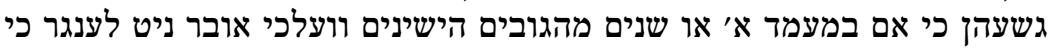

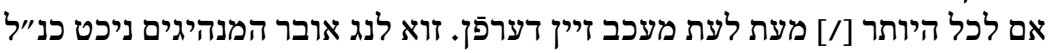

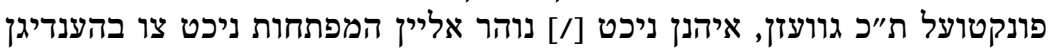

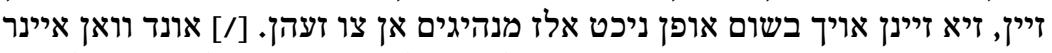

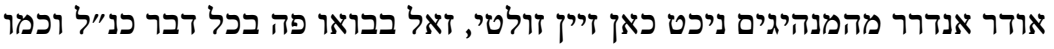

בתקנה [/] ך’ גיהלטין מהמיגים זיכטין.

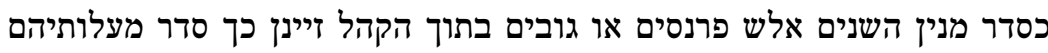

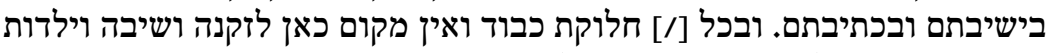

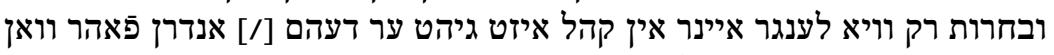

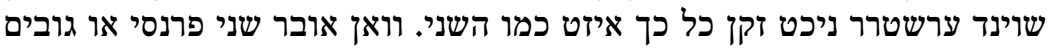

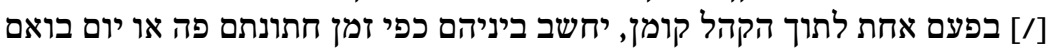

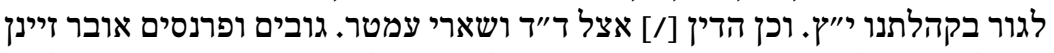

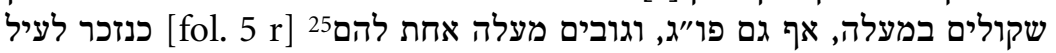
נומר' ך' מוז אלזוא כנ"ל אוב פובסערפיהרט ווערדן.

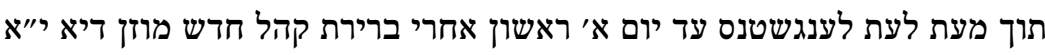

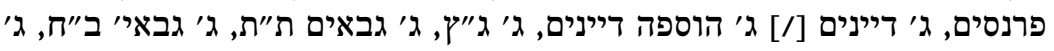

24 Nach 1 Sam 3,19.

25 Danach die Kustode כנזכר. 


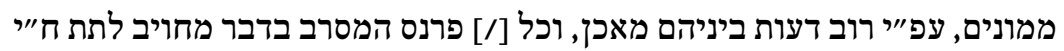

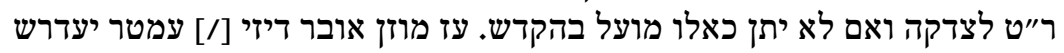

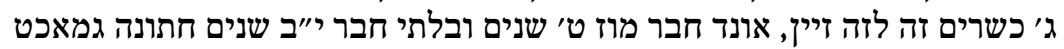

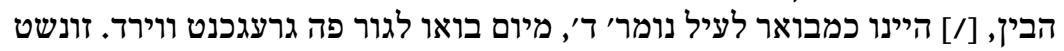

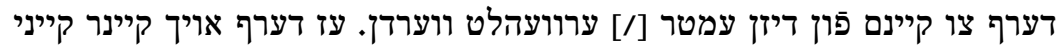

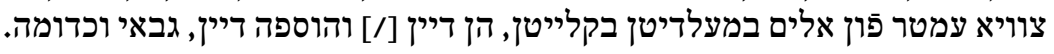

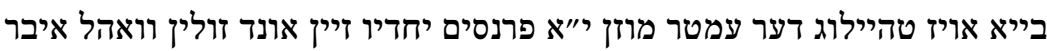

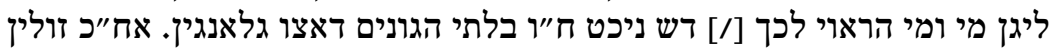

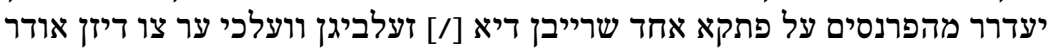

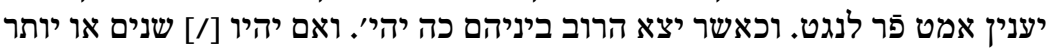

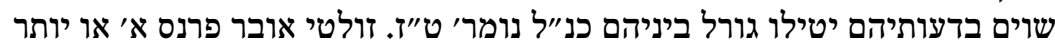

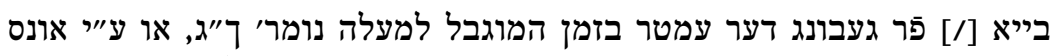

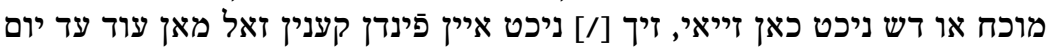

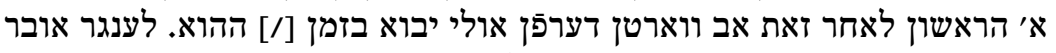

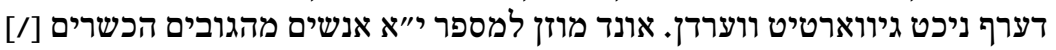

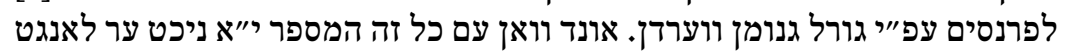

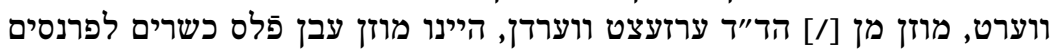

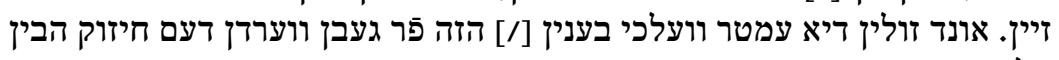
אלז וואן ע"וי י"א פרנסים גמאכט ווער ווערדן ווארדן.

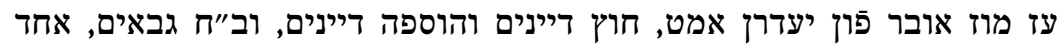
כ"ה

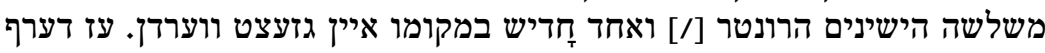

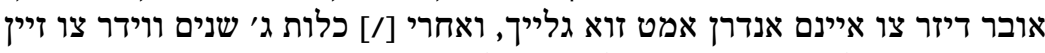

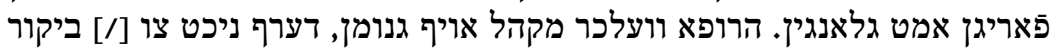
חולים גבאי גמאכט גלאנגין.

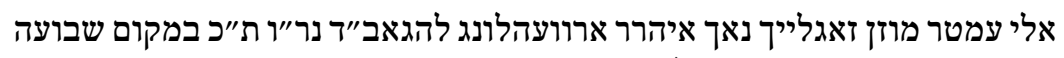

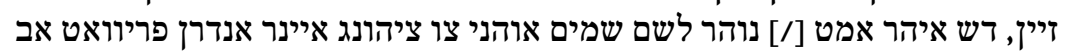

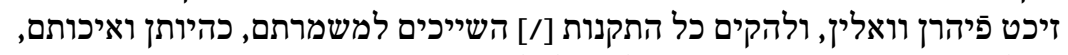

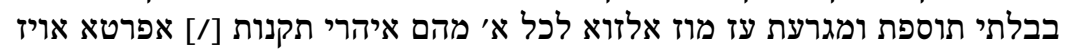

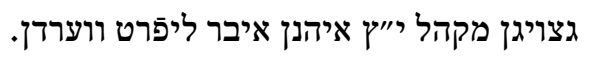

אחרי ברירת הקהל זולין פרנסים כנהוג פרנס החודש מאכן אונד אייני אורי אורדינונג

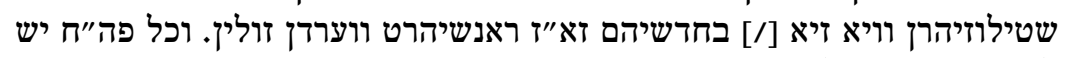
לו רשות בחדשו לאסוף הפרנסים מתי שירצה.

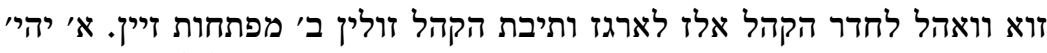
כ" כ

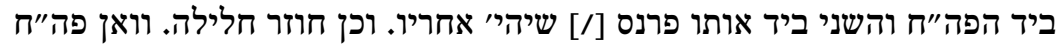

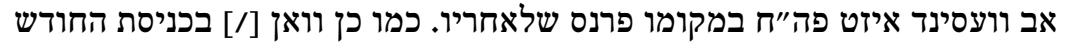

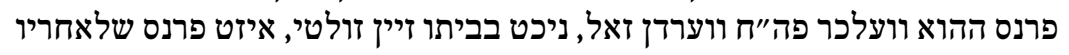


פה"ח. [/] אונד וואן זאלכש חדש רצוף בלי הפסק דויארט, גיהט עז ווייטר אויטר אין

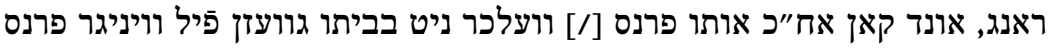

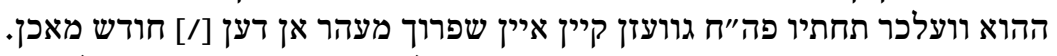

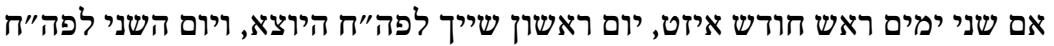

$$
\text { הנכנס.26 }
$$

כל יום א׳ אחרי תפלת השחר מוז הפה"ח קהל צו זאמן ביהטן לבוא לתוך חדר כ"ט

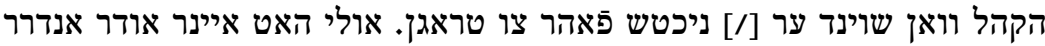

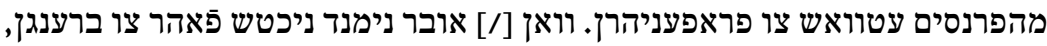

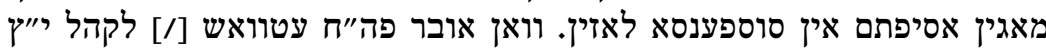

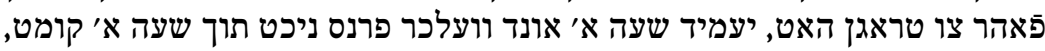

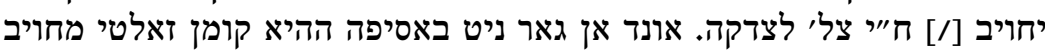

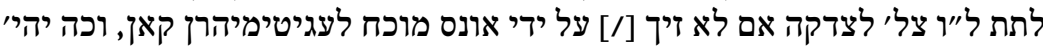

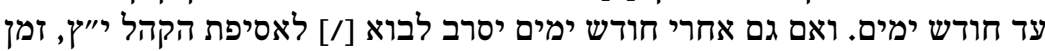

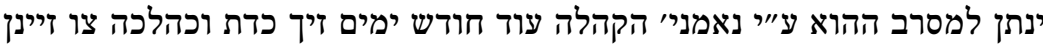

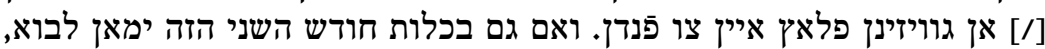

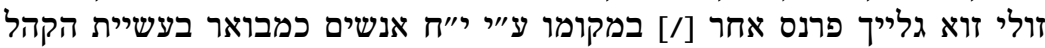

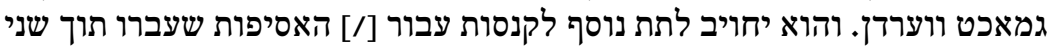

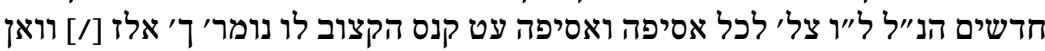

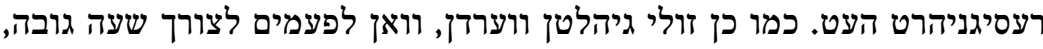

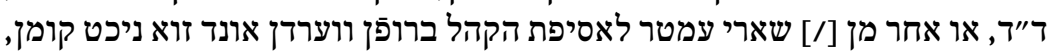

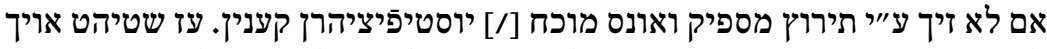

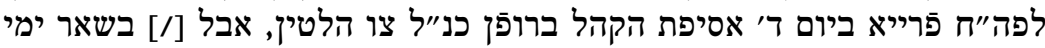

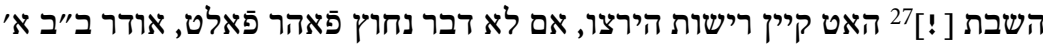

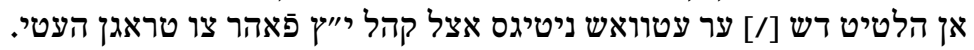

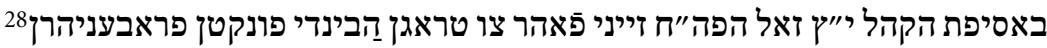

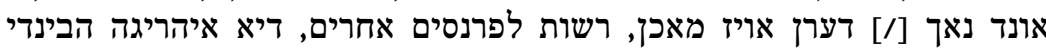

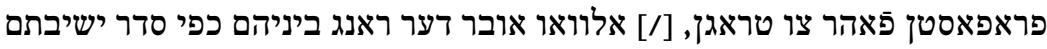

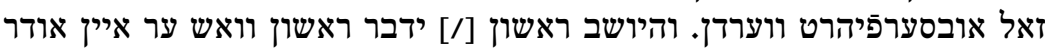

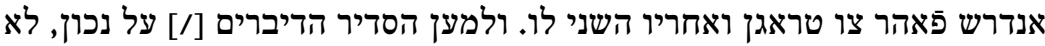

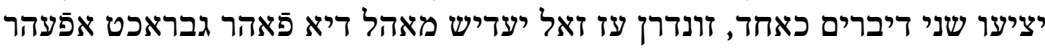

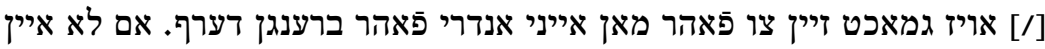

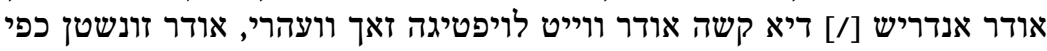

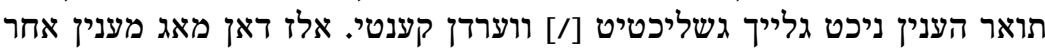
כסדר הנ"ל גשפראכן אונד דעל גלייך גשליכטיהרט ווערדן.

\footnotetext{
26 Danach die Kustode כל.

27 Gemeint ist wohl: השלוע.

28 Prävenieren, hier: vortragen.
} 


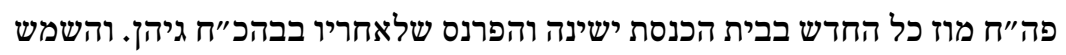

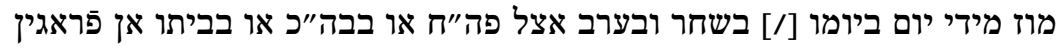
אויב עטוואש בענייני הקהלה צו בפעהלין זייאי

וואן פה"ח עטוואש בפעהלן וואלטי, ושנים [!] מנהיגים פָאר ראטזואהם בפינדן ל"ב

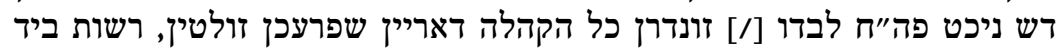

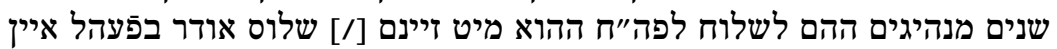

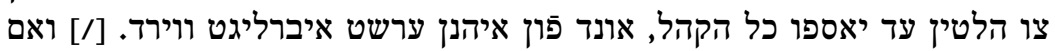

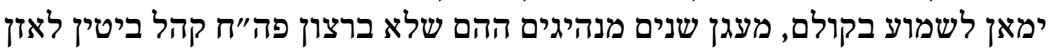

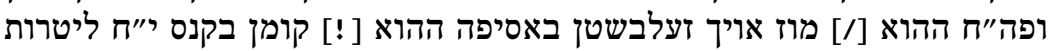
שעוה לצדקה וואו אלז דאן דער שלוס [/] מקהל י"י"ץ אב גיווערדיט וועי בועדן מוז.

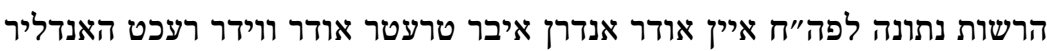

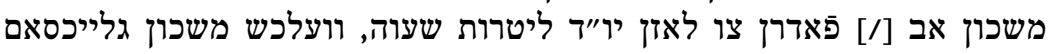

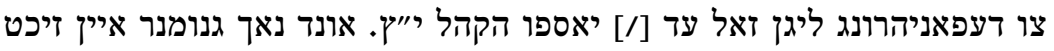

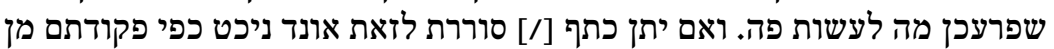

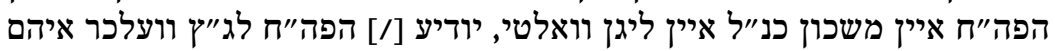

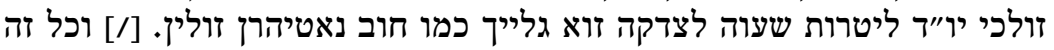

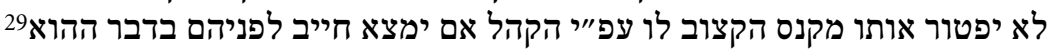

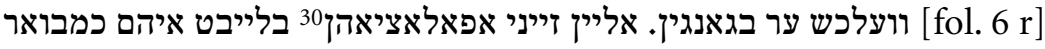

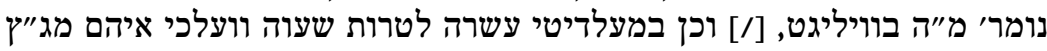

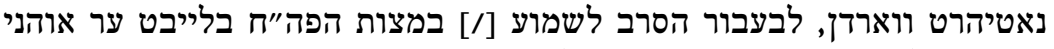

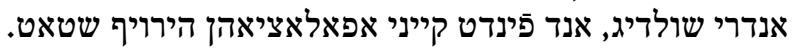

פה"ח מאג לעני אורח הגון ובן טובים שני זהו', שני פה"ח אוביח אובר ג' זהו' מקופת

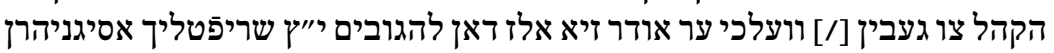

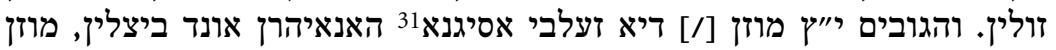

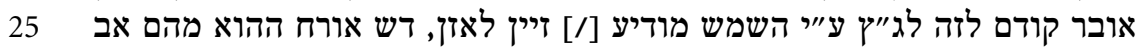

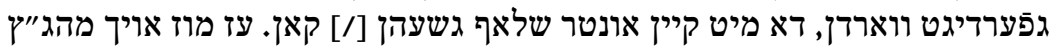

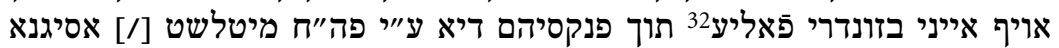

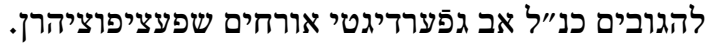

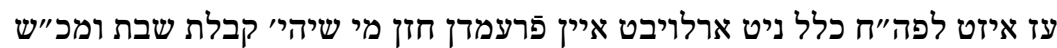

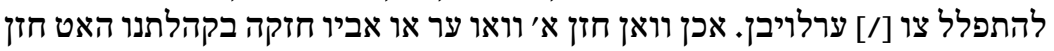

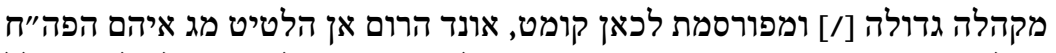

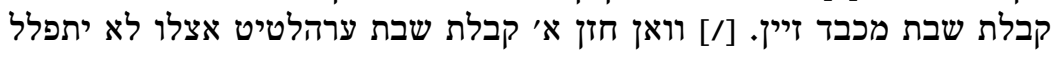

29 Danach die Kustode וועלכש.

30 Appellation.

31 Assignation $=$ Anweisung.

32 Von frz. feuille $=$ Blatt. 


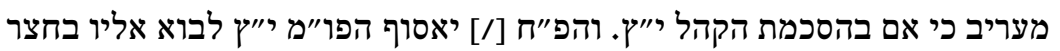

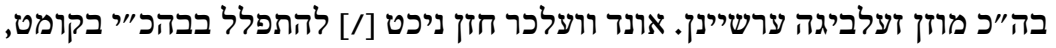

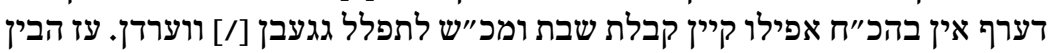

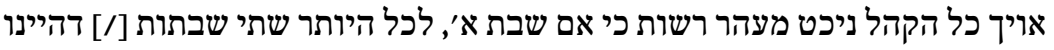

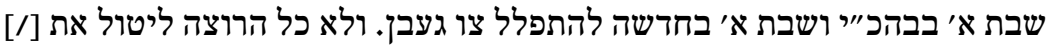

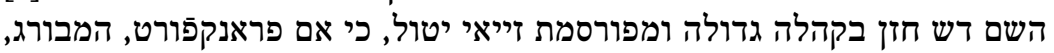

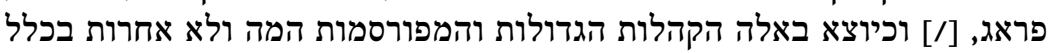

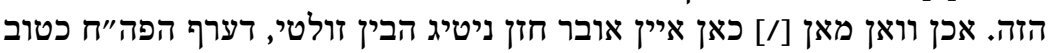

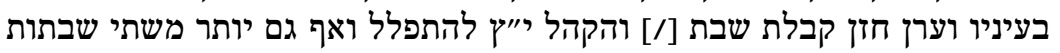

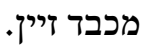

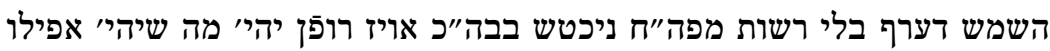

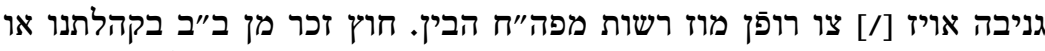

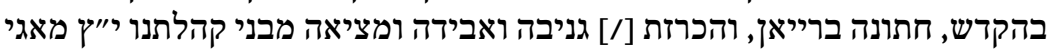
בלי רשיון מפה"ח אויז גרופכן ווערדן.

עז דערף קייני שבועה הן מב״ב בקהלתנו או מאיש אחר כאן אב גנומן ווערדן

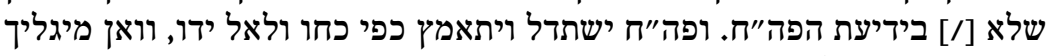

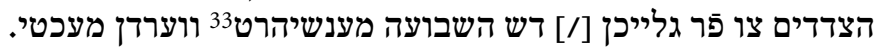

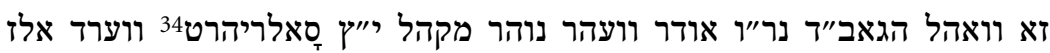

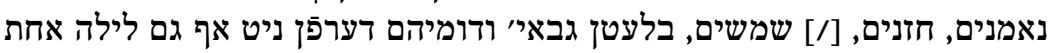

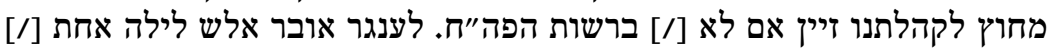

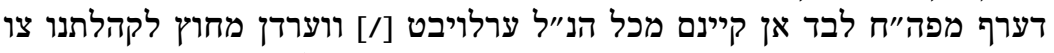

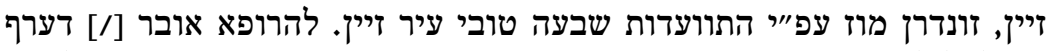
אפילו לילה אחת ניכט אנדרשט כי אם עפיות שבעי התוועי עירות שבעה טובי העיר ערובר ערויבט דער

ווערדן.

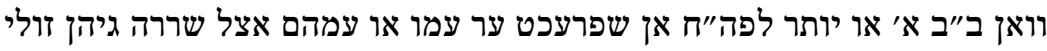
25

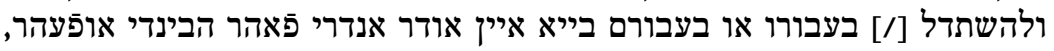

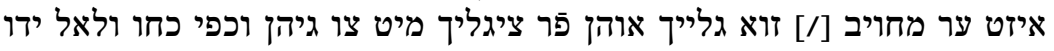

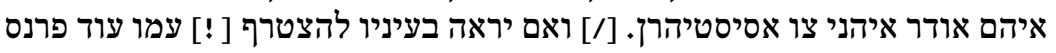

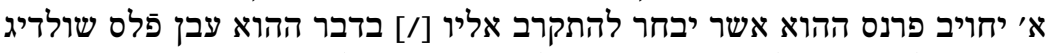

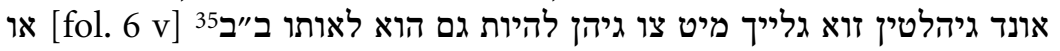
ל ל 15

ל ל

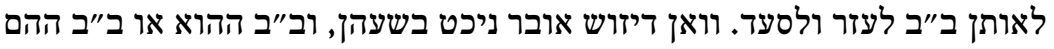

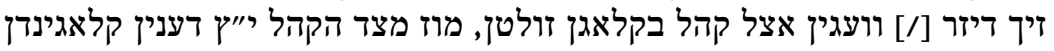

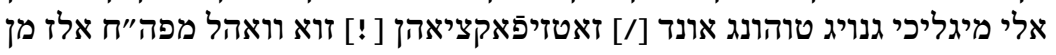

\footnotetext{
33 Von frz. ménager = ersparen.

34 Von frz. salarier = bezahlen, besolden.

35 Danach או als Zeilenfüller.
} 


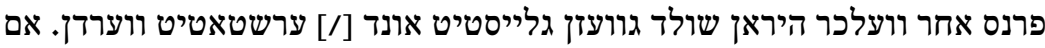

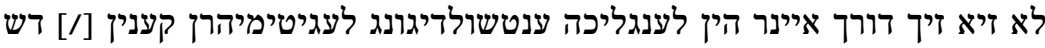

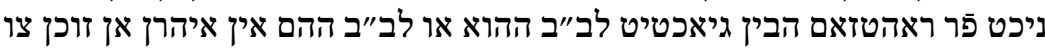

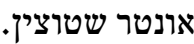

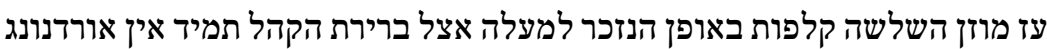
מו"ם

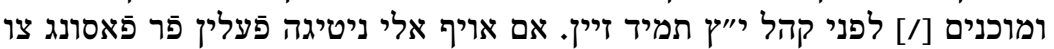

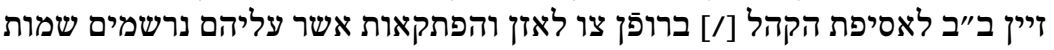

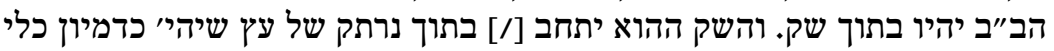

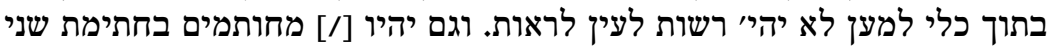

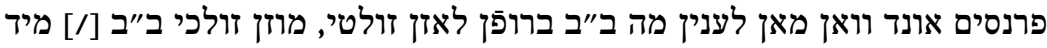

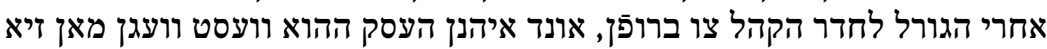

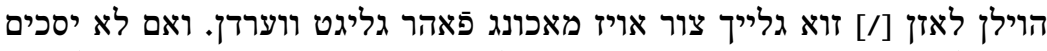

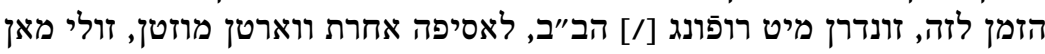

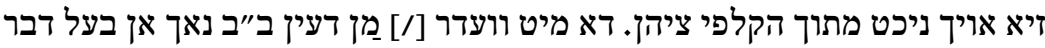

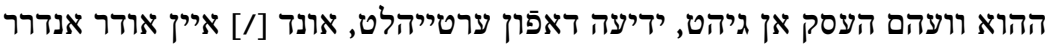

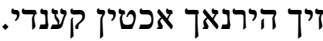

עז דערף אצל קהל י"ץ בשום דבר קיין שלוס מיט ווינקל דעות6י גמאכט ווערדן.

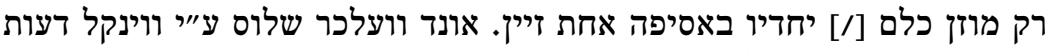

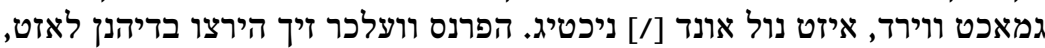

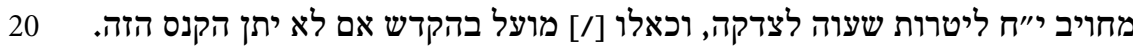

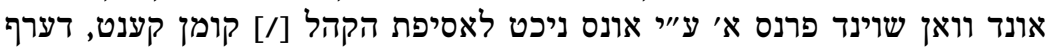

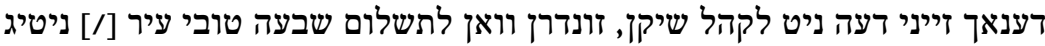

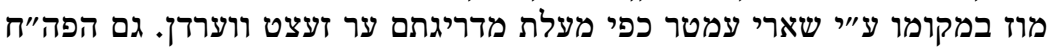

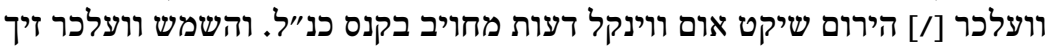

וואן איין אודר אנדרר פרנס או מנהיג מן פרנס אחר או מאיזה מהפיר מהם או גם מכולם

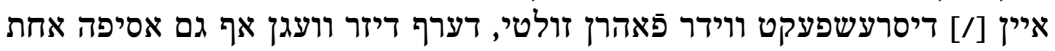

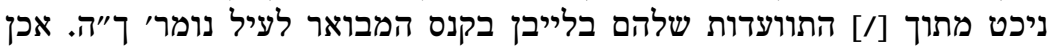

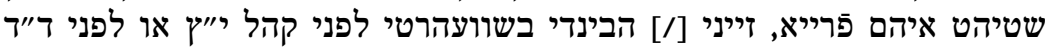

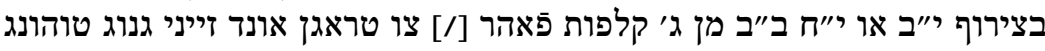
(וואן איהם אנדרשט דער גלייכן כפי ראות עינית פותם צות צו קומט) [/] מהם ער ווארטן.

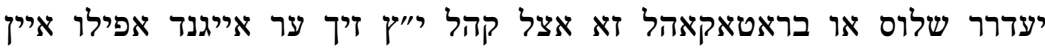
מו"ג

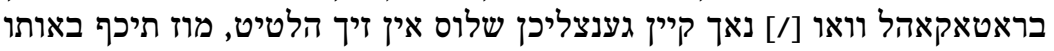

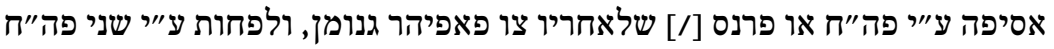

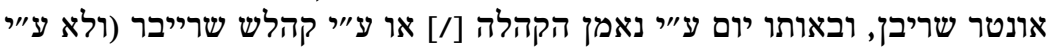

36 In Abwesenheit durch Dritte übermittelte Meinung in einer Angelegenheit. 
פה"ח) בתוך פנקס הפראטאקאהל המיוחד לכך איין [/] גטראגן ווערדן בהעתקת

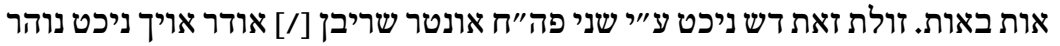

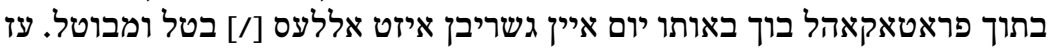

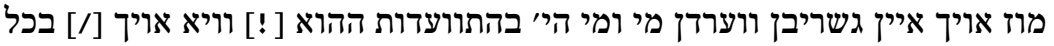

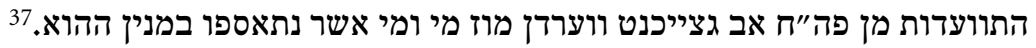

עז קען אצל קהל קיין התוועדות גיהלטן פַיל וויניגר איין שלוס אודר בראטאקאהל [fol. $7 \mathrm{r}$ ]

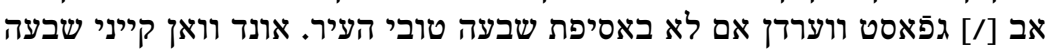

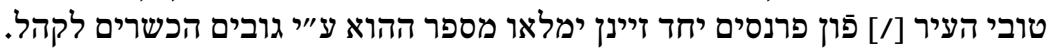

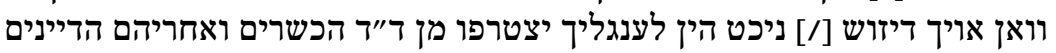

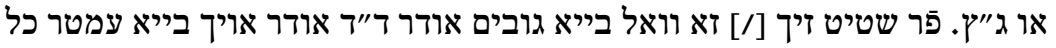

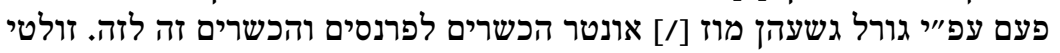

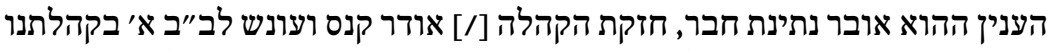

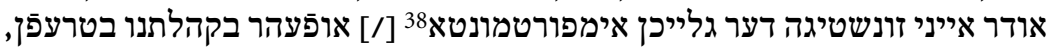

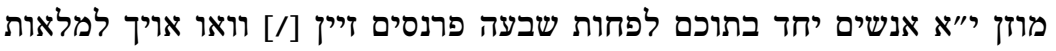
מוד

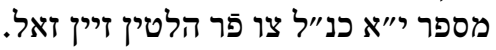

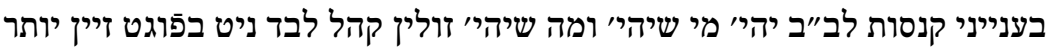
מו"ה

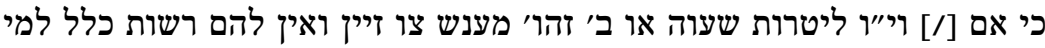

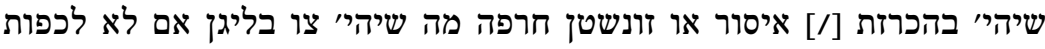

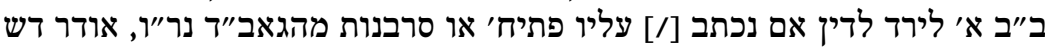

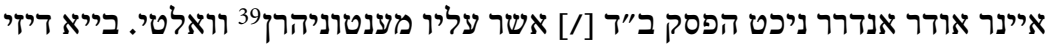

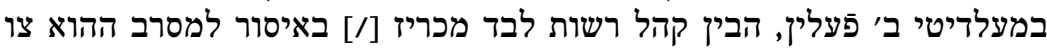

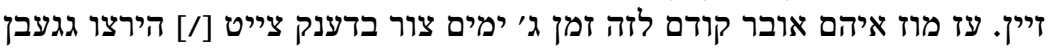

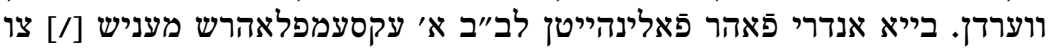

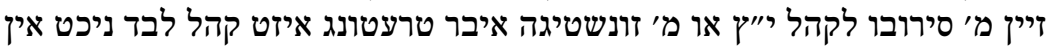

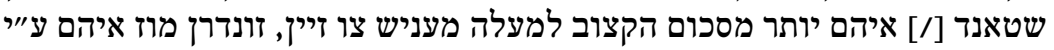

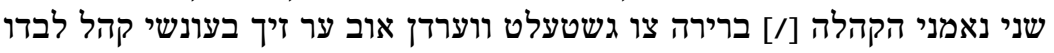

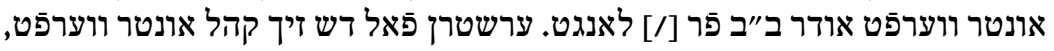

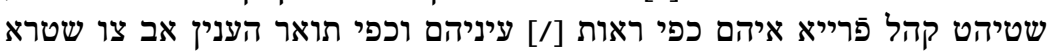

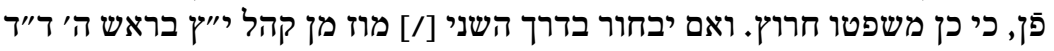

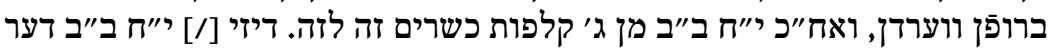

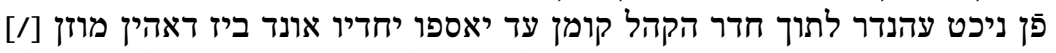

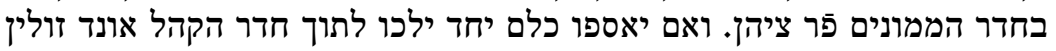

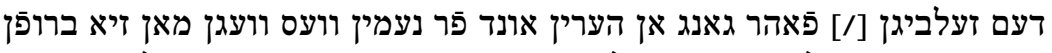

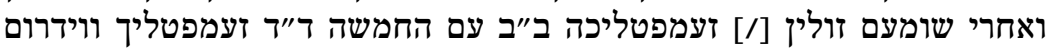

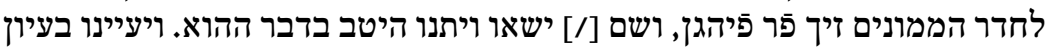

37 Danach die Kustode עז.

38 Von frz. important = bedeutend.

39 Von frz. maintenir $=$ aufrecht erhalten. 


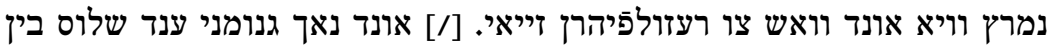

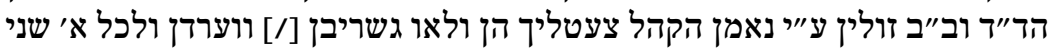

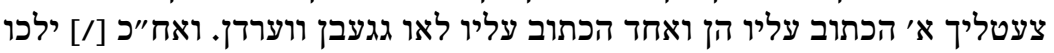

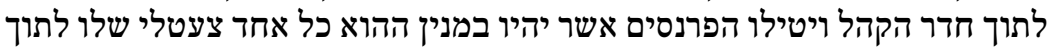

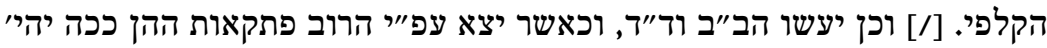

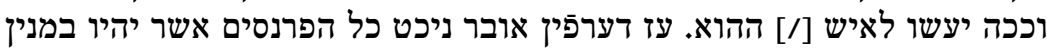

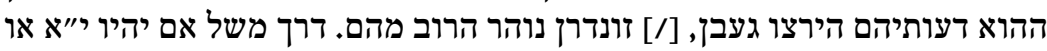

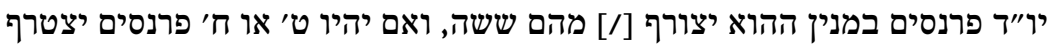

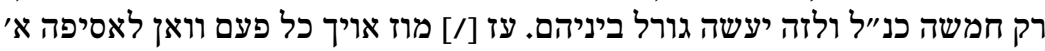

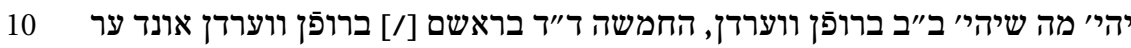

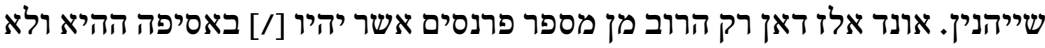

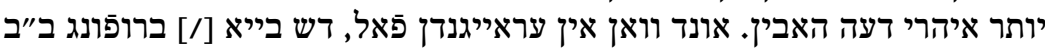

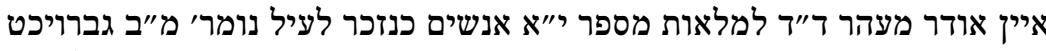

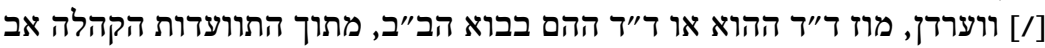

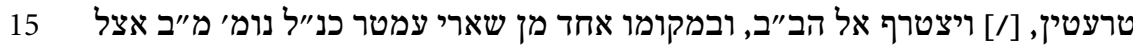
קהל למלאות סכום [/] ברופן ווערדן.

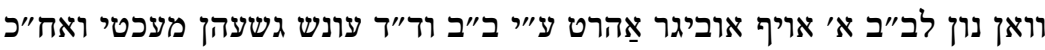
[fol. $7 \mathrm{v}$ ]

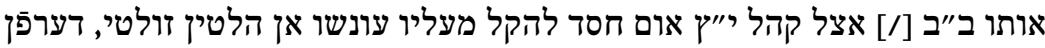

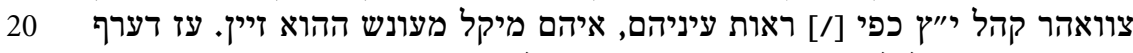

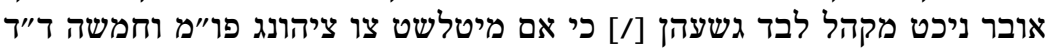
גשעהן. וכאשר יצא עפ"י רוב מן פרנסים [/] מנהיגים ודים מיד כה יקום.

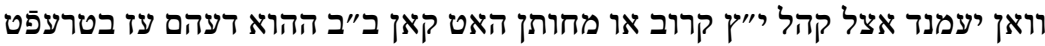

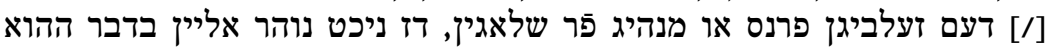

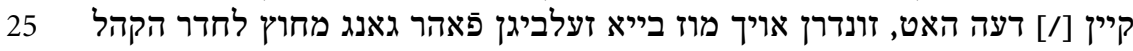

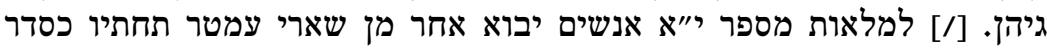

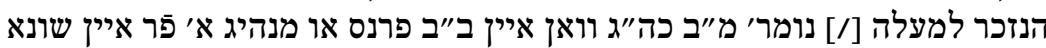

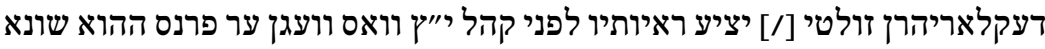

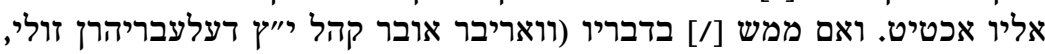

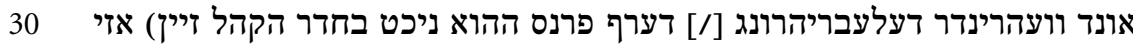

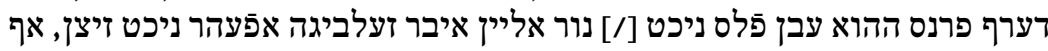
גם יהי' מחוץ לחדר הקהל זוא לאנג דיא [/] אופעהר פאיין פאהר גיהט.

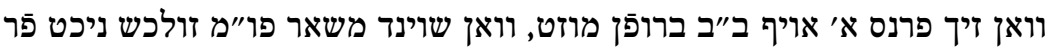

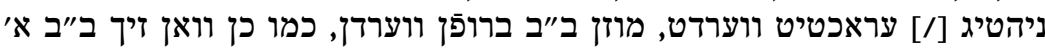

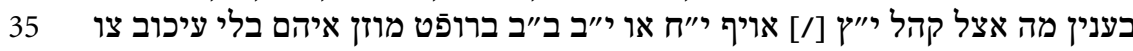

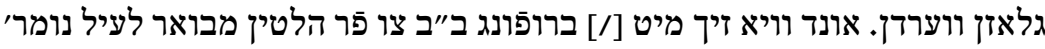

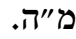

40 Danach die Kustode וואן. 


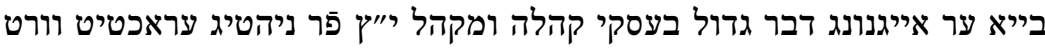
מ"ט

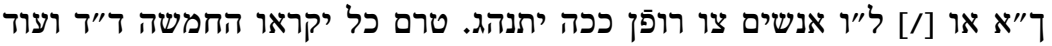

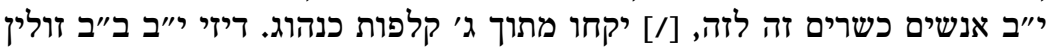

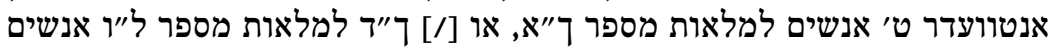

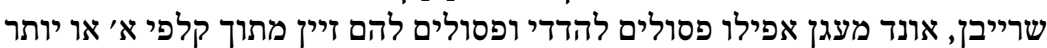

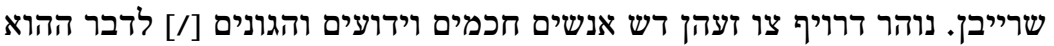

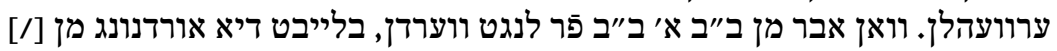
ג' קלפות אוהן אבגענדרט. ורוא.

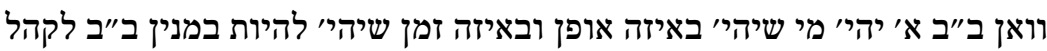

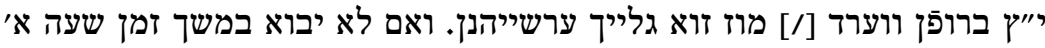

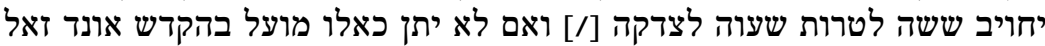

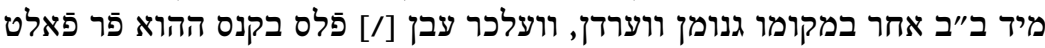

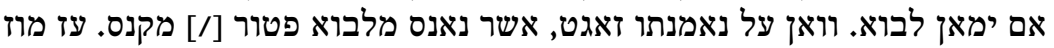

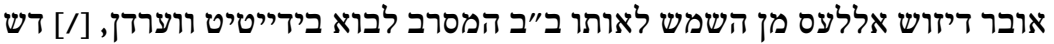

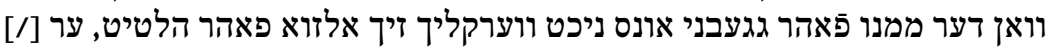

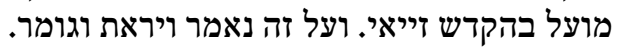

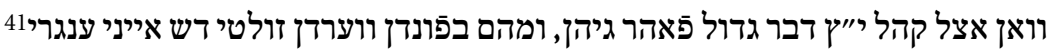

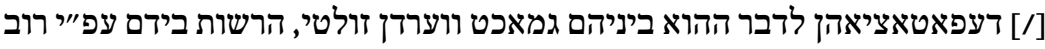

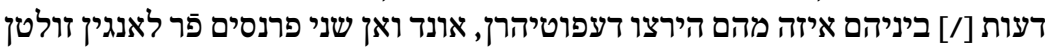

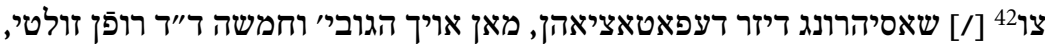

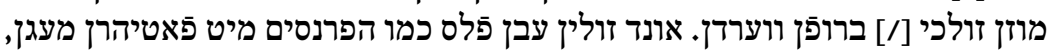

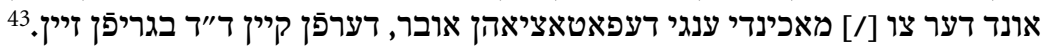

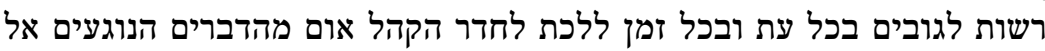

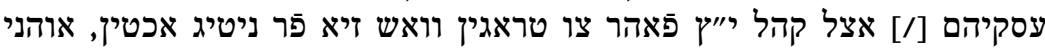

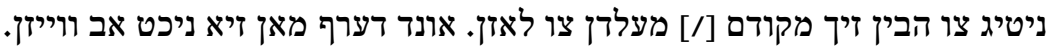

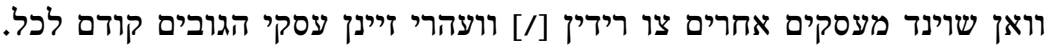

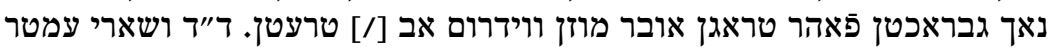

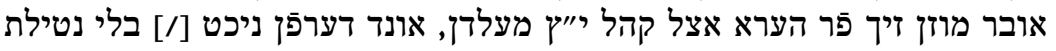

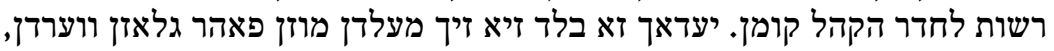
נ"א

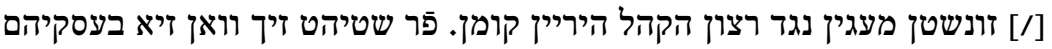

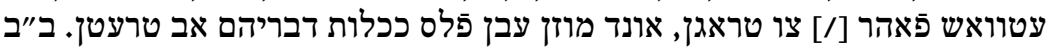

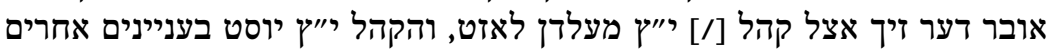

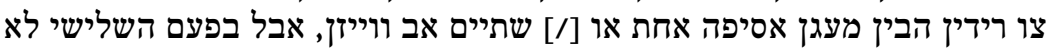

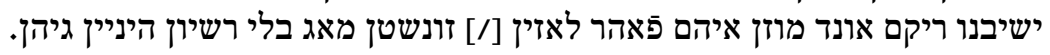

41 Danach ד als Zeilenfüller.
42 Danach ש als Zeilenfüller.
43 Danach die Kustode רשות. 
וואן ב״ב א׳ פה על חברו אייני תביעה הבין זולטי, ואח״כ ער איואי איהם חוב איין

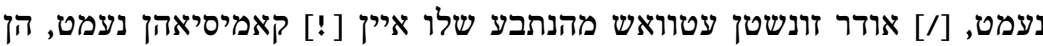

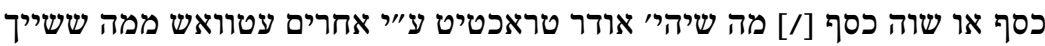

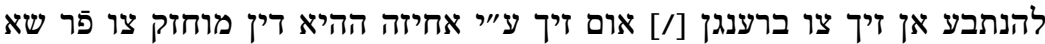

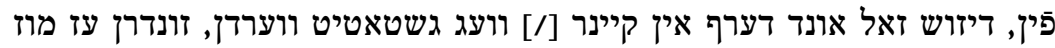

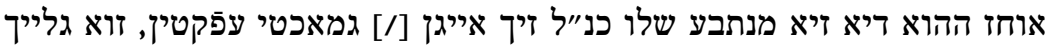

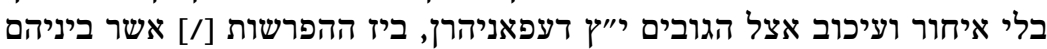

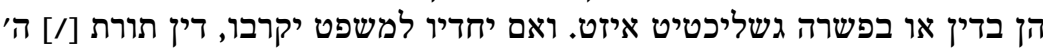

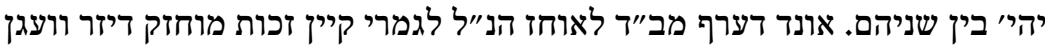

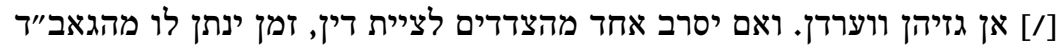

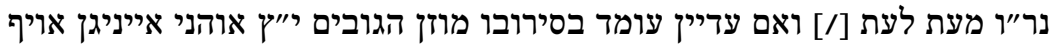

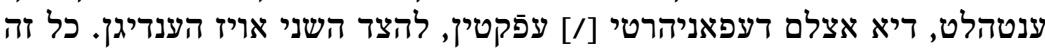

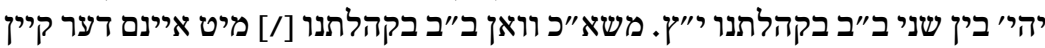

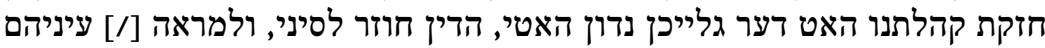

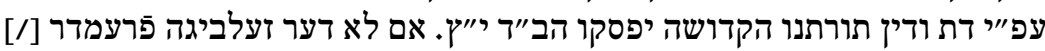

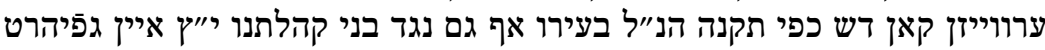

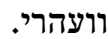

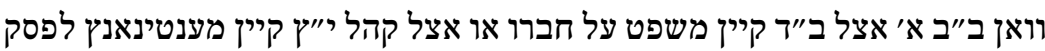

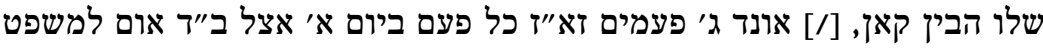

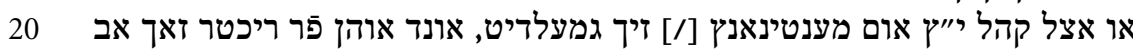

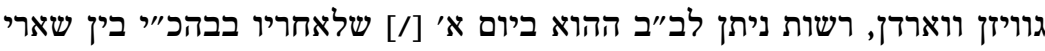

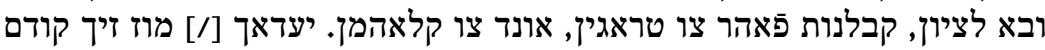

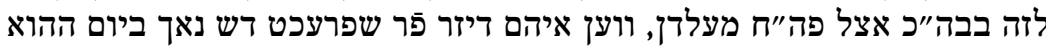

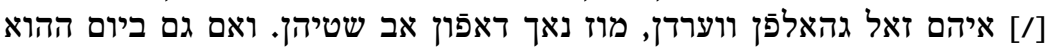

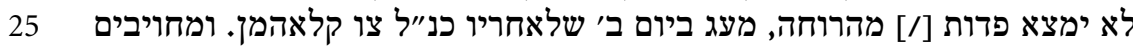

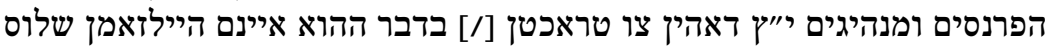

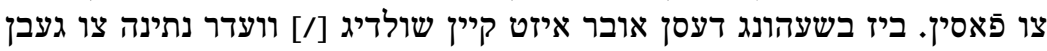

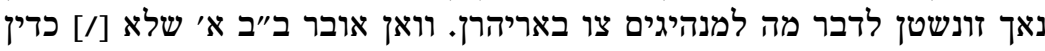

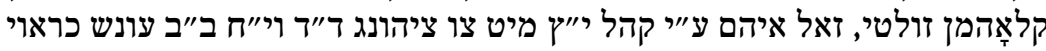

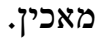

עז זאל אן יעדרן אמט בקהלתנו י"ץ איהרי אינשטרוקאציאהן [!"] כפי התקנות נ"ה

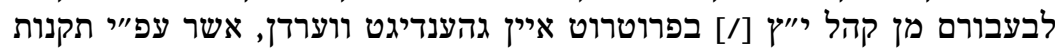

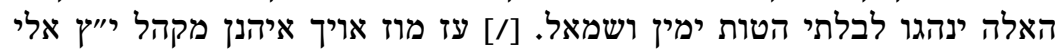

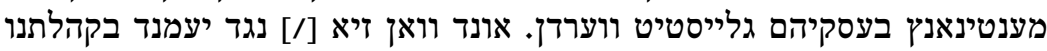

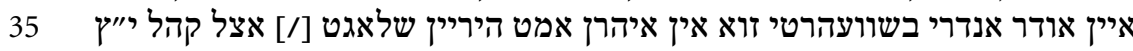
אן ברענגן מוז בלי נשיאת פנים דש גריכטואיאמי איתרן אויז גפייהרט ווערדן.

44 Danach die Kustode פרנס. 
פרנס או גובה או ד"ד או באמטר וועלכר בעל פליטה ווערדן אדר פַאלוטיהרץ נ"נ

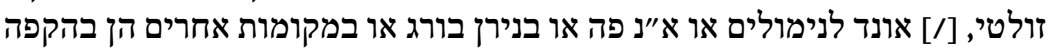

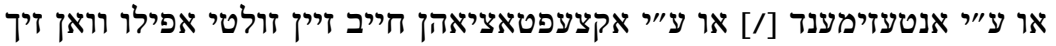

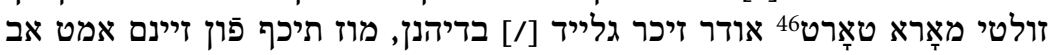

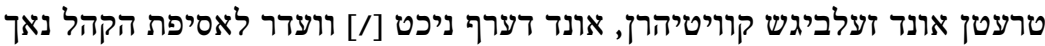

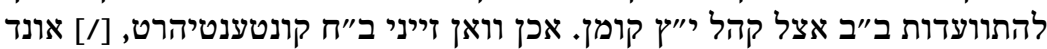

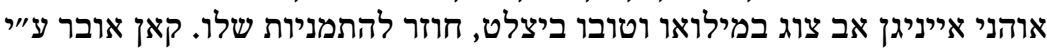

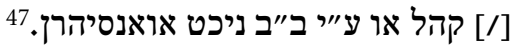

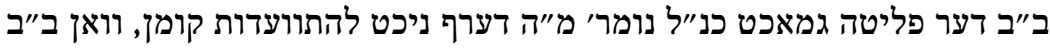

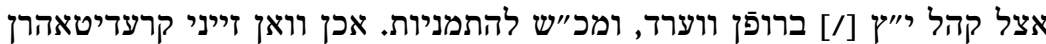

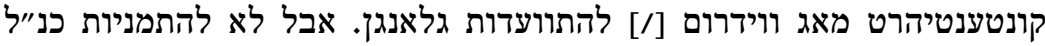

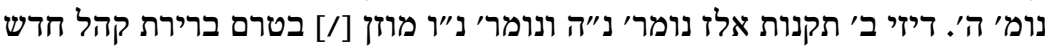

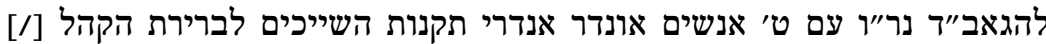

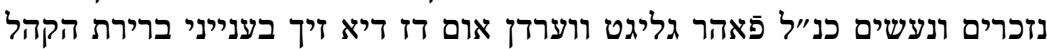

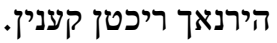

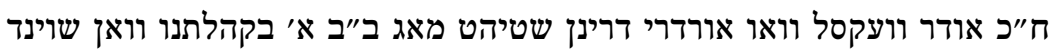

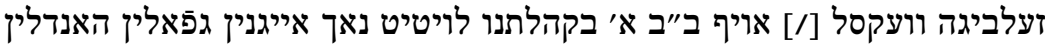

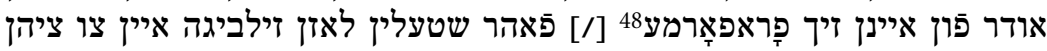

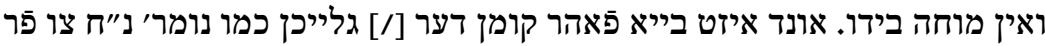

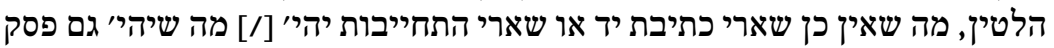

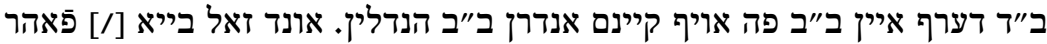

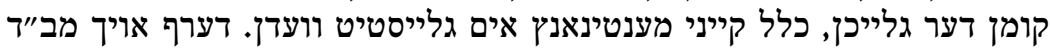

כלל ניכט [/] אן גיהערט ווערדן.

וואן ב״ב א׳ ת"כ על ב״ב בקהלתנו האט אונד בלאנגט איהם פו"מי י"ו"ץ מוזן איהם

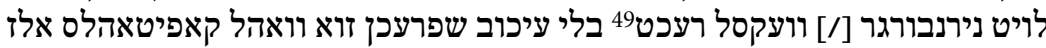

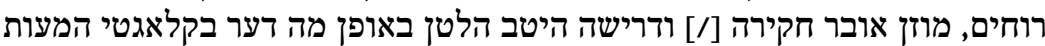

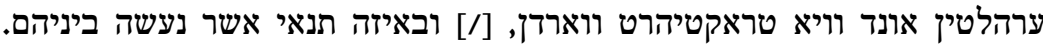

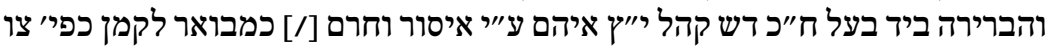

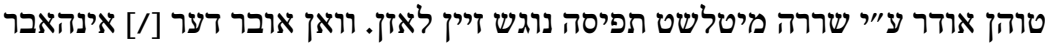

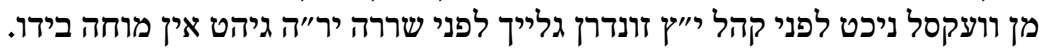

45 Valutieren = bewerten, hier wohl in der Bedeutung: vergleichen (nach Konkurs).

46 Vielleicht: moratoria $=$ Aufschübe.

47 Avancieren $=$ die Sache zu seinen Gunsten voran bringen.

48 Pro forma.

49 Nürnberger Wechselordnungen von 1654, 1697 und 1722. Hier ist wegen der zeitlichen Nähe sicher die letzte von 1722 gemeint. 


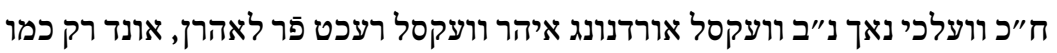

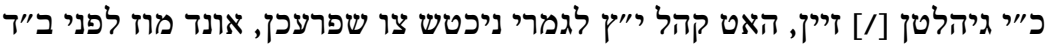

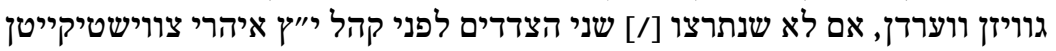

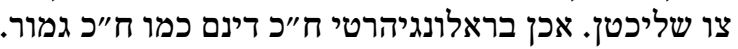

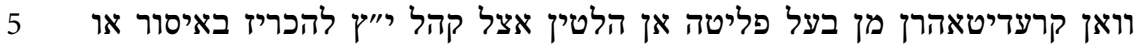

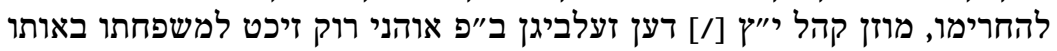

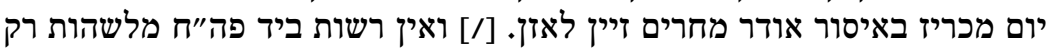

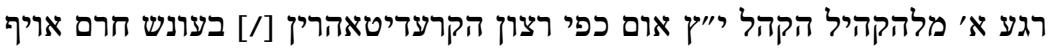

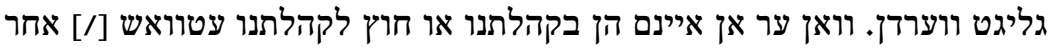

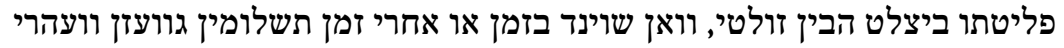

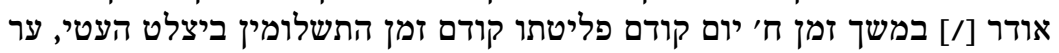

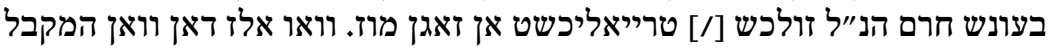

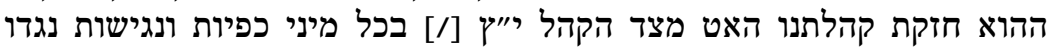

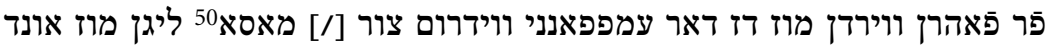

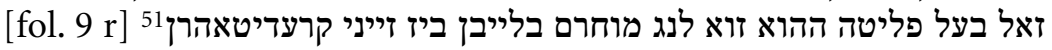

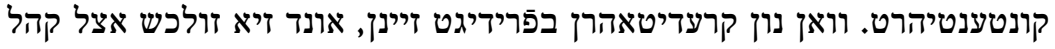

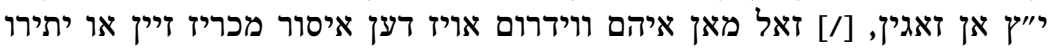

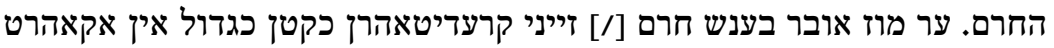

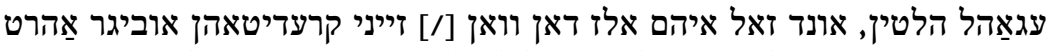

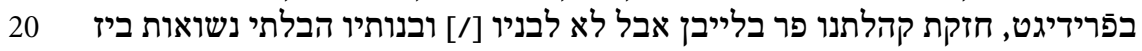

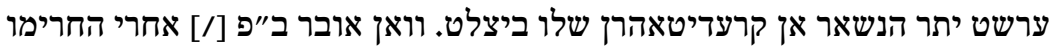

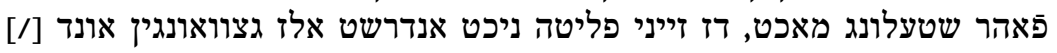

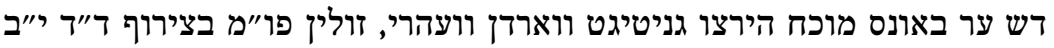

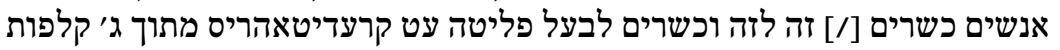

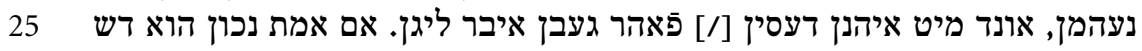

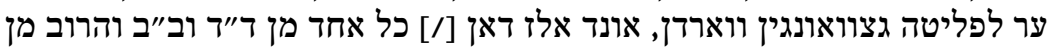

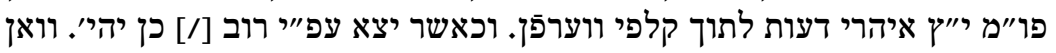

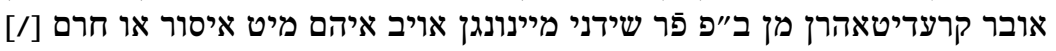

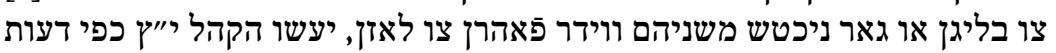

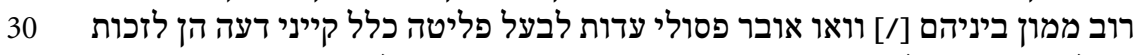

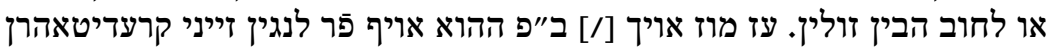

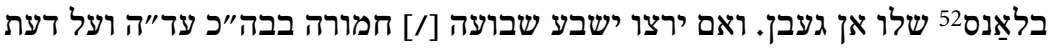

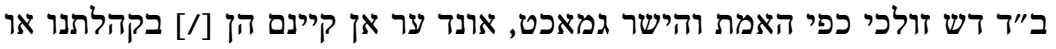

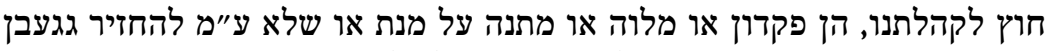

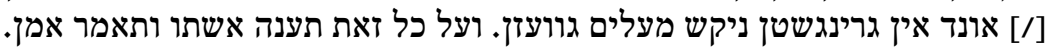

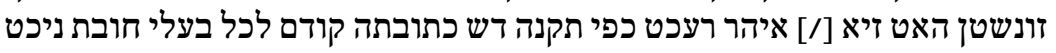

50 Konkursmasse.

51 Danach die Kustode קונטענטיהרט.

52 Von frz. balance $=$ Bilanz. 
צו גניסן. וואן אובר [/] ב״פ מחמת אונס איזט, ואונס ההוא בטרם גזירת החיר החרם

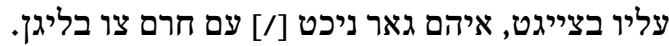

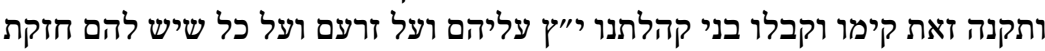

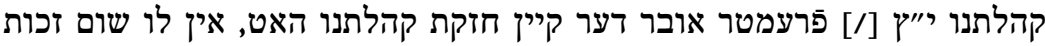

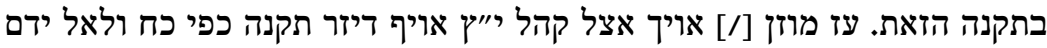

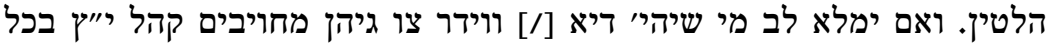

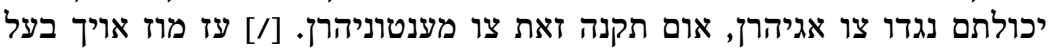

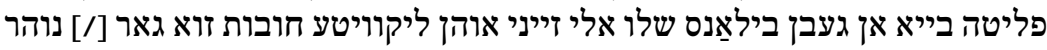

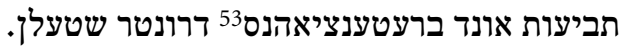

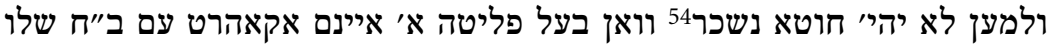

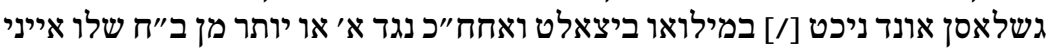

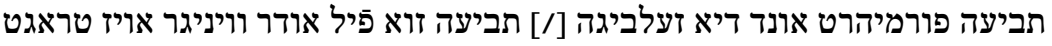

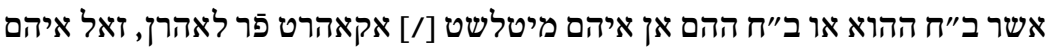

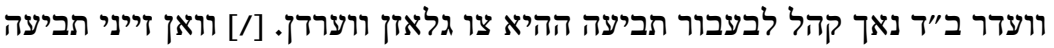

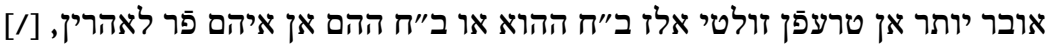

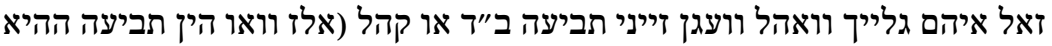

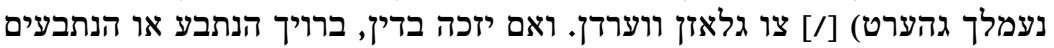

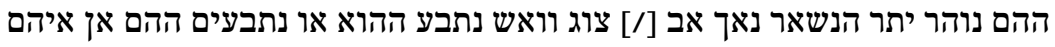

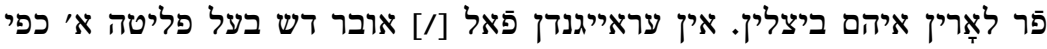

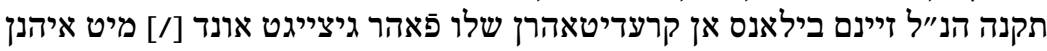

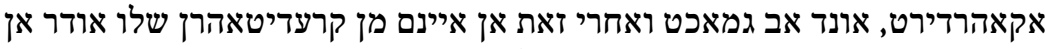

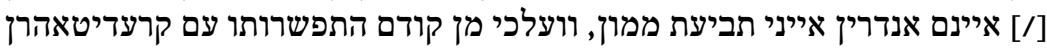

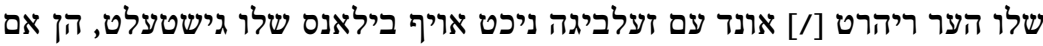

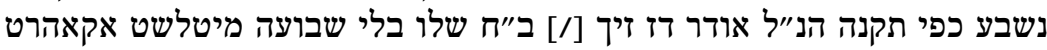

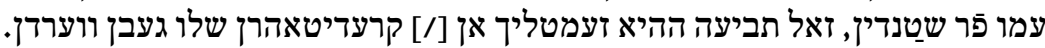

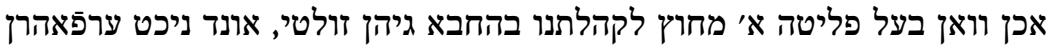
ס

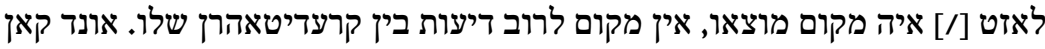

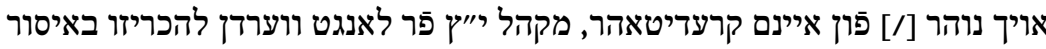

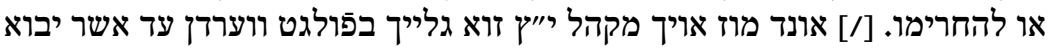

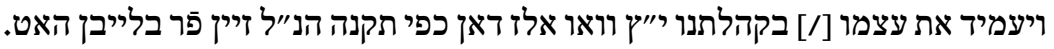

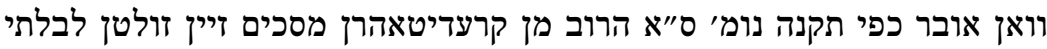

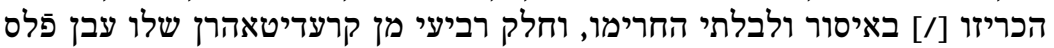

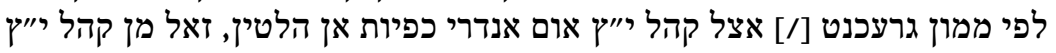

53 Prätentions = Forderungen.

54 Ketubbot 11a.

55 Danach die Kustode אכן. 


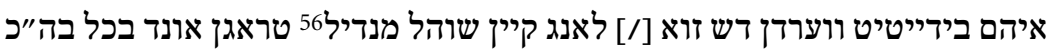

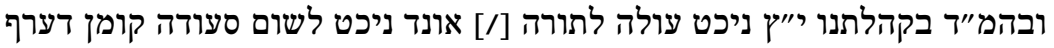
ביז דיזי בפפרידיגט.

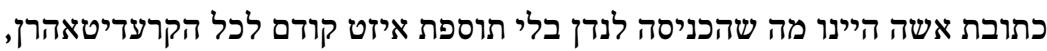
ס

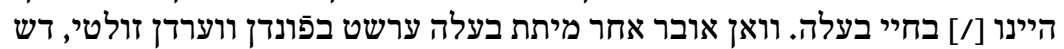

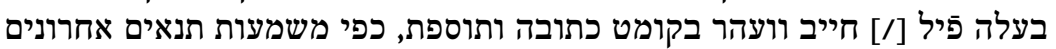

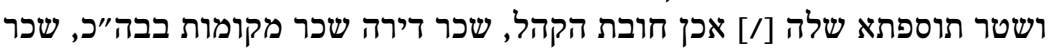

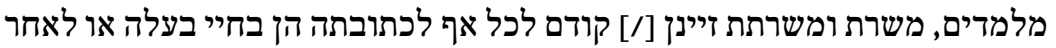

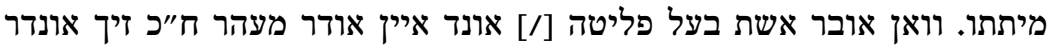

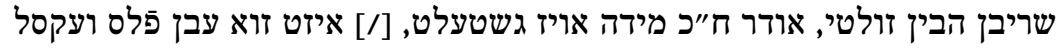

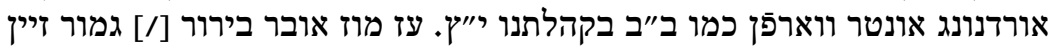

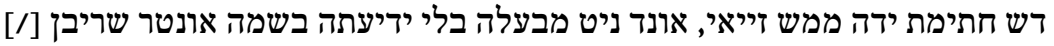

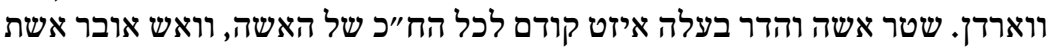

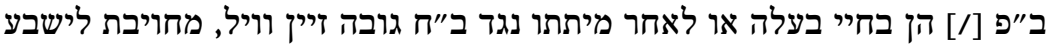
בבה"כ57/] במעמד נאמנים ומשועבדי הקהל י"יץ כמבואר בתקנת שבועת זיוער חתן.

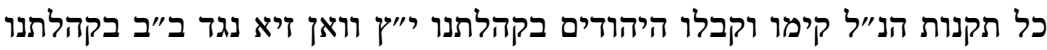

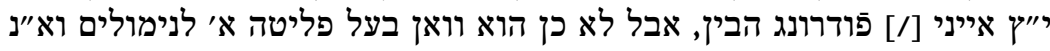

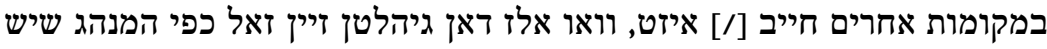

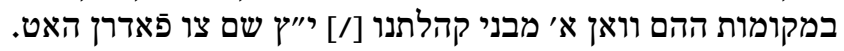

הכרזת איסור סתם דויארט שלשים יום, ובמשך זמן זה דערף וועדר מצוה קולי זויפן

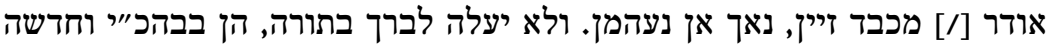

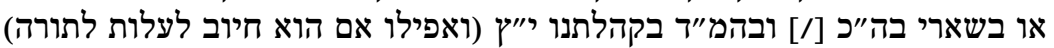

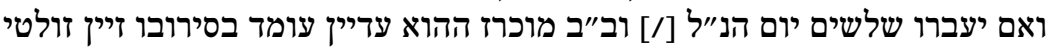

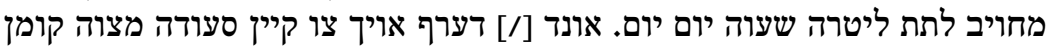

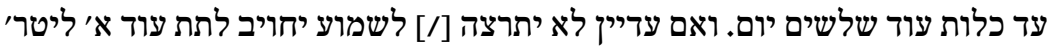

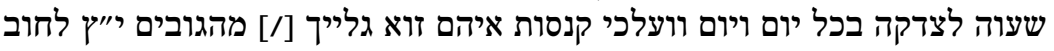

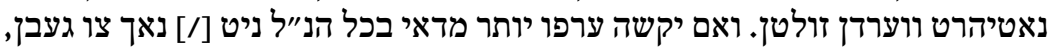

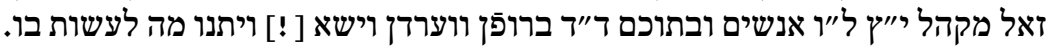

ס"ח וועהר אויז דען איסור גטאהן ווירד בקומט השמש ממנו ל"ז צל' וחצי.58

ס"ט

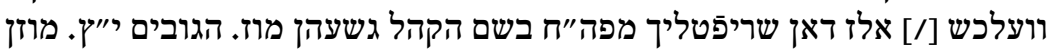

56 Schulmantel, Mantel für den Synagogenbesuch.

57 Danach ב als Zeilenfüller.

58 Danach die Kustode הפרנסים.

59 asignihrn= assignieren, anweisen. 


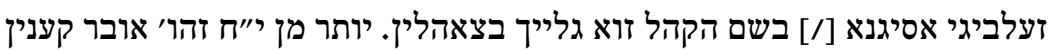

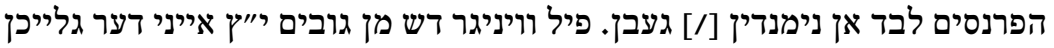

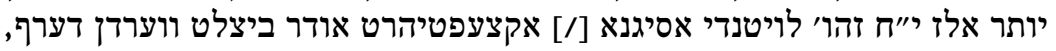

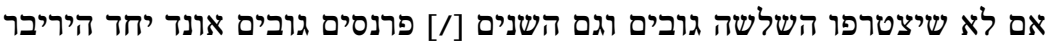

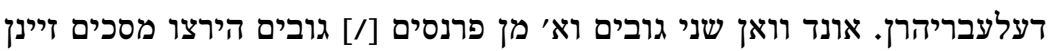

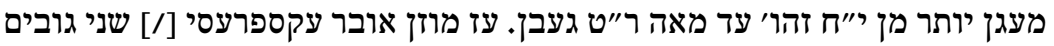

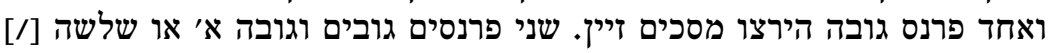

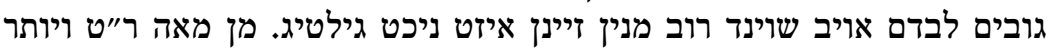

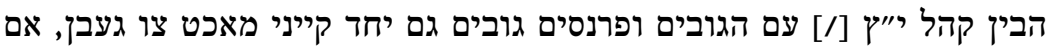

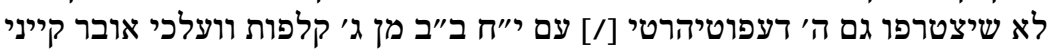

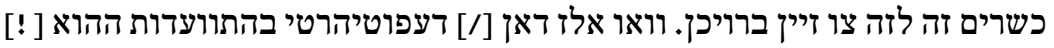

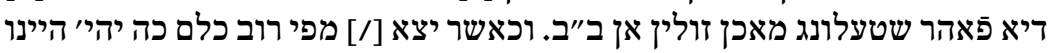

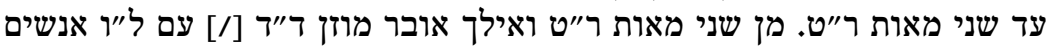
באופן המתבאר למעלה נומר׳ ס"ז מאי דאצו ברופין ווערדן.

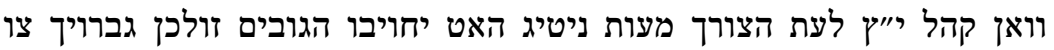
15

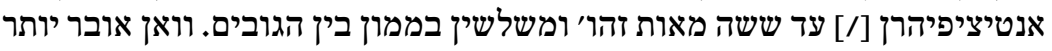

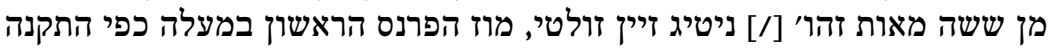

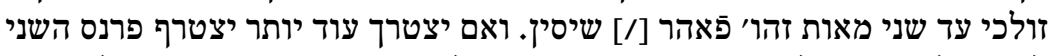

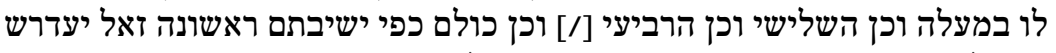

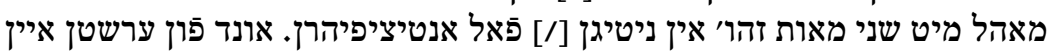

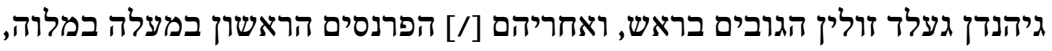

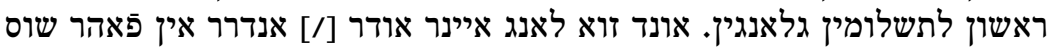

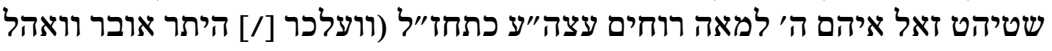

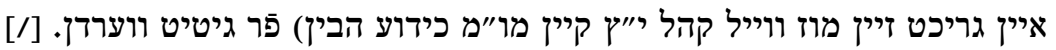

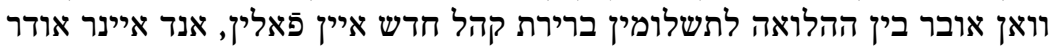

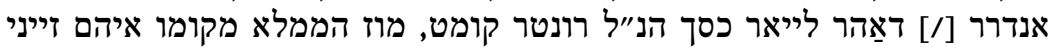

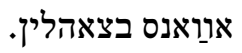

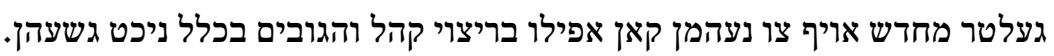

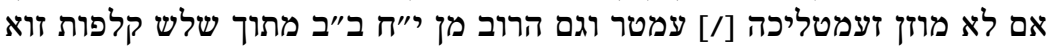

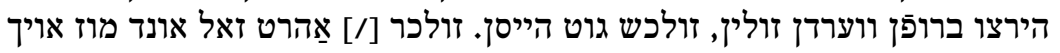

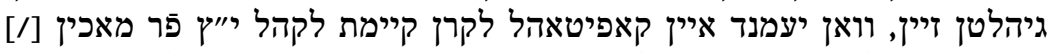

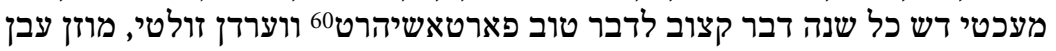

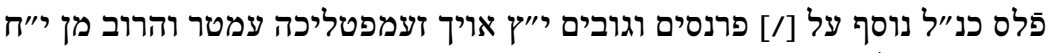

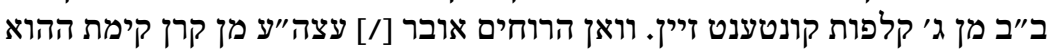

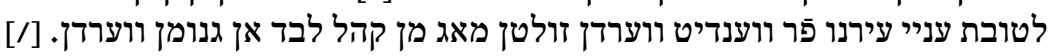
ע

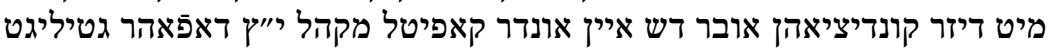
ווערד.

60 Überträgt. 


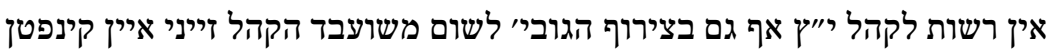
ע"ב

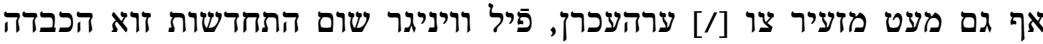

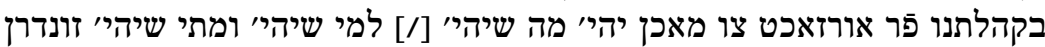

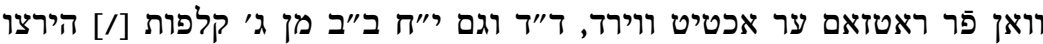

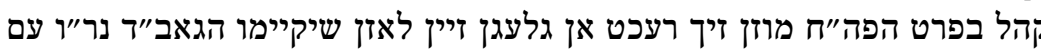
[fol. $10 \mathrm{v}]$

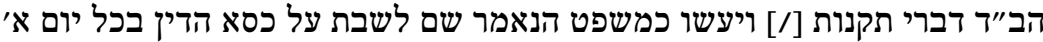

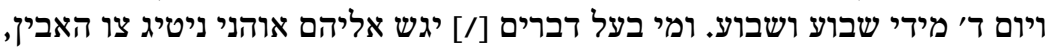

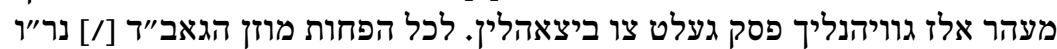

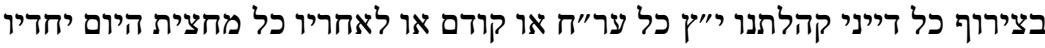

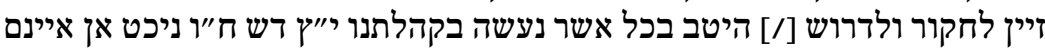

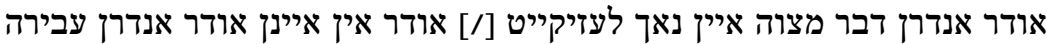

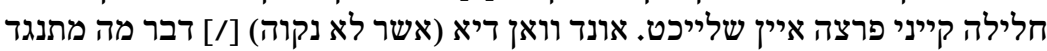

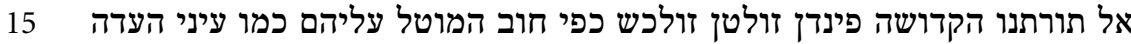

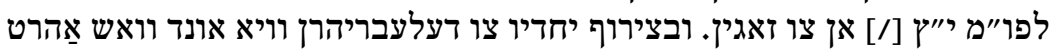

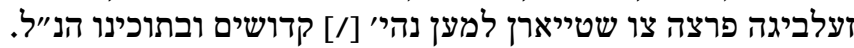

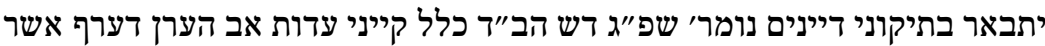

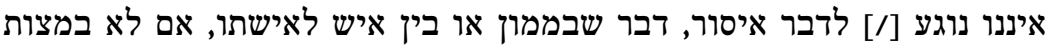
ופקודת כל הקהל יעוין שם.

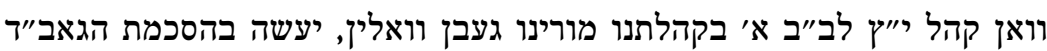

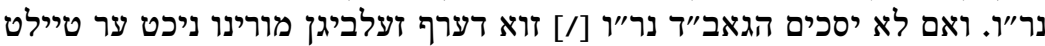

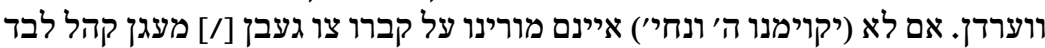

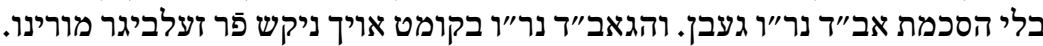

עז דערף נימנד בשעת החתונה החבר גגעבן ווערדן אם לא שהוא בחור מפורסיסם

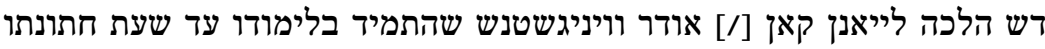

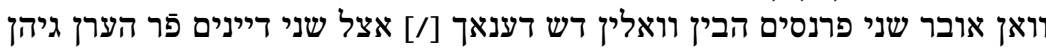

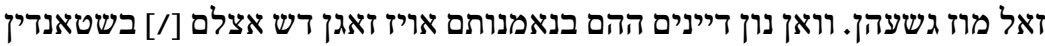

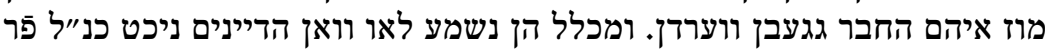

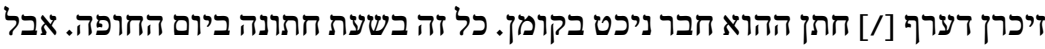

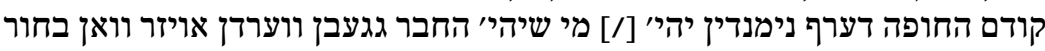

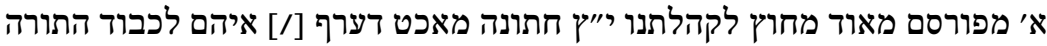

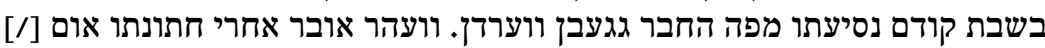

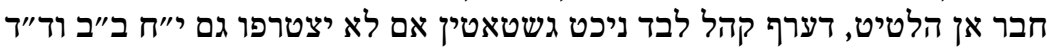

61 Danach die Kustode קהל. 


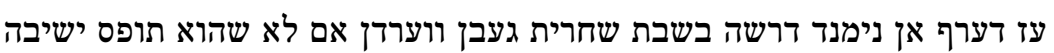
ע"ז

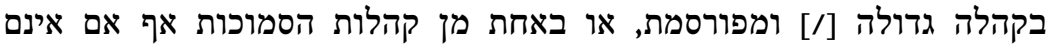

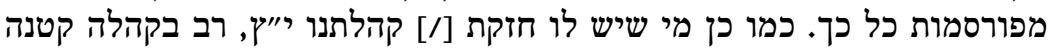

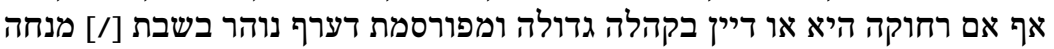

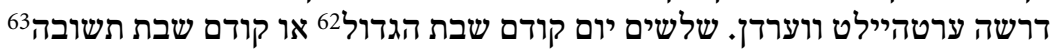

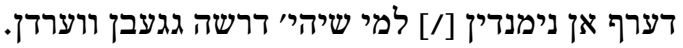

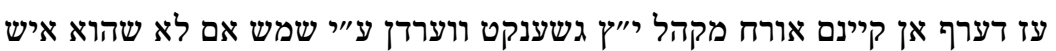

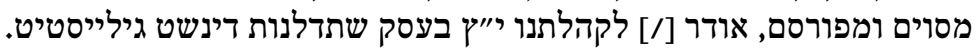

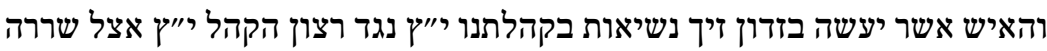

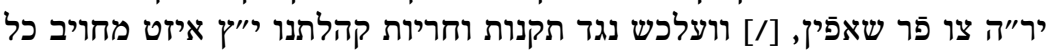

ע"ט

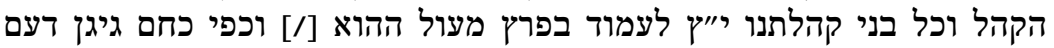

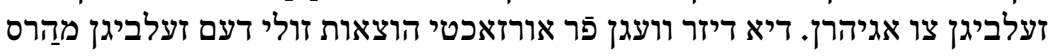

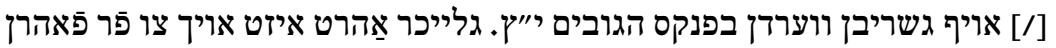

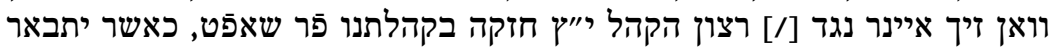
לקמן נומר' קצ"ז איר.

[fol. $11 \mathrm{r}$ ]

כל זמן דש קהל י"ץ החסד מהשררה גניהסט אונד סך קצוב לבעבור המס ביצלין,

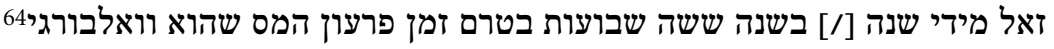

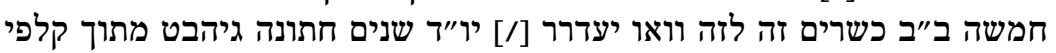

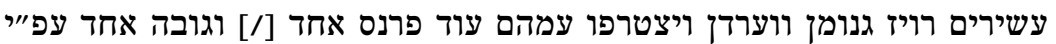

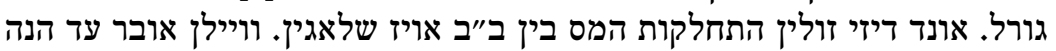

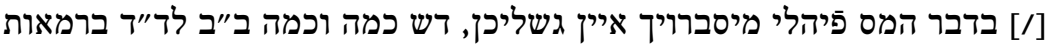

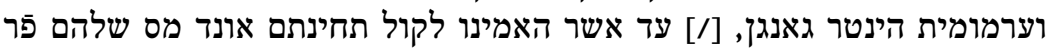

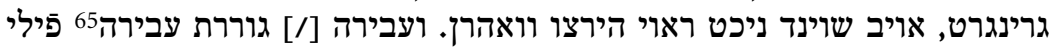

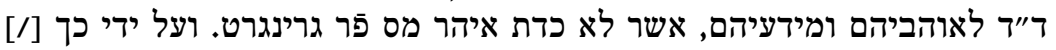

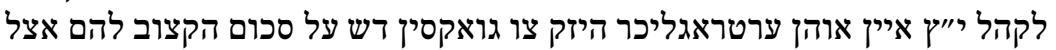

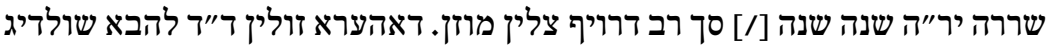

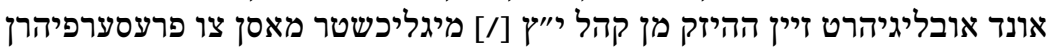

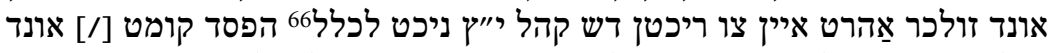

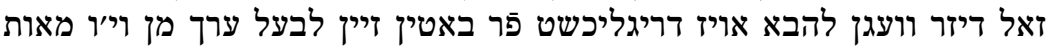
ע"ח

m"

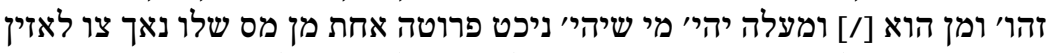

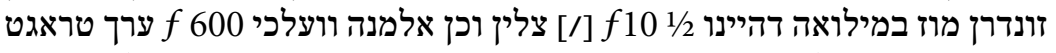

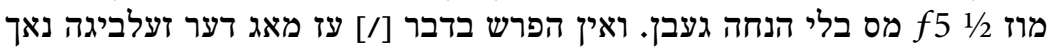

62 Der Schabbat vor dem Pessachfest.

63 Der Schabbat zwischen Neujahr und dem Versöhnungstag.

64 Steuer, die offenbar zu Walpurgis (25. Februar) fällig wurde.

65 Mischna Avot 4b.

66 In der Handschrift: ללכלל. 


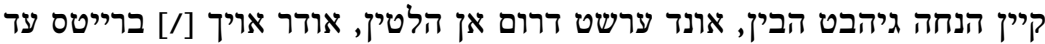

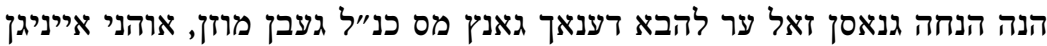

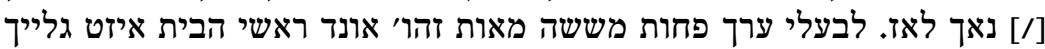

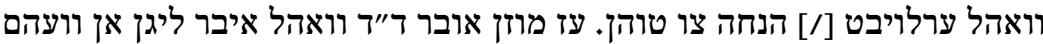

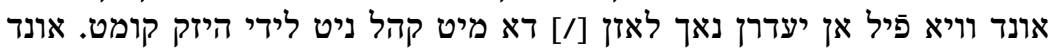

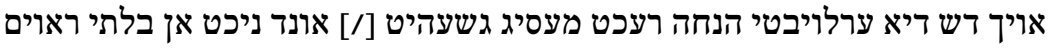

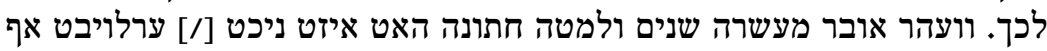

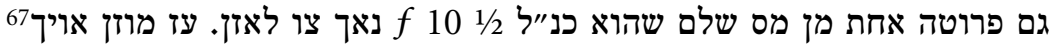

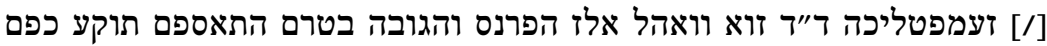

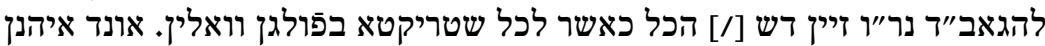

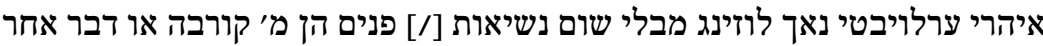

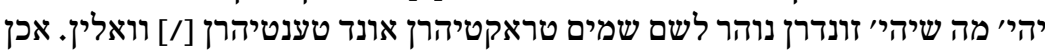

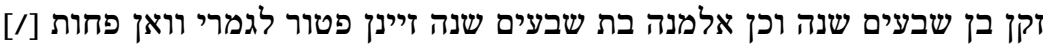

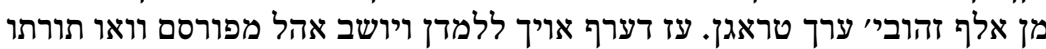

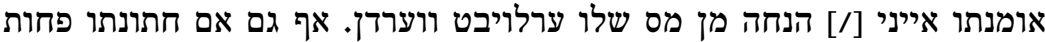

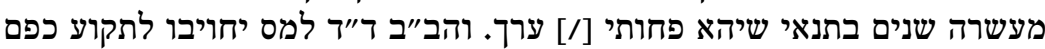

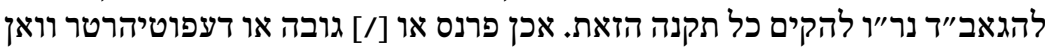

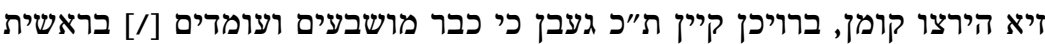

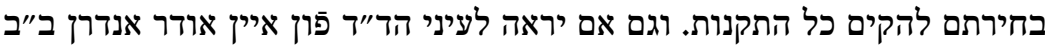

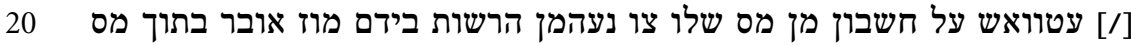

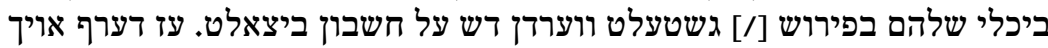

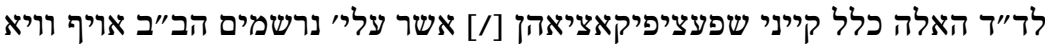

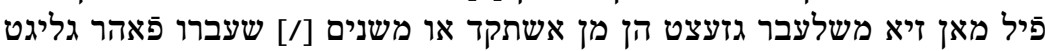

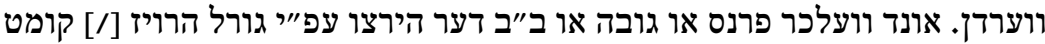

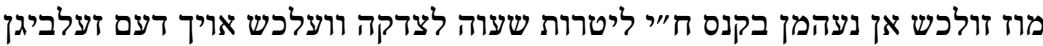

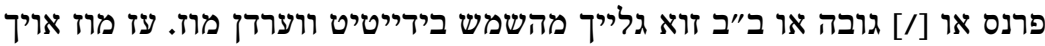

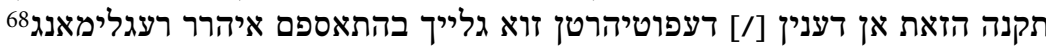

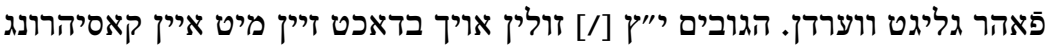

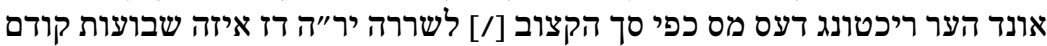

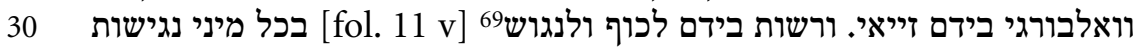

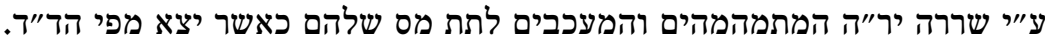

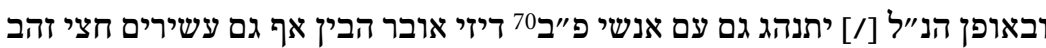

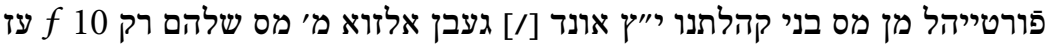

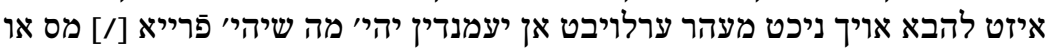

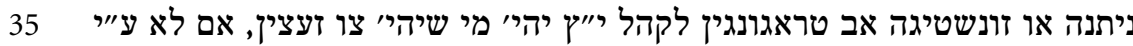

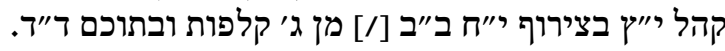

67 Danach r als Zeilenfüller.

68 Règlement.

69 Danach die Kustode בכהרינבא.

707 פעהרינבאך (Unter-)Farrnbach, heute Stadtteil von Fürth. 


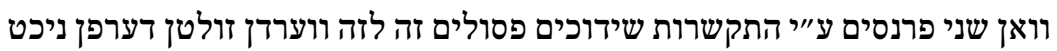
פ" פ

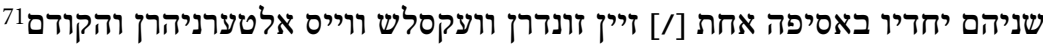
במעלה כפי תקנה ך"ב לו משפט הפיפ הקדימה.

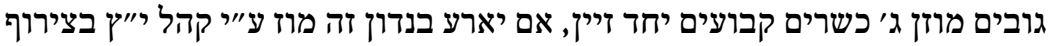
[/] ד"ד ושלשים וששה ב״בב דעלעבריהרט ווערדן וויא זים זיך צו פפר הלטין.

הנהגת שידוכי בנים

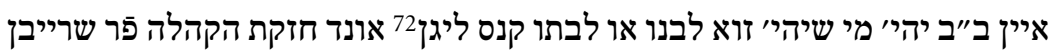

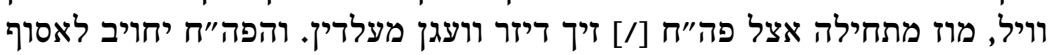

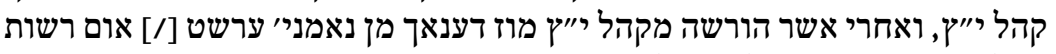

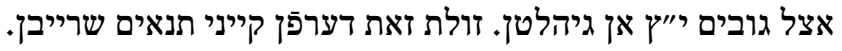

ב"ח לקהל י"ץ מוז זיך קודם הנחת קנס עם הגובים י"יץ אב פַינדן, זונשטן דערפין

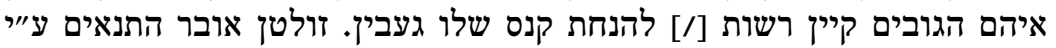

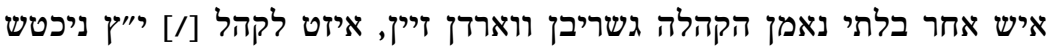

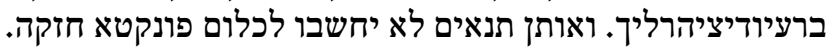

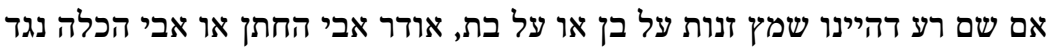

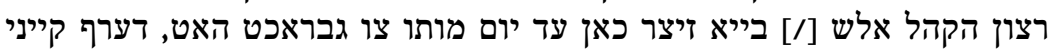

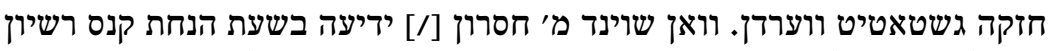

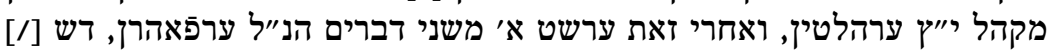

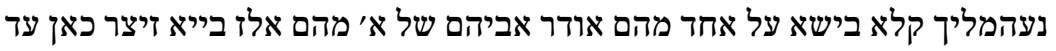

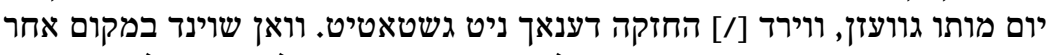

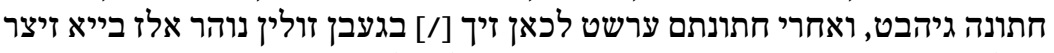

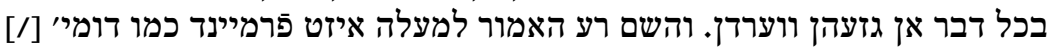

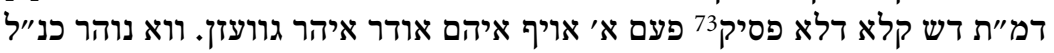

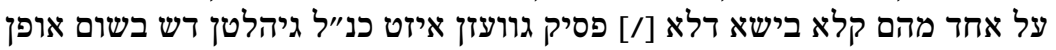

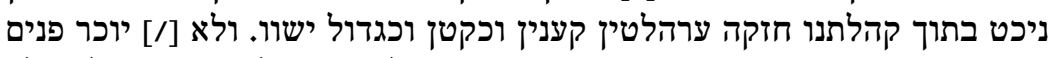

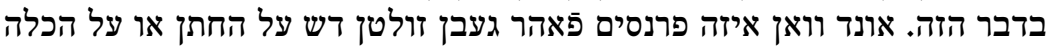

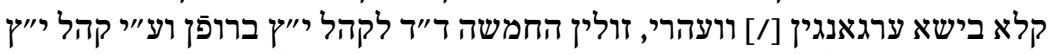

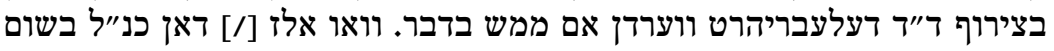

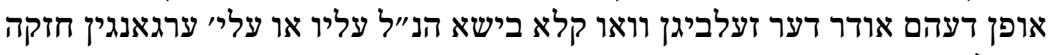
בקהלתנו י"יץ [/] גשטאטיט דער וועריון דערן דערף.

הן בחור או בתולה אלמן או אלמנה ממקום אחר וואן ענטוועדר זיא זעל זעלבשטים

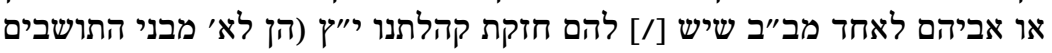

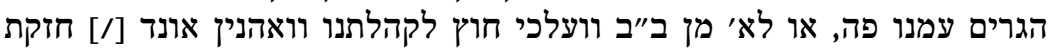

71 Davor gestrichen: והקרובים.

72 Verloben.

73 Mo'ed Katan 18b. קלא דלא פסיק (aram.) = Stimme, die nicht schweigen will. 


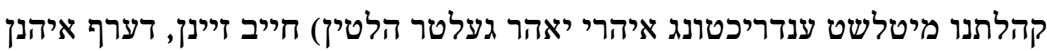

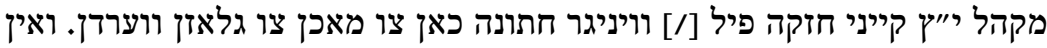

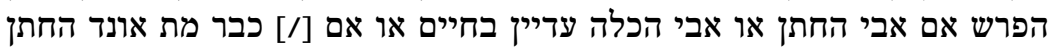

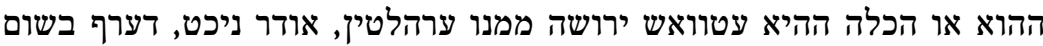

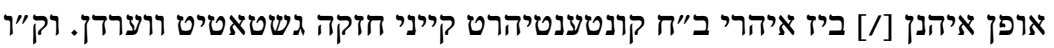

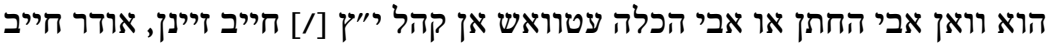

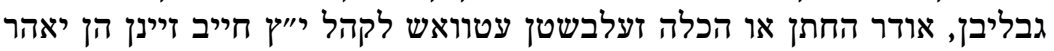

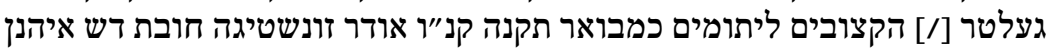

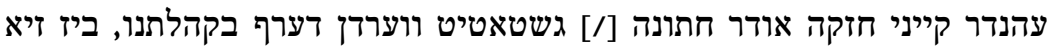

כמו כן וואן ב״ב א׳ מקהלתנו לא׳ מבניו או מבנותיו חתונה מאכין וויל מוז זייני פ"

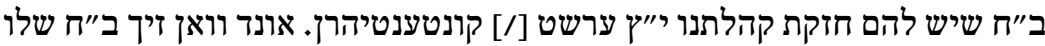

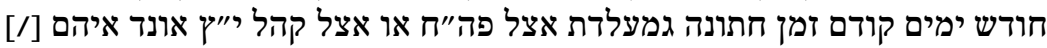

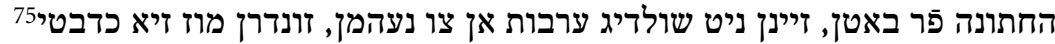

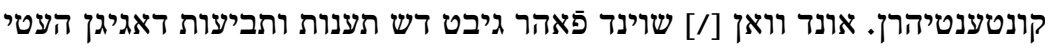

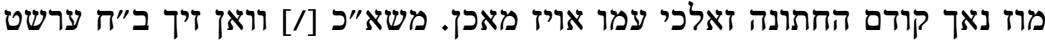

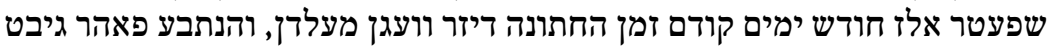

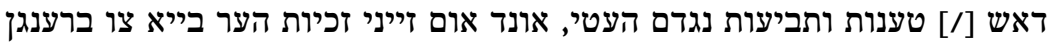

אייני דעלאציאהן

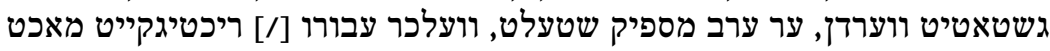

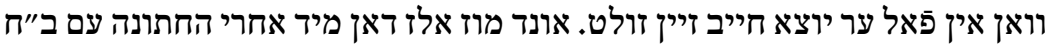

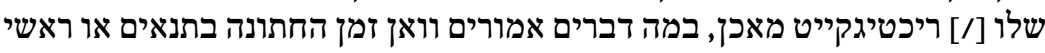

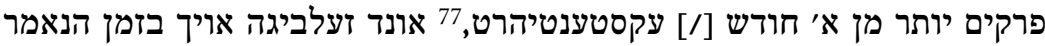

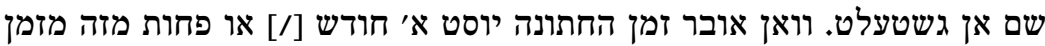

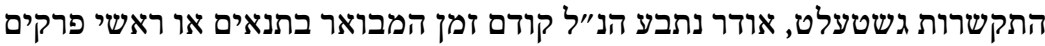

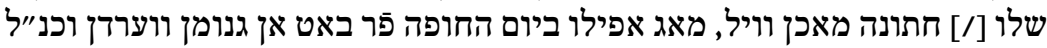
זיין פר בלייבן הבין. זולכר אהרט איזט אויך גיהליטן וילין וואן אלמן או אלמנה שיש להם כבר חזיקת קהלתתנו

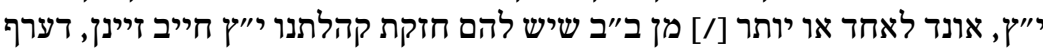

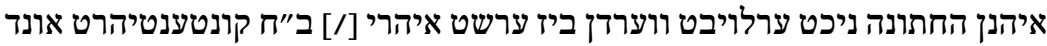

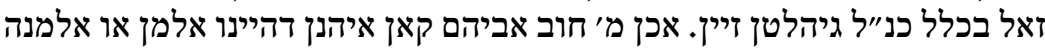
[/] וואן פَר הערא שוינד חזקה כאן גיהן גיהבט, החתונה ניכט פַר באטן ווערדדן.

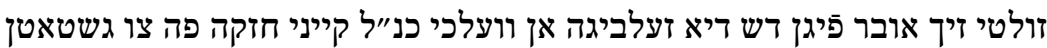

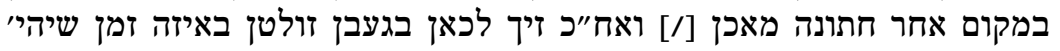

74 Danach כ״ כals Zeilenfüller.

75 Debit?

76 Delation, hier in der Bedeutung von Aufschub?

77 ekstentihrt $=$ extendiert, verlängert. 


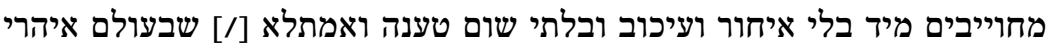

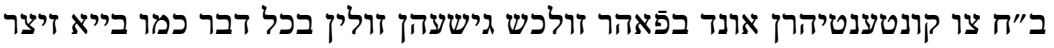

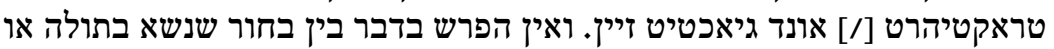

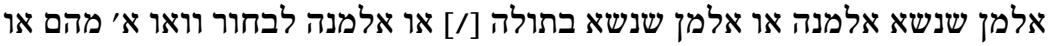

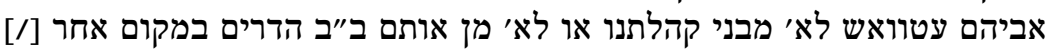

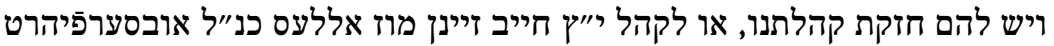

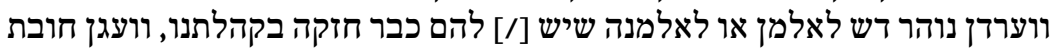
אביהם קייני חתונה פَר באטן ווירדן קאל.

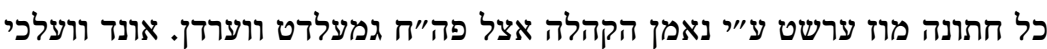

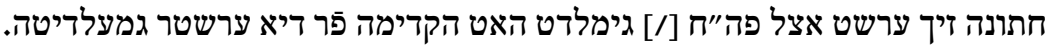

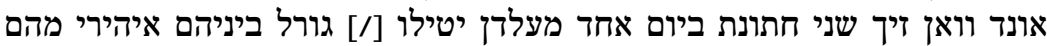

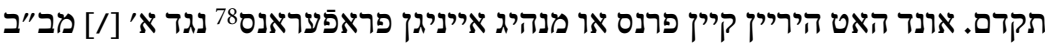

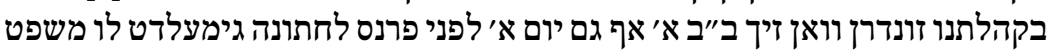

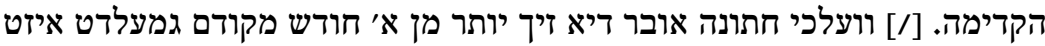

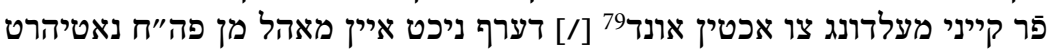

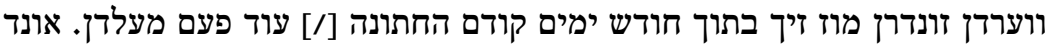

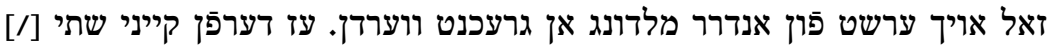

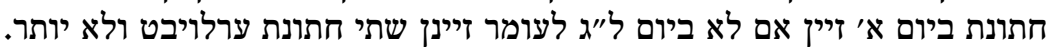

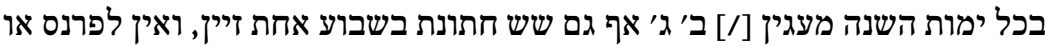

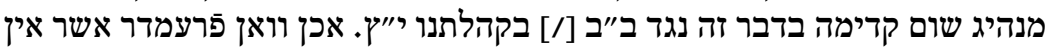
לו חזקת קהלתנו חתונה מאכין וואלטי באותו שבוע' הרשות ביד [/] ב״ב למחות ומרות.

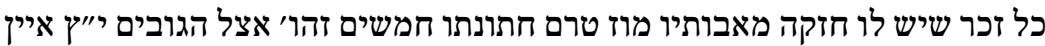

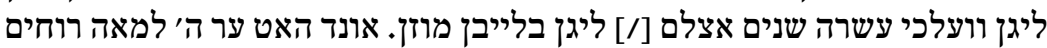

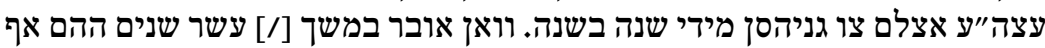

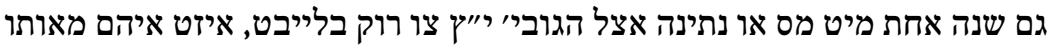

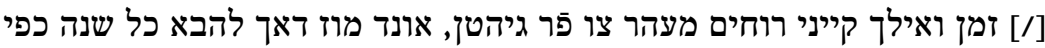

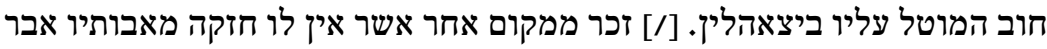

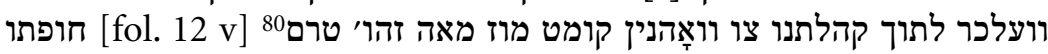

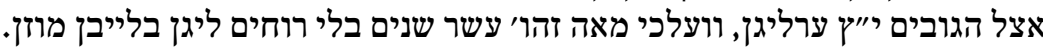

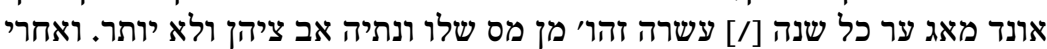

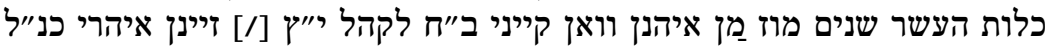

דעפאניהרטש מעות, אוהני אנדרש רעשטים מויטואיהרן.

אפס כי לא יהיי כל אביוני ועניים בתוכתו בגלל הדבר הזה איזט בענייני נדוניות

פ" פ

פ"ט פולגנדר אורדנונג [/] צו אובסערפיהרים בתוכתו

78 Von frz. préférence $=$ Vorzug.

79 Dieses Wort ein weiteres Mal am Beginn der folgenden Zeile.

80 Danach die Kustode חופתו. 


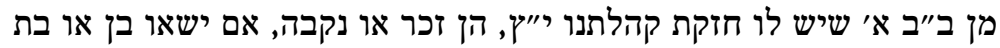

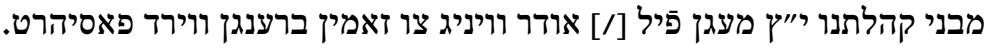

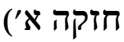

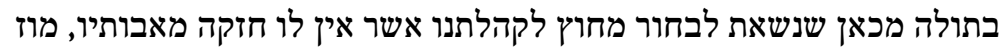
$f 750$

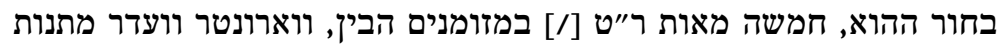

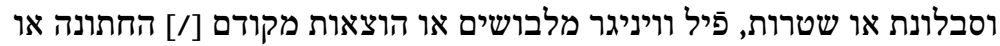

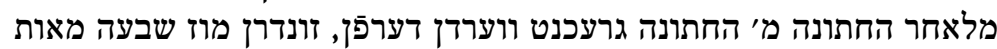

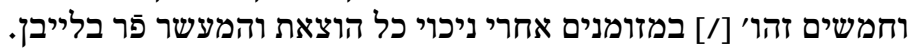
זכר מכאן שנשא בתולה ממקום אחר כנ״"ל מוז בתולה ההיא ד' מאות ר״ט. $\underline{f 600}$ באופנים למעלה הבין.

בתולה מכאן שנשאת לאלמן ממקום אחר וכן זכר שישא אלמנה ממקום אחר אם $f 750$

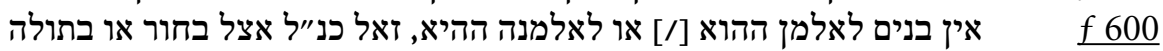

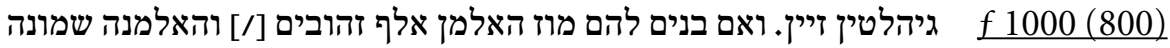
מאות זהו' במזומנים באופנים האמורים למעלה הבין.

בתולה שנשאת לבחור ממקום אחר מוזן אלף וחמשים ר״ּוּ צו זאמן ברענגן,

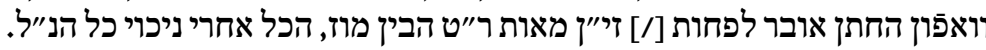

בחור שישא אלמנה ממקום אחר או אלמן ממקום אחר שישא בתולה מכאן ווירד

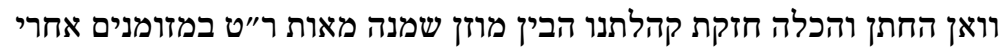
$f 1200$

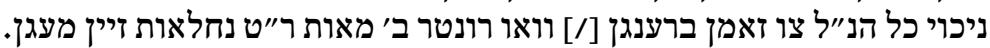

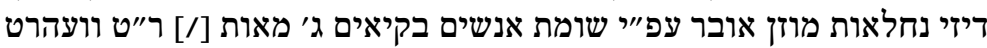

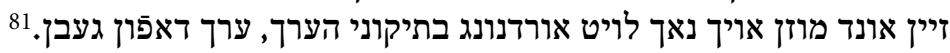

81 Danach die Kustode בתולה.

82 In der rechten oberen Blattecke erneut חזתה שלישית. 


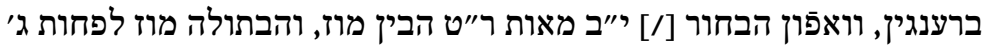

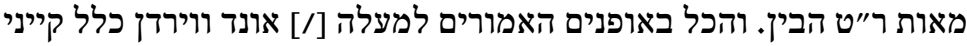

זכר שישא בתולה ממקום אחר מוז הבתולה הבין תשעה מאות ר״ט והבחור

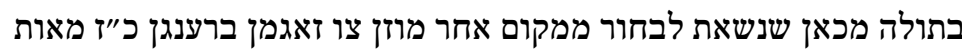

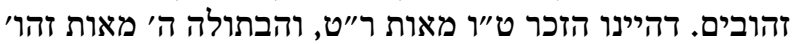

וחמשים

וואורונטר קייני נחלאות גרעכנט והכל בניכוי כנ״ל.

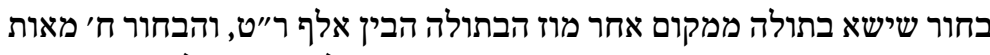

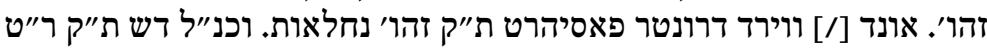

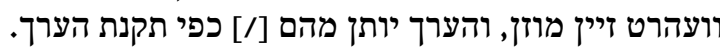

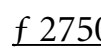
f 2250

$\underline{500}$ f2750

f 1500

$\underline{800} \quad 20$ f 2300

בחור שישא אלמנה ממקום אחר וכן בתולה שתינשא לאלמן מליש ממקום אחר בלייבט כנ"ל [/] להוסיף שלמה ממקום אליש אם שיש להם בנים.

חזקה חמשית) ומכאן והלאה חמקית חמשת

אם החתן והכלה שניהם יש להם חזקה קהלתנו י"ץ מוזן צו זאמין ברענגן ב'

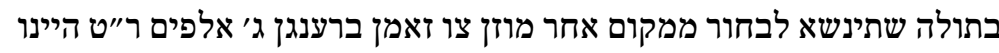
f 3000

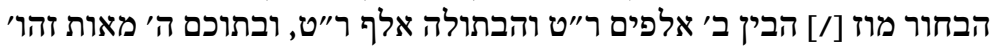




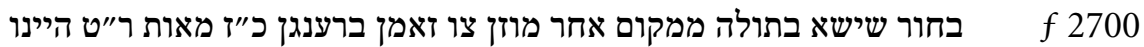

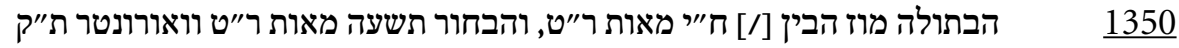

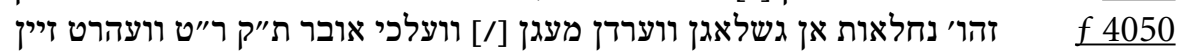

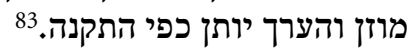

[fol. $13 \mathrm{v}$ ]

בחור שישא אלמנה ממקום אחר או בתולה שתינשא לאלמן ממקום אחר בלייבט כנ״ל להוסיף שליש.

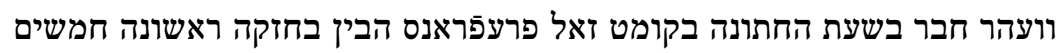
זהו', חזקה ב' [/] חמש ושבעת חעים זהו', בחזקה שלישית ומשם ומשם והלאה מאה זהובי'.

אלמנה שתינשא לאלמן ממקום אחר לגור פה מוז אלמן ההוא חמשה מאות ר״"ט

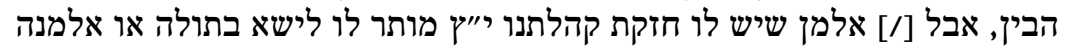
פה או ממקום אחר אף [למן שיש גם בחוסר כל.

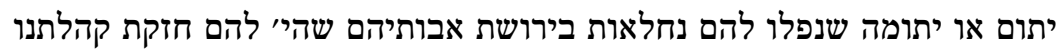

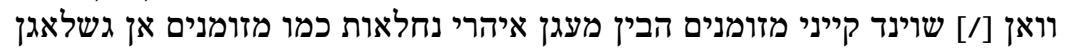
ווערדן בתנאי [/] שיהיו שוים עפ"י בקיאים מעומנים שליש מלבר, שלאגן.

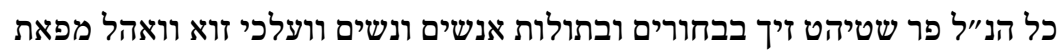

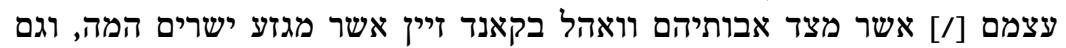

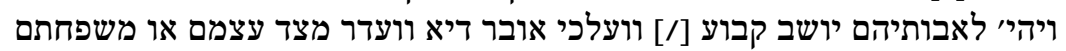

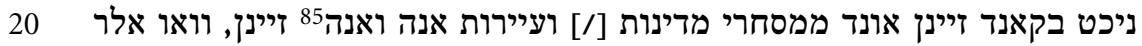

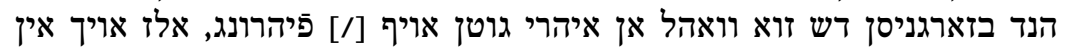

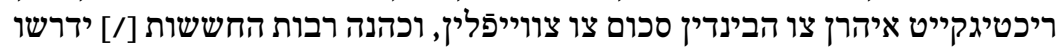

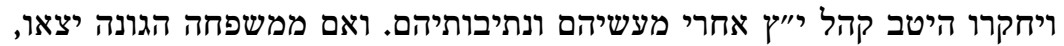
אונד [/] נאך רייפליכה איבר ליגונג דיספילס ישפטו כפי ראות עירי ואם ממיהם.

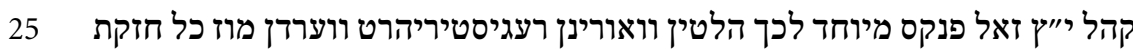

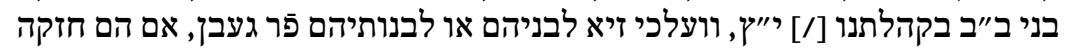

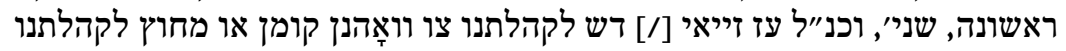

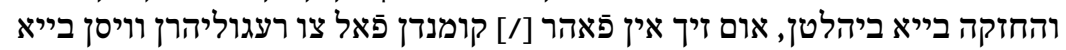

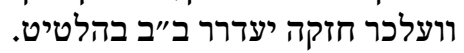

מכל האמורים למעלה דש סכום ידוע הבין אודר צו זאמין ברענגן, מוז החתן 30 $\lambda^{\prime \prime} צ$

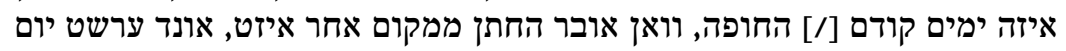

\footnotetext{
83 Danach die Kustode בחור.

84 Wertzuwachs.

$852 \mathrm{Kg} 5,25$; hier in der Bedeutung: hier und dort.
} 


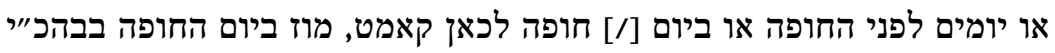

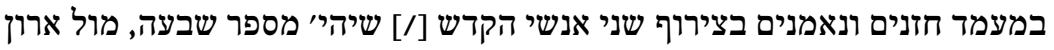

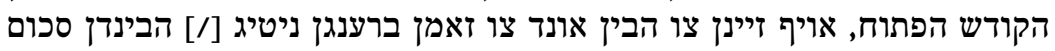

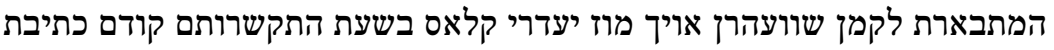

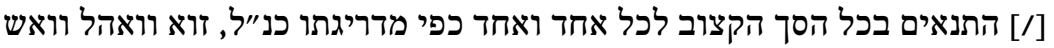

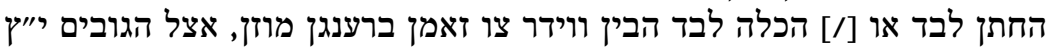

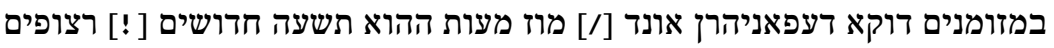

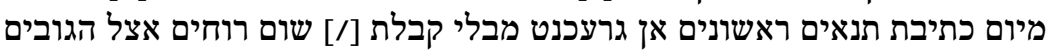

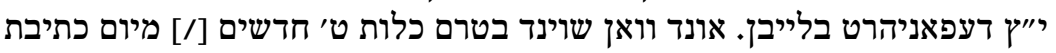

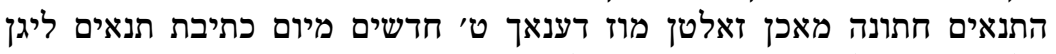

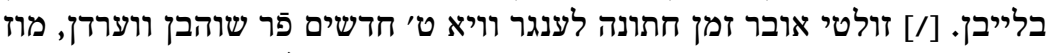

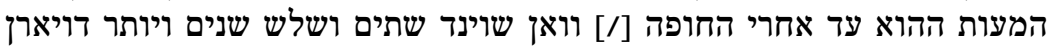

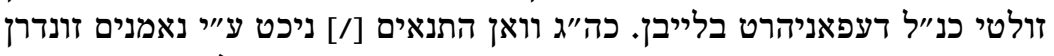

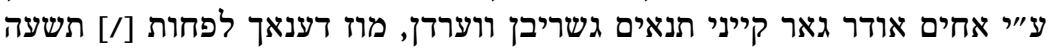

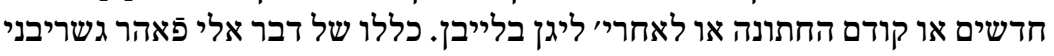

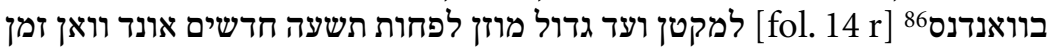

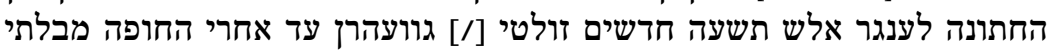

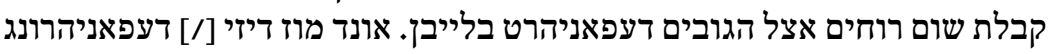

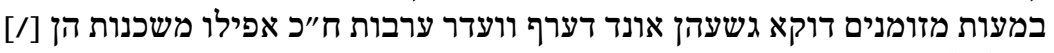

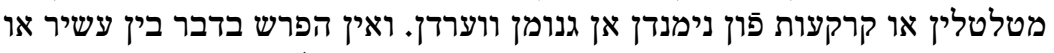

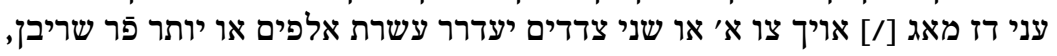

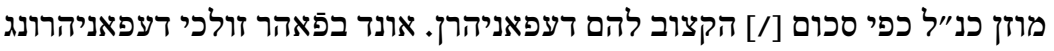

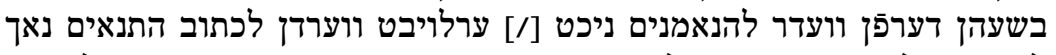

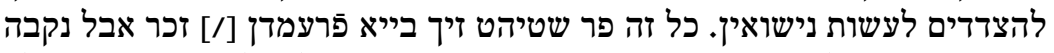

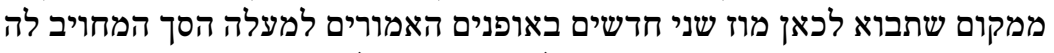

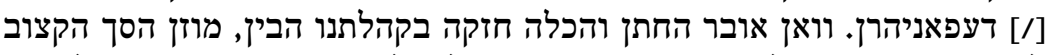

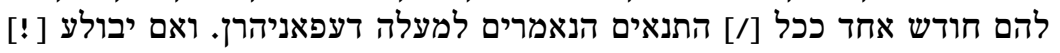

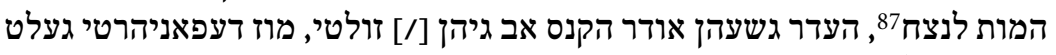

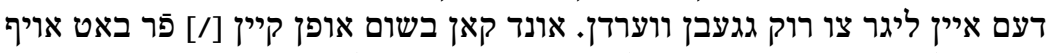

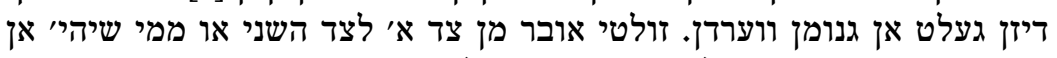

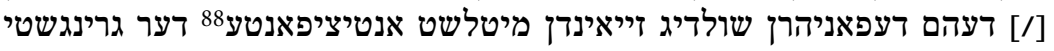

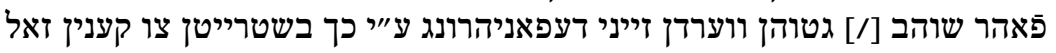

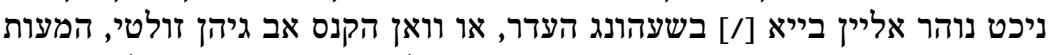

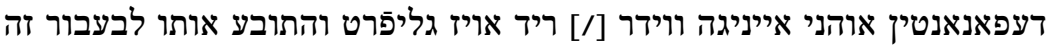

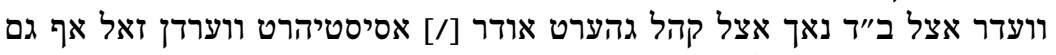

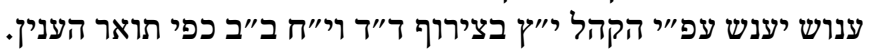

\footnotetext{
86 Danach die Kustode למקטן.

87 Nach Jes 25,8.

88 Vorher.
} 
קודם קבלת שבועת החתן זאל ענטוועדר ע״יי חזנים או נאמנים ושמשים אירים איהם בדברי כבושים

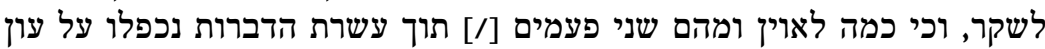

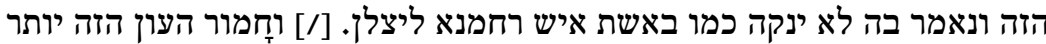

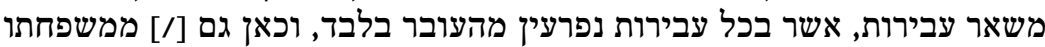

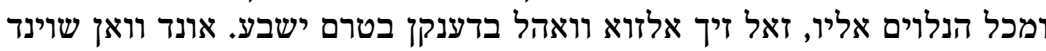

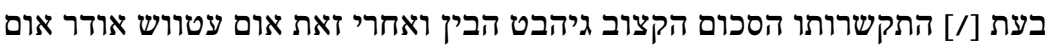

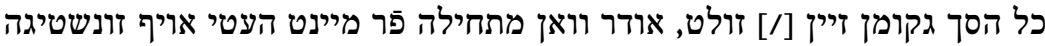

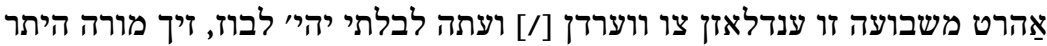

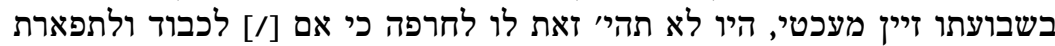

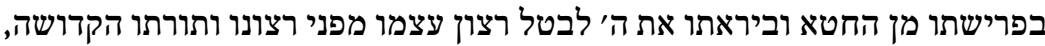

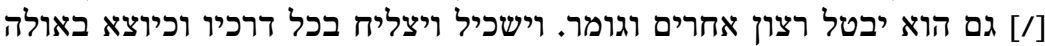

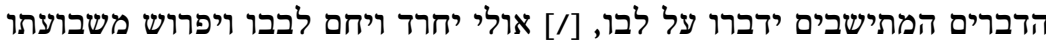

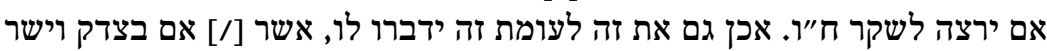

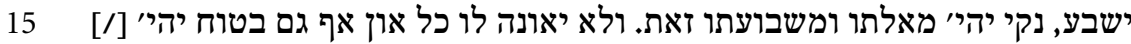

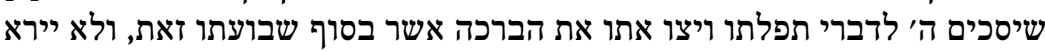

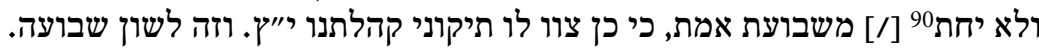

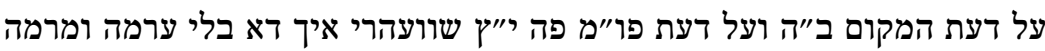

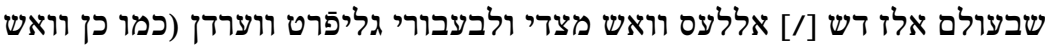

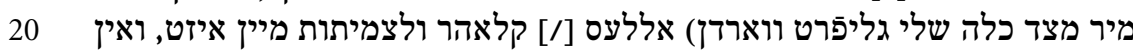

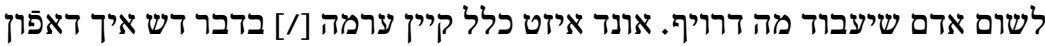

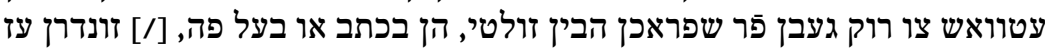

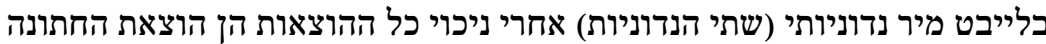

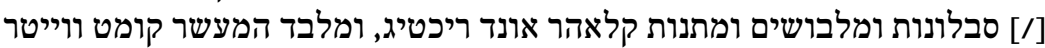

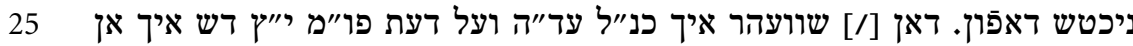

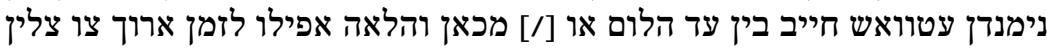
דש מן נדוני' שלי (שתי נדוניות) גנומן ווערדן מוזט.

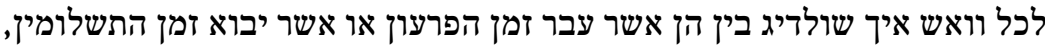

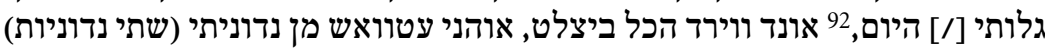

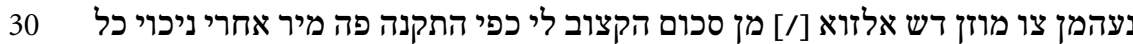

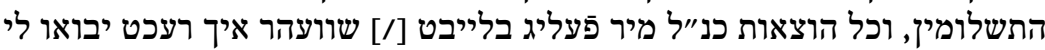

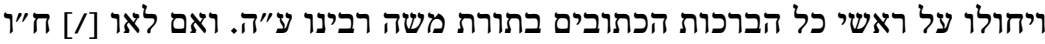
מכלל הן נשמע לאו וכל ישראל יהות הכתובים נקיים במורת משן

89 Mit eindringlichen Worten.

90 Jes 31,4 .

91 Danach die Kustode 7 .

92 Nach Jes 5,9. 


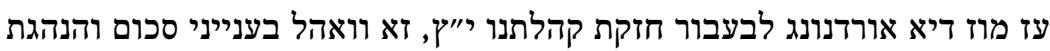
צ"ה

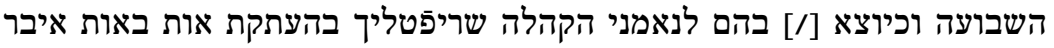

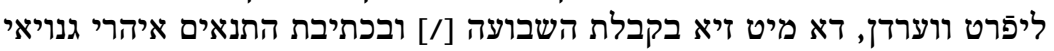
ריכטשנור היר נאך נעמן קענין ועין ולא יפילת הילו דבר ארצה מכל הנאמר בתוכם

אכן אם יתקשרו שני ב"ב לשניהם חזקת קהלתנו י"ץ יחדיו, וצד א׳ מהם פָר שרייבט

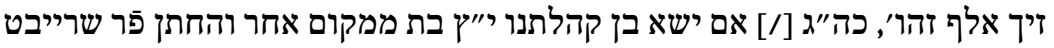

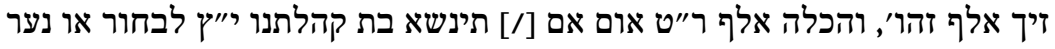

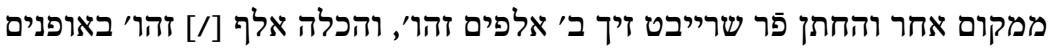

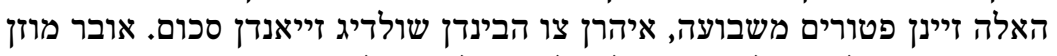

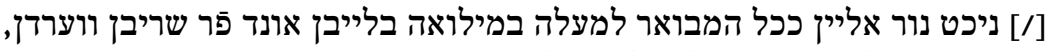

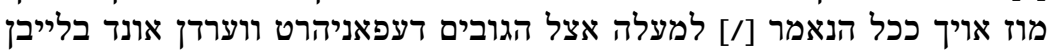
כנ"ל, רק משבועה פטורים.

ה' חפץ למען צדקו93 וגנ"ל94 לכן עם יעיר ה' לב טהור ורוח נכוץ95 יחדש בקרבינו

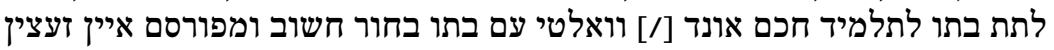

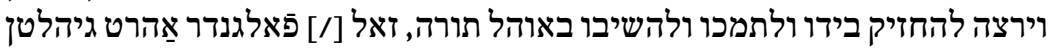

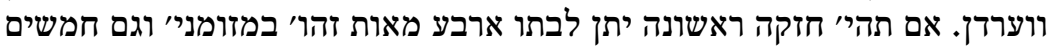

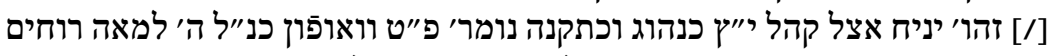

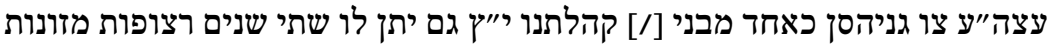

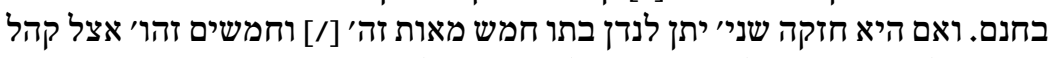

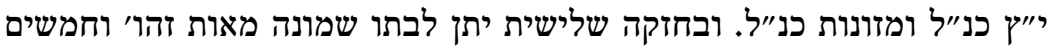

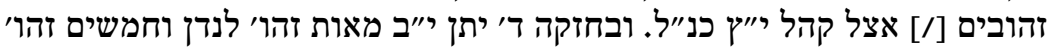

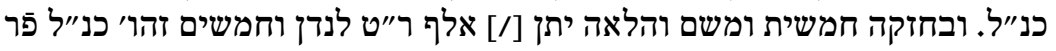

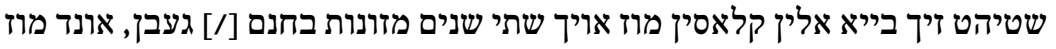

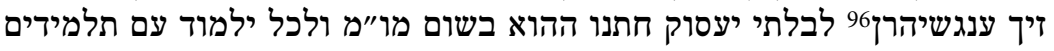

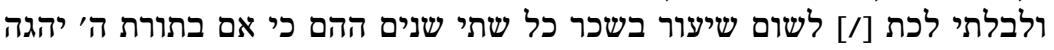

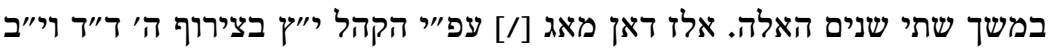

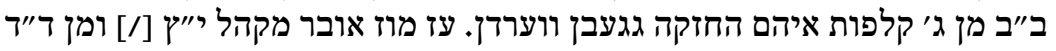

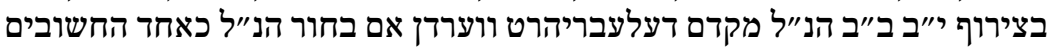

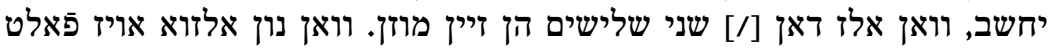

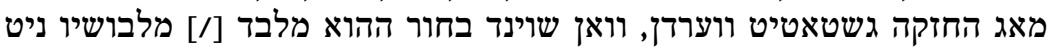

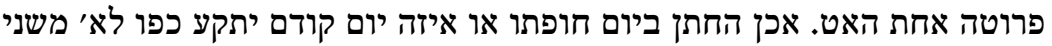

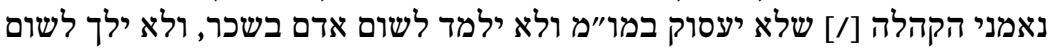

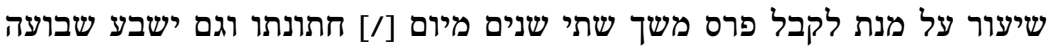

93 Jes $42,21$.

94 Die Auflösung dieser Ligatur ließ sich nicht erschließen. Nach dem Sinn muss die Bedeutung »und so weiter« lauten. Sie erscheint noch einmal in $\$ 100$.

95 Nach Ps 51,12.

96 Engagieren. 


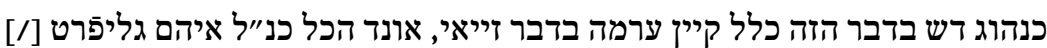

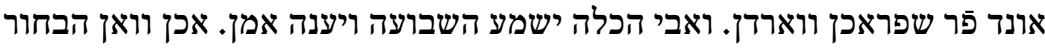

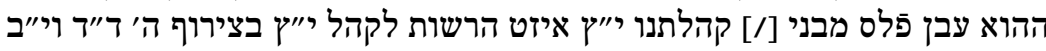

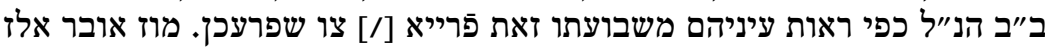

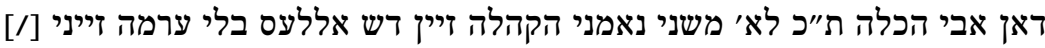

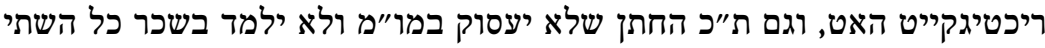

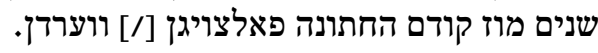

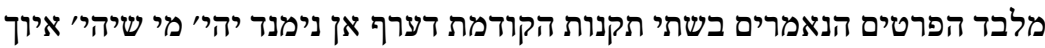

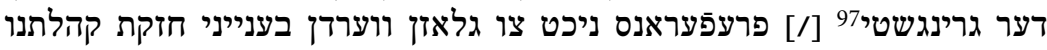

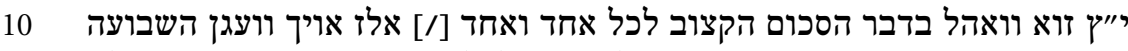

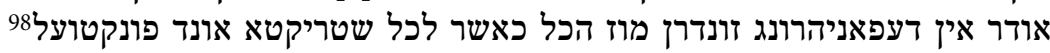
[fol. 15 r]

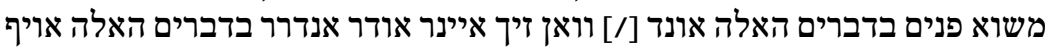

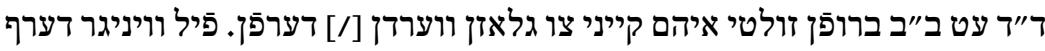

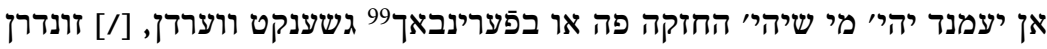
הכל יהיי כפי התקנות זוא וואהל כאן אלז בפעיתרינבאך.

זאלט זיך אובר עראייגנין דש איינר אודר אנדרר כמבואר בתקנה נומר' צ׳יר לבנו או

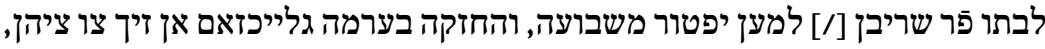

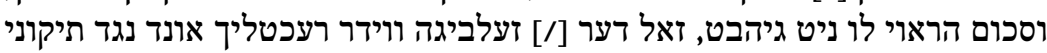

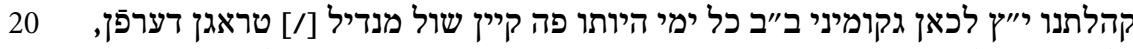

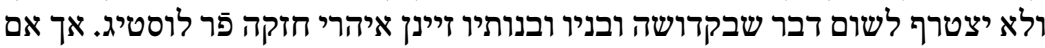

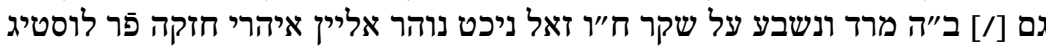

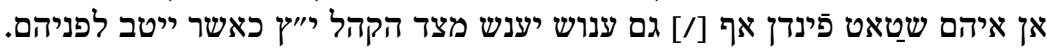

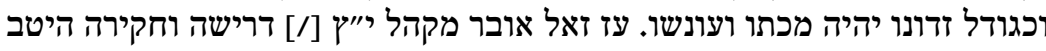

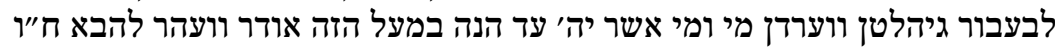

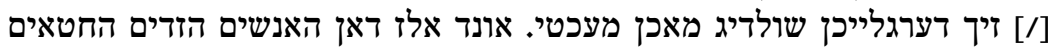

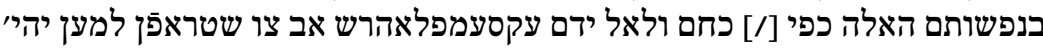

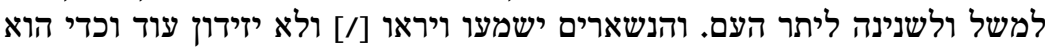

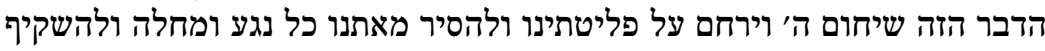

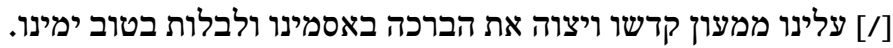

איין פَעמדר דער אצל ב״ב א׳ בקהלתנו משרת גוועזן, וואן שוינד בינתים במקום צ

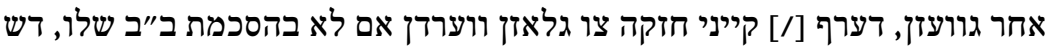

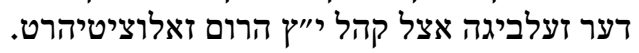

97 Danach פ als Zeilenfüller.

98 Danach die Kustode אוהני.

99 (Unter-)Farrnbach. 
לאב"ד בקהלתנו מאג אויף זיין אן הלטין מקהל י"ץ בצירוף ה'ד"ד וי" ו"ח ב"ב כנהוג

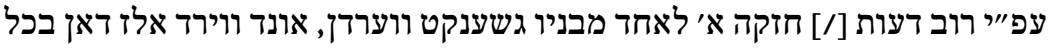

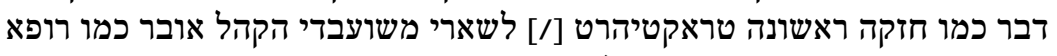

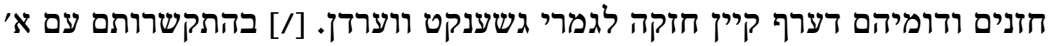

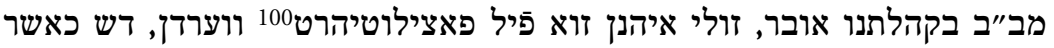

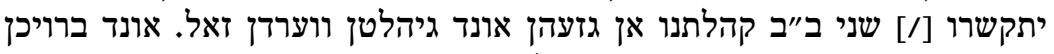

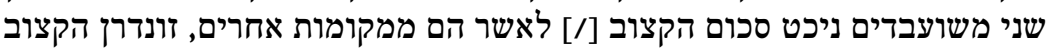

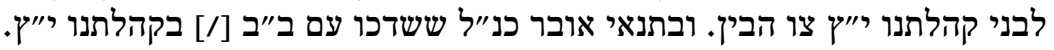

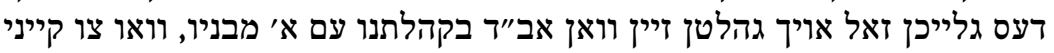

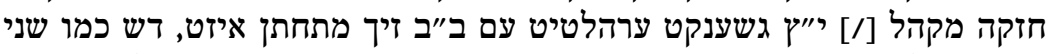

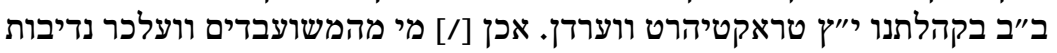

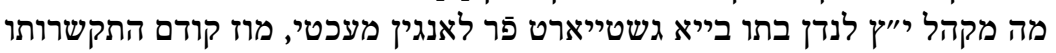

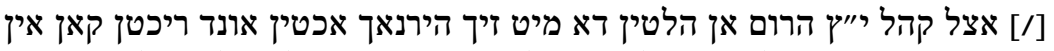

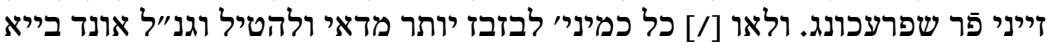

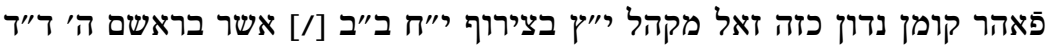

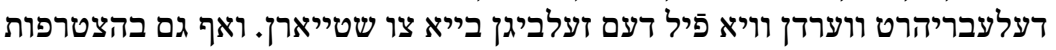

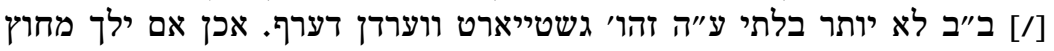

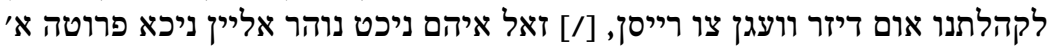

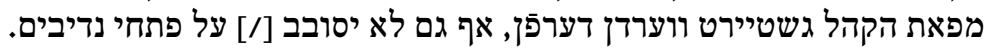

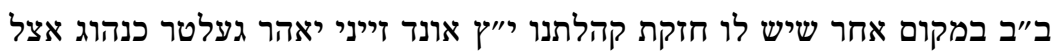

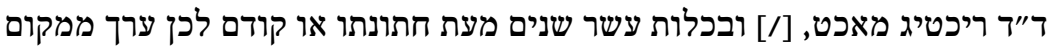

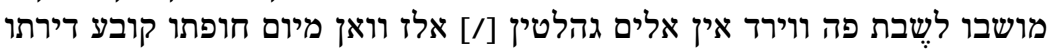

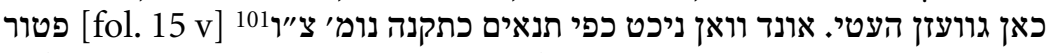

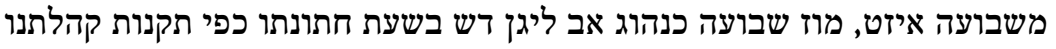

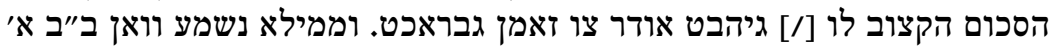

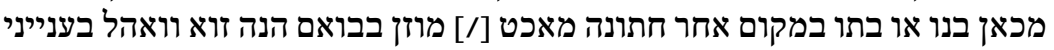

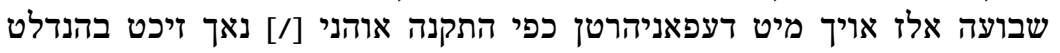

ווארדן.

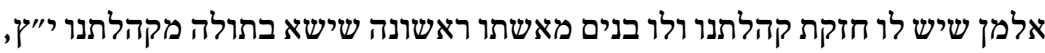
ק"ב

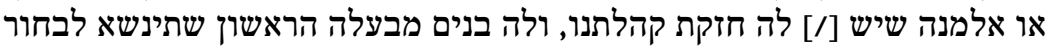

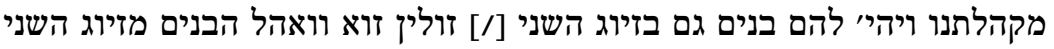

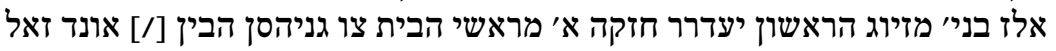

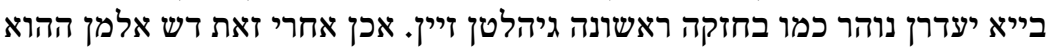

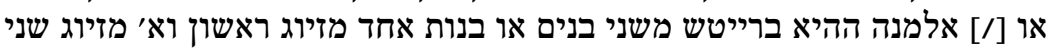

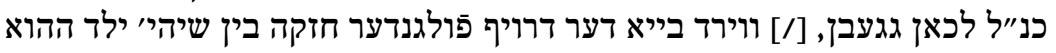

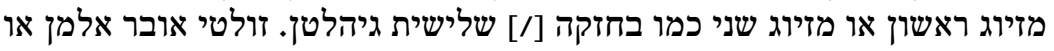

100 Von frz. facile = leicht; mühelos.

101 Danach die Kustode פטור. 
אלמנה אחת מפה שיש להם בנים מן זיוגם הראשון, בתולה [/] או בחור ממקום

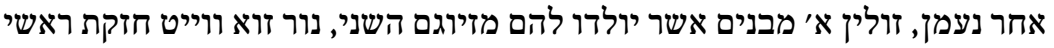

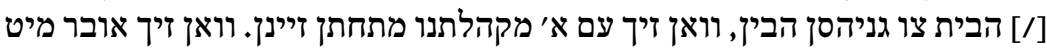

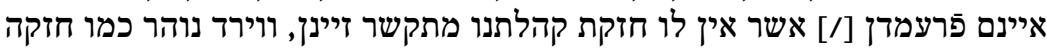

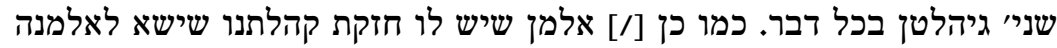

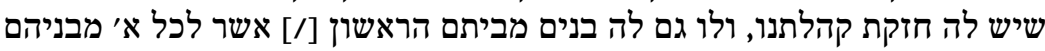

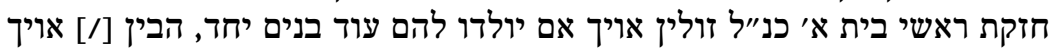

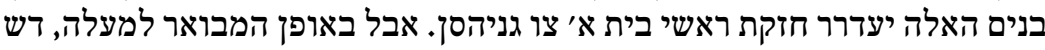

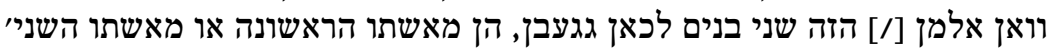

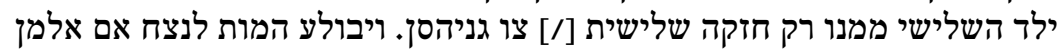

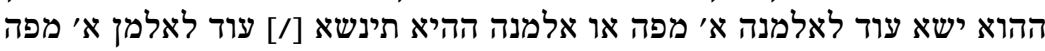

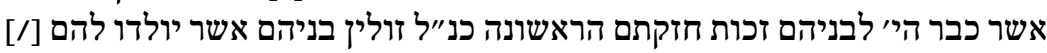

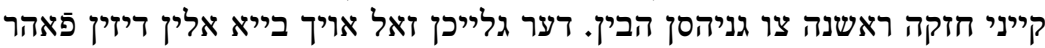

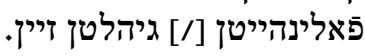

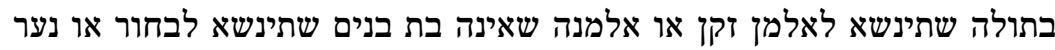

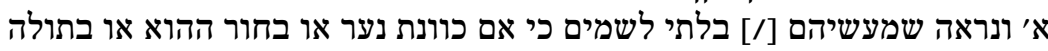

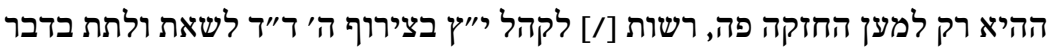

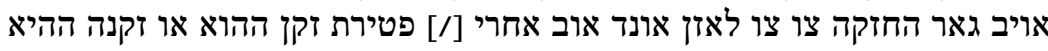

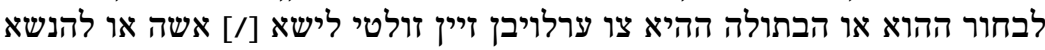
לאיש ממקום אחר.

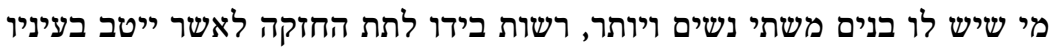

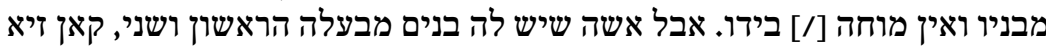

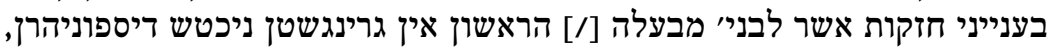

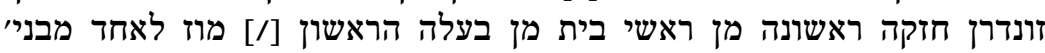

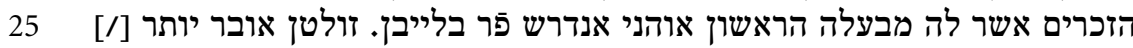

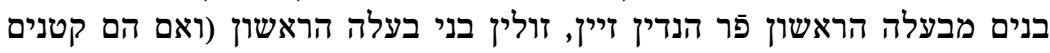

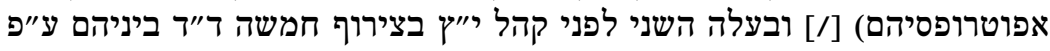

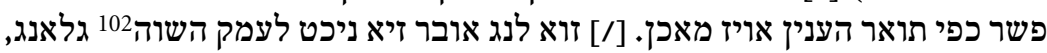

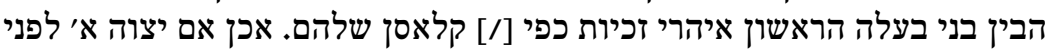

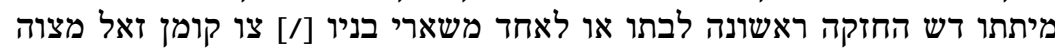
לקיים כנ"ל.

[fol. $16 \mathrm{r}$ ]

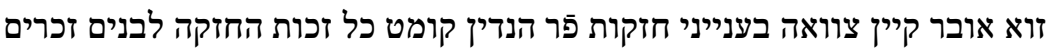

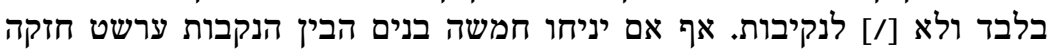

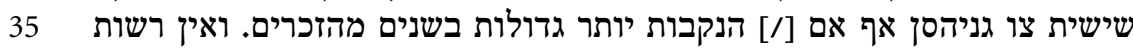

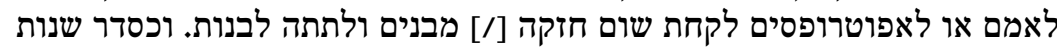

102 Gen 14,17.

103 Danach die Kustode זוא. 
הזכרים כן סדר החזקה ביניהם, הגדול החזקה ראשונה [/] ושלאחריו חזקה השנים וכים

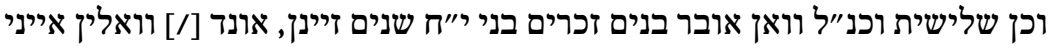

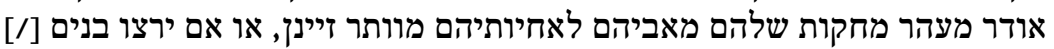

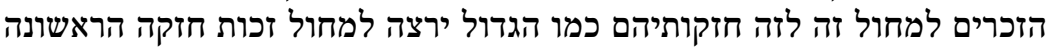

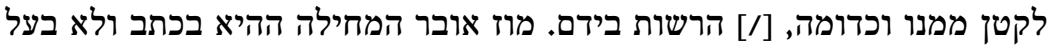

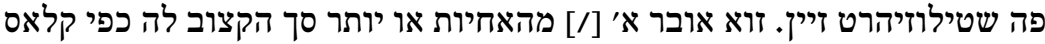

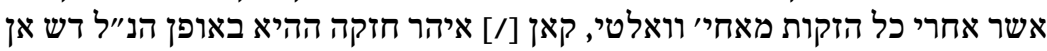

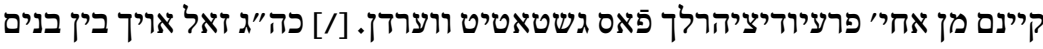

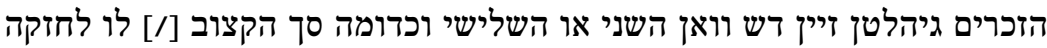

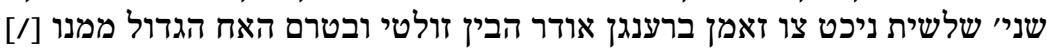

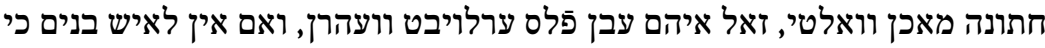
אם [/] בנות גיהן החזקות עבן פּלס כסדר מנין פלד ערלויבטותיהן.

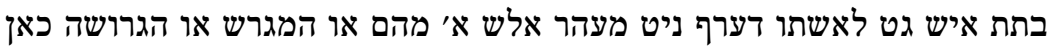

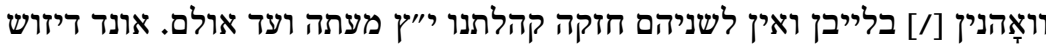

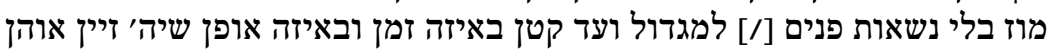

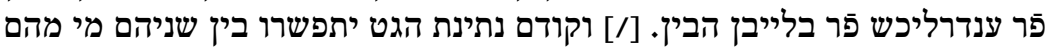

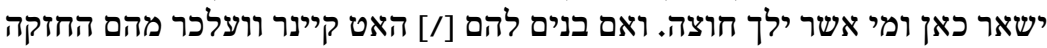

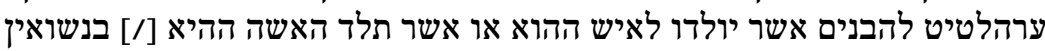

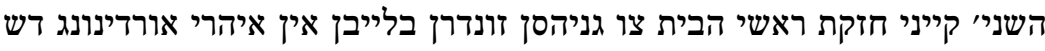

$$
\text { החזקות [/] כסדר גיהן. }
$$

ק"ה

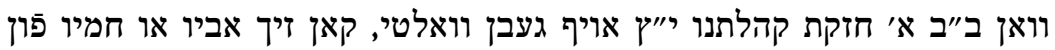

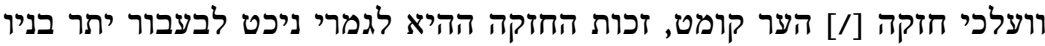

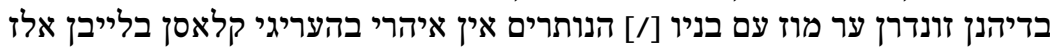

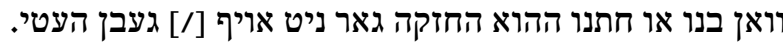

בשנת חזרה יבולע המות לנצחי104 בלייבט החזקה להאלמן או להאלמנה בין שהם

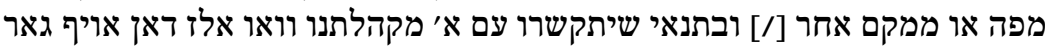

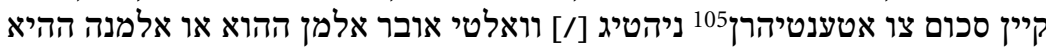

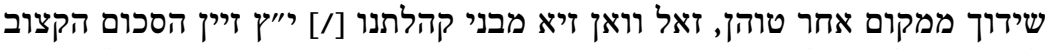

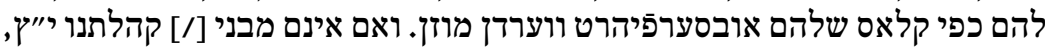

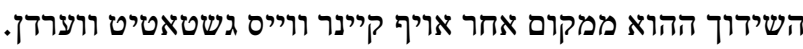




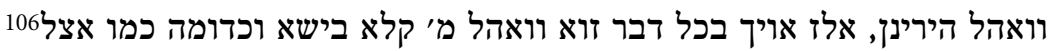
[fol. 16 v]

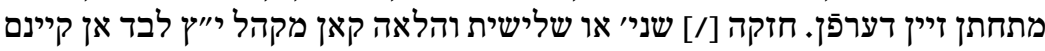

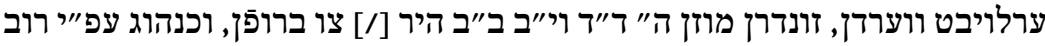

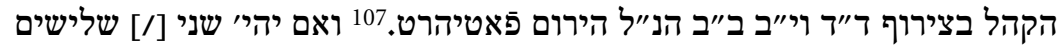

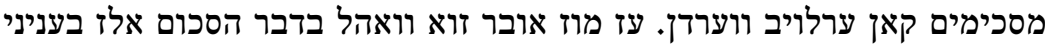

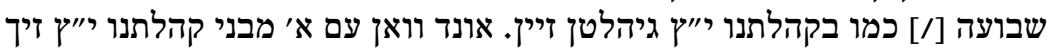

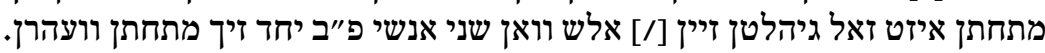

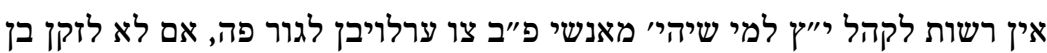
ק"ט

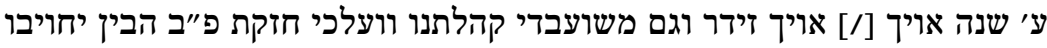

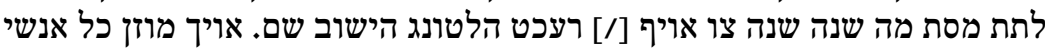

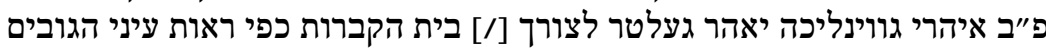

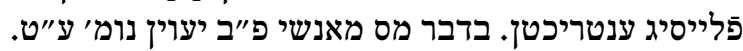

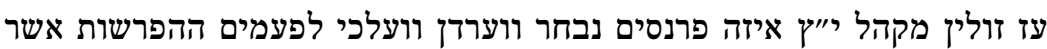

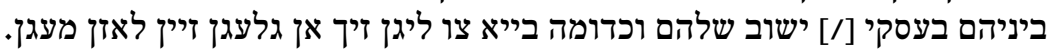

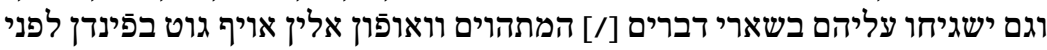
קהל י"ץ רעפאריהרן קענין.

תיקוני גובים קי"א

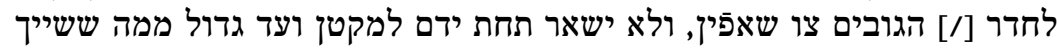
לעסקי קהל כמבואר נומ' א'ים

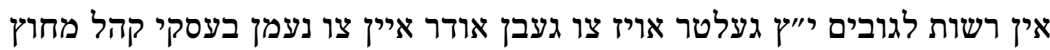

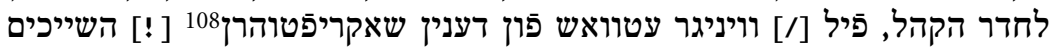

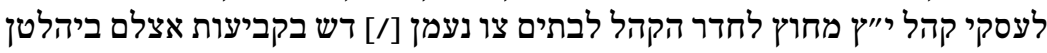

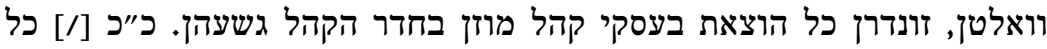

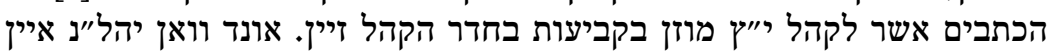

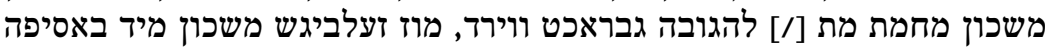
ראשונה לחדר הגוביי י"יץ גשאפט מובה גברערדן.

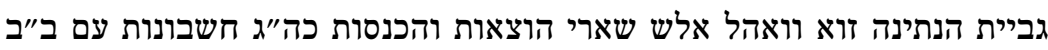

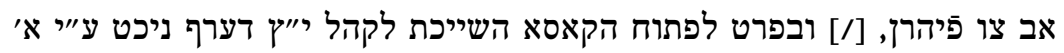

106 Danach die Kustode בני.

107 Votiert, stimmt ab.

108 Aufzeichnungen. Die lokale Aussprache des Begriffes hatte sich, wenn man die Schreibweise zugrunde legt, offenbar schon weit vom Original entfernt. 


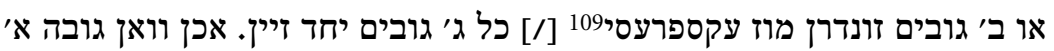

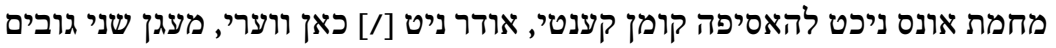

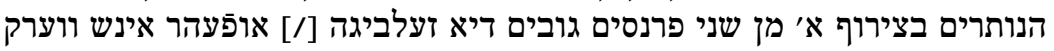

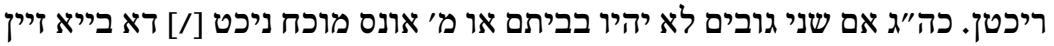

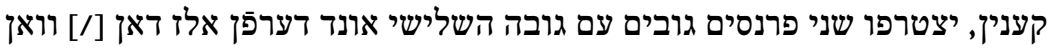

כל ג' גובים יחד וועהרן טראקטי פרנסים גובים עם גופי

להקל משא כבד מעליהם מעגן הגובים י"ץ איינם שרייבר זיך אן נעהמן לעמוד

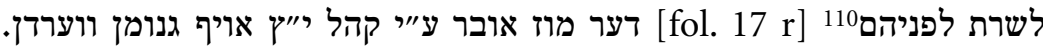

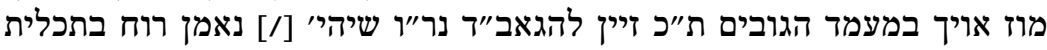

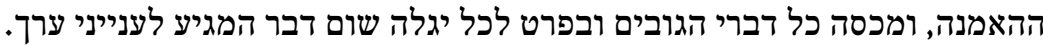

בכל ימות השנה יחויבו הגובים להתאסף לכל הפחות פעם א׳ בשבוע לעיין בעסקי

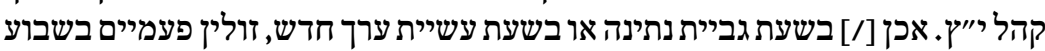

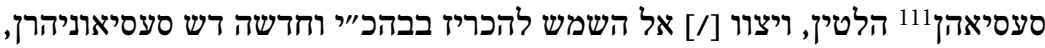

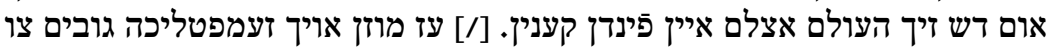

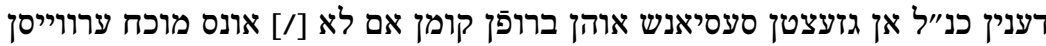

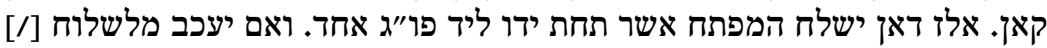

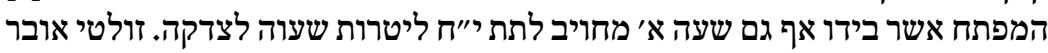

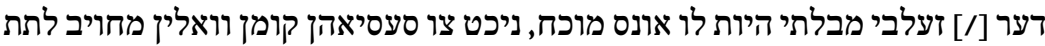

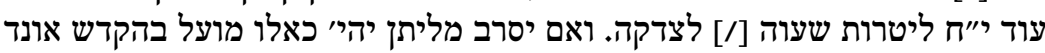

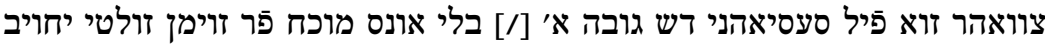

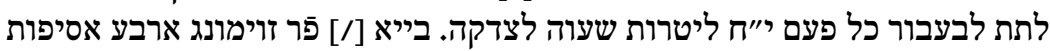

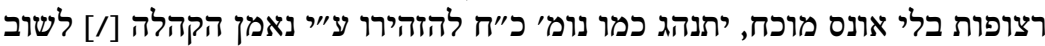

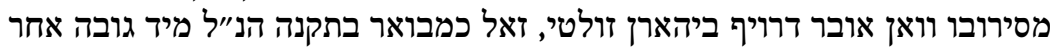

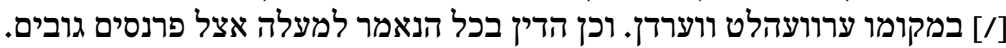

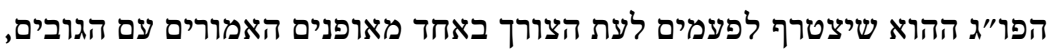

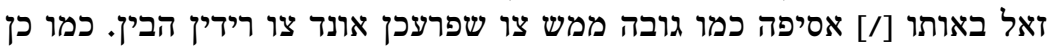

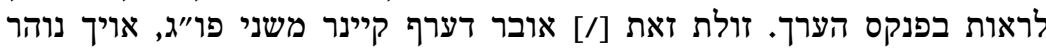

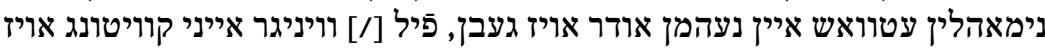

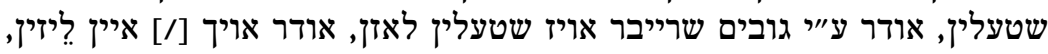

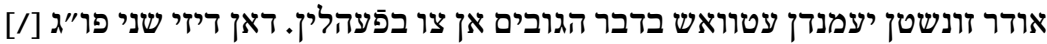

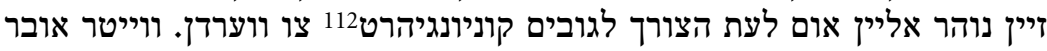

הבין זיא לגמרי [/] בעסקי הגובים ניקש צו קאמידיריה לגובים קוניוניהרן.113

קט"ר

109 Ausdrücklich.

110 Danach die Kustode דער.

111 sesyohn $=$ Session, Zusammenkunft.

112 Von frz. conjuguer $=$ beigesellen, miteinander verbinden.

113 Gemeint ist wohl: kommandieren. 


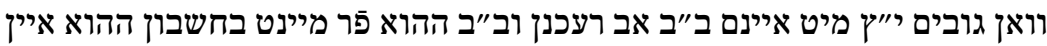

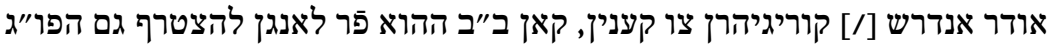

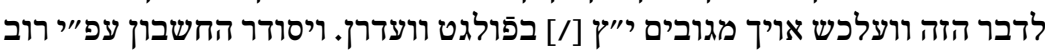
בין הגובים ובין הפרנסים וועל גובים מגובים ידים

5 קי"ח

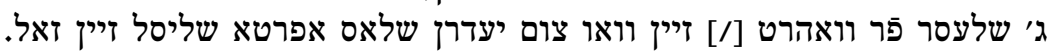

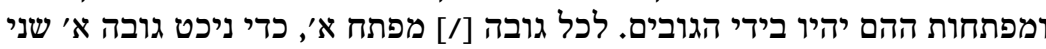

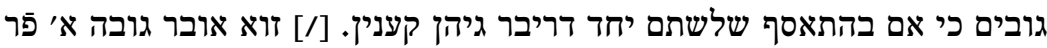

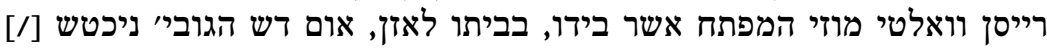

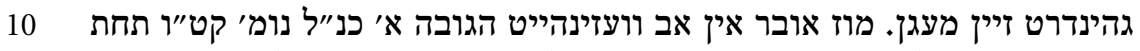

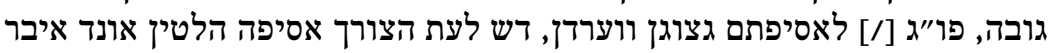

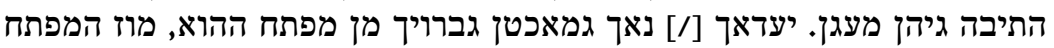

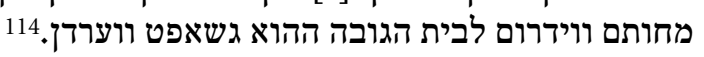

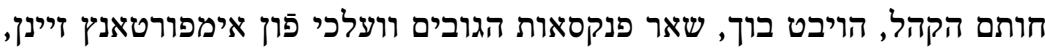
קי"ט

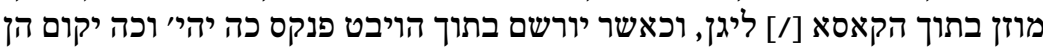

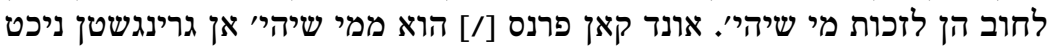

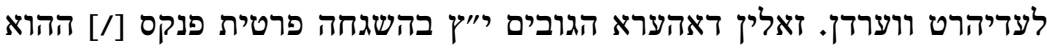

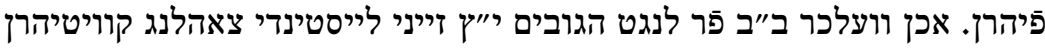

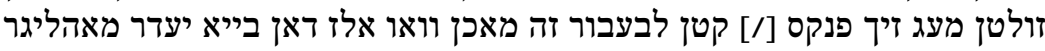

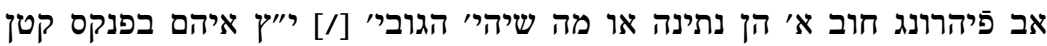

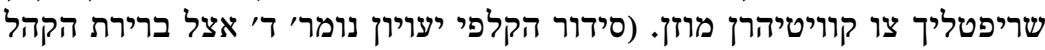

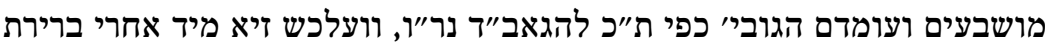

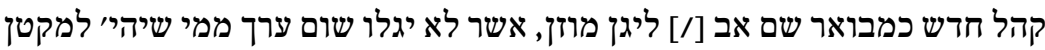

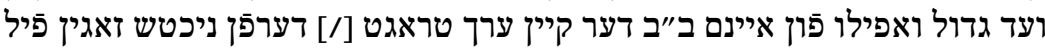

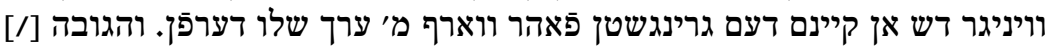

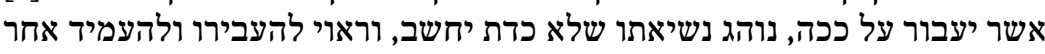

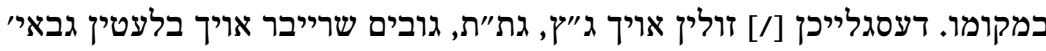

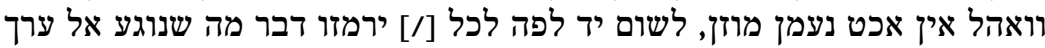
שום אדם.

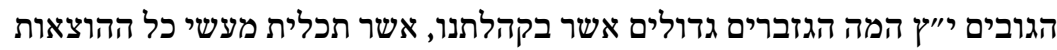

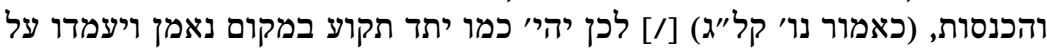

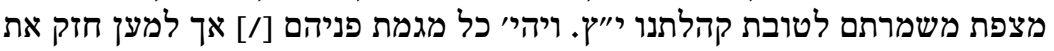

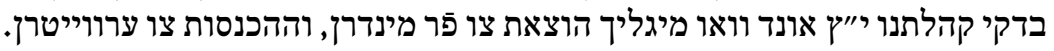

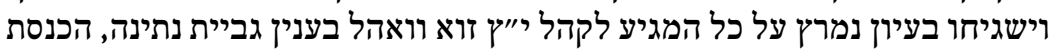

114 Danach die Kustode חותם. 


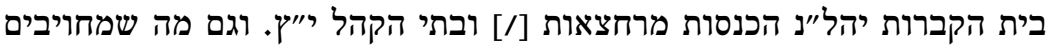

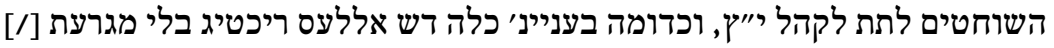

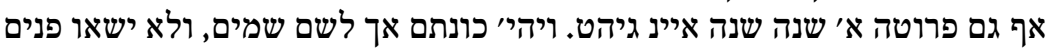

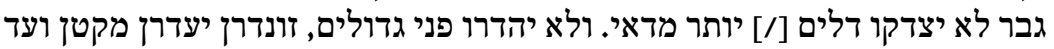

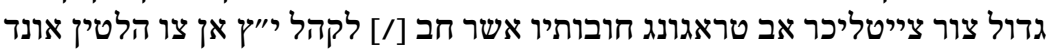

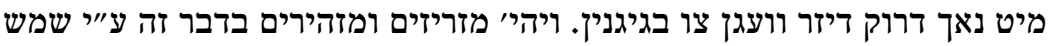

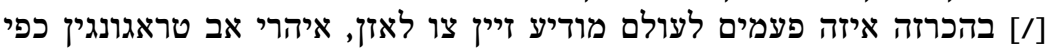

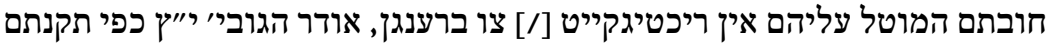
עם כפיות ונגישות נגד המתמהמהיהם אין ריכטיגיוט ומעכבים פَר פَאהרן ווערדן.

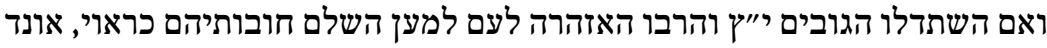

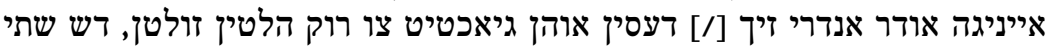

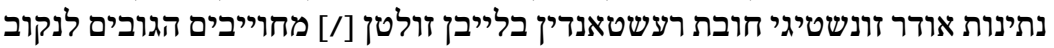

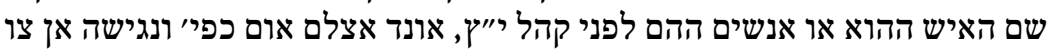

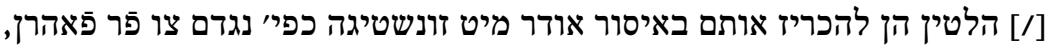

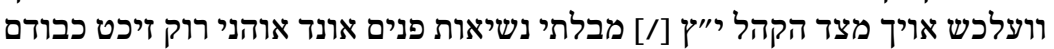

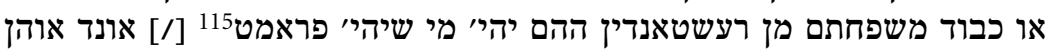

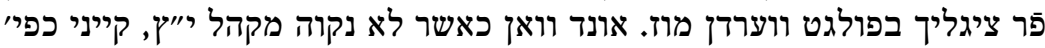

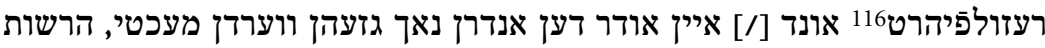

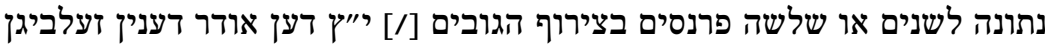

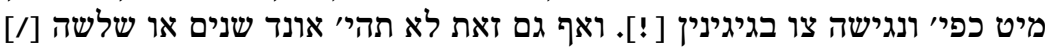

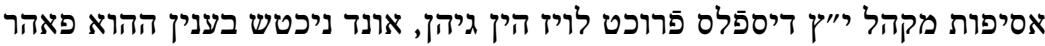

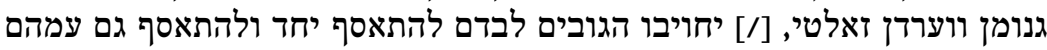

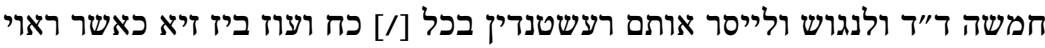

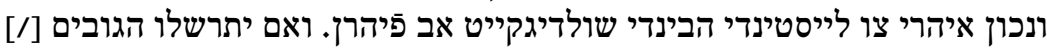

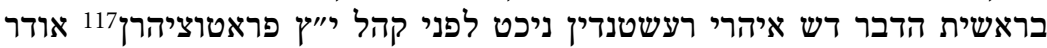

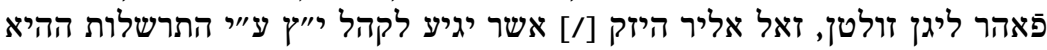

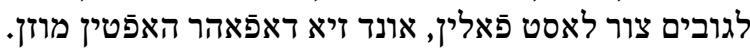

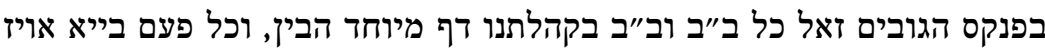

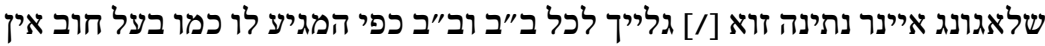

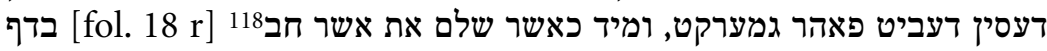

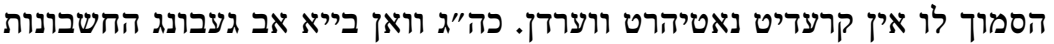

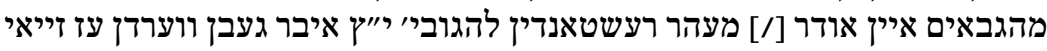

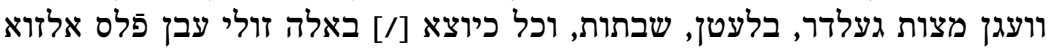

115 promt $=$ prompt, sofort.

116 Resolviert, beschließt, kommt überein. Dieser Begriff wurde in zahlreichen aschkenasischen pinkasim verwendet.

117 Produzieren, hier in der Bedeutung: darlegen.

118 Danach die Kustode בדף. 


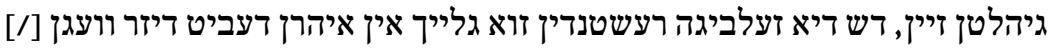

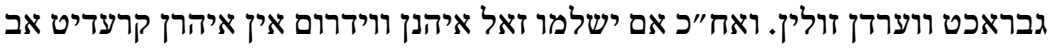

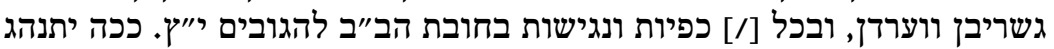

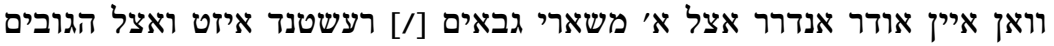
דאפאאהר אן גגעבן ווארדן, דש אללעם כניל נודר נומ' קכ"ב פַר פַאהרן ווערדן זולי.

וואן ב״ב א' לבנו או לבתו קנס ליגן וואלטי דערף איהם ניכט עהנדיר גשרט גשטאטיט

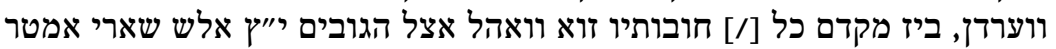

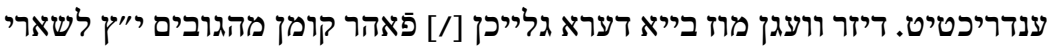

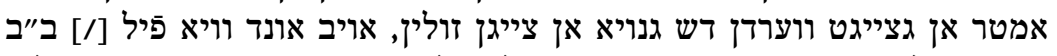

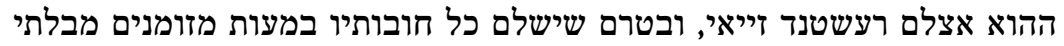

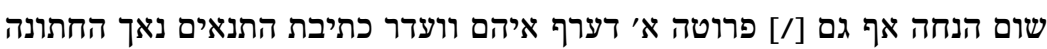

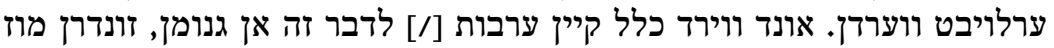

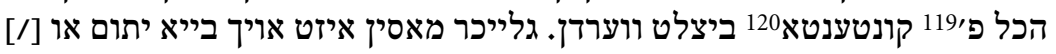

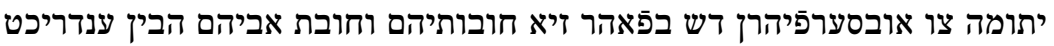

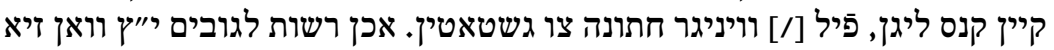

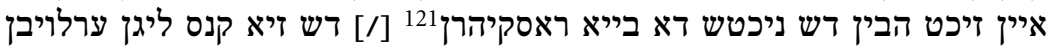

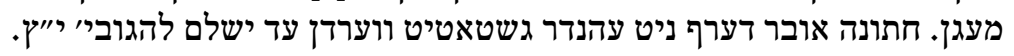

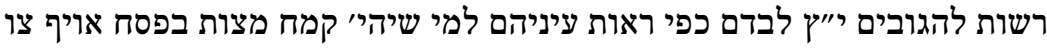
קכ"ה

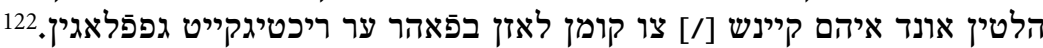

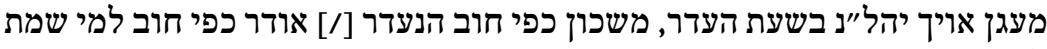

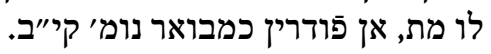

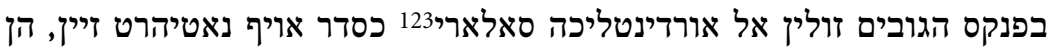
קכ"ו

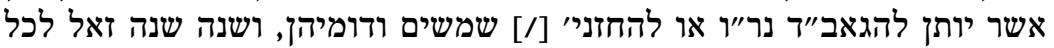

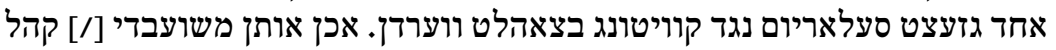

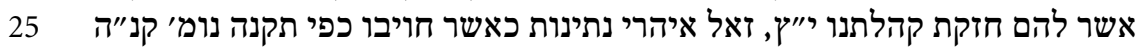

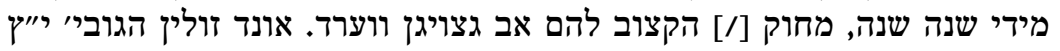

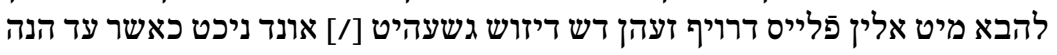
נעגלאשיהרט124 ווערדן מעכטי.

119 Die Auflösung der Ligatur ist unklar.

120 Von frz. contente = zufrieden; genügend.

121 Riskieren.

122 Durch die Vorenthaltung des rituell reinen und ungesäuerten Pessachmehls wäre die Begehung des Festes nach damaligem Verständnis unmöglich gewesen. Bei der außerordentlich hohen Bedeutung von Pessach im jüdischen Festzyklus wäre dies einer unermesslich hohen Strafe gleichgekommen.

123 Abgeleitet von Salär $=$ Verdienst.

124 negloshihrt = negligiert, vernachlässigt. 


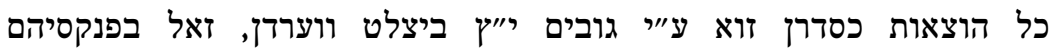

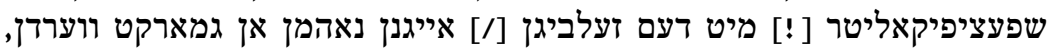

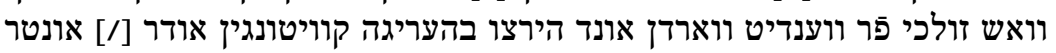
שריבני חשבונות יכונו יחדיו לענריט ווריו למשרת.

הגובים לבדם הבין קיין רשות ממעות קהל אן יעמנד דרך מתנה צו געבן, זונדרץ

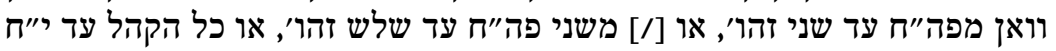

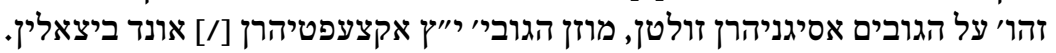

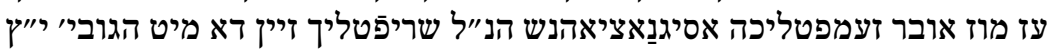

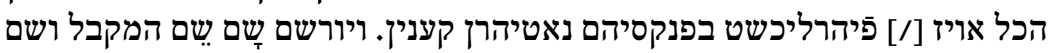

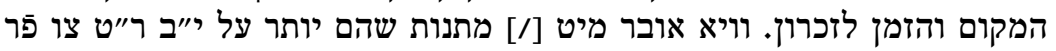
הלטין מבואר בהנהגת הקהל נומן לומרוֹ סובר מיט.

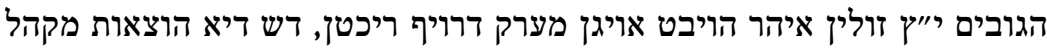

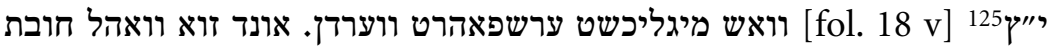

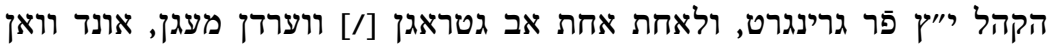

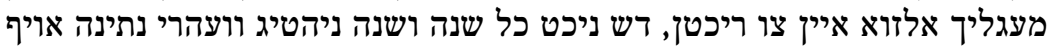

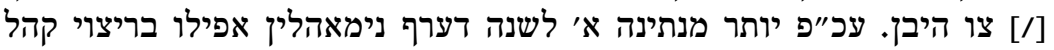

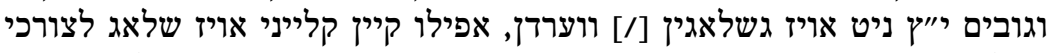

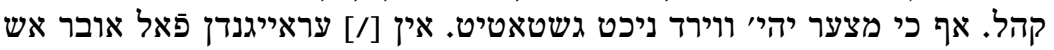

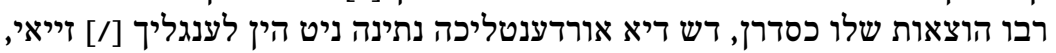

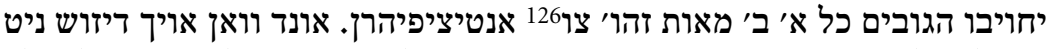

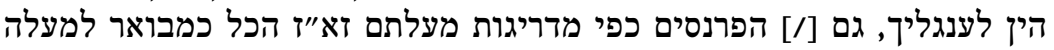

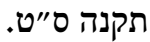

וואן לצורך שעה איין קאפיטאהל אויף גנומן ווערדן מוז, אונד זולכש כמבואר

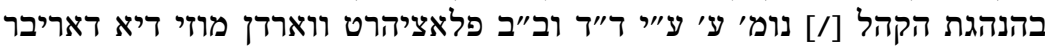

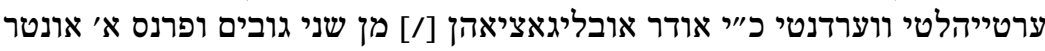

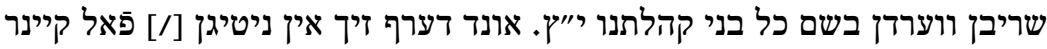

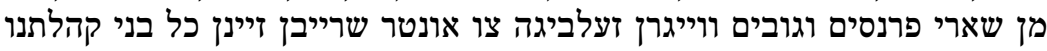

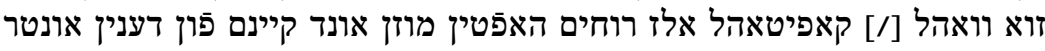

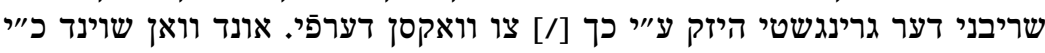

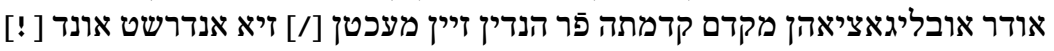

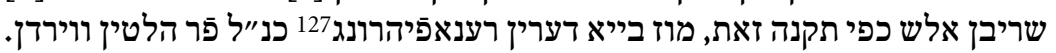

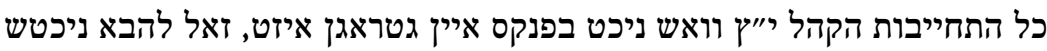

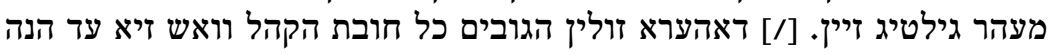

125 Danach die Kustode וואש.

126 Dieses Wort über der Zeile ergänzt.

127 Erneuerung der Schuldscheine. 
חייב זיינן אורדענטליך פَאהר מערקן, [/] ומה טוב וואן כ"י אודר אבליגאציאהן כמבואר בתקנה שלפני זאת גגעבן ווערדן קענטי פורי.

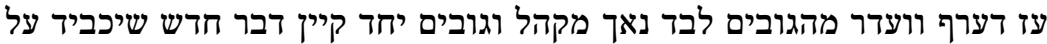

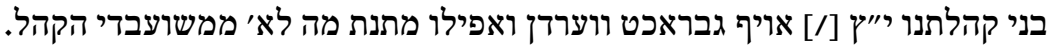

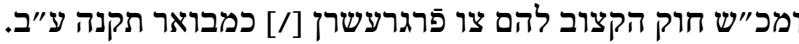

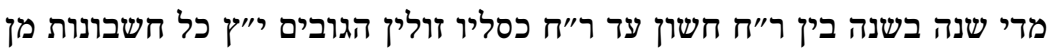

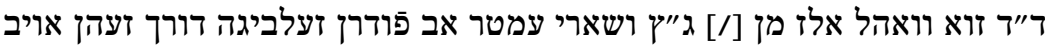

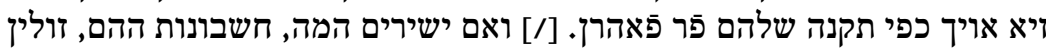
הגובים איהנן דריבר קוויטיהרן והחשבונות יהיו שמורים תחת [/] ידי הגובים י"יץ. זירין

מן ר"ח כסליו עד ר״ח טבת מוזן הגובים בקנס מאה ר"ט שפעצ׳128 לצדקה היינו 10

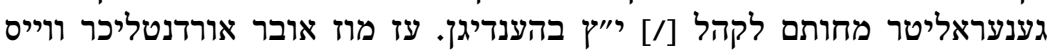

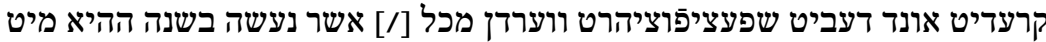

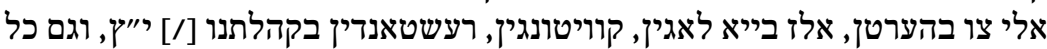

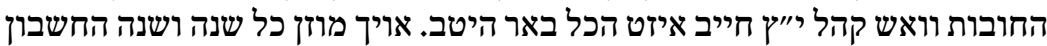

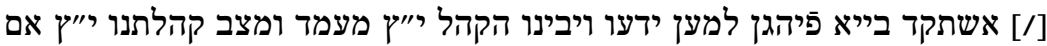

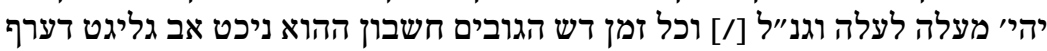

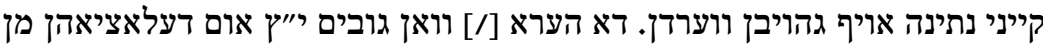

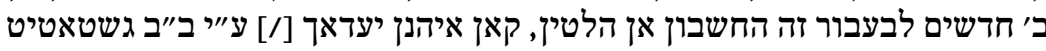
ווערדן הין גיגן מוז אויך כנ"ל מיט נתינה זלפון זוא לנג סופסענסאי 129 בלייבן.

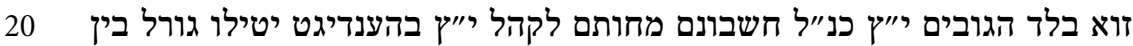

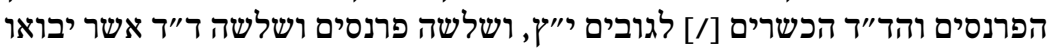

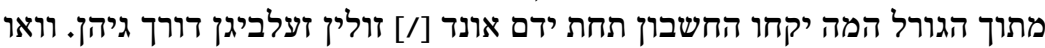

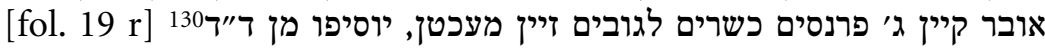

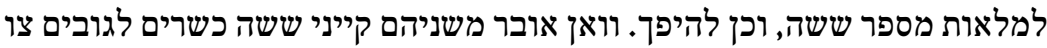

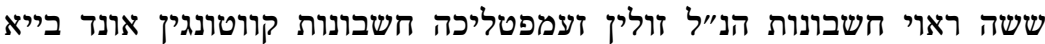

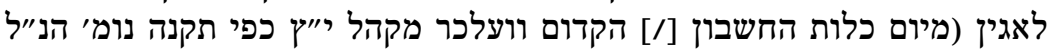

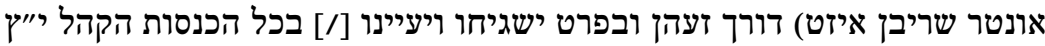

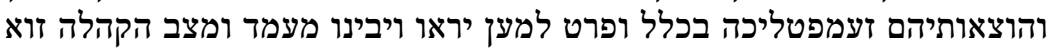

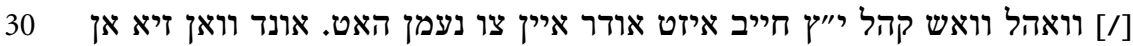

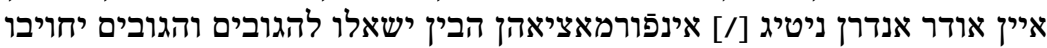

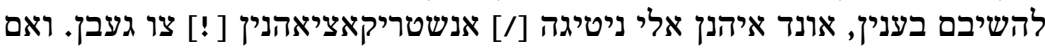

128 Speziesreichstaler, nach einem Konventionsfuß ausgeprägte Reichstaler.

129 Vorläufig ausgesetzt.

130 Danach die Kustode למלאות. 
נכון וישר מצאו חשבון הגובים זולין זיא זעלביגה אונטר שרייבן [/] והחשבון

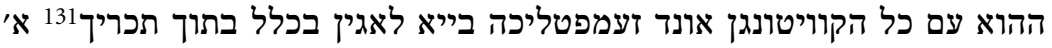

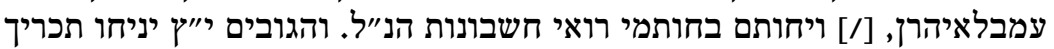

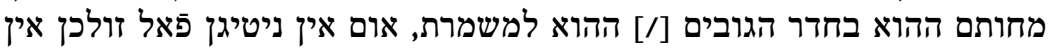

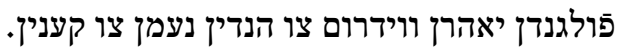

רואי חשבונות הנ״ל יתאספו בחדר הגובים אונד זולין ששה ר״יט מקוני מקופת הקהל קל"ז

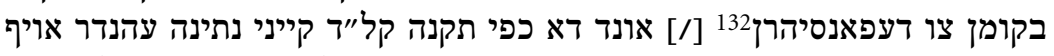

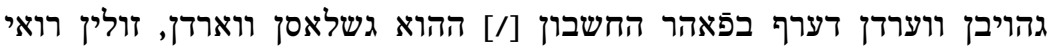

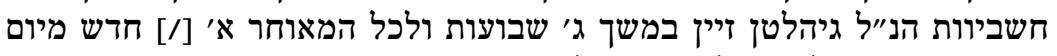

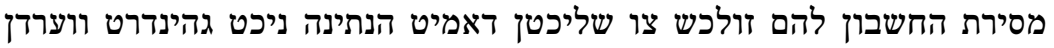

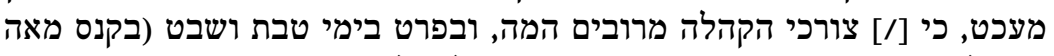

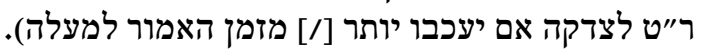

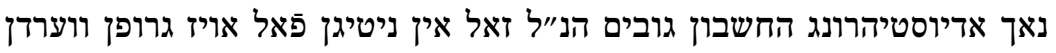

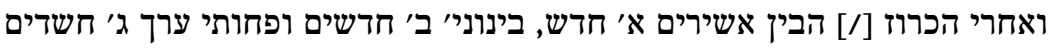

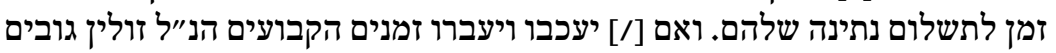

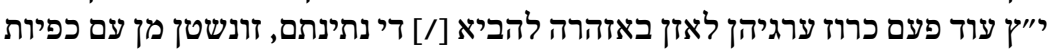

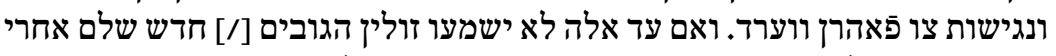

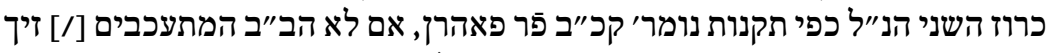

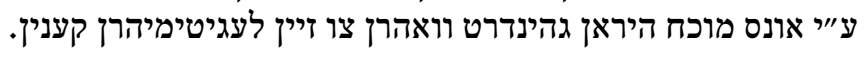

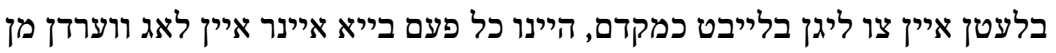

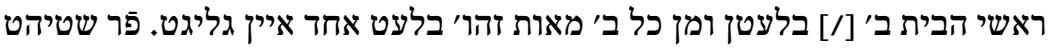

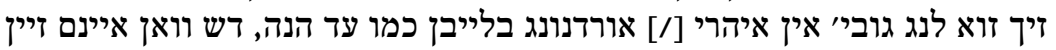

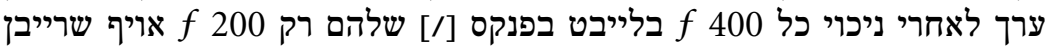

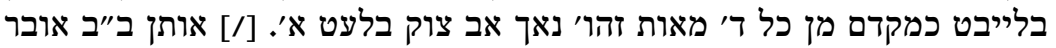

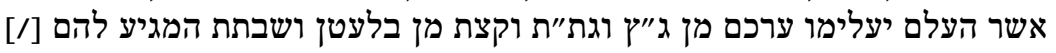

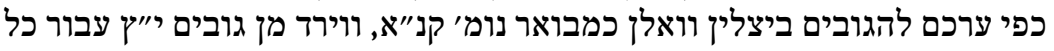

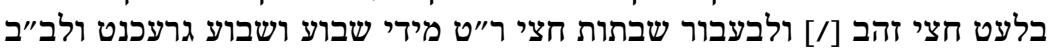

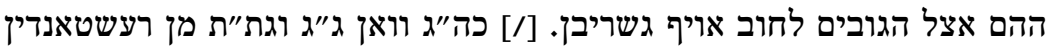

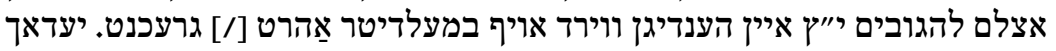

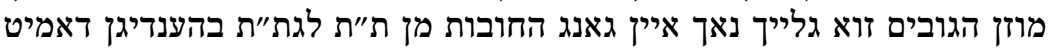

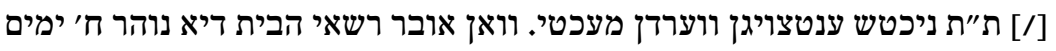

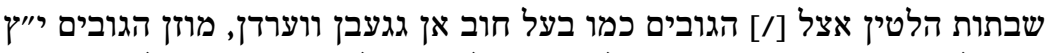

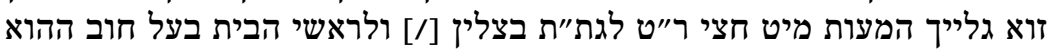

131 Bündel.

132 depansihrn = kompensieren; hier wohl als Entschädigung für Aufwendungen der Rechnungsprüfer zu verstehen.

133 Die Nummer קל"ט (139) wurde nicht vergeben. 
שטאט דעסן ב' בלעטן תמור ח' יום שבתות איין גליגט ווערדן [/] וועלכש זוא

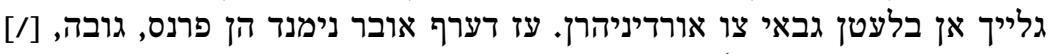

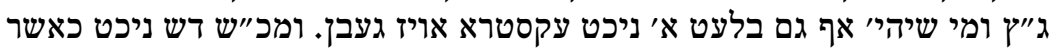

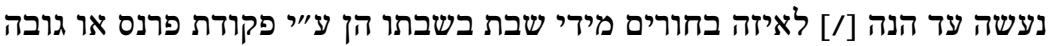

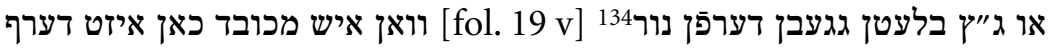

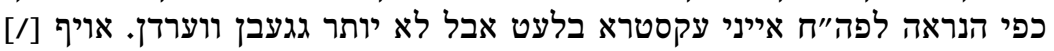

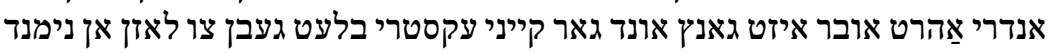

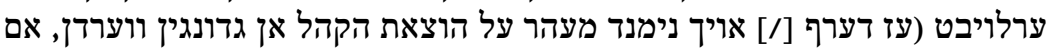

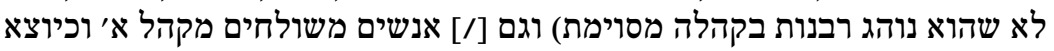

זוא135 וואהל לביקור חולים אלז לג"צ מוז מהגובים מעות די צרכם נגד קוויטונג

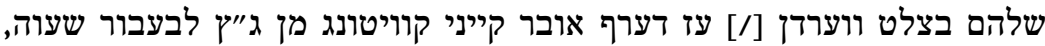

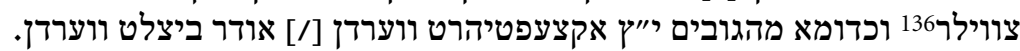

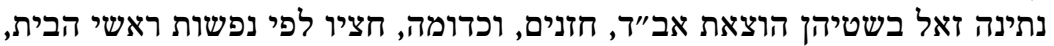
קמ"ב

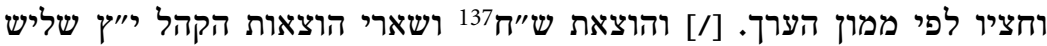

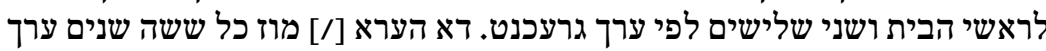
חדש גמאכט ווערדן דהיינו כ"פ בר"ח שבט אחר ברירת קהל חדש בכלות ששה

שנים. - שרשים

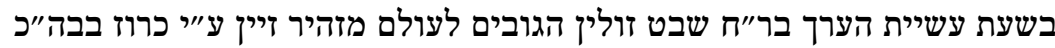

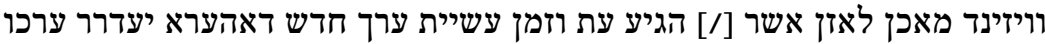

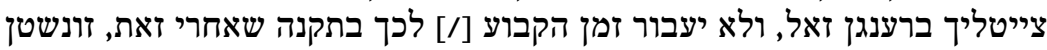

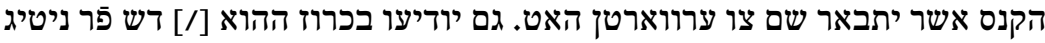

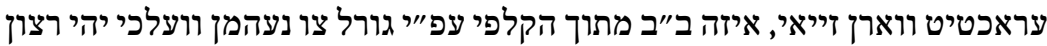

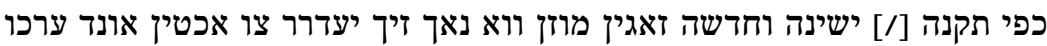
בנאמנות וישרנות אן זאגין וויל.

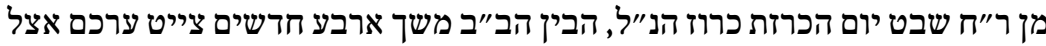

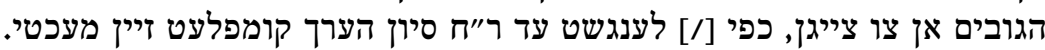

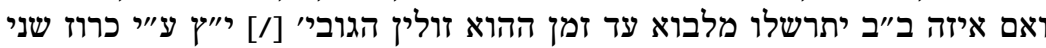

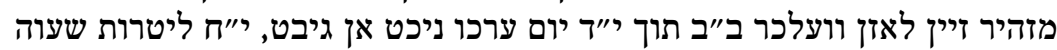

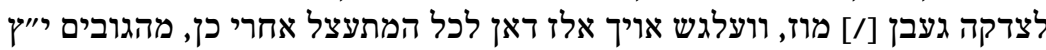

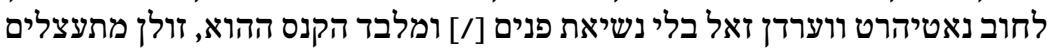

134 Danach die Kustode וואן בלקן.

135 Danach gestrichen: בלד.

136 Kleidungstück.

137 Neujahrsgeld, eine Form der den Juden auferlegten Abgaben. 


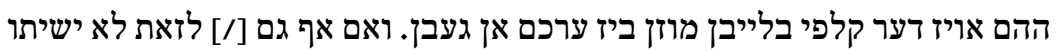

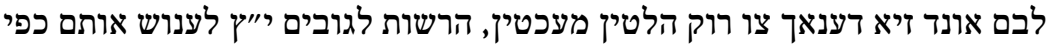

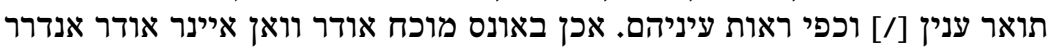

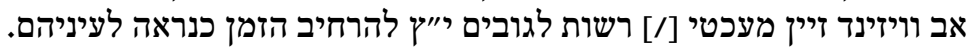

עז מוז יעדרר ב״ב ערכו בכתב על צעטל א׳ איין געבן אונד זולכן צעטיל בחדר

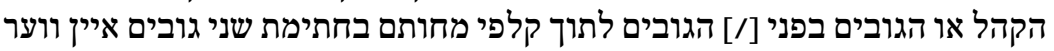

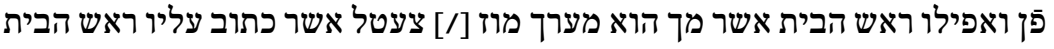

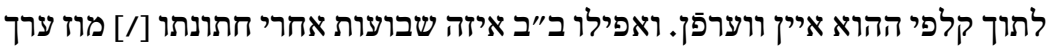

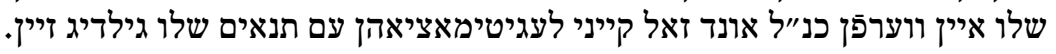

כל הנאמרים למעלה הן רה"ב או בעלי ערך ואפילו ב"ב איזה שבועות אחרי חתות שתונתו

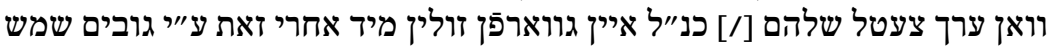

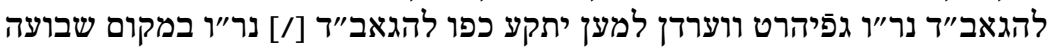

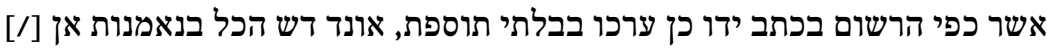

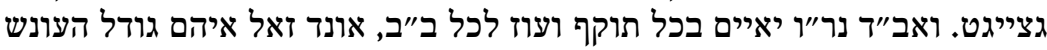

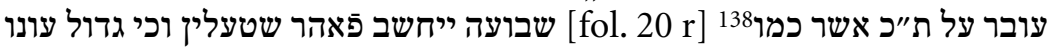

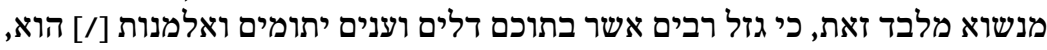

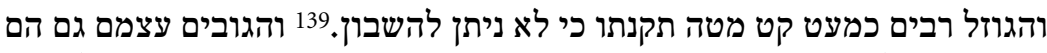

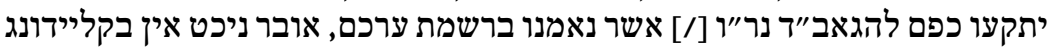

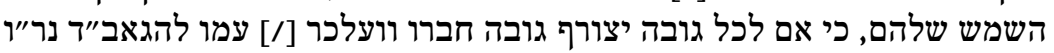

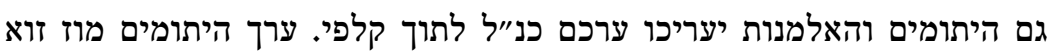

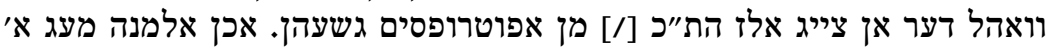

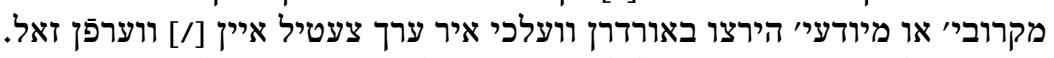

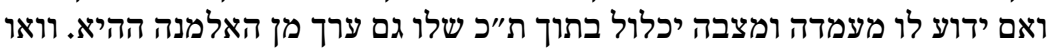

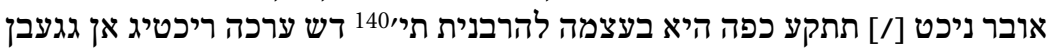
האט, ובמעמד הגאב"ד נר"וּו.

זמן ינתן לכל חתן וועלכר באיזה זמן שיהיי חתונה מאכט ג' חדשים מהכים אחרי

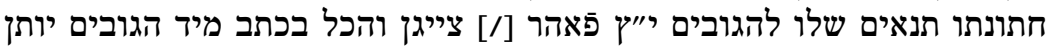

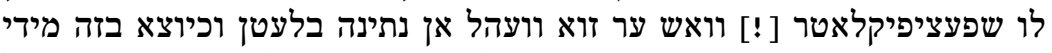

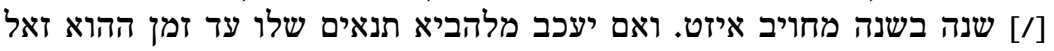

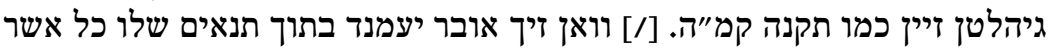

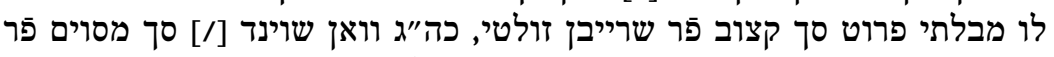

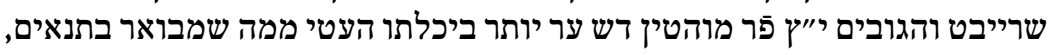

138 Danach die Kustode שבועה.

139 Eruvin 62a.

140 תחיה 
קענין איהם [/] ת״כ אב פַאדרן, וועלכש ער אויך אלז דאן צו לייסטן שולדיג דש ער ניכטש מן יכלתו מעלים זייאי.

מי שיש לו מאתים זהו' אן כסף וזהב מזומנים וחובות, ברויך נוהר בחציי אונד

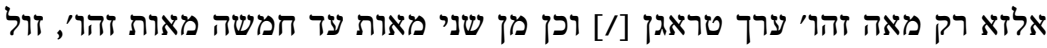

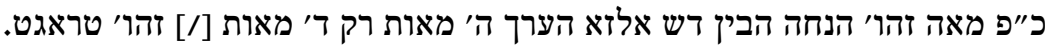

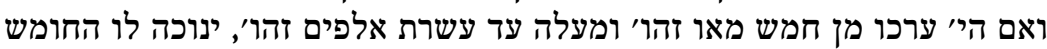

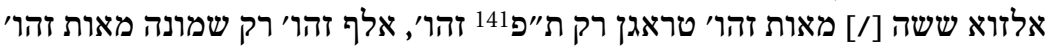

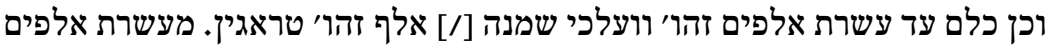

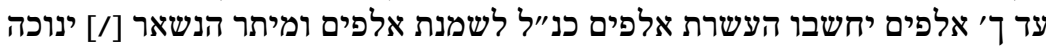

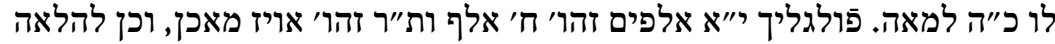

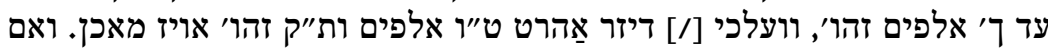

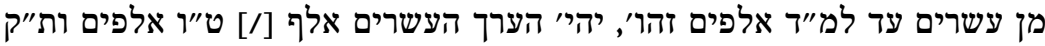

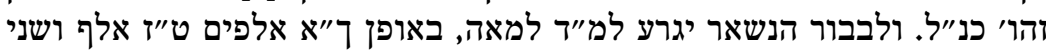

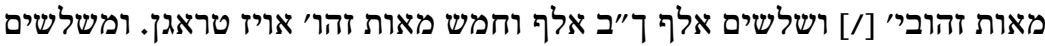

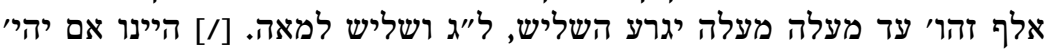

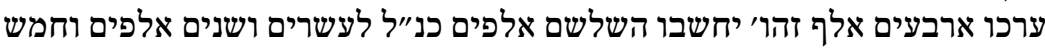

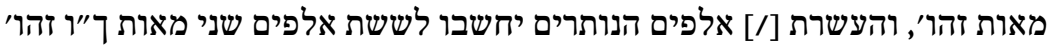

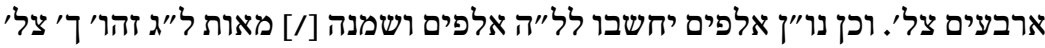
וכזה יחשב להלן אף גם בהחיק ה' ברכה לאיש עד בלי דים ושים

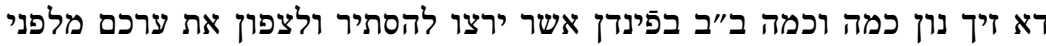

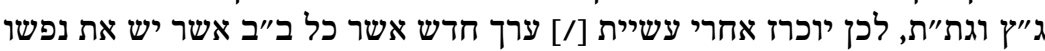

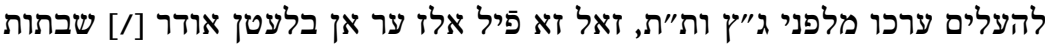

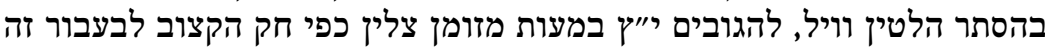

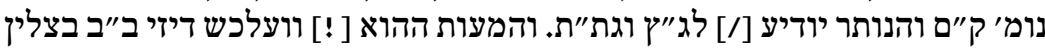

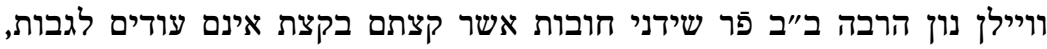

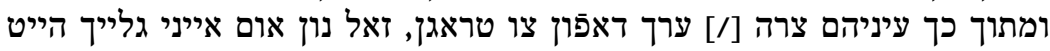

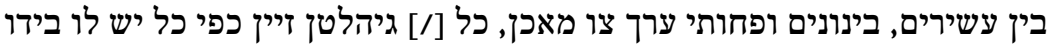

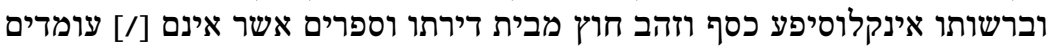

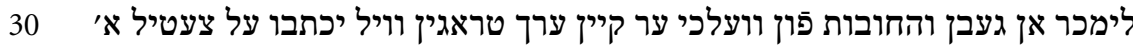

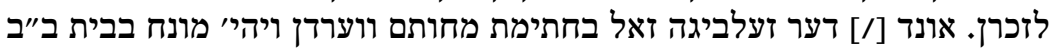

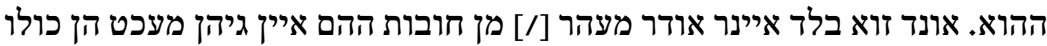

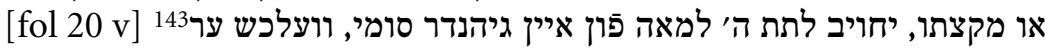

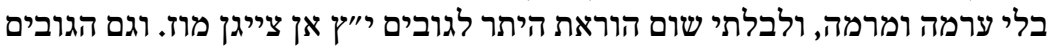

141 Ausgeschriebener Name des Buchstaben Tav, hier als Zahlenwert 400 verwendet. 142 Gebrauchen.

143 Danach die Kustode בלי. 


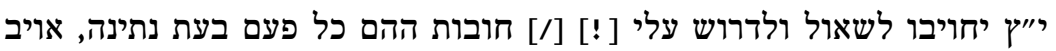

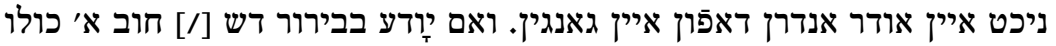

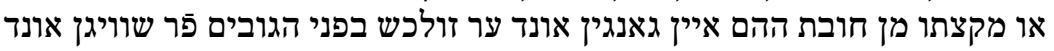

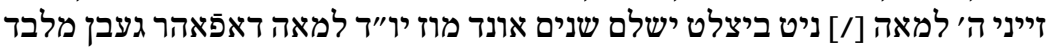

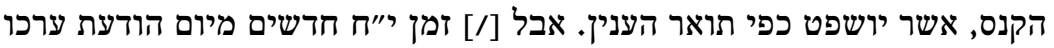

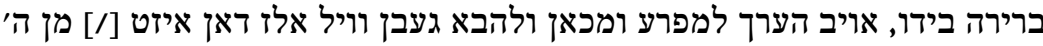

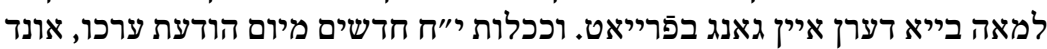

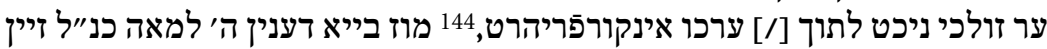

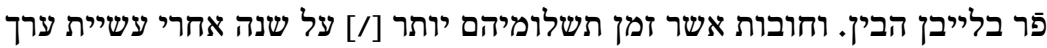

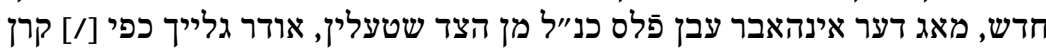

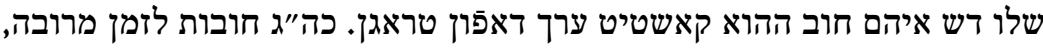

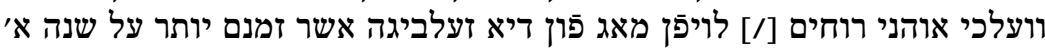
וי"ו למאה לשנה אב ציהן, והנותר אין ערך איפ אן געבן.

אם ישכיר איש ביתו או מקום בבה"כ לאחרים זאל מכל שמנה זהו' דש ער אייין

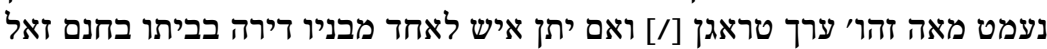

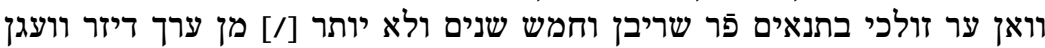

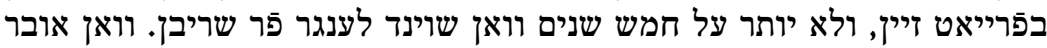

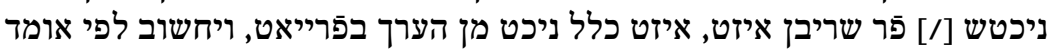

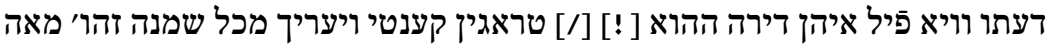

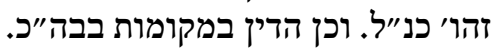

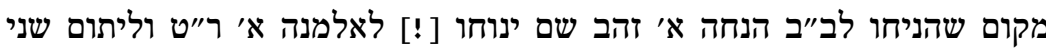

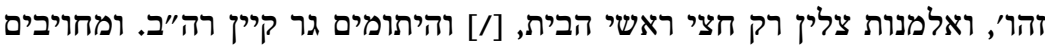

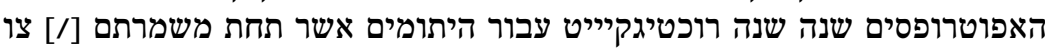

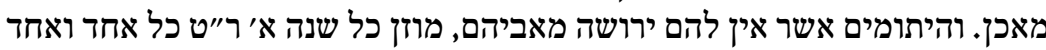

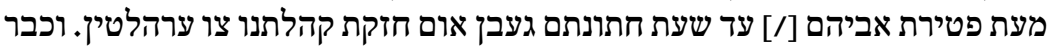

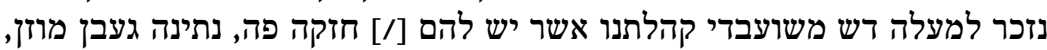

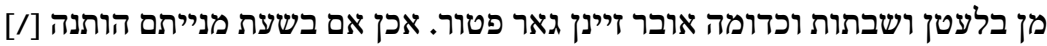

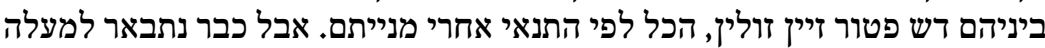

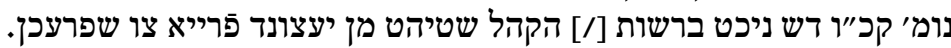

אם בתוך זמן ששת הדשנים נפל לאחד ירושת מה, אודר נדוניא ביקומט או זונשט

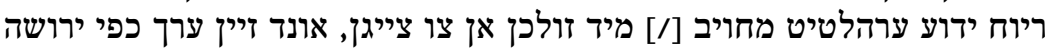

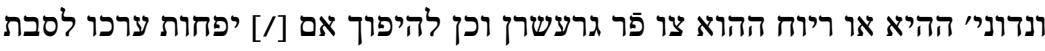

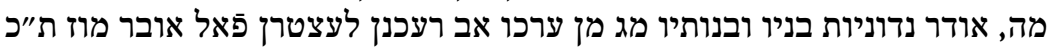

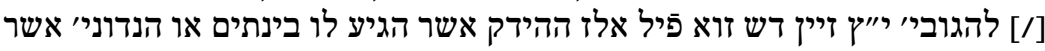

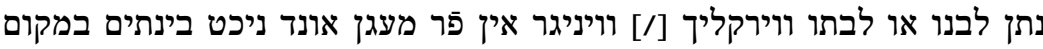

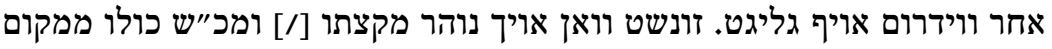

144 Inkorporiert, eingefügt. 


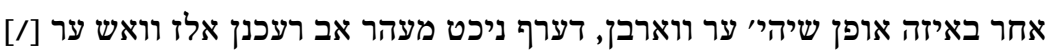

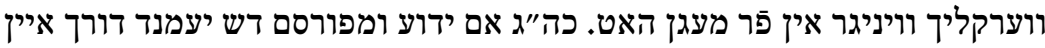

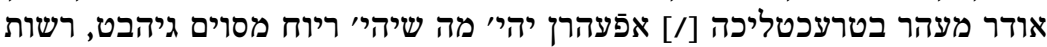

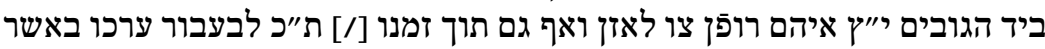
הוא שם אב צו פאדרן וועלכש ער אויך לייסטן מוז.

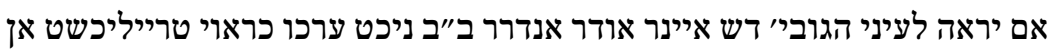

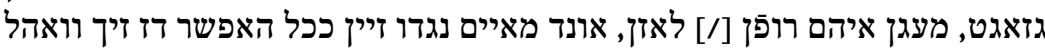

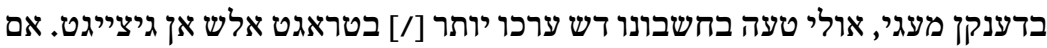

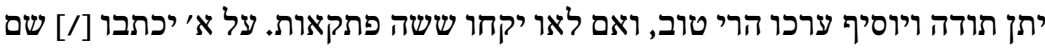

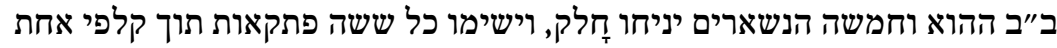

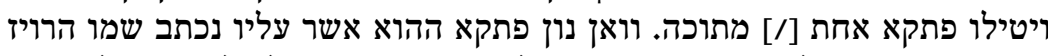

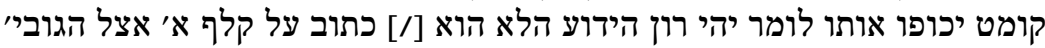

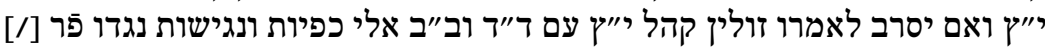

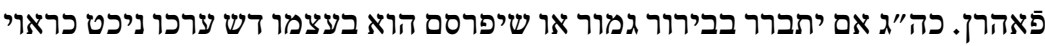
אן גגעבן [/] ענוש יענש כפי תואר הענין.

חצי שנה אחר החתונה, וכן ב״ב א׳ דער ממקום לפה קומט, חצי שנה אחרי בואו קנ״ו

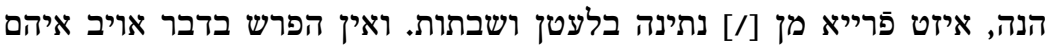

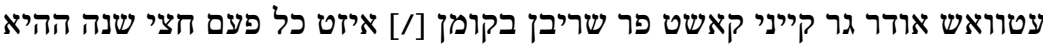

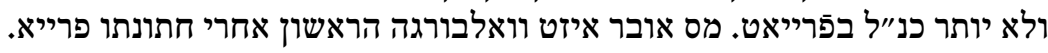

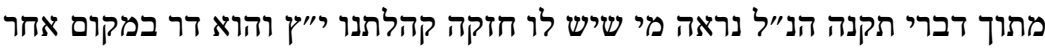

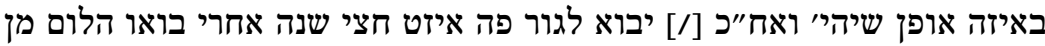

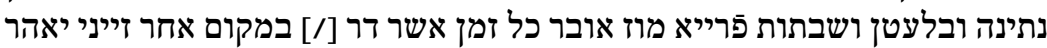

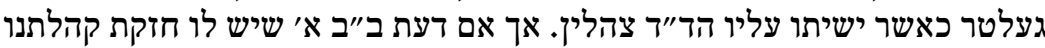

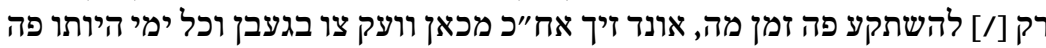

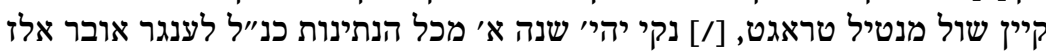

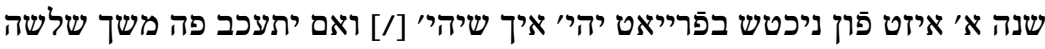

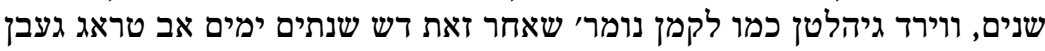

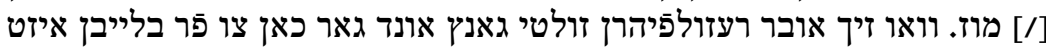
נוהר חצי שנה מעת [/] חתונתו פַרייא.

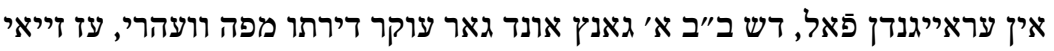
קנ"ח

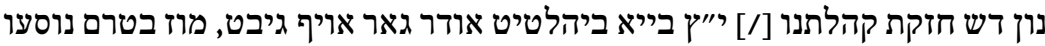

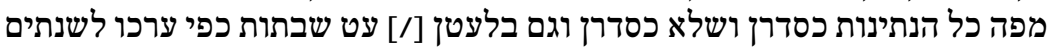

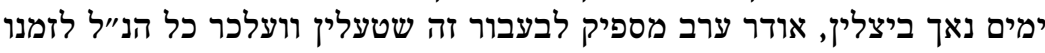

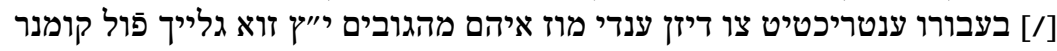

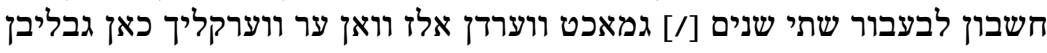

145 Danach die Kustode חצי 


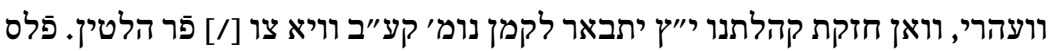

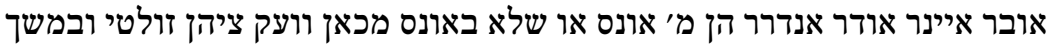

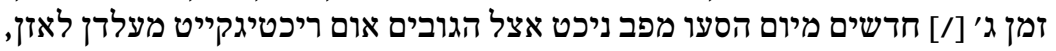

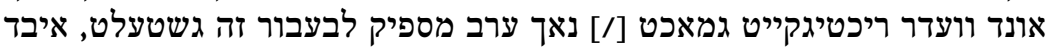

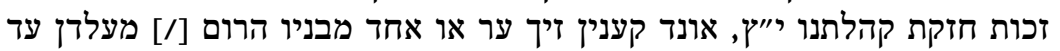

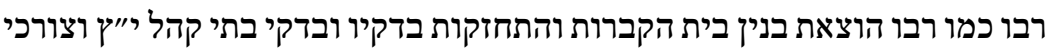

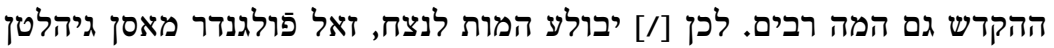

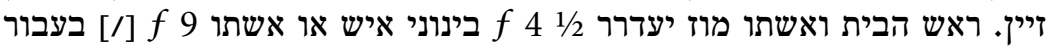

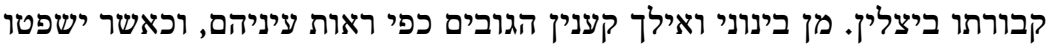

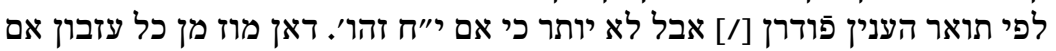

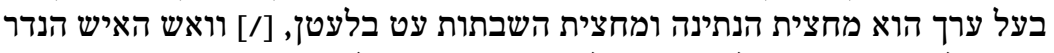

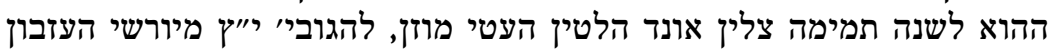

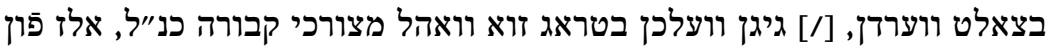

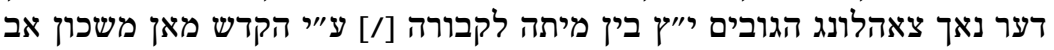

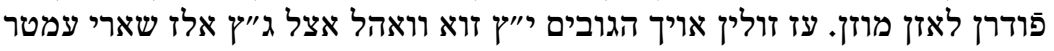

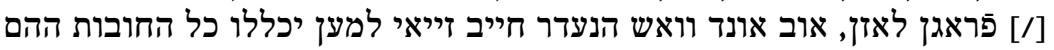

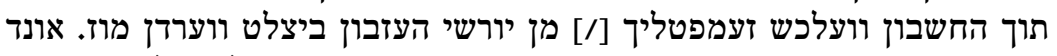

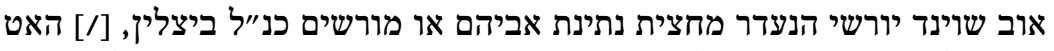

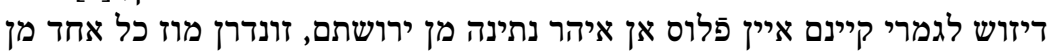

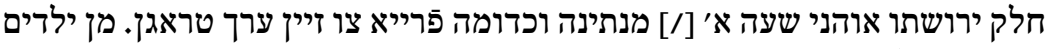

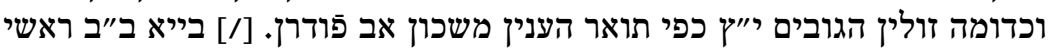

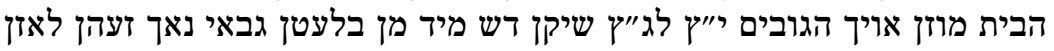

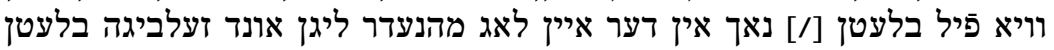

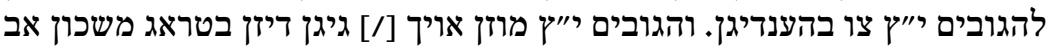

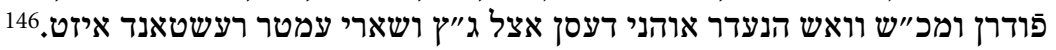

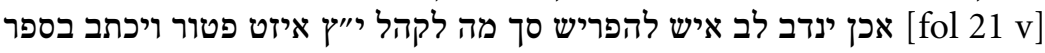

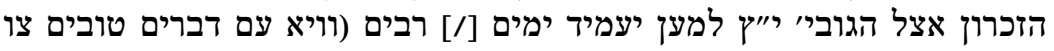

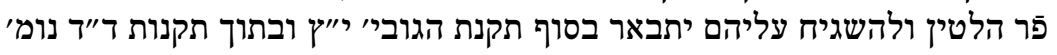

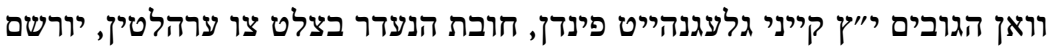
ק"

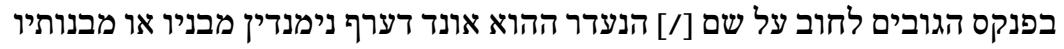

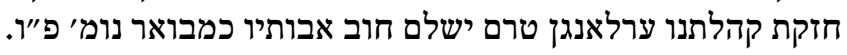

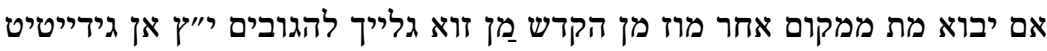

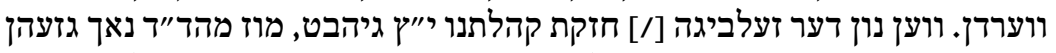
קס"

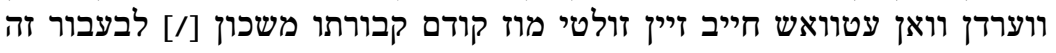

146 Danach die Kustode אכן. 
איין גליגט ווערדן. ואין הפרש בדבר בין איש או אשה או תינוק שיש לאביו חזקת

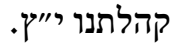

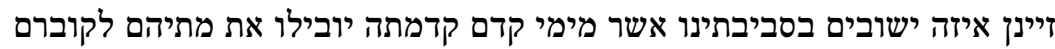
קס"ב

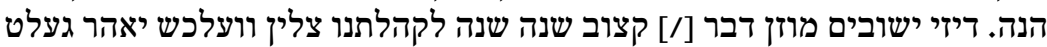

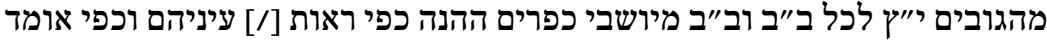

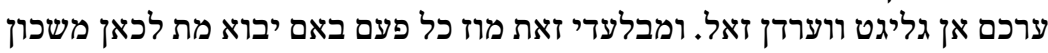
[/] איין ליגן עבן פَלס כפי אומד דעת הגובים ומבלים יעדיץ.

מ' בייא זיצר הבין הגובים י"ץ ניכטש צו שפרעכן זונדרן עפ"י שבעה טובי העיר

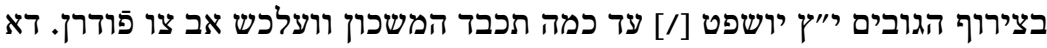

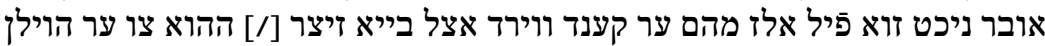

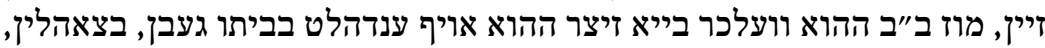

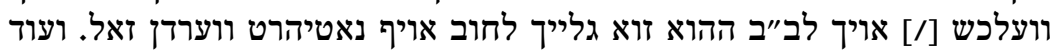

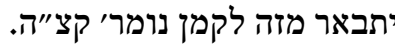

ולמען סיים בדבר טוב נצוה פה תיקון לדברים טובים אשר נעשים בקהלתותנו י"יץ.

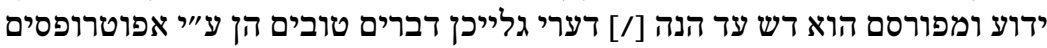

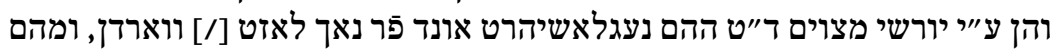

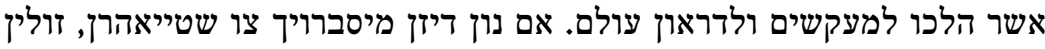

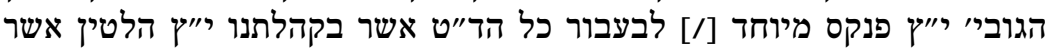

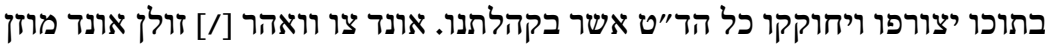

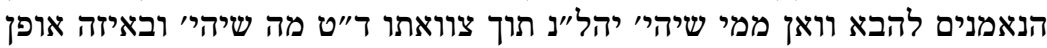

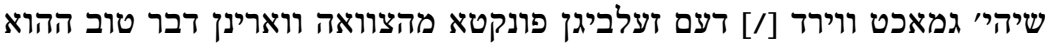

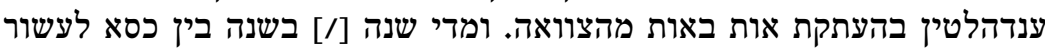

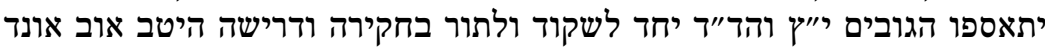

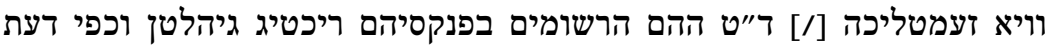

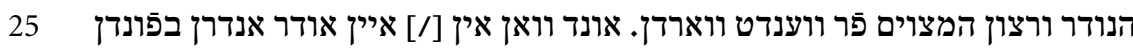

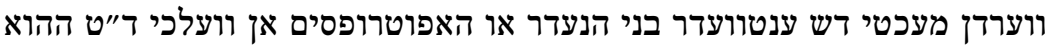

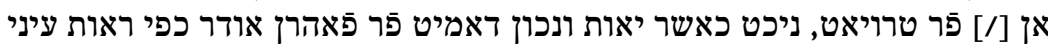

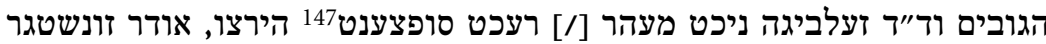

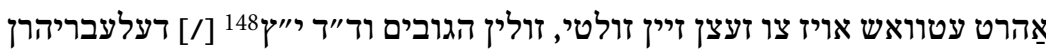

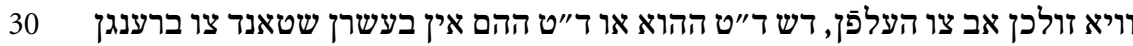

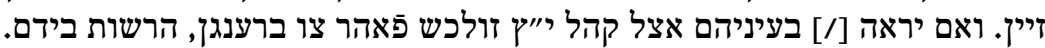

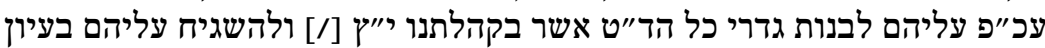

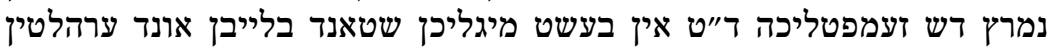

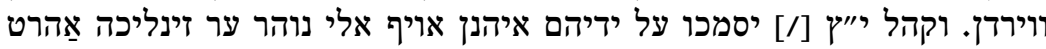

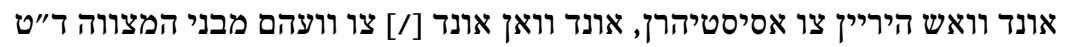

147 Suffizient, hinreichend.

148 Danach 7 als Zeilenfüller. 


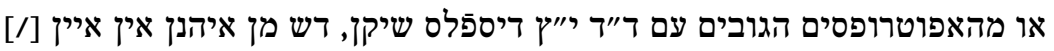

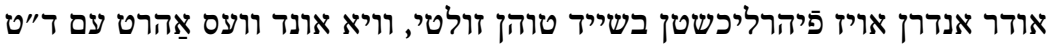

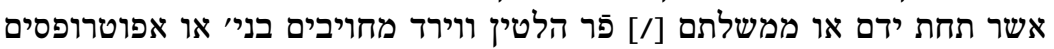

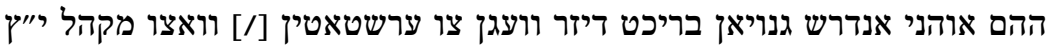

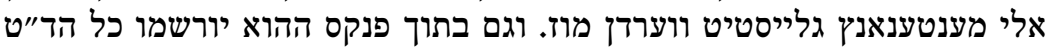

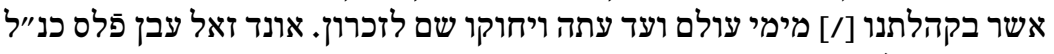

דאמיט בפּולגט ווערדן.

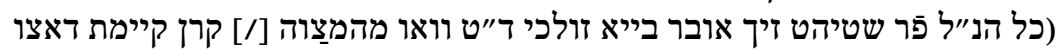

אויז גזעצט איזט ווארדן)

[fol. $22 \mathrm{r}$ ] 10

הנהגת דעפוטיהרטי

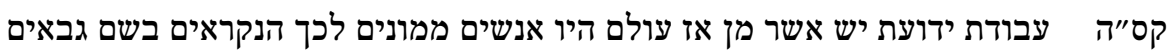

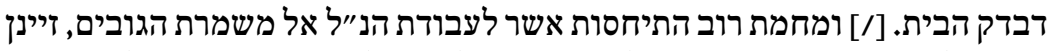

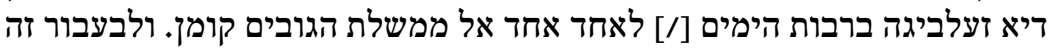

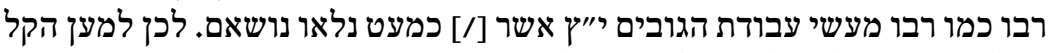

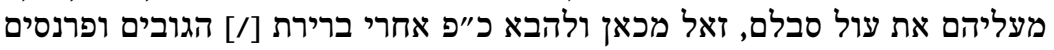

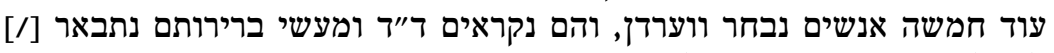
למעלה בתקנת ברירת הקהל, ואת אשר יעשרון וערון הנה נבאר.

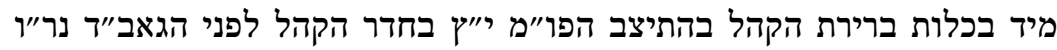

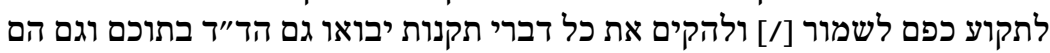

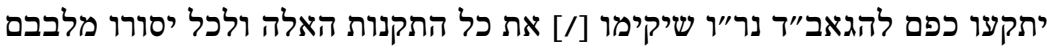

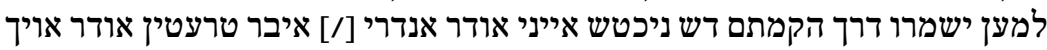

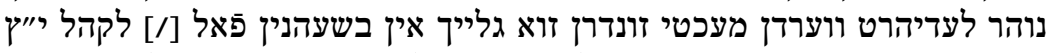

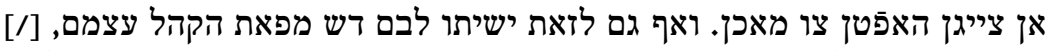

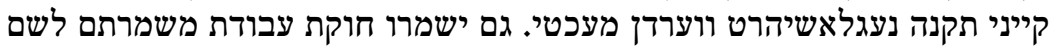

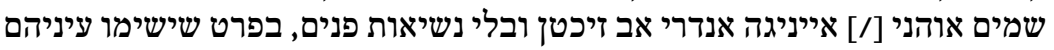

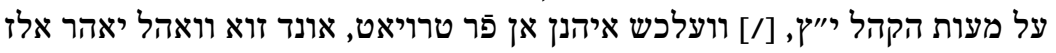

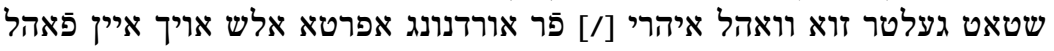
שטענדיגס תקנות בוך צו גשטר וואהל איריט ווערדן.

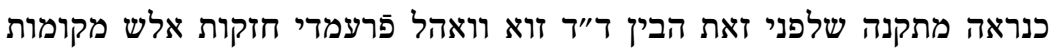

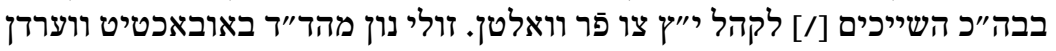

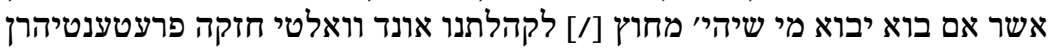

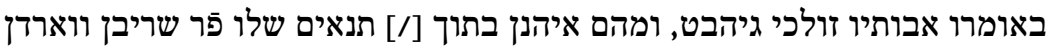

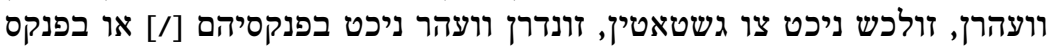

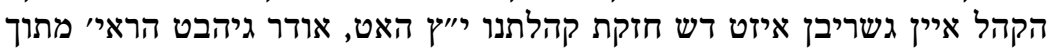

התנאי' [/] ניכטש גיל גשריל איוט רשיג זיין זאלי.

149 Danach die Kustode עבודת. 
וואן ב״ב אחד שיש לו חזקת קהלתנו י"יץ בנו או בתו מחוץ לקהלתנו גיבט, אונד

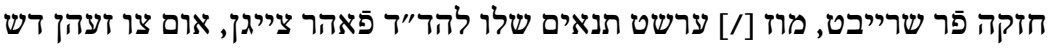

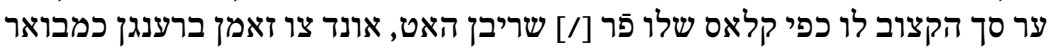

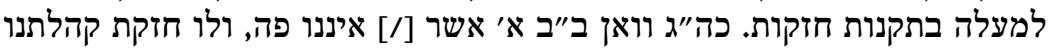

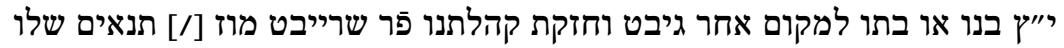

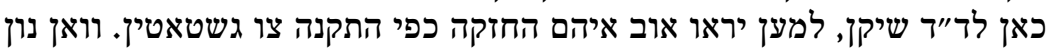

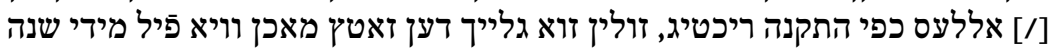

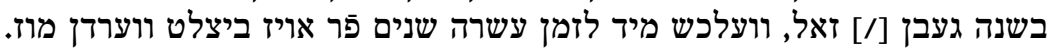

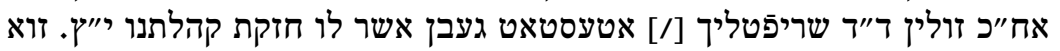

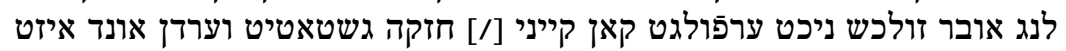

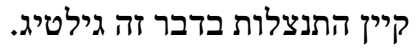

קס"ט וויא אובר דיא יאהר געלטר דאצו איין צו ריכטן יתבאר.150 f $1: 30$ ראשי הבית

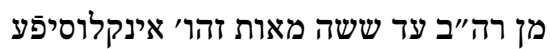

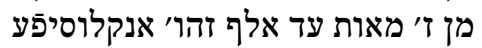
5

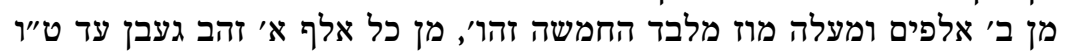

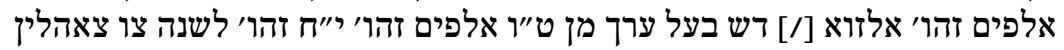

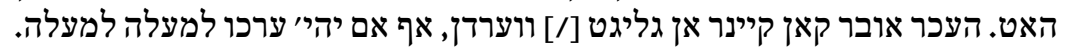

וועלכר ב"ב נון עשר שנים פَר אויז כנ"ל ביצאהלט האט מוז אלזוא פּר בלייבן עד

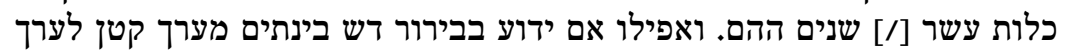

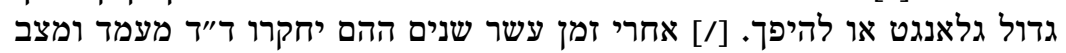

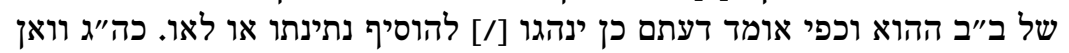

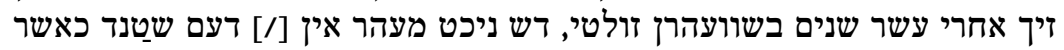

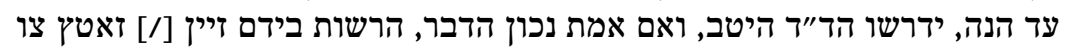

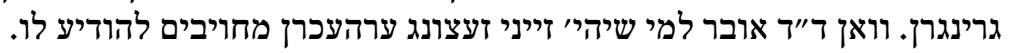

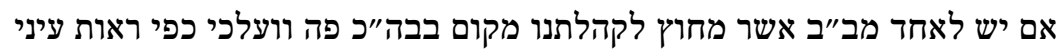
קע"א

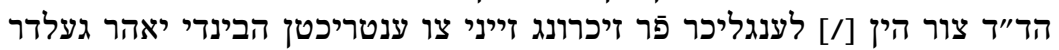

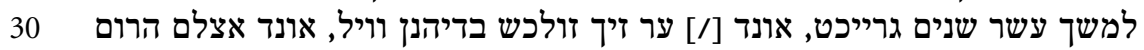

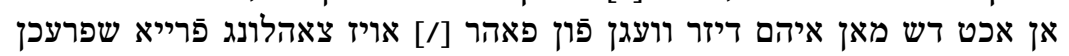

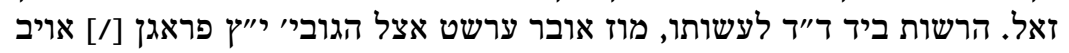

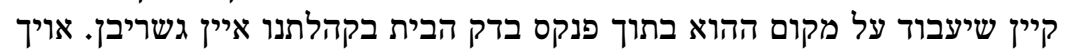

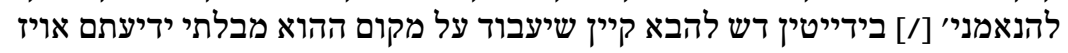

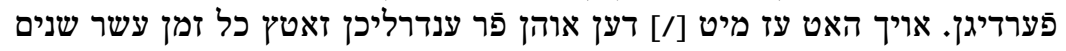
כמבואר בתקנה שלפני זאת זיין פּר בלייבץ.

150 Danach die Kustode רה", auf der folgenden Seite jedoch ausgeschrieben. 
וועלכר ב״ב במקום אחר מיט זייני צו ריכטן הבינדי יאהר געלטר זוים זעליג אילי איזט

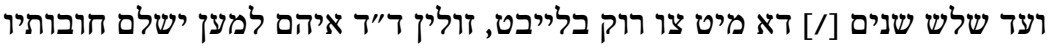

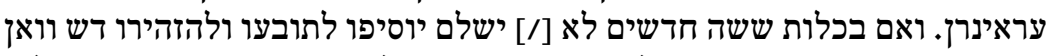

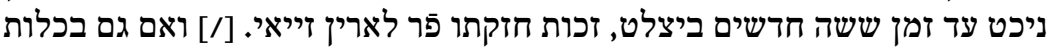

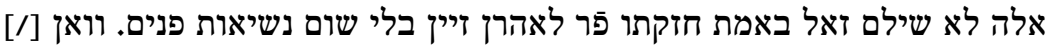

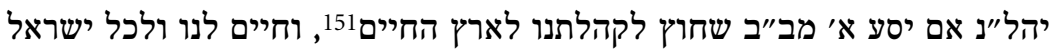

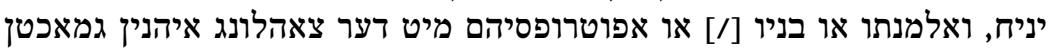

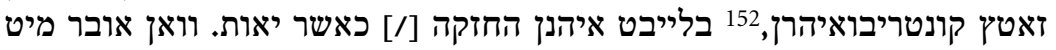
דער אורדענטליכה צאהלונג שלש שנים צוני צו רוק בלייבן ינהגו כמו [/] בתקנה

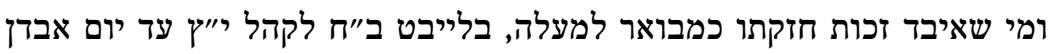

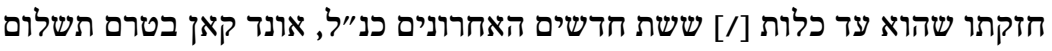

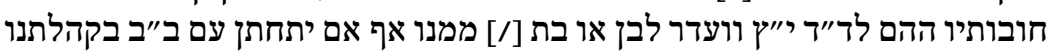

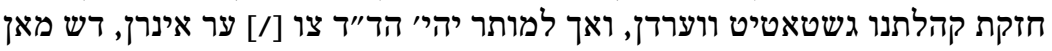

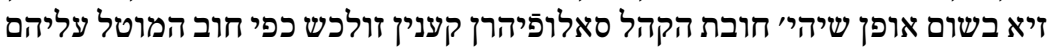
[/2 ובלתי התרשלות אינס ווערק ריכטן מוזן אונד זוליקלין.153

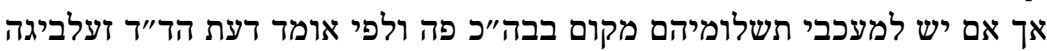
קע"ה

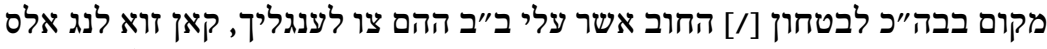

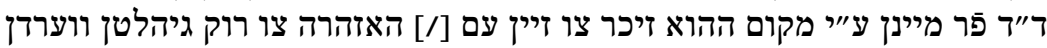

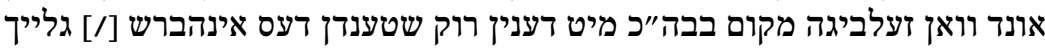

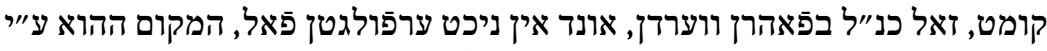

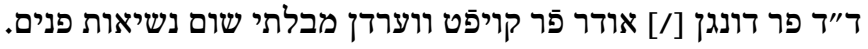

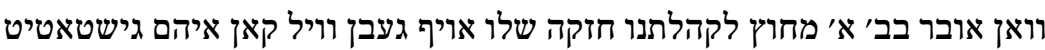

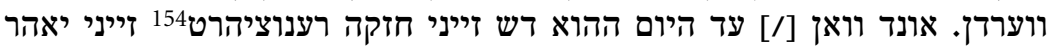

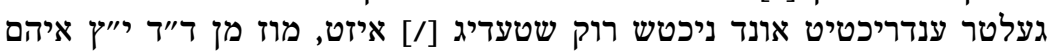

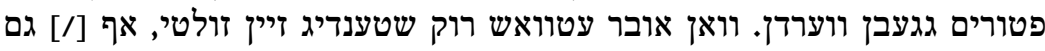

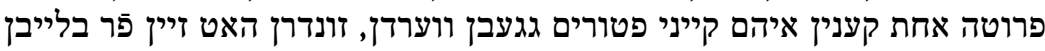

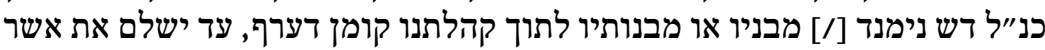

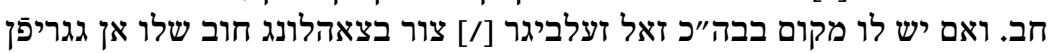

151 D. h. verstirbt.

152 kontribuihrn = kontribuieren, beitragen .

153 Danach die Kustode אך.

154 Von frz. renoncer $=$ verzichten. 


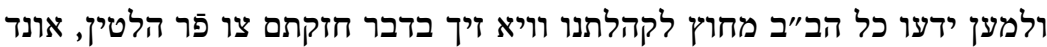

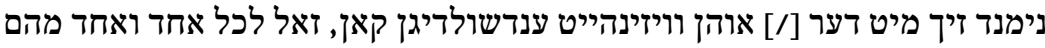

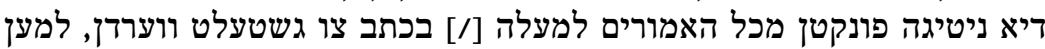
יהיי להם ולבניהם לזכרן ושמורים נצח. האמרים למעלה.

5

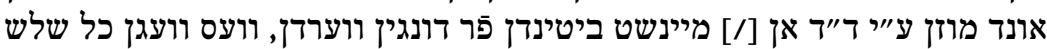

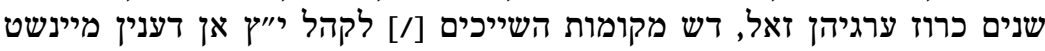

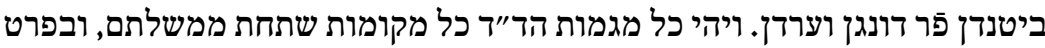

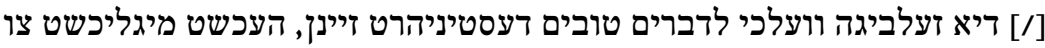

מידי שנה בשנה מוזן הב״ב אשר להם נשכרים המקמות ההם, איהר שטאט געלט קע"ט

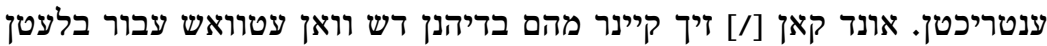

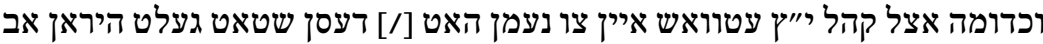

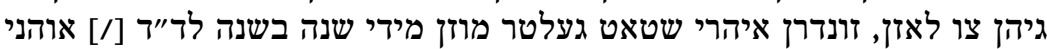

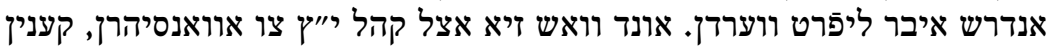

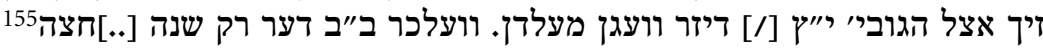

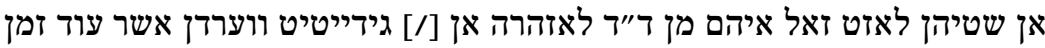

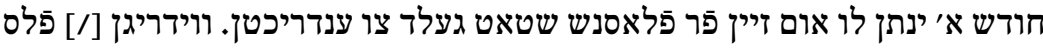

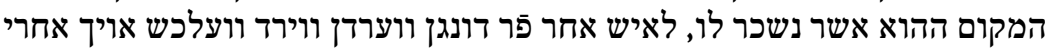

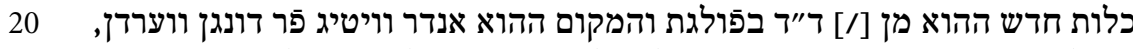

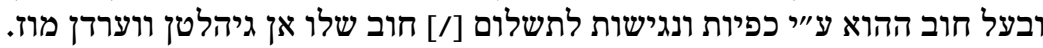

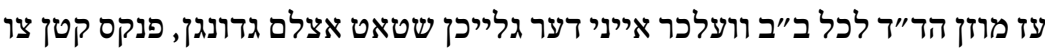

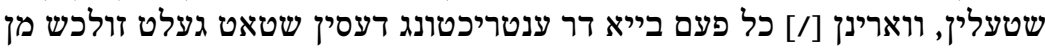

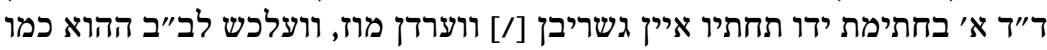

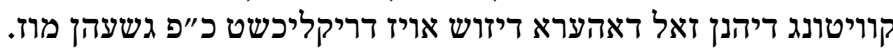

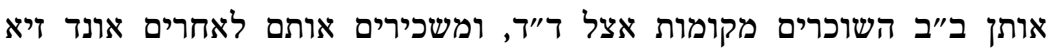

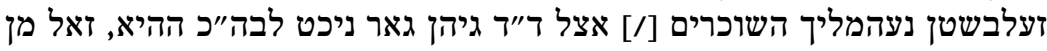

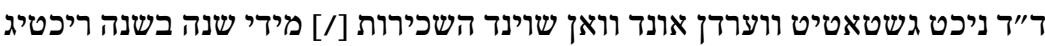

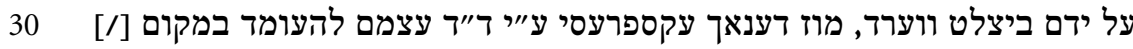

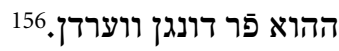
[fol. $23 \mathrm{v}$ ]

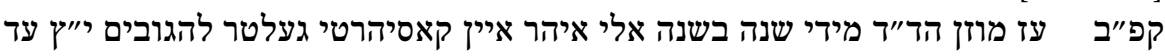

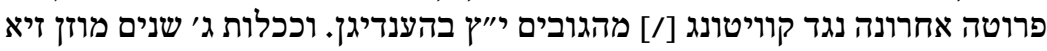

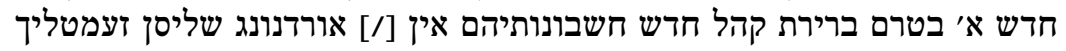

155 Durch Tinte verschmutztes Papier.

156 Danach die Kustode עז. 


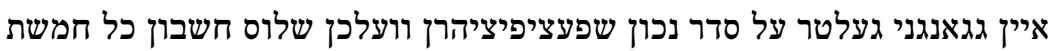

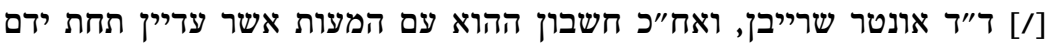
להגובי' נגד קוויטרונג איבר ליפריכן

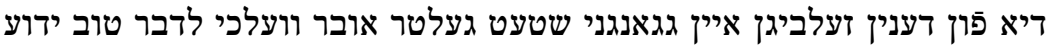

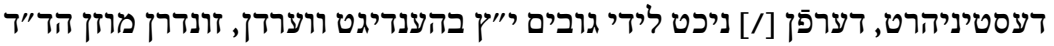

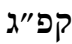

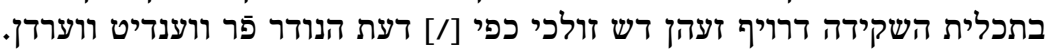

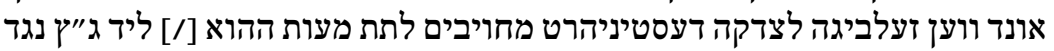

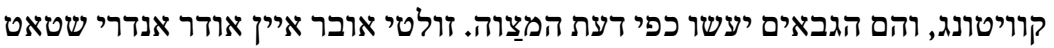

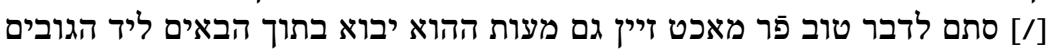

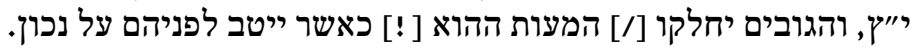

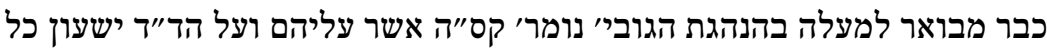

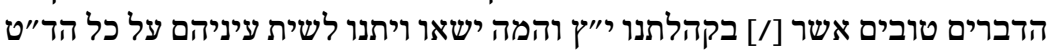

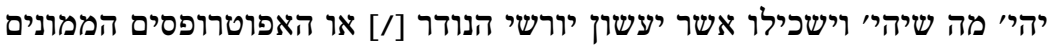

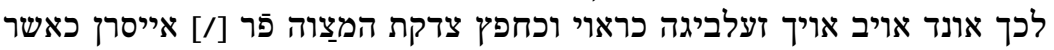
נתבאר שם באר היטב יעוין שם.

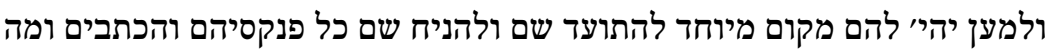

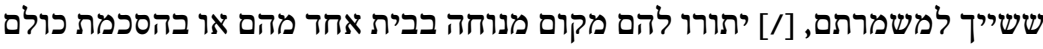

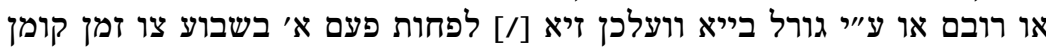

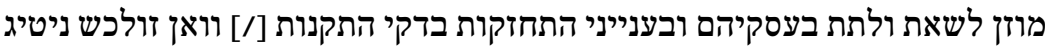

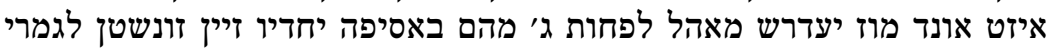

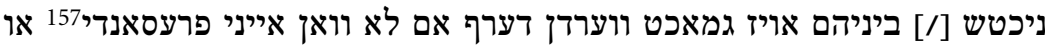

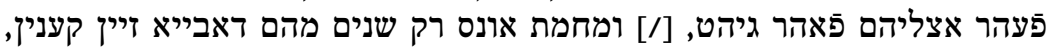

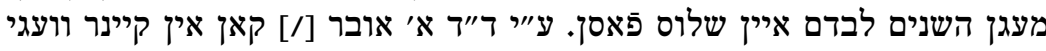

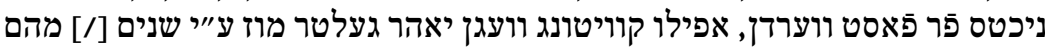

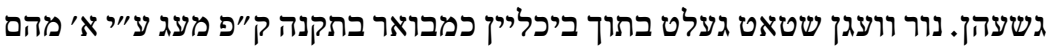
גשעהן.

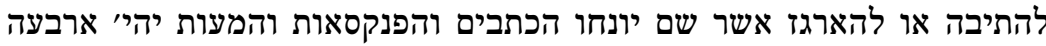

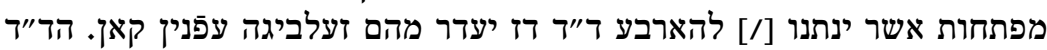

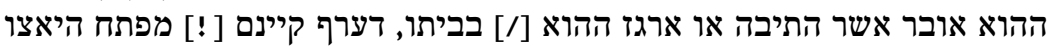

וואן מהד"ד להשמש מקהל י"ץ בעסקיהם עטוואש אויף גטראגין וועין ווערדן זולטי,

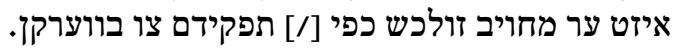

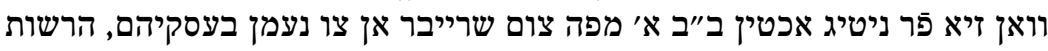

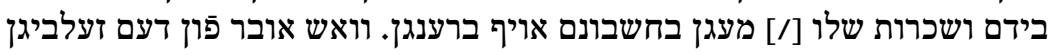

157 Von frz. pressant $=$ dringlich. 
שרייבר אויז גפעערדיגט ווירד מוז בחתימת [/] ידם אונטר שריבן זיין. אויך מוזן זיא בכל דבר פَר איהם הפ̄טין אונד קאפינטיהרץ.

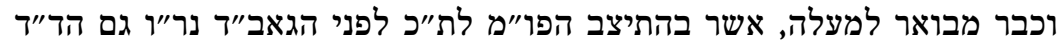
קפ"ח

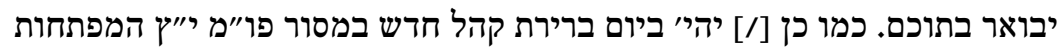

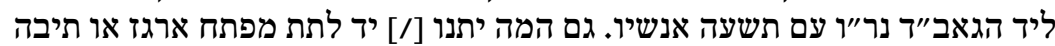

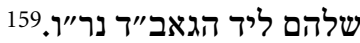

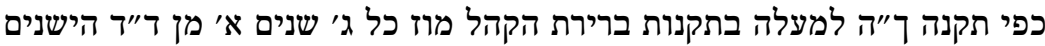
קפ"ט

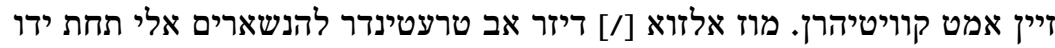

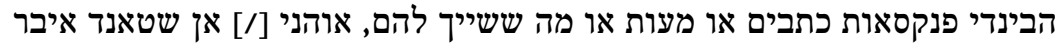

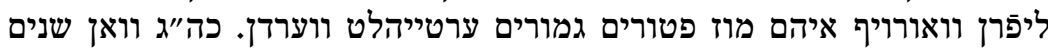

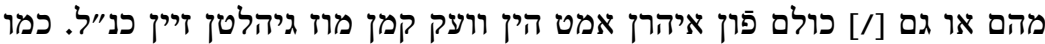

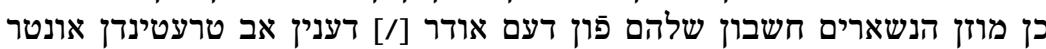

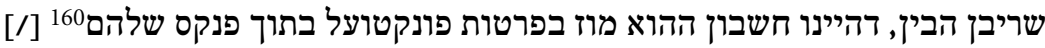

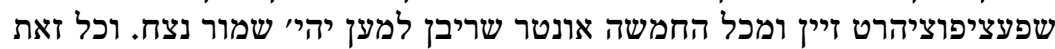

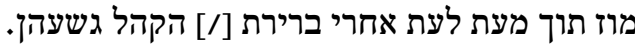

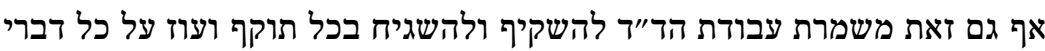

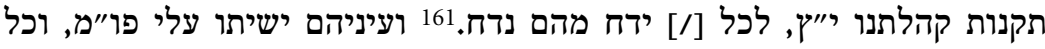

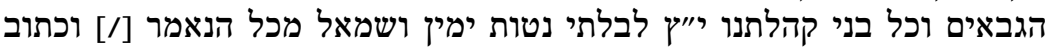

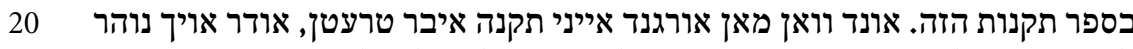

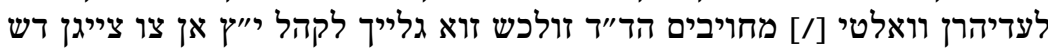

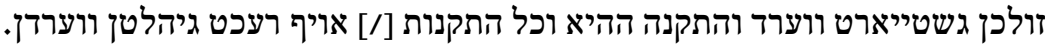

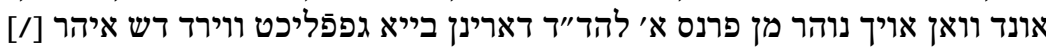

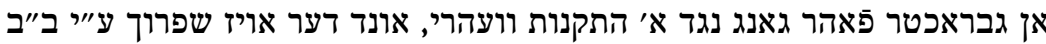

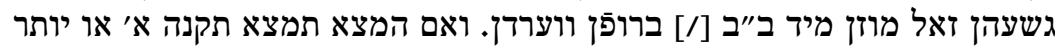

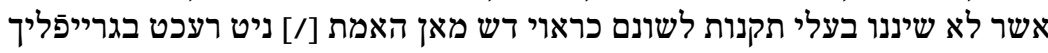

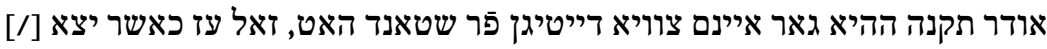

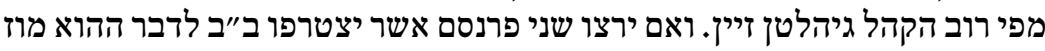

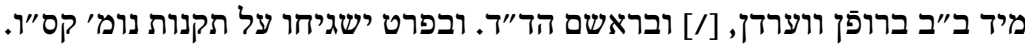

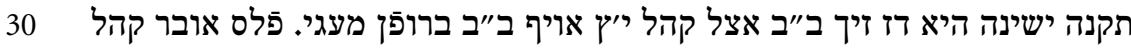

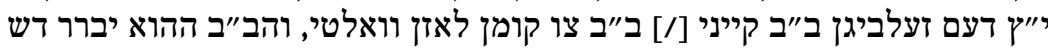

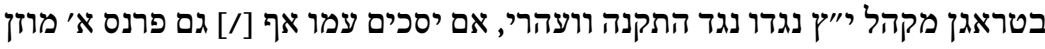

158 Von frz. coiffer $=$ kontrollieren.

159 Danach die Kustode כפי

160 Danach $\boldsymbol{w}$ als Zeilenfüller.

161 Nach 2 Sam 14,14. 
איהם י"ח ב"ב צו גלאזן ווערדן, אם דיא זעלביגה אופעהר צו ערע ניעטרין. 162 ואם

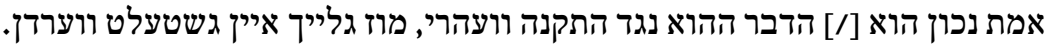

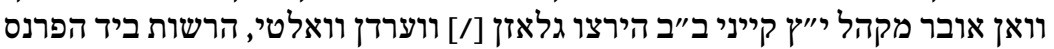

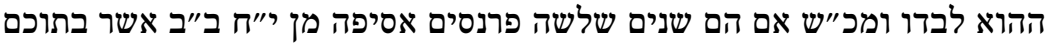

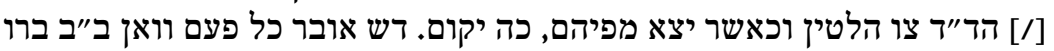

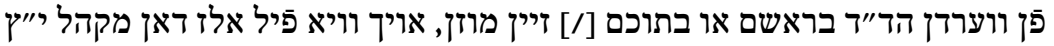

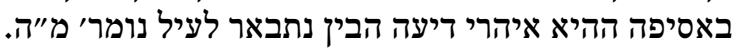

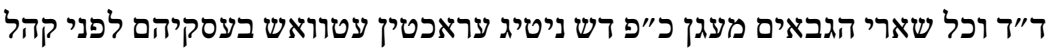

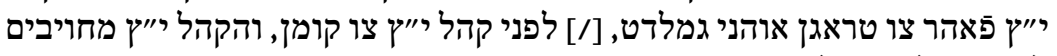

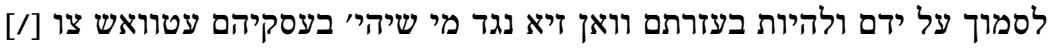

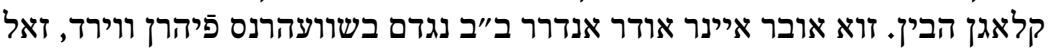

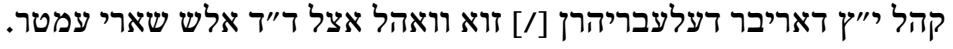

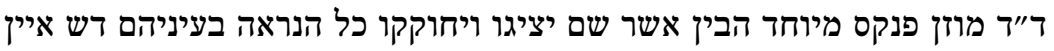

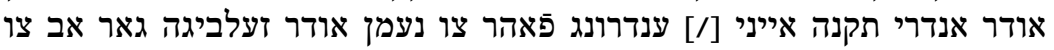

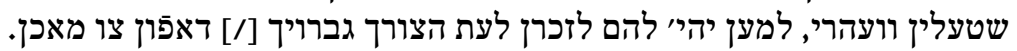

ירום הוד אדונינו השררה יר"ה אשר בע"ה שב"ה הרבה עמנו פדות להטיב קצ"ד תוני

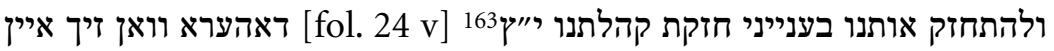

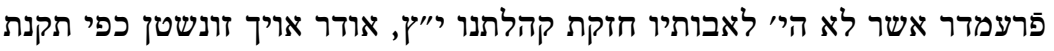

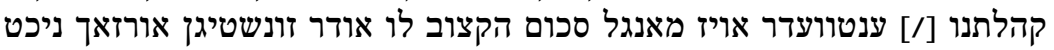

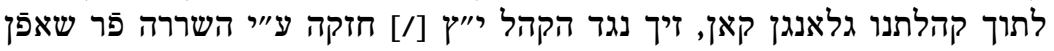

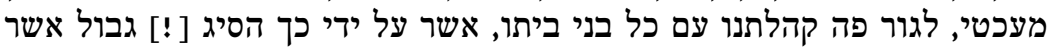

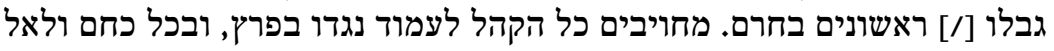

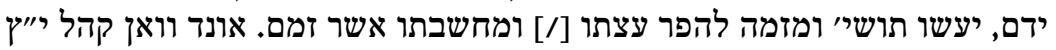

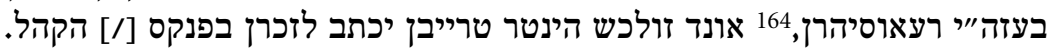

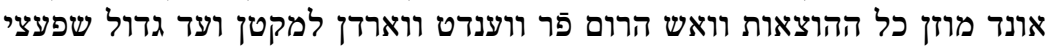

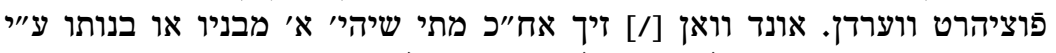

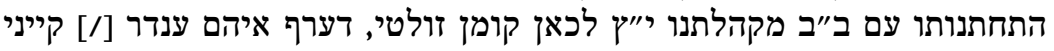

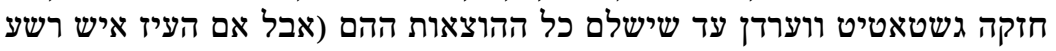

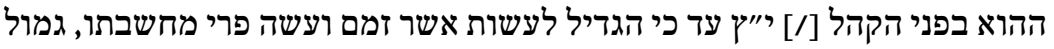
ידיו יעשה לו וכמו בקואי בייא זיצר יחשב בכל הדברים).

וועלכר פ̄רעמדר נון זיך עם כל בני ביתו נגד הקהל או שלא ברצונם אלז בייא זיצר

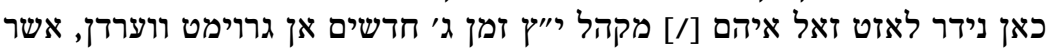

$162 \mathrm{Zu}$ erörtern.

163 Danach die Kustode דאהערא.

164 Reüssieren. 


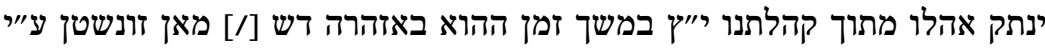

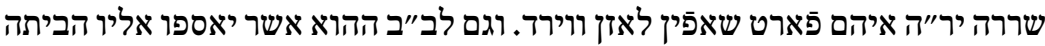

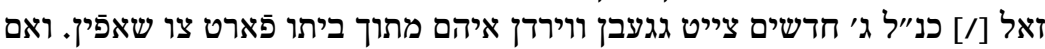

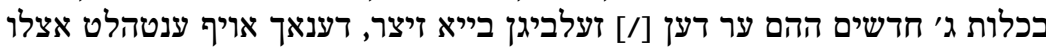

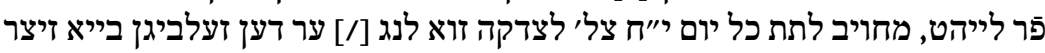

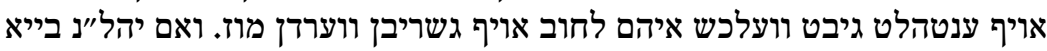

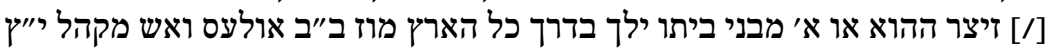

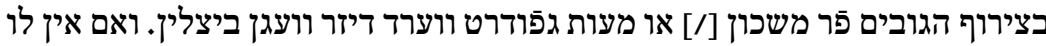

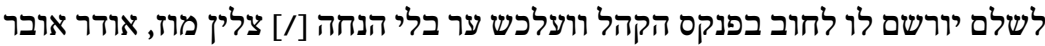

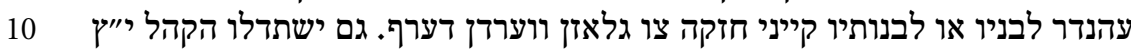

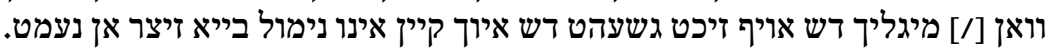

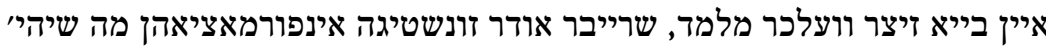

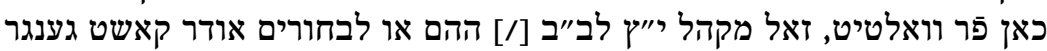

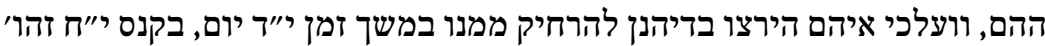

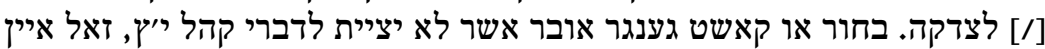

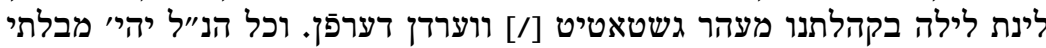

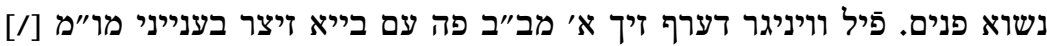

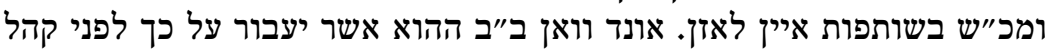

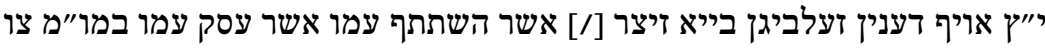

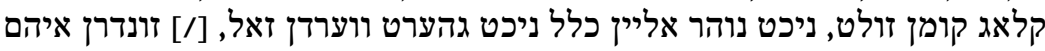

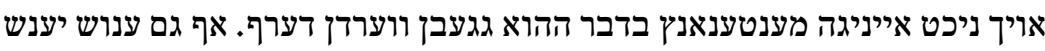

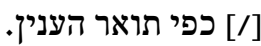

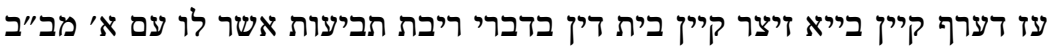

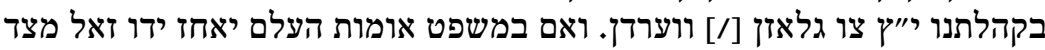

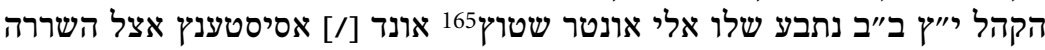

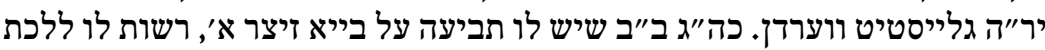

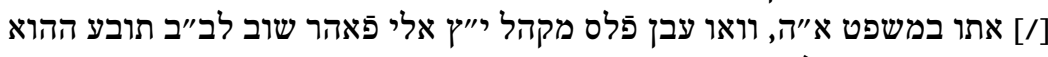

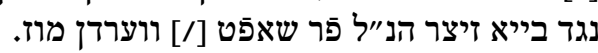

עז דערף נימנד בן או בת בייא זיצר למשרת או משרתת בדיהנן וואן אובר דענאך קצ"ח

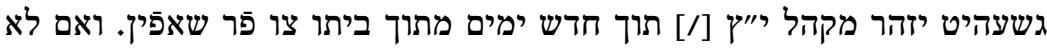
ישמע מחויב איש ההוא ליתן מיד יוף יום יום ח"י צל' לצדקה.

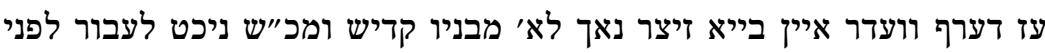
קצ"ט

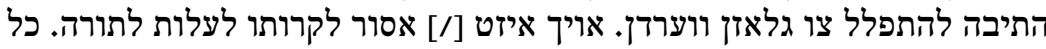

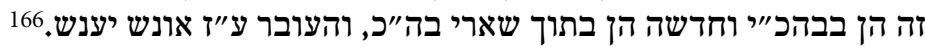

165 Unterstützung.

166 Danach die Kustode כל זמן. 
[fol. $25 \mathrm{r}$ ]

רי"ש כל זמן היותו בחיים והוא גר פה בלתי רצון הקהל דערף איהם ניכט גשטאטיט

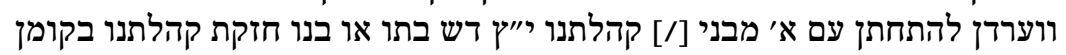

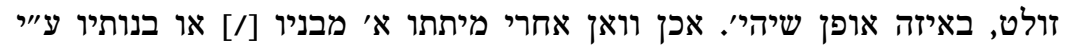

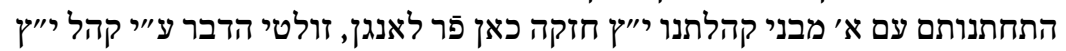

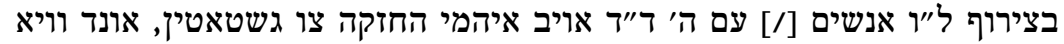

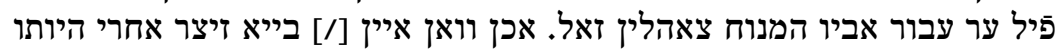

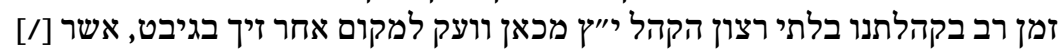

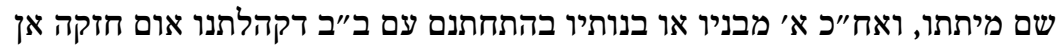

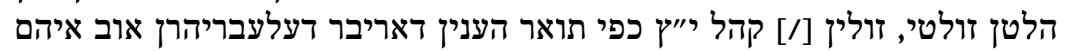
זולכי צו גשטאטין.

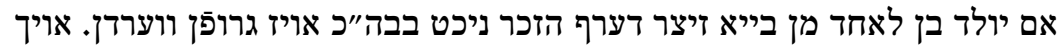

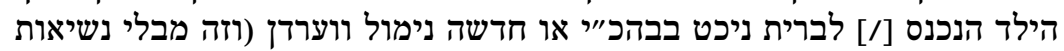

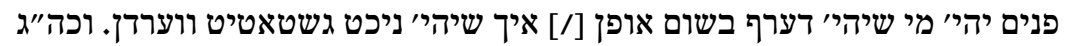
יהל"נ דערף בייא קיינם בייא זיצר וועדר להלוית המת נאך [/] למצוה גרופן ווערדן.

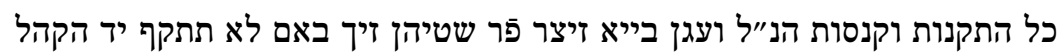

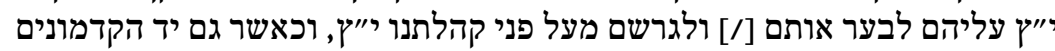

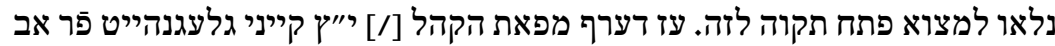

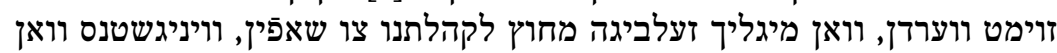

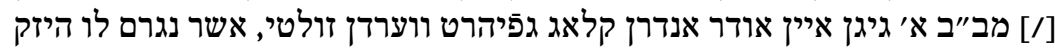

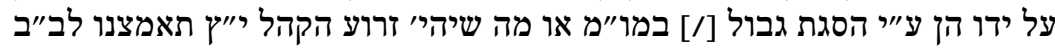

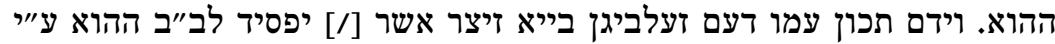
השררה יר"ה מחוץ לקהלתנו צו פַר שאפין זעין.

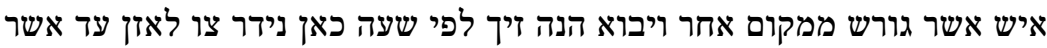

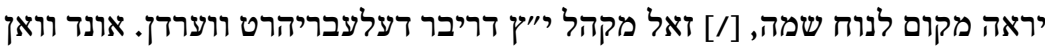

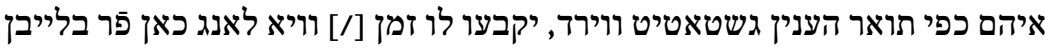
מאג. ואחרי זמן ההוא ווירד כמו בייא זיצר בכל יתבע לו זבר גיאכטיט אוני לאנד גיהלטין.

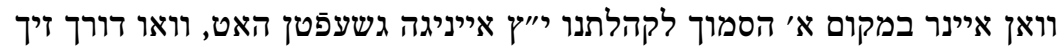

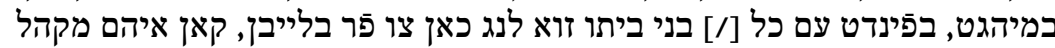

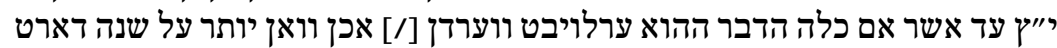
ישפטו לפי תואר הענין אוב איהם ווייטר צו ערלויבטווערויבן וועהרי.

ג"ר 25

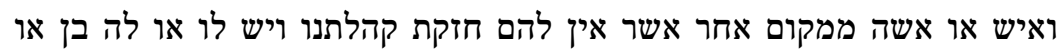

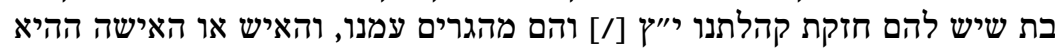

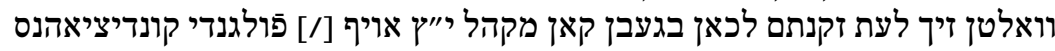

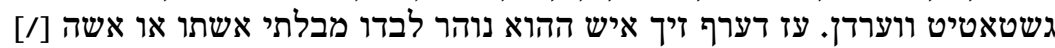

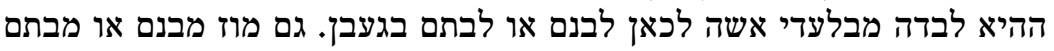




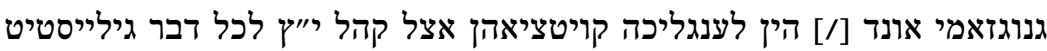

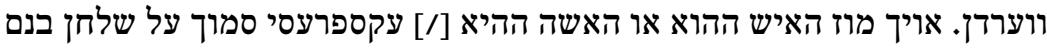

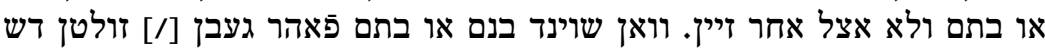

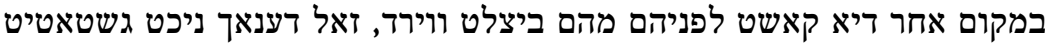

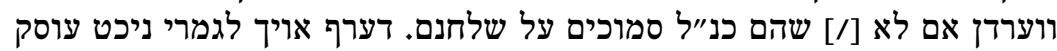

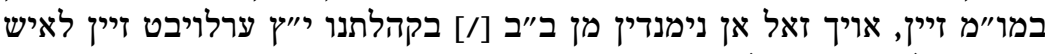

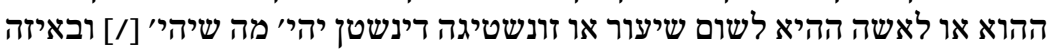

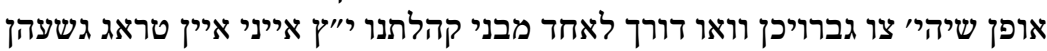

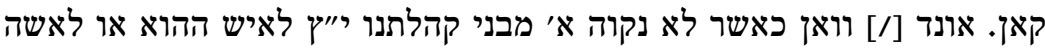

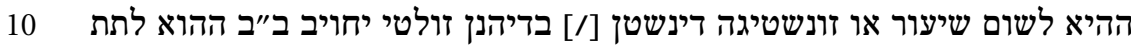

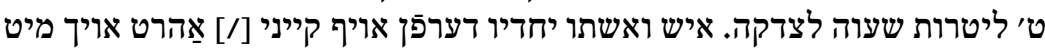

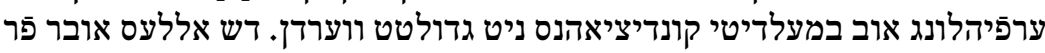

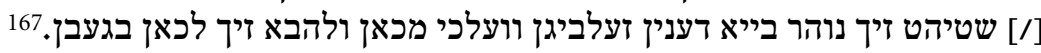

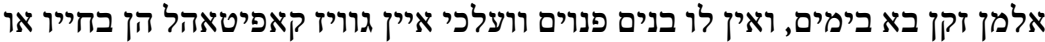
[fol. 25v]

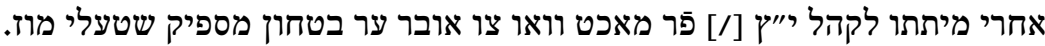

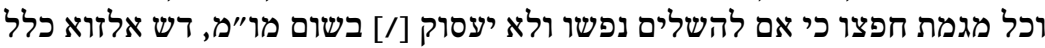

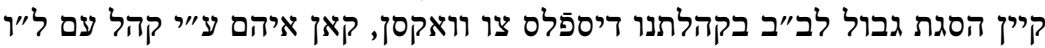

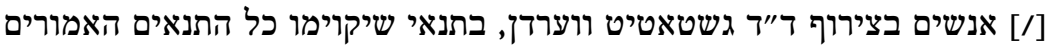

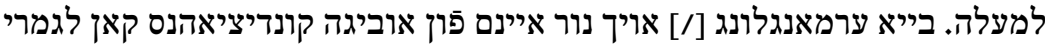

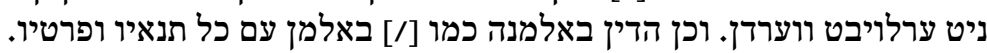

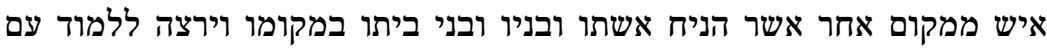
ר

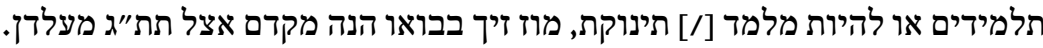

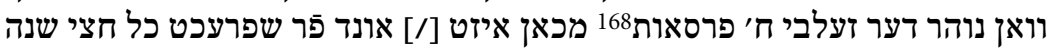

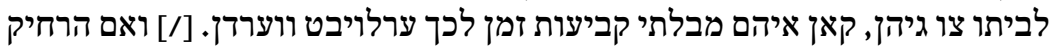

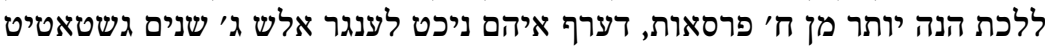

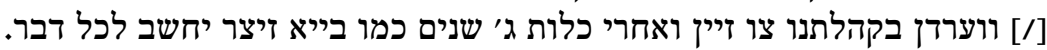

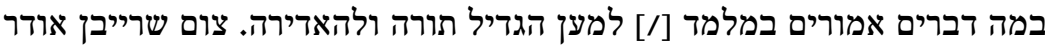

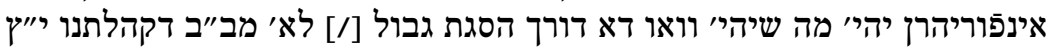

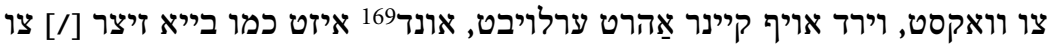

$$
\text { עסטימיהרן. }
$$

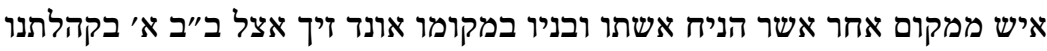
ח ר

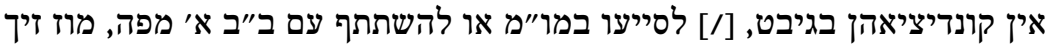

167 Danach die Kustode אלמן.

168 Antikes Längenmaß, hier möglicherweise als Bezeichnung für »Meile« verwendet. Eine Meile betrug zu damaliger Zeit gewöhnlich zwischen 7400 und 7500 Metern.

169 Danach gestrichen: מוז.

170 Von frz. estimer $=$ schätzen, ansehen. 
זוא גלייך בבואו הלום ערשט אצל ממוניי מעלדן [/] ודינו כמו בתקנה שלפני ליפים

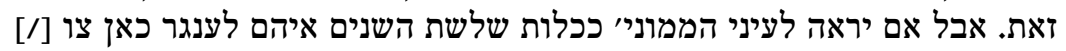

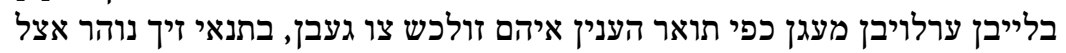

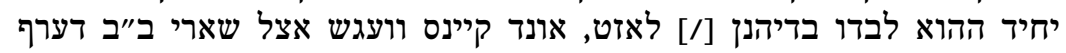

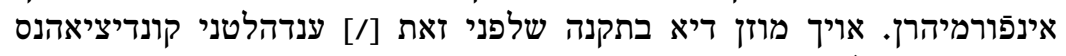

שטריקטא בפוֹולגט ווערדן.

אשה ממקום אחר אשר בעלה במקומה בסביבותינו, וועלכי זיך בקהלתרנו צו קינוד

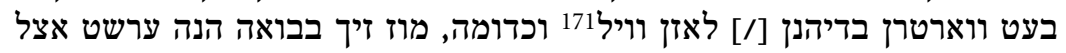

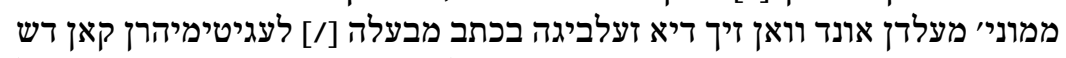

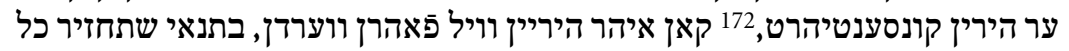

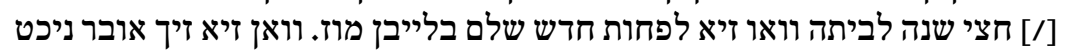

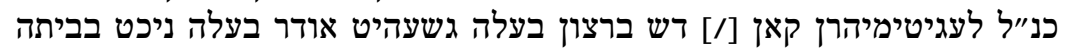

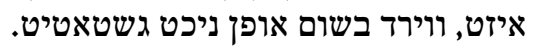

אשה אלמנה ממקום אחר וועלכי זיך צו קינד בעט ווארטרין וכדומומה פּר דינגן וויל,

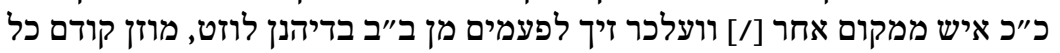
רשות מן ממוני' הבין.

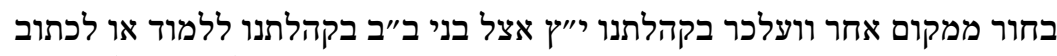

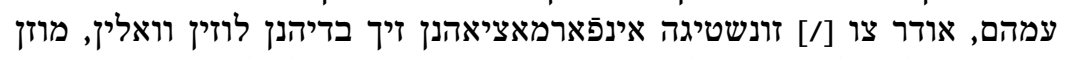

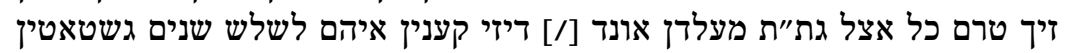

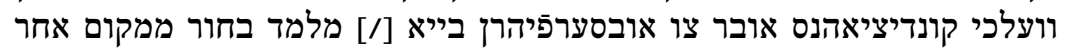

$$
\text { יעוין בתקנות גת"ת נומר' תי"ד. }
$$

ר

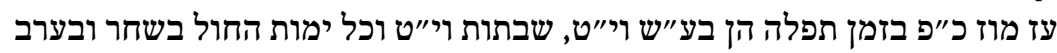

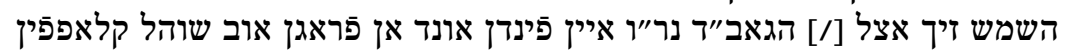

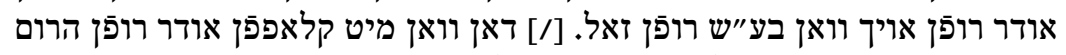

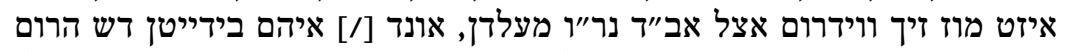

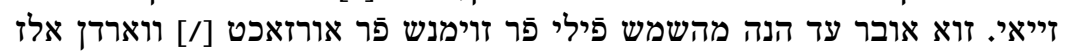

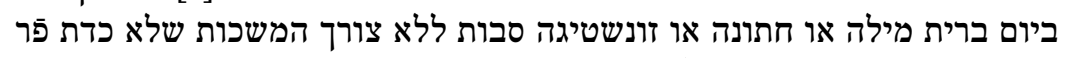

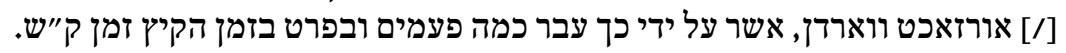

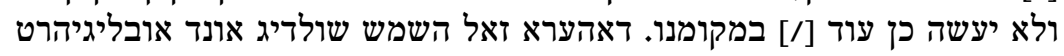

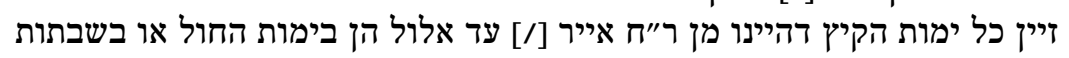

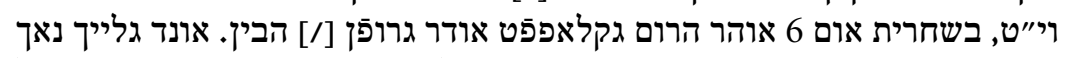

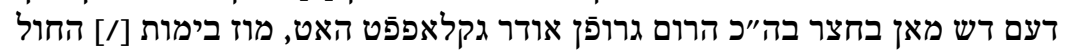

ריו"א רי״"ב

171 D. h. eine Frau, die als Pflegerin bei einer Wöchnerin tätig sein will.

172 konsentihrt = konsentiert, stimmt zu.

173 Danach die Kustode עז. 
בלי עיכוב תהילים, ובשבתות וי"ט זוא גלייך אדון עולם 174 אן גפַאנגן ווערדן. אונד

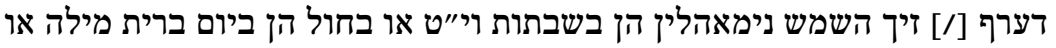

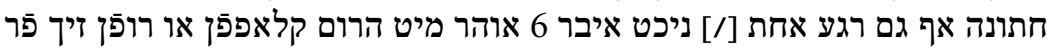

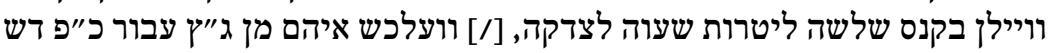

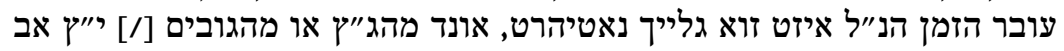

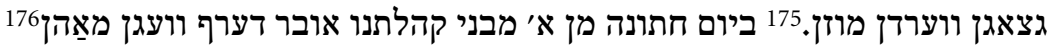

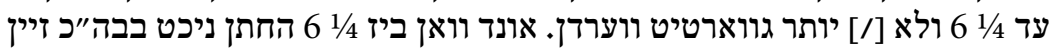

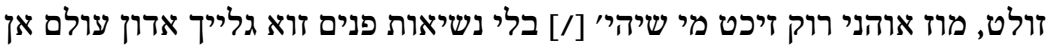

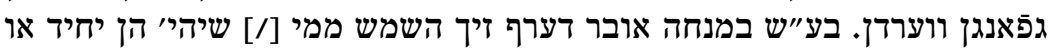

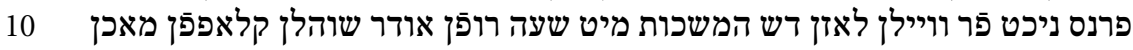

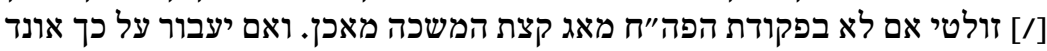

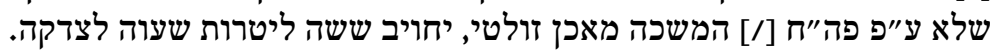

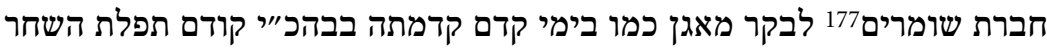
רייו"ג

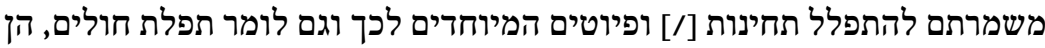

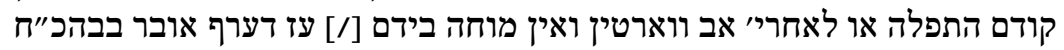

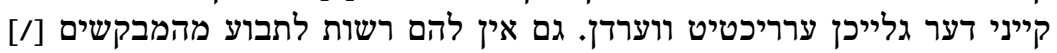

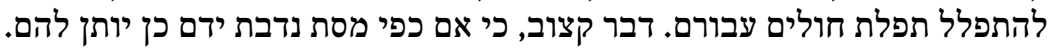

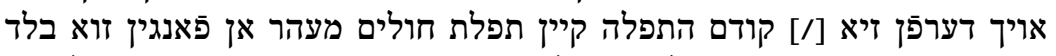

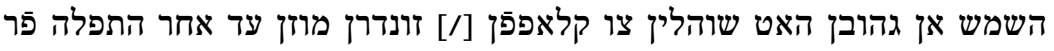

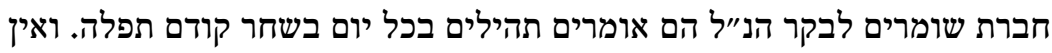
ריי"ד

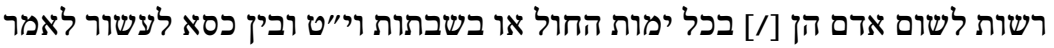

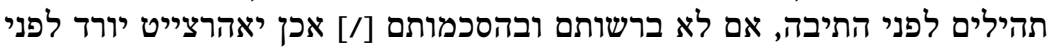

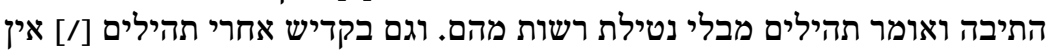

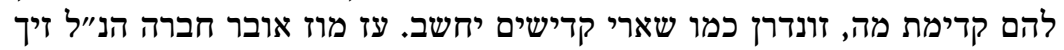

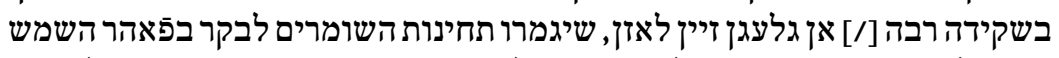

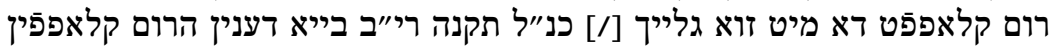

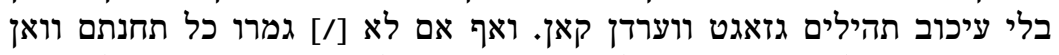

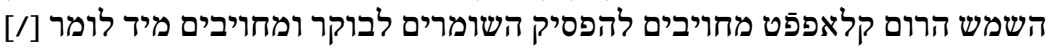

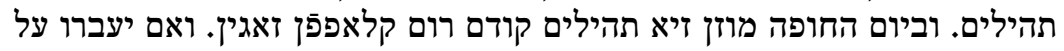

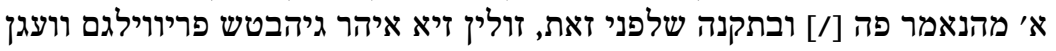
שומרים לבקר זוא וואהל [/] אלש של וועגן תהילים פַר לוסטיג זיין.

174 Pijut vor dem Morgengottesdienst.

175 Das Strafgeld sollte vom Monatsverdienst abgezogen werden.

176 Gemeint ist der Brauch des »Mannführens«, des Begleitens des Bräutigams zur Synagoge, der wegen der Beteiligung Dritter immer verzögert werden konnte.

177 Gemeint ist sicher die Hevrat Bikkur Holim, die wohltätige Gesellschaft für Krankenpflege, worauf auch der folgende Hinweis auf Gebete für Kranke verweist. 


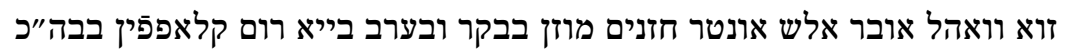
רט"ו

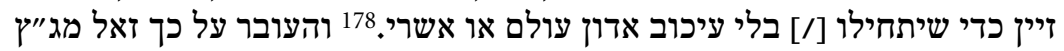

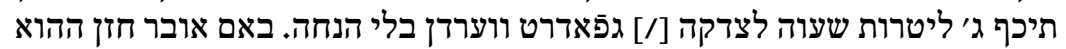

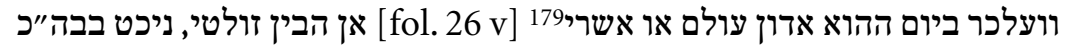

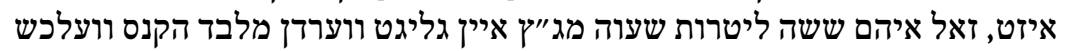

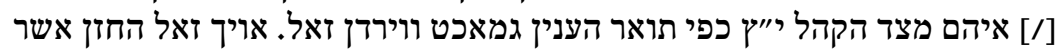

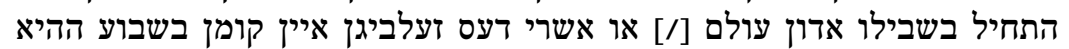

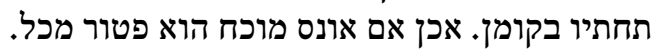

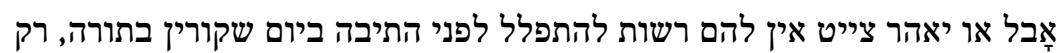

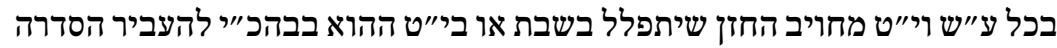
רי"זיז

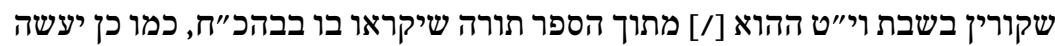

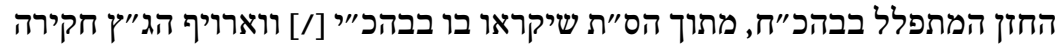

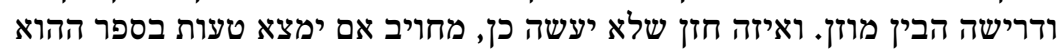

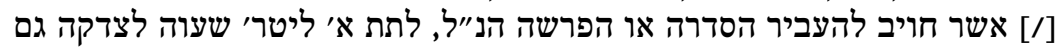

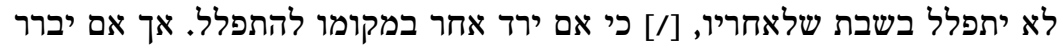

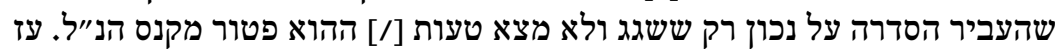

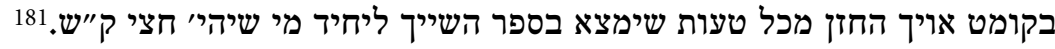

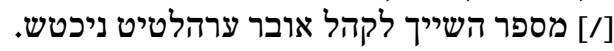

בשבתות וי"ט דערף עד אחרי ק"ש קיין משורר182 צו הלטין הן בקיץ או בחורף.

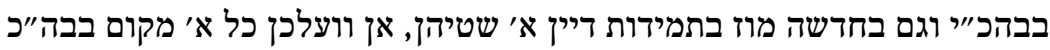
רי"ט

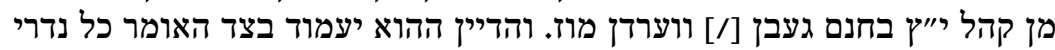

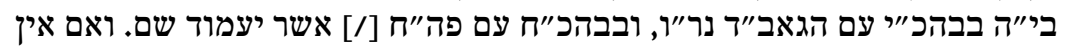

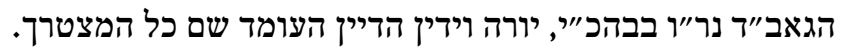

178 Teil des Morgens- und Mittagsgebets.

179 Danach die Kustode אן הבין.

180 Das Musaf-Gebet wird im Morgengottesdienst gesprochen, jedoch nur an solchen Tagen, an denen im antiken Tempel ein zusätzliches Opfer dargebracht wurde, also am Schabbat, an Festtagen, am jeweils Monatsersten und an den Zwischentagen von Pessach und dem Laubhüttenfest.

181 Kopfstück, Münze mit dem Herrscherbild, entsprach je nach Region zwischen 15 und 20 Kreuzer.

182 Dem Vorsänger beigesellter Sänger im Gottesdient. 


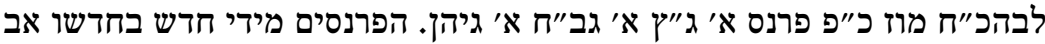

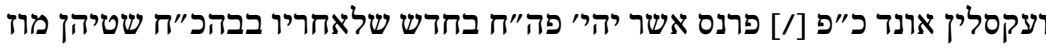

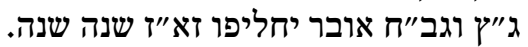

פה"ח בבהכ"י ופה"ח בבהכ"ח הבין צוואהר בכל דבר המתהוה צו קומאנדיהרן, רכ"א

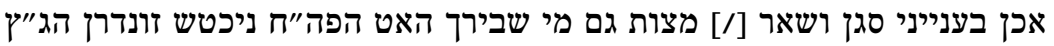

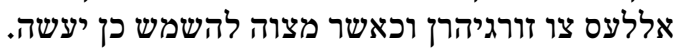

בשבת בחקתי183 ופ' כי תבאי184 מחויב השמש בהכרזת סגן להודיע גם אם תהיי רכ"ב

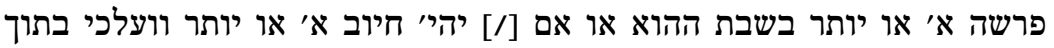

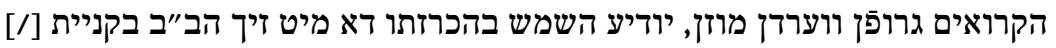

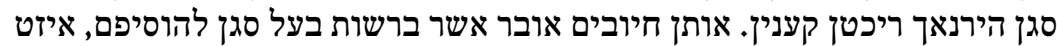

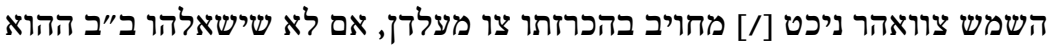

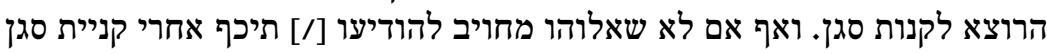

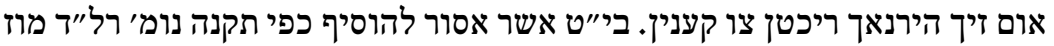

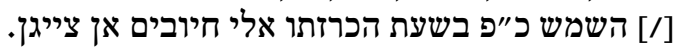

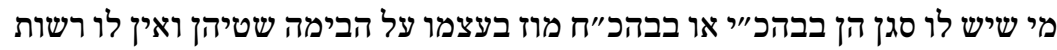
רכ"ג

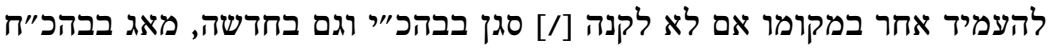

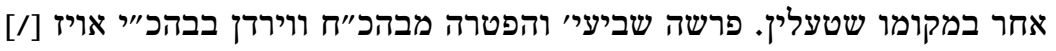
גרופן הן בשבת הן בי"טומט. שטלין.

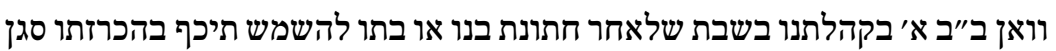
רכ"ד

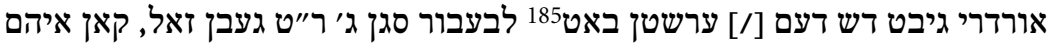

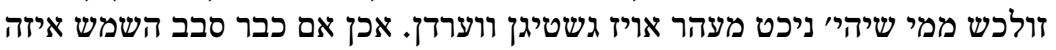

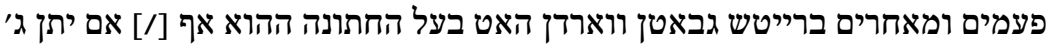

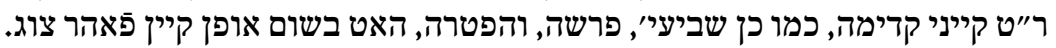

השמש לא יודיע ולא ירמוז בעת סיבובו לשום ב"ב וועהר אום דיזר אודר יענר מצוה ביהטיט, דא מיט [/] נימנד זיך הירת סיר נאך ריכטן לשום באל קענין. עז דערף קיין משועבד הקהל אף אם יש לו חזקת קהלתנו סגן קויפן. רכ"ו

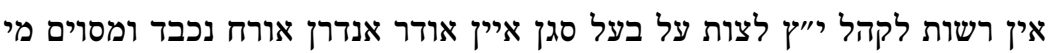
רכ"ז

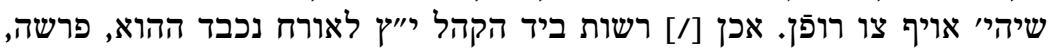

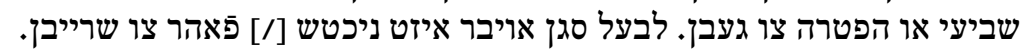

183 Wochenabschnitt der Tora: Lev 26,3-7,34.

184 Wochenabschnitt der Tora: Dtn 26,1-29,8.

185 Gebot bei der Versteigerung der Ehrenämter.

186 Danach die Kustode עז. 


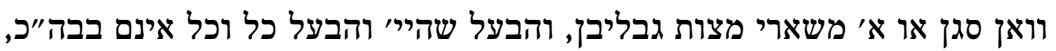

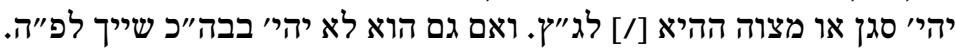

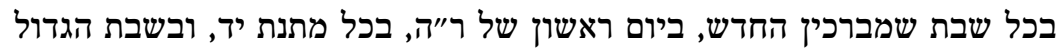
רכ"ט

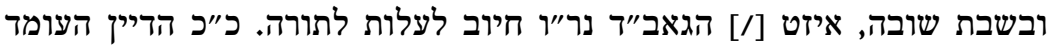

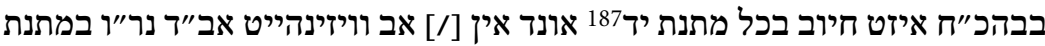
יד, איזט הדיין העומד בבהכ"י חיוב תחתיו.

ג"ץ העומד בבהכ"י וגם העומד בבהכ"ח זיינן בכל מתנת יד חיובים לעלות לתורה.

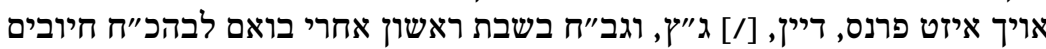

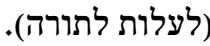

תוקע ביום ראשון של ר״יה, ואם חל בשבת ביום שני, חתן ביום חופתו אם הוא 10

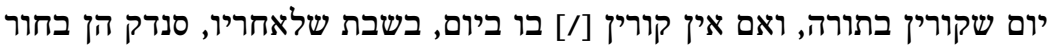

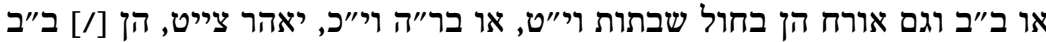

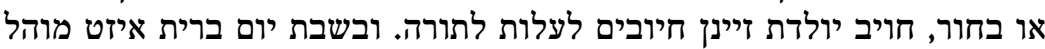

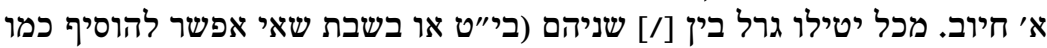

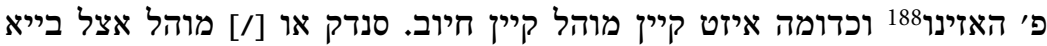

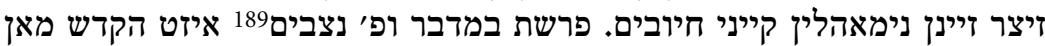

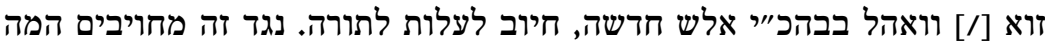

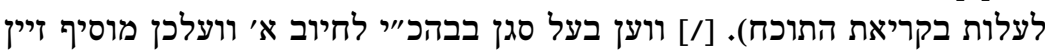

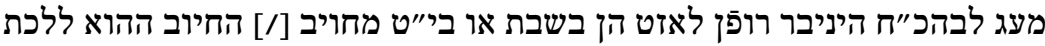
לבהכ"ח, זונשטן איזט הבעל סגן בבהכ"י ניכט שופת שולדיג איהם אויף צוּ צו רופן.

יאהר צייט או חיוב יולדת זוא ניכט בקביעות לבהכ"י או חדשה גיהן פַרעמדר בחור

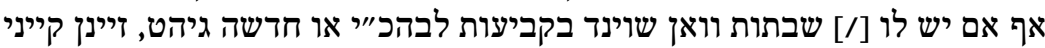

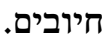

אב"ד נר״ו, פרנסים, וגובים, ד"ד, ודיינים וכל שארי גבאים אם יה יהיו חיובים מחויב רללגג

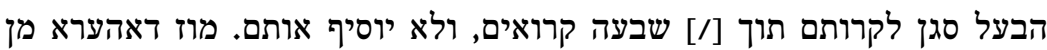

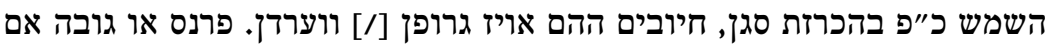

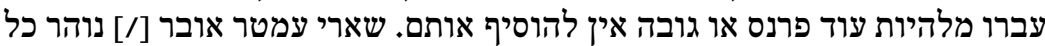
זמן דש איהר אמט בקליידן.

187 Besonderer Tag für Armenspenden, er fällt mit der Toralesung an den letzten Tagen der drei traditionellen Wallfahrtsfeste zusammen: Pessach, Wochenfest und Laubhüttenfest.

188 Wochenabschnitt der Tora: Dtn 32,1-52.

189 Wochenabschnitt der Tora: Dtn 29,9-30,20. 


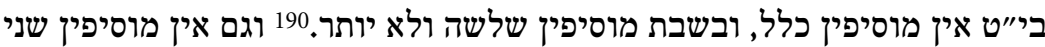

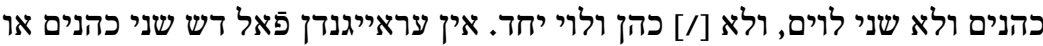

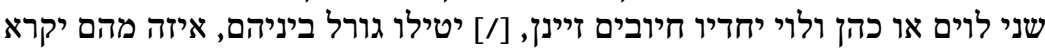

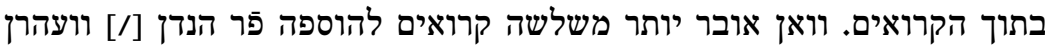

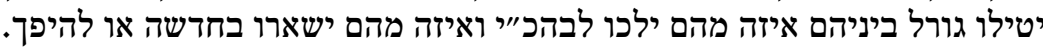

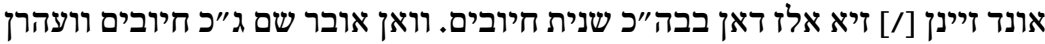

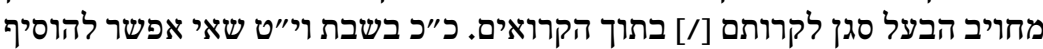

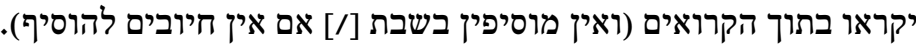

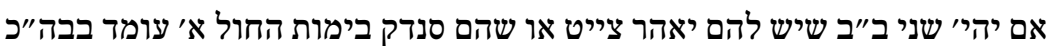

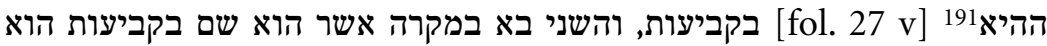

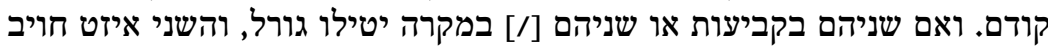

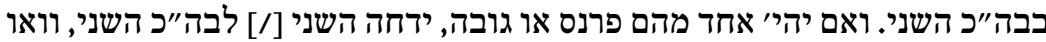

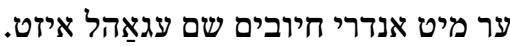

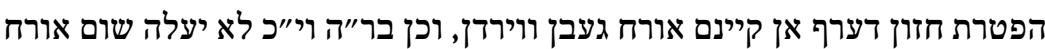
רללוך

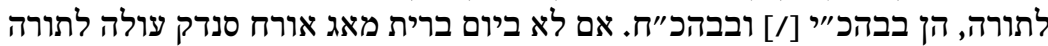

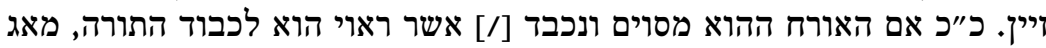

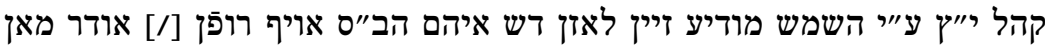
איהם שביעי או הפטרה קויפן מאג.

כל הדורש בשבת שחרית או מנחה הוא חיוב לעלות לתורה וגם יתכבד לו הוצאה רל"ז והכנסה ע״י [/] פה"ח אחרורית דורשו.

יאהר צייט בער"ח אף אם אינו ביום הכניסה איזט במנחה בקריאת ויחל192 בשום רל"ח

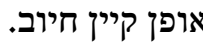

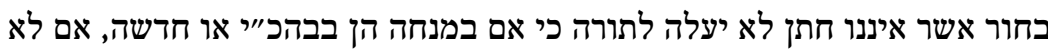

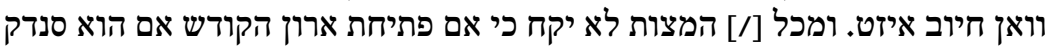

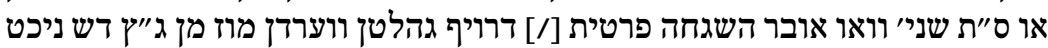

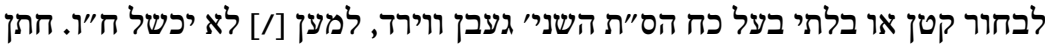

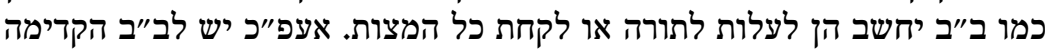
בעלי"[/] לתורה אף בלי גורל. ובר"ה ויה"כ דערף אפות אפילו חתן ניכט עולה לתורה זיין.

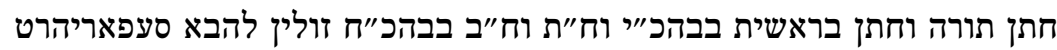

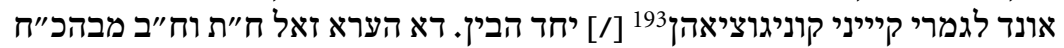

190 Gemeint sind zusätzliche Aufrufe zur Tora-Lesung.

191 Danach die Kustode בקביעות.

192 Wochenabschnitt der Tora: Ex 35,1-38,10.

193 Konjunktion, Verbindung. 


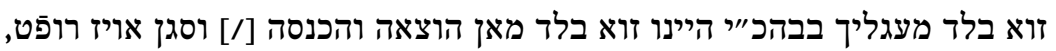

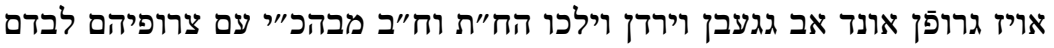

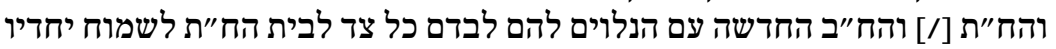

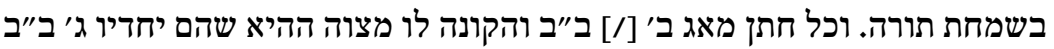

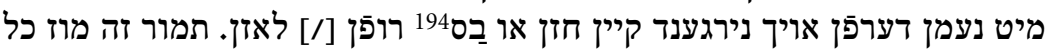

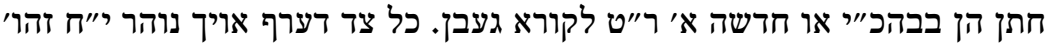

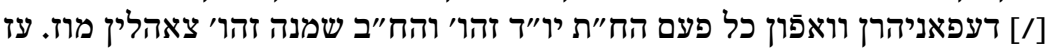

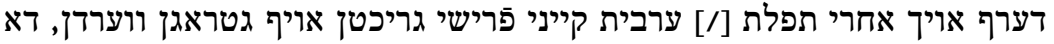

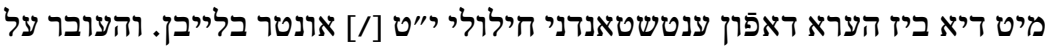

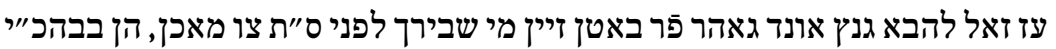
רמ"א

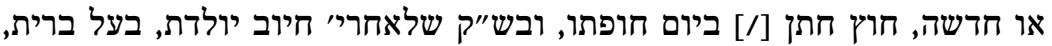

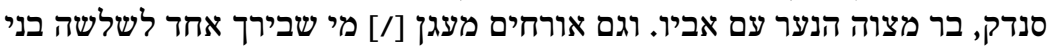

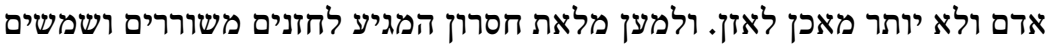

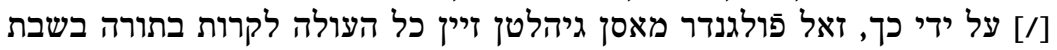

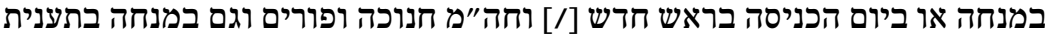

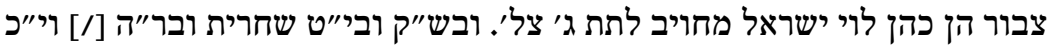

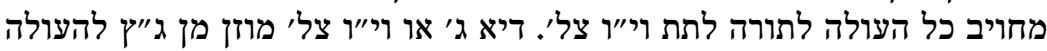

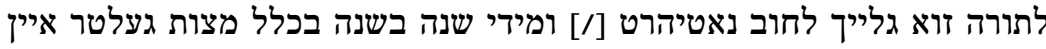

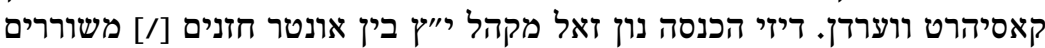

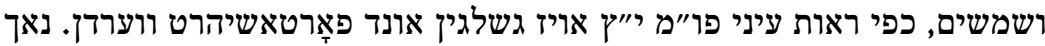

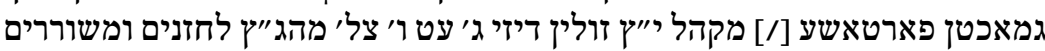

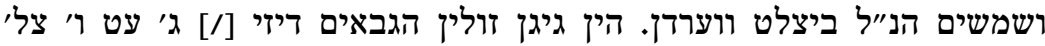

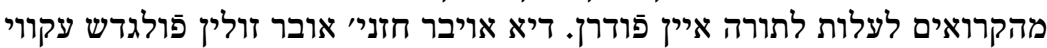

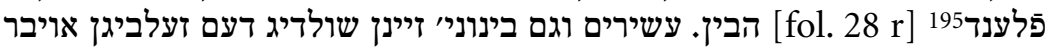

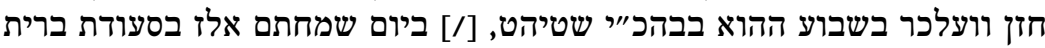

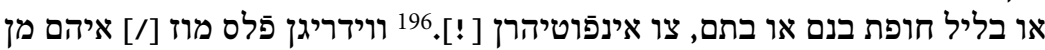

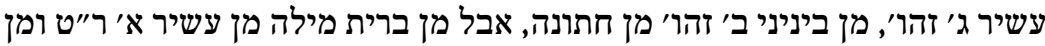

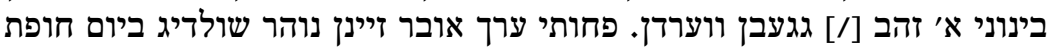

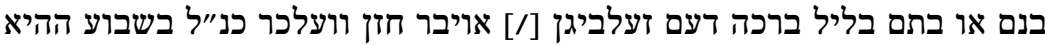

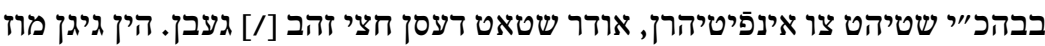

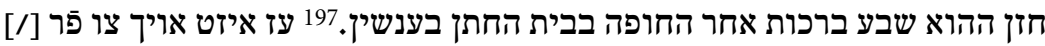

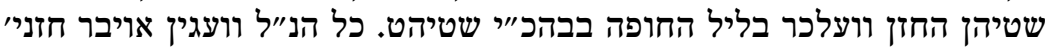

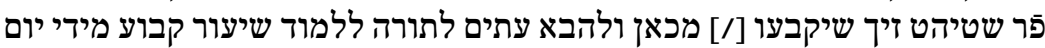

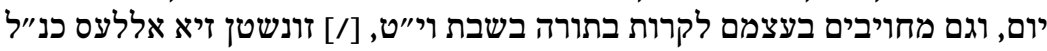

194 Bass, dem Vorsänger beigesellter Sänger.

195 Danach die Kustode הבין.

196 Invitieren, einladen.

197 Segenssprüche tun. 


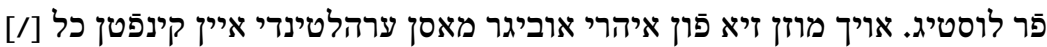

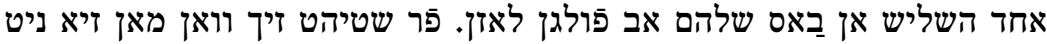

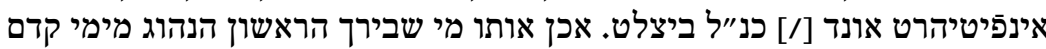

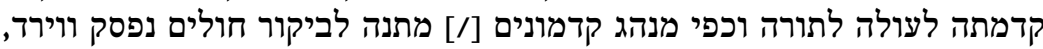

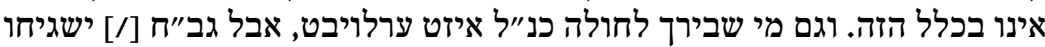

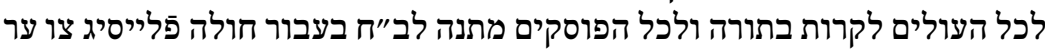
מאַהנין [/] שישלמו את נדבותם, למען לא יכשלו ח"ו בעות בעון נדרים.

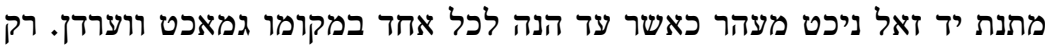
רמ״ב

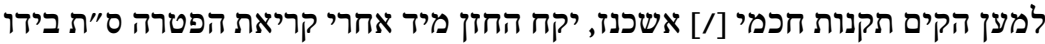

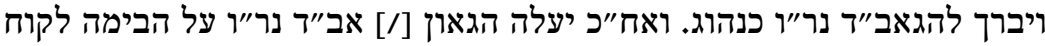

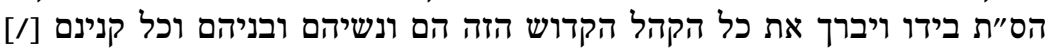

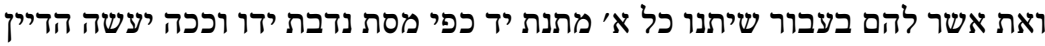

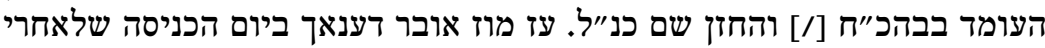

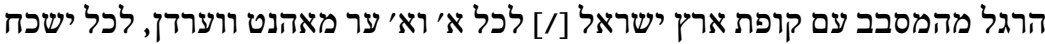
מתנת ידו לתת לקופת ארץ ישראל כנהוג.

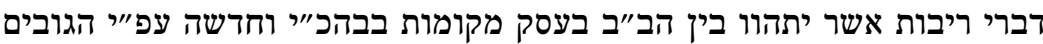
רמ"ג

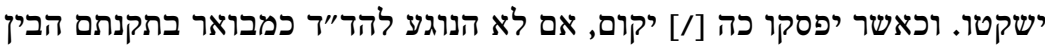
הגובים ניכטש צו שפרעכן.

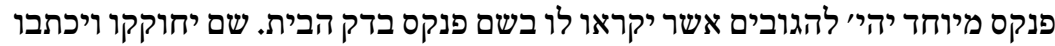
רמ"ד

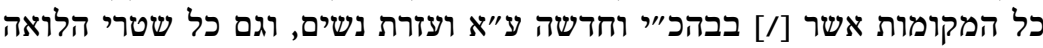

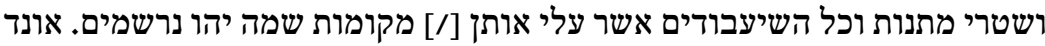

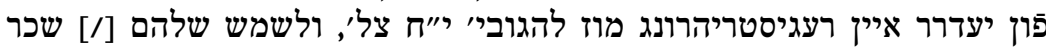

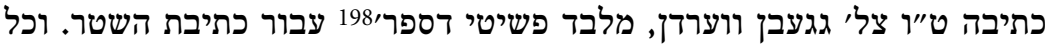

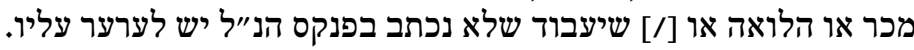

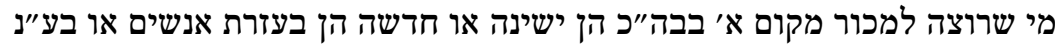
רמ"ה

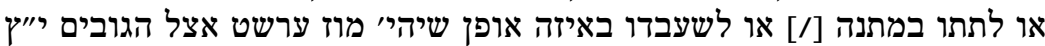

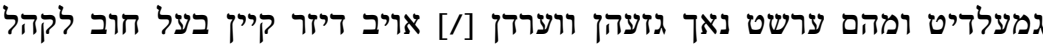

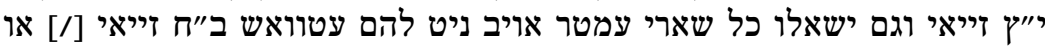

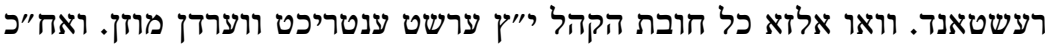

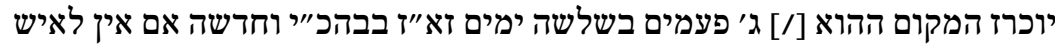

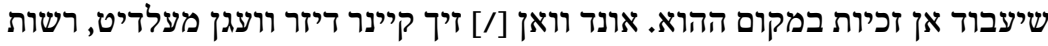
להגובים להחליט המקום ההוא.

פשיטי דספרי 198 (aram.) = Schreibgebühr. 


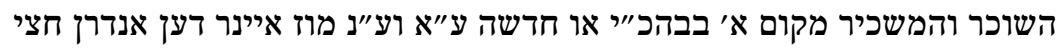

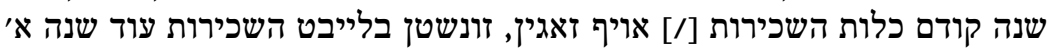

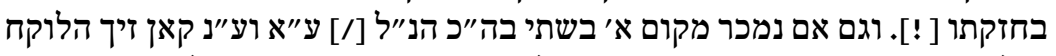

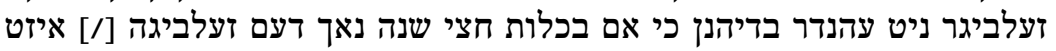

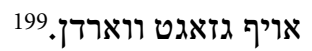

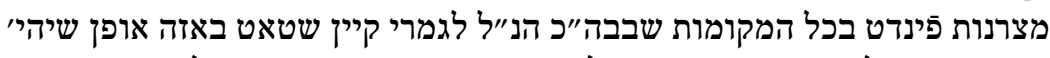
רמ"ז

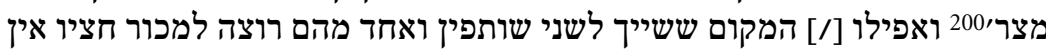

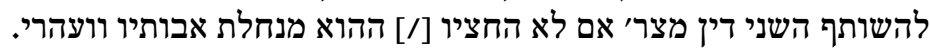

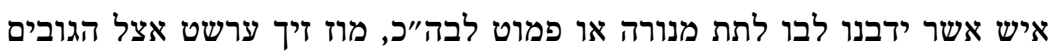
10

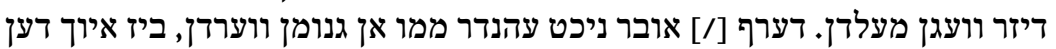

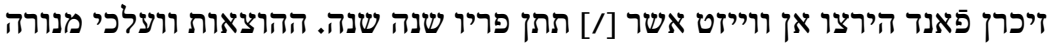

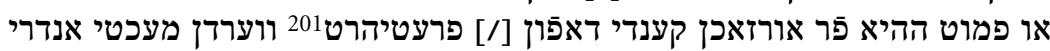

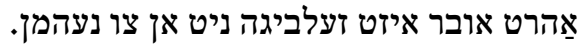

כלי ובגדי קודש יבואר בהנהגת ג"יץ איוך יתנהג בהם. להבא אובר דערף פּון נימדן

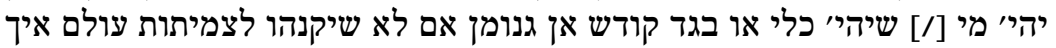

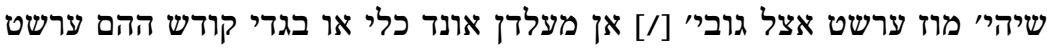

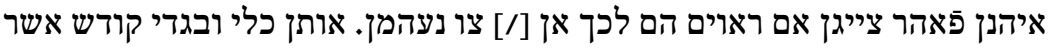

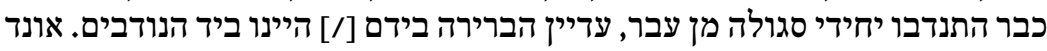

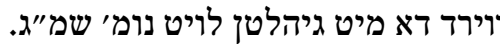

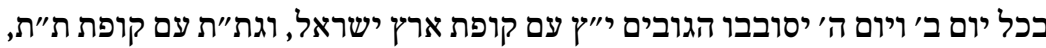

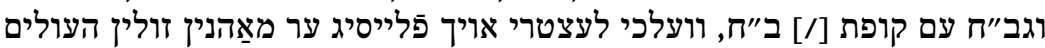

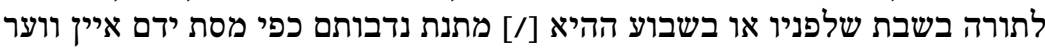

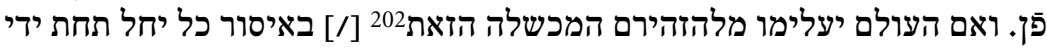

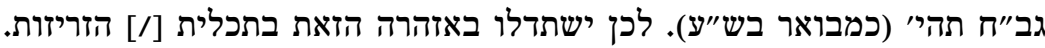

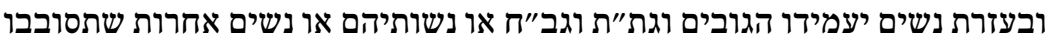

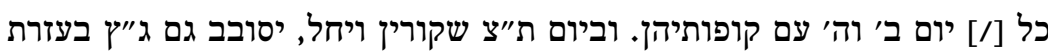

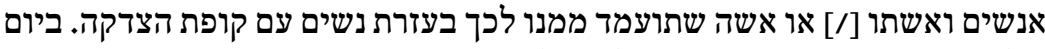

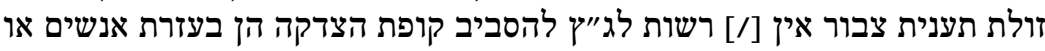

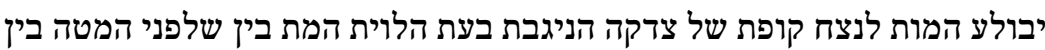
רנ"א

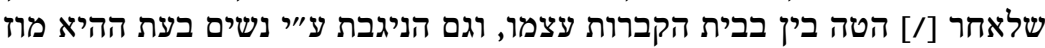

199 Danach die Kustode מצרנות.

Nachbarschaft.

201 prestihrt = prästiert, leistet, entrichtet.

202 Danach ב als Zeilenfüller. 
לידי גבאי חברת ג"ח [/] וקברנים בהענדיגט ועל ידם לעניי עירנו פאָרטאשיהרט

ווערדן.

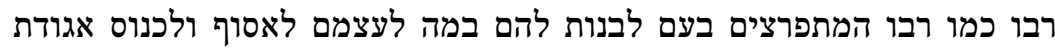
רנ"ב

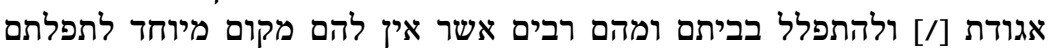

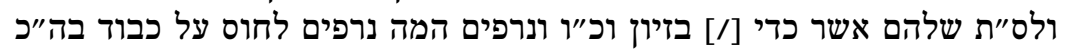

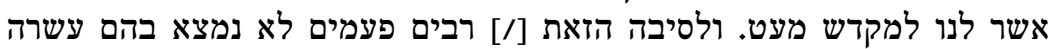

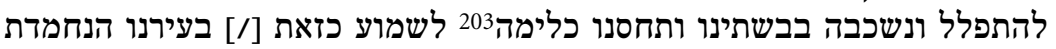

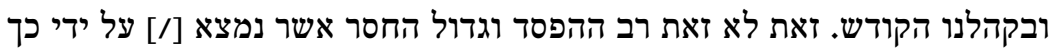

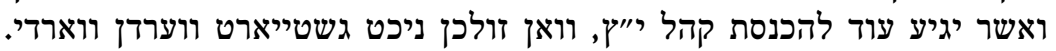

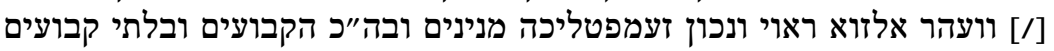

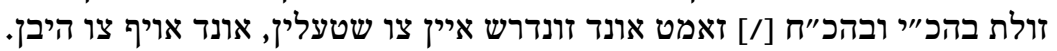

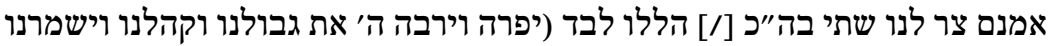

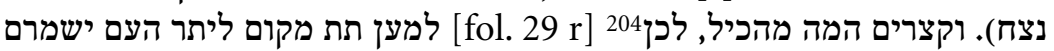

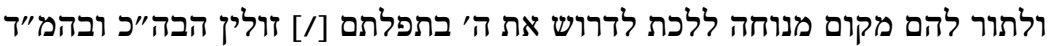

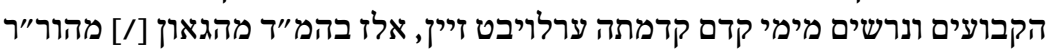

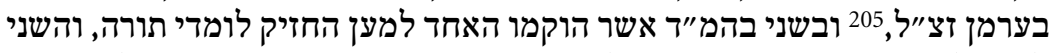

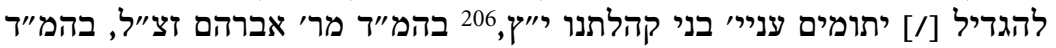

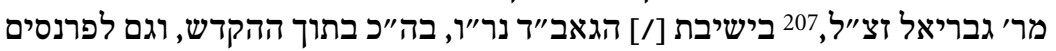

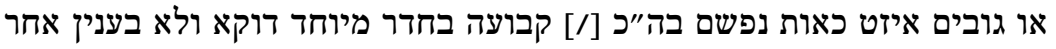

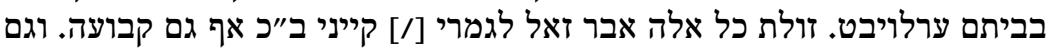

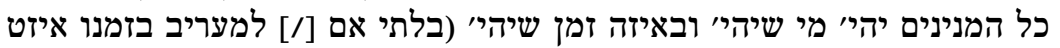

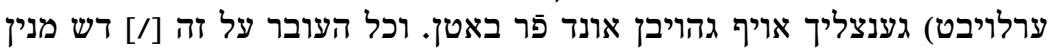

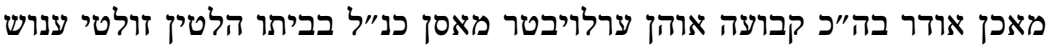

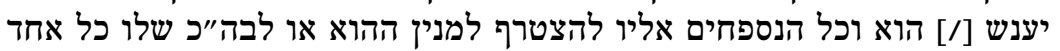

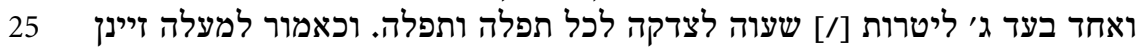

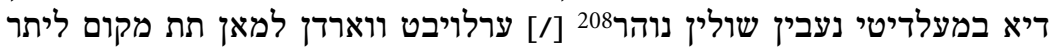

203 Nach Jer 3,25.

204 Danach die Kustode למען.

205 Bärmann Fränkel, der frühere Landesrabbiner des Fürstentums Ansbach mit Sitz in Fürth, gründete 1707 ein Lehrhaus (Klaus) aus seiner Privatstiftung, das nach seinem Tod 1708 in seinem Wohnhaus am Alten Marktplatz in der Stadt eingerichtet wurde; siehe Carsten Wilke, »Den Talmud und den Kant.« Rabbinerausbildung an der Schwelle zur Moderne, Hildesheim/Zürich/New York 2003, $64 \mathrm{f}$.

206 Das jüdische Waisenhaus in Fürth wurde 1763 eingerichtet, es war das erste seiner Art in Deutschland; siehe Baruch Zvi Ophir, Pinkas ha-kehillot. Germany - Bavaria, Jerusalem 1972, 344 f. (hebr.).

207 Am Fürther Dreikönigsplatz wurde ebenfalls 1707 ein weiteres Lehrhaus durch Gabriel ben Naftali Levi aus Fürth gestiftet; siehe Wilke, Rabbinerausbildung, 65.

208 Danach ע als Zeilenfüller. 
העם, קיינש וועגש אובר פَר בעלי ערך, זונדרן דיזי [/] מוזן לבהכ"י אורי או חדשה.

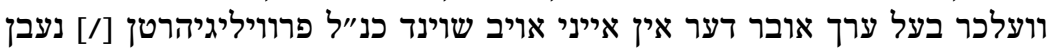

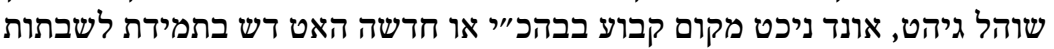

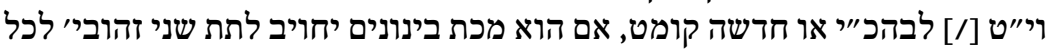

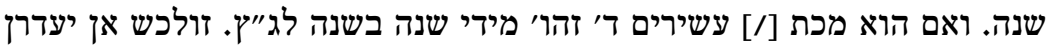

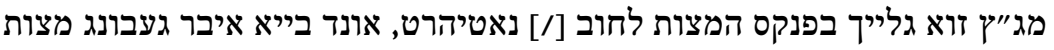

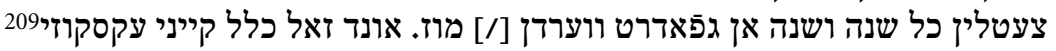

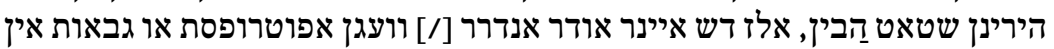

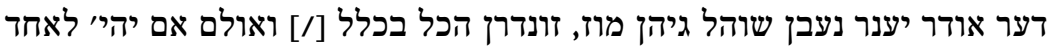

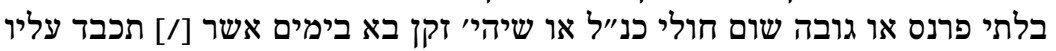

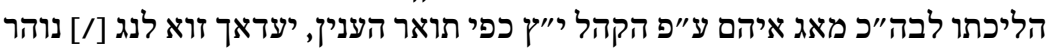

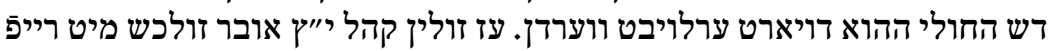

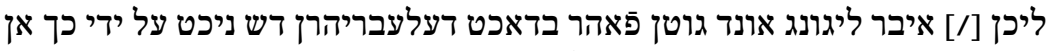

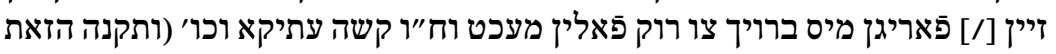

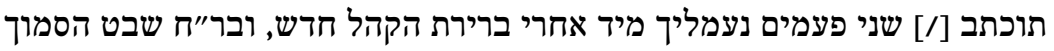

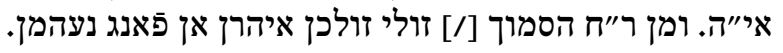

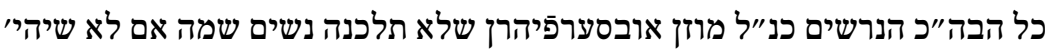

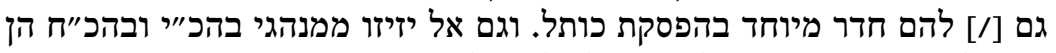

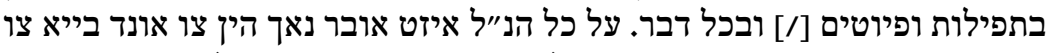

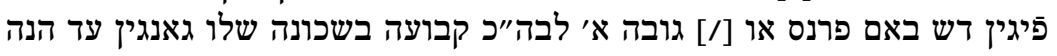

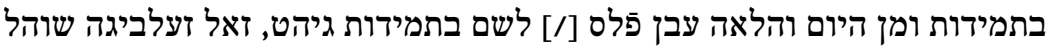

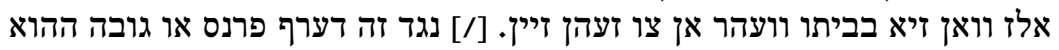
קייני בה"כ אף גם קביתו וועה בביתו הלטין.

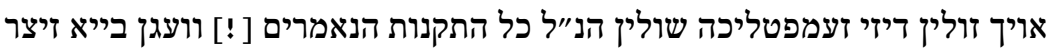

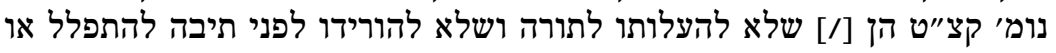
רנ"ד לומר קדיש בכל דבר שטריקטא [/] בפפולגן בקנס ששה ליטרוח לחורות שעוה לצדקה.

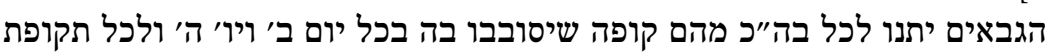
רנ"ה

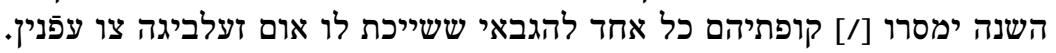

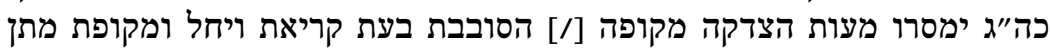

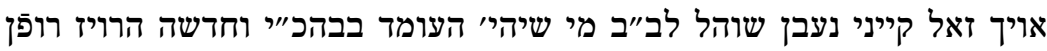
רנ"ו

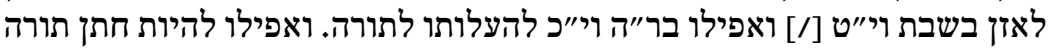

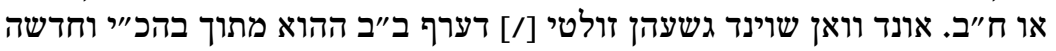

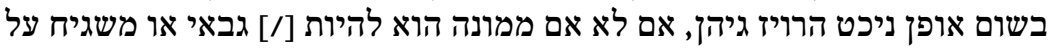

209 Von frz. excuse = Entschuldigung.

210 Danach die Kustode הגבאים. 


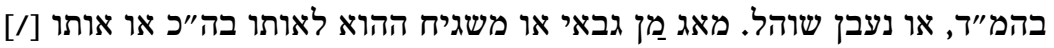

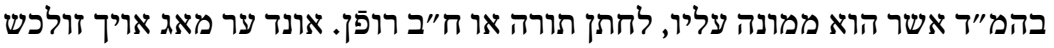

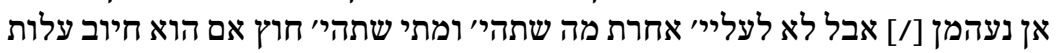

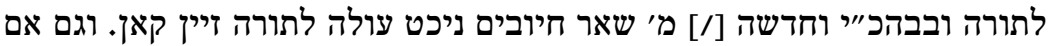

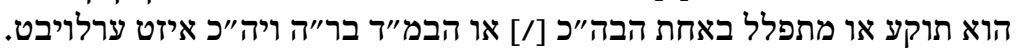

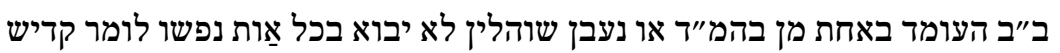
רנ"ז

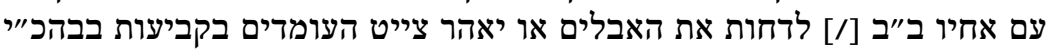

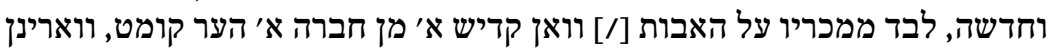

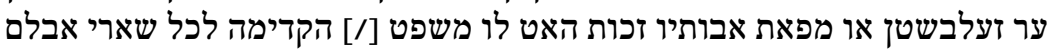
ויאהר צייט.

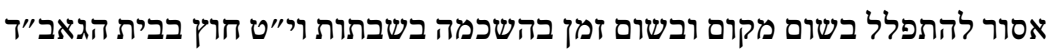
רנ״ח

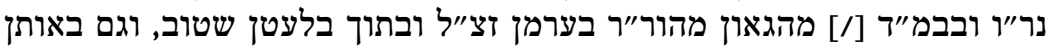

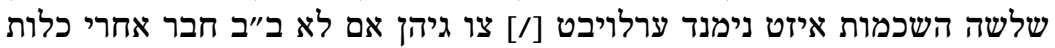

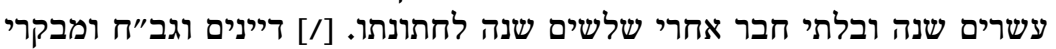

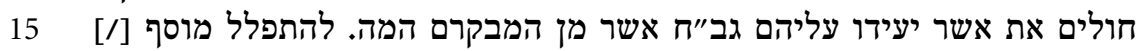

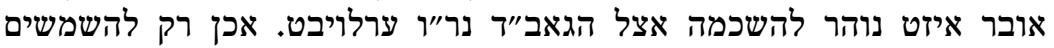

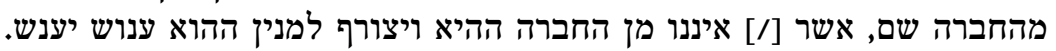

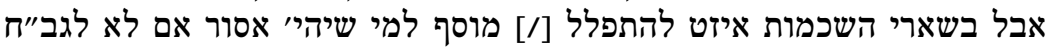

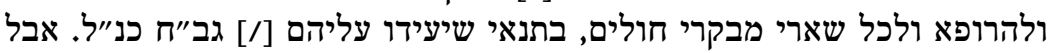

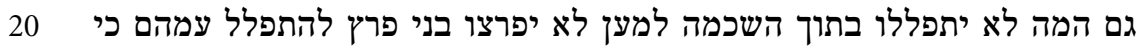

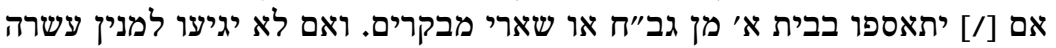

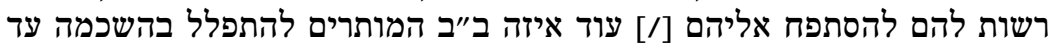

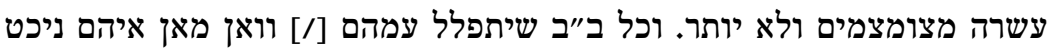

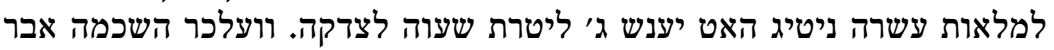

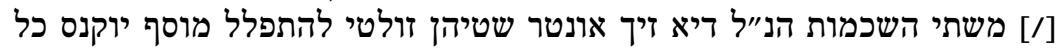

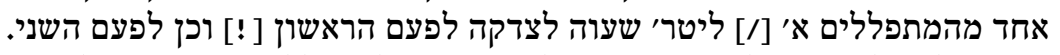

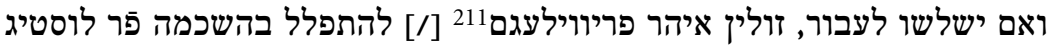

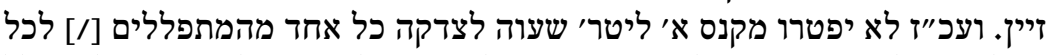

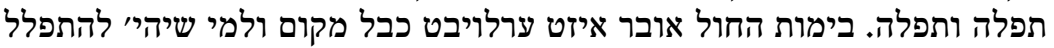

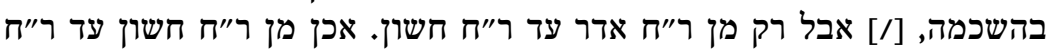

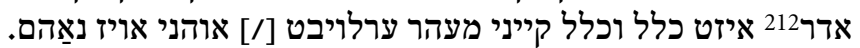

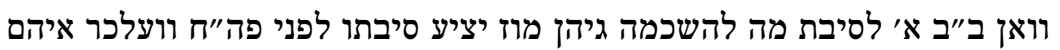
רנ"ט אלז דאן יעדאך [/] רק לפעיבת מה לחשכמה ובאקראי ולא בתמידת ערלוז סציבן מאג.

211 Danach ל als Zeilenfüller.

212 Das Frühgebet war demnach nur während der Zeit des Frühlings und Sommers gestattet..

213 Danach die Kustode בחורים. 
[fol. $30 \mathrm{r}$ ]

בחורים ונערים הן מבני קהלתנו או שבתות בחורים עט קאשט געניל להפר הבין בשום

ר"ר אופן קיין ערלויבנס [/] להתפלל בהשכמה.

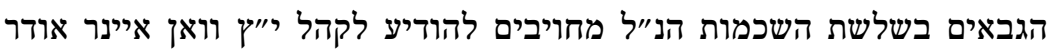
רס"א

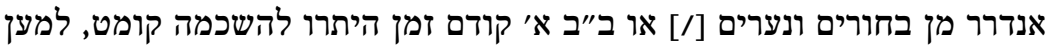

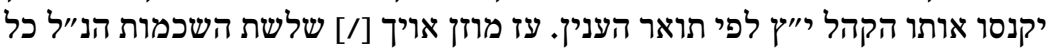
תיקוני בייא זיצר אובסערפיהרן בקנס ששה ליטרות שעוה לצקדה.

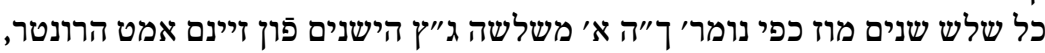
תיקוני ג"ל

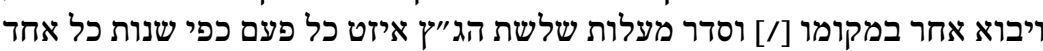
רסיקוני

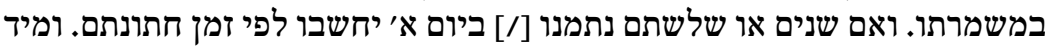

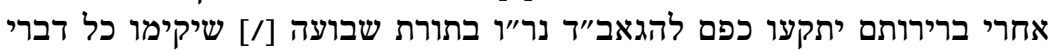

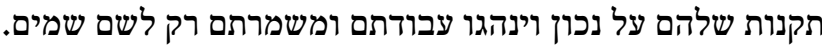

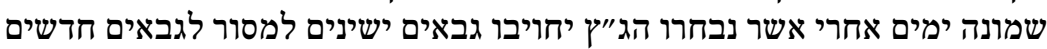

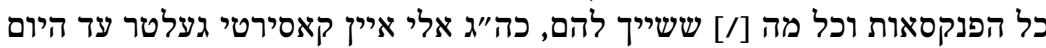

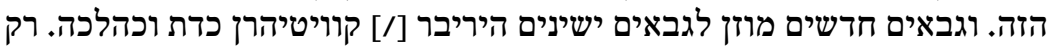

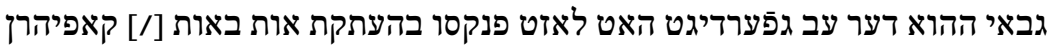

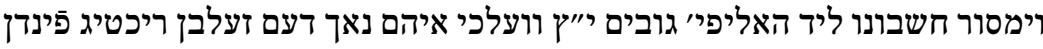

קוויטיהרן מוזץ.

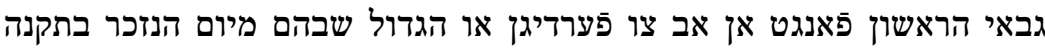
$x^{\prime \prime 07} \quad 20$

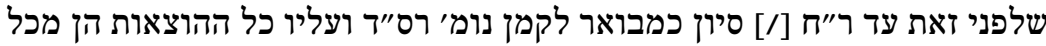

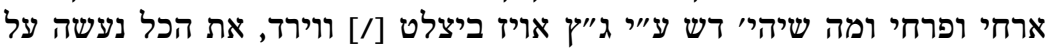

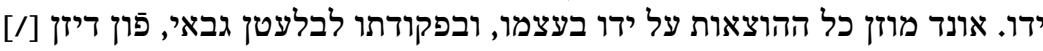

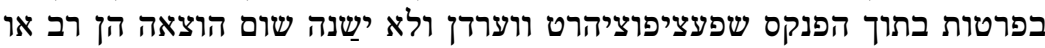

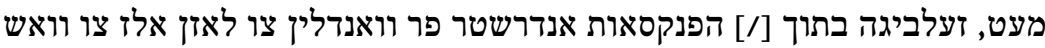

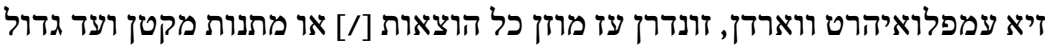

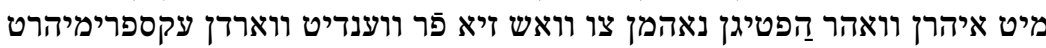

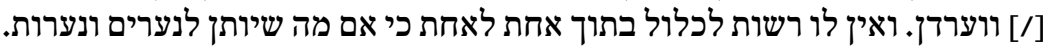

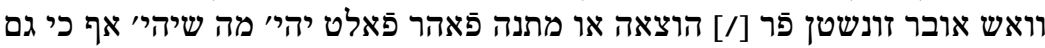

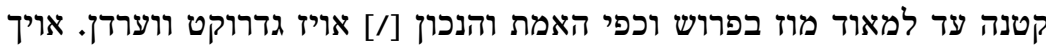

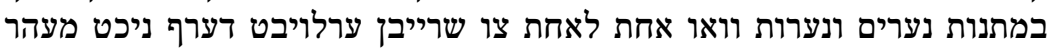

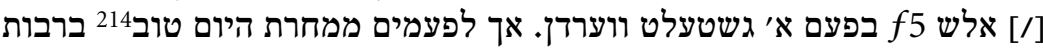

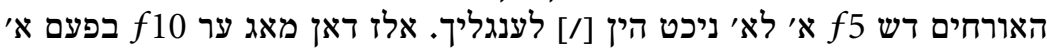

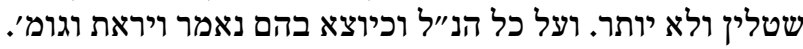

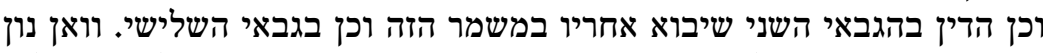

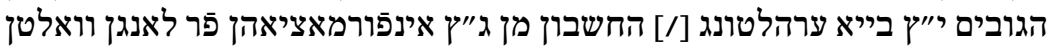

214 Dieses Wort über der Zeile ergänzt. 
וועגן אחת לאחת מוזץ הגבאי' ע"י פנקס האורחים זיך [/] לעגיטימיהרן קענין אשר שם יחוקקו כל שמות הנערים והנערות.

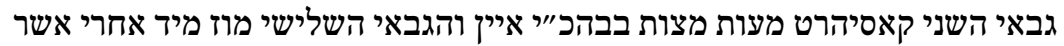
רס"ד

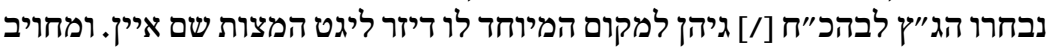

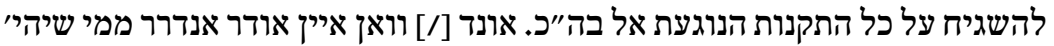

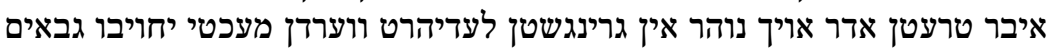

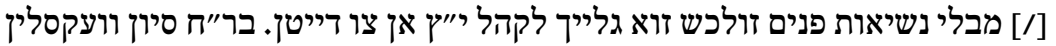
הגבאים פולגנדר אַהרט אב,

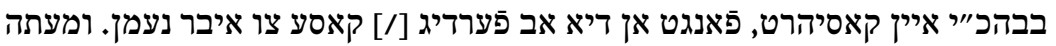

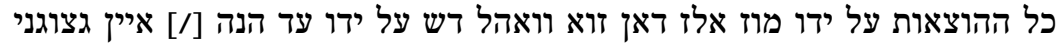

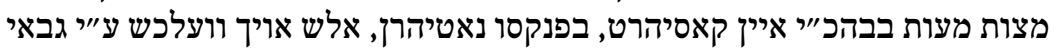

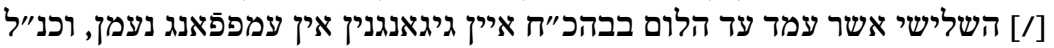

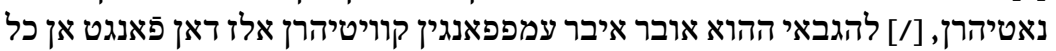

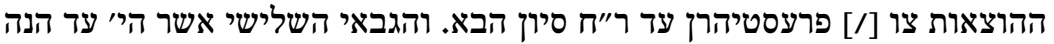

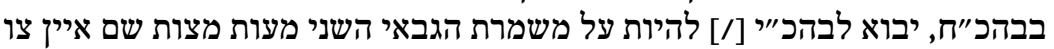

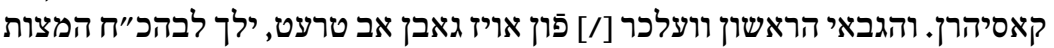

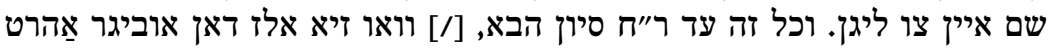

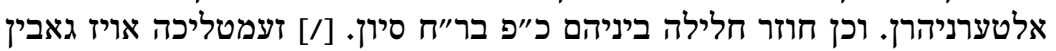

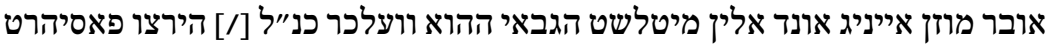

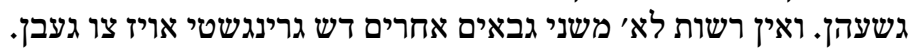

כל שלשה חדשים יצוה הגבאי וועלכר כנ"ל דיא אויז גאב האט להכריז בשתי

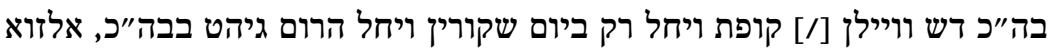

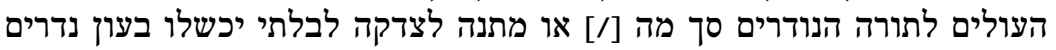

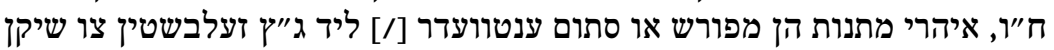

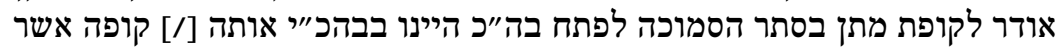

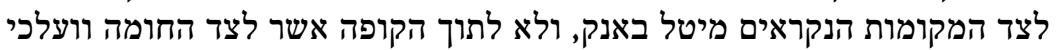

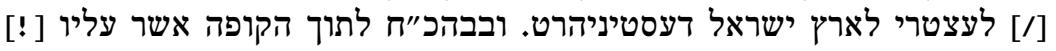

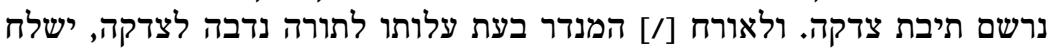

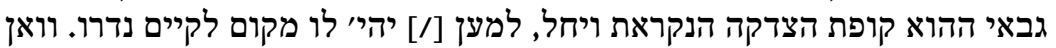

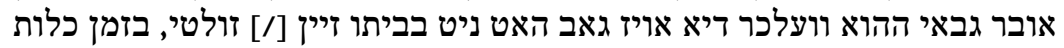

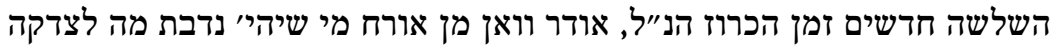

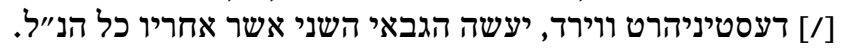

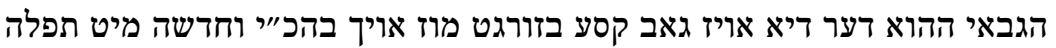

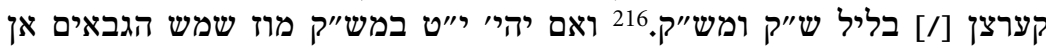

215 Danach die Kustode הגבאי.

216 Der Satz bleibt unvollständig, hier müsste folgen »ausstatten«. 
דען הירצו בבהכ"י וחדשה גשטעלטן [/] ליכטר בוצר 217 קערצליך געבן לאזן

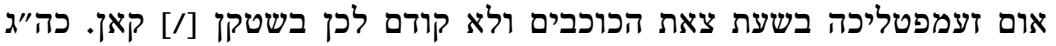

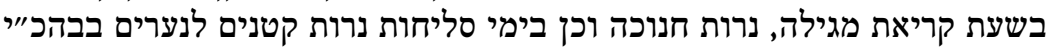

וחדשה.

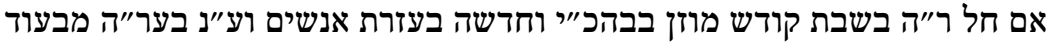

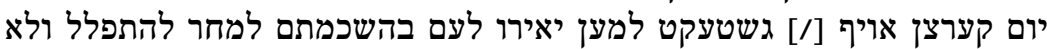

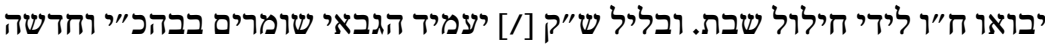

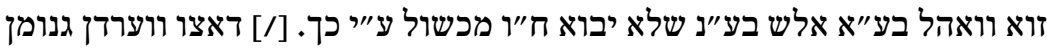

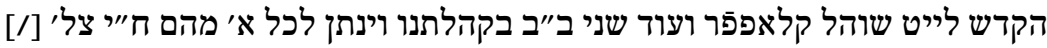
כה"ג ווירד בליל כל נדרי אובסערפיה שריט.

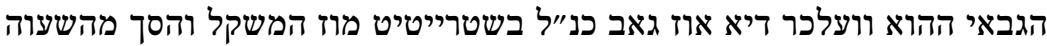
רס

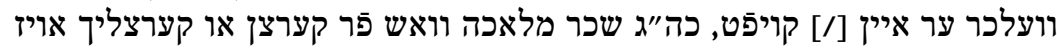

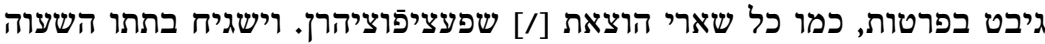

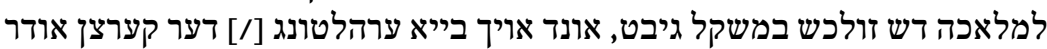
קערצליך ווידרום נאך זעהן אום דש ניכט ענטלצויב אויגן ווירד.

עז מוז אויך גבאי הנ״ל תמיד מוכן לפניו הבין צווילר, קיטלין, הויזן אויך צייג

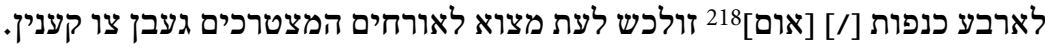
לעצטרש אויך ווירד לבחורים ענים

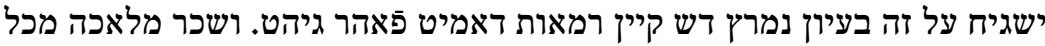
[/] הנ״ל יורשם בפנקס הגבאים.

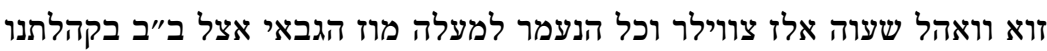
ר

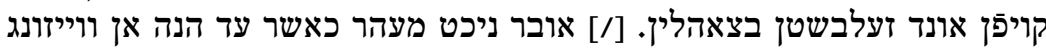

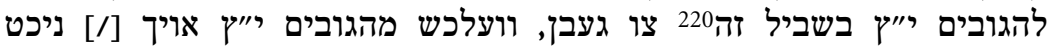

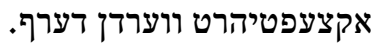

קיין גבאי דערף קייני אן ווייזונג לב"ב, אורחים אב צו פַערדיגן, חוץ על בלעט

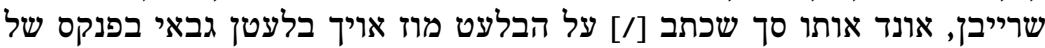

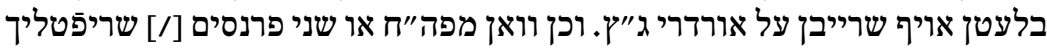

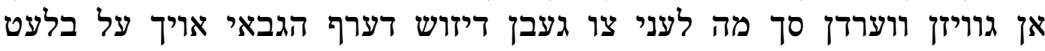

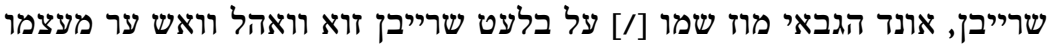

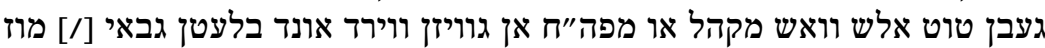

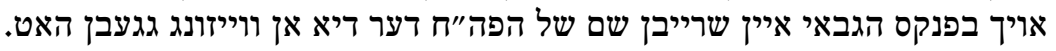

217 Lichterputzer, der Verantwortliche für das Reinigen und Bestücken der Kerzenhalter. 218 Über diesem Wort starke Veschmutzung durch Tinte.

219 Danach die Kustode הלומדים.

220 Davor ein verschriebenes Wort, durch Streichung unleserlich. 


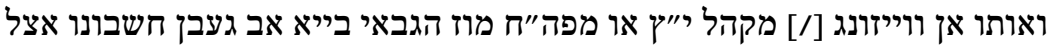

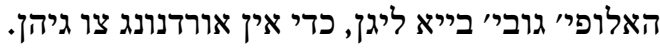

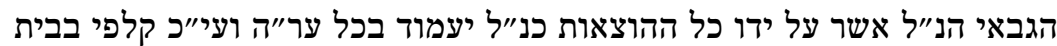

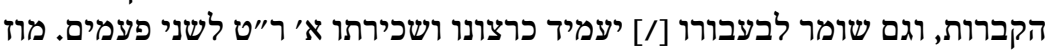

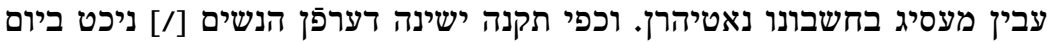

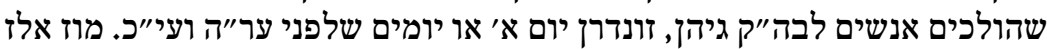

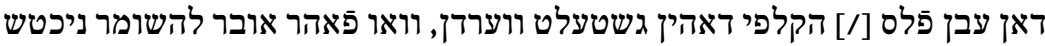

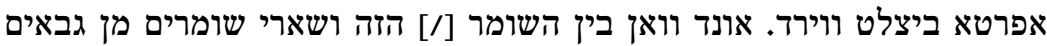

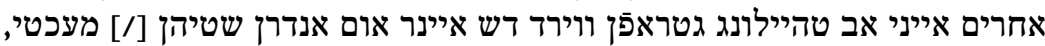

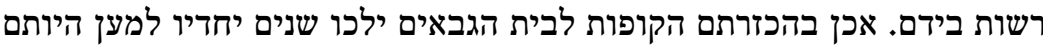
נקים מה' ומישראל.

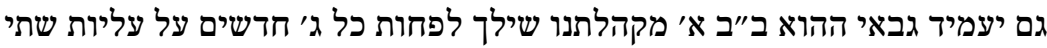
רע"ג

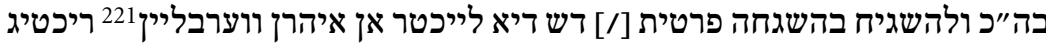

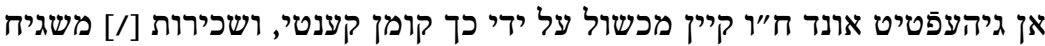

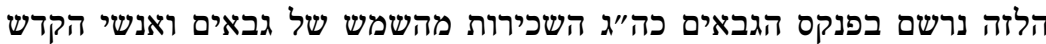

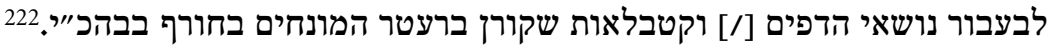

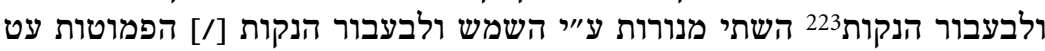

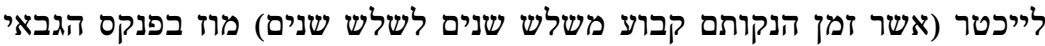

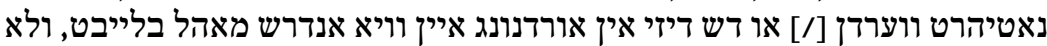

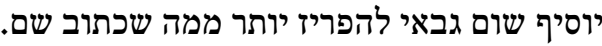

רגם ב"ב א׳ שישגיח על שעוה הנוטף [!] מהנרות יועמד ע"י גבאי הנ"ל. וב"ב רע"ד

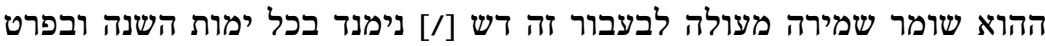

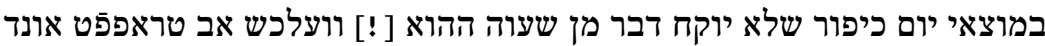

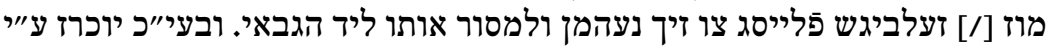

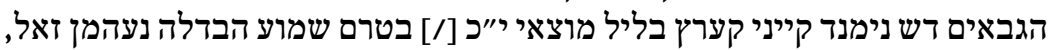

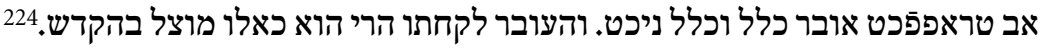

221 Diminutiv von Wirbel, wohl eine Rolle, an der die Leuchter beweglich aufgehängt waren.

222 Bedeutung unklar; vielleicht handelte es sich dabei um eine Auflage für den Fußboden zur Wärmedämmung oder zum Schutz vor Feuchtigkeit und Schmutz.

223 הִיָוּוּת

224 Diese Anordnung resultiert aus dem damals relativ hohen Preis für Wachs und Kerzen. Das abgetropfte und erstarrte Wachs sollte zweifellos gesammelt und erneut für die Herstellung von Kerzen für die Synagoge verwendet werden. Das Verbot richtete sich offenbar an diejenigen, die ebenso die Absicht hatten, das Wachs zu sammeln nur eben für private Zwecke. 


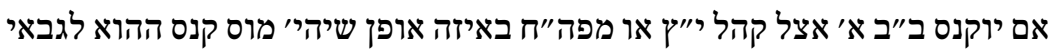
רע"ה

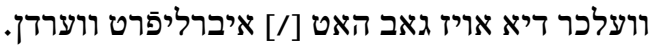

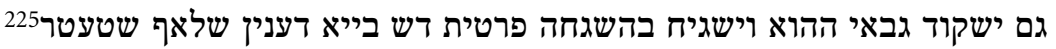

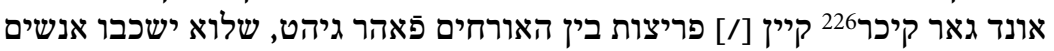

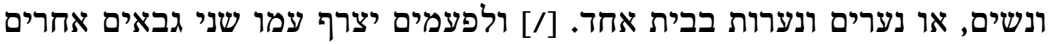

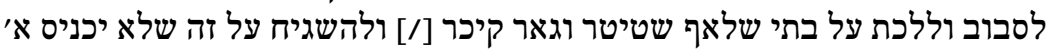

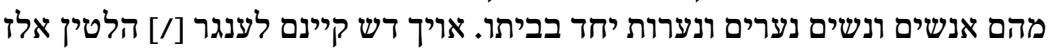

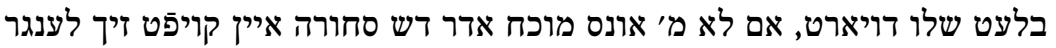

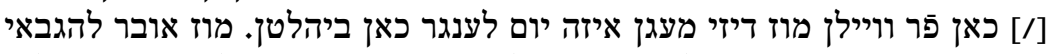

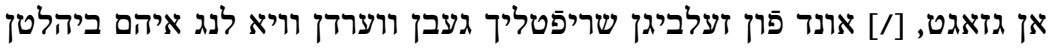

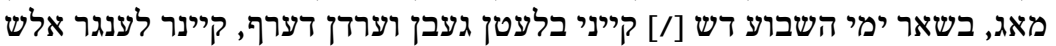

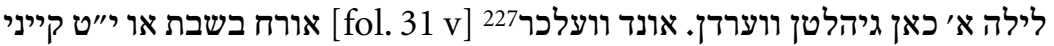

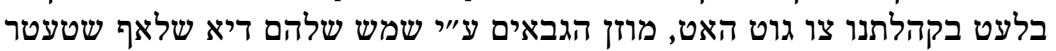

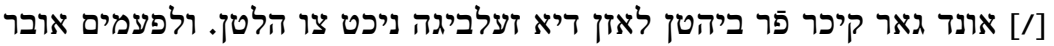

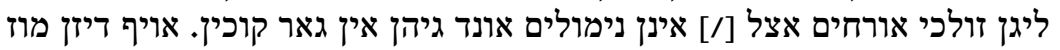
רע"ו

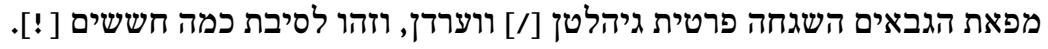

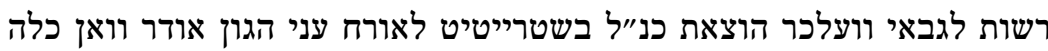

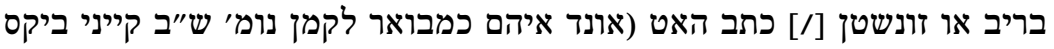

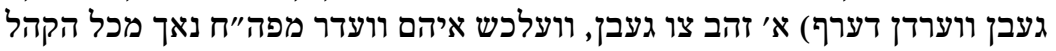

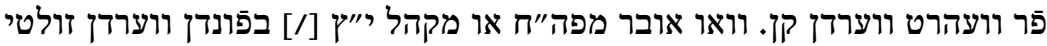

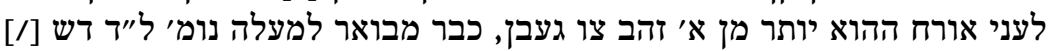

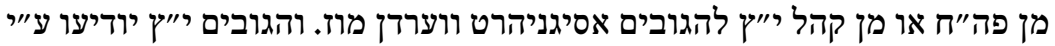

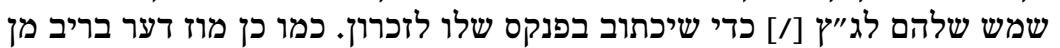

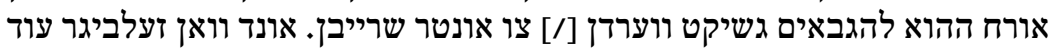

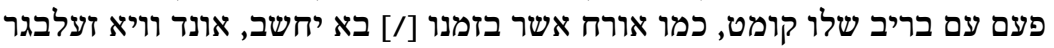

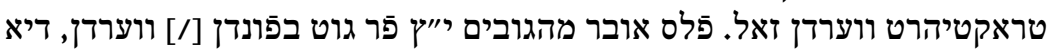

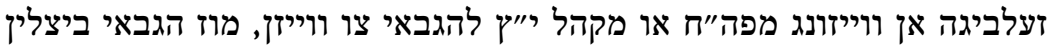

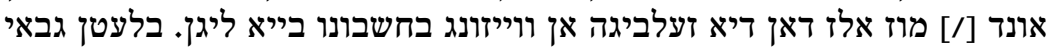

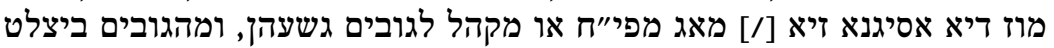

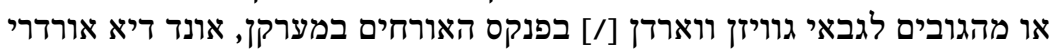

כל עי"ט מוז הגבאי ההוא וועלכר דיא אויז גאב האט בייא בלעטן אויז געבי ועי זירי זיצן.

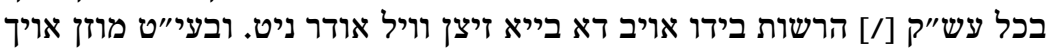

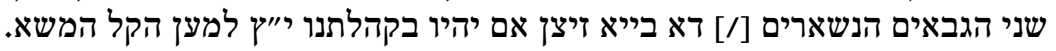

\footnotetext{
225 Herbergsleute, die einfache Unterkünfte für die durchreisenden Armen betrieben. 226 Garköche.

227 Danach die Kustode אורח.
} 


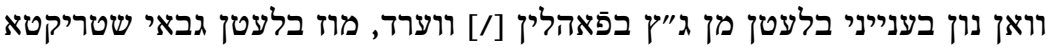

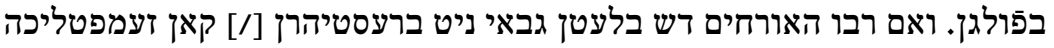

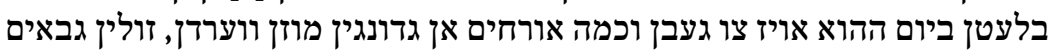

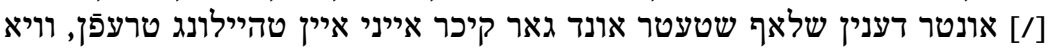

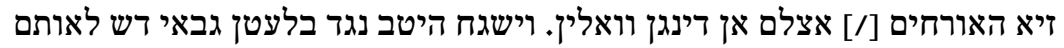
ב״ב דיא על חשבון הקהל הלטין [/] כסדר הנעשה ביניהם שיקט.

עז מוז אויך גבאי ההוא דער דיא אויז גאבן בשטרייטיט בזורגין דש בפורים

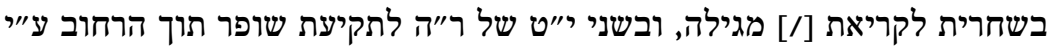
רע"ט השמש גרופן ווערד, ושכרו נקצב בפנקס גבאיי.

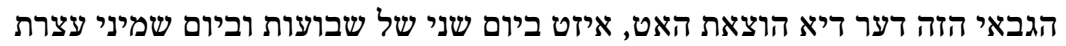

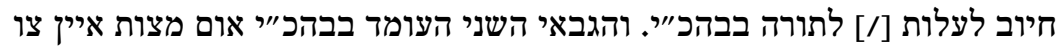

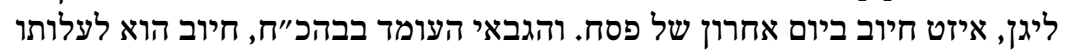

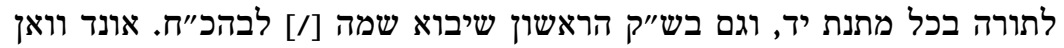

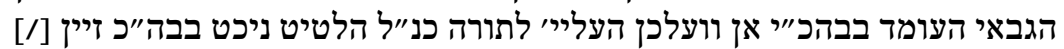

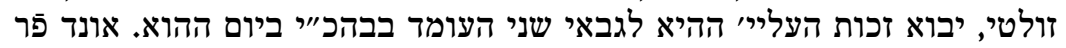

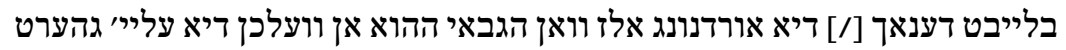

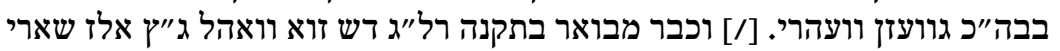

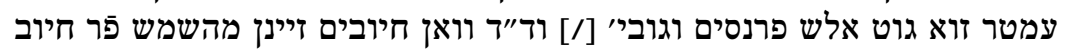
אויז גרופ̄ן ווערדן מוזץן.

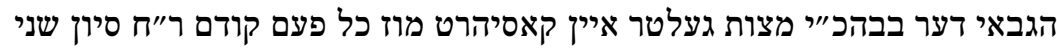
רפ"

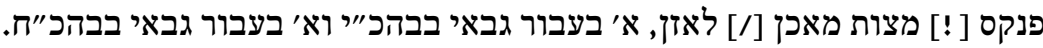

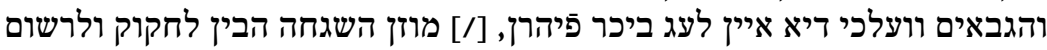

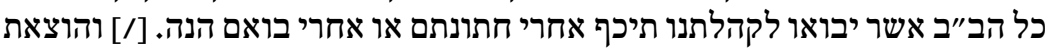

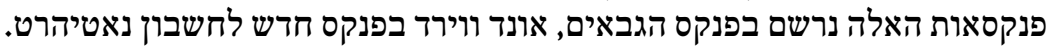

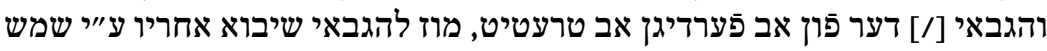

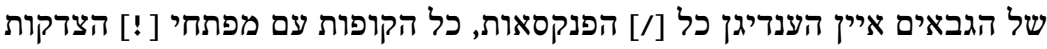

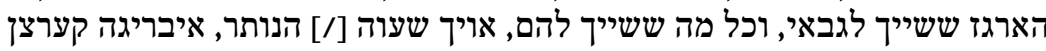

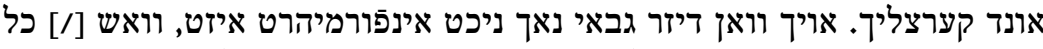

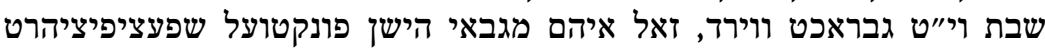
ווערדן אום זיך [/] הירנאך ריכטן צו קענירן.

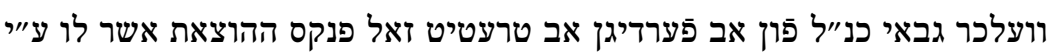

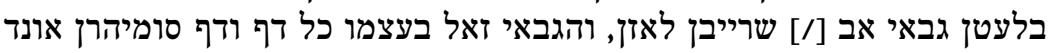

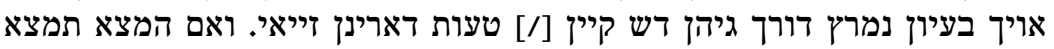

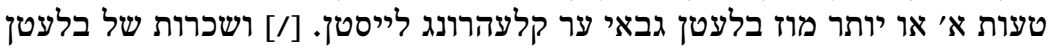
גבאי לבעבור העתקת פנקס ההוא יופסק עיוי שלשת הגבאים יחוני ליחד, אבל לא [/] 35

228 Danach die Kustode הגבאי. 
יבזבזו יותר מדאי אונד וואש229 פעם הראשון אויז גמאכט ווירד יוכתב לזכרוץ אום

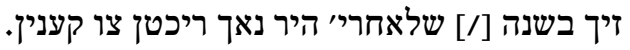

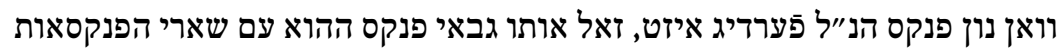

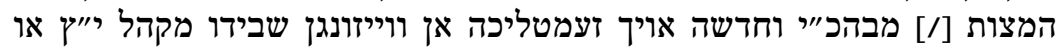

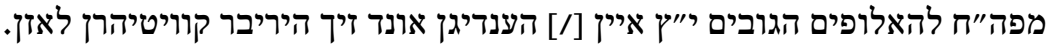

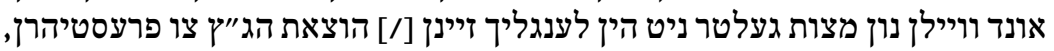

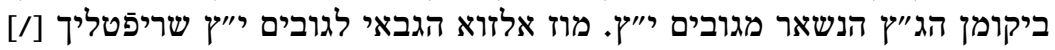

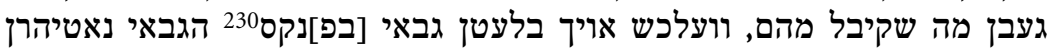
ובחשבונו איין געבן מוזל מהם, וועי

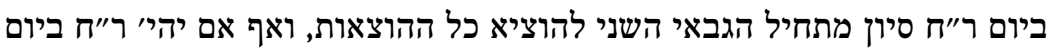

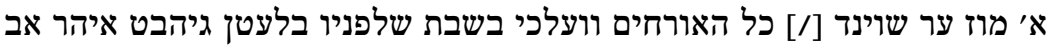
פערטיג געלט גערן מרונד

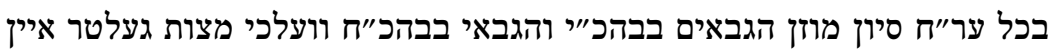
רפ"ה

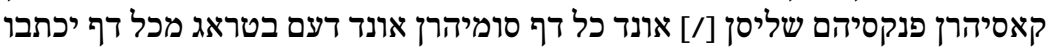

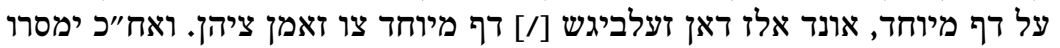

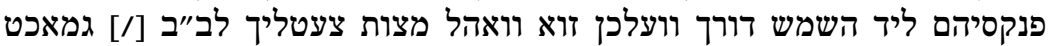

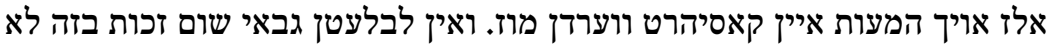

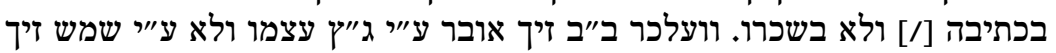

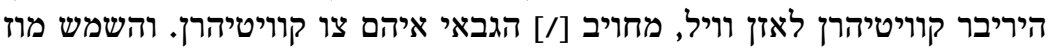

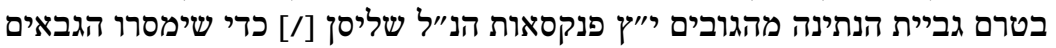

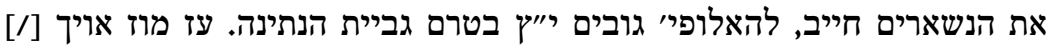

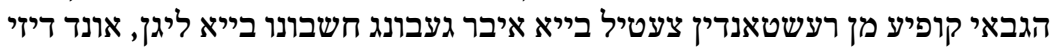

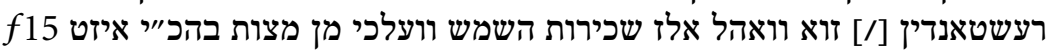

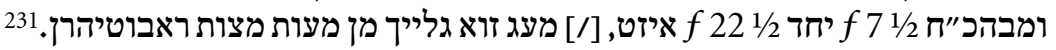

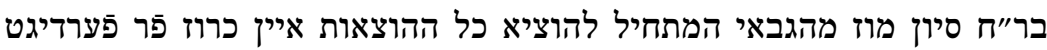

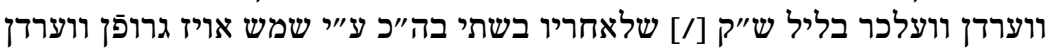

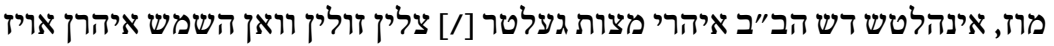
צוג ברענגט, וfol.32 v]

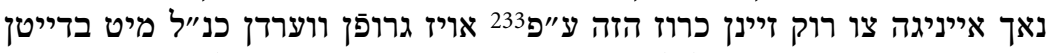

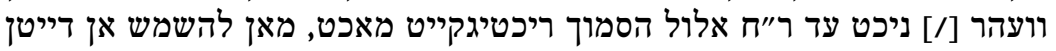

229 Dieses Wort über der Zeile erneut nachgetragen, da anstelle des Wortes in der Zeile ein Loch klafft, dass wahrscheinlich durch Tintenfraß verursacht wurde.

230 Loch im Papier durch Tintenfraß.

231 Verrechnen?

232 Danach die Kustode נאךך.

233 Hier fehlt vermutlich: השמש. 
ווערט איהם כתקנה [/] ישינה קייני מצוה מעהר צו קומן צו לאזן. ואם בכל זאת לא ישמע הבין זיך הגבאי' צו פר [/] הלטין כמו נומ'.234

בבהכ"י פַאנגט השמש כל המצות אויז צו רופןן מיט א׳ פץ"235 בימות החול, אבל

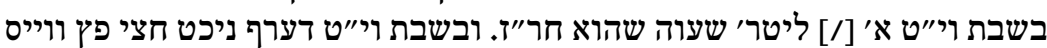

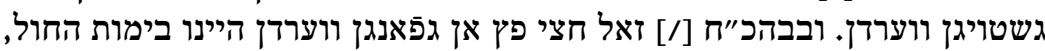

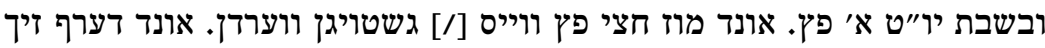

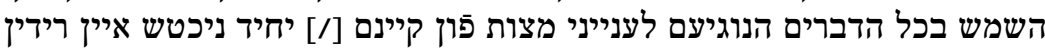

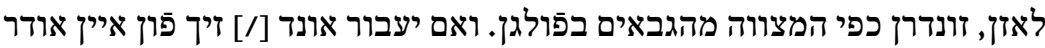

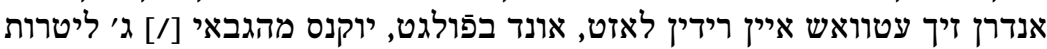

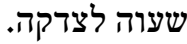

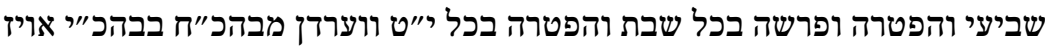
רפ"ח

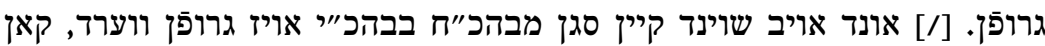

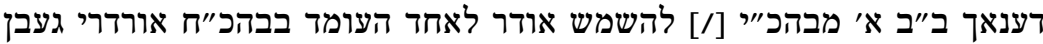

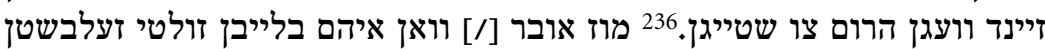

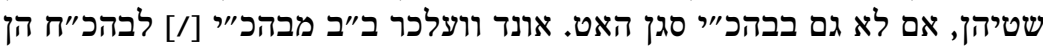

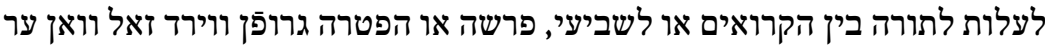

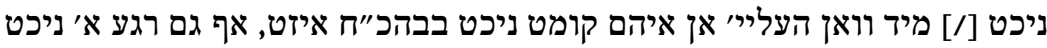

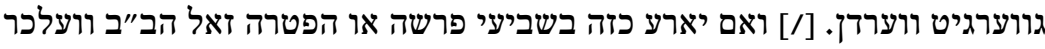

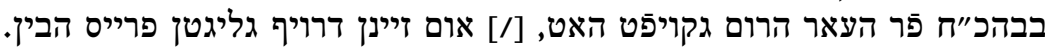

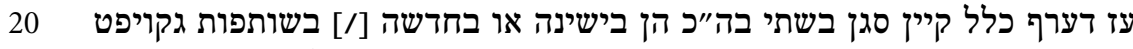

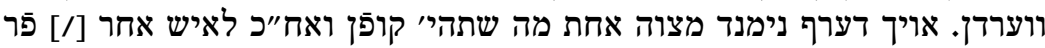

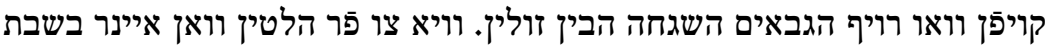

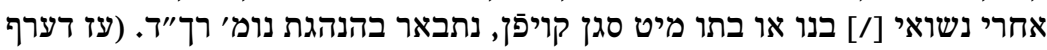

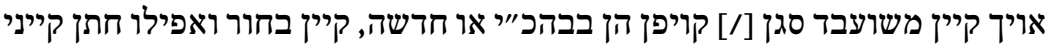

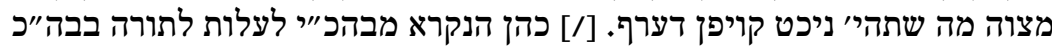

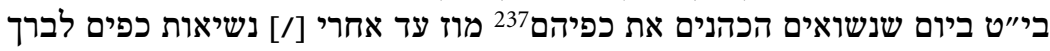

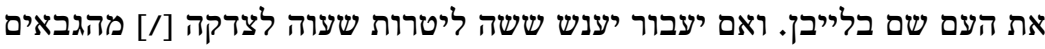

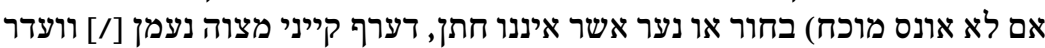

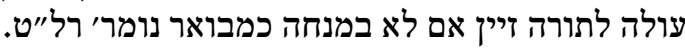

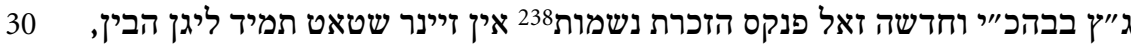
רפ"ט

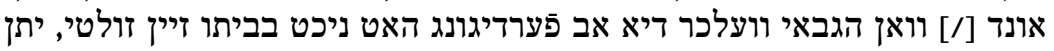

234 Die Paragraphennummer fehlt und der dafür vor dem Punkt vorgesehene Platz blieb ungenutzt.

235 Batzen, ein Batzen entsprach fünf Kreuzern.

236 Für ihn bei der Versteigerung mitzubieten.

237 Der durch die Kohanim erteilte Priestersegen.

238 Das Memorbuch. 
אותו לגבאי שלאחריו [/] דא מיט וואן יהל"נ איינר זיך זיך איין שרייבן לאזן וויל,

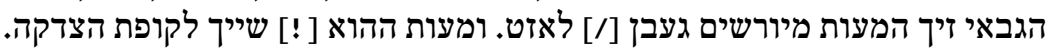

לא נגאלו ישראל אלא על שלא שינו את כסותם ולשונם. לכן יהיי תמיד מוכנים

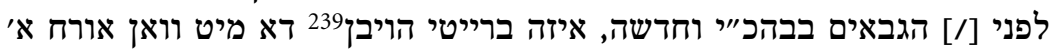

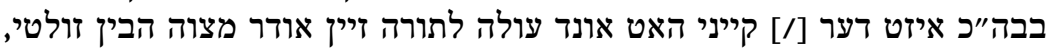
ץ"ר

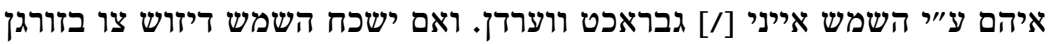
יוקנס מגבאי א׳ ליטר' שעוה לצדקה. 240

[fol. $33 \mathrm{r}$ ]

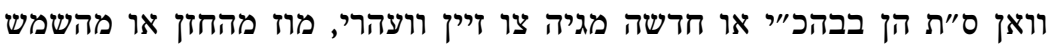
ריצ

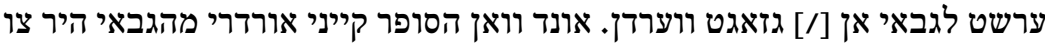

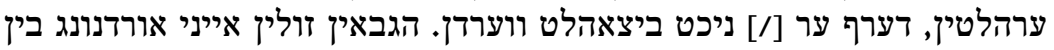

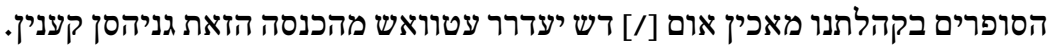

גבאי ב"ח געבן אן ווייזונג על ג"ץ וועגן דענין פוהרץ 241 זוא זיא מהקדש וועק שיקן

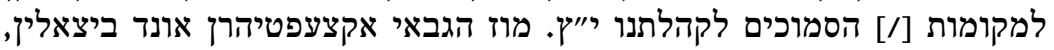

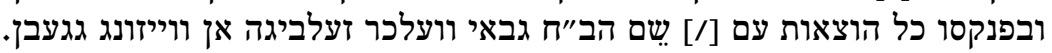

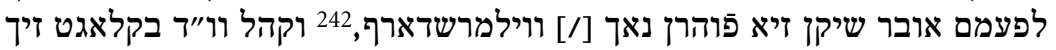

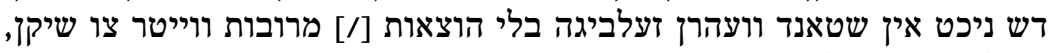

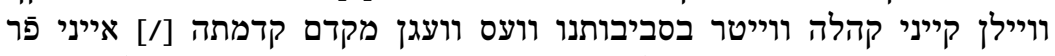

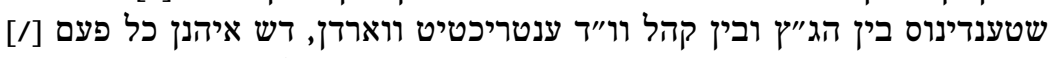

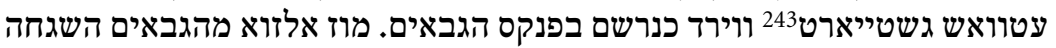

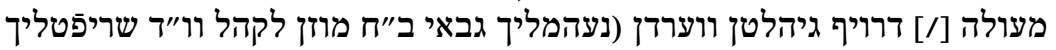

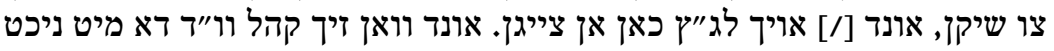

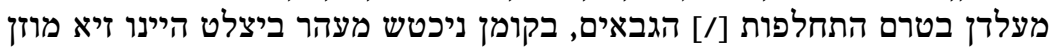

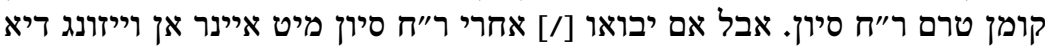

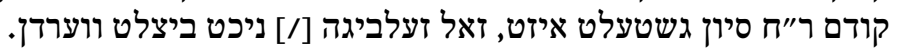

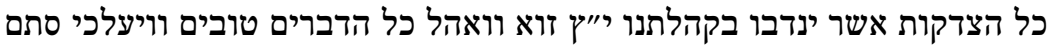
רา

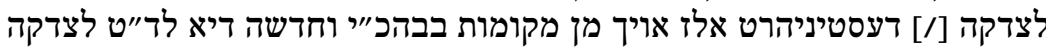

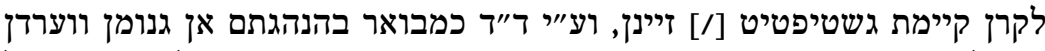

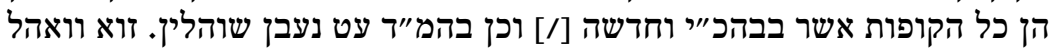

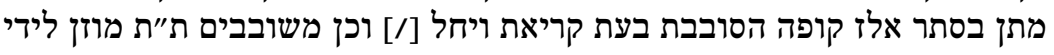

239 Gemeint ist wohl der »Schabbesdeckel«, die damals typische Kopfbedeckung von jüdischen Männern am Schabbat.

240 Danach die Kustode וואן.

241 Fuhren, womit hier Gruppen von durchreisenden Armen gemeint sind.

242 Wilhermsdorf, westlich von Fürth gelegen. Dort war eine der bedeutendsten hebräischen Druckereien angesiedelt.

243 Beigesteuert. 
הגבאים גליפרט ווערדן, וואו צו הד"ד איהנן בהילפיליך [/] זיין מוזן. וואש זיא

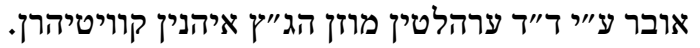

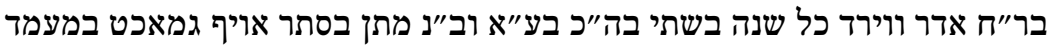
רצ"ד

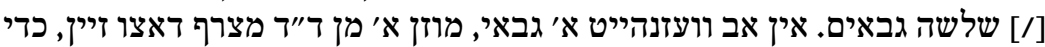

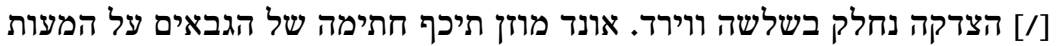

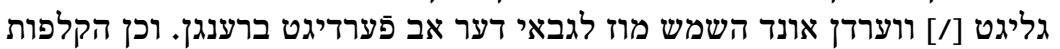

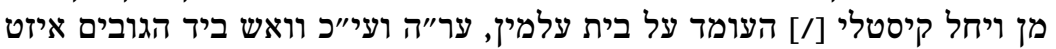

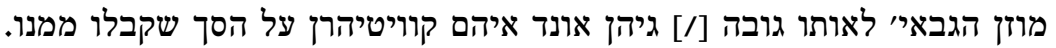

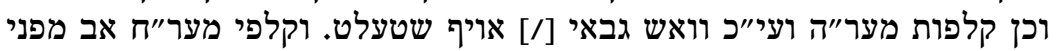

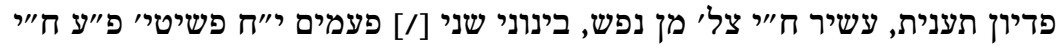

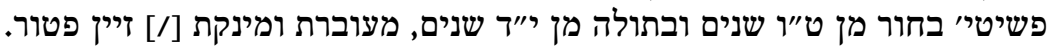

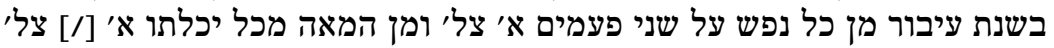

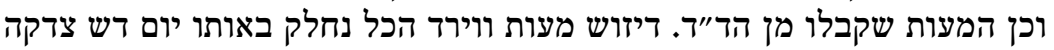

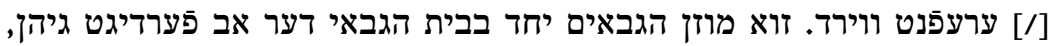

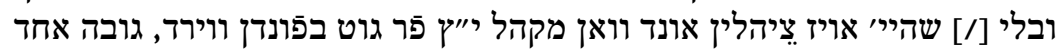

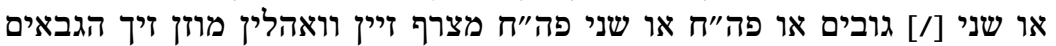

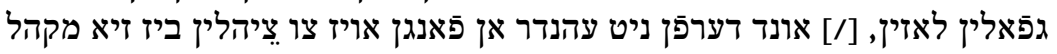

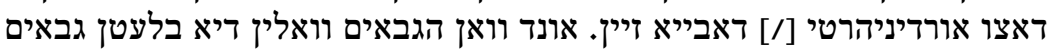

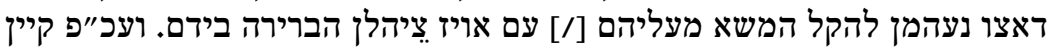

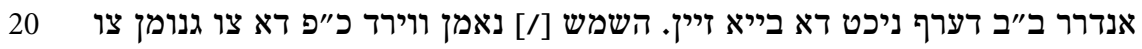

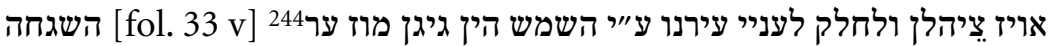

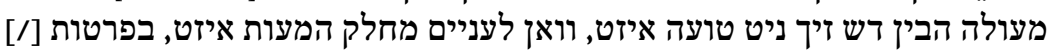

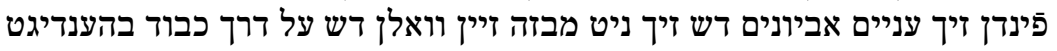

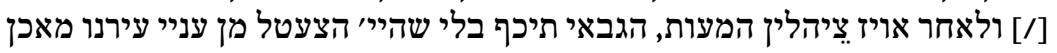

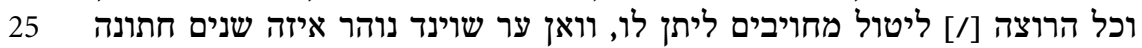

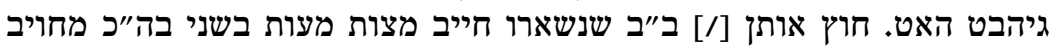

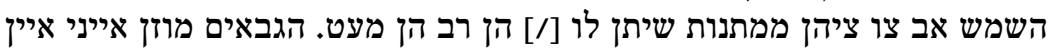

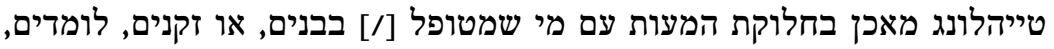

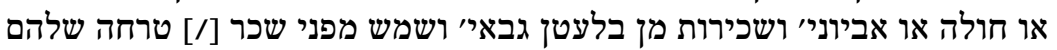

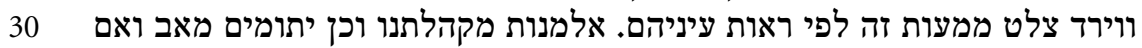

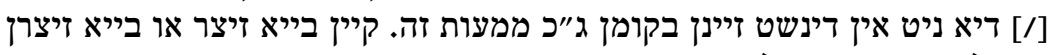

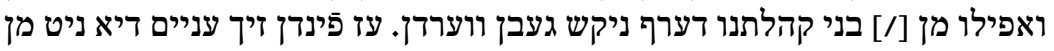

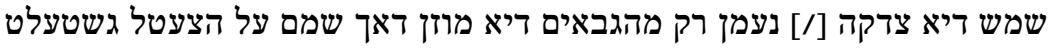

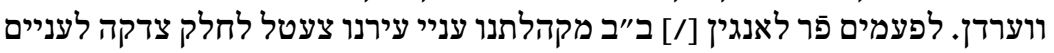

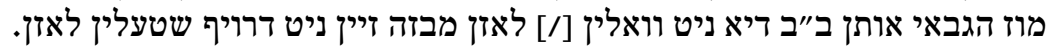

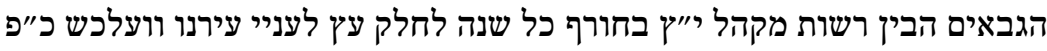

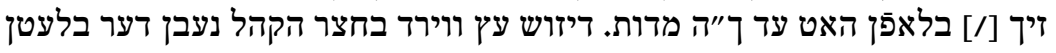




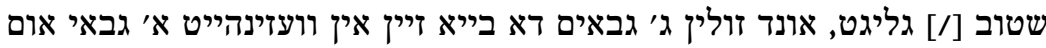

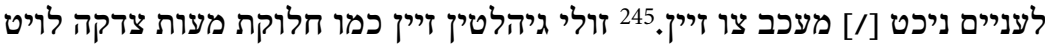

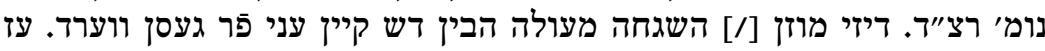

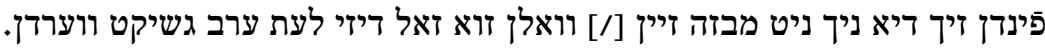

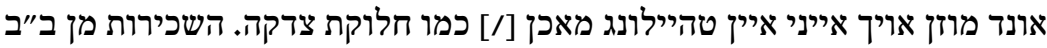

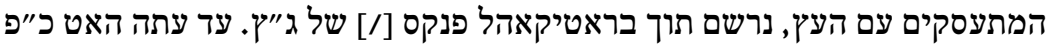

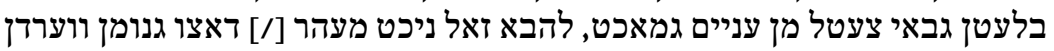

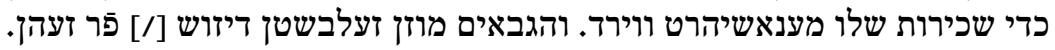

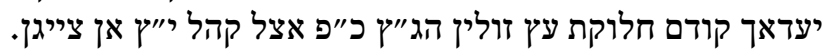

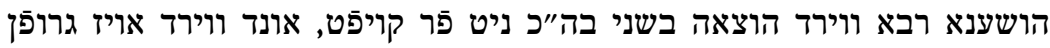

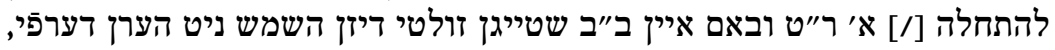

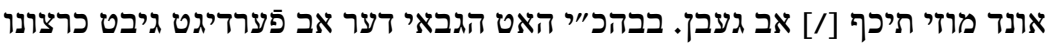

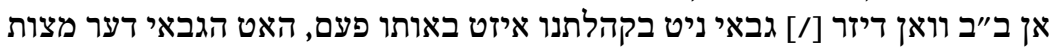

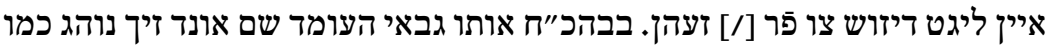

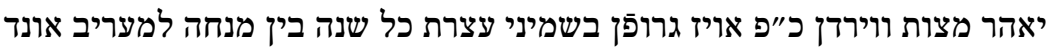
רצ"ז

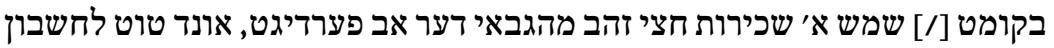

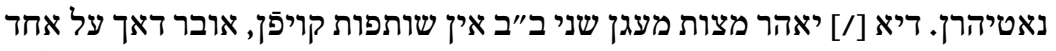

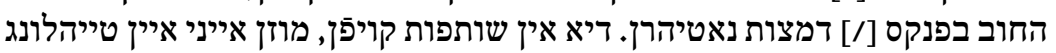

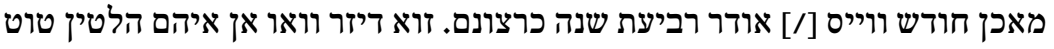

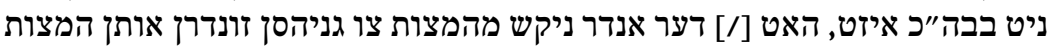

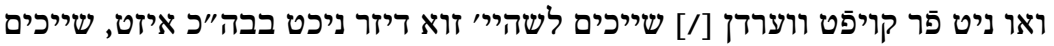

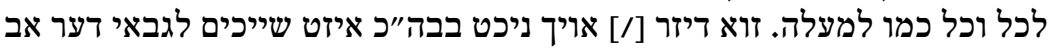

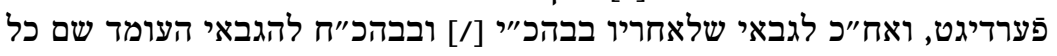

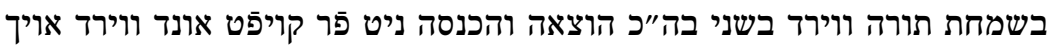

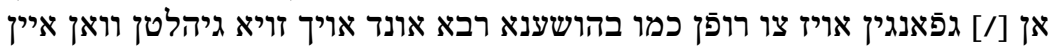

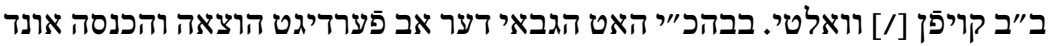

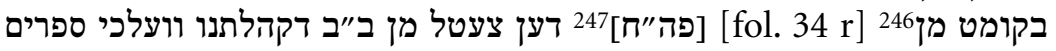

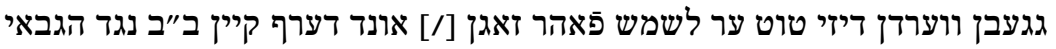

245 Dieser zweite Teil des Satzes ist etwas unklar. Offenbar ist gemeint, dass drei gabba ' $\mathrm{im}$ anwesend sein sollen, um selbst bei Abwesenheit von einem von ihnen die Holzverteilung zu garantieren.

246 Danach die Kustode פה"ח.

247 Dieses Wort wurde vom Schreiber am Beginn dieser Seite vergessen. Aus der vorausgehenden Kustode sowie aus dem Kontext ist jedoch ersichtlich, dass es hier hätte stehen müssen. 
ניקש רידין על זאת. וכאשר לא נקוה גשעהן זולטי [/] אזי מחויב קהל י"יקיץ לקנוס

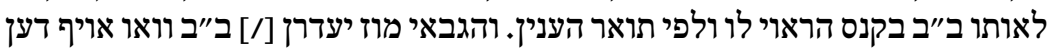

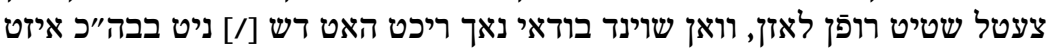

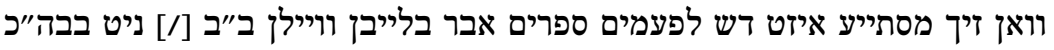

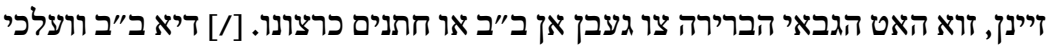

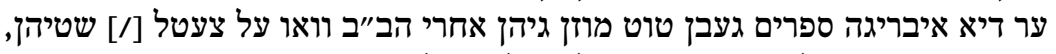

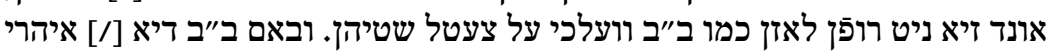

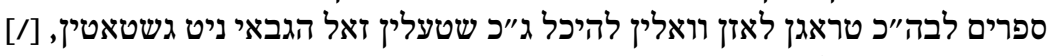

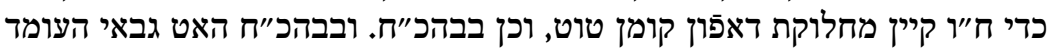

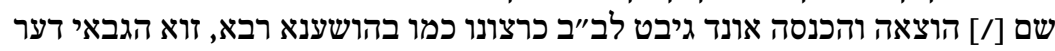

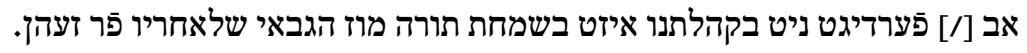

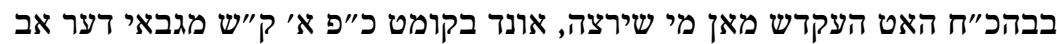
רצ"ט

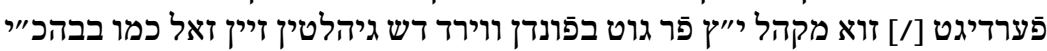

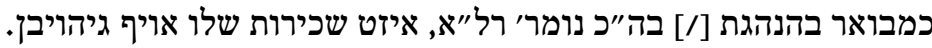

כל ער"ח מוזן השמש דגבאים לפני בית עלמין שטיהן דש קייני ב"ב או נשים 15

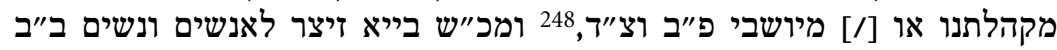

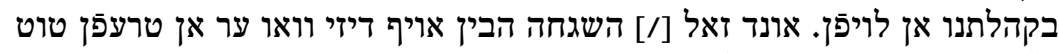
ולהגבאי אן צו זאגן כדי להענישם כראוי.

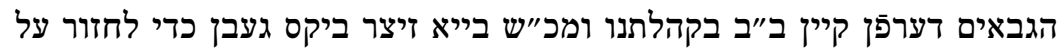
ש"א

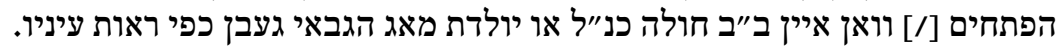

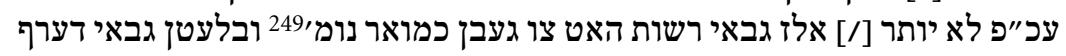

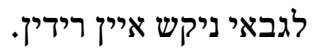

איין אורח שיש לו כלה בריב250 היינו מהרבניי שוואבך,251 פייארש דארף,252 ש״"ב

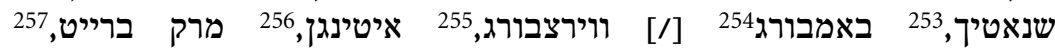

248 Zirndorf, südlich unweit von Fürth gelegen.

249 Die Angabe der Paragraphennummer fehlt.

250 Eine Bestätigung durch den Rabbiner, dass der Überbringer bald eine Tochter verheiraten wird, jedoch ohne Mittel für die Mitgift ist, weshalb ihm das Sammeln von Spenden gestattet wird.

251 Schwabach.

252 Baiersdorf.

253 Schnaittach.

254 Bamberg.

255 Würzburg.

256 Oettingen in Bayern.

257 Marktbreit. 


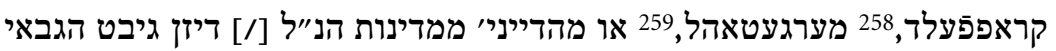

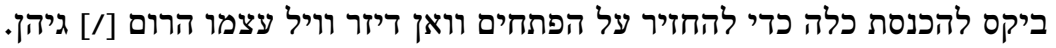

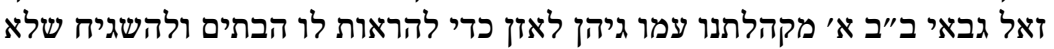

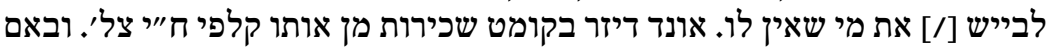

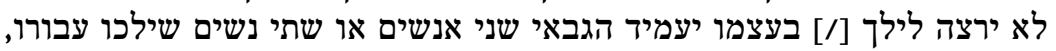

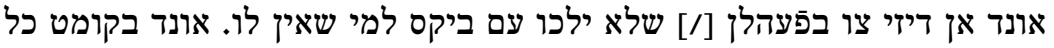

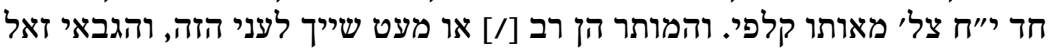

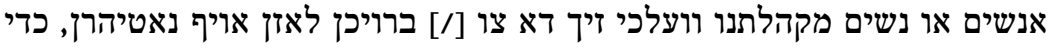

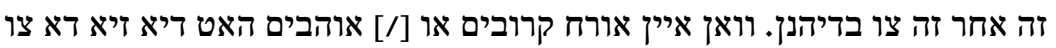

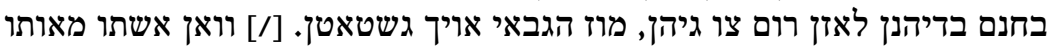

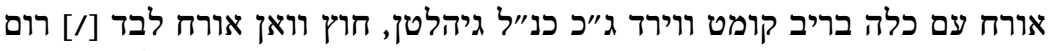

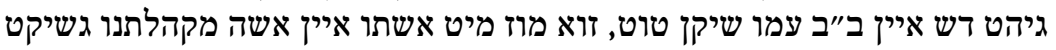

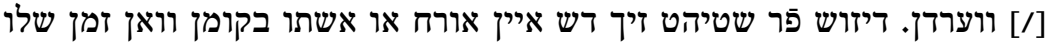

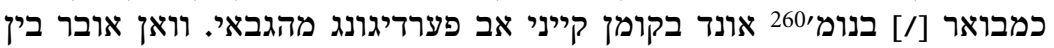

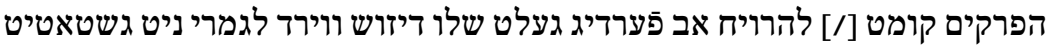

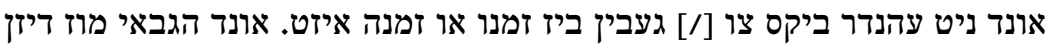

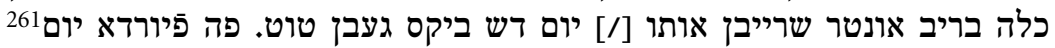

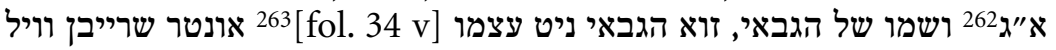

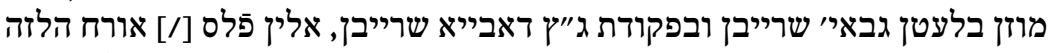

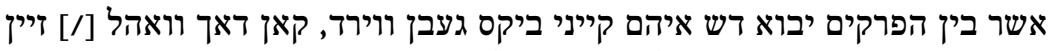

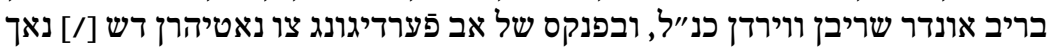

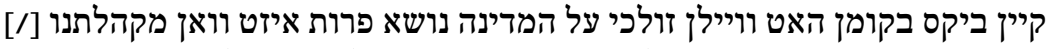

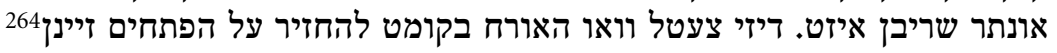

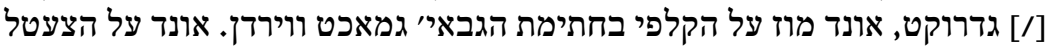

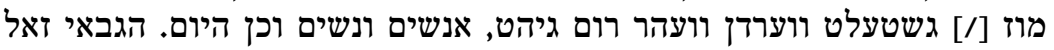

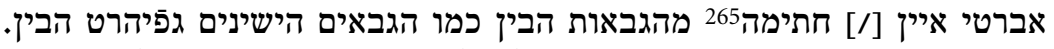

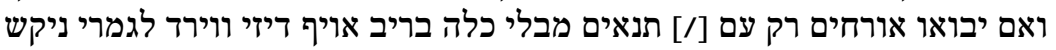

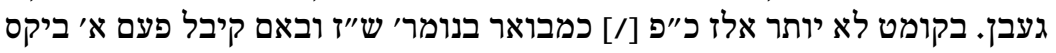

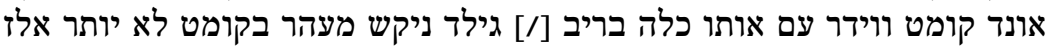

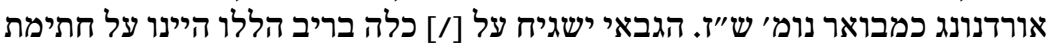

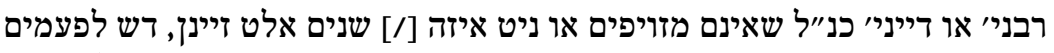

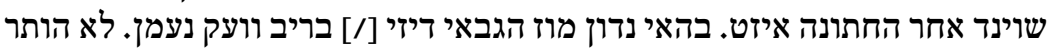

\footnotetext{
258 Grabfeld.

259 Mergentheim, in hebräischen Schriftstücken der Zeit immer »Mergental« genannt.

260 Die Angabe der Paragraphennummer fehlt.

261 Danach eine Lücke.

262 Auflösung unklar.

263 Danach die Kustode אונטר.

264 Danach ג als Zeilenfüller.

265 Siegel.
} 


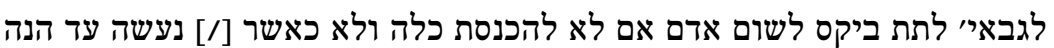

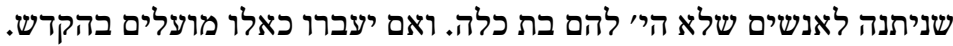

וואן אורחים עם בריב קומן וועלכי ניט מהרבני' הנ״"ל גשריבן זיינן דיזי ווערדן ש"ש

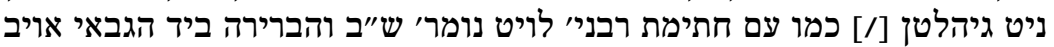

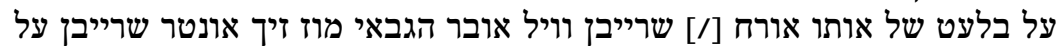

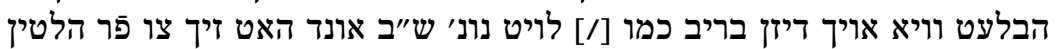

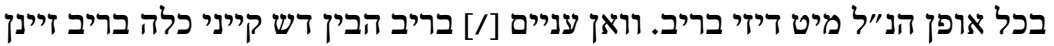

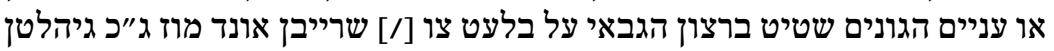
זיין כמבואר נומ' הנ"ל וכן על בריב שלהם צו אונים על צונטר שרייבן.

וואן גבאי דער אב פערדיגט אינו בביתו אונד פינדן זיך אורחים שיחים עם שיח בריב מוזן ש"ש

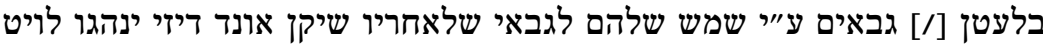

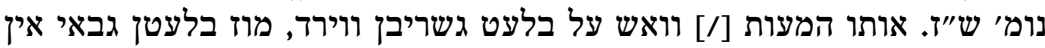

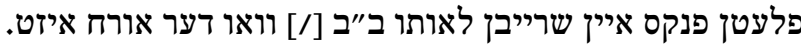

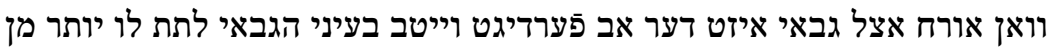
ש"ה

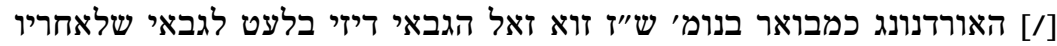

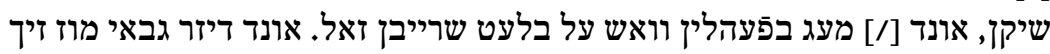
ג״כ אונטר שרייבן [/] כמבואר בנומ'.266

האורחים איזט פَר בוטן להחזיר על הפתחים וואו רויף ג' ב״״יב מקהלתנו גשטעלט

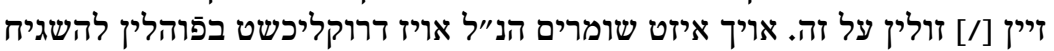

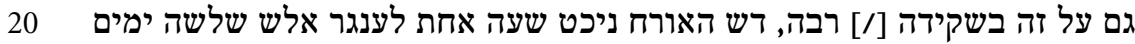

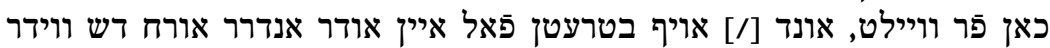

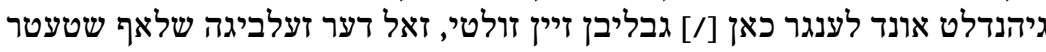

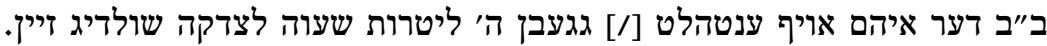

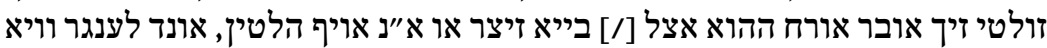

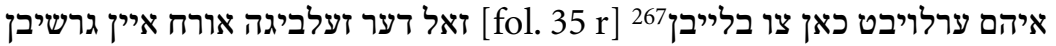

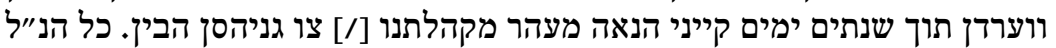

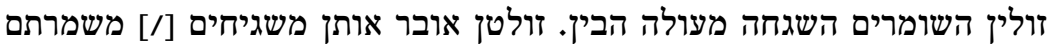

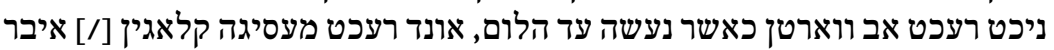

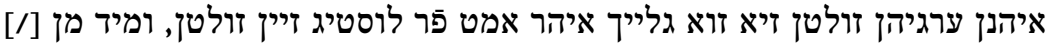

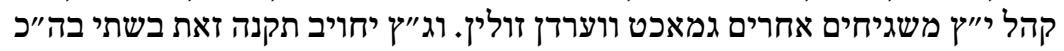

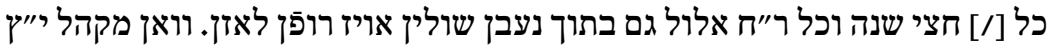

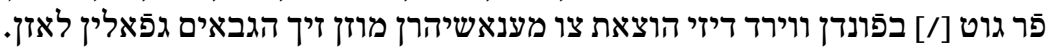

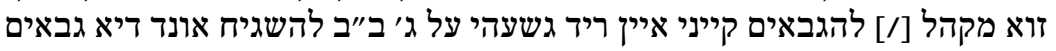

266 Die Paragraphennummer fehlt und der dafür vorgesehene Platz vor dem Punkt blieb frei.

267 Danach die Kustode זאל. 


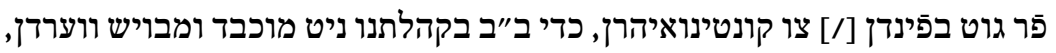

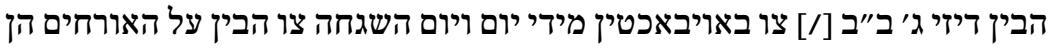

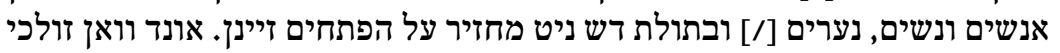

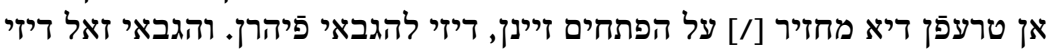

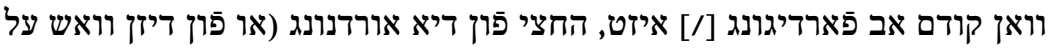

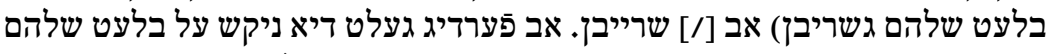

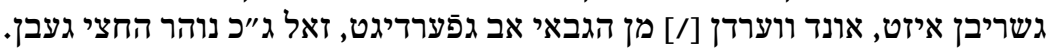

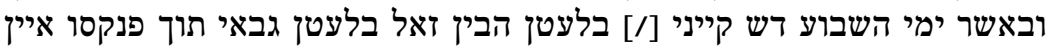

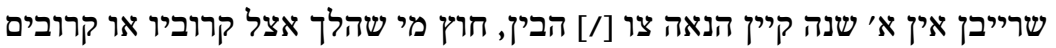

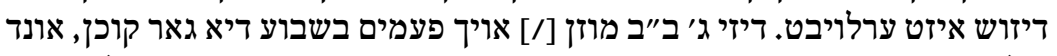

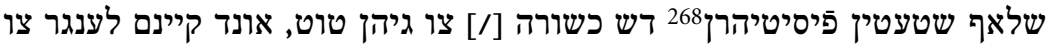

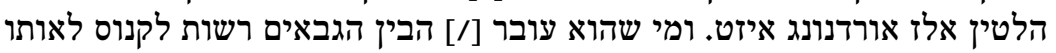

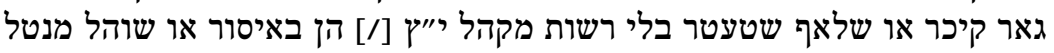

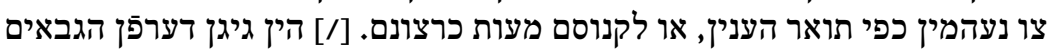

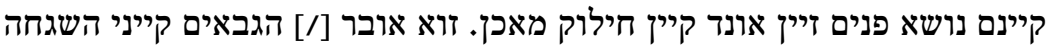

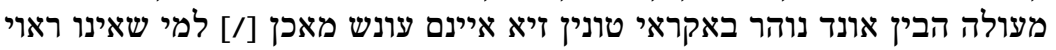

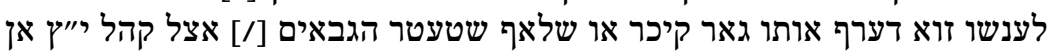
קלאגן, וקהל י"ץ מוז לערף אותו גבאר קיכר פָר נעמל דריבר.

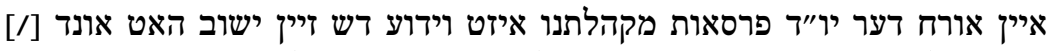
ש"ש

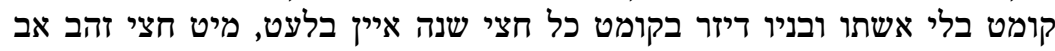

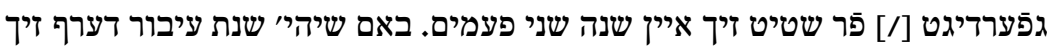

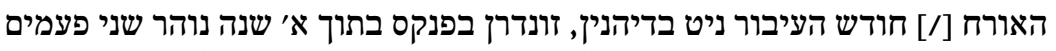

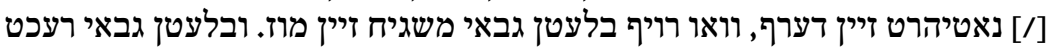

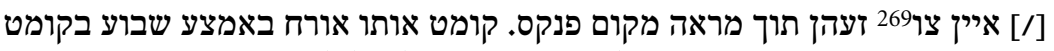

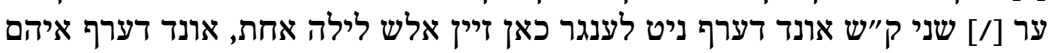

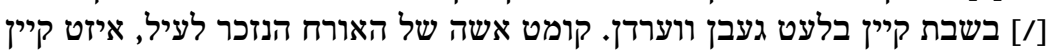

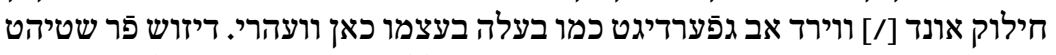

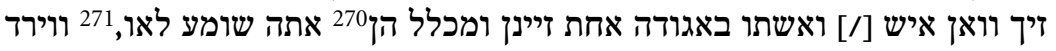

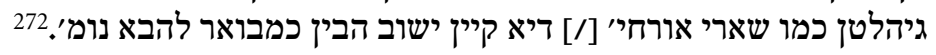

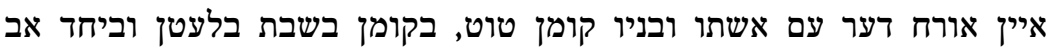

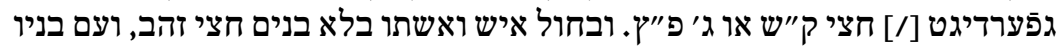

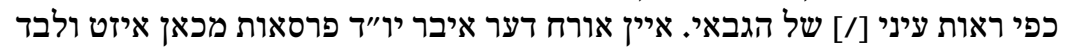

268 Visitieren, inspizieren.

269 Dieses Wort zwei Mal.

270 Dises Wort über der Zeile ergänzt, darunter gestrichen: לאו. Nach Nedarim 11b.

271 Dieses Wort über der Zeile ergänzt, darunter gestrichen: האר.

272 Die Paragraphennummer fehlt und der dafür vorgesehene Platz vor dem Punkt blieb frei. 


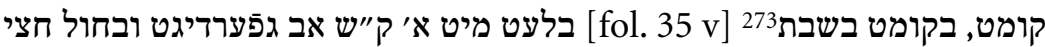

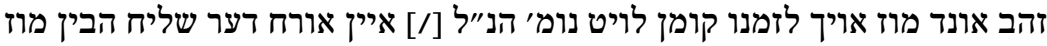

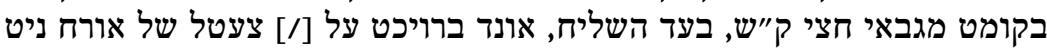

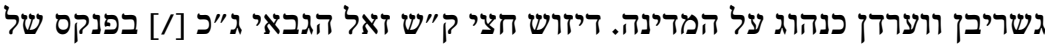

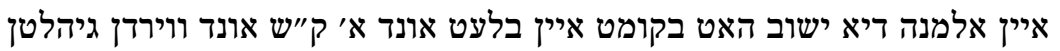
ש"ט

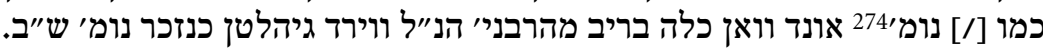

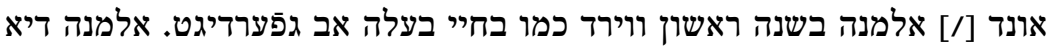

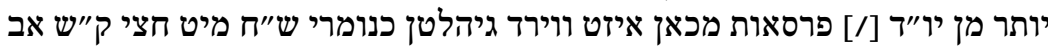

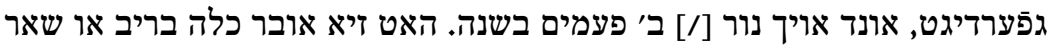

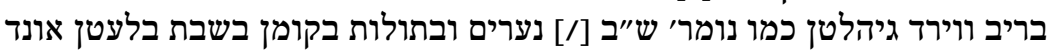

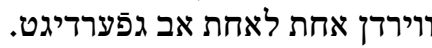

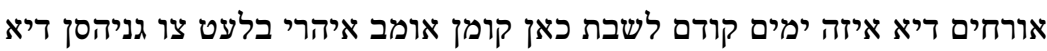

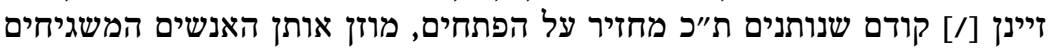

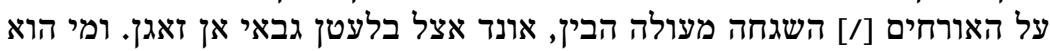

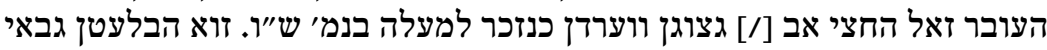

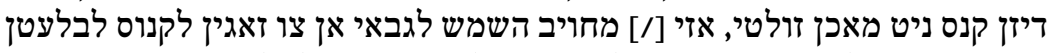

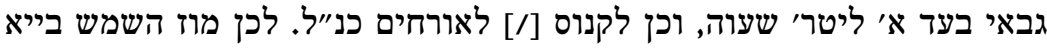

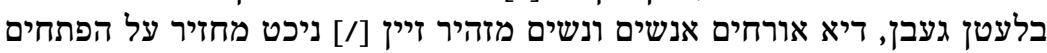

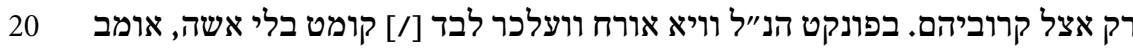

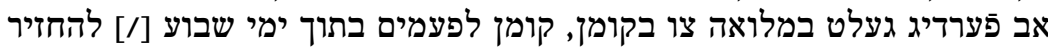

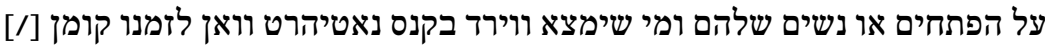

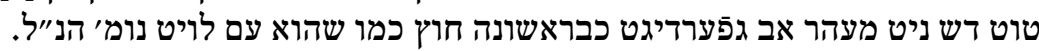

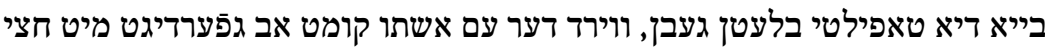
שי"

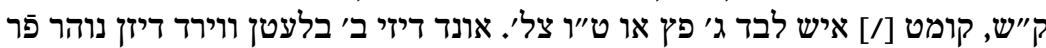

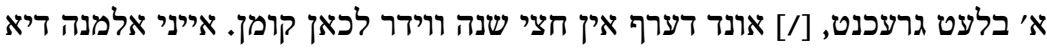

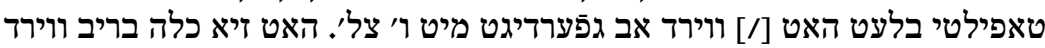

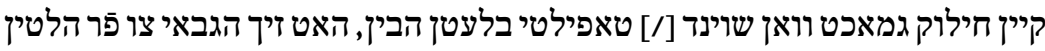

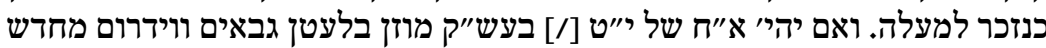

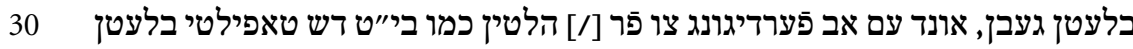

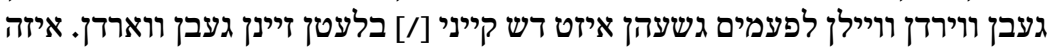

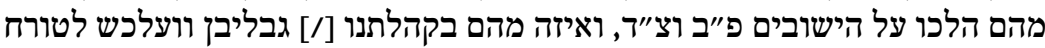

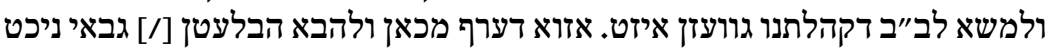

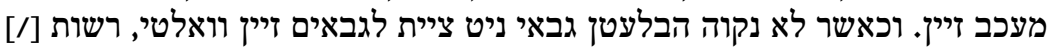
ביד הגבאים לקנוס לו בלי רשות מקהל י"יץ כפי רפי רצונם.

273 Danach die Kustode בלעט.

274 Die Paragraphennummer fehlt. 
עז מוזן להבא אלי דיא זעלביגה בלעטן וואו מיט האורחים ע"ח הקהל אי אי גדי גדונגן שי"ב

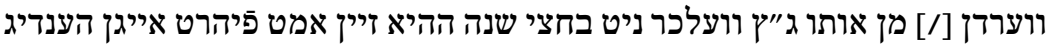

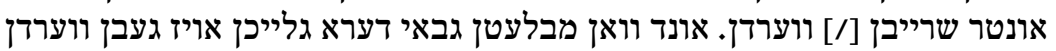

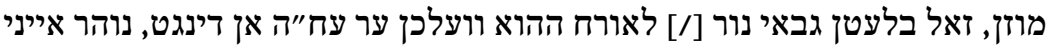

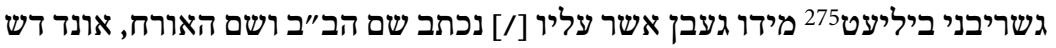

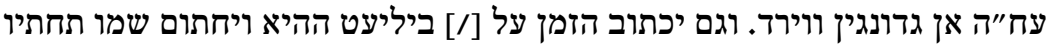

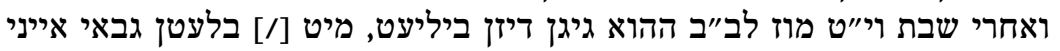

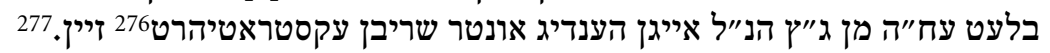

דיא זעלביגה בלעטן אובר דיא לפעמים לב"ב עח"ה גשיקט ווערן וויילן איהר

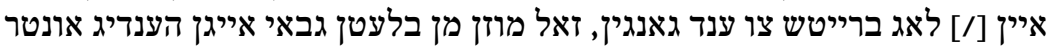
שריבן ווערדן.

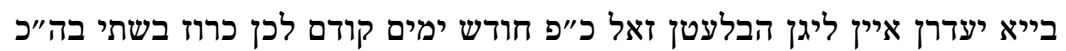

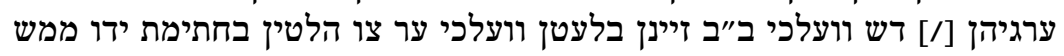

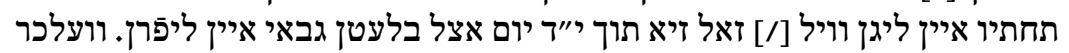

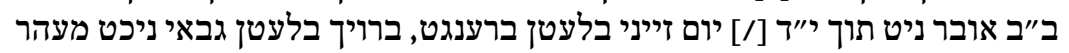
ממנו צו נעהמן, זונדרן [/] זעלבשר ניום זייני בלעטן איין ליגן.

שי"ד 15

בחור שבא לכאן הן ללמוד כאן או ליסע לקהלה אחרת וכן שהיי לומד כאן, אונד ש"ט

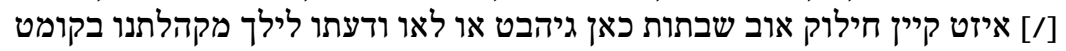

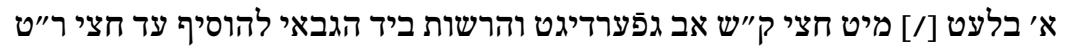

הגאב"ד נר"ו האט בחורים וועלכי מידי שבת בשבתו ד' דאפ̄ון בלעטן מוז געבן ש"ט

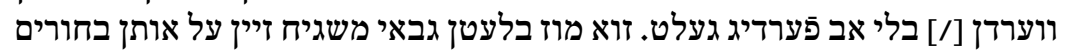
מיט גוטי בלעטן [/] בלי אב בערוגורגן כדי מן ב"ב אוא מוז בליינטי מתנה צו גניהסן.

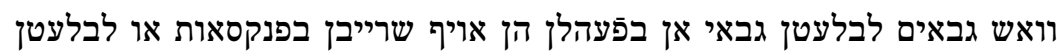

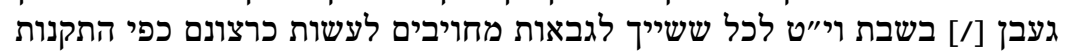

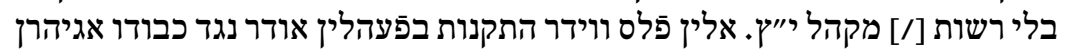

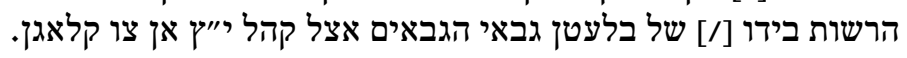

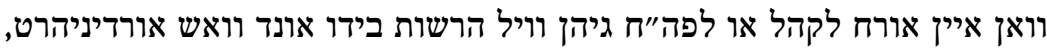
שיח"ח

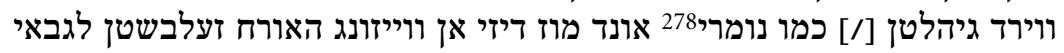
30

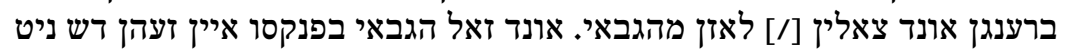

275 Billet.

276 Gestrichen.

277 Danach die Kustode דיא.

278 Die Paragraphennummer fehlt. 


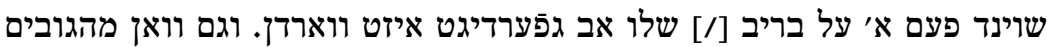

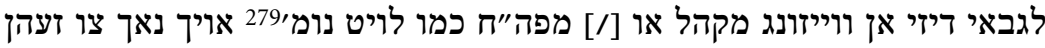

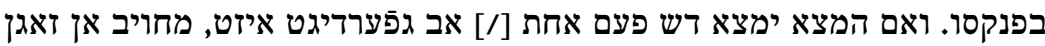

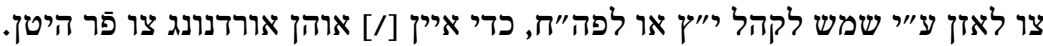

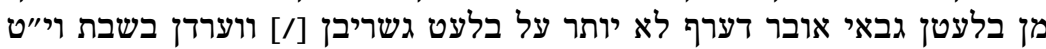

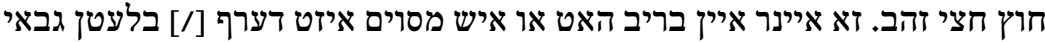

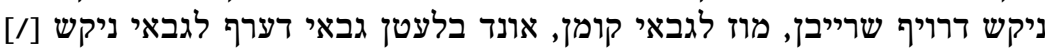

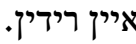

אלי בלעטן וואש דרויף אב גפּערדיגט איזט הן עיוי גבאי עצמו או עיוי בלעטן

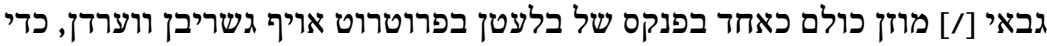

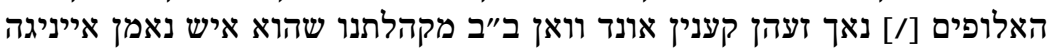

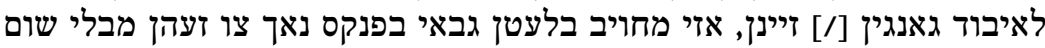

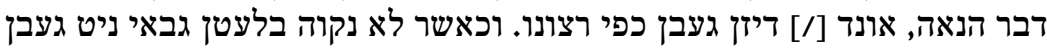

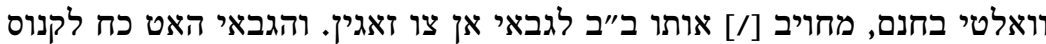

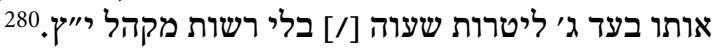

בחול כל ימי השבוע חוץ ע"ש ועי"ט מחי פחויב בלעטן גבאי עם שמש הגבאי' לילך ש"

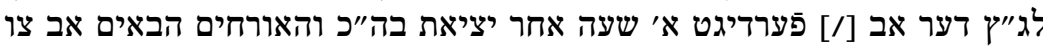

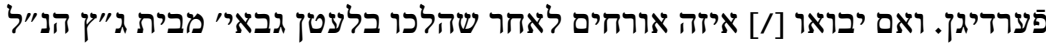

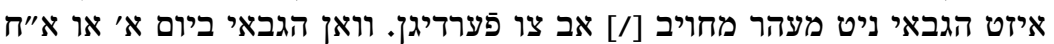

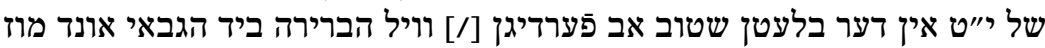
בלעטן גבאי עם הגבאי גיהן שלי

בלעטן גבאי ישגיח שלא ליתן אורח לב"ב מקהלתנו דש ער קרוע ובלוי או סגי ירוי שכ"א

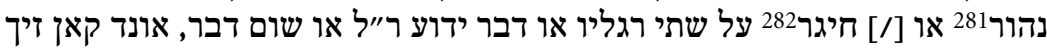

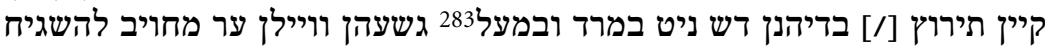

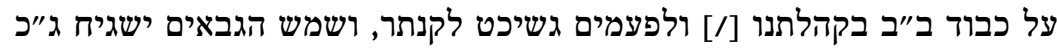

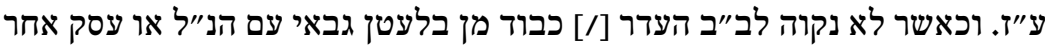

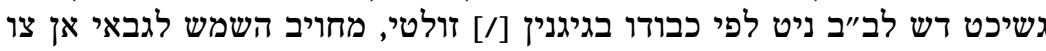

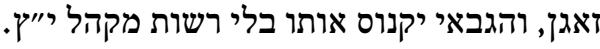

אורחים דז קיין בלעטן קאן גגעבן ווערדין, וואן אן גדונגין אצל ב״מב או אלמנות 30

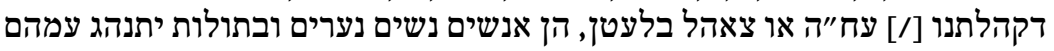

279 Die Paragraphennummer fehlt.

280 Danach die Kustode בחול.

281 Blind.

282 Lahm.

283 Nach Jos 22,22. 


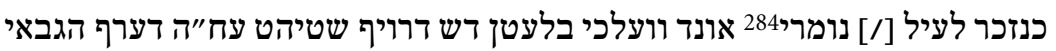

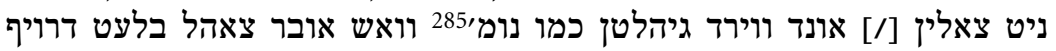

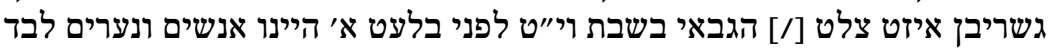

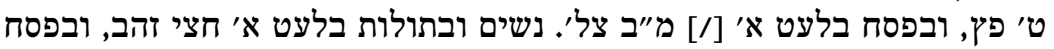

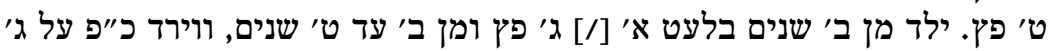

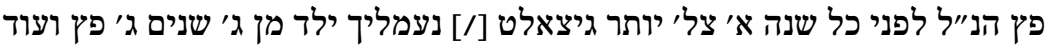

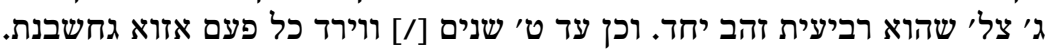

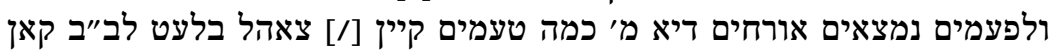

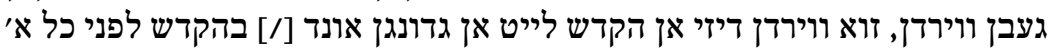

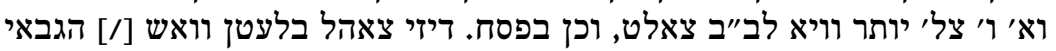

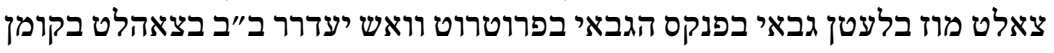
[/] - [אלט מוז באלין טראגן.

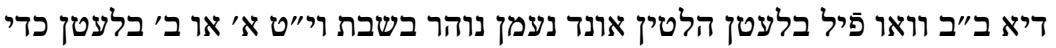

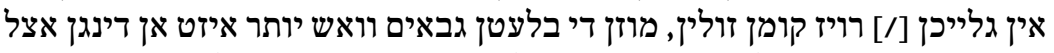

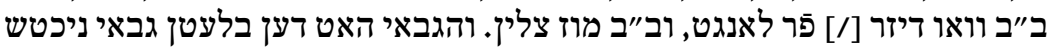

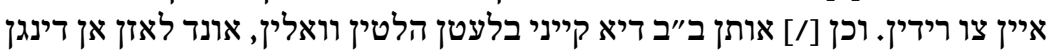

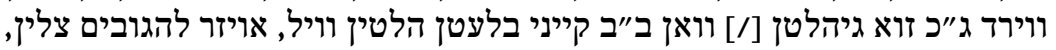
דערף ניט איין ליגן בחשבון הבלעטן.

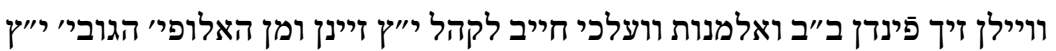

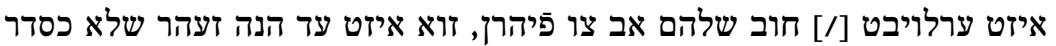
שכ"ד

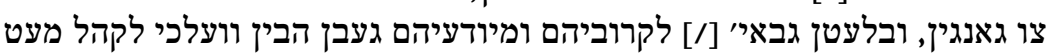

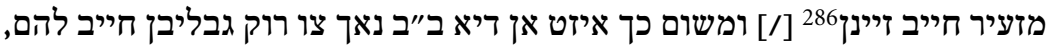

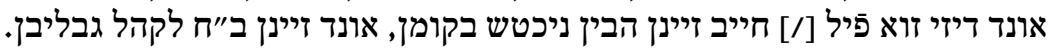

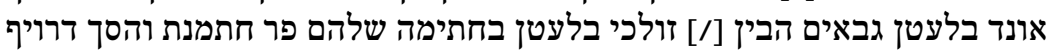

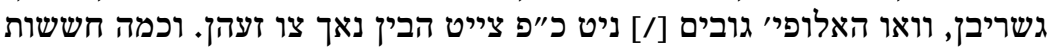
יש בדבר דש זיך כמה פעמים טועה

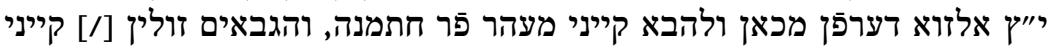

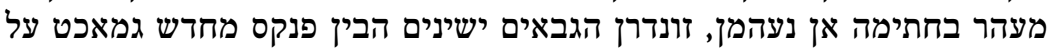

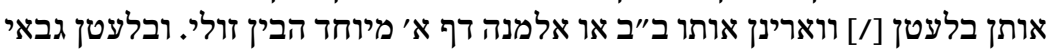

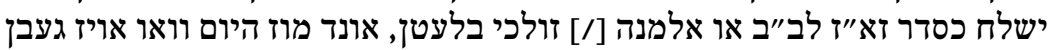

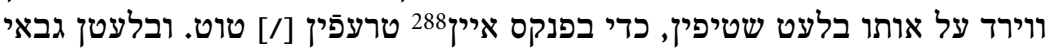

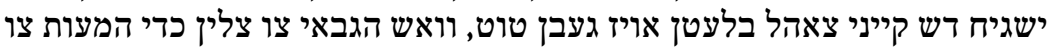

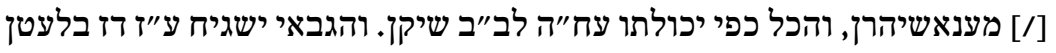

284 Die Paragraphennummer fehlt. 285 Die Paragraphennummer fehlt.

286 Danach gestrichen: הבין ניכטש בקומן.

287 Danach die Kustode זיין בקון

288 Davor gestrichen: אן. 


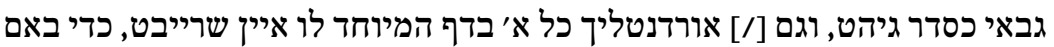

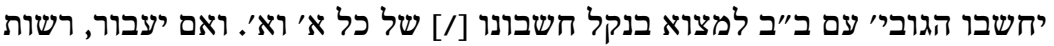

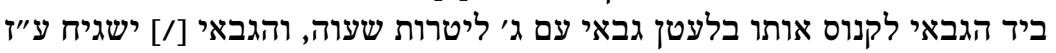

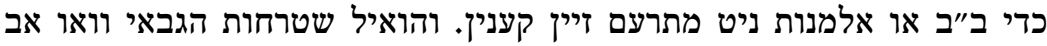

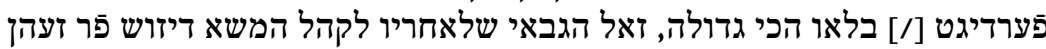

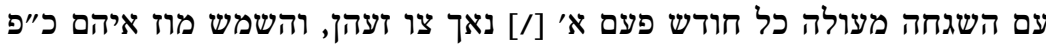

הפנקס ברענגן.

כל ע"ש וי"ט בייא בלעטן געבן זאל שמש דגבאי' דען אורח זיין בלעט ניט עהנדר

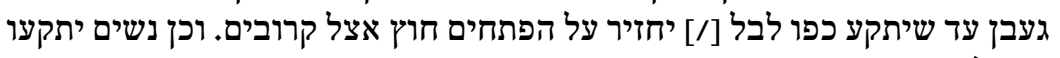

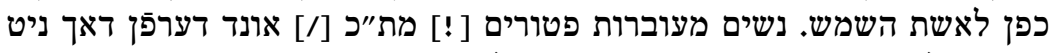

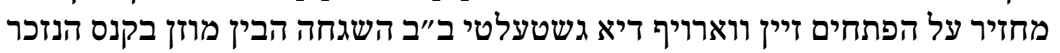

אורחים שהם מבני קהלתנו דיזי ווירדן בעסר גיהלטן עם אב פעריד פריגונונג כמו שארי שכ"ר

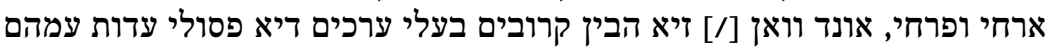

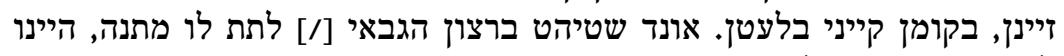

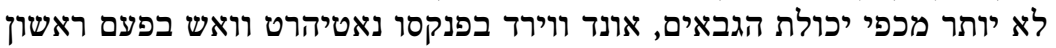

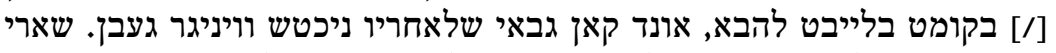

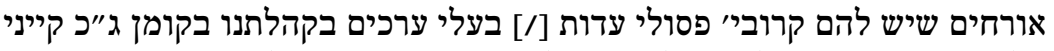

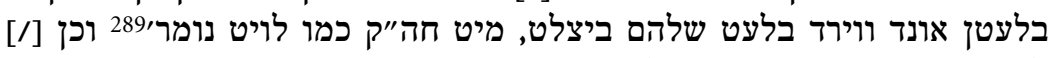

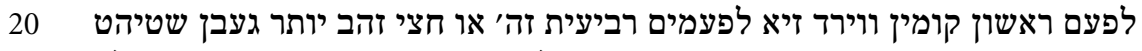

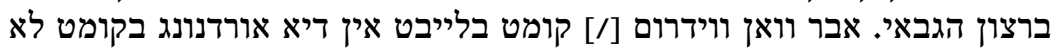
יותר כנזכר.

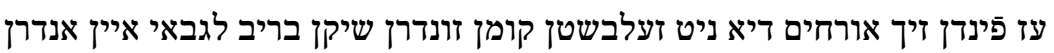

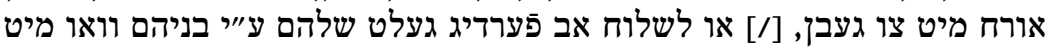
שכ"ז

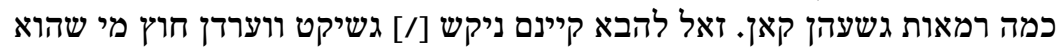

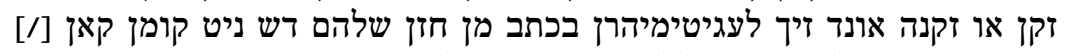

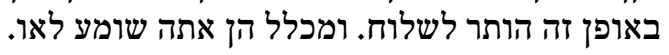

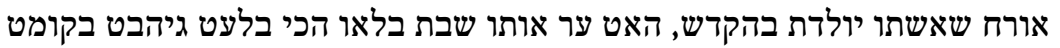
שכ"ח

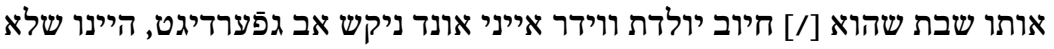

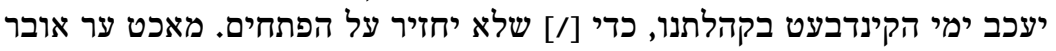

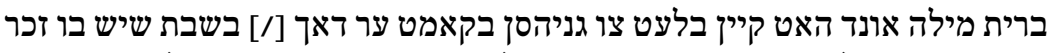

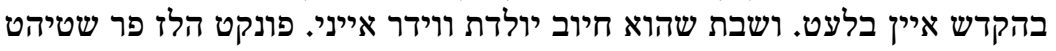

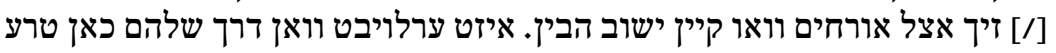

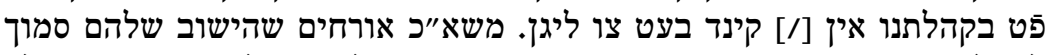

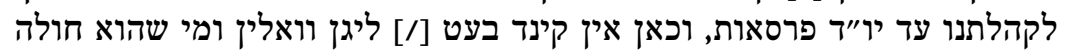

289 Die Paragraphennummer fehlt. 


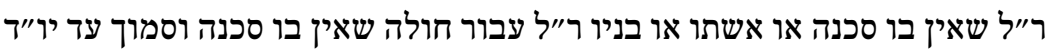

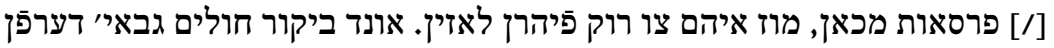

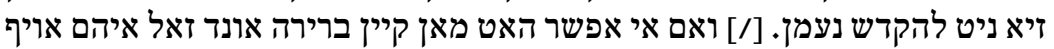

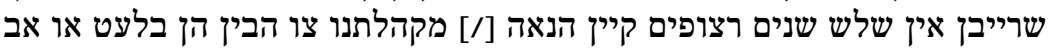

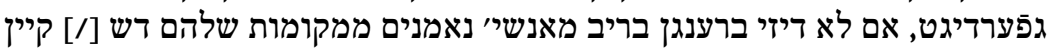

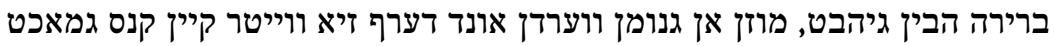
ווערדן.

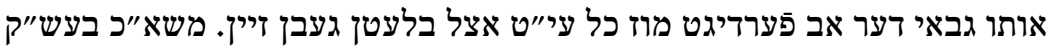

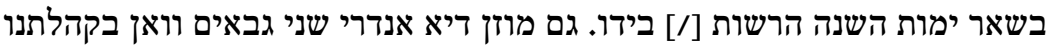

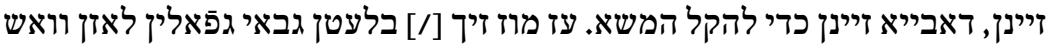

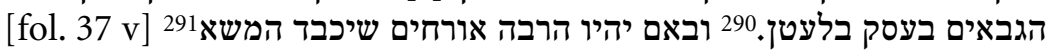

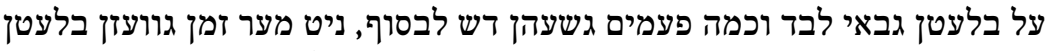

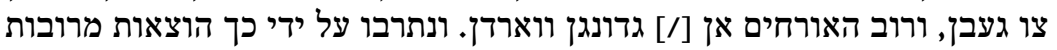

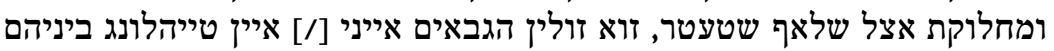

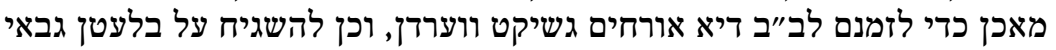
[/] דז דיזי ב"ב וועלכי עח"ב הליא הלטין כסדר געבן ווירד.

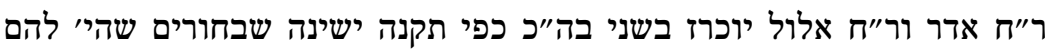

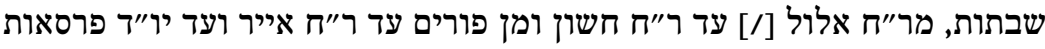

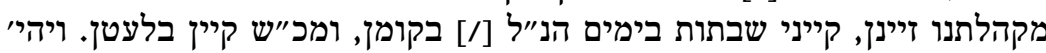

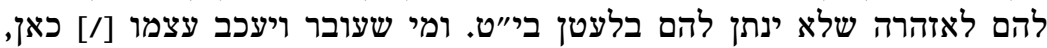

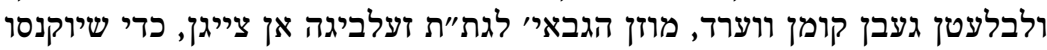

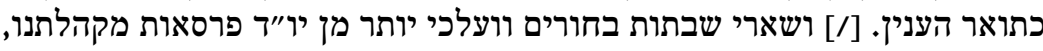

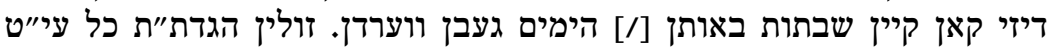

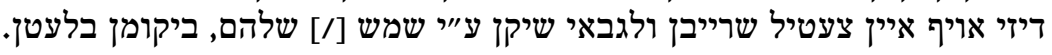

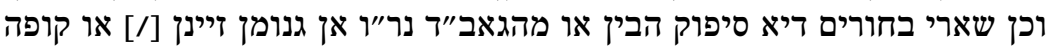

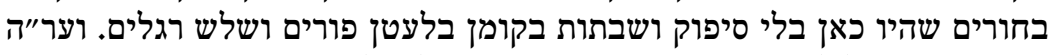

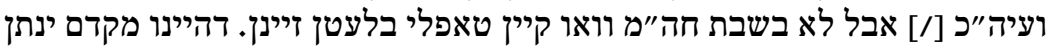

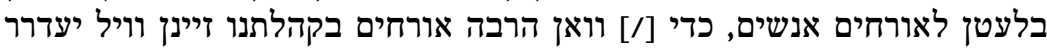

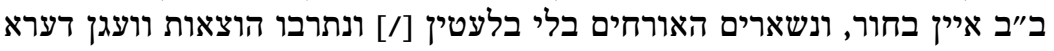

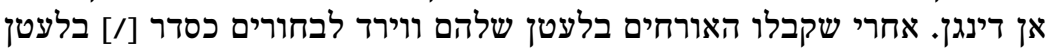

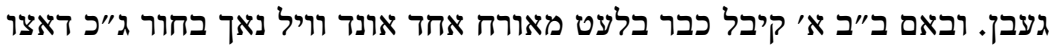

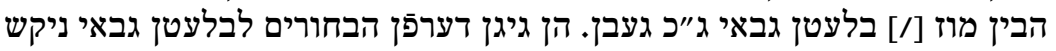

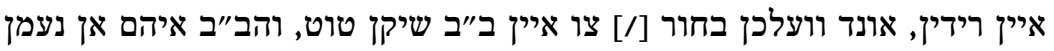

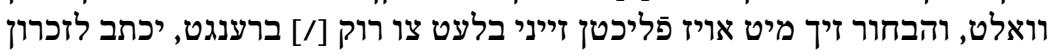

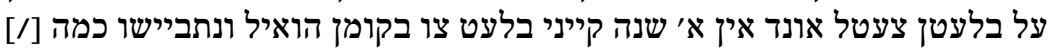

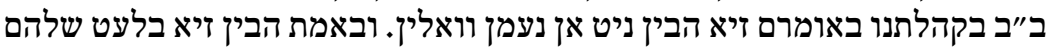

שכ"ט

290 Der Satz bleibt unvollendet.

291 Danach die Kustode על. 
גאר ניט אן געבן [/] והגבאי ישלח השמש לאותו ב"ב תוכן הדבר צו ערפאה כיטרן.

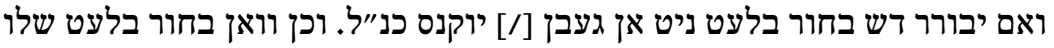

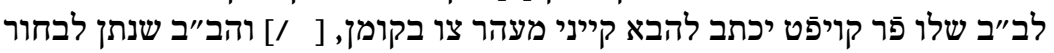
המעת דאפָאהר, מוז בלעט שלו ווידר איין גליגט להכי מער ווערדן.

בכרוז שיוכרז בבה"כ ע"י הגבאי זולי לב"ב דאבייא ער אינרץ דש וועהר קיין בלעט של

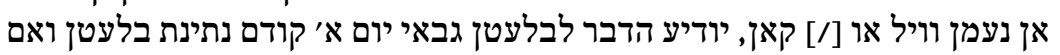

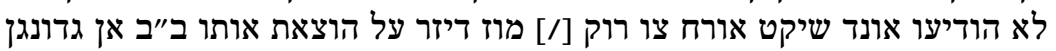

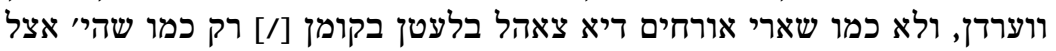

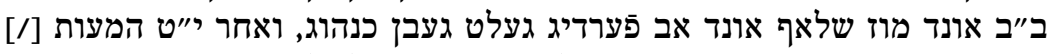

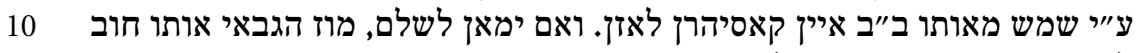

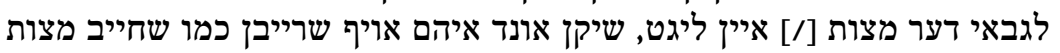

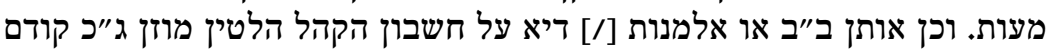

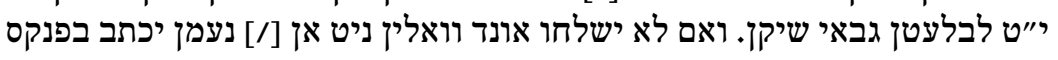
תוך א׳ שנה קייני מעהר צו שיקן.

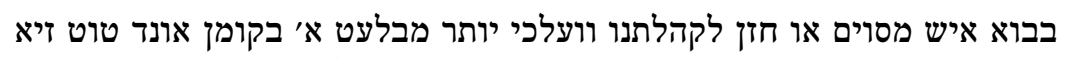
של"ב

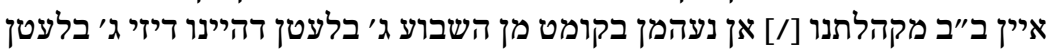

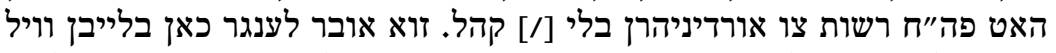

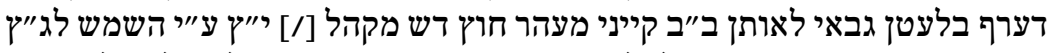

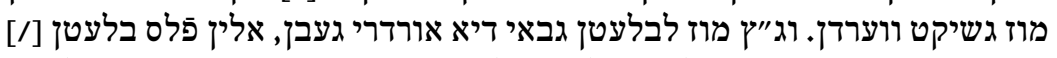

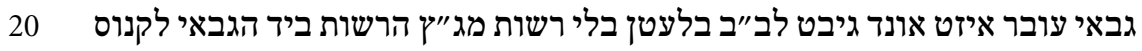

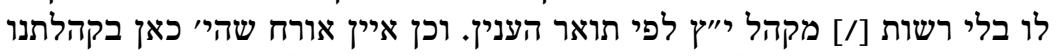

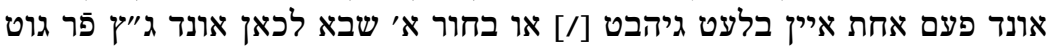

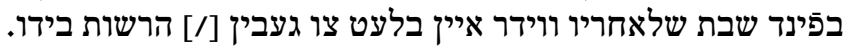

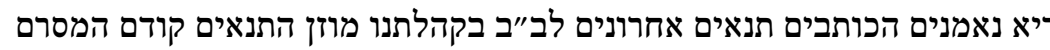
[fol. $38 \mathrm{r}$ ]

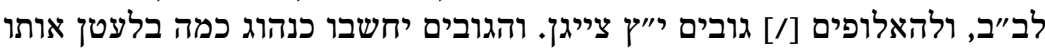

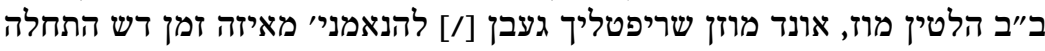

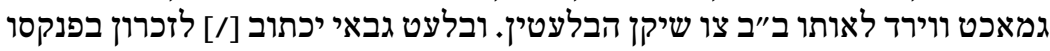

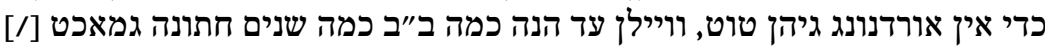

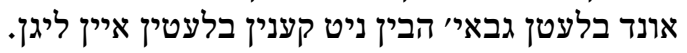

נול"נ וואן איין ראשי [!] בית נעדר ווירט מוזן הגובים לגבאי שיקן אונד דיזר מוז

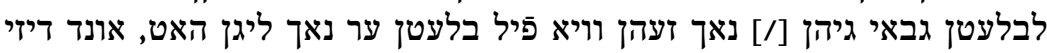

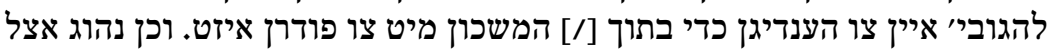
אלמנה.

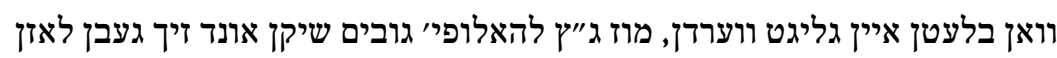

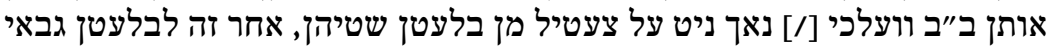

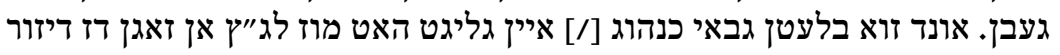

של"ד של"ה 


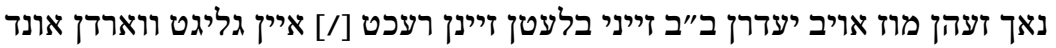

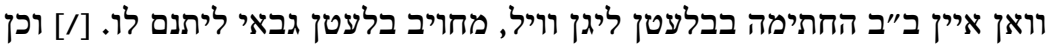

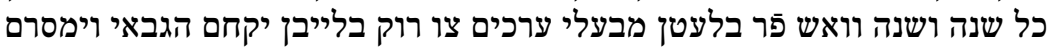

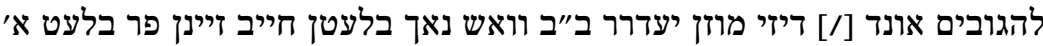

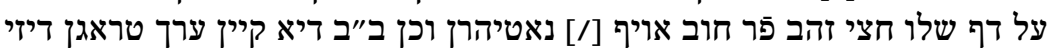

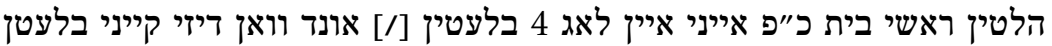

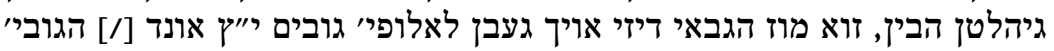

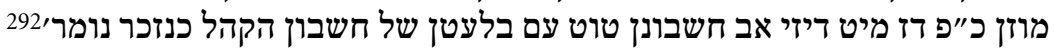

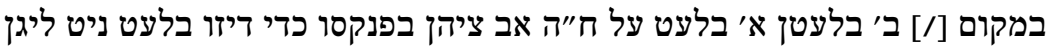
זאלין בלייבן.

ב"ח גבאים דערפן קיין אורח דער אין הקדש גלעגן ובעש"ק ועי"ט וואלן רויז גיהן

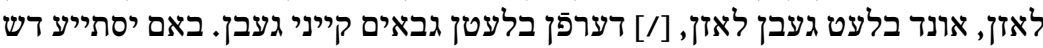

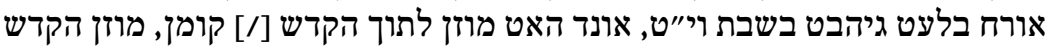

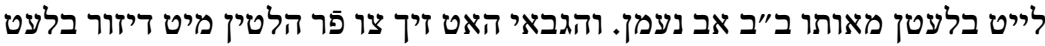

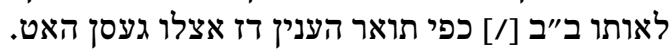

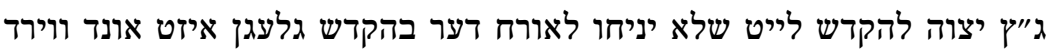
של"ז

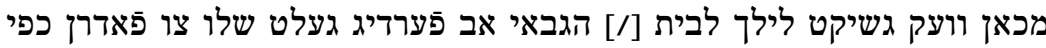

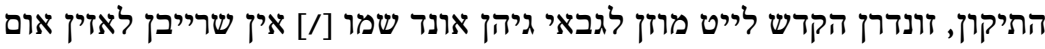
געבן כנהוג.

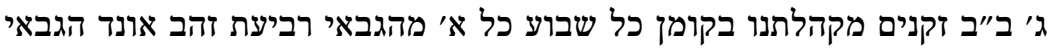
של 20

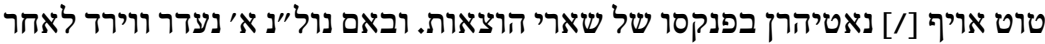

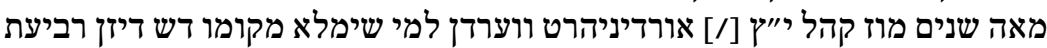

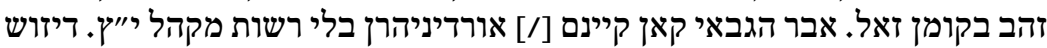
איזט ערלויבט איינם מי שראל הגבאי לאו לכך לפה"ח צו רקומנדיהרץ.

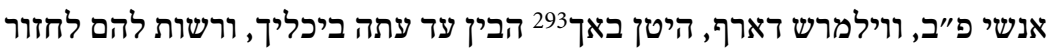
של"ט 25

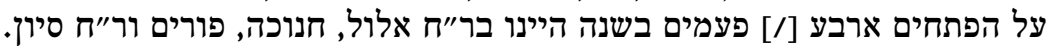

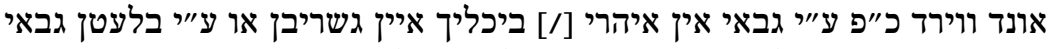

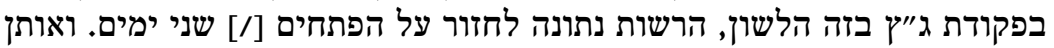

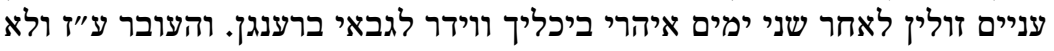

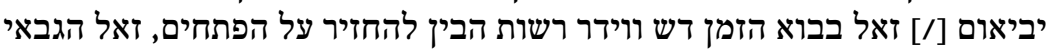

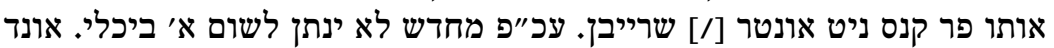

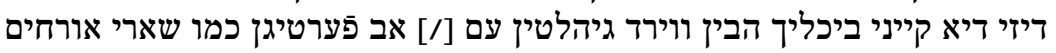

292 Die Paragraphennummer fehlt.

293 Hüttenbach, nordwestlich von Fürth gelegen, war eine der vier Gemeinden des Gemeindeverbands AShPAH, das hebräische Akronym der Gemeinden Ottensoos, Schnaittach, Forth und Hüttenbach. 


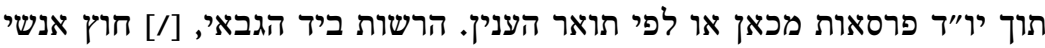

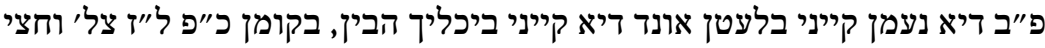

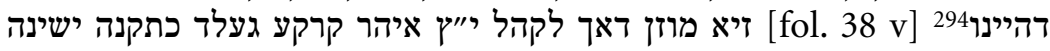
געבן.

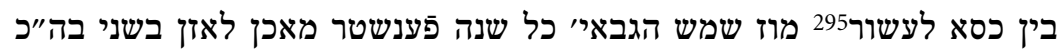
ש"מ

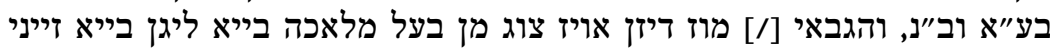

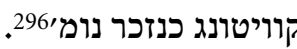

השמש של הגבאים מוז קודם פסח בזורגן קמח למצות לפני עניי' אורחי ופרחי.

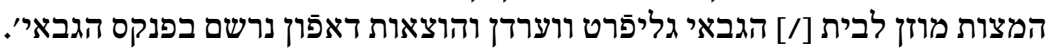

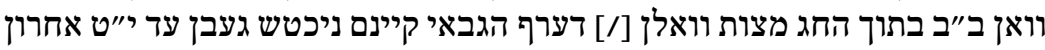

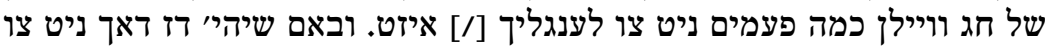

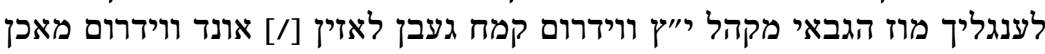

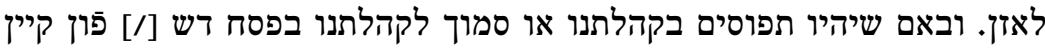

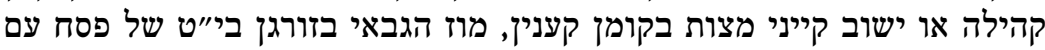
מצות [/] ודבר אכילה, ויין לארבע כוסות.

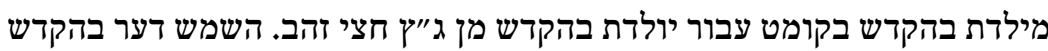

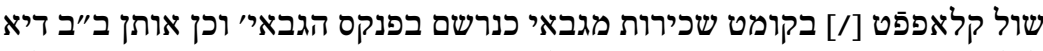

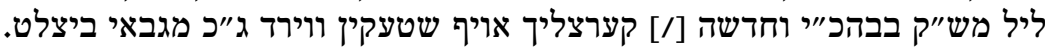

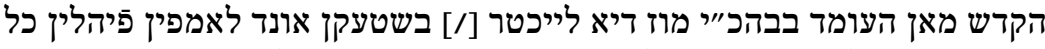

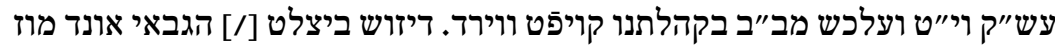

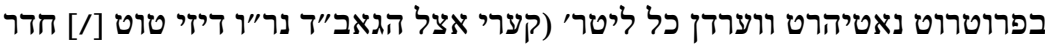

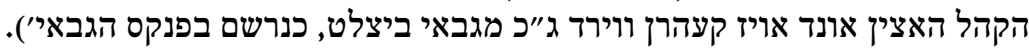

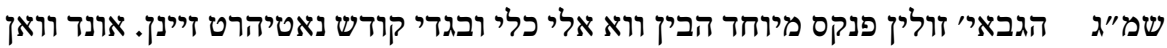

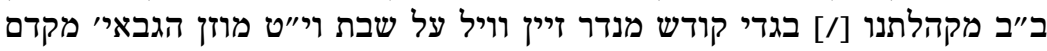

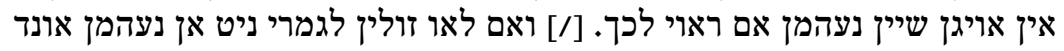

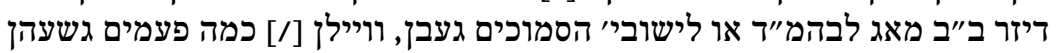

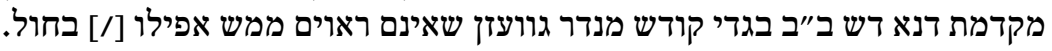

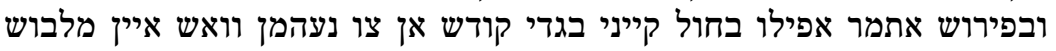
גוועזן איזט [/] כמבואר בהנהגת הגובי׳ נומי297.

294 Danach die Kustode זיא.

295 Die Tage zwischen Neujahr und dem Versöhnungstag.

296 Die Paragraphennummer fehlt.

297 Die Paragraphennummer fehlt. 
הנהגות דיינים

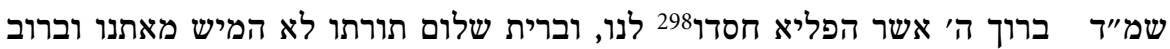

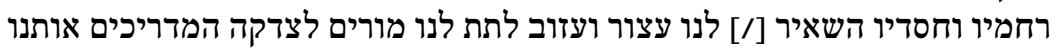

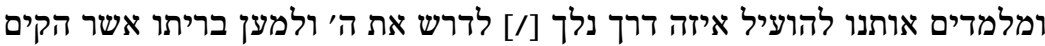

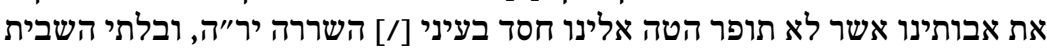

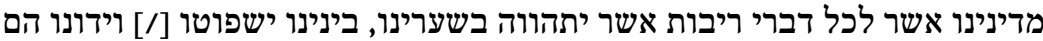

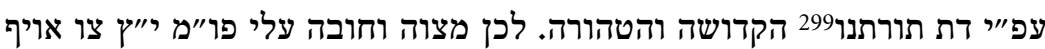

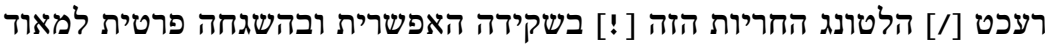

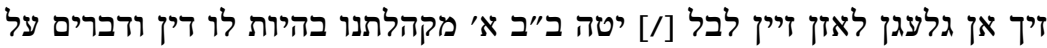

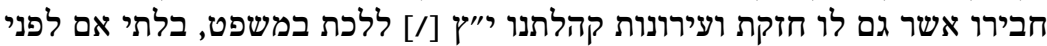

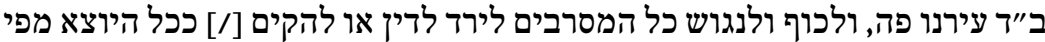
הב"ד י"ר עירנו פה. [fol.39 r]

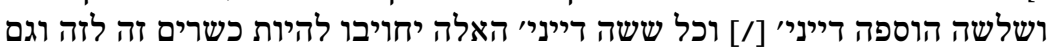

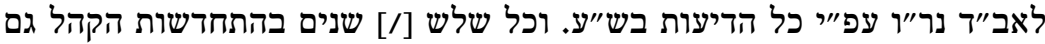

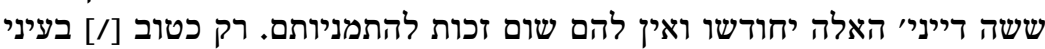

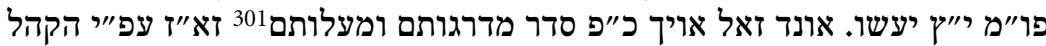

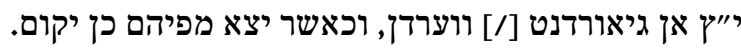

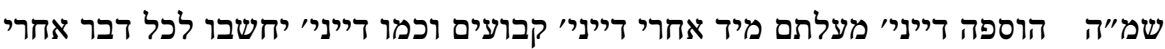

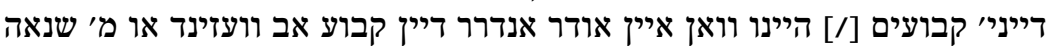

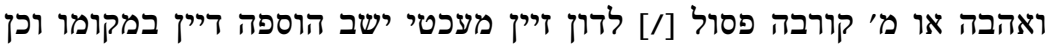

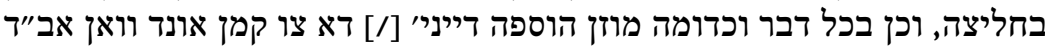

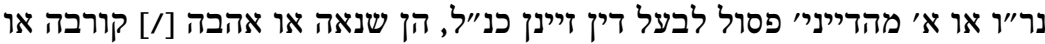

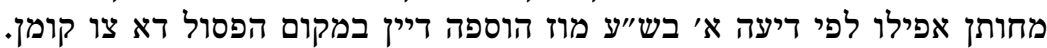

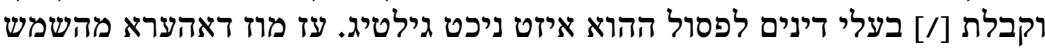

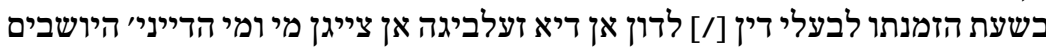

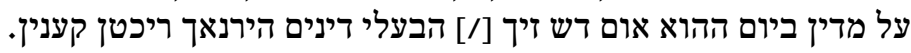

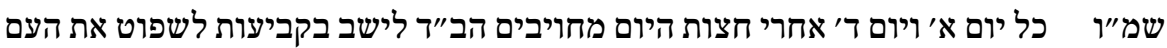

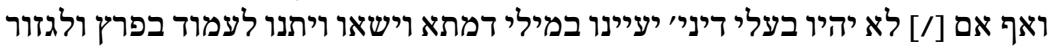

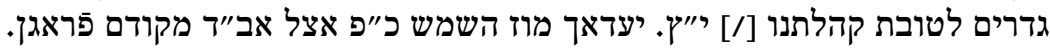

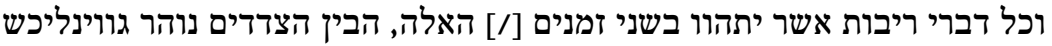

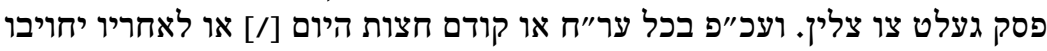

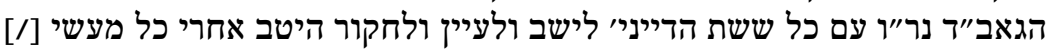

298 Ps $31,22$.

299 Die letzten beiden Wörter später blau unterstrichen.

300 Danach die Kustode ב"ד.

301 Gemeint ist die innere Hierarchie; danach waren nicht alle dayyanim (Richter) gleichgestellt. 


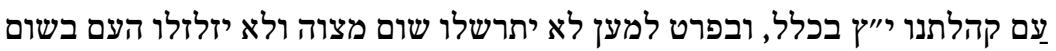

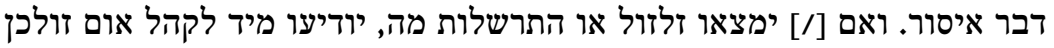

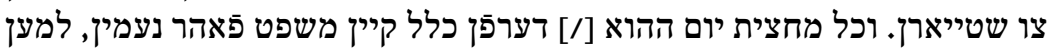

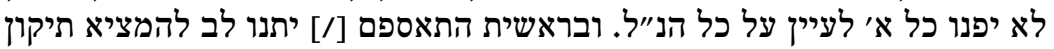

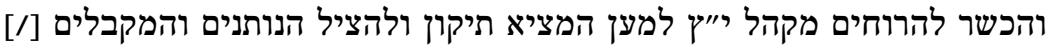
ממכשול עון רבית חמור.

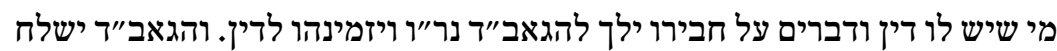

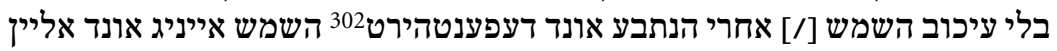

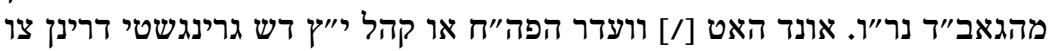

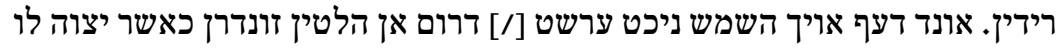
הגאב"ד נר"ו יעשה בלי עיכוב.

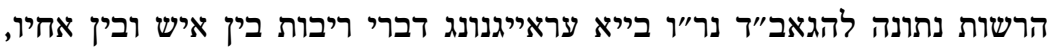

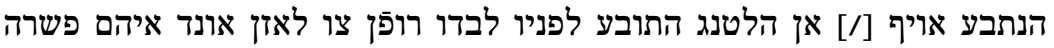

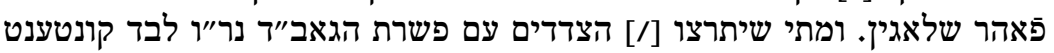

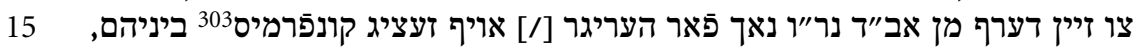

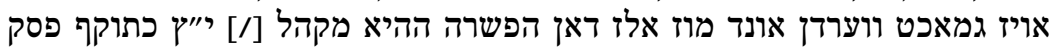

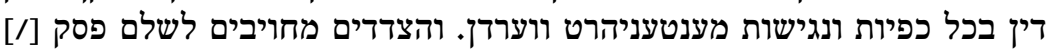

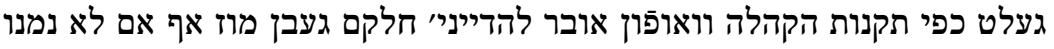

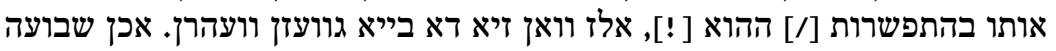

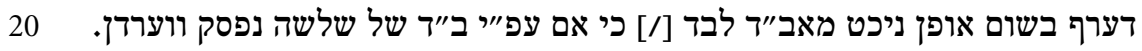

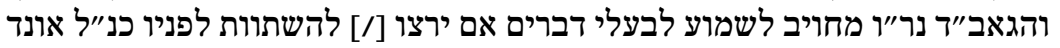

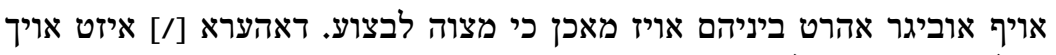

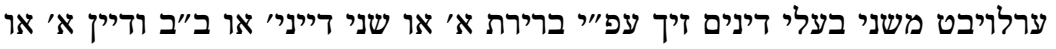

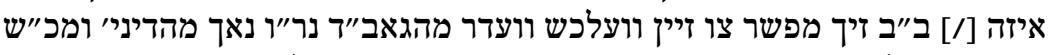

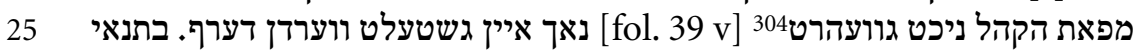

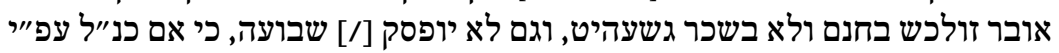

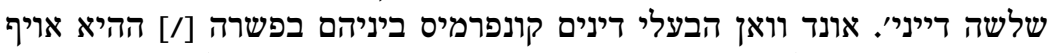

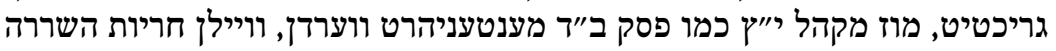

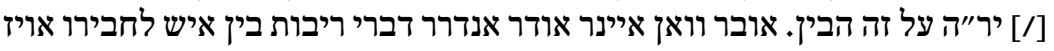

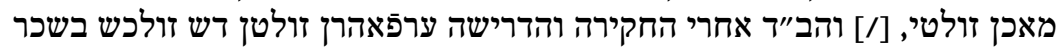

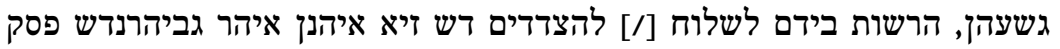

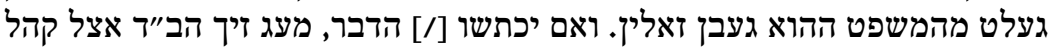

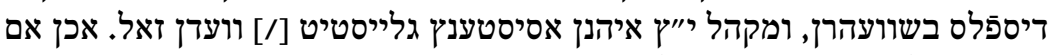

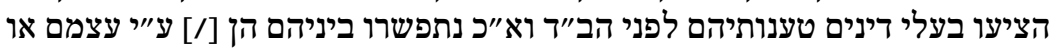

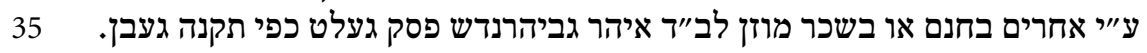

302 Von frz. dépendre $=$ unterstehen.

303 Kompromiss.

304 Danach die Kustode נאך. 


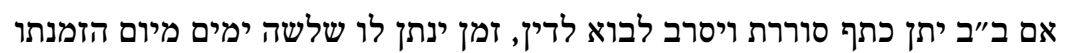

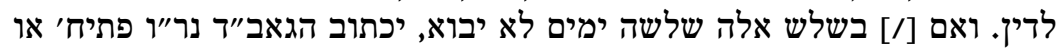

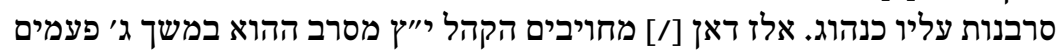

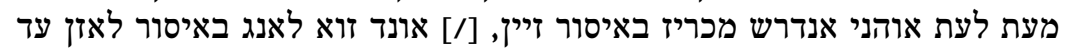

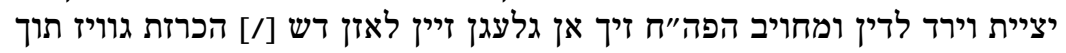

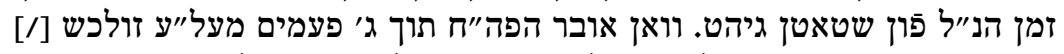

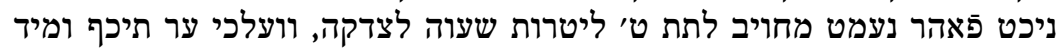

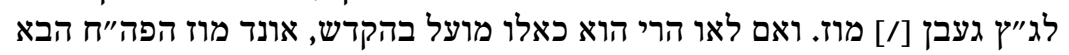

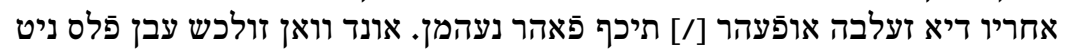

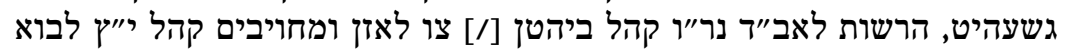

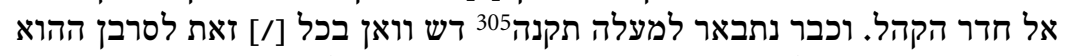

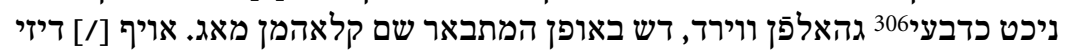

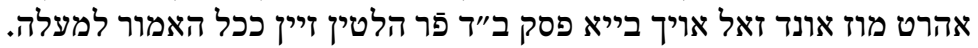

וואן נתבע אובר זיך אויף קהל ברופין מעכט, מוז אים אין פּלגינדי פּעל, אלז בדבר

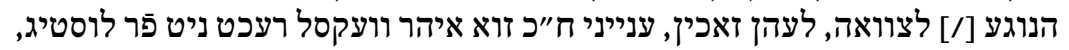

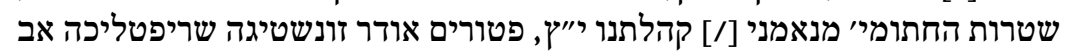

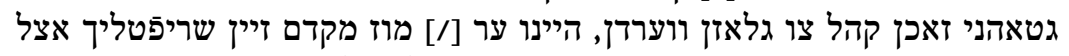

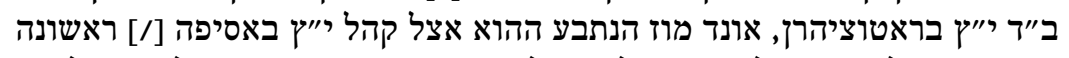

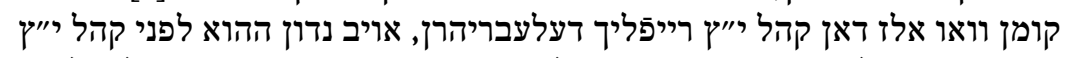

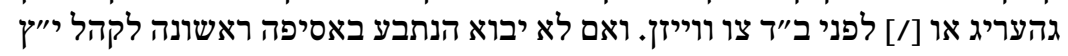

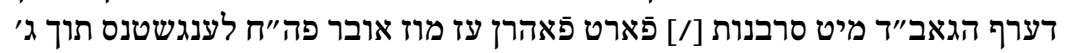

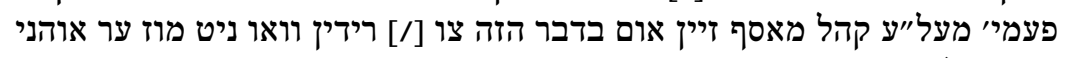
אנדרש לפני ב"ד שטיה מעלי מאסף

עז דערף וועדר מפה"ח אלז מפאת הקהל י"ץ לב"ד לגמרי ניקש אן איהרן פפאר

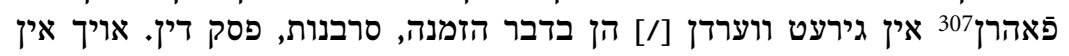
שנ"א

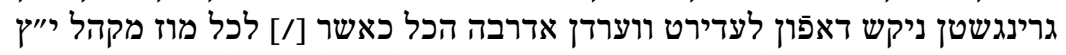

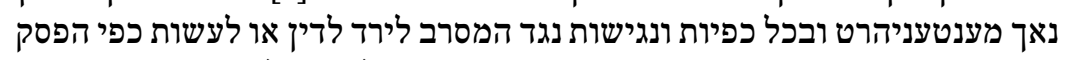

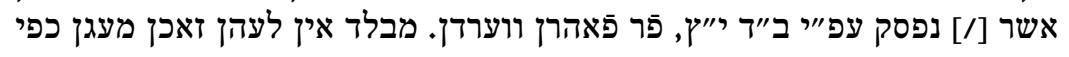

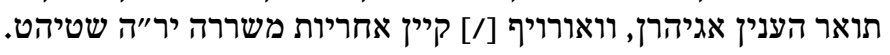

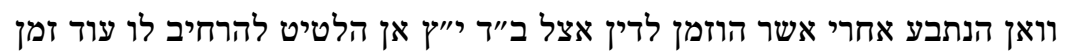

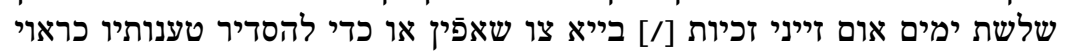

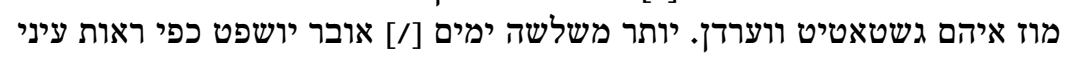

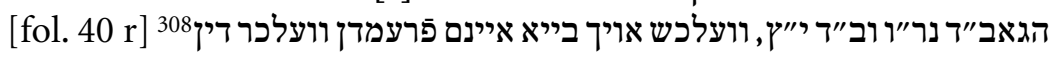

ש"ש

305 Die Paragraphennummer fehlt.

כדבעי (aram.) = wie es sein muss.

307 Verfahren.

308 Danach die Kustode ודברים. 


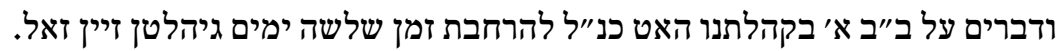

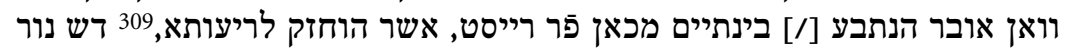

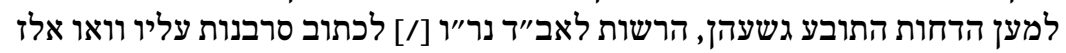

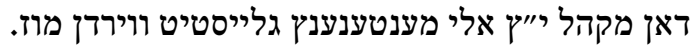

5

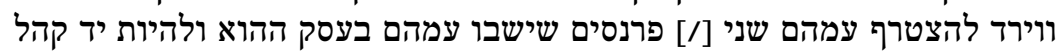

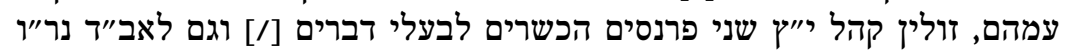

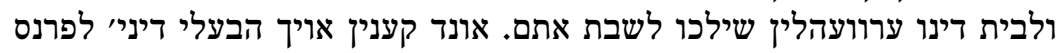

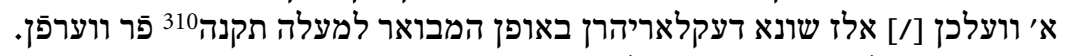

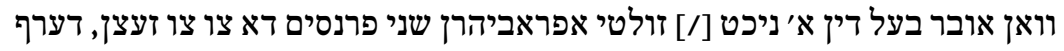

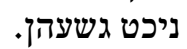

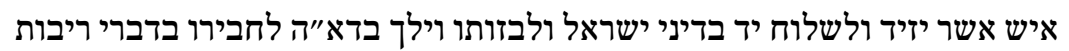

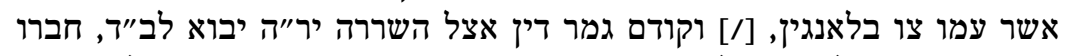

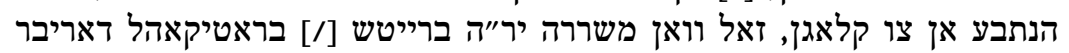

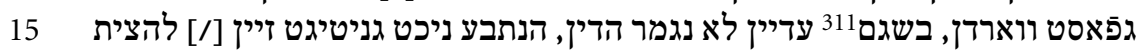

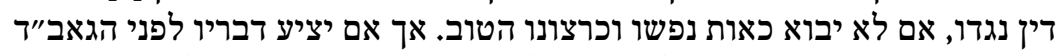

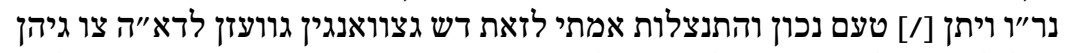

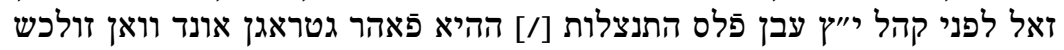

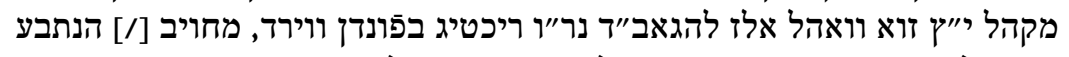

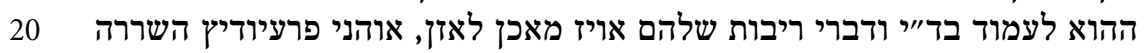
יר"ה.

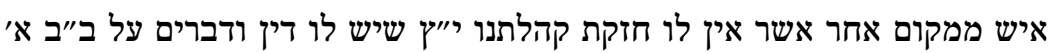

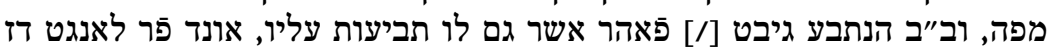

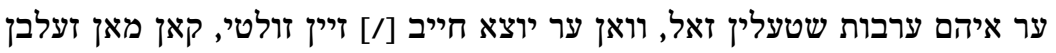

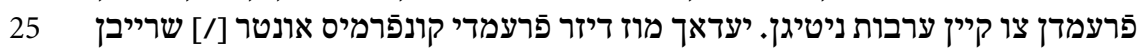

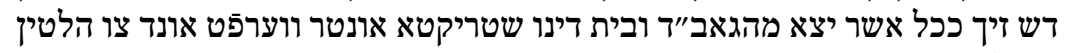

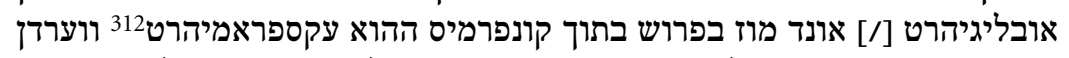

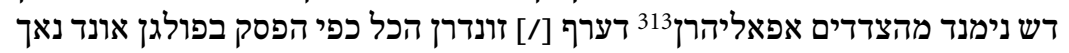

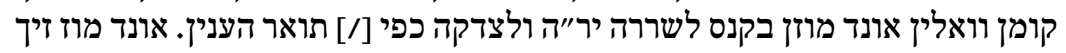

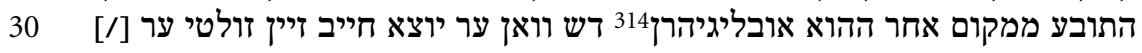

\footnotetext{
309 לריעותא (aram.) = zum schlechten, negativ.

310 Die Paragraphennummer fehlt.

311 Davor dasselbe Wort gestrichen.

312 Exprimiert, ausgedrückt.

313 Appellieren, in Revision gehen.

314 obligihr $=$ obligieren, sich verpflichten.
}

שנ"ג 


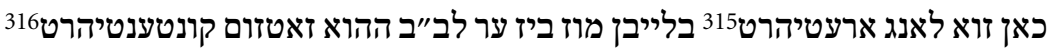

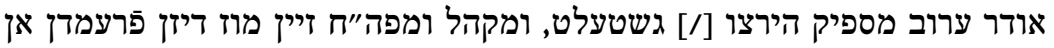

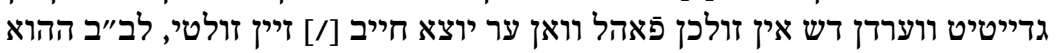

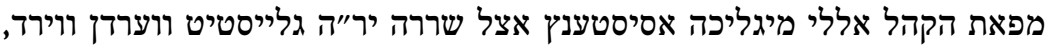

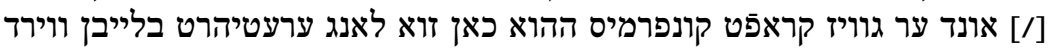

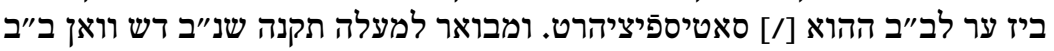

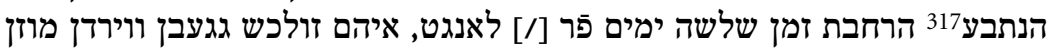
אבל לא יותר. ווירד אויך בשארי דברים כמים כמו תקנה הנ״, גיהם זיהלטן.

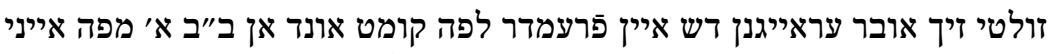

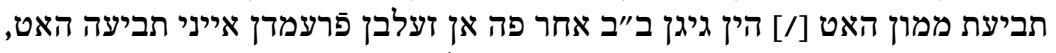

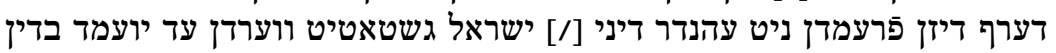

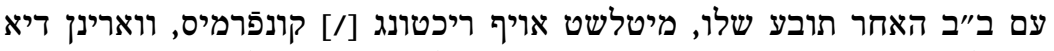

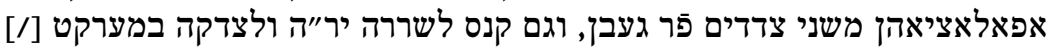

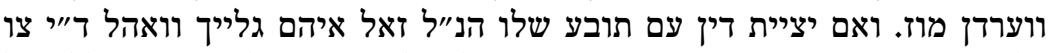

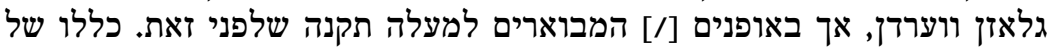

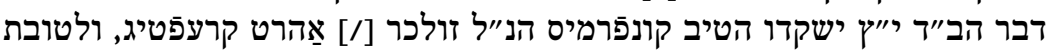

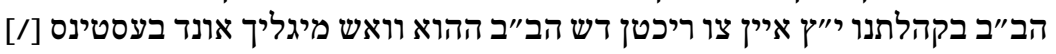

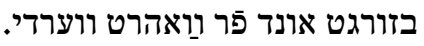

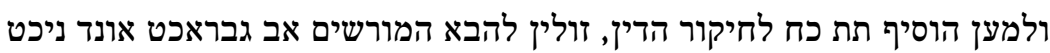

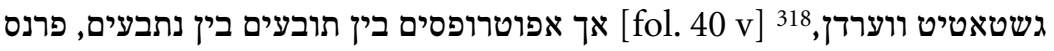
שנ"ז

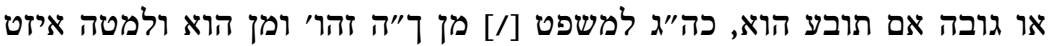

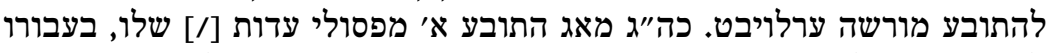

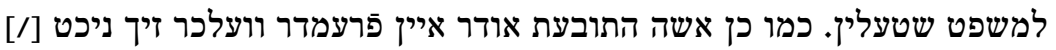

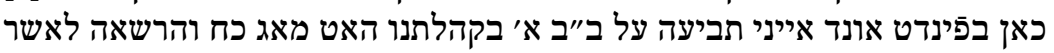

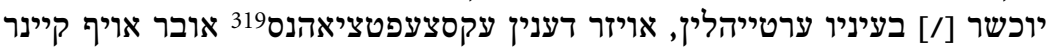

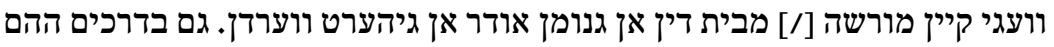

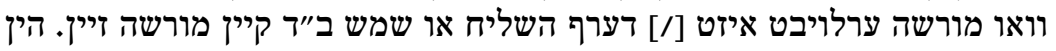

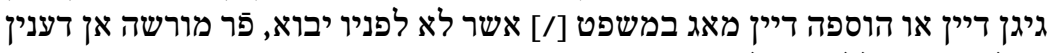
ערלויבטן פעללין כנ״ל בדיהנט ווערדן.

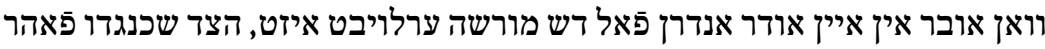

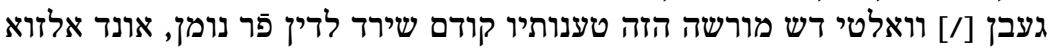

315 aretihrt = arretiert, hält fest. Hier ist wohl kaum »sperrt ein « gemeint, weil solch ein Akt das Exekutivrecht der jüdischen Gemeinde überschritten hätte.

316 kontentihrt $=$ kontentiert, stellt zufrieden.

317 Danach ein Wort nach Streichung unleserlich.

318 Danach die Kustode אך.

319 Von frz. exceptions = Ausnahmen. 


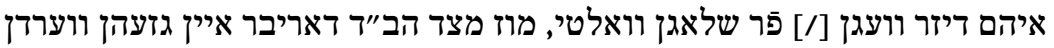

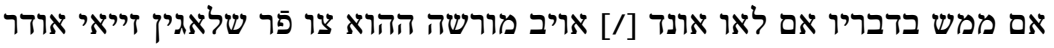

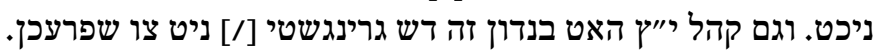

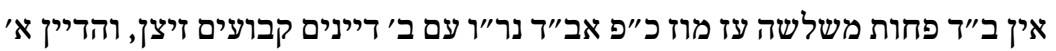
שנ"ט

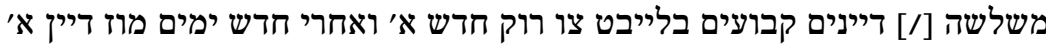

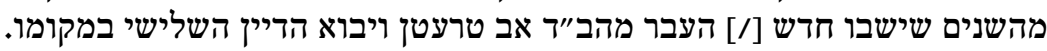

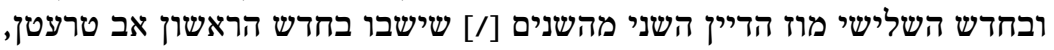

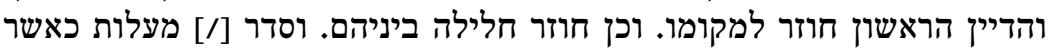

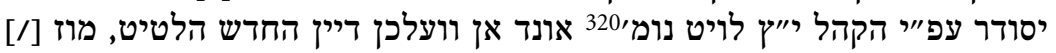

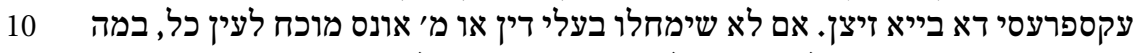

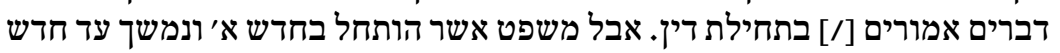

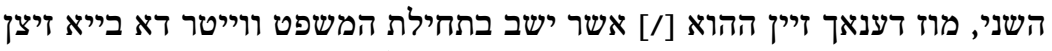

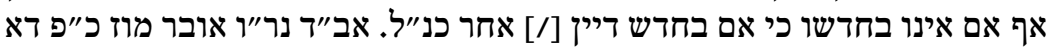
בייא זיצן.

סדר הוספה דיינים יסודר כמו כן עפ"י הקהל י"וץ אבל לא לחדשים כי אם לשבועות. 15

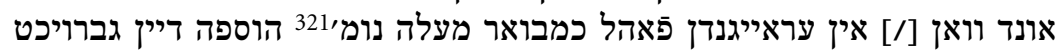
ש"ס ווירד מוז ההוספה אשר [/] איואי עראייגנרן פאותו שבוע דאצו גנומן מעלה ווערדן.

כל זמן שלא הציעו בעלי דברים טענותיהם לפני ב"ד י"ץ קאי קאן זוא וואהל התובע

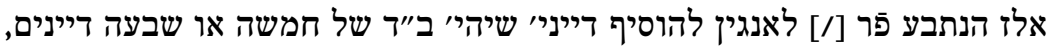

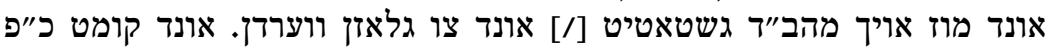

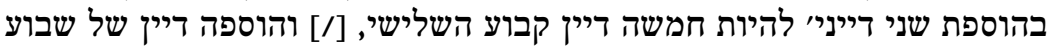

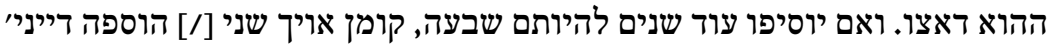

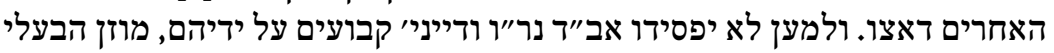

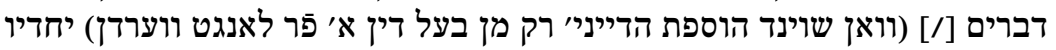

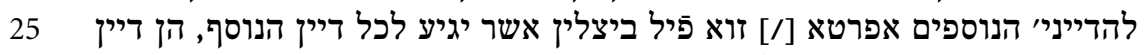

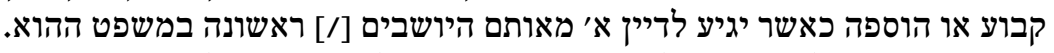

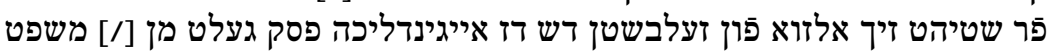

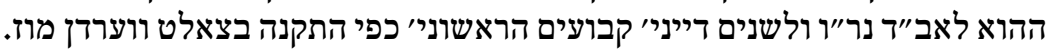

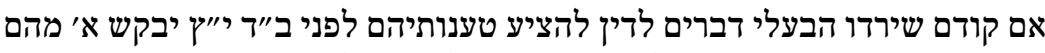
שס"ב

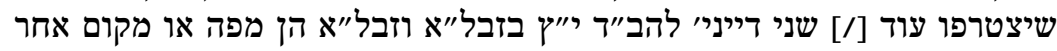

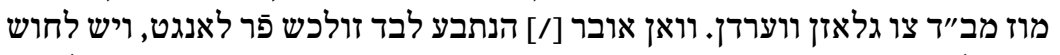

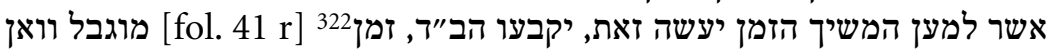

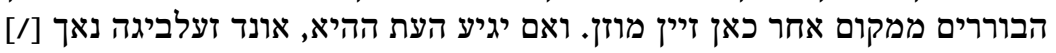

320 Die Paragraphennummer fehlt. 321 Die Paragraphennummer fehlt.

322 Danach die Kustode מוגבל. 
ניכט כאן זיינן, מוז עפ"י ב"ד לבד פַאהר גנומן אונד גשפראכן ווערדן. הבוררים

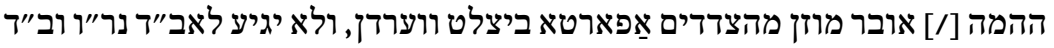

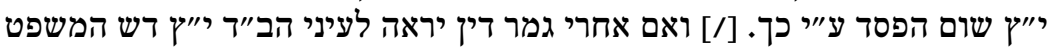

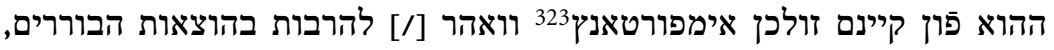

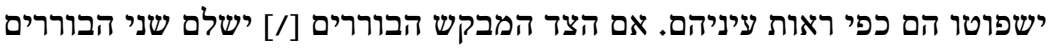

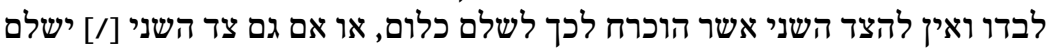

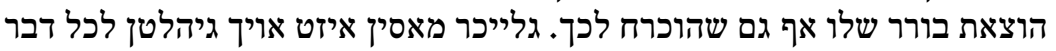

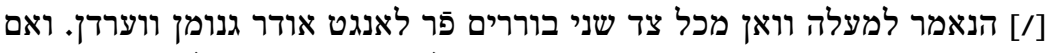

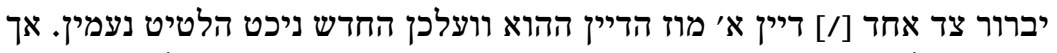

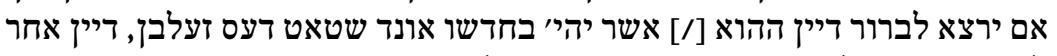

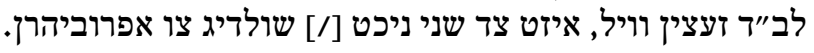

כל זמן שֶבת הב"ד למשפט אין רשות לשמש או שליח ב״ד ללכת מבית מקום שס"ג

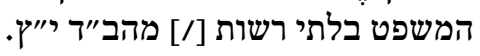

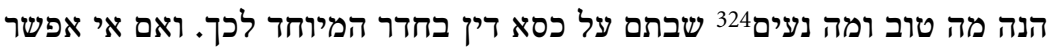

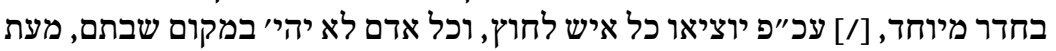

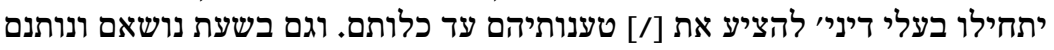

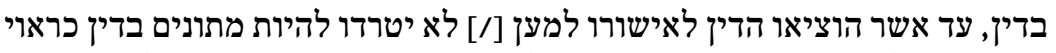

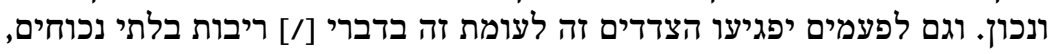

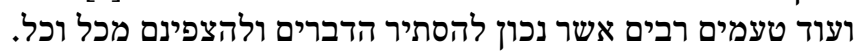

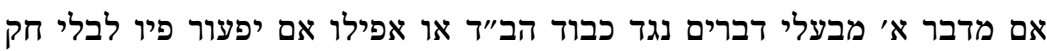
שס"ה 20

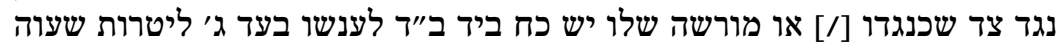

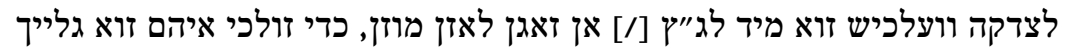

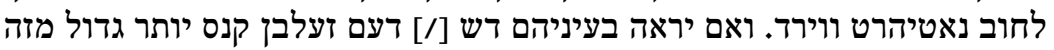

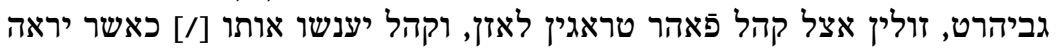

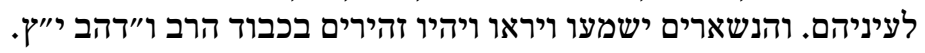

כל הפסקים אשר יופסקו מפיהם יכתבו מהם בעצמם ובכבודם דוקא ולא ע"י אחר

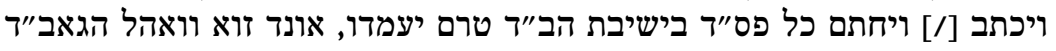

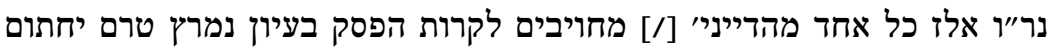

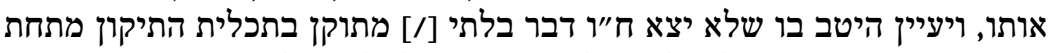

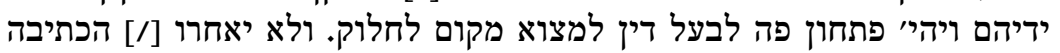

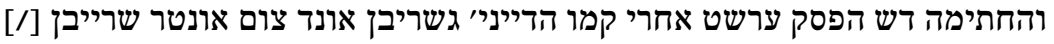

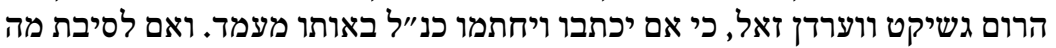

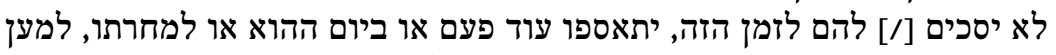
ישבו יחדיו בכתיבה וחתימה [/] ובזה יוציציאו כל משפט מחוד פעם מחוקק מאושר ומזוקק.

323 Importanz, Bedeutung.

324 Ps 133,1. 
עז דערף אויך אן נימנד מהצדדים הפסק קומניציהרט ווערדן עד אשר יכתב ויחתם

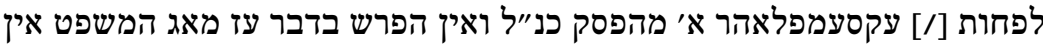

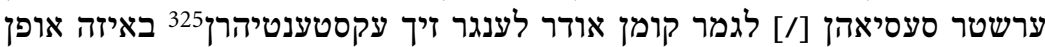

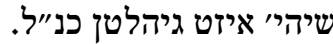

יחויבו הב"ד י"ץ לעשות להם פנקס מיוחד אשר בתוכו יעתיקו כל פסק שיופסק שס"ח

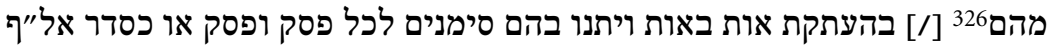

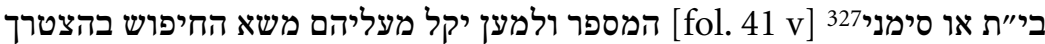

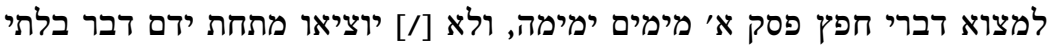
מועתק מהם בפנקסם כנ"ל.

אם לפעמים קצרו הב"ד לשונם בתוך פסק א׳ אשר על ידי כך יפול מחלוקת בין

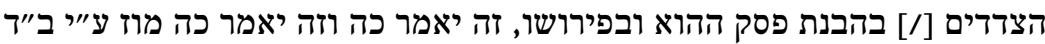

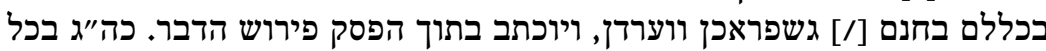

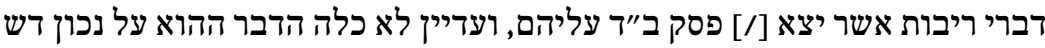

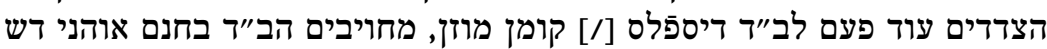

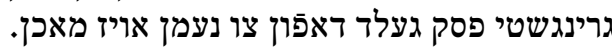

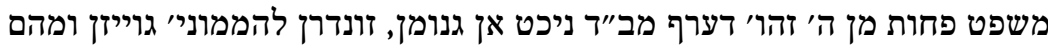

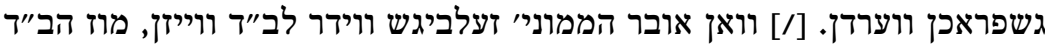
דארינן שפרעכן.

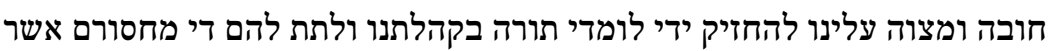
שע"א

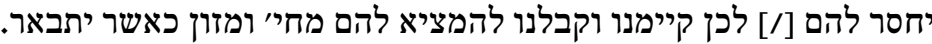

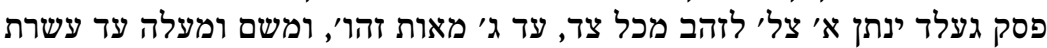

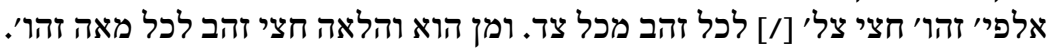

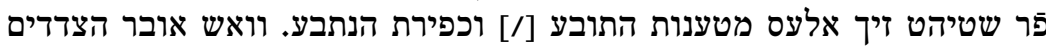

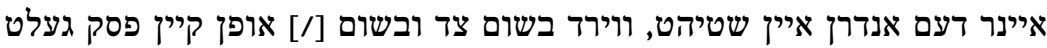

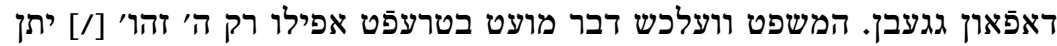

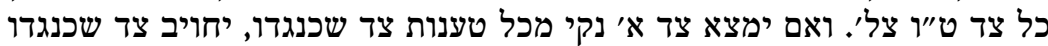

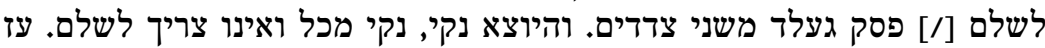

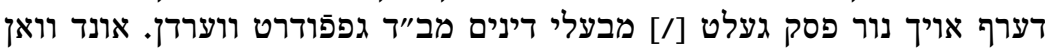

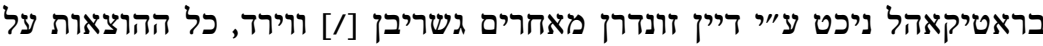

מעשי ב"ד או למנות אפוטרופסים או וואן איין אפוטרופוס אב זאגט, או אשר

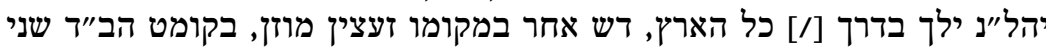

325 Extendieren, ausdehnen.

326 Danach ב als Zeilenfüller.

327 Danach die Kustode המספר. 
זהו'. ואין הפרש בין יהי' הסך ההוא אשר [/] יכתבו לבעבורו מעשה ב"ד או ימנו

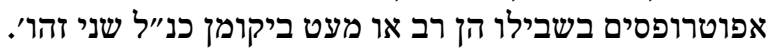

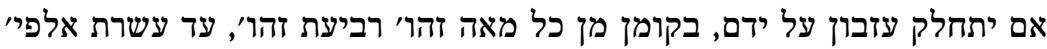

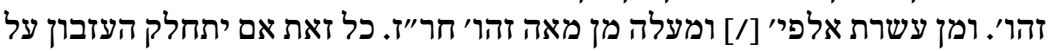

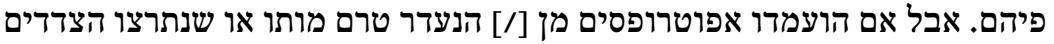

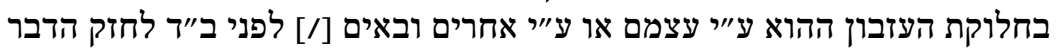

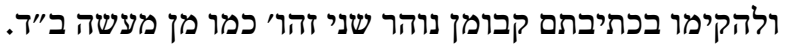

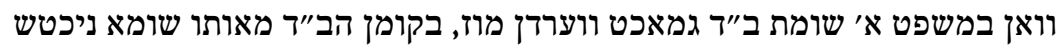

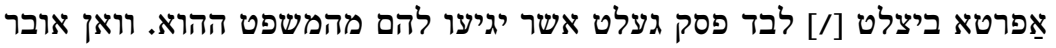

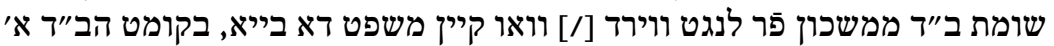

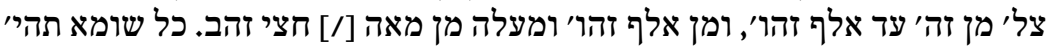

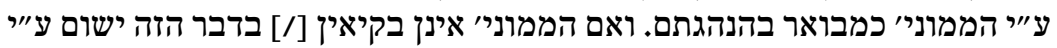
אחרים במעמד הממוניי לפני ב"ד.

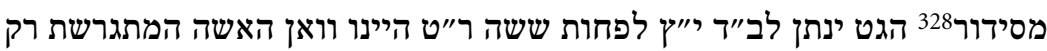

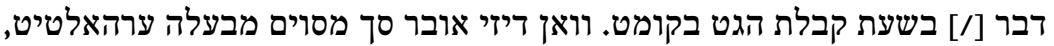
שע"ה

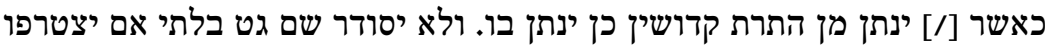

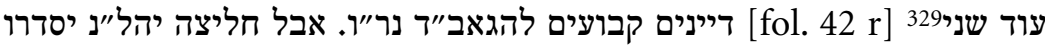

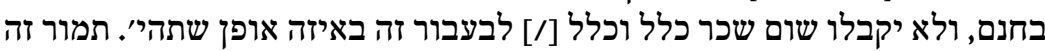

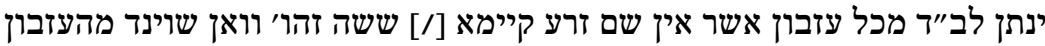

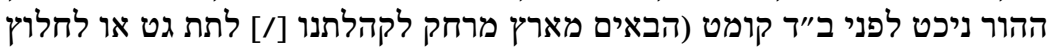

שע"ג

שע"ד

מוז בידיעת הקהל גשעהן).

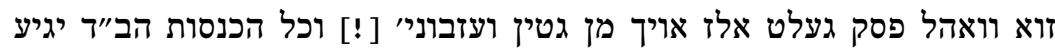

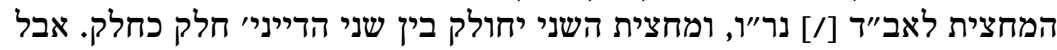

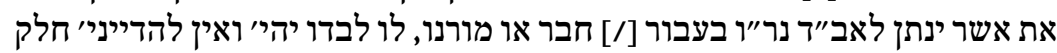

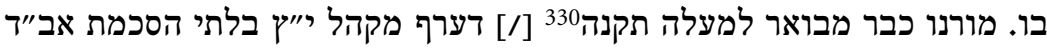

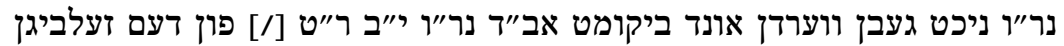

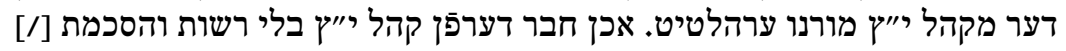

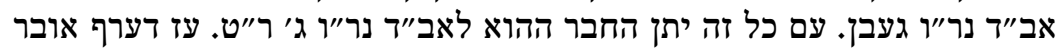

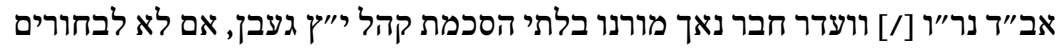

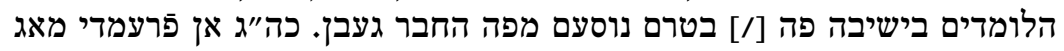

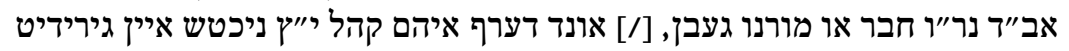

\footnotetext{
328 Davor gestrichen וואן.

329 Danach die Kustode דיינים.

330 Die Paragraphennummer fehlt.
} 
כי יפלא דבר למשפט בדבר סרסרות או שדכנות דש יותר מן סרסור א׳ אן מעל מעלדיט,

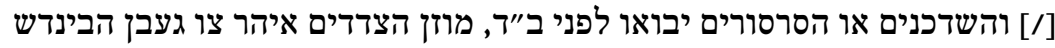

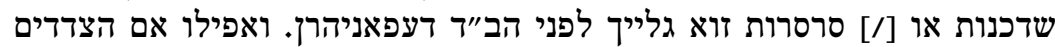

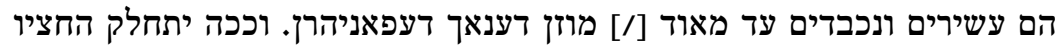

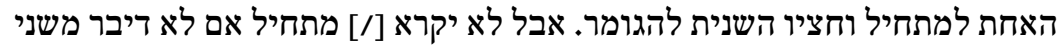

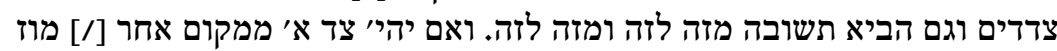

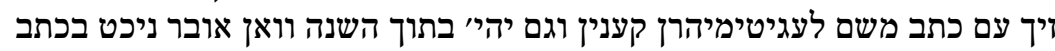

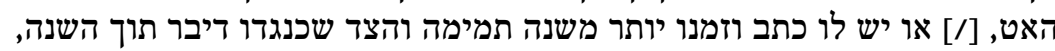

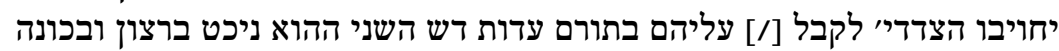

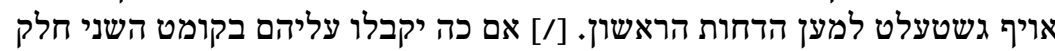

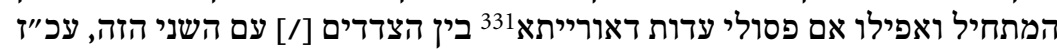

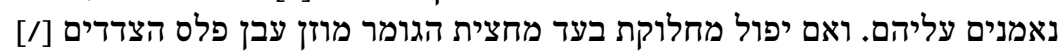

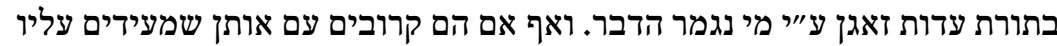

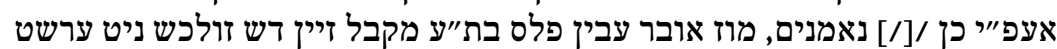

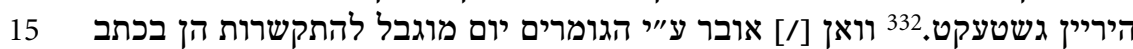

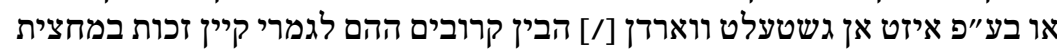

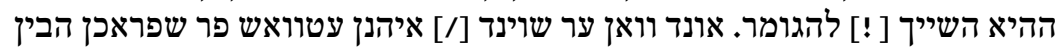

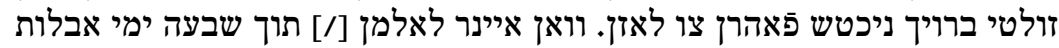

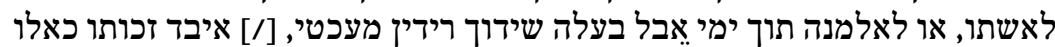

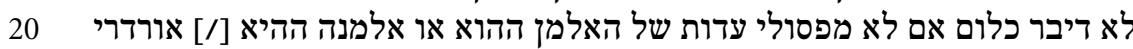
ערהלטין האט לדבר או לכתוב לדיל לדבק בקרוביי.

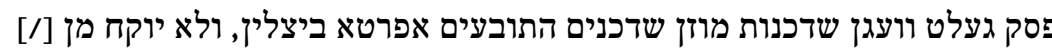
שע"ח השדכנות. דערף אויך לא יותר כי אם מן משפטי משפט אחר גנומן ווערדן.

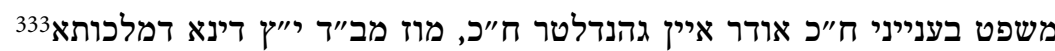

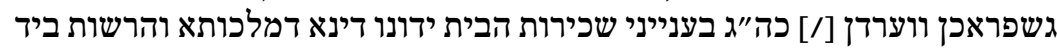

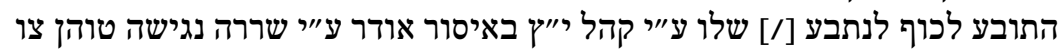
לאזן.

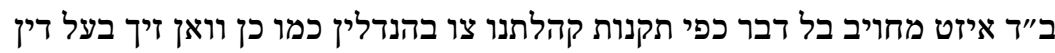
ש"פ

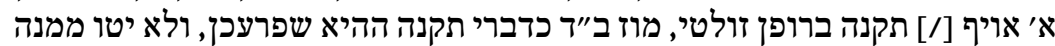

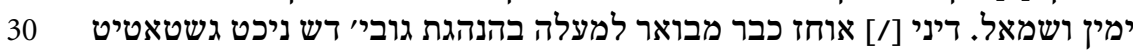
ווערדיט.334 יושמאיל

331 D. h., dass sie miteinander nahe verwandt sind.

332 Davor gestrichen גשיקט.

333 Nach allgemeinem Landesrecht.

334 Danach die Kustode אם. 


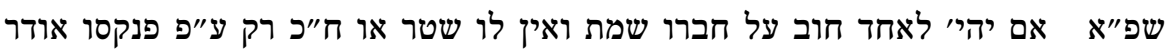

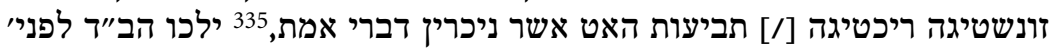

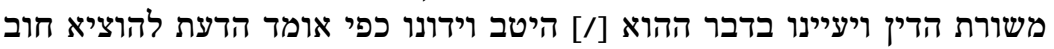

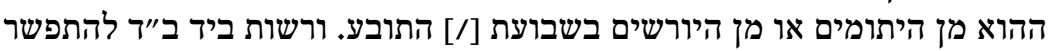
עם התובע ההוא או לתת רשות לאפוטרופסים336 להתפשר עמים המות ביד

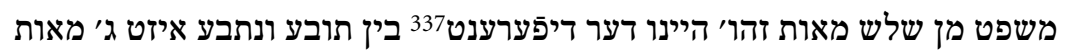

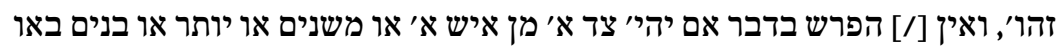

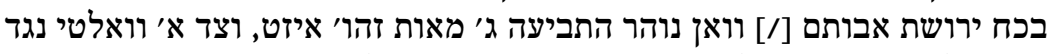

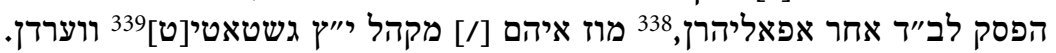

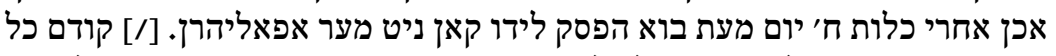

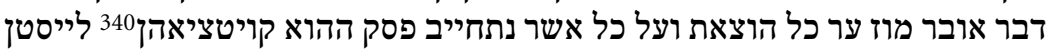

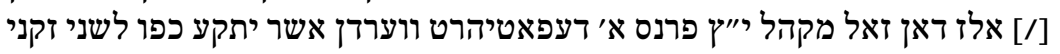

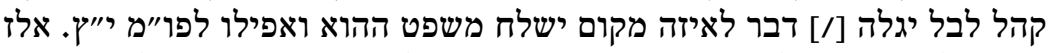

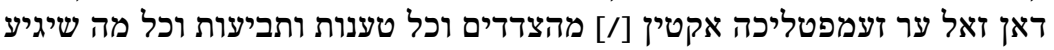

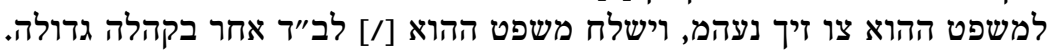

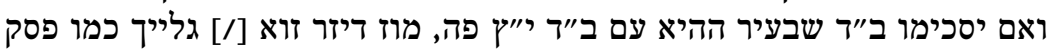

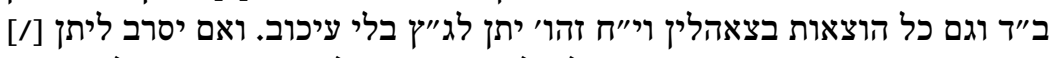

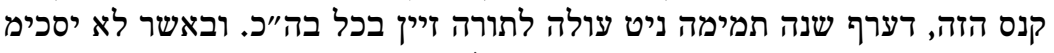

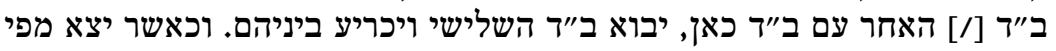

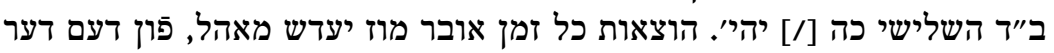

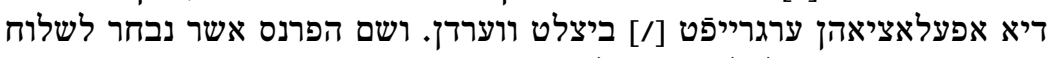

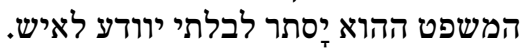

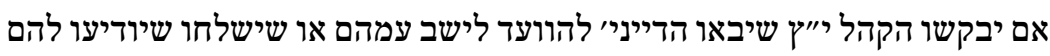
שפ"ג

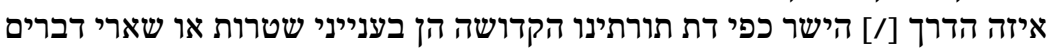
שפ"ב

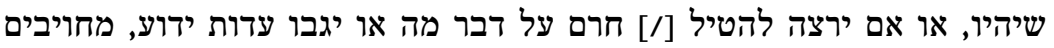

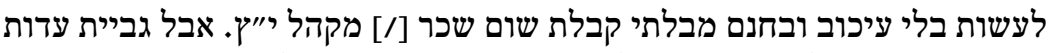

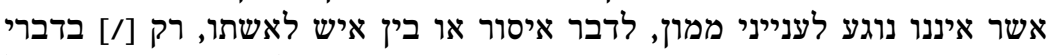

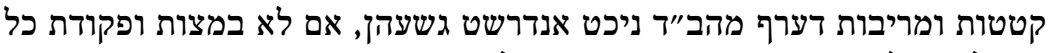
הקהל [/] ולא ע"י פרנס א׳ או או שנים או שלשה פרנסיכים.

\footnotetext{
335 Sota 9b.

336 In der Handschrift: לאפוטרופרים.

337 Differenz.

338 Einspruch erheben.

339 Der Schlussbuchstabe fehlt.

340 Kaution.
} 
שפ"ד וואן אב"ד נר"ו או הב"ד עטוואש אצל קהל פַאהר צו ברענגן, רשות בידם זולכש

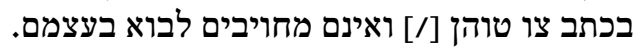

שפ"ה כל שלשה חדשים מחויבים ב"ד י"ץ השוחטים פר זיך פּאדרן לאזן בקהלתנו,

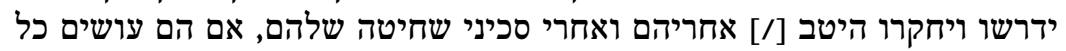

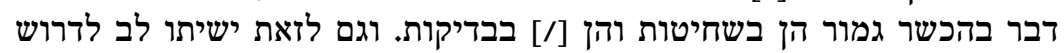

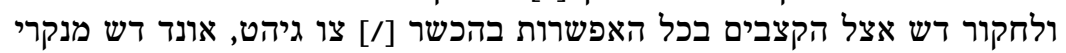

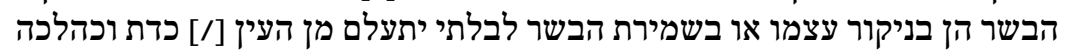
אובסערפיהרן.

כל פעם שיבקשו הממוני' שיסכים הב"ד עמהם לאסור יינם של מעכבי תשלומיהן שפ"ר

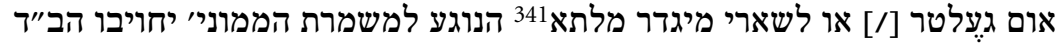

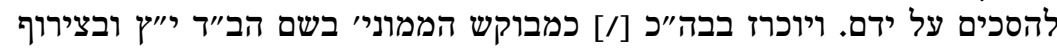

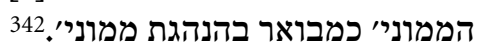

[fol. $43 \mathrm{r}$ ]

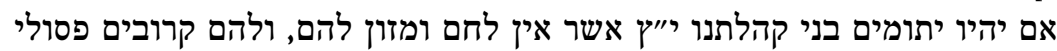
שפ"ז

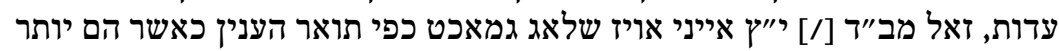

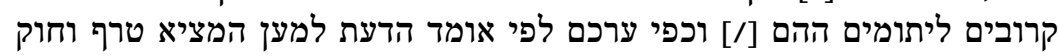

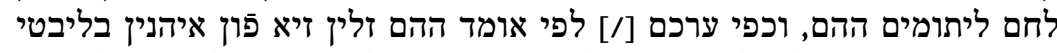

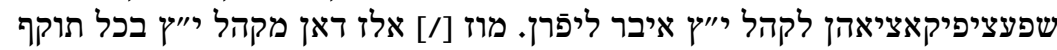

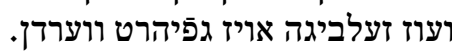

אב"ד נר"ו אשר זקן בא בימים שהגיע לכלל שבעים שנה לאי"ט, וכבד עליו הפיו הדבר שפ"ח

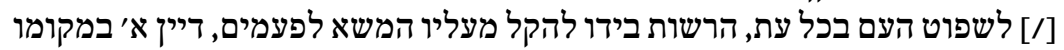

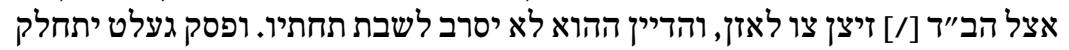

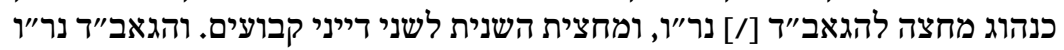

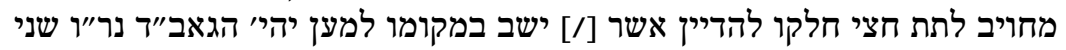

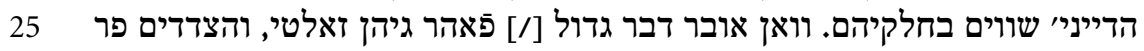

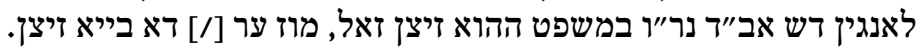

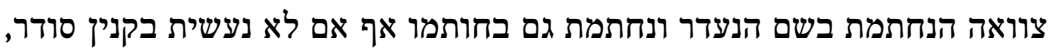
שפ"ט

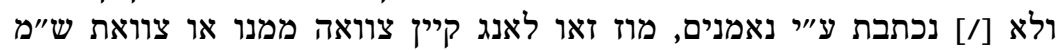

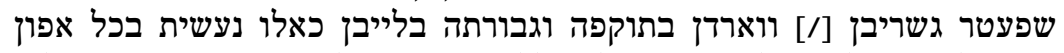

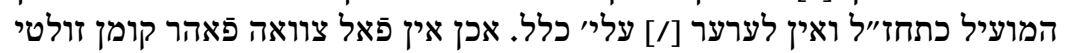

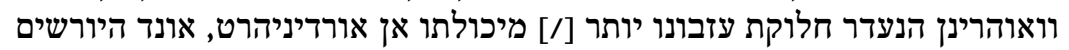

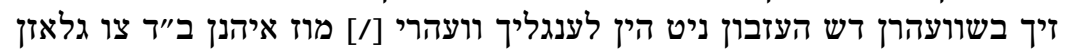
ווערדן.

341 מיגדר מלתא (aram.) = Bestimmung zur Verhütung einer Gesetzesübertretung. 342 Danach die Kustode מיגרו משל 
אב"ד ודייני' מחויבים בכל העדר יהל"נ צו אובסערפיהרן דש עכ"פ תוך שלשים

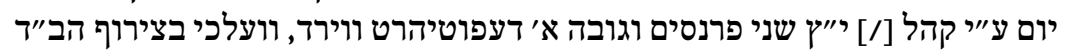
ץ"ש

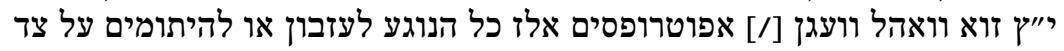

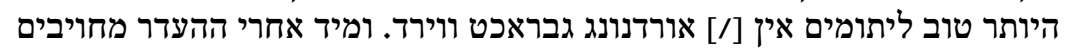

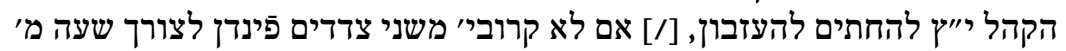

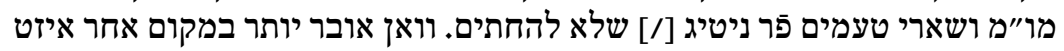

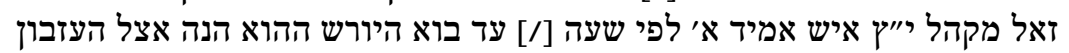

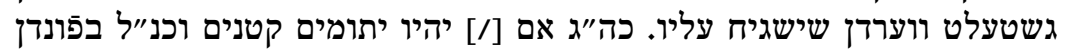

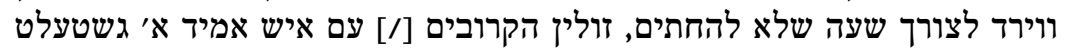

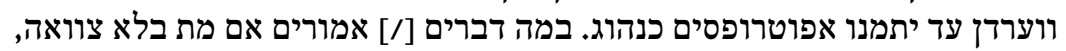

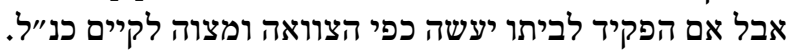

הנהגות גבאי ת"ת

שצ"א מבואר בתוך הנהגת הקהל דש כל שלש שנים ג' גת"ת וואורונטר אחד חדש זייין

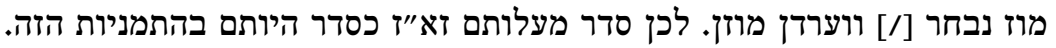

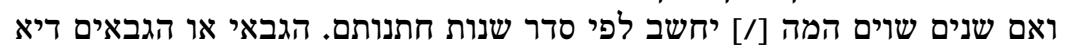
פון איהרן אמט קומן, מוזן להגבאים

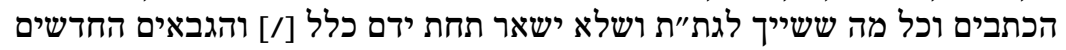
מוזץ חשבנותיהם דורך גיהן. ואם ישר מוצאם משת מוזיר ישאר תחת ירם מליהנן קוויטיהרץ. רשות לגת"ת שמש א’ צו נעמן ולשלם שכירות שלו מקופת ת"ת.

כל גבאי יעמיד על משמרתו ששה חדשים רצופים, נעהמליך מן ר״ח חשיח חשון עד ר־״ שצ"ג

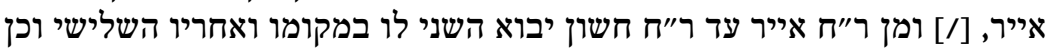

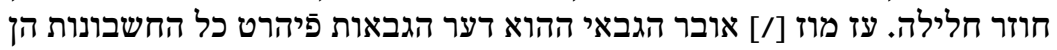

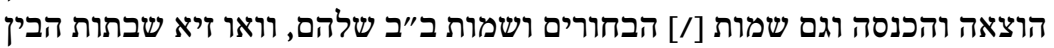

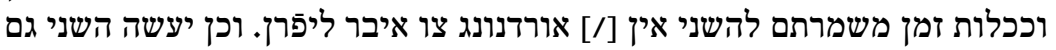
השלישי.

הגבאי ת"ת יבחור שלשה לומדים מופלגם, יתאספו כל יום עש"ק תום תוך בלעיטן

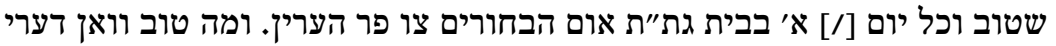

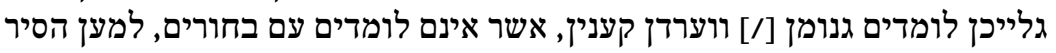

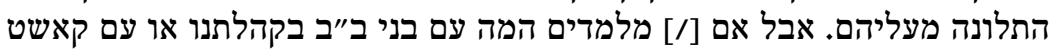

$$
\text { גענגר לית לן בה.344 }
$$

שצ"ה הגבאי ת"ת אן וועלכין הלטיט זאל רשימה מאכן אשר יורשמו עליי הבחורים

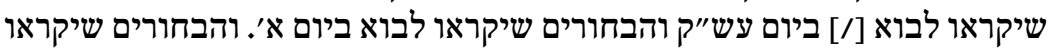

343 Danach die Kustode אחרים (aram.)= אחים

לית לן בה 344 (aram.) = so ist nichts dabei. Diese Phrase tritt häufiger im Talmud auf, so z. B. in Pesahim 111a. 
לבוא ביום א׳ זולין רק [/] בחורים חשובים זיין. והבחירה ביד גבאי ההוא וויא

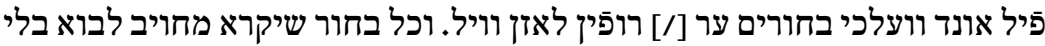

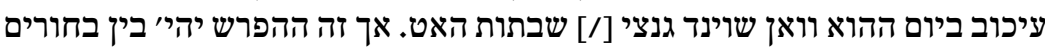

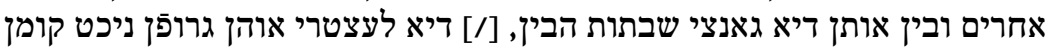

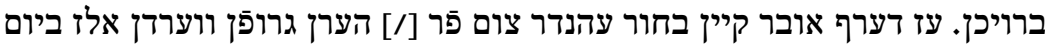

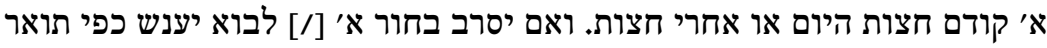

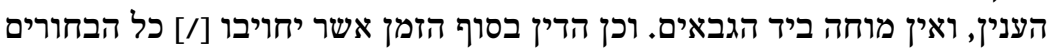

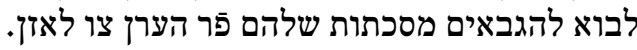

שבתות סתם או קלייני שבתות זמנם שתי שנים ולא יותר. וגם בזמן האחרון בקומט

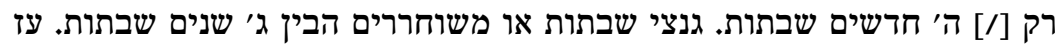

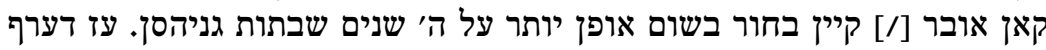

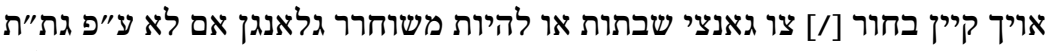

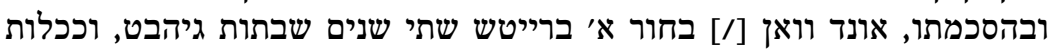

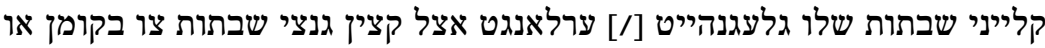

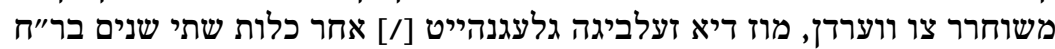

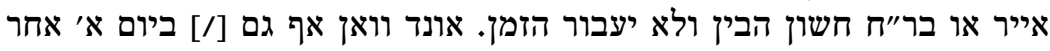

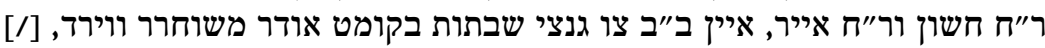

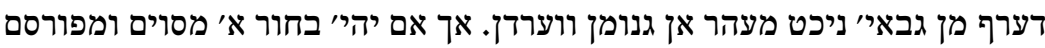

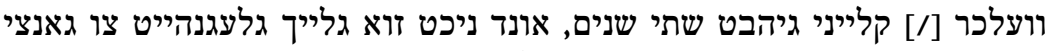

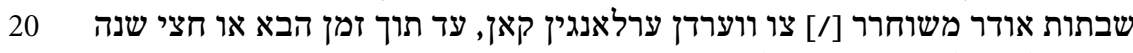

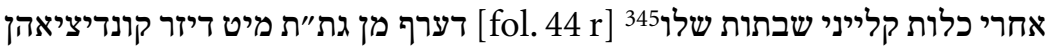

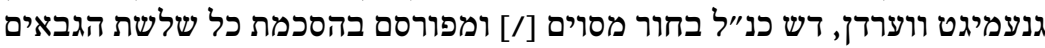

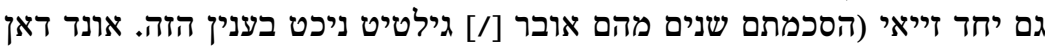

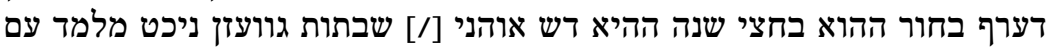
תלמידים גוועזן הבין דערף, זונשטן אור איבד זכות דשותו).

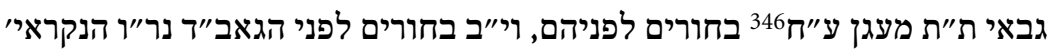

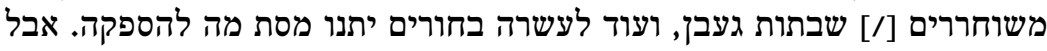

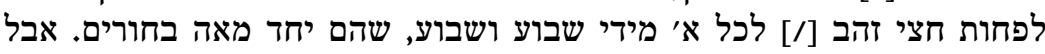

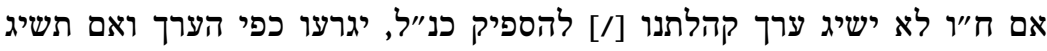

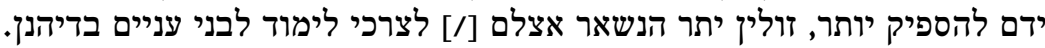

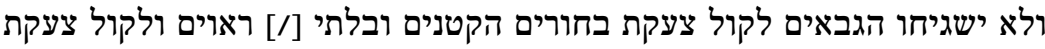

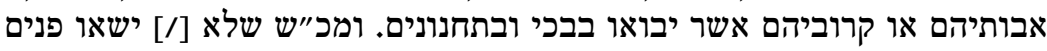

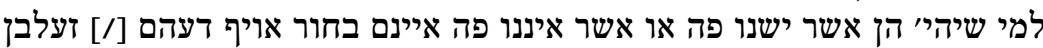

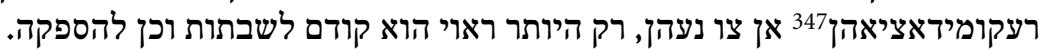

345 Danach die Kustode דערף.

346 Gemeint ist hier der Zahlwert 78.

347 Von frz. recommendation = Empfehlung. 


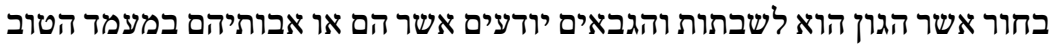
שצ"ח

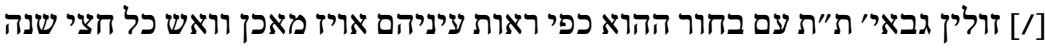

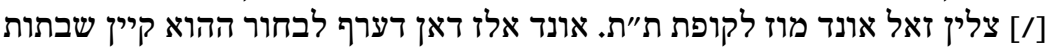

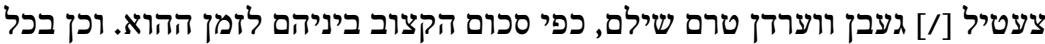

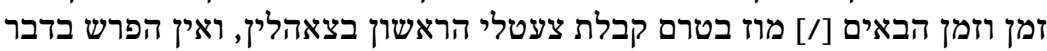

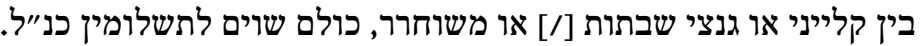

מן אז עולם נתקנה תקנה דש קיין בחור וועלכר קרובים פסולי עדות כאן האט קיפ קייני

שצ"ט

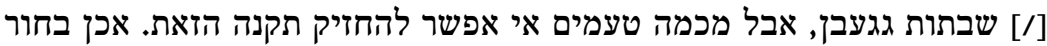

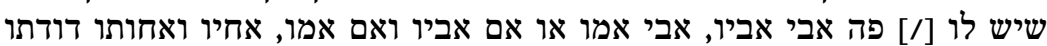

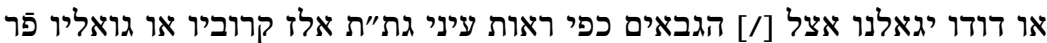

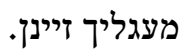

בחור שהוא קודם בן י"ג שנה, וכץ לנשוי דערף קייני שבתות געבן ווערדן.

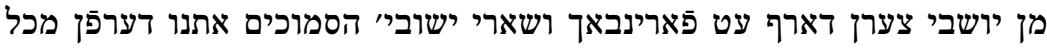

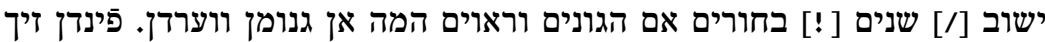

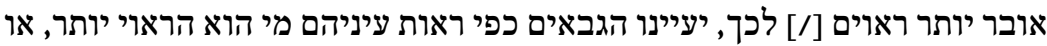

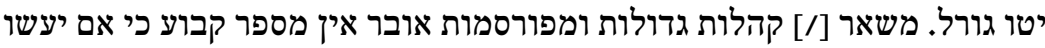
הגבאים כפי ראות עיניהם. משרות גורות

ישיב ה' את שביטינו ויציב את גבולינו עז איזט אובר כעת הזאת וועגן מיעות ת"ב

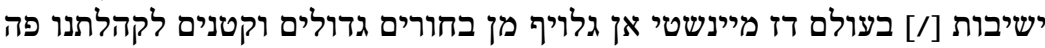

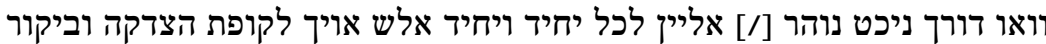

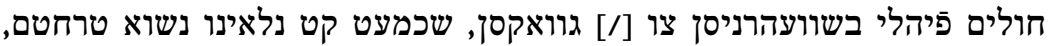

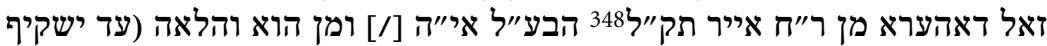

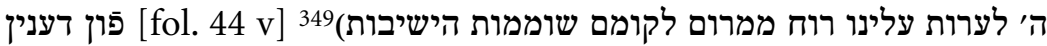

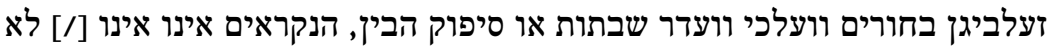

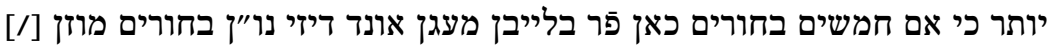

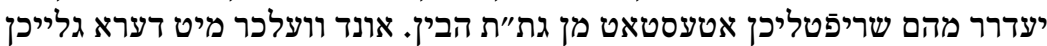

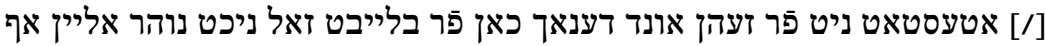

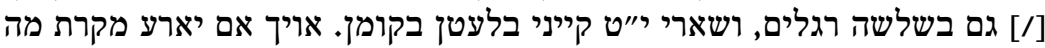

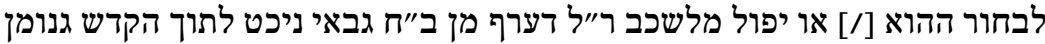

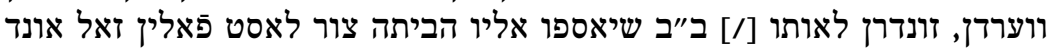

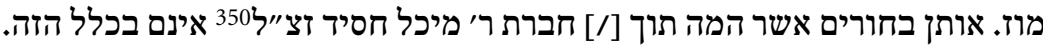

\section{IV 26.}

349 Danach die Kustode פ̄ פּ.

350 Michael Fürth (auch genannt Michael ben Abraham Kohn) betrieb eine Gesellschaft zur Verköstigung armer Knaben in der Gemeinde; siehe Leopold Löwenstein, Zur Geschichte der Juden in Fürth, 3 Teile in einem Bd., Hildesheim/New York 1974, 


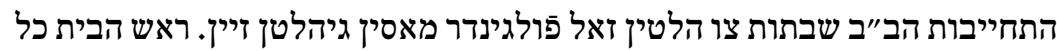

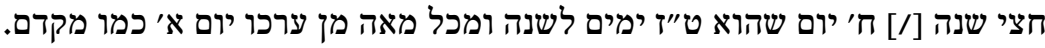

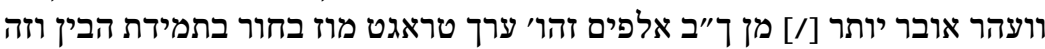

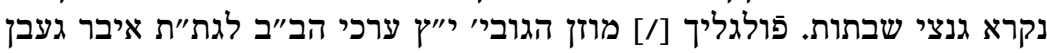

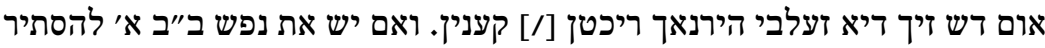

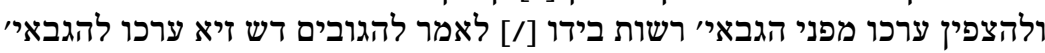

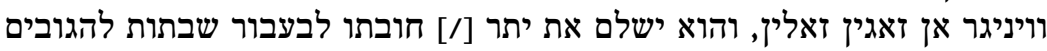

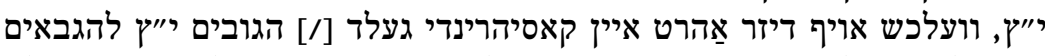

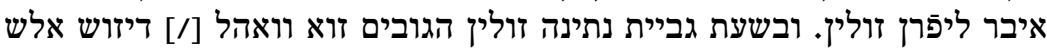
וואש יותר אלז גאנצי שבתות צו הלין ובשת גביין, איין קאסיהרין זולין הגובים זואין

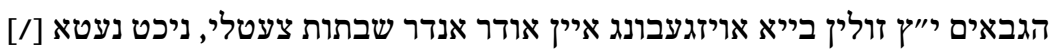

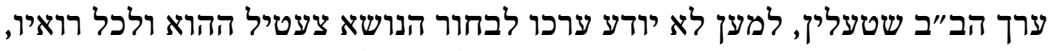

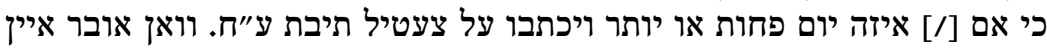

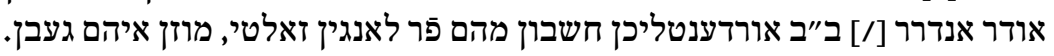

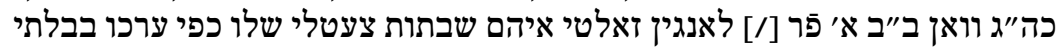

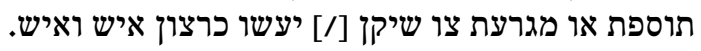

הגבאי' נאמני' בשליחותם ובפנקסיהם, כאשר ימצא שם כתוב כן יהיי אונד האט

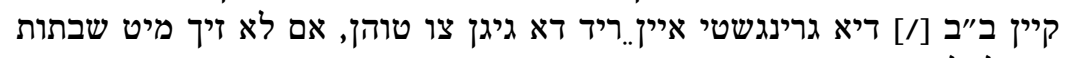

צעטלי לעגיטימיהרן קאן.

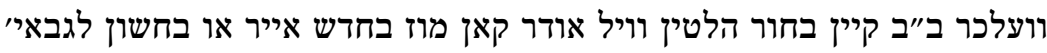
$ת$

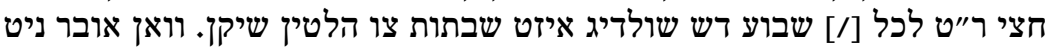

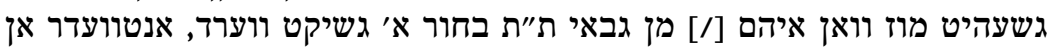

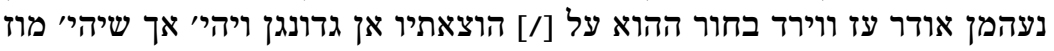

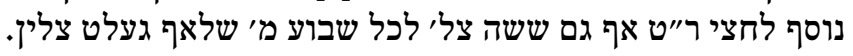

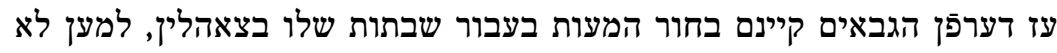
$ת$

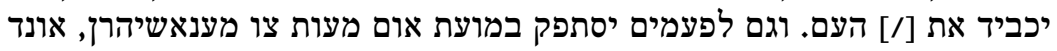

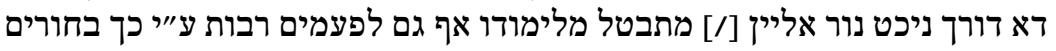

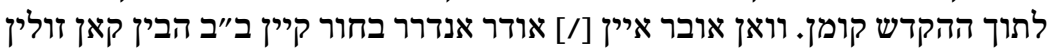

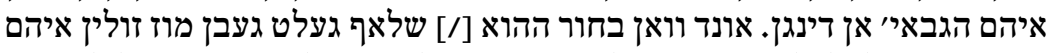

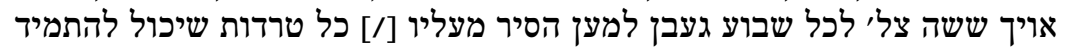

$$
\text { בלימודו.351 }
$$

Teil II: Rabbinatsbeisitzer und sonstige hervorragende Persönlichkeiten, 65-213, hier 103.

351 Danach die Kustode עז. 


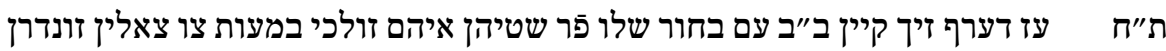

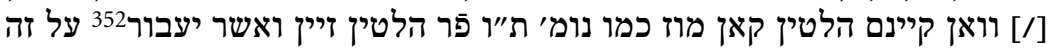

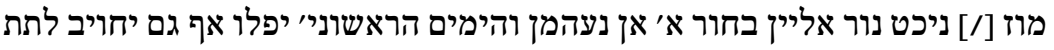

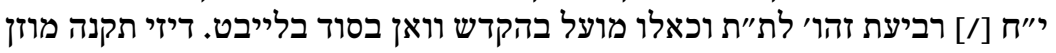

עז דערף קיין ב״ב, בחור מבלתי צעטלי מת"ת גבאי אן נעהמן וממילא נשמע דש ישיח

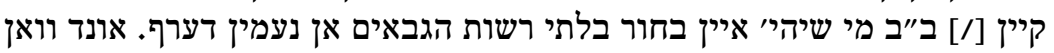

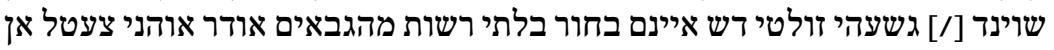

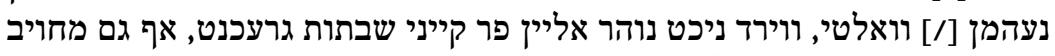
לתת [/] י"ח רביעת זהו' לקופת ת"ת.

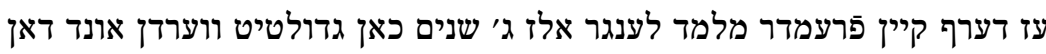

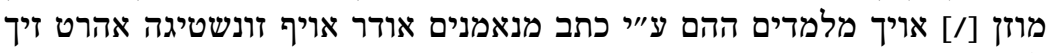

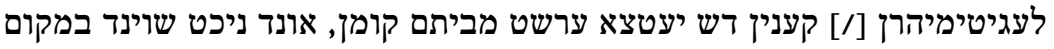
אחר זיך פَר וויילט.

ת"ט 10

ת"ו 15

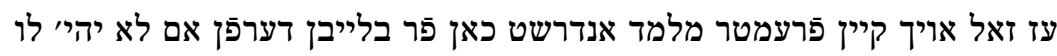

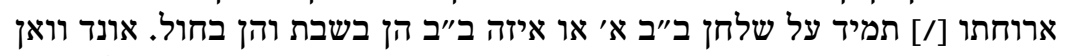

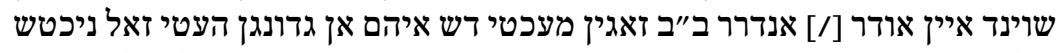

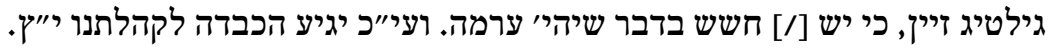

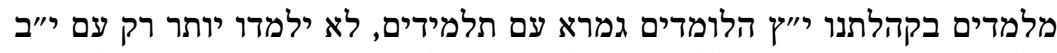

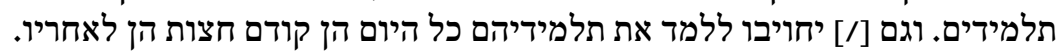

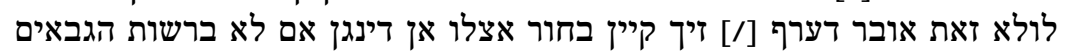

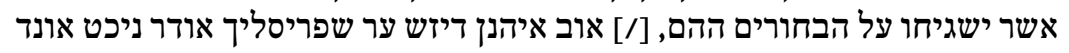

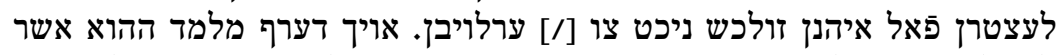

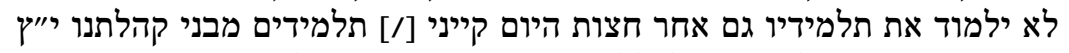
בשכר אן נעמן אם לא הגיעו ליעם לכלל בחרות.

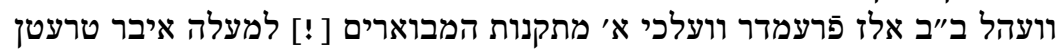

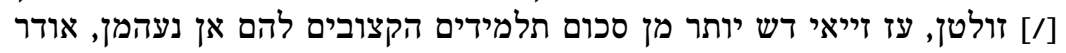

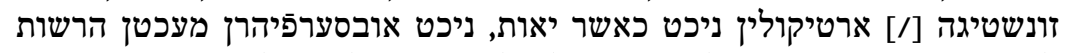

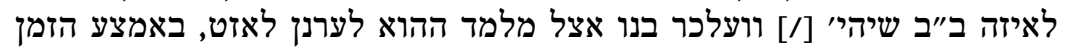

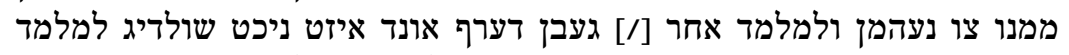
העובר ההוא אף גם פרוטה א׳ מן [/] שכור גבירות שלו צו צאהלין.

תי"א תי״ב 20

352 Davor ein Wort nach Streichung unleserlich.

353 Jugendalter. 


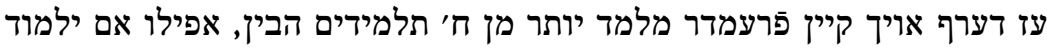
תי"ג

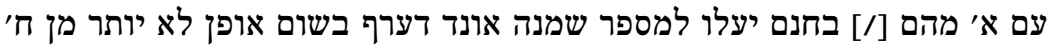

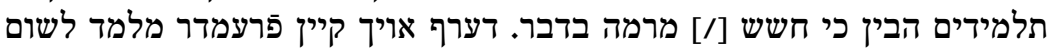

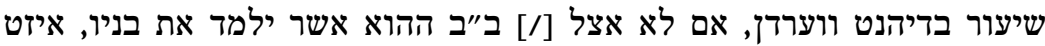

עז זאל להבא קיין בחור וועלכר אף גם עם בן ב"ב שלו לבדו ומכ"ש גם עם עם אחרים תי"ד

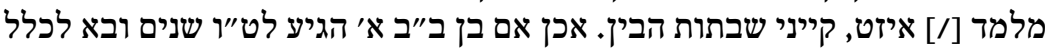

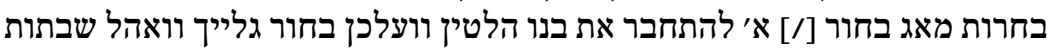

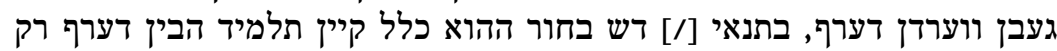

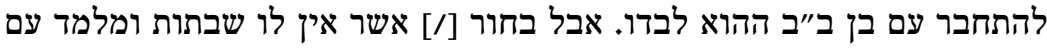

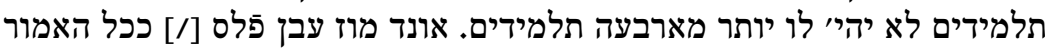

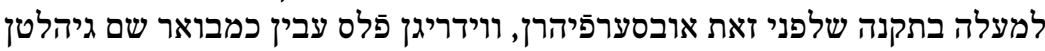

$$
\text { ] [יין זעלה בתקלי. }
$$

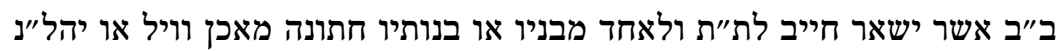
תט"ו

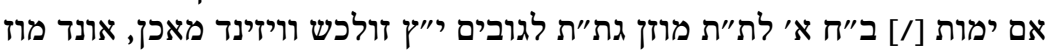

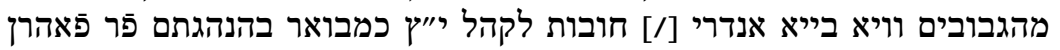
ווערדן.

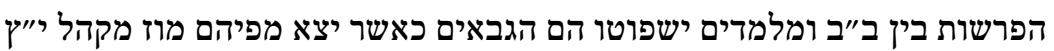
תט"ז

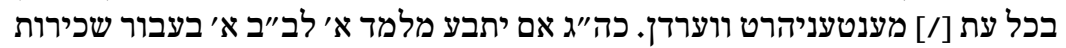

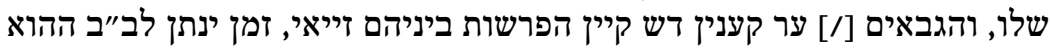

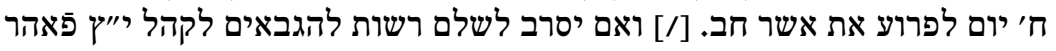

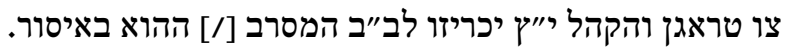

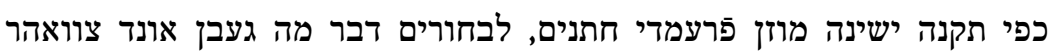
תייז

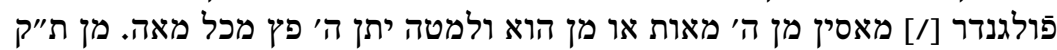

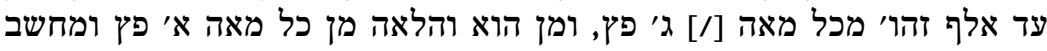

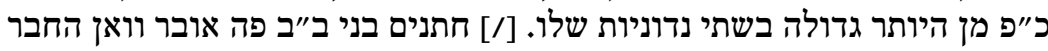

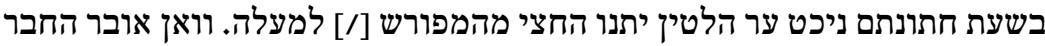

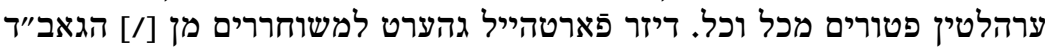

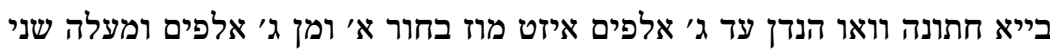
תי"ח

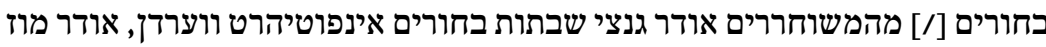

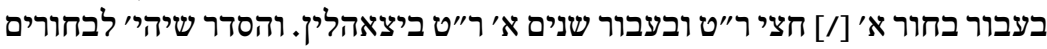

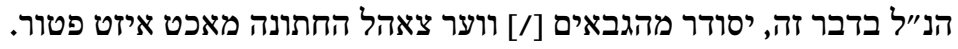

354 Danach die Kustode עז. 


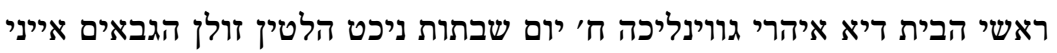
תי״ט

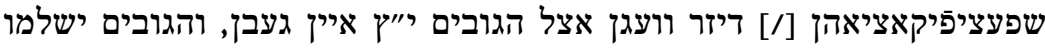

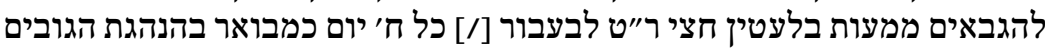

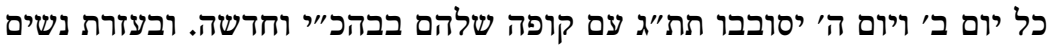

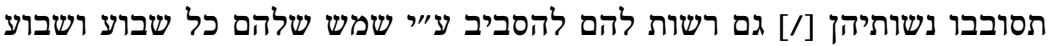

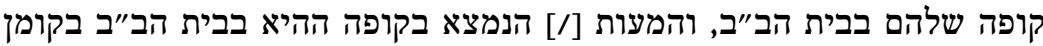

המשוחררים דאפון.

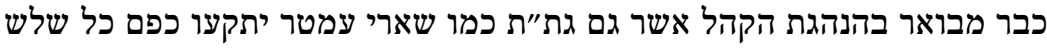

תכ"א

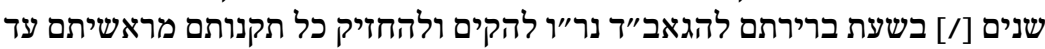

אחריתם.355 שנים

[fol. $46 \mathrm{r}$ ]

הנהגות ממונים

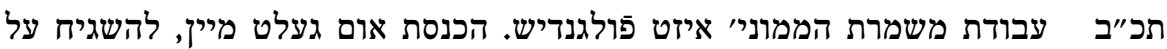

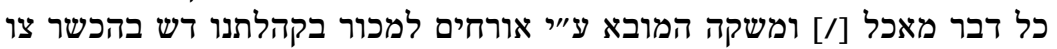

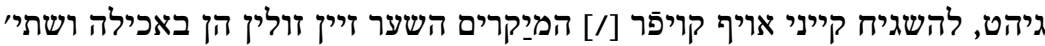

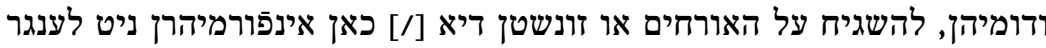

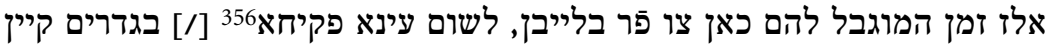

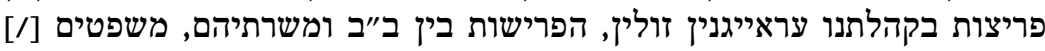

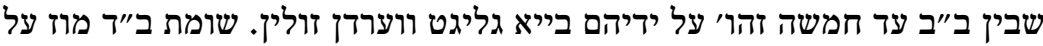

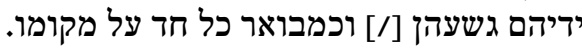

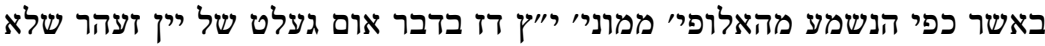

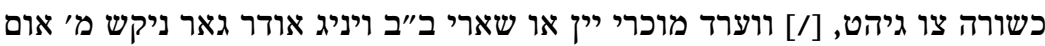

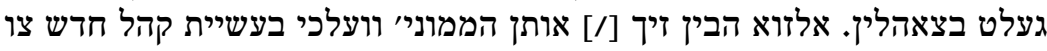

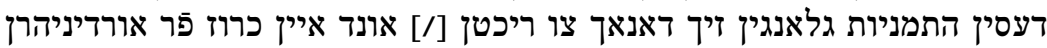

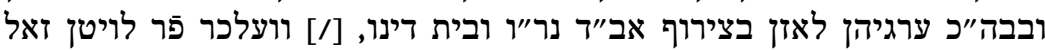

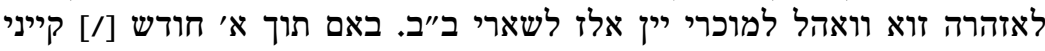

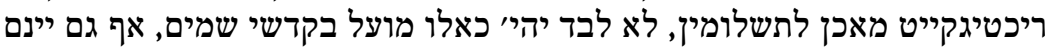
יהי' [/] אסור כיין נסך.

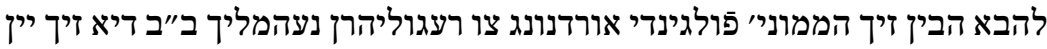
30

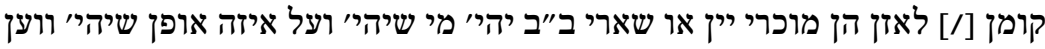

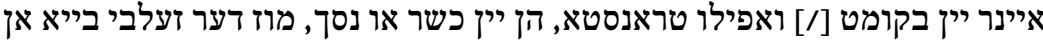

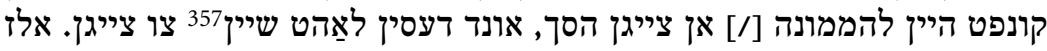

355 Danach die Kustode עבודת.

356 עינא פקיחא (aram.) = wachsames Auge.

357 Ladeschein, Versandpapiere. 


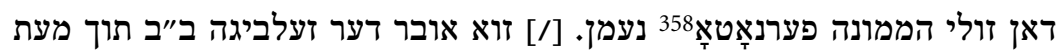

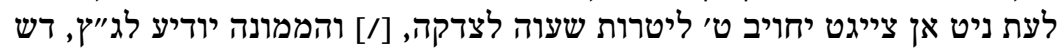

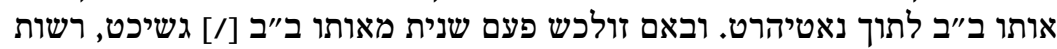
לממוני' בצירוף אב"ד נר"וך לאטירור ובאם זינו.

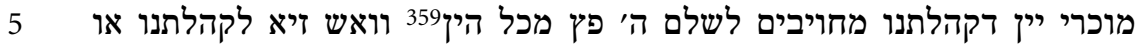

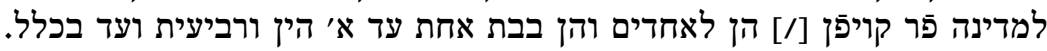

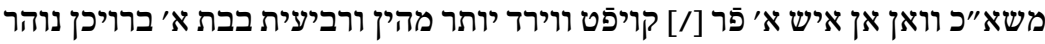

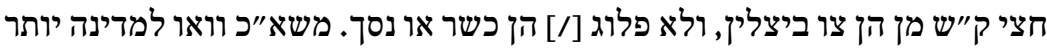

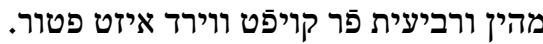

שארי ב״ב וועלכי יין לצורך ביתם ברענגן לאזן אונד ניט פָר קויפן, מוזן מכל הין תכ"ה

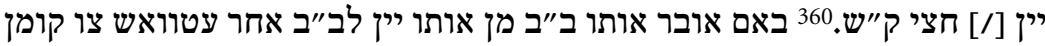

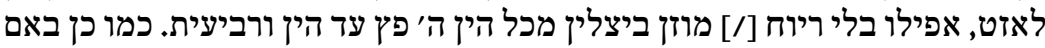

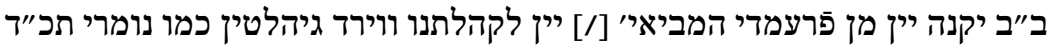

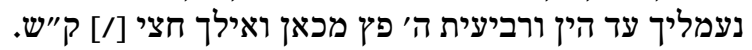

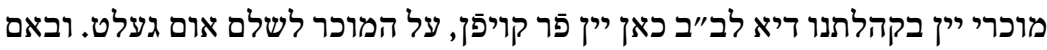
תכ"ו

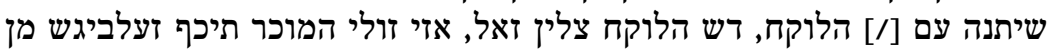

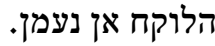

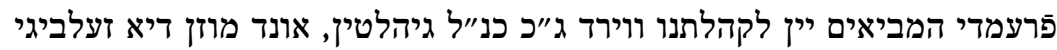
תכ"ז

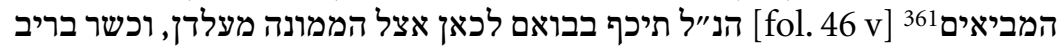

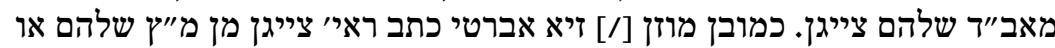

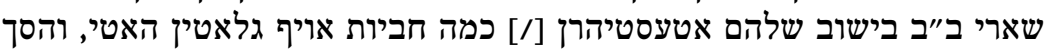

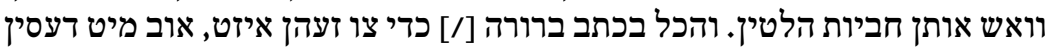

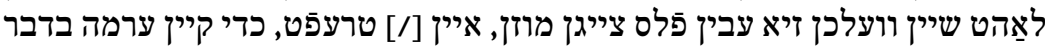

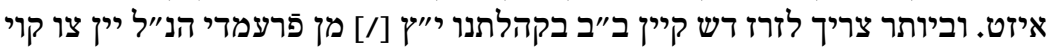

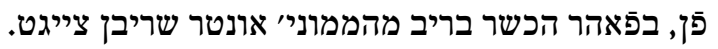

358 Von lat. per noto = wohlbekannt; hier wohl: zur Kenntnis.

359 Hohlmaß: 1 Hin entspricht in der Bibel ca. 3,6 Liter. Es ist schwerlich anzunehmen, dass die Fürther Juden diese Einheit in ihrer ursprünglichen Menge kannten oder zusätzlich zu der Vielzahl der damals gebräuchlichen Hohlmaße noch eine eigene Maßeinheit verwendeten. Wahrscheinlicher ist, dass es sich hierbei um die Entsprechung für einen Seidel (ca. 0,53 Liter) oder eine Kanne (je nach Region 1 bis 2 Liter) handelte.

360 Der Satz bleibt unvollendet; hier müsste noch erscheinen: »zahlen«.

361 Danach die Kustode הנית. 


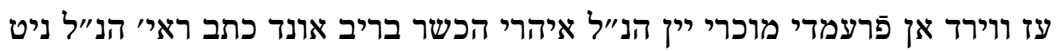
תכ"ח

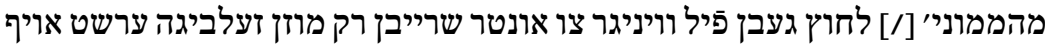

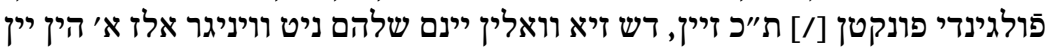

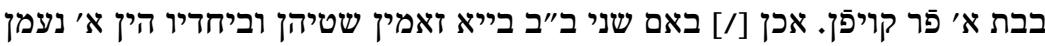

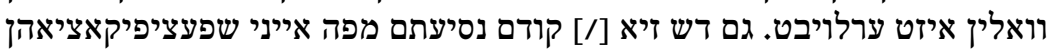

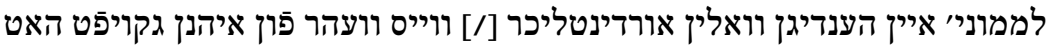

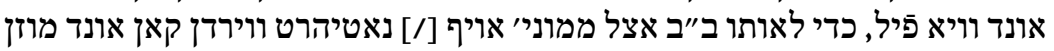

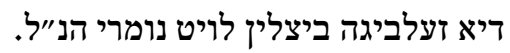

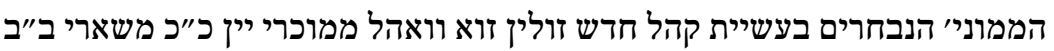

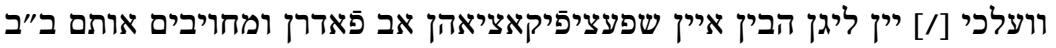
תכ"ט

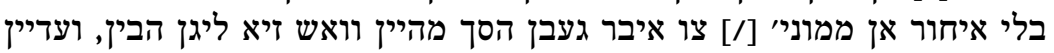

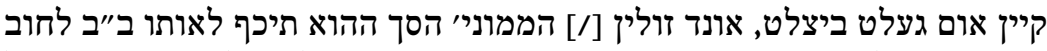

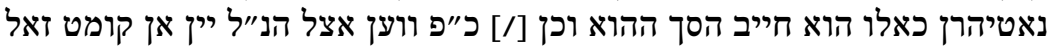

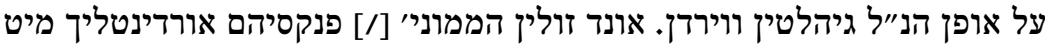

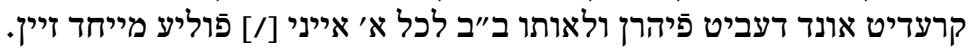

כל ג' חדשים מחוייבים מוכרי יין למסור חשבונם להממוני׳ וויא פַיל יין לאחדים ת"ל

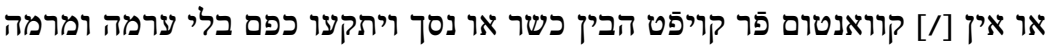

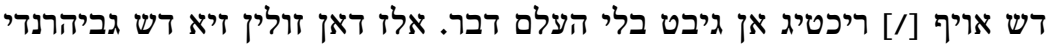

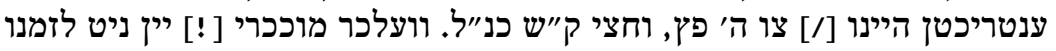

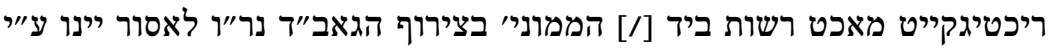

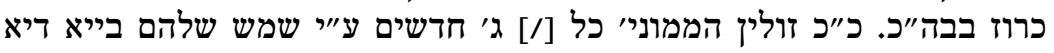

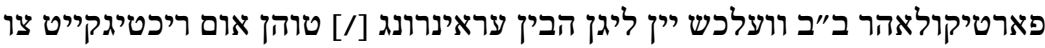

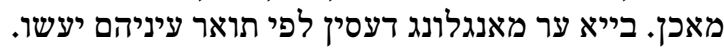

רשות לממוני' זיך מיט מוכרי יין צו פَר שטיהן מיט יעדרץ אב זונדר צו אקארטיהרץ תל"א

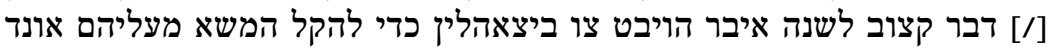

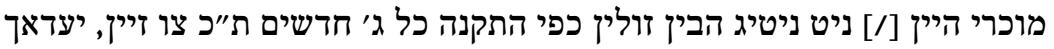

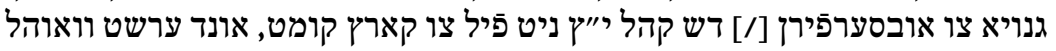

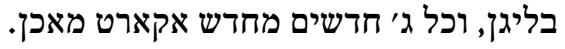

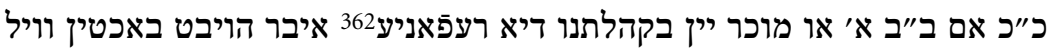
תל"ב

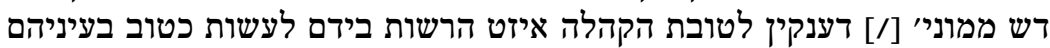

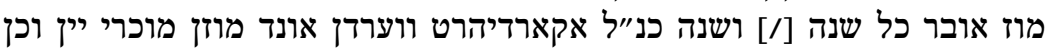

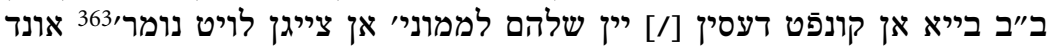

362 Deponie? Hier könnte ein gemeindlicher Weinvorrat gemeint sein. Das Verb »beachten« hätte dann hier die Bedeutung von »beaufsichtigen«.

363 Die Paragraphennummer fehlt. 


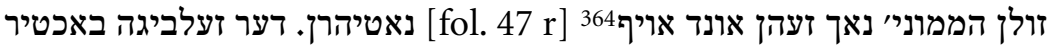

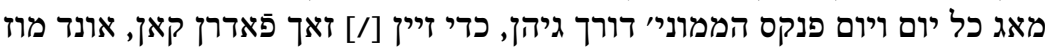

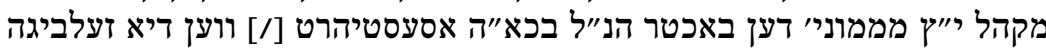

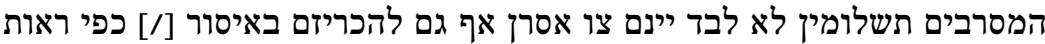

עז הבין הממוני' כח ורשות כטוב בעיניהם איין ציין צו אורדן באיזה אופן השגחה תל"ג

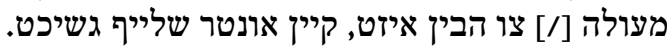

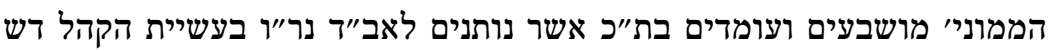

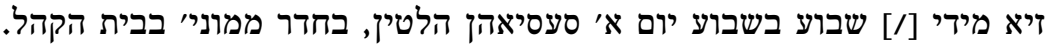

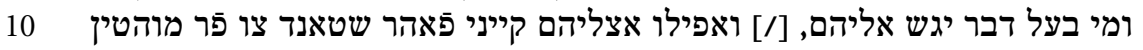

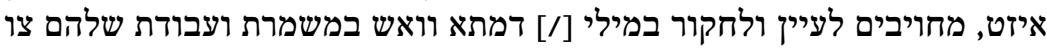

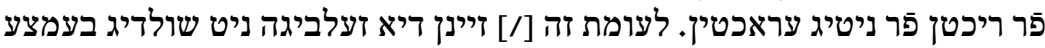

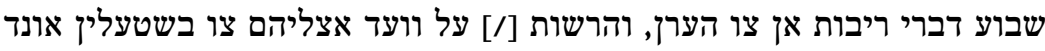

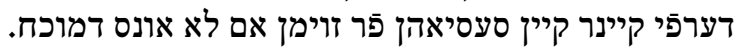

עז זולי תיבה מיוחדת לממוניי זיין, וכל כתבים ופנקסאות אונד באהר שאפט

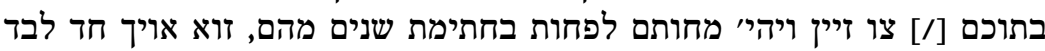

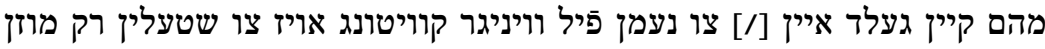

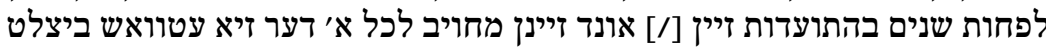
קוויטונג צו געבן והכל צו שפעציפוציהרן.

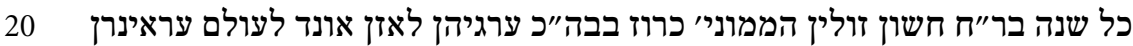

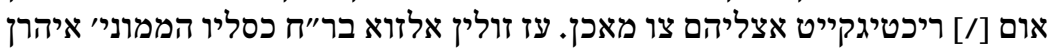

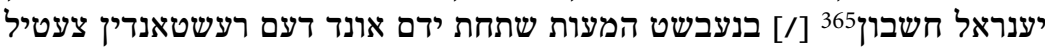

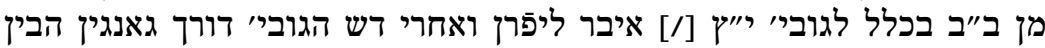
מחויבים דאריבר צו קוויטיהרן.

אותן הממוני' דיא בהתמניות הקהל חדש פּון איהרן אמט הירונטר קומן זירפ זיינן תלל"ח

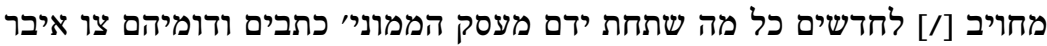

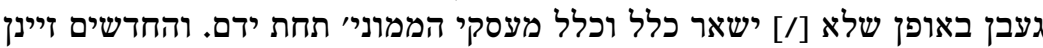

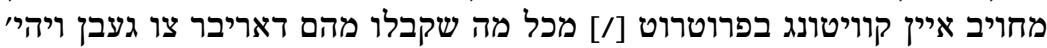

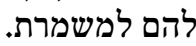

364 Danach die Kustode נאטיהרן.

365 Generalrechnung. 
כל דבר מאכל ומשקה יהיי מה שיהיי הן מה שנאכל חי או מבושל וואש אורחי' תל"ט

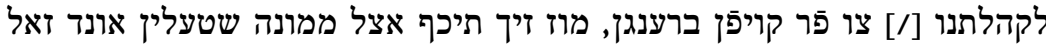

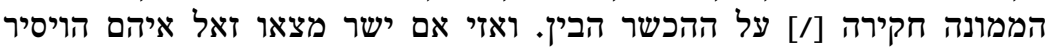

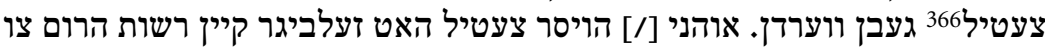
גיהן, ושמש הממוניי ישגיח על זה.

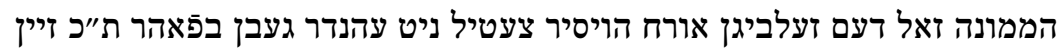
ת"מ

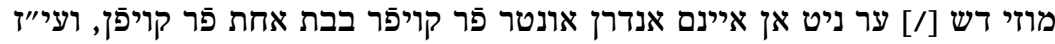

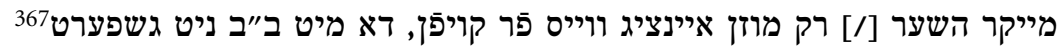

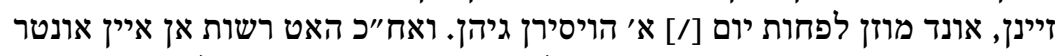

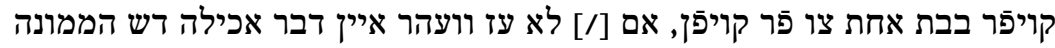

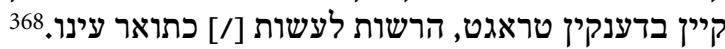

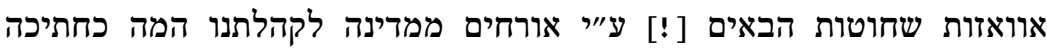
תמ"א

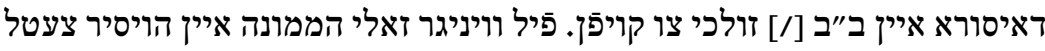

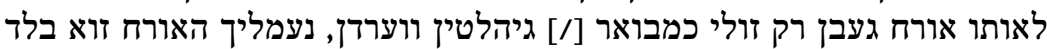

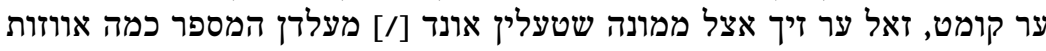

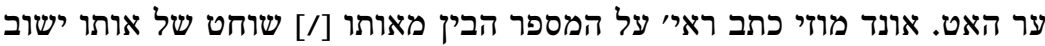

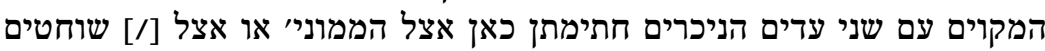

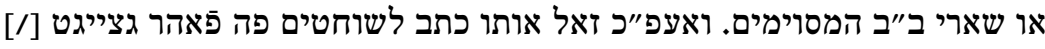

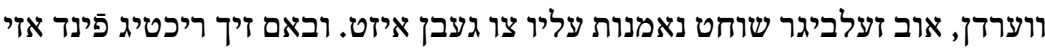

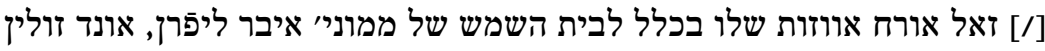

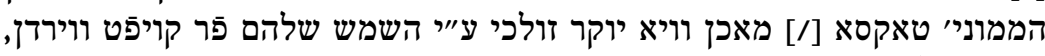

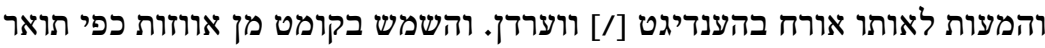

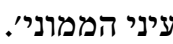

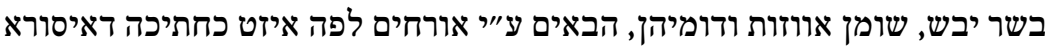
תמ"ב 25

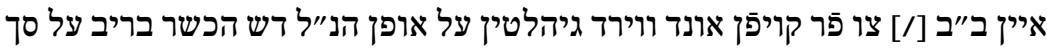

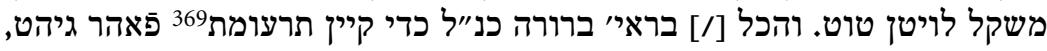

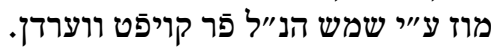

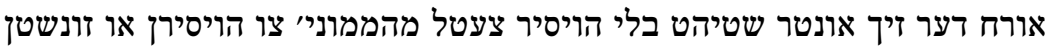
תמ"ג

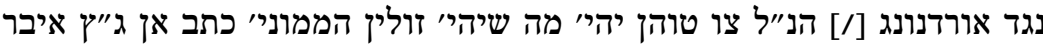
30

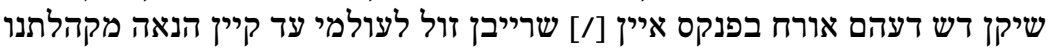

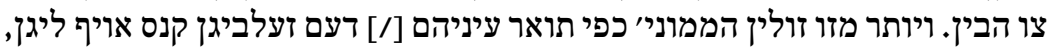

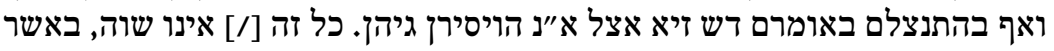

366 Hausierzettel, schriftliche Erlaubnis zum Warenverkauf durch Hausieren.

367 Gehemmt.

368 Danach die Kustode אווזות.

369 Beschwerde. 
על ידי זה קלקולים וערמה גשעהן קאן. ועל איזה אופן שתהיי מוזן [/] זיא כ"פ איין הויסיר צעטיל הבין.

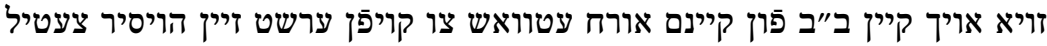

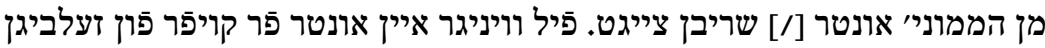

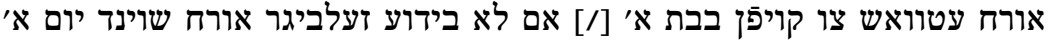

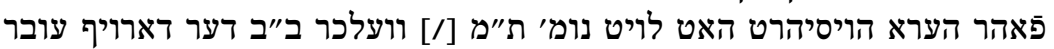

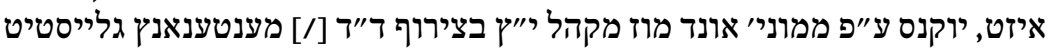

ווערדן.

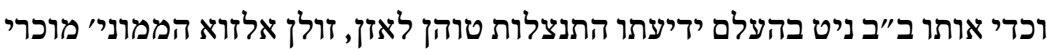
תמ"ה

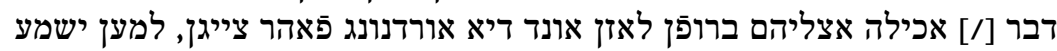
אונד פَר קנס [/] אין אכט נעמילין, ות״כ מהם מהם אב נעמן.

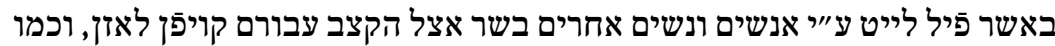
תמ"ו

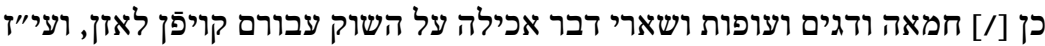

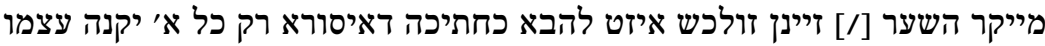

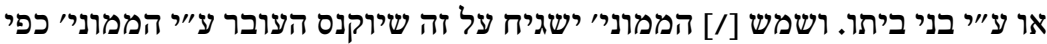

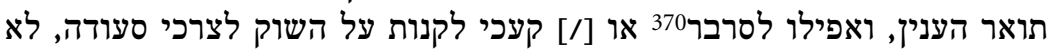
הותר כי אם בעל סעודה א' מבני ביתו מיט שיקו מכי לקוז.

תמ"ד [fol. $48 \mathrm{r}$ ] חדשים מקרוב באו ${ }^{371}$ דש ב״ב לאותן כפריי המביאים עץ למכור אין גיגן גיה גיהן, תמ"ז

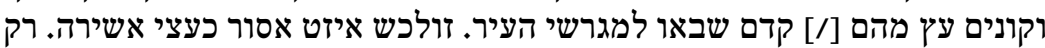

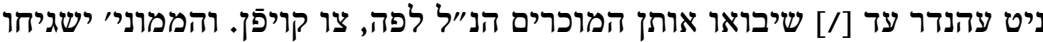
ע"ז לקנוס להעוברים כראוי.

הממוניי ישגיחו, באם הקצבים מיקרים שער בשר או מיקר, וכן אם מוכרי דגים

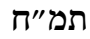

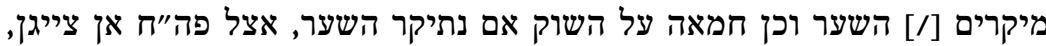
ויוכרז בבה"כ מי [/] שיעלה בדמים לקנות יהיי כמו חתיכה דאיסורא.

מעלבר372 מוכרי קמח אשר כאות נפשם מוכרים הקמח בשער הגובה ולפעמים תמ"ט

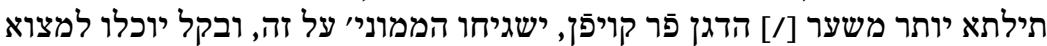
מבוא הדרך דש זעלביגי מאליהם [/] אום גרינגן פופר פרייס פָר קויפן מוזן.

לא הותר לב״ב דבר אכילה כמו פירות מבושלים כמו כן גקאכטז מן חלב פלי ודומיהן

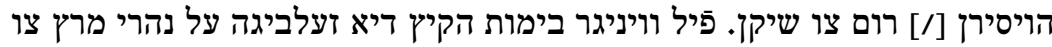

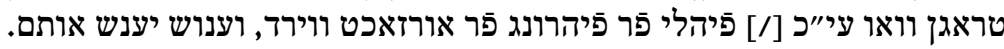

370 Servierer.

371 Dtn 32,17.

372 Mehlverkäufer? 


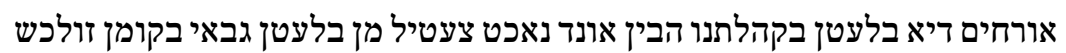

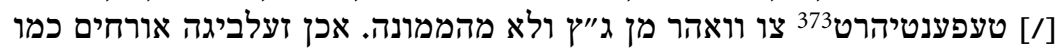

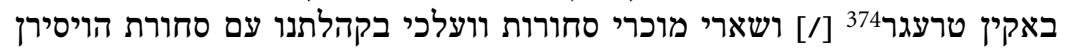

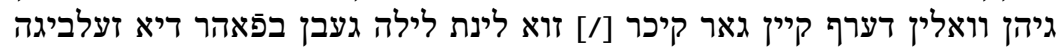

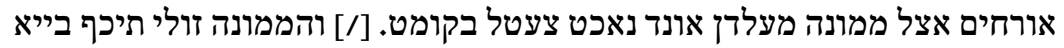

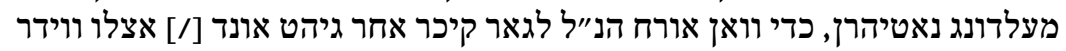

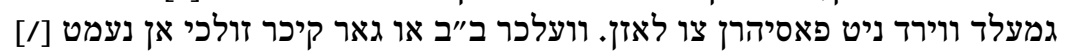

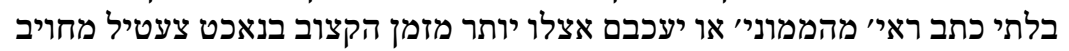

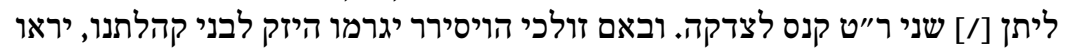

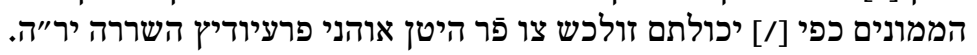

תנ"א

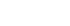

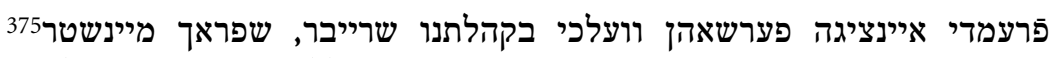

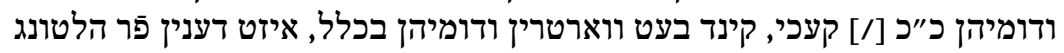

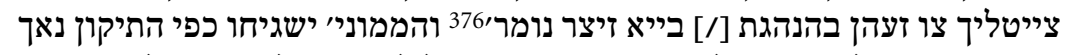
צו קומן דש זעלביגה ניט לענגר [/] מזמן זירן המוגבל להם בקהלתנו פַר בלייבן.

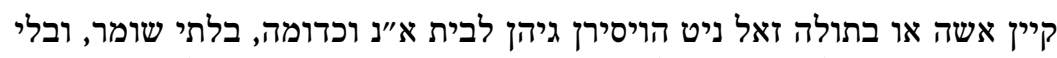

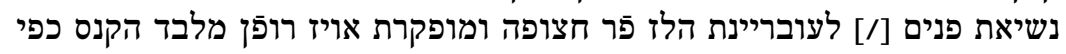

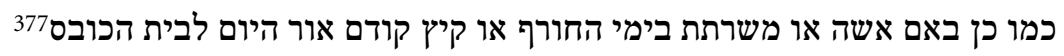

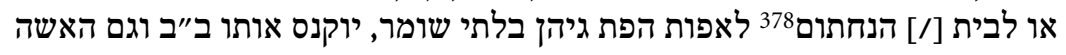

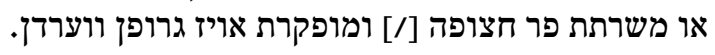

תנ"ד

כבר צווחו קמאי379 על אפקרותאי380 דש אנשים ובחורים בשבת ובי"ט עומדים תנ"ה

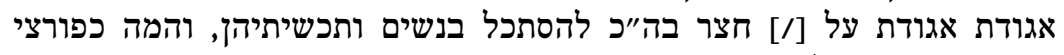

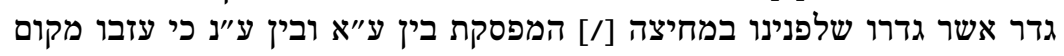

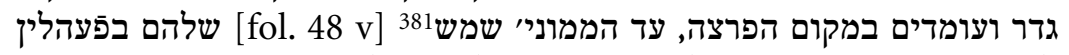

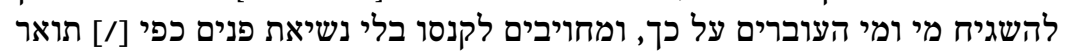

373 Dependiert.

374 baken treger $=$ Packenträger, Lastträger.

375 sprakh maynster $=$ Sprachlehrer.

376 Die Paragraphennummer fehlt.

377 Waschhaus.

378 Backhaus.

379 קמאי (aram.) = früher.

380 אפקרותא (aram.) = Missachtung.

381 Danach die Kustode שלהם אלתם. 


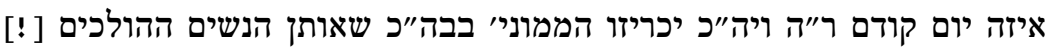

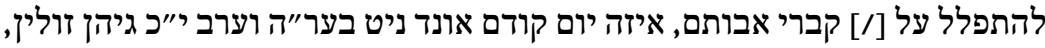

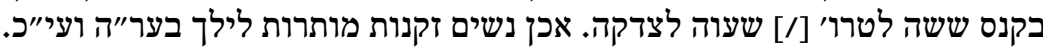

תשליך בר"ה מה טוב באם זולכר מנהג אצל נשים ובתולות פעליג אב גבאויכט תנ"ז

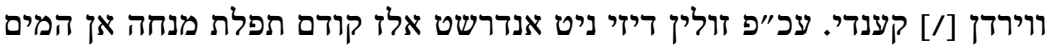

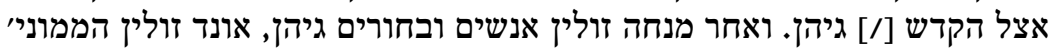

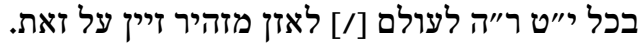

עז דערף קיין ב"ב אתרוג ולולב לעזרת נשים שיקן, בקנס ג' ליטרות שעוה לצדקה.

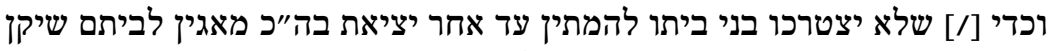

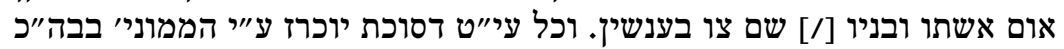
ויזהירו על זה.

באשר זיך נשים שאינן מהוגנות בעזרת נשים בשמחת תורה בדברי פריצות צו [/] ליפוים

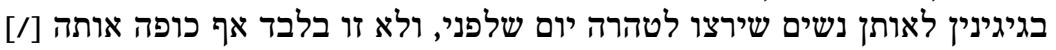

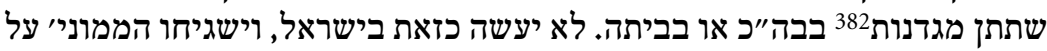

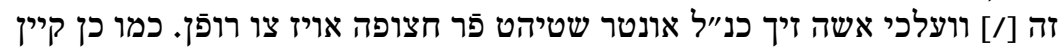

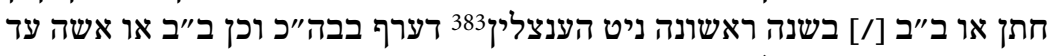
סעודה ניכט צו הענצלין.

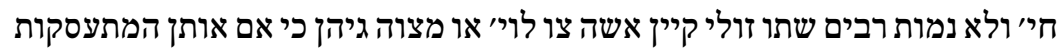

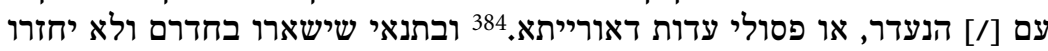

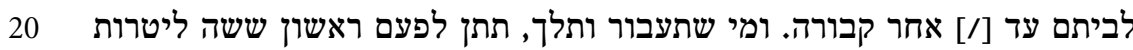

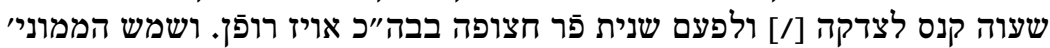
ישגיח ע"ז אונד אן צייגן.

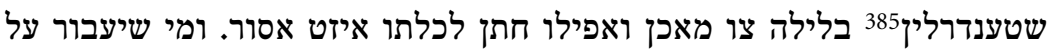
תס"א

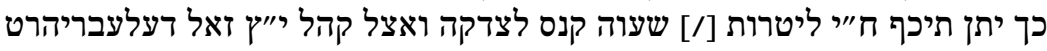

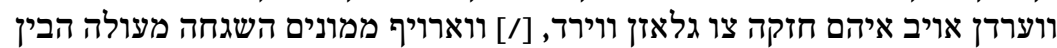

מוזץ.

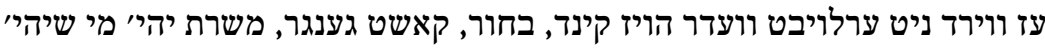
תס"ב

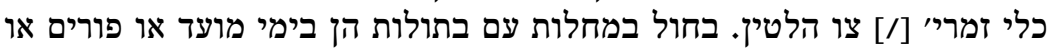

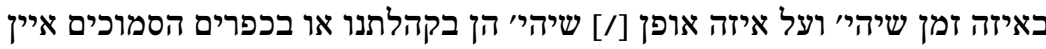

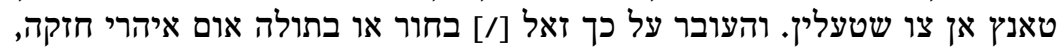

\footnotetext{
382 Süßigkeiten.

383 Bedeutung unklar.

384 Nahe Verwandte.

385 Ständchen.
}

תנ"ך

תנ"ח

תנ"ט

ת"ס 
שבתות בחור אום זייני שבתות גקנסת ווערדן, קאשט גענגר [/] ומשרת ומשרתת

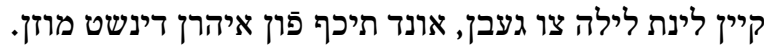

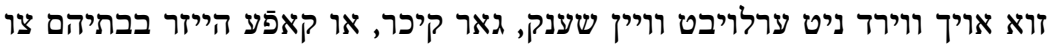
תס"ג

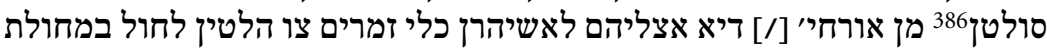

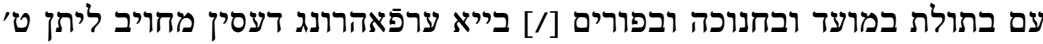

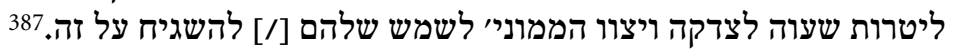

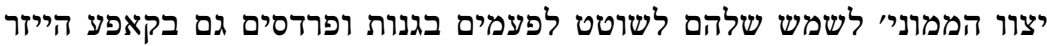
תס"ד

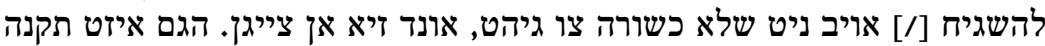

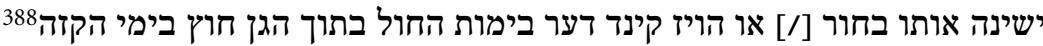

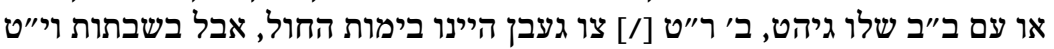

מותר לילך.

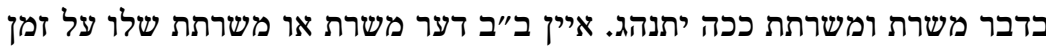
תס"ה

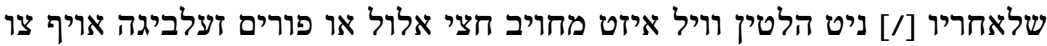

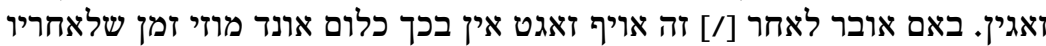

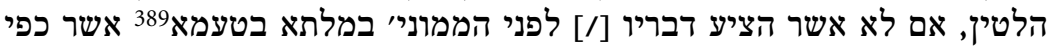
ראות עיניהם ישפוטו.

באם איין ב״ב לזמנו אויף גזאגט האט ואותו משרת או משרתת למקום אחר תס"ו

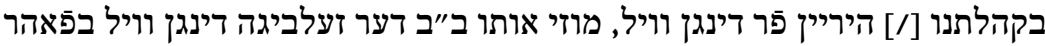

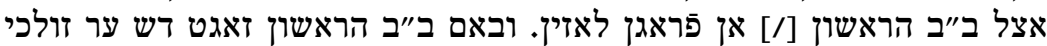

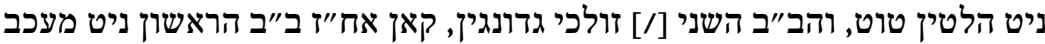

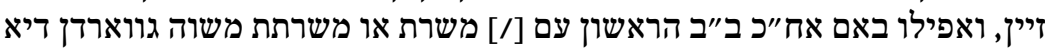

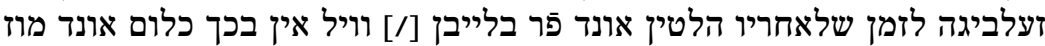

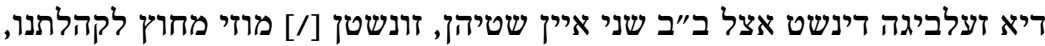

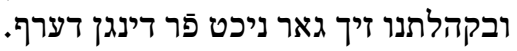

באם ב״ב משרת או משרתת שלו הלטין וויל אונד זיא ניט אצלו בלייבן וואלין, תס"ז

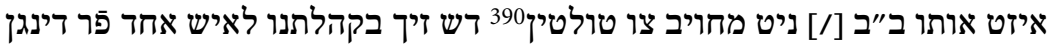

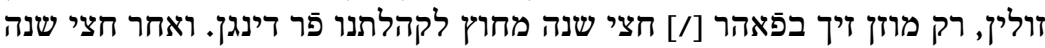

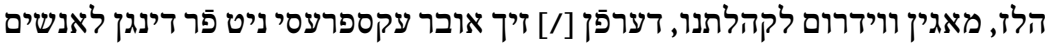

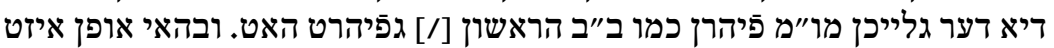

386 soltn = besolden, beschäftigen.

387 Danach die Kustode יצוי.

388 Hebr. hakaza bezeichnet »Aderlass«. In welchem Zusammenhang sich diese Bedeutung hier einpasst, ist unklar.

389 במלתא בטעמא (aram.) = mit begründeten Worten.

390 Dulden. 
ב"ב הראשון ניט מחויב זעלביגה איין שטיהן צו לאזין, רק [/] איזט מחויב מיות אותו

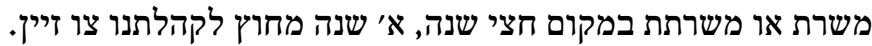

בני או בנות בייא זיצר דערפَן צו קייני דינשטן מב״ּב בקהלתנו אן גנומן ווערדן, תס"ח לויט [/] הנהגות בייא זיצר נומר'.391 בנרי דיני

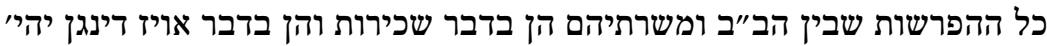
ת"ע

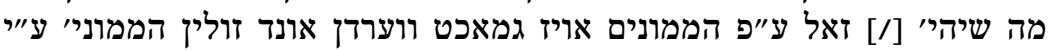

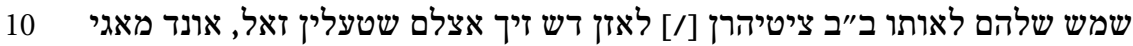

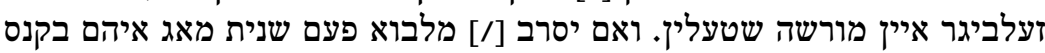

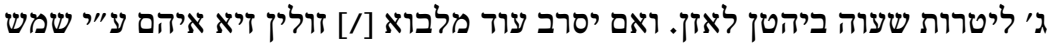

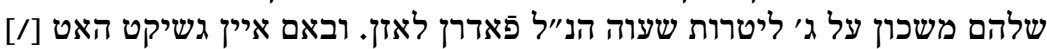

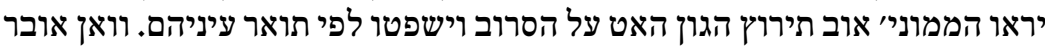

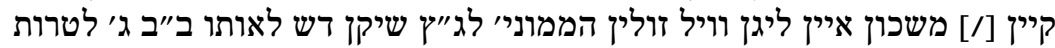

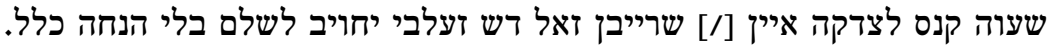

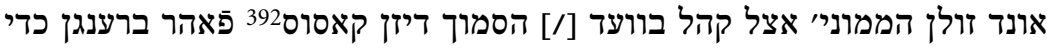

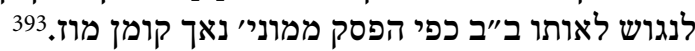

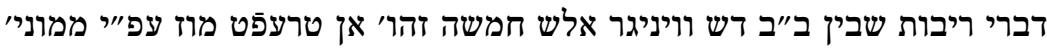
תע"א

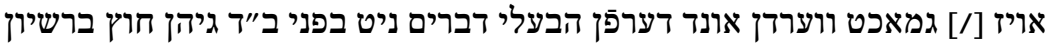
הממוני' [/] כמבואר בהנהגת דייני' נומ'.

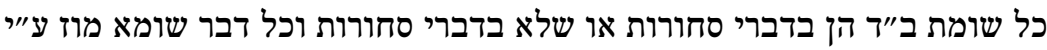
תע"ב

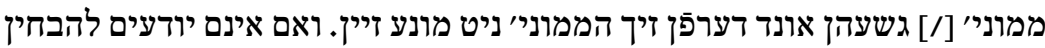

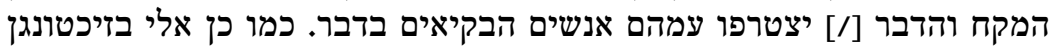

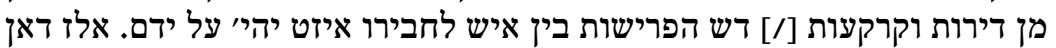

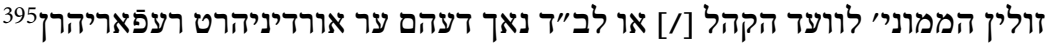

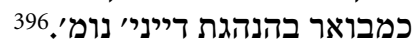

391 Die Paragraphennummer fehlt.

392 Casus (lat.) = Fall.

393 Danach die Kustode דברי

394 Die Paragraphennummer fehlt. 395 Referieren.

396 Die Paragraphennummer fehlt. 


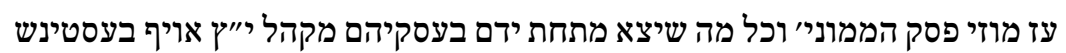
תע"ג

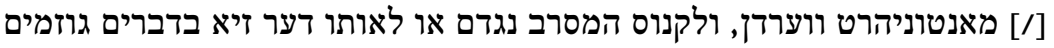
בגיגנט [/] בקנס לפי תואר הענין צו קנסקסן.

הנהגות מלבושים

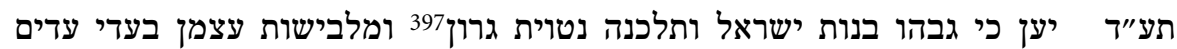
וישמחו [/] אל גיל בעמים.

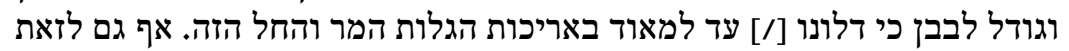

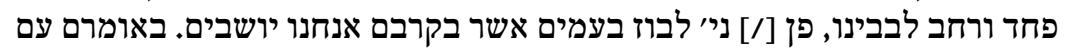

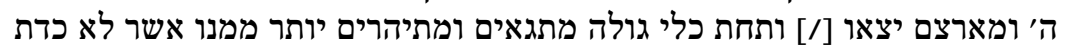

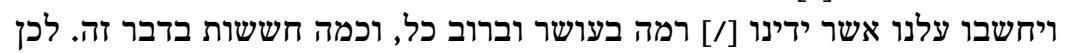

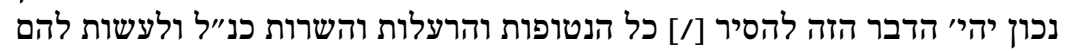

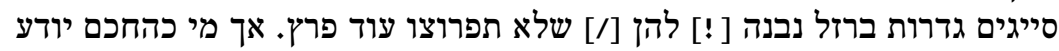

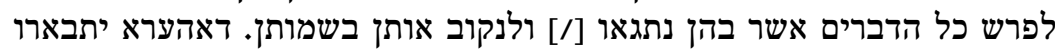

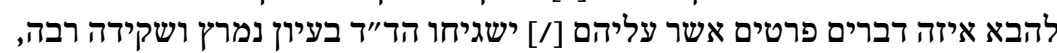

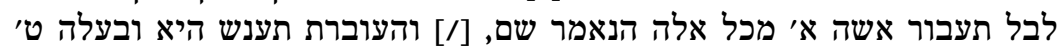

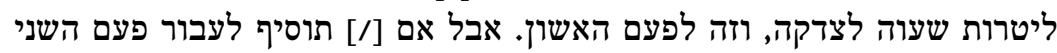

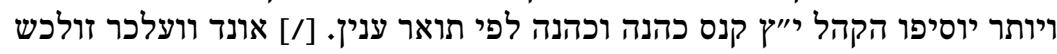

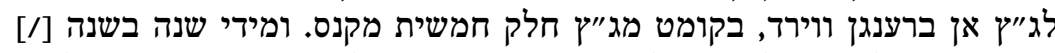

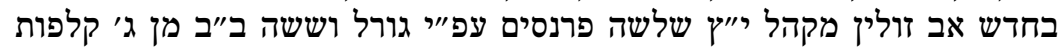

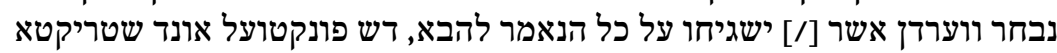

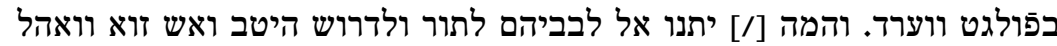

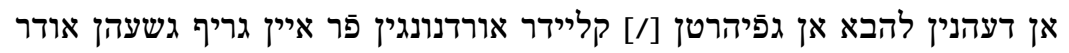

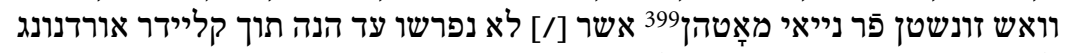

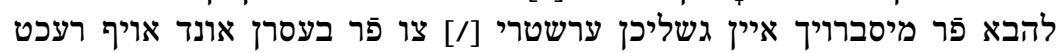

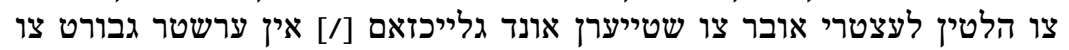
ערשטיקן.

[fol. $50 \mathrm{r}$ ]

תע"ה כסף וזהב איזט נור אויף הייבליך

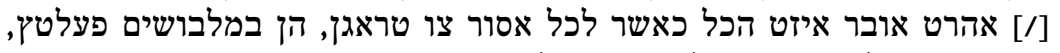
קרעגן, [/] הלז טיכר, מנעלים

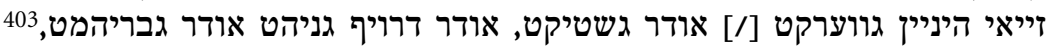

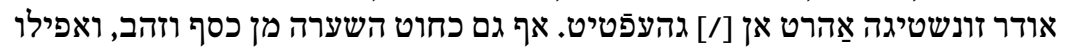

\author{
397 Jes 3,16. \\ 398 Nach Hos 9,1. \\ 399 Moden. \\ 400 Häubchen. \\ 401 Eine Art Kopfbedeckung. Siehe auch $\$ 479$. \\ 402 Schuhe. \\ 403 gebrihmt = verbrämt.
}




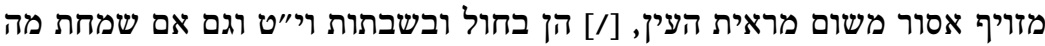

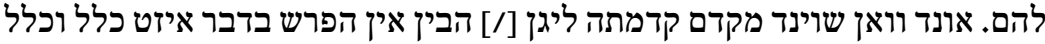
אסור מחוץ לחדרם צו טראגין.

בטבעתיי ונזמי ארוץ404 גם קאָרדיל שטיין405 זיינן אבנים יקרות אודר יובעלין איזט תע"ו

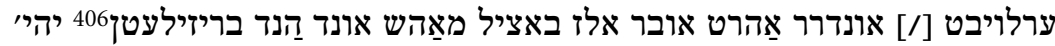
מה שיהיי איזט [/] אסור צו טראגן, ואפילו זיופים איל אסורים משום מרום מראית העין.

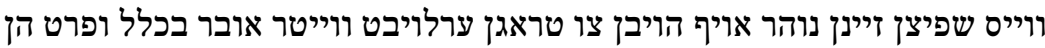
תע"ז

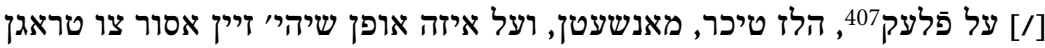

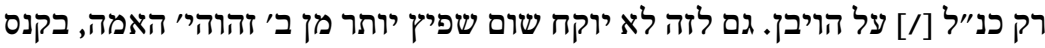

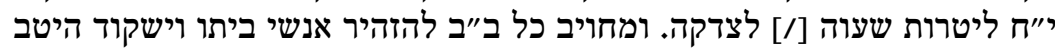

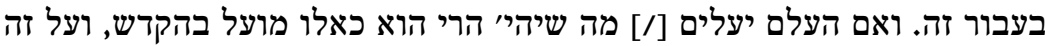
נאמר וכיוצא בזה ויראת וגור'.408 ואלים

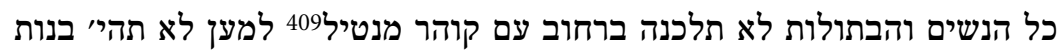
תע"ח

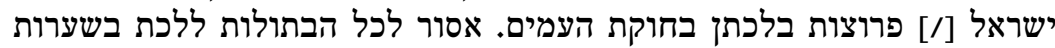

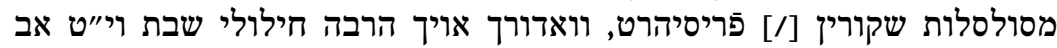
גווענדיט ווערדן. והעוברת על [/] א' מכל הנאמר למעלה תעורי הער בקנס הנ"ל. אשה אשר אין לה בנים נשואים דערף בטרם כלות ך"ה שנים מעת חתונתה ניכט תע"ט [/] אוהני שטערנלי לבה"כ גיהן נשואים

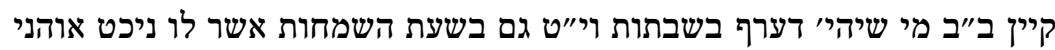
ת"פ

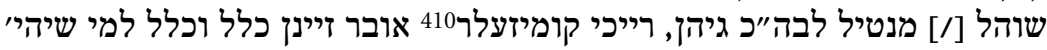
ובאיזה אופן [/] שיהי' אסור ברחוב צו טראגין.

הנהגות סעודות במספר הקרואים להסב לסעודת מצוה זול פַולגינדי פַר אורדנונג גמאכט ווירדן.

\footnotetext{
404 Ohrschmuck.

405 An einer Kordel befestigter Schmuckstein.

406 Schmuckgegenstände, genaue Bedeutung unklar.

407 Stoffstück.

408 וגומר

409 Bedeutung unklar, jedoch ist anzunehmen, dass es sich dabei um einen kurzen

Mantel handelte, der nicht den üblichen Vorstellungen über züchtige Kleidung von

Frauen und Mädchen entsprach.

410 Kamisol, westenartiges Kleidungsstück.
} 


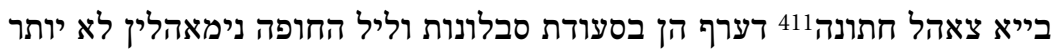
תפ"א

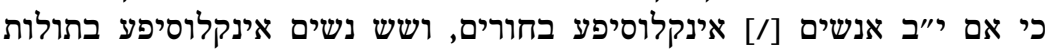

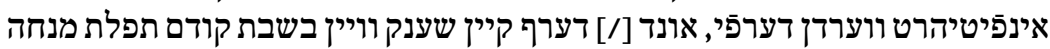

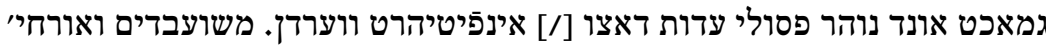

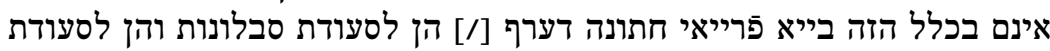

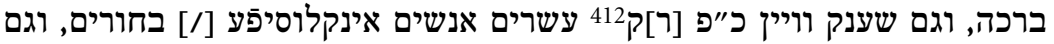

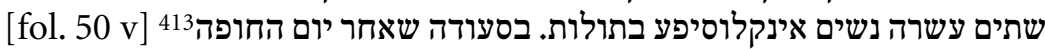

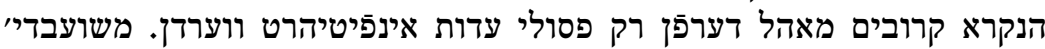

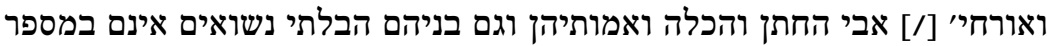
הנ"ל.

תפ"ב ברית מילה דערפן רק ט"ו אנשים אינקלוסיפע, הסנדק והמוהלים אורחי' ומשועבדי' [/] אינם בכלל.

בר מצוה רק ט"ו אנשים, ונשים כלל וכלל לא. משועבדים ואורחי' אינם בכלל, בר פורים תפ"ג - (- n מצוה [/] פר שטיהט זיך הן עשיר בינוני או פחותי ערך כולם של שוים.

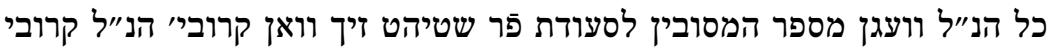
תפ"ד

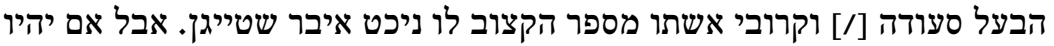

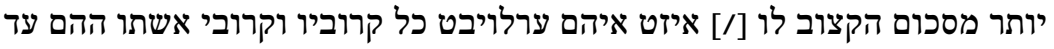

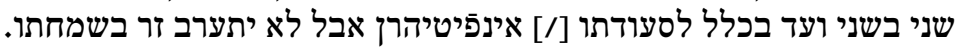

כל מקום שאתה מוצא ערוה אתה מוצא קדושה, תפ"ה

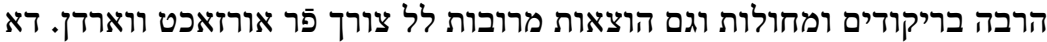
20

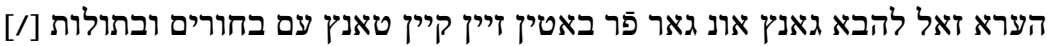

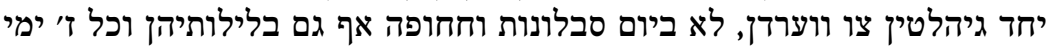

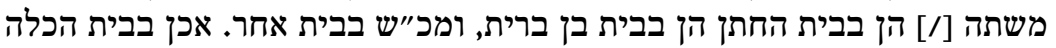

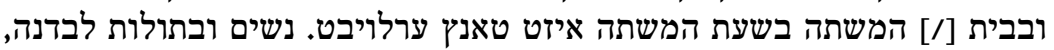

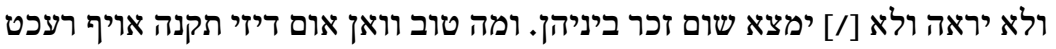

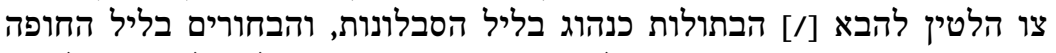

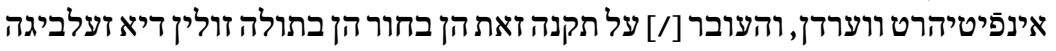

411 Eine Hochzeit von Unvermögenden oder nicht Ortsansässigen, die speziellen Regeln unterworfen war, um die finanzielle Belastung für die Familien von Braut und Bräutigam niedrig zu halten. Der sonst übliche Begriff in deutsch-jüdischen Gemeinden war Zehr-Hochzeit. Siehe Heinz Mosche Graupe (Hg.), Die Statuten der drei Gemeinden Altona, Hamburg und Wandsbek. Quellen zur jüdischen Gemeindeorganiation im 17. und 18 Jahrhundert, Bd. 1, Hamburg 1973, 163, Anm. 257.

412 Verschmutzte Stelle durch verwischte Tinte von der Zeile darüber.

413 Danach die Kustode הנקרא.

414 Nach Midrasch Levitikus Rabba, 24,6. 
בקנס חמור כפי תואר הענין [/] בלאנגט ווערדן וגם הבעל סעירודה וגירי וגם הלצנים והמזמרים וכל המסייעים לדבר העבירה [/] ההיא ווער יענשו.

ולמען עשה משמרת למשמרת זאל בייא קייני חתונה ערלויבט זיין להושיב אנשים תפ"ו

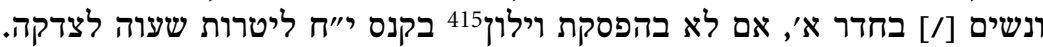

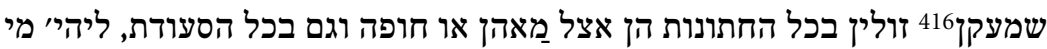
תפ"ז

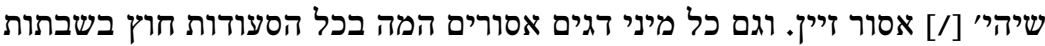

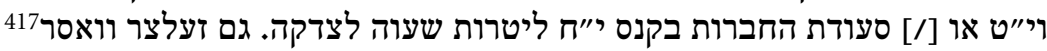
אסור בקנס הנ"ל.

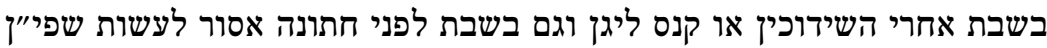
תפ"ח

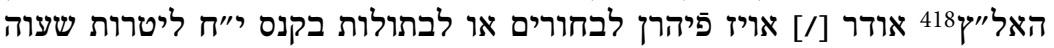

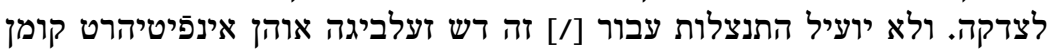

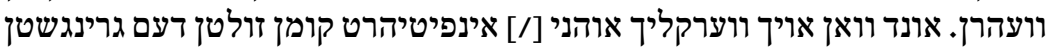

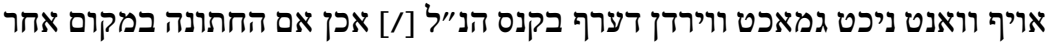
איזט בשבת שלפני הנשואין שפין האלץ ערלויבט.

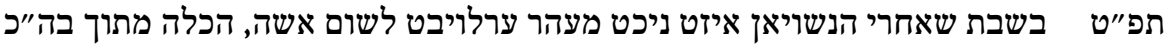

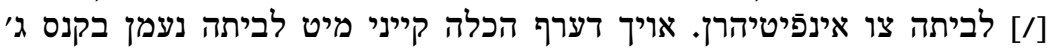
ליטרות [/] שעוה לצדקה.

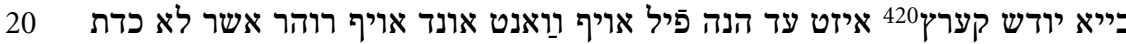
ת ת

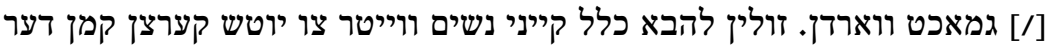

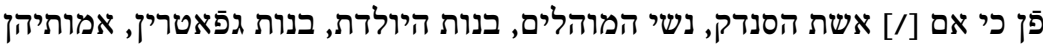

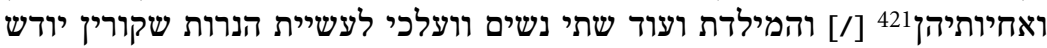

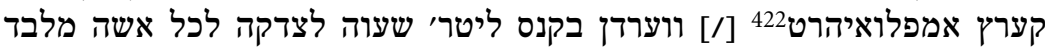

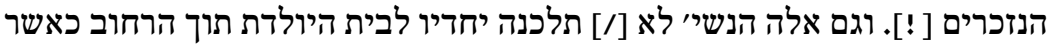

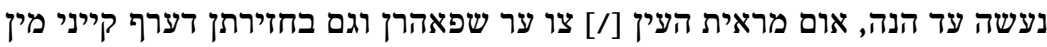

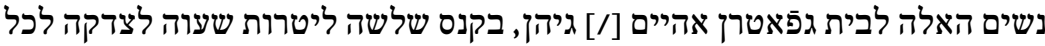

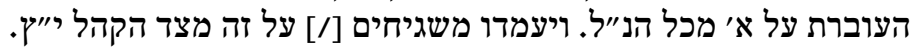

415 Durch Aufhängen eines Vorhangs, der den Raum teilte.

416 Tabak schnupfen.

417 Selterwasser.

418 Feier der Verlobten kurz vor der Hochzeit.

419 Danach die Kustode בשבת.

420 Feier anlässlich Herstellung von Kerzen für die Beschneidung.

421 In der Handschrift: ואיותיהן.

422 Von frz. employer = beschäftigen. 


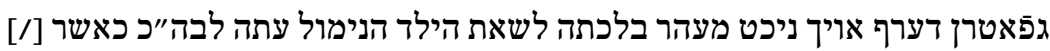
ת ת

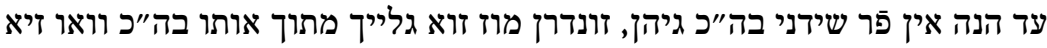

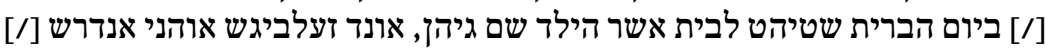
אב הוילין ולשאת אותו לבהכ"י בקנס לבית י"ח ליטרות שעוה לצדקה אם תעבור על זהת.

אצל יולדת בשבת צאתה מביתה לבה"כ דערף ווייטר נימנד מיט גיהן כי אם [/]

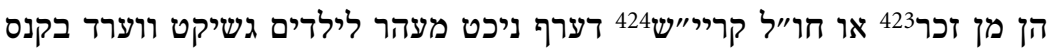

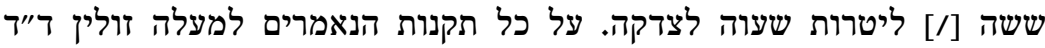

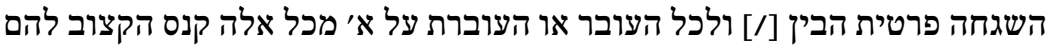

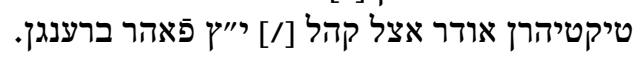

תקנות פרטיות

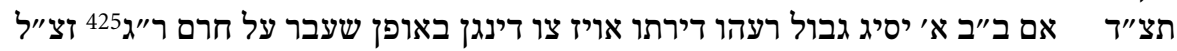

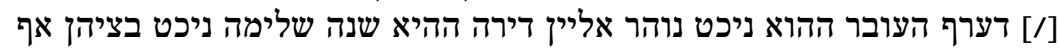

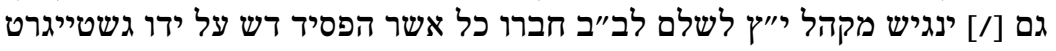

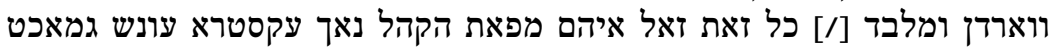
ווערדן.

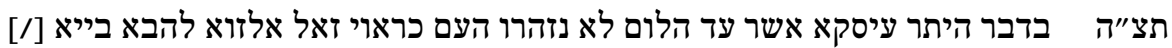

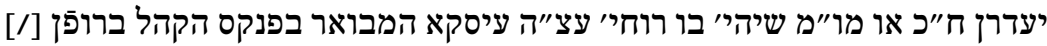

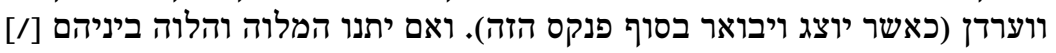
כך יהי' כאשר הקימו שטר עיסקא בסוף ביניהם.426.

תצ"ו אי לזאת נסלח אשר לא טובה השמועה אשר עם ה' מעבירים אשר רב וגדול שבר

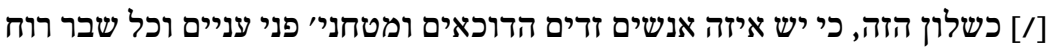

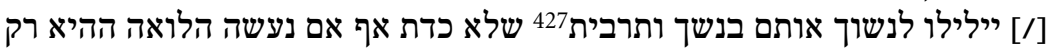

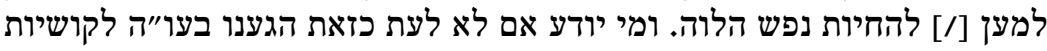

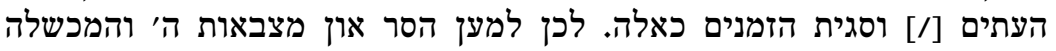
הזאת מקרבנו ויעיינו [/] הד"ד היטב בעבור זה בעינינים משון משוטטות וישיתו לבם ודמשלה

423 Symbolische Begrüßung eines männlichen Neugeborenen in der Synagoge am ersten Freitagabend nach der Geburt.

424 Namensgebungszeremonie.

425 Rabbenu Gerschom, Me“or ha-Gola (»Leuchte des Exils«, ca. 960-1028), berühmter Rabbiner in Mainz, der durch seine zahlreichen takkanot bekannt wurde, von denen viele bis heute Grundpfeiler der jüdischen Ethik darstellen.

426 Danach die Kustode אי לזאת.

427 Spr 28,8 . 
זה בשקידה האפשרית ואם [/] ישמעו שמץ מנהן

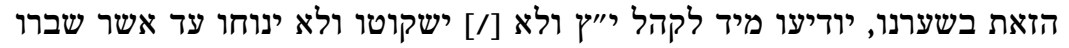

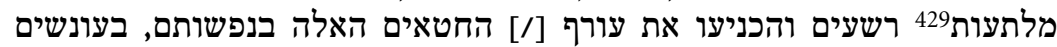

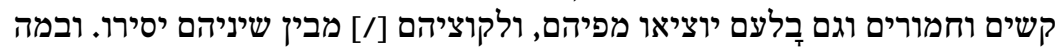

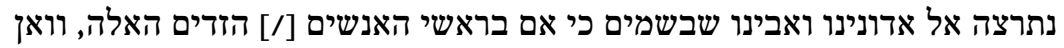

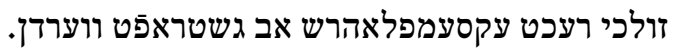

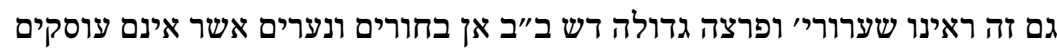

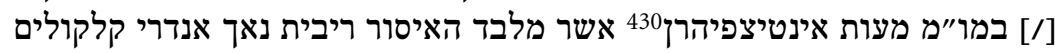

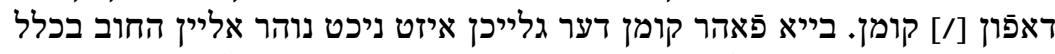

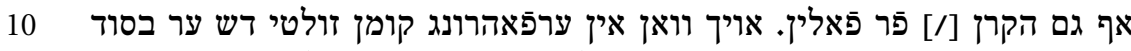

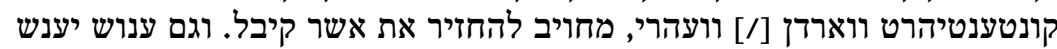

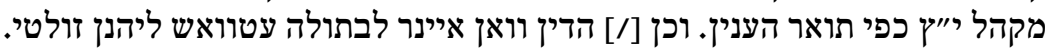

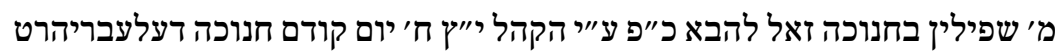
תצ"ח

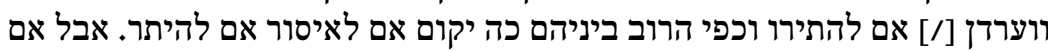

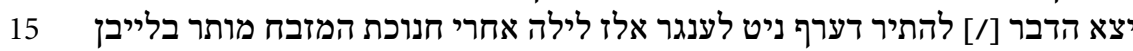

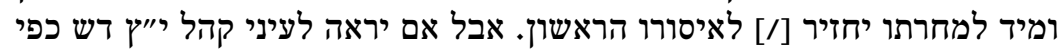

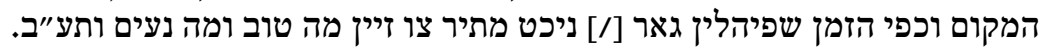

וואן ב"ב א' ומכ"ש פَרעמדר יהי' מי שיהי' עטוואש אויז בלעטן לאזן וויל ווירד

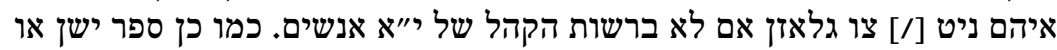

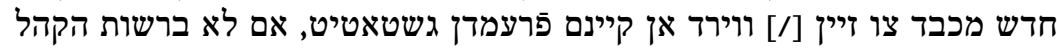

. ${ }^{\prime \prime \prime}$

כל דפוסי מדפיסים גיהנן קהל י"ץ לגמרי ניכטש אן וכל אשר נדפס על ידם

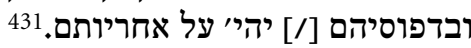

תצ"ט

תצ"ז

ת

תצ"ח

ת

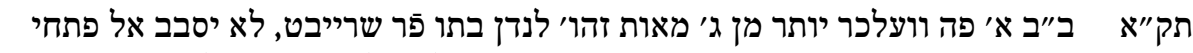

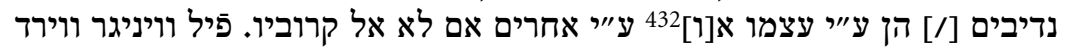

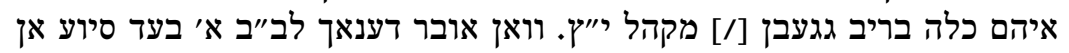

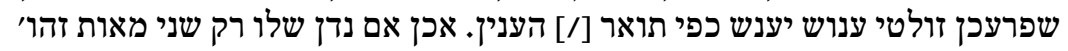

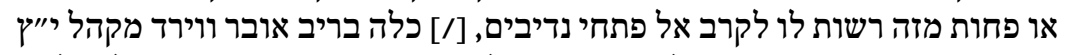

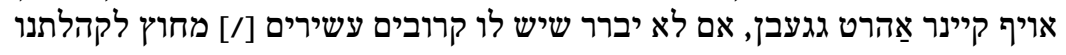

$428 \mathrm{Hi} \mathrm{4,12.}$

429 Davor gestrichen מתלעות.

430 Antizipieren (?), hier vielleicht in der Bedeutung von »vorschießen«.

431 Dieser Paragraph ist ein seltenes Zeugnis für die faktische Aufhebung der Druckzensur durch die Vorsteher der Gemeinde.

432 Das 1 fehlt in der Handschrift. 


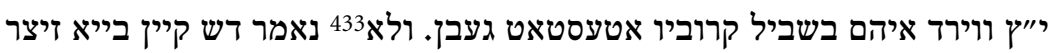

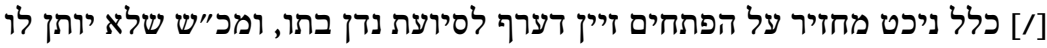
כלה בריב.434 כלל ניכט

[fol. $52 \mathrm{r}$ ]

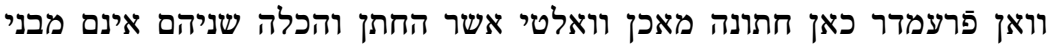
תק"ב

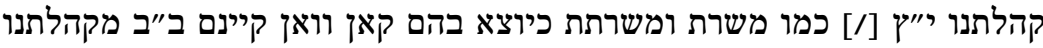

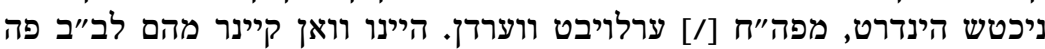

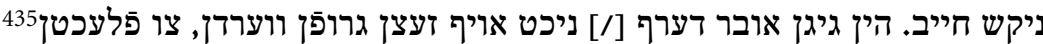
וגם לחופה אונד צו מאַהן

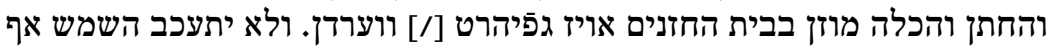

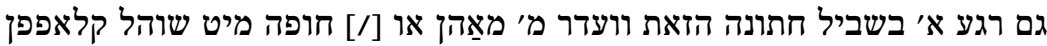

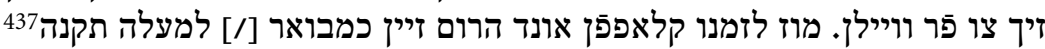

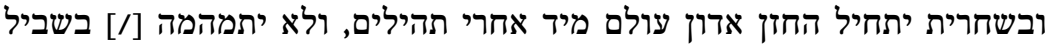

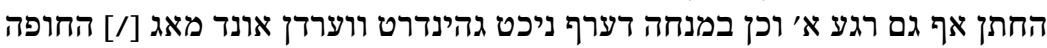

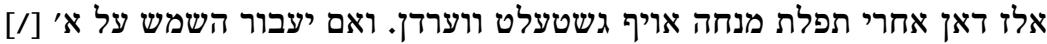

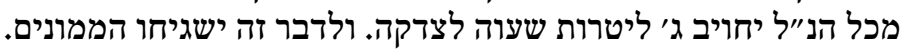

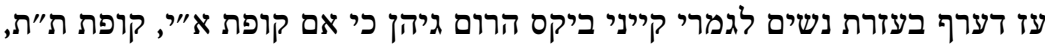
תק"ג

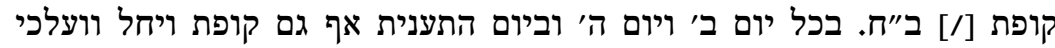

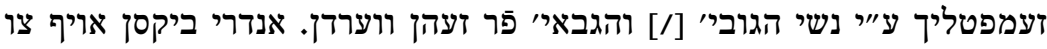

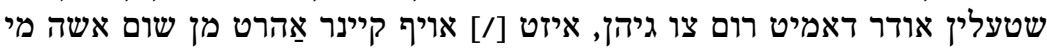

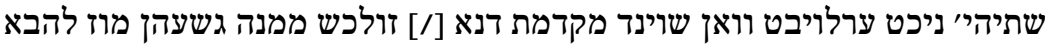

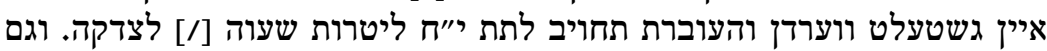
בעבור זה ישגיחו הממוני' היטב.

תק"ד עז דערף להבא קייני חברה לדבר טוב אויף גריכטיט ווערדן אם לא ברשות קהל

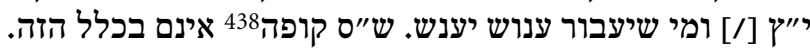

עז דערף קיין ב"ב לאורח קיינם יהי' מי שיהי' שענקן הן יין או שארי מיני מאכל הן

תק"ה בשבת [/] הן בי"ט בקנס ט' ליור ליטרות שעוה לצדקה.

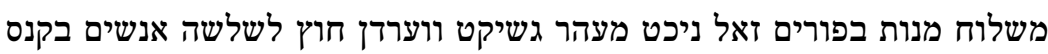

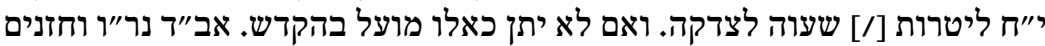

433 Davor gestrichen אם, das 1 wurde offenbar später hinzugefügt.

434 Danach die Kustode וואן.

435 Das Flechten der Haare der Braut vor der Hochzeit.

436 Mannführen.

437 Die Paragraphennummer fehlt.

438 Fonds für die Ausgaben, die durch das gemeinschaftliche Talmudstudium anfallen. 
עז איזט עד הנה עם מצבות גדולות וחזקות פילי מיסבירבויכט ווארדין וואדורך

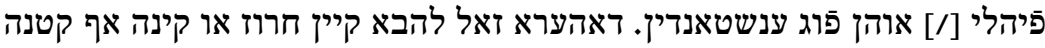

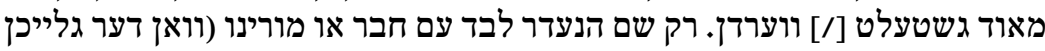

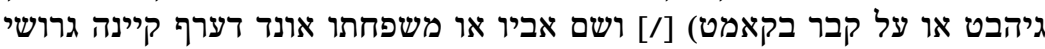

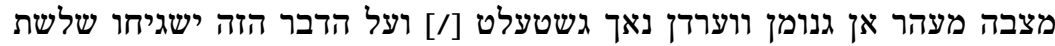

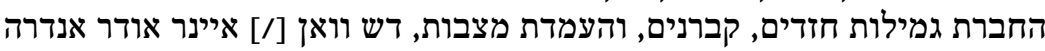

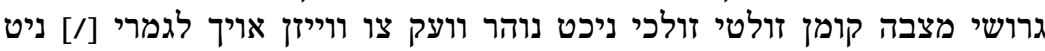

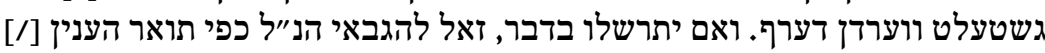
קנס גמאכט ווערדן.

10 [fol. $52 \mathrm{v}]$

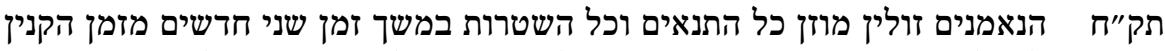

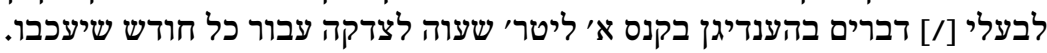

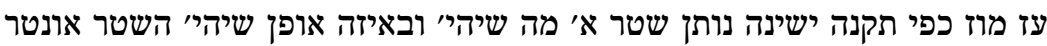

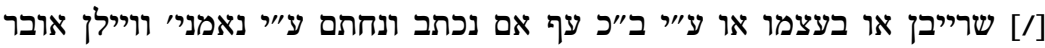

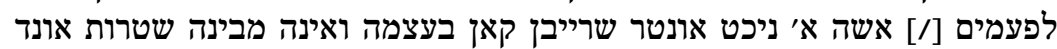

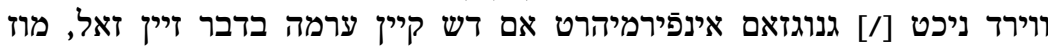

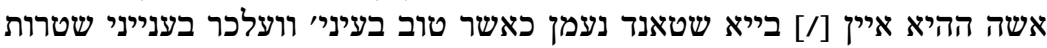

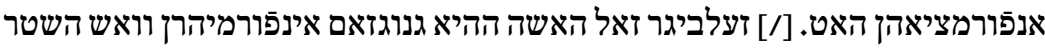

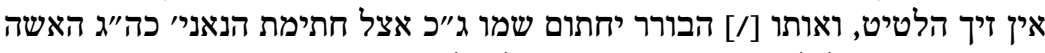

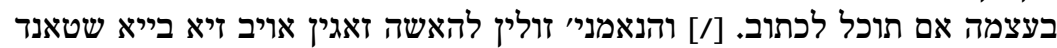

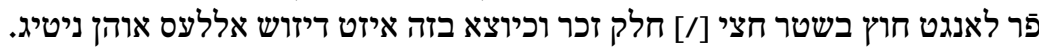

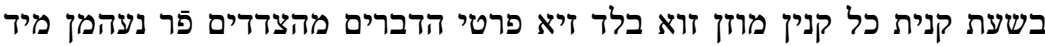

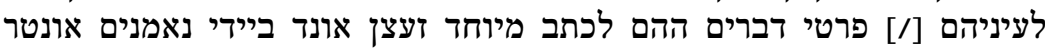

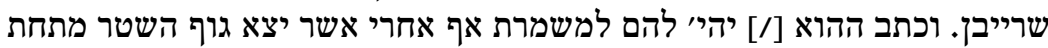
ידם יהי' אתו כתב הקנין [/] שמור לנצח, אום לעת הצורי למרך בדיהנן קענין.

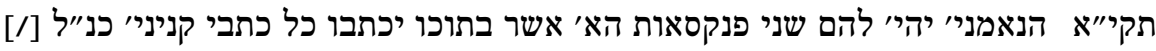

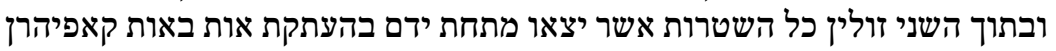

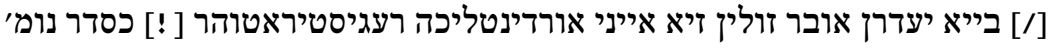
פיהרן.

תקי״ב אם יעכב ב״ב להנאמן ויסרב לחתום את השטר מוז עק מקהל י"יץ ע"י כפיות

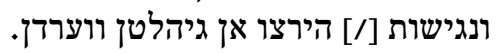

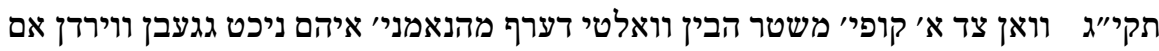

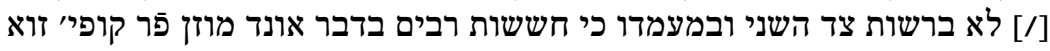

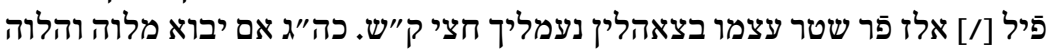

439 Danach die Kustode הנאמנים. 
אל הנאמן [/] אונד אן זאגן דש החוב כמשמעות השטר ריכטיג זייאי ומפנקי ומקס

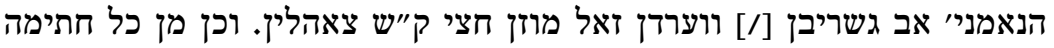

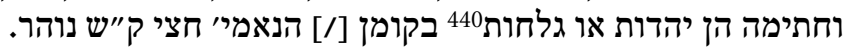

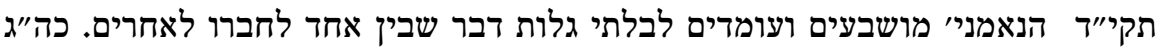

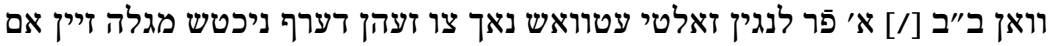

תקט"ו הנאמני' דערפَן אויף קיין פَר שטייג441 כלל ניכטש קויפَץ.442

[fol. $53 \mathrm{r}$ ]

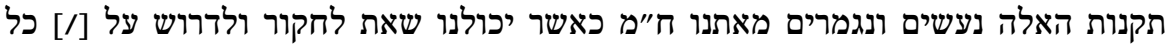

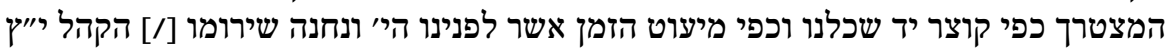

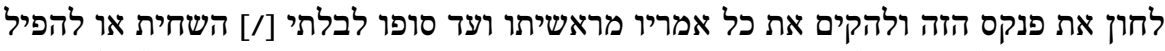

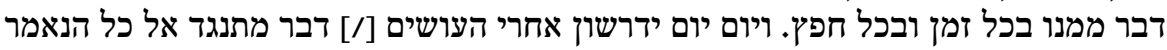

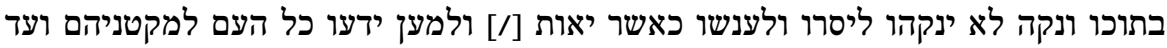

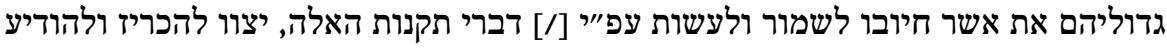

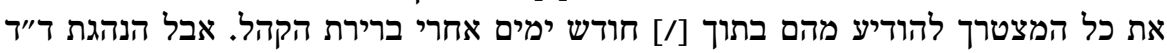

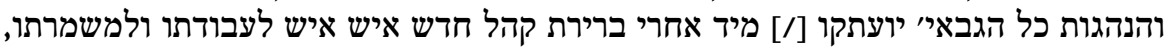

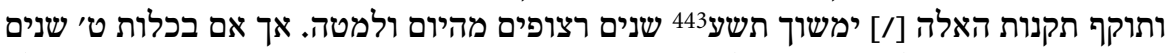

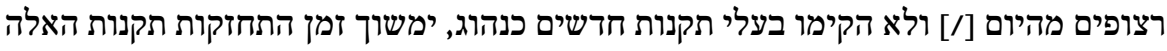

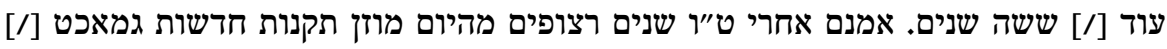

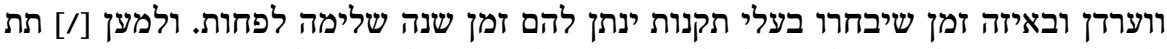

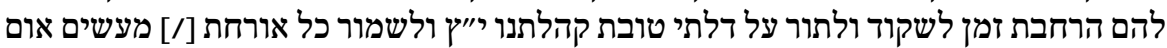

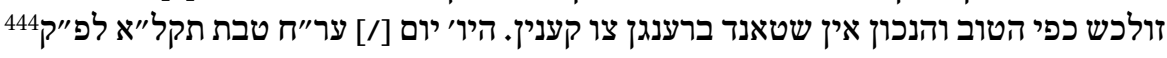

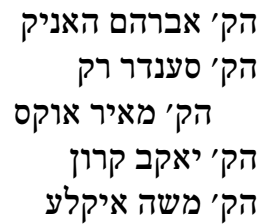

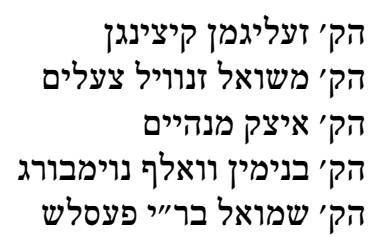

הק' זעליגמן קיצינגן

הק’ איצק מנהיים משואל הזיל

הק' שמואל בר"י פעסלי ורלי נימבור
הק' שמעון שוואבך

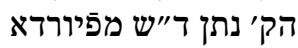

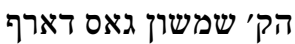

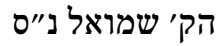
הק׳ ארי' ליב ברלין

440 Rasiert, bartlos, ein Synonym für »nichtjüdisch«, hier bezogen auf eine Unterschrift mit lateinischen Buchstaben.

441 Versteigerung.

442 Danach die Kustode תקנות.

443 Die letzten beiden Wörter nachträglich mit blauer Tinte doppelt unterstrichen.

4441770 XII 16. 

b) Landgemeinden

Ühlfeld (ca. 1683-1698)

Niederwerrn (1747) 



\section{Statuten aus Ühlfeld (ca. 1683-1698)}

\section{Quelle: Pinkas Ühlfeld, CAHJP, N29/19}

Die Statuten aus Ühlfeld sind ein seltenes Bespiel für die Fixierung einer innergemeindlichen Verfassung im ländlichen Raum des 17. Jahrhunderts. Es handelt sich bei ihnen offenbar um die ersten Statuten, die in diesem Ort überhaupt erlassen wurden. Zudem sind sie einer der wenigen Belege für die weitgehende Beteiligung des zuständigen Rabbiners bei ihrer Formulierung. Dieser, Ascher Enslen aus Schnaittach, war auch der Einzige, der den Text durch seine Unterschrift bestätigte, hier sogar am Ende eines jeden Paragraphen. Die eindeutige Datierung des Kerntextes ist kaum möglich, da sich kein abschließender Vermerk über das Inkrafttreten findet. Erst der erste Zusatz nach Paragraph 18 gibt ein Datum an (1683), sodass davon ausgegangen werden kann, dass die Statuten kurz vorher verfasst wurden.

Die takkanot sind Bestandteil des erhaltenen Gemeindeprotokollbuches. Dieser kleinformatige pinkas wurde offenbar gleichzeitig mit den Statuten angelegt, wofür zum einen deren Platzierung an erster Stelle spricht, zum anderen der Bericht in der Einleitung, wonach Ascher Enslen auf Bitten der Gemeindeführung ein Protokollbuch einrichtete, in das er die Statuten einschrieb. Trotz des hohen Alters des pinkas ist der Erhaltungszustand des Buchblocks recht gut, der Einband selbst fehlt jedoch. Alle Seiten mit den takkanot sind vorhanden und zeigen bis auf Blatt $1^{1}$ keine größeren Schäden.

Die meisten Abschnitte der Statuten wurden in leicht verständlichem Jiddisch verfasst, durchsetzt mit einigen hebräischen Phrasen. Lediglich die Einleitung erscheint vollständig auf Hebräisch, was durchaus typisch für die Zeit und das Genre ist.

Der Schreiber der meisten takkanot war ganz offensichtlich der Schnaittacher Rabbiner Ascher Enslen. Zu seinem Wirkungsbereich gehörten nicht nur die vier Gemeinden des Gemeindeverbands $A S h P a H,{ }^{2}$ sondern neben

1 Dieses Blatt wurde vor längerer Zeit nicht fachgerecht restauriert, weshalb heute einige Worte schwer lesbar sind. Durch eine fotografische Spezialaufnahme wurde der größte Teil des Textes jedoch wieder lesbar.

2 Das Akronym setzt sich zusammen aus den Anfangsbuchstaben der hebräischen Ortsbezeichnungen für Ottensoos, Schnaittach, Forth und Hüttenbach. Siehe Meir 
Ühlfeld auch noch Sulzbach und Bayreuth. ${ }^{3}$ Unter Anführung seiner Amtsbezeichnungen unterschrieb er jedoch nur einen Zusatz (auf fol. $4 \mathrm{v}$ oben), während er sich sonst auf die reine Nennung seines Namens beschränkte. Wie die Häufung der Ämter in seiner Hand ausweist, verfügte Ascher Enslen über großen Einfluss im fränkischen Judentum, woraus sich seine Schlüsselstellung beim Verfassen einiger takkanot der Region erklären könnte. Er verstarb 1693. Der mit der Nummer 20 versehene Zusatz von 1698 wurde von einem gewissen Mordechai Diesbeck unterschrieben, jedoch ohne weitere Nennung seiner Funktion. Desgleichen geschah in den beiden letzten Absätzen des Textes, die von Menachem aus Kaz[.. $\mathrm{ch}^{4}$ geschrieben und unterzeichnet wurden. ${ }^{5}$ Bei beiden Personen handelte es sich vielleicht um spätere, lokale Rabbiner oder Vertreter in dieser Position oder um Gemeindevorsteher.

Die Blätter der Handschrift sind in der oberen linken Ecke mit hebräischen Buchstaben in Quadratschrift nummeriert. Die einzelnen Paragraphen wurden am rechten Rand ebenfalls mit hebräischen Buchstaben versehen, jedoch in Kursiven. Nach Paragraph 18, dem letzten der ursprünglichen Version, sind die Zusätze weiter nummeriert worden. Allerdings wurde dabei nicht konsequent verfahren, sodass die Zählung Sprünge aufweist, wodurch einige der späteren Hinzufügungen unnummeriert blieben. Auch scheinen einige dieser Nummern längere Zeit nach dem Eintrag der Zusätze hinzugefügt worden zu sein, wie die letzten drei Paragraphen bezeugen: Paragraph 20 ist laut Datum die späteste Ergänzung von 1698, während der unnummerierte Abschnitt [21] fünf Jahre zuvor eingetragen wurde.

Die Paragraphen wurden nicht weiter durch Teilüberschriften strukturiert. Dennoch ergeben sich klar zusammenhängende Abschnitte, die jedoch bei dem überschaubaren Gesamtumfang der Ühlfelder takkanot jeweils nicht besonders lang sind. Zu Beginn werden Fragen des Besuchs und des Verhaltens in der Synagoge behandelt. Das Anmahnen der grundsätzlichen Pflicht zum Besuch des Gottesdienstes in der Synagoge zeigt, dass dies in der noch kleinen Gemeinde durchaus nicht selbstverständlich war, weshalb gelegentlich auch kein Gebetsquorum zustande gekommen sein dürfte. Weitere Themen sind Strafen für Säumige bei den Abgaben, diese selbst sowie deren Erhebung, das Handelsrecht und der Umgang mit durchreisenden Armen. Ein Zusatz von 1683 fixiert den Beschluss zur Finanzierung und Errichtung der Synagoge mittels einer Sondersteuer, insbesondere für neue, von auswärts

Hildesheimer, Pinkas kehillat Shnaitakh [Protokollbücher der Gemeinde Schnaittach], Jerusalem 1992, 15-22.

3 Ebd., 31.

4 Der Ortszusatz ließ sich nicht eindeutig entziffern.

5 Von ihm stammen noch weitere Einträge im Protokollbuch. 
hinzugekommene Mitglieder. Von Interesse ist schließlich noch die in Paragraph [21] dargelegte Honorarordnung für die Lehrer in der Gemeinde.

Insgesamt fällt die große Sauberkeit und Sorgfalt bei der Niederschrift der Statuten auf, wie auch die räumlich großzügige Platzierung der Paragraphen auf den Blättern des pinkas. 
[fol. $1 \mathrm{r}$ ] יען וביען כי העיד ה' את רוח אנשי קודש יושבי אילטפעלט וסביה וליבות'1 וקבלו [...]2 [/]

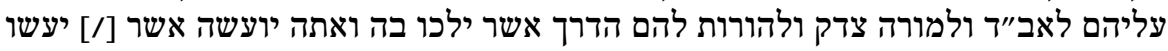

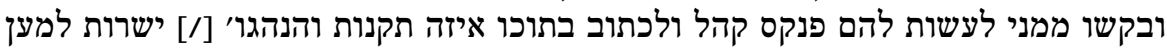

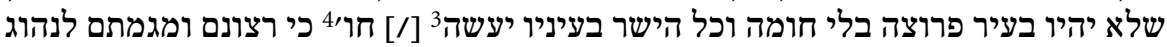

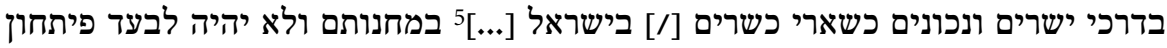

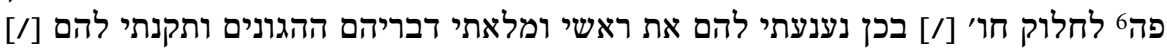

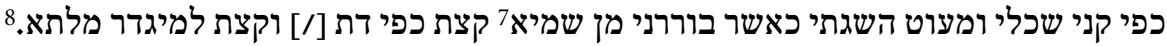

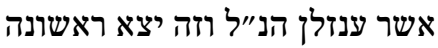

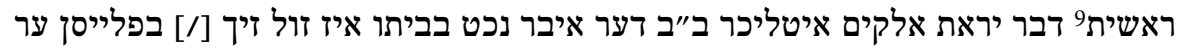

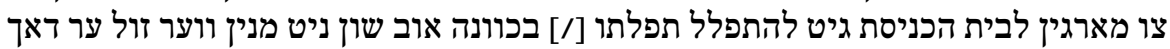

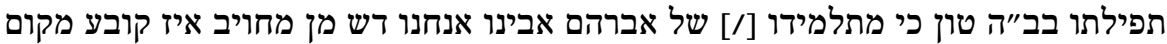

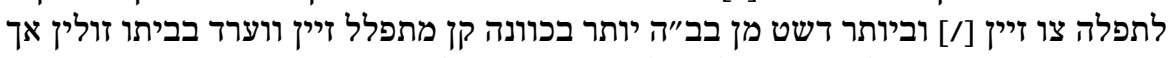

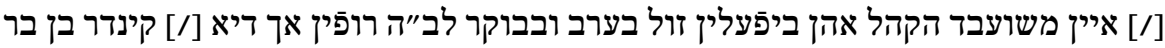

ומאחר זיא כהיום נאך מתי מספר10 זיינין קן מן על זה קיין קנס זעצין [/] אבר כל כל קריק

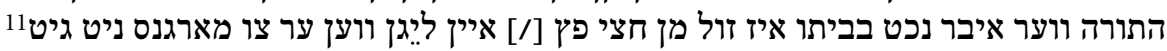

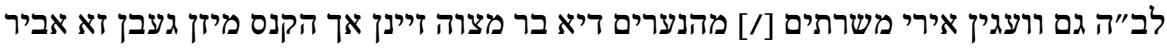

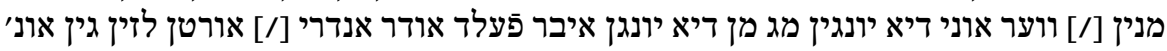

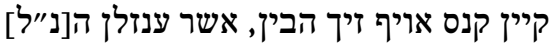
[fol. $1 \mathrm{v}$ ]

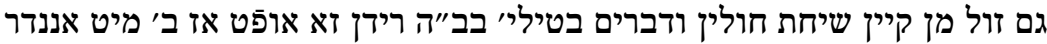

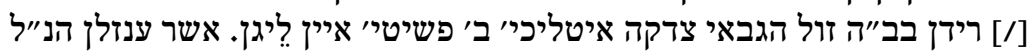

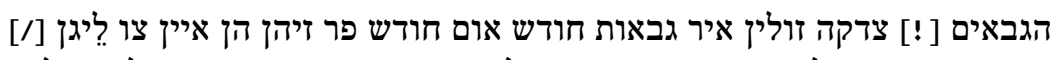

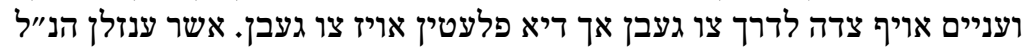

1 וסבובותיה.

2 Textverlust durch beschädigtes Papier.

3 Dtn 12,8.

4 חולי

5 Textverlust durch beschädigtes Papier.

6 Nach Ez 16,63.

7 שמיא (aram.) = Himmel.

8 מגדר מלתא (aram.) = Bestimmung zur Verhütung einer Gesetzesübertretung.

9 Dieses Wort größer geschrieben.

10 Wenige.

11 Das Wort über der Zeile. 
הגבאים זולין כל רביע' שנה דש לִיג ברעט אויז צִּילין אונ' גובה זיין [/] וואש אביר 17

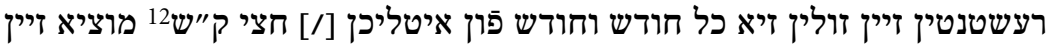

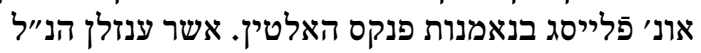

הגבאי' הבין רשות איינם מכריז לאיסור זיין וועלכיר זיין גבייה ניט [/] גיבן וויל.

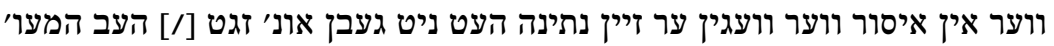

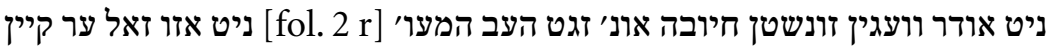

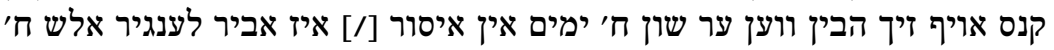

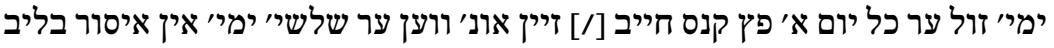

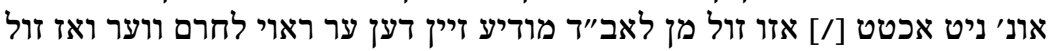

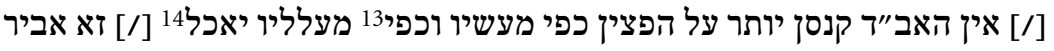

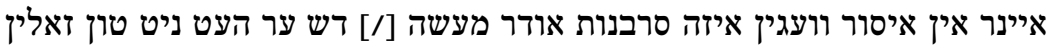

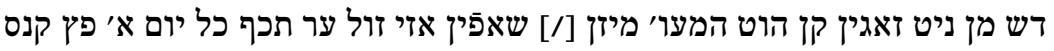

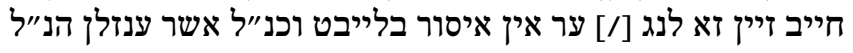

ווען אייניר אין איסור איז זול מן אים ניקשן שחטן ובדקן אך קיין [/] בשר לאזין

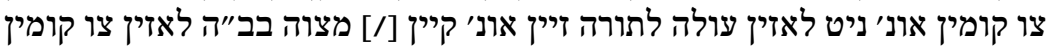

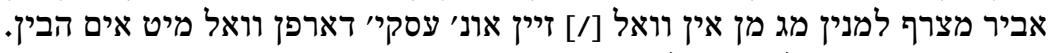

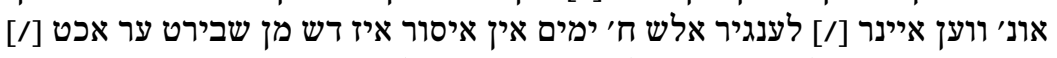

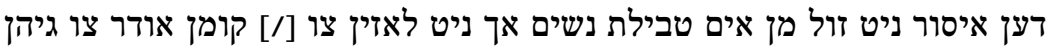

$$
\text { לאזין. אשר ענזלן הנול מיל }
$$

בענין קטריגות והסגת גבול זא בלד איין יהודי בבית ערל עש זייא מיט [/] בהמות $\pi$

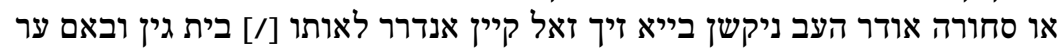

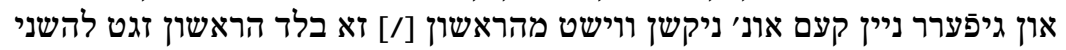

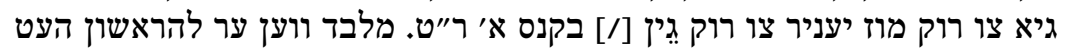

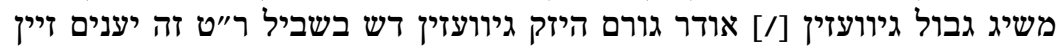

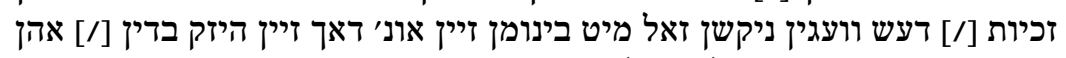

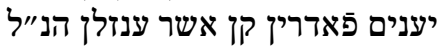

זאל אך קייניר קיינים ערל דארפיין זילזולי'געבן וועגין ער מיט אים אים [/] ניט גיה גיהנדלט

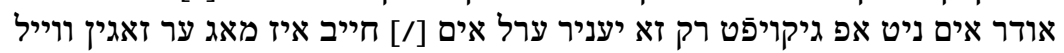
'ט

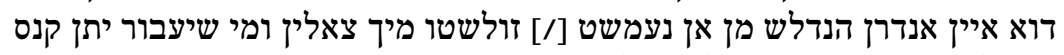

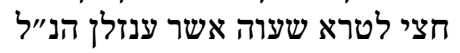

12 Kopfstück.

13 In der Handschrift zwei Yudim.

14 Nach Jes 3,10. 
יוד בענין הקנסות הנ"ל מוז הב"ב שטֵין עבור אשתו ובני ביתו אשר ענזלן הנ״ל

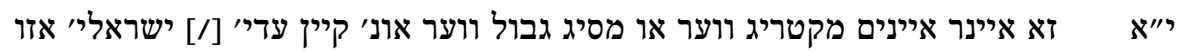

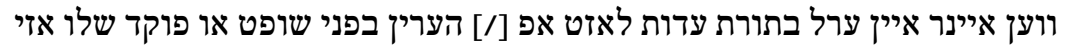

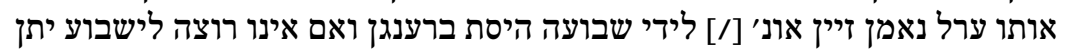

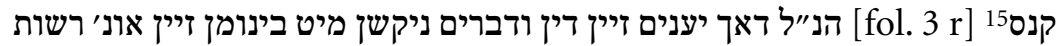

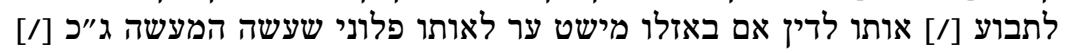
מרצה ומפייס זיין אשר ענזלן לתין אם באזלו מיל

כבר גזרנו בחרם חמור זול קיינר קיין אורח דער נחשד איז [/] ער זיך ניט באמונה י

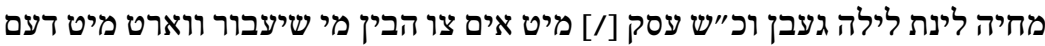

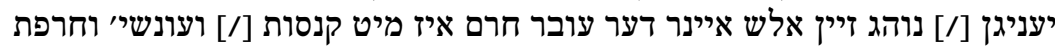

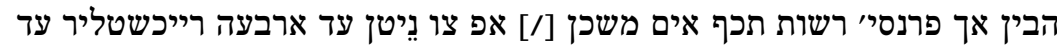

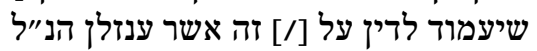

זאל אך קייניר קיין אורח עם אשה לביתו איין נעמן אויף זמן [/] מה ווען ער שון $\lambda^{\prime \prime \prime}$

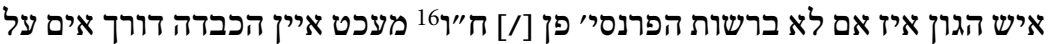

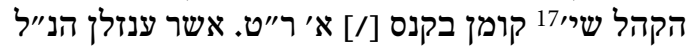

י"ד פארטיל של הסנדק יהיה ק"ש וחצי והסנדקי' לנשים תתנה ששה [/] צלמ' טוב מעו' אשר ענזלן הנ"ל של הסריל יהיל [fol. $3 \mathrm{v}]$

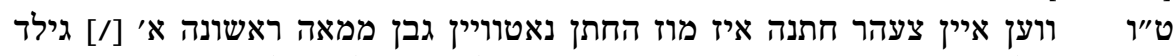

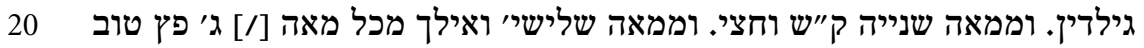

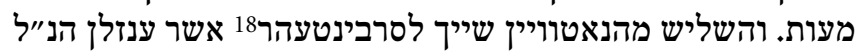

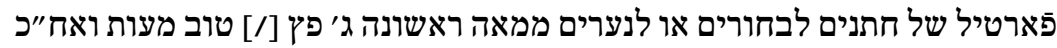
ט"ט

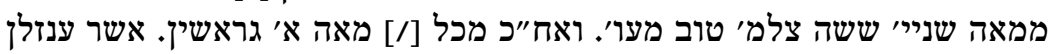

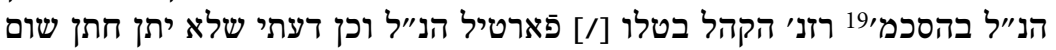

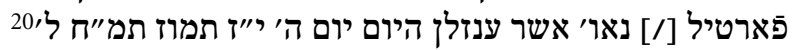

הפרנסי' הבין רשות צו קנסן ווען זיא זיהן אייניר עפיש טוט שלא כשורה [/] בייז $T^{\prime \prime}$

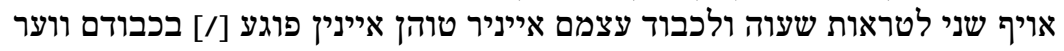

\footnotetext{
15 Darunter die Kustode הנ"ל.

16 חס וחללה.

17 שיחיה.

18 Über der Mitte des Wortes drei kleine Striche.

$19 \mathrm{Ab}$ hier bis zum Ende des Paragraphen spätere Hinzufügung, offenbar in der Handschrift des Rabbiners Ascher Enslen.

201688 VII 15.
} 
מעגין זיא לכבוד עצמם קנסן א׳ לטרא שעוה. [/] ובאם זיא זיה איהן איינר עפיש גיטיט מיטון

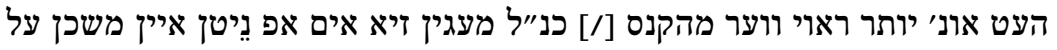

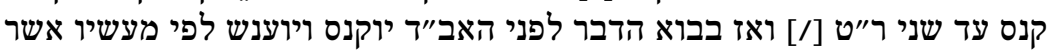

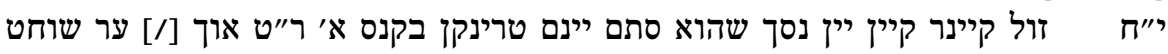

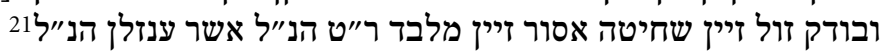

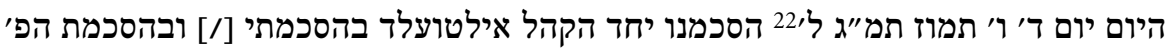

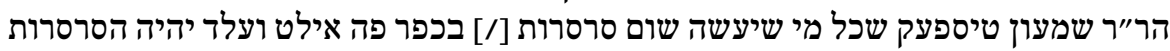

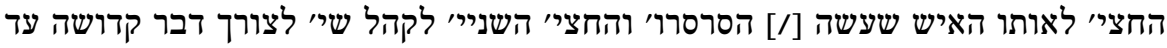

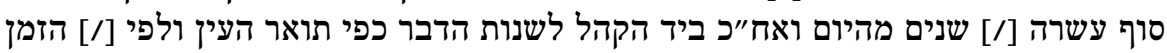

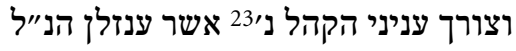

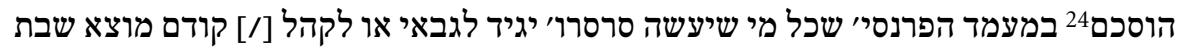

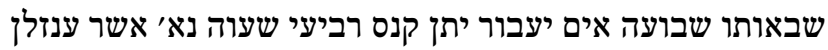

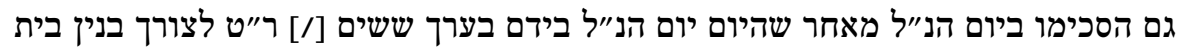
15

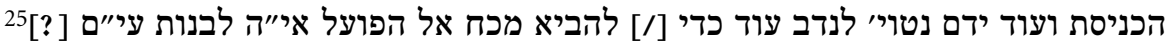

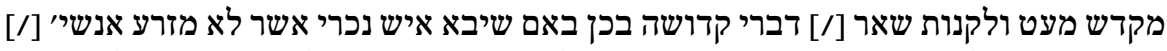

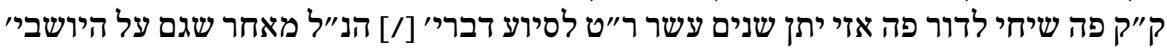

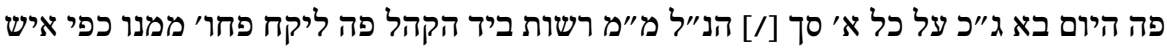

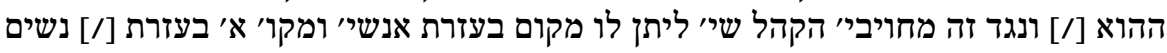

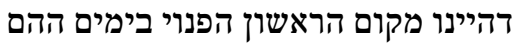

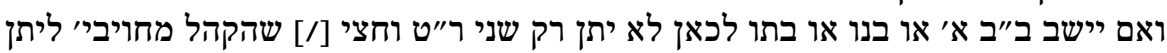

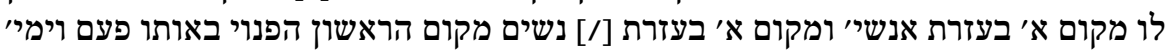
ההם אשר ענזלין הנ"ל בעזר אנשי" [fol. $4 \mathrm{v}]$

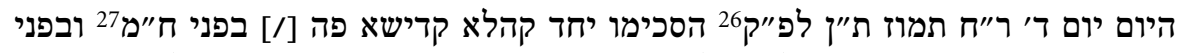

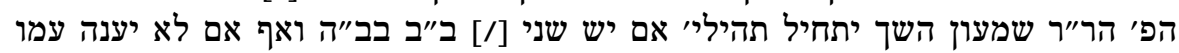

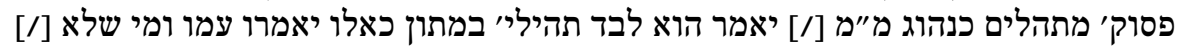

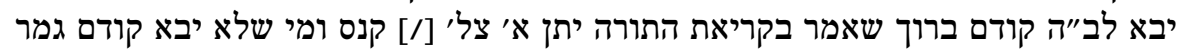

\footnotetext{
21 Bis hier der Text der ursprünglichen Version, im Weiteren spätere Ergänzungen.

221683 VI 30.

23 נאום

24 Zusatz in anderer Tinte.

25 על ידם?

261690 VII 5.

חתום מטה 27.
} 
אז ישיר28 אזי יתן קנס חצי פץ [/] ובשאר ימי החול יתן חציי' זה' אשר ענזלן חונה בק"ק

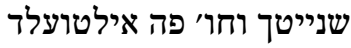

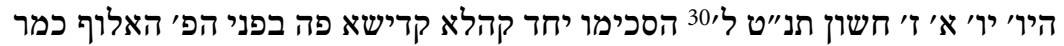
${ }^{29 \prime 7}$

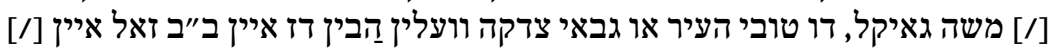

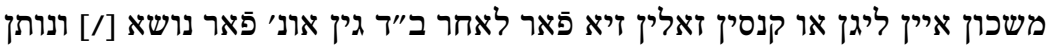

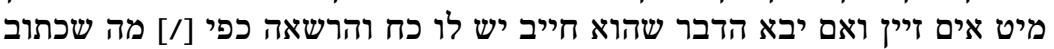
בתוך תקנות הקהל בוך נאום האיבר מרדכי טיס ביים ישק

[fol. $5 \mathrm{r}$ ]

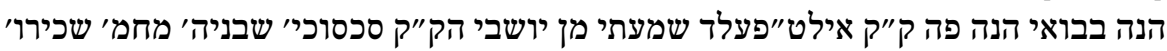

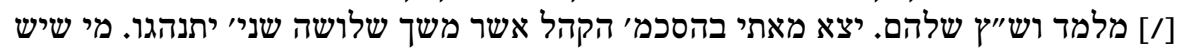

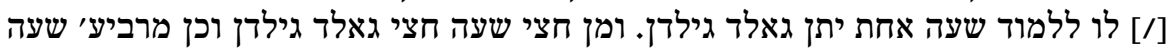

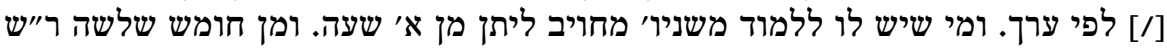

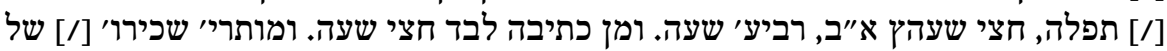

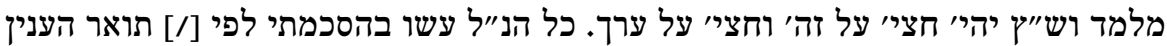

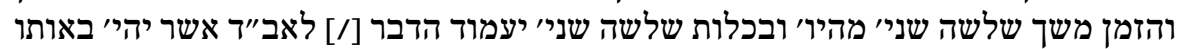

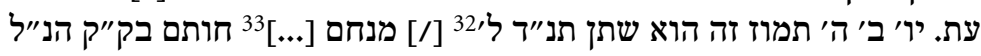

יושבי ק"ק אילפעלד יצ"ו בנה [!] בית הכנס' אשר הוא לתפארת. אך ורק מיעוטיי

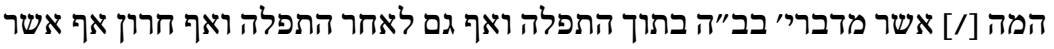

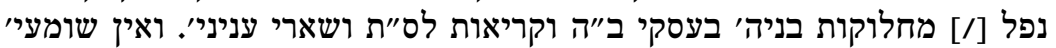

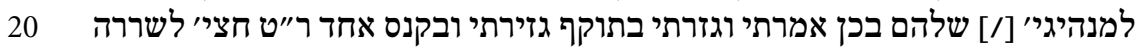

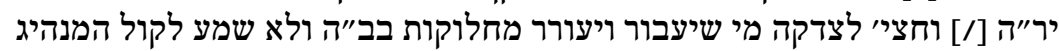

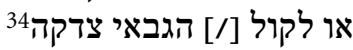

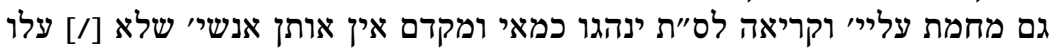

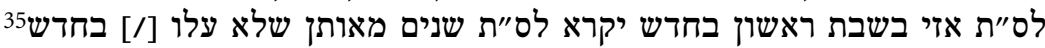

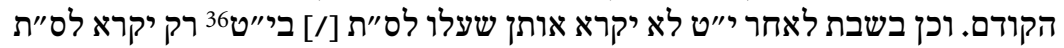

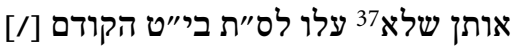
מנחם [....

28 אש ישיר משה, das so genannte, ,Meereslied“ (Lobgesang des Moses) aus Ex 15.

29 Die Nummerierung erfolgte offensichtlich später durch eine andere Hand.

$301698 \times 12$.

31 In der Handschrift: נאים.

321694 VI 28.

33 Namenszusatz nicht zu entziffern.

34 Der Rest der Zeile wurde vom Schreiber mit einer Linie ausgefüllt.

35 Gestrichen: הראש.

ביום טוב 36.

37 Dieses Wort gestrichen und erneut über der Zeile geschrieben. 


\section{Statuten aus Niederwerrn (1747)}

\section{Quelle: Pinkas Niederwerrn, CAHJP, D/Ni5/2}

Die jüdische Gemeinde im unterfränkischen Ort Niederwerrn, unweit von Schweinfurt gelegen, hat ihre Ursprünge offenbar in der zweiten Hälfte des 17. Jahrhunderts, vielleicht auch schon früher. ${ }^{1}$ Wie in Unterfranken häufig, war der Ort Teil eines reichsritterschaftlichen Besitzes, in diesem Fall der Freiherren von Münster. Ein Vertreter dieser Familie, Johann Philipp von Münster, war es dann auch, der 1747 der jüdischen Gemeinde im Ort die Statuten verlieh. Dieser Vorgang war nicht üblich, da in gewisser Hinsicht die Autonomie der Gemeinde unterlaufen wurde. Der Text muss somit als Verflechtung von statutarischer Ordnung und obrigkeitlicher Policey-Ordnung angesehen werden. Die Vorrede zur Verordnung, wie der Text genannt wird, verweist auch auf die bis Mitte des 18. Jahrhunderts offenbar gegebene administrative Grundlage des innergemeindlichen Lebens: einem Buch, das bei den Vorstehern lag und »zusammengeschrieben « war, jedoch ohne Vorwissen der Herrschaft. Sehr wahrscheinlich handelte es sich dabei um den pinkas der Gemeinde, der vielleicht auch Statuten enthielt.

Aus den Formulierungen der einzelnen Paragraphen wird ersichtlich, dass es sich bei dem überlieferten Dokument weitgehend um die Transkription eines ursprünglich deutschen Textes handelt, bei dessen Entstehung jedoch die Juden selbst beteiligt gewesen sein dürften. Somit ist die Bezeichnung »Verordnung«, die hier statt des zu erwartenden »takkanot« genutzt wird, erklärbar. ${ }^{2}$

Begründet durch die singuläre Entstehungsgeschichte ist das Bemühen um Beibehaltung der ursprünglichen deutschen Schreibung erkennbar, wie auch die deutsche Sprachdiktion klar aus dem Dokument hervortritt und sich der Text somit deutlich von den meist jiddischen Statutentexten der Epo-

1 Der erste sichere Beleg für eine Niederlassung von Juden im Ort stammt aus dem Jahr 1657, jedoch könnten auch bereits 1555 aus Schweinfurt ausgewiesene Juden im reichsritterschaftlichen Ort Zuflucht gesucht haben; siehe dazu Ulrich Debler, Die jüdische Gemeinde von Niederwerrn, Sennfeld 1988, 2.

2 Ein ähnlicher Text ist aus dem mittelfränkischen Sugenheim überliefert und wurde 1929 von Max Freudenthal ediert, siehe Anhang. 
che unterscheidet. Über den Schreiber lässt sich aus dem Text keine Information entnehmen.

Die Statuten sind Teil des erhaltenen Gemeindeprotokollbuches von Niederwerrn und eröffnen dieses. Nach der Beschreibung der Entstehungsgeschichte der Statuten ist dieser Befund absolut folgerichtig, löste doch das vorhandene Protokollbuch das bis dahin intern geführte zwangsläufig ab. Die 27 Paragraphen der Verordnung sind vollständig im pinkas erhalten.

Die Paragraphen wurden jeweils am rechten Blattrand mit hebräischen Buchstaben nummeriert, sodass sich hier der Text trotz seiner abweichenden Entstehung in das zeittypische Erscheinungsbild des Genres einordnet. Die Seiten der Handschrift sind in der linken oberen Blattecke mit arabischen Ziffern foliiert. Am Anfang jeder Seite findet sich das Kürzel ב"ה, was wiederum das äußere Erscheinungsbild als takkanot vervollständigt.

Inhaltlich beschäftigen sich mehrere Paragraphen mit den Befugnissen der Vorsteher und des Rabbiners, wie auch mit Fragen der Besteuerung, worin sich dieser Text letztlich kaum von innergemeindlichen takkanot unterscheidet. Paragraph 24 enthält den interessanten Hinweis, dass einige Juden in Niederwerrn offenbar ein Gasthaus betrieben; Paragraph 27 verweist auf die Tätigkeit anderer als Viehhändler. 


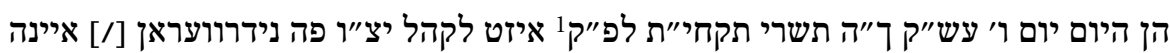

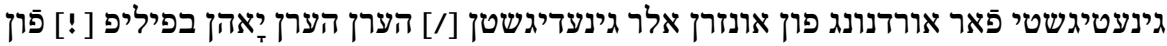

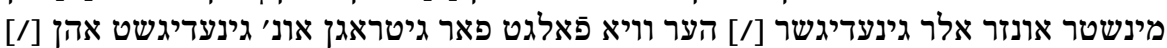
בפאלן ווארדן אלש נעמליך

נאך דעמי מאן פילל פעלטיג ער פאהרן וויא דז פַון פַר שיטענע [/] יאהרן הער פילילרלייא

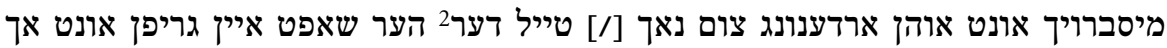

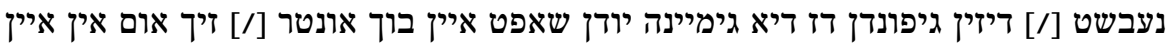

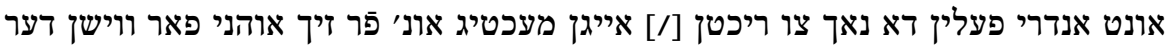

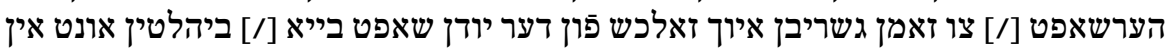

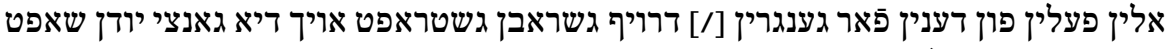

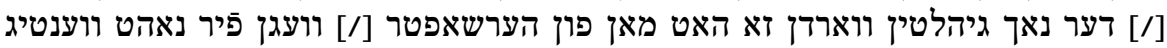

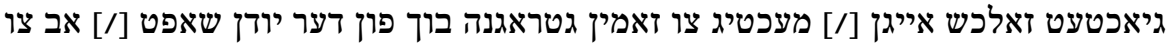

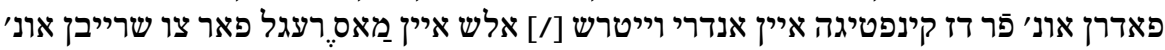
זאלכש פון [/] הערשאפט וועגן צו קונפרמיוירן.

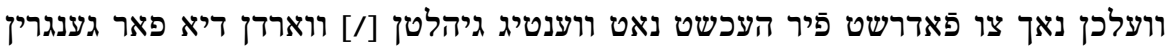

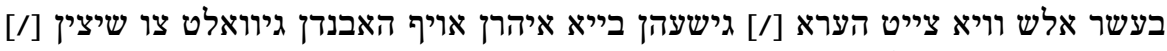
אונ' צוואהרן ערשטליך

\section{[fol. $1 \mathrm{v}] \quad 20$ ב"ה}

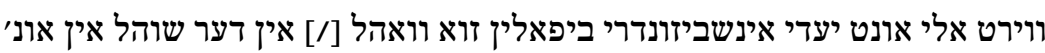
א

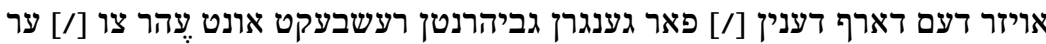

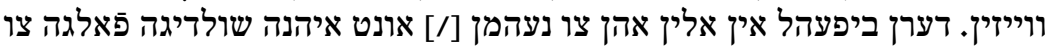

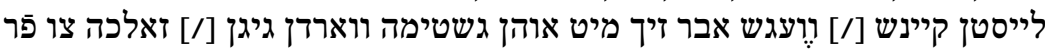

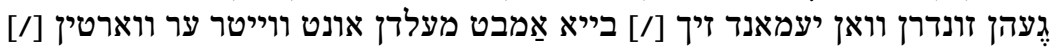
וואש איהמי אב אדר צו גשברכן ווירט ווערדן.

אין גלייכי ווייז ווירט דעני פאר גענגר היר מיט [/] אהן בפאהלן זין זין מיט דער

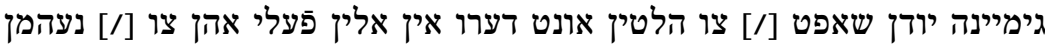

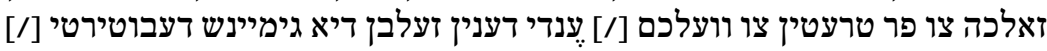

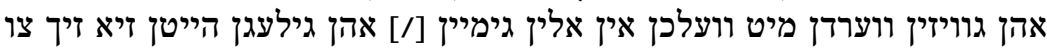
ביראטין האבן [/] זאלן.

1747 IX 18.

2 Danach gestrichen: גנעטיג. 


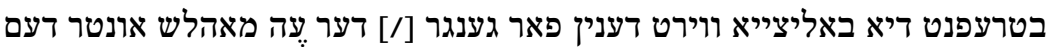
'ג שt 6 t

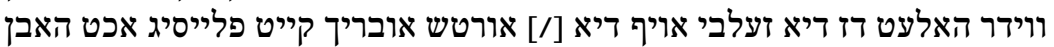

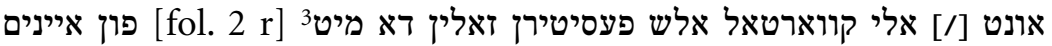
יעדים אינש ביזונדרי אלש גיזייברט ווערדן [/] מעלירי.

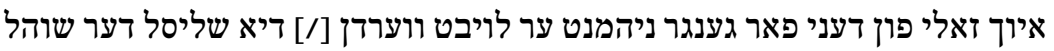

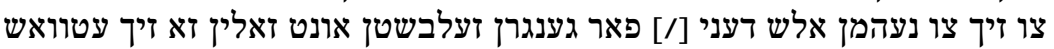

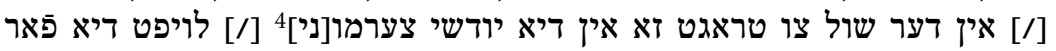

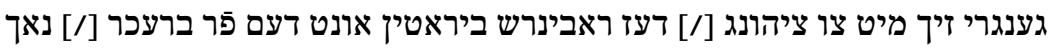

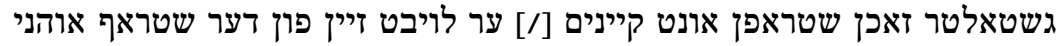

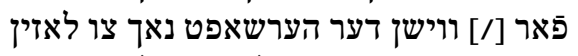

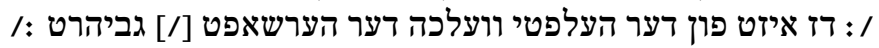

זאלטי זיך אבר איבר לנג אדר קורץ פיגן דז קיין ראבינר [/] זיך אין ניפריד זיוועהרין הי

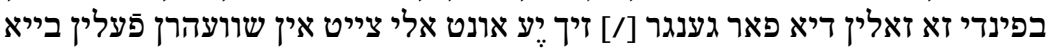

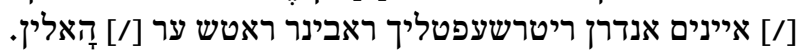

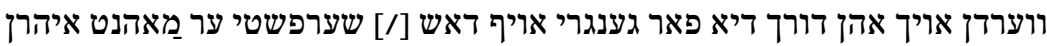

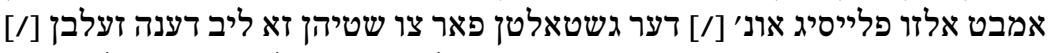

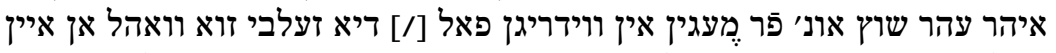

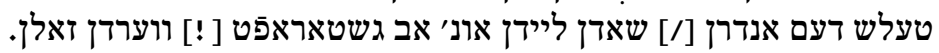

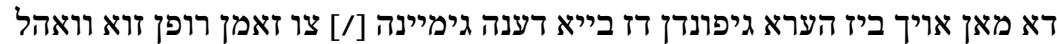

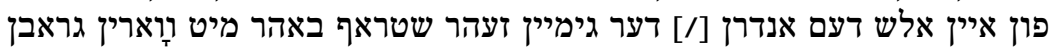

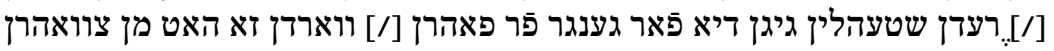

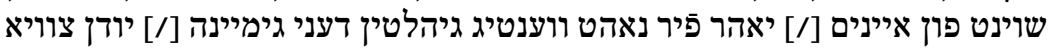

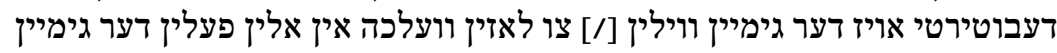

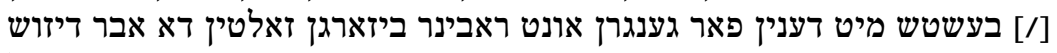

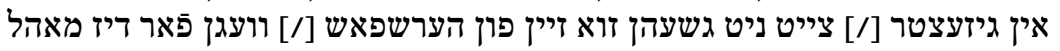

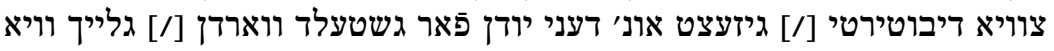

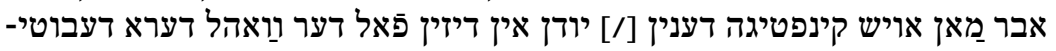

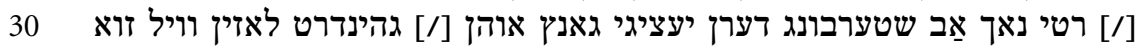

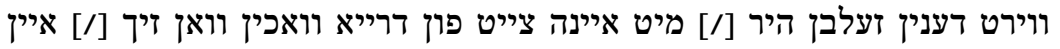

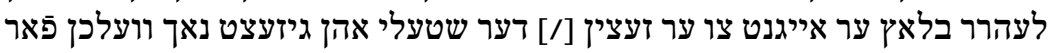

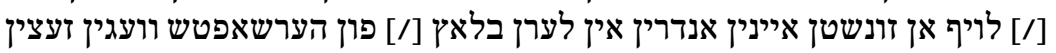

ווירט

3 Danach die Kustode פ̄i.

4 Textverlust durch beschädigten Blattrand. 


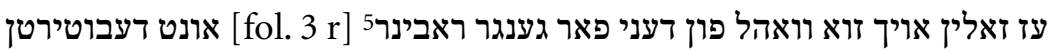
$\pi$

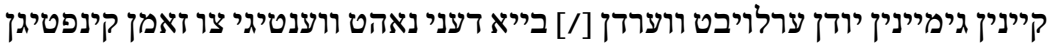

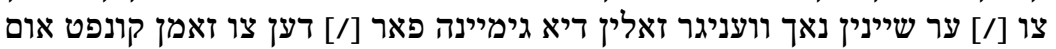

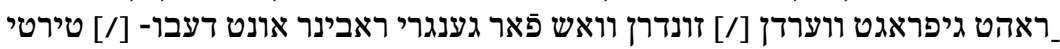

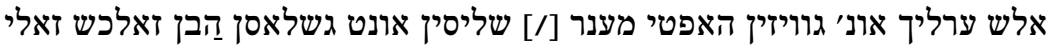

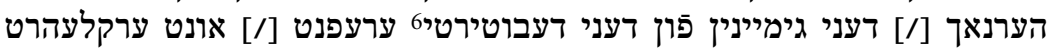

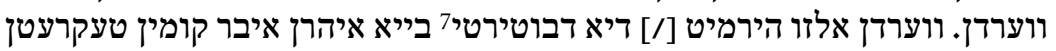

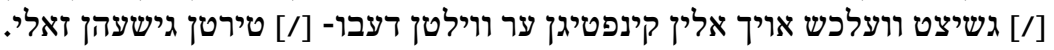

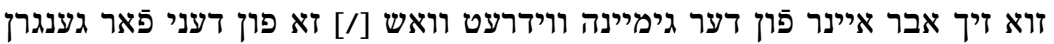

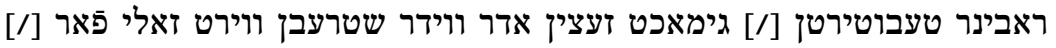

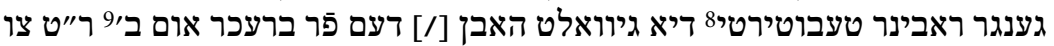

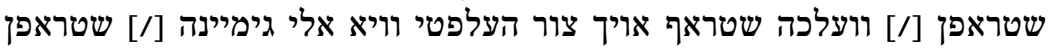

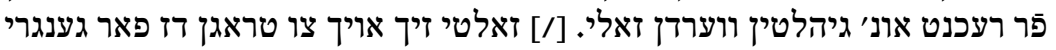

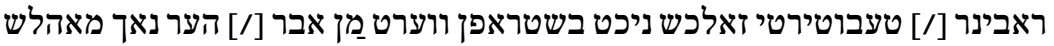

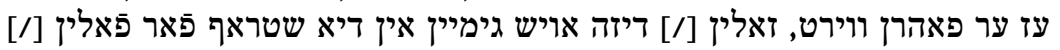
אונ' מיט עקסוקוציון דא צו אהן גיהלטין ווערדן

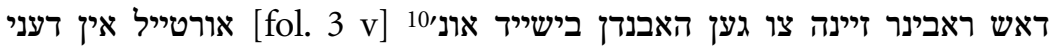

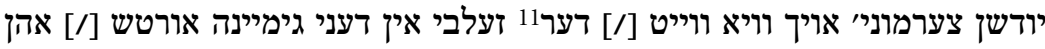

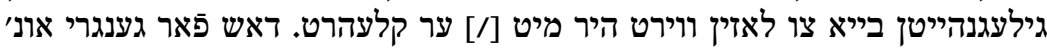

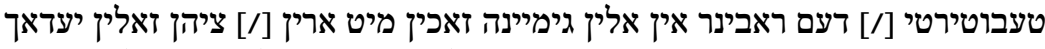

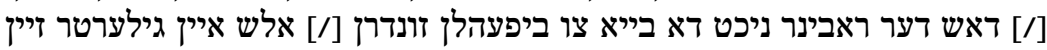

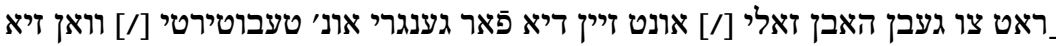

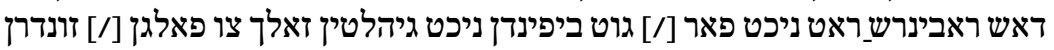

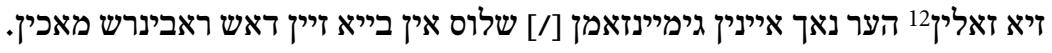

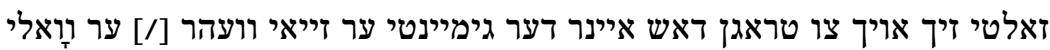

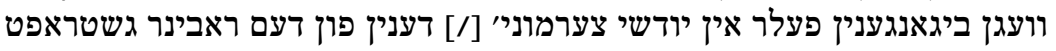

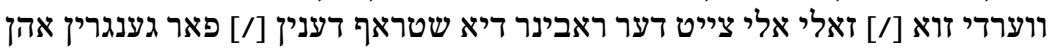

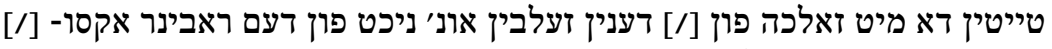

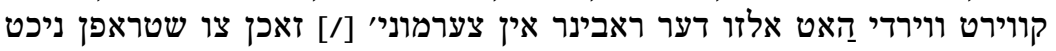

יו"ד

5 Danach die Kustode אונט.

6 In der Handschrift: דעבונטירטי

7 In der Handschrift: דעבונטירטי

8 In der Handschrift: טעבונטירטי : טעבירט.

9 Danach gestrichen: 'זהי

10 Danach die Kustode אורטייל

11 Davor ein Wort nach Streichung unleserlich.

12 Davor ein Wort nach Streichung unleserlich. 
אבר עט וואש אוהני [/] ווישן דער הערשאפט נאך צו לאזין נאירך פויר פיל [/] וויניגר

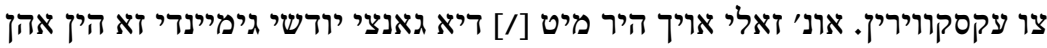

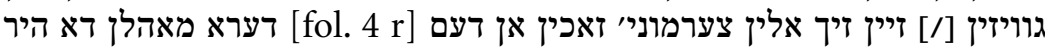

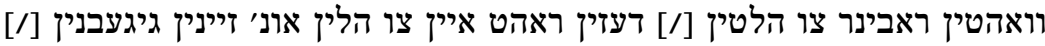
בישייד אין אלין נאך צו קומין.

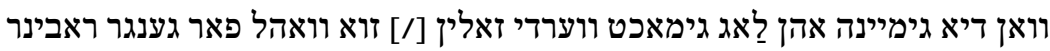

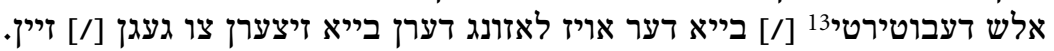

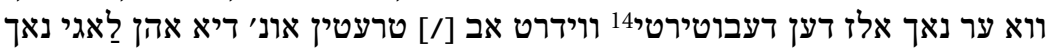
יודשין צערמוני' [/] פר פער דעברטיגן לאזין זאלין.

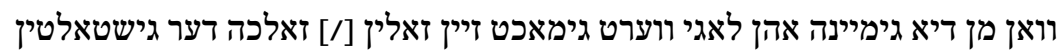

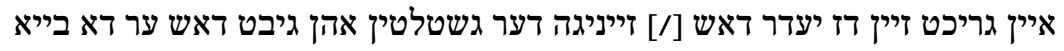

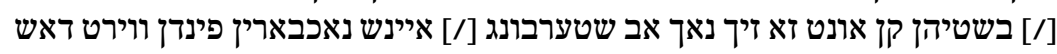

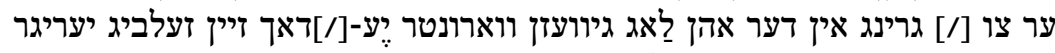

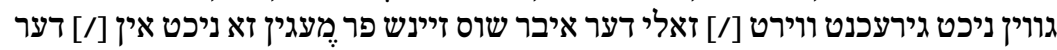

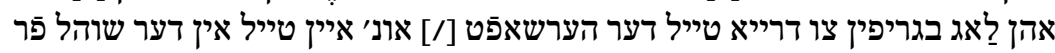

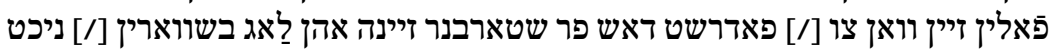

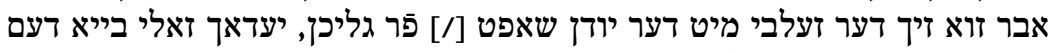

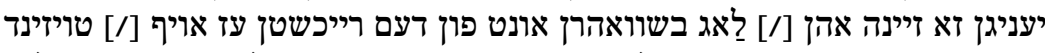

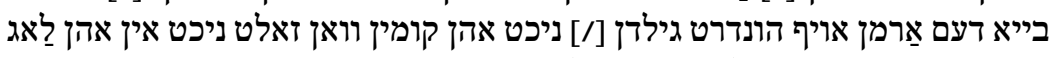

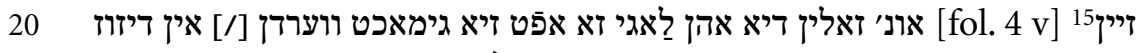

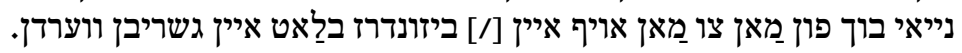

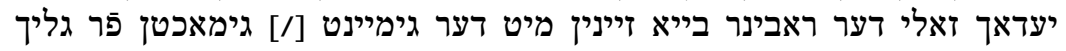

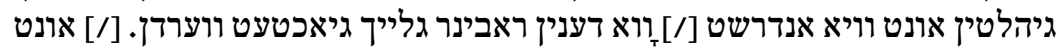

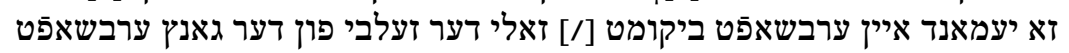

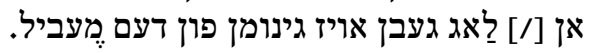

דיא איבריגן צייט הערא איין גשליכנה מיס ברייך [/] בטרעפנט זיין זאלכה דער

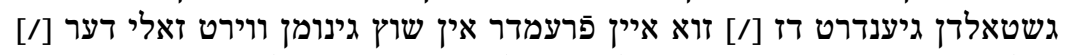

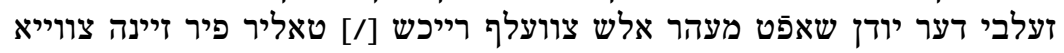

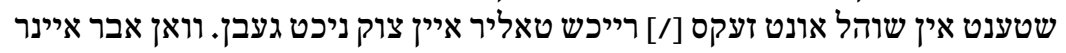

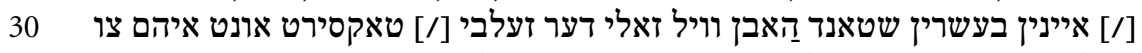

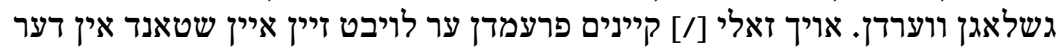

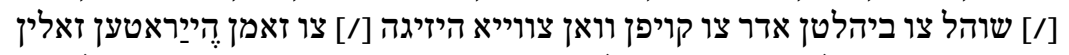

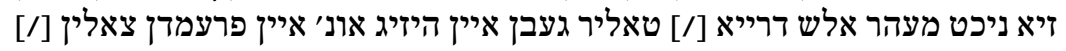
זעקס טאליר פאר דיא שטענט.

13 Die letzten fünf Buchstaben des Wortes gestrichen.

14 In der Handschrift: דעבורטירטי.

15 Danach die Kustode 'אורי : 
דאש טויג אדר זא גינאנדי מקוה בילאנקט זאלי דיא [/] גאנצי יודן שאפט זאלכש ט"ו

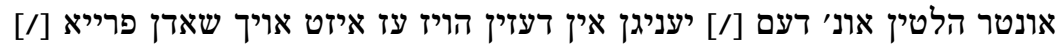
הַאלטין.

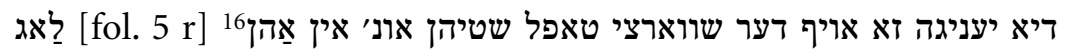
ט"ז

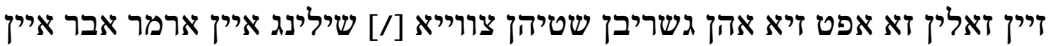

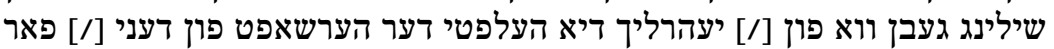

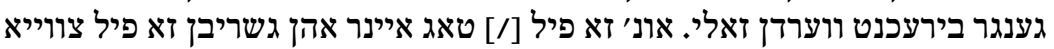

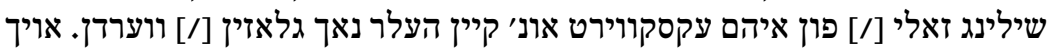

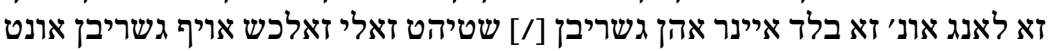

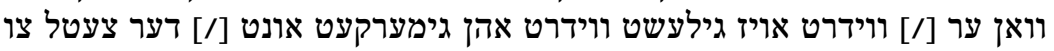

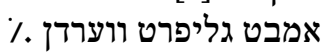

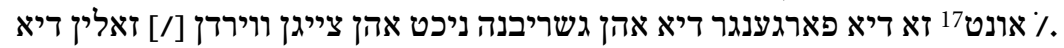

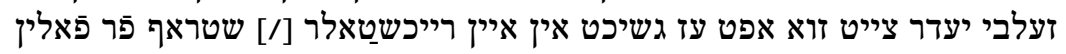

וואן איין היזיגש אורטש קינד זיך אין פרעמדי הערשאפט [/] פּר הייראט איראט אונט

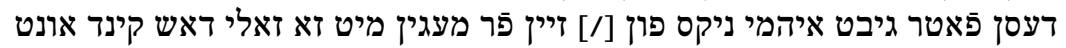

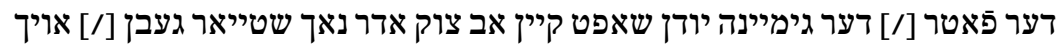

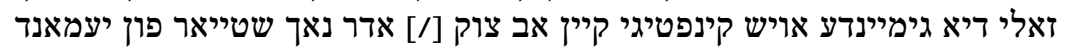

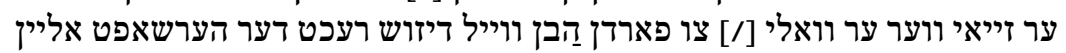

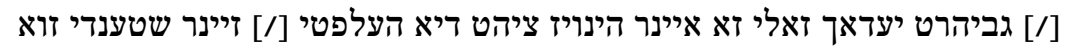

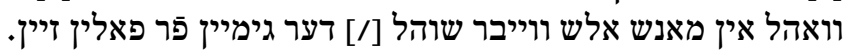

(1)




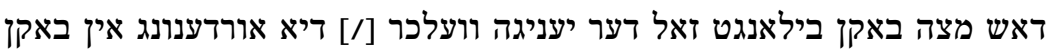

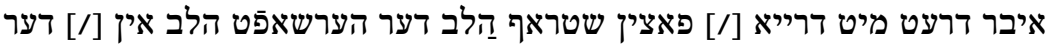
שוהל פَר פלין זיין.

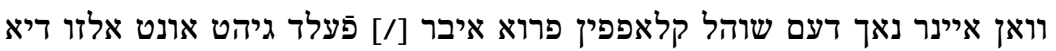

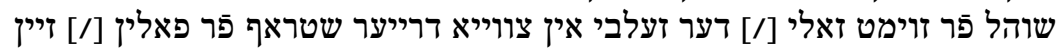

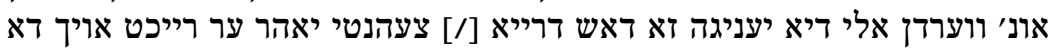

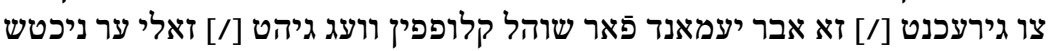

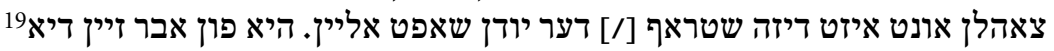
] [fol. 6 r]

זיאלטי איין נאך באהר שטערבן אונט עט וואש [/] שולדן הינטר לאזין אלזו דאר 10

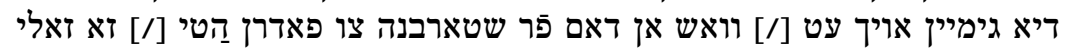

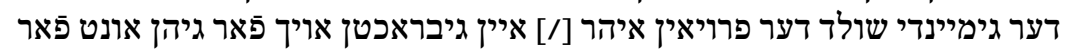
ערשט [/] בצאהלט ווערדן.

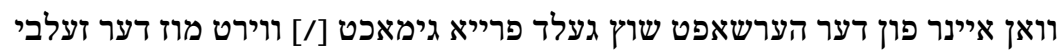

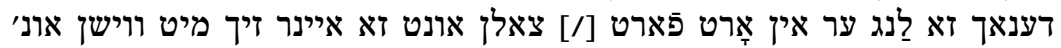

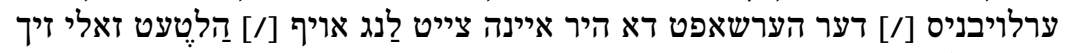

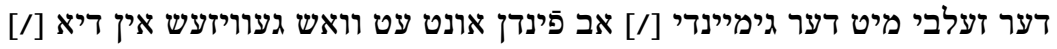
שוהל בצאהלן.

דיא גימיינה ווירט שענק בלאנגט איזט זאלכה דער דיכר [/] יודן שאפט אליין ארונט

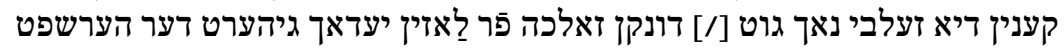

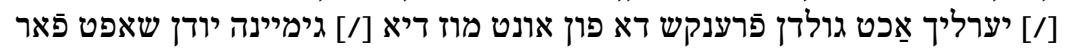

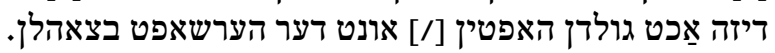

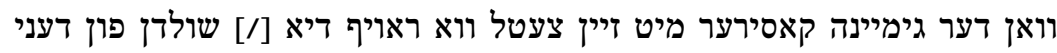

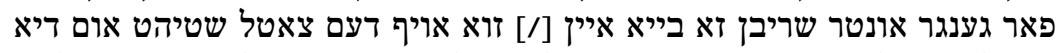

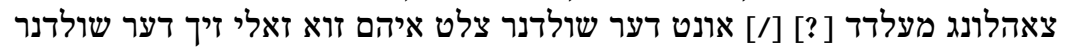

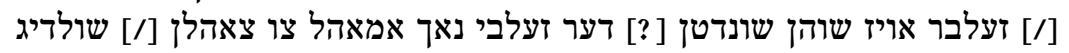

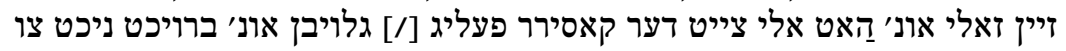
שוועהרן אין דיזין בונקט.20 [fol. $6 \mathrm{v}]$

וואש אן זאנזטן דיא געלדר זוא אין דער גימיינה יודן [/] שאפט פַאלין אדר איין 30

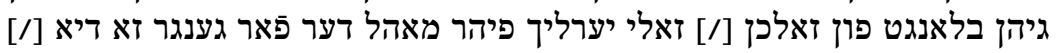

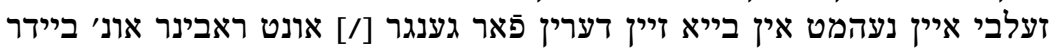
דעבוטירטי רעכנונג [/] טוהן.

19 Danach die Kustode דינשט.

20 Danach die Kustode כ" דינשי 


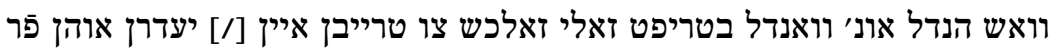

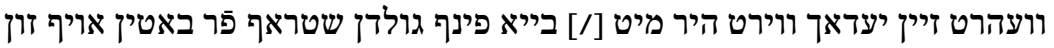

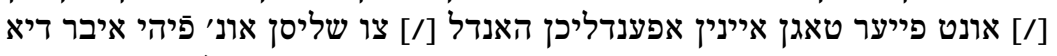

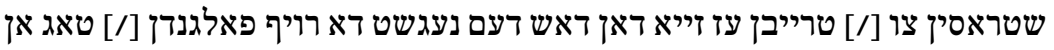
איינים אָרט מַאריק ווער

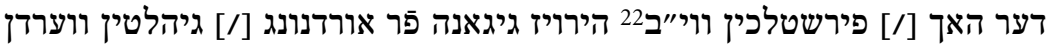

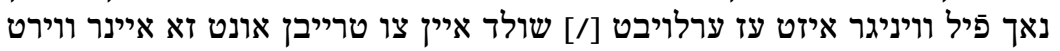

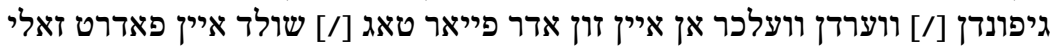

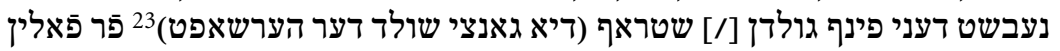

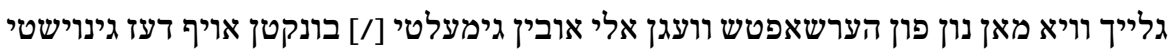

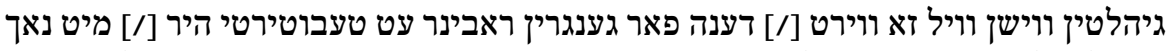

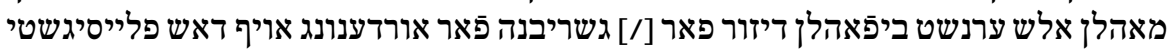

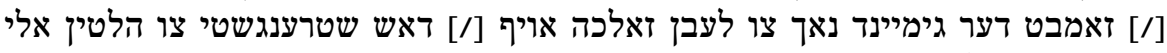

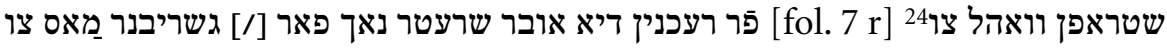

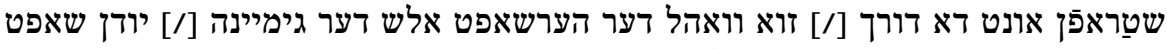

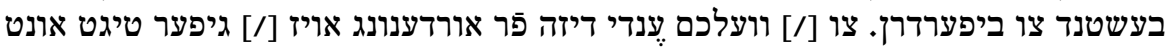

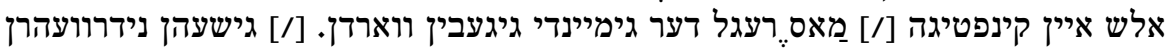
דעם 26t אלשיוקטאבר 1747 J. freyherr Von Munster25

211747 XI 28 wurde diese Bestimmung abgemildert und der Viehtrieb in den späten Nachmittagsstunden auf Bitten der Juden gestattet, siehe fol. $7 \mathrm{r}$ unten.

22 ווירצבורגישע.

23 Die Wörter in der Klammer gestrichen und darüber in deutscher Kursive »ist von mir selbsten auf getan «.

24 In der Zeile darunter die Kustode פ̄.

25 Eigenhändige Unterschrift. 



\section{Königreich Böhmen}

Neuzedlisch (1755, 1789-1849) 



\section{Takkanot Neuzedlisch (Nové Sedliště) (1755, 1789-1849)}

\section{Quelle: Pinkas Nové Sedliště, Archiv des Jüdischen Museums Prag, ohne Signatur}

Die takkanot aus der westböhmischen Landgemeinde Neuzedlisch (Nové Sedliště) sind ein seltenes Bespiel für Gemeindestatuten aus Böhmen überhaupt. Die bislang angestellten Untersuchungen haben ergeben, dass neben den vor längerer Zeit edierten, ausführlichen Statuten aus Chodová Planá (Kuttenplan) ${ }^{1}$ die aus Neuzedlisch die einzigen, heute bekannten Statuten sind, die sich aus Böhmen erhalten haben. ${ }^{2}$ Dieser Befund ist insofern überraschend, als das frühneuzeitliche böhmische Judentum für seine beispielhafte Gemeindeorganisation bekannt ist. Neben dem jüdischen Friedhof am Ort ist das Protokollbuch mit den Statuten eines der letzten Zeugnisse jüdischen Lebens in der Teilgemeinde des früheren Dorfes Alt-Zedlisch.

Insgesamt spiegeln die hier edierten Statuten den Geist einer ländlichen Gemeinde wider, in der die jüdische Tradition eine wichtige Rolle spielte. Fragen der Liturgie und des Ritus stellen einen hohen Anteil an den Regulierungen dar.

Die Statuten sind Teil des erhaltenen pinkas der Gemeinde. Dieser ist vor allem wegen seines bemerkenswert aufwändig gestalteten Titelblatts von Interesse, das in dieser Form für aschkenasische Protokollbücher bislang einmalig ist. Nach diesem und einem Einleitungstext erscheinen gleich die Statuten auf acht aufeinander folgenden Folioseiten. Der Text ist vollständig erhalten, wie auch die anderen Seiten des pinkas, von denen jedoch - nicht untypisch für eine Landgemeinde - viele unbeschrieben blieben. In der ursprünglichen Version umfassten die takkanot 18 Paragraphen, eine Zahl mit Symbolik, da ihre Wiedergabe mit hebräischen Buchstaben auch als das Wort hai (Leben) gelesen werden kann. Die späteren Ergänzungen wurden meist weiter nummeriert, sodass schließlich insgesamt 31 Paragraphen in den Statuten zu finden sind.

1 Schulim Ochser, Der Pinkas der Gemeinde Kuttenplan, in: Mitteilungen zur Jüdischen Volkskunde 13,1 (1910), 32-38; 13,2 (1910), 57-89.

2 Allerdings stehen hier noch weitere systematische Recherchen aus. Die Überprüfung von Handschriften aus den Archivbeständen des Jüdischen Museums in Prag hat, neben den hier edierten Statuten, keine weiteren takkanot ans Tageslicht befördert. 
Die vorherrschende Sprache der Statuten ist Hebräisch, wenn auch immer wieder einzelne Satzteile auf Jiddisch verfasst wurden. Dieser Befund lässt sich u.a. mit dem häufig religiösen Inhalt der Statuten begründen, die vorzugsweise auf Hebräisch geschrieben wurden. Auch die zahlreichen späteren Ergänzungen, die noch bis in die Mitte des 19. Jahrhunderts hinein erfolgten, wurden meist auf Hebräisch vorgenommen. Erst die beiden letzten (Paragraphen 30 und 31) von 1847 und 1849 sind nahezu vollständig auf Hochdeutsch (jedoch mit hebräischen Lettern) verfasst worden.

Über den Schreiber des Hauptteils der Statuten ist aus dem Text nichts zu erfahren. Weder nach Abschluss des ursprünglichen Hauptteils, noch in den ersten Hinzufügungen und auch nicht auf der Seite mit den Unterschriften gibt er sich als solcher zu erkennen. Unter den späteren Paragraphen 30 und 31 sowie der davor erfolgten Abänderung von Paragraph 25 findet sich jeweils die Unterschrift von Gerschon, zu Beginn des 19. Jahrhunderts offenbar der Schreiber der Gemeinde.

Die Nummerierung der Paragraphen erfolgte immer zentriert über dem Abschnitt mit Benutzung des Wortes »Punkt« vor jeder Zahl. Nur in den Paragraphen 21 und 22 wurde davon abgewichen, ganz offensichtlich, um die jeweils anfangs genutzten Bibelzitate in den Text einpassen zu können. Für die Zahlen selbst wurden hebräische Buchstaben in Quadratschrift verwendet. Bis Paragraph 18 sowie noch einmal bei 21 und 22 stellt jeweils der erste Buchstabe oder das erste Wort, manchmal auch die ersten Wörter des Abschnitts noch einmal die Nummer des Paragraphen dar, was eine Besonderheit dieses Textes ist. Die einzelnen Blätter der Handschrift sind jeweils in der linken oberen Ecke mit hebräischen Buchstaben nummeriert.

Wie schon angemerkt haben liturgische und rituelle Fragen eine große Bedeutung für den Inhalt der Statuten aus Neuzedlisch. Insbesondere die Versteigerung der synagogalen Ehrenämter und Beschränkungen dabei werden immer wieder thematisiert. Der Inhalt der Nachträge insbesondere aus der ersten Hälfte des 19. Jahrhunderts, beschäftigt sich nahezu ausschließlich mit diesem Thema, was letztlich auch den Wandel der Gemeinde von einer autonomen Körperschaft hin zu einer Religionsgemeinde widerspiegelt. Fragen der Steuerleistungen, die Mitgliedschaft in der Gemeinde sowie das Prozedere bei gerichtlichen Auseinandersetzungen werden ebenso thematisiert, fallen aber in der Quantität weit hinter die religiösen Angelegenheiten zurück. Aspekte der Säkularisierung bzw. des Alltags finden sich so gut wie gar nicht in den takkanot.

Bemerkenswert, wenn auch nicht singulär, ist die Weiterführung der Statuten über einen Zeitraum von fast 100 Jahren nach ihrer Entstehung. Nach dem Abschluss im Jahr 1755 wurden Ergänzungen in den Jahren 1789, 1808, $1809,1813,1821,1840,1842,1847$ und 1849 vorgenommen. Die fortlaufende 
Nummerierung der Ergänzungen zeigt, dass an der Grundgültigkeit der ursprünglichen Statuten von Seiten der Gemeindeführung keine Zweifel zugelassen wurden. 
[fol. $2 \mathrm{r}]$ אלו דברים שיש להם שיעור [/] אמרות טהורות לדורי דורות [/] אצורות מפושות ומפורשות

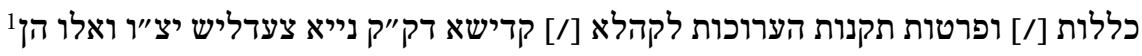

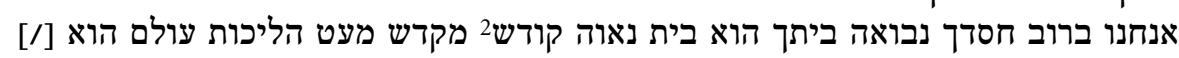

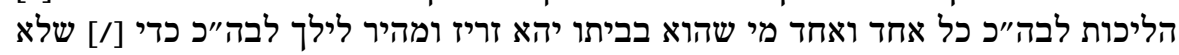

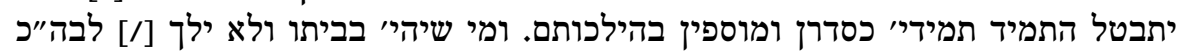

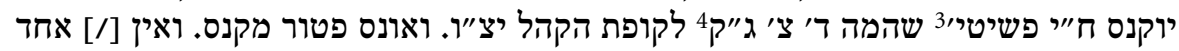

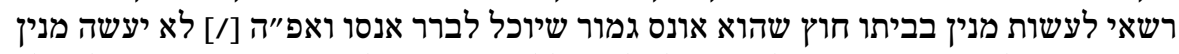

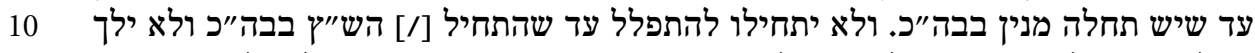

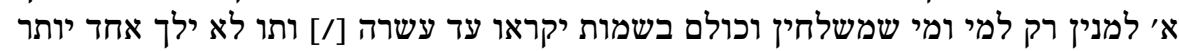

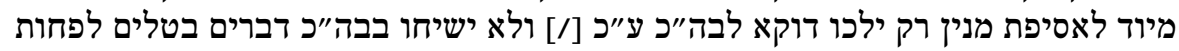

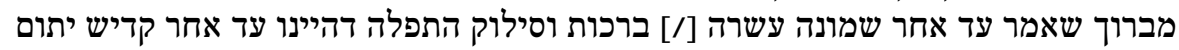

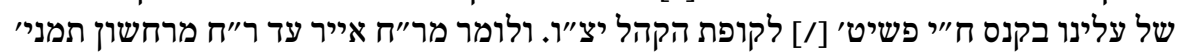

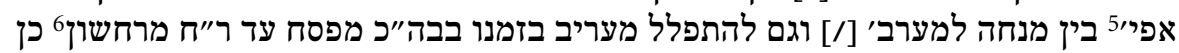

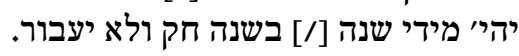

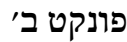

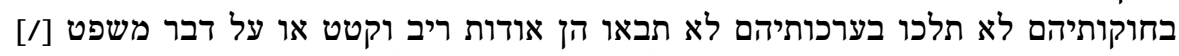

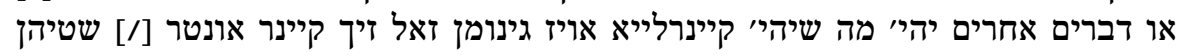

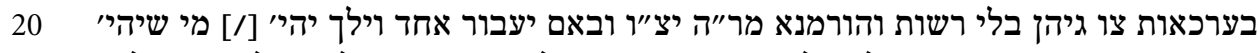

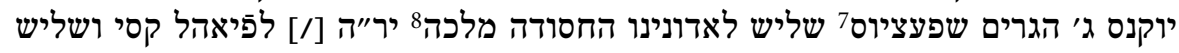

1 Bis hier in großer Quadratschrift, nachfolgend in Kursivschrift.

2 Aus der synagogalen Liturgie zum Freitagabend.

3 Dieses Wort später blau unterstrichen. פשיטים bezeichnet meist Pfennige.

4 Die Bedeutung von $>$ ist bislang unklar [drei Kreuzer?]. Die Abkürzung findet sich in keinem anderen, hier wiedergegebenen Text. Es scheint sich dabei um die Spezifizierung der Währung zu handeln, denn die Abkürzung erscheint hier generell immer in Verbindung mit Geldangaben in Höhe von einigen Kreuzern.

5 תמניא אפין (aram.: acht Gesichter) ist eine alternative Bezeichnung für Ps 119, dessen Verse jeweils acht Zeilen umfassen, die jeweils mit demselben Anfangsbuchstaben beginnen. Die Verse wiederum sind nach dem Alphabet geordnet.

6 Die letzten vier Wörter später blau unterstrichen.

7 Der Begriff bezeichnet eine hochwertige Münzeinheit. Dies ergibt sich zum einen aus dem zu ahnenden Vergehen, das hart bestraft werden sollte, um so eventuelle Übertretungen zu verhindern. Weiter ist der Nachsatz "Species« lediglich in Verbindung mit Talern oder Dukaten bekannt. Solche Münzen waren nach einem Konventionsfuß ausgemünzt. Es könnte sich also bei der Bezeichnung um einen Namen für Taler oder Dukaten handeln.

8 Gemeint ist Maria Theresia, Königin von Böhmen. 


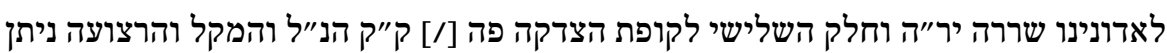

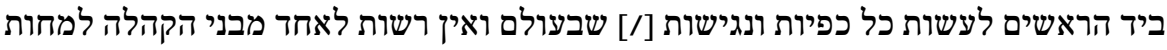

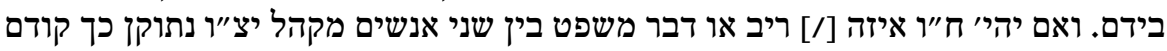

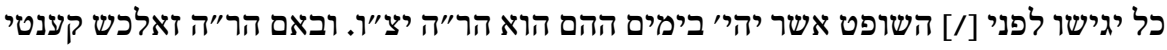

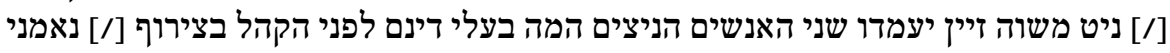

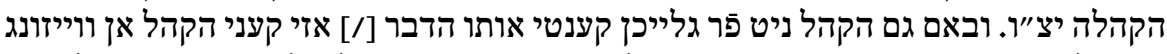

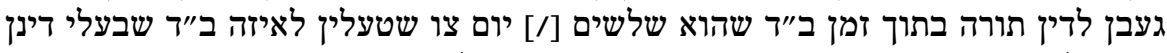

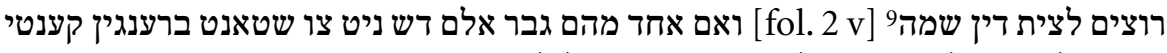

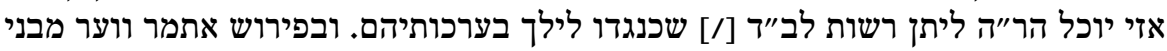

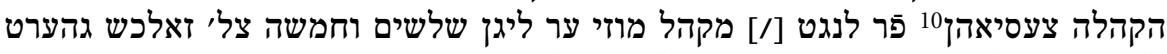

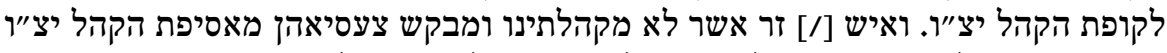

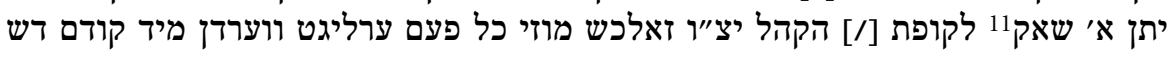

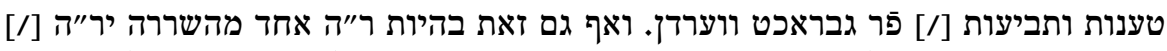

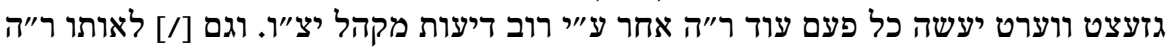

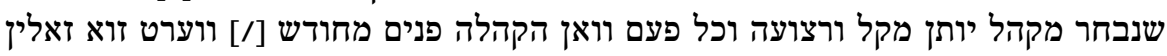

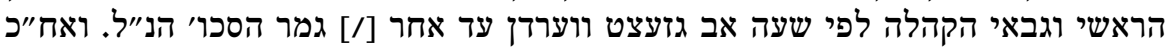

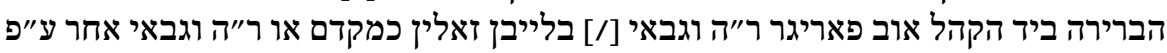

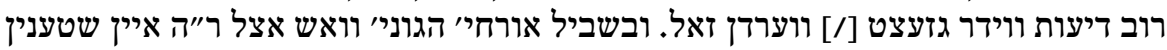

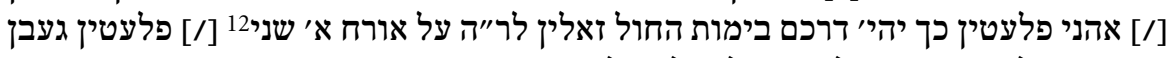
ווערדן אבל בשבת וי"ט לא יותי דריכם לו אלא פלעט אחת.

פונקט ג'ים

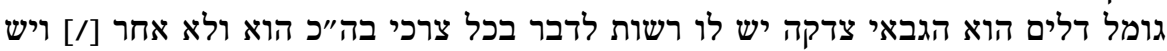

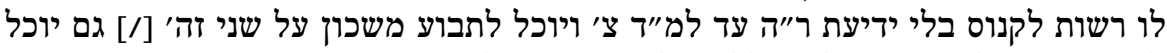

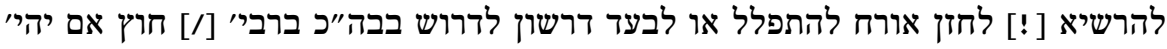

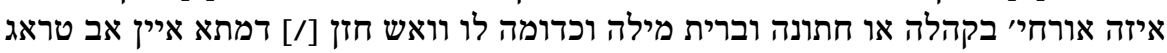

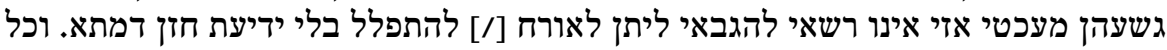

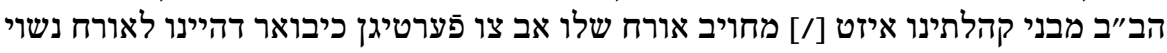

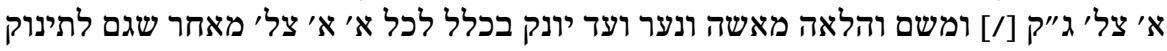

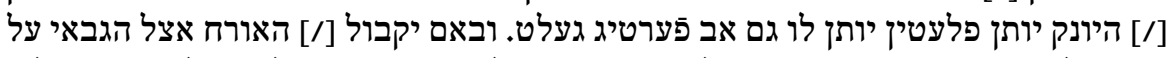

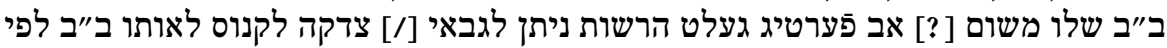
ראות עינו ע״כ.

\footnotetext{
9 Danach die Kustode ואם.

10 Prozessieren.

11 Schock, eigentlich ein Zählmaß. In Böhmen und Mähren gab es das Schock Groschen, was eine Summe, aber keine eigene Münze bezeichnete. Ein Schock entsprach zwei Reichstalern oder drei Gulden.

12 Danach פ als Zeilenfüller.
} 
פונקט ד' דרך אמונה בחרנו להחזיק טובה בישראל ואין טוב אלא תורה שיצא מהכל [/] פי פירות תנועת

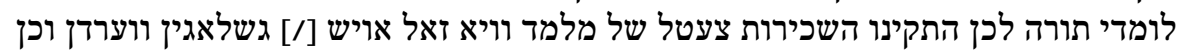

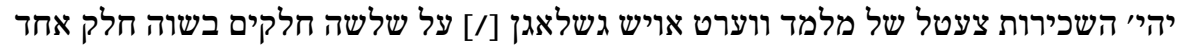

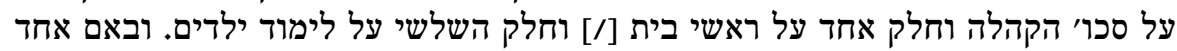

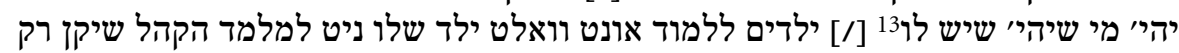

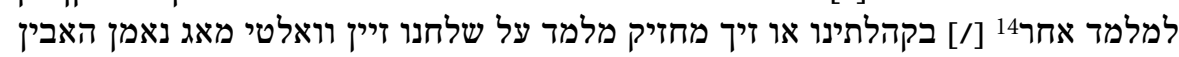

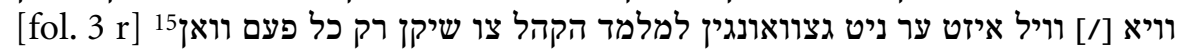

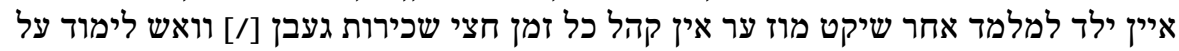

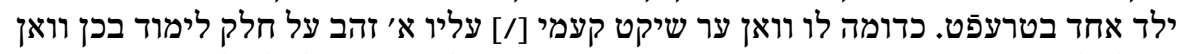

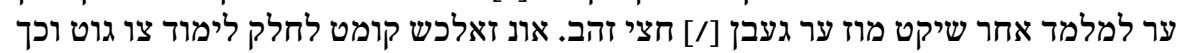

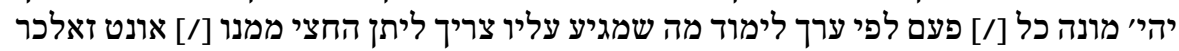

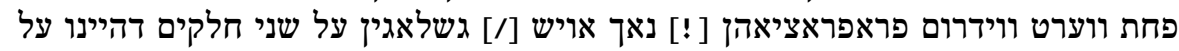

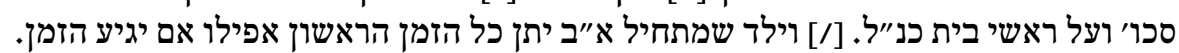

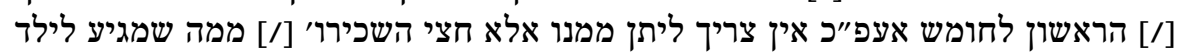

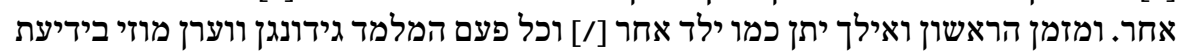

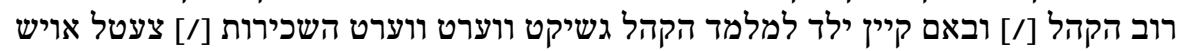

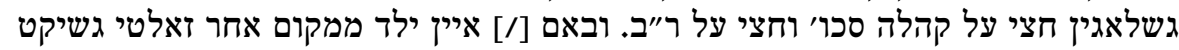

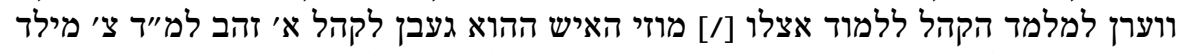

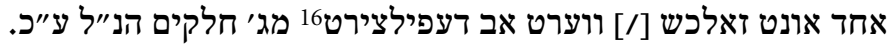

פונקט ה'

הסגן בבה"כ אצל הס"ת יחזור חלילה מידי חדש בחדשו לפי [/] הזקנה לכל אחד שלשים

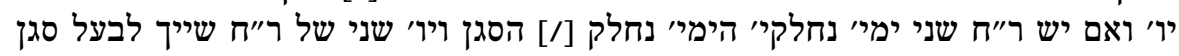

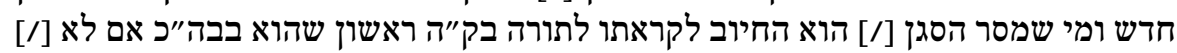

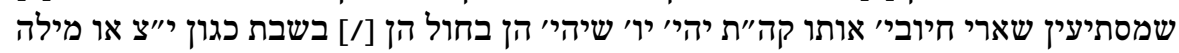

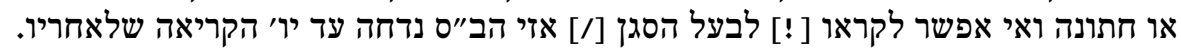

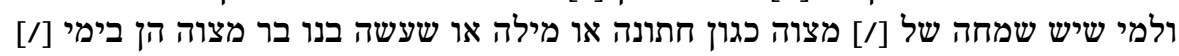

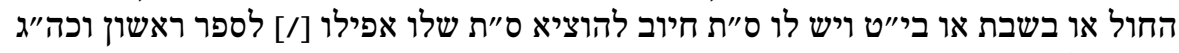
אם יש לו בגדי קודש. ברת או ביש.

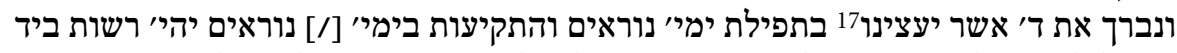

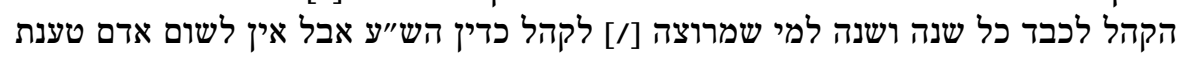

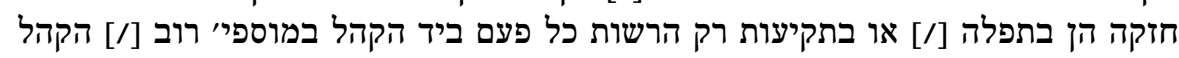

13 Danach' als Zeilenfüller.

14 Danach ב als Zeilenfüller.

15 Danach die Kustode איין.

16 Abgezogen.

17 Nach Ps 16,7. 
יצ"ו והתפלות ימים נוראי' יהיי נחלקים מקהל כל שנה בר"ח [/] אלול או בשבת שלפניו או בשבת שלאחרי וכן יקום.18 [fol. $3 \mathrm{v}$ ]

פונקט ז' זיר

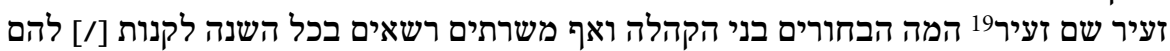

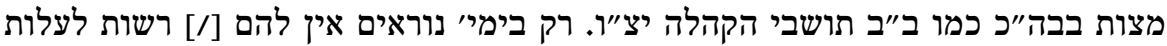

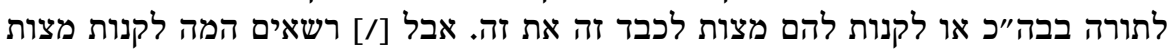
ולכבד לב"ב מבני הקהלה. לורה להם

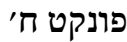

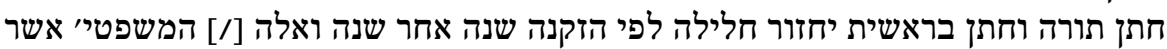

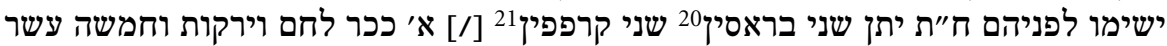

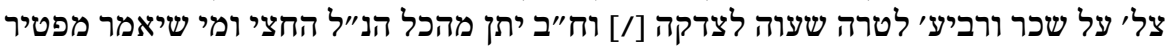

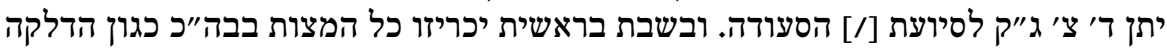

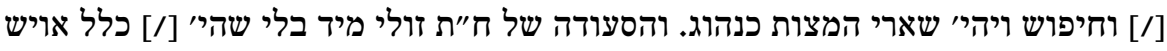

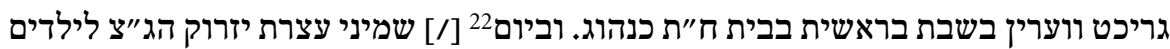

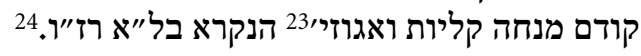

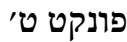

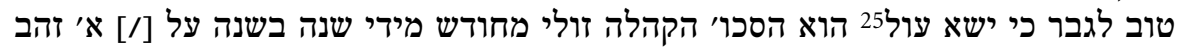

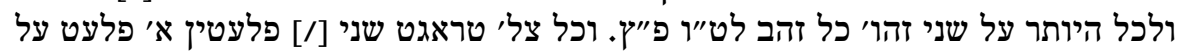

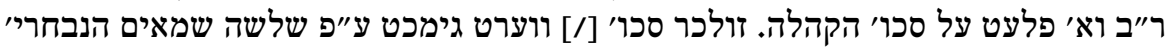

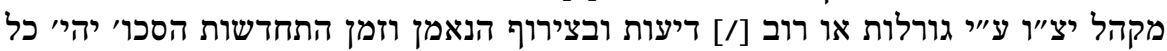

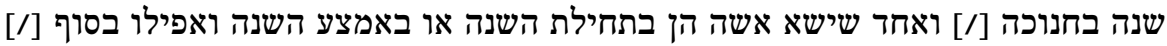

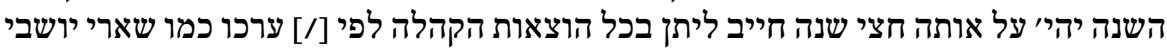

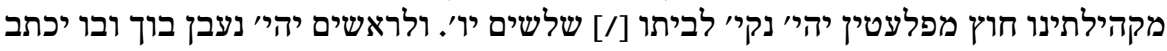

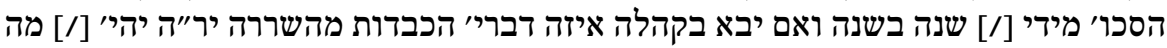

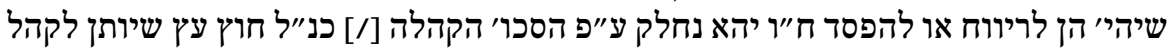

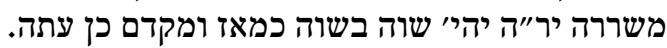

18 Danach die Kustode פונקט ז' זעיר.

19 Jes 28,10.13.

20 Brassen.

21 Karpfen.

22 Danach $ה$ als Zeilenfüller.

23 Pesahim 119b.

24 Eine Art Süßware.

$25 \mathrm{Klgl} \mathrm{3,27.}$ 
פונקט יו"ד יש רשות לכל ב"ב מקהלתינרינו להכניס בקהילתינו שלשה בנים או בנות [/] וליתן להם חזקה

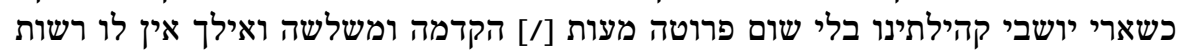

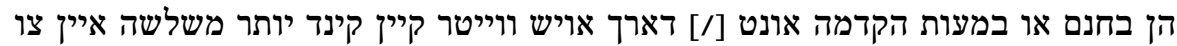

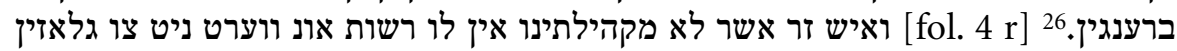

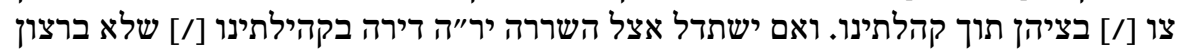

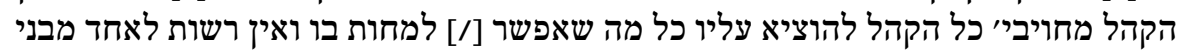

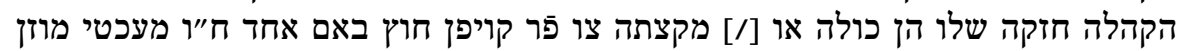

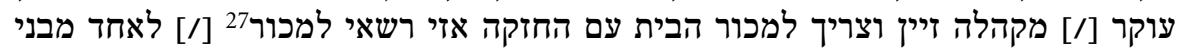

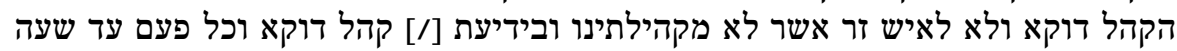

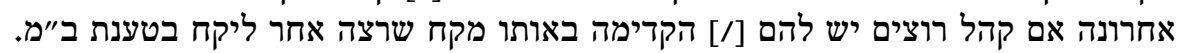

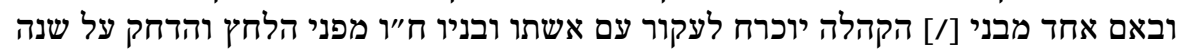

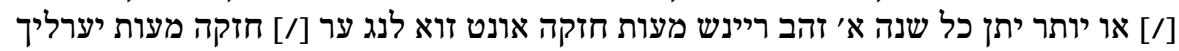

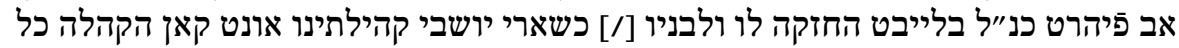

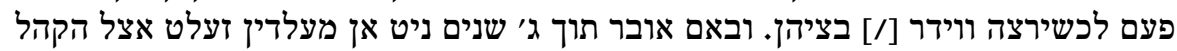

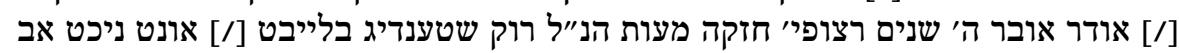

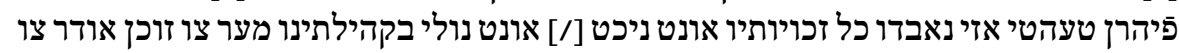

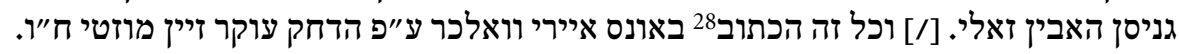

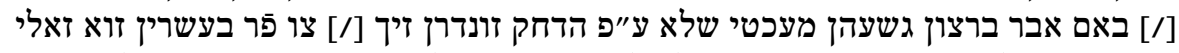

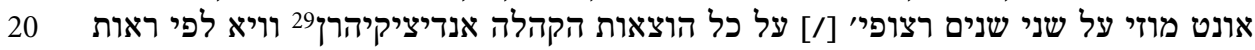

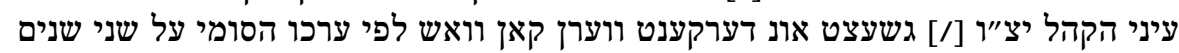

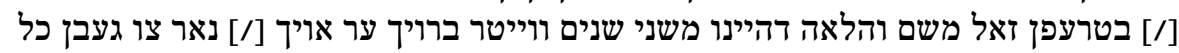

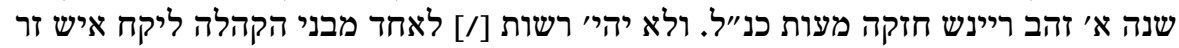

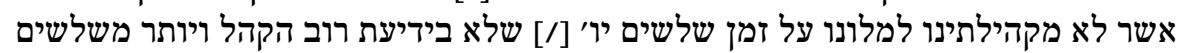

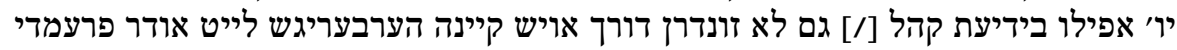

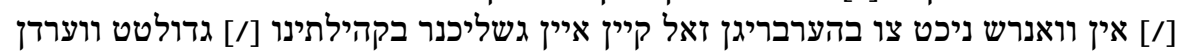

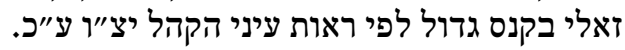

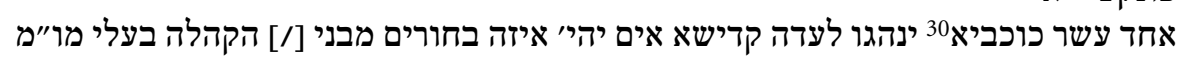

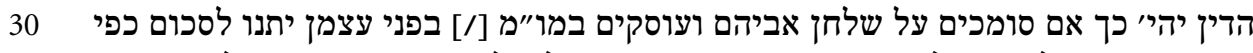

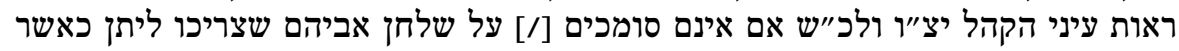

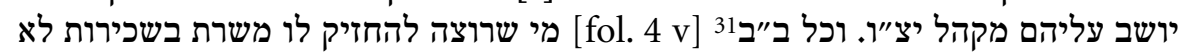

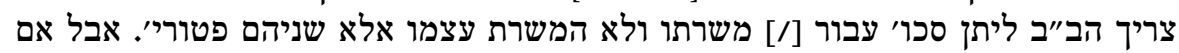

26 Danach die Kustode ואיש זר.

27 Danach ein weiteres, lang gestrecktes $\urcorner$ zur Füllung der Zeile.

28 Über dem Wort eine Ligaturlinie, deren Funktion nicht klar ist.

29 Indizieren, anzeigen, aufschlüsseln.

30 Aus dem Lied Ehad Mi Yodea der Pessach-Haggada.

31 Danach die Kustode מי שרוצה. 


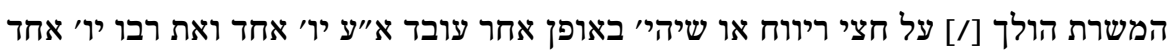
[/] צריך ליתן להסכו' המדינה לקהל כפי ראות עירות עיניהם באשר הוא שם.

פונקט י"ב

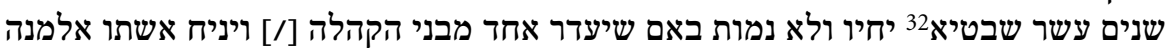

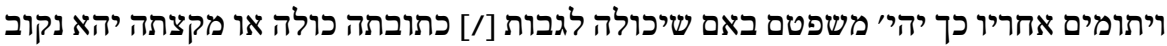

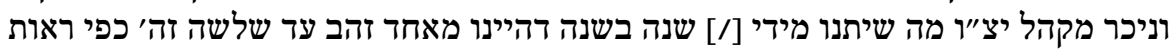

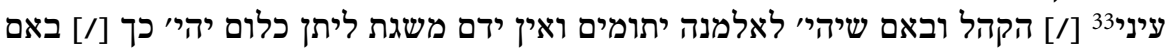

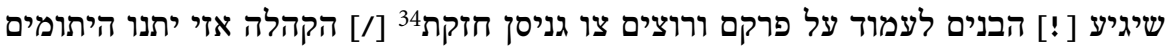

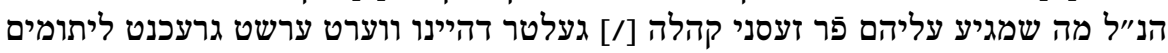

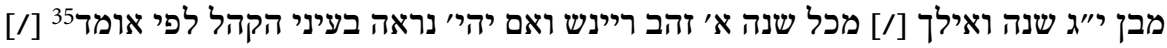

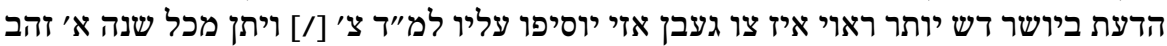

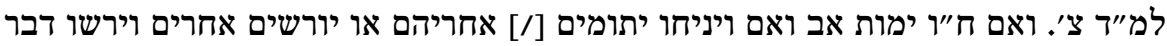

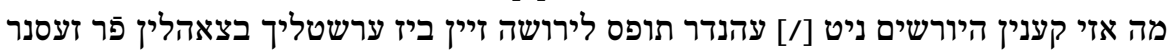
[/] געלטר כאשר יושם עליהם רוב הקהל יצ"ו ובלע מות לנצח כוריו כולם.36

פונקט י"ג 15

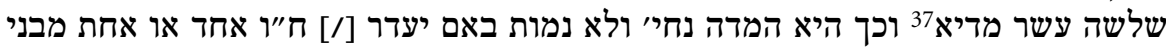

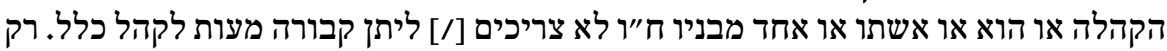

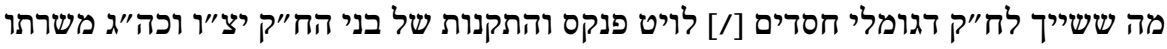

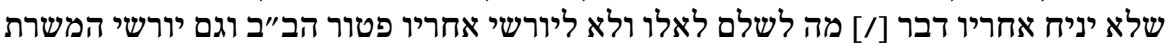

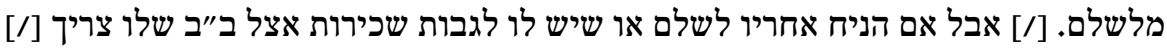

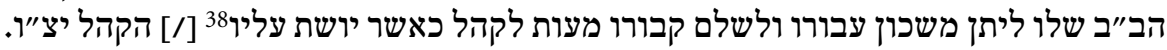

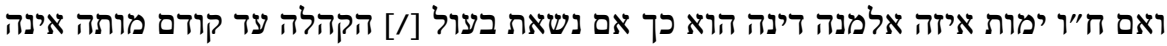

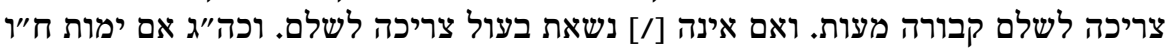

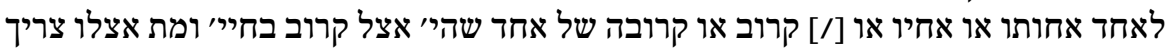

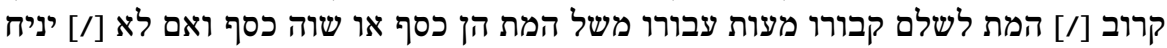

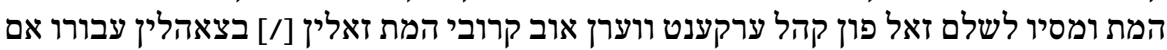

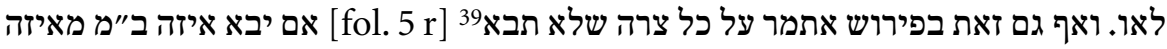

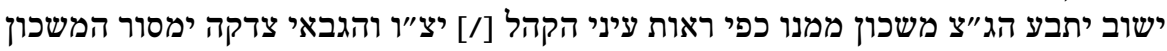
מיד לר"ה אשר יהייל להם בימיי ההם ובזמן הזה.

32 Aus dem Lied Ehad Mi Yodea der Pessach-Haggada.

33 Danach $\boldsymbol{B}$ als Zeilenfüller.

34 Danach $ה$ als Zeilenfüller.

35 Danach $\mathrm{n}$ als Zeilenfüller.

36 Jes 25,8 .

37 Aus dem Lied Ehad Mi Yodea der Pessach-Haggada.

38 Danach $ה$ als Zeilenfüller.

39 Mischna Ta'anit 3,8. Danach die Kustode אם יבא. 


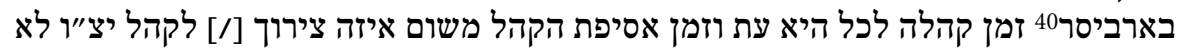

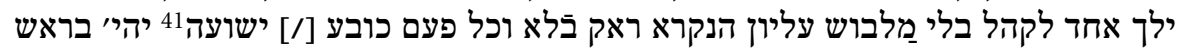

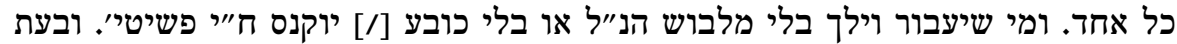

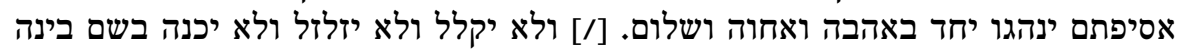

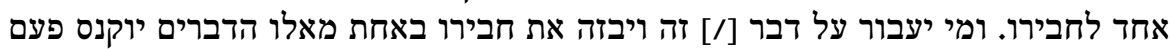

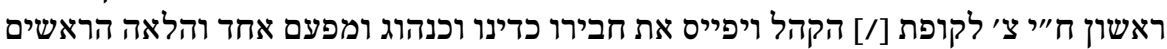

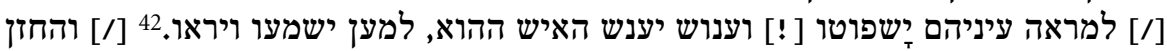

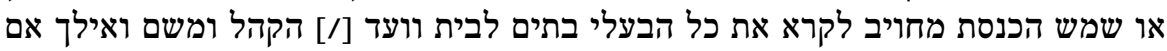

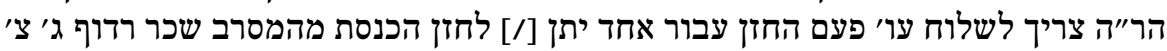

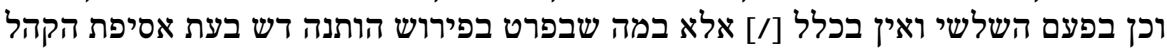

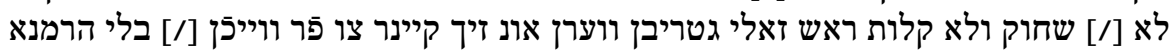

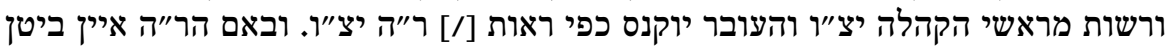

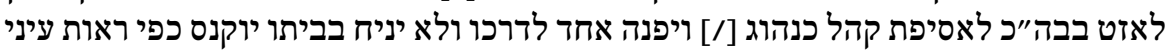

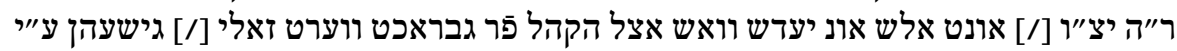

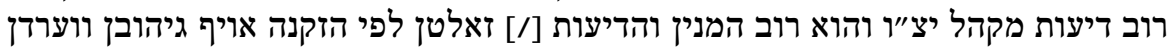

וכל יקום.

פונקט ט"ו

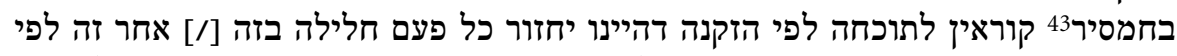

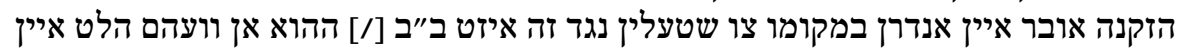

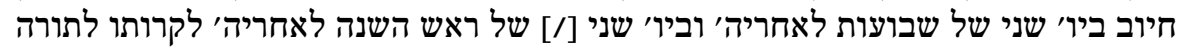

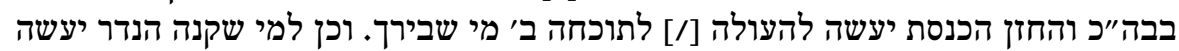

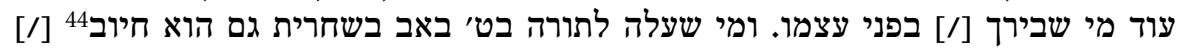

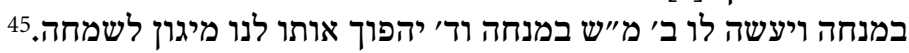

ששה עשר כללות ופרטות נאמרו46 מי שיהי' לו מצות סנדיקות [/] הנקרא קוואטר שפטי47

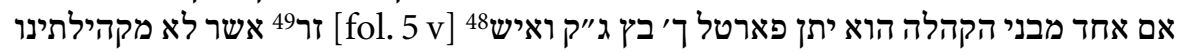

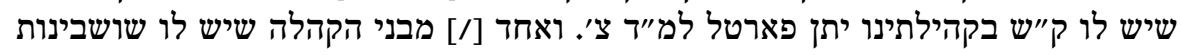

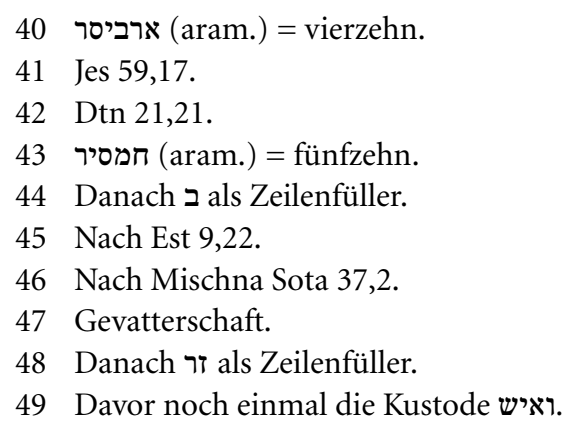




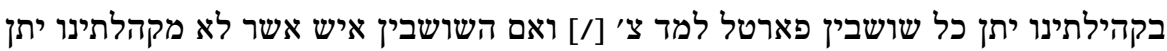

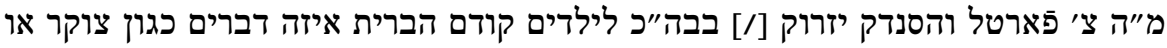

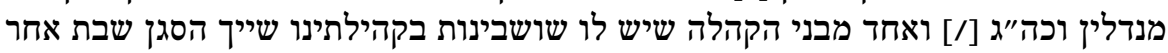

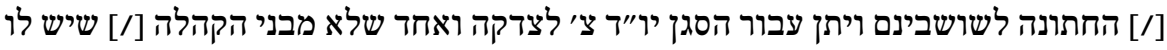

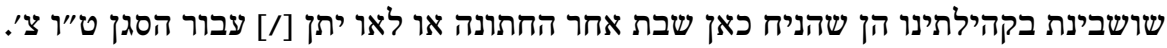

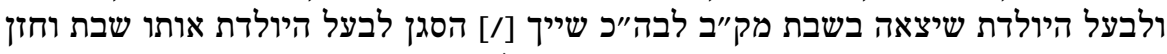

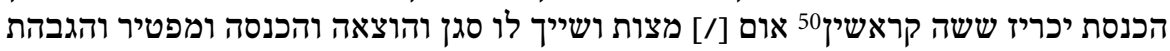

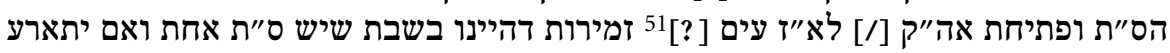

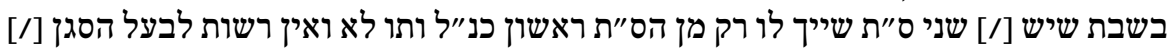

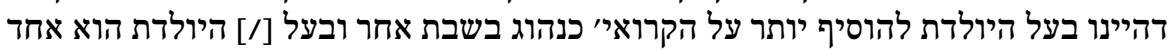

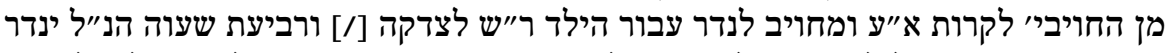

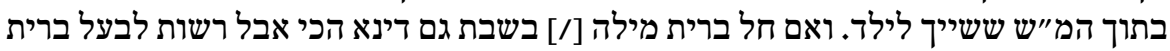

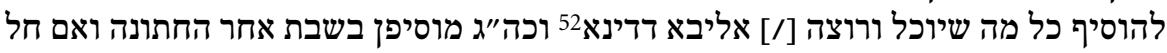

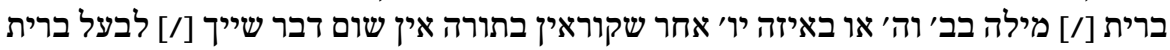

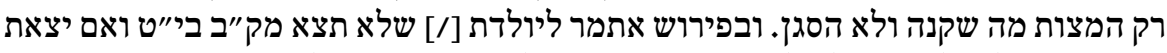

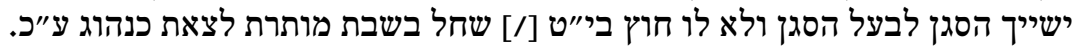

פונקט יו"ז

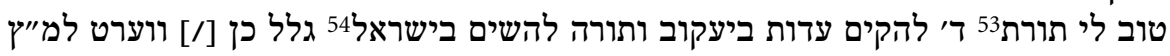

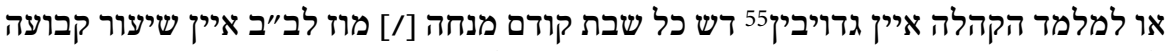
לערנין או בבה"כ או באיזה מקום [/] שיבחרו הקהל יצ"יכ"ור.

פונקט י"ח

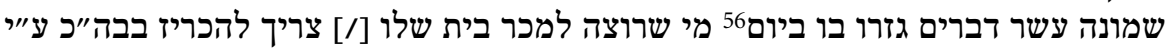

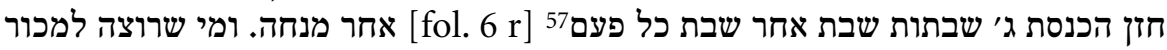

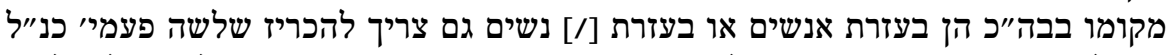

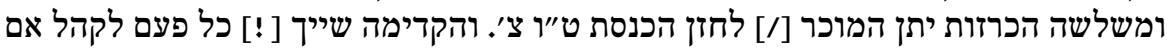

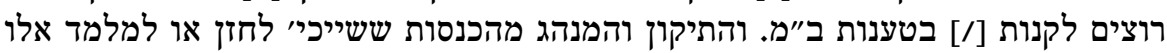

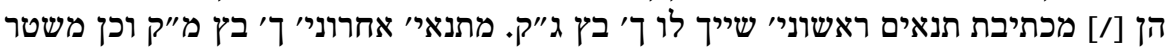

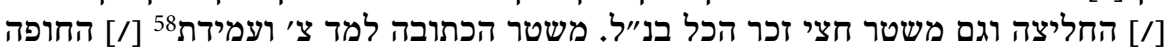

50 Groschen.

51 Wörter teilweise übereinander geschrieben, Lesung unklar.

52 אליבא דדינא (aram.) = nach dem Gesetz.

53 Ps $119,72$.

54 Nach Ps 78,5.

55 Anbefohlen.

56 Mischna Shabbat 13,2.

57 Danach die Kustode אחר מנחה.

58 Danach $ה$ als Zeilenfüller. 


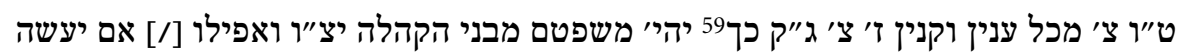

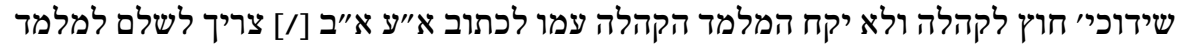

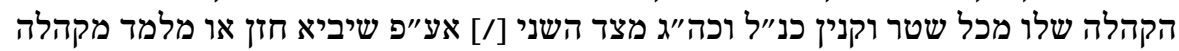

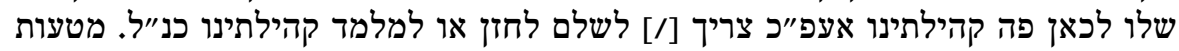

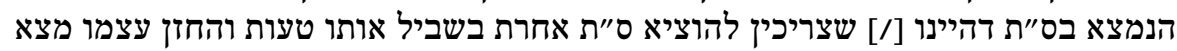

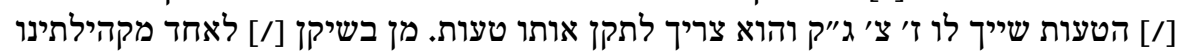

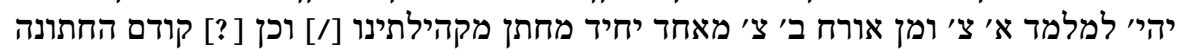

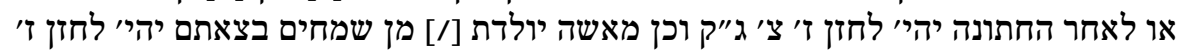

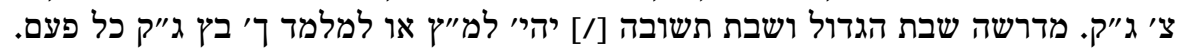

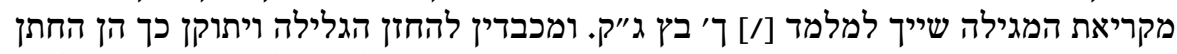

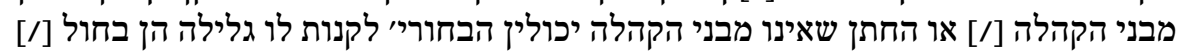

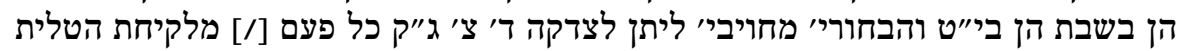

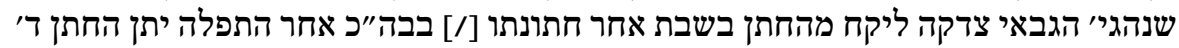

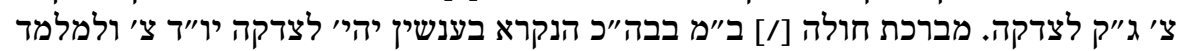

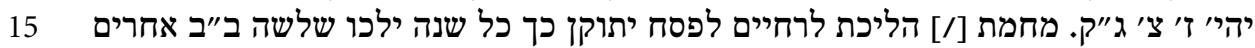

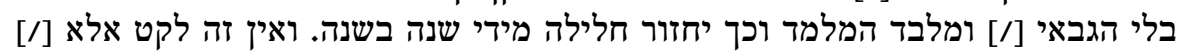

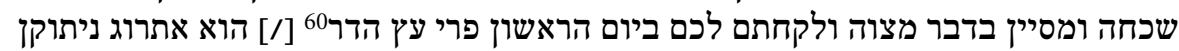

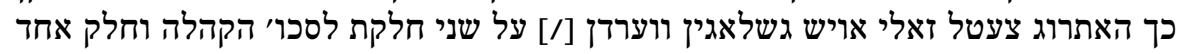

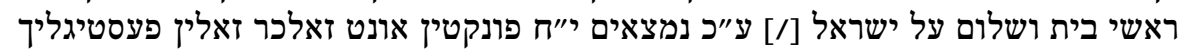

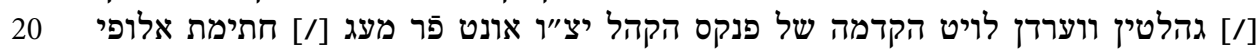

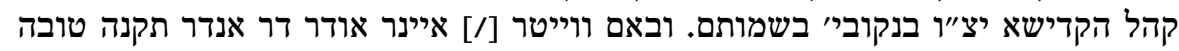

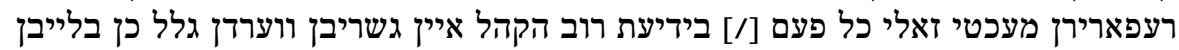
[/] ה'דפין שפאציום

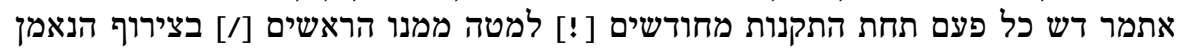

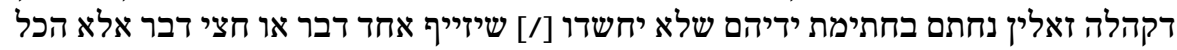

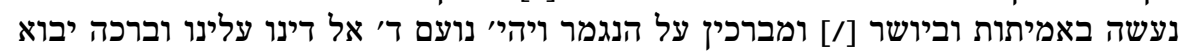

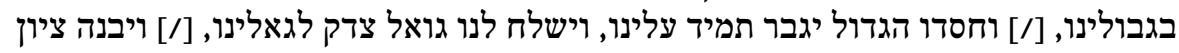

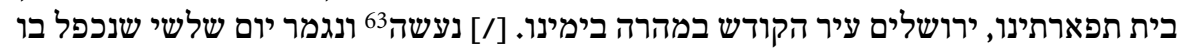

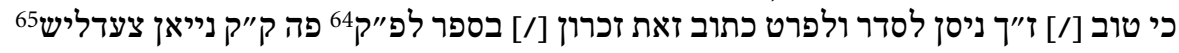

59 Darüber, wohl fälschlich, als Abkürzung gekennzeichnet.

60 Lev 23,40.

61 Spatium (lat.) = Raum, Platz.

62 Danach die Kustode ובפירוש.

63 Ab hier drei Zeilen in großer Quadratschrift.

641755 IV 8. Die Jahresangabe erfolgt durch die größer geschriebenen Buchstaben der vorausgehenden Wörter.

65 Die letzte Zeile dieses Abschnitts ist beidseitig jeweils durch einen aufwändig mit Tinte gezeichneten Stern dekoriert. 


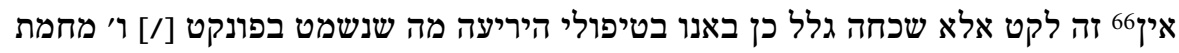

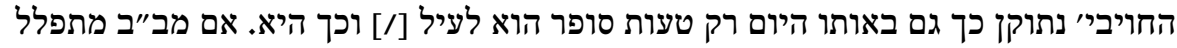

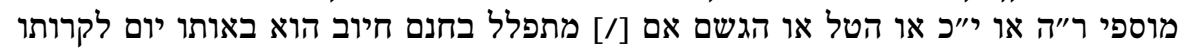

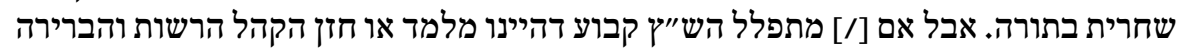

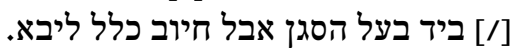

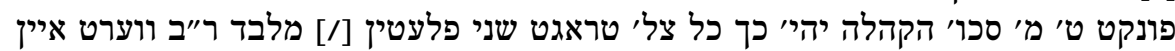

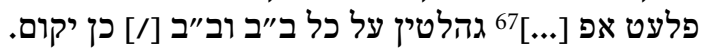

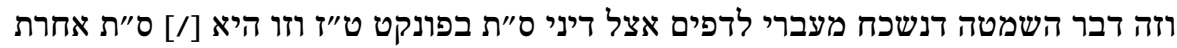

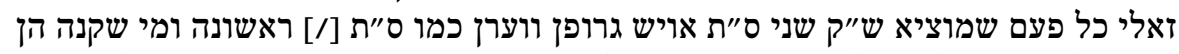

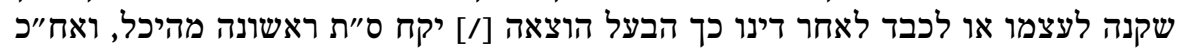

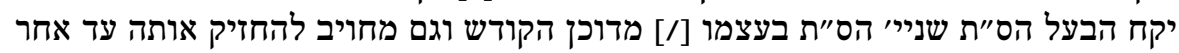

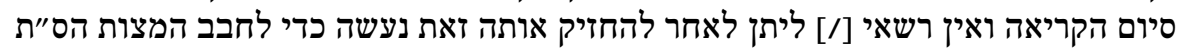
[/] [ניים ביותר וכן יקום.

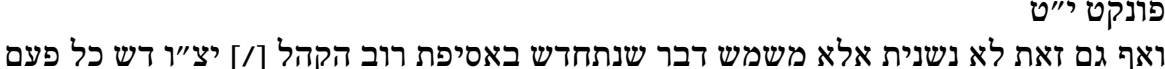

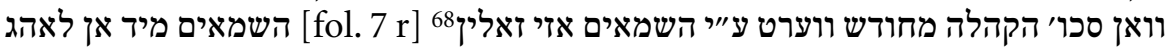

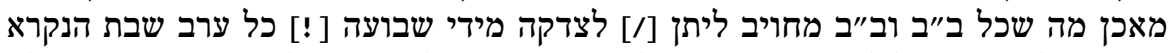

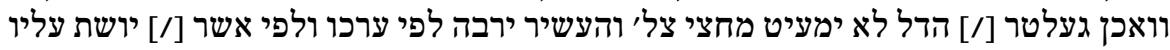

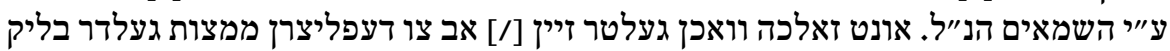

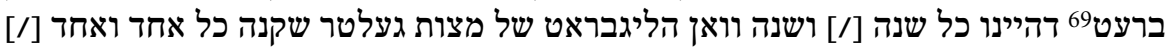

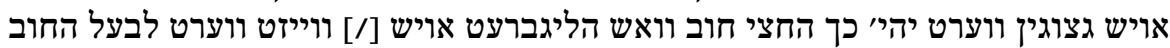

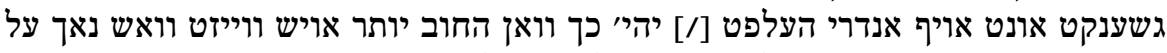

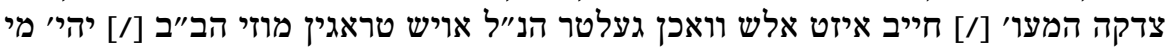

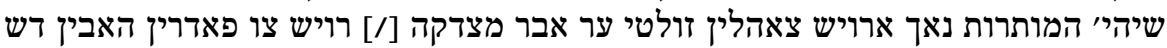

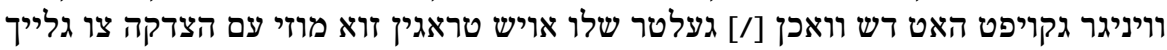
אויף היבן [/] אונ הצדקה ברויך איהם ניקש גלט ארויש צאהלין.

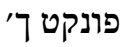

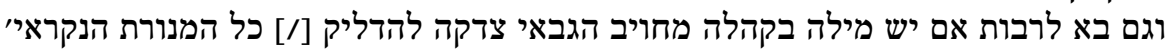

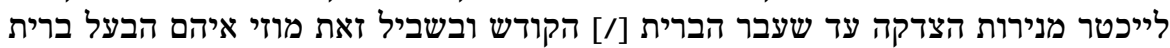

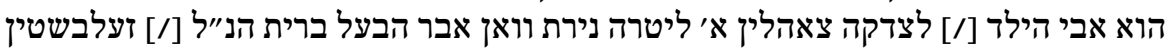

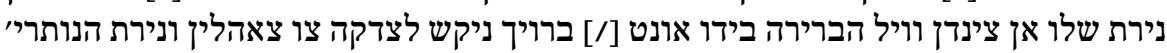

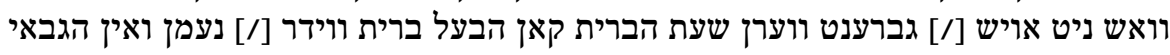

66 Ab hier spätere Ergänzungen.

67 Wort in kleinen Buchstaben, die fast vollständig durch die ausgeprägte Unterlänge des darüberstehenden Wortes verdeckt sind.

68 Danach die Kustode השמאים.

69 Legbrett. 
צדקה רשאי למחות בידו.

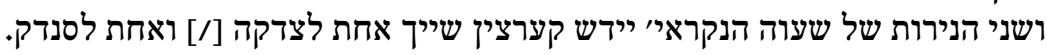

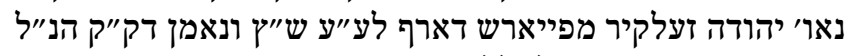

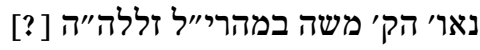

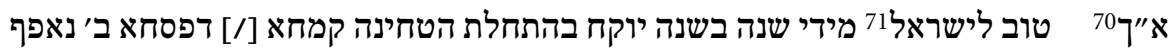

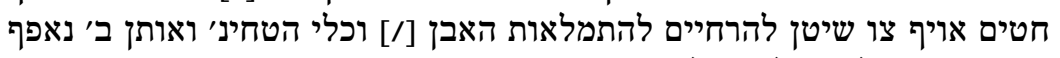

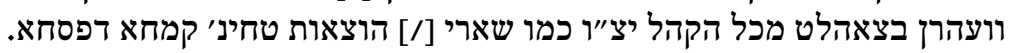

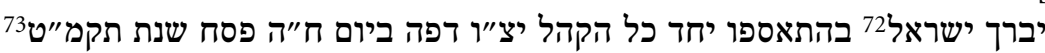

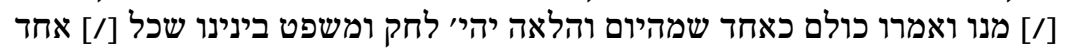

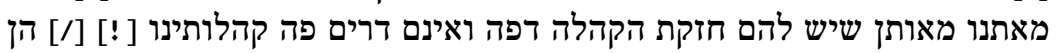

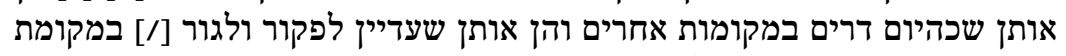

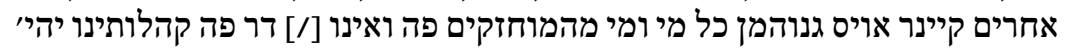

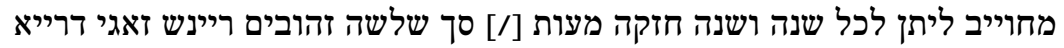

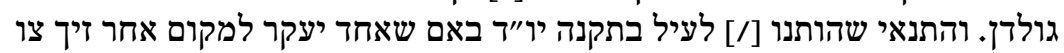

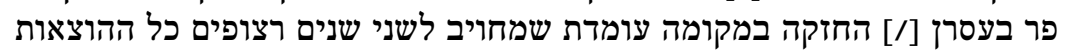
[/] הקהלה מיט צו האלטן ודלעיל.

בו ביום הנ"ל ענו ואמרו כולם כול כאחד שמהיום והלאה יהי' לחק ומשפט [/] אחד לכולנו

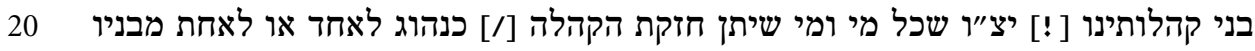

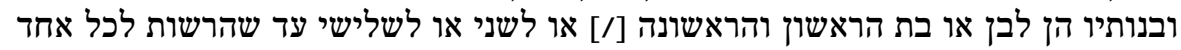

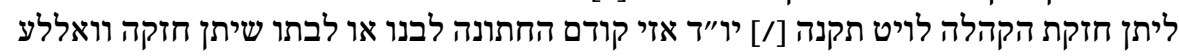

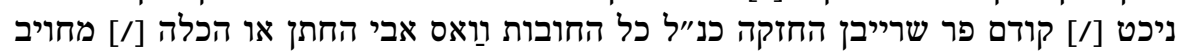

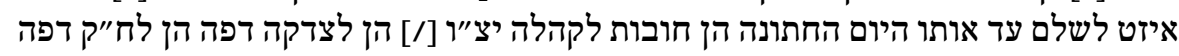

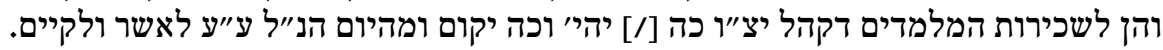

פונקט ך"ד

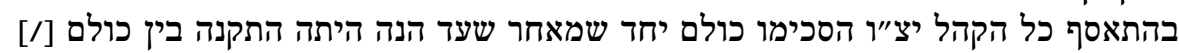

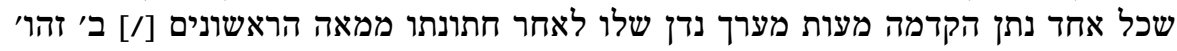

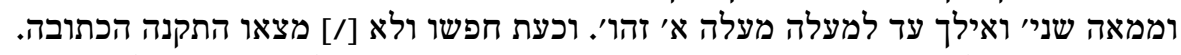

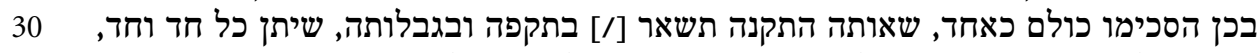

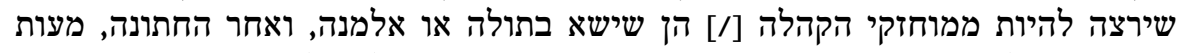

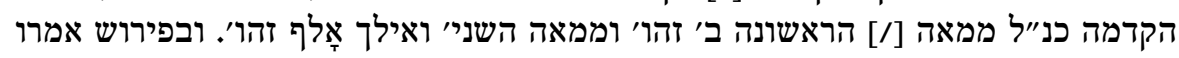

70 Bei diesem und dem folgenden Paragraphen erfolgte die Nummerierung in dieser abweichenden Form, um so die Bibelzitate einfügen zu können.

71 Ps 73,1

72 Gen 48,20 .

$73 \quad 1789$ IV 12. 


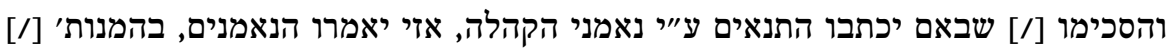

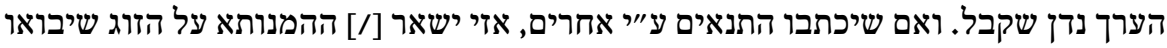

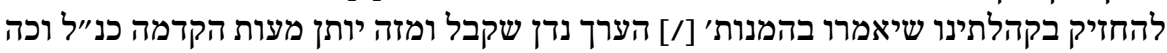

יהי' וכה יקום.

[fol. $8 \mathrm{r}$ ]

פונקט ך"ה

בהתאסף כל הקהל בחהמ"פ שנת תקט" תקס"ח

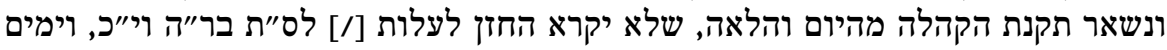

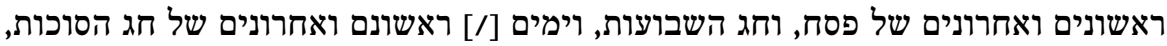

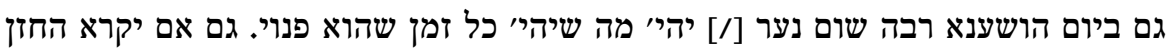

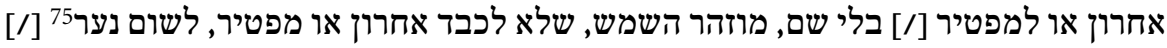

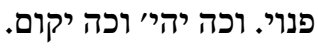

פונקט ך־"ו

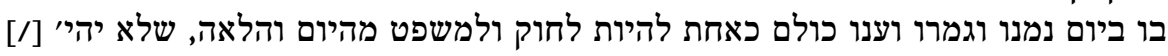

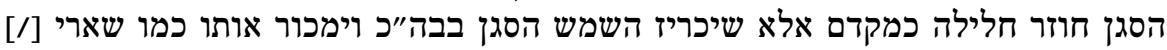

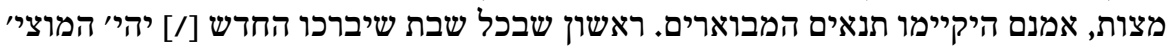

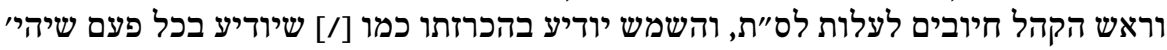

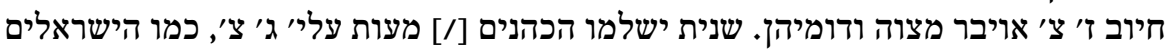

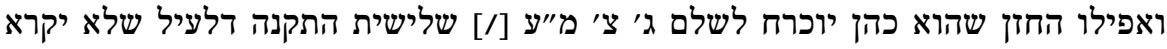

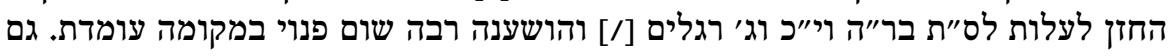

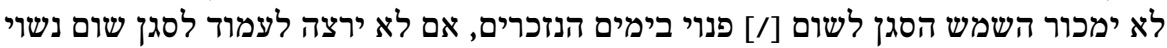

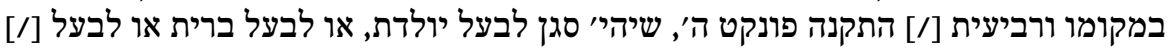

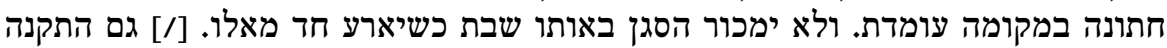

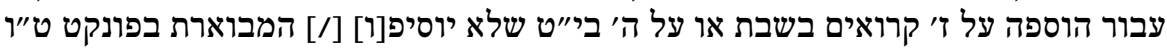

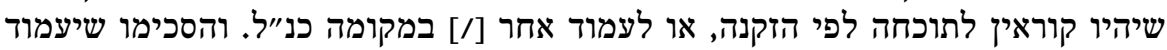

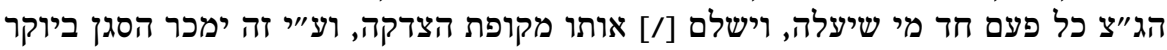

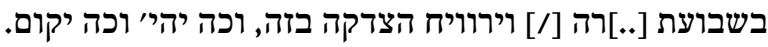

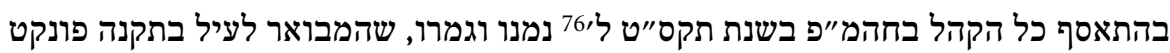

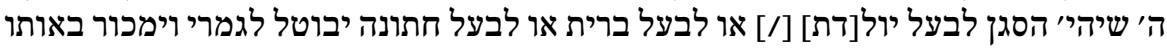

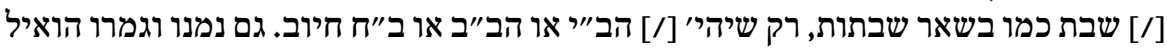

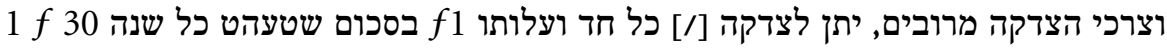

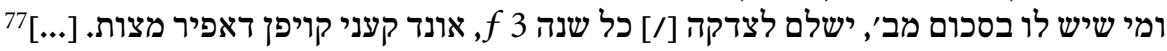
[fol. 8 v]

\footnotetext{
741808 IV 12-14.

75 Davor ein gestrichenes 9.

761809 IV 2-6.

77 Am unteren Blattrand noch drei wegen ihrer geringen Größe unleserliche Wörter.
} 
פונקט ך"ז

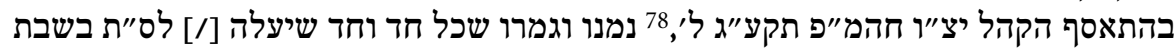

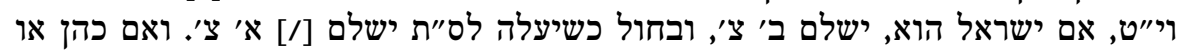

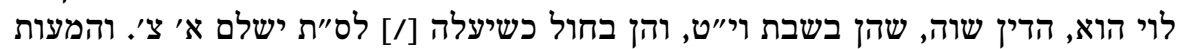

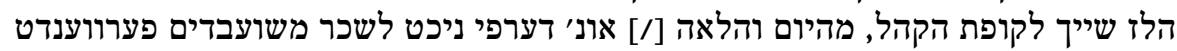

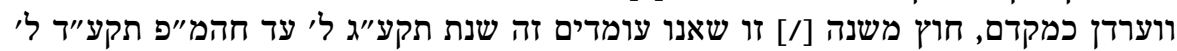

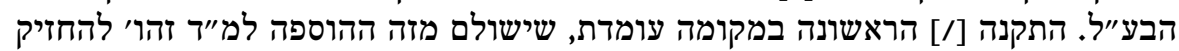

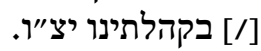

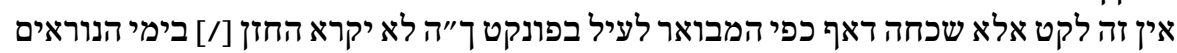

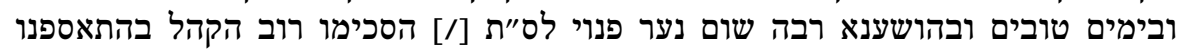

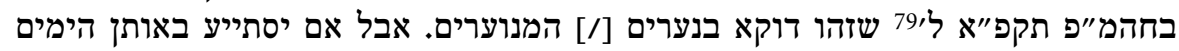

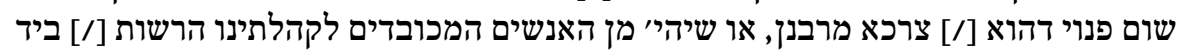

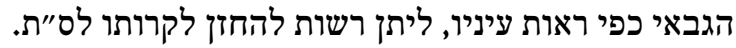

פונקט ך"ט

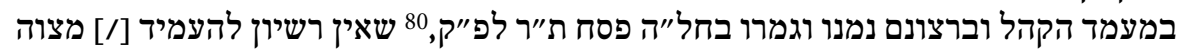

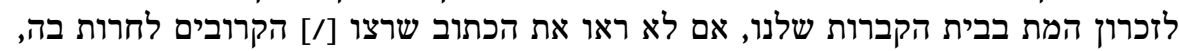

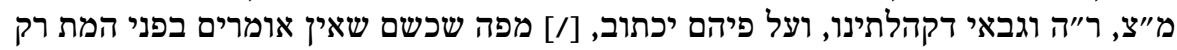

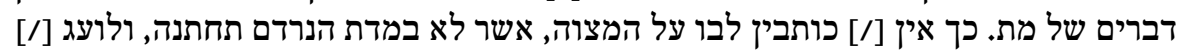

אבענדערונג דעס פונקטעס ך"ה

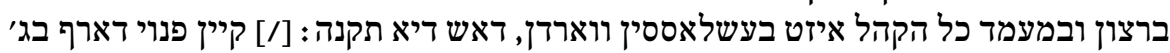

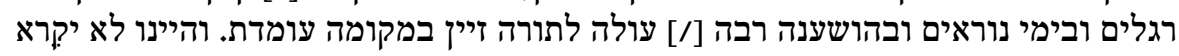

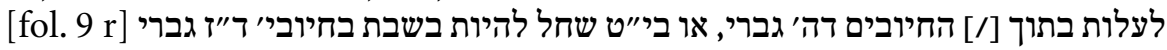

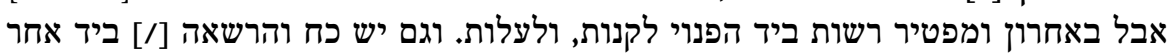

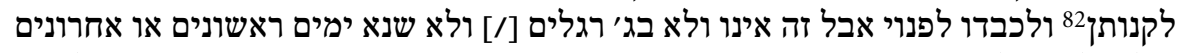

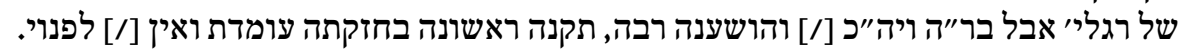

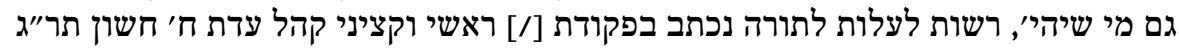

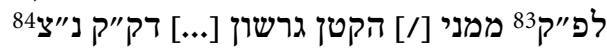

\footnotetext{
$78 \quad 1813$ IV $18-20$.

79 1821 IV 19-22.

801840 IV 20-23.

81 Spr 17,5.

82 In der Handschrift: לנקותן.

831842 X 12. Die Lesung des Monatsnamens unsicher; auch wurde das ' $\pi$ zweimal verwendet, sowohl für das Tagesdatum, als auch für den Beginn des Monatsnamens.

848
} 


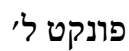

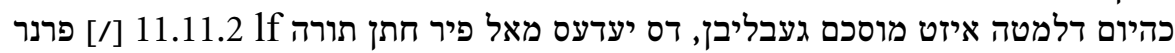

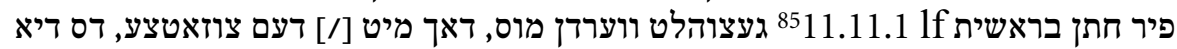

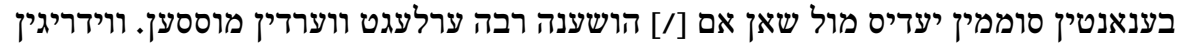

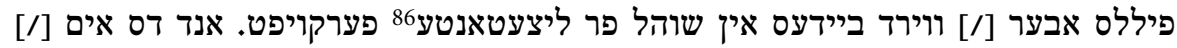
פולגנדין יאהרע געהט עם עם ווירד ביירעם דיוס דער רייהע נאך.

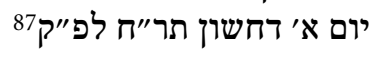

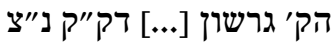

$$
\text { פונקט ל"א }
$$

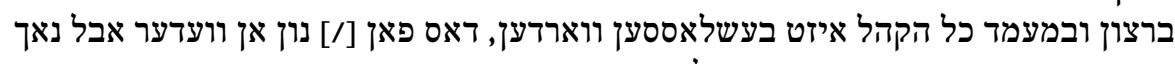

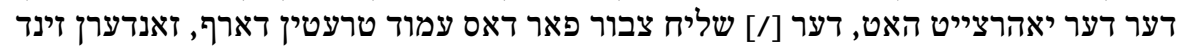

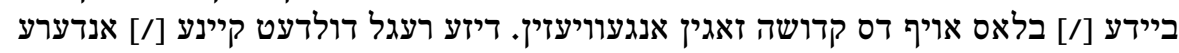

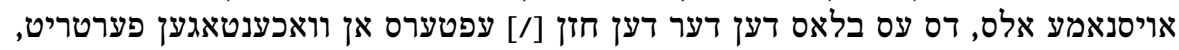

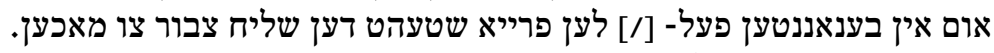

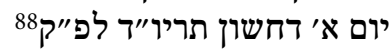

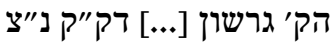

[fol. $12 \mathrm{r}]^{89}$

ואלו שמות בני ישראל הבאים [/] בחתימת ידיהם הנקובים בשמותם [/] כיבואר ואלה הן

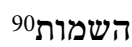

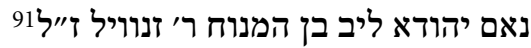

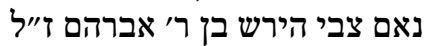

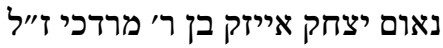

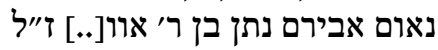

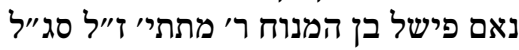

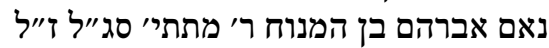

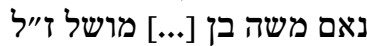

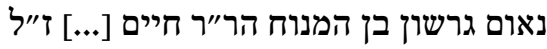

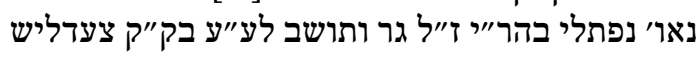


92 Zeile nach Streichung unleserlich.

93 Tachau.

94 In der Handschrift: יהואד.

95 Name durch Streichung unleserlich. 


\section{Republik der Vereinigten Provinzen der Niederlande}

Den Haag (1701, 1716, 1723)

Landesjudenschaft der Meijerij 's Hertogenbosch (1764) 



\section{Statuten aus Den Haag (1701)}

\section{Quelle: Pinkas Den Haag I, Gemeentearchief Den Haag, NIG, no.1}

Diese Statuten aus Den Haag sind die ältesten der damals gerade gegründeten aschkenasischen Gemeinde in der niederländischen Residenzstadt und darüber hinaus die ältesten, heute erhaltenen einer aschkenasischen Gemeinde aus dem Gebiet der Vereinigten Provinzen der Niederlande überhaupt. Mit der Abfassung wurden zwei einflussreiche sephardische Juden aus der schon länger bestehenden portugiesischen Gemeinde, Manuel Levy Duarte und Moses Pinto, von Seiten der Stadtregierung beauftragt. Sie sind in ihrem knappen Umfang nicht mehr als ein Grundgerüst für die gerade entstandene aschkenasische Gemeinschaft (Hoogduitsche Gemeente).

Die vorliegende Version mit 18 Paragraphen ist in einer Kopie des Textes enthalten, die sich im Protokollbuch der Gemeinde befindet, welches jedoch erst 1723 angelegt wurde. Offenbar gab es zu Beginn des 20. Jahrhunderts noch eine niederländische Version, die von Désiré S. van Zuiden in seinem Buch über die Haager aschkenasische Gemeinde abgedruckt wurde. Diese differiert jedoch von der hier edierten Vorlage insofern als der erste Paragraph fehlt und die Einleitung leicht abweichend formuliert ist. Eine weitere, undatierte Version in jiddischer Sprache findet sich im Synagogenbuch der Gemeinde. ${ }^{1}$ Auch sie umfasst 17 Artikel, enthält aber den ersten, während der letzte, der die Bekräftigung der Gültigkeit beinhaltet, dort fehlt. Somit ist der hier wiedergegebene Text wohl die vollständigste Version, die auch, zusammen mit einer Kopie der späteren takkanot von 1723, in das Protokollbuch der Gemeinde aufgenommen wurde. Jedoch datiert die Vorlage von van Zuiden 19 Tage (1701 I 24) später als die Kopie im pinkas. Da sich die nachfolgenden takkanot von 1716 auf einzelne Bestimmungen dieser ersten Statuten beziehen und dabei die in den jiddischen Versionen benutzten Paragraphennummern angeben, scheinen für den innergemeindlichen Gebrauch immer die jiddischen Versionen ausschlaggebend gewesen zu sein.

Der Text ist vollständig erhalten, die Blätter weisen keine Beschädigungen auf. Verfasst wurden die Statuten, wie allgemein in den niederländischen Gemeinden des 18. Jahrhunderts üblich, auf Jiddisch, das Einflüsse durch das Niederländische aufweist. Auffallend sind einige Lehnwörter und die typi-

1 Gemeentearchief Den Haag, NIG, no. 625, fol. 40-41. 
sche, mit dem Präfix »ge-« beginnende Partizipialform. Der Schreiber der Kopie, wie auch der im pinkas folgenden Kopie der Statuten von 1723 scheint Isaak bar Israel, ne'eman der Gemeinde, gewesen zu sein. ${ }^{2}$

Die Paragraphen wurden mit hebräischen Buchstaben in Quadratschrift nummeriert, die sich jeweils in größerem Abstand über dem Abschnitt befinden. Die Seiten der Handschrift sind jeweils in der oberen linken Blattecke foliiert.

Die Statuten befassen sich mit der Wahl und den Kompetenzen der Vorsteher, einigen Ehrenämtern in der Synagoge sowie der Aufnahme bzw. dem eventuellen Abgang von Gemeindemitgliedern. Zur Verhängung des Bannes bedurften die Vorsteher der Zustimmung der beiden Verfasser der takkanot, Manuel Levy Duarte und Moses Pinto. Im Falle von Differenzen lag laut Paragraph 16 die letzte Entscheidung beim Vorstand der aschkenasischen Gemeinde in Amsterdam. Der Text besaß offenbar noch während des gesamten 18. Jahrhunderts eine gewisse Gültigkeit, da spätere takkanot sich stets auf die von der Stadtobrigkeit in Auftrag gegebenen Statuten beziehen.

2 Siehe den pinkas der Gemeinde Den Haag, Gemeentearchief Den Haag, NIG, no.1, fol. 16, dort Unterschrift des Schreibers. 
[fol. $1 \mathrm{r}$ ] קופייא מן התקנות של קהל אשכנזים דען האג מה שנתנו מן השררה יר״ה מהשופטט

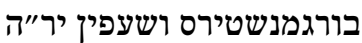

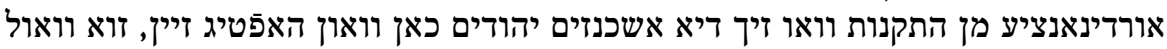

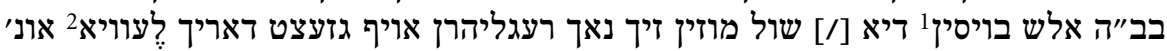

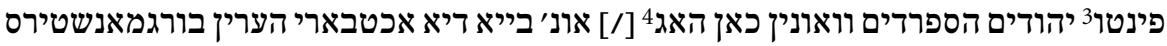

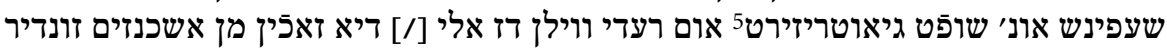

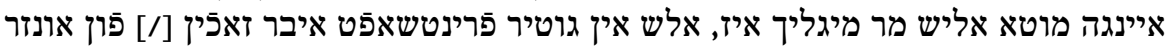
סארמונייע וגם התקנות צו אונטיר האלטין גלטי גלייך פَאליגטי פרינט

א׳6

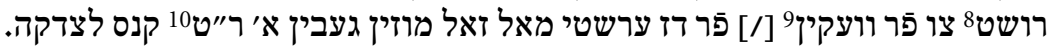

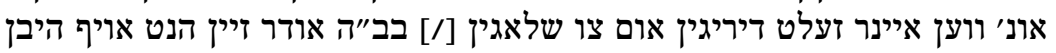

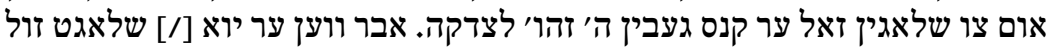

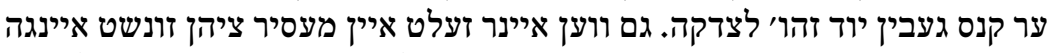

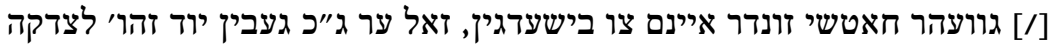

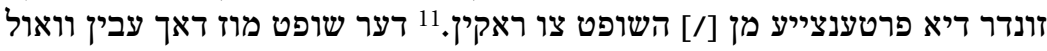
זיין קנס האבין ווען ער שוין יוד זהו' לצדקה מוז געבין.

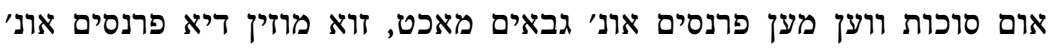

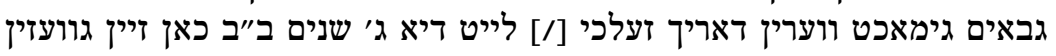

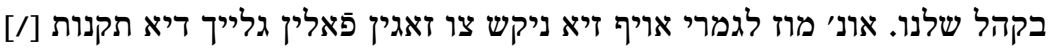

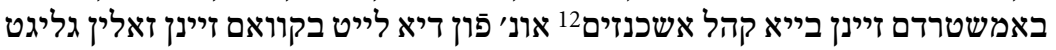

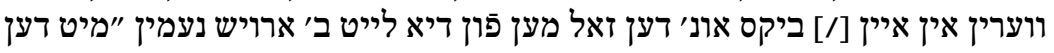

1 Von ndl. buiten $=$ außerhalb.

2 Manuel Levi Duarte.

3 Moses Pinto; In der Handschrift: פינטי

4 Danach ein Wort unleserlich gestrichen.

5 Das $v$ in der Wortmitte über der Zeile ergänzt.

6 Dieser Paragraph ist in der Edition von van Zuiden, Hoogduitsche Joden, nicht vorhanden.

7 Von ndl. ruzie $=$ Streit.

8 um rust, von ndl. onrust $=$ Unruhe.

9 Von ndl. verwekken = verursachen.

10 Ein Reichstaler entspricht 50 Stuiver.

11 Von ndl. raken = verletzen, berühren.

12 Die viel ältere Gemeinde in Amsterdam wurde hier, wie oft geschehen, zum Vorbild genommen. Jedoch ist ein früherer Amsterdamer Statutentext als der von 1711 bislang unbekannt, siehe dazu Elchanan Tal, Ha-kehilla ha-ashkenazit be-Amsterdam ba-me'a ha-y"ḥ (Die aschkenasische Gemeinde in Amsterdam im 18. Jahrhundert), Jerusalem 2010, passim. 


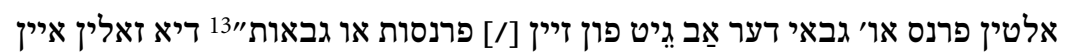

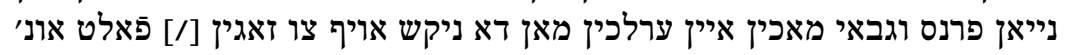

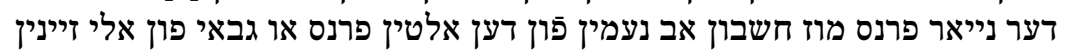
הוצאות [/] והכנסות אין פריזענטצייע פון פון כל הקהל.

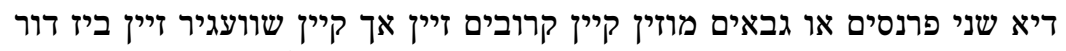

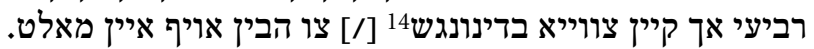

ווען מען איין פרנס או גבאי מאכט אונ' ער וויל עש ניט אן נעמין זוא ער מיד מוזין

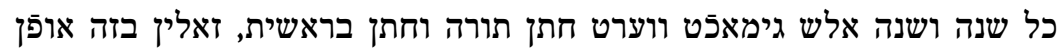
ה

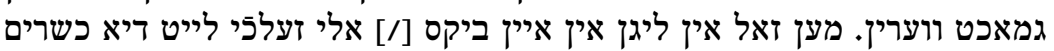

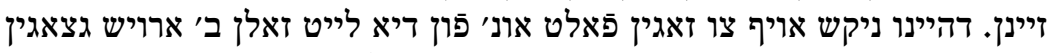

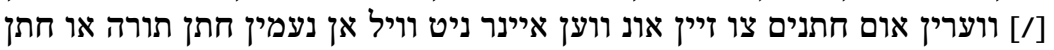

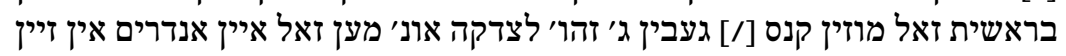

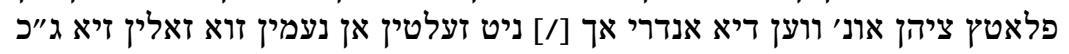

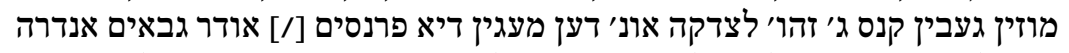

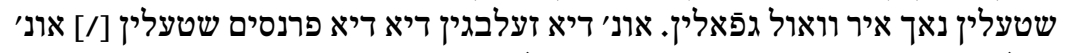

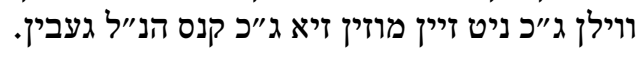

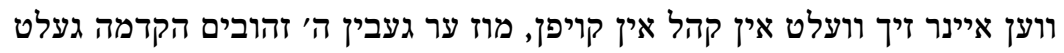

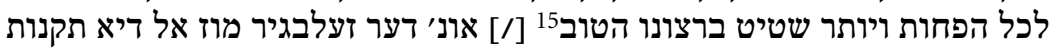

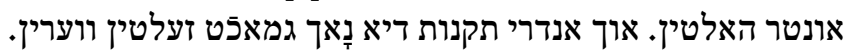

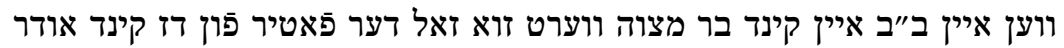

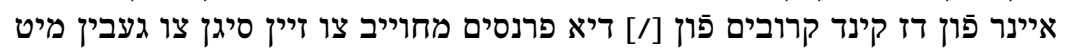

אלי דיא חתנים דיא בקהלתינו קומין מוזין צאלין רביעת למאה מסך איר נדוניא

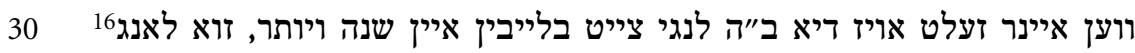
'ט

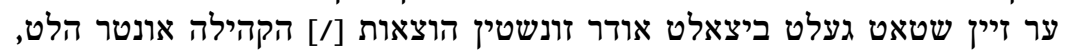

13 Dies könnte ein Zitat der nicht überlieferten, frühen Amsterdamer Statuten sein.

14 Bediensteter, Diener.

15 Dieses Wort über der Zeile.

16 Dieses Wort über der Zeile. 
מוז מען אים זיין פלאטץ אין שול אופן פ̄ר אים הלטין אונ' ניט דערפין אוועק

נעמין.

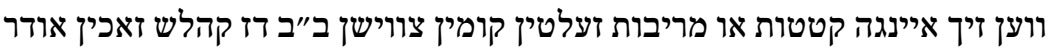

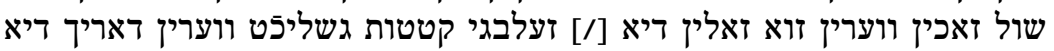

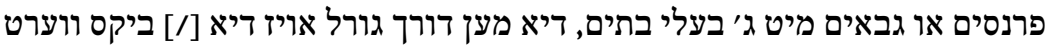

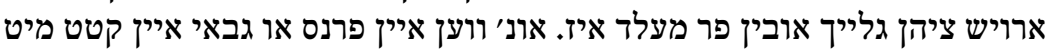

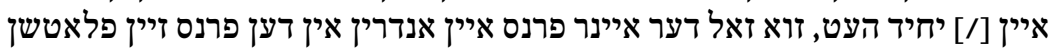

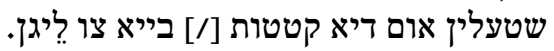

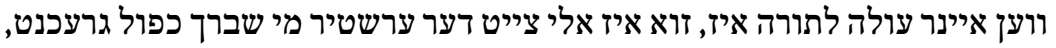

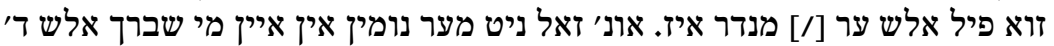
י

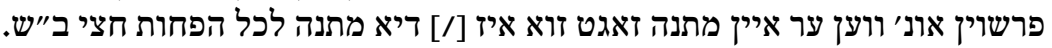

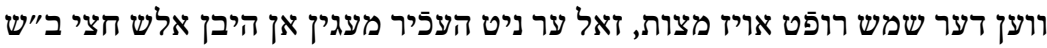

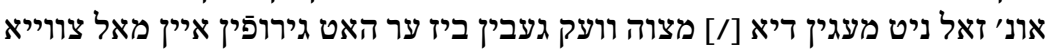

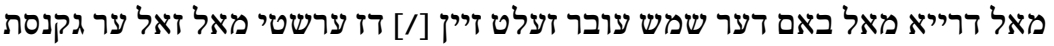

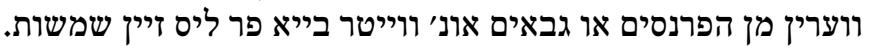

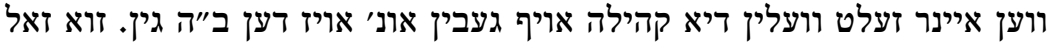
$\lambda^{\prime \prime}$

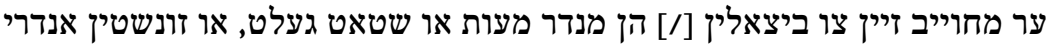

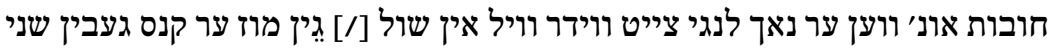

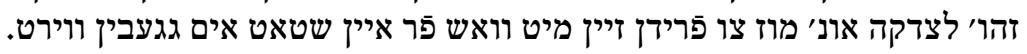

[fol. $3 \mathrm{v}$ leer 20

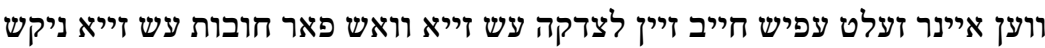
fol. $4 \mathrm{r}$ ]

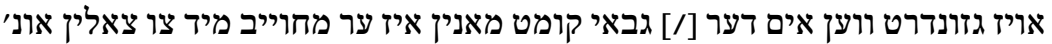

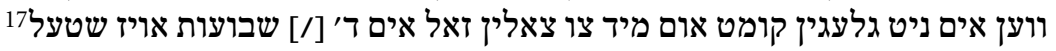

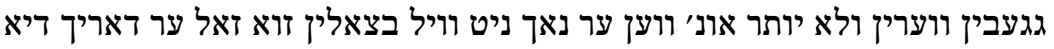

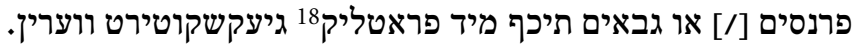

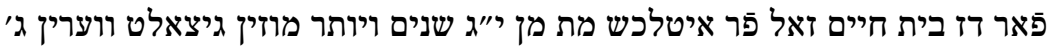

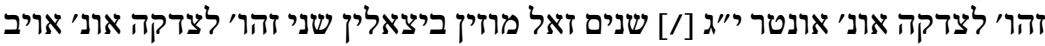

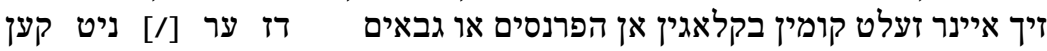

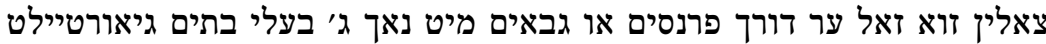

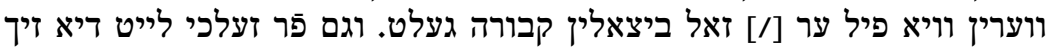

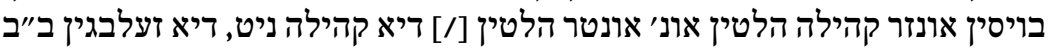

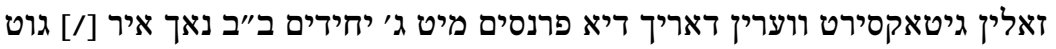

17 aus stel von ndl. uitstel $=$ Aufschub.

18 pratelik von ndl. paratelijk = unmittelbar. 
דונקין דאך ניט העכיר צו טאקסירן אלש ך"ה זהובים אוך דיא זעלבגין רעכטין דיא פּון פורטגיזן ווערין [/] בגראבין.

אין דעם דיא פרנסים או גבאים זעלטין וועלין איינם אין חרם טוהן, זוא זאלין

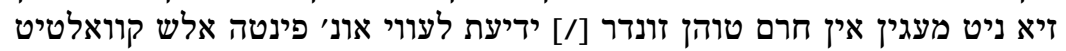

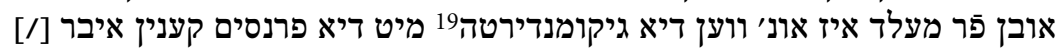

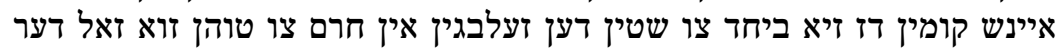

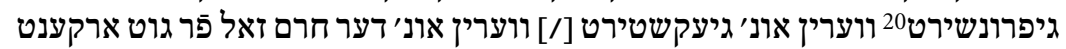

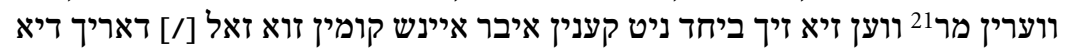

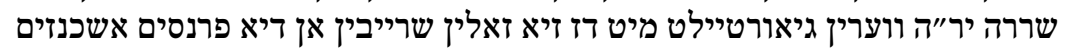

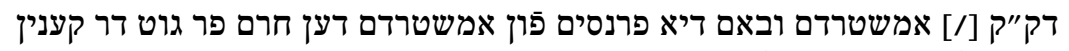
זוא זאל דער חרם גיהלטין וובמערין.

[fol. $4 \mathrm{v}$ leer fol. $5 \mathrm{r}$ ]

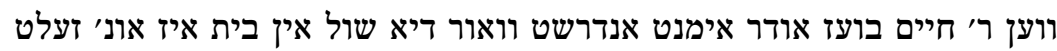

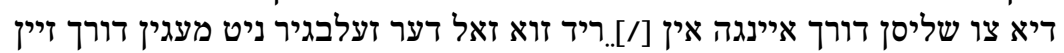

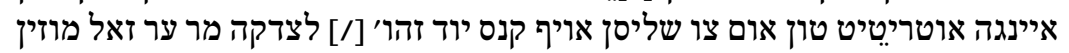

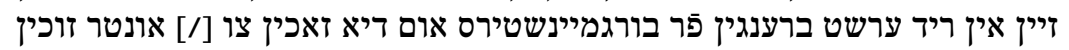
אודר צו אורטיילן.

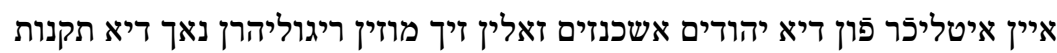

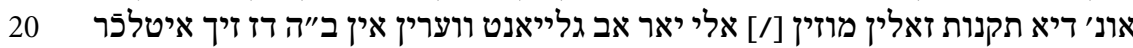

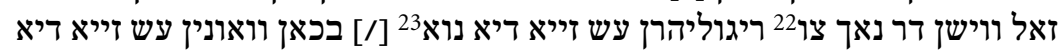

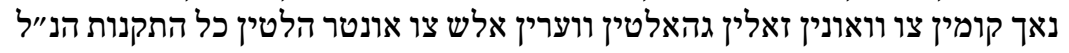

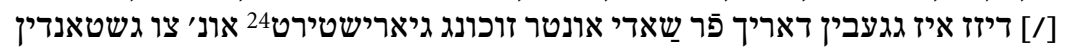

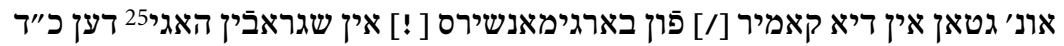

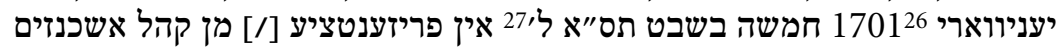

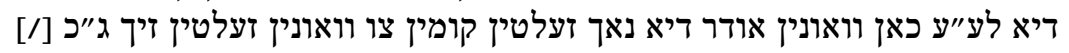

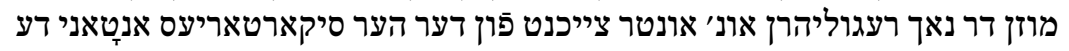

19 Von ndl. gecommenteerte $=$ Genannte.

20 Von ndl. geprononceerd = ausgesprochen.

21 Von ndl. maar $=$ aber, jedoch.

22 Dieses Wort über der Zeile.

$23 \mathrm{Nu}=$ jetzt.

24 Von ndl. gearresteert $=$ genehmigt.

25 's Gravenhage; das Gimmel in »hage« mit einem Rafe.

26 Die Jahreszahl über der Zeile.

$271701 \mathrm{I} 3$.

28 Antonis de Veer. 


\section{Statuten aus Den Haag (1716)}

\section{Quelle: Synagogenbuch, Gemeentearchief Den Haag, NIG, Nr. 625}

Der zweite überlieferte Statutentext aus der aschkenasischen Gemeinde in Den Haag von 1716 ist zugleich der erste eigenständige, den die Gemeinde sich gegeben hat. In keinem Paragraphen wird noch einmal auf die Rechtshoheit der beiden 1701 aktiven Sepharden hingewiesen, wie auch sonst jeder Hinweis auf klare Abhängigkeiten, etwa zur Amsterdamer Gemeinde, fehlt. Es scheint, dass die Haager Aschkenasim den Prozess der Gemeindeetablierung mit der Verabschiedung der neuen Statuten abgeschlossen hatten. Mehrmals wird jedoch auf die weitere Gültigkeit der von der Stadtregierung veranlassten takkanot von 1701 und sogar auf einzelne Paragraphen verwiesen. ${ }^{1}$ Da die Vorgänge in der Gemeinde aus der Zeit um 1716 nicht protokolliert wurden, fehlen jegliche Zeugnisse für die Entstehungsumstände des Textes.

Die Statuten wurden im damals in Gebrauch befindlichen Synagogenbuch niedergeschrieben. Die am Ende des Textes überlieferten eigenhändigen Unterschriften, mit denen sich die Gemeindemitglieder zum Einhalten der takkanot verpflichteten, belegen, dass es sich offenbar um die Originalausfertigung handelt. Bedingt durch diese Platzierung war der Text bis vor kurzem der Forschung unbekannt. Jedoch verdeutlicht die Aufnahme der Gemeindestatuten in das Synagogenbuch die enge Bindung von Gemeinde im religiösen und säkularen Sinn. Der Text blieb nur für einige Jahre in dieser Form in Kraft und wurde bereits sieben Jahre danach durch neue, wiederum umfangreichere Statuten abgelöst. Mit 45 Paragraphen waren die takkanot von 1716 wesentlich ausführlicher als die vorherigen und zeugen von der zunehmenden Ausdifferenzierung der Vorgänge in der aschkenasischen Gemeinde.

Die takkanot wurden in flüssigem und leicht verständlichem Jiddisch verfasst, in das einige Niederlandismen eingeflossen sind. Über den Schreiber ist nichts bekannt, er hat seinen Namen nicht unter den Text gesetzt. Die Foliierung der Blätter des Synagogenbuches erfolgte in der linken oberen Blattecke in arabischen Ziffern, während die Paragraphennummern am rechten Blattrand in hebräischen Lettern in Quadratschrift aufgeführt sind.

$1 \$ 4$ der neuen Statuten bezieht sich auf die gleiche Nummer der alten Statuten von $1701, \S 13$ auf $\S 6(1701), \S 20$ auf $\S 5(1701), \S 21$ auf $\S 11(1701)$ und $\S 32$ auf $\S 15$ (1701). 
Inhaltlich orientieren sich die takkanot von 1716 weitgehend an den früheren, gehen jedoch viel mehr ins Detail, wie etwa die genaue Beschreibung des Wahlprozederes, die sich so 1701 noch nicht findet. Die im Paragraph 31 beschriebenen Modalitäten einer Bannung beziehen sich ausschließlich auf innergemeindliche Bestimmungen; auswärtigen Instanzen werden keinerlei Befugnisse eingeräumt. 
[fol. $41 \mathrm{v}$ ]

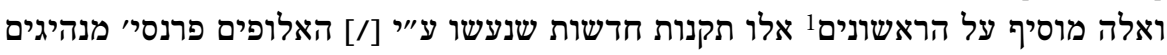

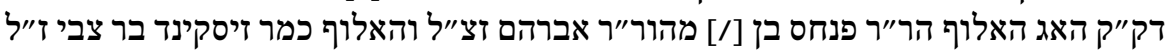

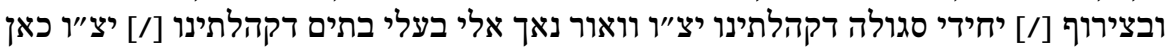
ק"ק האג זאלין זיך ווישן דער נאך צו ריגלירירין

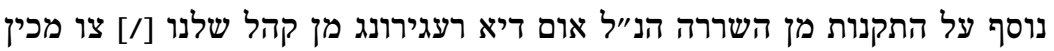
א

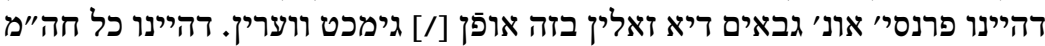

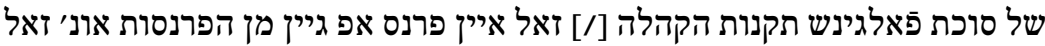

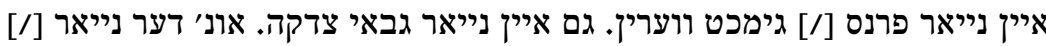

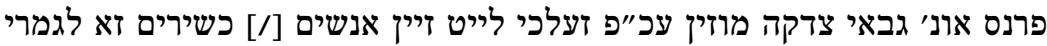

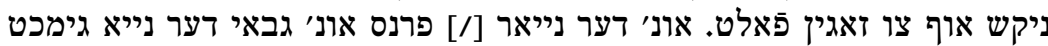

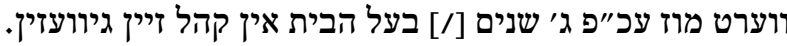

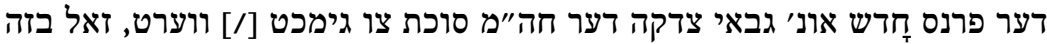

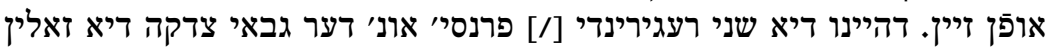

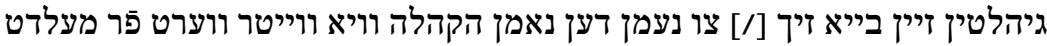

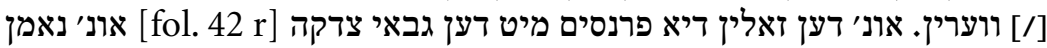

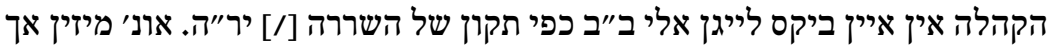

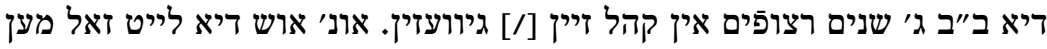

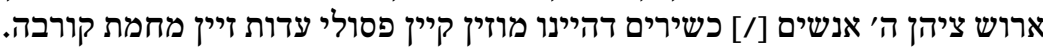

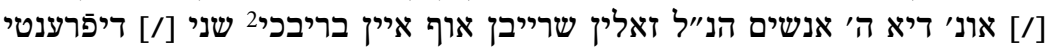

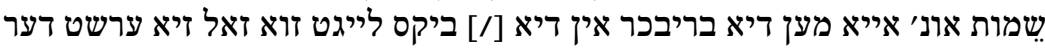

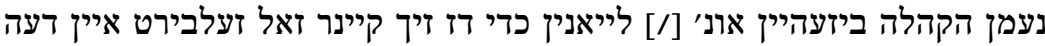

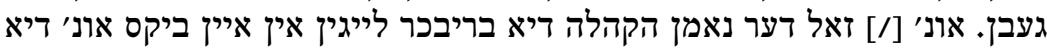

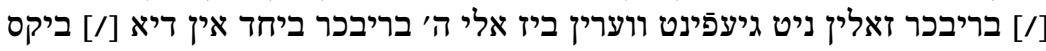

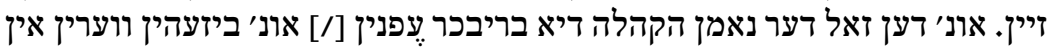

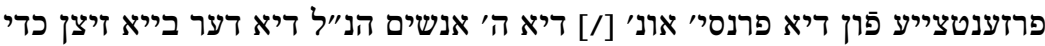

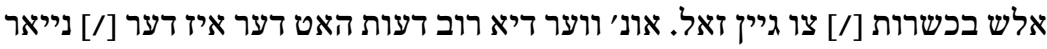

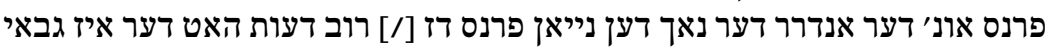

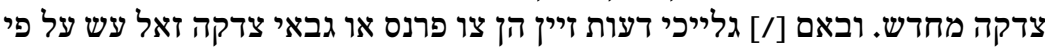

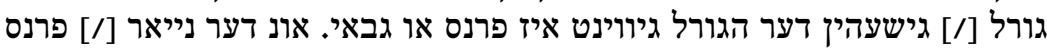

איז דער ערשטי פרנס החודש. 3

\footnotetext{
1 Gemeint sind die Statuten von 1701, die ebenfalls Teil dieser Edition sind.

2 Von ndl. briefje $=$ Zettel.

3 Der Rest der Zeile bis zum Ende mit Strichen gefüllt.
} 


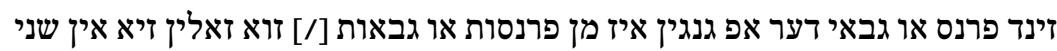

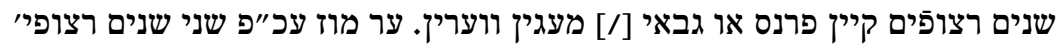

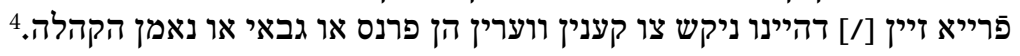

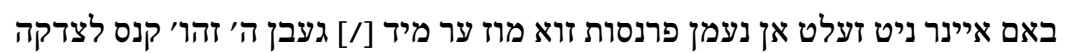
'ג

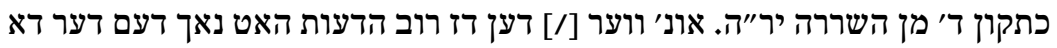

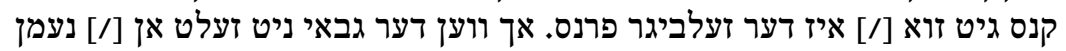

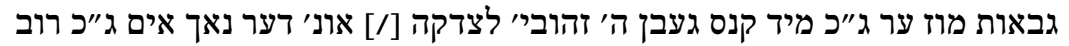
דעות האט דער איז ממלא מקומו.

דער נאמן הקהלה זאל גימכט ווערין, דורך ה' אנשים בזה אופן [/] דהיינו דורך דיא ה'

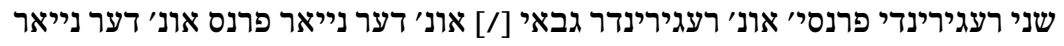

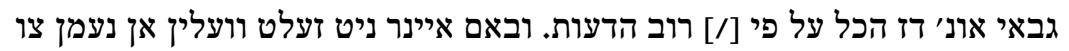

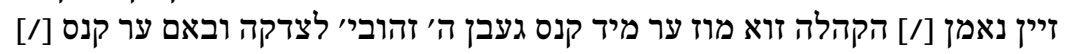
גיט זוא איז ער שנה הבע"ל פרייא אום צו פריד ווערין נאמן הקהלה זהובית.

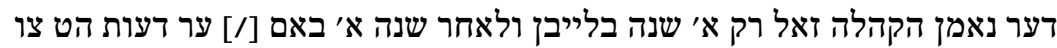
[fol. $42 \mathrm{v}$ ]

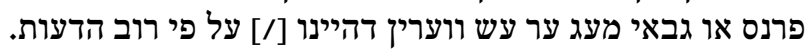

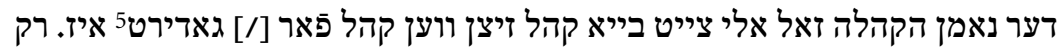
i

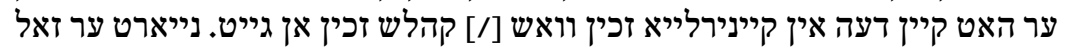

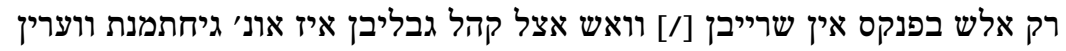
מן נאמן הקהלה.6

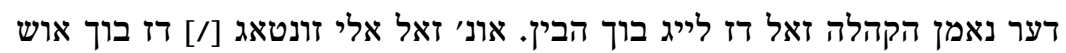
$\pi$

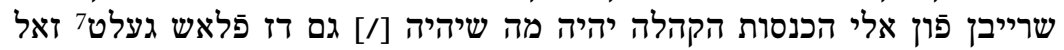

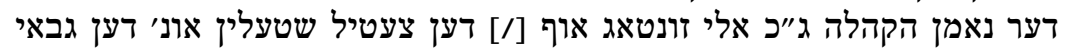

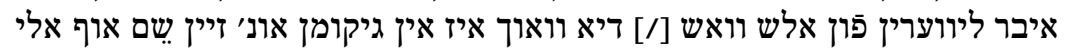

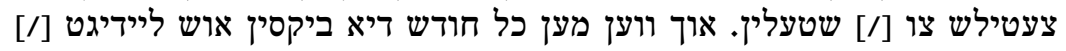

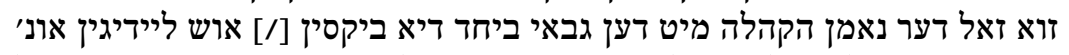

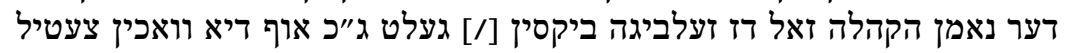
שטעלין.

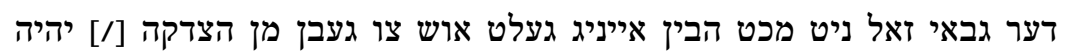

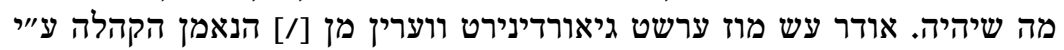

4 Von dieser Praxis wurde seit 1723 wieder abgewichen; ein Jahr Pause zwischen zwei Amtszeiten war dann die übliche Vorgehensweise.

5 Von ndl. vergadert $=$ versammelt.

6 Dieser Passus ist ein Hinweis auf die mögliche Existenz eines pinkas schon vor 1723.

7 Vielleicht Platzgeld, also Einkünfte aus der Vermietung von Synagogenplätzen. 


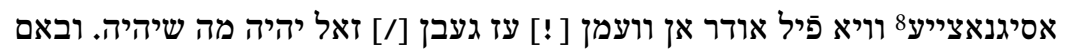

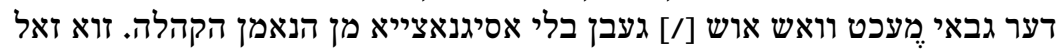

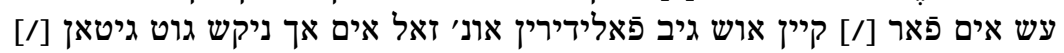

ווערין.

דער נאמן הקהלה זאל ניט מער מכט הבין אום דען גבאי צו [/] אורדנירן אוש צו

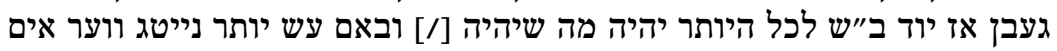

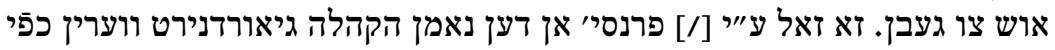

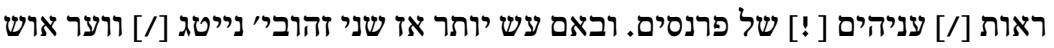

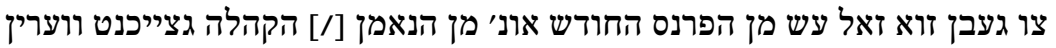

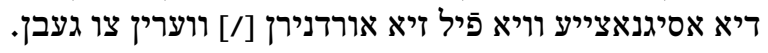

י"א דער גבאי צדקה זאל אלי הוצאות והכנסות טון דז גנצי יאר [/] דורך קוויטאנצייס

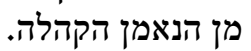

[fol. $43 \mathrm{r}$ ]

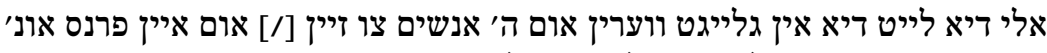
ב"י 15

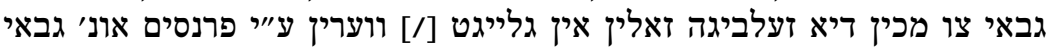

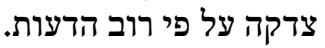

אלי ב״ב קינדר דיא זיך אין קהל וועלין אין קאפין הן בן או בת [/] זאלין מחויב זיין

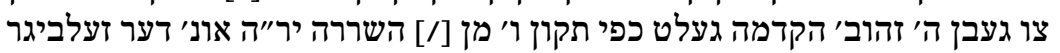

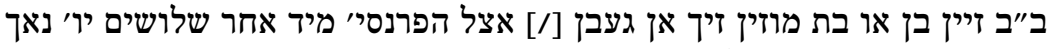

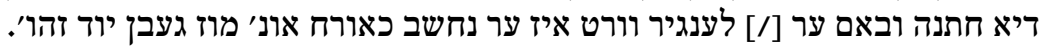

אלי פרעמדי דיא בכאן קומן וואנן אונ' ווילן אין קהל שלנו זיין [/] זיין זיא מיר מחויב

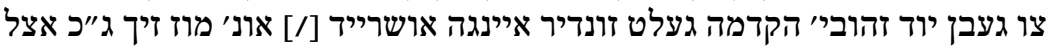

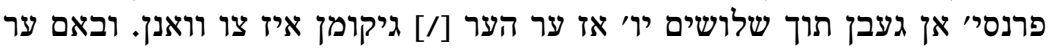

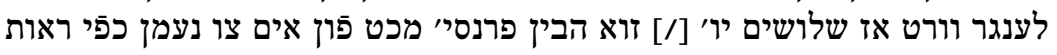

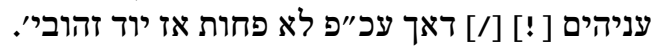

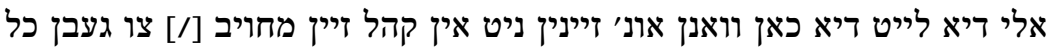

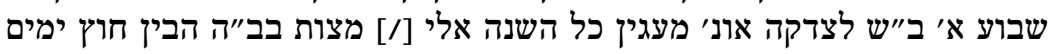

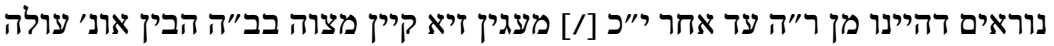
לתורה מעגין זיא [/] כלל וכלל דז גנצי בנצי שנה ניט זיין.

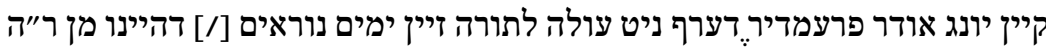

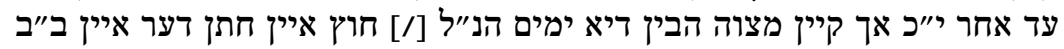

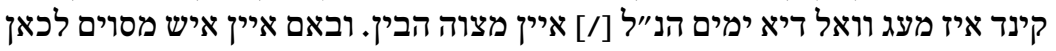

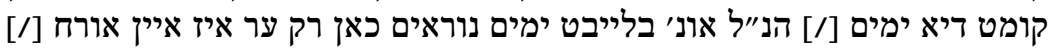

8 Assignate, Anweisung. 
זוא שטייט הברירה ביד הפרנסי' אונ' גבאי צדקה כפי ראות [/] עניהים [!!] אוב ער

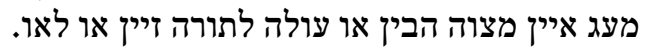

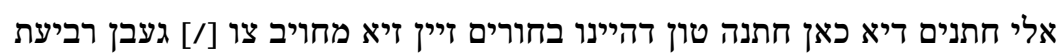
$T^{\prime \prime \prime}$

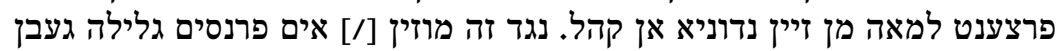

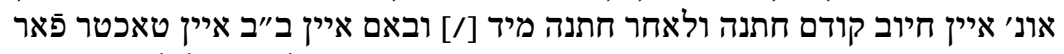

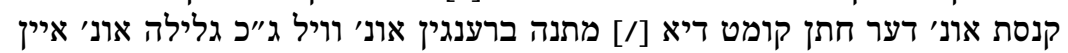

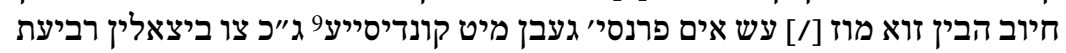

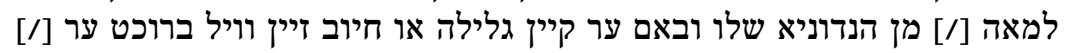
ניקש צו געבן.

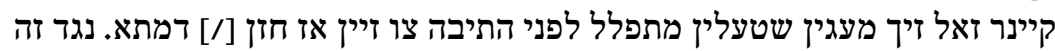
[fol. $43 \mathrm{v}$ ]

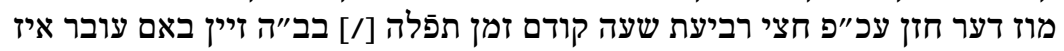

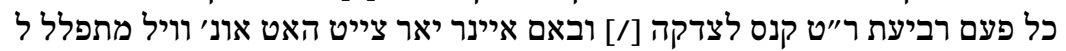

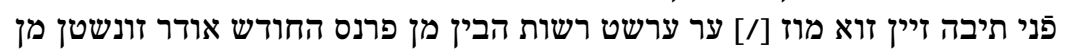

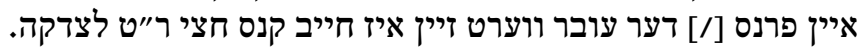

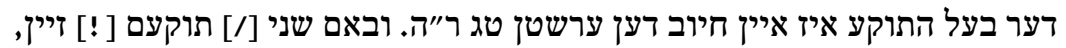
ט"ท

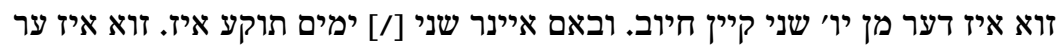
רק איין חיוב דען ערשטין יון' שנין ולא יותר. ובאם

חתן תורה אונ' חתן בראשית גריגלירט וויא זיא כל חה"מי סוכוכות [/] מוזין ווערין

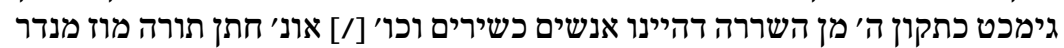

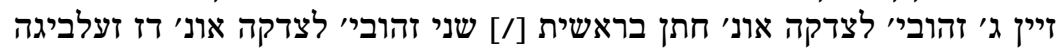

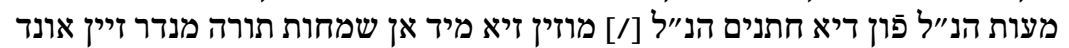

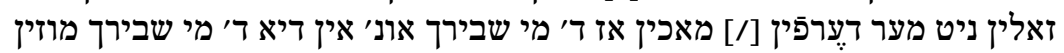

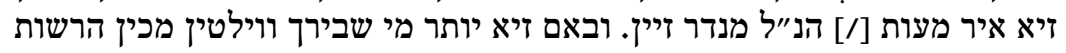

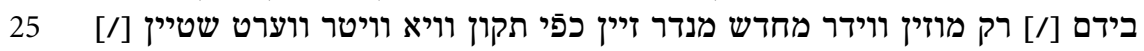

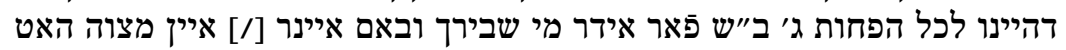

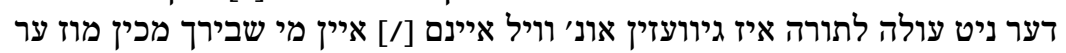

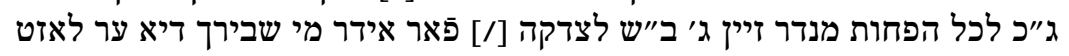

מכין.

אלי היגי ב״ב אודר פּרעמדי דיא כאן עולה לתורה זיין. זיין זיא [/] מחויב מנדר

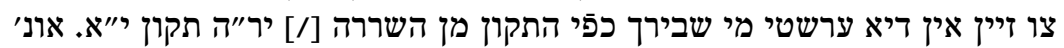

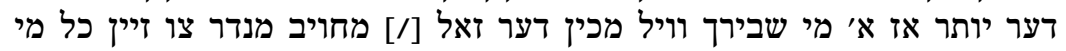

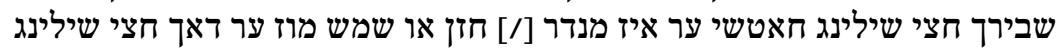

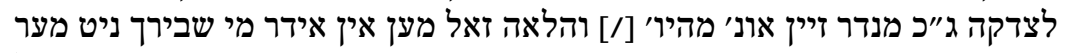

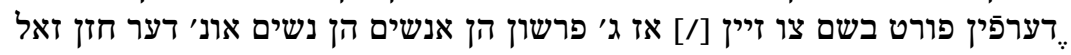

9 Von ndl. conditie $=$ Kondition, Bedingung. 
השגחה

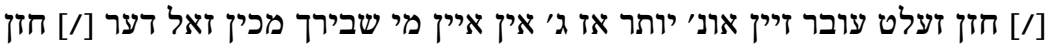

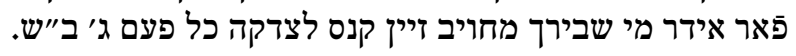

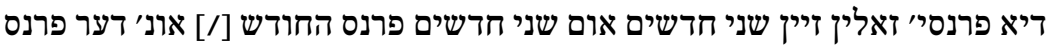

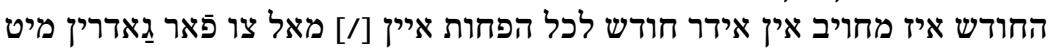

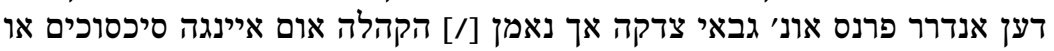

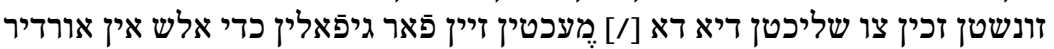

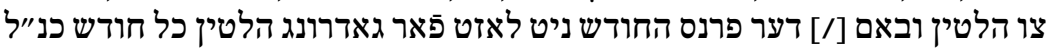

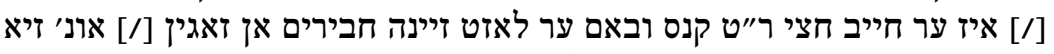

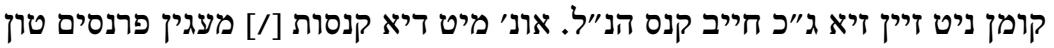

כפי ראות עניהים [?].

[fol. $44 \mathrm{r}$ ]

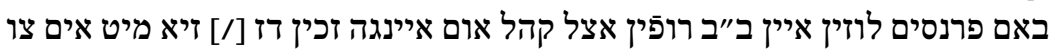
$\left.\lambda^{\prime \prime}\right\rceil$

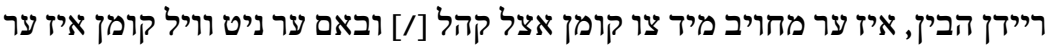

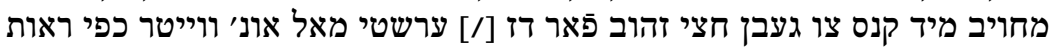

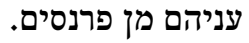

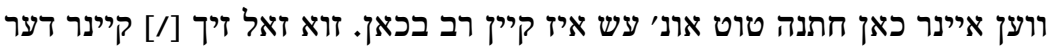

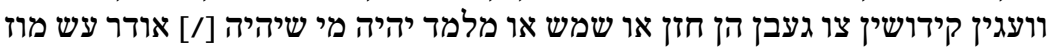

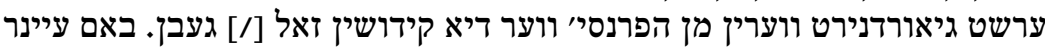

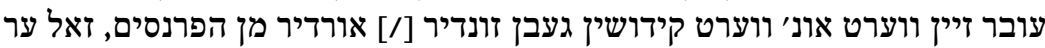

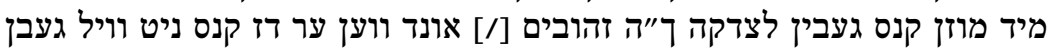

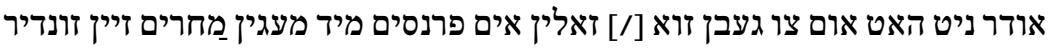
איינגה אוש רייד.

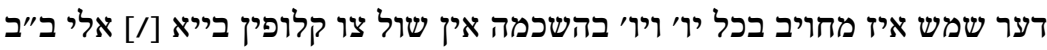

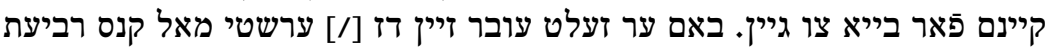

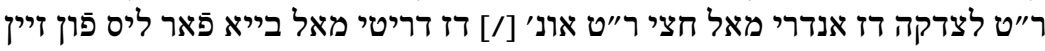

ך

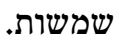

דער שמש איז מחויב בבקר ובערב עכ"פ חצי רביעת שעה קודם [/] זמן תפילה דיי דיא

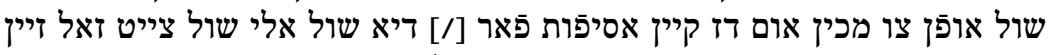
ובאם דער שמש עובר איז קנס [/] רביעת רספות פאר לצדקה.

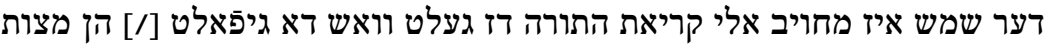

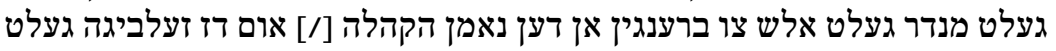

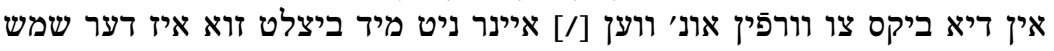

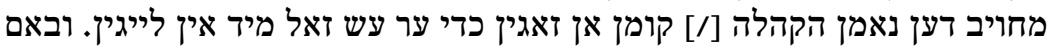

10 Das ש über der Zeile ergänzt. 


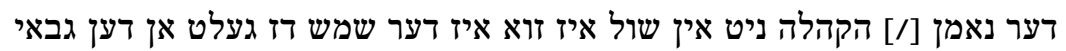

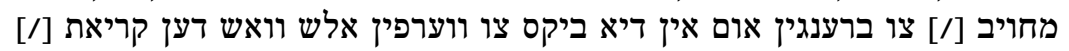
התורה גיפאלין איז. - n בענגין

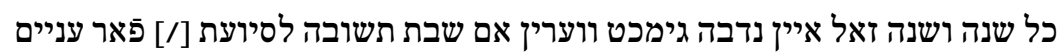

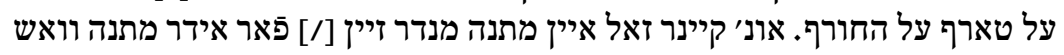

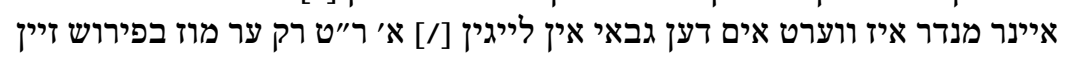
נדבה ארוש ריידין.

באם קהל זעלט איין רב או חזן או שמש אוף נעמן. אודר זונשטן [/] איין בדינטיר

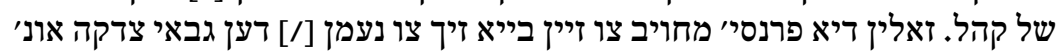

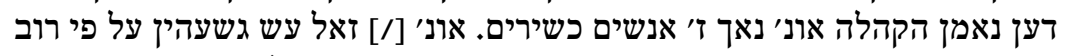

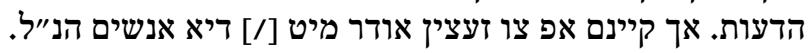

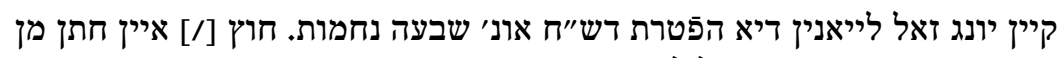

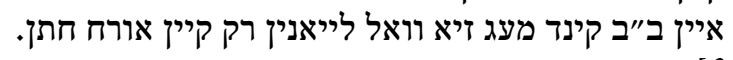

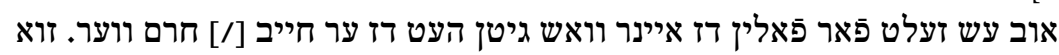
[fol. $44 \mathrm{v}$ ]

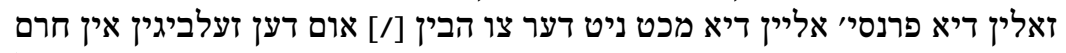

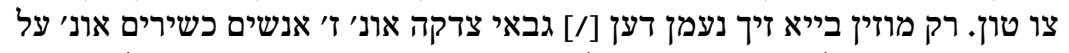

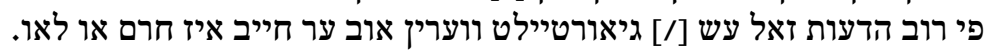

פאר דז בית חיים דז דיא ב"ב הבין מוזין געבן קרקע געלט ב' אונ' [/] ג' זהובי' ל

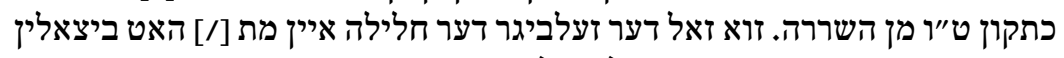

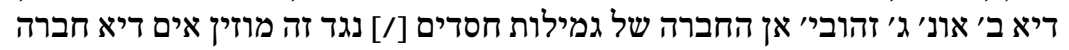

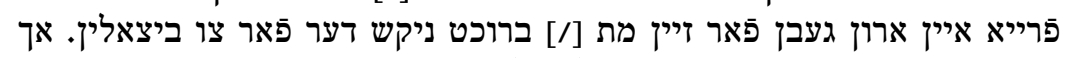

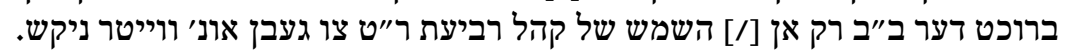
קיין פרנס זאל מכט הבין איין יחיד איין זילותו אן צו טון [/] אודר ער מוז ערשט

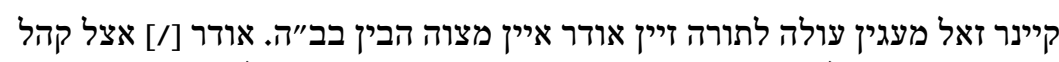
ל

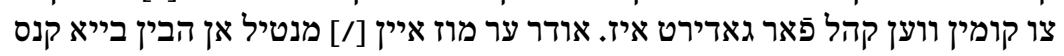

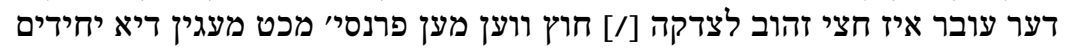
קומן וויא זיא גובר איז חוט דונקט.

בועץ איינר איין קינד אין שול ברענגט אום מחנך עץ חיים צו זיין [/] זוא זאל דער

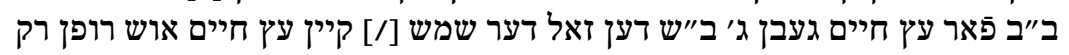

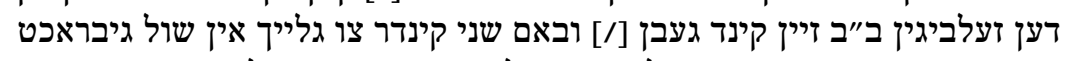

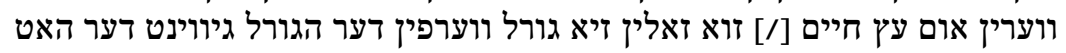




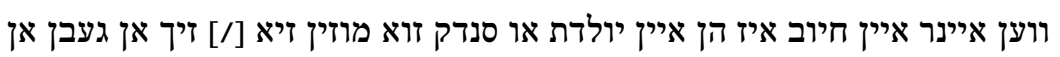
ל ל

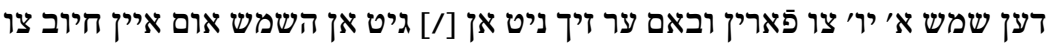

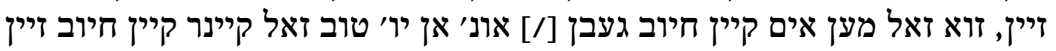

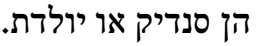

ווען איינר פרעמדיר סנדיק בכאן קומט אום איין קוואטירשפטט 11 צו [/] הבין בייא

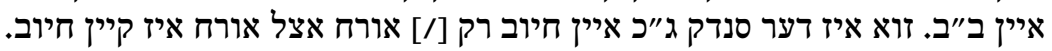

קיין פרנסי' מיט דען גבאי צדקה זאל מכט הבין מיט איינם איין [/] משפט צו פייהרן

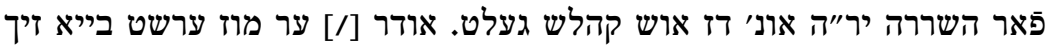

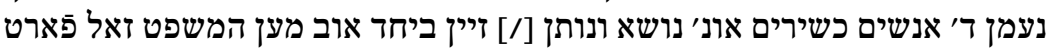

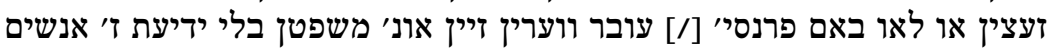

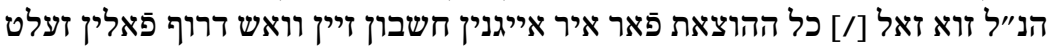
[/] כדי דז קהלש געלט ניר ניט זאל שלא לצורך וועק קומן.

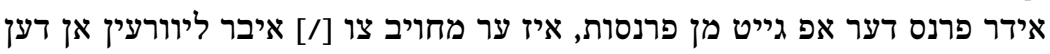
ל"

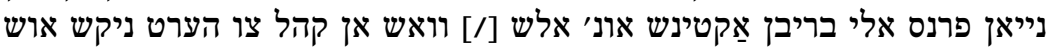

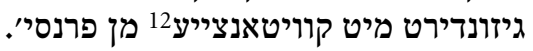

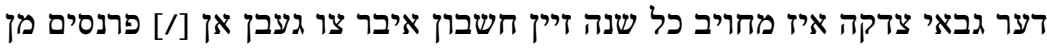

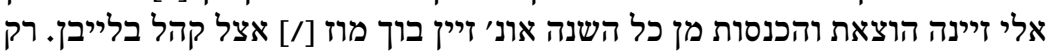

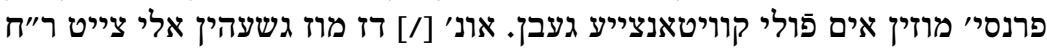

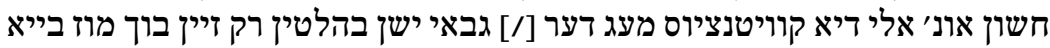

$$
\text { קהל בלייבן. }
$$

ווען איינר אין דער הכרזה איז אונ' האט ניט מיט קהל אפ גימכט [/] זוא מוז13 ער

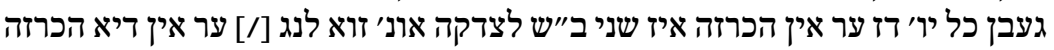

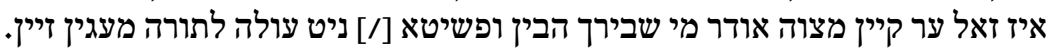

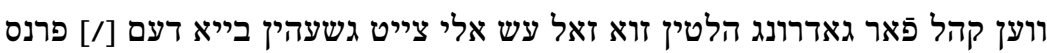

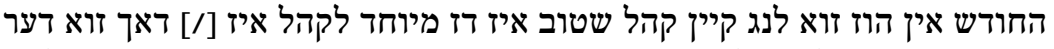

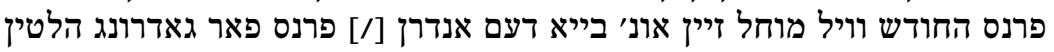
הרשות בידו.

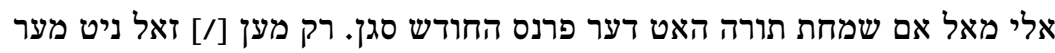
מו"ג

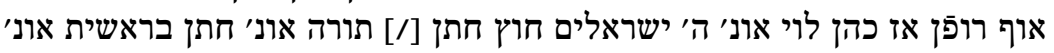
דז ווערט גיטאן אלש כדי קיין [/] הטרחות צבור צור צות הבין

\footnotetext{
11 Gevatterschaft.

12 Von ndl. kwitantie = Quittung, Bestätigung.

13 Dieses Wort über der Zeile.
} 


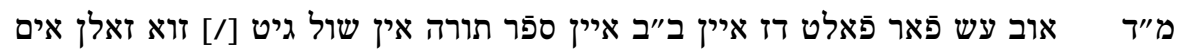

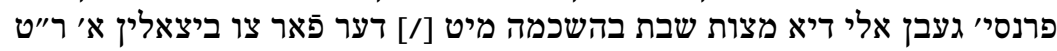

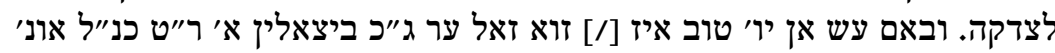

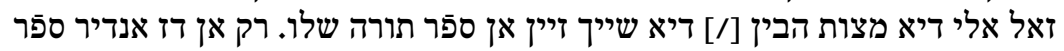

אלי דיא תקנות הנ"ל דיא ע"ע זיין גימכט גיווארין, איז אלש גימכט [/] ווארין מ"ה

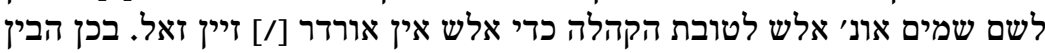

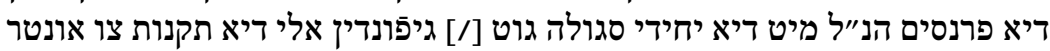

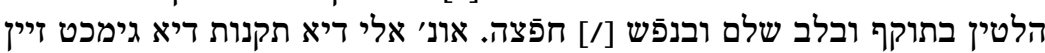

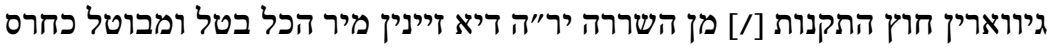

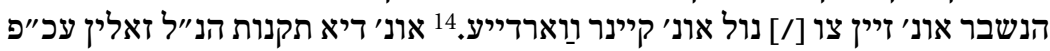

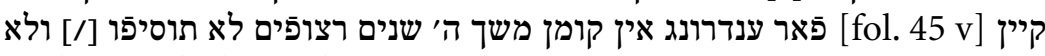

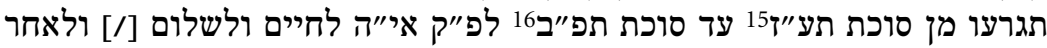

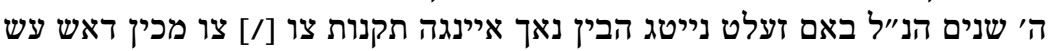

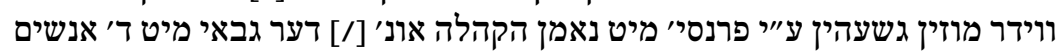

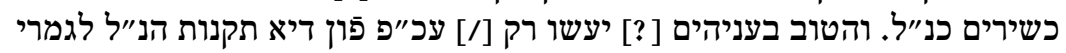

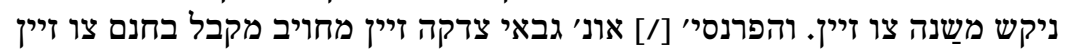

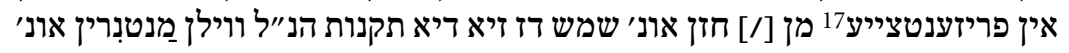

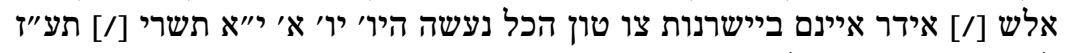

14 Von ndl. waardij $=$ Wert.

15 Herbst 1716.

16 Herbst 1721.

17 Von ndl. presentie $=$ Anwesenheit, Beisein.

181716 IX 27.

19 Dtn 33,1. Die gekennzeichneten Buchstaben ergeben den Zahlwert 477, also das jüdische Jahr (5)477. Daran schließen sich die Unterschriften von mehr als 50 Personen an, die diese Statuten anerkannt haben, unter ihnen Chajim ben Abraham und Tobias Boas, die beiden wichtigsten Personen des damals aufstrebenden Handels- und Bankhauses, das die Geschicke der Gemeinde über das gesamte 18. Jahrhundert bestimmte. 


\section{Statuten aus Den Haag (1723)}

\section{Quelle: Statutentext im Pinkas Den Haag I, Gemeentearchief Den Haag, NIG, Nr.1}

Bei den letzten bekannten frühneuzeitlichen Statuten der Haager Aschkenasim von 1723 handelt es sich zugleich auch um den detailliertesten Text dieser Gemeinde. Der Umfang hatte sich seit 1701 nahezu verdreifacht, was auf den gewachsenen Erfahrungsschatz in der Gemeindeaministration zurückgeführt werden kann. Sicher hatte die Erkenntnis der Vorteile klarer und verständlicher Regeln, die möglichst viele Eventualitäten des gemeindlichen Lebens abdecken sollten, zur Revision der takkanot von 1716 geführt. Auch dieser letzte Statutentext verstand sich als Ergänzung zum ersten von 1701, dessen Charakter und Gültigkeit als obrigkeitliche Verordnung weiter bestehen blieb, was aus der ersten Zeile der Einleitung hervorgeht.

Die hier edierte Vorlage war offenbar die Originalausfertigung, die, versehen mit dem Gemeindesiegel auf fol. 10 und mit den abschließenden Unterschriften der Vorsteher und Verfasser, am Anfang des Protokollbuches der Gemeinde eingebunden wurde. Von dieser Lage wurden jeweils nur die Vorderseiten beschrieben. Alle Blätter sind komplett erhalten und somit auch alle der 55 Paragraphen, einschließlich der kurzen Einleitung und der Schlussformel.

Der Text ist fast vollständig in gut verständlichem Jiddisch mit klaren niederländischen Einflüssen verfasst, lediglich in Einleitung und Schluss sind einige Zeilen Hebräisch enthalten. Der Schreiber war offenbar, wie auch bei der hier edierten Kopie der Statuten von 1701, Isaak bar Israel Jakob, ne'eman der Gemeinde. Die beschriebenen Blätter sind weder paginiert noch foliiert. Die Nummerierung der einzelnen Paragraphen erfolgte jeweils über dem Abschnitt mit hebräischen Buchstaben.

Inhaltlich folgt der Text den Vorgaben von 1701 und 1716, nur jetzt weit ausführlicher. Insbesondere Fragen zur Wahl der Vorsteher und ihrer Kompetenzen sowie zur Vergabe von Ehrenämtern im synagogalen Gottesdienst werden ausführlich behandelt. Insgesamt widmen sich 25 Paragraphen Angelegenheiten der Synagoge und des Gottesdienstes. Im abschließenden Paragraph 55 wird auch die Führung eines Seelengedächtnisbuches (Memorbuch) beschrieben, welches sich jedoch, sollte es tatsächlich in Den Haag geführt worden sein, sich offenbar nicht erhalten hat. Im Gegensatz zu takkanot aus 
anderen aschkenasischen Gemeinden wurden hier, wie auch in den beiden Haager Vorgängertexten, keine thematischen Überschriften zu Abschnitten mit verwandtem Inhalt verwendet. Solche Paragraphengruppen lassen sich zwar immer wieder ausmachen, werden aber durch Einschübe von Paragraphen zu anderen Themen wiederholt unterbrochen. Im Protokollbuch selbst folgen auf den Folios $16 \mathrm{v}$ bis $19 \mathrm{v}$ die Unterschriften der Gemeindemitglieder, die entweder kurz nach Inkrafttreten der Statuten oder bei der späteren Aufnahme als Mitglieder die takkanot anerkannten. 
[fol. $1 \mathrm{r}$ ] היום יום א׳ כ"ח מנחם תי"ו פי"א גימ"ל לפ"קי פה ק"ק האג יצ"ו

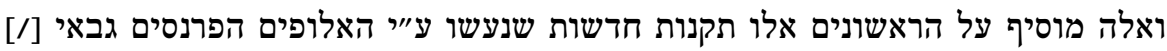

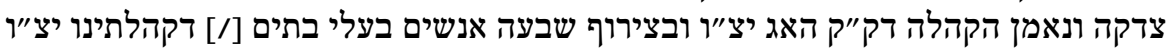

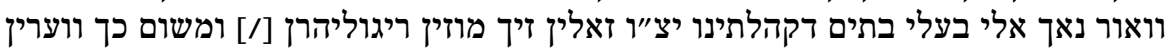

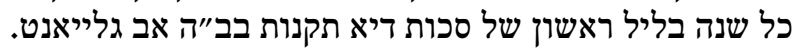

$$
\text { ר"ד ירואי }
$$

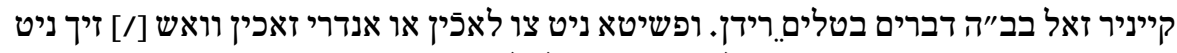

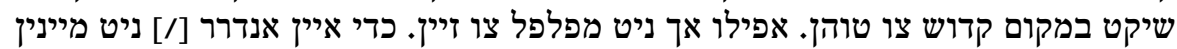

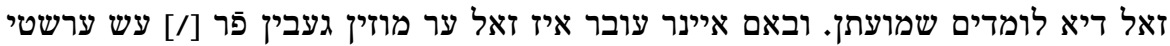

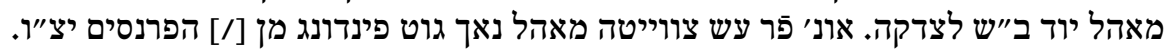

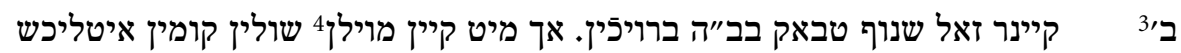

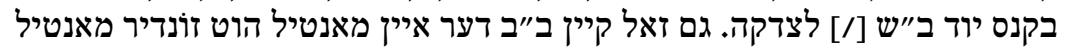

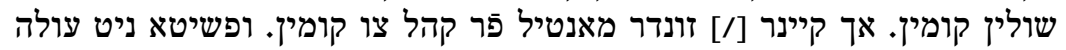

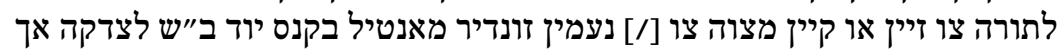

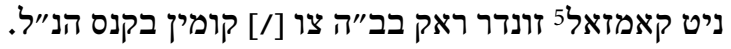

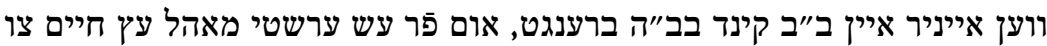

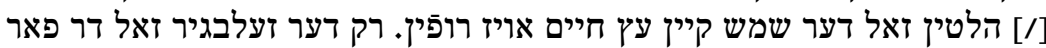

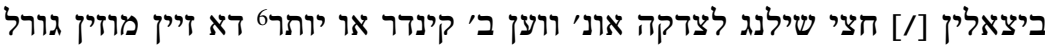

[fol. 1v leer

fol. $2 \mathrm{r}$ ]

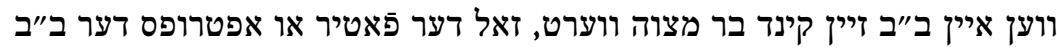
7

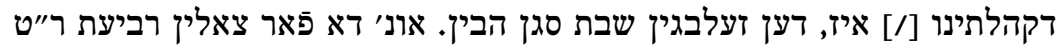

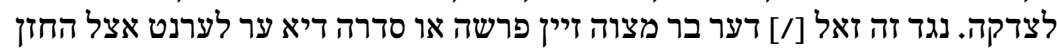
דמתא לערנין מוזין.

\section{VII 29.}

ראשית דברים יראת אלוהים.

3 Die Paragraphennummerierung erfolgte jeweils mittig über dem neuen Abschnitt.

4 Von ndl. muil = Pantoffel.

5 Kamisol, ein westenartiges Kleidungsstück.

6 Danach gestrichen: מער.

7 Dieser Artikel ist in ähnlicher Form schon in den Statuten von Den Haag aus dem Jahr 1716 enthalten, dort $\$ 35$. 
אן חול המועד סוכת זאל דיא ריגיהרונג מן קהל שלנו בזה אופן גימאכט ווערין

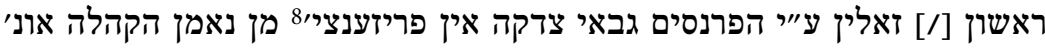

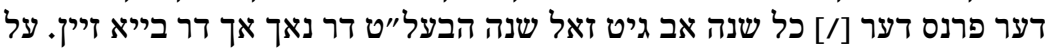

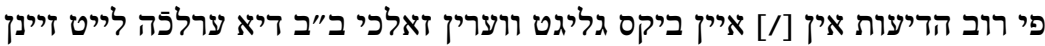

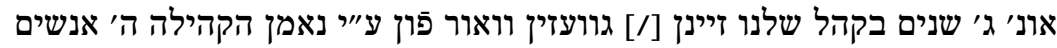

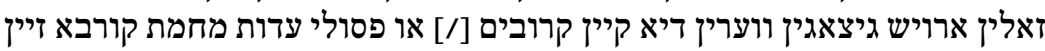

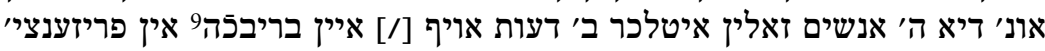

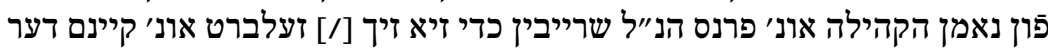
ניט ראוי דר צו איז קיין דעה געבין.

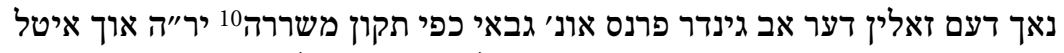
1

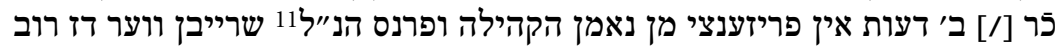

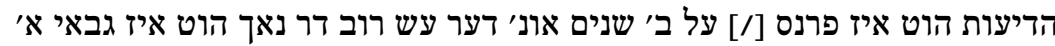

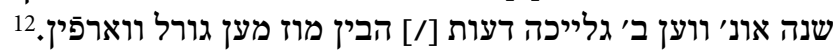

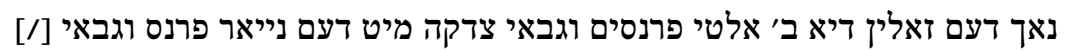
fol. $3 \mathrm{r}$ ]

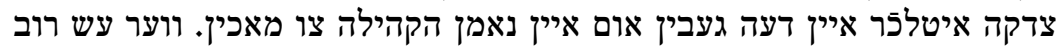
הדיעות [/] הוט איז נאמן הקהילה על א' שנה. איין

ווען איינר עש פרנסות ניט וועלט אן נעמין מוז ער געבין ה' זהובים קנס לצדיקה

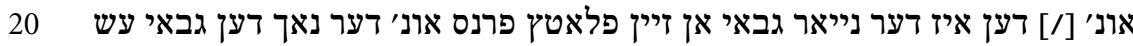
רוב [/] הדיעות הוט איז דען גבאי.

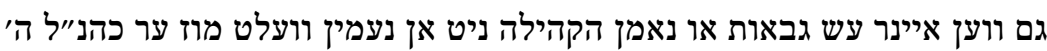
'ט זהו' [/] געבין קנס לצדקה אונ' דער נאך דיא רוב הדילה היעות נפמין הוט איט מוז גבאי או נאמן ה' הקהילה.

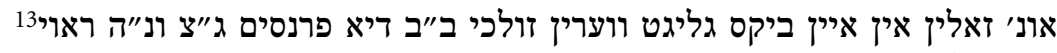

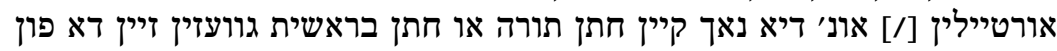

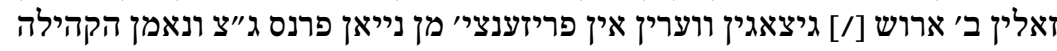

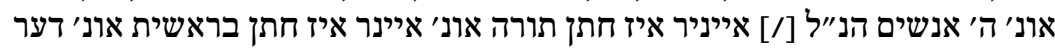

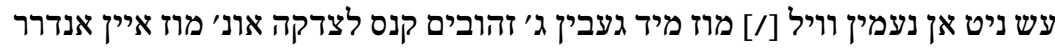

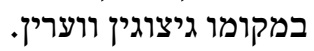

\footnotetext{
8 Von ndl. presentie $=$ Anwesenheit, Beisein.

9 Von ndl. briefje $=$ Zettel.

10 Gemeint sind die Statuten von 1701.

11 Die letzten beiden Wörter über der Zeile ergänzt.

12 Die Paragraphen 5 und 6 sind in den takkanot von $1716 \mathrm{im} \$ 2$ enthalten.

13 Dieses Wort über der Zeile ergänzt.
} 
[fol. 3 v leer

fol. $4 \mathrm{r}$ ]

י"א דער חתן תורה מוז אן שמחות תורה לכל הפחות ג' זהובים מנדר זיין לצדקה אונ'

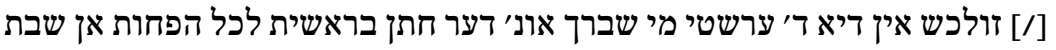

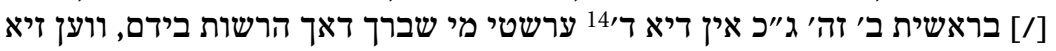

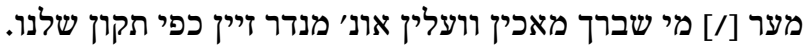

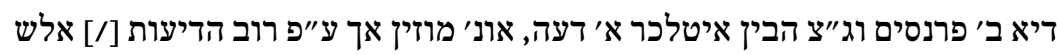

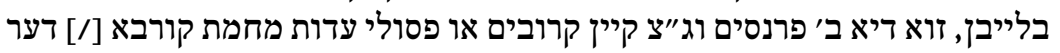

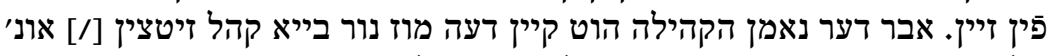

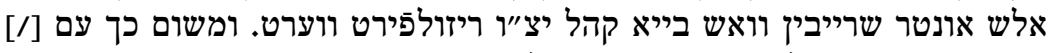

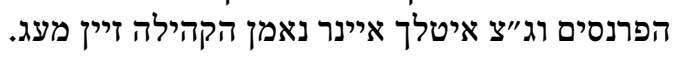

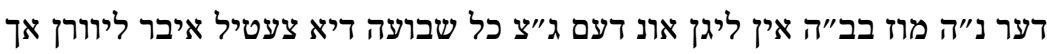

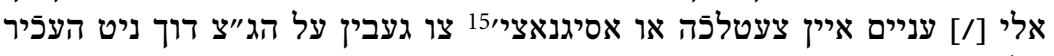

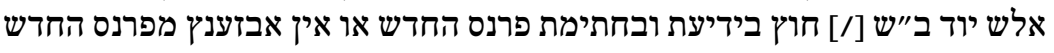
בידיעת [/] ובחתימת פרנס השני.

[fol. 4 v leer

fol. $5 \mathrm{r}$ ]

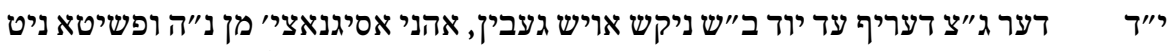

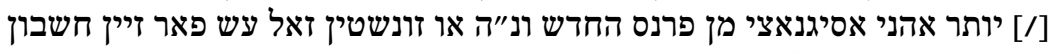

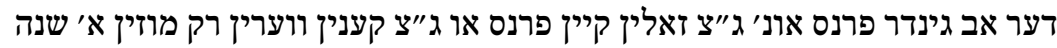

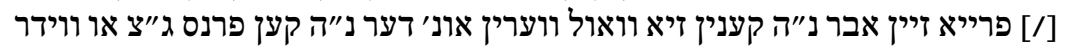

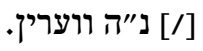

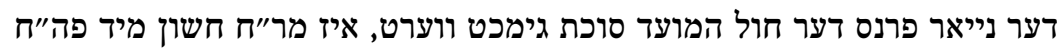

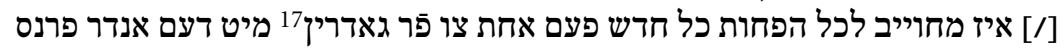

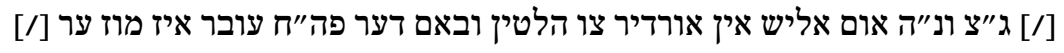

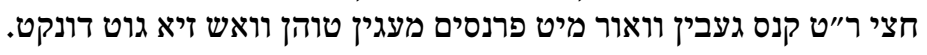

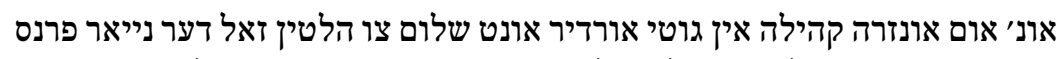
י

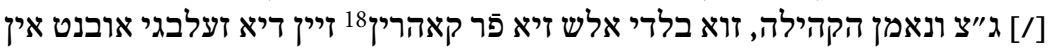

14 Die Zahl über der Zeile ergänzt.

15 Assignate, Anweisung.

16 Nächsten.

17 Von ndl. vergaderen $=$ versammeln.

18 Von ndl. verkoren = gewählt. 


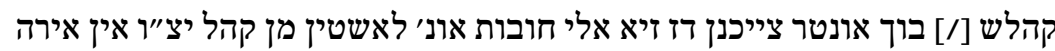

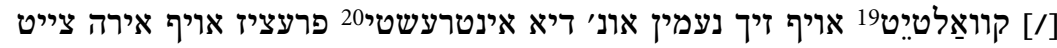

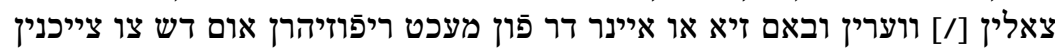

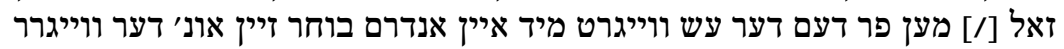

[fol. $5 \mathrm{v}$ leer fol. $6 \mathrm{r}$ ]

איטלכר פרנס ג'"צ ונאמן הקהילה זאלין גיהאלטין זיין פַר א׳ שנה דז זיא איר אין דיא ח"

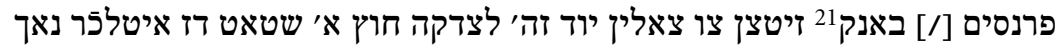

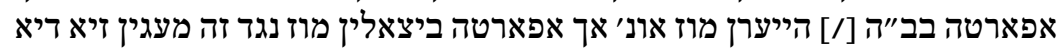

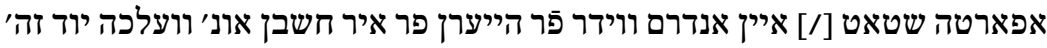

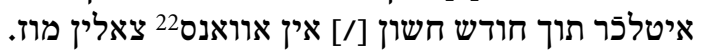

דער אב גינדר גבאי מוז זיין חשבן פובליק בב"ה אב געבין אונ' דעריף ניט לעיט לענגיר ט"י

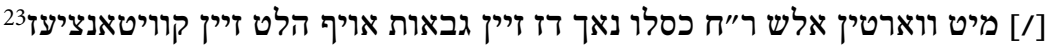

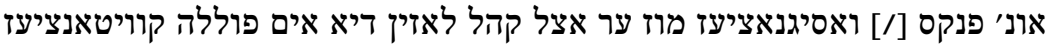

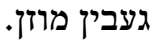

קיין ספר תורה זאל מען אויז דיא שול געבץ24 הן בייא איין חברה או אבל קיינם אויז [/] גיזונדרט בקנס חצי ר״וּט לצדקה.

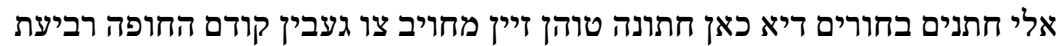
כ" כ

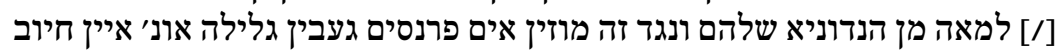

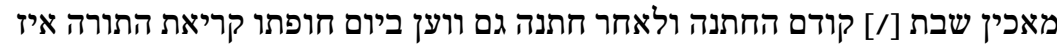

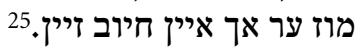
[fol. $6 \mathrm{v}$ leer fol. $7 \mathrm{r}$ ]

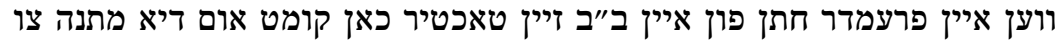
כ"ב

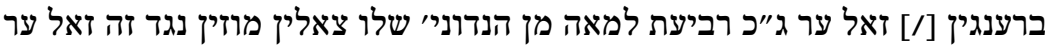

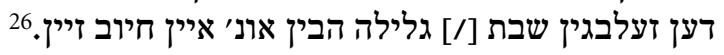

19 Von ndl. kwaliteit = Inhalt, Umfang.

20 Von ndl. interest $=$ Zins.

21 Ehrenplatz in der Synagoge.

22 Von ndl. avance $=$ vorher.

23 Von ndl. kwitantie = Beleg, Quittung.

24 Dieses Wort über der Zeile; gestrichen: הוילין.

25 Entspricht in Teilen $\$ 17$ der Statuten von 1716.

26 Enthalten in $\$ 17$ der Statuten von 1716. 


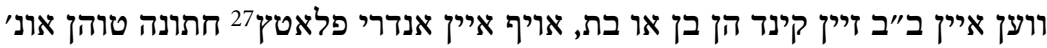
כ"כ

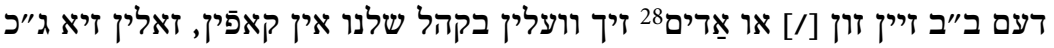

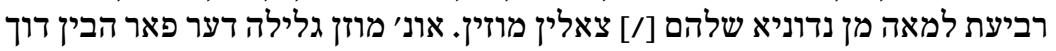

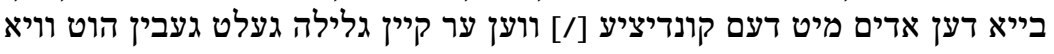

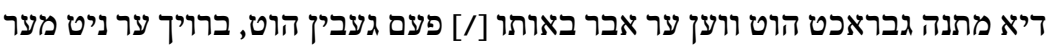
צו צאלין אלש איין ב״ב קינטר גוער געבין מוז אין קהל [/] צו זיין.

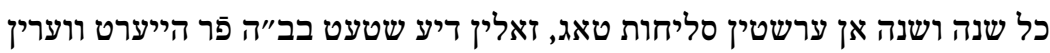

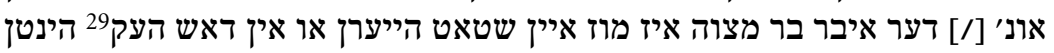
אן שטין.

אלי חתנים דיא כאן חתונה טוהן, זיין מחויב צו געבין קודם החופה פר קידידושי מיושין

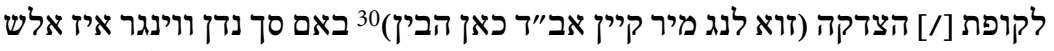

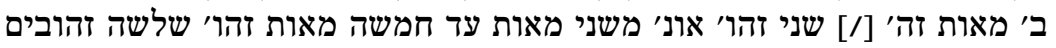

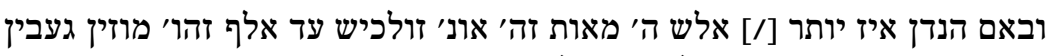

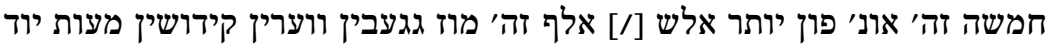

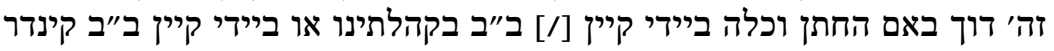

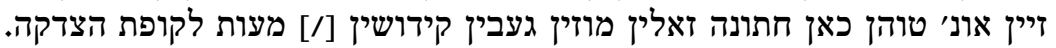

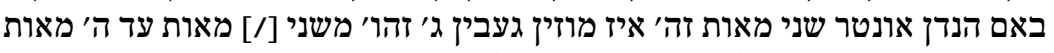

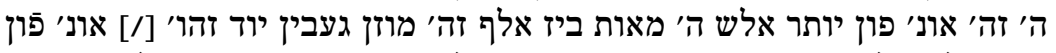

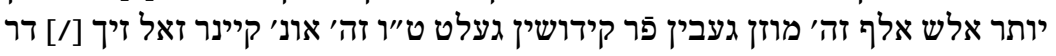

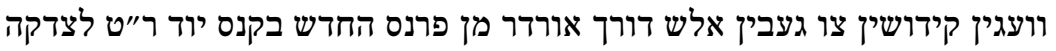

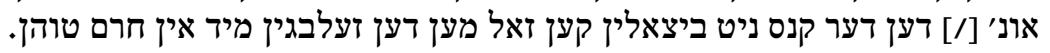

$[$ fol. 7 v leer fol. $8 \mathrm{r}$ ]

דער בעל התוקע איז יום ראשון של תקיעת שופר איין חיוב אום שלישי עולה [/] כ" לתורה צו זיין. אבר דער בעל תוקע מיום השל תשי השי איז קיין חיוב.

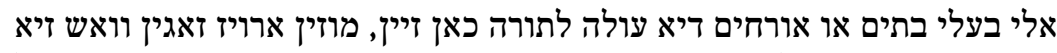
כ"כ

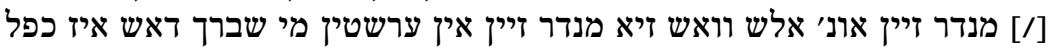

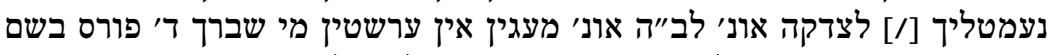

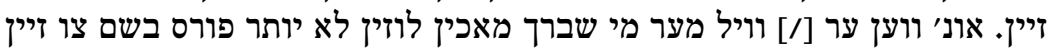

27 Dieses Wort über der Zeile ergänzt.

28 Schwiegersohn.

29 Von ndl. hek = Zaun; davon Abzäunung, Gitter oder auch hinterer Teil (der Synagoge).

30 Tatsächlich wurde erstmals 1724 mit Salman Loonstein ein Rabbiner in Den Haag angestellt, siehe Stefan Litt, Pinkas, Kahal, and the Mediene. The Records of Dutch Ashkenazi Communities in the Eighteenth Century as Historical Sources, Leiden/ Boston 2008, 115. 
אלש ג'. אונ' מוז לכל הפחות [/] חצי שילנג'31 מנדר זיין לצדקה. וועץ שוין אן חזן

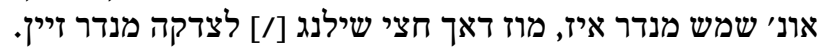

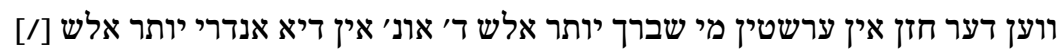
כ"ח ג' פורס בשם איז מוז דער חזן כל פעם געבין חשרך חצי שישר שילנג לצדקה.

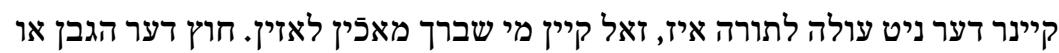
כ"ט

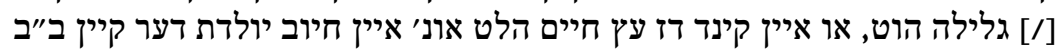

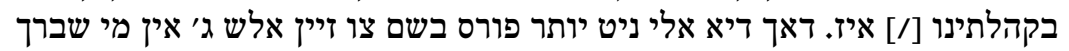

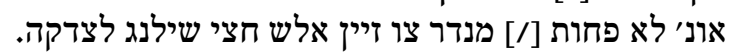

[fol. $8 \mathrm{v}$ leer

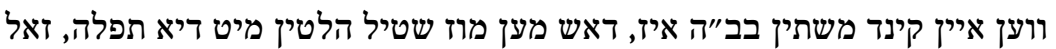
fol. $9 \mathrm{r}$ ]

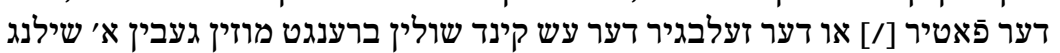

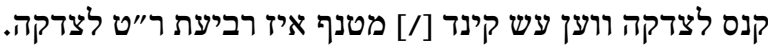

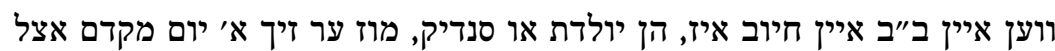
ל

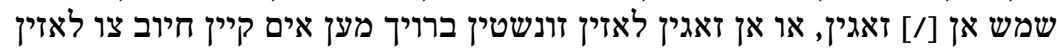

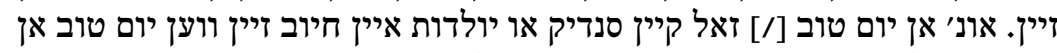

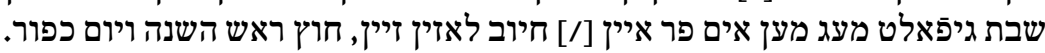

איין אורח דער מצוות סנדקת הוט, אצל ב״ב כאן איז ג״כ איין חיוב. אבר אורח ל אצל אורח [/] איז קיין חצר מצות סנרת

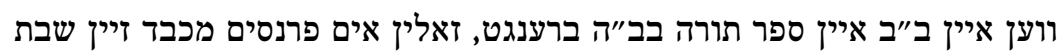
$x^{\prime \prime}$

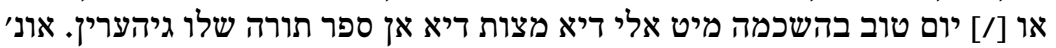

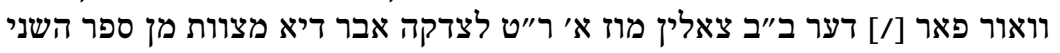

מוזין פר קויפּט ווערין.

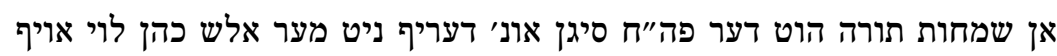
ל

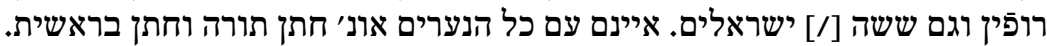

[fol. 9 v leer fol. $10 \mathrm{r}]$

ל"ה

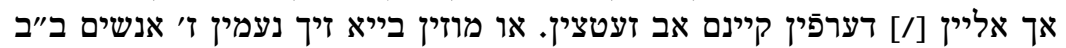

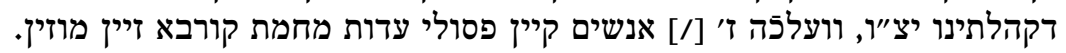

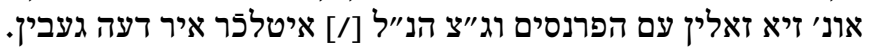

31 Ein Schelling entspricht sechs Stuiver. 


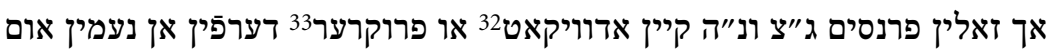
ל ל

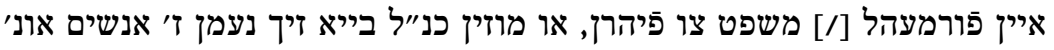

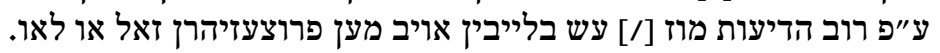

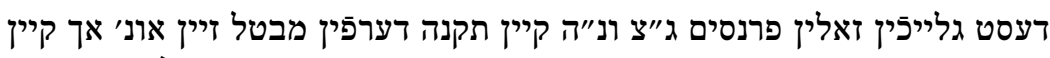
ל

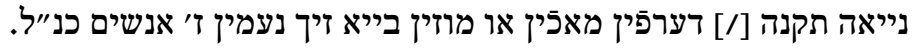

אן פורים זאל מען נור אן ד' שלוח מנות מעגין שיקן, חוץ מתנות לעניים ואביונים פעים ל

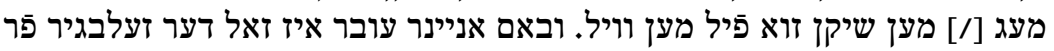

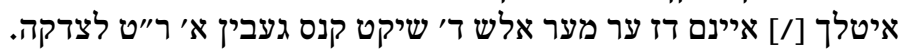

אלי זולכי לייט דיא בכאן וואונין אונ' ניט בקהל שלנו זיין, זאלין ניט עולה לתורה ל

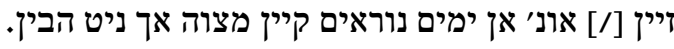

[fol. $10 \mathrm{v}$ leer fol. $11 \mathrm{r}]$

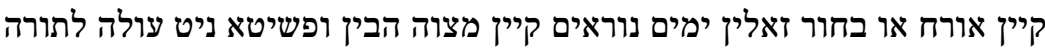
מי

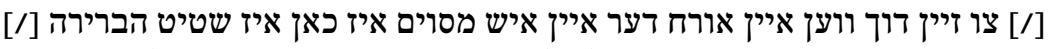

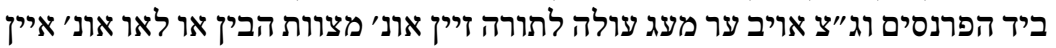

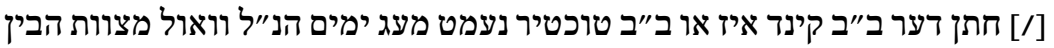

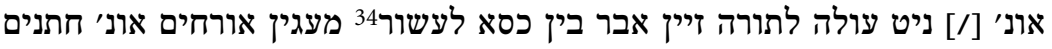
עולה לתורה אך [/] זיין אבר לתורה זיין אבר ביין יונג ניט.

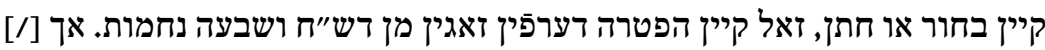
מ"א ניט יום ראשון של שבועות. אונ' ניט פרשת יתרו. אונ' ניט יום אחריון פריון של פסח.

קיינר אלש החזן דמתא זאל מעגין זיך שטעלין לפני התיבה אום מתפיל מתפלל צו זייל זיין. מיב

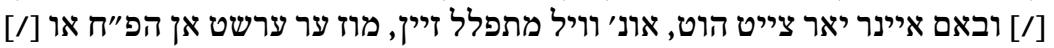

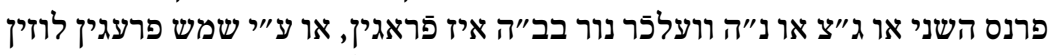

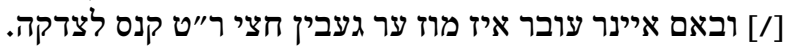

אלי ב״ב דיא יחידים בקהלתינו זיין, אונ׳ מכאן במקום אחר גיהנן וואונין, זאל [/] מ"ג 25

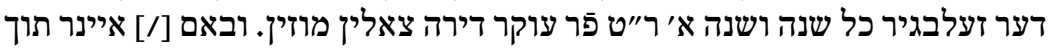

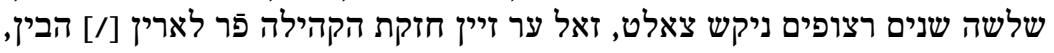
אונ' וויא איין אורח קונים רופים ניקריהרט ווערין.

\footnotetext{
32 Advokat.

33 Procureur.

34 בין כסא לעשור: die Tage zwischen Neujahr und dem Versöhnungstag.
} 
[fol. $11 \mathrm{v}$ leer fol. $12 \mathrm{r}$ ] מ"ד

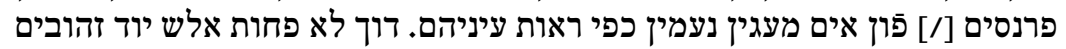

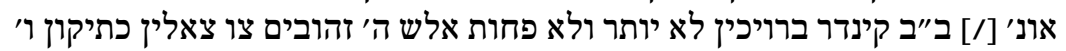

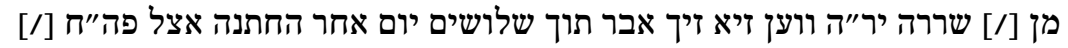

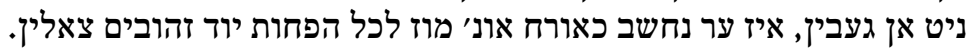

פּר דש קרקע מעות דש איין ב״ב (על כל צרה שלא תבא) הוט מוזין לצדקה געבין מו"ה

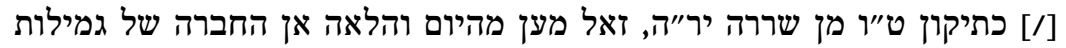

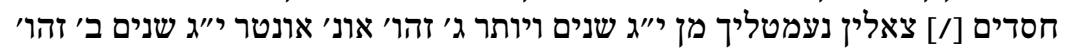

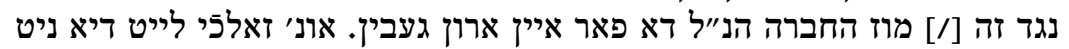

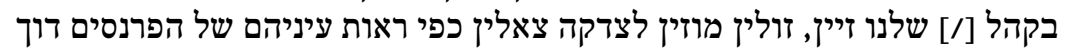

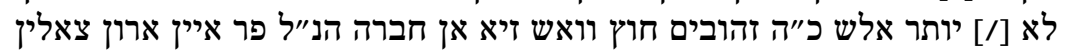

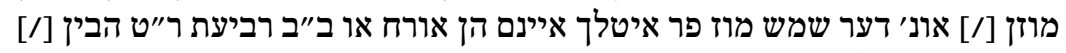

או' מוז אוך זעלברט מיט ארויז גין.

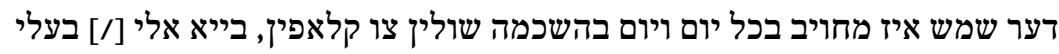
מ"ו

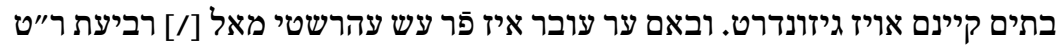

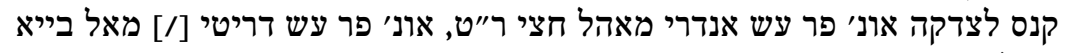

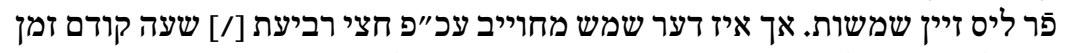

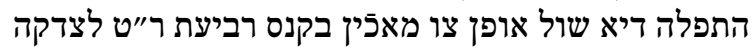

[fol. 12 v leer fol. $13 \mathrm{r}]$

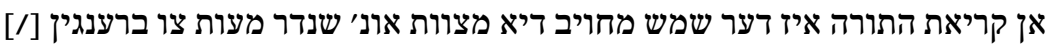
מ"ז

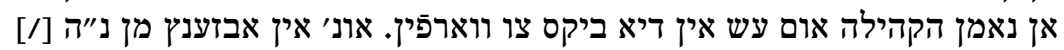
צו ברענגין אן הג"צ אונ' זונשטין אן איין פרנס.

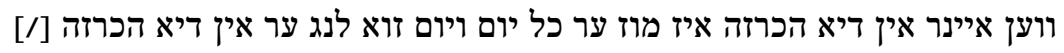
מו"ח

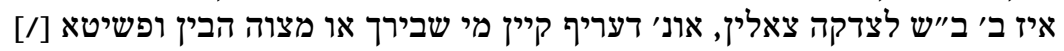
ניט עולה לתורה צו זייקה ציקלין.

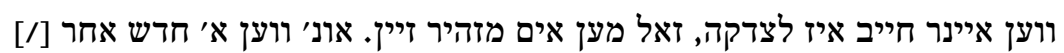
מוטט 30 הזהרה ניקש צאלט מעגין אים הפרנסים זעלים מיד עקשקוטים מיויהרן.35'

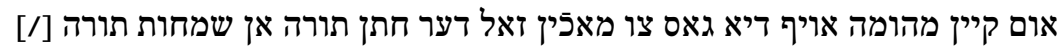
']

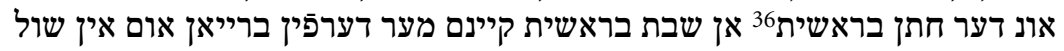
אונ' [/] דערהיים צו ברענגין אלש דיא אלטי פרנסינם מערים ג"צ ונ"ה מירי מיט דעם נייאר

35 Von ndl. executeren $=$ zwangsweise einfordern.

36 Dieses Wort über der Zeile ergänzt. 


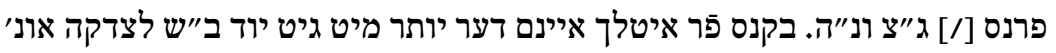

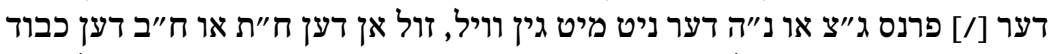

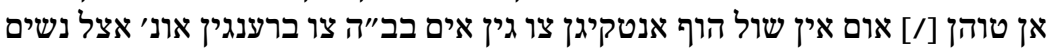
זול [/] עש אך אזוא ריגוליהרט זיין.

[fol.13 v leer 5 fol. $14 \mathrm{r}$ ]

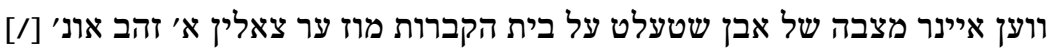
נ"

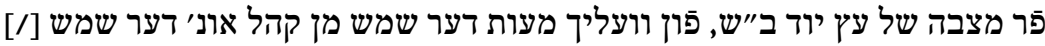

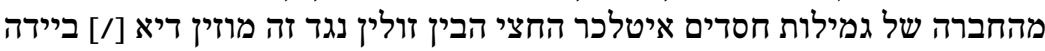

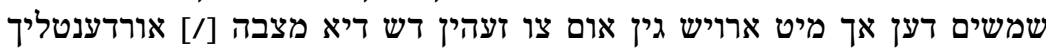

גישטעלט37 או גליגט ווערין.

קיין סנדיק זול ניט דערפיין געבין, אונ' קיין בעל ברית ניט דערפיין נעמין [/] קיין

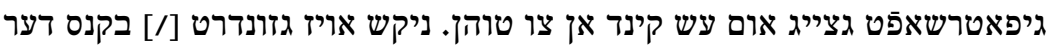

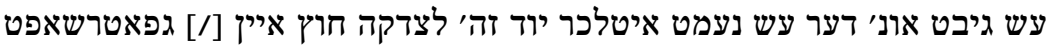

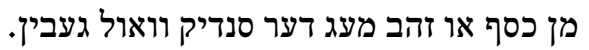

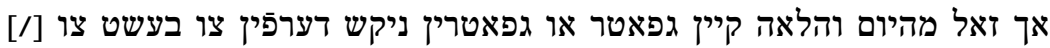
$\lambda^{\prime \prime}$

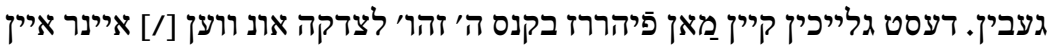

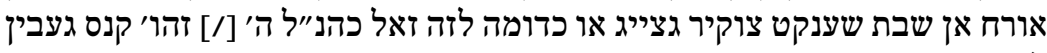
לצדקה.

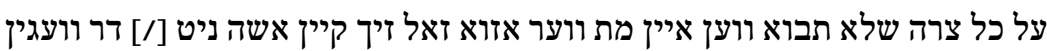
20

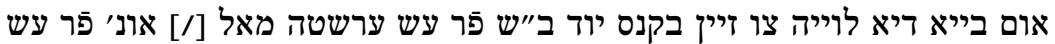
אנדרי מאל כפי ראות עיניהם של הפרנסים יצ"ו. ביר.

מהיום והלאה ווערט דער חזן אן שבת מזכיר נשמות זיין אונ' וועלכיר ב״ביב ווערט נ"ה

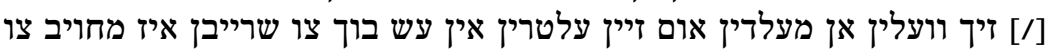

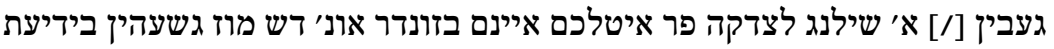

[fol. $14 \mathrm{v}$ leer fol. $15 \mathrm{r}$ ]

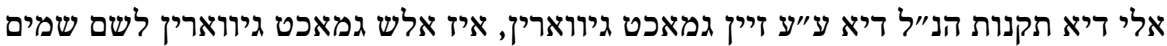

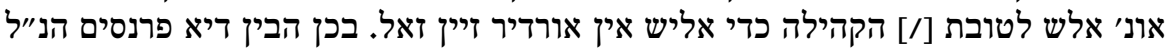
30

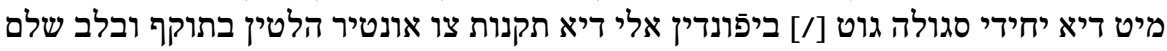

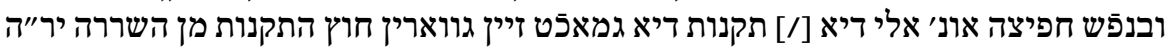

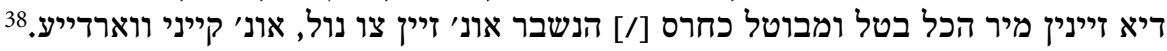

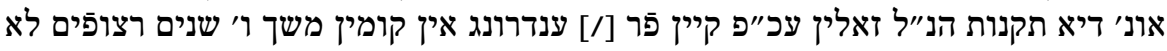

37 Dieses Wort über der Zeile ergänzt.

38 Von ndl. waardij $=$ Wert. 


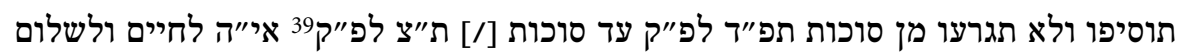

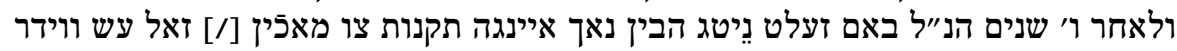

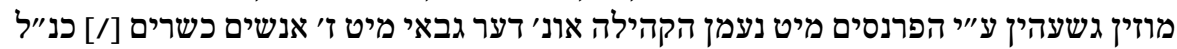

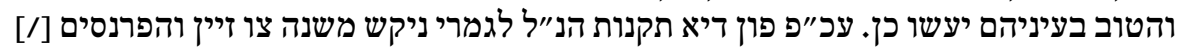

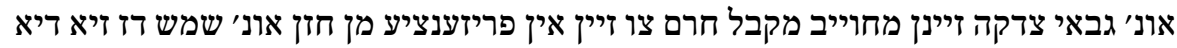
[/] תקנות הנ"ל וועלין מאנטנירן אונ' אליש אידר איינם ציינם בישרנות צו טון

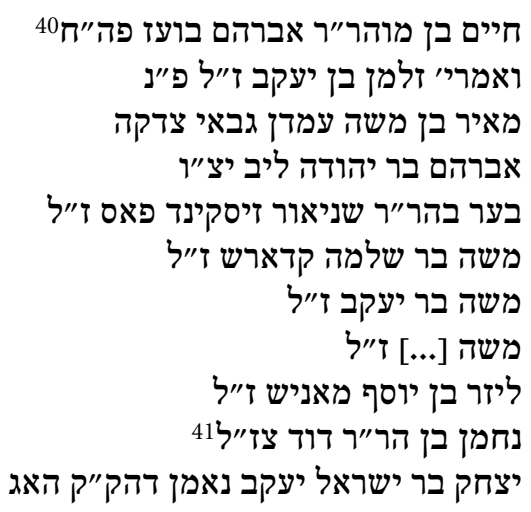

39 Anscheinend wurden während des gesamten 18. Jahrhunderts entweder keine weiteren Änderungen vorgenommen oder vollständig neue takkanot erlassen.

40 Chajim Boas, Mitgründer der aschkenasischen Gemeinde und Vater des Bankiers Tobias Boas.

41 Irrtümlich für לצ'? 


\section{Statuten der Landesjudenschaft in der Meijerij 's Hertogenbosch (1764)}

\section{Quelle: Pinkas Oisterwijk I, Bibliotheca Rosenthaliana, Ros. 282a}

Statuten von Landesjudenschaften sind im allgemeinen Korpus aschkenasischer takkanot nicht allzu häufig erhalten geblieben. ${ }^{1}$ Umso mehr trifft dies für das Gebiet der Vereinigten Provinzen der Niederlande zu. Dies hängt zunächst mit dem Umstand zusammen, dass es in den Niederlanden mit der zumeist liberalen Politik gegenüber den Juden kaum äußere Zwänge zur Errichtung überregionaler, korporativer Strukturen gab und sich diese demzufolge auch kaum finden lassen. In der Region der brabantischen Generalitätslande (Staats-Brabant), in der die Meijerij 's Hertogenbosch lag, gab es erst seit der Mitte des 18. Jahrhunderts einige Juden, die sich aufgrund ihrer weit verstreuten Niederlassung und sicher aus der Kenntnis des Modells einer Landesjudenschaft aus den Territorien des Reiches bald zu einer Korporation zusammenschlossen.

Die hier edierten Statuten von 1764 scheinen die ersten der jüdischen Korporation in der Meijerij gewesen zu sein, worauf der geringe Umfang und die begrenzte Auswahl an Themen verweisen. Sie wurden im ersten Protokollbuch der wohl größten Gemeinde, Oisterwijk, niedergeschrieben, vielleicht auch in anderen ähnlichen Büchern zusätzlicher Gemeinden, die sich jedoch nicht erhalten haben. Ihre Gültigkeit war zunächst auf drei Jahre beschränkt. Die Handschrift ist ein kleiner Band im Oktavformat, der durch eben diese Statuten eröffnet wird. Zusammen mit zwei ähnlichen Büchern aus Oisterwijk wird er in der Sammlung der Bibliotheca Rosenthaliana in Amsterdam aufbewahrt. Die takkanot wurden in jiddischer Sprache abgefasst, das hier weitgehend unbeeinflusst vom Niederländischen erscheint. Der Schreiber des Textes war der Landesrabbiner Jekutiel Süßkind Rofe, der, wie im Schlussteil beschrieben, diese Statuten auf Geheiß der Vorsteher zu Papier brachte.

Die Seiten der Handschrift wurden weder foliiert noch paginiert, die einzelnen Artikel der takkanot hingegen wurden mit hebräischen Lettern nummeriert. Neben einer kurzen Einleitung und einer Schlussformulierung gliedern sich die Statuten in vierzehn Artikel. Die Handschrift ist insgesamt in gutem Zustand, sodass der Text der takkanot ohne Verluste erhalten blieb.

1 Bekannt sind die publizierten Beispiele aus Mähren, Bamberg, Hessen-Kassel und Ansbach; siehe Anhang. 
Der Inhalt beschränkt sich auf Fragen der Aufbringung des Salärs für den Landesrabbbiner, wofür die gabba'im in den verschiedenen Orten verantwortlich waren. Ihre namentliche Nennung zeugt davon, wie sehr die Statuten aus der aktuellen Situation entstanden und weniger als Gesetzestext mit langer Gültigkeit verstanden wurden. Daneben wurden auch die Kompetenzen des Rabbiners in den Statuten geregelt.

Auffällig ist das völlige Fehlen jeglicher Interpunktion im Text. Das dadurch erschwerte Lesen wird etwas durch das große Schriftbild mit jeweils nur ca. 17 Zeilen pro Seite ausgeglichen. 


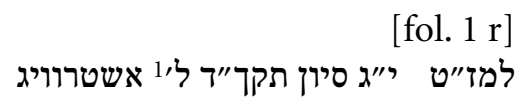

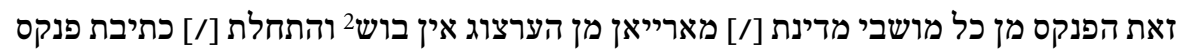

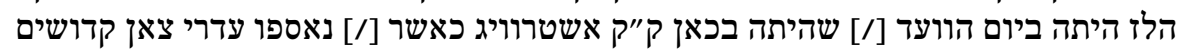

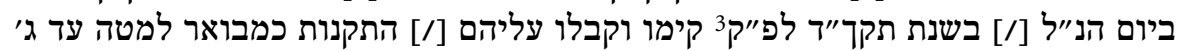

ראשון האבן כל בני מדינה ברצון הטוב [/] מפשר גיוועזן כל שני שנה צו צאלן שכר א

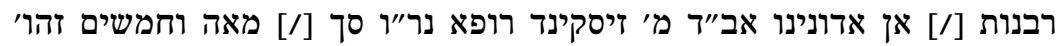

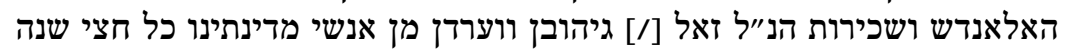

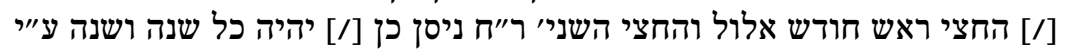

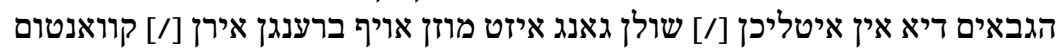

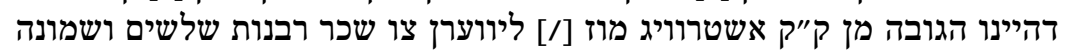

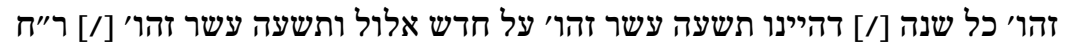

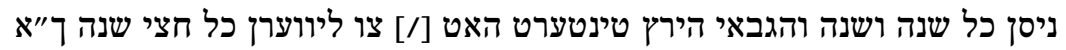

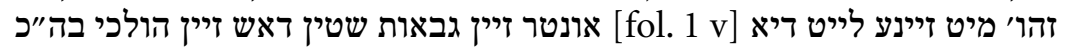

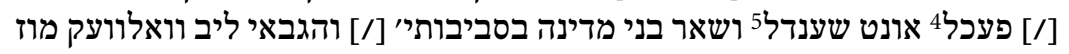

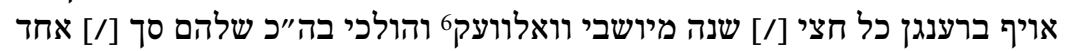
עשר זהו' כל חצי שנה. והגבאי יוזלי ענטהויבן מוז ליווערן כל חצי שנה [נה [נ] עשרים וארבע זהו' מן יושבי

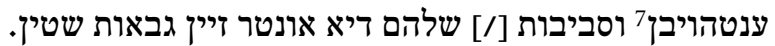

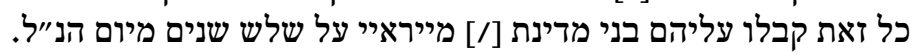

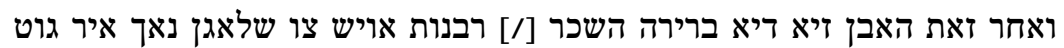

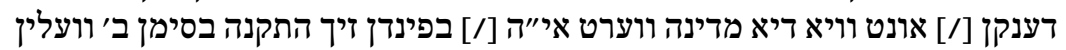

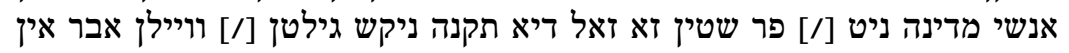

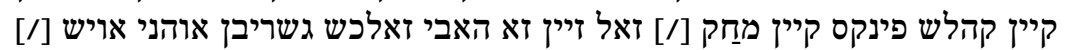

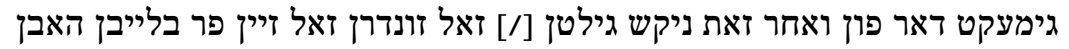
[/] דאש שכר רבנות עד ג' שנים וויא גימעלט [/] אילט זיזט.

\footnotetext{
$1 \quad 1764$ VI 13.

2 Andere Gemeinden, für die die takkanot Gültigkeit haben sollten, waren neben Oisterwijk noch Waalwijk, Schijndel, Dinther, Veghel und Eindhoven.

3 1763/64.

4 Veghel.

5 Schijndel.

6 Waalwijk.

7 Eindhoven.
} 
זאל יום הוועד זיין כל ג' שנים על החוב'[/] פינגשטן באיין באיזה מקום שירצה הגבאים [fol. $2 \mathrm{r}$ ]

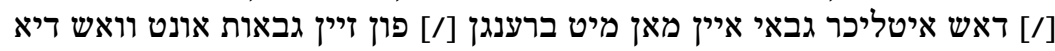

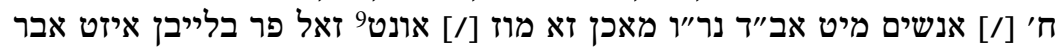
נימאנט [/] גיווערט צו קומן צום יום ווען דיא [/] גבאים אואר אואל פר שרייבן.

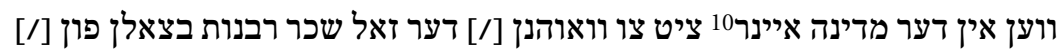

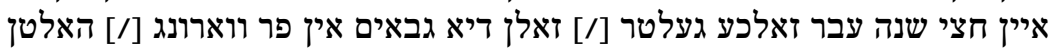

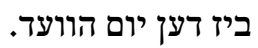

וועץ איין בן מדינה חתונה טוט [/] זא מוז ער שכר רבנות געבן אונט [/] איזט ניט מעהר פרייא אלז ד' שבועת [/] נאך זיין חתונה.

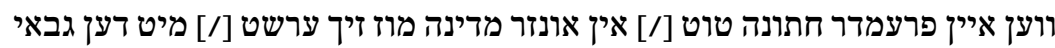
[fol. 2v]

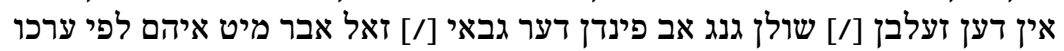

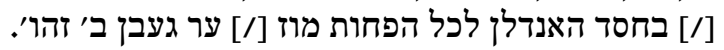

איין אונטר פירער צו דער חופה [/] זאל געבן ך"ה ב"ש11 פארטל פר [/] דער ז חתונה חברותה איין מַאן פירער אברותר אבר י״ב ב"ש [/] וחצי.

דער חתן בליל חופתו מוז ער [/] געבן אן דיא יונגן ט"ו ב"ש [/] אויש קויף געלט $\pi$

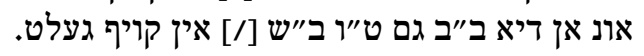

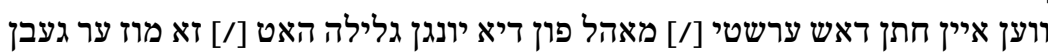
[fol. $3 \mathrm{r}$ ]

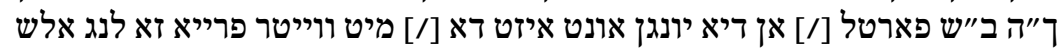
[/] ער זיין קנס גיט.

שכר קדושין אן אב"ד נר"ו [/] מיט שרייב געלט איזט גיזעצט [/] לכל הפחות א׳ יו"יו"

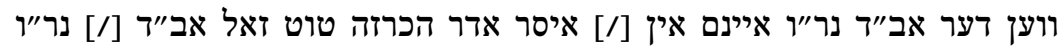
$\aleph^{\prime \prime \prime}$

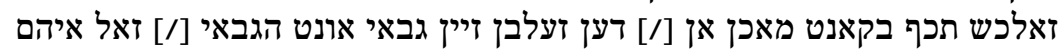

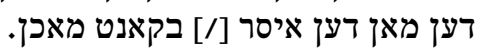

\footnotetext{
8 Pfingsten. Es ist unklar, ob jedoch konkret das christliche Fest oder das zeitnahe jüdische Wochenfest (Schawu'ot) gemeint ist.

9 Dieses Wort später am Anfang der Zeile hinzugefügt.

10 Wort über der Zeile.

11 Stuiver, Stüber.

12 Wahrscheinlich groot $=$ Groschen; ein groot entspricht einem halben Stuiver.
} 
[fol. $3 \mathrm{v}$ ]

י״ב זאלן דיא גבאים דיא מאכט האבן [/] דיא שחיט ביטה צו פר ביטן אויך דער [/] קיין

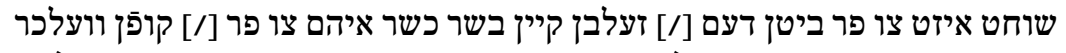

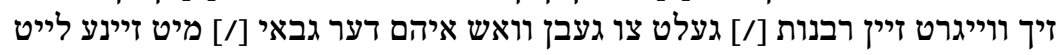

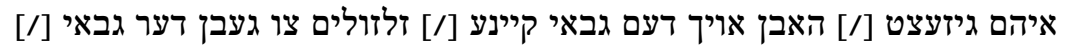

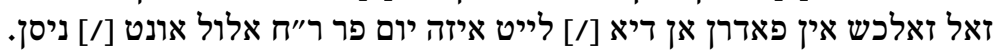

יו"ג דיע זעלבי לעדיגי יונגן דיא אין [/] אונזר מדינה מוּ"מ טרייבן מוזן [/] זיך בייא

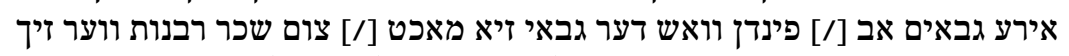

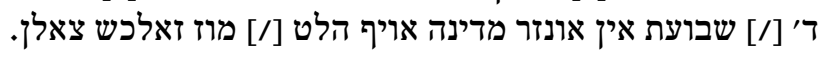

[fol. $4 \mathrm{r}] \quad 10$

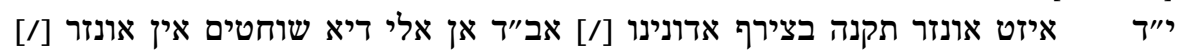

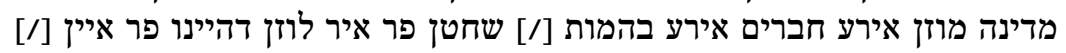

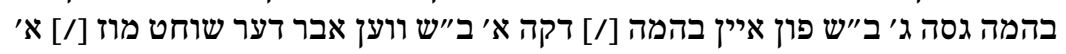

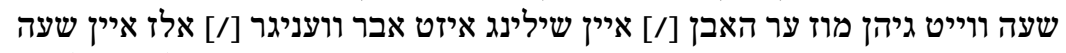

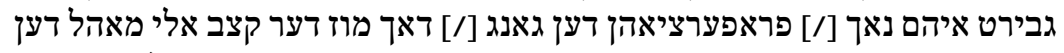

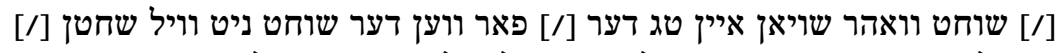

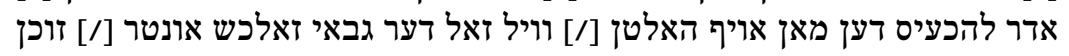

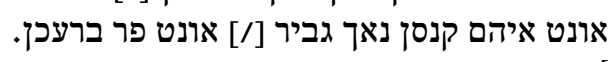

[fol. $4 \mathrm{v}$ ]

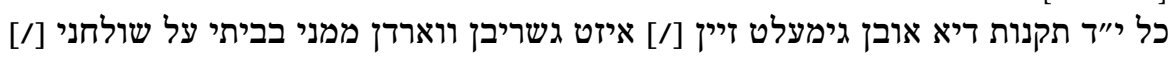
20

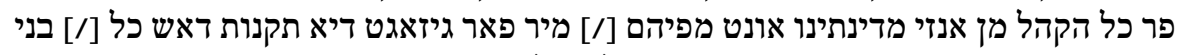

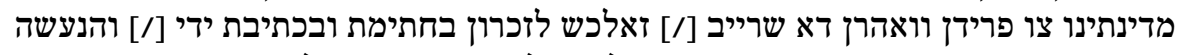

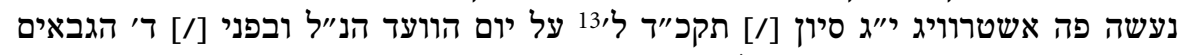

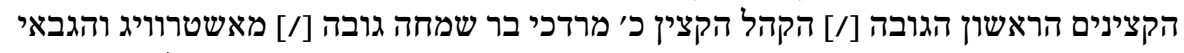

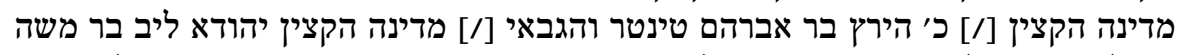

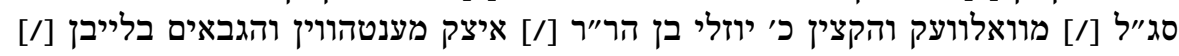

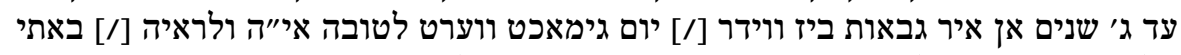

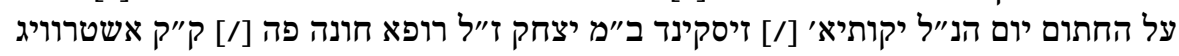
ומדינת מיירייא מן בוש.

$13 \quad 1764$ VI 13. 



\section{Königreich Frankreich}

Metz (1769) 



\section{Statuten aus Metz (1769)}

\section{Quelle: Pinkas Metz, Jewish Theological Seminary of America, MS 8136'}

Die umfangreichen Metzer Statuten sind bislang die einzigen bekannten aus der Hauptgemeinde Frankreichs während der Frühen Neuzeit. Sie erstrecken sich auf nicht wenige Gebiete des gemeindlichen Lebens, jedoch wurden sämtliche Regeln bezüglich der Wahl von Vorstehern ausgenommen; diese finden sich, häufig revidiert, in mehreren Versionen im pinkas der Gemeinde. Wie aus den Paragraphen 74 und 75 hervorgeht, gab es in Metz noch im Jahr 1769 ein Statutenbuch, das jedoch aus unbekannten Gründen für die Niederschrift des vorliegenden Textes nicht genutzt wurde.

Stattdessen wurde der Text in seiner Originalausfertigung im großformatigen pinkas der Gemeinde (in Gebrauch 1749-1789) eingeschrieben. Aus einer einleitungsähnlichen Eintragung unmittelbar vor den Statuten geht hervor, dass der Vorgängertext 139 Paragraphen umfasste, die teilweise in der neuen Version bestätigt bzw. unter Bezugnahme auf die alten Artikel verändert wurden. Eine fragmentarische Vorgängerversion aus der letzten Dekade des 17. Jahrhunderts hat sich bis heute erhalten und wurde vor einiger Zeit von Simon Schwarzfuchs ediert. ${ }^{2}$ Der vorliegende Text hat 125 Paragraphen, die alle erhalten sind. Lediglich bei den Versoseiten sind einige Wörter am jeweils linken Seitenrand durch die Bindung unlesbar geworden, die jedoch teilweise aus dem Kontext erschlossen werden konnten.

Bis zur Mitte der Statuten wurden diese in einem Gemisch aus Hebräisch und Jiddisch verfasst, in das Lehnwörter aus dem Französischen einflossen. Der hebräische Anteil überwiegt jedoch fast immer und dominiert in der zweiten Hälfte des Textes mit Ausnahme von Paragraphen 109 und 125. Möglicherweise sind diese deutlichen Unterschiede durch Übernahme älterer

1 Mit freundlicher Genehmigung des Jewish Theological Seminary of America; Mikrofilm des Protokollbuches in der Israelischen Nationalbibliothek Jerusalem, F 49761.

2 Dabei handelt es sich offenbar um eine Vorlage für die Ausrufung in der Synagoge; siehe Simon Schwarzfuchs, Über das Wesen der Takkonaus, der jüdischen Gemeindeordnungen. Von der Provence bis Metz (13.-17. Jahrhundert), in: Christoph Cluse, Alfred Haverkamp, Israel J. Yuval (Hg.), Jüdische Gemeinden und ihr christlicher Kontext in kulturräumlich vergleichender Betrachtung. Von der Spätantike bis zum 18. Jahrhundert, Hannover 2003, 465-503. 
Statuten entstanden, während stark modifizierte bzw. gänzlich neue Bestimmungen in einem anderen Idiom niedergeschrieben wurden. Der Schreiber war Jidel Katz, Schreiber und Sekretär der Gemeinde, der die Niederschrift eigenhändig unterschrieb. Von ihm sind im pinkas weitere Einträge vorhanden.

Die Blätter der Handschrift sind in der oberen linken Ecke mit hebräischen Buchstaben nummeriert. Auch die einzelnen Paragraphen wurden unter Nutzung hebräischer Buchstaben jeweils am rechten Seitenrand nummeriert. Auf thematische Gliederungsüberschriften, wie sie sich sonst häufig bei Texten dieses Umfanges finden, wurde hier verzichtet. Trotzdem sind artverwandte Paragraphen in einzelnen Textabschnitten zusammengefasst, die nicht eigens kenntlich gemacht wurden. Dass in der Redaktionszeit der takkanot in Metz auch diese Variante erwogen wurde, zeigt die teilweise erhaltene Handschrift von 1768/69, die 1970 von Simon Schwarzfuchs ediert wurde. Unter den Kategorien »Tora « und »Gebet « wurden dort Paragraphen zusammengefasst und in anderer Reihenfolge als in der hier publizierten Vorlage nummeriert. Jedoch ist diese kleine Handschrift unvollständig erhalten, sodass Schwarzfuchs nur die 24 erhaltenen Paragraphen herausgeben konnte. Die vollständige Version im pinkas war ihm offenbar noch unbekannt. Im Apparat der vorliegenden Edition wird auf die teilweise nahezu identischen Artikel in der älteren Publikation verwiesen. Samuel Kerner legte schließlich 1972 eine vollständige Übersetzung der Statuten ins Französische vor, die für diese Edition insbesondere bei der korrekten Entzifferung der französischen Lehnwörter unverzichtbar war.

Wie schon weiter oben bemerkt, sind alle Angelegenheiten der innergemeindlichen Wahlen nicht Bestandteil diese Statuten. Dafür finden sich gleich zu Beginn umfangreiche Bestimmungen für die Kleiderordnung und andere Luxusgesetze, die in dieser detaillierten Dichte aus anderen Gemeindestatuten unbekannt sind. Besonders auffällig sind die detaillierten Angaben $\mathrm{zu}$ verschiedenen erlaubten und verbotenen Stoffarten, die mit ihren französischen Bezeichnungen, jedoch mit hebräischen Buchstaben wiedergegeben wurden. An vielen Orten wurden solche Bestimmungen in separaten Luxusgesetzen erlassen. In Metz gab es eine längere Tradition beim Erlass von Luxusgesetzen durch die Vorsteher, die seit 1690 nachweisbar ist und auch durch ähnliche Bestrebungen in der christlichen Gesellschaft Frankreichs beeinflusst wurde. ${ }^{3}$ Bemerkenswert ist die in $\$ 39$ angedeutete Praxis - offenbar

3 Jay R. Berkovitz, Rites and Passages. The Beginnings of Modern Jewish Culture in France, 1650-1860, Philadelphia 2004, 39. Eine Edition von einzelner Statuten zu ausgewählten Themen, unter ihnen auch Luxusgesetze, findet sich bei Schwarzfuchs, Takkonaus, 465-503. 
zur Präsentation - Soldaten bei Hochzeiten vermögender Leute anzumieten. Weitere Statuten betreffen etwa das Handelsrecht, hier ist von Interesse $\$ 114$, der durch die Nennung zahlreicher Ortsnamen die wichtigen Pferdemärkte der Region in der Entstehungszeit der takkanot benennt. Liturgie und Gebete, das Erbschaftsrecht und Fragen der Mitgliedschaft in der Gemeinde werden ebenfalls ausführlich behandelt. 
[fol. $76 \mathrm{r}$ ] אחרי שה"ה ח"י אנשיי עושיי רעגלמאן

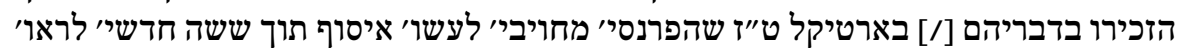

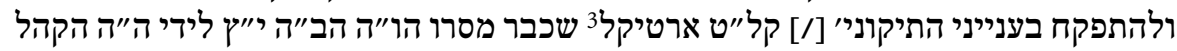

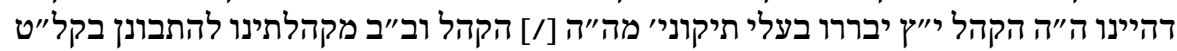

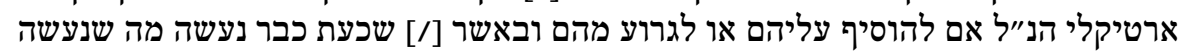

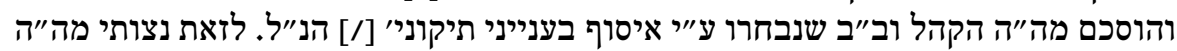

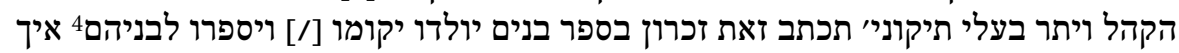

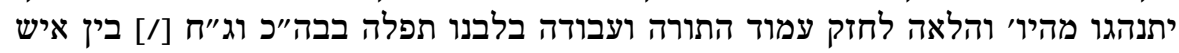

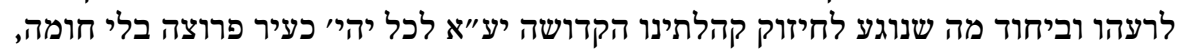

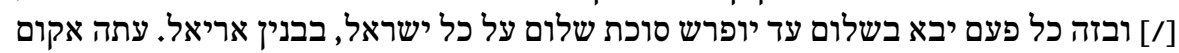
[/] יאמר ה'5 ב"ב אמן.

הכרוז שהכרזתי בבה"כ הישינה קודם שנכרזו התיקוניי

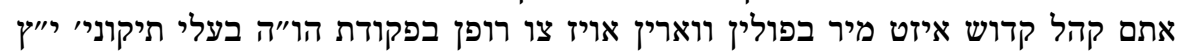

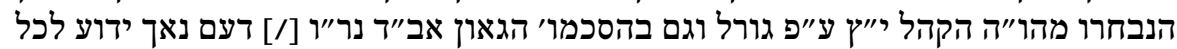

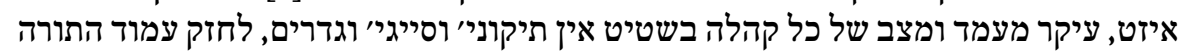

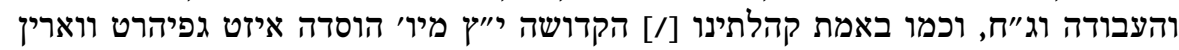

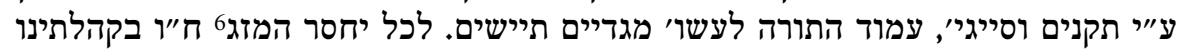

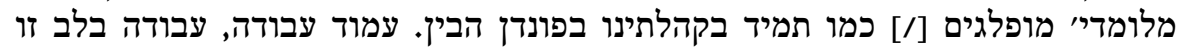

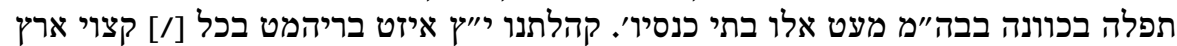

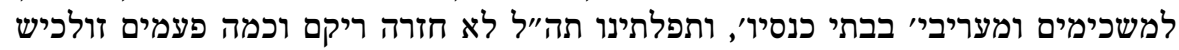

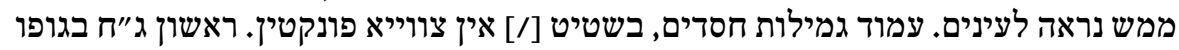

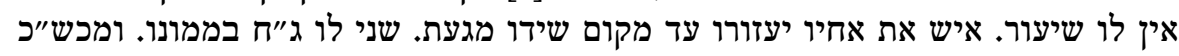

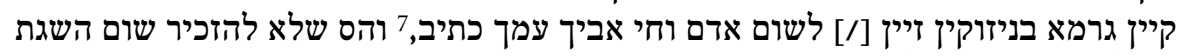

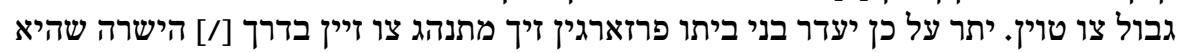

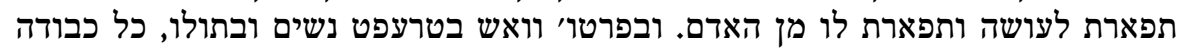

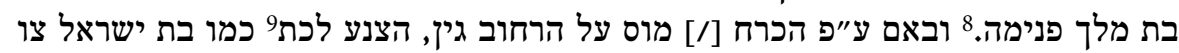

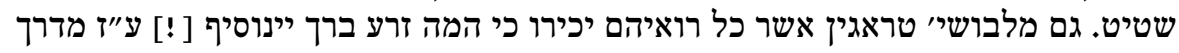

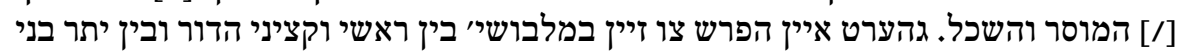

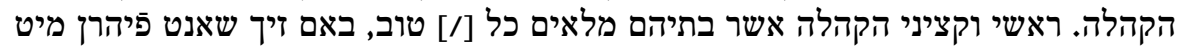

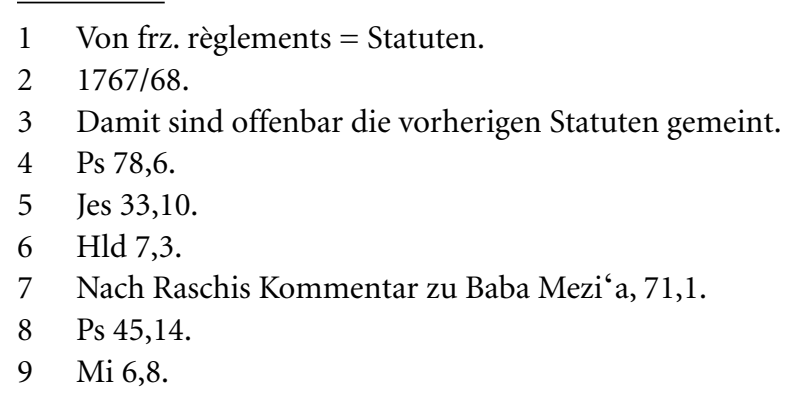




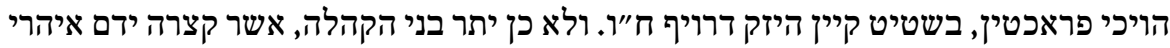

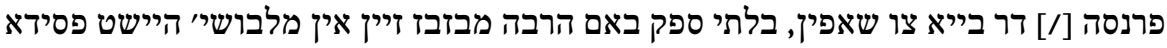

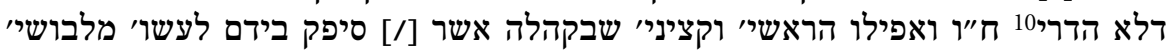

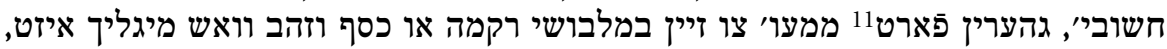

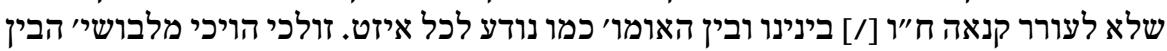

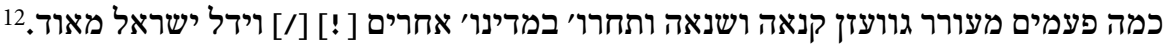

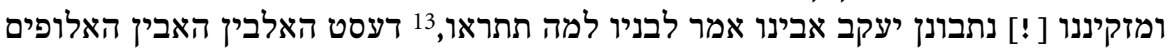

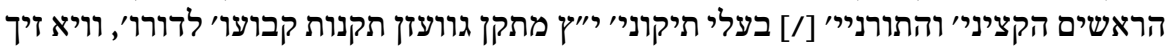

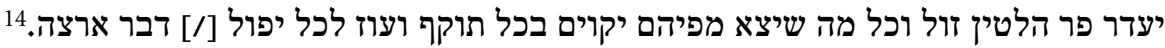

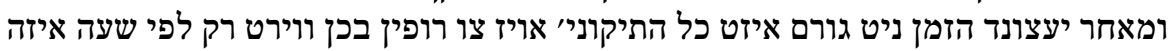

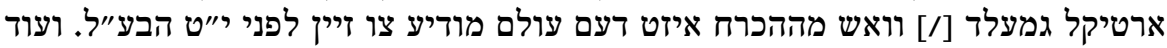

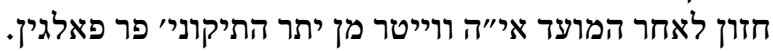
[fol $76 \mathrm{v}$ ] וזה יצא ראשונה א' איהי' מי שיהיי אנשים או בחורי' ונערים מי"ג שני' ואילך דיא דברים בטלי' רידין

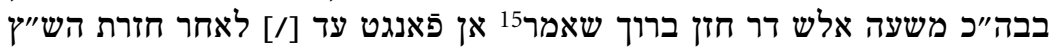

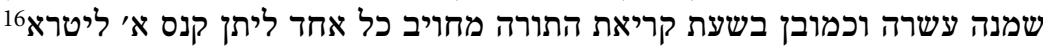

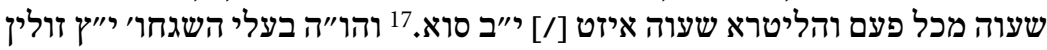

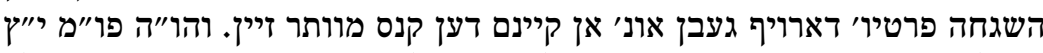

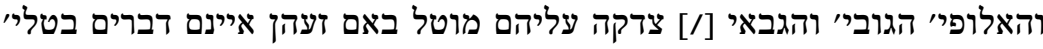

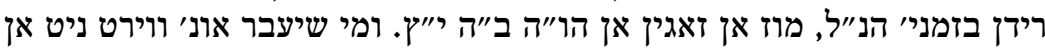

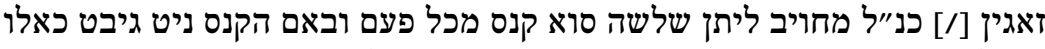

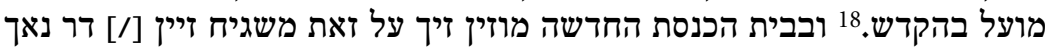
פה"ח וגבאי דת"ת הכל בקנס בכל אופניי ופרטיטי" הנו"ל.

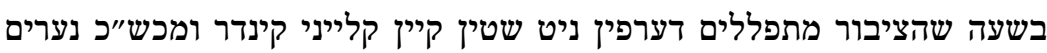

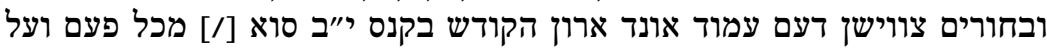

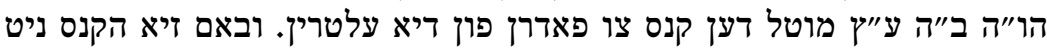

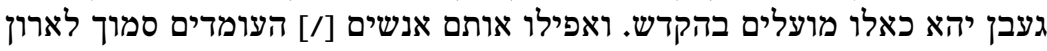

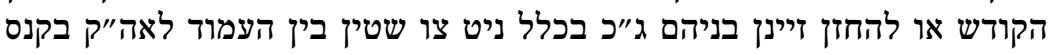

10 Mischna Baba Batra 21, 2.

11 Von frz. fort = bedeutend, vermögend.

12 Ri 6,6.

13 Gen 42,1.

14 Nach 1 Chr 22,8 und 2 Kön 10,10.

15 Eröffnungssegen der Psuke de-Zimra im Morgengottesdienst.

16 Pfund.

17 Sou, französische Münze, ein Sou (Sol) entspricht 12 Deniers.

18 כאלו מועל בהקדש in der Bedeutung: so, als ob er öffentliche Gelder veruntreut.

19 Korrespondiert mit $\$ 11$ bei Schwarzfuchs, Règlement, 30-33. 


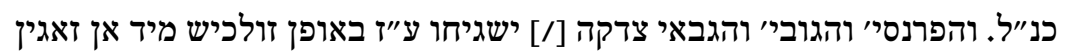

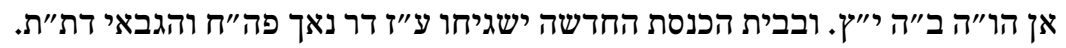

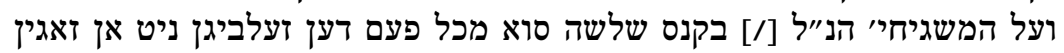
ובאם לא יתנו הקנס כאלו מועל בקלי בהקדש.20

5

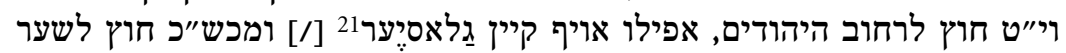

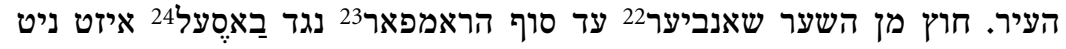

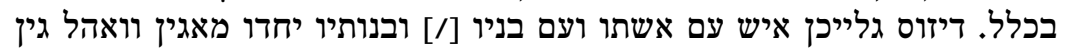

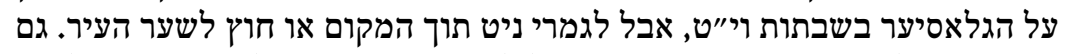

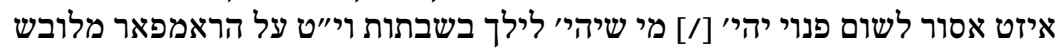

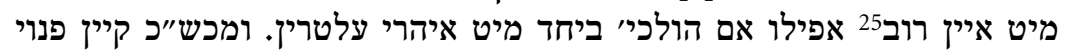

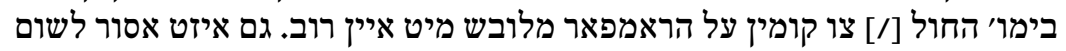

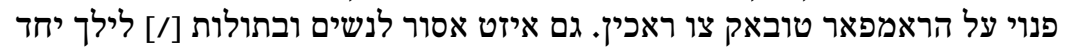

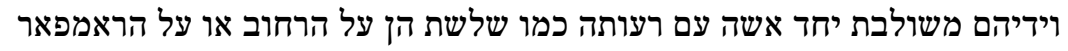

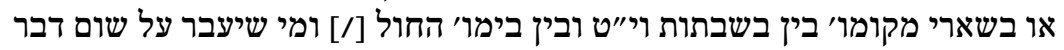

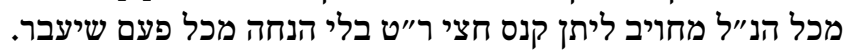

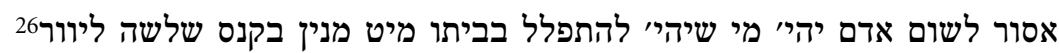

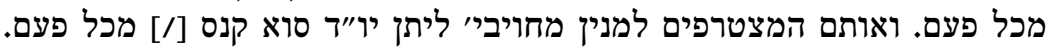

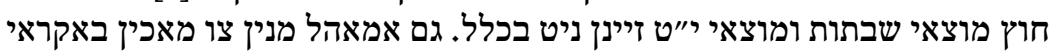

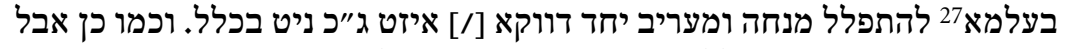

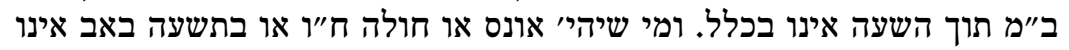

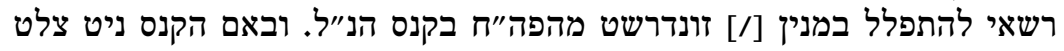

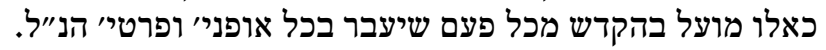

20 Korrespondiert mit $\$ 12$ bei Schwarzfuchs, Règlement, $32 \mathrm{f}$.

21 Glacière: dem jüdischen Wohnviertel benachbarter Stadtteil; siehe Berkovitz, Rites, 50.

22 Chambière: Tor an der Nordseite der mittelalterlichen Stadtbefestigung.

23 Von frz. rempart = Wall (der Stadtbefestigung). Denkbar wäre auch die Bezeichnung für die Metzer Uferpromenade Quai du Rimport, oder in alter Bezeichnung Rhinport.

24 Unklare Ortsangabe.

25 Von frz. robe = mantelähnlicher Umhang.

26 Von frz. livres, eine Rechnungswährung, die fast nie ausgeprägt wurde. Ein Livre entspricht 20 Sou.

27 einfach so. 
וואש אן לאנגט תכשיטי נשים יתנהג מהיו' והלאה כמו ווייטר פאליגט. דהייפונו היא

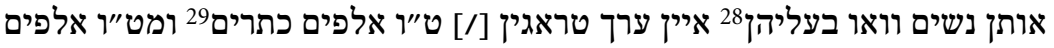

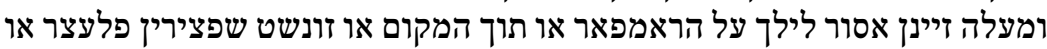

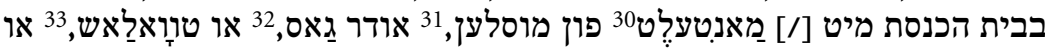

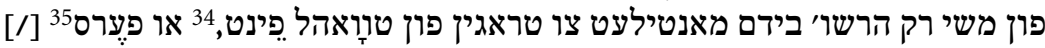

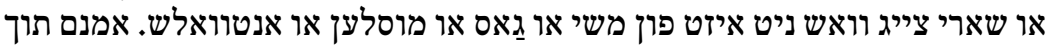

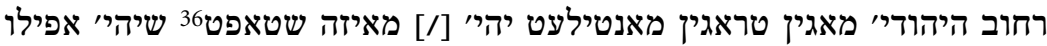

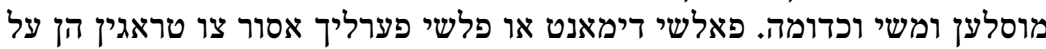

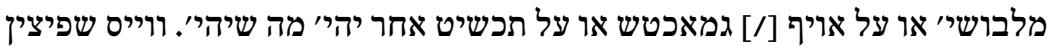

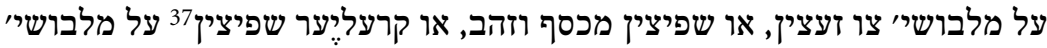

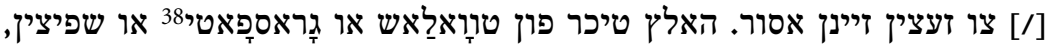

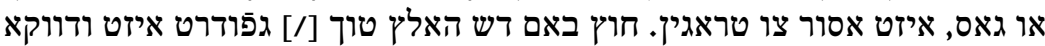

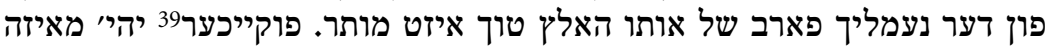

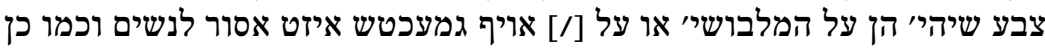

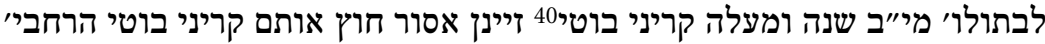

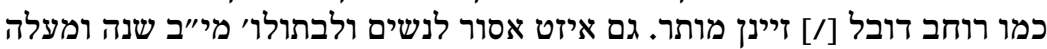

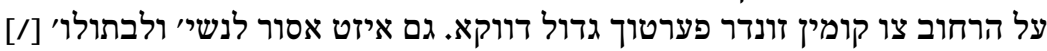

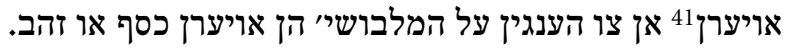

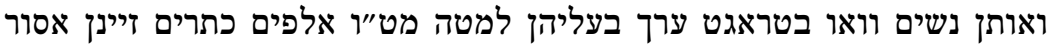
ויו

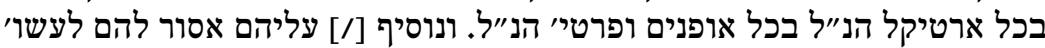

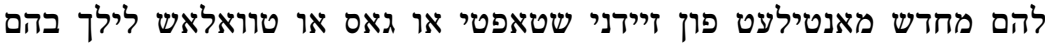

28 Davor gestrichen: הערך.

29 Von frz. couronnes = Kronen, eine im damaligen Frankreich eigentlich ungebräuchliche Münzbezeichnung, daher ist ihr Gegenwert nicht eindeutig zu bestimmen. Da üblicherweise ein Vermögen in Livres oder Reichstaler angegeben wurde, wäre denkbar, dass es sich um eine volkstümliche Parallelbezeichnung dieser Währungs- bzw. Münznamen handelt.

30 Mantilla, feingewebtes Kleidungsstück, wird über Kopf und Oberkörper getragen.

31 Mousselin.

32 Gaze.

33 Toilage, an den Rändern gezackter Stoff.

34 Toile finette, ein leichtes Leinen.

35 Perse, ein bedrucktes bzw. bemaltes Leinen.

36 Stoff.

37 Eine besondere Spitzenqualität, genaue Bedeutung unklar.

38 Genaue Bedeutung unklar, dass hier »grobe«, frz. grosse, Tücher für Halstücher Verwendung fanden, scheint zweifelhaft.

39 Eine Art Besatzstoff? Genaue Bedeutung unklar.

40 Graines de beauté $=$ Schönheitspflaster.

41 Uhren. 


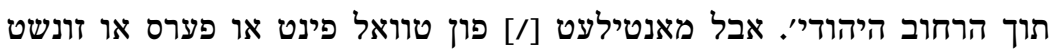

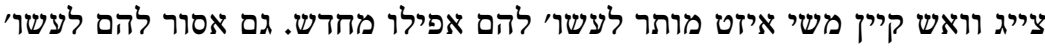

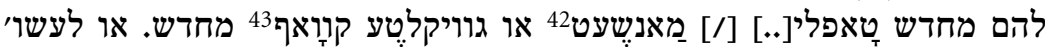

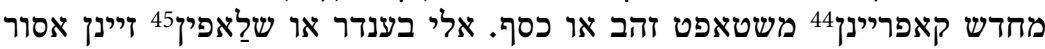

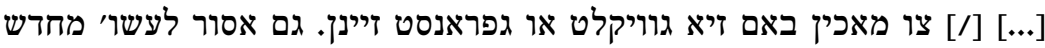
קוֹואף מטוֹואלַש, שיקטיר,

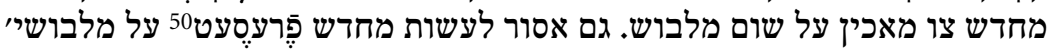
חוץ אויף קאזיקיער מאלין שיזט מלבושר.

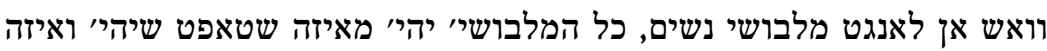

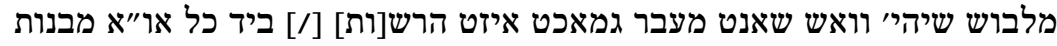

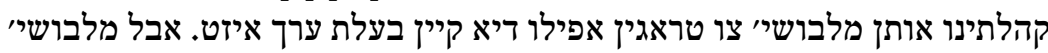

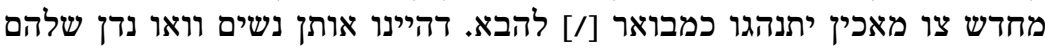

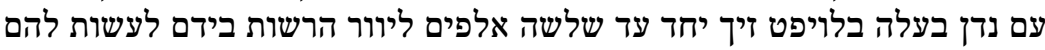

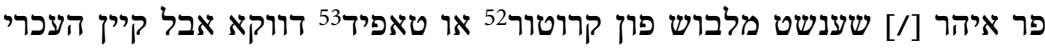

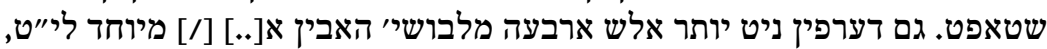

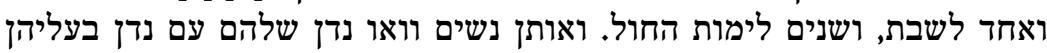

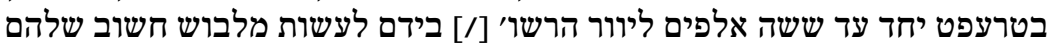

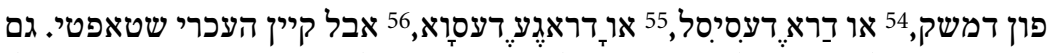

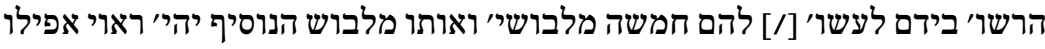

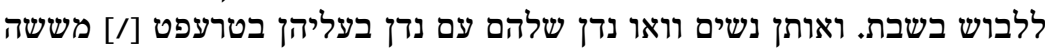

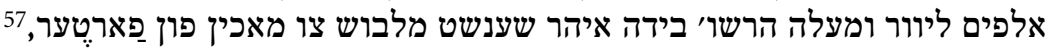

42 Doppelte Manschetten.

43 Coiffe $=$ Kopfhaube.

44 Eine Art Kopfbedeckung?

45 Schleifen.

46 Bedeutung unklar.

47 Blonde $=$ Seidenspitze.

48 Von frz. falbala = Falbel, Faltensaum; zur Verzierung an Röcken und Ärmelbündchen angebracht.

49 Cordonnet $=$ Schnürseide.

50 Kleine Krause.

51 Vielleicht »calicot« (dt. Kaliko,), ein Baumwollstoff, der nach dem indischen Kalikut/ Kozhikode benannt ist.

52 Gros de Tours, ein Seidengewebe.

53 Taft.

54 Damast.

55 Drap de Sicile, eine Stoffart.

56 Droguet de soie $=$ Seidengewebe.

57 Parterre, offensichtlich eine Stoffart. 


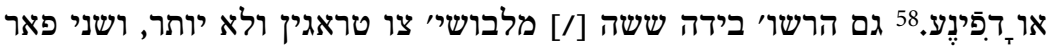

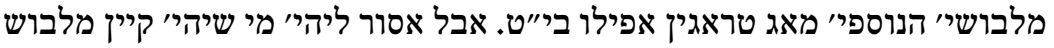

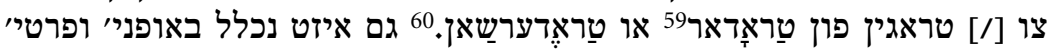

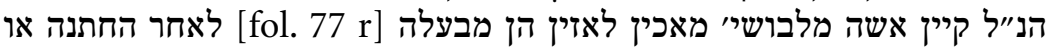

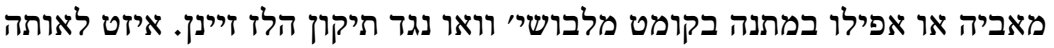

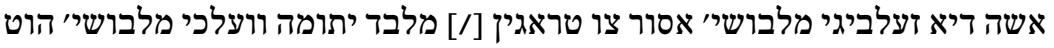
מאבותיה מג זיא מלבושי׳ טראגין אפורילו ווען נגרד התיקון זיין.

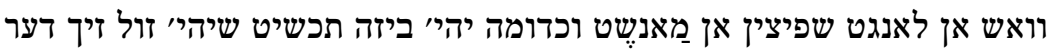

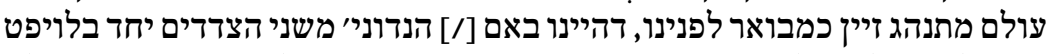

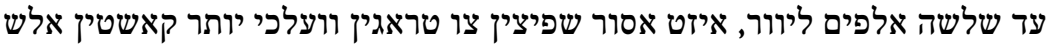

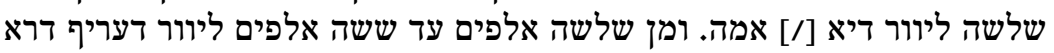

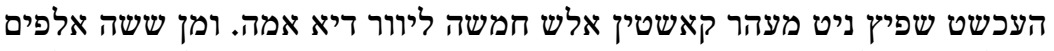

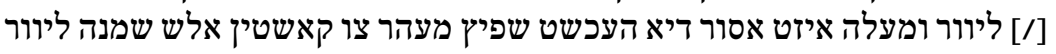

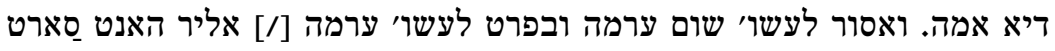

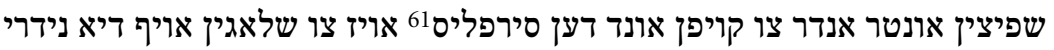

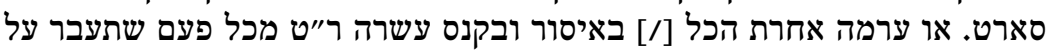

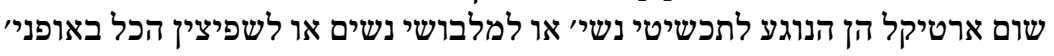

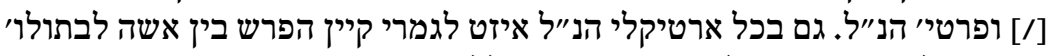

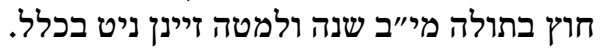

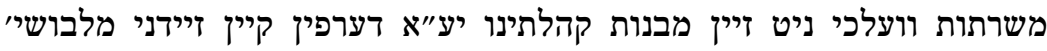

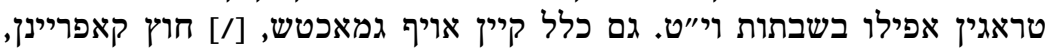

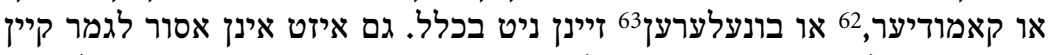

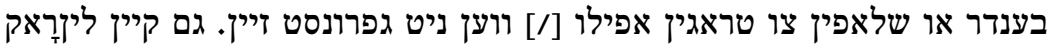

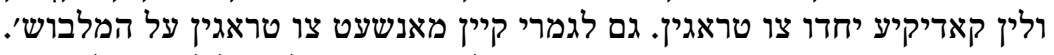

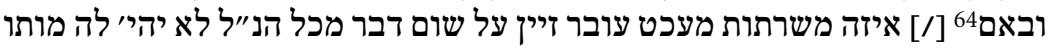
חית

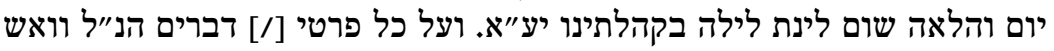

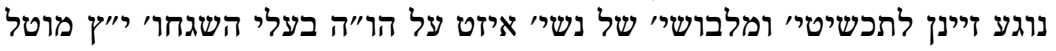

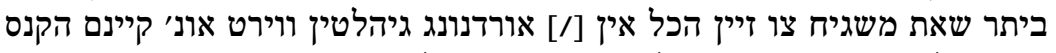
נאך צו לאזין יהי' מי שיהי' בלי התחסדו' שבעולם.

58 Dauphiné: leichtes, bedrucktes Seidengewebe.

59 Drap d'or $=$ Goldstoff.

60 Drap d'argent = Silberstoff.

61 Surplus = Überschuss.

62 Vielleicht frz. "que (eigentl. qu'à la) mode d'hier« = nach der mode von gestern.

63 Von frz. bonnets les reines (Königinnenhäubchen), Form unklar.

64 Dieses Wort noch einmal am Beginn der folgenden Zeile. 


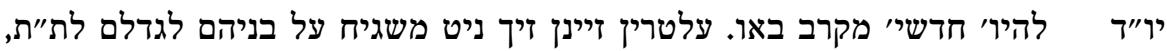

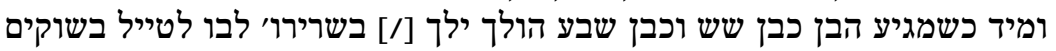

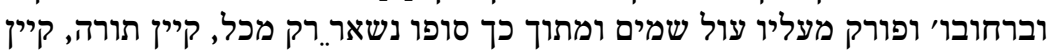

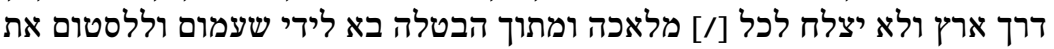

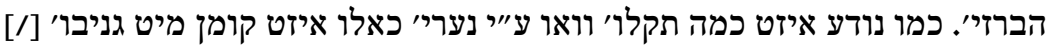

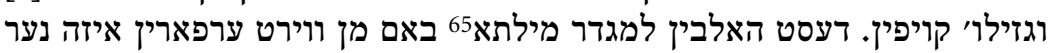

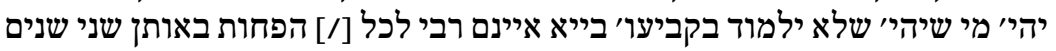

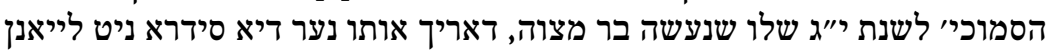

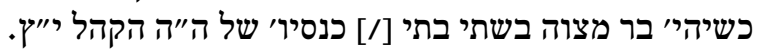

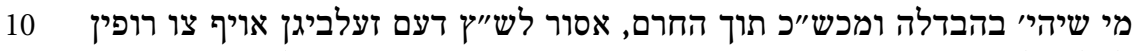
$\aleph^{\prime \prime \prime}$

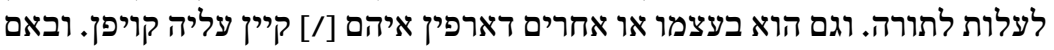

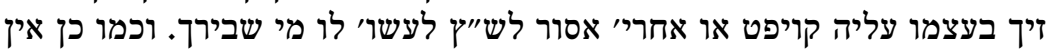

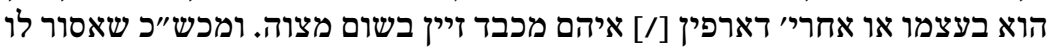

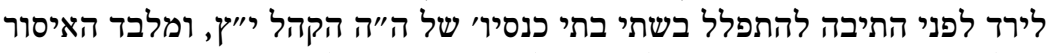

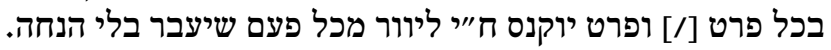

בשעת התפלה איזט אסור לשום אדם גדול או קטן נער או זקן, קילו קיין ליכט צו נען $2^{\prime \prime \prime}$

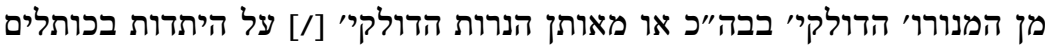

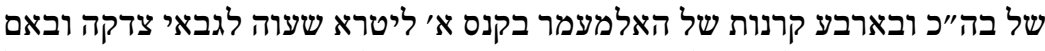

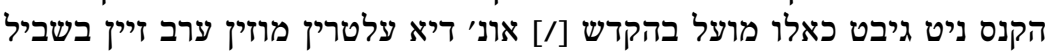

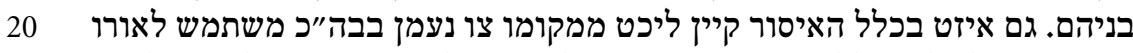

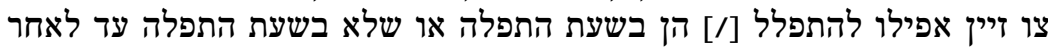

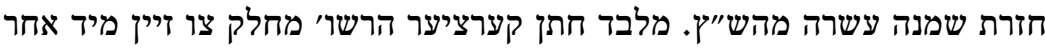

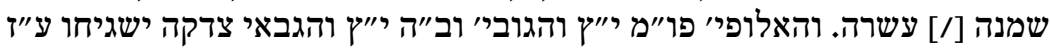

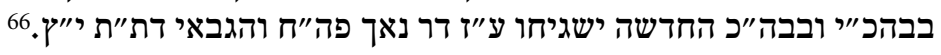

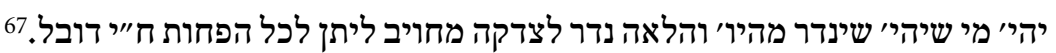

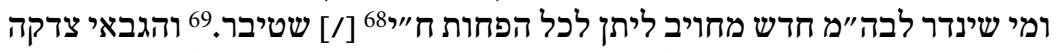

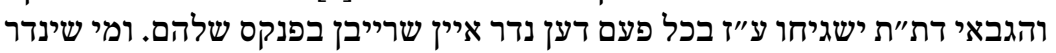

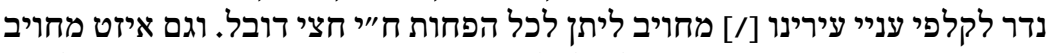

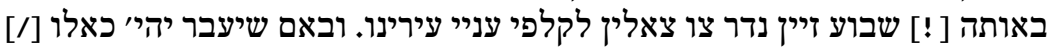
מועל בהקדש.70

65 למגדר מילתא (aram.) = Bestimmung zur Verhütung einer Gesetzesübertretung.

66 Korrespondiert mit $\$ 15$ bei Schwarzfuchs, Règlement, 32-35.

67 Kleinmünze: Ein double entspricht zwei deniers.

68 Danach gestrichen דובל.

69 Silbermünze, vor allem in Nordwestdeutschland und in den Niederlanden in Gebrauch.

70 Korrespondiert mit $\$ 18$ bei Schwarzfuchs, Règlement, $34 \mathrm{f}$. 
מהיו' והלאה אין רשאי שום אדם לעמוד סגן בעצמו רק השמש יעמוד סגן במקומן בומו, $7^{\prime \prime}$

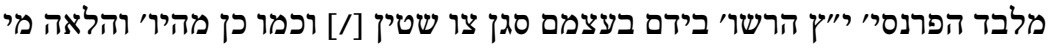

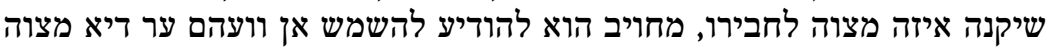

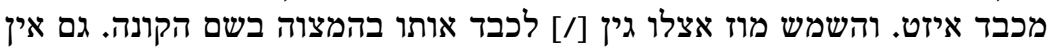

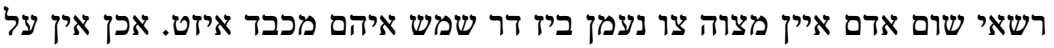

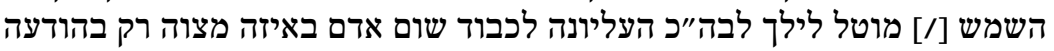

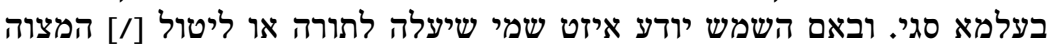

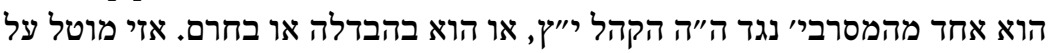

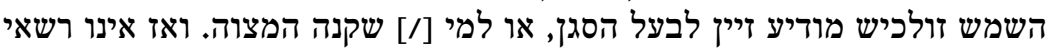

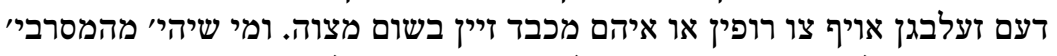

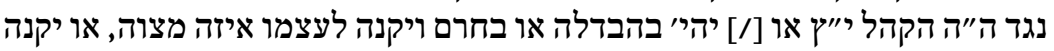

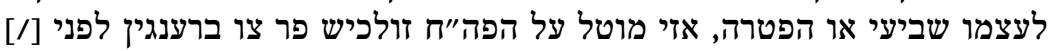

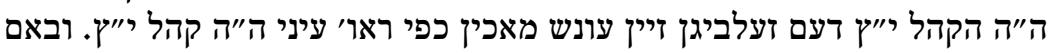

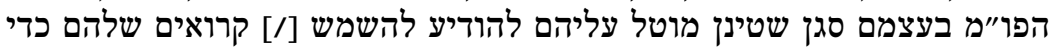

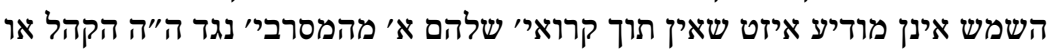

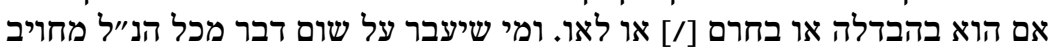

ליתן קנס שלשה ליוור מכל פעם וכאלו מועל בהקדש כל זמן שלא יתו שרן הקנס.71

מי שיקנה איזה מצוה באחת משתי בתי כנסיו' של ה"ה הקהל י"יץ, מחויב לשלם [fol. $77 \mathrm{v}$ ]

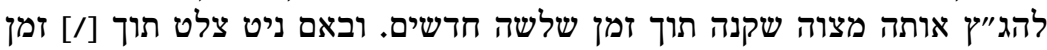

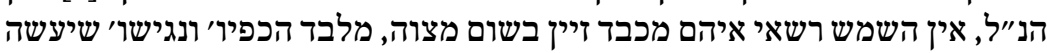

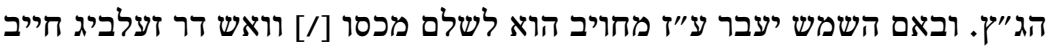
איזט בשביל אותה מצוה.

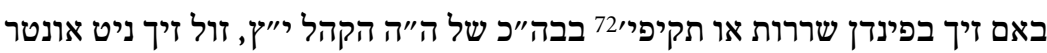

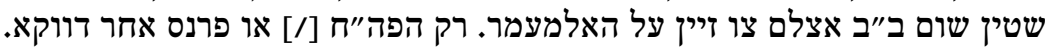
ט"ט

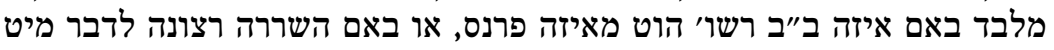

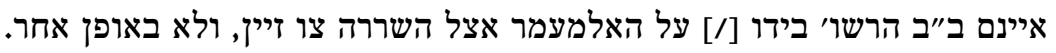

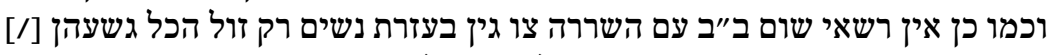

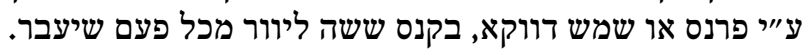

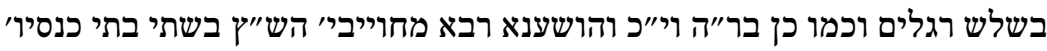
$T^{\prime \prime \prime} \quad 30$

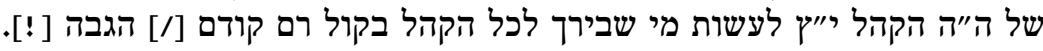

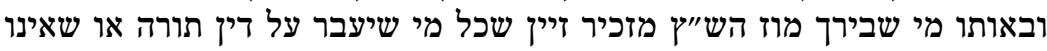

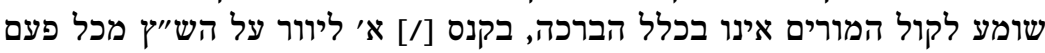

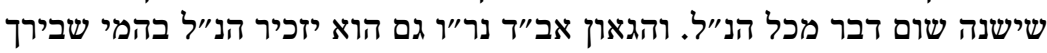
שעושה על האלמעמר בשלש [/] רגלים.

71 Korrespondiert mit $\$ 20$ bei Schwarzfuchs, Règlement, $36 \mathrm{f}$.

72 Gesetzliche Vertreter, Beamte. 


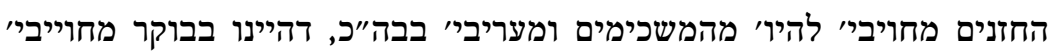

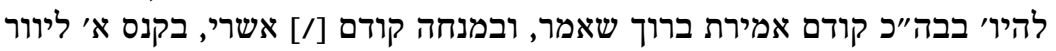

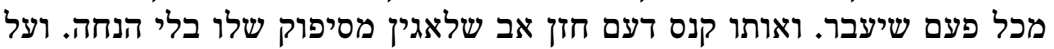

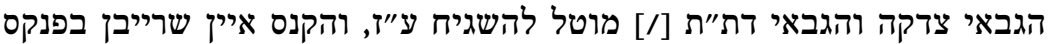

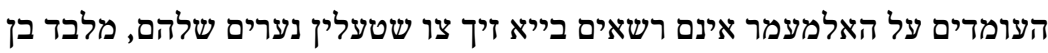
ט"

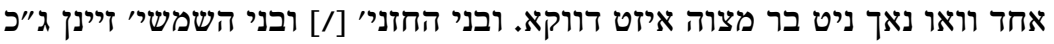

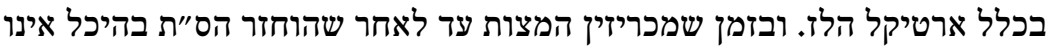

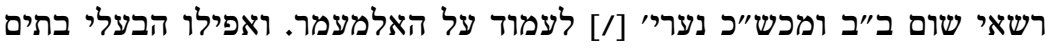

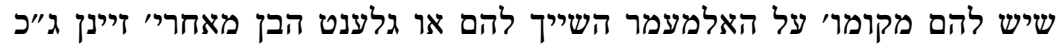

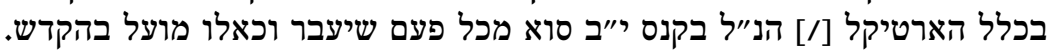

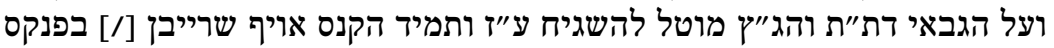

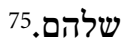

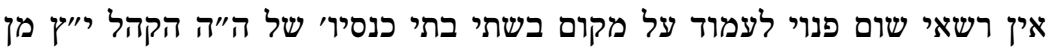
כף

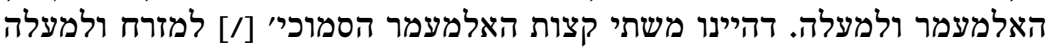

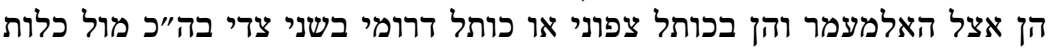

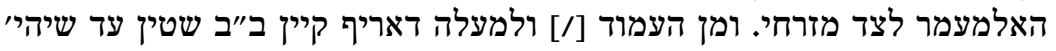

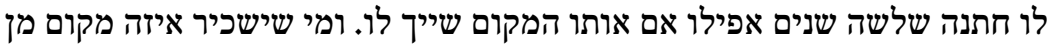

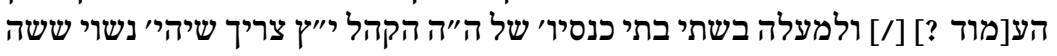
שנים דווקא. ומי שיעבר על שום דבר מכל הנ"ל מחויב ליתל כליתן [/] קנס ח"י ליוור.76

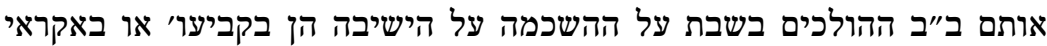
כ" כ

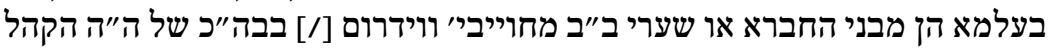

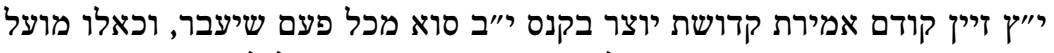

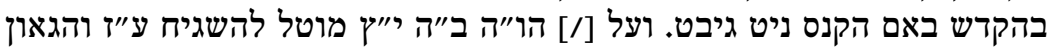

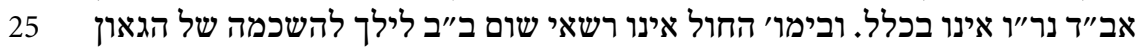

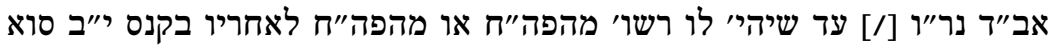

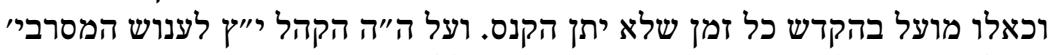

[/] ליתן קנס שלהם. אמנם הרופאים אינם בכל הכליל.

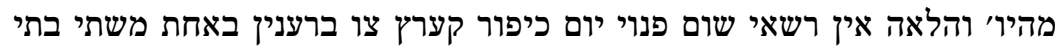

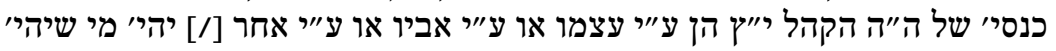

73 Absichtliche Verdrehung der Buchstaben, um die Wortbedeutung von (Leben) hervorzuheben.

74 אונס דמוכח רחמנא פטריה (aram.) = wer zur Übertretung genötigt wurde. Korrespondiert mit $\$ 13$ bei Schwarzfuchs, Règlement, $32 \mathrm{f}$.

75 Korrespondiert mit $\$ 19$ bei Schwarzfuchs, Règlement, 34-37.

76 Korrespondiert mit $\$ 16$ bei Schwarzfuchs, Règlement, $34 \mathrm{f}$. 


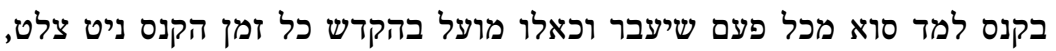

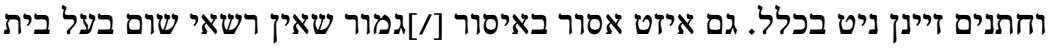

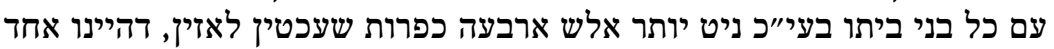

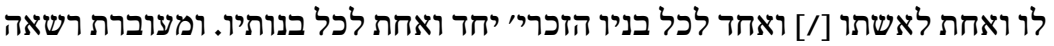
[! [וד אחד צו נעמן בשביל עוברה.

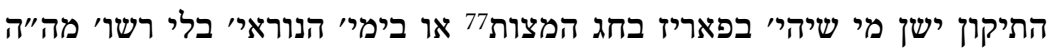

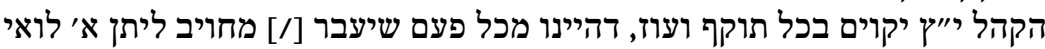

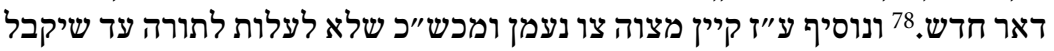

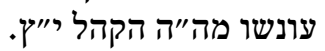

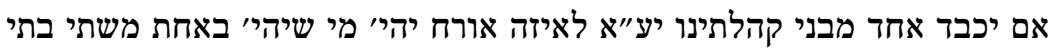

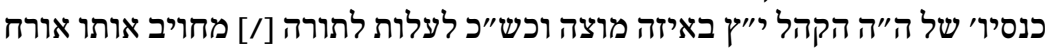

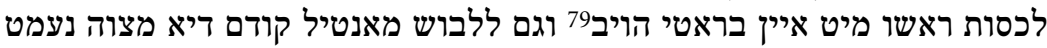

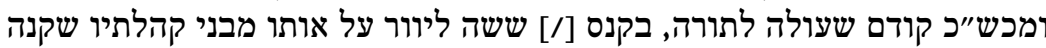
המצוה או העלי' לתורה.

השלשה הפטרו' דהיינו הפטרת חזון ויונה ומרכבה, יפטיר דווקא מי שיה שיש לו חבר כ"ה 15

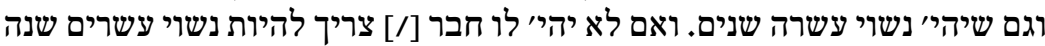
דווקא, בקנס שלשה ליוור על הקונה.80

אין רשאי שום אדם להיו' חתן תורה או חתן בראשית עד שיהיי לו חבר וגם יהיי

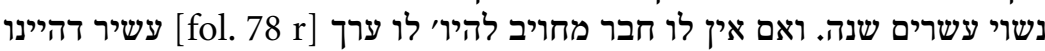

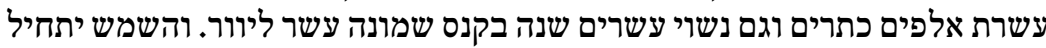

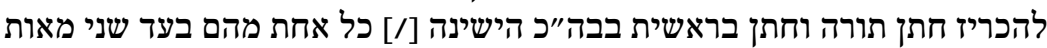

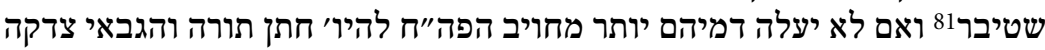

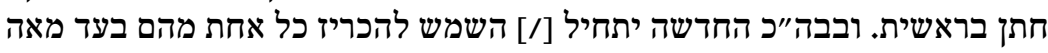

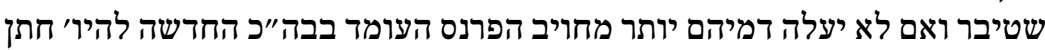

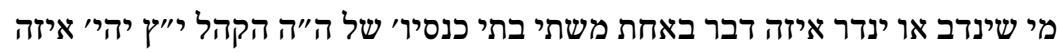

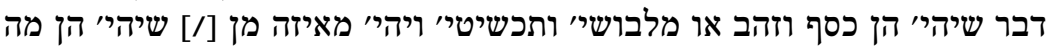

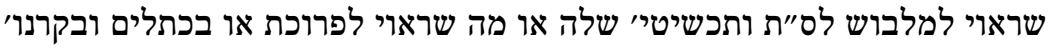

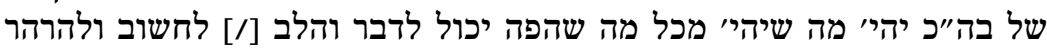

\footnotetext{
77 Pessach.

78 Neuer Louis d'Or.

79 Breite Haube, »Schabbesdeckel« (Kopfbedeckung).

80 Korrespondiert mit $\$ 22$ bei Schwarzfuchs, Règlement, 36-39.

81 Davor gestrichen: ליוור.

82 Korrespondiert mit $\$ 23$ bei Schwarzfuchs, Règlement, 38 f.
} 


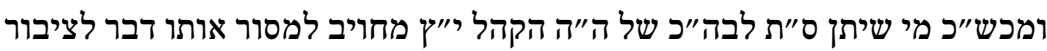

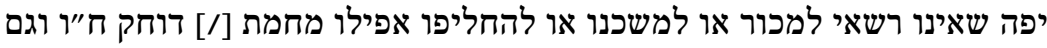

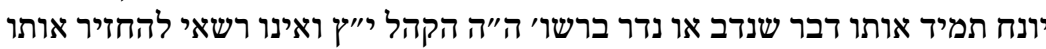

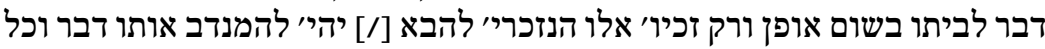

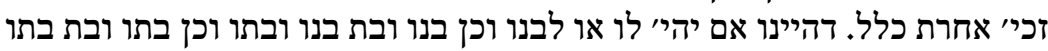

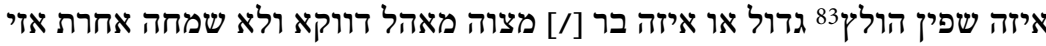

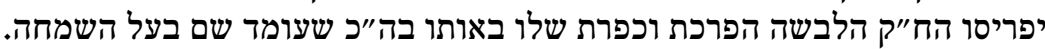

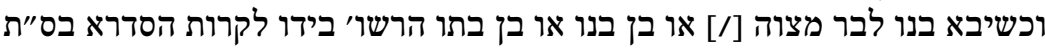

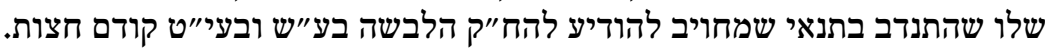

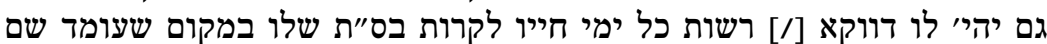

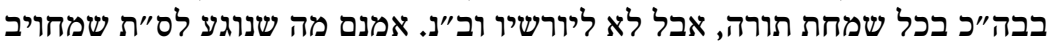

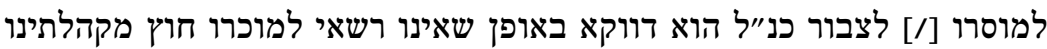

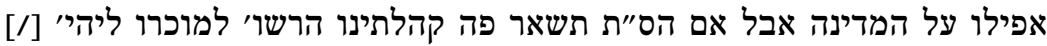

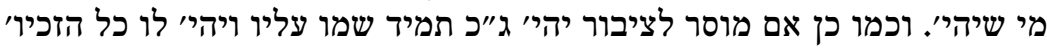
הנזכרי' למעלה אצל מקדיש שום מלבוש.84

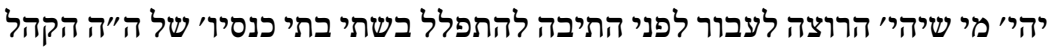

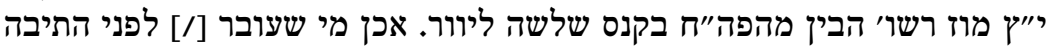

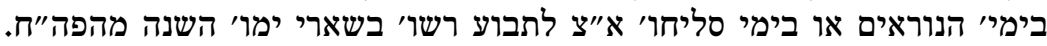

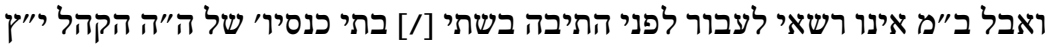
עד שיהי' לו רשו' מכל הקהל י'י"ץ.

בשלש רגלים מכש״כ בימים הנוראי״ אין רשאי שום פנוי עולה לתורה צו זיין בשתי כ"ט

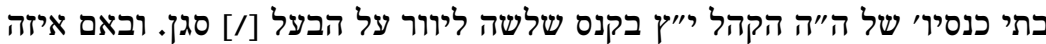

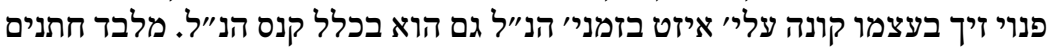

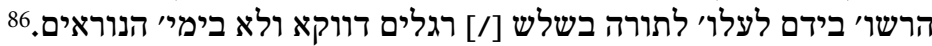

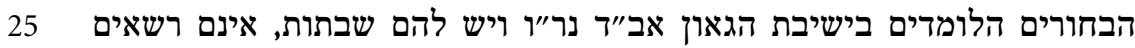

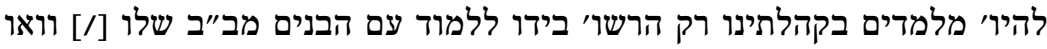

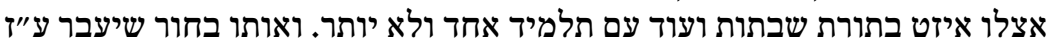

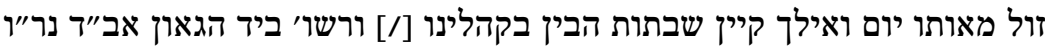

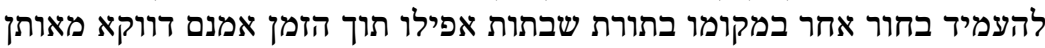

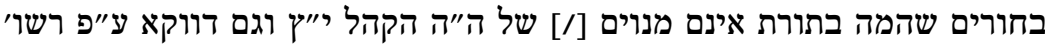

83 Feier der Verlobten kurz vor der Hochzeit.

84 Korrespondiert mit $\$ 24$ bei Schwarzfuchs, Règlement, 38-41.

85 Korrespondiert mit $\$ 14$ bei Schwarzfuchs, Règlement, $32 \mathrm{f}$.

86 Korrespondiert mit $\$ 21$ bei Schwarzfuchs, Règlement, $36 \mathrm{f}$.

87 Dieser Artikel wurde später noch einmal bekräftigt; siehe Schwarzfuchs, Règlement, 26-29, $\$ 4$. 


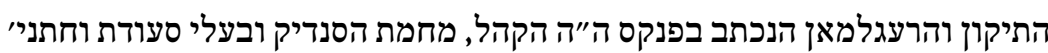
ל ל

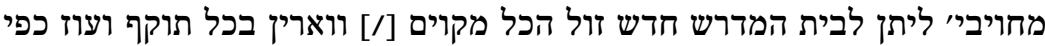
שנכתב שם, בלי שינוי.

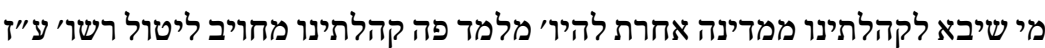
ל"ב

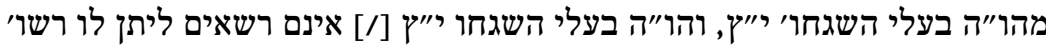

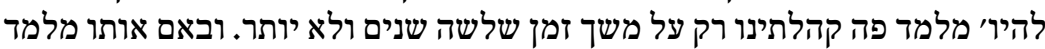

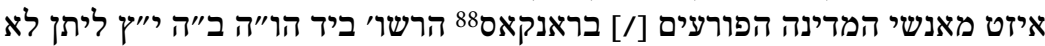

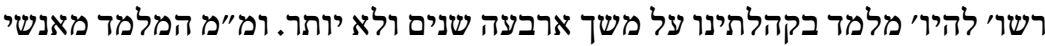

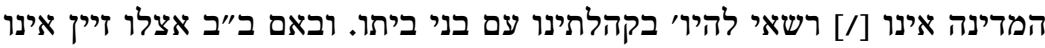

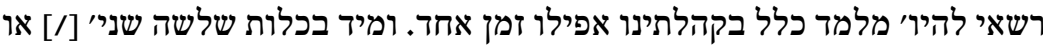

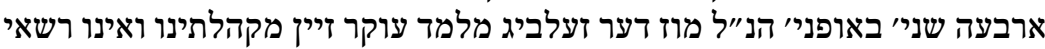

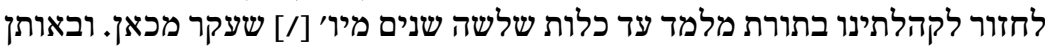

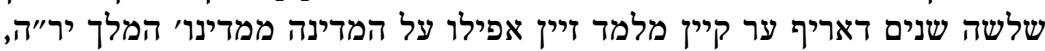

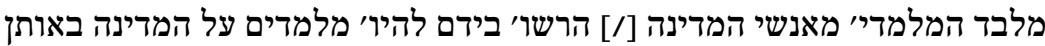

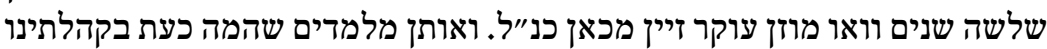

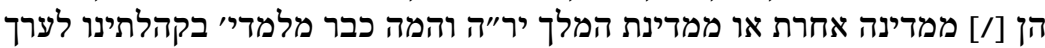

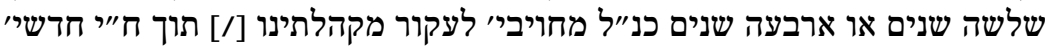

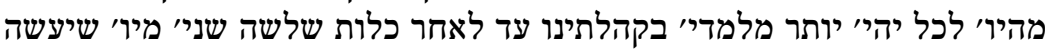
עקירה מכאן כנ"ל.

התיקון והרעגלמאן הנוגע להקלפו' של עניי עירינו יקוים בכל תוקף ועוז כאשר 20

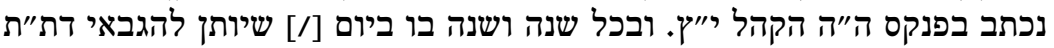

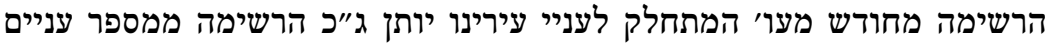

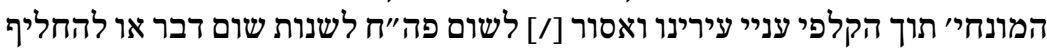

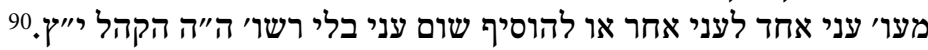

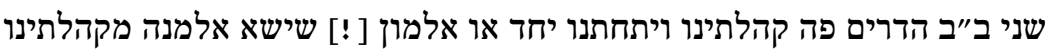

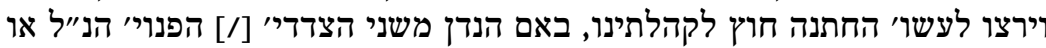

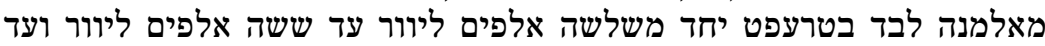

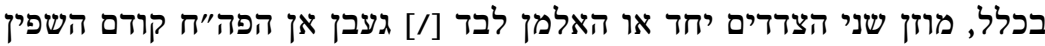

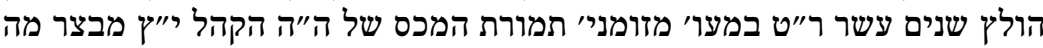

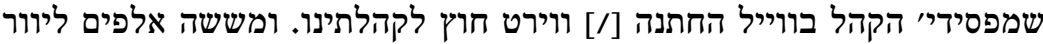

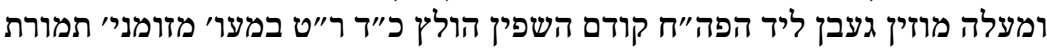

88 Steuer, die an die adlige Familie Brancas entrichtet wurde und um deren Abschaffung sich die Metzer Gemeinde lange Zeit bemühte; siehe Samuel Kerner, Les démarches des envoyés de la communauté juive de Metz à Paris et à Versailles relatives à la »taxe Brancas«, in: Annales de l'Est 26 (1974), 217-264.

89 Korrespondiert mit $\$ 6$ bei Schwarzfuchs, Règlement, $28 \mathrm{f}$.

90 Korrespondiert mit $\$ 17$ bei Schwarzfuchs, Règlement, $34 \mathrm{f}$. 


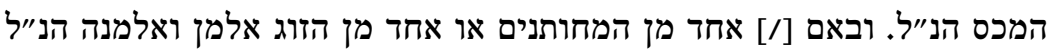

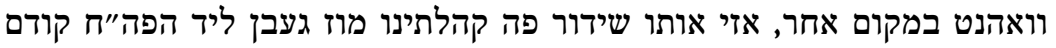

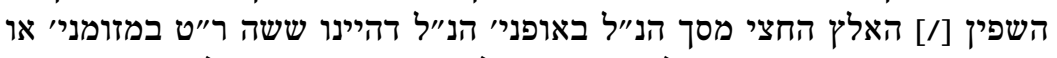

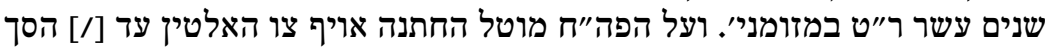

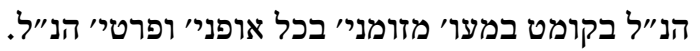

[fol. $78 \mathrm{v}$ ]

ל"ה

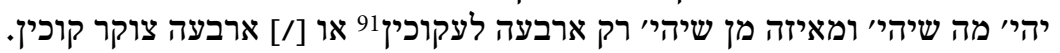

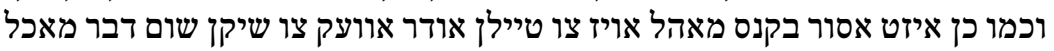

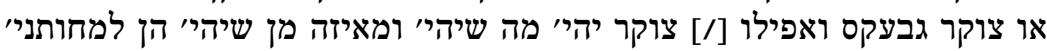

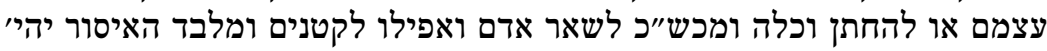

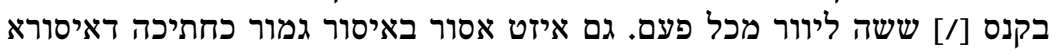

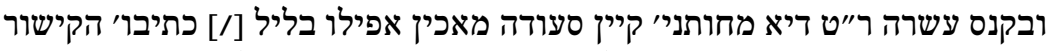

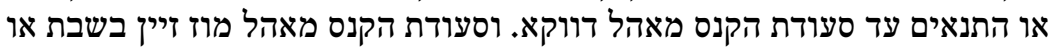

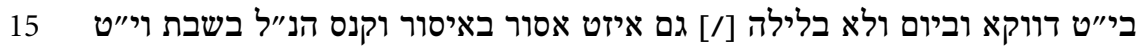

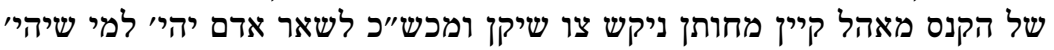

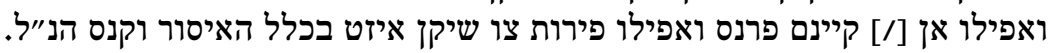

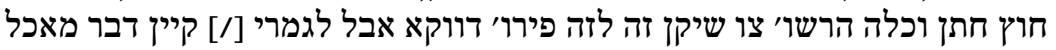

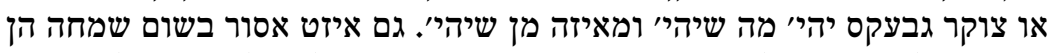

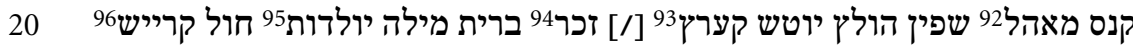

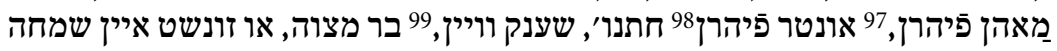

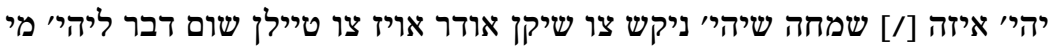

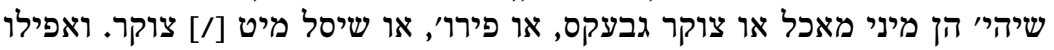

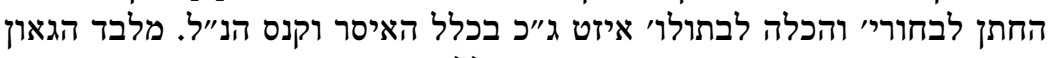

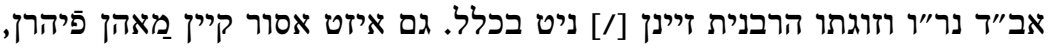

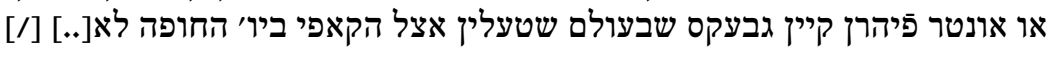

91 Lebkuchen.

92 Verlobungsmahl.

93 Herstellen der Kerzen für die Beschneidung; siehe auch die Statuten aus Fürth 1770, $\$ 490$.

94 Symbolische Begrüßung eines männlichen Neugeborenen in der Synagoge am ersten Freitagabend nach der Geburt.

95 Feier bei dem ersten Synagogenbesuch einer Wöchnerin am Schabbat nach der Geburt eines Jungen.

96 Namensgebungszeremonie.

97 Das Geleiten der Braut bis zur Synagoge, wo die Hochzeit stattfindet; siehe Samuel Kerner, Le règlement de la communauté juive de Metz de 1769 1769, in: Annales de l'Est 24 (1972), 201-253, hier: 218, Anm. 3

98 Das Geleiten der Braut zum Traubaldachin; siehe ebd., Anm. 4.

99 Schabbat nach der Hochzeit. 
לאחר יציאת בה"כ שחרית רק קאפי או שאקעלאדאן100 ולא שום דבר אחר כלל גור

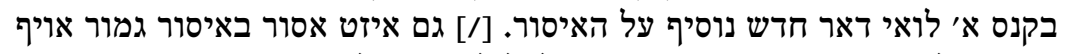

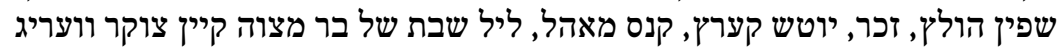

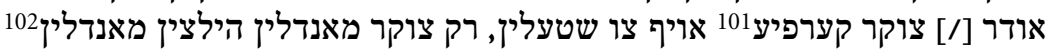

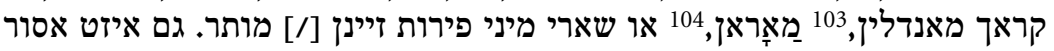

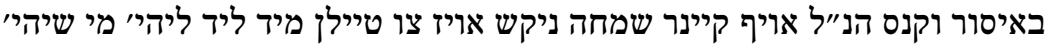

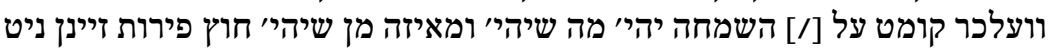

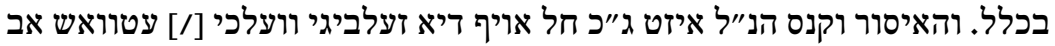

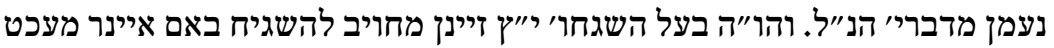

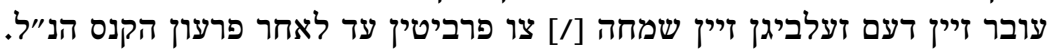

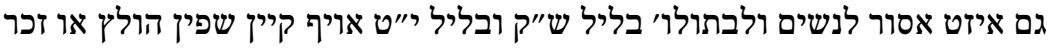

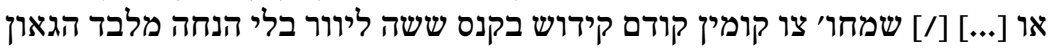
אב"ד נר"ו וזוגתו הרבנית זיינן ניט בכלל איסודם בקור וקנס הנ"ל.

בכל החתנו' איזט אסור בחתיכא דאיסורא ובקנס ששה ליוור קיין סעודה צו מאכין

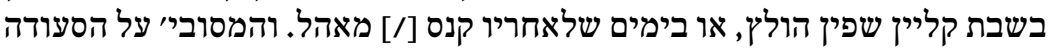

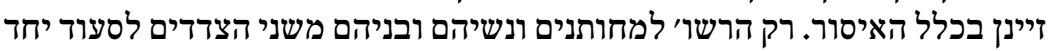

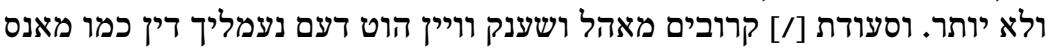

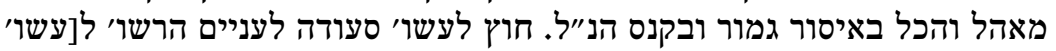

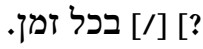

בליל וואך נאכט קודם הברית מילה אסור על הבעל ברית ועל המסוביי ניט יותר

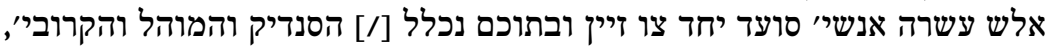

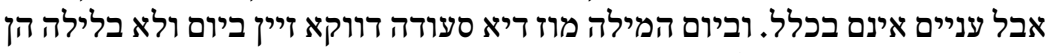

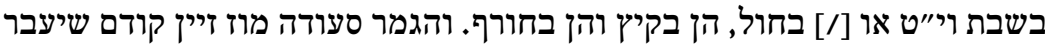

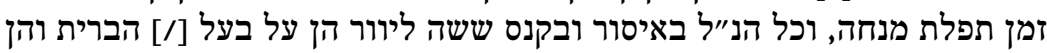
על המסוביי, מלבד בי"ט התענית היעי באורה הסעודה בלילה. ל ל 15

20

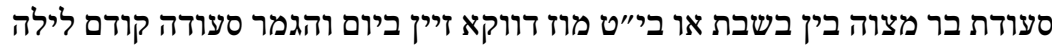

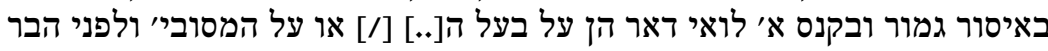

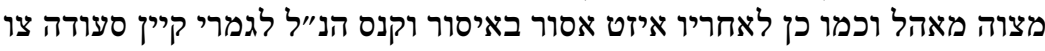

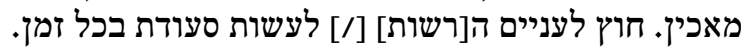

יעדר חתנה וואו הנדוניי משני צדדים בלויפט עד ששה אלפים ליפ ליוור ולא עד בכלל, 30 דארפין ניט יותר אלש שלשה לצנים האלטין [/] מדויפטים וכמו כן ניט יותר אלש שלשה בלורל

100 Trinkschokolade.

101 Eine Art Zuckergebäck.

102 Holzmandeln?

103 Gebrannte Mandeln?

104 Maronen. 


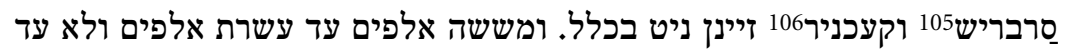

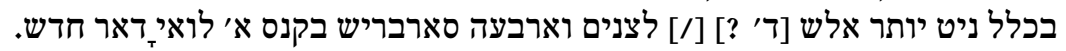

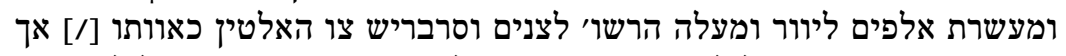

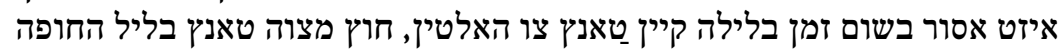

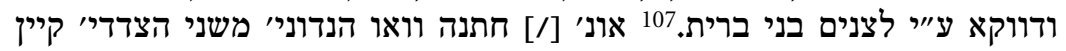
עשרת אלפים בטרעפט איזט אסור בעלי מלחמו' צו האלטין אויף דער חתנה.

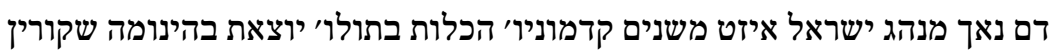
מו"ם

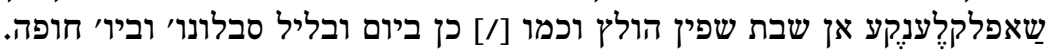

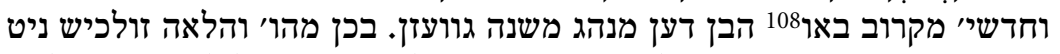

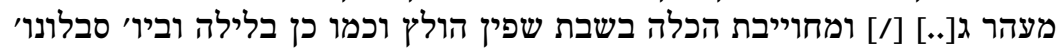

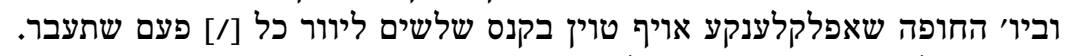

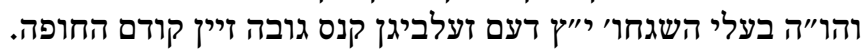

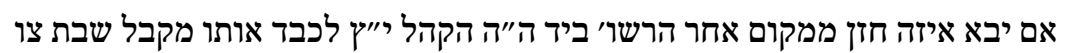

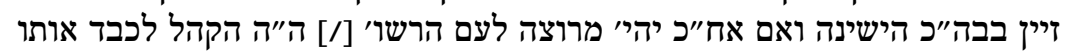

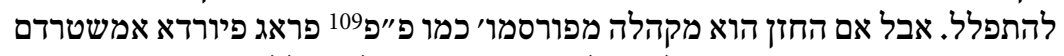

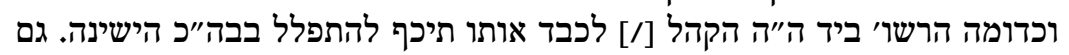

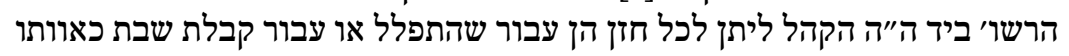
[/] אמנם החזן לא יעכב עצמו תוך קהלתינו רוז רק ששה שבועו' ולא יותר.

באם מן מעכט ערפארין אלש בחורים ובתולו' הבין עובר גוועזן על איסוסור יחוד

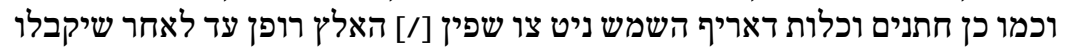

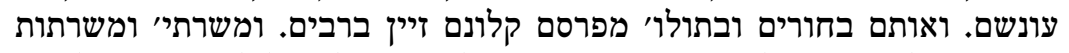

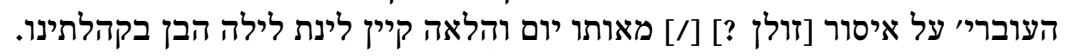

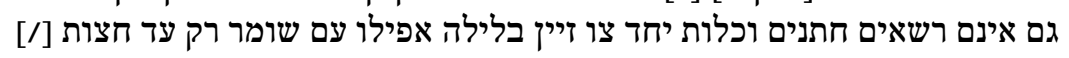
ואם יעברו ע"ז יפרסמו אותם ברבים.

מ״"ג

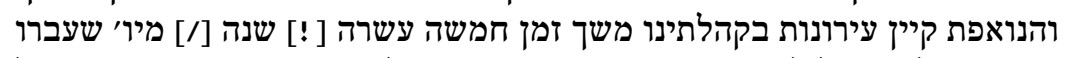

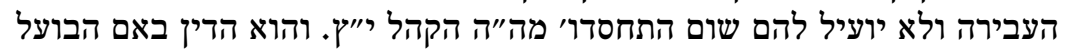

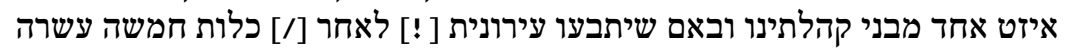

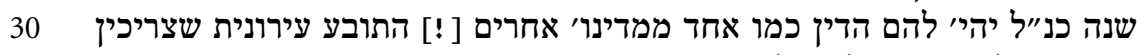

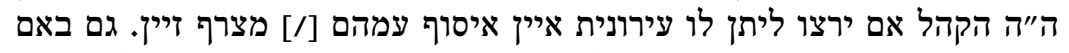

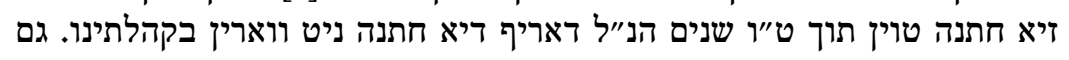

105 Servierer.

106 Köche.

107 »Beschnittene«, also jüdische Gaukler.

108 Shulhan Arukh, Orah Hayim, 150, 9.

109 Frankfurt a. M. 


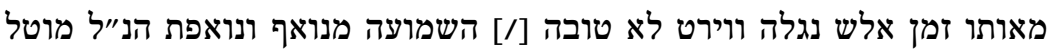

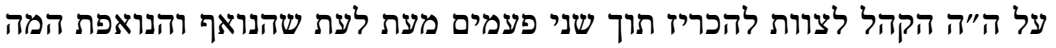

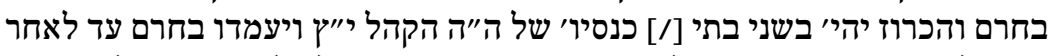

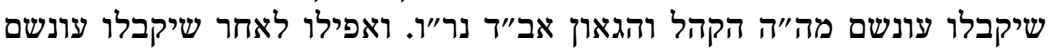

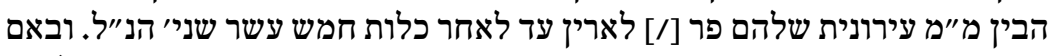

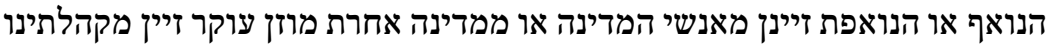

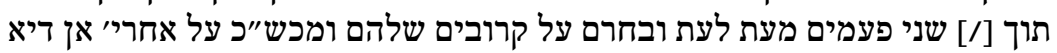
לינת לילה יותר צו געבן וגם מעת בקנס מארם ליוור.

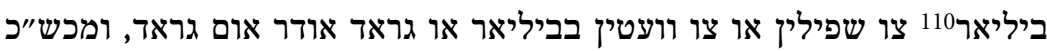

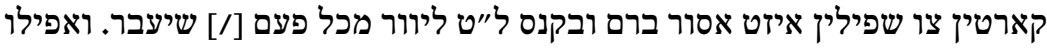
מו"ד

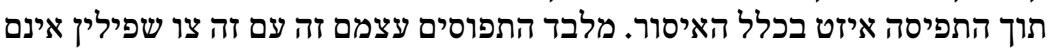

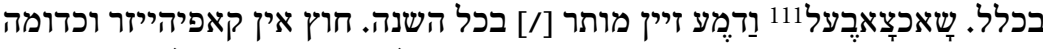

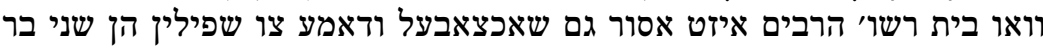

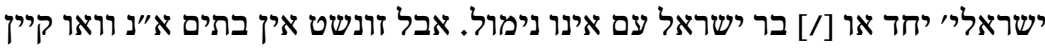

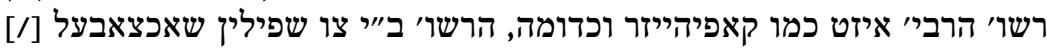

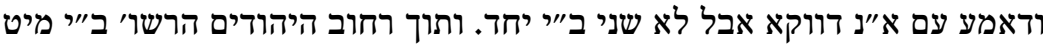

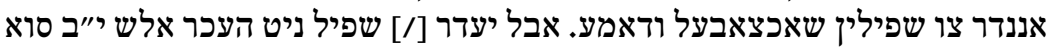

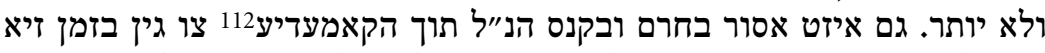

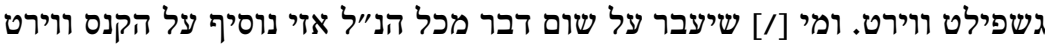

$$
\text { מן מפרסם קלונו ברבים זיין. }
$$

אם יבא איזה אורח איש מכובד בקהלתינו או חתן או כלה ממדינת המלך ירוּור

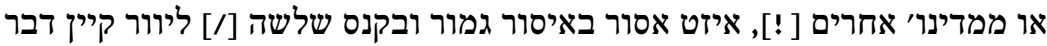

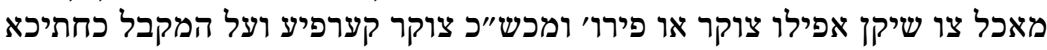

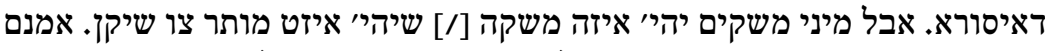

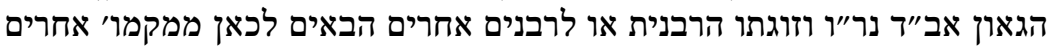

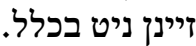

אסור לשום נער לעסוק במו״ימ תוך המקום פה עד לאחר שיהי' בן ט"ו שנה דווקא.

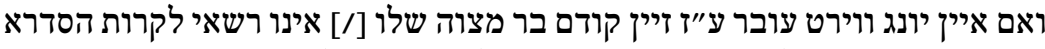

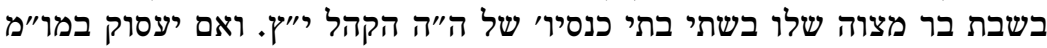

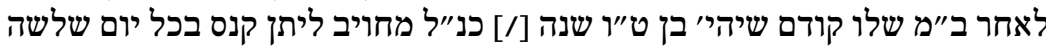

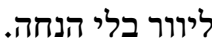

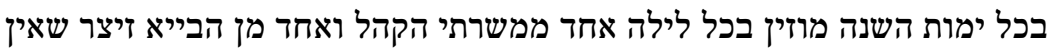
מו"ז להם חזקת עירונית בקהלתינו שמל למירה האלר ממין בבית [/] המיוחד לכך, וגם להכריז זיצריז
110 Billard.
111 Schach.
112 Von frz. comédie, gemeint ist hier wohl das Theater. 


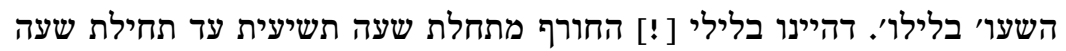

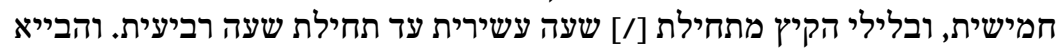

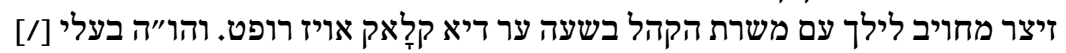

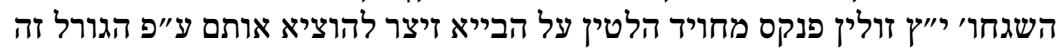

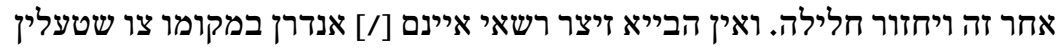
אם לא ע״יי אונס דמוכח.

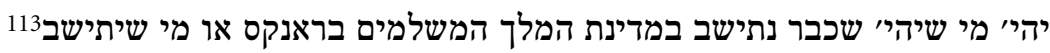

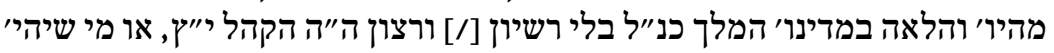

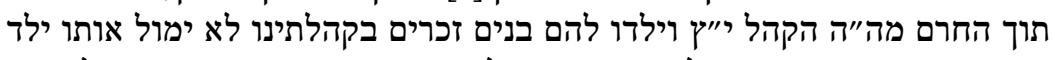

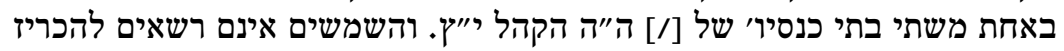

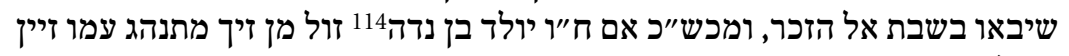
כנ"ל.

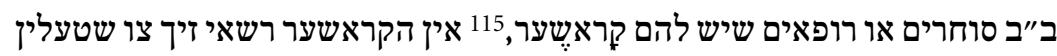

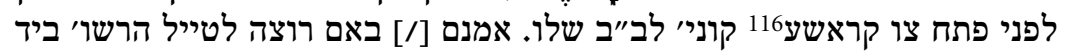

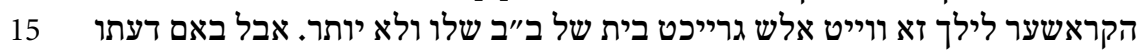

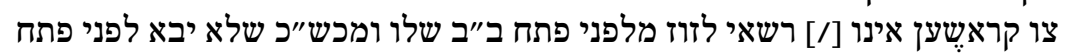

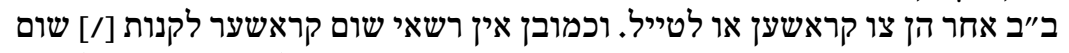

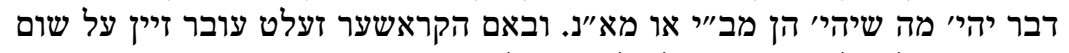

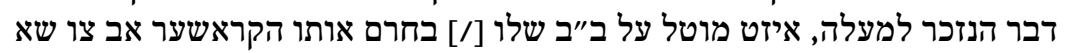

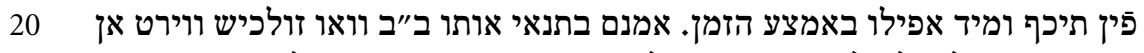

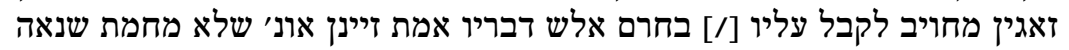

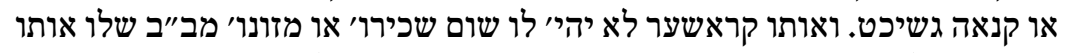

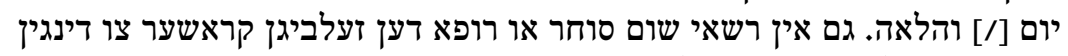

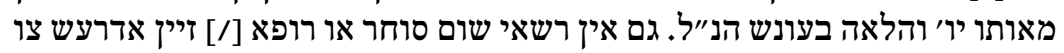

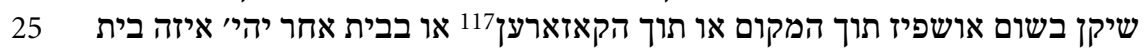

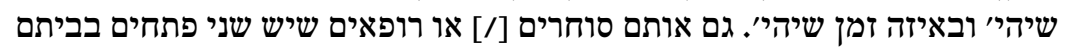

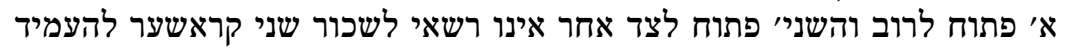

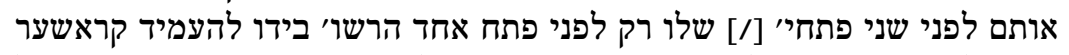

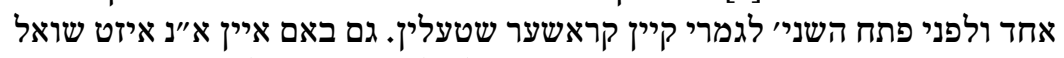

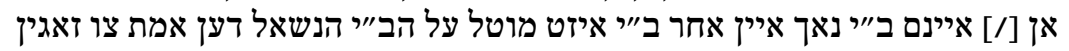

113 Davor ein Wort durch Streichung unleserlich.

114 Gemeint ist ein während der »unreinen« Menstruationszeit der Frau gezeugtes Kind. Obwohl eine solche Zeugung biologisch nahezu unmöglich ist, hing man dem Glauben an, dass solche Kinder irgendein auffälliges Merkmal aufweisen müssten, da sie zu einer Zeit gezeugt wurden, in der Sexualverkehr den Ehepartnern verboten ist.

115 Ausrufer.

116 Davor gestrichen קומן.

117 Kaserne. 


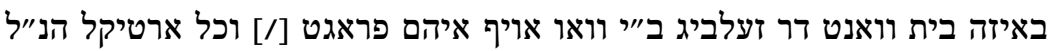

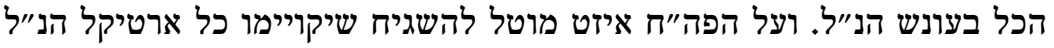

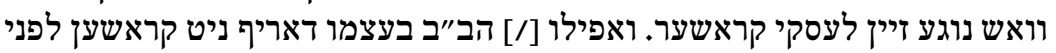

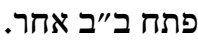

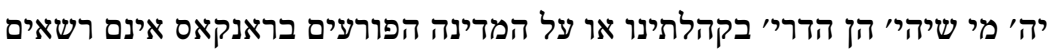

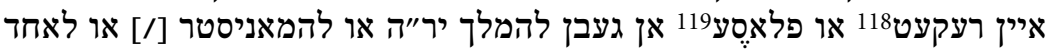
מיעציו זונדר רשו' וידיעת ה"ה הקהל י"ו"ץ בקנס מאל מאה ליוור בלי הנחה.

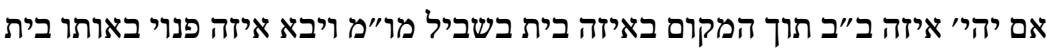

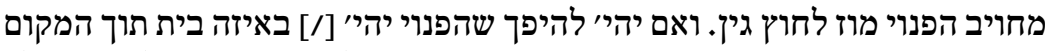

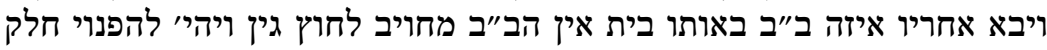

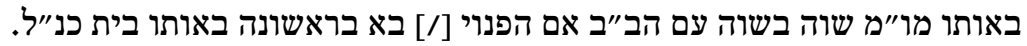

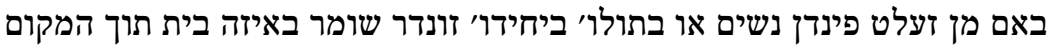

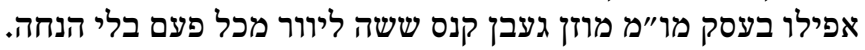

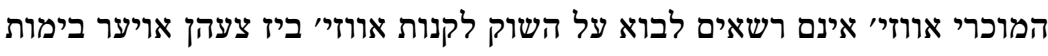

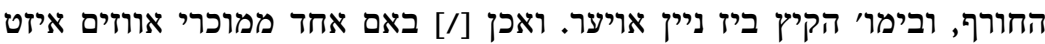

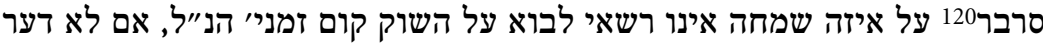

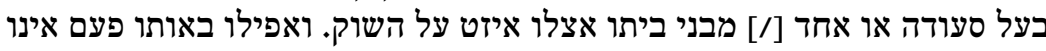

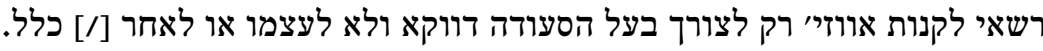

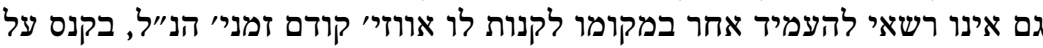

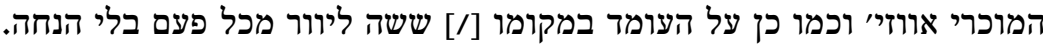

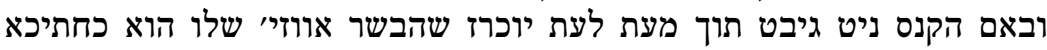

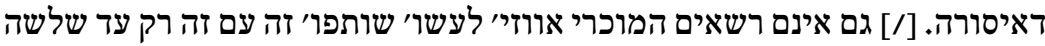
יחד ולא יותר הכל בקנס ובכפי' הנ"ל.

אסור לשום אדם לקנות דגים הן מעט או הרבה יחד יהי' איזה דגיי' שיהי' למכור 25

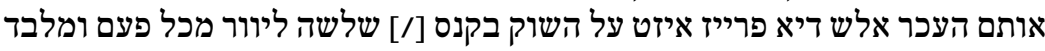

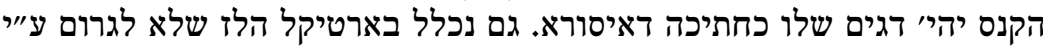
דגים שלו מיקר ה[מחיר ? שלו כתחיכה דאיסורא.

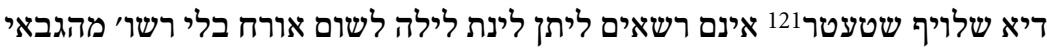
נ"ה

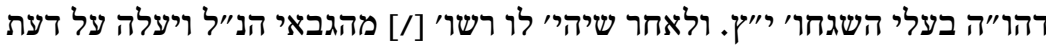
איזה אורח להתעכב בקהלתינו איזה זמן איזיז אין השלויף שטעטר רשאי אותו אורח

118 Von frz. requête $=$ Gesuch .

119 Von frz. placet $=$ Bittschrift.

120 Servierer.

121 Herbergsleute. 


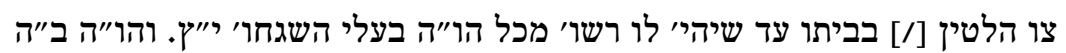

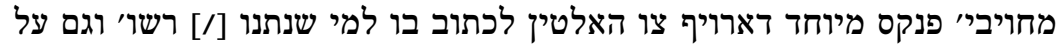
אותו זמן שנתנו לו רשו'.

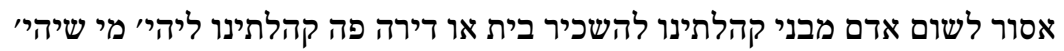
נ"נ

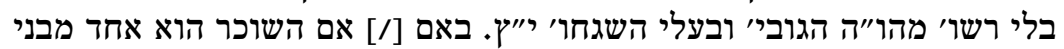

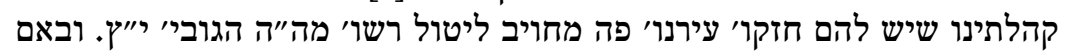

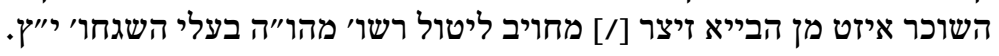

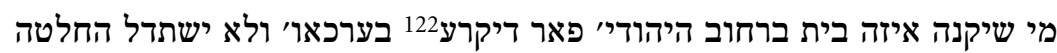

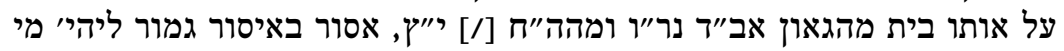

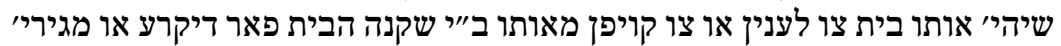

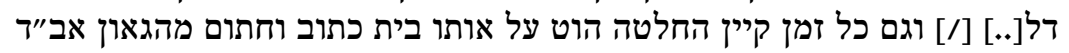

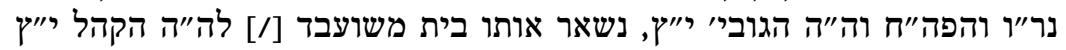

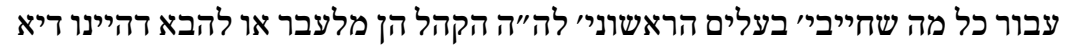

זעלביגה בעלים וואו בית שלהם איזט [/] נמכר גווארין בעריה מלכאו' פאר דיקריע.

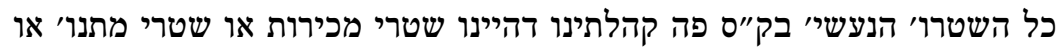
נ" ני

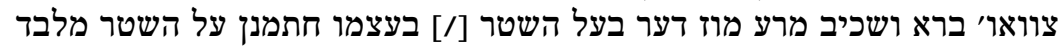

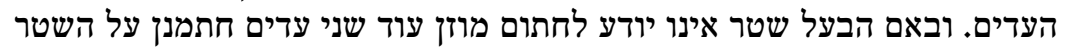

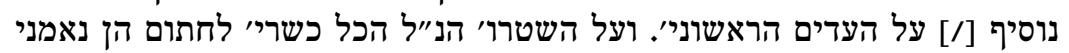

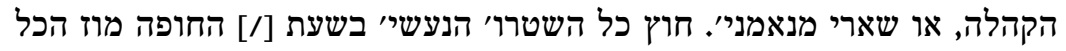

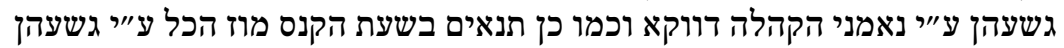

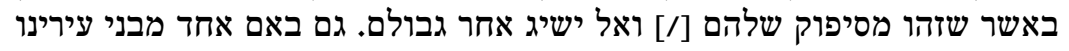

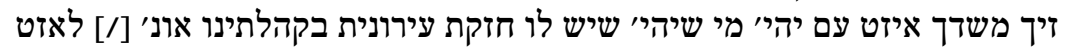

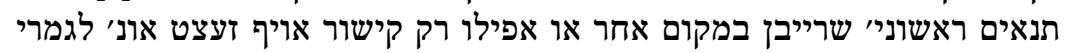

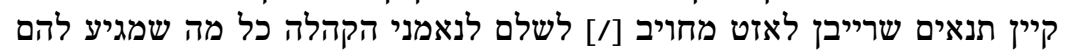

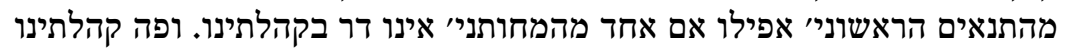

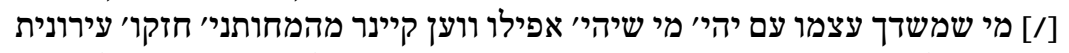

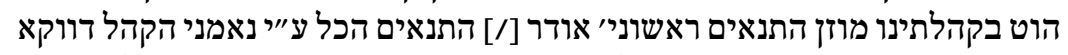

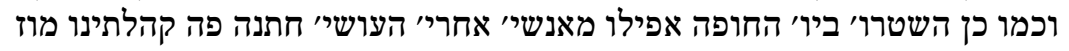

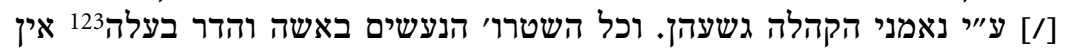

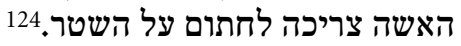

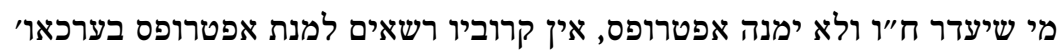
נ"ט

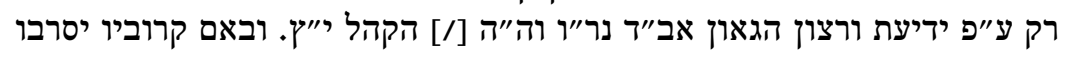

122 Par décret $=$ auf Anordnung.

123 Ein Vertrag, der zuerst mit der Frau abgeschlossen und dann von ihrem Mann bestätigt wurde.

124 Korrespondiert mit $\$ 7$ bei Schwarzfuchs, Règlement, $28 \mathrm{f}$. 
לבוא לפני ה"ה הקהל והגאון אב"ד נר"ו, או ווירן ממנה אפטרופס זיין ניון נגד רצון

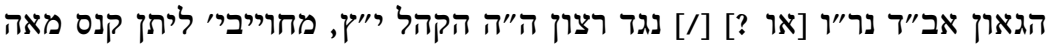

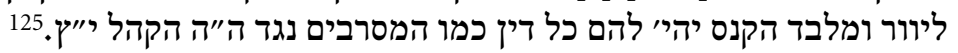

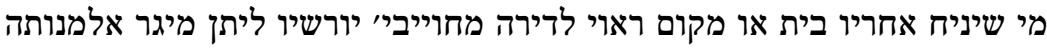
סמ"ך

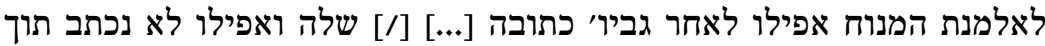

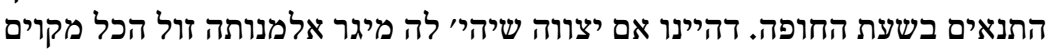

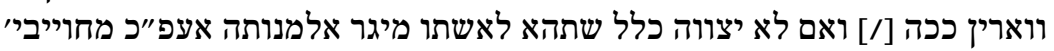

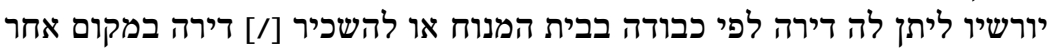

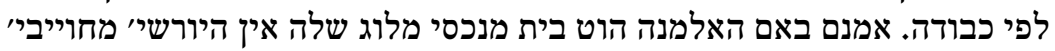

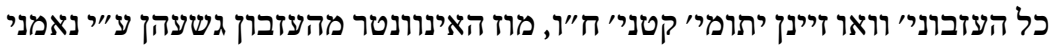
ס

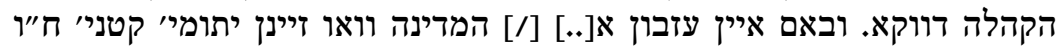

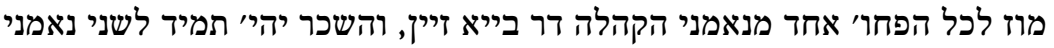

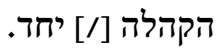

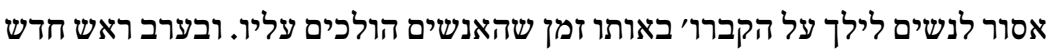
ס"ס

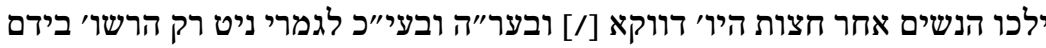

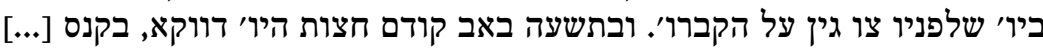

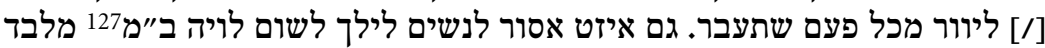

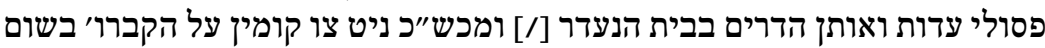

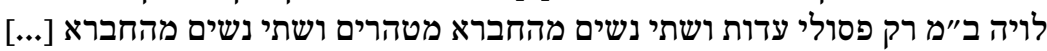

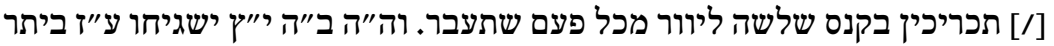
שאת כי חמירא סכנתא מאיסורא. 128 [fol. $80 \mathrm{r}$ ]

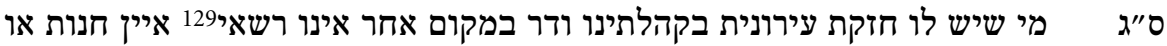

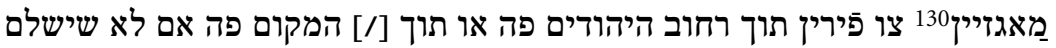

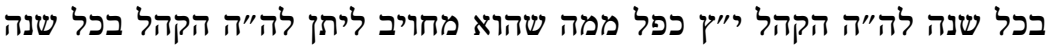

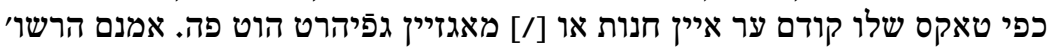

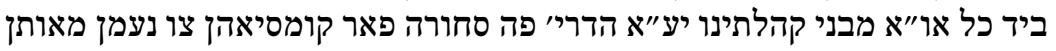

125 Korrespondiert mit $\$ 9$ bei Schwarzfuchs, Règlement, $30 \mathrm{f}$.

126 Wohnrecht für eine Witwe. Der Paragraph korrespondiert mit $\$ 10$ bei Schwarzfuchs, Règlement, $30 \mathrm{f}$.

בר מנין = לא עלינו 127.

128 Mischna Hullin, 10,1; in der Bedeutung, dass die die Gesundheit betreffenden Gebote bedeutender sind, als die, die den Geist betreffen; also der Friedhofsbesuch aus medizinisch-hygienischen Gründen vermieden werden soll.

129 Danach ein Wort nach Streichung unleserlich.

130 Von frz. magasin $=$ Laden. 
שאינם [/] דרים כאן ומי שנתן הסחורה פאר קומסיאהן א"צ ליתן כלום עבור

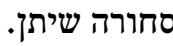

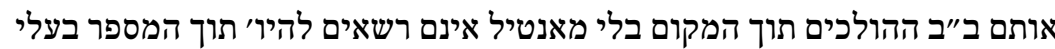

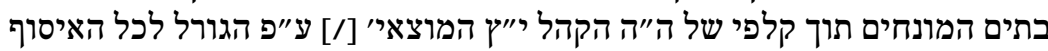

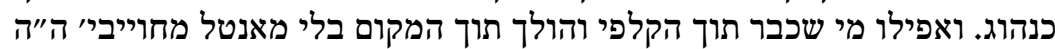

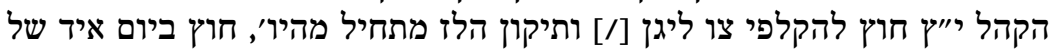

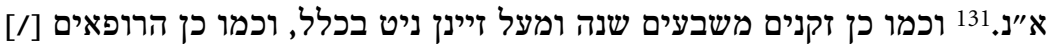
ומוכרי בהמו' וסוסים אינם בכלל.

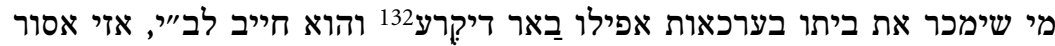
ה"ס

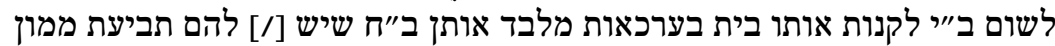

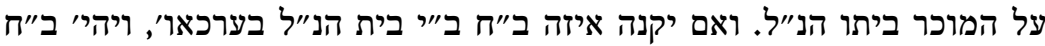

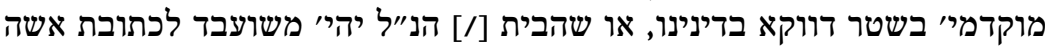

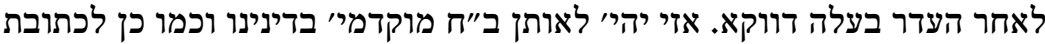

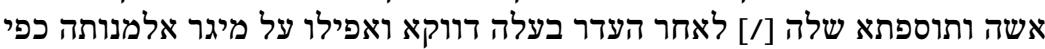

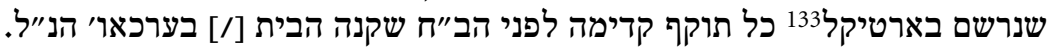

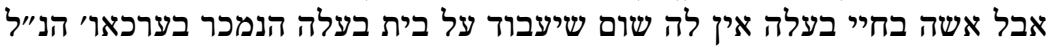

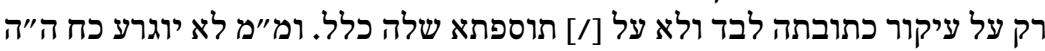

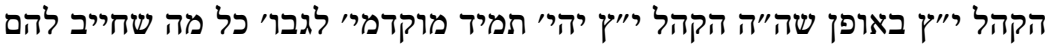

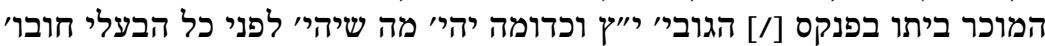

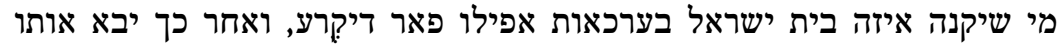

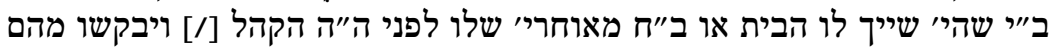

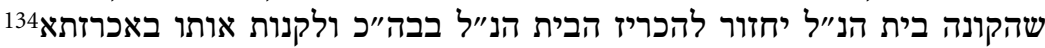

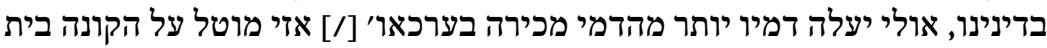

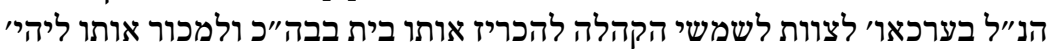

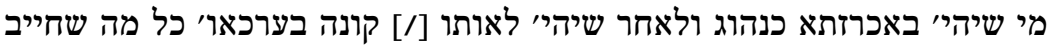

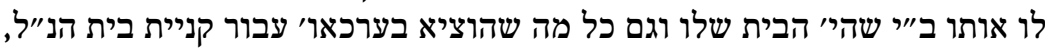

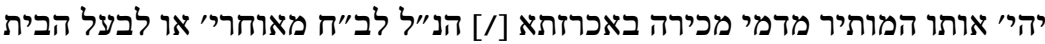

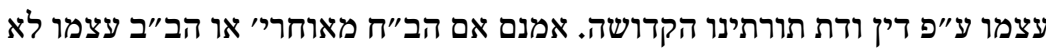

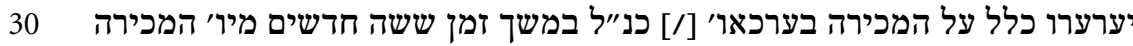

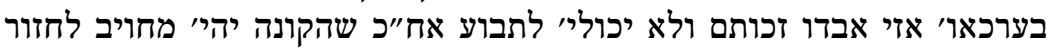

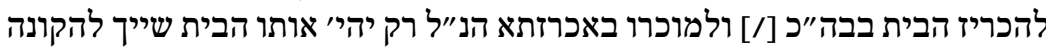

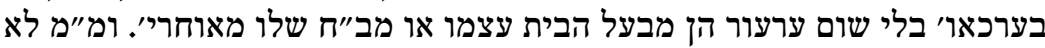

131 Christlicher Festtag.

132 Par décret $=$ auf Anordnung.

133 Danach Lakune, die Paragraphennummer fehlt; gemeint ist wohl $\$ 60$.

באכרזתא 134 (aram.) = öffentliche Versteigerung. 
יוגרע [/] כח ה"ה הקהל י"ץ שיהיי הם מוקדמי' על מה שחייב להם אותות שיתו שהי'

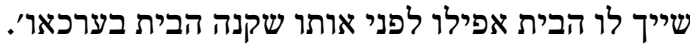

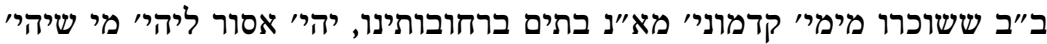
ס

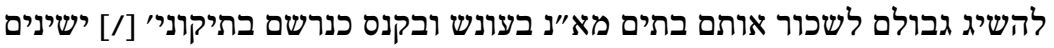

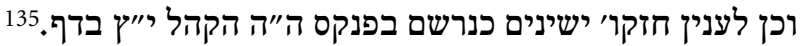

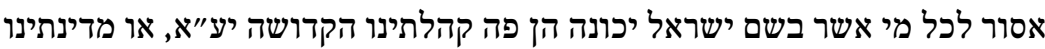
$\pi^{\prime \prime}$

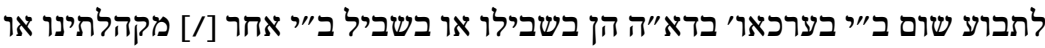

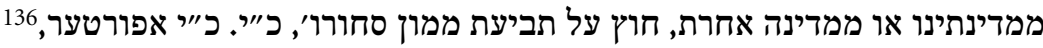

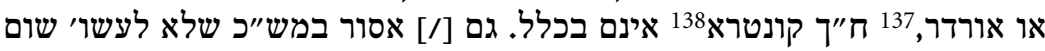

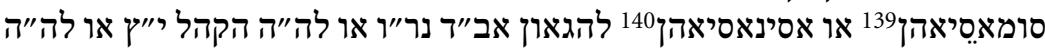

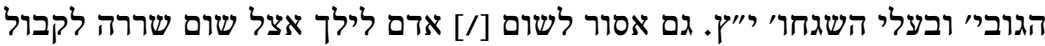

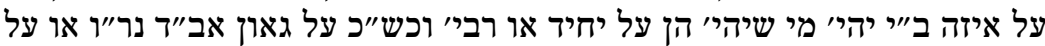

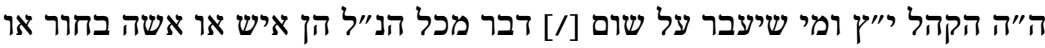

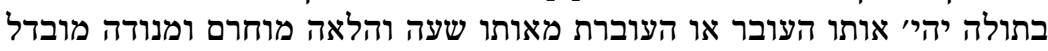

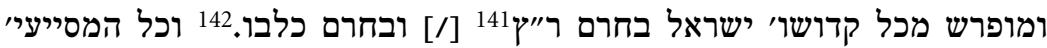

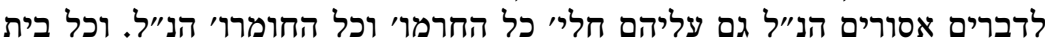

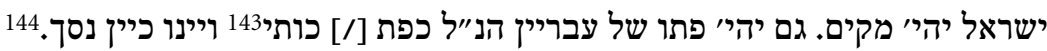

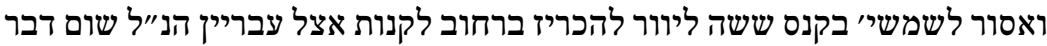

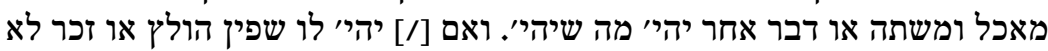

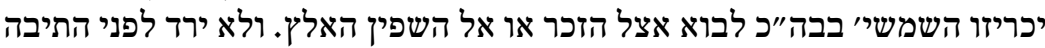

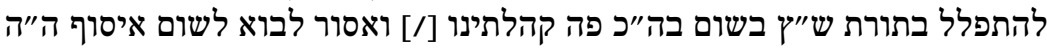

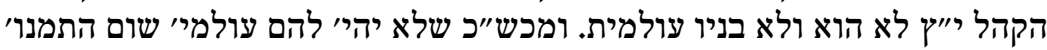

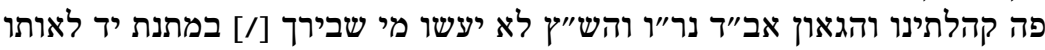

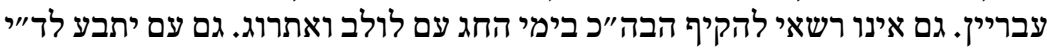

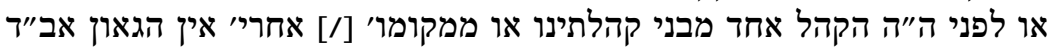

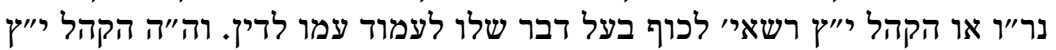

135 Die Seitenzahl fehlt.

136 Von frz. porteur = Träger, Überbringer. In Verbindung mit כתב יד wohl in der Bedeutung von »Wechsel«.

137 Orderpapier.

138 Von frz. contrat $=$ Vertrag.

139 Von frz. sommation = Mahnung.

140 Von frz. assignation $=$ Vorladung.

141 Hinter der Ligatur verbirgt sich sehr wahrscheinlich der Name des Rabbiners, auf den das Verbot zurückgeht. Die Auflösung des Namenskürzels ist unklar.

142 Sefer Kolbo, eine anonyme halachische Abhandlung aus dem Mittelalter.

143 Brot von Nichtjuden = nicht-koscheres Brot.

144 Nicht-koscherer Wein. 


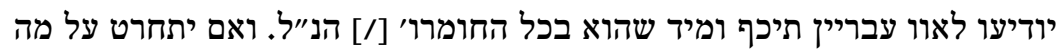

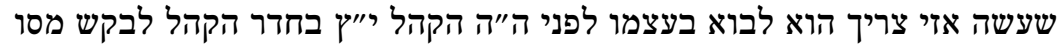

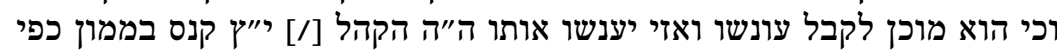

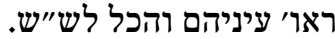

התיקון והרעגלמאן שנעשה ביו־145 על אנשי המדינה מחמת השגת גבול לבני 0

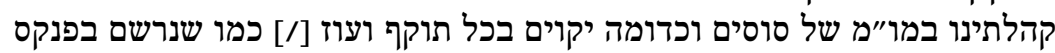

$$
\text { ה"ה הקהל י"יץ בדף. } 146
$$

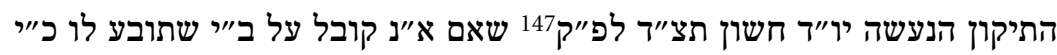

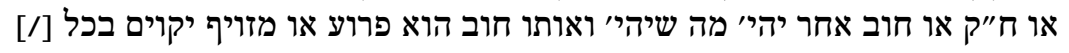

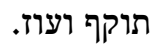

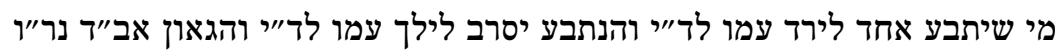
ע"

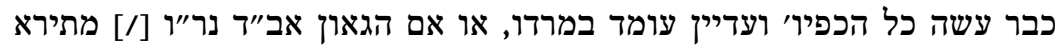

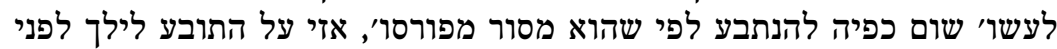

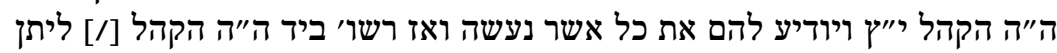

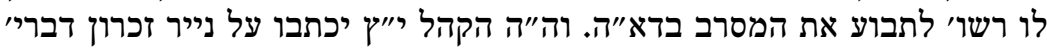

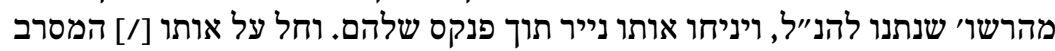

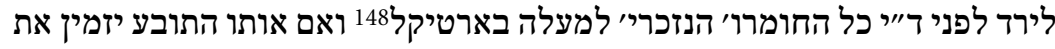

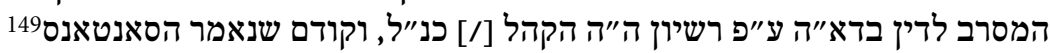

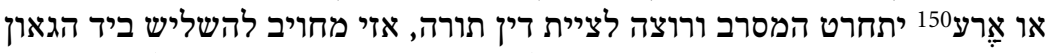

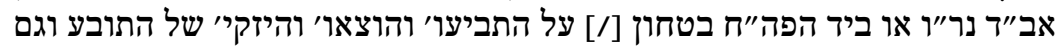

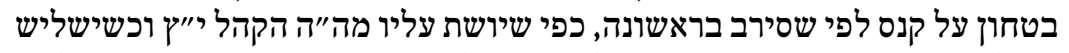

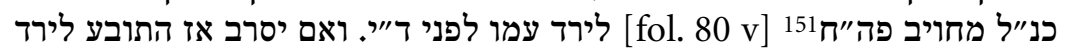
עמו לפני ד"י, אזי יהי' חליי על התובע כל החומרו' הנרשמירי בארטיקל.

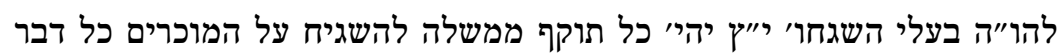

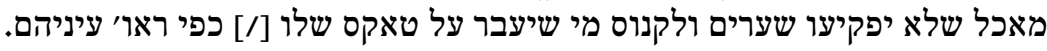

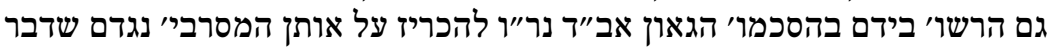

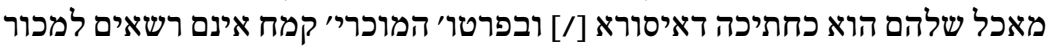

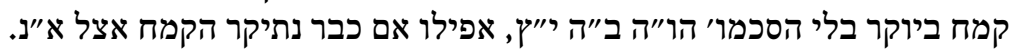

145 Danach Lakune, das Datum fehlt.

146 Danach Lakune, die Seitenzahl fehlt.

1471733 X 18.

148 Danach Lakune, die Paragraphennummer fehlt.

149 Von frz. sentence $=$ Urteil.

150 Von frz. arrêt $=$ Arrest.

151 Lesung unsicher, die Ligatur ist durch Verschmutzung an der Blattecke kaum sichtbar.

152 Danach Lakune, die Paragraphennummer fehlt. 


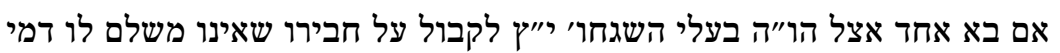

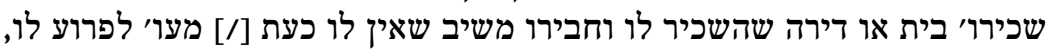

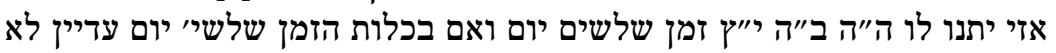

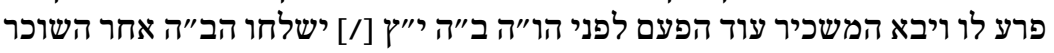

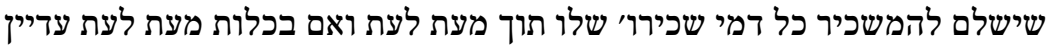

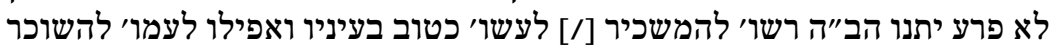

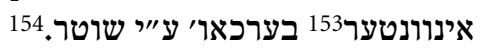

מה שנוגע לעסקי מצרנות או גוד או איגוד יקוים בכל תוקף ועוז כמו שנרשם ע" בפנקס התיקוני' בארטיקל. מצרנות מוגור

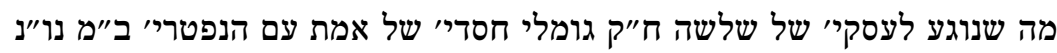
10

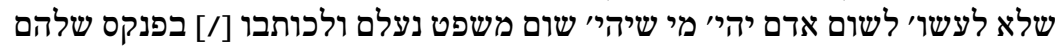

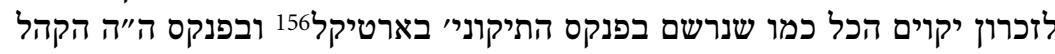

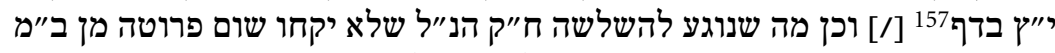

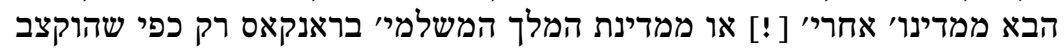

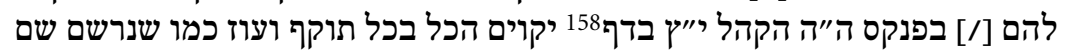
לבליפול דבר ארצה.

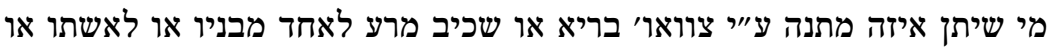

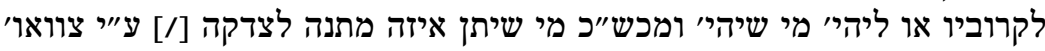

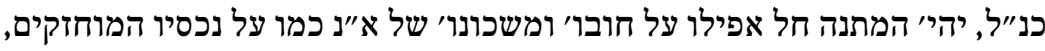

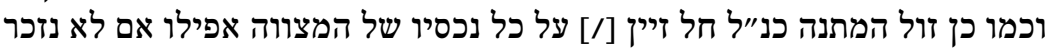

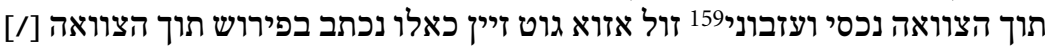
מכל נכסי ועזבוני.160

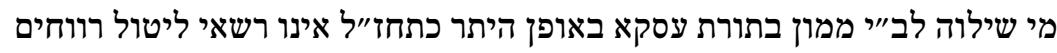
ע" ע

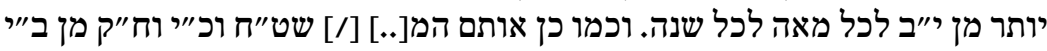

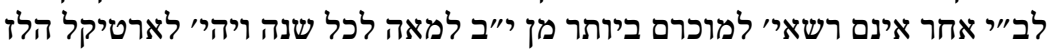

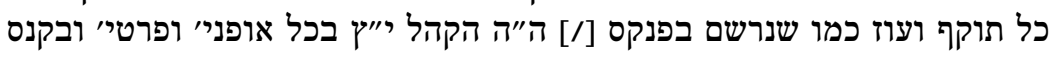

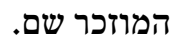

153 Von frz. inventaire $=$ Inventar.

154 Inventarerstellung zum Zweck der Pfändung.

155 Danach Lakune, die Paragraphennummer fehlt.

156 Danach Lakune, die Paragraphennummer fehlt.

157 Danach Lakune, die Seitenzahl fehlt.

158 Danach Lakune, die Seitenzahl fehlt.

159 Die letzten beiden Worte sind als genaue Vorgabe für den Testamentstext zu verstehen.

160 Korrespondiert mit $\$ 8$ bei Schwarzfuchs, Règlement, $30 \mathrm{f}$. 


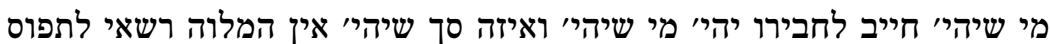

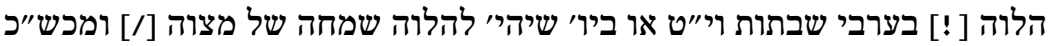

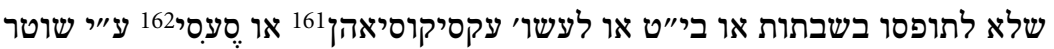

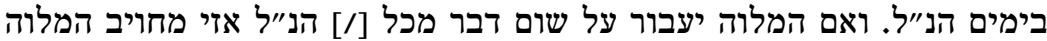

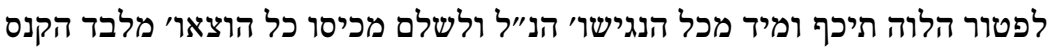

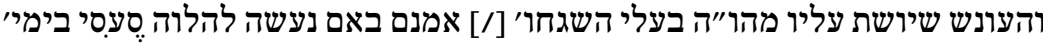

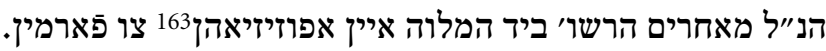

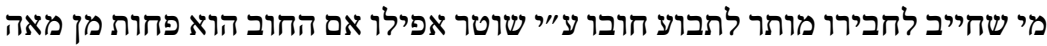
ע

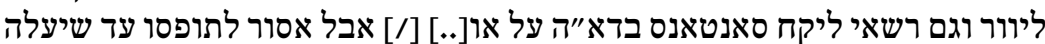

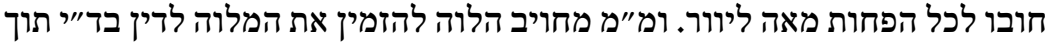

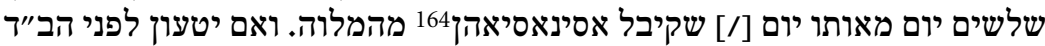

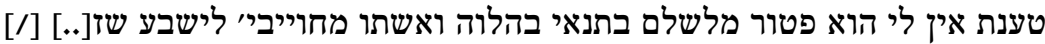

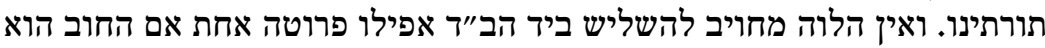

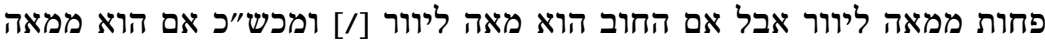

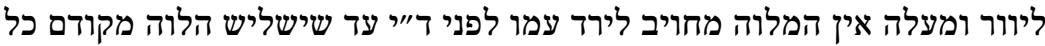

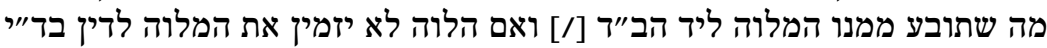

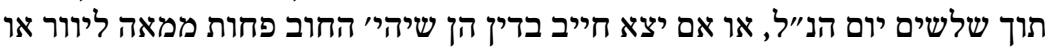

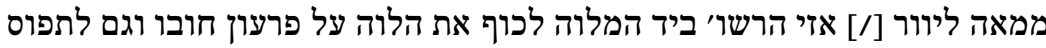

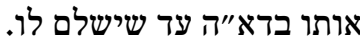

התיקון ישן הנעשה בשנת תפ"ח לפ"קיקי165 שלא להתעסק במו"מ עם פנוים או עם פיא

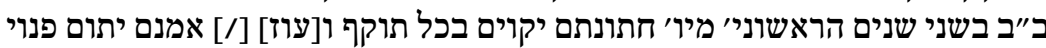

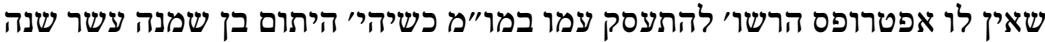

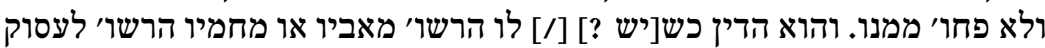

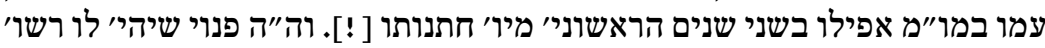

מאביו יכול ל[עסוק] [/] עמו במו"מ אפילו קודם שיהי' בן שמנה עשרה שנה.

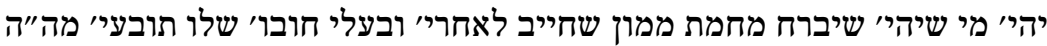
פ"פ

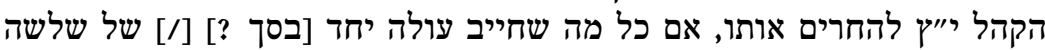

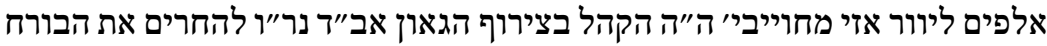

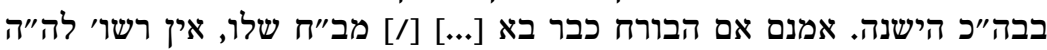

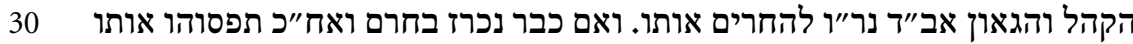
ב"ח שלו מחוייבי'ה"ה [הקה" להחל ?] [/] להוציאו מחוץ לחרוץ לחרם. וגם אינו רשאי הבורח

161 Von frz. execution = Beschlagnahmung.

162 Von frz. saisie $=$ Pfändung.

163 Von frz. opposition = Einspruch.

164 Von frz. assignation $=$ Vorladung.

165 1727/28. 


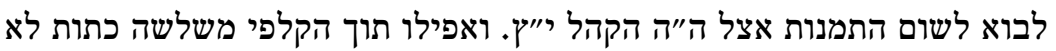

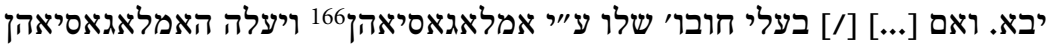

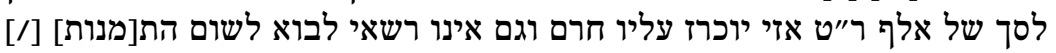

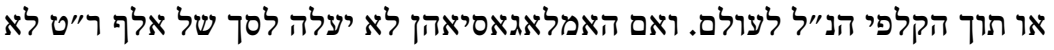

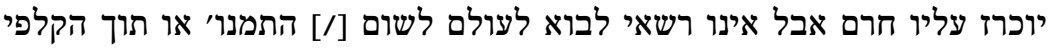

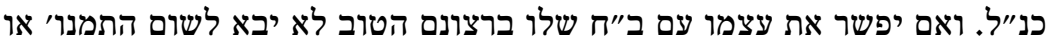

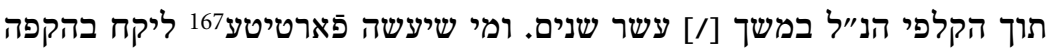

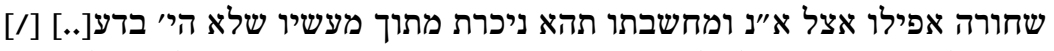

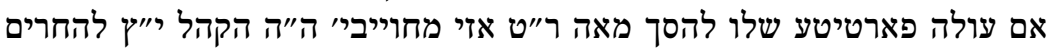

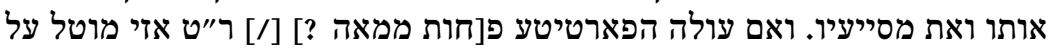

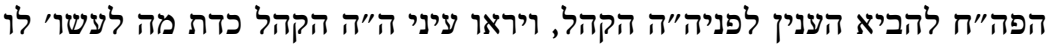

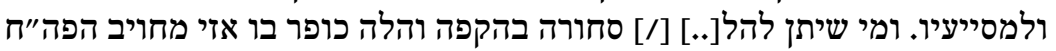

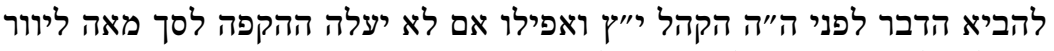

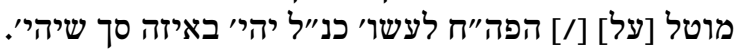

[fol. $81 \mathrm{r}] \quad 15$

התיקון לבחור ששה אנשי' משלשה כתות לחלק האתרוגיי יקוים בכל תוקף ועוז פ"ב

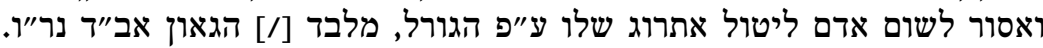

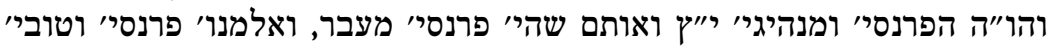

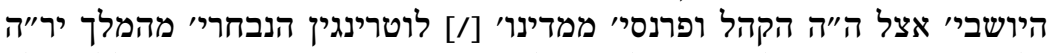

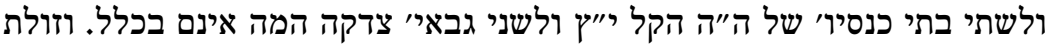

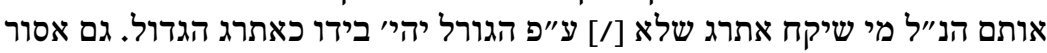

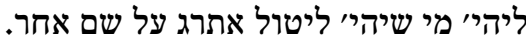

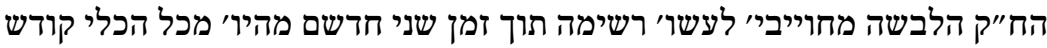

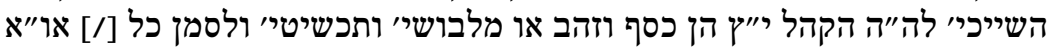

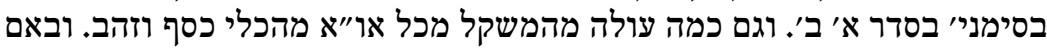

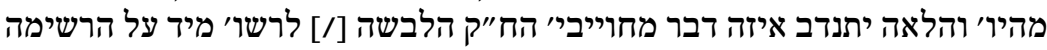

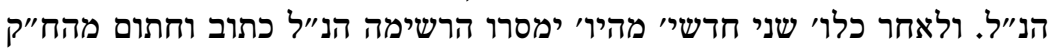

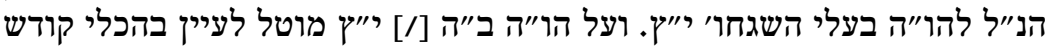
בכל שנה ושנה בין כסא לעשור אטגוץ הכל הכל בעיר כפיה הרשימה שבידם.

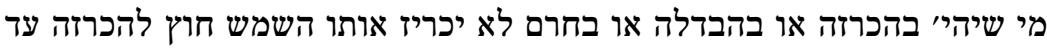

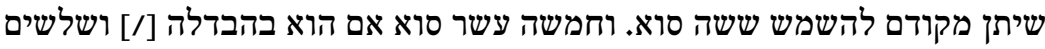

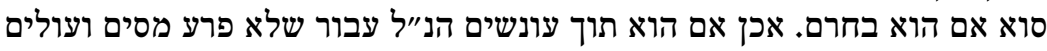

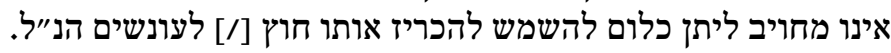

166 Von frz. homologation = gerichtliche Bestätigung.

167 Von frz. fortuité = günstige Gelegenheit? 


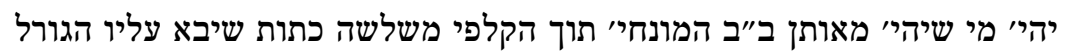

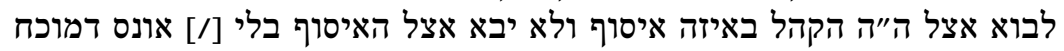

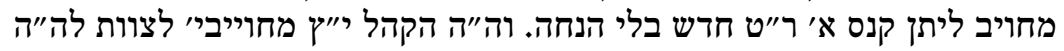

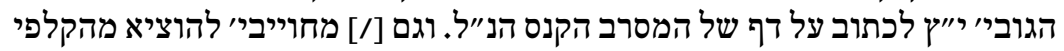
משלשה כתות איש אחר במקומו לבא אל אותו איסוף.

התיקון לברור גוביי וב"ה מחדש בכל שלשה שניי יקוים תמיד. ובשעת ברירו'

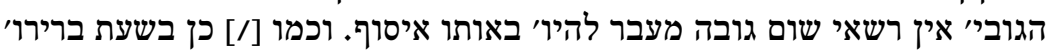

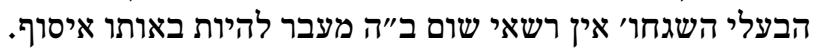

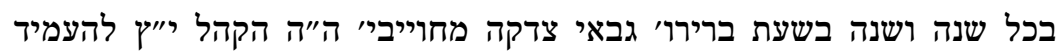

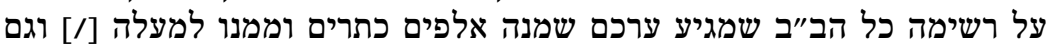

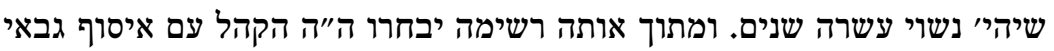

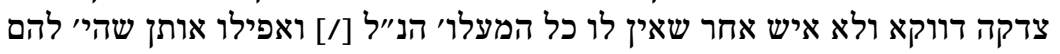

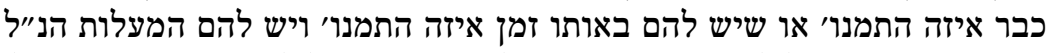

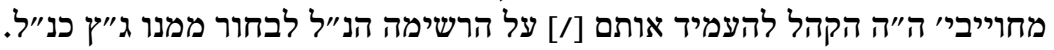

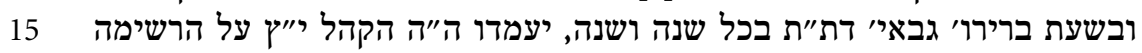

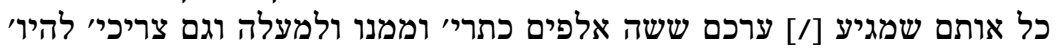

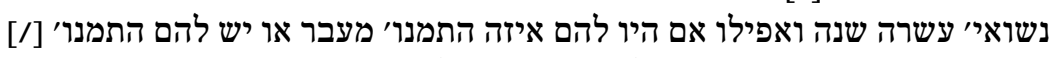

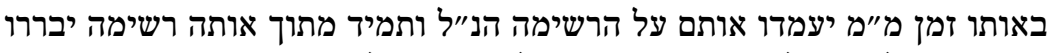

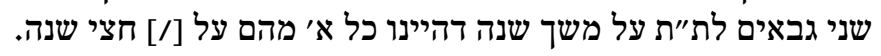

מי שלא היי מעולם פרנס או גובה הקהלה או אחד מבעלי השגחו' פה קהלתינו

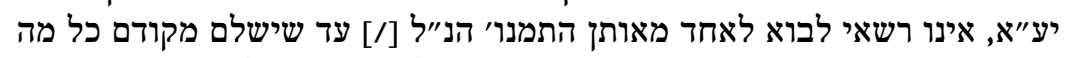

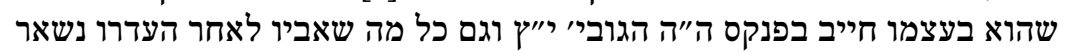

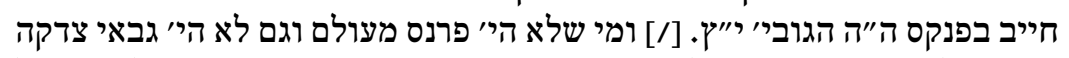

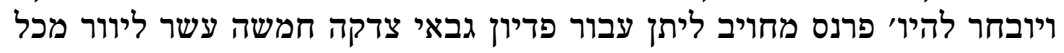

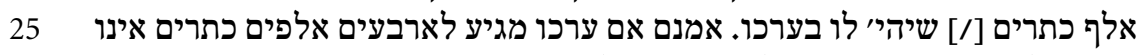
מחויב ליתן רק ששה מאות ליוור בין הכל.

התיקון והרעגלמאן מפרען הנתינו' ממסים ועולים יקוים בכל תוקף ועוז כמו

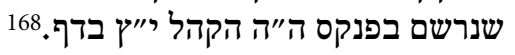

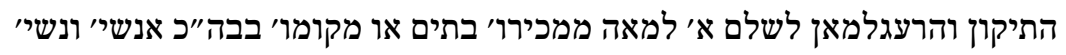

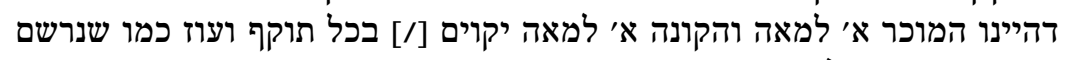
בפנקס ה"ה הקהל י"יץ בדף. 169

פ"ה 


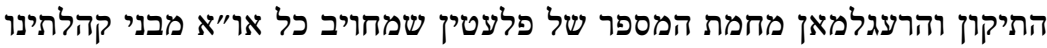
צ

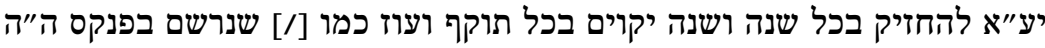

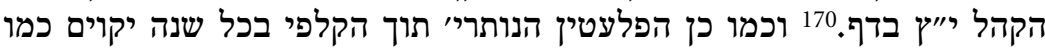

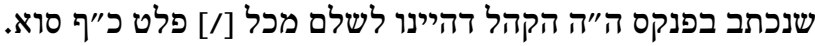

הרעגלמאן הנעשה מה"ה הקהל י"יץ עם איסוף ב"ב ביו־171 כמו שנרשם בפנקס

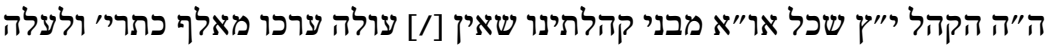

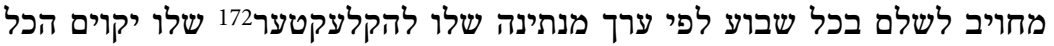

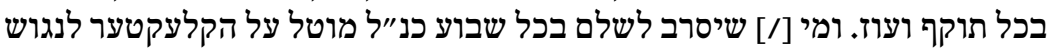

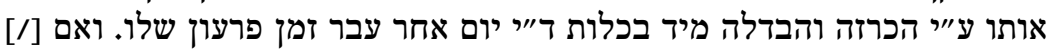

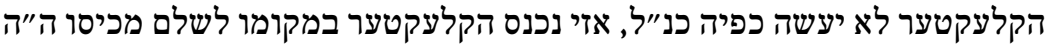

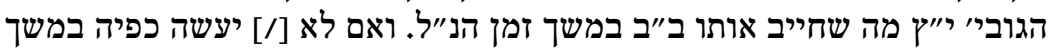

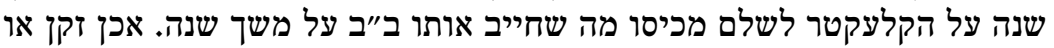

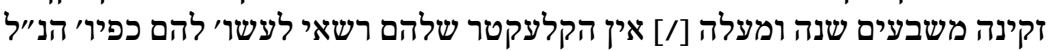

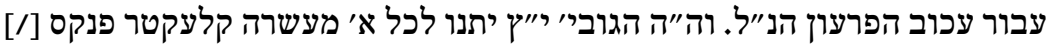

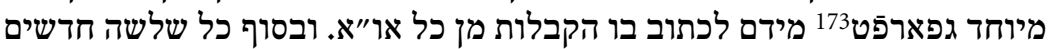

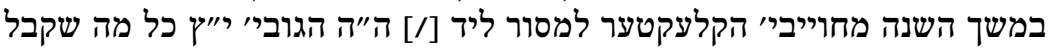

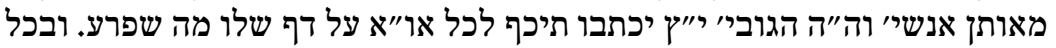

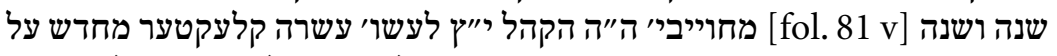
משך שנה. וה"ה הגוביי י"יץ המה יבחרו ע"פ הגורל עשרה קלעקטער בכל שנה [/]

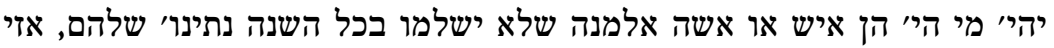

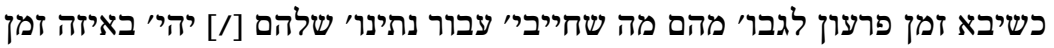

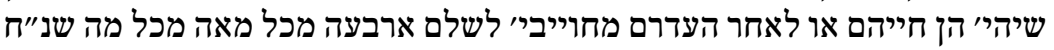

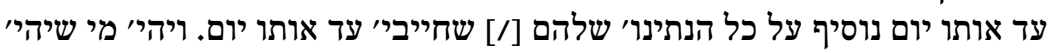

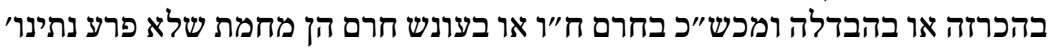

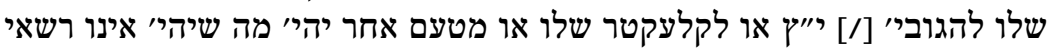

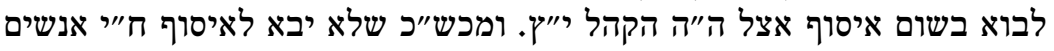

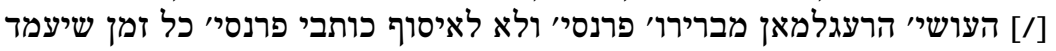

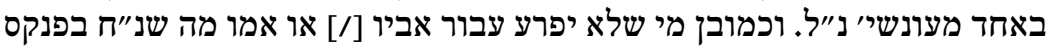
הגוביי י"ץ אינוני רשאי לבוא לשום אילוס איסוף כנ"ל.

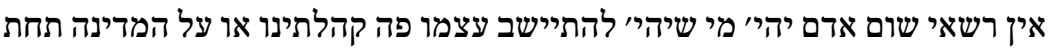

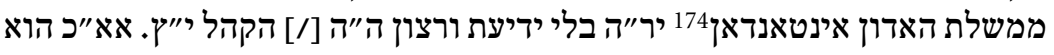

170 Die Seitenzahl fehlt.

171 Danach Lakune, das Datum fehlt.

172 Von frz. collecteur $=$ Kollektor.

173 Geprüft.

174 Von frz. intendant $=$ Verwalter, Gouverneur. 


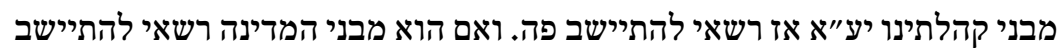

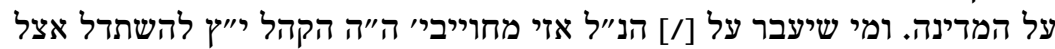

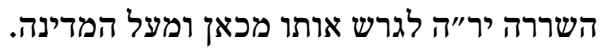

פנוי יהיי מי שיהיי שיעסוק במו״מ הן פה במדינו' צרפת או במדינו' לוטרינגין צ צ

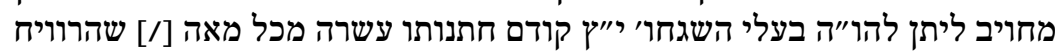

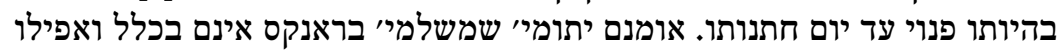

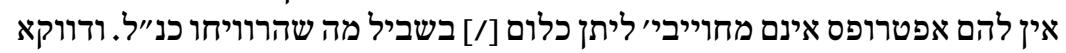

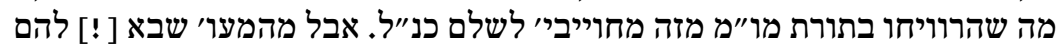

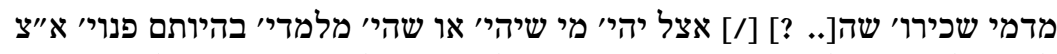

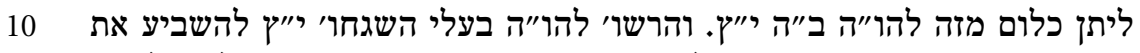

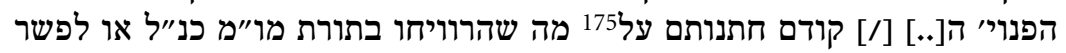

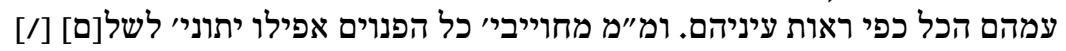

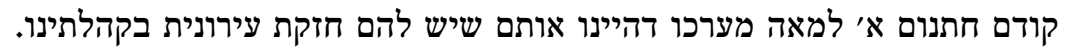

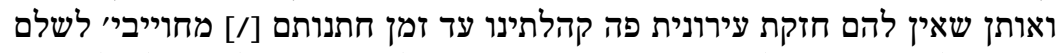

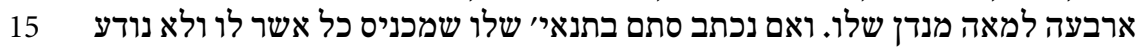

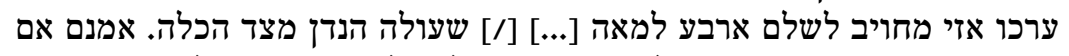

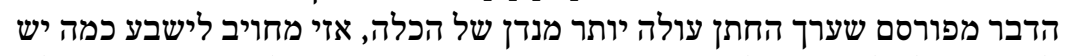

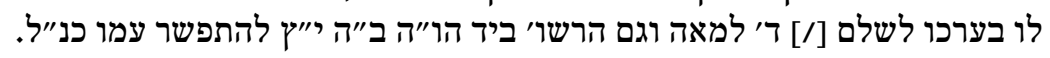

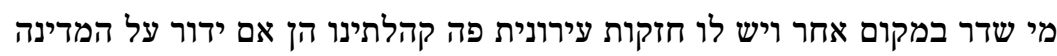

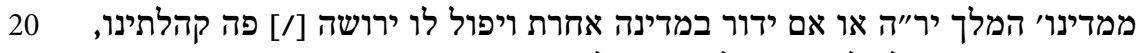

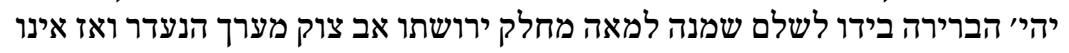

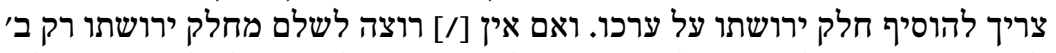

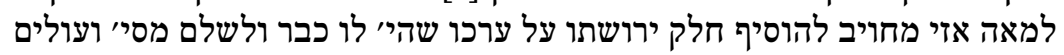

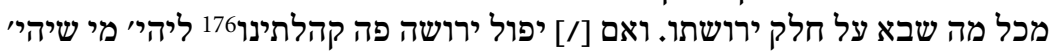

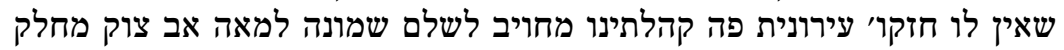

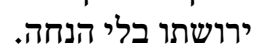
גם אותם שיש להם חזיקת עירונית בקהלתינו ודריי במקום אחר מחוייבי' להעמיד

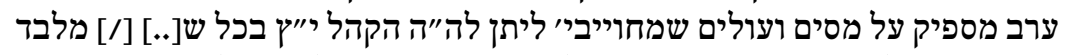

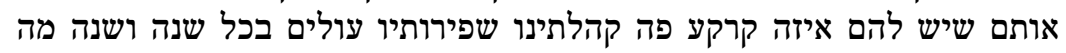

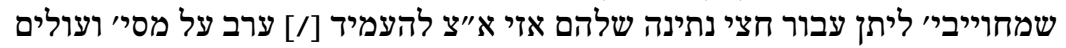

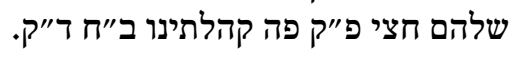

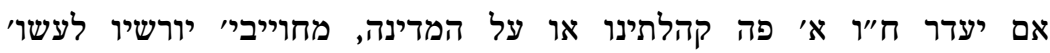

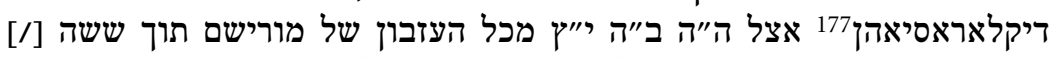

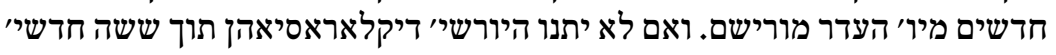

175 Dieses Wort über der Zeile, darunter ein Wort durch Streichung unleserlich. 176 Die beiden letzten Worte über der Zeile ergänzt.

177 Von frz. déclaration = Erklärung. 
כנ"ל, אזי יוקח מהעזבון מסיי ועולים כפי [/] שהיי עולה הערך ממורישם כאילו

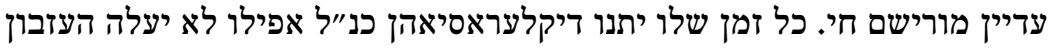

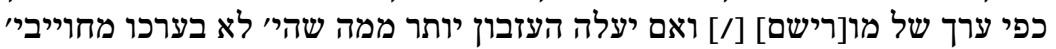

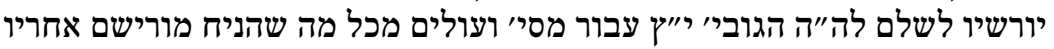

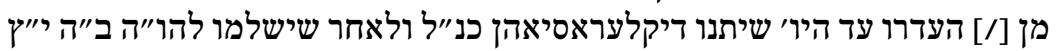
בפארצענטין178 מהעזבון כנזכרו הפור.

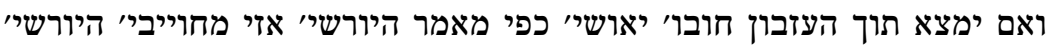

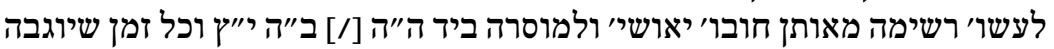

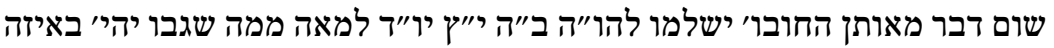

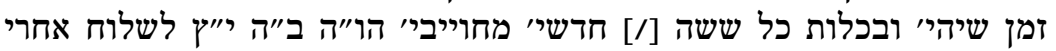

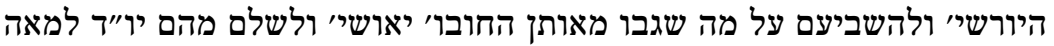

מי שדר פה קהלתינו בחזקת עירונית ורוצה לעקור דירתו מקהלתינוו ולסלק עצמו

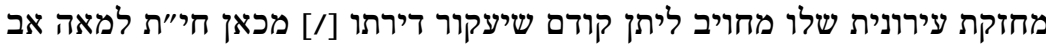

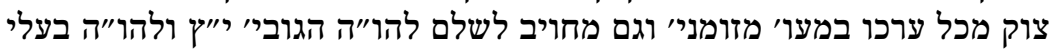

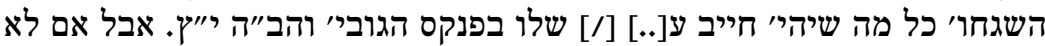

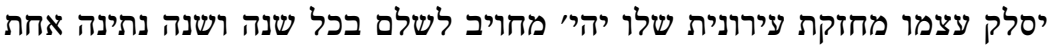

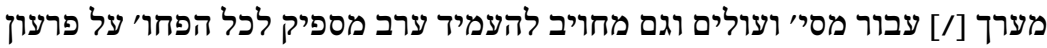

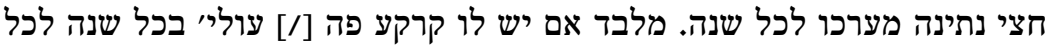

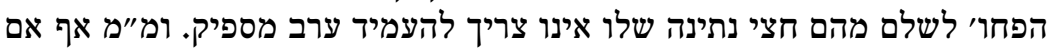

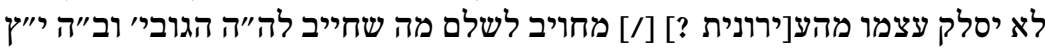

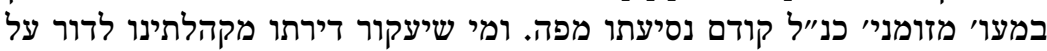

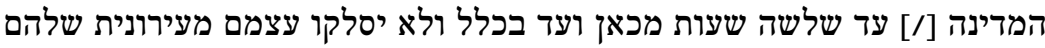

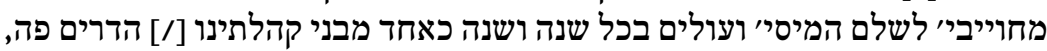

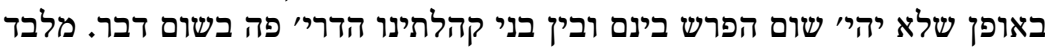

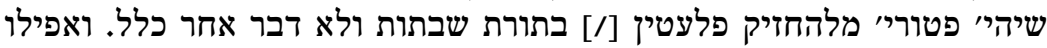

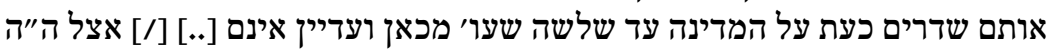

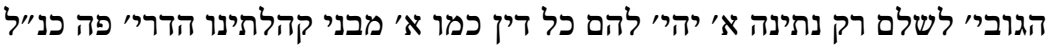

$$
\text { חצי חצי דה"קלם }
$$

[fol. 82 r] 30

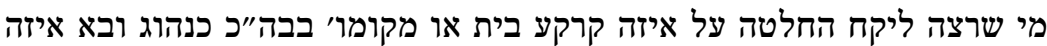
צ'

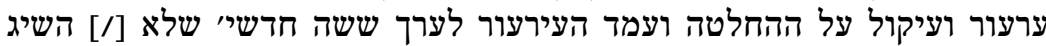

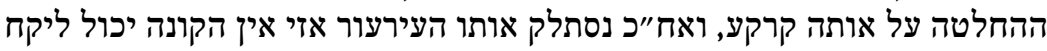

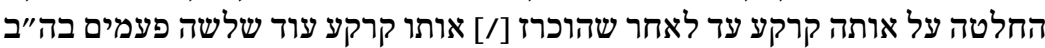

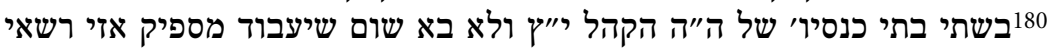
ח"צ

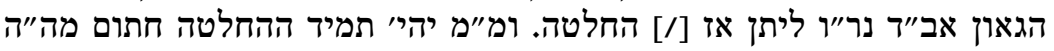

178 Prozent.

179 Die Bedeutung dieser Ligatur ist nicht eindeutig zu klären.

= ב' ה' ב' Montag, Donnerstag, Montag. 


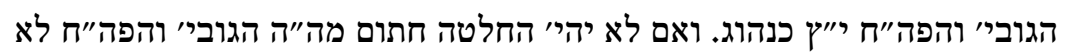

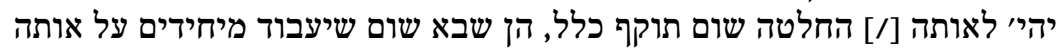

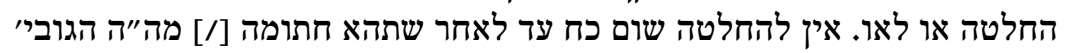
והפה"ח י"ץ ולא באופן אחר כלל.

$5 \quad 5$

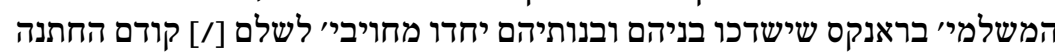

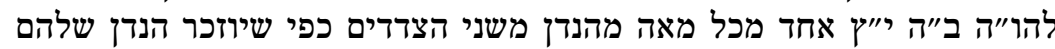

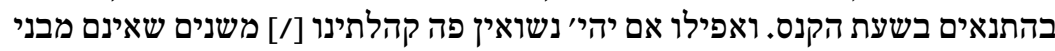

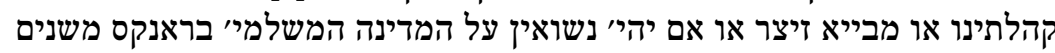

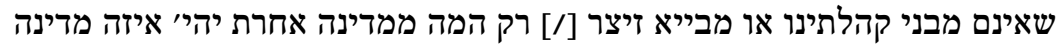

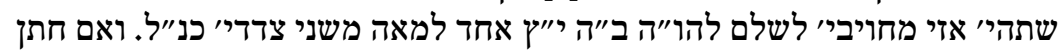

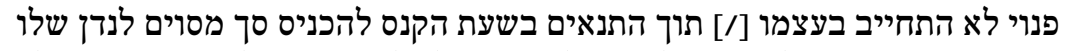

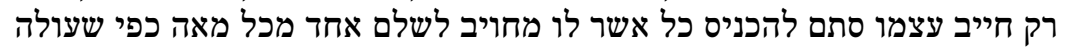

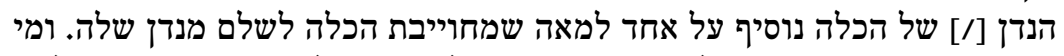

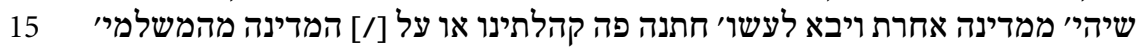

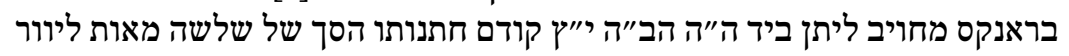

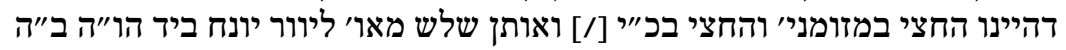

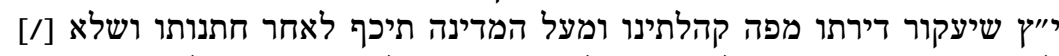

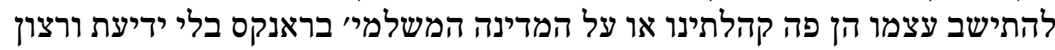

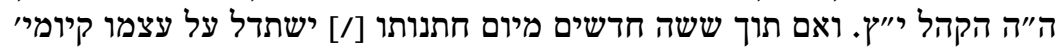

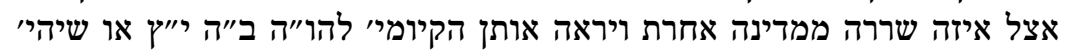

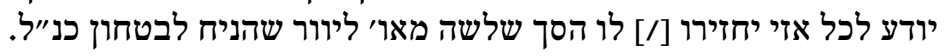

ארטיקל א׳ מתקוני הקהלה מן 181 מה שנוגע לעסקי עירונית ושם נאמר שהחתן

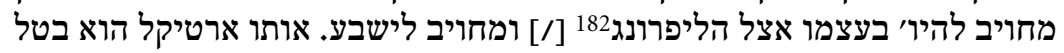

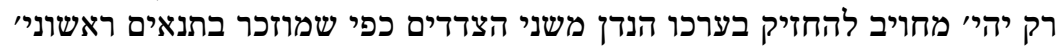

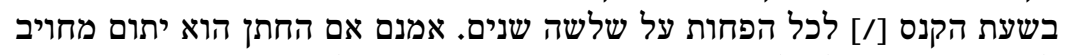

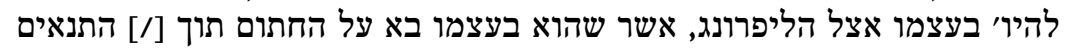

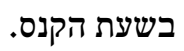

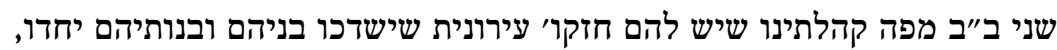

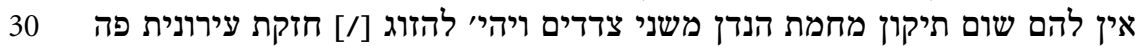

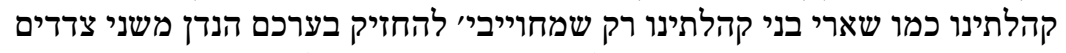

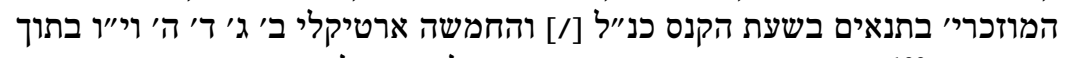

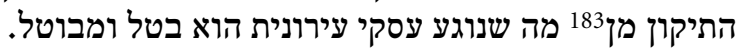

181 Danach Lakune, das Datum fehlt. 182 Verleihung (der Mitgliedschaft).

183 Danach Lakune, das Datum fehlt. 
אם אחד שאין לו חזקת עירונית בקהלתינו רוצה לשדך בתו עם פנוי מבני קהלתינו

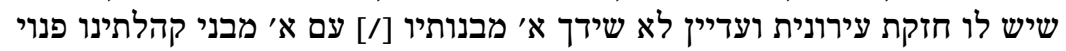

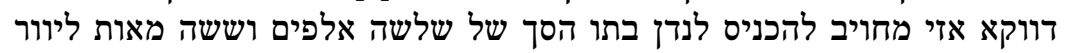

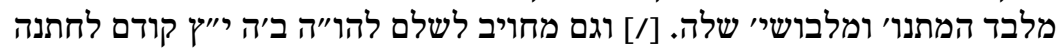

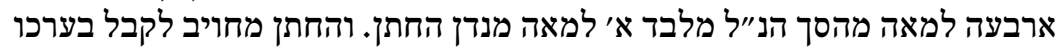

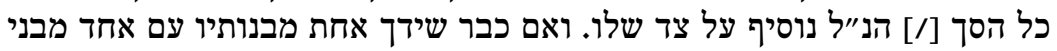

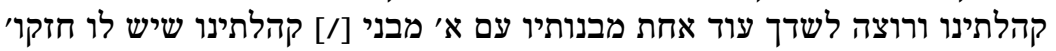

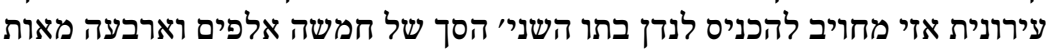

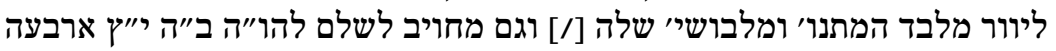

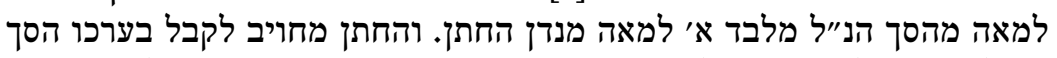

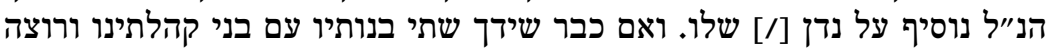

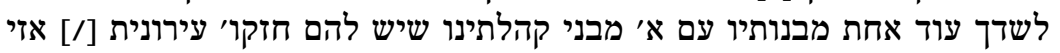

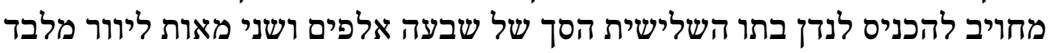

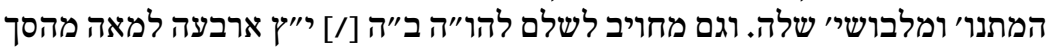

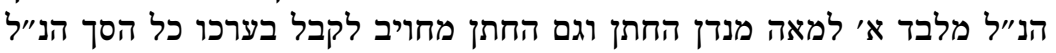

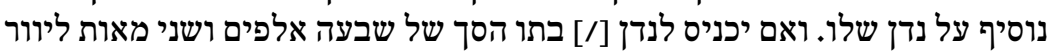

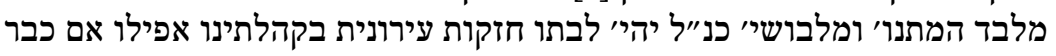

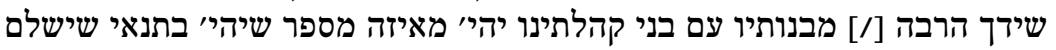

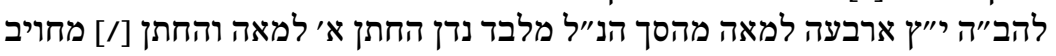

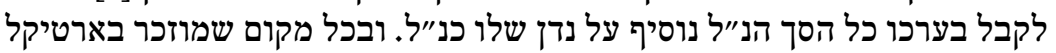

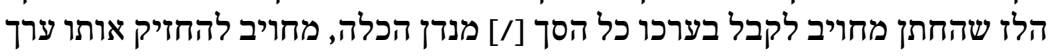

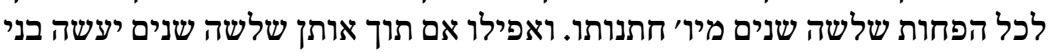

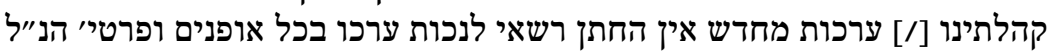

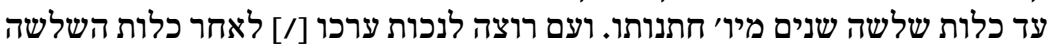
שנים מחויב לישבע כנהוג.

אחד מבני קהלתינו שיש לו חזקת עירונית או מן הבייא זיצר שרוצא לעשו' נשואין

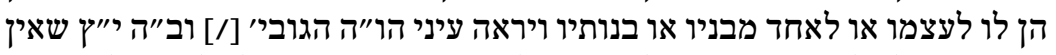

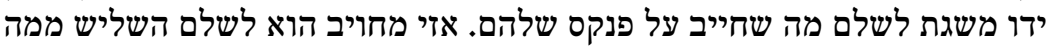

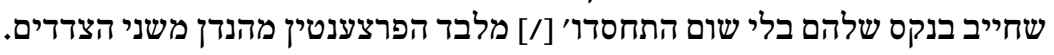

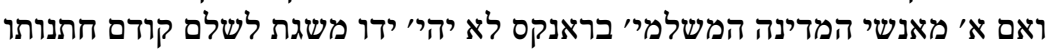

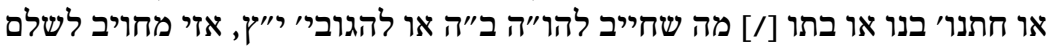

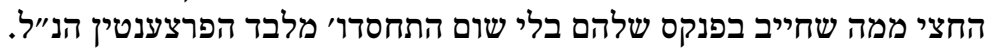

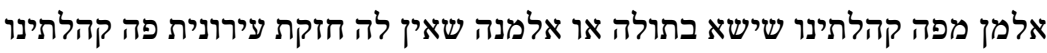

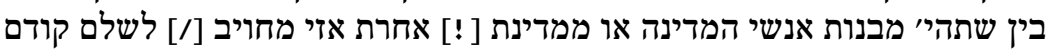

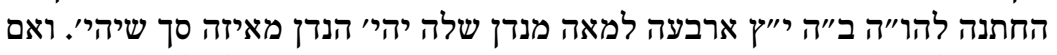

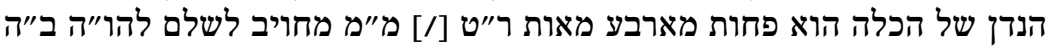

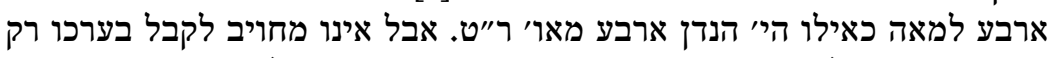

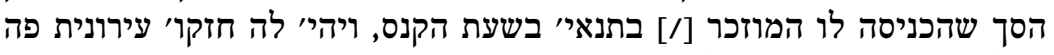
קהלתינו כאחת מבנו' קהלתינוּ. 
[fol. $82 \mathrm{v}$ ]

ק"ו

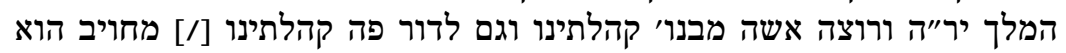

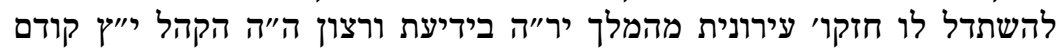

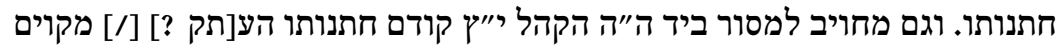

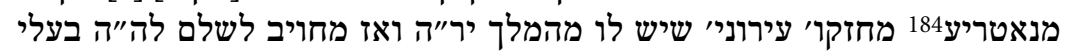

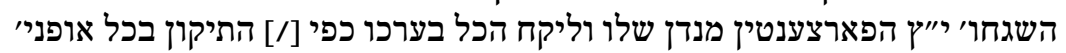

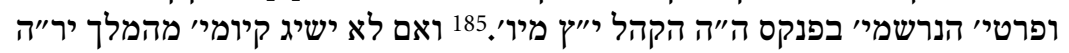

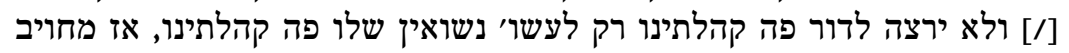

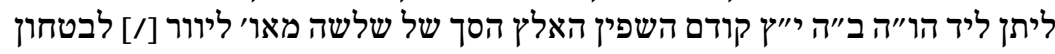

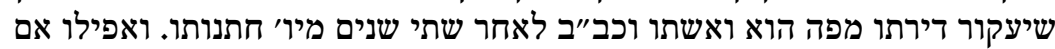

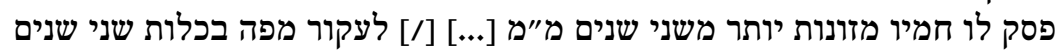

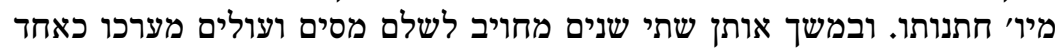

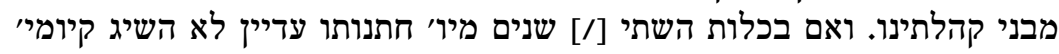

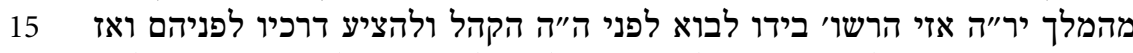

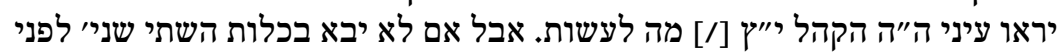

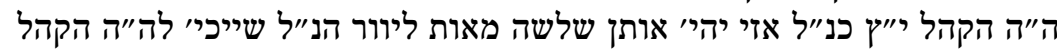

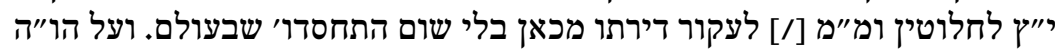

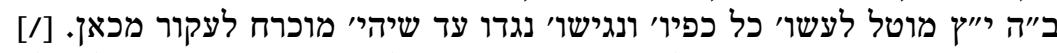

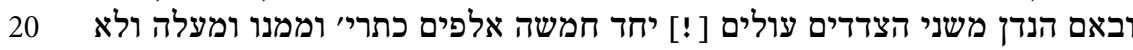

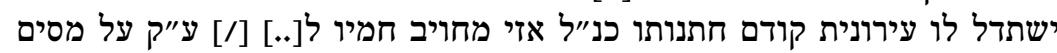

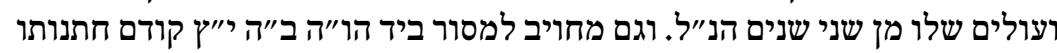

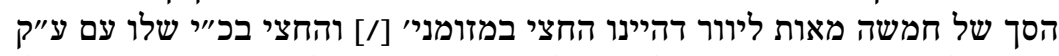

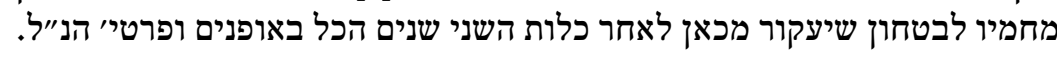

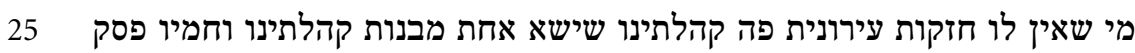

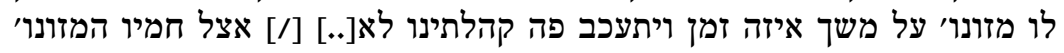

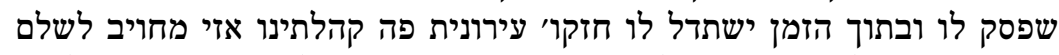

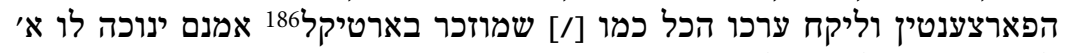

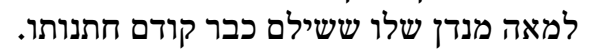

אין הגאון אב"ד נר"ו או באי כחו רשאים ליתן התרת קידושין ליהיי מי שיהיי הן 30

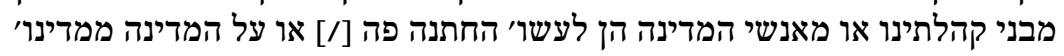

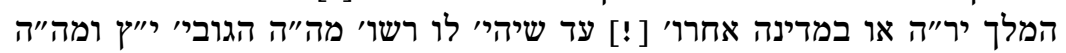

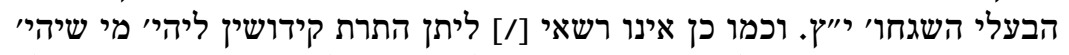

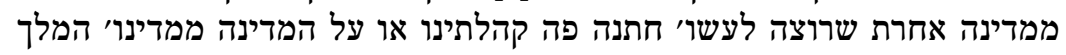

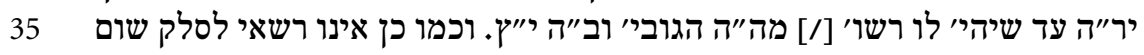

184 Notar.

185 Danach Lakune, das Datum fehlt.

186 Danach Lakune, die Paragraphennummer fehlt. 


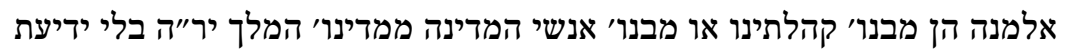

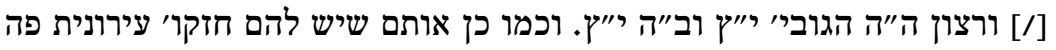

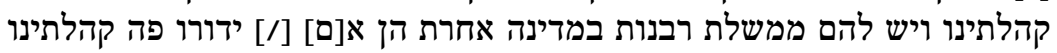

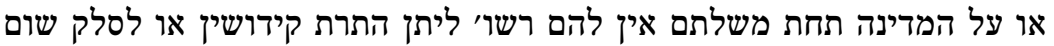

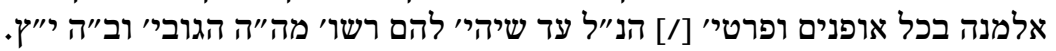

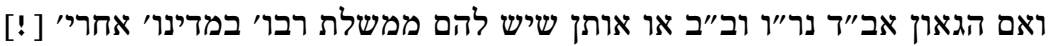

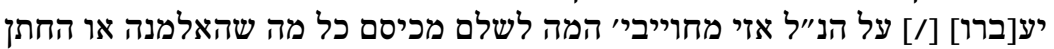

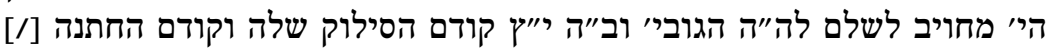

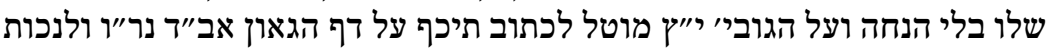

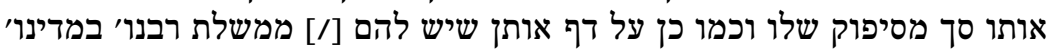

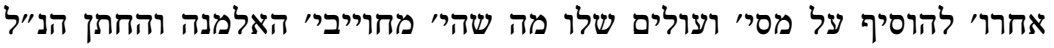
לשלם.

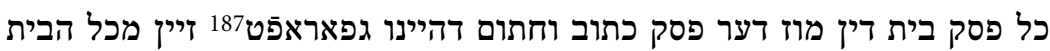

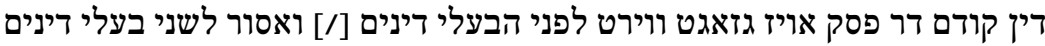

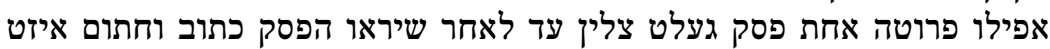

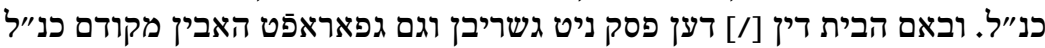

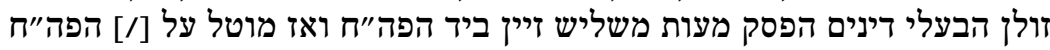
כפיה צו טוין לקיים ארטיקל הלז. מעות משליק

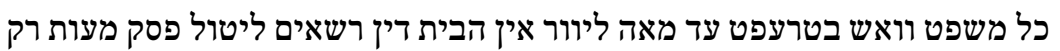

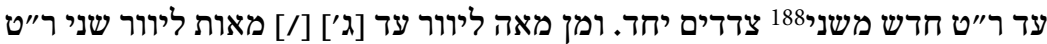

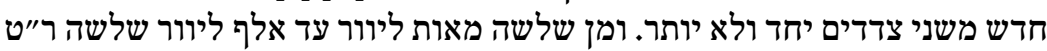

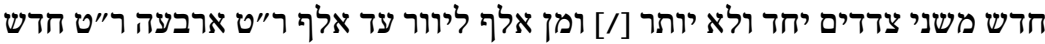

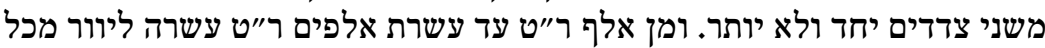

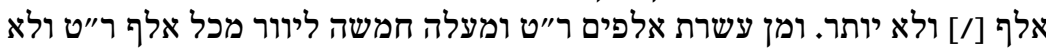

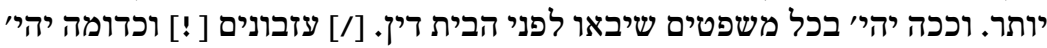

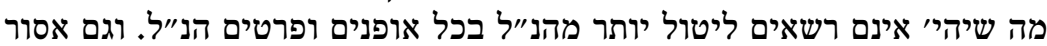

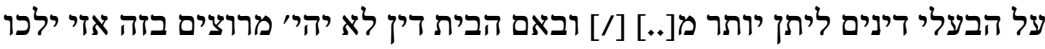

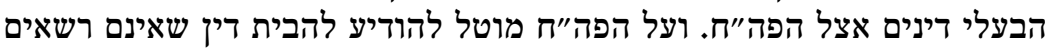

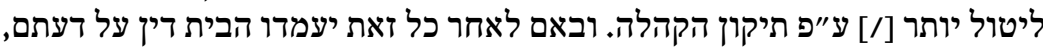

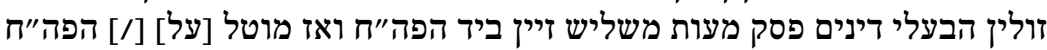
להשתדל בכל כחו להוציא מהבית דין הפסק שיש שנתנו באותו משפט. מיר.

ק"ט 15

קיו"ד

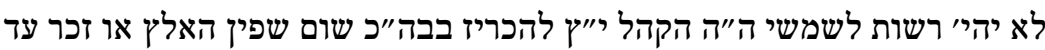

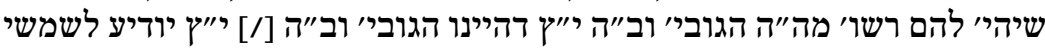

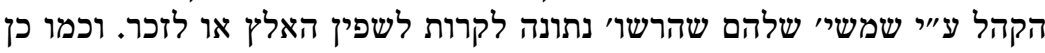

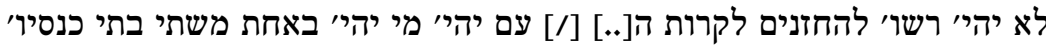

187 Geprüft.

188 Das im Wort kunstvoll über der Zeile verlängert. 
של הקהל י"ץ בזמן שיהי' בר מצוה בלי רשו' מה"ה הגובי' וב"ה י"ץי, בקנס על

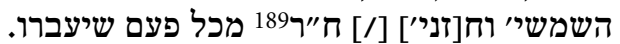

[fol. $83 \mathrm{r}$ ]

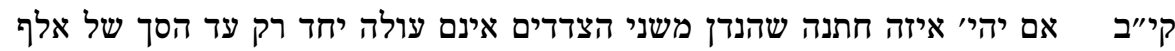

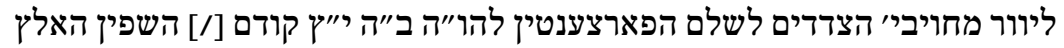

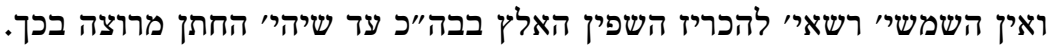

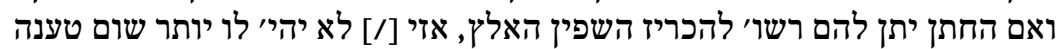

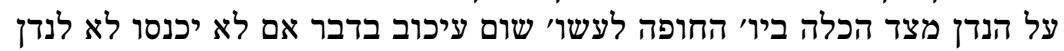

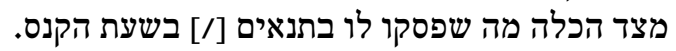

ארטיקל י"ד הנוגע לעסקי תיקוני עירוניי בפנקס ה"ה הקהל במה שנוגע לצוואו', 10

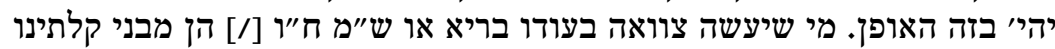

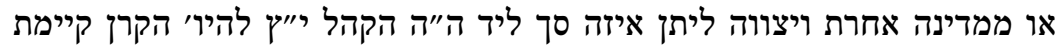

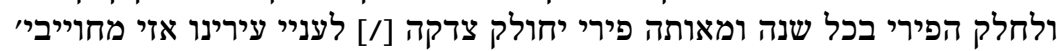

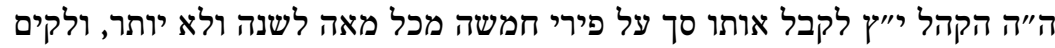

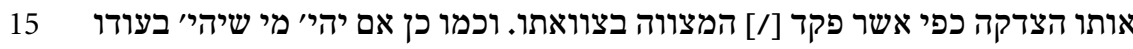

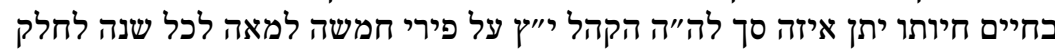

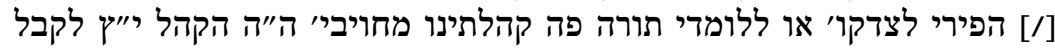

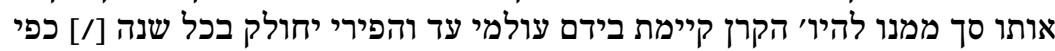

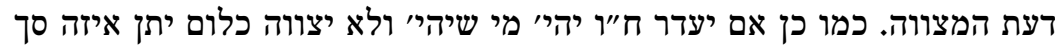

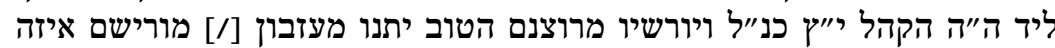

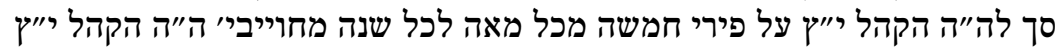

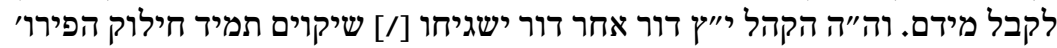

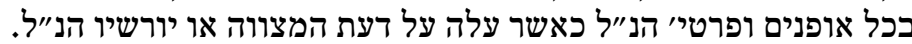

המוכרי סוסים יהי' מי שיהי' הן מבני קהלתינו שיש להם חזקו' עירונית או שאין

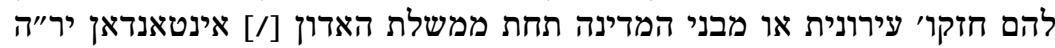

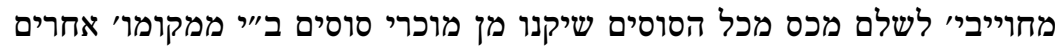

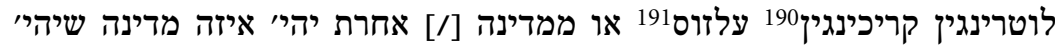

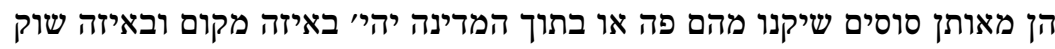

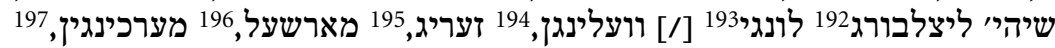

\author{
189 חצי רייכשטלר? \\ 190 Kriechingen, ehem. Reichsgrafschaft. \\ 191 Elsass. \\ 192 Luxemburg. \\ 193 Longuich? \\ 194 Saarwellingen. \\ 195 Sierck. \\ 196 Marsal. \\ 197 Mörchingen.
}




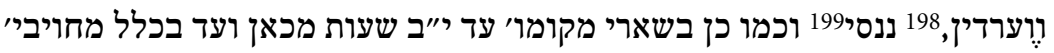

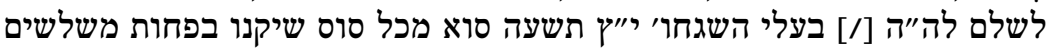

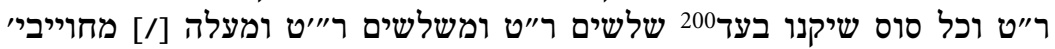

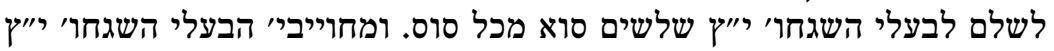

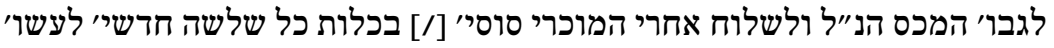

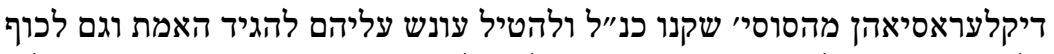

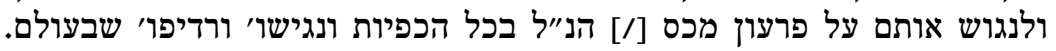

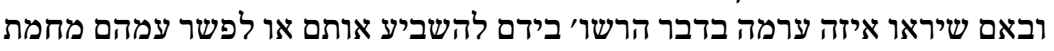

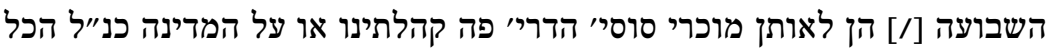

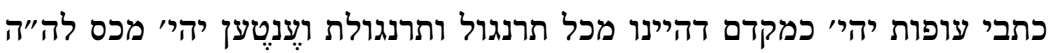

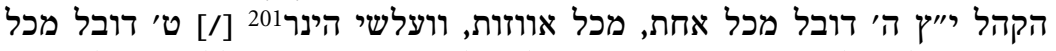

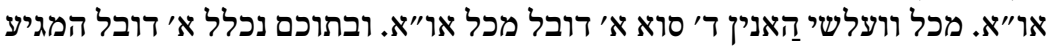

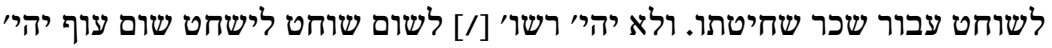

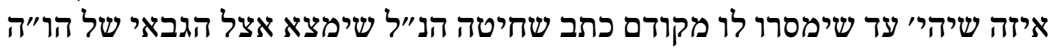

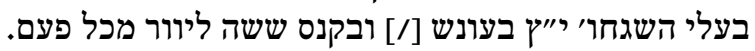

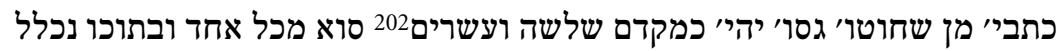

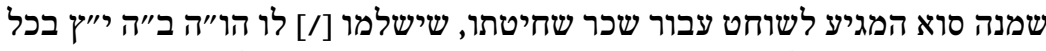

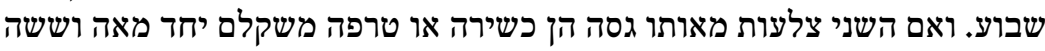

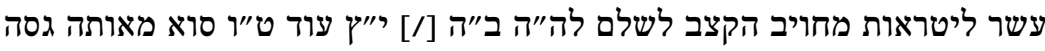

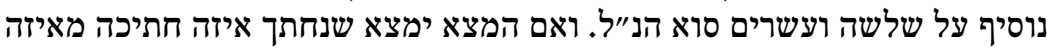

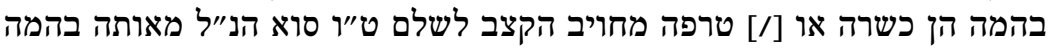

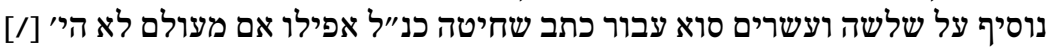

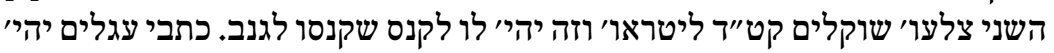

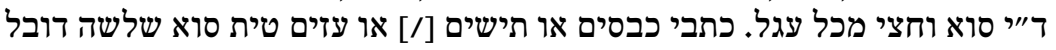

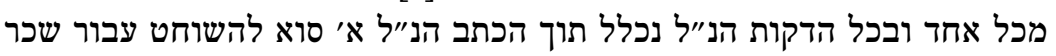

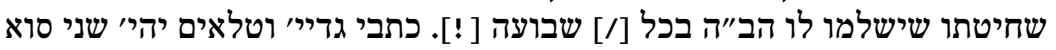

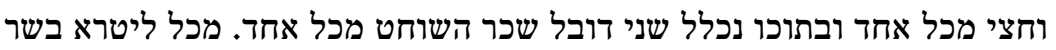

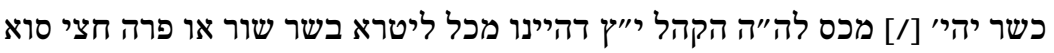

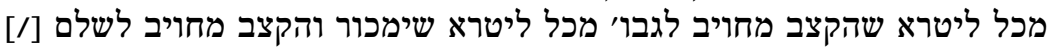

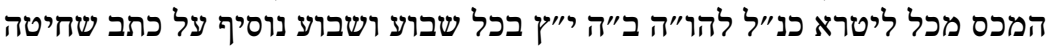

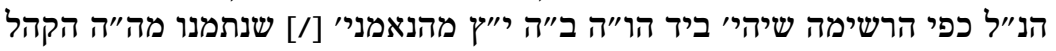

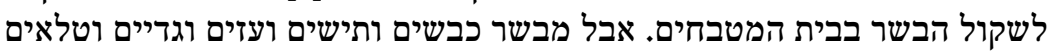

198 Verdun.

199 Nancy.

200 Davor gestrichen: משלשים ר"ט ומעלה.

201 Welsche Hühner, zeitgenössische Bezeichnung für Truthähne.

202 Das ש im Wort kunstvoll über der Zeile verlängert. 
אין הקצב מחויב ליתן המכס שני [/] דובל מכל ליטר ליטרא להו"ה ב"ה י"ים ו"ץ ורשו' ביד

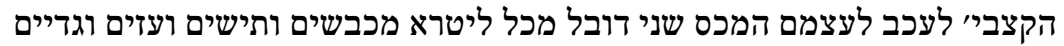

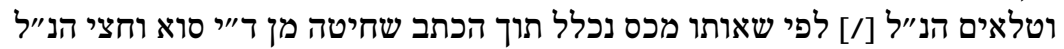

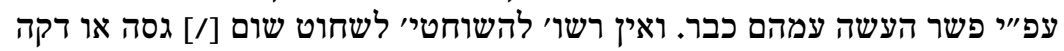

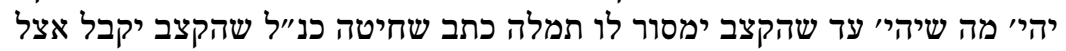
הגבאי של הו"ה ב"ה י"יץ בקנס שלשה ליוור [/] מכל פעם של שי שיעבר.

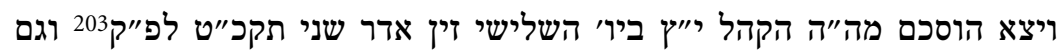

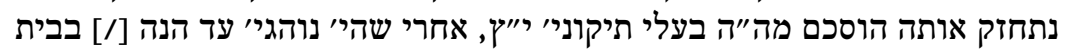

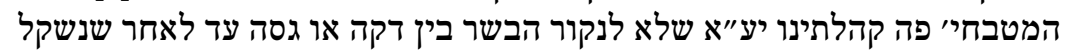

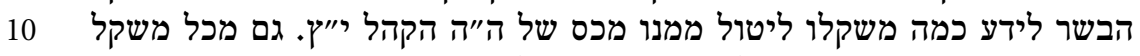

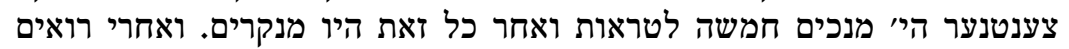

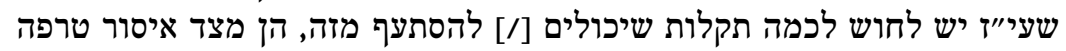

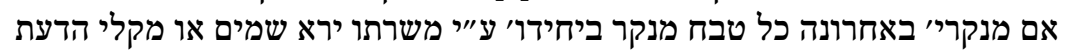

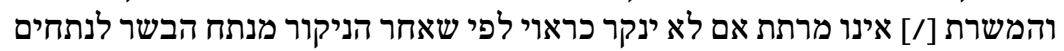

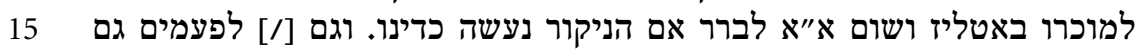

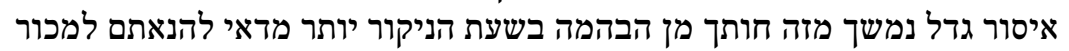

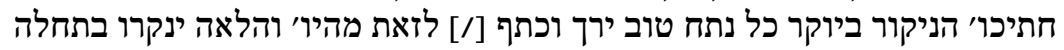

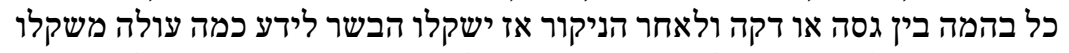

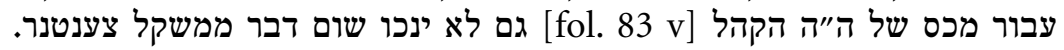

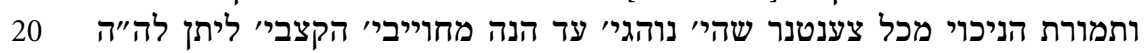

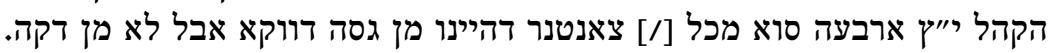

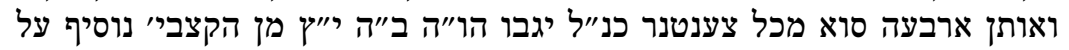

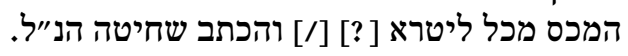

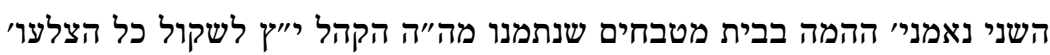

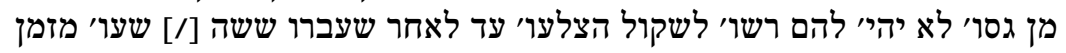

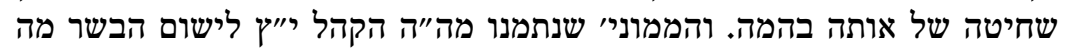

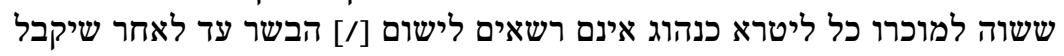

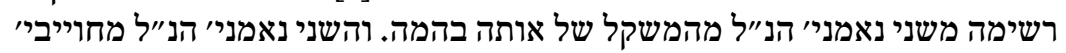

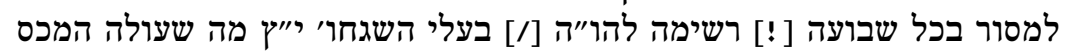

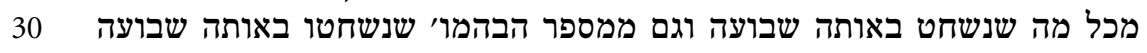

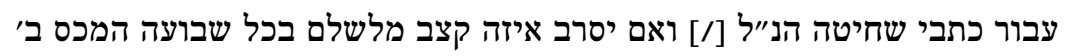

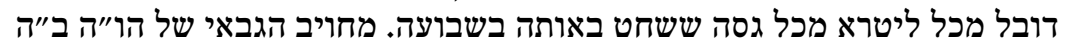

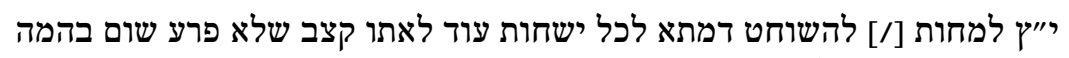

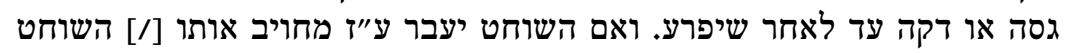

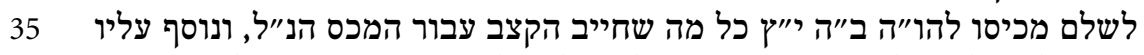

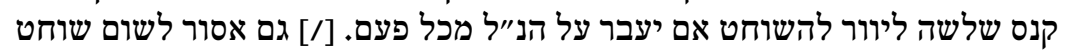

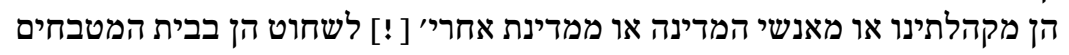

2031769 IV 14. 
פה קהלתינו או תוך המקום עבור שום [/] אחד מבני קהלתינו או מאנשי המדינה

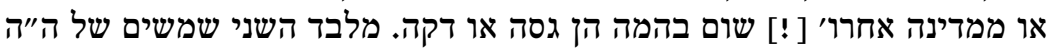

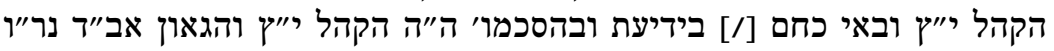

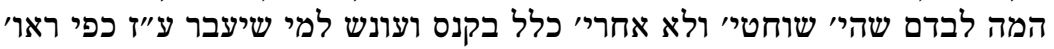

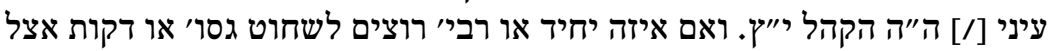

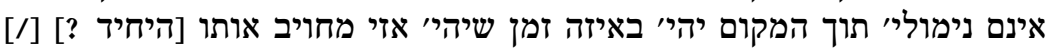

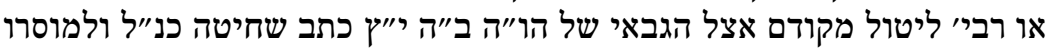

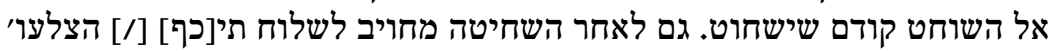

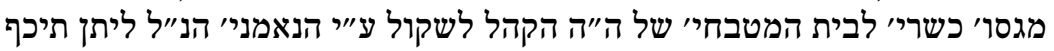

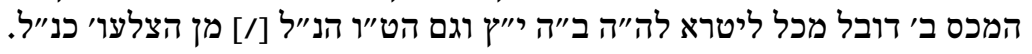

אסור לשום אדם הן מבני קהלתינו או מאנשי המדינה או ממדינו' אחרי' [!] למכור

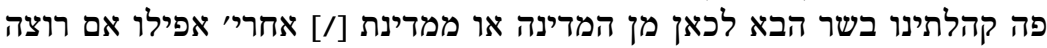

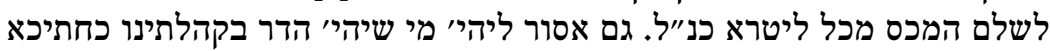

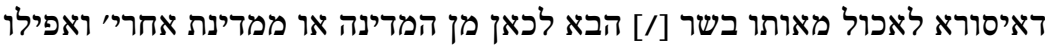

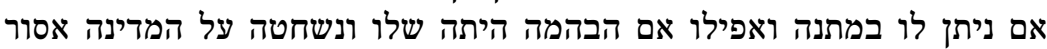

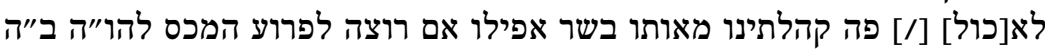

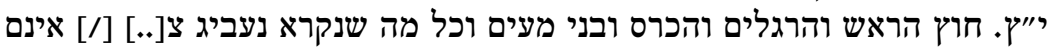

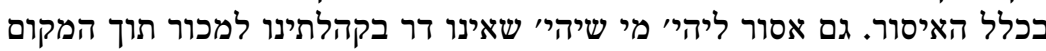

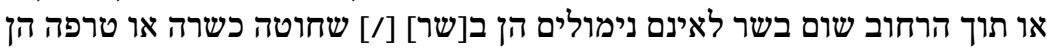

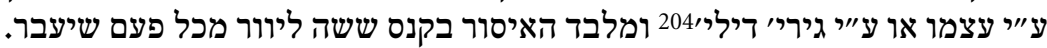

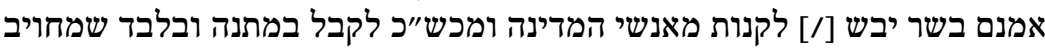

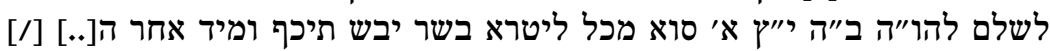

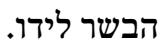

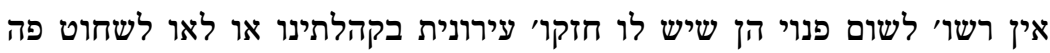

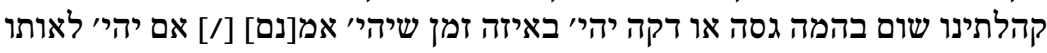

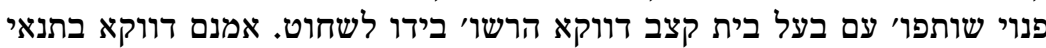

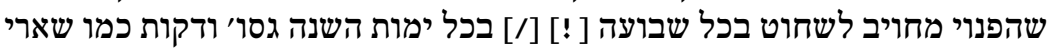

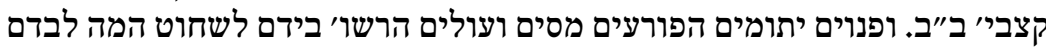

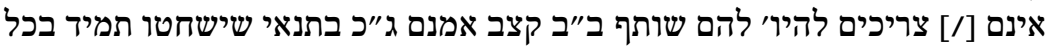

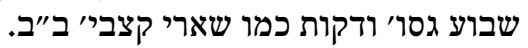

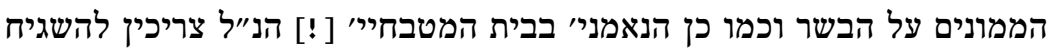

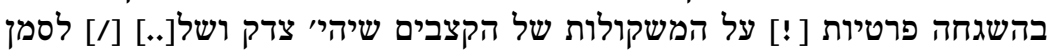

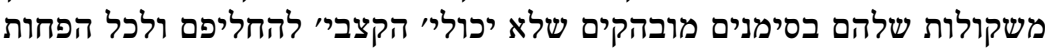

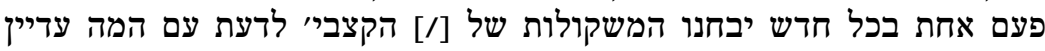

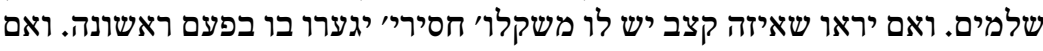
יהיי שונה [/] באוולתו [!] אזי יקנסו אותו משו כפי ראו' עיניהם. 


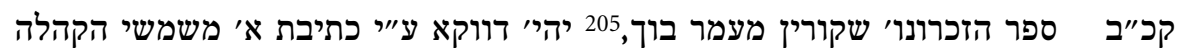

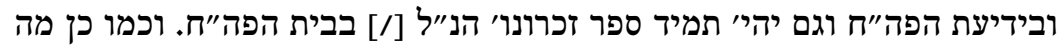

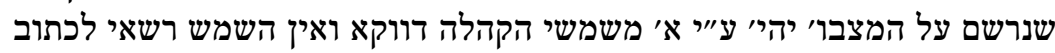

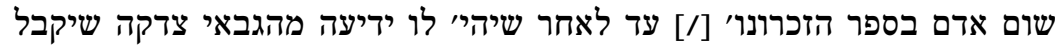
ארבעים וחמשה סוא כנהוג.

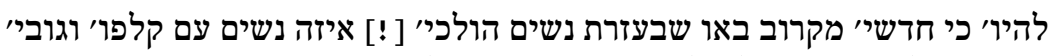

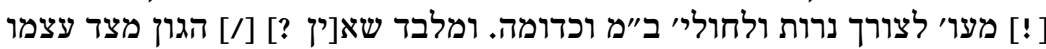

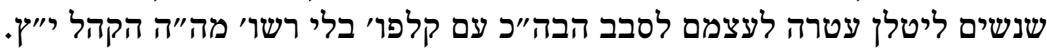

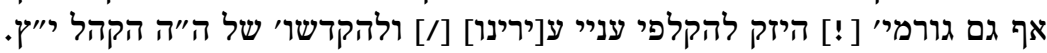

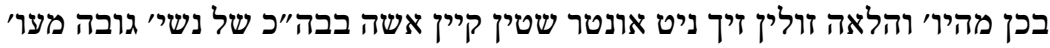

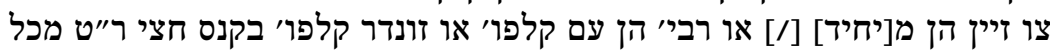

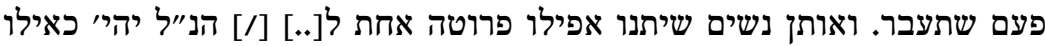

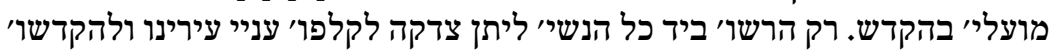

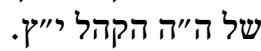

יהיי מי שיהי' הן מבני קהלתינו או מבני המדינה אינם רשאים לקיל ליפנות שום בהמה

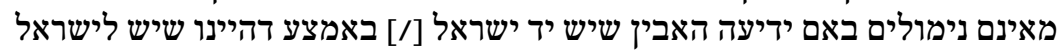

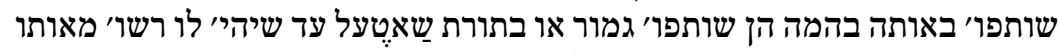
ב״״י משותף [/] בקנס עשרים וארבע ליוור. קכ"ג - (20) - n [fol. $84 \mathrm{r}$ ]

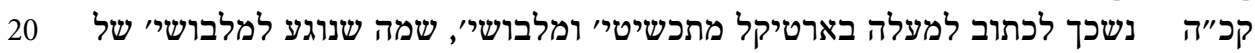

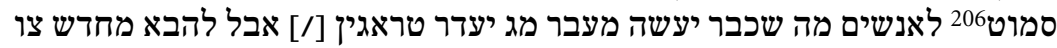

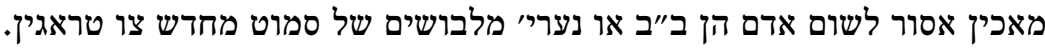

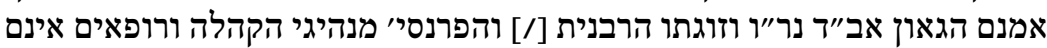

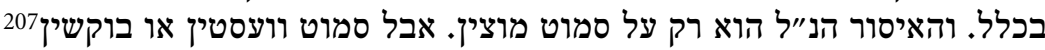

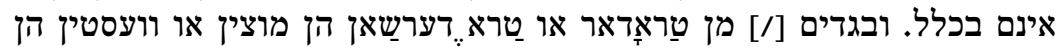

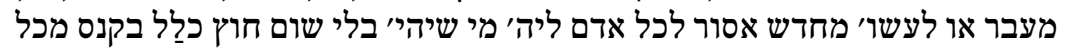

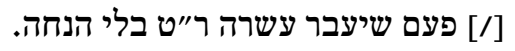

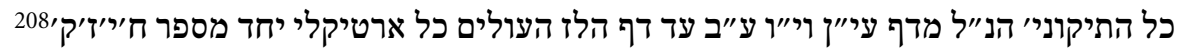

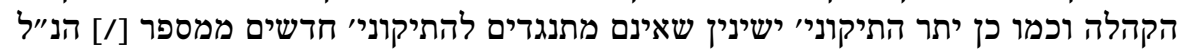

\footnotetext{
205 Memorbuch, ein Seelengedächtnisbuch.

206 Samt.

207 Hosen.

208 Die Buchstaben entsprechen dem Zahlenwert 125, der Anzahl der Artikel. Zudem ist durch die Anordnung der Buchstaben auch der Wortsinn »verstärkt « gegeben, der in Verbindung mit dem folgenden Wort zu verstehen ist. Alle vier Buchstaben sind in größerer Quadratschrift geschrieben.
} 


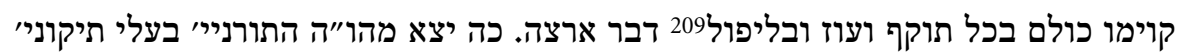

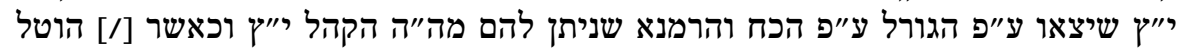

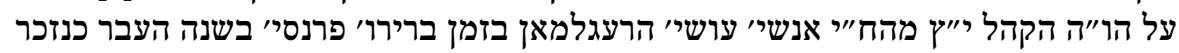

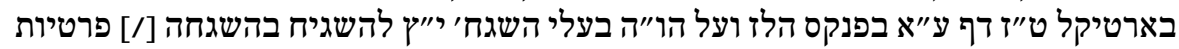

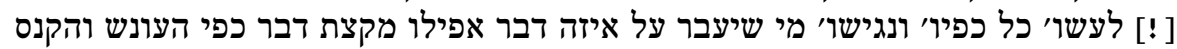
5

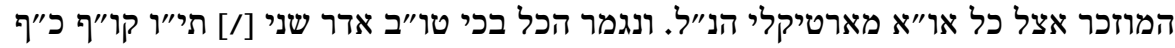

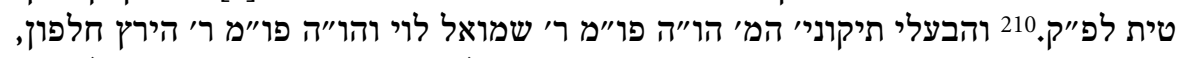

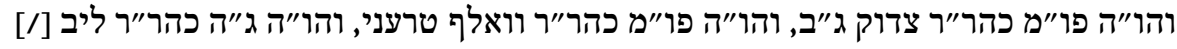

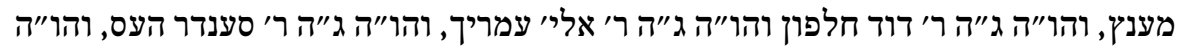
10

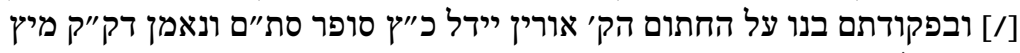

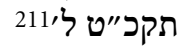

209 Offenbar Zusammenziehung der Wörter יפול und בלי

2101769 III 26.

2111769 . 

5. Königreich Polen-Litauen

Dubno (1717) 



\section{Statuten aus Dubno (1717)}

\section{Quelle: Pinkas Dubno, National Library of Israel, Heb. $4^{\circ} 349$}

Bei den Statuten der wolhynischen Gemeinde Dubno, heute in der Ukraine gelegen, handelt es sich um eines der wenigen Beispiele von erhaltenen takkanot aus dem östlichen Europa. Sowohl im Umfang als auch in der Bedeutung stehen sie den Statuten aus Krakau von 1595 kaum nach. Der Text veranschaulicht den hohen Organisationsgrad des polnischen Judentums und ist gleichzeitig ein Zeugnis des intensiven Gebrauchs des Hebräischen für einen säkularen Kontext lange vor der Haskala, beziehen sich doch die Statuten fast ausschließlich auf die administrativen Belange in der Gemeinde. Der religiöstraditionelle Inhalt rückt hingegen in den Hintergrund. Der Text ist Bestandteil des umfangreichen pinkas Dubno, der heute in der Israelischen Nationalbibliothek aufbewahrt wird und in dem sich auch noch ergänzende, teils umfangreiche Bestimmungen zur Besteuerung der einzelnen Berufsgruppen und Handwerker finden. Bei dem hier edierten Text handelt sich offenbar nicht nur um eine Kopie, sondern, wie aus den verschiedenen Unterschriften am Schluss hervorgeht, um eine Originalausfertigung, die im Protokollbuch platziert wurde. Die Statuten umfassen 174 Paragraphen zuzüglich zweier unnummerierter Artikel am Ende. Teile der Statuten sind unwiederbringlich verloren; so ist das gesamte Blatt 35 aus der Handschrift herausgerissen worden, wie auch an weiteren Blättern jeweils die unteren äußeren Ecken fehlen, sodass bei einer Reihe von Paragraphen der Text lückenhaft bleibt.

Die hebräischen takkanot weisen hier und dort zeittypische Besonderheiten in der Morphologie auf. Vereinzelt sind Wörter auf Jiddisch enthalten, die dann oft als Ligatur gekennzeichnet wurden, allerdings geschah dies nicht durchgängig. Eine Besonderheit im Schriftbild stellen zwei Versionen des Buchstaben Shin dar. Die zusätzliche und unübliche Variante mutet wie eine diagonale Spiegelung der normalen Kursivschreibung an und erinnert an das moderne Zeichen für die Zahl Sechs. Vom Schreiber wurden beide Varianten verwendet, ohne dass sich eine Regel erkennen ließe. Zeitweilig finden sich beide Varianten sogar im selben Wort.

Die einzelnen Paragraphen sind mit hebräischen Lettern nummeriert. Bei vielen wurde vom Schreiber eine spiralenförmige Linie als Zeilenfüller der jeweils letzten Zeile eines Artikels eingefügt, um so spätere Hinzufügungen zu erschweren. Bei der Nummerierung wurde einmal eine Nummer (8) 
ausgelassen. Im Text wurden kaum spätere Verbesserungen vorgenommen. Die Blätter der Handschrift wurden zeittypisch jeweils in der linken oberen Blattecke mit hebräischen Buchstaben foliiert. Die Reihenfolge einiger Blätter im pinkas wurde bei einer späteren Neubindung verwechselt, sodass heute die folgende Reihe erscheint: 41, 43, 42, 45, 44.

Inhaltlich sind die takkanot stark auf Fragen der Besteuerung fixiert, auch wenn durchaus andere Themen wie die der Wahlen zu den Gemeindeämtern - mehr als 20 Paragraphen zu Beginn des Textes - und den Kompetenzen der Funktionäre enthalten sind. In $\$ 22$ werden dabei alle Ämter in der Gemeindeführung aufgelistet. Fragen der Aufnahme in die Gemeinden als Vollmitglieder, wie sie in mitteleuropäischen takkanot häufig eine Rolle spielen, sind hier völlig ausgeklammert. Themen, die mehr in den Bereich des religiösen Brauchtums fallen, finden sich in kleiner Zahl lediglich am Ende der Statuten und unterstreichen den insgesamt recht säkularen Charakter des Textes. Insgesamt ist der Text inhaltlich klar strukturiert; die Überschriften über elf thematischen Abschnitten (mit Ausnahme des ersten) erleichtern die Auffindung von Passagen, was bei der Benutzung des umfangreichen Textes nicht unwichtig gewesen sein dürfte.

Schon einmal erfolgte eine vollständige Edition der takkanot Dubno durch Yizchok Levitats im Jahr 1937. Er erwähnte eine detailgenaue Kopie des pinkas, die in der Bibliothek des YIVO in Wilna aufbewahrt wurde, während der pinkas selbst - offenbar das Original - bereits 1937 in der Jerusalemer Universitätsbibliothek lag. Welche der beiden Varianten von ihm genutzt wurde, ist nicht völlig klar, es gibt jedoch Hinweise, dass es nicht die Jerusalemer Vorlage war. Levitats verzichtete in seiner Edition auf die Wiedergabe der fragmentarisch erhaltenen Teile von Blatt 35. Die Transkription der Artikel 150-155 auf fol. 42 erfolgte nur teilweise ( $\$ \$ 150-153$ ) und ohne Zuordnung in die Reihenfolge, die Levitats durch die falsche Bindung bzw. durch die unkommentierte Kopie nicht erkannte. Es liegt daher nahe zu vermuten, dass er die Wilnaer Kopie benutzte, die an dieser Stelle und an anderen offenbar ungenau war, wie zahlreiche falsche Lesungen und Auslassungen belegen. Da diese Edition in Historishe shriftn nur schwer zugänglich ist, schien die erneute vollständige Publikation des Textes angebracht.

Kürzlich erfolgte, offenbar auf der Grundlage von Levitats' Edition, eine Teilwiedergabe der takkanot von Anna Michałowska, die sich allerdings auf die Paragraphen 1-37 beschränkt. Dieser Teil wurde von der Herausgeberin zudem ins Polnische übertragen und kommentiert. 
[fol. $33 \mathrm{r}$ ]

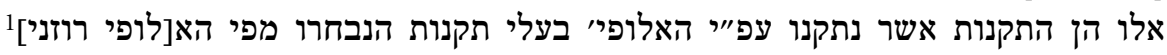

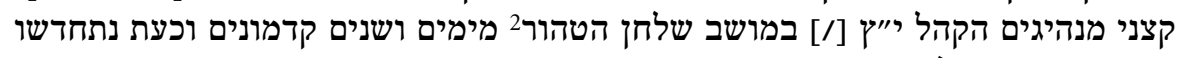

בתוספות מרובה לפי הזמן.

באשר שלפי דת תורתינו הקדושה כל איש שבשם ישראל יכונה מחויב ליתן לצורך א 5

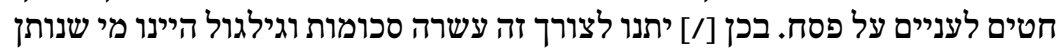

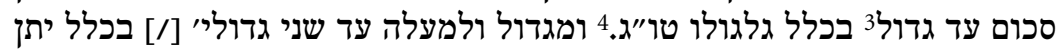

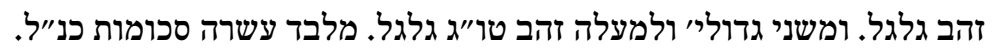

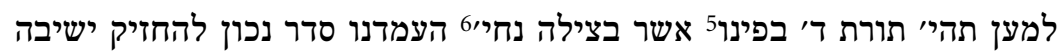

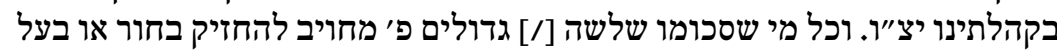
10

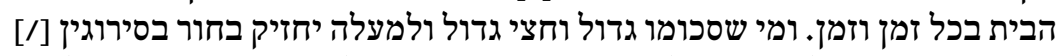

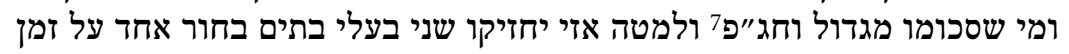

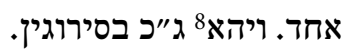

המפורסמת אין צריכין ראיי גודל העניות שנתרבה כעת והוצאות גלוּ גדולות המוטל ג'

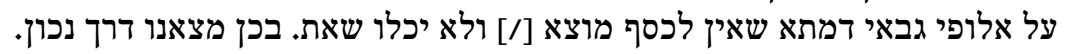
15

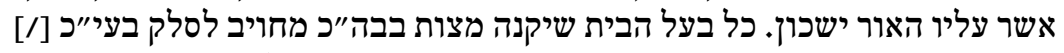

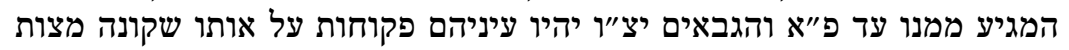

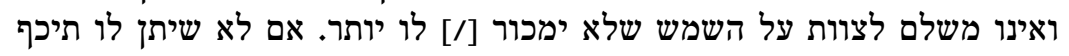
משכון עבור המצות שיקנה.

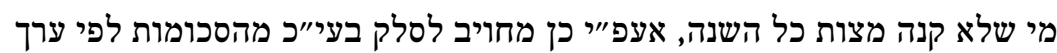
17 20

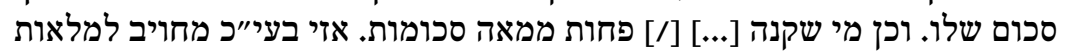

$$
\text { עד מאה סכומות כפי ערך [...] }
$$

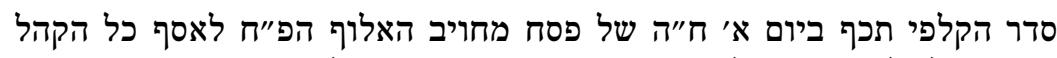

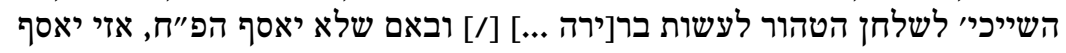

1 Textverlust durch beschädigten Blattrand. Die fehlenden Worte konnten durch eine Abschrift der Titelzeilen unmittelbar unter dem Originaltitel ergänzt werden. Über diesem und dem folgenden Wort wurden später mehrere Wörter offenbar als Schreibübungen niedergeschrieben. Diese meisten dieser Wörter stammen aus dem Titel.

22 Chr 13,11.

3 Grosz (Groschen).

4 ט"ו גדולים.

5 Ex 13,9.

$6 \mathrm{Klgl} 4,20$.

7 וחצי גדול פוליש.

8 Dieses Wort auch als Abkürzung gekennzeichnet. 


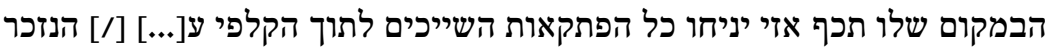

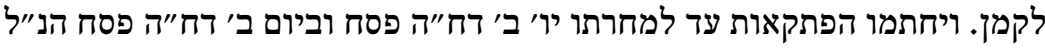

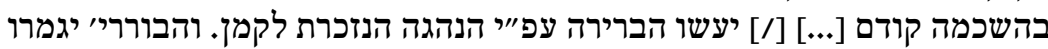

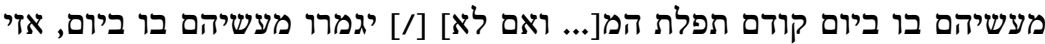
בטלים מעשיהם ומבוטלים ואין ממש בהם.

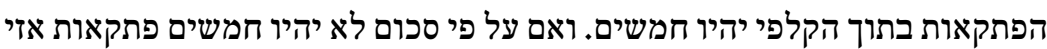

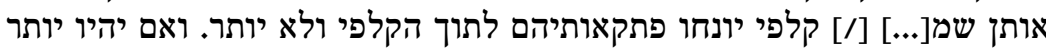

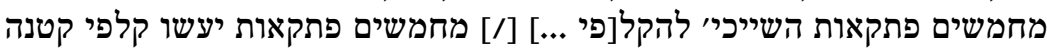

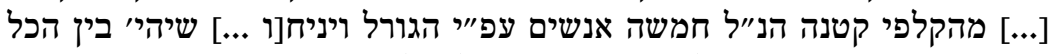

חמשה וחמשים פתקאות ולא יותר ובתוך הקלפי לא יונח אף אי אי מהבוררי' [...]

ואלו הן השייכים לקלפי בקביעו[ת ..]ם ראשוני' מהקלפי ראשים פרים טובים עיקורים

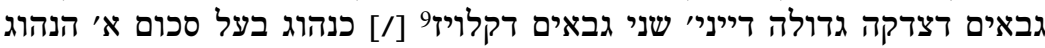

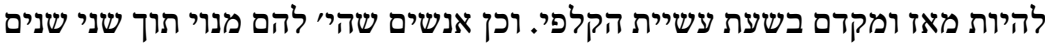

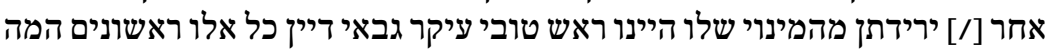

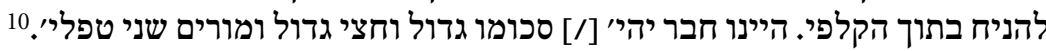

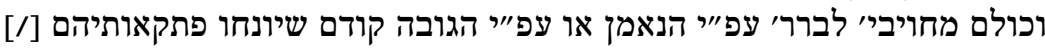

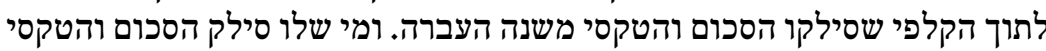

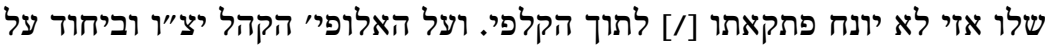

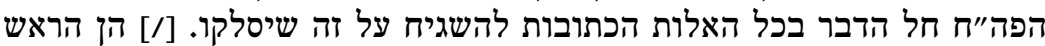

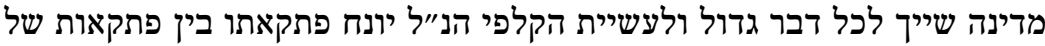

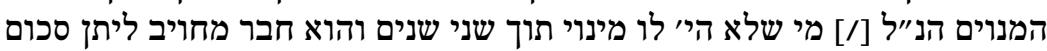

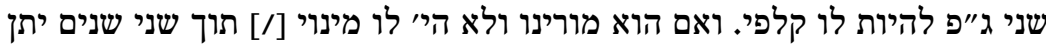

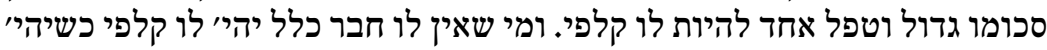

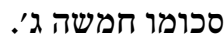

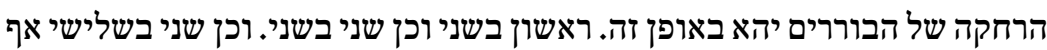

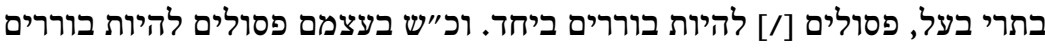
יחד. וכן שלישי בשלישי בעצמים ליות בוררים אבל שלישי בשלישי [/] בחד בעל כשרים. וכלים בורים

9 Klaussynagoge, aus privaten Mitteln errichtete Institution, diente mitunter auch als Jeschiwa.

10 Kleine Kupfermünze; wurde von Mordechai Nadav mit »szelag« (Schilling) identifiziert; Mordechai Nadav, The Minute Book of the Jewish Community Council of Tykocin. 1621-1806, Bd. 2, Jerusalem 1999, 101 (hebr.).

11 Die Nummerierung ' $\pi$ (8) wurde offenbar versehentlich ausgelassen. Levitats hat diese Auslassung in seiner Edition entweder übersehen bzw. nahm die von ihm verwandte Vorlage darauf keine Rücksicht, siehe Yizchok A. Levitats, Der pinkas fun Dubner kahal [Das Protokollbuch der Dubnoer Gemeindeführung], in: Elias Tscherikower (Hg.), Historishe shriftn, Bd. 2, Wilna 1937, 80-114. 


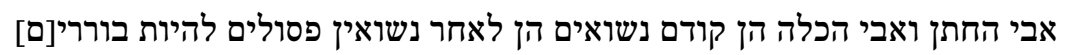

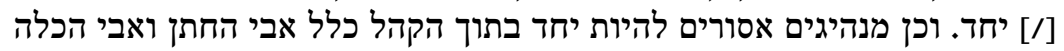
הן קודם נשואין והן לאחר נשואים אסורים לחיות יחים

ב....

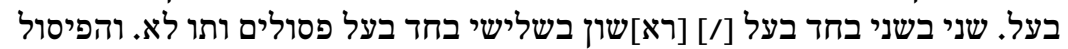

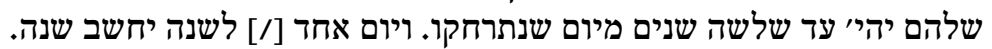

א.... רים ככב יהי' לאחר שיניחו הפתקאות לתוך הקלפי על ידי הבעל סכום כנ"ל כשים

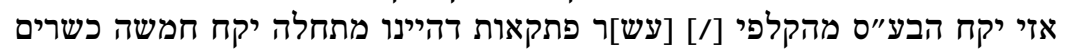

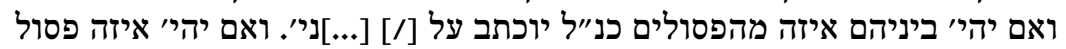

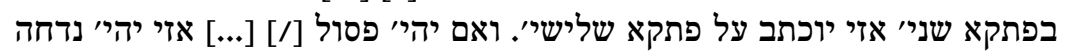

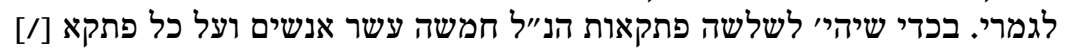

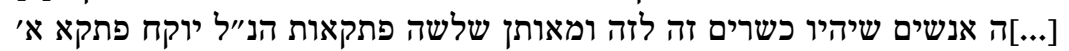

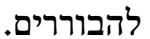

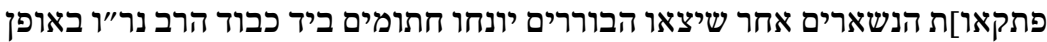

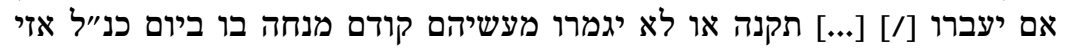

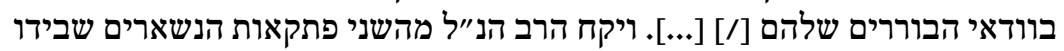
פתקא א' והמה יהיו בוררים.

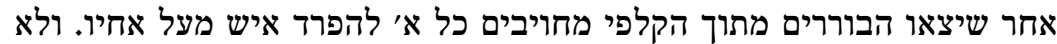
[fol. $34 \mathrm{r}$ ]

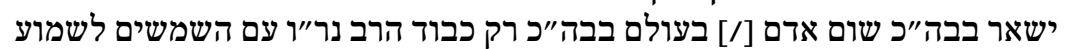
השבועה מפי הבוררים.

השבועה של הבוררים יהי׳ כן שלא יעברו על שום דבר וחצי דבר מהתקנות האלה.

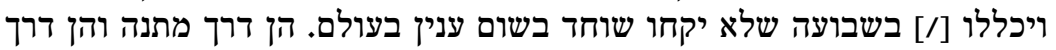

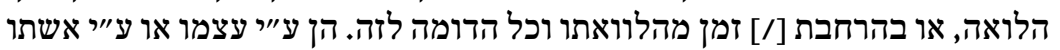

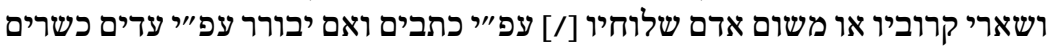

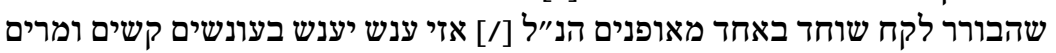

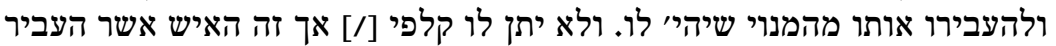

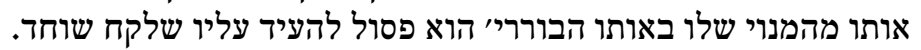

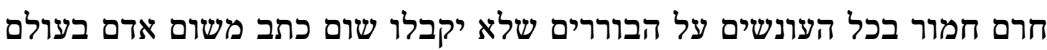
ט"ט

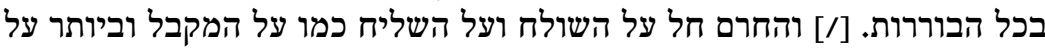
30

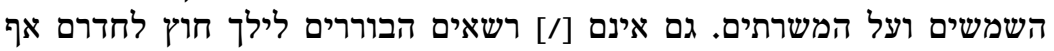
פסיעה אחת אם לא שיהיי נאמשן עמים גמם אינם 
ט"ז

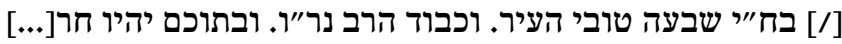

י"ח כשיגמר התמנות אצל הבוררי' מחויבים המה לחתום [...] [/] כל הבורריי לדבר

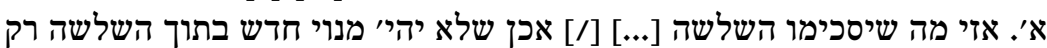

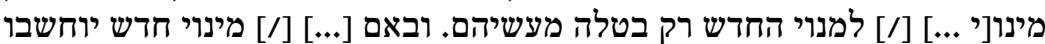

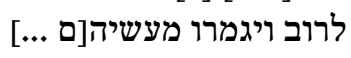

י"ט הבוררים מחויבים לכלול בשבועתם הנ"ל שלא לעשות לשום אדם שום מנוי

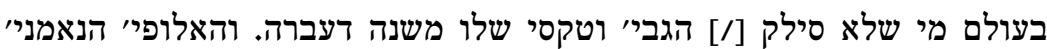

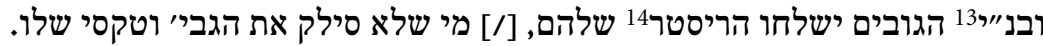

לאחר שיגמרו הבוררי' את הריסטר התמנות יביאו מיד את הריסטר ליד כבוד הרב

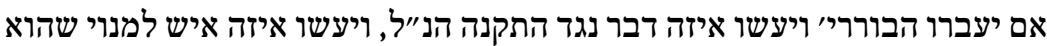

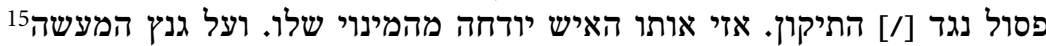

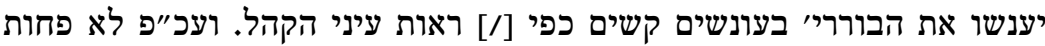

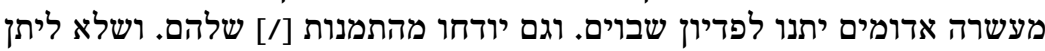
לו שום מנוי להבא עד אחר שלשה שנים.

באשר שרעה ראינו בפשע הארץ16 רדו שררי' ויוסף יערי דעת כנ"ל, עלה במוסכם

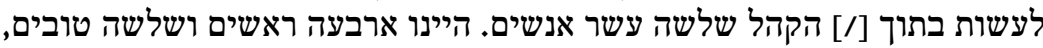

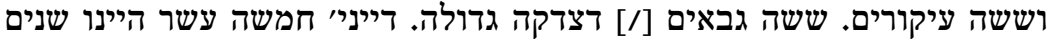

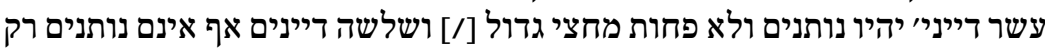

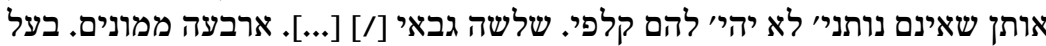

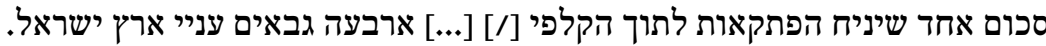

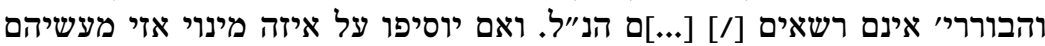
בטלים [/] [...] דבריהם ברצון הקהל. וא' יכול לעכב על זה יהי' מי שיה'.

12 Die gesamte linke untere Blattecke fehlt.

13 Lesung unklar.

14 Register, Verzeichnis über die eingenommenen Gelder pro Person. Dieser Begriff scheint für Osteuropa üblich gewesen zu sein, in den anderen hier edierten takkanot findet er keine Verwendung.

15 Dieses Wort über der Zeile.

16 Spr 28,2.

17 Koh 1,18 . 


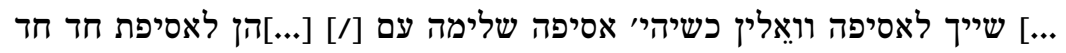
]

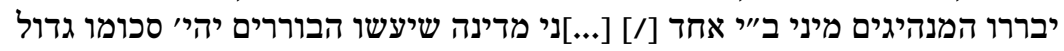
ולמעלה [/] [...]יך מינוי [...] יעשוי אחורו לאיש אחד כנהוג מאז ומקדם.

18 [fol. $35 \mathrm{r}$ ]

ד"ד

[…] [ ד

$[\ldots] \quad[1,]$,

ך"ז לענין שיועמד במינוי [...] [/] שלו בין הכל יהי' שלשה [...]

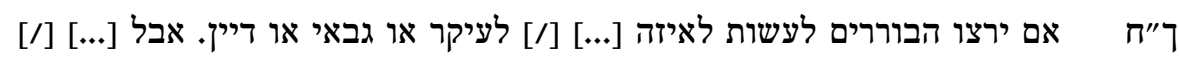

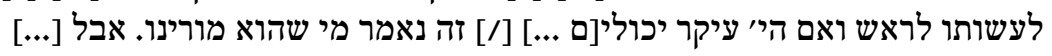

אם יעלה על דעת הבוררי' לעשו]ת ...] [/] אף שנה אחת יכולין לעשות [...] [/] תוך

ך הארבעה ראשים רק של....

[fol. $35 \mathrm{v}$ ]

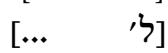

15

$\left[\begin{array}{ll}\cdots & \\ & \end{array}\right]$

[ל"ג . ...] השלחן. ועיקורים [/] [...] יהי' כסדר הנ"ל. [/] [...]ים עליו שני ראשים. ועיקורים [/...]

[ל"ד .....]רדים יתקיים על נשיאתו אזי יגמור [/] [...] אחר החכמה והזקנה כנרשמים [/] $[\ldots]$

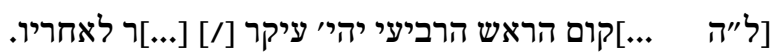

[fol. $36 \mathrm{r}$ ]

ל"ו

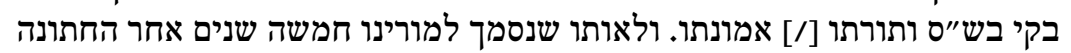

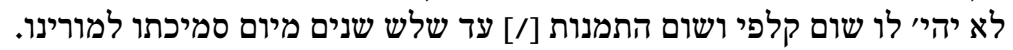

18 Folio 35 ist fast vollständig aus der Handschrift herausgerissen worden, lediglich die Anfänge der Zeilen sind noch vorhanden. Levitats verzichtete in seiner Edition auf die Wiedergabe der Fragmente. 
ל"ז כשיהי' אסיפה שלימה אזי יבחרו הקהל מנהיג אחד ושמאי לאסיפה עפ״י הן ולאו

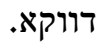

ענייני19 גבאי דצדקה גדולה

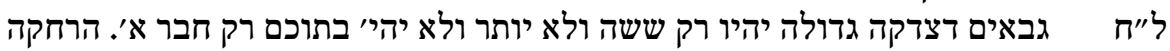

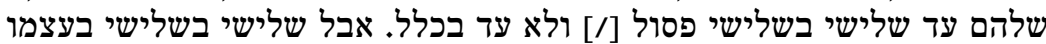

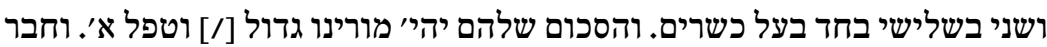

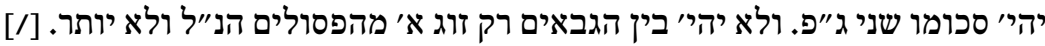

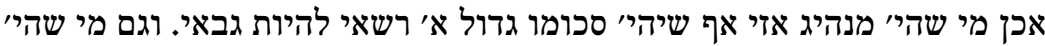

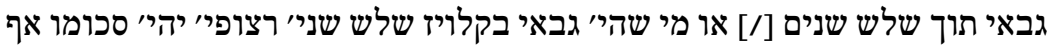

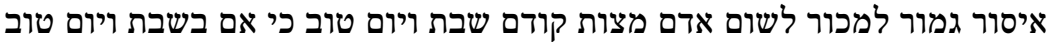
ל"ט

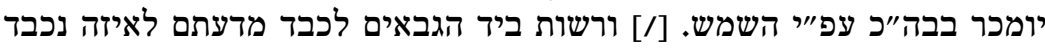
עמידות או שאר כיבוד בחנם היינו לבעל החתונה או לבעל בעיר ברית.

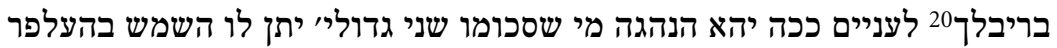
מם

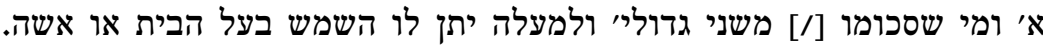

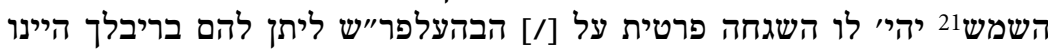

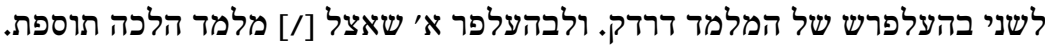

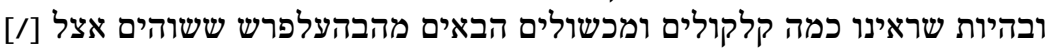
המלמדים זמני' הרבה. בכן חלילה וחלילה על המלמדים הכים להחזים כליק בהעלפר א׳ יותר

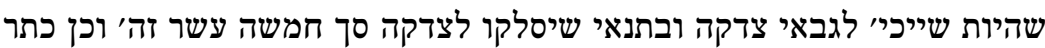
מו"א

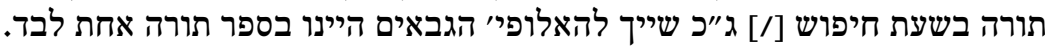
בין בשבת בין ביום טוב בימים נוראים. [//] והשאר ימכרו. הופבים

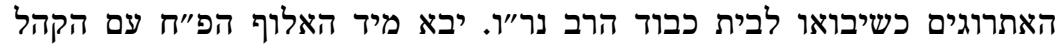

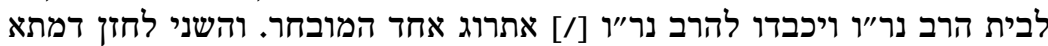

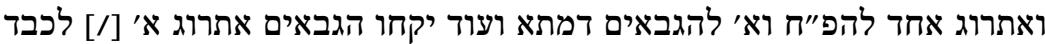

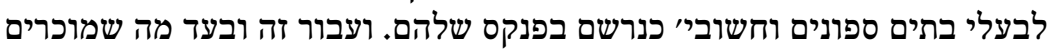

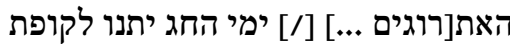
הקהל ח[מש] יושים ושלשים זה'.

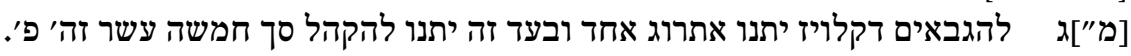

19 Am rechten Blattrand, gestrichen: $\pi$ "ל.

20 Offenbar andere Bezeichnung für pleten, die Verköstigungsscheine für Arme.

21 Danach ein Wort gestrichen. 
ענייני גבאי דקלויז

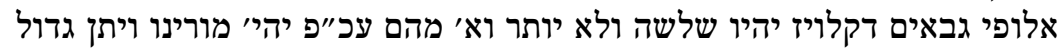
מו"ד

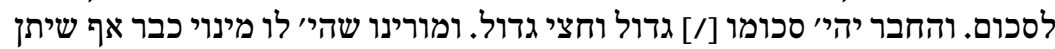

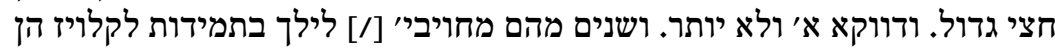

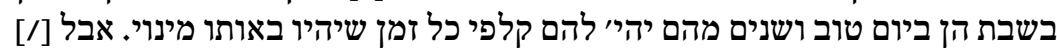

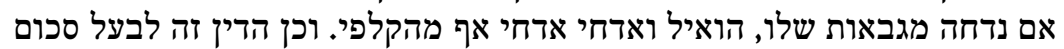

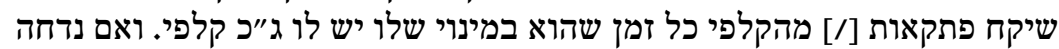

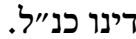

הגבאים דקלויז לא יעשו הבוררי' כי אם שיהיי לו ששה שנים החתונה שלו. וכן

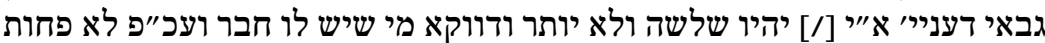

מו"ה משלשה שנים אחר החתונה.

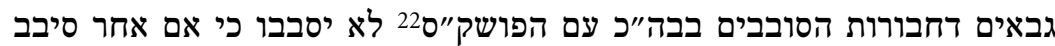
מ"ו הגבאים דמתא. [/] ואם יעברו אזי רשות ביד הגבים הגבאים דמתא לגעור בהם ולקנוס ליפוס

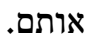

ענייני דיינים 15

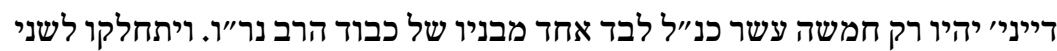
מוזז

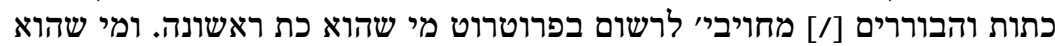

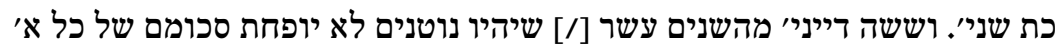
וא׳ משני טפלי' וח' טפל. וששה יהי' סכומם חצי גדול.

ריחוק של הדיינים יהיי חדא דרגא יותר מדין תורה. היינו ראשון בשני וכן שני 20 בשני אף בתרי [/] בעל וכן שני בשלישי חד בעל לא ישרי חורו בכת אחת.

הדייני' לא ישבו למקום קבוע למשפט בבית כבוד הרב נר"ו. חוץ מדבר הקטן מו"ט

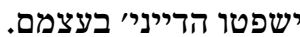

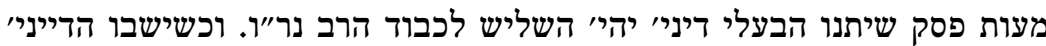

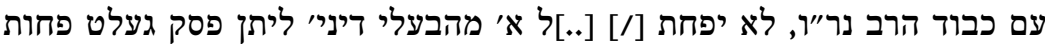
[נין] 25

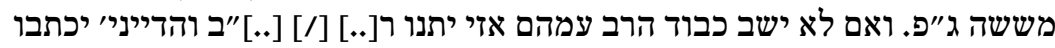
ויחת[מו] הפסק תכף ומיד קודם שיצאו ממקום מושב משרם.

[fol. $37 \mathrm{r}$ ]

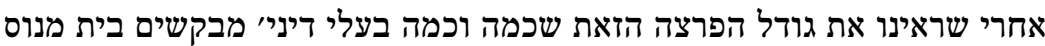
30

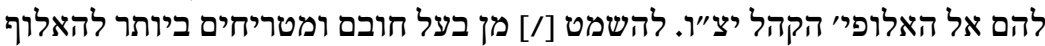

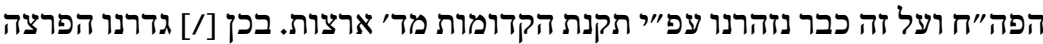

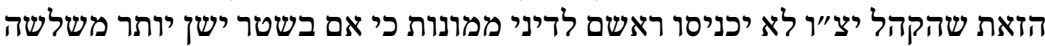

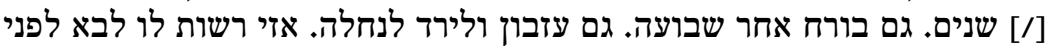

22 Sammelbüchsen. 
הקהל. וזולתיה חל החרם [/] על הפה"ח שלא לאסף את הקהל עבור דיני ממונות

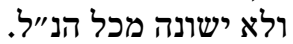

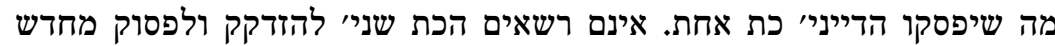
נ"ב

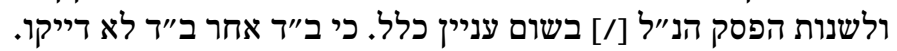

פסק דין לישבע בפני שני הדייני' אינם רשאים הדייניי ליקח יותי יותר מששה גדוליו $\left.\lambda^{\prime \prime}\right]$

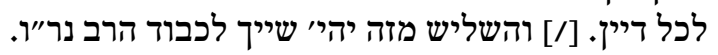
שומא בב"ד יתן הבעל שומא מכל מאה הנרשם שנים עשר ג״פ. ]

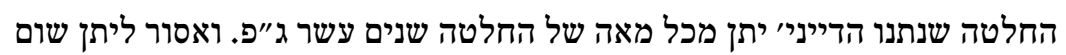
נ"ה 10

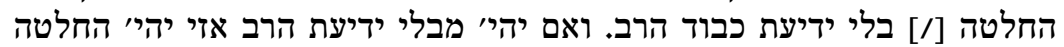
בטילה.

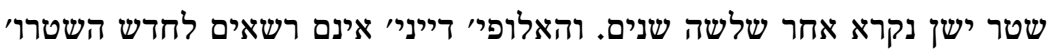
I"y

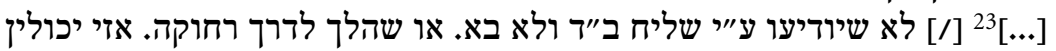

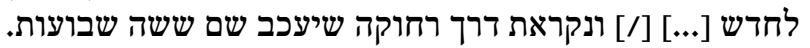

שטר ישן ונכתב פסק ודת"ן יתהגו הדייני' כפי הנהגה שהי' מאז ומ[תמיד ...] $T^{\prime \prime}$

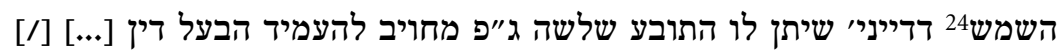
$\left[\pi^{\prime \prime}\right]$

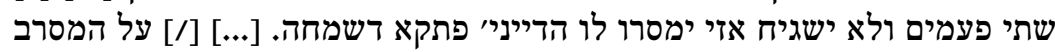

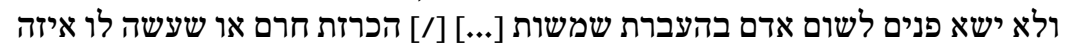

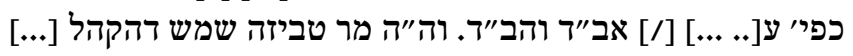

באסרו חג של פסח מחויב האלוף הפה"ח לאסף את כל השייכיי להקלפי דשמאות ט["נ]י בלי שום התנצלות [/] בעולם שלא יהור הורס ח"ו מעמד ומסת ומצב הקהלה.

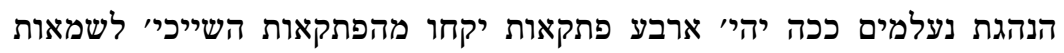
10

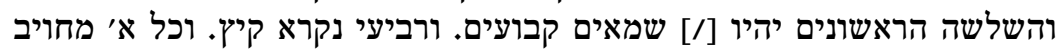
לעשות הערכה על כל בני הקהלה לבד הפסולים [/] שלו. וכן השונא שלו לא יעים יעריך 25 הנעלם.

[0]"א השמאים מחויבי' לישבע בפני השמש או בפני הנאמן שיתנהג עם כל א׳ וא' לשם

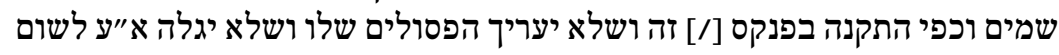

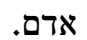

23 Die rechte untere Blattecke fehlt.

24 Dieser Artikel wurde von Levitats ausgelassen. 


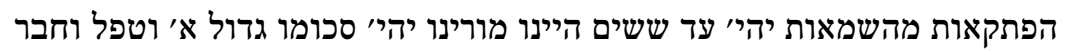

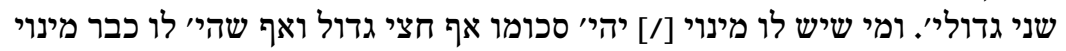

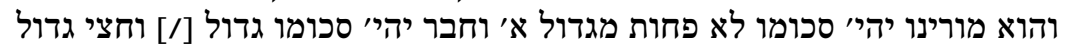

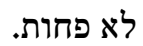

בתוך ארבעה שמאים הנ״ל לא יהי׳ רק אחד שנותן חצי גדול אף שיש לו מינוי. והשמאי הנעלם לא יהי' כי אם [/] עשרה שנים אחר החתונה שלו.

של.... 7"0]

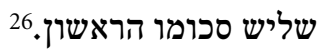

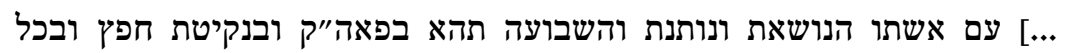

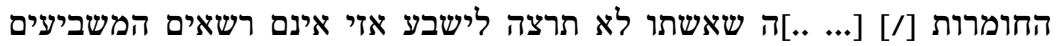
"0] לפחות סכומו מריסטר [/] [...] בריסטר כה יהי סכומו.

[.... 1"ס]

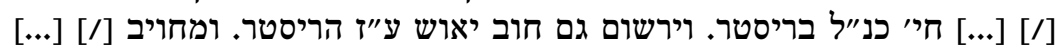

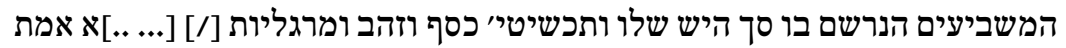

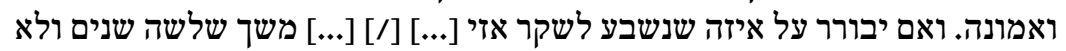

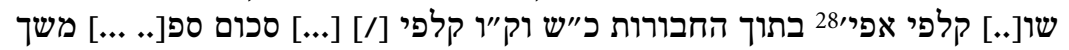

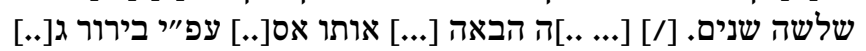
$\left[x^{\prime \prime} 0\right] \quad 5$

[ב"ס] 5

קודם שימסרו האלופי' נאמני' הריסטר של הנעלמים להקהל מחויבי' הקהל ליקח T"O

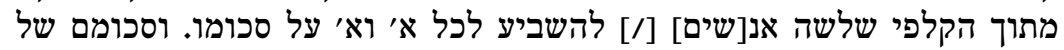

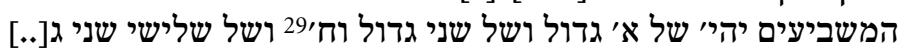

ריחוק בין השמאים הן גלוים והן נעלמים והן איב"ר שמאים בין המעריך להיך להנערך $\pi^{\prime \prime 0}$

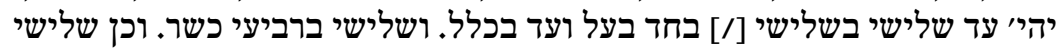
בשלישי בחד בעל כשר לאיב״יר שמאי ובלבד שלא יעריך בליך [/] השלישי שלו.

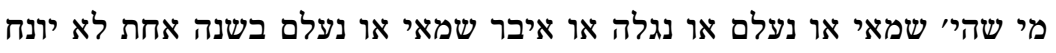
0 10 15 פתקאו לתוך השמאות [/] בשנה שלאחריו. הן באור בשמאות והן באיבר שמאות.

25 Textverlust durch fehlende rechte untere Blattecke.

26 Darunter zwei Zeilen, die offenbar zum Paragraphen gehörten, später aber gestrichen wurden.

27 Dieser Artikel wurde von Levitats ausgelassen.

28 אפילו

29 וחציו 28. 
לאחר שיגמרו הריסטר של הארבעה שמאים כנ"ל אזי השלשה הראשונים הנקראים

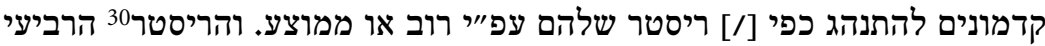
לא ידון ולא ידרש לשום דבר. רק להעריך [/] הפסולים לתר שלת על של שלשה הראשונים.

מי שהוא בעיר ויעלה פתקאו מהקלפי להיות שמאי ולא ירצה אחת דתו להעבירו ע"א

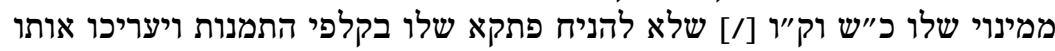
כפל כפי סכומו דאשתקד.

מי שאינו בעיר בשעת הקלפי של שמאות אינו רשאי להיות איבר שמאי אף שיבא אחר השמאות.

הסוחר או חנווני31 יהא ערכו מכל מאה זה' חצי טפל. בעלי הלוואות יתנו ערכם ע"ג

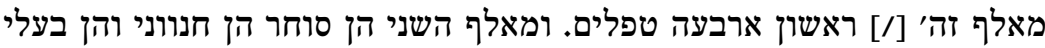

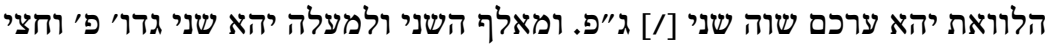
גדול.

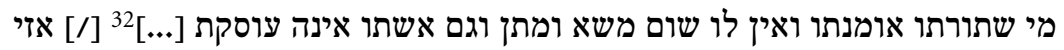
Y ע

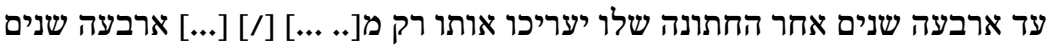

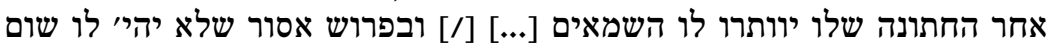

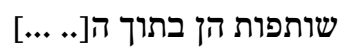
מי שיש לו אסיג33 או חובות על איזה קהלה והן קצת מחוסר גובי[.....] ע"ה

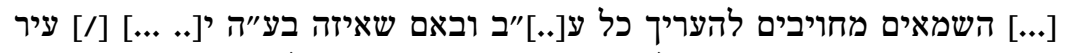

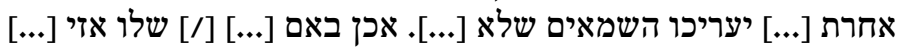

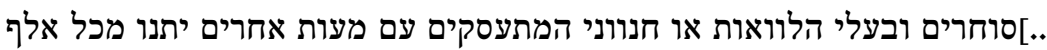

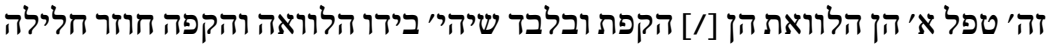

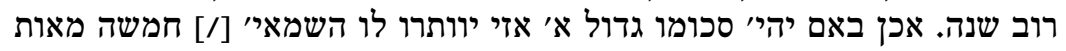

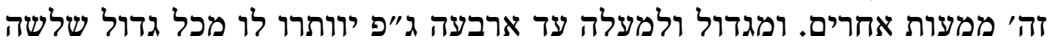

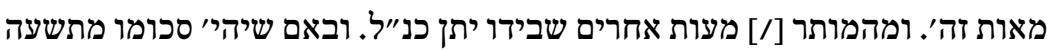

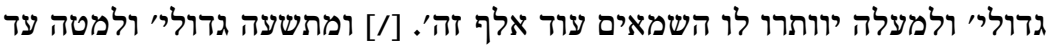

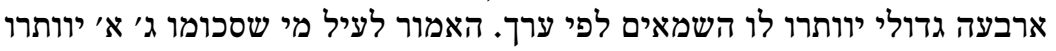

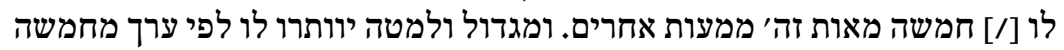

30 Gemeint ist wohl: שמאי.

31 Ladenbesitzer.

32 Textverlust durch fehlende linke untere Blattecke.

33 Anweisung. 
תכשיטי כסף וזהב ואבנים טובות אלמוגים ומרגליות. כל בעה"ב שניותי שליותן לסכומו ["ע]

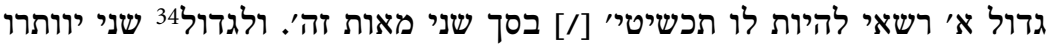

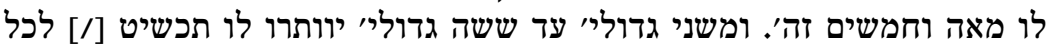

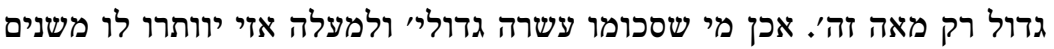

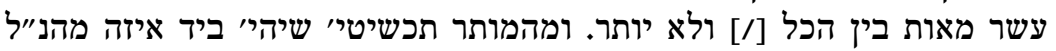

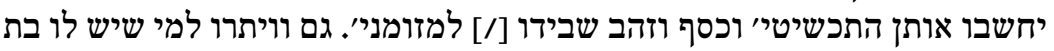

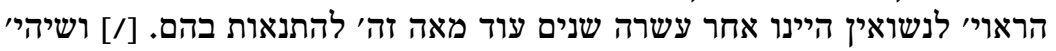

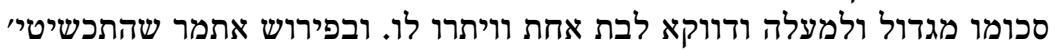

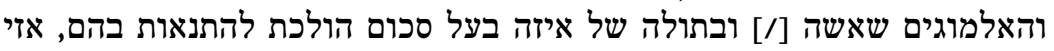

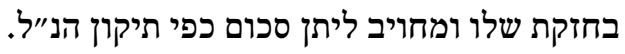
10

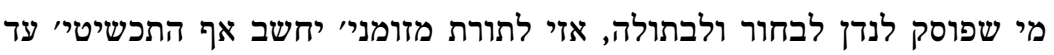

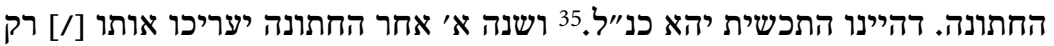

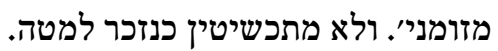

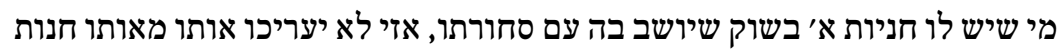

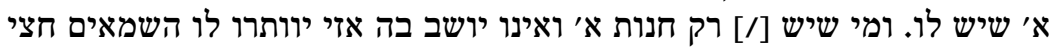

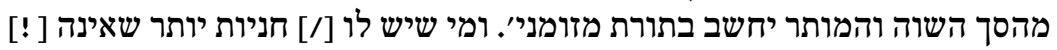

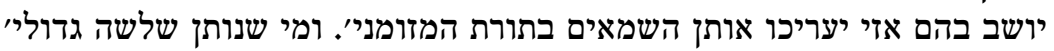

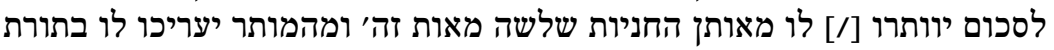

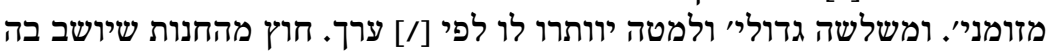

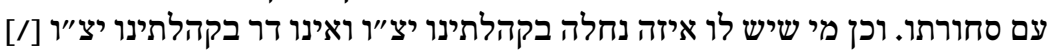
אזי השכירות מאותן הנחלאות שייכי' להקהל עד על שיסלק המגיע לפיר לפי התקנה.

ע"ט פי36 15 20

מי שיושב בחנות שלו, אף שיש לו מעט מזער רק שהוא יושב בחנות שלו, אזי לא יופחת סכומו מחצי גדול. [/] [...] ${ }^{37}$ בחנות המושכרת. מער מזיק לא יו יופחת סכומו מטפל. ...

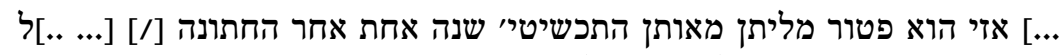

פ״"ד מי שקנה בית או חנות או איזה נחלה לבד מקומות בבה"כ, אזי מחויב ליתן שנה

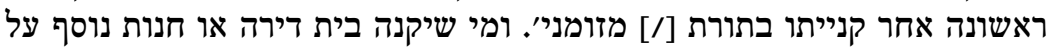

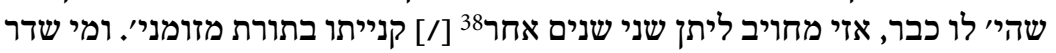

34 Danach ein durch Streichung unleserliches Wort.

35 Die letzten vier Worte über der Zeile hinzugefügt.

36 In der Handschrift: $\boldsymbol{N}^{\prime \prime}$.

37 Textverlust durch fehlende untere rechte Blattecke.

38 Danach ein durch Streichung Wort unleserlich. 


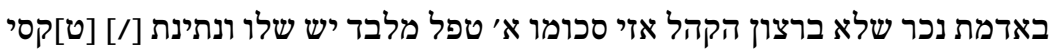

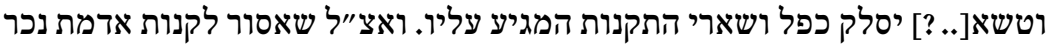

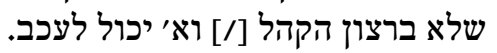

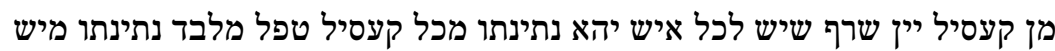

הנהגת המוזגים

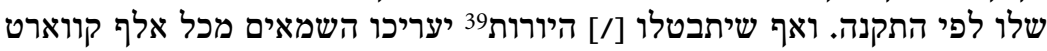

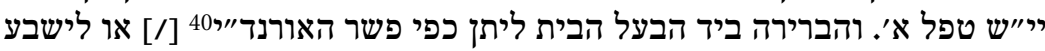
וליתן מכל אלף קווארט יי"ש אחר שישבע שני פשירי כפיטים מלבד היש שלו.

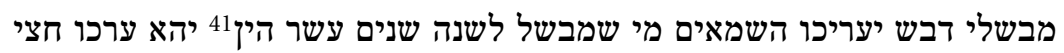
פ"ר גדול מלבד היש שלו. וה"ה לפ"ע מעים [/] להוסיף ולגרוע.

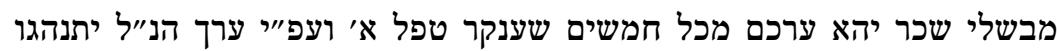
פ"ז

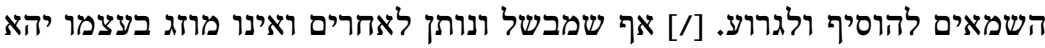
נתינתו ג"כ כנ"ל מלבד הוסיף ולגרוע. שלו.

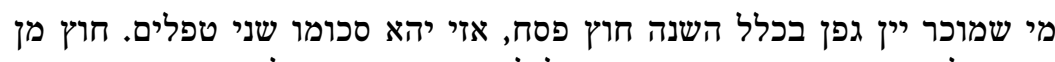
פ"פ

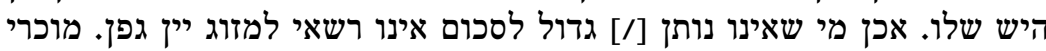

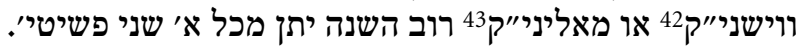

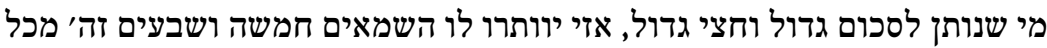
פ"ט

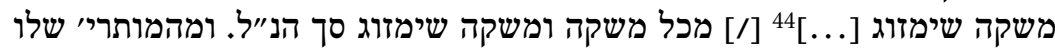
יעריכו אותו כפי התקנה אף [...]

מי שיש לו ברייא הוי"ז.45 אזי יעריכו אותו מן ברייא הוי"ז שני טיש טפלים חוץ מיש

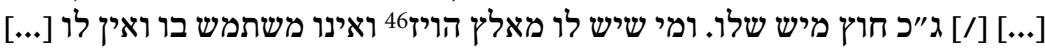

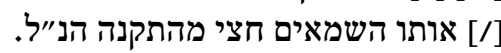

מבתי אכסניאות שעוברים ושבים מצוים שם, אזי הדר בו יתן [...] [/] זה יתן צ

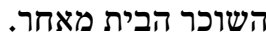
אכן מי שהבית שלו ודר בתוכ]ו ...] [/] ושארי התקנות.

39 Kessel.

40 Arrende, Pachtkontrakt.

41 Biblisches Hohlmaß.

42 Kirschlikör.

43 Himbeerlikör.

44 Textverlust durch fehlende linke untere Blattecke.

45 Brauerei.

46 Mälzerei. 
צ"ב מי שיש לו משכנות של כסף וזהב ויין של ערלים שאינו יכול למכור [...] [/]

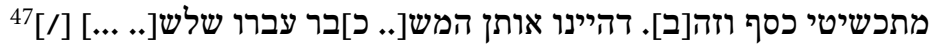

[fol. $39 \mathrm{v}$ ]

צ"ג

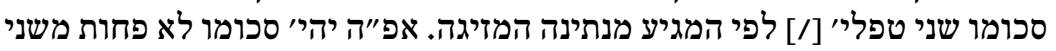

טפלי'. והוא שמחזיק שני [/] לפי המגיע מנתינה.

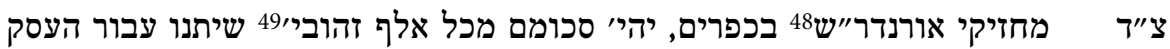

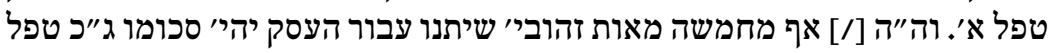

אחד.

צ"ה

10

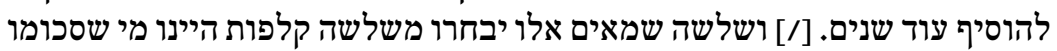

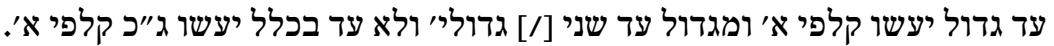

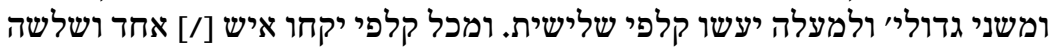
אלו יהיו שמאים. וכן הדין לאיבר שמאלים שלפים שלישית.

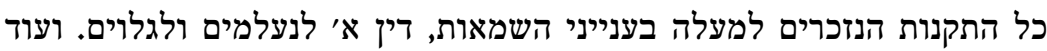

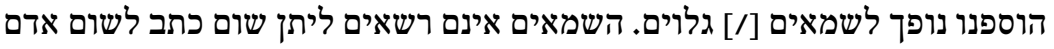

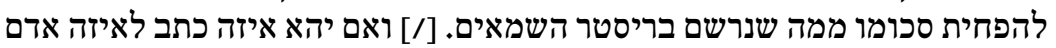

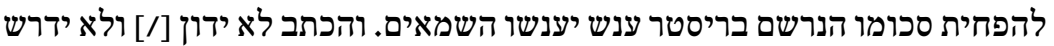

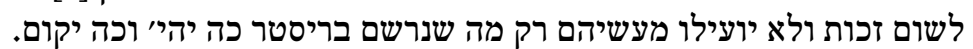

ש...

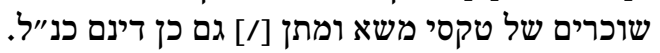

ן.... יעריכון ש1 שום אדם לטקסי ערך פחות מסכום. רק תורה א׳ ומשפט א׳ לסכום

ש...] אזי יעריכו אותו שלא בפניו ובבואו לביתו יכולין השמאים לפחות [/] [... ...]

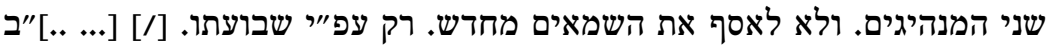
חלוק או שיכתבו בריסטר יבא לפנינוּו ואסת השמים

47 Danach folgen noch zwei Zeilen, von denen lediglich die unleserlichen Anfänge erkennbar sind.

48 Pächter.

49 Lesung unsicher.

50 Textverlust durch fehlende rechte untere Blattecke.

$51 \$ \$ 98$ bis 102 wurden von Levitats nicht wiedergegeben. 
[ק"א

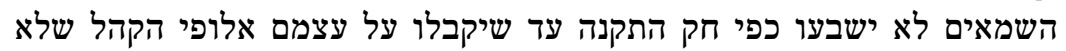
ק"ב

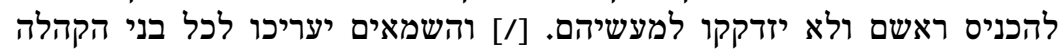

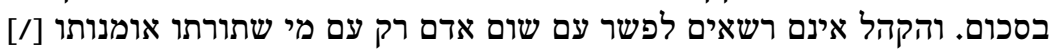

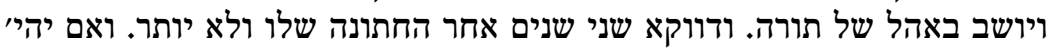
סכסוך בין השמאים אחרי [/] רבים להטות וכן יקום.

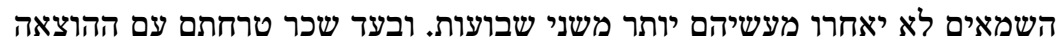
[ג”ק]

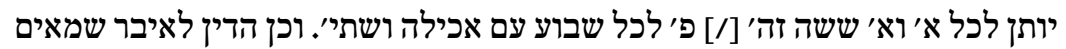
ששה זה' לשבוע לכל א'. ומחויבים לגמור מעשיהם בשבוע [/] אחת ולא יותר. השמאים אחר שיגמרו הריסטר יחתימו את הריסטר בחתימה וימסרו הריסטר ליסרי ליד ומריד כבוד הרב נר"ו. ויהא צרור וחתום, [/] עד אחר גמר הריסטר שחר של איבר שמאי.

אם יהי' מוסכם אצל השמאים להשביע איזה איש על סכומו מחויבי' השמאים

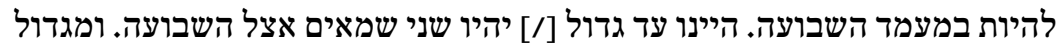
ולמעלה יהיו כל השמאים במעמד השבועה.

השמאים יהיו עיניהם פקוחות על כל איש מי שהוא מטופל בבנים והוצאה שלו כופו מרובה או שיש לו הוצאות הכרחיות [/] או פו יתומים מוטרוא מטלים עליו ועל אים איש כזה שלו יעיינו להקל מעליו סכומו.

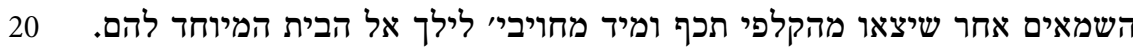

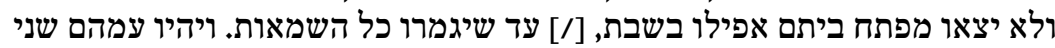

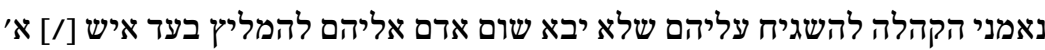

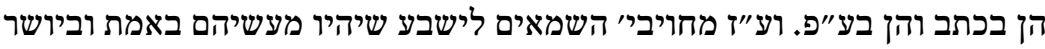

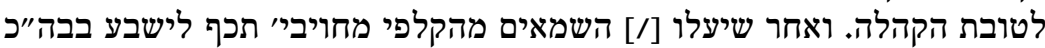

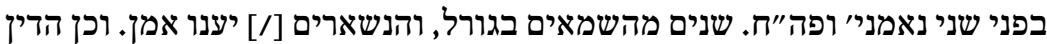
באיבר שמאים.

מי שהיי לו שונא אצל השמאים יבא לפני אלופי הקהל יצ"ו, וכבוד הרב נר"ו. ק

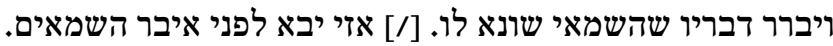

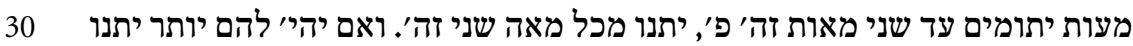

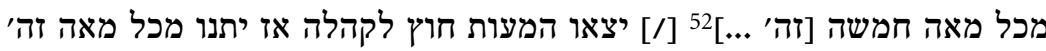

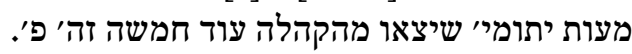

52 Textverlust durch fehlende untere linke Blattecke. 


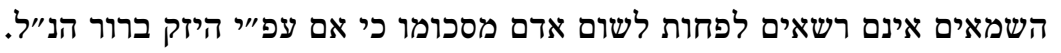

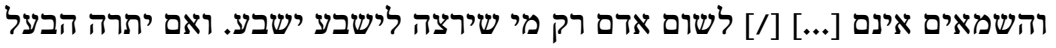

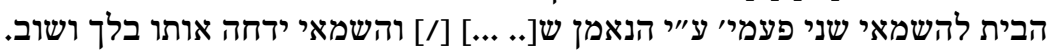

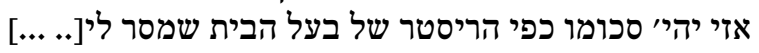

השמאים אינם רשאים לגלות סך ערך שלו כ"ש של חבירו ויכלול בשבועה זו. 5

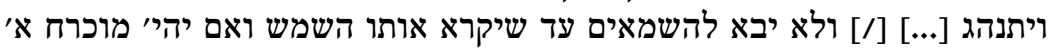

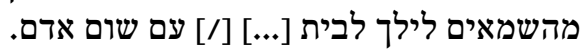

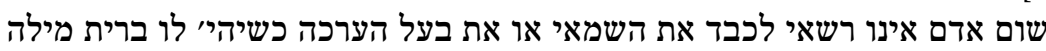
[fol. $40 \mathrm{v}$ ]

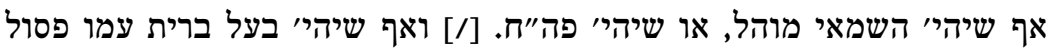
קי"ב

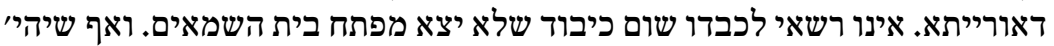

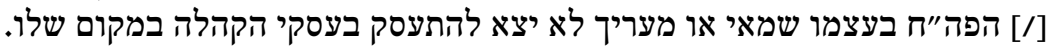
והוא יהי' עם השמאים. בעצמי

השמאים יהי' עינם פקוחות על אותן אנשי ז"ץ שיש להם משא ומתן זולת מחי' קיגוג קצבות להעריך אותם כפי ראות פיחות על עיתות אניהם.

מי שנותן לנדן בתו או מזומני' לבנו כשיוצא הנדן או המזומי' חוץ לקהלה מחויב

הנהגת השמאים גלוים או המשביעים שיעלו עפ"י גורל באסיפת הקהל וירצי או לפו לפשר קט"ר

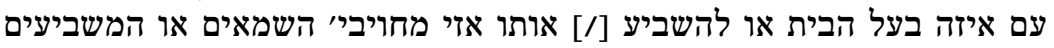

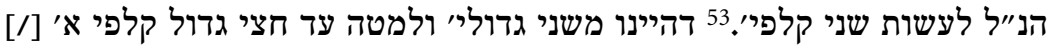

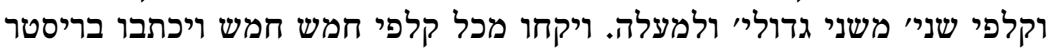

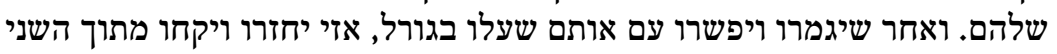
קלפות חמש חמש אנשים אחרים, כנ"ל.

אלמנת שיש להם הכנסה מנחלאות או מחניות יתנו מהכנסה ההיא חלק חמשה

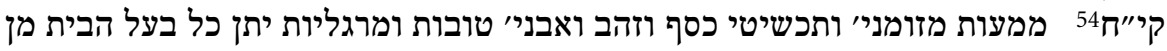

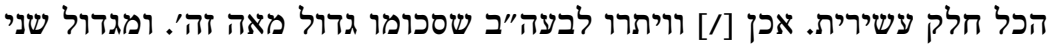

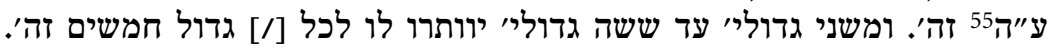

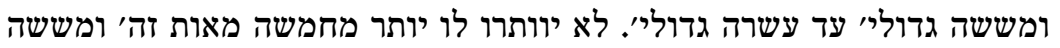

53 קלפיות

54 Hier hätte eigentlich קיפו"ז folgen müssen, was vom Schreiber aber offenbar vergessen wurde.

55 ע"ה hier für den Zahlwert 75. 


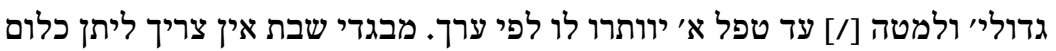

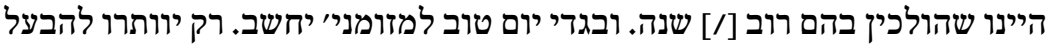
הבית מבגדי יו"ט מאה זה' ולא יותר.

מי שיש לו חובות או אסי"ג56 על קהלתינו יצ"ו אזי מחויב לכתוב קבלה על חלק

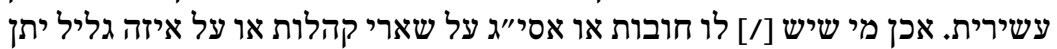
אפשריפט על חלק עשירית ג'וכ כנובות.

כל .... כ"ק]

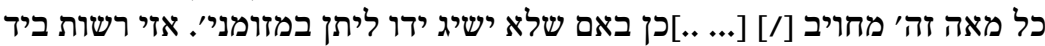

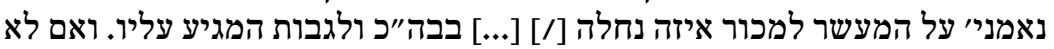

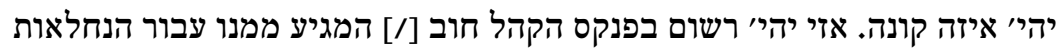
הנ"ל.

א.......

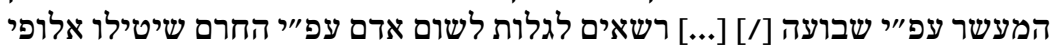

]קך הקהל עליהם.

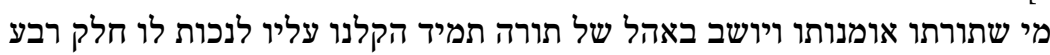
קך"ב

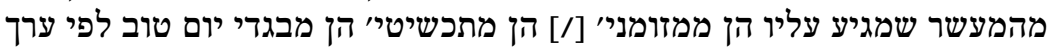

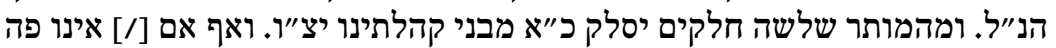
יסלקה [!] אשתו. היינו שלשה שנים אחרק החתונים מכונה.

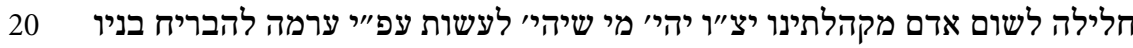

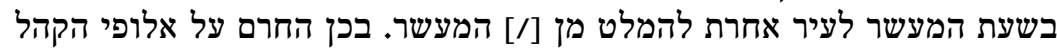

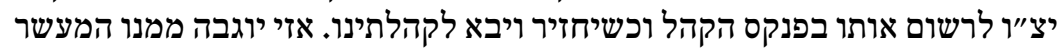
[/] עפ"י שבועה כאלו הי' בשעת המעשר ואף א׳ יכול לעכב.

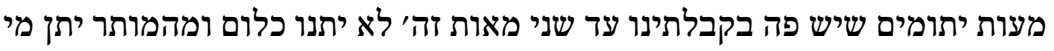
שהמעות בידו מכל מאה זה' [/] שבעה זה' שת מחצי.

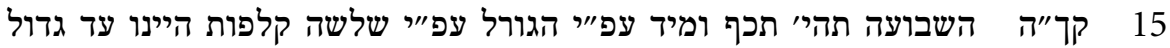

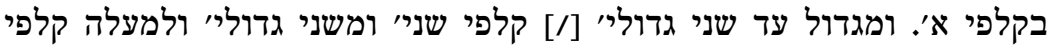

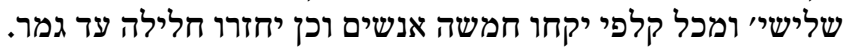

56 אסיגנציה.

57 Textverlust durch fehlende untere rechte Blattecke. 


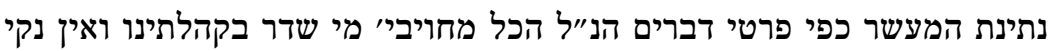

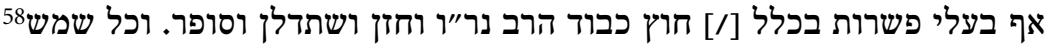

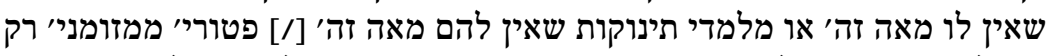

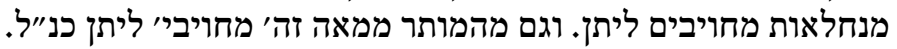

קך"ז מי שישבע על המעשר ויגרע עליו מעט מזער אעפ״י כן מחויב לסלק חמשה עשר 5

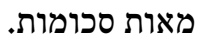

בשעת השבועה יתן כל איש ואיש ריסטר שלו על הסך שלו ועל כל הנ״יל ויתן

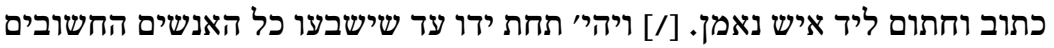
קר"ט

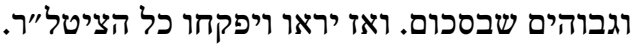

ושני הסעיפי' הנרשמים למטה שייכי' לשמאות 10

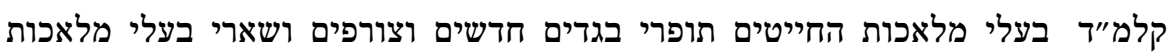

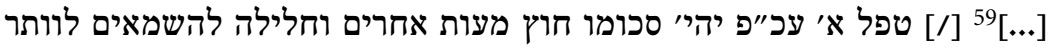
לו...]

קל"א בעלי מלאכות קירזנר60 אזי מי שיושב בחניות שלו יהי' סכנומו ...] [/] אותו השמאים כנ"ל. ומי שיושב בחנירזנר מזיות המושכרת [...]

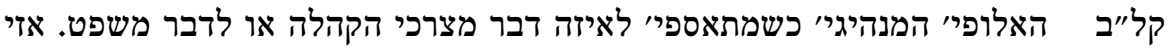

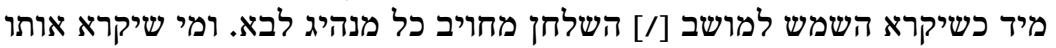

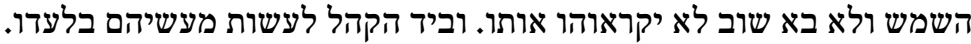

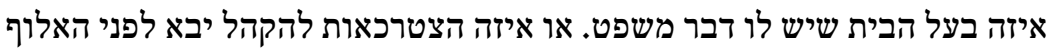

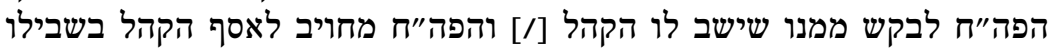

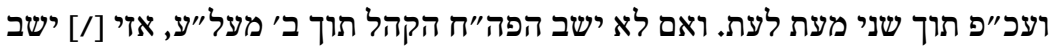

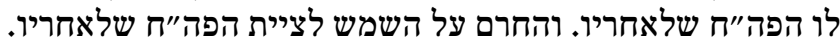

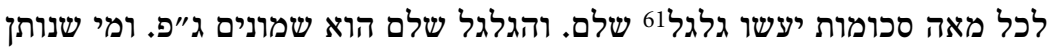

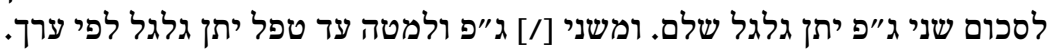

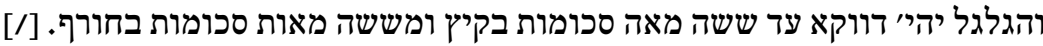

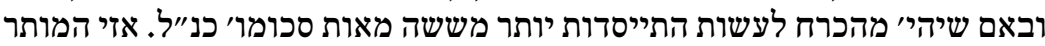

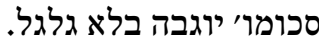

\footnotetext{
58 Dieses Wort über der Zeile.

59 Textverlust durch fehlende rechte untere Blattecke.

60 Kürschner.

61 Kopfsteuer, siehe Levitats, Pinkas, 94, Anm. 114.
} 


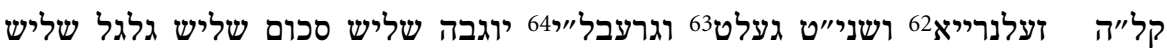

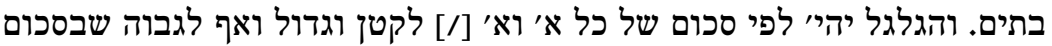
יחשב הגלגל לכל גדול וגדול בלי ישום של אי ואי

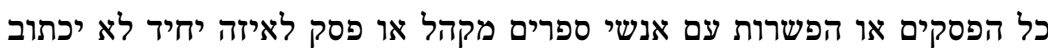
קל"ו

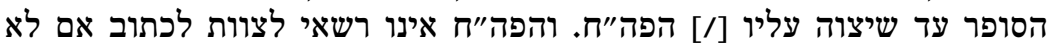

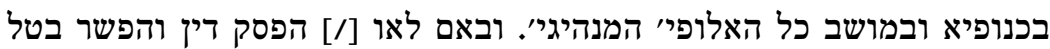

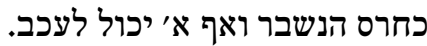

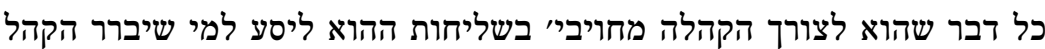

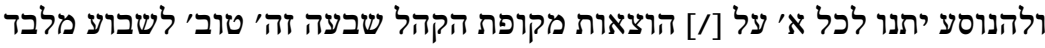

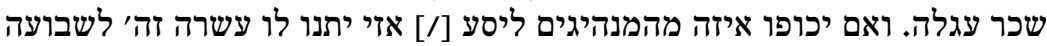

[ [!] [לבד שכר עגלה.

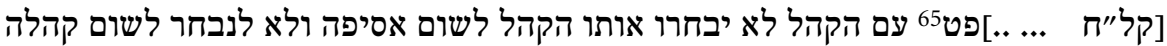
כלל. ושום יחיד [/] [.....]ל לאסיפה כי אם אחר שיצר שיציע דבריו לפני הקהל.

[קל"ט66....] לבא בימים נוראים וימים טובים ובארבע פרשיות אל67 הקהל ועל זה ישגיחו

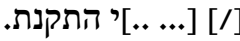

[ק"ם . ... פ]"ה לאסף את הקהל בצירוף כבוד הרב לפקח בענין [/] [...] ימים לפני הזמן. [fol. $42 \mathrm{r}$ ]

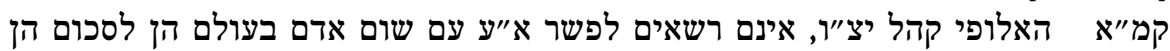

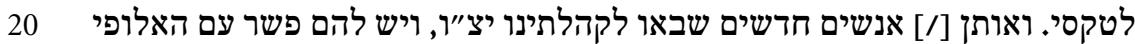

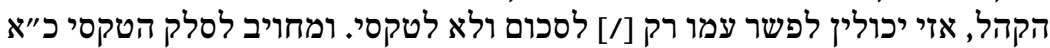

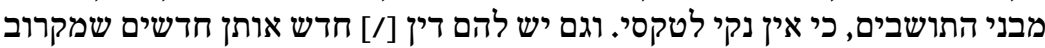

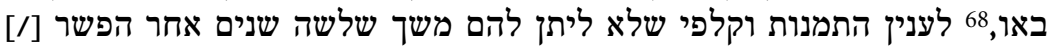
שלו.

62 Söller bezeichnet die obere Etage eines Hauses, die oft als Speicher diente. Offenbar ist hier eine Lagergebühr für Getreide gemeint, worauf der nächste Terminus hindeutet.

63 Schnittgeld, offenbar eine Erntesteuer.

64 Levitats, Pinkas, 111, Anm. 115, bezieht sich auf die Herkunft vom polnischen "grobla«, in der Bedeutung von Barre, Damm. Gemeint könnte damit vielleicht eine Art Wegzoll für Waren sein, insbesondere aber für Getreide.

65 Textverlust durch fehlende rechte untere Blattecke.

66 Dieser und der folgende Paragraph fehlen in der Edition von Levitats.

67 Das $\boldsymbol{x}$ wurde über ein zuvor fälschlich geschriebenes ע geschrieben.

68 Dtn $32,17$. 
בית השוה אלף זה' ומאלף זה' ולמעלה נקרא בית גדול, כפי הפסק מכבוד הרבניי

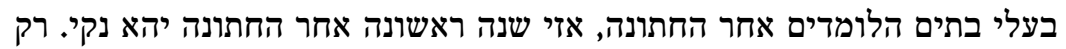

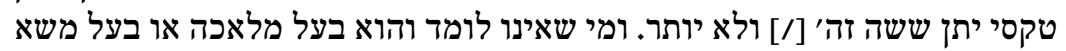

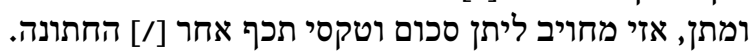

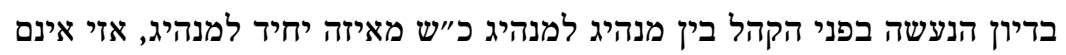

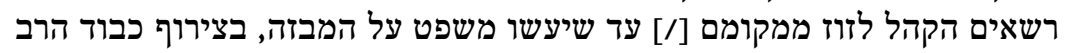

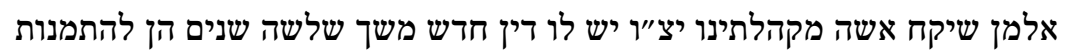

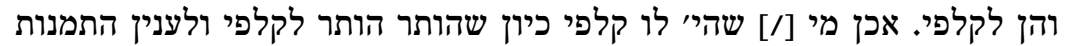

כשיהי' שררה בעיר וילכו כל הקהל עם הדורן, ${ }^{70}$ אינו רשאי שום יחיד לילילך עמהם קמ"ו

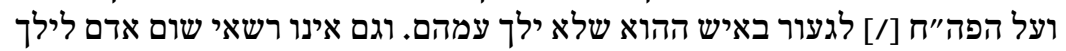

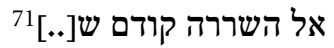

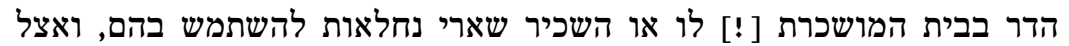

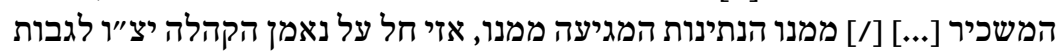

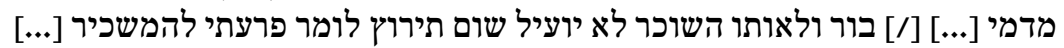

\section{שום אדם לא יהא לו שני מינוים מהמינוים הנרשמים בריסטר [...]}

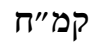

מי שהוא חיוב בשבת כגון יאר צייט או שהייתה אשתו יולדות [...] [/] לקרותו

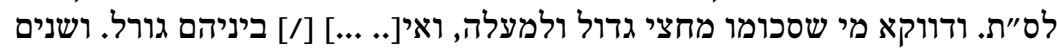
קמ"ט

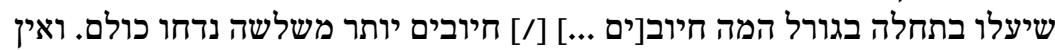

[ק"72] תקנה קדומה היא בכל תפוצת ישראל. איזה משפט בין יחין יחיד ליחיד לא יצא מקיר

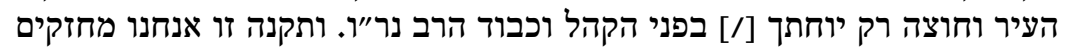

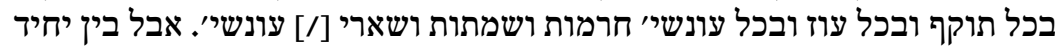
לקהל, או בין רבים לקהל אזי יציע הכלי התובע בפני הקהל ואחר הצעת דבריו יוחקר

69 D. h. nach der internen Rangordnung, die sich u. a. durch bisher ausgeübte Funktionen in der Gemeinde definierte.

70 Geschenk an die Obrigkeit.

71 Textverlust durch fehlende linke untere Blattecke.

72 \$ 150-155 fehlen bei Levitats. 


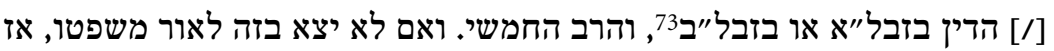

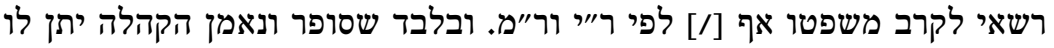

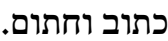

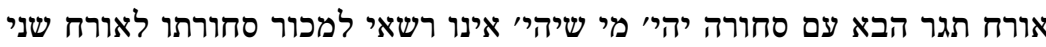

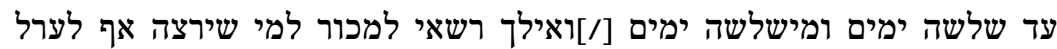

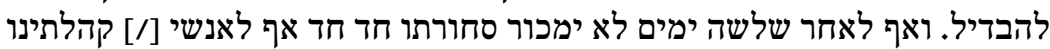

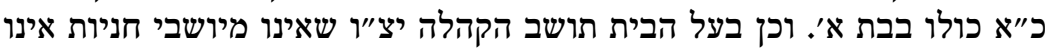

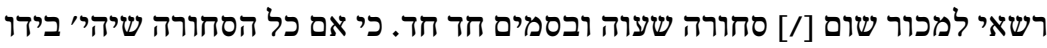

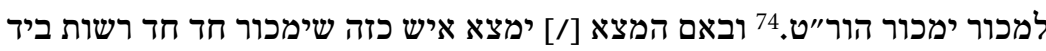

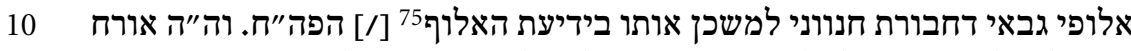

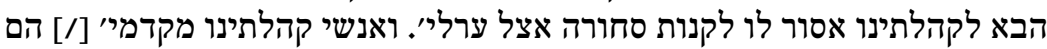

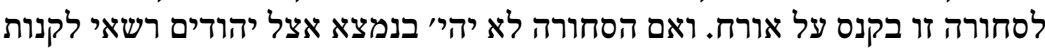

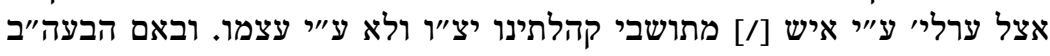
דקהלתינו ירצה לקנות לעצמו מויי משדם הוא לאורח.

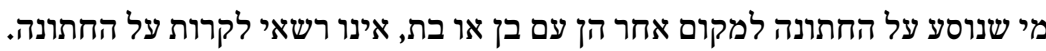
ופשיטא שלא לשלוח לו [/] לעק"ח.

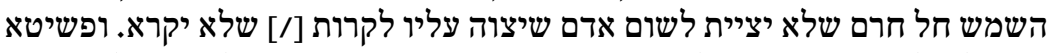

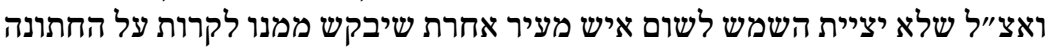
בעונש חרם הנ"ל.

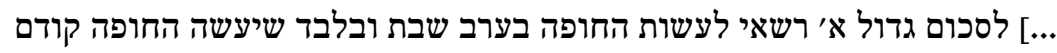

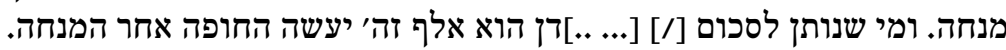

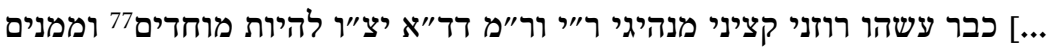

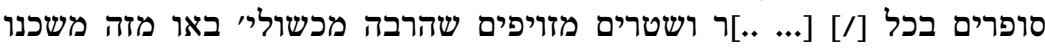

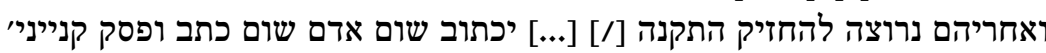

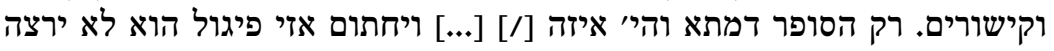

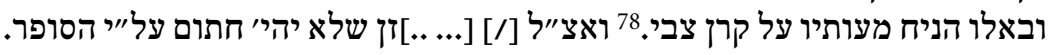
ואף שהקנין יהי' בכתובת וחתימת [/] [......

ש...]. כל פ' החדש בחדשו החיוב לקרותו לס״ת פעם א׳ בחדשו מצד [/] [...] באיזה [קנ"ה]

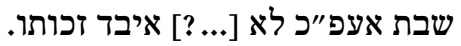

73 D. h. durch von beiden Seiten ausgewählte Schiedsrichter.

74 Hort, gesamte Ladung.

75 Dieses Wort auch zu Beginn der folgenden Zeile.

76 Vielleicht: לערב קודם חופה

77 מאוחדים? Lesung unklar.

78 Ketubbot 13b. 
[fol. $43 \mathrm{r}$ ]

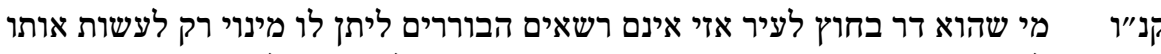

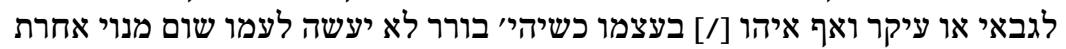

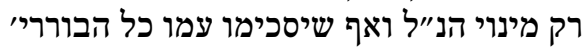

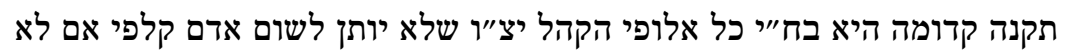

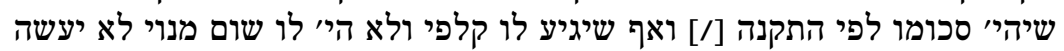

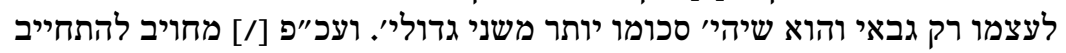

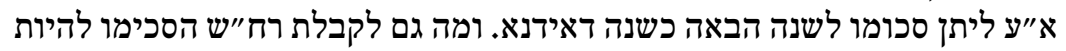

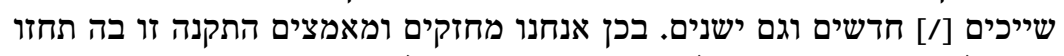

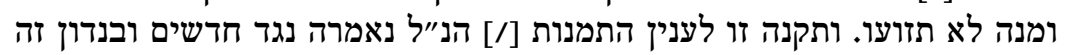

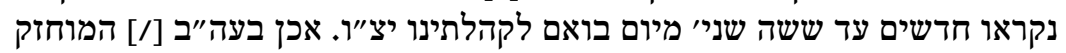
ומושך בעול בקהלתינו דינו נזכר שריות בואיל בסעיף חיתינות.

5

הנהגת הסעודת מניח

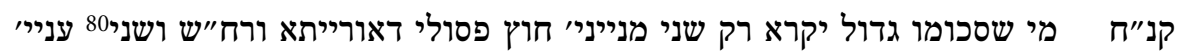

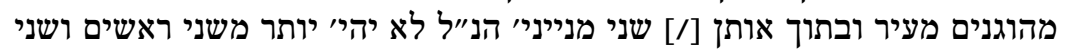

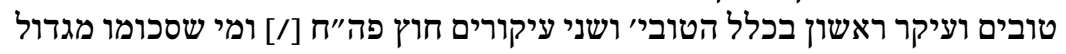

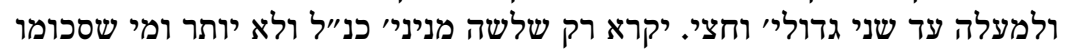

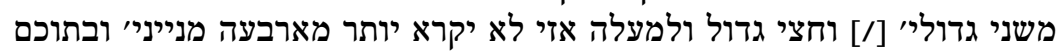

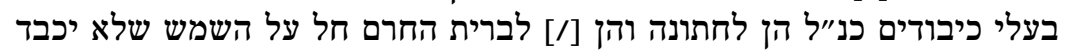

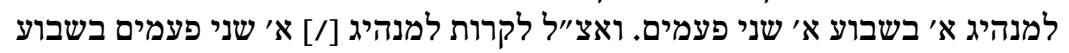

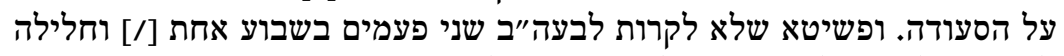

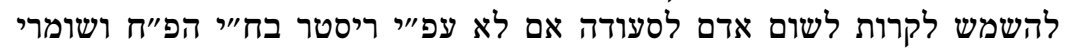

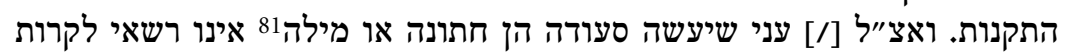
יותר משני מנייני' עם פסולי דאורייתא. פעורה העור

הכבודים בברית מילה לא יהיי יותר מששה לבד הסנדק ואב"ד היושב על הכסא של אליהו. [/] חוץ הנושא הילד מילי מן הבימה לברכה.

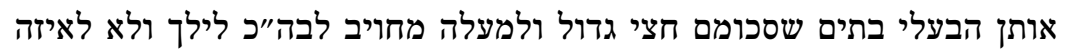

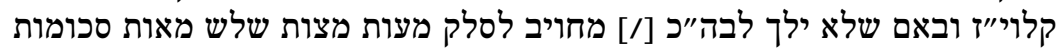
בלי שום אמתלאה בעולם.

חזנים העוברים מעיר לעיר אם יבא להאלוף הפה"ח ביפוח ביום ו' בהשכמה מחויב השמש תכף בבואו לשלוח [/] אותו למקום אחר ובאלוף הפה שיבא אחר חצות אזיר יבמי החרם מחובי

79 Der Anfangsbuchstabe נ wurde zwei Mal geschrieben.

80 Über dem Wort: ומוכיח.

81 Gemeint ist die Beschneidung Brit Mila. 
מהקדמוני' חל על פה"ח שלא ישב הקהל עבורו [/] שיתפלל לפני התיבה. והשמש לחוש

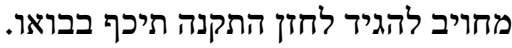

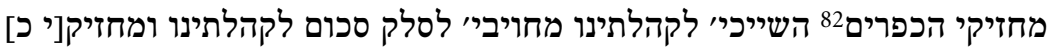

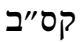

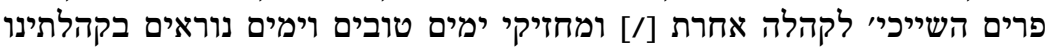
5

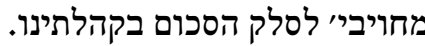

בערב שבת שלפני ר"ח אייר ולפני ר״ח חשון מחויבי' אלופי' [...] הרב נר"ו לחלק

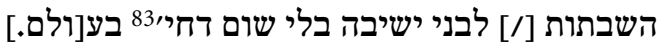

עלה במוסכם שאיסורו איסור גמור לקרות לס"ת בשבת יותר מעשרה אנשים כהן [fol. $43 \mathrm{v}$ ]

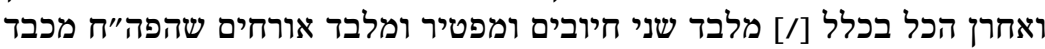

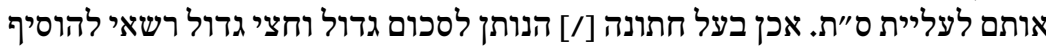

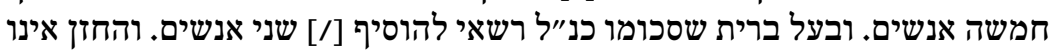

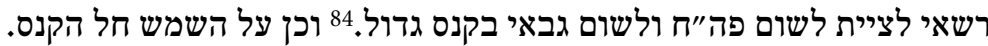

קס"ה שלם זכר הנהוג לילך בשבת אצל היולדת ילכו רק פסולי דאורייתא ולא יותר.

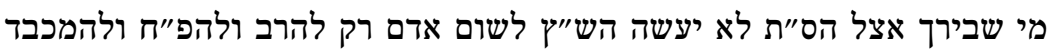
קס"ו - - - - n

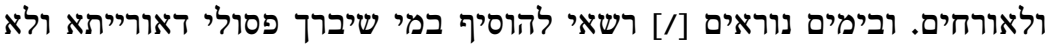

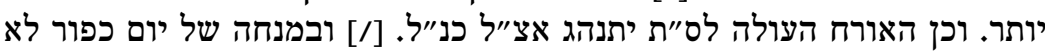
יעשה החזן מי שבירך כלל.

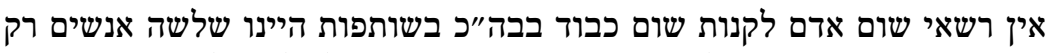

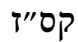

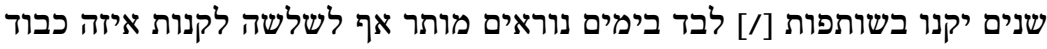
קס"ד בשותפות. - (- בנים יקור.

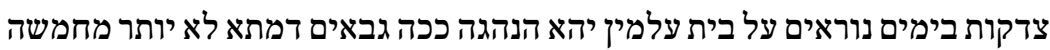

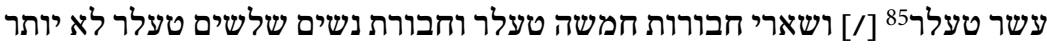

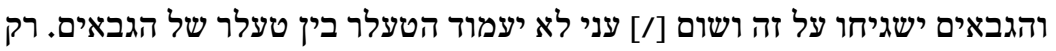
יעמוד הטעלר אצל טעלר העניים.

בעי"כ אינם רשאים לישב בפאלי"ש86 שום חברה בעולם זולת גבאי דצדקה גדולה

קס"ט וחבורה ב״"ח. - בעירינם

82 Ansässige in umliegenden Dörfern.

83 דחייה.

84 Dieses Wort stark verwischt.

85 Teller, gemeint sind wohl Sammelteller für Kollekten.

86 Bedeutung unklar, offenbar könnte damit eine bestimmte Lokalität, wie etwa das Gemeindehaus, gemeint sein. 


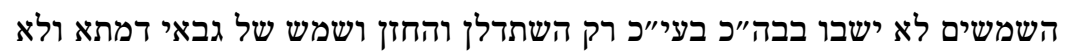

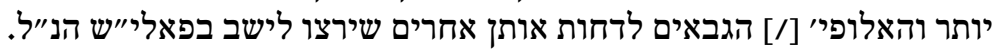

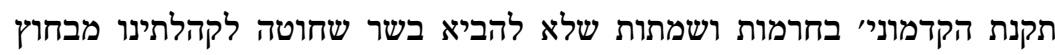

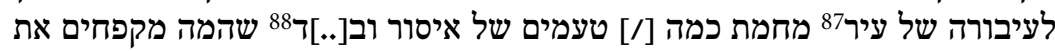

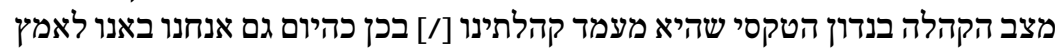

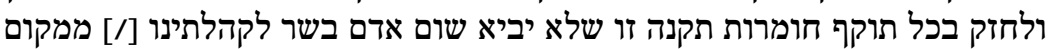

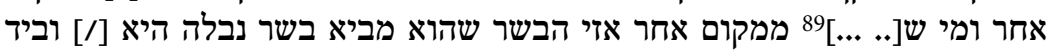

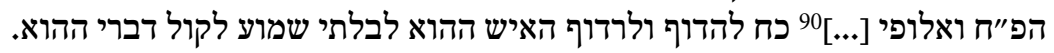

10

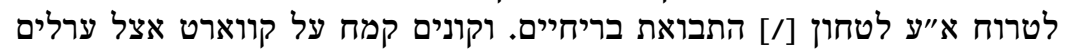

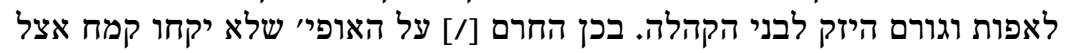

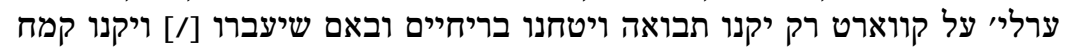

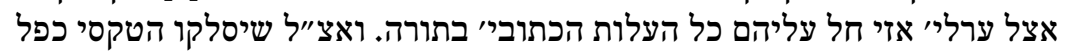

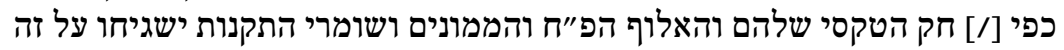

להדוף ולרדוף אותו איש.

חק ומשפט של הטקסי

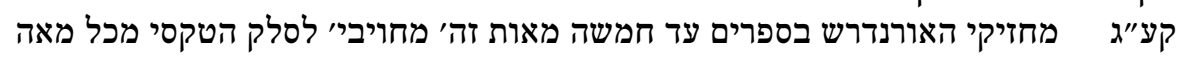

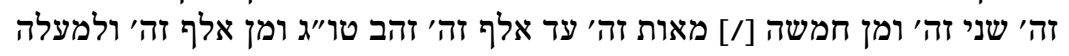

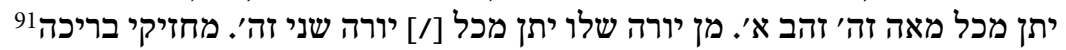

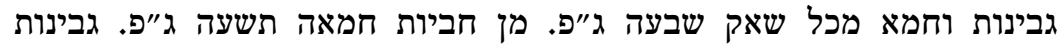
קע"ד

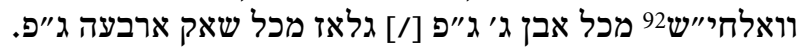

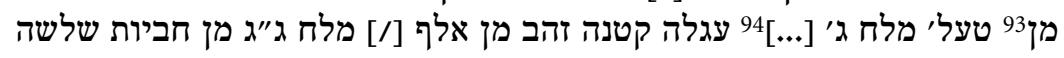

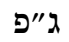

מוכרי מנעלים יתנו מכל מאה זהב טו"ג [/] ספיאן95 ג״״כ מכל מאה זהב טו"ג ובשארי דברים יקוים כפי הפסי מכל מנת זית

87 Vororte der Stadt.

88 Textverlust durch beschädigtes Papier. Levitats, Pinkas, 96: וביחוד.

89 Textverlust durch beschädigten unteren Blattrand. Levitats, Pinkas, 96, an dieser Stelle: שיעבור ע"ז ויביא בשר.

90 Levitats, Pinkas, 96: מחזיק פיערי

91 Pächter von Seen.

92 Käse aus der Wallachei.

93 Ab hier erfolgt die Aufstellung der Taxe in zwei Spalten.

94 Unklares Wort.

95 Saffian. 
דגים מלוחים שמוכרים לאחדים מן חביות [/] שני זה'. המוכר חביות בבת אחת

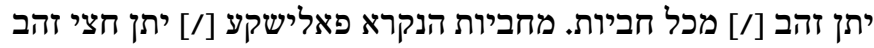

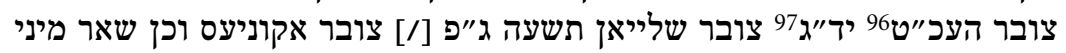
דגים ששה ג"פ הערינג מכל חביות הנמכר לאחדים יתן זהב [/] [...] והנמכר בבת אחת דינו זהב מן

מאה הערינג

וואסצשינסי98 מכל זהב א׳ גדול

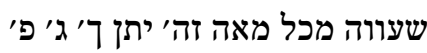

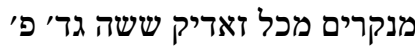

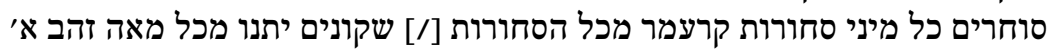

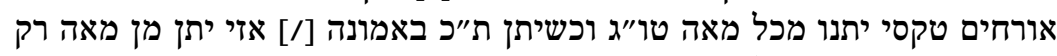

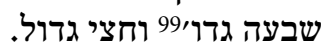

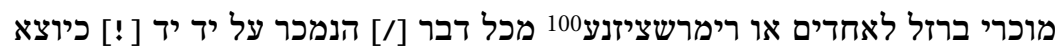

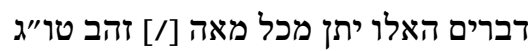

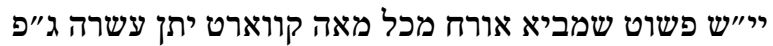

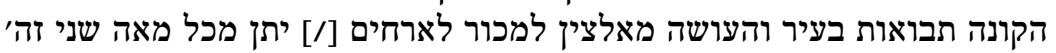

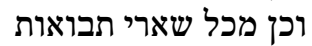

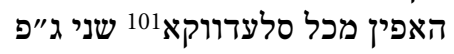

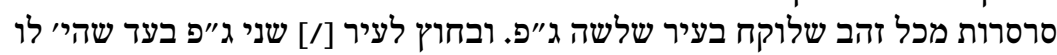

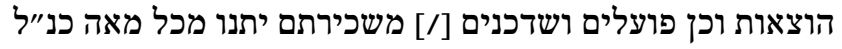

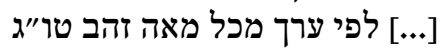
[fol. $44 \mathrm{v}$ ] זובחי צדק כפי הכתב רצוי בח"י הנכתב על [/] הגוילולי עם עם כל החבורה שלהם.

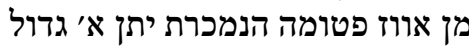

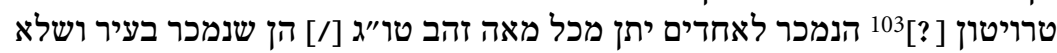
בעיר טרויטוק קירזנר ושערי בעלי מלאכות שלא נזכרו בחק הטקסי [/] מי שלוקח סחורה לצורך

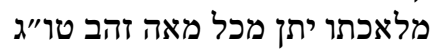
סחורה שאינו רואה פני העיר היינו שלוקח ומוכר [/] בעיר בעיר אחרת יתן מכל מאה

96 Hecht. Levitats, Pinkas, 96, an dieser Stelle: הערינג?

97 ?"יד גדולים

98 Levitats, Pinkas, 112, Anm. 144, vermutete die Bedeutung: Wachslichter.

99 גדולים.

100 Levitats, Pinkas, 112, Anm. 145, vermutete eine Art Riemenschneider.

101 Levitats, Pinkas, 112, Anm. 146: Trog.

102 Pergament.

103 Tintenfleck auf dem Wortanfang; Levitats, Pinkas, 97, liest תכשיטין, was jedoch nicht verifiziert werden kann. Lesung hier: Truthahn. 


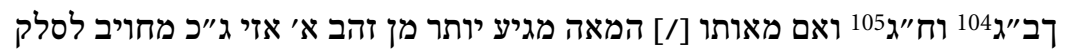

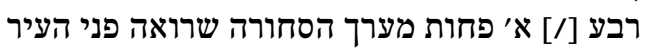

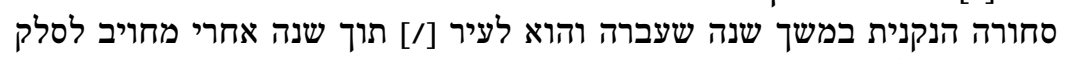

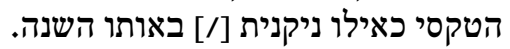

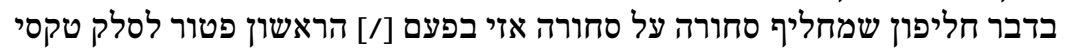

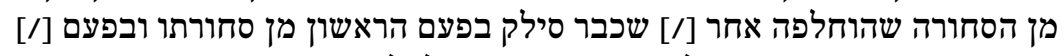

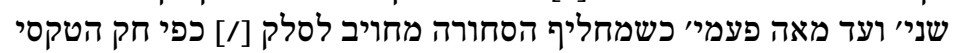
סחורות שאינם נזכרי' בחק הטקסי מחלי מחויביי לסלק [/] מכל מאה זהפי לא פחות פחות מזהב אי סאות שיכות בעה"ב שאינם נרשמים בריסטר הסכום רק בוואך [/] געלט מחויביבי' לסלק הטקסי

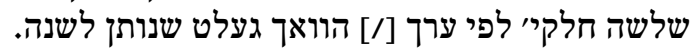

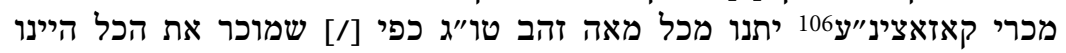

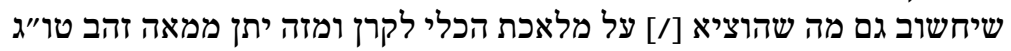

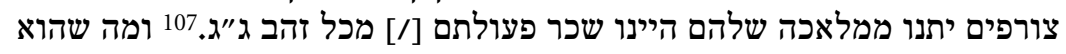

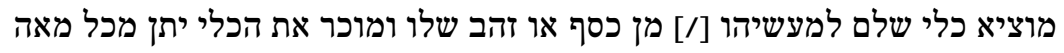

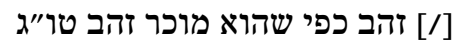

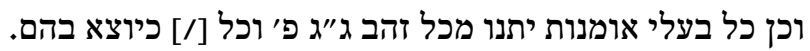

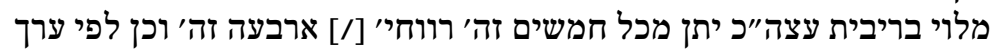

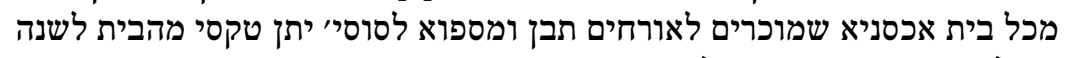

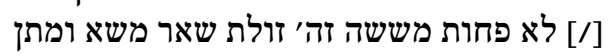

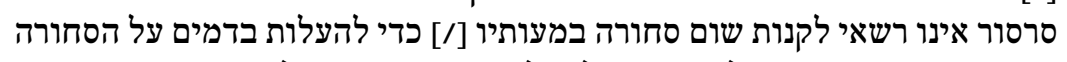

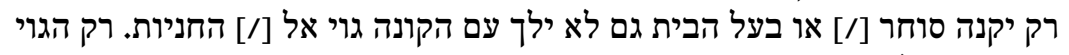

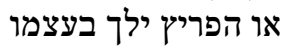

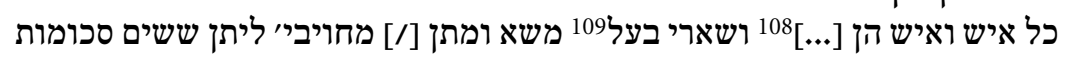

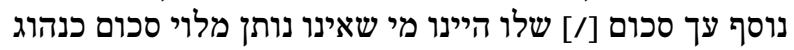

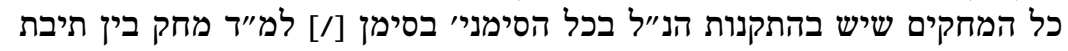

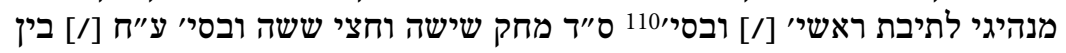

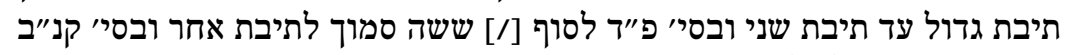

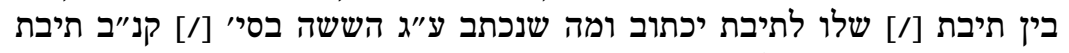
ומוכיח דק׳ נא' עזריאל בחרם לתיכת ונאי ומוכיחי ונא' אשר אנשיל ורגל

\footnotetext{
ד"ב גדולים 104.

105 וחצי גדולים 105.

106 Levitats, Pinkas, 112, Anm. 148, vermutete: Eisengruben.

107 ג' גדולים

108 Dieses Wort nicht zu entziffern.

109 Dieses Wort über der Zeile.

ובסימן 110.
} 
ונא' [נפת]לי וני הירץ בהר"ר מאיר מרדכי

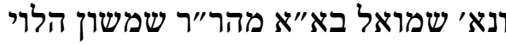

[fol. $45 \mathrm{r}]^{112}$

[...] ${ }^{113}$ תקנה קדומה114 שלא ילכו עם שום פושקא בלתי ידיעת הפה"ח בכץ אנחנו מחזקי'

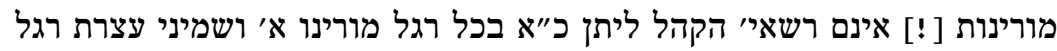

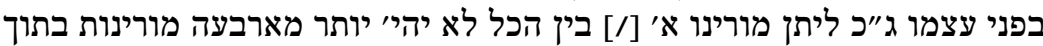

שנה

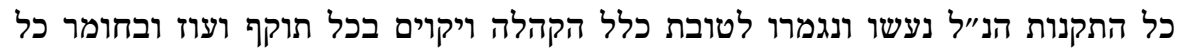

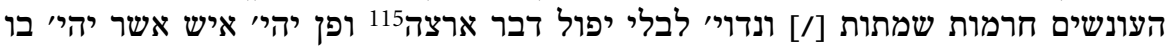

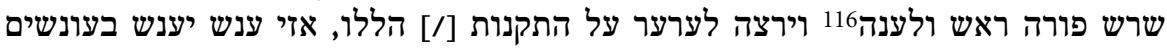

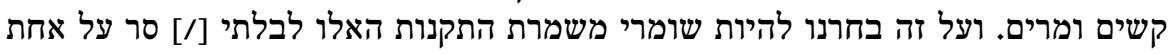

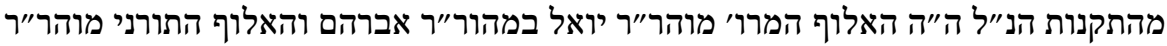

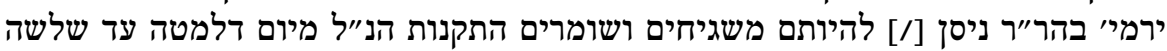

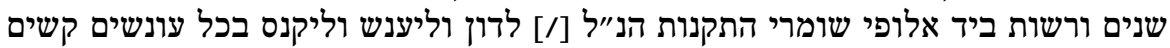

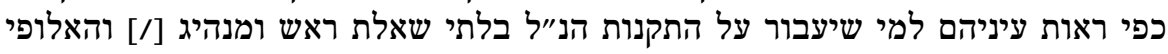

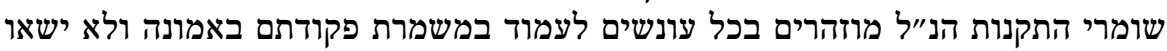

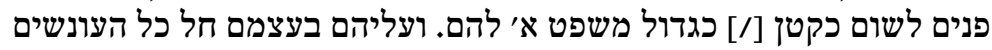

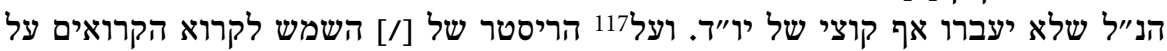

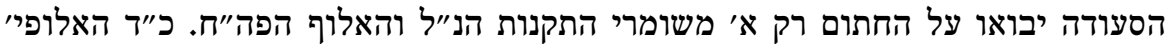

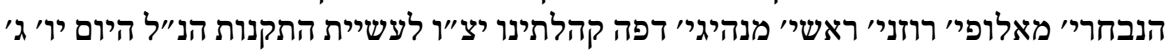

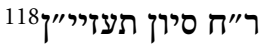

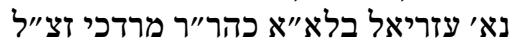

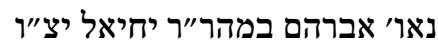

111 Textverlust durch beschädigtes Papier.

112 Fol. 44 ist in der Handschrift nicht erhalten.

113 Die Nummerierungen der letzten Artikel sind durch Überkleben des Blattrandes nicht mehr identifizierbar.

114 Dieses Wort über der Zeile.

115 Nach 1 Sam 3,19.

116 Dtn 29,17.

117 Von hier bis zum Ende des Textes wurde der Abschnitt in Levitats' Edition an den Artikel 171 angehängt.

1181717 IV 30. 


\section{Königreich Ungarn}

Deutschkreutz (1816) 



\section{Statuten aus Deutschkreutz (1816)}

\section{Quelle: Pinkas Deutschkreutz, Burgenländisches Landesarchiv Eisenstadt, A II/1}

Die Statuten aus Deutschkreutz bilden eines der wenigen vollständigen Texte der Gattung, die sich aus einer der bedeutenden burgenländischen Siebengemeinden erhalten haben. Faktisch stellen sie neben den von Max Grunwald 1924/25 edierten Statuten aus Mattersdorf ${ }^{1}$ den einzigen überlieferten Text dieser Art aus der Region dar. Die takkanot aus Deutschkreutz sind ein insgesamt recht spätes Beispiel von Statuten dieses Charakters, die - trotz ihres Entstehungsjahres 1816 - noch immer den Geist der vormodernen Zeit versprühen.

Eine Ursache dafür könnte die in der Einleitung genannte Entstehungsgeschichte sein, wonach die vorliegenden Statuten lediglich die erweiterte Version eines früheren Textes darstellen, der in der Gemeinde Deutschkreutz selbst verloren war und sich erst nach längerem Suchen in einer anderen Gemeinde, wahrscheinlich Csala Rendek, in einer beglaubigten Abschrift wieder fand. Letztlich ist auch diese plastische Schilderung der zeitgenössischen Textüberlieferung eine Besonderheit für takkanot.

Die Statuten sind Teil des erhaltenen, doch sehr schwer beschädigten pinkas der Gemeinde Deutschkreutz. Sie finden sich dort, eingebettet in andere Einträge aus den ersten Dekaden des 19. Jahrhunderts, auf den Folios 106 v - 112 r. Insgesamt umfassen die Statuten 46 Paragraphen. Aus den am Ende der takkanot befindlichen Unterschriften aus jeweils unterschiedlicher Hand wird ersichtlich, dass es sich um die Originalausfertigung handelte, die von 40 Personen unterzeichnet und damit beglaubigt wurde. Durch offenbar jahrelange, unsachgemäße Lagerung der Handschrift wurden sowohl die Bindung als auch die Blätter selbst schwer beschädigt. Bei fast allen fehlt am unteren Blattende ca. ein Fünftel, das entweder durch Feuchtigkeit oder Mäusefraß verloren ging. Bedingt durch diese Schäden weist der Text heute einige Lücken auf: die Paragraphen 5 und 18 fehlen vollständig; die Paragraphen 2, $13,23,24,27,28,33,34,39,40$, und 45 haben sich nur teilweise erhalten.

1 Grunwald, Mattersdorf, 505-524 (takkanot). Leider wird aus dem Text selbst nicht ersichtlich, ob es sich dabei wirklich um einen Mattersdorfer Text handelt, zudem ist er in Grunwalds Edition undatiert. Das Original scheint heute verschollen. 
Die Sprache der Statuten ist nicht einheitlich. Während die Einleitung und der Schlussteil genretypisch auf Hebräisch verfasst wurden, sind die Paragraphen selbst in einem teilweise sehr modern anmutenden, dem Deutschen sehr ähnlichen Jiddisch verfasst, in dem sich sowohl Lehnwörter aus dem christlichen administrativen Sprachgebrauch finden, wie auch klare Hinweise auf eine gewisse Annäherung an die deutsche Orthografie.

Die Seiten der takkanot sind, wie auch die übrigen Blätter des pinkas insgesamt, mit hebräischen Buchstaben in Quadratschrift auf der linken oberen Blattecke foliiert. Wegen der schlechten Erhaltung der Handschrift fehlen sie bereits auf einigen Blättern.

Der Grund für den Erlass der takkanot könnte, neben der oben genannten »Wiederentdeckung « auch die Neufixierung des Schutzverhältnisses der Deutschkreutzer Juden gewesen sein, die 1813 zustande kam. ${ }^{2}$ Inhaltlich sind die Statuten auf Fragen der Wahlen und Kompetenzen der verschiedenen Gemeindebeamten und auf Aspekte der Finanzen und Steuerleistungen fixiert. Eine wichtige Rolle spielen die Gerichtskompetenzen der Vorsteher, die sehr deutlich über die des rabbinischen Gerichts gestellt wurden (siehe $\$ 22$ ). Ferner finden sich einige Bestimmungen zur Rangfolge der Toralesungen in der Synagoge. Bemerkenswert ist die in Paragraph 44 aufscheinende neue Haltung der Gemeinderepräsentanten gegenüber unmoralischen Sitten: So wurde eine Frau, die ein uneheliches Kind zur Welt gebracht hatte, zwar vom öffentlichen Lebens weitgehend ausgeschlossen, insbesondere von der Teilnahme an allen religiösen Zeremonien wie Beschneidung und Hochzeiten. Jedoch wurde sie nicht mehr, wie in früheren Zeiten und in vielen anderen Gemeinden üblich, aus der Gemeinde verstoßen.

In einigen, meist längeren Paragraphen finden sich, in alphabetischer Reihenfolge eingestreut, hebräische Buchstaben, beginnend mit Bet. Sie könnten zur Untergliederung dieser längeren Paragraphen verwendet worden sein, oder auch zur Kennzeichnung von Textteilen für eine spätere Revision. Dieses Phänomen konnte bislang nur in diesem Text festgestellt werden.

Eine nahezu vollständige Übersetzung ins Deutsche, bzw. Transkription der deutschen Passagen wurde von Shlomo Spitzer 1995 in einer kompakten Abhandlung zur Deutschkreutzer Gemeindegeschichte vorgelegt. ${ }^{3}$

2 Siehe dazu Peter F. N. Hörz, Jüdische Kultur im Burgenland. Historische Fragmente volkskundliche Analysen, Wien 2005, 332.

3 Shlomo Spitzer, Die jüdische Gemeinde von Deutschkreutz, Wien/Köln/Weimar 1995, 137-151. Dort wurden auch die späteren Satzungen der lokalen Synagogengemeinde abgedruckt; ebd., 153-158. 


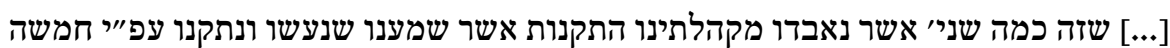

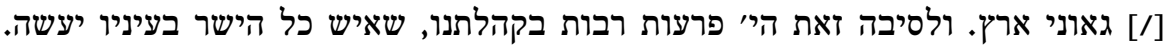

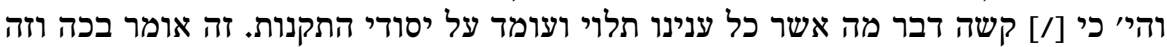

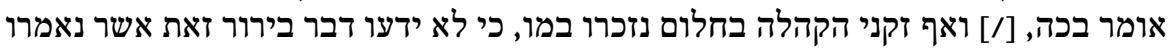

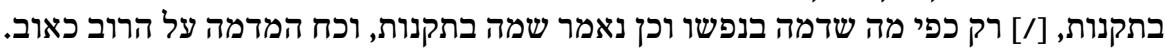

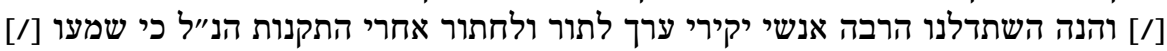

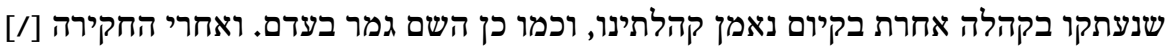

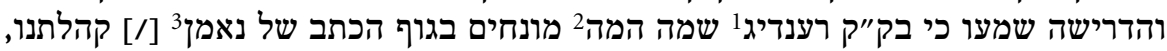

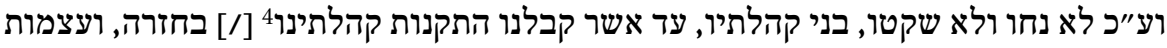

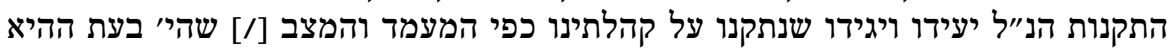

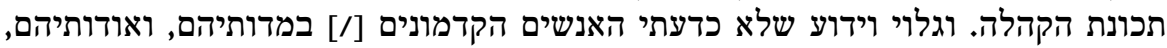

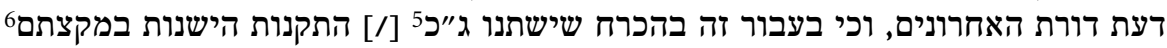

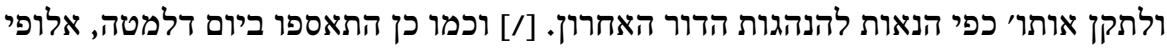

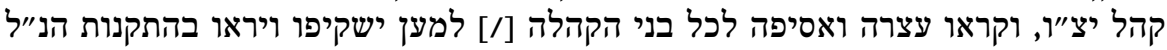

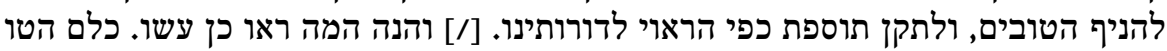

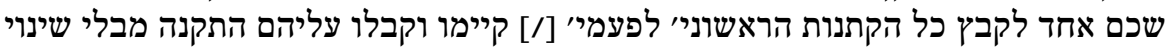

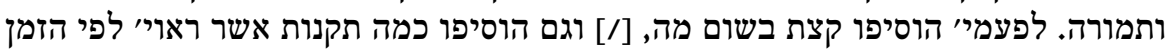

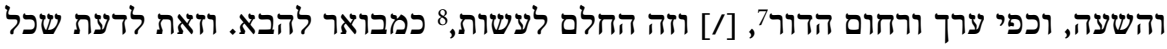

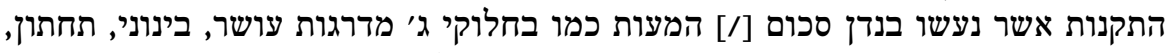

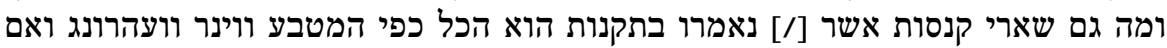

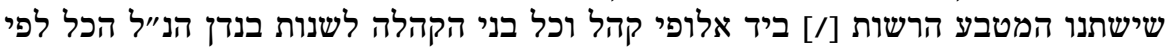
הזמן.

בני הקהלה בשטעהן אין דרייא קלאסען נעמליך עושר, בינוני, תחתון. דער יעניגר

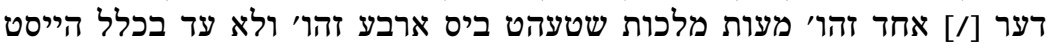

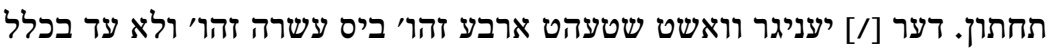

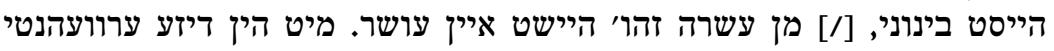

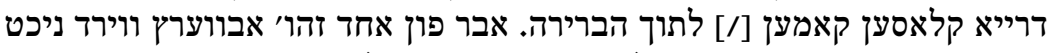

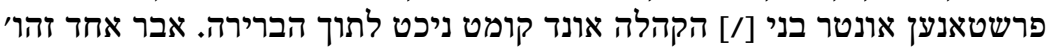

1 Csala Rendek, im westungarischen Komitat Zala gelegen; siehe Spitzer, Deutschkreutz, 137.

2 Davor gestrichen: נמצאו.

3 Danach $p$ als Zeilenfüller.

4 Danach $\beth$ als Zeilenfüller.

5 Danach $\boldsymbol{i}$ als Zeilenfüller.

6 Dieses Wort gesperrt geschrieben.

7 Davor ein Wort durch Streichung unleserlich.

8 Gen 11,6. 
קאמט אללע צייט לתוך [/] הברירה מיט דען אויסדרוק דס דער יעניגר דער אחד זהו' מ"מ שטעהט מוס ל[..] [/] זיין שוצגעלד צאהלען מיטן.

$9\left[\begin{array}{ll}\ldots & 2\end{array}\right]$

[fol. $107 \mathrm{r}$ ]

5

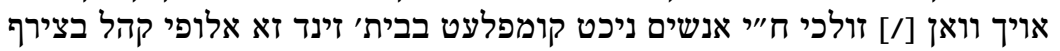

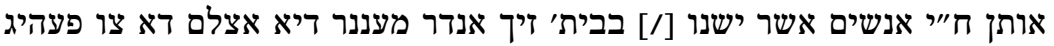

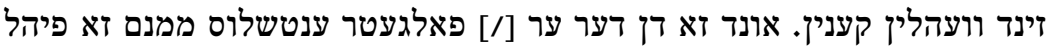

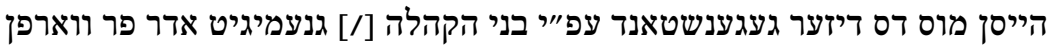

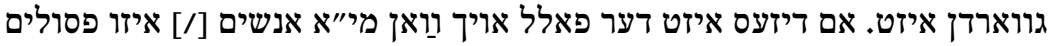

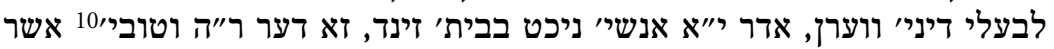

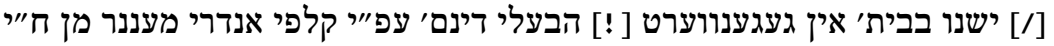

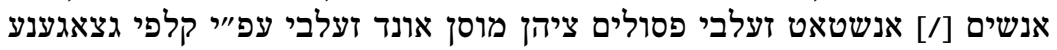

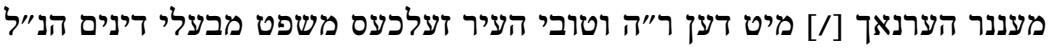
אויס מאכען כפי יושר שכלם.

15

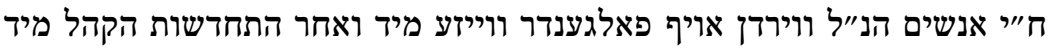

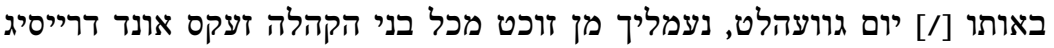

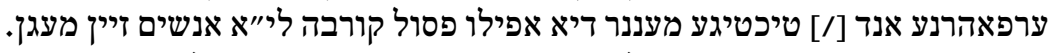

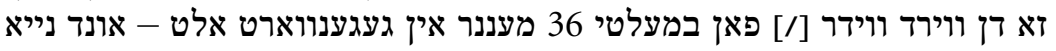

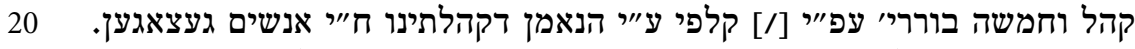

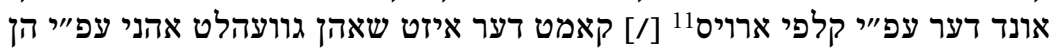

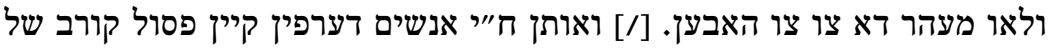
ראשון בראשון האבען דך שני בשני המה כשר.

בייא איין וויכטיגען געגענשטאנד אלס צום עקסעמפל אויף צו נעהמן רח"ש, אדר

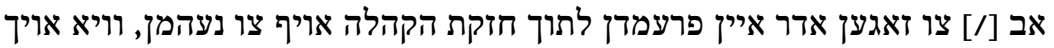

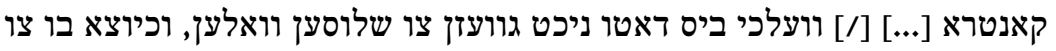

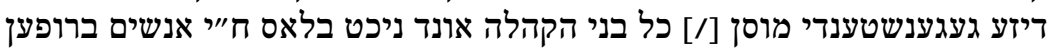

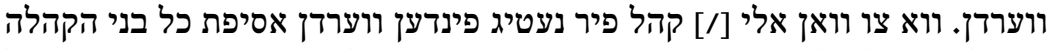

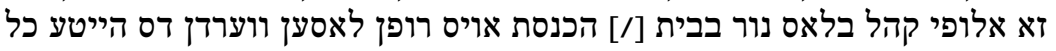

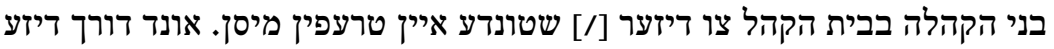

9 Bedingt durch die schweren Schäden am jeweils unteren Blattrand ist $\$ 2$ zu großen Teilen verloren.

טובי העיר wörtl. »die Guten der Stadt«; bei diesen handelte es sich um Beigeordnete des Vorstands, denen, wie aus dem Text hervorgeht, in Deutschkreutz Kompetenzen in Bagatellfällen zukam. Ferner vertraten sie die Amtsträger, wenn diese verhindert waren.

11 Danach $p$ als Zeilenfüller. 


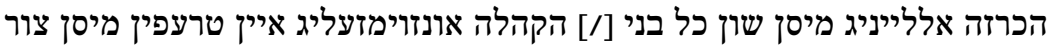

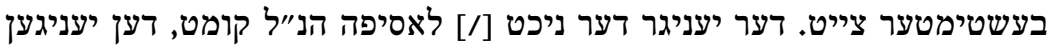

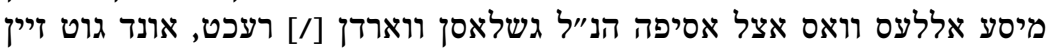

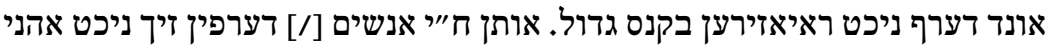

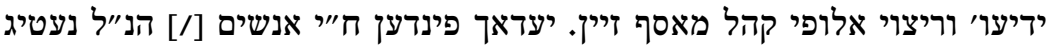

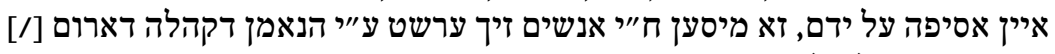
אנפראגען אצל אלופי [...]

$$
\begin{array}{rr}
{ }^{12}\left[\begin{array}{lr}
\ldots & 5
\end{array}\right] \\
{[\text { fol.107 v }}
\end{array}
$$

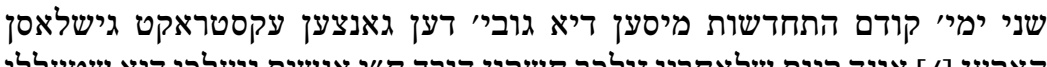

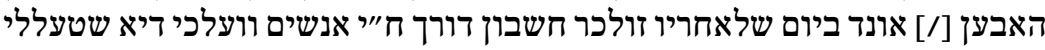

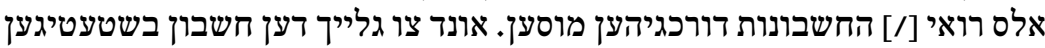

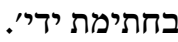

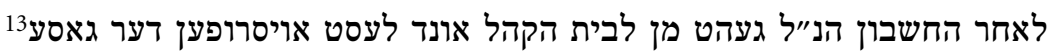

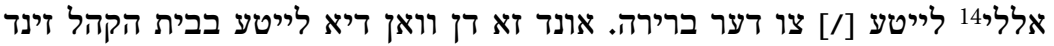
15

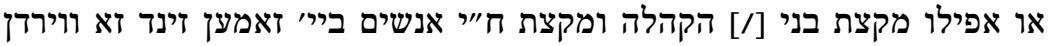

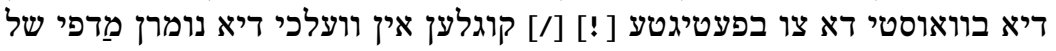

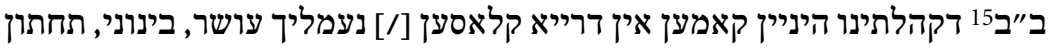

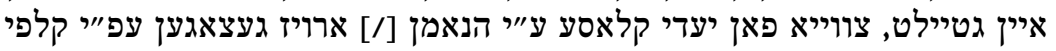

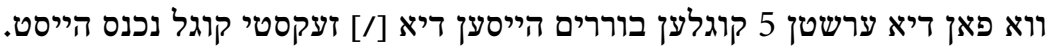

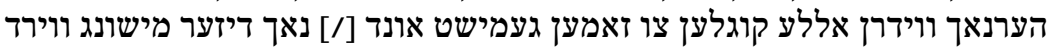

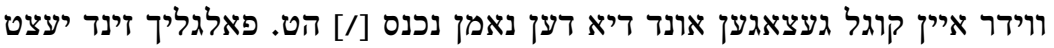

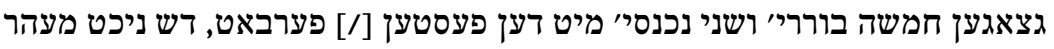

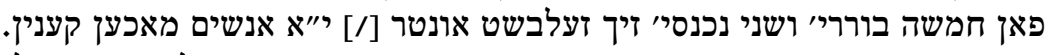

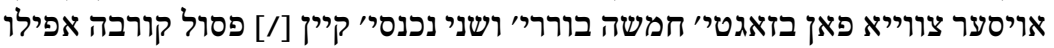

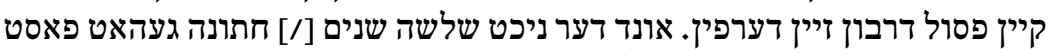

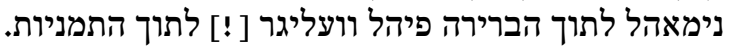

12 Bedingt durch die schweren Schäden am jeweils unteren Blattrand ist $\$ 5$ vollständig verloren. Er scheint jedoch von nur geringem Umfang gewesen zu sein.

13 Danach ein unverständliches Zeichen.

14 Dieses Wort gesperrt geschrieben.

15 In geordneten Gemeinden wurden die Steuerleistungen ihrer Mitglieder in einem Register vermerkt. Jedem Haushaltsvorstand wurde eine Doppelseite in dem Register zugewiesen, auf der Soll und Haben der Abgaben verzeichnet wurden. Die Blätter waren foliiert, sodass die jeweilige Folionummer hier als Zuordnung für die wählbaren Personen genutzt wurde. 


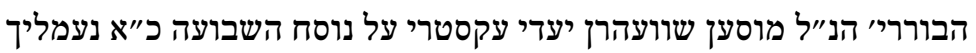
8

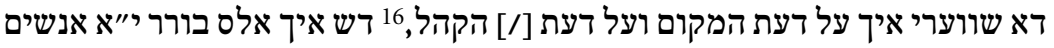

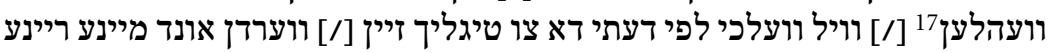

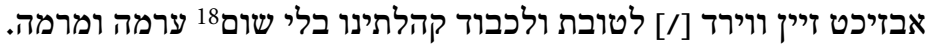

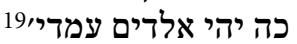

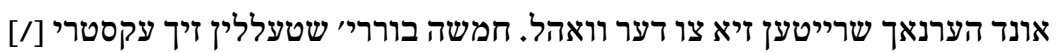

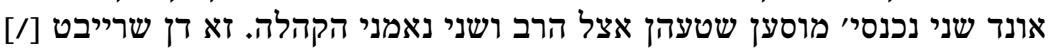

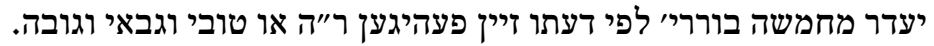

דער ר״יה מוס פאלגענדע פעהיגקייטן האבען ער מוס ערשט שלשה שניי תוך

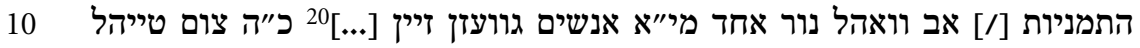

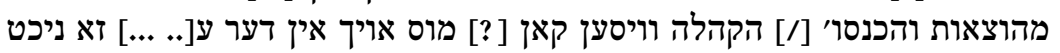

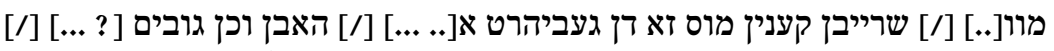

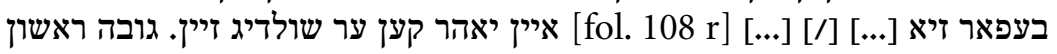

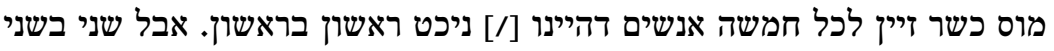

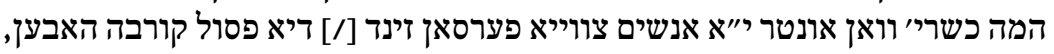

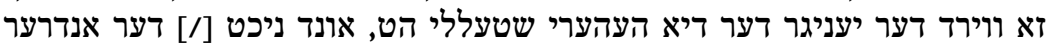

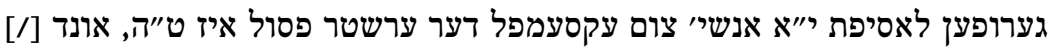

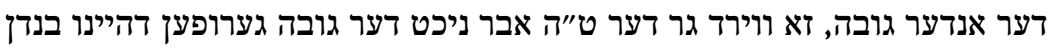

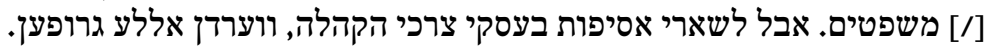

דער ערשטר גובה מוס זיין איין עושר. דיא אנדרע צוויי' גובי' קענין בינוני' זיין 20 דיכרין

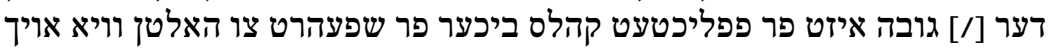

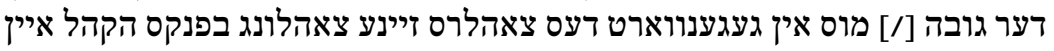

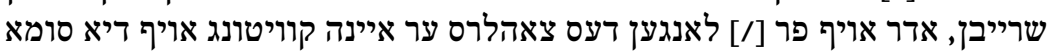

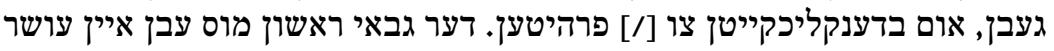

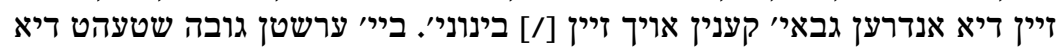

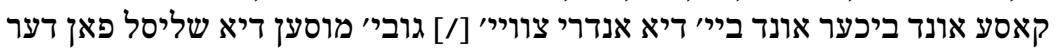

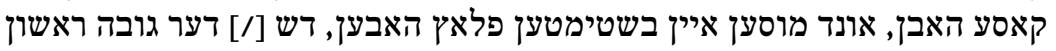

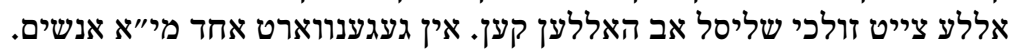

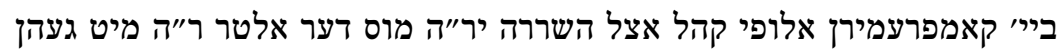

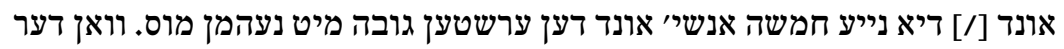

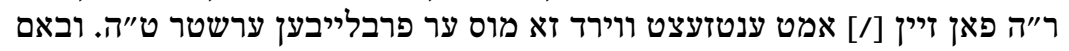

16 Zwischen den beiden letzten Wörtern ein späterer Einschub, dieser nach Streichung unleserlich.

17 Dieses Wort über der Zeile ergänzt, darunter ein Wort durch Streichung unleserlich.

18 Dieses Wort über der Zeile ergänzt.

19 Gott mit mir.

20 Textverlust durch beschädigten unteren Seitenrand. 
שיקרה דס דער אלטער21 ר"ה [/] צו דען נייען ר"ה פסול ווערי, זא בלייבט ער גבאי ראשון.

אלופי קהל מוסען זיך מאסף זיין בבית הקהל ולא בבית ראש הקהל או אחד משארי

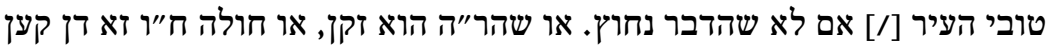

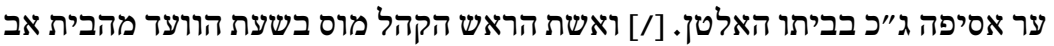

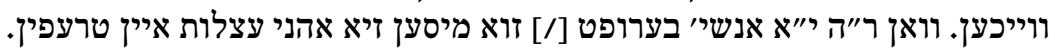

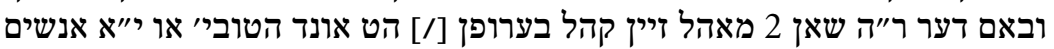

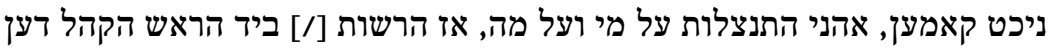

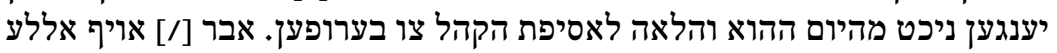

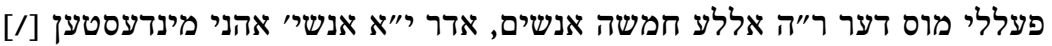

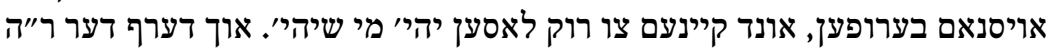

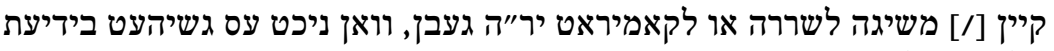

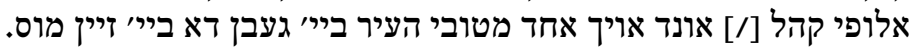

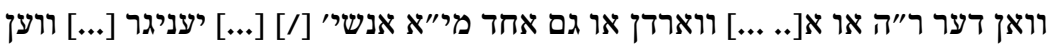

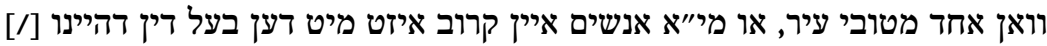

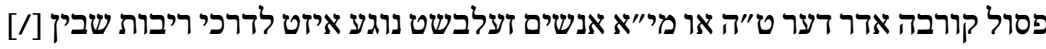

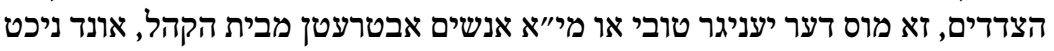

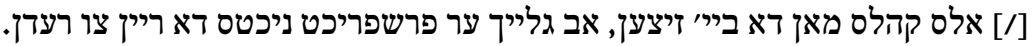

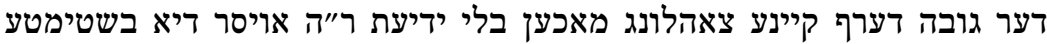

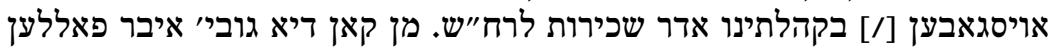

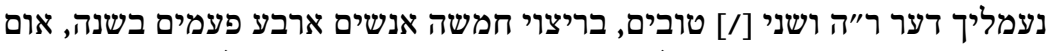

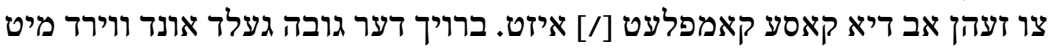

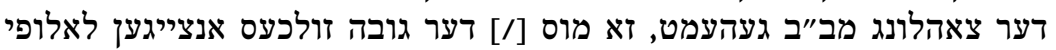

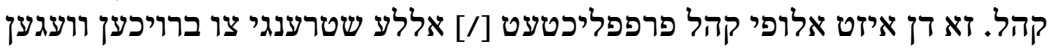

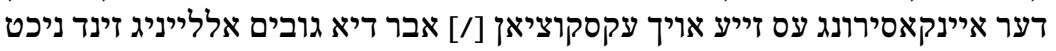

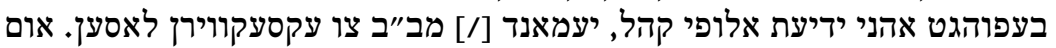

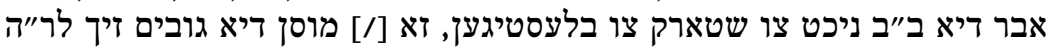

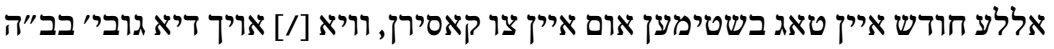

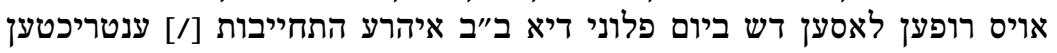

$$
\text { זוללען.23 }
$$

21 Dieses Wort über der Zeile ergänzt.

22 Über dem Paragraphen und am rechten Blattrand finden sich mehrere Einfügungszeichen, die auf Inserte am unteren Blattrand verweisen, diese sind jedoch wegen der starken Beschädigung verloren.

23 Danach ein ב, offenbar zur Kennzeichnung der Textteile bei einer späteren Revision. 


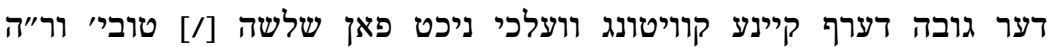
16

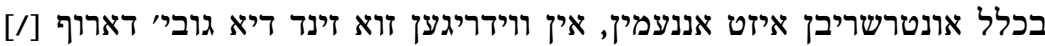

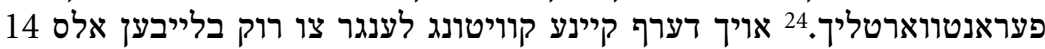

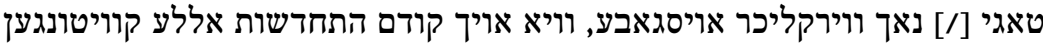

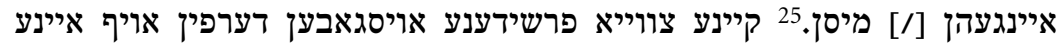

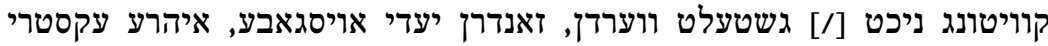

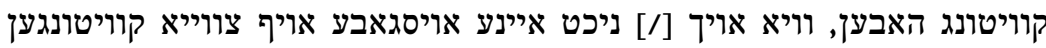

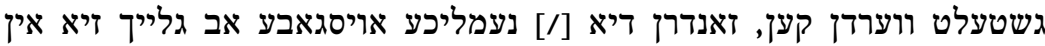

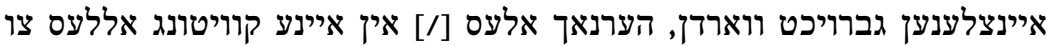

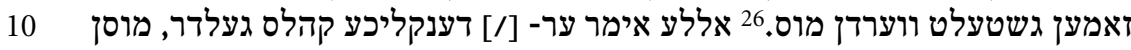

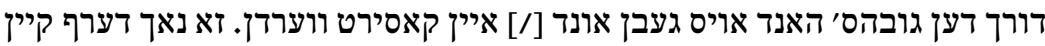

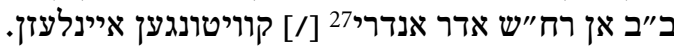

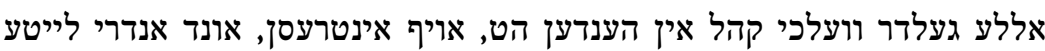

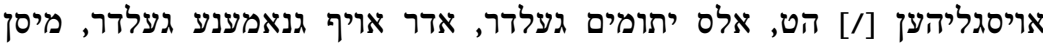

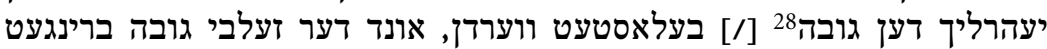

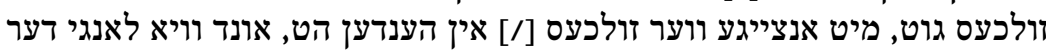

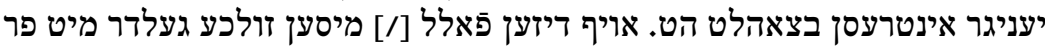

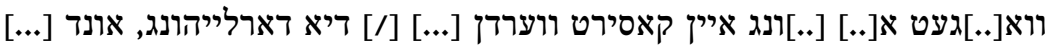

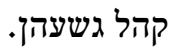

איין משפט מיט עשרה זהו' קאן איין ט"ה אויס מאכען ווא דער ר"ה דען נעמליכען

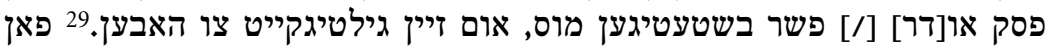

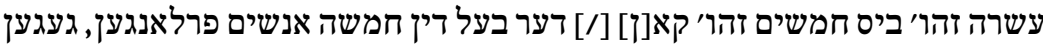

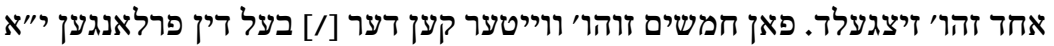

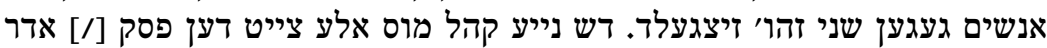
פשר פאן אלט קהל בקרעפטיגען, אונד אימער איהרע גיל גילטיגליגייט געבין.

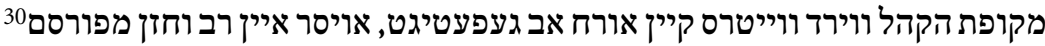

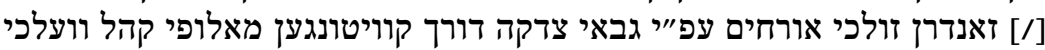
אנווייזען דיא [...] [/] וויא פיהל אן דען אבירי צורח צו געבן, אב געפערטיגיגט ווערדן. 30

\footnotetext{
24 Danach ein $\lambda$.

25 Danach ein 7.

26 Danach ein $\pi$.

27 Danach $p$ als Zeilenfüller.

28 Danach ב als Zeilenfüller.

29 Danach ein 2.

30 Danach gestrichen: $[\ldots]$ או
} 
צו דער גבאי דערף אויך ניכט דיא [...] [/] געלדר לעניי עירירינו בכל שבוע ושבוע,

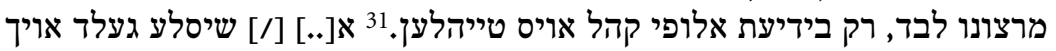

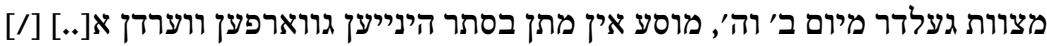

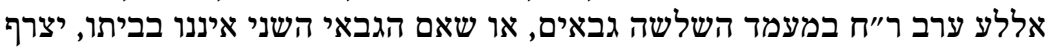

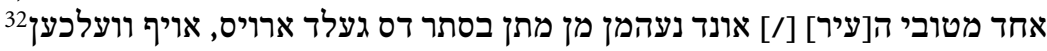

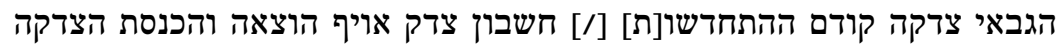

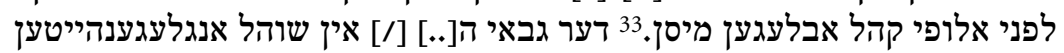

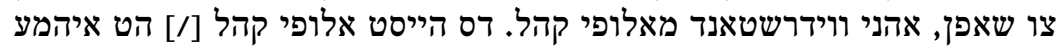

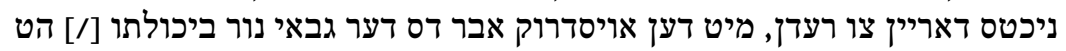

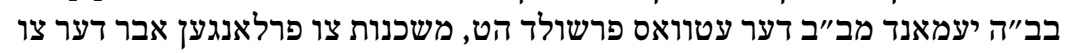

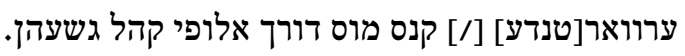

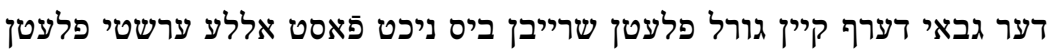

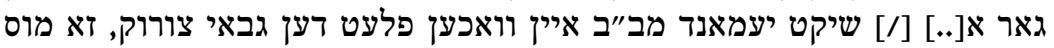

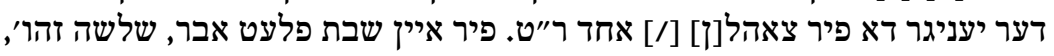

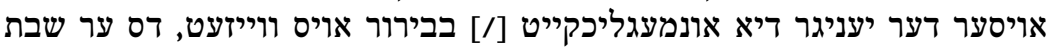

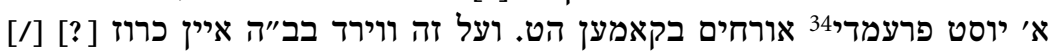
ערגעהן.

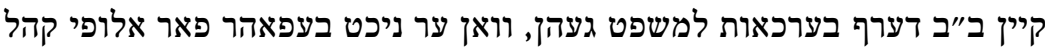

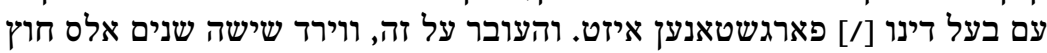

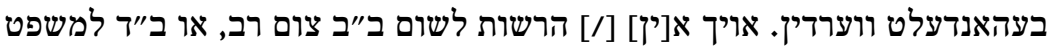

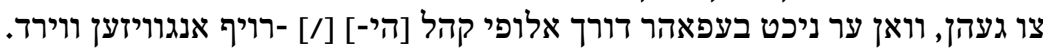

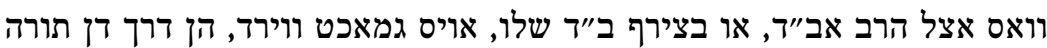

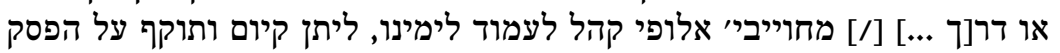

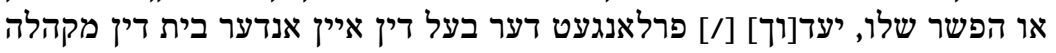

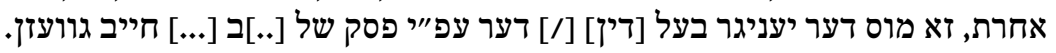

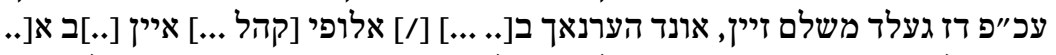

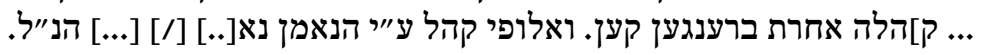

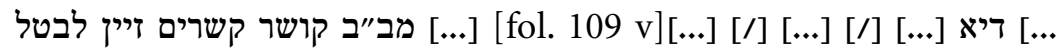

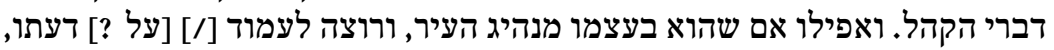

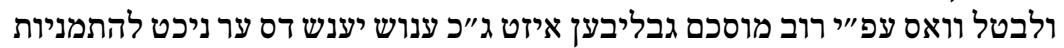

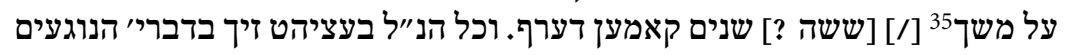

31 Danach ein $\lambda$.

32 Danach ein $\lambda$.

33 Danach ein 7.

34 Dieses Wort über der Zeile ergänzt.

35 Danach $\boldsymbol{w}$ als Zeilenfüller. 
אל מעמד ומצב ולטובת הקהלה. ולא [/] [...] מדבריי שאינם נוגעי' בעסקי וטובת הקהלה.

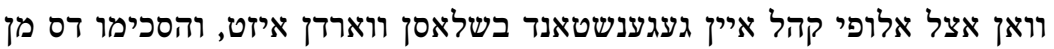
25

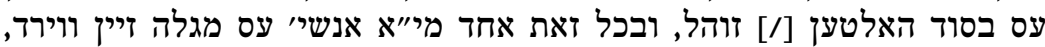

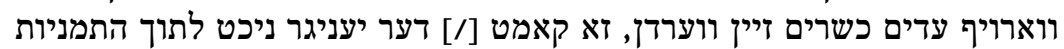

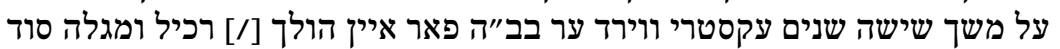

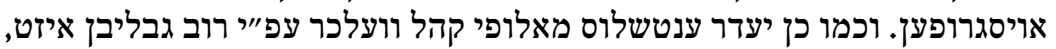

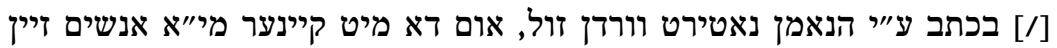
גשלאסענען רעזולטאט [/] ניכט אבשטעהן קאן.

כל בני קהלתינו מחוייביי לנהוג בכבוד מנהיגי הקהלה, וויא אויך מן מוס מוס בתפילת 10

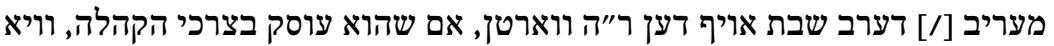

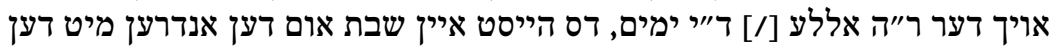

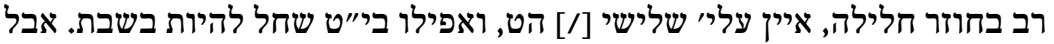

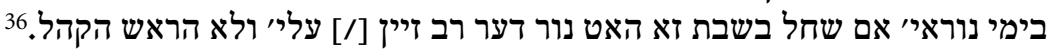

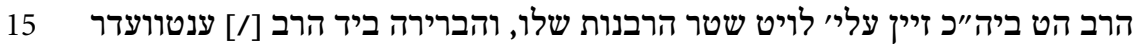

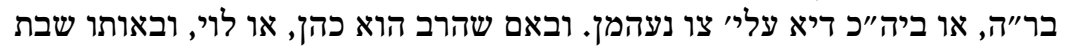

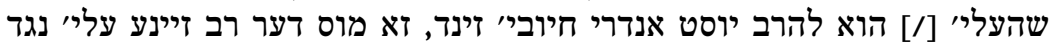

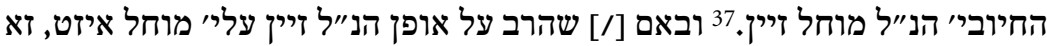

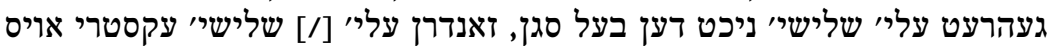

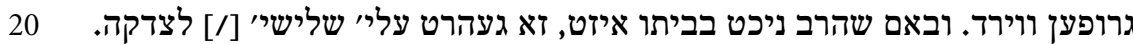

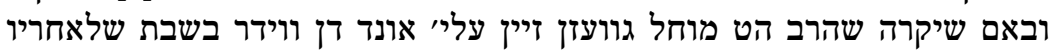

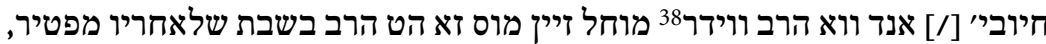

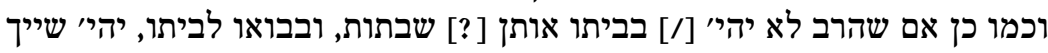
עלי' שלישי' לראש הקהל או שארי חיובי כנ״ל [/] או שיתות שייך להרב מפטיר.

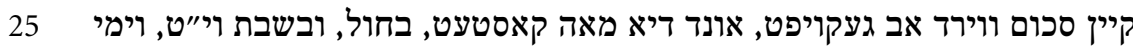

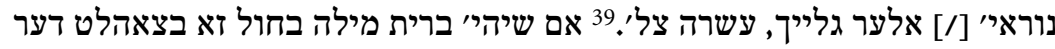

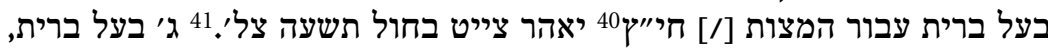

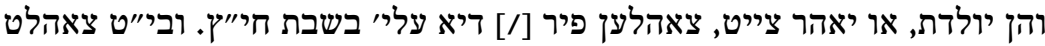

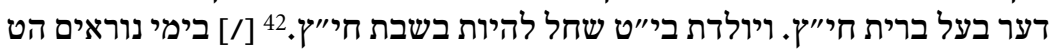

\footnotetext{
36 Danach ein $ב$.

37 Danach ein $\lambda$.

38 Dieses Wort über der Zeile ergänzt.

39 Danach ein ב.

ח"י צעלמר 40.

41 Danach ein ג.

42 Danach ein 7.
} 


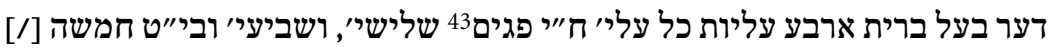

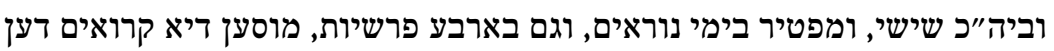

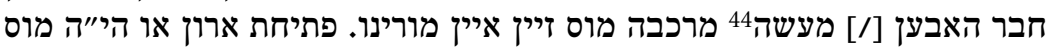

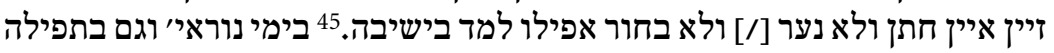

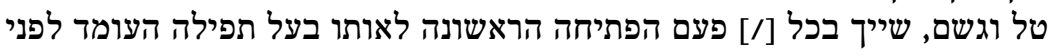
התיבה ואותו מאן דהוא דער [/] שארי פתיחות קויפת הרנט מות מוס דארוף שאן קונפער ...]

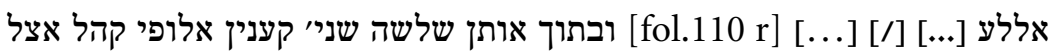

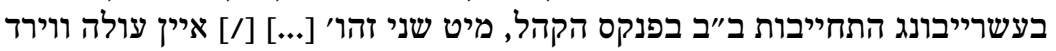

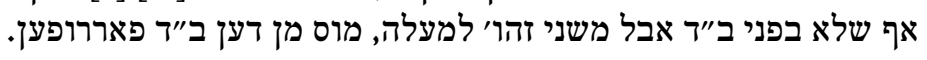

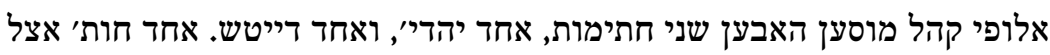

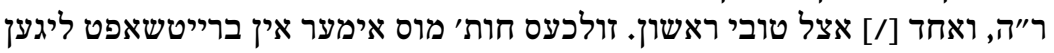

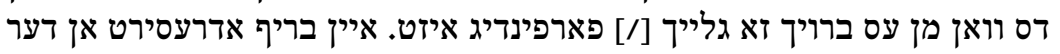

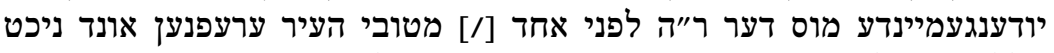

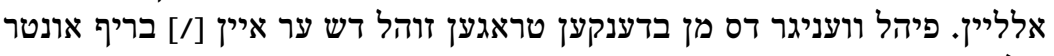
שלאגען הט. - (אלייו. 15

אצל חילוק תפילות בימי נוראי' מוסען דיא גבאיי אין געגענווארט זיין, וויא אויך

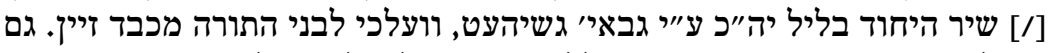

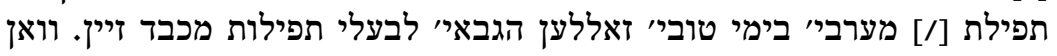

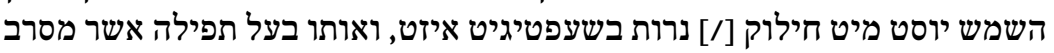

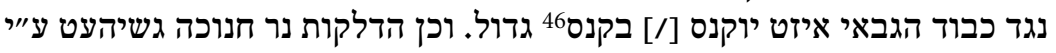

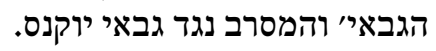

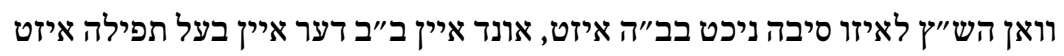

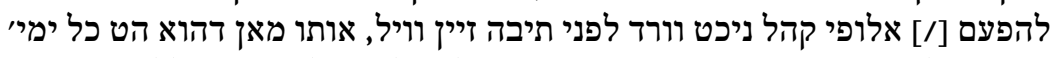

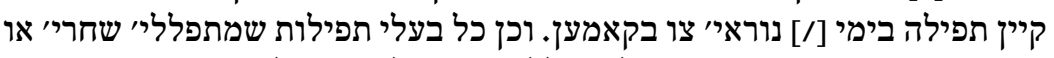

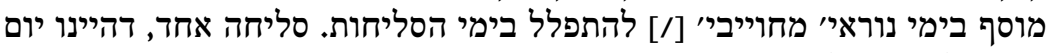

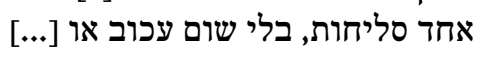

הושענה רבה, ביום ווירדן אצל הספרי' קודם מוסף אנגרופען וויא פאלגעט [/] המרים

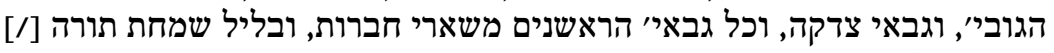

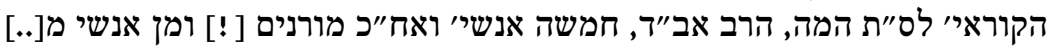

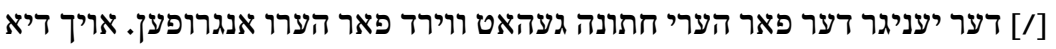
אייגנע [/] ספרים האבען בב"ה ווירדן אנגרופן הער. ביי' לעגלאד אויסציר פריהן, מיסען זיין

43 Danach ein $\pi$.

44 Davor 7 "

45 Danach ein r.

46 Davor ein Wort durch Streichung unleserlich. 


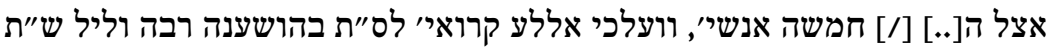

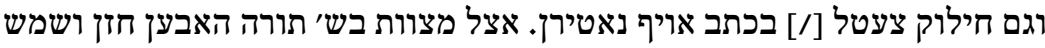

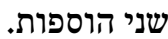

מקופת הקהל דערף גר ניכטס פרצעהרט ווערדן יעדאך פור דיא זיצגעלדר מיט [...]

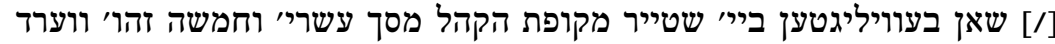

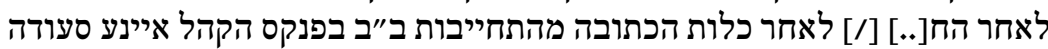

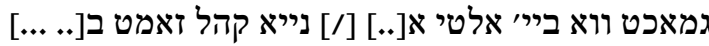

אללע זא[.......]אץ אבר ווירד יום א'דסליחות או לכל [...] [/] ח"ה סוכות פ[.....]

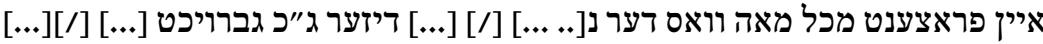

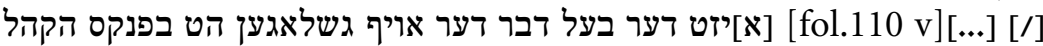

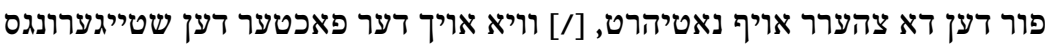
צעטל אונטר שרייבען מוס.

אותן ב"ב הדרי' בישובי' או בקהלה אחרת, וועהר מעהר אלס שלשה שני' שולדיג

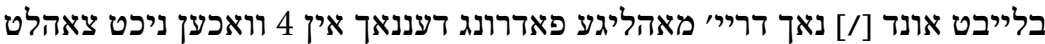

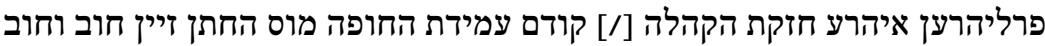

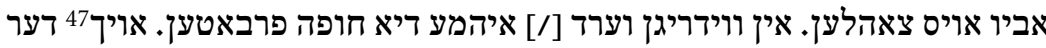

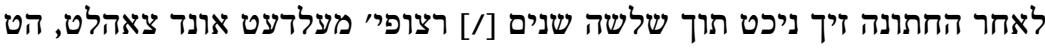

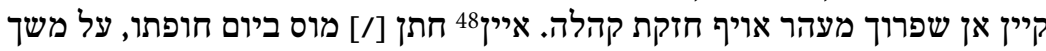

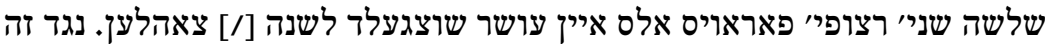
איזט ער גאנצי שלשה שניי בעפרייט שוצגעלד צו צאיוס פהלען.

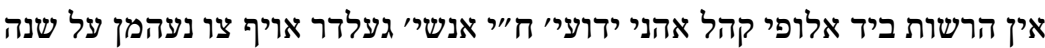

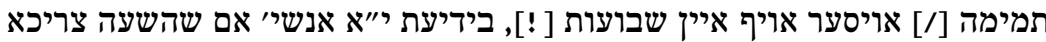

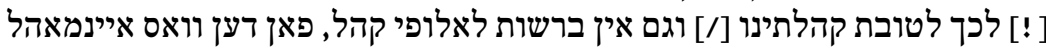

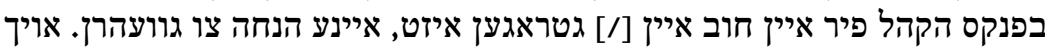
ניכט איינע קוויטונג לרח"ש אהני [/] ח"י אנשיי אורים צוריס צו פאלגען.

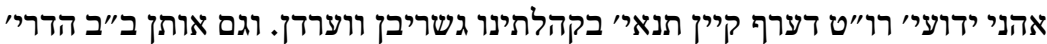

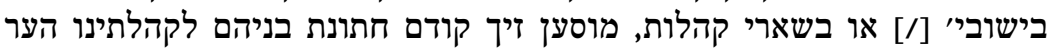

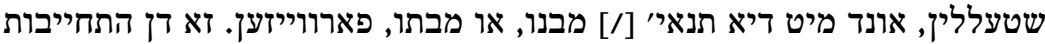

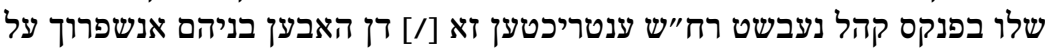
חזקו' הקהלה. אין ווידריגען הבען בניה' קיין אנשפרוך [/] על חזקת קהלת עיתינו.

$\begin{array}{ll}47 & \text { Davor ein } ב . \\ 48 & \text { Davor ein ג. }\end{array}$ 
אותן בעלי בתי' הדרי' בשארי קהלות במדינתינו, או בישובי' אונטר איין אנדר 38

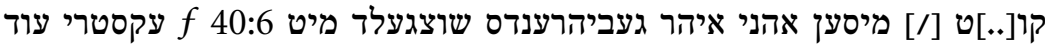

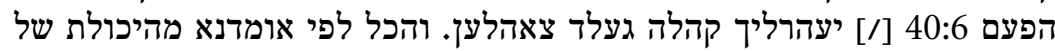
אותו מאן דהוא.

רח"ש איזט וויא פאלגעט. להרב אב"ד מכל מאה ך"ה פגיי ופחות ממאה מאי כמאי כמאה.

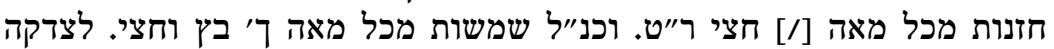

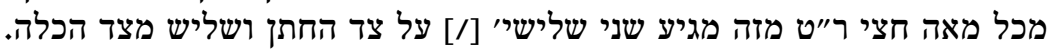

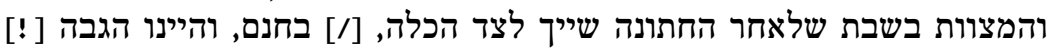

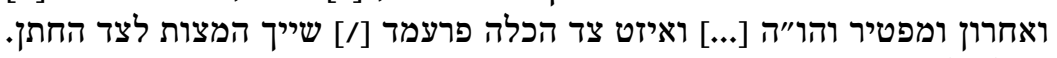

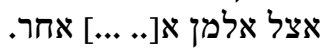

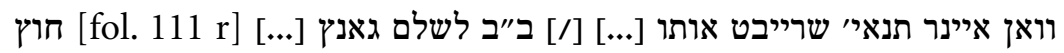
לקהל אונד קאמט הערנאך לקהלתינו, מוס צאהלען רח"ש.

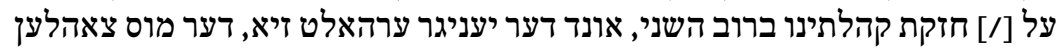
רח"ש אף שכבר עבר.

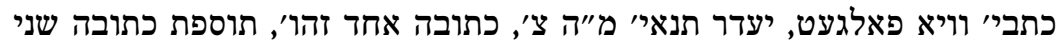

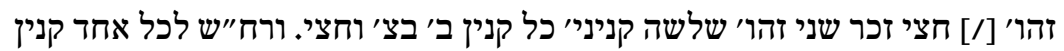
אחר.

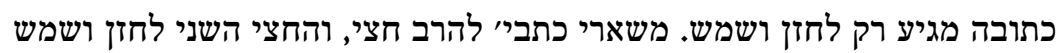

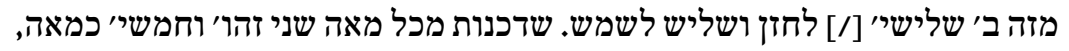
פחות מחמשי' כחמשים משים.

האנדשלאג על כל מו"מ גילטעט בקהלתינו מעהר אלס דראנגעלד, והמתחרי

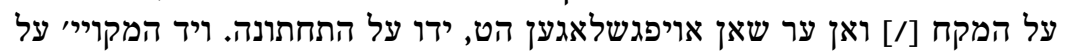

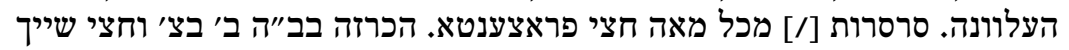

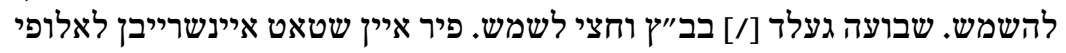

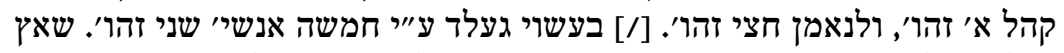

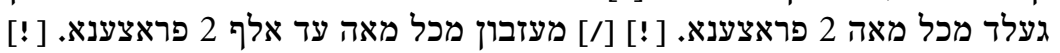

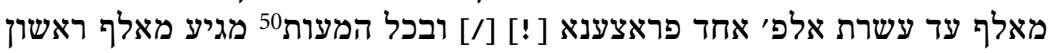
שני פראצענטא.

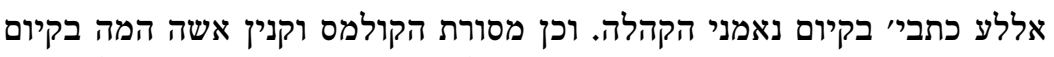

אם שאחת מבנות ישראל תהי' הרה לזנוניי זא ווירד דיא חופה ביום חתונתה [/]

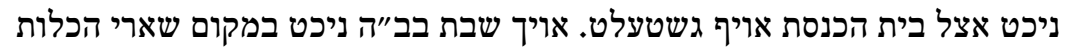

49 Dieses Wort über der Zeile ergänzt.

50 In der Handschrift: העות. 
[/] שטעהן דערף. אויך קיין דעק טוך טראגען ואם המליטה זכר יהיי הבריי בביתה

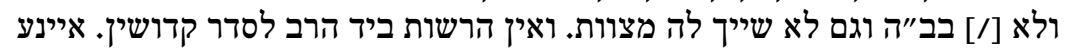

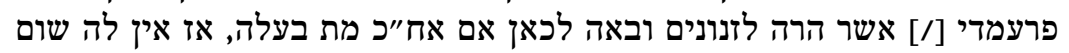
זכות ויפוי כח על חזקת הקהלה הזה ונים

קודם חנוכה ופורי' אין שום רשות לכלי זמר' או משוררי' אין דער הייזער צו געהן, 5

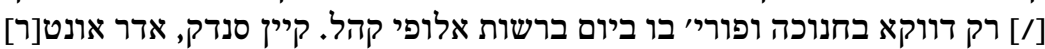

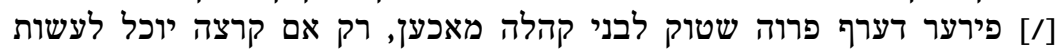

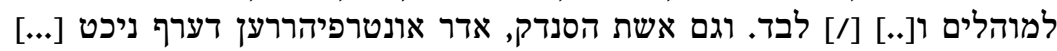

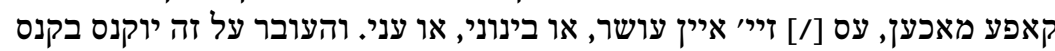

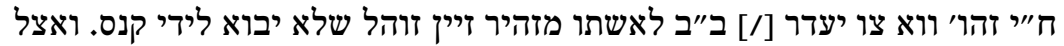

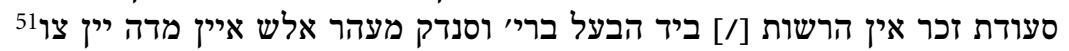

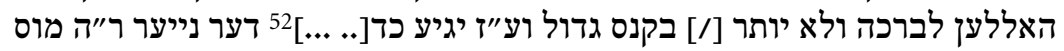

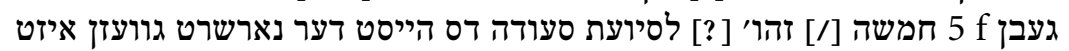

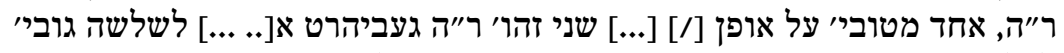

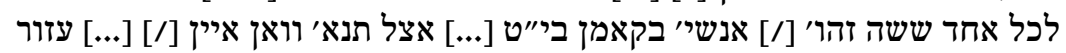

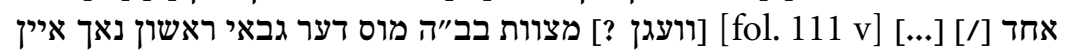

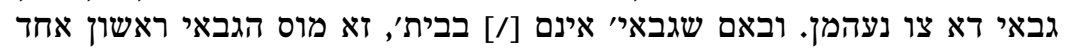
מטובי העיר דא צו נעהן.

וואן איין נער מיט איין ב"ב אין מו"מ צו זאמען קאמען זא בקאמט דער נער נור

כל התקנות הנ"ל אשר נקבצו מהתקנות הישנות, וגם נוספו על הראשונים קיימו וקיבלו

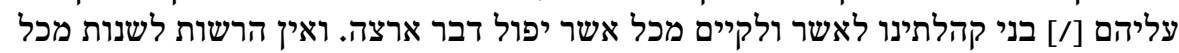

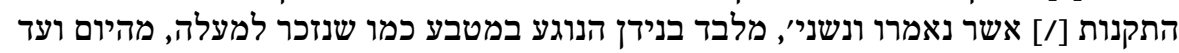

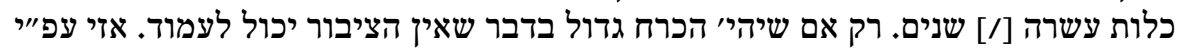

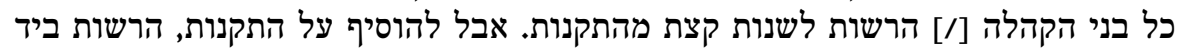

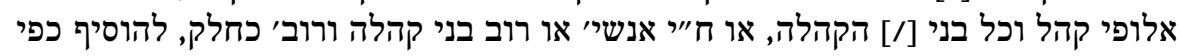

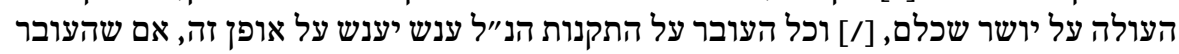

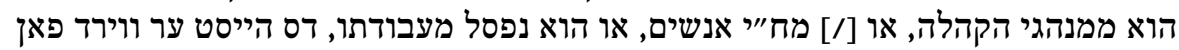

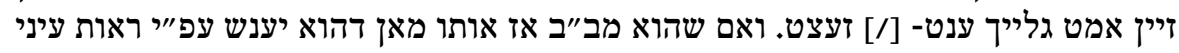

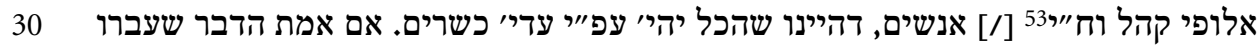

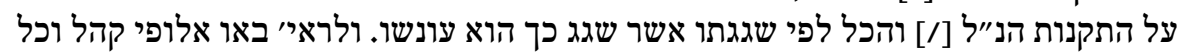

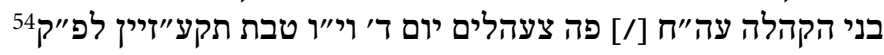

51 Danach dasselbe Wort noch einmal, jedoch gestrichen.

52 Tinte stark verblichen.

53 Danach $\times$ als Zeilenfüller.

541816 XII 25. 


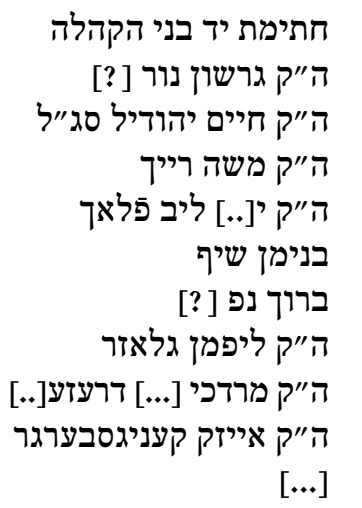

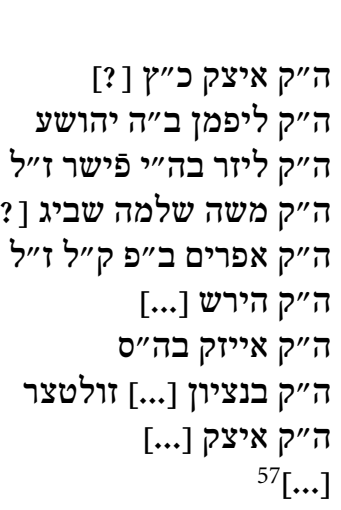

$[\cdots]$
חתימת יד אלופי קהל, וח"י אנשי"

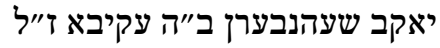

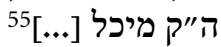

ה"ק מאיר המ"ה שלמה בישיץ

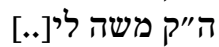

ה"ק זנוויל ב"ה אברהם ז"יל משיר

ה"ק מאיר שפיצר

ה"ק ישראל ליפשיץ מאיר

ה"ק מרדכי [...]

ה"ק עוזר קעניגסבערגר

ה"ה שיקור

ה"ק שמואל [...]

[fol. 112r]

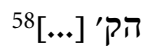

הק' יודא ב' הרץ

הק' [....

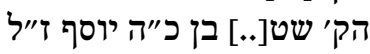

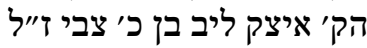

גרשון רפאל היצי

20

$[\ldots]$

הק׳ משה העש

הק׳ [... הקי משה

ואף גם [...] בהסכמה עלה על התקנות הטובים [?] מעלץ ל[..]ף [/] י]..]יע חוץ מה שנכתב בפונקט תשעה

55 Einige Unterschriften sind unleserlich oder die Lesung ist unsicher.

56 Stelle frei geblieben.

57 Davor eine Zeile gestrichen.

58 Unleserliche Unterschrift.

59 Daran schließt sich noch die Bestätigung durch den Ortsrabbiner Moses Halevi aus Glogau an, der einige Änderungen in $\$ \$ 9,13,26$ und 27 vermerkte. Dieser Absatz ist so schwer lesbar, dass hier auf seine lückenhafte Wiedergabe verzichtet wurde. Auch Spitzer verzichtete auf große Teile in der deutschen Übertragung; siehe Spitzer, Deutschkreutz, 150 f. Bemerkenswert ist, dass diese Bestätigung, oder vielleicht eher eine Art Revision, erst zehn Jahre später erfolgte, nämlich am 16. Tewet 586 nach der kleinen Zeitrechnung (1825 XII 26). 



\section{Ausgewählte deutsche Übersetzungen}





\section{Worms (1650)}

[S. 1]

Angelegenheiten des Lernens

1 Der Beginn der Weisheit ist die Gottesfurcht, ${ }^{1}$ daher sind wir übereingekommen, ständig eine Jeschiwa für Jugendliche und junge Männer zu unterhalten. In jedem Fall sollen acht Seelen in unserer Gemeinde am Schabbat wie an Wochentagen auf Kosten der Mitglieder der Gemeinde verpflegt werden, vier Jugendliche und vier junge Männer. Die Art und Weise ihres Unterhalts und wie bei der Aufteilung ihres Unterhalts und ihrer Mahlzeiten verfahren werden soll, wird immer durch drei Männer geregelt. Zwei Monate vor Beginn der Zeit ${ }^{2}$ sollen die Befehlshaber und parnasim zwei Männer wählen, die mit dem weisen Vorsitzenden des Gerichts, ${ }^{3}$ Gott schütze ihn, sitzen sollen, um die Angelegenheit zu überwachen.

2 Die Schabbatot ${ }^{4}$ sollen immer durch zwei parnasim und den Rabbiner, er möge leben!, zugewiesen werden. Einer der beiden soll vom Vorjahr weiter amtieren, während der andere vom Vorstand neu erwählt werden soll. Die Liste über die Verteilung der Schabbatot soll in der Hand des einen verbleiben und eine Abschrift davon soll beim Synagogendiener sein.

3 Bei einem Sohn, der noch von seinem Vater oder Schwiegervater unterhalten wird, ${ }^{5}$ sollen die Verteiler der Schabbatot prüfen, wie viele Schabbatot ihm nach seinem Vermögen zugeteilt werden sollen, und so viel muss er unterhalten bzw. diese anderweitig gegen die Hälfte der Summe einmieten. ${ }^{6}$

\footnotetext{
1 Ps $110,10$.

2 Des Unterhalts.

3 Gemeint ist der Rabbiner der Gemeinde.

4 Solche Schabbatot, die Studenten der Jeschiwa bei Gastfamilien verbrachten.

5 Aber bereits geheiratet hat.

6 D.h. die zu verpflegenden Studenten bei Herbergsleuten gegen Bezahlung unterbringen.
} 
4 Einem Jugendlichen oder jungen Mann, der in der Jeschiwa lernt und Gast bei einem Hausherrn ist, muss das Vorrecht bei diesem Hausherrn eingeräumt werden, und er muss, gemäß den Anteilen des Hausherrn, bei diesem vorrangig an den Schabbatot verpflegt werden. ${ }^{7}$

5 Der Rabbiner und die Mitglieder der Jeschiwa können untereinander ausmachen, welchen $\operatorname{Traktat}^{8}$ sie lernen möchten und die Lehrer können dies nicht verhindern.

6 Kein Lehrer soll mehr als acht Unterrichtsstunden mit Jugendlichen annehmen. Zwei Wiederholungen jedoch werden als eine Stunde gerechnet. Wenn er aber mehr Stunden geben sollte, wird das Honorar für die Überstunden für die Armenkasse eingezogen.

7 Jeder, bei dem noch keine fünf Jahre vergangen sind, seit er den Titel Haver ${ }^{9}$ erhalten hat, muss in jedem Fall in jedem ersten Monat zwei Mal wöchentlich und in jedem zweiten Monat einer Lernperiode einmal wöchentlich zur Jeschiwa gehen. ${ }^{10}$ Andernfalls wird eine Strafe von einem halben Kopfstück ${ }^{11}$ erhoben für jedes Mal, dass er dies übertritt und nicht geht, wie oben vorgeschrieben.

8 In jedem Fall muss in jeder ersten Woche der Lernperiode jeder, der den Haver-Titel trägt, zwei Mal in die Jeschiwa gehen, bei erwähnter Strafe.

9 Jeder Hausherr ist verpflichtet, an jedem Tag eine Zeit für das Studium der Tora festzusetzen. Dafür sollen sich Gruppen zusammenfinden und Fonds einrichten und jede Gruppe soll sich einen schriftkundigen Unterweiser wählen, der ihnen jeden Tag eine Lektion gibt, aus welchem Buch auch immer. Wer innerhalb von 30 Tagen nach Bekanntgabe dieser Bestimmung noch immer keinem Studierquorum beigetreten ist, zahlt eine Strafe von einem halben Taler. Die genannte Gesellschaft soll untereinander eine Strafe für jeden Tag festlegen, an dem die feste Lektion ausfällt. Die genannte Strafe von einem halben Taler fällt auf ein Vierteljahr [?], in dem er es versäumt, dem Quorum beizutreten.

7 Gemeint ist das Vorrecht gegenüber außerordentlichen Gästen wie durchreisenden Armen oder anderen Personen.

8 Talmudtraktat.

9 Titel, der das fortgeschrittene Studium religionsgesetzlicher Schriften bestätigt.

10 Offenbar sollte so gesichert werden, dass in einer Lernperiode wenigstens während der ersten zwei Monate ein minimaler Besuch des Lehrhauses realisiert wurde.

11 Eine Münze, die meist mit dem Bildnis des Münzherrn versehen war. Ihr Wert war oft auf 1/3 Gulden bzw. 20 Kreuzer festgesetzt. 
10 Wenn der Abschluss des Studiums eines Talmudtraktats in der Gemeinde begangen wird, soll dies in der Gemeindestube stattfinden und jeder, der gebildet ist, muss kommen um zu lernen und der Predigt des Rabbiners, Gott schütze ihn, zuzuhören. Zum Umtrunk ${ }^{12}$ müssen alle Bräutigame von jedem Hundert, das sie besitzen, und von jedem Hundert, das sie als Mitgift erhalten, einen Viertel Gulden von 100 geben. Und sogar eine Braut, die hier ohne Bräutigam lebt, muss nach dem Wert der Mitgift, die sie dem Bräutigam gibt, von jedem Hundert wie erwähnt geben und dies wird dem Bräutigam später auf die Mitgift angerechnet. Jeder Hausherr soll einen halben Batzen ${ }^{13}$ Haussteuer geben und von jedem Hundert Gulden, die in seiner Steueranlage sind, soll er einen halben Albus ${ }^{14}$ geben. ${ }^{15}$ Hingegen braucht kein Hausherr Wein zum Abschlussumtrunk beisteuern, wenn er nicht auch mitisst. Wer einen halben Gulden beigesteuert hat, braucht für das Essen nichts zu zahlen, ein anderer jedoch soll ein halbes Kopfstück für das Essen geben.

Angelegenheiten der Synagoge

11 Vor dem Barukh she-Amar ${ }^{16}$ muss der Vorsänger Ruhe während des Gebets anmahnen und vor der Lesung in der Tora muss er gleichfalls zur Ruhe während der Lesung ermahnen.

12 Beim Segen Yishtabeah ${ }^{17}$ soll nicht innegehalten werden und, was bislang üblich war, nämlich, dass der Synagogendiener an Neujahr und am Versöhnungstag sowie den Wallfahrtsfesten ${ }^{18}$ einen Gebetsmantel für denjenigen bringt, der vor dem Yishtabeah vor die Lade tritt, soll nicht mehr geschehen, nur noch vor dem Barukh she-Amar. Wenn der Monatsparnas beim Barukh she-Amar nicht in der Synagoge sein sollte und dem Synagogendiener nicht vorher befohlen hat, wen er beten lassen soll, so muss der Synagogendiener den vorherigen parnas oder einen anwesenden parnas fragen und diesen noch vor dem Barukh she-Amar damit beehren, bei Strafe für den Synagogendiener, wenn er dies nicht befolgt.

12 Teil des feierlichen Abschlusses eines Traktats.

13 Scheidemünze, im Rheinland galt ein Batzen für vier Kreuzer.

14 Albus (Weißpfennig) entspricht acht Pfennigen.

15 Marginalie am rechten Blattrand: Wenn er aber trotzdem dort isst.

16 Eröffnungssegen der Psuke de-Zimra am Morgengottesdienst.

17 Abschlusssegen der Psuke de-Zimra am Morgengottesdienst.

18 Pessach, das Wochenfest und das Laubhüttenfest. 
13 Wenn der Synagogendiener mit dem Schulklopfen ${ }^{19}$ fertig ist, soll er nur ein Wachslicht von der Länge eines Fingerglieds entzünden und darf nicht den Morgengottesdienst beginnen, bevor dieses Licht heruntergebrannt ist.

14 Man darf das Kaddisch ${ }^{20}$ nicht zu Beginn sagen, wenn noch keine zehn Männer anwesend sind, die »Amen« antworten können. Wenn keine zehn kommen, soll man auch nicht das Kaddisch sagen, bis die Gemeinde das Achtzehn-Bitten-Gebet ${ }^{21}$ beendet hat. Dann erst darf die Menge "Amen« sagen.

15 Die Aushebung und Einhebung 22 sollen verkauft werden, sei es am Schabbat, an einem Feiertag oder in der Woche. Wenn der Vorsitzende des Gerichts am Schabbat eine Predigt hält, muss er zur Toralesung aufgerufen werden und auch die Aushebung und Einhebung gehören dem Vorsitzenden des Gerichts zu Ehren der Predigt.

16 Wer die Aus- und Einhebung am Laubhüttenfest hat, soll das Ehrenamt der Aushebung auch an den Hosha'not ${ }^{23}$ haben, kann damit aber beehren, wen er will.

17 Kein Ehrenamt darf unter einem Batzen ausgerufen ${ }^{24}$ werden. Wenn das Ehrenamt nicht ersteigert wird, soll es nach der Reihenfolge der Plätze in der Synagoge vergeben werden. Wenn derjenige Hausherr, auf den es fällt, nicht in der Synagoge ist, soll das Ehrenamt an den ihm nächsten Hausherrn vergeben werden, bis der eigentlich bedachte in der Synagoge erscheint. Dann soll jenem das Ehrenamt gegeben werden. Wenn jemand das Ehrenamt ersteigert, soll es nicht für weniger als 4 Pfennige sein.

18 An Shmini Azeret ${ }^{25}$ soll drei Stunden vor Einbruch der Nacht zum Nachmittagsgottesdienst gerufen werden. Bei diesem einen Mal sollen die Eh-

19 Der morgendliche Aufruf zum Gottesdienst, bei dem der Synagogendiener oder manchmal auch ein besonderer Schulklopfer mit einem Holzhammer an die Haustüren oder Fensterläden der Juden schlug.

20 Bedeutendes Gebet im jüdischen Gottesdienst, daneben findet es auch als Totengebet Verwendung.

21 Zentrales Gebet an den wochentäglichen Gottesdiensten. Es wird von jedem Betenden leise für sich gesprochen.

22 Das Heben der Torarolle aus dem Toraschrein und in ihn zurück.

23 Hosha'na Rabba, der siebte Tag des Laubhüttenfests.

24 Zur Versteigerung.

25 Der achte Tag des Laubhüttenfestes. 
renämter ${ }^{26}$ nach dem Gottesdienst ausgerufen werden und alle sollen vor Einbruch der Nach von hier weggehen. Ez Hayim ${ }^{27}$ und die Erhebung, ${ }^{28}$ die Toralesungen, das Suchen und das Aufrollen sollen jeweils zu drei Teilen vergeben werden.

19 Der hekdesh ${ }^{29}$ darf keine Ehrenämter zurückhalten, sondern muss diese vor dem Abendgottesdienst aufgeben, außer den Maftir, ${ }^{30}$ der nicht anderweitig vergeben werden muss. In jedem Fall sollen am Morgengottesdienst vom Fest der Torafreude keine Ehrenämter ausgerufen werden, sondern jedes soll zu seiner Zeit verkauft werden. Die zweite Torarolle zu halten, einschließlich der ersten Erhebung, soll jedes Mal in diesem Moment ausgerufen werden, und nicht an Shmini Azeret.

20 Das ganze Jahr über darf bei Strafe von einem halben Pfund Wachs das Amt des Segen[-Sprechens] nur an jemanden vergeben werden, der verheiratet ist.

$21^{31}$ Niemand darf ein Kind in die Synagoge mitbringen, das noch nicht reinlich ist. Falls einer dies übertritt und - behüte! - etwas Unwürdiges geschehen sollte, muss der Vater eine Strafe von einem Pfund Wachs zahlen. Jeder soll sein Kleinkind bei sich halten und obige Bestimmung soll auch für die Frauenabteilung gelten.

22 Die Torarolle soll vom Augenblick des letzten Segens eines Aufgerufenen bis zum ersten Segen des nachfolgenden Lesers bedeckt bleiben.

23 Die Torarolle darf nicht erhoben werden, bis derjenige, der das Rollen übernimmt, nicht auf der Bima ${ }^{32}$ ist, bei Strafe von einem halben Pfund Wachs für denjenigen, der die Erhebung hat.

26 Gemeint sind offenbar die Ehrenämter für das Abendgebet des sich anschließenden Fests der Torafreude.

27 Ehrenamt des Haltens des hölzernen Griffes der Torarolle.

28 Erheben der geöffneten Torarolle vor der Gemeinde, damit diese die zu lesende Stelle sehen kann.

29 Jüdisches Spital und Armenhaus; gemeint ist hier der Gemeindeangestellte des hekdesh.

30 Die letzte der sieben Toralesungen am Schabbat. Der Maftir beinhaltet auch das Lesen der Haftara, des jeweiligen Abschnitts aus den Prophetenbüchern.

31 Dieser Paragraph wurde über der Zeile ergänzt, darunter gestrichen: Wenn der Vorstand einen Mann zur Toralesung bestellt, soll dessen Name aufgerufen werden und nicht vor dem Pult [...].

32 Der erhöhte Platz in der Synagogenmitte, wo die Lesung stattfindet. 
24 Für die Psuke de-Zimra sollen die parnasim einen Hausherrn benennen, der sie immer im Verlauf des gesamten Jahres sagt. Im Sommer soll sie der Synagogendiener oder der Untervorsänger gemeinsam mit ihm vortragen.

25 Am Ausgang des Schabbat muss der gabbai durch zwei Wächter jedem Hausherrn eine Wachskerze von der Länge eines Fingers schicken lassen, jedoch keine für die Jugendlichen selbst. ${ }^{33}$

26 Wer keine Kerze für den Versöhnungstag im Gewicht von einem Pfund hat, darf sie auch nicht vor dem Vorsänger in den Leuchter stecken, bei Strafe von einem halben Pfund Wachs.

27 An den Hohen Feiertagen sollen zwei Eisenketten an den beiden Seiten des Pultes des Vorsängers angebracht werden, damit keiner den für diesen vorgesehenen Platz betritt.

[S. 2]

28 Bezüglich der Betenden an den Hohen Feiertagen: Wenn einer den Titel eines Moren $u^{34}$ trägt, muss er zur Toralesung entweder an Neujahr oder am Versöhnungstag aufgerufen werden. Wer keinen Morenu-Titel trägt, muss im Monat Tischri ${ }^{35}$ aufgerufen werden, der amtierende Vorsänger jedoch wird gar nicht aufgerufen. Wer in das Widderhorn bläst, muss am selben Tag zur Lesung aufgerufen werden. Wer dies an zwei Tagen tut, muss nur am ersten davon zur Toralesung aufgerufen werden.

29 Am Tag nach dem Versöhnungstag soll vom Vorstand ein Dukat für einen Umtrunk zu Ehren der Vorsänger vom Neujahr und vom Versöhnungstag gegeben werden.

30 Die Namen aller Hausherren in der Gemeinde, außer den parnasim, sollen in eine Urne gelegt werden und an jedem Schabbat des Jahres soll einer von ihnen am Vorabend des Schabbat aufgerufen werden, damit er zur Toralesung komme, bei Strafe von einem Pfund Wachs an die Armenkasse.

31 Kein Gast oder Fremder darf ohne Zustimmung der Mehrheit der parnasim vor der Lade beten. Die Zustimmung des Monats-parnas allein genügt nicht.

33 Der Grund für diesen Brauch lässt sich aus dem Paragraphen nicht erschließen.

34 Rabbinatsapprobation, die jedoch nicht automatisch das Innehaben eines Amtes als Rabbiner einschloss.

35 Der erste Monat des jüdischen Kalenders, in dem die Hohen Feiertage stattfinden. 
32 Kein Gast soll eine Predigt halten dürfen, falls er nicht nachweist, dass er Vorsitzender einer Jeschiwa in einer mittleren Gemeinde, und nicht nur in einer kleinen war.

33 Kultgeräte, die verpfändet wurden, sollen wieder ausgelöst werden. Dafür soll jedes Hochzeitspaar sein zu entrichtendes Einzugsgeld dem Rabbiner übermitteln, damit er es für die Auslösung von Pfändern zurücklegt. Der Rabbiner darf die Ehe nicht schließen, bis ihm die genannten Gelder gegeben wurden. Auch was von bereits abgeschriebenen Steuern dennoch eingenommen wird, soll für die erwähnte Auslösung verwendet werden, bei Strafe von zwölf Talern, je zur Hälfte an das hekdesh und an die Obrigkeit. Niemand soll in der Synagoge Dinge mit Nichtjuden - und noch weniger mit Nichtjüdinnen - bereden. Vielmehr sollen sie hinausgehen und dort mit ihnen reden, bei Strafe von einem Pfund Wachs für die Beleuchtung in der Synagoge.

Der $^{36}$ amtierende Vorsänger soll keine Melodie am Schabbat anstimmen, nur an 'Guten Schabbatot ${ }^{37}$ ist eine Melodie erlaubt, die der Torarolle gewidmet ist. Er darf weder das Nekadesh ${ }^{38}$ noch das Na'arizkha ${ }^{39}$ anstimmen.

34 Das Klamen ${ }^{40}$ in der Synagoge darf nicht ohne Erlaubnis des Vorsitzenden des Gerichts oder des Monats-parnas geschehen, bei Strafe von einem halben Taler.

35 Am Schabbat nach Purim oder wenn Shushan Purim auf einen Schabbat fällt, erhalten die Jugendlichen alle Ehrenämter.

Das Pfenniggeld 41

36 Bezüglich des Pfenniggelds: Wenn hier am Ort etwas bis zu einer Höhe von zehn Gulden eingekauft wird, braucht man dafür nichts abführen. Von zehn Gulden und mehr muss jedoch davon wie bisher etwas abgeführt werden, d.h. jeder Einzelne muss aufschreiben, was er jedes Mal für Waren gekauft hat, und am Ende eines halben Jahres muss mit ihm Abrechnung gemacht werden, was seinen Handel anbetrifft. Bis zur Hälfte

36 Ab hier späterer Nachsatz in anderer Schrift.

37 Schabbatot mit besonderen Segnungen.

38 Beginn des Kedusha-Gebetes im Morgengottesdienst.

39 Beginn der Kedusha im Musaf-Gebet.

40 Unterbrechen des Gottesdienstes durch eine Person zur Einforderung ihres Rechts in dringenden Fällen.

41 Eine Art Umsatzsteuer. 
seines Vermögens soll er befreit sein und braucht nichts dafür abzuführen, z.B. wenn jemand ein Vermögen von 1000 Reichstalern hat und sein Geschäft einen Umfang von 500 Reichstaler hat, ist er von allem befreit. Jedoch von dem, was darüber liegt, muss er das Pfenniggeld in voller Höhe abführen in der Art, das er einmalig im Jahr für einen Teil von 500 Reichstalern, aber nicht mehr, befreit ist. Bei jedem wird die Hälfte des Vermögens einmal im Jahr ${ }^{42}$ abgezogen und nicht mehr. Jeder muss am Ende eines Jahres schwören, dass er nichts unterschlagen und alles korrekt aufgeführt hat.

37 Wer auf einmal Waren für mehr als zehn Gulden verkauft, obwohl er sie einzeln eingekauft hat, muss davon etwas abführen. Wer jedoch einen Laden hat und er kauft und verkauft alles einzeln, muss von dem, was er eingekauft hat, etwas abführen. Von seinem Handel soll ihm die Hälfte seines Vermögens abgezogen werden.

38 Die Ablöse vom Pfenniggeld ${ }^{43}$ ist wie in einer alten Bestimmung ${ }^{44}$ dargelegt (d.h. von allem, was gekauft werden wird, müssen je Taler acht Pfennige für alle Arten von Waren abgeführt werden), sogar von Eisen, Federn, Zinn und Kupfer, Blei und ebenso von ganzen Stücken Ware, die er komplett weg gibt. Von Mehl und von Getreide, das gewinnbringend an Nichtjuden verkauft wird, sollen sechs Pfennige je Taler gegeben werden. Von unreinem Licht, ${ }^{45}$ Kleinkram und von Wein, rein oder unrein, hat man es verringert und jetzt soll von jedem Fuder ${ }^{46}$ ein halber Gulden abgeführt werden.

39 Wenn ein Jude einem anderen etwas abkauft, muss er nichts davon abführen. Nur wenn jemand einem Nichtjuden etwas verkauft, muss er etwas abführen.

42 Vom Umsatz.

43 Im Original steht hier der hebräische Begriff pshitim, bis hier sonst immer das aus dem Deutschen stammende Wort.

44 Am Rand ergänzt: »Nur das ist verringert worden, dass von heute an bis zum Ende der Gültigkeit der alten Bestimmung bis [...] Chanukka 411 [Mitte Dezember 1650] nur vier Pfennige von jedem Taler gegeben werden sollen. Von jenem Chanukka an sollen sechs Pfennige pro Taler gegeben werden, sonst bleibt alles, wie bisher.

45 D.h. aus Talg von nichtkoscheren Tieren.

46 Hohlmaß, das vor allem für Wein Anwendung fand, und der Ladung eines zweispännigen Wagens entsprach. Dementsprechend groß ist die Spannweite der Einheit und reicht von ca. 800 bis 1800 Litern. 
40 Wegen der Fremdengelder ${ }^{47}$ haben wir beschlossen, dass die Regel wie bisher bleiben soll, wonach man davon nichts abführen muss. Nach einem Jahr, d.h. bei Erneuerung der Steueranlage, soll derjenige, der einen Kommissionshandel hat, Pfenniggeld abführen wie von seinem eigenen Handel. Wenn sie redlich sind, sollen diese für das Fremdengeld eine Bestimmung erlassen, und dies soll nach Anweisung der Statutenkommission geschehen.

41 Weiter haben wir beschlossen, dass niemand eine Geschäftspartnerschaft mit jemandem von außerhalb der Gemeinde eingehen soll, bei Strafe nach dem Ermessen der parnasim, Gott schütze sie.

Über die Steuerschätzer

42 Die Wahl der Steuerschätzer soll auf folgende Art durchgeführt werden: Die parnasim wählen sie und jeder soll auf einem Zettel die Namen der parnasim aufschreiben, die nach seiner Meinung Steuerschätzer sein sollen. Diese Zettel werden einer nach dem anderen in eine Urne getan. Wenn ein Name aus der genannten Urne gezogen wird, soll jeder sofort seine Stimme für oder gegen ihn abgeben. Wenn die Mehrheit für ihn ist, soll es so sein. So soll mit allen verfahren werden, auch mit den Steuerschätzern, die von den Hausherren gewählt werden.

43 Diejenigen unter den parnasim, die aus verwandtschaftlichen Gründen nur begrenzt stimmberechtigt sind, dürfen nur als eine Stimme zählen. Dies geschieht, indem sie untereinander auslosen, wer von ihnen seine Entscheidung schriftlich abgeben darf, und beim nächsten Mal soll ein anderer den Vorrang haben und so weiter. Der Monats-parnas jedoch hat vor allen seinen Verwandten Vorrang, denn er geht allen vor. Seine Verwandten stehen nach ihm und es braucht nicht gelost zu werden, so ist es und so soll es bleiben. In allen Angelegenheiten von Wahlen und Strafen sowie Urteilen, die von den parnasim gefällt werden, und für die ein Quorum erforderlich ist, sollen die Verwandten als eine Stimme gerechnet werden. Nachdem, was wir gesehen haben, gibt es einige Widerspenstige und Ablehnende gegen diese Bestimmung. Um zu vermeiden, dass sich die Komplikationen in dieser Angelegenheit ausweiten, haben wir alle parnasim und noch weitere Männer hinzugezogen und haben aufrichtig [darüber beraten], und dabei wurde durch die Mehrheit der Kommission beschlossen, dass diese Bestimmung unumstößlich ist und als Gesetz gültig sein soll, das nicht übertreten werden darf. Jedoch sollen die Rechte

47 Offenbar eine Steuer für auswärtige Händler. 
der Obrigkeit unbenommen bleiben. Bei der Wahl der parnasim können sogar auch die Verwandten ihre Stimme abgeben.

44 Insgesamt soll es fünf Steuerschätzer geben, zwei parnasim und drei Hausherren. Sie dürfen nicht verwandt sein, sondern müssen für das Amt diesbezüglich geeignet sein. Ferner sollen zwei als Stellvertreter bestimmt werden, ein parnas und ein Hausherr. Auch diese müssen befähigt sein ${ }^{48}$ und dürfen in keiner Weise verwandt sein.

45 Wenn man sich während der Wahl für die Steuerschätzer nicht auf einen parnas einigen kann, so soll dieser parnas die Kommission verlassen, wie auch seine Verwandten kein Stimmrecht haben. Wenn man über einen Verwandten eines parnas abstimmt, so soll der Regel entsprechend der mit ihm verwandte parnas die Versammlung verlassen.

46 Sobald ein Steuerschätzer gewählt wurde, der kein parnas ist, darf man nicht mit der Abstimmung über den zweiten Steuerschätzer beginnen, bis nicht der erste in der Gemeindestube erschienen ist. Erst danach soll der zweite gewählt und sofort danach in die Gemeindestube gerufen werden. Anschließend soll der dritte Steuerschätzer gewählt werden. Unmittelbar nachdem alle fünf Steuerschätzer gewählt sind - auch die Stellvertreter sollen sie sich in einem eigenen Raum versammeln und dort gemeinsam bleiben und nicht auseinander gehen. Wenn die Nacht schon anbrechen sollte, müssen sie Nahrung und Bettzeug mitbringen und dürfen nicht auseinander gehen. Die zusätzlichen Steuerschätzer sollen ebenfalls beieinander vor dem besonderen Raum bleiben und nicht auseinander gehen, bis die Vermögensschätzung beendet ist. Auch der Synagogendiener soll bei ihnen bleiben und bei Geldstrafe nicht von ihnen weichen, damit keiner bis zum Ende der Vermögensschätzung weggeht, bei Strafe von zwei Dukaten zugunsten der Armenkasse ohne Nachlass für jeden, der dies übertritt und sich entfernt.

47 Die fünf Steuerschätzer und auch die beiden Stellvertreter sollen durch Übergabe eines Gegenstands ${ }^{49}$ geloben, dass sie niemanden überreden, jemandem auf seine angemessene Festsetzung Nachlass zu gewähren oder jemandem eine höhere Steuer aufzuerlegen, als nach ihrer Meinung angemessen ist. Es soll nur in Wahrheit und Aufrichtigkeit, ohne Zuneigung oder Ablehnung geschehen.

48 In verwandtschaftlicher Hinsicht.

49 Symbolische Übergabe eines Gegenstandes als Pfand für das Versprechen. 
48 Wenn jemand über einen der Steuerschätzer sagt, das dieser ihm nicht wohlgesinnt sei, soll man nicht auf ihn achten und ihm dies nicht glauben, es sei denn, dass er nachweisen kann, dass der Steuerschätzer mit ihm drei Tage wegen einer Auseinandersetzung nicht geredet habe, die von der Art ist, dass sie das Prozedere ungültig macht und er deswegen [S. 3] sagt, dass jener ihm nicht wohlgesinnt sei.

49 Wer auf sein Vermögen einen Eid ablegen möchte, muss dies innerhalb von fünf Tagen nach der Steuerschätzung tun und muss eine Aufstellung mitbringen. Wenn acht Tage vergangen sind und er noch immer nicht seinen Eid auf das Vermögen geleistet hat, muss er nach der vollen Anlage zahlen. Auch die Ehefrau des Eidleisters muss beim Eid in der Synagoge anwesend sein und muss mit "Amen" antworten. Nur eine Schwangere ist davon befreit. Auf jeden Fall hat dann der Vorstand das Recht, von ihr nach der Entbindung den Eid abzufordern.

50 Zwei Steuerschätzer und der Synagogendiener sollen beim Schatzungseid anwesend sein. Sie sollen untereinander losen, einschließlich der zusätzlichen Steuerschätzer, wer beim Eid anwesend sein soll. Wenn sich durch die Ausgelosten eine Verzögerung ${ }^{50}$ ergeben sollte, muss jeder eine Strafe von einem halben Taler zahlen.

51 Wer aus Furcht vor einer Strafe bei seinem Eid noch etwas hinzufügen möchte zu dem, was er in der Aufstellung angegeben hat, kann dies unter der Bedingung tun, dass er nicht mehr als den zwanzigsten Teil hinzufügt, d.h. fünf von hundert. Andernfalls gibt es den Anschein, dass seine Liste betrügerisch angefertigt wurde und deswegen soll man ihm den Eid nicht abnehmen. Vielmehr soll er gemäß seiner Schätzung alles zur Gänze bezahlen und muss alles so beeiden, wie es in der Aufstellung steht.

52 Wenn es sich - behüte! - ergeben sollte, dass jemand unnötigerweise einen Eid geleistet hat, soll er mit einem Drittel seines Kapitals bestraft werden.

53 Schulden, die in die Schätzung der Steuerschätzer einfließen, sollen so besteuert werden, wie in einer alten Bestimmung festgelegt. Sonst soll er ${ }^{51}$ sie beim Vorstand, Gott schütze ihn, als abgeschriebene Schulden eintragen lassen.

50 Bei der Eidesleistung.

51 Der Gläubiger, für den die Schätzung gemacht wird. 
54 Wenn jemand Schulden angibt, die er bei anderen hat, und ersucht, dass ihm diese Schulden von seinem Vermögen abgezogen werden sollen, müssen die Steuerschätzer genauestens prüfen, welcher Art diese Schulden sind. Schulden, die schon zwei Jahre ausstehen und für die er keine Zinsen bezahlt hat, soll man gegen Schulden, die andere bei ihm haben, nach der Summe aufrechnen, Schuld gegen Schuld, alles in gleicher Höhe. Auch wenn er innerhalb eines Jahres die Schulden begleichen sollte, können sie auf keinen Fall [von seinem Vermögen] abgezogen werden.

55 Für Schulden, die bei ihm ${ }^{52}$ durch andere während der Gültigkeit der Schätzung beglichen werden, und für die er bis dahin noch keine Abgaben an den Vorstand in voller Höhe entrichtet hat, müssen die Abgaben rückwirkend beim Vorstand entrichtet werden. In jedem Fall muss er nicht mehr als zwei vergangene Jahre rückwirkend nachzahlen. D.h., wenn er zwei Jahre nach Beginn der Vermögensschätzung im Monat Kislew $511^{53}$ etwas einnimmt, braucht er nicht mehr als für die beiden letzten Jahre rückwirkend zu bezahlen. Wenn er jedoch nicht die gesamten Außenstände zurückerstattet bekommt, sondern nur einen Teil, soll er rückwirkend für zwei Jahre nachzahlen entsprechend der Abrechnung, ${ }^{54}$ für die er dem Vorstand noch nichts entrichtet hat.

56 Haushaltsgegenstände wie Bettzeug, Tischdecken, Handtücher, Bezüge, Zinn und Kupfer ${ }^{55}$ und Messing kann jeder Einzelne im Wert von 50 Talern besitzen, der wenigstens Hundert ${ }^{56}$ an Vermögen hat. Dafür braucht er keine Abgaben zu leisten. Für jede hundert Taler, die er zusätzlich an Vermögen besitzt, darf er an genannten Haushaltsgegenständen weiteres im Wert von 15 Talern besitzen. Falls er jedoch mehr an den genannten Haushaltsgegenständen über die 50 Reichstaler für die ersten Hundert und die 15 für die weiteren Hunderte haben sollte, muss er für das $\mathrm{Zu}$ sätzliche Abgaben zahlen. Für Geräte aus Holz, Keramik und Eisen sowie für Kleidung braucht man jedoch nichts zu entrichten.

57 Für alles aus Gold und Silber muss in voller Höhe die Steuer entrichtet werden, selbst wenn sie an Kleidungsstücken befestigt sind.

52 Der Gläubiger, für den die Schätzung gemacht wird.

531640 IX.

54 Über die Teilrückzahlung.

55 Gemeint sind vor allem Geschirr und Kochgeräte.

56 Taler. 
58 Getreide, Wein und Mehl, die jeder in seinem Haus hat, dürfen für den eigenen Bedarf für ein halbes Jahr angerechnet werden. Was noch darüber vorhanden ist, muss versteuert werden.

59 Die Vermögensschätzung soll vollständig gemacht werden, ohne Abzug von einem Drittel. ${ }^{57}$

60 Wer keine 500 Reichstaler Vermögen aufbringen kann, soll durch die Steuerschätzer nach ihrem Ermessen veranlagt werden. Doch selbst bei dem Ärmsten der Armen darf man das Vermögen nicht geringer veranschlagen als 75 Reichstaler, von denen sie ihre Abgaben leisten müssen.

$[61 \ldots]^{58}$ Monat haben.

[62 ...] Jahre, und dann soll die Vermögensschätzung erneut für zwei Jahre gemacht werden [...] des Jahres nicht abschwören kann, nur zu Beginn des zweiten Jahres ist er berechtigt, einen Eid zu leisten, wenn er [...] wenn er sich zum Eid meldet. Aber wer $\$ 3$ von der anderen Seite [?] übertritt, von dem darf der Eid [...] einer zu Beginn des zweiten Jahres schwört und danach sein Vermögen im Verlauf des zweiten Jahres weiter abnehmen sollte. ${ }^{59}$

[63 ...] rückwirkend für jeden Hausherrn angerechnet hat, was gezahlt wurde vom Beginn des vergangenen Monats Kislew [... (...] und wer für die verflossene Zeit noch etwas herausgeben muss.)

[64 ...] andere Steuerschätzer auf oben genanntem Weg, die eine Vermögensschätzung für die ersten Steuerschätzer vornehmen sollen, bei Strafe [...] nur sollen sofort andere Steuerschätzer gewählt werden, und diese sollen nicht davon gehen, bis [...] Verfertigung der Vermögensschätzung, was auf sie nach der neuen Vermögensschätzung fällt.

[65 ...] wie erwähnt auf die Gemeindestube gerufen werden, und dürfen nicht auseinander gehen, bis [...]

57 Möglicherweise war dies eine frühere Praxis.

$58 \mathrm{Ab}$ hier bis zum Ende der Seite fragmentarische Paragraphen, da das rechte untere Viertel der Seite fehlt.

59 Marginalie am linken Blattrand: »Die Steuerschätzer müssen vor dem Wochenabschnitt Zakhor gewählt werden, bei Strafe von zwei Dukaten an das hekdesh ohne Nachsicht für den Monats-parnas. Ebenso soll die genannte Strafe für einen parnas gelten, der dies übertritt. So soll es, wenn Gott will, nach zwei Jahren gehalten sein, bei genannter Strafe.«Vielleicht sollte diese Ergänzung somit erst nach zweijähriger Verzögerung in Kraft treten. 
[Umgang mit Gästen?]

[66 ...] wenn er am Donnerstag kommt, darf er bis Sonntag bleiben, und derselbe Hausherr, der [...]

[67 ...] einen Zettel oder zwei geben, jedoch nicht mehr.

[68 ...] mehr als dies, wird ihm ein Zettel gegeben.

[69 ...] soll er nur drei Batzen geben und einer Frau zwei Batzen. Man soll keinen herum gehen lassen, falls er nicht $[\ldots]$ keinen Zettel ${ }^{60}$ hat, der vom Monats-parnas und dem gabbai geschrieben und unterzeichnet ist. Wenn der Armenpfleger glaubt, einem etwas über die drei Batzen dazu geben zu können, falls er aus gutem Haus kommt und ein ordentlicher Mensch ist, ist er ohne Zustimmung seines Amtskollegen und des Monats-parnas dazu nicht berechtigt.

[Über die pa] rnasim

$[70 \ldots]$ durch den Synagogendiener, zu welcher Stunde sie es vor die Versammlung bringen wollen, damit die Länge [...] alte bleibt eine halbe Stunde über diese Zeit, soll er eine Strafe von einem Batzen zahlen. Wenn er eine Stunde draußen [...] bleiben sofort nach dem Verlassen der Synagoge und darf keiner fehlen bei Strafe von zwei Batzen.

$[71 \ldots]$ obigen $[\ldots]$.

$[72 \ldots]$ reden und die Sache verwirren, die der Monats-parnas vorgebracht hat, bei Strafe von einem Batzen.

[S. 4]

73 Es ist dem Monats-parnas bei Bannstrafe verboten, etwas mutwillig zu vernachlässigen und einen anderen parnas dazu zu verleiten, jemandes Strafe nicht sofort auf einer Liste zu vermerken. Vor Ablauf seines Amtsmonats muss er diese Liste dem Vorsitzenden des Gerichts übergeben, und dieser soll ihm helfen, die genannten Strafgelder einzutreiben, bevor der ihm nachfolgende Monats-parnas sein Amt aufnimmt.

74 In jedem Fall hat der Monats-parnas Macht und Befugnis, während der Versammlung eine Geldstrafe auszusprechen, wenn die Sache dies erfordert. Niemand soll nach eigenem Befinden von der Versammlung weggehen, sondern vielmehr helfen, die Strafe durchzusetzen.

60 Zettel (plette) war der Verköstigungsschein, der an ortsfremde Arme ausgegeben wurde. 
75 Der Monats-parnas ist verpflichtet darüber zu wachen, dass die parnasim nicht streiten und auf den Tisch schlagen. Er soll dieses bestrafen oder selbst eine Strafe von einem Batzen aus seiner Tasche an die Armenkasse entrichten.

76 Wenn es sich ereignen sollte, dass eine Angelegenheit vorfällt, die einen Verwandten eines parnas berührt, wodurch er nach dem Gesetz der Tora ausgeschlossen $^{61}$ ist, muss er die Versammlung verlassen, bei Strafe von einem Dukaten. In jedem Fall muss der Monats-parnas ihn dazu veranlassen, die Versammlung zu verlassen, andernfalls muss der Monatsparnas aus eigener Tasche einen Dukaten Strafe zahlen. Gleiches gilt für jemanden, dem einer der parnasim nicht wohlgesinnt ist und der vor diesen aber eine gerichtliche Verhandlung haben will. Wenn er nachweisen kann, dass dieser parnas ihm tatsächlich nicht wohlgesinnt ist und dies nicht nur als Ausrede benutzt, so muss der parnas bei Ersuchen des Hausherrn die Versammlung bei obiger Strafe verlassen.

77 Jeder Beschluss, der vom Vorstand getroffen wird, soll zwei Mal beraten werden, bevor er bekannt gemacht wird. In jedem Fall muss die Angelegenheit innerhalb von drei Tagen erneut vorgebracht werden und wie sie dann beschlossen wird, so soll sie sofort und ohne Änderungen niedergeschrieben werden. Wenn der Monats-parnas die Sache erneut zum dritten Mal vorbringen sollte sind mindestens zwei [parnasim] nötig, um eine erneute Beratung zu verhindern.

78 Wenn etwas vorfällt und der Monats-parnas es versäumt, die Angelegenheit vor den Vorstand zu bringen, obwohl ihn drei parnasim aufgefordert haben, die Sache vor den Vorstand zu bringen und er es dennoch ablehnt, so haben dieselben parnasim die Befugnis, die Angelegenheit vorzubringen, und es muss über sie nach deren Angaben abgestimmt werden.

79 Wenn der Monats-parnas um Meinungen ${ }^{62}$ bittet, soll kein parnas seine Meinung sagen, bevor er an die Reihe kommt, bei Strafe nach Ermessen des Monats-parnas. Die Meinung von nahen Verwandten soll wie in $₫ 43$ dargelegt als eine Stimme gezählt werden. ${ }^{63}$

61 Von der Verhandlung ausgeschlossen.

62 In einer zu beratenden Sache.

63 Marginalie: gemäß [...] und auf jeden Fall [...] Batzen nicht [...] oder er muss es aus seiner Tasche zahlen. 
80 Wenn der Vorstand abends nach dem Verlassen der Synagoge in einer dringenden Angelegenheit einberufen wird, darf [bei Strafe der Ausrufung für acht Tage] kein parnas fehlen. Dies gilt auch, wenn er am Mischna-Studium teilnimmt, es sei denn, dass er gerade an diesem Tag mit der Leitung der Lektion an der Reihe ist. Der Monats-parnas ist verpflichtet, die Strafe durchzusetzen.

81 Das Protokollbuch des Vorstands soll immer in einer Kiste verschlossen sein. Der Monats-parnas darf dazu keinen Schlüssel haben, nur der parnas, der vor ihm an der Reihe war. Das Buch des Monats-parnas soll ebenfalls immer in der Kiste sein und er darf es nicht mit zu sich nach Hause nehmen, bei Strafe von einem Dukaten. Der Monats-parnas soll seine Abrechnungen zu Papier bringen und zum Rechnungsabschluss soll er diese im Beisein von zwei anderen parnasim in das erwähnte Buch übertragen. Gegen diese Abrechnung können sie nicht länger als acht Tage Einspruch erheben, bei Strafe von einem Taler. In jedem Fall muss er seine Rechnung innerhalb des auf seine Amtsperiode nachfolgenden Monats vorlegen, bei Strafe von einem halben Taler für jede Woche, die er über den Monat nach ihm die Sache verzögert. Die Strafe soll mit seiner Abrechnung verrechnet werden. Es soll nichts in das Protokollbuch des Vorstands geschrieben werden, dass nicht zuvor in schriftlicher Form dem Vorstand vorgelegt wurde. Der Monats-parnas muss die Abschriften immer $[\ldots]$

82 Die parnasim, Gott schütze sie, sind verpflichtet, unverzüglich bei Bekanntgabe der Statuten zwei Männer aus der Gruppe der parnasim zu erwählen, die bereit sind, für ein Jahr als Fürsprecher zu fungieren, wann immer sie jemand in irgendeiner Angelegenheit und aus irgendeinem Grund benötigt. Diese sollen jedes Jahr neu gewählt werden.

83 Bezüglich der Externen ${ }^{64}$ soll es folgendermaßen gehalten werden: Jeder einzelne parnas kann nach Belieben jemanden benennen. Es darf aber niemand benannt werden, der mit mehr als einem Mitglied des Vorstands verwandt ist. Keiner der Externen darf mit mehr als einem anderen von ihnen verwandt sein. In dieser Versammlung sollen alle eng Verwandten im Vorstand als einzelne Stimmen gerechnet werden, jeder mit seiner eigenen Meinung. Für den Fall, dass wegen einer wichtigen Angelegenheit eine größere Anzahl von Externen erforderlich ist, soll jeder der parnasim zwei Hausherren auf [Zettel] schreiben und diese sollen in eine Urne

64 Nicht zum Vorstand gehörenden Männer, die bei bedeutenden Entscheidungen hinzugezogen wurden. 
gelegt werden. Dann soll jeder einen Zettel aus der Urne nehmen, solange, bis die Zahl von 23, einschließlich der parnasim, für ein Quorum nach Art des kleinen Sanhedrins erreicht wird. ${ }^{65}$ Alle, die aus der Urne gezogen werden und mit mehr als einer Person verwandt sind, werden verworfen und die Zettel zerrissen und andere kommen dafür zum Zuge. In jedem Fall soll immer mit Ja oder Nein abgestimmt werden.

84 Wenn ein Rabbiner, Vorsänger oder Synagogendiener gewählt werden soll, sollen die Männer [... $]^{66}$ keine Stimme abgeben. Verwandte dritten und vierten Grades dürfen jedoch [...]

85 Wenn - behüte! - einer der parnasim sterben sollte, und man statt seiner einen anderen ernennen will [...]

86 Wenn ein neuer Hausherr in die Gemeinde aufgenommen werden soll durch Verleihung der Mitgliedschaft, soll [...]

Über Hochzeiten in der Gemeinde

87 Bei Hochzeiten soll folgendermaßen verfahren werden: Bei Verwandten ersten Grades, d.h. wer [...] Söhne der Stadt müssen sie wenigstens 200 Taler zusammen aufbringen und sie sind nicht berechtigt [...] ausgibt und setzt stattdessen einen Fremden oder eine Fremde ein, müssen sie wenigstens zusammen [...] von dem, was er hat, damit er dafür bürgen kann, wenn das Paar 200 besitzt.

88 Verwandte zweiten Grades ${ }^{67}$ wenn sie beide aus der Stadt kommen, müssen zusammen wenigstens [...] einer von den genannte Söhnen, der auch sein anderes Kind in die Gemeinde gegeben hat, müssen sie in jedem Fall zu [...] Jüngling, der für die Tochter eines Hausherrn nimmt, der das andere Kind in die Gemeinde gibt, kann er ein Kind [...]

89 Verwandte zweiten Grades, ${ }^{68}$ die beide aus der Stadt kommen, müssen wenigstens 400 [Taler] zusammen bringen [...] müssen wenigstens 600 Taler zusammen bringen und Großcousins, die aus der Stadt kommen $[\ldots]$ Und wenn der zur Ehe vermittelte ein Jüngling ist, selbst, wenn

65 Vorbild ist hier der in der Mischna, Sanhedrin 1,6 beschriebene Gerichtshof in der Antike.

66 Bei den folgenden Paragraphen bis zum Endes der Seite fehlt jeweils die rechte Hälfte des Textes, da das untere rechte Viertel der Seite nicht mehr vorhanden ist.

67 Gemeint ist hier die im Judentum statthafte Vermählung von Onkel und Nichte.

68 Hier sind Onkel und Großnichte gemeint. 
er ein Fremder ist, so ist die Regel für ihn wie für einen aus der Stadt, der seine Urgroßnichte [?] heiratet [... $]^{69}$

90 Bei allen genannten Eheschließungen gilt, wenn der Jüngling aus der Stadt kommt, er das Anrecht haben [...]

91 In jedem Fall muss bei jedem, der in unserer Gemeinde eine Hochzeit hält, das Paar den Teil haben [...]

92 Für den Fall, dass einer in ausstehende Schulden die Mitgift einfließen lassen will, darf er nicht weniger als [...] er in die Mitgift hinein gibt, muss er jedoch einen Eid leisten, dass dieser Teil seines Vermögens ist, so [...] zum Beispiel, wenn einer bei der genannten Hochzeit 400 Taler gibt, kann er ein Viertel weniger geben [...] genannten [...] Taler, und in jedem Fall muss er einen Eid leisten, wie erwähnt, dann ist die Schuld der Dörfler [...] im selben Vermögen, und gibt davon für ein volles Vermögen, muss er ihn auch in der Mitgift vollständig [...] über sich geben, soll es nicht gerechnet werden, wenn er dem Paar nicht $[\ldots]$ gibt $[\ldots]$

$[\text { S. 6 }]^{70}$

In den Statuten, die im Monat Nissan $411^{71}$ abgeschlossen wurden, gibt es 105 Paragraphen. In der Woche nach Chanukka 516 nach der kleinen Zeitrechnung $^{72}$ sollen die Befehlshaber ${ }^{73}$ und parnasim, Gott schütze sie, unter Hinzuziehung der Externen, also zusammen 23 Männer, entscheiden, ob und wie lange diese Statuten gültig bleiben sollen, oder ob man erneut eine Statutenkommission wählen soll, die die alten Statuten prüfen soll, um zu sehen, was davon noch länger fest und gültig bleiben kann, oder ob dazu etwas hinzugefügt oder etwas gestrichen bzw. ersetzt werden kann, und es soll nach der Mehrheit ihrer Stimmen sein und gehalten werden. So wurde es gemäß der obigen Bestimmung nach dem vergangenen Chanukka entschieden und beschlossen. Unter den 23 Männern wurde beraten und beschlossen, erneut eine Kommission zu wählen, die die alten Statuten prüfen und sichten soll, was davon gut ist, erhalten zu werden bzw. was davon außer Kraft gesetzt oder ergänzt werden muss. So wie sie es beschließen, so sei es vollkommen recht und gültig für eine Dauer von drei Jahren. Die 23 erwähnten Männer

$69 \mathrm{Ob}$ ein solch entferntes Verwandtschaftsverhältnis hier gemeint ist, ist wegen des fragmentarischen Erhaltungszustands des Textes ungewiss.

70 Seite 5 der Handschrift ist mit zahlreichen Entwürfen zur Neuformulierung einzelner Paragraphen gefüllt, auf deren Wiedergabe hier verzichtet wurde.

$711651 \mathrm{III} / \mathrm{IV}$.

721655 XII.

73 Gemeint ist der Vorstand. 
haben durch Mehrheitsentscheid sieben Mitglieder der Statutenkommission gewählt, so, wie schon im Jahr 411, d.h. drei parnasim, drei Hausherren, und der Rabbiner ${ }^{74}$ an ihrer Spitze. Diese sieben sollen in jeder Angelegenheit mehrheitlich die klügste Entscheidung treffen, was zur Ehre Gottes und zum Recht und Wohl der Gemeindestatuten verfasst werden soll. Und dies sind diejenigen, die von den parnasim erwählt wurden: das Haupt, der Vorsitzende und parnas, der ehrenwerte und hohe Herr Anschel Oppenheim, das Oberhaupt und der parnas, der ehrenwerte Herr Wolf Oppenheim, ${ }^{75}$ und der parnas, der erhabene, ehrenwerte und hohe Herr Meir. Dies sind die von den Hausherren erwählten: der Befehlshaber und erhabene, ehrenwerte und hohe Herr Mordechai, der teure und erhabene, ehrenwerte und hohe Herr Leib Essi und der erhabene, ehrenwerte Herr Itzik Ballin.

74 Moses Simson Bacharach (ca. 1607-1670), wurde 1650 zum Rabbiner von Worms ernannt und starb in diesem Amt am 19. April 1670. Er war Vater des berühmten Religionsgelehrten Jair Chajim Bacharach; siehe David Kaufmann, R. Jaïr Chajim Bacharach (1638-1702) und seine Ahnen, Trier 1894, 28, $53 \mathrm{f}$.

75 Offenbar der Vater des späteren Hoffaktors Samuel Oppenheimer; siehe Max Grunwald, Samuel Oppenheimer und sein Kreis. Ein Kapitel aus der Finanzgeschichte Österreichs, Wien/Leipzig 1913, 37. 


\section{Frankfurt a. M. (1674/75)}

[fol. $138 \mathrm{r}$ ]

Nachdem wir in unserer Gemeinde einige Skandale gesehen haben und jeder tat, wie ihm Recht dünkte gegen unsere heilige Tora und gegen die Obrigkeit, ihre Pracht sei erhaben, und nichts vom Wanken unserer Gemeinde wahrnahm, sich sorgte oder es sich zu Herzen nahm, war es notwendig, Statuten gemäß der Stellung und Situation unserer Gemeinde zu erlassen, um diesen Makel zu beheben und die Gemeinde auf ihren erhabenen Platz zu stellen, zu ihrem eigenen Besten und für den Ehrfurcht Gebietenden in der Höhe. Daher kam es zum mehrheitlichen Beschluss, die Namen von 60 Männern in drei Urnen zu tun, 20 Reiche in eine, 20 mit mittlerem Vermögen in eine andere und 20, deren Vermögen weniger als 1000 Gulden beträgt, in eine weitere. Von den jeweils 20 Namen einer Urne sollen fünf gewählt werden. Diese 15 Männer sollten dann die Statuten zum Besten der Gemeinde verfassen. So geschah es und sie verfassten die Statuten und durch das Los wurden die ehrwürdigen Männer bestimmt, deren Namen am Rand des Blattes stehen. ${ }^{1}$ So geschah es und sie erließen die Statuten, wie im Folgenden dargelegt, durch die Mehrheit der Gemeinde, nämlich stimmten 192 Hausherren zu und 42 lehnten ab, entsprechend den Stimmzetteln, die von den ne'emanim, ${ }^{2}$ Herrn Samuel Ne'eman und Herrn Moses Sofer, gezählt wurden. Doch bei alledem geschah der hochlöblichen Obrigkeit nichts Abträgliches und es wurde in Nichts eingegriffen, vielmehr bleibt alle Zeit ihr Herrschaftsrecht erhalten.

1 Dies wurde zuerst bestimmt: Wer seinen Nächsten vor dem Monats-parnas verklagt, dass er ihm eine Schuld gemäß eines Schuldscheins oder eines Urteils bezahle, soll durch den Monats-parnas unterstützt werden, indem dieser den shammash ${ }^{3}$ der Stadt beauftragt, den Schuldner im Verlauf von 30 Tagen auszurufen, wenn er die Zahlung verweigert. Dies geschehe auch, wenn die 30 Tage in die Amtszeit des nächsten Monatsparnas hineinreichen. In jedem Fall soll der Monats-parnas, bei dem die Sache zuerst anhängig wurde, den zahlungsunwilligen Schuldner ausru-

\footnotetext{
1 Sie erscheinen nicht hier, sondern erst am Ende der Statuten.

2 Beauftragte mit notariellen Funktionen.

3 Diener, Pedell.
} 
fen lassen ${ }^{4}$ und ihn nach 30 Tagen durch laufende Sanktionen zum Einlenken zwingen. In jedem Fall soll er damit nicht mehr als 30 Tage warten, nur unter der zweifachen Bedingung, dass der Kläger zum Monats-parnas wenigstens einmal in der Woche kommt und ihn im Verlauf dieses Monats von den Beschwernissen gegen den Prozessgegner unterstützt. Der Kläger ist jedoch nicht berechtigt, in seiner Angelegenheit das Gebet im Morgengottesdienst vor dem La-Menazea ${ }^{5}$ oder zum Abendgebet vor dem Barkhu zu unterbrechen. ${ }^{6}$ Wenn aber der Kläger innerhalb dieses Monats das Morgengebet vor dem La-Menazeah und zum Abendgebet vor dem Barkhu gegen den Willen des gabbai unterbricht, muss er sofort drei Gulden Strafe zahlen. Wenn aber der gabbai ihn nicht im Laufe des Monats unterstützt, dann ist der Kläger berechtigt, das Gebet am Morgen vor La-Menazeah und am Abend vor dem Barkhu zu unterbrechen. Jedes Mal, wenn der Kläger nach Ablauf des genannten Monats das Gebet unterbricht, muss der gabbai drei Gulden Strafe zahlen. Und der vorherige gabbai muss unter Strafandrohung in den pinkas der Gemeinde, Gott schütze sie, die Strafe einschreiben. Auf jeden Fall ist es allen und jedem, unabhängig vom Grund und der Zeit bei 20 Reichstalern Strafe untersagt, das Morgengebet vor dem Yishtabeah und das Abendgebet vor Mincha ${ }^{7}$ zu unterbrechen. Und wer, behüte!, das Morgengebet vor Yishtabeah oder das Abendgebet vor Mincha ${ }^{8}$ unterbricht, muss sofort dem shammash eine Schuldschein über 20 Reichstaler aushändigen, wonach er sofort nach dem Verlassen der Synagoge die 20 Reichstaler zahlen wird. Wenn er die Verschreibung dem shammash nicht geben sollte, muss der gabbai den Übertreter sofort in der Synagoge vor allen durch den shammash bannen lassen. Er soll 30 Tage unter Bann stehen. Wenn er in dieser Zeit die Sache nicht bereinigen sollte, muss der gabbai die Sache vor den Vorstand bringen und ihm angeben, wer der Mann ist und was sein Vergehen war, damit die Vorsteher wissen, wie mit ihm zu verfahren sei. All das Obige muss bei Bannstrafe strikt eingehalten werden. Auch soll es keiner wagen, vor Yishtabeah oder La-Menazeah vor das Gebet-

4 D.h., mit dem kleinen Bann belegen.

5 Teil des Morgengottesdienstes, bei dem die ersten Worte von Ps 20 gesprochen werden. In der Liturgie kommt er nach der Toralesung.

6 Gemeint ist das so genannte »Klamen«, wobei der Kläger, dessen Angelegenheit nicht beendet wurde, das synagogale Gebet unterbrechen und um Beistand bitten darf.

7 Mincha ist der Nachmittagsgottesdienst, der oft unmittelbar vor dem Abendgottesdienst stattfindet. Offenbar sollte hier statt Mincha Ma’ariv stehen, also vor dem Abendgottesdienst.

8 Desgleichen. 
spult zu treten, um etwas zu beeiden oder der Öffentlichkeit seine Angelegenheiten und Taten darzulegen. Wer dies übertritt, muss vom gabbai gebannt und ausgeschlossen werden und soll unter Bann stehen, bis er die 20 Reichstaler Strafe zahlt. Im Abendgottesdienst soll dies überhaupt nicht geschehen, bei Androhung der oben genannten Strafe.

2 Falls der Beklagte vom Kläger fordern sollte, sich an die Richter zu wenden, weil noch einige Angelegenheiten bezüglich der Urkunde oder des Urteils ungeklärt sind, muss der Beklagte den Kläger zwei Mal innerhalb einer Frist auffordern, mit ihm vor die Richter zu treten. Wenn aber der Beklagte den Kläger nicht vorher zwei Mal auffordert, mit ihm die Sache vor dem Rabbinatsgericht zu verhandeln, muss das Recht durchgesetzt werden und der gabbai ist bei oben genannter Strafe verpflichtet, den Beklagten mit allen möglichen Sanktionen zu zwingen, dem Kläger die Schuld ohne weiteren Aufschub zu begleichen.

3 Wenn der Beklagte vom gabbai des Vorstands, Gott schütze ihn, verlangen sollte, mit seinem Kontrahenten vor dem Vorstand zu erscheinen, so muss der gabbai bei oben erwähnter Strafe die Gegner sofort vor den Vorstand bringen. Wenn aber der gabbai versäumen sollte, die Kontrahenten innerhalb von 14 Tagen vor den Vorstand zu bringen, hat der Kläger das Recht, so wie oben erwähnt, den Morgen- oder Abendgottesdienst zu unterbrechen, und der gabbai muss die genannte Strafe zahlen.

[fol. $138 \mathrm{v}$ ]

4 Was die Haussteuer für die Obrigkeit anbetrifft, so muss der gabbai sofort dem Kläger beistehen, damit der Beklagte mit ihm innerhalb einer Frist vor die Richter treten wird. Er ist verpflichtet, den Säumigen auszurufen oder, wenn es ein Urteil gibt, den Säumigen sofort wegen der Zahlung bei oben genannter Strafe ausrufen zu lassen.

5 Wenn einer jemanden schmäht oder gar schlägt und der Geschmähte oder Geschlagene vom Vorstand, Gott möge ihn schützen, Hilfe erbittet, so muss der gabbai bei der oben genannten Strafe den Vorstand, Gott möge ihn schützen, innerhalb von acht Tagen einberufen, um einen angemessenen Prozess durchzuführen. Der Schmäher oder Schläger muss dem gabbai sofort ein Pfand im Wert von 10 Reichstalern aushändigen, jedoch steht seine Strafe vom Vorstand weiter aus. Wenn der gabbai den Vorstand nicht innerhalb von acht Tagen einberuft, um diese Sache zu bereinigen und zu beenden, so hat der Geschmähte oder Geschlagene das Recht, das Gebet vor La-Menazeah zu unterbrechen oder zur Abendzeit vor dem Barkhu. Der gabbai muss dann die oben genannte Strafe zahlen und ihm die in jeder Hinsicht auferlegte Hilfe zukommen lassen. Der 
gabbai oder irgendein anderer parnas haben nicht das Recht, eine andere Angelegenheit vor den Vorstand zu bringen, bis nicht die Angelegenheit des ersten Klägers erörtert und beendet wurde. Nur wenn es sich um Gemeindeangelegenheiten handeln sollte, haben der gabbai oder ein anderer parnas das Recht, diese zuerst vor den Vorstand zu bringen.

6 Die Vorfahren, ihr Angedenken zum Segen, haben eine große Verordnung erlassen bezüglich der Ausrufung, damit einem Gläubiger die Tür nicht verschlossen sei. ${ }^{9}$ Da den Leuten der rechte Glaubens verloren ging und sich einige nicht um die Ausrufungen durch den Vorstand, Gott schütze ihn, geschert haben, sind auf uns die Pflichten der Erklärung gelegt, wie sich Leute in der Zeit der Ausrufung zu verhalten haben.

Der Ausgerufene darf erstens nicht außerhalb seines Hauses essen, auch nicht auf einem halachisch gebotenen Festmahl. Andere dürfen nicht mit ihm in seinem Haus essen. Zweitens soll ihn der Vorstand zu keinen heiligen Handlungen zulassen, und der gabbai soll den segen ${ }^{10}$ benachrichtigen, dass dieser ihn nicht zur Toralesung aufrufen darf. Auch ist er [der Ausgerufene] nicht berechtigt, in der Synagoge andere mit Ehrenämtern auszuzeichnen, wie auch andere für ihn keine solchen erwerben dürfen oder er sich auch selbst keine kaufen darf. Wenn er in der Trauerzeit ist oder die Jahrzeit ${ }^{11}$ begeht soll er nicht vor die Lade treten und die Gemeinde zum Gebet führen. Er soll nicht einmal das La-Menazeah beten. Wenn all dies nicht ausreicht, um ihn innerhalb eines Monats zum Einlenken zu bewegen, ist der gabbai verpflichtet, seinen Namen auf die schwarze Tafel in der Synagoge zu schreiben und ihn so in der Öffentlichkeit anzuprangern. Wenn sein Name 14 Tage an der Tafel gestanden und auch dies nichts bewirkt hat, soll ihm der gabbai den weiteren Synagogenbesuch untersagen und er wird nach den Gesetzen über den Umgang mit Übeltätern nicht mehr zum Gottesdienst zugelassen. Wenn er sich auch daran nicht hält und gegen den Willen des gabbai zur Synagoge geht, muss ihn der gabbai sofort bannen. Wenn er sich aber nach den Anweisungen des gabbai richtet und nicht zur Synagoge kommt und sich wie ein Ausgeschlossener verhält, dann sei ihm noch eine Frist von sechs Wochen zur Begleichung der Schuld und zur Zahlung des Geldes eingeräumt. Falls er diese nicht innerhalb von sechs Wochen bei seinem

9 D.h., dass er sein Recht bekommen kann.

10 Eigentlich: ba'al segen (wörtl. Stellvertreter), Ehrenamt beim Gottesdienst. Der Inhaber verfolgt die Toralesungen und ruft die einzelnen Gemeindemitglieder zur Lesung auf.

11 Jährliches Totengedenken am Sterbetag. 
Gläubiger begleichen sollte, muss der gabbai ihn dennoch bannen. Wenn er vor den heiligen Vorstand, Gott schütze ihn, tritt und eindringlich darlegt, dass es ihm unmöglich ist, in der oben genannten Zeit zu zahlen, ist der Vorstand berechtigt, ihm noch einmal eine Verlängerung von zwei Monaten einzuräumen, jedoch nicht mehr. Jeder, der für ein Vierteljahr unter Bann steht, muss vom gabbai in der Synagoge bekannt gegeben werden, damit ihn jeder als Gebannten behandelt. Und so sei die Regel für einen Gebannten: alle Vierteljahre soll er erneut durch den gabbai in der Synagoge als Gebannter bekannt gegeben werden. Alles Obige muss vom gabbai unter Strafe des Bannes eingehalten werden.

[fol. $139 \mathrm{r}$ ]

7 Einige Zeit vor den Vorsteherwahlen müssen die parnasim durch den Gemeindediener an einem der Versammlungstage öffentlich bekannt machen, dass niemand bei den Wahlen irgendwelche Betrügereien begehen dürfe, welche auch immer, sondern alles solle ohne Unregelmäßigkeiten und Täuschungen ablaufen, [um festzustellen] wer zum parnas gewählt werden soll und wer nicht. Auch soll keiner mit denen, die dazu bestimmt wurden, die parnasim zu wählen, darüber reden, wer gewählt werden soll und wer nicht. Wer würdig ist, zum parnas gewählt zu werden, wird nach der bisherigen Bestimmung der 15 Männer vom Jahr 418 nach der kleinen Zeitrechnung ${ }^{12}$ festgelegt. Würdig für das Amt des parnas der Gemeinde ist ein Hausherr, der einen Vorfahren aus unserer Gemeinde hat und der nicht jünger als 35 Jahre ist. Wer keinen Vorfahren aus unserer Gemeinde hat, muss 40 Jahre alt sein, wenn er zum parnas der Gemeinde gewählt werden möchte. Alles Obige muss der gabbai bei Bannstrafe einhalten.

8 Die Vorsteherwahl im Tammus 436 nach der kleinen Zeitrechnung ${ }^{13}$ verläuft folgendermaßen: Die 20 Hausherren, die die parnasim wählen, sind berechtigt zu wählen, wen sie wollen, sogar bis zu zwölf neue parnasim. Jedoch müssen zumindest zwei parnasim aus dem Amt scheiden. Diejenigen, die unter den parnasim die wenigsten Stimmen erhalten, sollen für drei Jahre aus dem Amt scheiden. Diejenigen zwei Hausherren, die von allen Hausherren die meisten Stimmen erhalten, sollen ins Amt kommen, selbst wenn sie weniger Stimmen erhalten als die bisherigen parnasim. Sollte, behüte!, einer der parnasim vor den Wahlen sterben, müssen dennoch zwei bisherige parnasim aus dem Amt scheiden. Sollten aber zwei parnasim vor der Wahl sterben, braucht nur noch einer von den Übrigen aus dem Amt zu scheiden.

$12 \quad 1657 / 58$.

131676 VI-VII. 
Einen Monat vor der Vorsteherwahl, also im Tammus $439^{14}$ und im Jahr $442,{ }^{15}$ sind die parnasim bei strenger Bannstrafe verpflichtet, sich mit 50 hervorragenden Hausherren zu versammeln und zusammen zu beraten, wie bei den Vorsteherwahlen verfahren werden soll, nämlich ob man zwei, einen, oder gar keinen aus dem Amt scheiden lassen soll. Auch sollen sie beraten, ob wiederum 15 Männer aus drei Urnen gewählt werden sollen, wie oben beschrieben, damit diese über den rechten Weg für die oben genannte Vorsteherwahl beraten. Jedoch sollen sie nur in dieser Sache beraten und in nichts anderem, da all das, was die 15 namentlich genannten Männer an Statuten erlassen haben, weiter absolut gültig bleiben soll. Bei der Vorsteherwahl soll der Vorsitzende des Gerichtes ${ }^{16}$ anwesend sein.

Weiter soll man zehn der bedeutendsten Ältesten auswählen, die in jenen Tagen leben werden und dafür geeignet sind und ihre Namen in eine Urne tun. Davon sollen fünf herausgezogen werden, die die Mitglieder der Gemeinde gut kennen, damit keine Unwürdigen gewählt werden, und deswegen sollen es fünf Älteste sein. Es sollen aber nicht mehr gewählt werden, wer immer es sei. Diese fünf Ältesten müssen den 20 Wahlmännern einschärfen, dass zwei der bisherigen parnasim aus dem Amt scheiden und an ihre Stelle zwei Hausherren treten müssen. Auch wenn ein parnas, behüte!, vorher sterben sollte, müssen zwei aus dem Amt scheiden und nur wenn zwei parnasim sterben sollten, behüte!, braucht lediglich einer der bisherigen aus dem Amt zu scheiden. Alle diese Dinge müssen sie den 20 Wahlmännern vor der Wahl sagen. Diese fünf Ältesten, die bei der Wahl anwesend sind, dürfen aber nicht zu parnasim gewählt werden. Die 20 Wahlmänner müssen, sofort nachdem sie den Zettel mit den zwölf parnasim geschrieben haben, noch die neun Männer ${ }^{17}$ wählen, bevor sie sich in die neue Synagoge begeben. Dieser Zettel soll in eine besondere Urne geworfen werden. Die 20 oben genannten Wahlmänner sollen keine engen Verwandten oder drei Verschwägerte wählen, gemäß einer Bestimmung der Vorfahren. Alles Obige soll bei strenger Banndrohung eingehalten werden.

[fol. $139 \mathrm{v}$ ]

9 Von heute an kann einer, der zum parnas gewählt wurde, aber noch nicht das Amt des gabbai zedaka innehatte, vom Vorstand, Gott schütze ihn, in der Zeit der Wahlen zum hekdesh gabbai zum gabbai zedaka gewählt

141679 VI-VII.

151682.

16 Der Oberrabbiner.

17 Deren Aufgabe wird hier nicht benannt. 
werden. Alternativ können sie anbieten, dass er 100 Gulden gebe, um sich von der Last des Amtes als hekdesh gabbai freizukaufen. Nur diejenigen, die schon parnasim waren, sind von diesen 100 Gulden befreit. Wenn der Gewählte jedoch vor der Wahl zum hekdesh gabbai sagen sollte: »Ich gebe die 100 Gulden und will nicht gabbai zedaka sein.«, so ist er von diesem Amt für immer befreit.

10 Kein parnas oder Hausherr darf mehr als ein Amt haben, auch darf ein parnas oder Hausherr, der ein Steuererheber ist, weiter kein Amt haben. Beisitzer am rabbinischen Gericht zu sein, ist ein Amt. Nur die neun Männer und die zwei parnasim, die als gabba'im zur Weinschätzung fungieren, wie auch die Beauftragten, stellen keine Ämter dar. Sonst sind alle Funktionen, die länger als ein Jahr bekleidet werden, als Ämter angesehen. Alles ist bei Bannstrafe einzuhalten.

11 Die parnasim müssen zur Zusammenkunft des Vorstands erscheinen, wenn der gabbai diese durch den Gemeindediener anordnen lässt. Wenn ein parnas nicht zur Zusammenkunft erscheinen sollte, auch nachdem er drei Mal durch den shammash geladen wurde, muss er zwei Reichstaler an die Steuererheber zahlen und darf für ein halbes Jahr nicht zur Zusammenkunft des Vorstands erscheinen. Die gabba'im müssen bei oben genannter Strafe die Steuererheber anweisen, dass sie die zwei Reichstaler auf sein Blatt im Steuerbuch vermerken. Wenn der Vorstand den shammash zu einem Hausherrn schickt, damit jener mit ihm berate, und er nach zwei Malen nicht sofort erscheint, muss auch dieser die erwähnte Strafe an die Steuererheber zahlen und an seiner Stelle soll ein anderer gerufen werden und seine Strafe soll in jeder Hinsicht wie die für einen nicht erschienenen parnas sein. Es soll eine neue Tafel angebracht werden, auf die oben die Strafe für nicht beim Vorstand Erschienene geschrieben sein soll und darunter die Namen der einzelnen parnasim. Die gabba'im sollen die nicht Erschienenen so kennzeichnen. Wenn ein parnas oder Hausherr sich entschuldigen will, dass er nicht hätte kommen können wegen Kopfschmerzen oder aus einem anderen Grund, und es den Anschein hat, dass er lügt und dies nur sagt, um sich von seiner oben genannten Strafe zu befreien, so wird er gebannt. Die gabba'im haben alles Genannte bei Bannstrafe einzuhalten.

12 Wenn zwei eine Auseinandersetzung haben oder eine Unstimmigkeit zwischen einem und seinem Nächsten oder sonst eine Angelegenheit bestehen sollte, und er diese an den Vorstand zur Entscheidung gibt, und ein parnas die Versammlung verlässt, um sich aus der Angelegenheit herauszuhalten; so müssen die gabba'im diesen warnen, die Versammlung zu 
verlassen. Vielmehr soll er auch dabei bleiben und diese Sache bis zu ihrem Ende mitverhandeln, bei Strafe von einem Kopfstück. ${ }^{18}$ Sollte er sich aber nicht nach den Worten des gabbai richten und nicht wiederkommen, um die Sache weiter anzuhören, muss der gabbai sofort einen Namen aus der Urne mit den Namen der Hausherren ziehen und dieser sei an Stelle des parnas. Von dieser Stunde an ist der parnas, der die Versammlung des Vorstands verlassen hat, nicht weiter berechtigt, in dieser Angelegenheit weiter mit dem Vorstand zu sitzen und sich zu dieser Sache zu äußern. Auch soll er für ein halbes Jahr nicht mehr in den Vorstand gerufen werden. Der Vorstand darf niemanden mehr als höchstens drei Mal zur Versammlung rufen. Die gabba’im müssen sich ohne jegliche Veränderung nach dem richten, was als Beschluss beim Vorstand zustande kam, bei der oben genannten Strafe. Der gabbai ist verpflichtet in ein besonderes Buch einzuschreiben, was bei jeder Versammlung beraten wird. Bevor seine Amtszeit zu Ende geht, soll er vor dem Vorstand verlesen, was in seiner Amtszeit beschlossen wurde. Was im pinkas des Vorstands, Gott schütze ihn, eingeschrieben werden muss, soll dort eingeschrieben werden. Das Übrige soll vernichtet werden, bei obiger Strafe.

[fol. $140 \mathrm{r}$ ]

13 Kein parnas außer dem Monats-parnas darf eine Angelegenheit zur Beratung vorbringen. $\mathrm{Zu}$ dem, was von diesem vorgebracht wird, muss jeder andere parnas seine Meinung sagen und sich nicht enthalten, bei obiger Strafe. Wenn der gabbai eine Sache nicht vorbringen möchte, darf ein anderer parnas dies tun und der Vorstand muss die Sache beraten, bei obiger Strafe.

14 Alle Gelder, die an die Obrigkeit geliefert werden, was immer es sei und zu welchem Amt es auch bestimmt sei, sollen durch den Monats-parnas überbracht werden. Es soll immer durch zwei Personen überbracht werden, wovon einer der Monats-parnas sein muss, bei Strafe in Höhe der Summe, die der andere parnas ohne den Monats-parnas überbracht hat. Der Monats-parnas ist bei Bannstrafe verpflichtet, die gabba'im anzuweisen, dem anderen parnas dieselbe Summe auf seinem Blatt ${ }^{19}$ zu vermerken.

15 Wenn ein parnas als Schlichter zwischen zweien auftrat und die Streitsache schließlich vor den Vorstand kommt, so sei das Verfahren so, wie es

18 Eine Münze, die meist mit dem Bildnis des Münzherrn versehen wurde. Ihr Wert war oft auf 1/3 Gulden bzw. 20 Kreuzer festgesetzt.

19 Im Steuerbuch. 
im kleinen pinkas $^{20}$ des Vorstands, Blatt $12 \mathrm{v}$, festgelegt wurde: Derselbe parnas muss sofort die Versammlung verlassen und darf noch nicht einmal die Darlegungen der Kontrahenten vor dem Vorstand, Gott möge ihn schützen, anhören, geschweige denn die Sache mit dem Vorstand verhandeln. Auch darf er keine Aussagen machen, selbst nicht in der Eigenschaft als Zeuge, wenn es sich um die Sache handelt, in der er zuvor als Schlichter tätig war. Der Vorstand hat auch beschlossen dass, wenn ein parnas Schlichter war, dieser von dem Tag an, an dem er die Schlichtung übernommen hat, bis zur Neuwahl von parnasim keine Sache mit beraten soll, die denjenigen betrifft, der ihn als Schlichter angerufen hat. Ebenso sei es mit dem Sohn oder dem Schwiegersohn des parnas, wenn diese Schlichter in der Sache waren und diese schließlich vor den Vorstand, Gott schütze ihn, kommt. In diesem Fall darf derselbe parnas die Sache nicht mitverhandeln.

16 Ein Hausherr, der Angelegenheiten mit dem Vorstand zu regeln hat, ist berechtigt, einen der parnasim ohne Angabe von Gründen abzulehnen, bevor er seine Darlegungen in dieser Sache vor den Vorstand vorbringt. Wenn sich jedoch bei ihm der Verdacht rührt, dass einer der parnasim ihm nicht wohlgesinnt sei, so soll er vor dem Vorstand einen Eid auf das Gebetbuch leisten, dass er diesen Verdacht hat, und dieser parnas muss daraufhin die Versammlung verlassen, bevor der Hausherr vor dem Vorstand spricht und sich mit ihm in dieser Sache berät. In jedem Fall darf er nicht mehr als zwei parnasim ablehnen, sei es aus Abneigung oder ohne Grund, nur insgesamt zwei. Und wenn zwei Kontrahenten vor den Vorstand treten, so sind die Regeln für jeden so wie oben dargestellt. Wenn ein Hausherr einen parnas zu seiner Angelegenheit zulässt, er aber danach noch eine weitere Sache mit dem Vorstand zu regeln hat, so kann er den parnas dennoch ersuchen, die Versammlung, ${ }^{21}$ wie oben beschrieben, zu verlassen. All dies muss bei Strafe des Bannes eingehalten werden.

17 Wenn einer der 15 Männer oder einer seiner Söhne oder Schwiegersöhne eine rechtliche Angelegenheit vor dem Vorstand, Gott schütze ihn, zu regeln haben, sind sie berechtigt, drei parnasim ohne Angabe von Gründen abzulehnen. Wenn es noch weitere parnasim geben sollte, von denen er glaubt, dass sie ihm nicht wohlgesinnt seien, so hat er das Recht, so viele ihm beliebt, abzulehnen, unter der Bedingung, dass er, wie oben gesagt, einen Eid auf etwas Heiliges leistet. Die parnasim, die er entweder ohne Angabe von Gründen oder wegen Abneigung abgelehnt hat, sollen durch

20 Diese Handschrift ist offenbar verloren.

21 Vor Besprechung der zweiten Angelegenheit. 
Leute aus der oben genannten Urne ersetzt werden, so, wie es auf der nächsten Seite im Paragraph 19 beschrieben ist. Es werden so viele genommen, wie er ohne Grund oder wegen Abneigung abgelehnt hat, so wie sie gezogen werden und sie dürfen nicht eng miteinander verwandt sein, auch nicht mit dem Ansuchenden oder mit den parnasim. ${ }^{22}$ Wenn zwei von den 15 Leuten eine Angelegenheit vor dem Vorstand haben, soll jeder nach den obigen Regeln handeln dürfen. Nur wenn einer ausdrücklich sagt: »Ich will keine Hausherren und alles, was ihr mir auftragt, will ich tun.", und dann noch sechs parnasim übrig sind ${ }^{23}$ und einer oder zwei von den 15 Männern zum Vorstand kommt, der nur noch aus sechs nicht abgelehnten parnasim besteht, so haben die von den 15 Männern das Recht, diesen parnasim zu sagen: »Alles, was ihr mir auftragt, werde ich tun." Daraufhin sollen diese das Strafmaß allein festlegen. ${ }^{24}$ Wenn aber einer der 15 Männer doch weitere Hausherren aus der Urne wünschen sollte, der zweite jedoch nicht, so darf der erste aus der Urne so viele, wie er wegen Abneigung oder ohne Angabe von Gründen abgelehnt hat, ziehen, wie sie zufällig kommen. Alles Obige muss bei schwerer Bannstrafe eingehalten werden.

18 Diejenigen parnasim, die in zwei Jahren ihr Amt verlieren, d.h. ab dem Jahr 436, ${ }^{25}$ danach aber wieder ein Amt haben wollen, dürfen nicht in Angelegenheiten, die die 15 Männer bzw. deren Söhne oder Schwiegersöhne betreffen, hinzugezogen werden. Wenn einer der 15 Männer einen parnas im Amt ablehnen möchte, so hat er das Recht dazu. Wenn er unter Eid auf etwas Heiliges, wie oben erwähnt, anzeigt, dass noch einer unter den amtierenden parnasim sei, der ihm nicht wohlgesinnt sei, wer es auch sei, so muss dieser parnas die Versammlung bei Bannstrafe verlassen.

[fol. $140 \mathrm{v}$ ]

19 Die parnasim sind nicht berechtigt, einen Hausherrn mit mehr als zwölf Reichstalern Strafe zu belegen oder ihm weitere Schmach anzutun. Wenn sie sehen, dass er es wert wäre, mit einer höheren als der oben genannte Strafe belegt zu werden und ihm eine weitere Schmach auferlegen oder gar beides zusammen, so müssen sie dem Hausherrn vorher ankündi-

22 Marginalie am rechten Blattrand: Wenn er einen Eid auf das Gebetbuch geleistet hat, dass er die gelosten Hausherren im Verdacht hat, ihm nicht wohlgesinnt zu sein, so soll er andere aus der Urne ziehen und so weiter und er soll immer wieder einen Eid leisten können, bis solche Leute kommen, von denen er nicht diesen Verdacht hat.

23 Nachdem er andere abgelehnt hat.

24 Bis zu dieser Stelle war im Paragraphen von keinen strafbaren Vergehen die Rede, die Kohärenz des Textes ist hier nicht mehr deutlich.

$251675 / 76$. 
gen, dass er mit einer höheren Geldstrafe belegt werden müsse oder man ihm weitere Schmach auferlegen werde, eines von beiden. Sodann steht es dem Hausherrn frei zu sagen: »Ich bin in eurer Hand, alles, was ihr mir sagt, werde ich tun, und ich will keine Hausherren hinzuziehen.« Er kann jedoch auch sagen: »Ich wünsche vier Hausherren aus der Urne zu ziehen.« Und diese dürfen untereinander weder mit den parnasim noch mit dem Beklagten eng verwandt sein. Und diese vier Hausherren werden folgendermaßen bestimmt: Die Namen von solchen Hausherren, die 30 Jahre oder älter sind und deren Vermögen 10000 Gulden oder mehr beträgt, von denen, die 40 Jahre oder älter sind, auch wenn ihr Vermögen nur 5000 Gulden oder mehr beträgt und von denen, die 40 Jahre oder älter sind und den Haver-Titel tragen, auch wenn sie keine 5000 Gulden Vermögen besitzen, wie oben erwähnt, werden in eine besondere Urne gelegt. Aus dieser Urne sollen die vier gezogen werden. Die Urne soll mit den Siegeln der beiden gabba'im des Vorstands, Gott schütze ihn, vor dem Vorstand versiegelt und darf nicht ohne dessen Wissen geöffnet werden. Nachdem sie aus der Urne gezogen wurden, sollen sie sofort zurückgelegt werden und so sei es immer. Alles soll bei Bannstrafe eingehalten werden.

20 Der Vorstand ist nicht berechtigt, eine Verhandlung in Abwesenheit des Angeklagten abzuhalten. Vielmehr soll nach ihm geschickt und er gezwungen werden, die Vorwürfe gegen ihn zu hören. Anschließend soll weiter verfahren werden, wie im vorherigen Paragraphen beschrieben ist. Alles soll bei Bannstrafe eingehalten werden.

21 Wenn Ämter beim Vorstand vergeben werden, parnasim, Beisitzer beim Gericht, Steuererheber oder Steuerschätzer gewählt werden, müssen die Steuererheber vorher eine Liste an die Gemeindestube liefern, damit solche, die schon drei Raten ${ }^{26}$ schuldig sind, zu keiner Funktion gewählt oder mit einem Amt versehen werden. Auch sollen sie nicht mit den Namen der übrigen Hausherren in eine Urne getan werden. Die parnasim müssen die Steuererheber darüber unterrichten, wen sie mit einem Amt versehen wollen, damit die oben genannte Liste ausgehändigt wird. Auch all dies soll bei Bannstrafe eingehalten werden.

22 Der Vorstand ist verpflichtet, 19 Männer zu wählen, die Klarheit in die Angelegenheiten der Gemeindemitgliedschaft bringen, wie auch Regeln für Bräutigame nach der Hochzeit in Hinsicht auf ihre Handelstätigkeit erlassen. Dies muss spätestens vier Wochen nach Bekanntmachung der

26 Ihrer Abgaben. 
Statuten geschehen. Dies muss ohne Verzögerung bei Bannstrafe eingehalten werden.

23 Der Vorstand soll innerhalb von 14 Tagen nach Bekanntmachung der Statuten noch einen weiteren Schächter neben Herrn Mendel Rapp wählen. Dies soll ohne Verzögerung und bei Bannstrafe eingehalten werden.

24 Der Vorstand muss Vorsänger und shammashim ${ }^{27} 14$ Tage nach Bekanntmachung der Statuten wählen. Die geschehe folgendermaßen: In eine Urne sollen die Namen der gegenwärtigen und ehemaligen Spitalpfleger seit $400^{28}$ bis heute gelegt werden und auch alle Namen der Hausherren, die vierzig Jahre oder älter sind und deren Vermögen 5000 Gulden und mehr beträgt. Aus dieser Urne sollen 20 Namen gezogen werden und der Vorstand unter Hinzuziehung der Hausherren wählt die Vorsänger und shammashim für die Dauer von drei Jahren. So sei es und so muss es alle drei Jahre im Monat Elul gemacht werden, bis die Gültigkeit der Statuten abläuft. Die anderen Angestellten müssen vom Vorstand jedoch jährlich zu Chanukka neu gewählt werden. Zuvor müssen die alten Inhaber von ihren Funktionen zurücktreten. So soll es ebenfalls bei der Übergabe der Funktionen der Vorsänger und shammashim geschehen. Alles Obige muss bei Bannstrafe eingehalten werden.

25 Wenn ein Fremder, der nicht zur Gemeinde gehört, einem hiesigen Hausherrn etwas schuldet, und dieser Hausherr den gabbai bittet, den Schuldner nach den Festlegungen der Urkunde, des Gerichturteils oder der mündlichen Klage zum Zahlen zu zwingen, muss der gabbai dem Fremden ausrichten lassen, dass er entweder dem Hausherrn die Schuld bezahlen soll oder mit ihm vor das Gericht und die Richter zu gehen habe. Wenn er sich nicht danach richten sollte, muss der gabbai dem Hausherrn Vollmacht erteilen, gegen den Schuldner mit allen Mitteln nach den Regeln der Nichtjuden vorzugehen, jedoch auf Verantwortung des Hausherrn. ${ }^{29}$

26 Die Ausgaben, die der Vorstand wegen der Verhandlungen über die Krämer und Kleiderhändler hatte, müssen vom Vorstand und unter Hinzuziehung der hervorragenden Steuererheber und der Beauftragen, Gott schütze sie, vor Nissan $435^{30}$ von denjenigen zurückgeholt werden, die

27 Synagogen- und Gemeindediener.

$281639 / 40$.

29 Diese Einschränkung wurde wegen der bei Einbindung nichtjüdischer Instanzen immer latent vorhandenen Gefahr für die gesamte Gemeinde vorgenommen.

$301675 \mathrm{III} / \mathrm{IV}$. 
sie zurückzahlen müssen. Der Vorstand, Gott schütze ihn, hat das Recht, dazu noch weitere Hausherren zu berufen. Dies soll bei Bannstrafe und ohne Verzögerung eingehalten werden.

[fol. $141 \mathrm{r}$ ]

27 Der Vorstand muss eine Entscheidung treffen bezüglich derjenigen Hausherren, die Kleiderhändler und Krämer sind und die ihren Eid in Bezug auf ihren Handel gebrochen haben, den sie vor Adar $435^{31}$ bei ihrer Hochzeit geleistet haben. In der Synagoge soll bekannt gegeben werden, dass jeder, der von einem weiß, der den Eid gebrochen hat, diesen bei Bannstrafe beim gabbai anzeigen soll.

28 Bei Geld- und anderen Strafen [zahlbar] an den Vorstand soll kein Hausherr Fremde in sein Haus lassen, auch nicht dessen Frau, Söhne und andere Familienmitglieder, die hier keine Gemeindemitgliedschaft haben, sich aber hier in unseren Gassen oder unserer Stadt aufhalten, sei es allein oder mit Frau und Söhnen, und die hier gegen den Willen des Vorstands ständig Handel treiben. Die Mitglieder unserer Gemeinde sollen ihn und seine Familienmitglieder so behandeln, wie hier ein Gebannter behandelt wird, in keiner Sache mit ihm oder seinen Familienmitgliedern ein Geschäft haben, ohne jegliche Ausnahme und Betrug. Er soll auch nicht zum Gebetsquorum geladen werden und im Leben wie im Tod keine Dienste von unserer Gemeinde bekommen. Weiter soll bei Geld- und anderer Strafe niemand für ihn etwas wechseln oder gar mit ihm wechseln, auch keinen Kredit von ihm nehmen, ihm etwas leihen oder eine Teilhaberschaft mit ihm eingehen. Es soll auch nichts für ihn oder durch ihn vermittelt werden, ohne jeglichen Betrug oder Hintergehung. Welcher Hausherr dies, bewahre!, missachten sollte, wird mit der oben erwähnten Bannstrafe belegt. Jedoch sei nichts von den Herrschaftsrechten der Obrigkeit, ihre Pracht sei erhaben, geschmälert. Die parnasim haben sich bei Bannstrafe zu bemühen, dem nachzukommen.

29 Der Vorstand ist verpflichtet, nach Bekanntmachung der Statuten innerhalb eines halben Jahres die »Huren « ${ }^{32}$ aus unserer Gemeinde auszuweisen, die durch Hurerei schwanger geworden sind. Es ist ihnen bei Bannstrafe verboten, hier weiter zu verweilen oder gar zurückzukehren. Innerhalb eines halben Jahres ist es ihnen verboten, ihr Haus zu verlassen.

$31 \quad 1675$ II/III.

32 Gemeint sind Frauen, die voreheliche sexuelle Beziehungen hatten. 
30 Wer ein Kind ohne heilige Trauzeremonie [gezeugt oder] bekommen hat, wer auch immer es sei, Mann oder Frau, darf hier nicht in den Ehestand gebracht werden. Umso mehr soll er keine Mitgliedschaft hier in unserer Gemeinde haben und kein Rabbiner oder Vorstand hat das Recht, über diese Bestimmung hinweg zu gehen, selbst wenn er dem Vorstand dafür all sein Geld geben möchte, bei Strafe mit dem Bann. Ein Monats-parnas, der zu dessen Gunsten vor dem Vorstand spricht, soll eine Strafe von 100 Dukaten zahlen. Ein Vater, dessen Tochter wegen Hurerei schwanger geworden ist, wird aufs strengste angewiesen, diese nach einem halben Jahr von hier zu weisen. Bei Bannstrafe ist es ihr verboten, hier zu verweilen oder zurückzukehren und innerhalb des halben Jahres ist es ihr verboten, vor ihre Haustür zu treten. Wenn sie hinausgehen sollte, muss sie sich sofort und ohne Verzug von hier davon machen. Die Durchsetzung dessen ist dem Vorstand, Gott schütze ihn, auferlegt, bei Bannstrafe auf all das Obige.

31 Wenn ein oder mehrere parnasim von hier wegziehen sollten oder vor der Wahl sagen, dass sie kein parnas mehr sein möchten, dann sollen diese nicht bei den zwangsweise bei den Wahlen scheidenden parnasim eingerechnet sein, wie in Paragraph 8 dargelegt. In jedem Fall müssen zwei aus dem Amt scheiden.

32 Wenn eine Angelegenheit im Vorstand vorgeht, die die Hinzuziehung weiterer Männer aus der Gemeinde erfordert, so sollen die vier Fürsprecher, die bis jetzt fungierten, hinzugezogen werden. Wenn sie weitere Männer aus der Gemeinde benötigen, so sollen sie diese aus der Urne bestimmen, die laut Paragraph 38 auf der Rückseite dieses Blattes, für die Wahl der Gerichtsbeisitzer gemacht wird, nehmen. Wenn sie Ausgaben beraten und die Kopfsteuer, sollen sie weitere Männer aus der Gemeinde aus den drei Urnen für Reiche, Leute mit mittlerem Vermögen und Arme nehmen. Dies soll bei Bannstrafe eingehalten werden.

33 Die parnasim, Gott schütze sie, sind verpflichtet, einen Vorsitzenden des Gerichts innerhalb von drei Monaten nach Bekanntmachung der Statuten zu wählen.

34 Die parnasim, Gott schütze sie, sind verpflichtet, 19 Männer auf folgende Art zu wählen. In eine Urne sollen Namen von allen parnasim getan werden und aus dieser werden vier gezogen. Danach sollen drei Urnen für Reiche, Leute mit mittlerem Vermögen und Arme gemacht werden, jedoch ohne die Namen der parnasim. Aus diesen Urnen sollen je $20 \mathrm{Na}-$ men gezogen werden. In jeder Hinsicht soll weiter so verfahren werden wie bei der Wahl der 15 Männer, so wie auf der ersten Seite beschrieben. 
Die 19 Männer dürfen untereinander nicht eng verwandt sein. Dies soll bei Bannstrafe eingehalten werden.

[fol. $141 \mathrm{v}$ ]

35 Bei der Ernennung der Vorsänger und shammashim, wie im Paragraphen 24 erläutert, sollen von Anfang an mit den parnasim, Gott schütze sie, auch die drei Hausherren, die das Amt der Steuererheber innehaben, Gott schütze sie, und auch die vier Fürsprecher, die bis jetzt fungieren, anwesend sein. Anschließend sollen 20 Namen von Hausherren aus der Urne gezogen werden, wie im Paragraphen 24 erläutert.

Die Steuererheber

36 Die Wahl der Steuererheber geschehe folgendermaßen: Der Vorstand, unter Hinzuziehung der vier Fürsprecher, die bisher fungierten und die durch den Vorstand gewählt wurden sowie weitere Männer aus der Gemeinde sollen noch 36 hervorragende Hausherren einladen und mit ihnen zusammen sieben Männer wählen. Unter diesen sieben sollen wenigstens drei Hausherren sein. ${ }^{33}$ Diese sieben Männer wählen sieben Wahlmänner, die dann die Steuererheber und Steuerschätzer bestimmen. Auch unter den sieben Wahlmännern sollen wenigstens drei Hausherren sein. Innerhalb der beiden genannten Siebenergruppen dürfen die Leute nicht eng miteinander verwandt sein. Alles Obige müssen parnasim den erwähnten 40 Hausherren mitteilen, dass alles wie oben erwähnt festgelegt sei. Dies soll bei Bannstrafe eingehalten werden.

37 Unter den Steuererhebern sollen zwei parnasim und drei Hausherren sein. Wenn einer der Hausherren zum parnas gewählt werden sollte, soll sofort ein anderer Hausherr für ihn gewählt werden. Sollte einer der Steuererheber sterben, behüte!, so soll sofort nach 30 Tagen $^{34}$ ein anderer an seiner Stelle gewählt werden, ein parnas für einen parnas und ein Hausherr für einen Hausherrn. Die drei Hausherren sollen gemeinsam jeden Sonntag in ihrer besonderen Stube sitzen und die Steuern der Hausherren entgegen nehmen, bei Strafe von einem Reichstaler bei Übertretung. Auch sollen sie die Last der Steuer für die, die nichts haben, erleichtern. Wenn ein Hausherr ihnen jede Woche die Steuern übergeben möchte, soll dies nacheinander auf seinem Blatt als Summe vermerkt werden. Die Hausherren, die schon längere Zeit einen Betrag schuldig und nicht in der Lage sind, diesen auf ein Mal den Steuerhebern zu geben, sollen von den Steuererhebern milde behandelt werden. Es soll ihnen Aufschub ge-

33 Während die Übrigen parnasim sind.

34 Die offizielle Trauerzeit. 
währt und die Zahlung der Schuld in Raten über den Verlauf eines Jahres gestattet sein. Es steht ihnen auch frei, bis Ablauf des Jahres einen großen Betrag zu zahlen. Die Steuererheber müssen jede Steuerrate pünktlich von jedem Hausherrn erheben. In jedem Fall dürfen sie auf keinen Hausherrn länger als zwei Zahlungstermine warten. Und wer es ablehnt, drei aufeinander folgende Raten zu zahlen, darf nicht gewählt werden und auch selbst nicht wählen. Die Steuererheber müssen vor ihrer Sitzung in ihren Amtseid, der in ihrem pinkas steht, aufnehmen, dass sie all das einhalten werden, was die 15 Männer in Fragen der Steuererheber festgelegt haben. Die Steuererheber müssen zusammen in ihrer Stube, abgesehen vom Sonntag, noch zwei Mal wöchentlich sitzen und die Steuern einnehmen, bei Strafe von einem Dukaten für jedes Mal. All das Obige muss bei Bannstrafe eingehalten werden.

Das rabbinische Gericht

38 Die Wahl des rabbinischen Gerichts ${ }^{35}$ findet - bei Bannstrafe und ohne Verzögerung durch die sieben Männer - jedes Mal am ersten des Monats Adar oder einen Tag danach statt. Man legt dazu die Namen aller zwölf parnasim in ein Gefäß und soll anschließend vier davon herausnehmen. Diese vier parnasim sollen helfen, das Gericht zu wählen. Weiter soll man eine Urne nehmen und die Namen derjenigen Hausherren hineinlegen, deren Vermögen mehr als 10000 Gulden beträgt und die 50 Jahre oder älter sind. Auch sollen dazu diejenigen kommen, die vierzig Jahre alt sind und deren Vermögen 5000 Gulden oder mehr beträgt, jedoch müssen diese schon einmal ein Amt in unserer Gemeinde bekleidet haben, also Spitalpfleger, Beauftragter, Fleischschätzer, Weinschätzer, Kassenwart. Auch diejenigen, die 50 Jahre alt sind und deren Vermögen 5000 Gulden oder mehr beträgt, sollen mit dazu kommen, auch wenn sie noch kein Amt in unserer Gemeinde bekleidet haben. Von diesen Hausherren sollen drei gezogen werden, die nicht mit den parnasim und untereinander eng verwandt sind. Diese sieben Männer ${ }^{36}$ sollen das Gericht wählen. Die genannten sieben Wahlmänner müssen einen Eid schwören, dass sie keine heimlichen Absprachen treffen werden und nur solche Richter wählen werden, die dafür würdig sind. Wer solche wählt, die schon einmal [fol. 142 r] Richter in unserer Gemeinde waren, kann dies tun und entspricht damit seinem Eid. Ein Richter, dessen Vermögen 2000 beträgt, darf zugelassen werden nach dem Kleinen pinkas des Vorstands, Gott schütze ihn. All das Obige muss bei Bannstrafe eingehalten werden.

35 Gemeint sind die Richter.

36 Vier parnasim und drei Hausherren. 
39 Von denjenigen, die vor die Richter kommen, um einen Streit zu verhandeln, kann jeder einen ablehnen und nicht mehr. Er kann dies tun, weil er den Verdacht hat, dass dieser ihm nicht wohlgesinnt sei oder weil er meint, dass er ein Freund seines Kontrahenten sei. Dies kann nur unter der Bedingung geschehen, dass er vor der Verhandlung beim Gericht einen Eid auf das Gebetbuch leistet, dass er den Verdacht hegt, dass dieser ihm nicht wohlgesinnt oder ein Freund seines Kontrahenten sei. Nur wenn er behauptet, dass dieser ${ }^{37} \mathrm{ihm}$ nicht wohlgesinnt sei und er ihn ablehnt, ist er davon befreit, ihm die Urteilsgebühr zu zahlen. Wenn er ihn aber ablehnt wegen vermeintlicher Freundschaft zu seinem Kontrahenten, so muss er diesem Richter dennoch seinen Anteil an der Urteilsgebühr zahlen. So wird es auch bei den in Reserve stehenden Richtern gehandhabt. All dies soll bei Bannstrafe eingehalten werden.

40 Bezüglich der Betten, Leinentücher, Bezüge und Tücher, die von Toten in das hekdesh kommen: Solange es im hekdesh noch keine sechs gemachten Betten, zwölf Paar Leinentücher und zwölf Kopfbezüge gibt, ist es allen Spitalpflegern bei Bannstrafe untersagt, den Armen, die im hekdesh sind oder dorthin wollen, etwas von diesen Sachen zu geben. ${ }^{38}$

41 Bezüglich der Fleischer: Wer hier als Fleischer arbeiten möchte, muss dies mit den anderen Fleischern durch Losverfahren bestimmen. Wer dabei gewinnt, soll für drei Jahre einer der sechs Fleischer sein, denen von Seiten des Rats, seine Pracht sei erhaben, hier das Schächten erlaubt ist. Und so soll es alle drei Jahre geschehen. Die parnasim müssen sich bei der Obrigkeit darum bemühen, dass der alte Fleischer gestrichen und der neue eingeschrieben wird.

42 Die Entscheidung in Immobiliensachen liegt beim Vorsitzenden des Gerichts und den shammashim, insbesondere die Ankündigung der Pfändung von Immobilien. Die Bezahlung für die Pfändung sei für den Vorsitzenden des Gerichts und die shammashim je ein halbes Kopfstück. Entscheidungen hierüber dürfen nicht ohne vorherige Konsultation der Steuererheber und der Spitalpfleger geschehen.

43 In unserer Gemeinde dürfen keine Speisen und Getränke verkauft werden, ohne dass sie von den Beauftragten geschätzt wurden. Auch soll keiner eine Ladung von Speisen oder Getränken ohne Kenntnis und Erlaubnis der Beauftragten aufkaufen, bei Strafe von sechs Reichstalern.

37 Der Richter.

38 Offenbar sollte zunächst für sechs vollständig ausgestattete Betten im hekdesh Sorge getragen werden. 
Darüber hinaus soll keiner Wein in unserer Gemeinde aufkaufen, um ihn wieder zu verkaufen. Jedoch darf ein Hausherr Wein kaufen, um ihn gegen Pacht auszuschenken. Die Beauftragten sind bei Bann verpflichtet, dies zu überwachen und zu klären. ${ }^{39}$

44 Von jetzt an soll der Vorsitzende des Gerichts bei Eidesleistung auf den Ehevertrag von Witwen mit einem Vermögen von 1000 Reichstalern und mehr zwei Reichstaler erhalten, und bei einem Vermögen von weniger als 1000 Gulden soll sie ihm einen Reichstaler geben. Bis zur Ankunft eines Vorsitzenden des Gerichts in unserer Gemeinde soll keine Witwe bei Eidesleistung auf den Ehevertrag mehr als oben genannt an den Vorstand, Gott schütze ihn, geben.

45 Wegen der Lehrer sei es wie zuvor. Es soll den gabba'im für Talmud-Tora ${ }^{40}$ vom Vorstand auferlegt werden, darauf zu achten, dass kein Lehrer mehr als acht Stunden am Tag lehrt. Gezahlt werden vier Reichstaler pro Stunde bis zur Gemara und darüber hinaus, fünf Reichstaler für eine Stunde Tosefta. ${ }^{41}$ In den Sommertagen sind neun Stunden am Tag gestattet. Jedoch dürfen die Lehrer, die nicht aus unserer Gemeinde stammen, auch an Sommertagen nicht mehr als acht Stunden annehmen. Kein Lehrer soll einen Hilfslehrer oder jungen Mann anstellen, um die Stundenzahl zu erhöhen. Wenn ein Lehrer nicht volle sechs Monate unterrichtet, kann der Hausherr ihm die Fehlzeit vom Lohn abziehen. All das Obige soll bei Bann eingehalten werden, ohne Betrug oder weitere Festlegungen.

46 Eine verheiratete Frau wie auch eine $» H u r e «^{42}$ dürfen bei Bannstrafe bei keinem Hausherrn als Mägde arbeiten, nicht einmal unentgeltlich. Wenn jedoch der Hausherr wöchentlich zwei Reichstaler Strafe zahlt, ist er vom Bann befreit. Wenn die Zeit verstreicht und er nicht vor Schabbat zahlt, verfällt er dem Bann.

47 Bezüglich der ne'emanim der Gemeinde soll es gehalten werden wie auf Seite 12 im Protokollbuch vermerkt. Wenn sich der Gerichtsgänger weigern sollte, seine Unterschrift zu leisten, sollen die ne'emanim im Protokollbuch vermerken, dass er sich geweigert hat.

39 In Streitfällen.

40 Aufseher über die Schule.

41 Wahrscheinlich sind hier nicht Einzelstunden, sondern wöchentliche Stunden gemeint, da sonst die Löhne ausgesprochen hoch und völlig untypisch bemessen wären. Siehe auch im selben Paragraphen die Bestimmung über die Unterrichtsdauer von sechs Monaten.

42 Siehe $\$ \$ 29$ und 30 dieser Statuten. 


\section{[fol. $142 \mathrm{v}$ ]}

48 Alle Sorten von Spielen, außer Schach, sind bei Bann verboten. Lediglich zu Chanukka und Purim ist es erlaubt, acht Tage zu spielen und nicht mehr. Am neunten Tag wird in der Synagoge verkündet, dass ab jetzt wieder das Verbot wie zuvor gilt. Kein Mensch auf der Welt hat das Recht, die Zeit noch um einen Tag zu verlängern. Wöchnerinnen ist es erlaubt, mit zwei weiteren Frauen zu spielen, also insgesamt drei, aber nicht mehr. Auf gar keinen Fall soll sie mit einem Mann oder einem Unverheirateten spielen. Andere Frauen dürfen nicht spielen, wenn die Wöchnerin nicht mitspielt. Es ist bei Bannstrafe verboten, dass die Wöchnerin der Pflegerin für die Zeit des Spielens mehr als einen Reichstaler Lohn zahlt, ohne jeglichen Betrug, d.h. insgesamt einen Reichstaler

49 Bezüglich der Heiratsvermittler soll es gehalten werden laut der Bestimmung der 15 Männer vom Jahr 418.43 Nur wenn der Hausherr bei Bannstrafe vor dem Gericht beteuert, dass er in dieser Sache keinerlei Betrug begangen hat und es nur geschah, weil er die Vermittlung dem einen mehr gönnt als dem anderen [dürfen Ausnahmen geschehen].

50 Die Wahlmänner für den Kassen-gabbai sind alle verpflichtet, zu den Steuererhebern zu gehen und von ihnen die Liste einzufordern, worauf vermerkt ist, was die Hausherren für den Unterhalt des Kassenjungen ${ }^{44}$ schuldig sind.

51 Die Steuerschätzer müssen jeden Tag von ein Uhr mittags an beisammen sitzen. Wenn die Steuerschätzer jemanden drei Mal vorladen, um seine Steuern zu veranlagen, und der Geladene nicht erscheint, müssen sie ohne Verzögerung allein seine Steuerveranlagung machen. Wenn ein Hausherr auf das Gebetbuch einen Eid leistet, dass er den Verdacht hat, dass ein Steuerschätzer ihm nicht wohlgesinnt sei, so darf derjenige an dieser Schätzung nicht teilnehmen. In jedem Fall sollen die Steuerschätzer bei Bann nicht länger als drei Wochen tätig sein.

52 Die Beauftragten müssen sich wöchentlich zwei Mal versammeln. Wenn einer dies übertritt, muss er einen Dukaten Strafe zahlen. An den Messetagen müssen sie sich wöchentlich drei Mal versammeln. ${ }^{45}$

53 Unter den Beauftragten sind zwei parnasim und drei Hausherren, die nicht eng miteinander verwandt sein dürfen. Sie sind nicht berechtigt,

\footnotetext{
$43 \quad 1657 / 58$.

44 Offenbar ein Gehilfe für die gabba'im der Kasse.

45 Dies wegen ihrer Funktion als Marktaufseher.
} 
höhere Geldstrafen als vier Reichstaler zu verhängen, aber wenn sie zwei gabba'im des Vorstands, Gott schütze ihn, hinzuziehen, können sie Geldstrafen bis sechs Reichstaler verhängen, jedoch nicht mehr. Dies soll bei Bannstrafe eingehalten werden.

54 Der Schreiber ist verpflichtet, innerhalb von 14 Tagen nach Abschluss eines Geschäfts die Schuldurkunden an den Gläubiger zu liefern. Eheverträge und spätere Hinzufügungen ${ }^{46}$ und alle Urkunden, die dem Ehepaar gehören, muss er an den Gerichtsgänger innerhalb eines Monats nach der Vermählung übergeben. Bei der Vermählung von Fremden, die nicht aus unserer Gemeinde stammen, soll der Bräutigam vor der Eheschließung dem gabbai des Vorstands geben, was ihm zusteht, und sofort nachdem er dem gabbai die Vermählung angezeigt hat, muss der gabbai dem Schreiber das Geld geben, das ihm zusteht. Darauf steht jedoch nicht die Bannstrafe. Die ne'emanim sind verpflichtet, dem Schreiber unverzüglich die Geschäftsabschlüsse zukommen zu lassen, damit er diese in seinem Buch vermerken kann. Auch müssen sie jede Woche die Urkunden ohne Ausrede und bei großer Strafe unterzeichnen, wie auch das Buch des Schreibers.

Der Lohn für die Ärzte soll bei Bann so sein, wie es im Protokollbuch vermerkt ist.

[fol. $143 \mathrm{r}$ ]

55 Niemand, wer es auch sei, soll fertige Kleidungsstücke wie Koller, Hosen, Wamskoller, Mützen, Mäntel oder jegliche andere Ware in die Herberge bringen. Ein Kleiderhändler darf zwischen den Messen auch kein Silber, Gold und Edelsteine dahin bringen, in einem Zimmer lagern oder dem Wirt bzw. dessen Gesinde zur Aufbewahrung übergeben. Auch soll er nichts durch einen Nichtjuden hineinbringen lassen oder gar ein Zimmer bei einem Nichtjuden mieten, um einen Käufer dahin zu führen oder den Käufer in das Haus eines anderen Nichtjuden zu bestellen. Lediglich wenn er einen Käufer hat, darf er ihn in die Judengasse bringen. Sogar nach Abschluss des Geschäfts darf er die Ware nicht aus der Judengasse heraus tragen, sondern er muss sie dort dem Käufer übergeben und damit ist die Sache beendet. Wenn ein Jude ein Kleidungsstück hat, das aus Samt oder Seide gemacht ist bzw. gar mit Gold bestickt und bei dem klar ist, dass es kein Nichtjude tragen wird, es sei denn, dass er ein großer und bedeutender Mann ist, und er es verkaufen kann, so kann er beim gabbai des Vorstands um Erlaubnis bitten, es dennoch in die Herberge zu bringen. So steht es in einem alten Schriftstück. In ein anderes Haus, das keine

46 Zur Vergrößerung der von der Frau eingebrachten Mitgift. 
Herberge ist, dürfen Kleiderhändler zwei Stücke bringen und nicht mehr. Wenn einer allein oder zwei Handelspartner gemeinsam in einem Haus sind, soll kein weiterer Kleiderhändler oder Marktschreier dort hinein gehen, bis die ersten wieder heraus kommen. Es darf sich sogar keiner vor dem Haus aufhalten.

56 Kein Kleiderhändler oder Marktschreier soll in der Stadt nach dem Morgengottesdienst vor dem Ausgang der Synagoge stehen, auch nicht in der Abendzeit. Es sei denn, dass er gerade mitten im Abschluss eines Geschäfts ist und deswegen in der Stadt aufgehalten wurde.

57 Spitzenhändler dürfen Leinenspitzen in Wirtshäuser bringen, ${ }^{47}$ sonst aber keine Ware, so sie der Wirt nicht bestellt hat.

58 Auch an den anlegenden Marktschiffen soll sich keiner finden lassen. Niemand soll am Wassertor ${ }^{48}$ stehen, um Ware anzubieten, Nichtjuden anzusprechen oder um Waren anzupreisen.

59 Wenn Nichtjuden in die Judengasse kommen, sei es in Kutschen oder auf Pferden, soll ihnen keiner nachlaufen oder ihnen etwas zurufen.

60 Die Kleiderhändler sollen keine Geschäfte mit Nichtjuden machen und ihnen nichts von ihren eigenen Waren verkaufen, insbesondere nicht als Zwischenhändler Waren nach der Elle verkaufen. Wenn sie selbst Ware haben, dürfen sie diese aus der Stadt in einen anderen Ort ausführen oder sie einem Juden hier verkaufen. Jedoch dürfen sie komplette Stücke verkaufen. Nur die Reste von wollenen Tüchern, die nach dem Anfertigen von Kleidern übrig bleiben, dürfen nach der Elle verkauft werden. Doch darf die Elle nicht teurer als ein Gulden sein. Kleider jedoch dürfen frei verkauft werden, von Kopf bis Fuß. ${ }^{49}$ Auch was an Resten von Futtertuch aus Leinen übrig bleibt, darf nach der Elle verkauft werden, jedoch nicht teurer als ein Viertel Gulden pro Elle. Silberne und goldene Spitzen und silberne Tressen sollen pfundweise verkauft werden.

61 Ein Kleiderhändler soll keinen Herbergswirt oder Leute aus dessen Haus, wer es auch sei, mit einem Kredit bestechen, sonstige Tricks und Betrügereien anwenden oder ihn überreden, damit er ihn allein in der Herberge wohnen lässt und keinen anderen. Sobald der Verdacht aufkommt, dass

47 Um sie dort zu verkaufen.

48 Gemeint ist vielleicht die alte Fischerpforte, die dem Frankfurter Brückenturm am nächsten lag.

49 D.h. alle Arten von Kleidungsstücken. 
Betrug im Spiel ist, da nur er in die Herberge darf und kein anderer, muss er ein ganzes Jahr lang draußen bleiben. ${ }^{50}$

[fol. $143 \mathrm{v}$ ]

62 Wenn ein Kleiderhändler oder ein Geschäftsvermittler bei einem Nichtjuden ist, entweder in einer Herberge, auf der Straße oder im Haus eines anderen Nichtjuden vor dessen Zimmer, und dem Nichtjuden dort etwas anbietet, soll, solange der erste dort ist, kein anderer Kleiderhändler oder Marktschreier dorthin gehen oder den Nichtjuden ansprechen oder durch einen anderen ansprechen lassen. Er muss warten, bis der erste Jude von dem Nichtjuden weggegangen ist. Darüber hinaus sollen sie nicht gruppenweise in einer Herberge, davor oder an anderen Orten stehen oder gar sitzen. Wenn der erste schon einen halben Tag im Haus eines Nichtjuden gewesen ist, aber kein Geschäft hat abschließen können, darf der andere hinein gehen.

63 Es ist bei Bann gänzlich verboten, jemanden zum Anbahnen von Geschäften in oder vor das Haus einen Nichtjuden zu stellen. Der Bann soll sowohl denjenigen treffen, der dort steht, wie auch den Auftraggeber.

64 Die Kleiderhändler dürfen ihre Ware, was es auch sei, nicht zum doppelten Preis anbieten. D.h. sie dürfen es nicht für die Hälfte des anfangs gesagten Preises verkaufen.

65 An Sonntagen soll niemand Ware anpreisen und muss alle Nichtjuden und Nichtjüdinnen in Frieden lassen und darf sie nicht ansprechen. Wenn es eine fremde Jungfrau oder ein Hausangestellter dennoch tut, sollen sie sobald als möglich aus unserer Gemeinde geschafft werden. Jeder Hausherr ist für die Bewohner seines Hauses verantwortlich. Jungfrauen dürfen während der gesamten Woche keine Ware anpreisen.

66 Kein Hausherr oder Hausherrin, wer es auch sei, darf einen Nichtjuden oder Juden, der durch die Judengasse geht, an einer anderen Stelle ansprechen oder Ware anpreisen als vor seiner Haustür. Der Hausherr darf bis zur Gosse auf seiner Seite mit ihm gehen und nur vor dem Haus, in dem sie wohnen, dürfen der Hausherr und seine Frau dem Nichtjuden oder Juden Ware anpreisen. Kein Hausherr soll vor einem anderen Haus stehen und dort Ware anpreisen, es sei denn, dass er den Nichtjuden zufällig in der Straße trifft, dann darf er diesen ansprechen.

50 Gemeint sein könnte, dass er die Herberge für ein Jahr nicht nutzen darf oder überhaupt für ein Jahr vom Handel ausgeschlossen bleibt. 
67 Wenn ein Nichtjude oder eine Nichtjüdin nach einem bestimmten Hausherrn fragt, dann soll jeder, der sich zu Israel zählt, bei großem Bann denjenigen an die richtige Person weisen ohne jegliche Verzögerung.

68 Kein Kleiderhändler soll die Ware eines anderen schmähen, und nicht seine eigene billiger anbieten. D.h. dass er vor oder nach dem Kauf nicht dem Nichtjuden sagen soll: »Ich will dir meine Ware für diesen oder jenen Preis geben. «, wobei jedoch klar ist, dass es kein reeller Preis ist, sondern er dies nur sagt, um dem Nichtjuden das Geschäft zu verderben. ${ }^{51}$

69 Ein Kleiderhändler oder Krämer darf bei Bann keinen Gehilfen haben, sogar, wenn der Gehilfe Mitglied in der Gemeinde ist. Umso mehr darf er auch keinen Auswärtigen oder Beisassen ${ }^{52}$ als Gehilfen in seinem Haus haben. Einer, der zuvor als Gehilfe bei einem Kleiderhändler war, darf für diesen nichts weiter vermitteln oder mit ihm gar eine Geschäftspartnerschaft eingehen. Auch darf bei Bann kein Jugendlicher ihm bei den Verhandlungsgeschäften helfen. Selbst einem Gehilfen, der nicht zu seinem Haushalt gehört und der ihm gelegentlich ein Geschäft vermittelt, darf er nichts bezahlen.

70 Ein Krämer oder Kleiderhändler, der sechzig Jahre alt ist ${ }^{53}$ und keinen Sohn hat, der schon 13 Jahre zählt, oder einen Sohn, der 13 ist und jeden Tag zu seinem Lehrer in das Lehrhaus geht, kann einen Gehilfen annehmen um die Verrichtungen bei ihm im Haus vorzunehmen. Jedoch darf er ihn auf keinen Fall geschäftliche Verhandlungen machen lassen oder ihn dabei zu Hilfe zu nehmen. Wenn er aber einen Sohn über 13 Jahren hat, der nicht jeden Tag ins Lehrhaus geht, darf er keinen Gehilfen für die Verrichtungen im Haus annehmen oder gar für die geschäftlichen Tätigkeiten.

[fol. $144 \mathrm{r}$ ]

71 Ein Krämer oder Kleiderhändler, der sechzig Jahre alt ist und nicht mehr in der Stadt aus- und eingehen kann, darf einen seiner Söhne das Geschäft mit Kleidung oder Krämerei machen lassen. Jedoch muss der Hausherr vorher bei Bannstrafe zusagen, dass er selbst keinerlei Geschäfte in der Stadt tun wird. Er darf nur Esswaren und andere übliche Dinge kaufen. Der junge Mann muss zu jeder Messe fünf Reichstaler an die 19 Männer zahlen. Wenn der Hausherr noch weitere Söhne hat, selbst wenn sie schon 20 Jahre alt sind, ist es ihnen bei Bann verboten, in der Stadt zu

51 Eigentlich ist gemeint: »dem jüdischen Konkurrenten das Geschäft zu verderben«.

52 In der Gemeinde geduldeter Jude, der jedoch nicht die Mitgliedschaft hat.

53 Oder älter. 
handeln. Ein Kleiderhändler oder Krämer, der jünger als 60 ist, darf bei Bann keinen seiner Söhne in der Stadt Handel treiben lassen, selbst wenn er 20 ist, ist dies dennoch bei obigem Bann verboten. Auch wenn er die erwähnten fünf Reichstaler geben will, muss er jedes halbe Jahr bei den Beauftragten die Erlaubnis einholen, dass er berechtigt ist zu handeln. Ohne Erlaubnis verfallen sie dem Bann und dürfen nicht weiter handeln.

72 Bis zum 12. Lebensjahr muss jeder Sohn eines Hausherrn in den Cheder gehen und bei seinem Lehrer lernen. Von zwölf bis 20 Jahren, selbst wenn er nicht lernen geht, ist er nicht berechtigt, in der Stadt herumzugehen und Geschäfte zu machen und schon gar nicht in unserer Gasse Ware anzupreisen. Wenn er etwas vermittelt, darf man ihm bei Strafe auf keinen Fall auch nur eine pruta ${ }^{54}$ Vermittlungsgeld zahlen, auf welchem Weg auch immer. Er soll auch nicht in der Natur umhergehen, wenn ihn nicht sein Vater oder seine Mutter auf ihr Geheiß weggeschickt haben. Wenn er 20 Jahre oder älter ist, darf der Sohn eines Hausherrn in die Stadt gehen und Handel treiben, wie es ihm beliebt. Er soll sich dabei jedoch redlich verhalten, ohne Verletzung der Rechte anderer und ohne Entweihung des heiligen Namens. Er darf nicht in die Herberge gehen. Zur Unterstützung der Unterrichtsgebühren für die Söhne unserer Gemeinde zahle er an die Steuererheber fünf Reichstaler. Wenn sein Vater bei den Steuererhebern schon mit zwei Raten der Abgaben in Verzug ist, darf der Sohn überhaupt keine Geschäfte machen, bis die Steuererheber zufrieden gestellt wurden. Die Waisen jedoch, die keinen Vater haben, aber die hier die Mitgliedschaft besitzen, dürfen von 14 Jahren an in der Stadt Krämerei oder Kleiderhandel betreiben und auch jede andere Art von Geschäft. Diese Waisen dürfen nur zwei Jahre lang Krämerei und Kleiderhandel betreiben, selbst, wenn sie dann noch ledig sind. Wenn sie zwei Jahre als Ledige gehandelt haben, soll nach ihrer Hochzeit die Bestimmung der 19 Männer gelten, wonach sie sechs Jahre lang keine Krämerei oder Kleiderhandel betreiben dürfen. Sollten sie aber als Ledige keine zwei Jahre mit Krämerei oder Kleidern gehandelt haben, dürfen sie dies sofort nach ihrer Hochzeit, so wie die anderen Hausherren, tun. Ware anzupreisen, ist hier nicht inbegriffen. Als Lediger darf er Ware anpreisen, solange er dies will, nur soll er dazu in keine Herberge gehen.

73 Es soll kein Kleiderhändler an den drei Toren zu unseren Gassen einen Raum mieten, also am Obertor bis zum Haus zum Hecht und parallel dazu auf der anderen Seite der Gasse. Am mittleren Tor vom Haus zum

54 Antike Kleinmünze, im hebräischen Sprachgebrauch bis heute als Bezeichnung von Kleinstbeträgen üblich. 
fröhlichen Mann bis zum Haus am Notstall und parallel dazu auf der anderen Seite. Schließlich vom Haus des Herrn Kalman Cohen bis zum Haus von Gerschon Dorheim und weiter.

74 Keine Witwe und schon gar kein Hausherr darf mit einem Kleiderhändler oder Krämer eine Geschäftspartnerschaft haben. Er soll nur ein Geschäft haben.

75 Großhändler, die ballenweise Waren hierher bringen, dürfen, so sie nicht mehr als Waren im Wert von 4000 Reichstaler im Jahr hierher bringen, ihre Waren nach der Elle ausmessen. ${ }^{55}$ Wenn er Waren für mehr als 4000 Reichstaler hierher bringt, darf er nicht nach der Elle Stücke zurechtschneiden. Geschäftspartner, die Waren im Wert von 6000 Reichstalern im Jahr hierher bringen, dürfen diese nach der Elle zurechtschneiden. Sollten es aber mehr als für 6000 Reichstaler jährlich sein, dürfen sie nicht nach der Elle zurechtschneiden. Dies soll bei Bannstrafe eingehalten werden.

76 Gehilfen bei hiesigen Hausherren, die Pferdehändler sind oder auswärtige Pferdehändler sollen bei Bann und Strafe kein anderes Geschäft betreiben als Handel mit Pferden und sonst nichts. Dies betrifft sowohl sie selbst als auch andere, ${ }^{56}$ ohne jeglichen Betrug. Wer dies übertritt soll als Übertreter eines strengen Verbots bekannt gemacht werden und soll von unserer Gemeinde weiter keine Dienste erhalten. Kein Hausherr ist berechtigt, einem der oben genannten Gehilfen Vermittlungsgeld zu zahlen, falls ein solcher ihm etwas vermittelt. Kein Gehilfe eines Pferdehändlers soll sich im Sommer nach neun Uhr und im Winter nach acht Uhr noch auf unserer Straße sehen lassen. Sollte er gesehen werden, darf der Hausherr ihn mit sofortiger Wirkung nicht mehr beschäftigen. Er und noch weniger sein Gehilfe dürfen ohne vorherige Erlaubnis durch den Vorstand, Gott schütze ihn, solche, die nicht immer zum Haushalt des Pferdehändlers gehörten, im Stall beherbergen und erst recht kein Nachtquartier geben. All dies wird bei Bannstrafe eingehalten.

[fol. $144 \mathrm{v}$ ]

77 Nachdem es ein strenges Verbot der Vorfahren ist, nicht zu »streichen «, ${ }^{57}$ wird jetzt erneuert, dass niemand, Mann oder Frau, Jüngling oder Jung-

55 Und verkaufen.

56 In ihrem Auftrag.

57 Dies ist die Übernahme des jiddischen Begriffs, dessen Bedeutung trotz vieler Versuche nicht zu klären war. Er scheint mit Wechselgeschäften in Zusammenhang zu stehen. 
frau »streichen « soll. Es spielt keine Rolle, ob er mit dem Nichtjuden von vornherein wechseln wollte, um zu »streichen «, oder ob er danach oder in der Mitte oder am Ende den Tausch tun wollte. Auch soll er ihm das Geld nicht billiger geben, umso mehr, dass er es billiger gibt, damit ein anderer den Irrtum begehe. Derjenige, der das Geld an diese Menschen, die dafür gehalten werden, verleiht, soll überhaupt gebannt, abgesondert und abgeschieden von allem Heiligen in Israel sein, er selbst und auch der, der, wie auch immer, dabei geholfen hat.

78 Die Rabbiner von Aschkenas haben in jeglicher Form die Diebe, die in Aschkenas umherziehen und wegen denen Juden und Nichtjuden in ihren Häusern nicht sicher sind, gebannt und abgesondert und sie von jeder Heiligkeit Israels ausgeschlossen. Nicht nur sie sollen gebannt sein, sondern auch alle, die mit ihnen irgendwelche Geschäfte machen. Auch jene sollen gleich ihnen gebannt sein. Es ist bekannt, dass Gesetzesübertreter sich an nichts halten. Daher werden obige Verbote wieder bekräftigt und sie sollen verstärkt eingehalten werden, denn es ist hinreichend bekannt, dass wir in den Augen der Völker als ein Beschwernis angesehen werden. Daher soll jeder, der sich zu Israel zählt, selbst eine Grenze ziehen und mehr auf das Interesse aller denn auf seinen persönlichen Vorteil achten, denn in ihren ${ }^{58}$ Herzen ist keine Gottesfurcht. Daher wird hiermit der Öffentlichkeit bekannt gegeben, dass wenn einer, wer es auch sei, behüte!, nur in geringster Weise von den obigen Verboten abweicht, nicht verschont werden wird, ohne Rücksicht auf die Ehre seiner Familie. Auch wird er mit schweren Strafen gestraft werden, jedermann höre und vernehme dies. Ferner wird bekannt gegeben, dass einer, der jemanden, der für einen Dieb gehalten wird, bei sich beherbergt und damit die obigen Verbote übertritt, behüte!, sowie bei ihm Geld wechseln oder leihen will, auf welche Weise auch immer, und der Übeltäter ihm Geld gibt, der obige Bann auf beide fällt. Deswegen hat sich jedermann sehr in Acht zu nehmen, denn es handelt sich um Angelegenheiten von höchster Wichtigkeit. Gott erkennt die Gedanken und die unredlichen Vorhaben der Menschen. Desgleichen wird bei obigem Bann gewarnt, nichts von jemandem zu erhandeln, wenn bekannt ist, dass der Verkäufer ein Dieb oder Beutelschneider ist, ${ }^{59}$ selbst wenn er ein Nichtjude ist. Solche Geschäfte, die, behüte!, die gesamte Judenschaft beschweren, sollen nicht geduldet werden.

58 Der Diebe.

59 Ergänzung am rechten Blattrand: Oder wenn man merkt, dass es ein Diener ist, der seinen Herrn hintergeht. 
79 Die Hausherren beklagen sich sehr darüber, dass die Garköche Diebe [bei sich] beherbergen. Deswegen seien sie in ihren Häusern vor Diebstahl nicht sicher, wie auch nicht vor den übrigen verdeckten und offenen Vergehen, die durch die Diebe in den Häusern der Garköche geschehen, insbesondere mit Hurerei, und dies, obwohl ein Verbot von den Rabbinern in Aschkenas erlassen wurde, wonach man mit diesen Dieben überhaupt keine Geschäfte machen und sie schon gar nicht beherbergen solle. Um all dies zu verhüten, hat man für gut befunden, dass von heute an kein Garkoch irgendjemandem Essen geben oder bei sich ein- und ausgehen lassen darf, sofern er kein Schreiben von den Beauftragten vorweisen kann, wie lange er diesen beherbergen will, oder dass der Gast eine plete für eine Nacht bringt, dann soll dieser eine Nacht dort bleiben. Jeder Garkoch soll einen echten Eid leisten, nichts von dem zu übertreten. Desgleichen sollen auch alle Hausherren darauf achten, keinem von diesen Leuten Unterschlupf zu gewähren. Wenn ein Garkoch dies übertritt, soll er für ein ganzes Jahr niemanden mehr beherbergen und noch viel weniger beköstigen dürfen, abgesehen von der Strafe, die er vonseiten des Vorstands, Gott schütze ihn, zu erwarten hat. Es wird öffentlich bekannt gemacht werden, dass seine Garküche für jedermann verboten ist.

80 Die neun Männer sollen keinem der oben genannten jungen Männer hier die Mitgliedschaft geben, sofern er keine schriftliche Bestätigung von den Beauftragten hat, dass er alle halbjährlich schuldigen Gelder beglichen hat.

81 Ein Hausherr oder ein fremder Jude, der einem anderen Hausherrn unserer Gemeinde etwas schuldet, und dieser den Kredit verliert, weil der Erste einen Eid geschworen hat, dass er kein Geld mehr habe, oder auch aus anderen Gründen, darf, abgesehen von den anderen Strafen, auf Lebenszeit kein Kind in unsere Gemeinde bringen. Und wer nur schwört, um sich vom Zins zu befreien, aber die Summe bezahlen kann, soll für vier Jahre von heiligen Handlungen ausgeschlossen bleiben, selbst dann, wenn er wegen einer Jahrzeit ${ }^{60}$ oder aus einem anderen Grund zum Aufruf verpflichtet ist, ganz zu schweigen davon, dass er kein Amt bekommen soll und sein Name nicht in die Urne gelegt werden soll. Dies soll bei Bannstrafe eingehalten werden. Selbst ein Fremder, der in vergangenen Zeiten Pleite gemacht hat, soll wie oben beschrieben bestraft werden. Der Vorstand darf kein Geld von ihm nehmen, um ihm oder seinen Söhnen die Gemeindemitgliedschaft zu verleihen.

60 Das jährliche Gedenken an einen Verstorbenen an dessen Todestag. 
[fol. $145 \mathrm{r}$ ]

82 Sofort nach der Niederlassung eines Vorsitzenden des Gerichts hier, muss dieser all die Statuten, die von den 15 Männern formuliert wurden, ${ }^{61}$ bei Bannstrafe unterschreiben und dieselben Statuten der 15 Männer durch seine Autorität bekräftigen.

83 Die Statuten der 15 genannten Männer gelten von heute an für eine Zeit von neun aufeinander folgenden Jahren. Solange keine neuen Statuten erlassen wurden, sollen bei Bannstrafe die der 15 Männer ihre Gültigkeit behalten.

84 Derjenige parnas, der sagt: »Ich will nicht weiter parnas sein.«, soll niemals wieder ein Amt in unserer Gemeinde bekleiden dürfen, auch nicht seine Söhne. Sie können sich davon auch nicht mit Geld freikaufen und der Vorstand, unter Hinzuziehung des Vorsitzenden des Gerichts und weiterer Hausherren, dürfen ihm und seinen Söhnen in dieser Frage nicht entgegen kommen. Zusätzlich dazu muss er, ohne Abschlag, 100 Dukaten Strafe zahlen, je zur Hälfte an die Obrigkeit und an die Armenkasse. Jedoch vor der Vorsteherwahl im Jahr $436^{62}$ können ein parnas oder Hausherr zum Vorstand sagen: »Ich möchte von heute an nicht mehr zur Vorsteherwahl aufgestellt werden, denn ich möchte nicht parnas sein." In diesem Fall ist er von der oben genannten Strafe befreit. Dies soll bei Bannstrafe eingehalten werden.

85 Wenn ein parnas, Vorsitzender des Gerichts oder Hausherr, wer es auch sei, vom Vorstand oder von der Versammlung von Gemeinde und Vorstand fordert, selbst nur eine kleine Sache an den Statuten der 15 Männer aus dem Jahr 434 nach der kleinen Zeitrechnung ${ }^{63}$ zu ändern, sei gebannt, ausgestoßen und abgeschieden von aller Heiligkeit Israels. Sein Begräbnis soll unwürdig sein und er wird keinen Anteil an der kommenden Welt haben. Ferner soll er an unseren Herrn, den Kaiser, seine Pracht sei erhaben, 500 Reichstaler, an die Obrigkeit 500 Reichstaler und an die hiesige Armenkasse 500 Reichstaler Strafe zahlen. Wer vernimmt, dass jemand dies tut, muss dies bei Bann dem Königtum, der Obrigkeit und dem Armenpfleger anzeigen, damit dieser die Schuld eintreiben kann.

86 In vergangenen Zeiten, vor etwa 17 Jahren, sah man, dass die Generation vor einer Bresche stand - denn mit den Zeiten ändern sich die Bräuche - und hat einen Zaun gezogen. Dafür wurden durch die Mehrheit

61 Gemeint ist der vorliegende Text.

$621675 / 76$.

$631673 / 74$. 
des Vorstands, Gott schütze ihn, 15 Männer gewählt, um nach bestem Gewissen Statuten zum Wohl der Gemeinschaft zu verfassen. So taten es die 15 Männer in jener Zeit und haben Statuten für eine Zeit von neun Jahren verfasst. Diese Zeit ist schon längst verflossen. Da die jetzige Generation solches sah, wurden ebenfalls 15 Männer durch die Mehrheit der Gemeinde gewählt, wobei 198 Hausherren zustimmten und 42 ablehnten. Als ne'emanim wurden Herr Samuel Ne'eman und Herr Moses Sofer ernannt. Daher haben wir, die 15 unten unterzeichnenden Männer, Statuten nach bestem Gewissen zum Wohl der Gemeinde verfasst, so, wie sie jetzt vor uns liegen. Dafür haben wir uns, bei strengem Bann, unter Eid auf die Bibel und nach symbolischer Übergabe eines Gegenstandes ${ }^{64}$ mutig und fest zusammengetan, um eine Entwurf oder vorläufige Niederschrift zu machen. Sollte es aber, behüte!, geschehen, dass einer von uns 15 erwähnten Männern Einbußen hat und uns vorhält, dass wir eine Angelegenheit, in welchem Paragraphen auch immer, behüte!, nicht richtig verfasst hätten, so sind wir 15 unterzeichnende Männer verpflichtet, diesen zu entschädigen und ihn finanziell aus der Kasse des Vorstands, Gott schütze ihn, zu unterstützen. D.h., die Steuererheber, Gott schütze sie, müssen sofort nach ihrer Ernennung und bevor sie sich versammeln, um die Steuern zu erheben, einen Eid auf etwas Heiliges leisten, dass sie sofort aus den Gemeindefinanzen den Schaden ersetzen werden, bei 500 Reichstalern Strafe für jeden der Steuererheber, Gott schütze sie, aus seiner Tasche an den Kaiser, seine Pracht sei erhaben, 500 Reichstaler an die Obrigkeit, ihre Pacht sei erhaben, und 500 Reichstaler an das hekdesh. Auch muss dies dem Kaiser, seine Pracht sei erhaben, und der Obrigkeit, ihre Pracht sei erhaben, angezeigt werden und die Steuererheber müssen es unterschreiben. Der Vorstand, Gott schütze ihn, soll mit dem großen Bann belegt werden, wenn er den Steuererhebern die oben genannten Mittel zur Entschädigung verweigert, oder ihnen die Zahlung nicht gestattet. In diesem Fall sind wir 15 Männer verpflichtet, den Geschädigten zu entschädigen und ihn durch Fürsprache bei der oben genannten Obrigkeit von Pfändungen zu befreien, soweit es uns möglich ist, oder entsprechend dem persönlichen Kapital dazu Geld zu leihen, bis die Summe vom Vorstand, Gott schütze ihn, eingelöst ist. All das Obige haben wir bei himmlischer und irdischer Strafe auf uns genommen; ein jeder soll sich der Sache annehmen, so, als ob es um ihn selbst ginge, und wir werden dem Geschädigten Hilfe und Unterstützung sein in all unserem Handeln und Vermögen.

64 Als Bürgschaft für eine große Angelegenheit. 
[fol. $145 \mathrm{v}$ ]

87 Alle Anweisungen über das Verhalten der Kleiderhändler, wie sie in diesen Statuten dargelegt sind, sollen bei Bann eingehalten werden. Wer einen kleinen Teil davon übertritt, verletzt das Verbot. Der Vorstand, Gott schütze ihn, ist bei Bann verpflichtet, den Übertreter angemessen und nach eigenem Gutdünken zu bestrafen als jemanden, der ein Verbot übertreten hat. Die Bestimmung bezüglich der Kleiderhändler soll von heute an bis zum Cheschwan $437^{65}$ gelten, und sobald die Zeit gekommen ist, sind die Vorsteher bei Bann verpflichtet, die Beauftragten und sechs Hausherren, die keine Kleiderhändler oder Krämer sind, aus der Urne hinzuzuziehen und ausführlich zu beraten, ob etwas zu ergänzen oder zu streichen sei oder ob es bei den obigen Bestimmungen bleiben soll. Solange sie die Zeit verstreichen lassen und es so versäumen, die Bestimmungen über die Kleiderhändler zu beraten, soll alles weiter gültig bleiben, wie es die 15 Männer, so wie oben erläutert, verfasst haben. Den parnasim ist es entweder allein oder unter Hinzuziehung von Hausherren bei Bann verboten, einem Kleiderhändler irgendeins von den oben erläuterten Verboten zu gestatten. Selbst wenn er dafür viel Geld verspricht, ist es ihnen trotzdem bei Bann untersagt, etwas von den oben den Kleiderhändlern verbotenen Dinge zu gestatten.

88 Es ist jedem Hausherrn bei Bann verboten, irgendeinen Nichtjuden zu bestechen, damit er ihm die Gelegenheit vermittle, auf Hochzeiten oder Trauerfeiern von Nichtjuden etwas zu verkaufen. Er darf es nur, wenn ein Nichtjude oder eine Nichtjüdin ihn dazu einladen. Dieses Verbot und seine Dauer sind genau so lange gültig wie die für die Kleiderhändler.

89 Alle Ausfertigungen von Privilegien, die dem Vorstand gehören, sich aber in Händen von parnasim oder Hausherren befinden, müssen von diesen in die Stube der gabba'im oder in die des Vorstands, Gott schütze ihn, gebracht werden. Er darf bei Bann nichts davon in seinem Haus behalten.

90 Wenn ein Hausherr ein Pfand ${ }^{66}$ beim Vorstand oder Monats-parnas hinterlegen will, muss er dieses sofort in die Stube des Vorstands bringen und darf es nicht in seinem Haus behalten. Der Monats-parnas ist bei Bann verpflichtet, die Angelegenheit in seiner Amtszeit zu Ende zu bringen.

$651676 \mathrm{X}$.

66 Als Bürgschaft für ausstehende Strafzahlungen oder Steuerleistungen. 
91 Es ist bei Bann verboten, zu einer Amtsernennung vom vergangenen Chanukka $435^{67}$ noch ein weiteres Amt hinzuzufügen, was es auch sei. Selbst wenn der Ernannte bereit ist, sein erstes Amt abzugeben, kann er dennoch kein anderes bekommen, außer einer Ernennung zum Steuererheber. Diese kann in jedem Fall ausgesprochen werden, selbst wenn er schon ein Amt innehat. Wenn einer zum Steuererheber bestimmt werden sollte, müssen die parnasim ihn bei Bann von seinem ersten Amt befreien und umgehend einen anderen an seiner Stelle wählen.

92 Alle Gerichtsurteile müssen von den drei Richtern unterzeichnet werden. Sollten nur zwei unterzeichnet haben, ist der dritte Richter bei Bann verpflichtet, auch zu unterschreiben. Sollte er sich weigern zu unterschreiben, soll ihn der Vorstand von seinem Amt entheben und er darf drei Jahre lang nicht Richter in unserer Gemeinde sein. Wenn nicht drei Richter unterzeichnet haben, soll kein gabbai zur Durchsetzung des Urteils agieren. Lediglich dort, wo die Unterschriften von Wahlmännern nötig sind, reichen zwei aus. Nachdem das Gericht eine Entscheidung über die Kontrahenten gefällt hat, darf es anschließend keine weiteren Schriftstücke in der Sache ausstellen, es sei denn, dass beide Kontrahenten anwesend sind. Wenn das Gericht seinen Diener nach einem der Kontrahenten schickt, muss jener vor dem Gericht erscheinen. Sollte er nicht kommen, darf das Urteil dennoch ausgehändigt werden, obwohl der eine Kontrahent nicht erschienen ist.

93 Ein Hausherr, der regelmäßig in der alten Synagoge ist, muss bei einer Jahrzeit zur Toralesung aufgerufen werden, sowohl an Feiertagen als auch an den übrigen Tagen des Jahres. Nur die, die in der Synagoge auf den Treppen stehen oder neben ihrem Platz, soll man nicht aufrufen.

94 Die Vorsänger und shammashim dürfen auf keiner Festmahlzeit einen Segen über Personen aussprechen, welche Mahlzeit es auch sei.

95 Die Auslegung der Statuten der 15 unterzeichnenden Männer geschieht durch die Mehrheit dieser.

96 Alle Angelegenheiten der Verkäufe und Einkäufe durch Kleiderhändler, Krämer und Großhändler, die oben aufgeführt sind, gelten während des Jahres; jedoch zu Messezeiten ist alles erlaubt, auch die Verbote betreffend der ledigen Jugendlichen.

$67 \quad 1674 / 75$ 
[fol. $146 \mathrm{r}$ ]

97 Vor einiger Zeit hat sich in unserer Gemeinde ein Skandal ereignet, von dessen Art mehr als 100 Jahre nichts gehört wurde, und bei dem einige widerwärtige Leute sich unterstanden haben, in einer Streitsache mit einem anderen Juden sofort zur Obrigkeit, ihre Pracht sei erhaben, zu gehen. Obwohl es sich dabei nur um Nichtigkeiten handelte, hat es der Obrigkeit, ihre Pracht sei erhaben, großen Aufwand verursacht. Dabei haben auch die parnasim, Gott schütze sie, versagt, da sie die Leitung der Gemeinde nicht recht in der Hand hatten. Aus diesem Anlass wurden von der Obrigkeit, ihre Pracht sei erhaben, mehrmals Verweise ausgesprochen, wonach die Leitung besser geregelt werden müsse, da die Obrigkeit, ihre Pracht sei erhaben, von solchen Dingen unbelästigt bleiben wolle. Daraus ist auch eine große Krise erwachsen, denn fast kein Jude wollte mehr mit einem anderen Geschäfte machen oder Kredit geben aus Furcht vor unkalkulierbaren Folgen. Dadurch ist der gesamte Handel zurückgegangen und die Lage unserer Gemeinde hat sich sehr verschlimmert. Auch zuvor war der Lebensunterhalt schlecht gewesen und hat sich täglich verringert und es ist deutlich, dass noch, behüte!, großer Verlust für die meisten Söhne unserer Gemeinde entstehen kann, wenn dieser Missstand nicht abgestellt wird, abgesehen von weiteren Ungelegenheiten, die hier nicht beschrieben werden können.

Daher wurde für gut erachtet, dass der Vorstand, Gott schütze ihn, die Rechtsprechung in Fällen von Handgreiflichkeiten, Beleidigungen und Geldern übernehmen soll, um so unsere Obrigkeit, ihre Pracht sei erhaben, nicht zu bemühen, wie es auch in unseren Regeln schon dargelegt wurde und wie es die parnasim in vergangenen Tagen gehandhabt haben. Sollte es geschehen, dass sich einer weigert, dies anzuerkennen, und die Obrigkeit, ihre Pracht sei erhaben, bemüht, indem er seinen jüdischen Kontrahenten vor sie bringt, so sollen die parnasim die vier bisherigen Fürsprecher und vier Hausherren aus der Urne hinzuziehen und sollen zusammen zwei Personen wählen, die zum Zweck der Fürsprache zur Obrigkeit, ihre Pacht sei erhaben, gehen sollen. Dieser sollen sie die Sache berichten und sich mit all ihren Kräften und ohne jegliche Ausflüchte bemühen, den Fall wieder zurück zu bringen. ${ }^{6}$ Sollten einer der beiden Männer oder beide zusammen das oben Erwähnte ablehnen oder vernachlässigen, sollen sie gebannt, abgeschieden und verstoßen aus aller Heiligkeit Israels sein und jeder muss 100 Reichstaler an die Obrigkeit, ihre Pracht sei erhaben, und 100 Reichstaler an die Armenkasse zahlen.

68 D.h. wieder vor eine jüdische Instanz. 
Wenn der Fall von der Obrigkeit, ihre Pracht sei erhaben, wieder an den Vorstand oder die Richter verwiesen wird, müssen die parnasim die Richter und die vier bisherigen Fürsprecher hinzuziehen. Die parnasim und die vier erwähnten Fürsprecher sollen noch einige Hausherren dazu bestimmen, wen sie wollen und so viel sie wollen. Wenn der Beklagte ${ }^{69}$ für schuldig gehalten wird, darf er sein ganzes Leben zu keiner heiligen Handlung zugelassen werden, ganz zu schweigen von einer Ernennung zu einem Amt. Darüber hinaus muss er 50 Reichstaler Strafe an die Obrigkeit, ihre Pracht sei erhaben, und 50 Reichstaler an die Armenkasse zahlen, zusätzlich zu der Begleichung aller entstandenen Kosten. Der Vorstand ist nicht berechtigt, ihm etwas von seinen oben genannten Strafen nachzulassen, selbst wenn er dafür Geld zahlen wollte. In dieser Angelegenheit kann der Beklagte auch keinen parnas ablehnen..$^{70}$ All das Obige müssen die parnasim bei himmlischer und irdischer Strafe einhalten und derjenige parnas, der es ablehnt, so, wie oben beschrieben, zu handeln, und durch Ausflüchte und Betrug die Sache verzögern oder beenden will, ist als blutgieriger Betrüger vor dem Herrn ein Gräuel. Er sei gebannt, abgeschieden und verstoßen von aller Heiligkeit Israels und muss 500 Reichstaler Strafe an den Kaiser, 500 Reichstaler an die Obrigkeit und 500 Reichstaler an die Armenkasse zahlen. Ausdrücklich soll er in der Zeit der Wahlen aus seinem Amt entfernt werden, zusätzlich zu den zwei parnasim, die ausscheiden müssen. Auch soll er ein unwürdiges Begräbnis bekommen und er, seine Söhne und Schwiegersöhne dürfen in ihrem Leben kein Amt in unserer Gemeinde innehaben. Wenn er streitsüchtig und aggressiv sein sollte, sodass man von ihm die Strafe nicht bei Lebzeiten einziehen kann, soll es nach seinem Tod geschehen.

Und wir 15 unterzeichnende Männer, Gott schütze sie, sind bei Bann verpflichtet, uns fortlaufend jedes Vierteljahr bis zur nächsten Wahl im Tammus $436^{71}$ zur Versammlung zusammenzusetzen, um zu beraten und zu prüfen, ob die parnasim die obigen Dinge, und insbesondere diesen Abschnitt, eingehalten haben. Wenn, behüte, herausgefunden wird, dass man etwas vom Obigen übertreten hat oder sie es nicht vermögen, den Fall wieder zurück zu bringen, sind wir 15 Männer bei Bann verpflichtet, noch weitere 30 Männer von den Besten der Hausherren zu wählen und müssen die Sache eingehend prüfen, um zu wissen, was in der Angelegenheit noch gemacht werden muss und wie sie weiter angegangen werden soll, damit der alte Glanz zurückgebracht wird. Und wenn einer von uns

69 Derjenige, der den Fall vor das nichtjüdische Gericht gebracht hatte.

70 Aus Befangenheit oder persönlichen Gründen.

$711675 \mathrm{VI} / \mathrm{VII}$. 
15 unterzeichnenden Männern oder einer der 30 Gewählten widerspenstig sein sollte und nicht zur Versammlung kommt, die obige Sache vernachlässigt und sich herausredet, muss er sofort 100 Reichstaler an die Obrigkeit, ihre Pracht sei erhaben, und 100 Reichstaler an die Armenkasse zahlen. Zudem soll er alle seine Tage zu keiner Heiligkeit Israels und noch weniger zu einem Amt kommen. Die gabba'im, die jedes Vierteljahr amtieren, sollen ebenfalls gebannt, abgeschieden und der obigen Strafe verfallen sein, wenn sie es verzögern sollten, die Männer zur Versammlung zu rufen. Der erste Termin für die Versammlung ist der 1. Ijjar 435.72

Die gabba'im des Vorstands, Gott möge sie schützen, müssen bei Bann die Schlüssel der Stube des Vorstands sofort, wenn er es verlangt, an den gabbai der 15 Männer senden.

Bezüglich der Kleidung von Frauen und dem Verkauf von Wein ohne vorherige Schätzung soll der heilige Vorstand, Gott schütze ihn, einige Männer wählen, die nach ihrem Gutdünken Verordnungen erlassen sollen. Alles, was sie erlassen, müssen die Beauftragten bei Bann einhalten.

[fol. $146 \mathrm{v}$ ]

Nachdem es wegen einiger Mängel und Missstände längere Zeit um die Führung unserer Gemeinde hier nicht zum Besten bestellt war und man eine Verbesserung herbeiführen musste, wurden durch den heiligen Vorstand, Gott schütze ihn, unter Hinzuziehung weiterer Männer aus der Gemeinde und durch die Mehrheit der Hausherren 15 Männer erwählt, um zu Gottes Wohlgefallen Statuten zu erlassen, die zur Stärkung des Glanzes der Gemeinde nötig sind. Nachdem nun ihre Statuten fertiggestellt sind, kam in ihrer Seele der Wunsch auf, Gültigkeit und Macht ihrer Worte und Statuten zu stärken. Auch sollen die 15 Männer gegen jeden irgendwie denkbaren Schaden und Verlust abgesichert sein, der ihnen wegen der obigen Statuten entstehen könnte, sei es einem Einzelnen, mehreren oder allen, entweder durch Juden oder durch Nichtjuden, was immer es sei. Der gesamte Vorstand, Gott schütze ihn, ist verpflichtet, sie ohne jeglichen Aufschub, Ausrede oder Einwand sofort bei einsetzender Schädigung und Verlust zu entschädigen, und er kann nicht sagen: »Zeige mit die Urkunde, ${ }^{73}$ und ich werde dich entschädigen. «Die Steuererheber, Gott schütze sie, sind verpflichtet, sie sofort für Schaden und Verlust aus der Gemeindekasse zu entschädigen oder dafür zu sorgen, dass den 15 Männern kein Verlust und Schaden entstehen. Daher stimmten der heilige Vorstand und die erwähnten hinzugezogenen Männer zu, ihre Bitte zu erfüllen und alles schriftlich und unterschrieben durch die im Namen

721675 IV 17.

73 Darüber ergänzt: Dass du schon erwähnten Schaden und Verlust hattest. 
unseres Lehrers Ermächtigten hier in unserer Gemeinde zu geben. Dazu wurden wir heute namentlich aufgerufen, am 8 . Tewet 435 nach der kleinen Zeitrechnung, ${ }^{74}$ wir, die unten Unterzeichnenden, dies in das Protokollbuch des Vorstands, Gott schütze ihn, einzuschreiben und durch Unterschrift zu bestätigen, damit es lange Tage Bestand habe. Deswegen verbieten wir bei strengem Bann und Eid sowie aller Eindringlichkeit und Macht jedem Übeltäter, irgendetwas von all den obigen Statuten, die von den 15 erwähnten Männern gemacht wurden, zu verletzen. Die Strafe für den Übeltäter soll niemand anders treffen als nur ihn selbst. Auch soll bekannt gemacht werden, dass der heilige Vorstand, Gott schütze ihn, unter Hinzuziehung der zusätzlichen Gemeindemitglieder übereingekommen ist, dass der Vorstand die genannten 15 Männer für jeden Schaden und Verlust entschädigen muss, wie oben dargelegt. Auf dem Blatt soll zur Zeugenschaft niedergeschrieben werden: »Du hattest schon Schaden und Verlust.", wie oben erläutert. Bei einem Schuldner geht die Regel vor, ${ }^{75}$ und alles ist fest und gültig. Auch wir unten Unterzeichnende stimmen mit allen Strafen und Bußen überein, die die hervorragenden 15 Männer für diejenigen festgesetzt haben, die etwas von dem übertreten, was sie verfasst haben. Der Übeltäter kommt für drei Jahre zu keiner heiligen Handlung und kann sich auch nicht mit viel Geld von der obigen Strafe erlösen, abgesehen von den übrigen Strafen, die ihm der heilige Vorstand, Gott schütze ihn, auferlegen wird; dies wird bei Bann eingehalten. Bei allem soll der Obrigkeit nichts benommen und ihre Herrschaftsrechte nicht im Geringsten geschmälert sein, [geschehen] am obigen Tag. bestätigt von dem geringen Hirz Ahrweiler

bestätigt von Moses, Sohn meines Herrn Vaters Salomon Halevi, das Angedenken des Gerechten zum Segen für das Leben in der kommenden Welt

bestätigt von dem geringen Meir Scht[..]

der geringe Nathan Cohen

bestätigt von dem geringen Moses Cohen

bestätigt von dem geringen Josef Cohen

Jechiel Katz ${ }^{76}$

Moses Ulif

Doters Oppenheim

David Reis

741675 I 25.

75 Die Übersetzung der beiden Abkürzungen ב"ד u"ק ist nicht sicher.

$76 \mathrm{Ab}$ hier sind es offenbar die Namen der Mitglieder der Statutenkommission (»15 Männer«). 
Samuel, Sohn des Israel Jakob, seligen Angedenkens, Bacharach Abraham Levi Oettingen Models

Nachum Och

Sanwil Langibach

Salman Scheuer

Meir Levi Schnapper

Moses Waag Bacharach

Naftali, Sohn unseres Lehrers, des Herrn Moses Segal, das Angedenken des Gerechten zum Segen

Jehuda, Sohn des Ischai, seligen Angedenkens

Elieser, Sohn meines Herrn Vaters, unseres Lehrers, Herrn Jakob Katz Schiff

Jakob, Sohn des Haver Herrn David, seligen Angedenkens, Schwelim 


\section{3. Ühlfeld (ca. 1683-1698)}

[fol. 1]

Gott hat den Sinn der heiligen Männer, die in Ühlfeld und der Umgebung wohnen, erleuchtet, und sie haben einen Vorsitzenden des Gerichts und gerechten Lehrer angenommen, um ihnen den Weg zu weisen, auf dem sie gehen sollen. Und dabei sei dies zum Beistand: Sie haben beschlossen mich zu bitten, ihnen ein Protokollbuch des Vorstands anzulegen und in dieses einige rechte Statuten und Bestimmungen einzuschreiben, damit in der Stadt keine Bresche ohne Mauer sei und gar jeder das tue, was ihm beliebt. Es ist ihr Wille und ihre Neigung, die geraden und rechten Wege zu beschreiten, wie die übrigen Reinen in Israel. [... $]^{1}$ in ihrem Lager und niemand erhebe mehr das Wort, um die Meinungen zu spalten. So habe ich ihnen mein Haupt zugeneigt, ihrer gerechten Rede entsprochen und ihnen Statuten nach meinem besten Vermögen verfasst. Ich habe nur weniges getan, da ich doch vom Himmel erwählt wurde. Einiges ist nach den Regeln der Religion, andere sind unverrückbare Bestimmungen. Der genannte Ascher Enslen. Dies wurde zuerst gemacht:

Der Anfang aller Dinge ist die Gottesfurcht. Jeder Hausherr, der über Nacht in seinem Haus ist, soll sich am Morgen befleißigen, in die Synagoge zu gehen, um dort sein Gebet innig zu verrichten. Auch wenn kein Quorum zustande kommt, soll er dennoch in der Synagoge beten, denn wir sind die Schüler Abrahams, unseres Vaters, sodass wir verpflichtet sind, einen Platz für das Gebet festzulegen. Dazu kann man in der Synagoge noch inniger beten als zuhause. Es soll auch einem Untergebenen des Vorstands anbefohlen sein, abends und morgens zur Synagoge zu rufen. Auch sollen die Kinder, sowohl Bar Mizwa² als auch die jüngeren, daran gewöhnt werden.

Weil es derzeit noch wenige ${ }^{3}$ sind, kann noch keine Geldstrafe deswegen ${ }^{4}$ verhängt werden. Allerdings soll für jede Toralesung ein halber Batzen ${ }^{5}$ gefordert werden, wenn jemand in der Nacht in seinem Haus war, am

1 Textverlust durch beschädigtes Papier.

2 Diejenigen Knaben, die über 13 Jahre alt sind.

3 In der Gemeinde.

4 Auf das Nichterscheinen in der Synagoge.

5 Scheidemünze, ein (schwerer) Batzen galt im Fränkischen fünf Kreuzer. 
Morgen aber nicht zur Synagoge geht. Auch die Diener, die zwar Jugendliche, aber schon Bar Mizwa sind, müssen die Strafe zahlen. Wenn ein Quorum ohne die Jugendlichen zustande kommt, soll man die Jugendlichen übers Feld oder an andere Orte gehen lassen, ohne dass es eine Geldstrafe nach sich zieht. Der genannte Ascher Enslen.

[fol. $1 \mathrm{v}$ ]

2 Auch soll kein alltägliches oder unwürdiges Gerede in der Synagoge sein. So oft zwei miteinander in der Synagoge reden, soll der Kassenwart von jedem zwei Pfennige fordern. Der genannte Ascher Enslen.

3 Die Kassenwarte sollen monatlich wechseln. Sie sollen sowohl Geld einnehmen, als auch die Armen mit Wegzehrung versehen und die pleten ausgeben. Der genannte Ascher Enslen.

4 Jedes Vierteljahr sollen die Kassenwarte das Legbrett ausrechnen und einnehmen, was $\operatorname{sie}^{6}$ an Rückständen haben. Von jedem sollen sie monatlich ein halbes Kopfstück ${ }^{7}$ einziehen und gewissenhaft ein Buch darüber führen. Der genannte Ascher Enslen.

5 Die gabba'im haben das Recht, jemanden, der seine Abgaben nicht zahlen will, ausrufen zu lassen. ${ }^{8}$ Der genannte Ascher Enslen.

6 Wer ausgerufen wurde, weil er seine Abgaben nicht entrichtet hat und sagt, dass er das Geld nicht habe, oder es wegen sonstiger Schulden [ihm nicht zur Verfügung stehe], [fol. 2 r] soll nicht mit einer Geldstrafe belegt werden, wenn er bis zu acht Tage in der Ausrufung ist. ${ }^{9}$ Wenn er aber länger in der Ausrufung ist, muss er jeden Tag einen Batzen Strafe hinterlegen. Wenn er 30 Tage in der Ausrufung verbleibt und sich nicht darum schert, soll er dem Vorsitzenden des Gerichts angezeigt werden, denn er ist es wert, mit dem Bann belegt zu werden. Auch soll ihn dann der Vorsitzende des Gerichts mit einer höheren Geldstrafe als mit dem einen Batzen belegen. Entsprechend seinen Handlungen und Taten soll er dafür aufkommen. Wenn aber jemand wegen einer Verweigerung oder einer Handlung, die er nicht hätte tun sollen, in der Ausrufung ist, sodass man nicht sagen kann, dass er nur das Geld beschaffen müsse, soll er sofort für jeden Tag mit einem Batzen Strafe belegt werden, solange er in der erwähnten Ausrufung bleibt. Der genannte Ascher Enslen.

6 Die Gemeindemitglieder.

7 Kopfstück, Münze mit dem Herrscherbild, entsprach je nach Region zwischen 15 und 20 Kreuzer.

8 Mit dem kleinen Bann belegen.

9 Gemeint ist der kleine Bann. 
7 Wenn einer in der Ausrufung ist, soll für ihn nichts geschächtet oder geprüft ${ }^{10}$ werden. Auch soll man ihm kein Fleisch zukommen lassen und ihn nicht zur Toralesung aufrufen. Er soll auch keine Ehrenämter in der Synagoge erhalten, zum Quorum jedoch darf er zugelassen werden. Geschäfte dürfen mit ihm gemacht werden. Wenn einer länger als acht Tage in der Ausrufung ist und man merkt, dass er diese nicht achtet, soll wegen ihm seiner Frau die Nutzung des Tauchbades untersagt werden. Der genannte Ascher Enslen.

[fol. $2 \mathrm{v}$ ]

8 In Sachen Anschuldigungen und Verletzungen von Rechten anderer: Sobald ein Jude im Haus eines Nichtjuden ist, sei es mit Vieh, Waren oder auch ohne irgendetwas, darf kein anderer in dasselbe Haus gehen. Wenn jemand zufällig hinein geht, ohne etwas vom ersten zu wissen, und der erste zum zweiten sagt: »Geh zurück!«, muss jener zurückgehen, bei Strafe von einem Reichstaler Wenn der zweite aber des ersten Rechte verletzt oder ihm Schaden zugefügt hätte, ist mit dem einen Reichstaler die Sache nicht abgegolten und ersterer kann vor Gericht seinen Schaden einfordern. Der genannte Ascher Enslen.

9 Niemand soll einen Nichtjuden verächtlich behandeln, weil jener mit ihm nichts gehandelt oder bei ihm nichts gekauft hat. Nur wenn jener Nichtjude ihm etwas schuldet, darf er zu ihm sagen: »Weil du jetzt einen anderen Handelsmann annimmst, musst du mich bezahlen.« Wer dies übertritt, muss ein halbes Pfund Wachs als Strafe geben. Der genannte Ascher Enslen.

10 In Sachen Geldstrafen muss ein Hausherr für seine Frau und die Mitglieder seines Haushalts einstehen. Der genannte Ascher Enslen.

11 Wenn jemand einen anderen beschuldigt oder dessen Rechte ${ }^{11}$ verletzt und dafür keine jüdischen Zeugen vorhanden sind, so genügt auch ein Nichtjude, der nach den Regeln der Zeugenschaft von dessen Richter oder Obrigkeit verhört wurde, um den Übertreter zur eidesstattlichen Erklärung zu zwingen. Wenn dieser den Eid nicht leisten will, muss er eine Geldstrafe [fol. 3 r] wie oben angegeben zahlen. Dem Kläger hingegen ist damit nichts benommen und er hat das Recht, ihn vor Gerichtzu fordern. Wenn er Recht bekommt, muss er doch demjenigen, der die Tat begangen hat, verzeihen und sich mit ihm versöhnen. Der genannte Ascher Enslen.

10 Rituelle Fleischprüfung.

11 Gemeint sind hier vor allem Geschäftsrechte. 
12 Wir haben bereits bei strengem Bann entschieden, dass niemand einen Gast, der im Verdacht steht, sein Leben nicht rechtschaffen zu führen, bei sich über Nacht beherbergen oder gar mit ihm ein Geschäft machen darf. Wenn jemand dies übertritt, wird mit ihm verfahren wie mit einem, der den Bann verletzt hat und wird mit Geldbußen, Strafen und mit Schmach bestraft. Die parnasim haben auch das Recht, ihm sofort ein Pfand bis zu vier Reichstalern abzufordern, bis er deswegen vor Gericht gestellt wird. Der genannte Ascher Enslen.

13 Niemand soll ohne Erlaubnis der parnasim einen Gast mit dessen Frau für einige Zeit beherbergen, es sei denn, dass es sich um einen ehrenwerten Mann handelt. Andernfalls könnten durch ihn Beschwernisse für den Vorstand - er soll leben! - entstehen, alles bei Strafe von einem Reichstaler. Der genannte Ascher Enslen.

14 Die Zuwendung ${ }^{12}$ von einem Paten ${ }^{13}$ beträgt eineinhalb Kopfstück. Weibliche Paten geben sechs Kreuzer guter Währung. Der genannte Ascher Enslen. [fol. $3 \mathrm{v}]$

15 Wenn eine Zehr-Hochzeit ${ }^{14}$ abgehalten wird, muss der Bräutigam Notwein ${ }^{15} \mathrm{im}$ Wert von einem Goldgulden für die ersten $100^{16}$ bringen, von dem zweiten Hundert eineinhalb Kopfstück. Ab dem dritten Hundert drei Batzen guter Währung. Ein Drittel vom Notwein gebührt den Servierern. Der genannte Ascher Enslen.

16 Die Zuwendung von Bräutigamen für die Jugendlichen oder Jünglinge beträgt vom ersten Hundert drei Batzen guter Währung. Danach vom zweiten Hundert sechs Kreuzer guter Währung. Danach von jedem Hundert einen Groschen. Der genannte Ascher Enslen. Durch Beschluss der Herren des Vorstands ist diese Zuwendung gestrichen worden. So ist es auch meine Ansicht, dass kein Bräutigam eine Zuwendung geben muss. Bekräftigt von Ascher Enslen, heute, Donnerstag, den 17. Tammus 448 nach der Zeitrechnung. ${ }^{17}$

17 Die parnasim haben das Recht, jemanden, der etwas tut, das nicht der Ordnung entspricht, mit einer Strafe von bis zu zwei Pfund Wachs zu ihren Gunsten zu belegen. Wenn jemand sie in ihrer Würde verletzen sollte,

12 Geldbetrag für den festlichen Umtrunk.

13 Bei einer Beschneidung.

14 Eine Hochzeit von Minderbemittelten.

15 Mindestmenge an Wein.

16 Gulden der Mitgift.

171688 VII 15. 
können sie diesen mit einem Pfund Wachs zu ihren Gunsten bestrafen. Wenn jemand etwas getan hat, dass mit einer höheren Strafe als der genannten geahndet werden muss, dürfen sie ihm ein Pfand für bis zu zwei Reichstalern Strafe abfordern. Sobald die Sache vor den Vorsitzenden des Gerichts kommt, wird der Übeltäter entsprechend seinen Handlungen bestraft. Der genannte Ascher Enslen.

[fol. $4 \mathrm{r}$ ]

18 Keiner soll nichtkoscheren Wein, der der Wein der Nichtjuden ist, bei Strafe von einem Reichstaler trinken. Schächter und Prüfer dürfen zudem ihre Tätigkeit nicht mehr ausüben. Der genannte Ascher Enslen.

Heute, Mittwoch, den 6. Tammus 443 nach der Zeitrechnung, ${ }^{18}$ hat der Vorstand von Ühlfeld zusammen mit mir und dem parnas, dem Hohen Herrn Simon Diesbeck, beschlossen, dass jeder, der eine Geschäftsvermittlung hier im Dorf Ühlfeld macht, den halben Gewinn für sich hat und die andere Hälfte an den Vorstand - er möge leben! - fällt. Dies soll um einer heiligen Sache ${ }^{19}$ willen für die kommenden zehn Jahre gelten. Anschließend obliegt es dem Vorstand, dies nach Stand der Dinge und der Zeit sowie den Bedürfnissen des Vorstands zu ändern. Bekräftigt von Ascher Enslen.

Bei Anwesenheit der parnasim wurde beschlossen, dass jemand, der eine Geschäftsvermittlung vornimmt, dies dem gabbai oder dem Vorstand vor Ausgang des Schabbat in derselben Woche mitteilen muss. Wer dies übertritt, gibt ein Viertel [Pfund] Wachs. Bestätigt von Ascher Enslen.

Auch wurde weiter am obigen Tag beschlossen: Da sie in etwa 60 Reichstaler zum Zweck der Errichtung einer Synagoge in ihren Händen haben und in ihrer Absicht steht, noch weiter zu sammeln um die Sache - so Gott will - ins Werk zu setzen, und durch sie [die Vorsteher] eine Synagoge zu errichten sowie die übrigen Kultgegenstände zu erwerben, soll ein fremder Mann, der den Männern der hiesigen heiligen Gemeinde sie möge leben! - unbekannt ist und hier leben möchte, zwölf Reichstaler zum genannten Zweck geben. Dies, weil auch auf jeden der gegenwärtigen Einwohner der genannte Betrag fällt. In jedem Fall hat der hiesige Vorstand das Recht, von jenem Mann auch weniger zu nehmen, je nach seinen Möglichkeiten. Dafür ist der Vorstand - er möge leben! - verpflichtet, ihm jeweils einen Platz in der Männer- und Frauenabteilung zu geben, d.h. den ersten Platz, der in jenen Tagen frei werden wird.

$18 \quad 1683$ VI 30

19 Offenbar die Finanzierung der Errichtung der Synagoge. 
Wenn sich ein Hausherr, bzw. sein Sohn oder seine Tochter hier niederlassen, braucht er diesen Betrag nicht zu geben, sondern nur zweieinhalb Reichstaler, für die der Vorstand verpflichtet ist, ihm einen Platz in der Männerabteilung und einen in der Frauenabteilung zu geben, die ersten, die dann in jenen Tagen frei werden. Der genannte Ascher Enslen.

[fol. $4 \mathrm{v}$ ]

Heute, am Mittwoch, dem ersten Tammus 450 nach der kleinen Zeitrechnung, ${ }^{20}$ hat die gesamte heilige Gemeinde hier vor mir, dem Unterzeichnenden, und vor dem parnas, dem hohen Herrn Simon Heschech, beschlossen, dass das Aufsagen der Psalmen folgendermaßen begonnen werden soll: Wenn zwei Hausherren anwesend sind, sollen sie sie zusammen aufsagen. Wenn der eine jedoch nicht, wie sonst üblich, mit einem Psalmenvers antworten sollte, muss der andere leise diesen sagen, so als ob jemand mit ihm aufsagen würde. Wer an Tagen der Toralesung nicht vor Barukh she-Amar ${ }^{21}$ in die Synagoge kommt, muss einen Kreuzer Strafe geben. Wer nicht vor dem Ende vom Meereslied ${ }^{22}$ kommt, muss einen halben Batzen Strafe zahlen und an anderen Wochentagen einen halben Gulden. Ascher Enslen, Rabbiner der heiligen Gemeinde Schnaittach und Rabbiner hier in Ühlfeld.

20 Heute, Sonntag, den 7. Cheschwan 459 nach der Zeitrechnung ${ }^{23}$ hat die heilige Gemeinde hier vor dem parnas, dem Befehlshaber, dem ehrenwerten Herrn Moses Gaikel beschlossen, dass wenn die Vorstandsmitglieder oder der Kassenwart von einem Hausherrn ein Pfand abfordern oder ihm eine Geldstrafe auferlegen, sie zuvor zum rabbinischen Gericht gehen müssen, um dort mit ihm die Sache vorher zu verhandeln. Wenn es sich ergeben sollte, dass er zur Zahlung verpflichtet ist, hat $\mathrm{er}^{24}$ Macht und Erlaubnis gemäß dem im Statutenbuch des Vorstands Geschriebenen. Bestätigt von Mordechai Diesbeck.

[fol. $5 \mathrm{r}$ ]

Bei meinem Kommen hierher in die heilige Gemeinde Ühlfeld habe ich von den Einwohnern der heiligen Gemeinde über Auseinandersetzungen gehört, die unter ihnen im Gange sind wegen der Entlohnung für ihren Lehrer und Vorsänger. Daher habe ich mit Zustimmung des Vorstands beschlossen, dass sie sich für drei Jahre folgendermaßen verhalten sollen:

201690 VII 5.

21 Segensspruch im Morgengottesdienst, am Beginn der Psuke de-Zimra.

22 Lobgesang des Moses aus Ex 15, Teil der Psuke de-Zimra.

$231698 \times 12$.

24 Gemeint ist offenbar der Kassenwart. 
Wer eine Stunde zu lernen hat, gibt einen Goldgulden. ${ }^{25}$ Für eine halbe Stunde einen halben Goldgulden und für eine Viertelstunde entsprechend dem Vermögen. Wer aus der Mischna lernt, muss für eine Stunde zahlen. Für Bibel gebe er für eine dreiviertel Stunde, für Gebete eine halbe Stunde, für das Alphabet eine Viertelstunde. Nur für Unterricht im Schreiben eine halbe Stunde. Die übrigen Entlohnungen für den Lehrer und Vorsänger sind zur Hälfte nach Gulden, zur anderen Hälfte nach dem Vermögen. All das Obige wurde mit meiner Zustimmung und nach der Lage der Angelegenheit und der Zeit auf drei Jahre fixiert, von heute an gerechnet. Am Ende dieser drei Jahre soll die Angelegenheit erneut vor den Vorsitzenden des Gerichts, der in jener Zeit amtieren wird, kommen. Montag, den 5. Tammus 454 nach der Zeitrechnung ${ }^{26}$ Menachem Kaz[..] $\mathrm{ch},{ }^{27}$ unterschrieben in der genannten heiligen Gemeinde

22 Die Einwohner von Ühlfeld, Gott möge sie schützen, haben eine prachtvolle Synagoge errichtet. Nur wenige reden während oder nach den Gebeten, und doch entstand großer Unmut und Streit unter ihnen in den Angelegenheiten der Synagoge, den Aufrufen zur Toralesung und anderen Dingen. Sie hören nicht auf ihre Oberhäupter, weshalb ich gesprochen und ausdrücklich entschieden habe, dass wer dies übertritt, Streit in der Synagoge hervorruft und nicht auf die Stimme des Oberhaupts hört, einen Reichstaler je zur Hälfte an die Obrigkeit, ihre Pracht sei erhaben, und an die Armenkasse in die Hände des Kassenwart geben muss.

Auch bezüglich der Aufrufe und Lesungen aus der Tora sollen sie sich verhalten wie seit alters her. Danach darf es keine Männer geben, die nicht zur Tora aufgerufen werden. Am ersten Schabbat eines Monats soll man zwei von denen aufrufen, die im letzten Monat nicht zum Zuge kamen. Auch sollen nach einem Feiertag nicht schon wieder diejenigen lesen, die am [letzten] Feiertag aufgerufen wurden, sondern nur die, die am letzten Feiertag nicht an die Reihe kamen.

Menachem Kaz[..]ch

25 Dies ist nicht der Stundenlohn, sondern der Gesamtbetrag für eine Lernperiode, in der wöchentlich eine Stunde gelernt wurde.

261694 VI 28.

27 Namenszusatz nicht zu entziffern. 


\section{Den Haag (1701)}

[fol. $1 \mathrm{r}$ ]

Kopie der Statuten der aschkenasischen Gemeinde Den Haag, die von der Obrigkeit, ihre Pracht sei erhaben, den Richtern, den Bürgermeistern und den Schöffen, verliehen wurden.

Verordnung der Statuten, nach denen sich die hier wohnenden, aschkenasischen Juden sowohl in der Synagoge als auch außerhalb dieser zu richten haben, verfasst durch Levy und Pinto, hier im Haag wohnende sephardische Juden. Und von den achtbaren Herren Bürgermeistern, Schöffen und dem Richter wurde angeordnet, dass alle Angelegenheiten der Aschkenasim über Fragen unserer Zeremonie und der Statuten weitgehend und in bester Eintracht geregelt werden sollen wie folgt:

1 Sollte jemand in der Synagoge laut schreien oder rufen und so Streit oder Unruhe verursachen, so wird er beim ersten Mal mit einem Reichstaler Strafe zugunsten der Armenkasse belegt. Wenn einer sich in der Synagoge anschickt, zu schlagen oder die Hand zum Schlag erhebt, muss er fünf Gulden Strafe zugunsten der Armenkasse zahlen. Sollte er tatsächlich handgreiflich werden, so muss er zehn Gulden an die Armenkasse geben. Auch wenn jemand ein Messer oder ein sonstige Waffe ziehen sollte, auch wenn er niemanden damit verletzt, muss er ebenfalls zehn Gulden an die Armenkasse geben, ohne jedoch damit die Kompetenzen des Richters ${ }^{1}$ zu berühren. Der Richter muss dennoch auch sein Strafgeld einfordern, trotzdem schon zehn Gulden [vom Übeltäter] an die Armenkasse entrichtet wurden.

2 In der Zeit des Laubhüttenfestes, wenn die parnasim und gabba'im gewählt werden, müssen diese durch solche Leute gewählt werden, die bereits drei Jahre in unserer Gemeinde Hausherren² waren. Sie müssen einen reinen Leumund haben, so wie es in den Statuten der Amsterdamer Aschkenasim festgelegt ist, und sie müssen für die Aufgabe geeignet sein. Ihre Namen sollen in eine Urne gelegt werden und von diesen sollen zwei herausgezogen werden »von dem alten parnas oder gabbai, die ihre

1 Gemeint ist der städtische Richter.

2 Vollgültige Mitglieder. 
Amtszeit beendet haben $\aleph^{3}$ und diese sollen einen neuen parnas bzw. einen neuen gabbai wählen, ${ }^{4}$ der einen guten Leumund haben muss. Der neue parnas muss vom vorigen parnas oder gabbai die Kasse übernehmen mit allen Ausgaben und Einnahmen in Anwesenheit des gesamten Vorstands.

[fol. 1v leer

fol. $2 \mathrm{r}$ ]

3 Die beiden parnasim bzw. gabba'im dürfen nicht blutsverwandt oder verschwägert sein bis in die vierte Generation und auch nicht zwei gemeinsame Diener gleichzeitig haben.

4 Wenn ein parnas oder gabbai gewählt wird und der Gewählte die Wahl nicht annimmt, so muss er sofort eine Strafe von fünf Gulden an die Armenkasse zahlen.

5 Bei der jährlichen Wahl der Ehrenämter der letzten und ersten Toralesung ${ }^{5}$ soll folgendermaßen verfahren werde: Alle Namen von geeigneten, also gut beleumundeten Leuten sollen in ein Gefäß gelegt werden und von diesen sollen zwei herausgezogen werden, um die Ehrenämter zu erhalten. Wenn jemand diese Ehrenämter nicht annehmen will, muss er drei Gulden Strafe an die Armenkasse zahlen. Statt seiner soll ein anderer gezogen werden und sollte auch dieser ablehnen, so muss er ebenso drei Gulden Strafen an die Armenkasse zahlen. Daraufhin sollen die parnasim oder gabba'im andere nach ihrem Ermessen bestimmen. Sollten auch diese von den parnasim Bestimmten ablehnen, so müssen auch sie die oben erwähnte Strafe zahlen.

6 Wenn sich jemand in die Gemeinde einkaufen will, muss er wenigstens fünf Gulden Einzugsgeld entrichten; einen zusätzlichen Betrag zu zahlen ist ihm freigestellt. Derselbe muss die Statuten einhalten und auch die, die zukünftig erlassen werden sollten.

7 Wenn ein Kind eines Hausherrn Bar Mizwa wird, so muss der Vater des Kindes oder einer der Verwandten des Kindes von den parnasim ver-

3 Die Passage in Anführungszeichen könnte vielleicht ein Zitat aus den genannten Amsterdamer Statuten sein.

4 Eine klare Festlegung der Ämterbezeichnung hatte es offenbar beim Verfassen der Statuten noch nicht gegeben.

5 Innerhalb des jährlichen Lesezyklus. 
pflichtet werden, segen $^{6}$ zu sein. Die Gebühr für den ba'al segen ist ein Viertel Reichstaler für die Armenkasse.

[fol. 2 v leer

fol. $3 \mathrm{r}$ ]

8 Alle jung verheirateten Männer, die in unsere Gemeinde kommen [um hier zu wohnen], müssen ein Viertel von Hundert von ihrer Mitgift an die Armenkasse entrichten.

9 Wenn jemand längere Zeit, ein Jahr oder länger nicht in der Synagoge erscheinen sollte, muss ihm der Platz in der Synagoge erhalten bleiben, solange er sein Platzgeld oder andere Gemeindesteuern entrichtet hat, und darf nicht anderweitig vergeben werden.

10 Sollten Auseinandersetzungen oder Streit wegen Gemeinde- oder Synagogenangelegenheiten zwischen Hausherren aufkommen, so müssen sie durch die parnasim oder gabba'im mit drei weiteren Hausherren geschlichtet werden. Diese drei sollen durch Zufall aus dem Gefäß bestimmt werden, wie oben beschrieben ist. Wenn ein parnas oder gabbai eine Auseinandersetzung mit einem Mitglied hat, so soll der parnas durch den anderen vertreten werden, um die Auseinandersetzung beizulegen.

11 Wenn einer zur Toralesung kommt, so wird immer der erste Segensspruch doppelt gerechnet, soviel auch gespendet wird. Es dürfen nicht mehr als vier Personen in einem Segensspruch eingeschlossen sein. Wenn der Aufgerufene ein Geschenk ankündigt, so hat dieses wenigstens den Wert von vier Stübern zu haben.

12 Wenn der Synagogendiener Ehrenämter versteigert, soll er nicht höher anfangen als bei einem halben Stüber. Er darf das Ehrenamt nicht vergeben bis er gerufen hat: »Zum ersten, zum zweiten, zum dritten.« Sollte der Synagogendiener dies nicht beachten, so wird er beim ersten Mal von den parnasim oder gabba'im bestraft, im wiederholten Fall jedoch verliert er sein Amt.

13 Wenn einer die Mitgliedschaft in Gemeinde und Synagoge aufgeben will, so ist er verpflichtet, versprochene Zuwendungen, das Platzgeld oder sonstige andere Schulden zu zahlen. Wenn er nach längerer Zeit jedoch wieder in die Synagoge kommen will, muss er eine Strafe von zwei Gulden an die Armenkasse zahlen und muss mit dem ihm dann zugewiesenen Platz zufrieden sein.

6 Eigentlich: ba'al segen, Ehrenamt beim Gottesdienst. Der Inhaber verfolgt die Toralesungen und ruft die einzelnen Gemeindemitglieder zur Lesung auf. 
$[$ fol. 3 v leer

fol. $4 \mathrm{r}]$

14 Sollte einer etwas der Armenkasse schuldig sein, was für Schulden es auch seien und ohne Ausnahme, und der gabbai zu ihm kommt um ihn zu mahnen, so muss der Schuldner sofort zahlen. Wenn er nicht sofort zahlen kann, wird ihm Aufschub von vier Wochen gewährt und nicht mehr. Wenn er immer noch nicht zahlen will, soll er durch die parnasim oder gabba'im sofort und unmittelbar gepfändet werden.

15 Für jede Beerdigung auf dem Friedhof müssen bei jedem Verstorbenen von 13 Jahren an drei Gulden an die Armenkasse gezahlt werden und unter 13 Jahren müssen zwei Gulden an die Armenkasse entrichtet werden. Sollte sich jemand bei den parnasim oder gabba'im beklagen, dass er nicht zahlen könne, so soll er durch die parnasim oder gabba'im und drei weitere Hausherren eingeschätzt werden, wie viel Beerdigungsgeld er geben soll. Personen, die nicht zur Gemeinde gehören und diese nicht unterstützen, sollen durch die parnasim und drei weitere Hausherren, die Mitglieder sind, nach deren Gutdünken eingeschätzt werden. Jedoch sollen sie nicht mit mehr als 25 Gulden belangt werden. Im Übrigen gelten dieselben Regeln wie bei denen, die von den portugiesischen Juden begraben werden.

16 Für den Fall, dass die parnasim oder gabba'im jemanden bannen wollen, so dürfen sie den Bann nicht ohne Vorwissen von Levy und Pinto verhängen, die als Verantwortliche oben erwähnt sind. Und wenn die Genannten mit den parnasim übereinstimmen und denselben bannen wollen, so soll dieser Bann ausgesprochen, durchgesetzt und für gut befunden werden. Jedoch wenn sie sich nicht einigen können, soll durch die Obrigkeit, ihre Pracht sei erhaben, geurteilt werden, indem diese sich an die aschkenasischen parnasim in der heiligen Gemeinde Amsterdam wendet. Wenn die parnasim von Amsterdam den Bann als rechtmäßig anerkennen, soll dieser gültig sein.

[fol. 4 v leer

fol. $5 \mathrm{r}$ ]

17 Wenn Chajim Boas ${ }^{7}$ oder jemand anderes vor dem Gottesdienst in der Synagoge sein sollte und diese wegen irgendwelcher Einwände zuschließen sollte, so darf dieser seine Autorität so nicht ausnutzen und die Synagoge schließen, bei Strafe von zehn Gulden für die Armenkasse. Vielmehr

7 Chajim Boas war einer der Gründer der aschkenasischen Gemeinde in Den Haag, er war Vater des später ebenso einflussreichen und vermögenden Bankiers Tobias Boas; siehe van Zuiden, Hoogduitsche Joden, 33. 
soll er seine Einwände erst vor die Bürgermeister bringen, um die Angelegenheiten zu untersuchen oder zu entscheiden.

18 Jeder von den aschkenasischen Juden soll sich nach den Statuten richten und diese sollen jährlich in der Synagoge verlesen werden, sodass sich jeder danach richten kann. Sowohl die, die jetzt hier wohnen, als auch die, die sich hier noch niederlassen werden, sind angehalten, all die obigen Statuten einzuhalten. Dieses ist nach eingehender Prüfung genehmigt, zugebilligt und geschehen in der Stube der Bürgermeister in 's Gravenhage, den 24. Januar 1701, 5. Schwat 461 nach der kleinen Zeitrechnung, in Anwesenheit der gegenwärtig hier existierenden aschkenasischen Gemeinde. Die, die noch hierher zu wohnen kommen, müssen sich ebenfalls danach richten. Unterzeichnet vom Herrn Sekretär Antonis de Veer. 


\section{Neuzedlisch $(1755,1789-1849)$}

[fol. $2 \mathrm{r}$ ]

Diese Worte sind Sprüche der Reinheit für die folgenden Generationen, rechtschaffen und [für jeden] verständlich zusammengetragen, allgemeine und detaillierte Statuten, erstellt für die heilige Gemeinde Neuzedlisch, Gott schütze sie:

Punkt 1, Der Anfang der Dinge ist die Gottesfurcht

Wir befinden uns in deiner großen Gnade und der Verheißung deines Hauses, des schönen und heiligen Gebäudes, der Synagoge. Der allgemeine Brauch ist ebenso bedeutsam wie der der Synagoge. Ein jeder, der in seinem Haus ist, soll sich eilen und schnell zur Synagoge kommen, auf dass das tägliche Opfer nicht in seiner Ordnung unterbrochen und die Gesetze weiter praktiziert werden. Wer aber in seinem Haus ist und nicht zur Synagoge kommt, wird mit 18 Pfennigen bestraft, das sind vier Kreuzer, und sie kommen in die Kasse des Vorstands, Gott schütze ihn. Bei Zwangssituationen wird die Strafe nicht verhängt. Niemand ist berechtigt, in seinem Haus einen Privatgottesdienst abzuhalten, außer bei nachweisbaren und schweren Zwangssituationen. Auch dann soll er den Privatgottesdienst nicht vor dem in der Synagoge beginnen. Man soll mit dem Gebet nicht vor dem Vorsänger in der Synagoge beginnen und keiner soll zum Privatgottesdienst gehen, nur diejenigen, die dorthin geschickt wurden und namentlich dazu aufgerufen wurden. Es sollen nur zehn sein und nicht mehr und keiner außer den zehn soll zum Privatgottesdienst gehen, sondern nur in die Synagoge. In der Synagoge sollen keine nichtigen Dinge geredet werden, wenigstens nicht in der Zeit von Barukh she-Amar bis nach den 18 Segnungen und dem Abschluss des Gottesdienstes, d.h. bis nach dem Kaddisch Yatom von Alenu, ${ }^{1}$ bei Strafe von 18 Pfennigen an die Kasse des Vorstands, Gott schütze ihn. Von Beginn des Monats Ijjar bis zum Beginn von Cheschwan soll zwischen dem Nachmittags- und Abendgottesdienst ${ }^{2}$ Psalm 119 gesprochen werden und der Abendgottesdienst soll zu seiner Zeit in der Synagoge von Pessach bis zum Beginn des Monats Cheschwan stattfinden. So soll es in jedem Jahr wie ein Gesetz beachtet werden und nicht davon abgewichen werden.

1 Darin sind die zentralen Teile des Morgengottesdienstes enthalten.

2 Diese beiden wurden oft aufeinander folgend abgehalten. 


\section{Punkt 2}

Nach ihren ${ }^{3}$ Gesetzen sollt ihr nicht wandeln und zu ihren Behörden nicht gehen, sei es wegen Streit und Zank, einer Gerichtssache oder wegen anderer Dinge, ohne Ausnahme, was es auch sei. Es soll sich keiner unterstehen, ohne Erlaubnis des Gemeindevorstehers, Gott schütze ihn, zu den [christlichen] Behörden zu gehen. Sollte dies irgendjemand übertreten und dennoch gehen, so soll er mit einer Strafe von drei Speziestalern bestraft werden, jeweils zu einem Drittel zugunsten unserer frommen Königin, ihre Pracht sei erhaben, ${ }^{4}$ der Fiol-Kasse ${ }^{5}$ und unseren Herren von der Obrigkeit, ihre Pracht sei erhaben. Den Häuptern der Gemeinde ist freie Hand gegeben um alle möglichen Zwangsmittel anzuwenden und niemandem aus der Gemeinde ist es gestattet, dagegen zu protestieren. Wenn es, behüte!, einen Streit oder eine Gerichtssache zwischen zwei Männern aus unserer Gemeinde, Gott schütze sie, geben sollte, so wird für diesen Fall festgelegt: Zuerst sollen sie es dem Richter, der in jenen Tagen amtieren wird, vorlegen, und dies ist der Vorsteher der Gemeinde, Gott schütze ihn. Sollte dieser die Sache nicht beilegen können, so sollen die Kontrahenten vor den Vorstand unter Hinzuziehung der ne'emanim ${ }^{6}$ der Gemeinde, Gott schütze sie, gerufen werden. Kann auch der Vorstand die Sache nicht zu einem Vergleich bringen, so kann dieser Anweisung geben, die Angelegenheit nach den Regeln der Tora innerhalb von 30 Tagen vor ein rabbinisches Gericht zu bringen, dem sich beide Kontrahenten unterwerfen wollen. [fol. $2 \mathrm{v}$ ] Sollte einer von ihnen ein widerspenstiger Mann sein, wegen dem die Sache nicht zustande kommt, so hat der Vorsteher der Gemeinde das Recht, dem rabbinischen Gericht zu gestatten, gegen den Widerspenstigen die Behörden anzurufen. Ausdrücklich wird bestimmt, dass jeder von den Gemeindemitgliedern, der prozessieren will, einen Betrag von 35 Kreuzern an den Vorstand, Gott schütze ihn, zahlen muss, der diesen Betrag in seine Kasse legt. Ein Fremder, der nicht aus unserer Gemeinde stammt, aber vom Vorstand, Gott schütze ihn, eine Verhandlung erbittet, soll ein Schock an die Kasse des Vorstands, Gott schütze ihn, zahlen. Diese Gelder müssen jedes Mal entrichtet werden, bevor die Aussagen und Forderungen vorgebracht werden. Für den Fall, dass der Vorsteher von der Obrigkeit eingesetzt wurde, soll ein weiterer Vorsteher durch die Mehrheit des Vorstands, Gott schütze in, bestimmt werden. Dieser vom Vorstand so bestimmte Vorsteher soll zum Verhängen von Urteilen ermächtigt werden. Jedes Mal, wenn die Gemeinde einen neuen Vorstand wählt, sollen die bis dahin amtierenden

3 D.h. der Nichtjuden.

4 Gemeint ist Maria Theresia.

5 Offenbar ein spezieller Fond für Einnahmen aus jüdischen Quellen.

6 Eine Art Notar. 
Vorsteher und gabba'im der Gemeinde bis zum Ende der dabei fälligen Steuerveranlagung abgesetzt werden. Nach der Wahl ist es in der Hand des Vorstands zu entscheiden, ob der vorige Vorsteher und gabbai weiter amtieren, oder ob die Ämter durch Wahl neu besetzt werden sollen. Wenn ein angesehener Gast kommt, für dessen Beherbergung ohne pleten ${ }^{7}$ der Vorsteher zuständig ist, ist Folgendes vorgesehen: An Wochentagen sollen dem Vorsteher für einen solchen Gast zwei pleten gutgeschrieben werden, jedoch am Schabbat und an Feiertagen soll es nicht mehr als eine sein.

\section{Punkt 3}

Der Verantwortliche für die Unterstützung Mittelloser ist der Armenpfleger. ${ }^{8}$ Ferner ist nur er und kein anderer berechtigt, in allen Angelegenheiten der Synagoge zu entscheiden, und er kann ohne Wissen des Vorstehers Strafen von bis zu 30 Kreuzern auferlegen. Er kann auch Pfänder bis zum Wert von zwei Gulden fordern. Einem als Gast hier weilenden Vorsänger kann er gestatten, die Gebete vorzutragen und einem Prediger kann er das öffentliche Predigen in der Synagoge erlauben. Nur im Fall, dass sich Gäste wegen einer Hochzeit, einer Beschneidung oder ähnlichem in der Gemeinde befinden, weswegen der hiesige Vorsänger aufgrund der Ehrung anderer eine Einbuße haben könnte, darf der Armenpfleger einem Gast das Vorbeten verbieten, ohne den hiesigen Vorsänger vorher deswegen zu fragen. Jeder Hausherr aus unserer Gemeinde muss seinen Gast wie folgt unterstützen: Ein verheirateter Gast erhält einen Kreuzer und weiter auch eine Frau, ein Jugendlicher bis hin zum Säugling, erhalten alle einen Kreuzer. Da auch für einen Säugling pleten gegeben werden, muss ihm auch das Abfertigungsgeld ${ }^{9}$ gegeben werden. Wenn sich ein Gast beim Armenpfleger wegen des Hausherrn, bei dem er war, wegen des Abfertigungsgeldes beschweren sollte, so ist der Armenpfleger berechtigt, diesen Hausherrn nach seinem Gutdünken zu bestrafen.

\section{Punkt 4}

Wir haben den Weg des Glaubens erwählt um das Gute in Israel zu erhalten und es gibt nichts Besseres als die Tora, die sich durch die, die sie studieren, über alles erhebt. Aus diesem Grund wurde bezüglich der Honorars für den Lehrer und seines Wertes Folgendes festgelegt: Der Wert des Lehrerhonorars setzt sich aus drei gleichen Teilen zusammen: ein Teil gemäß der Steuerveranlagung für die Gemeinde, ein Teil aus der Haussteuer und der dritte Teil nach den Lektionen für die Kinder. Sollte einer, wer es auch sei, seine Kinder

7 Verpflegungsschein.

8 Gleichzeitig auch Kassenwart.

9 Ein geringes Handgeld für die Weiterreise. 
zum Lernen nicht zum Gemeindelehrer schicken, sondern sie zu einem anderen Lehrer in unserer Gemeinde geben wollen oder sich gar einen privat im Haus hält, egal, wer es ist, so ist er durchaus nicht gezwungen, die Kinder zum Gemeindelehrer zu schicken. Jedoch muss er jedes Mal, [fol. $3 \mathrm{r}$ ] wenn er ein Kind zu einem anderen Lehrer gibt, an den Vorstand die Hälfte vom üblichen Honorar entrichten. So muss er zum Beispiel für den Fall, dass er für den Gemeindelehrer einen Gulden zahlen, sein Kind aber zu einem andren Lehrer gibt, jetzt einen halben Gulden geben. Dies wird nach dem Anteil der Lektionen berechnet, und jedes Mal soll es so gerechnet werden, dass er die Hälfte von dem, was er zahlen müsste, geben soll. Der Fehlbetrag soll wiederum, wie oben erwähnt, anteilig nach der Steuerveranlagung und der Haussteuer errechnet werden. Für ein Kind, das das Alphabet erlernt, muss für die ganze erste Zeit bezahlt werden, selbst, wenn diese schon fast vorüber ist. Für die erste Zeit im Bibelunterricht muss der Vater dennoch nicht mehr als das halbe Honorar entrichten. Vom Anfang an jedoch muss er wie für ein anderes Kind voll bezahlen. Jedes Mal, wenn mit Wissen des Vorstands ein Lehrer angestellt werden muss, aber kein Kind zu ihm gegeben wird, wird das Honorar je zur Hälfte nach der Steuerveranlagung in der Gemeinde und nach der Haussteuer errechnet. Wenn ein Kind aus einem anderen Ort zum Gemeindelehrer geschickt werden sollte, damit es bei ihm lerne, muss der Vater dem Vorstand einen Gulden und 30 Kreuzer für ein Kind geben, und dieses Geld wird von den drei erwähnten Teilen abgezogen.

\section{Punkt 5}

Jeder Mann soll in der Reihenfolge des Alters einen Monat, 30 Tage lang, se$g e n^{10}$ für die Toralesung in der Synagoge sein. Wenn in einem Monat der Monatsbeginn zwei Tage lang begangen wird, werden die beiden Tage zwischen dem amtierenden und dem neuen segen aufgeteilt. Wer das Amt einem anderen übergeben hat, muss zur ersten Lesung in der Tora aufgerufen werden, sobald er wieder anwesend ist. Wenn er nicht anwesend ist, soll diese Lesung von den anderen Aufgerufenen aufgespart werden bis zu einem anderen Tag, sei es in der Woche oder am Schabbat, wie z.B. bei der Gelegenheit einer Jahrzeit, Beschneidung oder Hochzeit. Sollte es unmöglich sein, den segen aufzurufen, so soll dies bis zur nächsten Lesung danach verschoben werden. Wer ein freudiges Gebot erfüllt und Hochzeit oder Beschneidung feiert oder sein Sohn Bar Mizwa wird, sei es in der Woche, am Schabbat oder an einem Feiertag, und er eine Torarolle besitzt, so ist er verpflichtet diese auszuheben, sogar als erste Aushebung. Umso mehr gilt dies auch beim Besitz von liturgischer Kleidung.

10 Der den Gottesdienst leitende Mann, der auch die Aufrufe zur Toralesung regelt. 


\section{Punkt 6}

Gesegnet sei Gott, der uns beraten hat. Bei den Gebeten an den Hohen Feiertagen und beim Blasen des Widderhorns an denselben hat der Vorstand das Recht, in jedem Jahr jemanden nach seinem Gutdünken nach den Regeln des Shulhan Arukh ${ }^{11}$ zu beehren. Jedoch hat niemand irgendwelche Ansprüche weder hinsichtlich der Verteilung der Gebete, noch hinsichtlich des Blasens in das Widderhorn zu stellen, alles liegt ausschließlich jedes Mal beim Vorstand, Gott schütze ihn, und seinem mehrheitlichen Entschluss. Die Gebete an den Hohen Feiertagen sollen vom Vorstand jedes Mal am Ersten des Monats Elul, am Schabbat davor oder danach vergeben werden und so soll es bleiben.

[fol. $3 \mathrm{v}$ ]

\section{Punkt 7}

Wenig hier, wenig dort gelten die jungen Männer in der Gemeinde. Auch die Knechte sind berechtigt, sich während des gesamten Jahres Ehrenämter in der Synagoge zu kaufen, gleich den Hausherren und Beisassen in der Gemeinde, Gott schütze sie. Nur an den Hohen Feiertagen haben sie kein Recht, eine Toralesung in der Synagoge zu bekommen oder sich gegenseitig mit Ehrenämtern zu bedenken. Jedoch haben sie das Recht, Ehrenämter zu erwerben und diese an Hausherren aus der Gemeinde zu geben.

\section{Punkt 8}

Die letzte und die erste Toralesung ${ }^{12}$ werden der Reihe nach dem Alter Jahr für Jahr vergeben. Dies sind die Regeln, die den damit Beehrten vorher dargelegt werden müssen: Der Inhaber der letzten Lesung muss zwei Brassen, zwei Karpfen, einen Laib Brot, Gemüse und 15 Kreuzer als Lohn geben, schließlich ein Viertel Pfund Wachs an die Armenkasse. Der Inhaber [der dann folgenden] ersten Lesung gibt von allem oben Genannten die Hälfte. Wer Maftir ${ }^{13}$ sagt, steuert 4 Kreuzer zur Finanzierung der Mahlzeit bei. Am Schabbat Bereshit ${ }^{14}$ werden alle Ehrenämter in der Synagoge verkündet, wie das Entzün-

11 Religionsgesetzliches Standardwerk, verfasst im 16. Jahrhundert durch Josef Caro in Safed, die Adaption für das aschkenasische Judentum erfolgte durch Moses Isserles aus Krakau kurz darauf.

12 Im einjährigen Lesezyklus, der am Fest der Torafreude (Simhat Tora) beendet und wieder von neuem angefangen wird.

13 Der letzte von sieben Teilen, in die der wöchentlich gelesene Tora-Abschnitt eingeteilt ist; seine Lesung gilt als besonders ehrenvoll. Der Inhaber dieser Lesung übernimmt anschließend auch die Haftara, die traditionelle zusätzliche Lesung aus den Propheten.

14 Der Schabbat, an dem der erste Wochenabschnitt aus der Tora gelesen wird. 
den der Lichter, das Suchen, ${ }^{15}$ und ebenso wird wie gehabt mit den übrigen Ehrenämtern verfahren. Die Festmahlzeit des Inhabers der letzten Lesung muss ohne jegliche Verzögerung an Schabbat Bereshit im Haus des Beehrten wie üblich ausgerichtet werden. An Shmini Azeret ${ }^{16}$ soll der Armenpfleger den Kindern vor dem Nachmittagsgebet Süßigkeiten und Nüsse zuwerfen, die in der Sprache von Aschkenas ${ }^{17}$ rasu genannt werden.

\section{Punkt 9}

Es geziemt einem Mann an einer Last zu tragen, und das ist die Gemeindesteuer. Sie soll jährlich erneuert werden und beträgt einen Gulden, höchstens jedoch zwei Gulden, jeder Gulden zu 15 Batzen. ${ }^{18}$ Jeder Kreuzer wird für zwei pleten gerechnet, eine plete gemäß der Haussteuer und eine nach der Gemeindesteuer. Diese Gemeindesteuer wird durch drei Schätzer festgelegt, die vom Vorstand, Gott schütze ihn, entweder durch Losverfahren oder durch Stimmenmehrheit unter Hinzuziehung des ne'eman gewählt werden. Die Anlage für die Gemeindesteuer wird jährlich zu Chanukka vorgenommen. Wer eine Frau heiratet, sei es am Beginn, in der Mitte oder sogar am Ende des Jahres, muss in diesem Jahr die Hälfte des jährlichen Betrags für die Ausgaben der Gemeinde, entsprechend seiner Anlage, wie die übrigen Mitglieder unserer Gemeinde besteuern. Lediglich bei den pleten bleibt sein Haus für 30 Tage ausgenommen. Die Vorsteher sollen ein Nebenbuch führen, worin die jährliche Gemeindesteuer eingetragen werden soll. Sollten von der Obrigkeit, ihre Pracht sei erhaben, irgendwelche Beschwernisse auf die Gemeinde kommen, was es auch sei, Gewinn oder Verlust - behüte! -, soll dies ebenfalls gemäß der Gemeindesteuer umgelegt werden, wie oben dargelegt. Lediglich das Holz, das dem Vorstand von der Obrigkeit, ihre Pracht sei erhaben, übergeben wird, soll - wie seit alten Zeiten - gleich verteilt werden.

\section{Punkt 10}

Jeder Hausherr aus unserer Gemeinde hat das Recht, ohne Zahlung von Einzugsgeld drei Söhne oder Töchter in unsere Gemeinde als vollberechtigte Mitglieder eintreten zu lassen. Mehr als drei Kinder dürfen nicht eingebracht werden, sei es mit oder ohne Zahlung von Einzugsgeld. [fol. 4 r] Ein fremder Mann, der nicht aus unserer Gemeinde stammt, hat kein Recht in unsere

15 Das Suchen des entsprechenden Abschnitts in der Torarolle.

16 Der Tag nach dem Fest der Torafreude, gleichzeitig das Ende der Feiertagsfolge im Herbst.

17 Jiddisch.

18 Scheidemünze, ein (schwerer) Batzen galt im benachbarten Fränkischen fünf Kreuzer. 
Gemeinde zu ziehen und es wird ihm auch nicht gestattet. Wenn er sich aber direkt bei der Obrigkeit, ihre Pracht sei erhaben, gegen den Willen des Vorstands um das Wohnrecht bemühen sollte, muss der Vorstand alle möglichen Mittel gegen ihn einsetzen. Niemand aus der Gemeinde hat das Recht, seine Mitgliedschaft teilweise oder ganz zu verkaufen. Nur für den Fall, dass einer behüte! - gezwungen ist, aus der Gemeinde wegzuziehen und sein Haus und die Mitgliedschaft zu verkaufen, so ist er berechtigt, mit Zustimmung des Vorstands einem Mitglied aus der Gemeinde das Haus mit der Mitgliedschaft zu verkaufen, aber keinem Fremden, der nicht von hier ist. Jedes Mal hat der Vorstand bis zum letzten Moment durch gerichtlichen Einspruch das Vorkaufsrecht in derartigen Geschäften. Sollte ein Mitglied aus der Gemeinde aus Not gezwungen sein, von hier mit Frau und Kindern für ein Jahr oder länger fortzuziehen - behüte! -, so kann er durch die jährliche Zahlung von einem Gulden rheinisch als Mitgliedsbeitrag sich und seinen Nachkommen das Recht der Mitgliedschaft wahren, so wie die übrigen Einwohner unserer Gemeinde, und wann immer er will, kann er wieder in die Gemeinde ziehen. Wenn er sich aber innerhalb von drei Jahren nicht beim Vorstand melden sollte oder gar fünf Jahre hintereinander mit dem Mitgliedsbeitrag in Rückstand ist und ihn nicht zahlt, so hat er alle Rechte verloren und hat in unserer Gemeinde nichts mehr zu suchen oder von ihr etwas zu erwarten. All dies gilt jedoch nur bei klarer Not bei jenen, die zwangsweise wegziehen mussten - behüte! Sollte es jedoch freiwillig und nicht aus Zwang geschehen und wenn sich einer verbessern möchte, so soll und muss er für die beiden darauf folgenden Jahre bei allen Ausgaben der Gemeinde aufschlüsseln, wie er vom Vorstand, Gott schütze ihn, eingeschätzt wurde und wie er nach seinem Vermögen in den kommenden beiden Jahren beitragen soll. Von da an, d.h. nach zwei Jahren, braucht er auch nur noch jährlich einen Gulden rheinisch Mitgliedsbeitrag zu geben.

Keiner von den Mitgliedern der Gemeinde hat das Recht, einen Fremden, der nicht aus unserer Gemeinde stammt, 30 Tage ohne Vorwissen der Mehrheit des Vorstands zu beherbergen. Über 30 Tage ist dies auch mit Wissen des Vorstands nicht möglich, vielmehr sollen Logiergäste oder fremde Einwohner nicht beherbergt werden und kein Eingeschlichener soll in unserer Gemeinde geduldet werden, bei großer Strafe nach Gutdünken des Vorstands, Gott schütze ihn.

\section{Punkt 11}

Elf Sterne leiteten die heilige Gemeinschaft. Wenn es ledige junge Männer aus Familien der Gemeinde geben sollte, die ein Geschäft betreiben, werden auf sie folgende Regeln angewandt: Wenn sie von ihren Vätern versorgt werden, aber selbst ein Geschäft betreiben, müssen sie zur Gemeindesteuer beitra- 
gen nach Gutdünken des Vorstands, Gott schütze ihn. Umso mehr gilt dies, wenn sie nicht von ihren Vätern versorgt werden, dann müssen sie viel geben, wie ihnen vom Vorstand, Gott schütze ihn, auferlegt wurde. Jeder Hausherr, [fol. $4 \mathrm{v}$ ] der einen Knecht beschäftigen möchte, ist von Steuern für diesen befreit. Auch der Knecht selbst muss nichts geben; beide sind befreit. Wenn der Knecht aber zur Hälfte am Gewinn beteiligt ist oder sei es auf andere Weise, nämlich dass er einen Tag für sich selbst arbeitet und den anderen für seinen Herrn, muss er beim Vorstand nach dessen Gutdünken zur Landessteuer beitragen, solange er dort ist.

\section{Punkt 12}

Zwölf Stämme sollen leben und wir werden nicht sterben. Wenn einer aus der Gemeinde sterben sollte und seine Frau als Witwe und dazu [noch] Waisen hinterlässt, so ist ihre Rechtslage folgende: Wenn die Frau den Betrag aus dem Ehevertrag ${ }^{19}$ vollständig oder teilweise aus der Erbmasse entnehmen kann, soll vom Vorstand, Gott schütze ihn, aufgeführt und anerkannt werden, dass sie Mitglieder verbleiben, wenn sie jährlich etwas entrichten, d.h. zwischen einem und drei Gulden, nach Gutdünken des Vorstands. Falls die Witwe jedoch noch verwaiste Kinder hat und sie über keine Mittel verfügen, jährlich etwas zu geben, soll in folgender Art verfahren werden: Wenn die Söhne mündig werden und die Mitgliedschaft in der Gemeinde erwerben möchten, so müssen die erwähnten Waisen die ausstehenden Gemeindegelder nachzahlen. Jedoch werden diese erst bei Waisen ab 13 Jahren gerechnet, für jedes Jahr einen Gulden rheinisch. Wenn dem Vorstand nach gründlicher Prüfung der Lage scheint, dass sie durchaus mehr geben können, sollen noch 30 Kreuzer mehr veranschlagt werden, also soll er für jedes Jahr einen Gulden und 30 Kreuzer geben. Wenn - behüte! - Vater und Mutter sterben sollten und Waisen hinterlassen oder andere Erben und diese etwas erben sollten, so können sie dieses Erbe nicht eher antreten, als bis sie die ausstehenden Gelder, so wie von der Mehrheit des Vorstands, Gott schütze ihn, festgelegt, entrichtet haben. Und er wird den Tod auf ewig verschlingen. ${ }^{20}$

\section{Punkt 13}

Es gibt 13 Grundsätze und so ist der eine: Wir werden leben und nicht sterben. Sollte - behüte! - einer oder eine aus der Gemeinde sterben, er oder seine Frau oder einer seiner Söhne - behüte! -, so brauchen sie kein Beerdigungsgeld an den Vorstand zu entrichten, nur das, was der Hevra Kaddisha laut deren Buch und Statuten zusteht. Ebenso ist es bei einem Knecht,

19 Der Betrag der von der Frau eingebrachten Mitgift.

20 Jes 25,8 . 
der nichts an Besitz nach seinem Tod hinterlässt, es muss vor allem an die Hevra Kaddisha etwas entrichtet werden und nicht an seine Erben. Sein Herr jedoch und auch die Erben sind von jeglichen Zahlungen ${ }^{21}$ befreit. Wenn er aber etwas hinterlassen sollte, wovon etwas gezahlt werden kann oder noch Lohn von seinem Herren aussteht, so muss sein Herr für ihn ein Pfand einlegen und für den Knecht das Begräbnisgeld an den Vorstand entrichten, wie es durch diesen veranschlagt wurde. Wenn - behüte! - eine Witwe sterben sollte, so sind die Regeln folgende: Wenn sie bis zur ihrem Tod an den Gemeindelasten teilhatte, so braucht für sie kein Begräbnisgeld entrichtet zu werden. Wenn sie jedoch nicht an den Lasten teilhatte, muss etwas gezahlt werden. Umso mehr gilt das, wenn - behüte! - einem seine Schwester oder sein Bruder sterben sollte bzw. weitere Verwandte, die bei ihm lebten und bei ihm gestorben sind; in diesem Fall muss der Verwandte des Verstorbenen für diesen Begräbnisgeld in Form von Geld oder einen Gegenwert zahlen. Wenn er aber nichts hinterlassen hat und noch Steuern von ihm ausstehen, soll vom Vorstand festgelegt werden, ob die Verwandten des Verstorbenen diese bezahlen müssen oder nicht. Auch sei ausdrücklich gesagt, dass bei jeder Sorge - sie möge nicht kommen! - [fol. $5 \mathrm{r}$ ] wie etwa ein Toter, der von einem anderen Ort zu uns gebracht wird, ${ }^{22}$ der Armenpfleger ein Pfand nach Gutdünken des Vorstands, Gott schütze ihn, für diesen verlangen muss und der Armenpfleger dieses Pfand sofort an die Vorsteher übergeben muss, damit es zu ihrer Verfügung steht.

\section{Punkt 14}

Zum Vierzehnten: Die Gemeinde existiert immerdar. In Zeiten der Zusammenkunft des Vorstands wegen irgendeines Anliegens des Vorstands, Gott schütze ihn, komme niemand ohne Überbekleidung in Form eines Rocks, und jedes Mal mit einer Kopfbedeckung ${ }^{23}$ auf dem Haupt eines jeden. Wer dies übertritt und ohne die genannte Kleidung oder ohne Kopfbedeckung geht, wird mit 18 Pfennigen bestraft. In der Zeit ihrer Versammlung sollen $s^{2} e^{24}$ in Liebe, Achtung und Frieden miteinander verkehren. Sie sollen einander nicht fluchen oder geringschätzig reden, auch nicht einander mit abfälligen Namen schimpfen. Wer dies übertritt und seinen Nächsten mit einem dieser Dinge beschämt, wird beim ersten Mal mit 18 Kreuzern zugunsten der Vorstandskasse bestraft und muss seinen Nächsten ehrlich um Verzeihung bitten. Beim wiederholten Mal sollen die Vorsteher denjenigen nach eige-

21 Für die Beisetzung des Knechts.

22 Um ihn hier zu bestatten.

23 Wörtlich: Kopfbedeckung des Heils, nach Jes 59,17.

24 Gemeint sind offenbar die Vorsteher. 
nem Gutdünken richten und bestrafen, in Erfüllung von: Sie werden aufhorchen und sich fürchten. ${ }^{25}$ Der Vorsänger oder der Synagogendiener sollen alle Hausherren zum Gemeindehaus bestellen. Sollten danach die Vorsteher den Vorsänger extra noch einmal zu einem Hausherrn schicken müssen, so muss dieser ein Botengeld von drei Kreuzern an den Vorsänger entrichten, dies auch im Fall eines dritten Mals. Es gilt auch nichts anderes als das, was bereits beschlossen wurde, nämlich dass in der Zeit der Versammlung des Vorstands weder Kurzweil noch Leichtmütigkeit getrieben werden sollen. Auch darf sich keiner ohne Erlaubnis des Vorstands, Gott schütze ihn, von der Versammlung entfernen, und wer dies übertritt, wird nach Gutdünken der Vorsteher, Gott schütze sie, bestraft. Wenn die Vorsteher jemanden auf übliche Weise zur Vorstandsversammlung in die Synagoge bitten lassen, dieser aber woanders hingeht und keine Nachricht in seinem Haus hinterlässt, soll er nach Gutdünken der Vorsteher, Gott schütze sie, bestraft werden. Alles, was beim Vorstand vorgebracht wird, soll durch die Mehrheit des Vorstands, Gott schütze ihn, beschlossen werden, wobei die Mehrheit der Anwesenden ausreichend ist. Die einzelnen Meinungen sollen nach der Reihenfolge des Alters vorgebracht werden und all dies ist gültig.

\section{Punkt 15}

Zum Fünfzehnten wird die Lesung in der Schrift ${ }^{26}$ nach dem Alter vorgenommen, immer nach der Reihenfolge des Alters. Ein Hausherr kann einen anderen statt seiner nur dann bestellen, wenn dieser zum Aufruf verpflichtet ist und nur am zweiten Tag des Wochenfestes und am zweiten Tag von Neujahr, jeweils nach allen anderen, kann einer in der Synagoge so zur Tora aufgerufen werden. ${ }^{27}$ Der Vorsänger soll für den Aufgerufenen zwei Segenssprüche sprechen. Wer ein Ehrenamt durch ein Gelöbnis gekauft hat, soll noch einen Segensspruch allein sprechen. Wer am 9. $\mathrm{Aw}^{28} \mathrm{im}$ Morgengottesdienst zur Toralesung aufgerufen wird, muss auch am Nachmittag noch einmal aufgerufen werden und kann zwei Segenssprüche sprechen, und so hat der Herr diesen Tag von Trauer in Freude verwandelt.

\section{Punkt 16}

Sechzehn allgemeine und spezielle Regeln wurden erlassen. Wer eine Patenschaft innehat, die "Gevatterschaft" genannt wird, und aus der Gemeinde kommt, gibt dafür 20 Batzen. Ein [fol. 5 v] Fremder, der nicht aus unserer

25 Dtn 21,21.

26 Gemeint ist die Tora.

27 D.h. außer der Reihe.

28 Der Gedenktag der zweimaligen Tempelzerstörung in der Antike an diesem Datum. 
Gemeinde stammt und eine Gevatterschaft hier hat, gibt dafür 30 Kreuzer. Einer aus der Gemeinde, der Brautführer in unserer Gemeinde wird, muss, wie jeder andere, 30 Kreuzer geben. Wenn der Brautführer nicht aus unserer Gemeinde stammt, gibt er 35 Kreuzer. Der Pate soll den Kindern in der Synagoge vor der Beschneidung Süßigkeiten wie Zucker oder Mandeln zuwerfen. Darüber hinaus hat einer aus der Gemeinde, der eine Brautführerschaft in unserer Gemeinde hatte, das Amt des segen am Schabbat nach der Hochzeit, und muss dafür 14 Kreuzer an die Armenkasse geben. Einer, der nicht aus der Gemeinde ist, hier aber eine Brautführerschaft hat, muss, unabhängig davon, ob er am Schabbat nach der Hochzeit hier ist oder nicht, für den segen 15 Kreuzer zahlen. Der Vater eines neugeborenen Knaben, der am Schabbat vom Kindbett in die Synagoge kommt, hat das Vorrecht auf den segen an diesem Schabbat und der Vorsänger soll die Ehrenämter zu sechs Groschen ausrufen. Dem Vater kommen das Amt des segen, Aus- und Einhebung der Torarolle, Maftir, Erhebung der Torarolle und das Öffnen des Toraschreins $\mathrm{zu}$, auch das Sprechen der Zmirot, ${ }^{29}$ allerdings nur am Schabbat, an dem es nur eine Torarolle gibt. Wenn es einmal zwei Torarollen an einem Schabbat geben sollte, so gehören ihm nur die genannten Ehrenämter in Hinsicht auf die erste Torarolle und nicht mehr. Wenn der Inhaber des segen der Vater eines neugeborenen Knaben ist, hat er kein Recht, mehr Lesungen zur Tora zuzulassen, als an einem anderen Schabbat; der Vater ist einer der zum Aufruf verpflichteten und muss sich selbst aufrufen. Er ist verpflichtet für den Knaben ein Viertel Pfund Wachs für die Armenkasse zu geloben und dieses soll er im Segensspruch für das Kind geloben. Wenn an einem Schabbat eine Beschneidung stattfindet, ist die Regel gleichermaßen. Jedoch hat der Vater des zu beschneidenden Knaben das Recht, nach dem Gesetz und wie es ihm beliebt, noch mehr hinzuzufügen. ${ }^{30}$ Umso mehr werden am Schabbat nach einer Hochzeit noch weitere hinzugefügt. Wenn sich die Beschneidung an einem Montag oder Donnerstag ereignen sollte oder einem anderen Tag, an dem aus der Tora gelesen wird, hat der Vater des Kindes keinerlei Ansprüche und hat nur die Ehrenämter, die er gekauft hat, nicht jedoch das des segen. Ausdrücklich wird gesagt, dass die Wöchnerin nicht an einem Feiertag aus dem Kindbett gehen soll, andernfalls gehört das Amt des segen dem turnusgemäß Amtierenden und nicht dem Vater des Kindes. Nur wenn der Feiertag auf einen Schabbat fällt, darf sie das Kindbett wie üblich verlassen.

29 Liturgische Dichtungen.

30 Gemeint sind offenbar Aufrufe zur Toralesung. 


\section{Punkt 17}

Das Gesetz Gottes ist mir lieb und er richtete ein Zeugnis auf in Jakob und gab ein Gesetz in Israel. Daher wird dem Vorsänger oder dem Lehrer anbefohlen, an jedem Schabbat vor dem Nachmittagsgebet eine regelmäBige Lektion mit der Gemeinschaft zu lernen, entweder in der Synagoge oder an einem Platz, der vom Vorstand, Gott schütze ihn, dazu bestimmt wurde.

\section{Punkt 18}

Achtzehn Dinge wurden an einem Tag entschieden. Wer sein Haus verkaufen möchte, muss dieses durch den Vorsänger in der Synagoge an drei aufeinander folgenden Schabbatot, jedes Mal [fol. 6 r] nach dem Nachmittagsgebet, verkünden lassen. Wer seinen Platz in der Synagoge verkaufen möchte, sei es in der Männer- oder Frauenabteilung, muss dieses, wie erwähnt, drei Mal verkünden lassen, und für die dreimalige Ausrufung soll der Verkäufer dem Vorsänger 15 Kreuzer zahlen. Das Vorkaufsrecht hat jedes Mal der Vorstand, wenn er durch gerichtliche Verfügung den Erwerb tätigen will. ${ }^{31}$

Die Festlegung und der Brauch bezüglich der Einnahmen, die dem Vorsänger bzw. Lehrer zukommen, sind so, dass er für das Schreiben des ersten Verlobungsvertrags 20 Batzen erhält. Für den letzten Verlobungsvertrag ebenfalls 20 Batzen und für eine Urkunde über die Befreiung von der Leviratsehe ${ }^{32}$ sowie für eine Urkunde über den halben Anteil eines männlichen $\operatorname{Erbes}^{33}$ so viel wie oben gesagt. Für einen Ehevertrag 30 Kreuzer und für die Aufstellung des Traubaldachins 15 Kreuzer, für jede geschäftliche Übereinkunft sieben Kreuzer, so seien ihre Konditionen bei Beurkundungen für Mitglieder der Gemeinde, Gott schütze sie. Selbst wenn jemand eine Ehe außerhalb der Gemeinde anbahnt und den Lehrer seiner Gemeinde für das Schreiben nicht mitnimmt, sondern dies selbst tut, so ist er dazu nicht berechtigt, sondern

31 Offenbar in Fällen, in denen der Verkäufer der Gemeinde Abgaben schuldete, die dann durch die faktische Pfändung ausgeglichen wurden.

32 Nach biblischem Gesetz muss der Bruder eines verstorbenen Mannes dessen Witwe ehelichen; lehnt er die Leviratsehe ab, wird er zum Ritual der haliza (er zieht der Witwe einen Schuh aus) gezwungen - Witwe und Schwager sind danach frei, anderweitig zu heiraten. Seit der Antike wurden halachische Wege gesucht, um das Ritual der ḩaliza zu vereinfachen; im Mittelalter war es unter den aschkenasischen Juden die Regel (um die dadurch im Prinzip mögliche Polygamie zu verhindern) und wurde durch eine gerichtliche Prozedur ersetzt.

33 Eine Urkunde, die der Vater einer Braut bei deren Eheschließung übergibt, worin festgelegt wird, dass sie die Hälfte des Erbteils eines ihrer Brüder erhalten soll. Nach jüdischem Recht sind andernfalls verheiratete Töchter vom Erbe ausgeschlossen. 
muss dem Lehrer seiner Gemeinde für jede Urkunde und geschäftliche Übereinkunft wie oben erwähnt etwas zahlen. Selbst wenn er den Vorsänger oder Lehrer seiner Gemeinde hierher in unsere Gemeinde mitbringt, muss er dennoch an den Vorsänger oder Lehrer unserer Gemeinde die obigen Gebühren entrichten. Für einen vom Vorsänger gefundenen Schreibfehler in einer Torarolle, der dazu führt, dass man eine andere Torarolle ausheben muss, erhält der Vorsänger sieben Kreuzer und er muss diesen Fehler korrigieren. Für das Vorladen einer Person aus unserer Gemeinde soll der Lehrer einen Kreuzer erhalten und für das Vorladen eines Gastes zwei Kreuzer. Für das Vortragen von Ehad Yahid ${ }^{34}$ vor oder nach der Hochzeit erhält der Vorsänger von einem Bräutigam aus unserer Gemeinde sieben Kreuzer. Für eine gerade Entbundene erhält der Vorsänger anlässlich der Erwähnung ihres ersten Ausgangs aus dem Haus sieben Kreuzer. Für eine Predigt am Schabbat vor Pessach und am ersten Schabbat nach Neujahr erhalten der more zedek ${ }^{35}$ oder der Lehrer jedes Mal 20 Batzen. Für die Lesung der Rolle ${ }^{36}$ erhält der Lehrer 20 Batzen und der Vorsänger wird mit dem Einrollen beehrt.

Weiter wird festgelegt, das sowohl für einen Bräutigam aus der Gemeinde wie für einen, der nicht aus der Gemeinde stammt, die jungen Männer das Ehrenamt des Einrollens der Torarolle kaufen können, sei es in der Woche, am Schabbat oder an einem Feiertag, und die jungen Männer müssen an die Armenkasse jedes Mal dafür vier Kreuzer entrichten. Für das Annehmen des Gebetmantels, den die Armenpfleger ${ }^{37}$ vom Bräutigam am Schabbat nach der Hochzeit in der Synagoge nach Abschluss des Gottesdienstes bekommen, muss der Bräutigam vier Kreuzer an die Armenkasse entrichten. Für das Segnen eines Kranken - behüte! - in der Synagoge, das benshen ${ }^{38}$ genannt wird, erhalten die Armenkasse zehn und der Lehrer sieben Kreuzer.

Bezüglich des Betriebs der Mühlen an Pessach wird Folgendes festgelegt: Jedes Jahr gehen drei Hausherren ohne den gabbai und nur mit dem Lehrer [in die vertraglich gebundenen Mühlen zur Herstellung des Pessachmehls], und so soll es jedes Jahr erneut gehalten sein.

Dies ist nichts Verlorenes, sondern etwas Vergessenes, und es wird geendet mit dem Gebot: Ihr soll am ersten Tag Früchte nehmen von den

34 Eine liturgische Dichtung, die bei Aufruf eines Bräutigams zur Toralesung vorgetragen wird.

35 Eine in der Tradition gut gebildete Person, manchmal auch Bezeichnung für den Rabbiner.

36 Gemeint ist die Lesung des Buches Ester am Purimfest.

37 Hier in der Pluralform genannt.

38 Jiddisches Wort für segnen. 
Zitrusbäumen, ${ }^{39}$ und das ist der Etrog. ${ }^{40}$ Die Rechnung für den Etrog soll so aufgestellt werden, dass der Beitrag zu zwei Teilen nach der Gemeindesteuer und zu einem Teil nach der Haussteuer berechnet wird und nicht anders.

So sind die 18 Punkte und so sollen sie getreulich eingehalten werden laut der Vorrede im pinkas des Vorstands, Gott schütze ihn, und durch Unterschrift der Befehlshaber des heiligen Vorstands, Gott schütze ihn, die namentlich genannt sind. Falls weiter die eine oder andere der guten Bestimmungen verbessert werden sollten, soll diese jedes Mal mit Wissen der Mehrheit des Vorstands eingeschrieben werden, weshalb auch fünf Blätter zwischen den takkanot und den Unterschriften frei bleiben, damit hier weiter eingeschrieben werden kann. [fol. $6 \mathrm{v}$ ] Ausdrücklich wird bestimmt, dass jedes Mal unter den erneuerten Bestimmungen von den Vorstehern und dem ne'eman der Gemeinde die eigenhändigen Unterschriften geleistet werden sollen, damit nicht der Verdacht aufkommt, dass eine Sache oder auch nur eine halbe Sache gefälscht seien. Vielmehr soll alles mit Wahrheit und Ehrlichkeit geschehen und das Beendete sei gesegnet und sei dem göttlichen Gesetz für uns genehm, der Segen sei in unserer Abgrenzung verstärkt und Seine große Gnade sei immer über uns. Er schicke uns einen Erlöser für unsere Rettung und der wird Zion als Heim unserer Herrlichkeit errichten, bald auch Jerusalem, die Heilige Stadt, in unseren Tagen. Geschehen und abgeschlossen am dritten Tag, ${ }^{41}$ an dem »Und es war gut « verdoppelt wurde. ${ }^{42} 27$. Nissan nach der Ordnung und der Rechnung, so sei es zur Erinnerung im Buch geschrieben, nach der kleinen Zeitrechnung, ${ }^{43}$ Neu Zedlisch.

Dies ist nichts Verlorenes, sondern etwas Vergessenes, deswegen sind wir bei der Begutachtung des Wissens auf das gestoßen, was im Punkt 6 vergessen wurde wegen der zum Aufruf Verpflichteten, und so wird, da es nur ein Versehen beim Schreiben war, am selben Tag festgelegt: Wenn einer der Hausherrn

39 Lev 23,40.

40 Der Etrog, eine zitronenähnliche Frucht, ist Bestandteil des Feststraußes beim Laubhüttenfest. In der Entstehungszeit der takkanot gelangten jeweils nur wenige Exemplare des Etrog, einer in Europa nördlich der Alpen nicht heimischen Frucht, in eine Gemeinde und wurden für hohe Summen verkauft.

41 Dienstag.

42 In Anspielung auf die Schöpfungsgeschichte in Gen 1,9-13.

43 In dieser Wortgruppe wurden einzelne Buchstaben stark hervorgehoben, um die Jahreszahl 515 nach der kleinen Zeitrechnung darzustellen, Dies entspricht 1755 IV 8. 
das musaf ${ }^{44}$ an Neujahr oder dem Versöhnungstag, das Taugebet ${ }^{45}$ oder das Regengebet ${ }^{46}$ unentgeltlich spricht, ist er am selben Tag zur Toralesung im Morgengottesdienst verpflichtet. Wenn der amtierende Vorsänger betet, das heißt der Lehrer oder der Hazan der Gemeinde, liegt es in der Hand des segen die Aufrufe zu vergeben, aber es bleiben die zur Lesung Verpflichteten gemäß der Regel.

Bezüglich Punkt 9, wegen der Gemeindesteuern, ist es so: Jeder Kreuzer macht zwei pleten aus, abgesehen von der Haussteuer wird eine plete ab [...] gehalten für jeden einzelnen Hausherrn und so soll es sein.

Dies ist eine Sache, die auf den vorigen Seiten bei den Regeln für die Torarolle im Punkt 16 vergessen wurde und sie ist folgendermaßen: Eine weitere Torarolle soll jedes Mal, wenn am heiligen Schabbat zwei Rollen ausgehoben werden, wie die erste Torarolle ausgerufen werden und im Fall, dass sich daraufhin jemand für sich selbst oder zu Ehren eines anderen Ehrenämter erwirbt, soll es folgendermaßen gehalten werden: Der Ausheber nehme die erste Rolle aus dem Schrein und nach ihm soll der andere Ausheber selbst die zweite Rolle aus der heiligen Lade ausheben. Auch soll er sie bis zum Ende der Lesung halten und keinen anderen damit beauftragen. Dies wurde gemacht, um die die Ehrenämter der Torarollen zu würdigen, jedoch höchstens bei zwei Rollen und so soll es sein.

\section{Punkt 19}

Auch dies wurde nicht verändert sondern ist eine Angelegenheit, die auf einer Versammlung der Mehrheit des Vorstands, Gott schütze ihn, erneuert wurde, wonach jedes Mal, wenn die Gemeindesteuer durch die Schätzer neu festgelegt wird, [fol. $7 \mathrm{r}$ ] diese sofort eine Anlage machen sollen, wie viel jeder einzelne Hausherr wöchentlich, an jedem Vorabend eines Schabbat, an die Armenkasse zu zahlen verpflichtet ist. Diese werden Wochengelder genannt. Ein Armer soll nicht weniger als einen halben Kreuzer geben und ein Reicher soll nach seinem Vermögen geben und nach der Anlage, die ihm durch die genannten Schätzer gemacht wird. Solche Wochengelder sind mit den

44 Ein Gebet im Morgengottesdienst, das jedoch nur zusätzlich an den Tagen gesprochen wird, an denen im antiken Tempel ein zusätzliches Opfer dargebracht wurde, also an den Schabbatot und an den Feiertagen, den Zwischentagen und den Monatsersten.

45 Teil des Musaf am ersten Tag von Pessach.

46 Teil des Musaf an Shmini Azeret, dem Ausgang des Festes der Torafreude. 
Mizwotgeldern, ${ }^{47}$ die auf dem Legbrett erscheinen, zu verrechnen. D.h. jedes Jahr, wenn das Legbrett zur Feststellung von dem, was jeder gegeben hat, abgerechnet wird, wird die Hälfte von dem, was das Legbett ausweist, dem Schuldner erlassen und bezüglich der anderen Hälfte wird folgendermaßen verfahren: Wenn die ausgewiesene Schuld höher ist als die noch ausstehenden Armengelder, das sind die erwähnten Wochengelder, muss der Hausherr, wer es auch sei, die Differenz nachzahlen. Sollte es aber so sein, dass er von der Armenkasse etwas zu fordern hätte, weil er weniger gekauft hat, als seine Wochengelder betragen, so soll ihm die Armenkasse alles erlassen, jedoch nichts auszahlen.

\section{Punkt 20}

Weiter wird festgelegt, dass wenn eine Beschneidung in der Gemeinde stattfindet, der Armenpfleger alle Lichter, die Leuchter genannt werden, aus den Kerzen der Armenkasse entzünden soll und sie sollen bis nach der heiligen Beschneidung brennen. Dafür soll ihm der Vater des zu beschneidenden Kindes für die Armenkasse ein Pfund Kerzen geben. Wenn aber der erwähnte Vater lieber eigene Kerzen entzünden möchte, so steht ihm das frei und er braucht nichts an die Armenkasse zu zahlen. Was von den Kerzen während der Beschneidung nicht heruntergebrannt ist, kann der Vater des Kindes wieder einsammeln und der gabbai zedaka ist nicht berechtigt, dagegen etwas zu sagen.

Von den beiden Kerzen, die Beschneidungskerzen genannt werden, gehört eine der Armenkasse und eine dem Paten.

Unterschrieben von Jehuda Selker aus Baiersdorf, Vorsänger und ne'eman der oben genannten Gemeinde

Unterschrieben von dem geringen Moses, Sohn unseres Lehrers, des Herrn L., sein Angedenken zum Segen für das Leben in der kommenden Welt

21 Aber es ist gut für Israel, dass jedes Jahr zu Beginn des Mahlens von Pessachmehl zwei Arbeiter bestellt werden, um den Weizen auf den Mühlstein zu schütten. Die beiden Arbeiter werden vom Vorstand, Gott schütze ihn, bezahlt, wie auch die übrigen Ausgaben für das Pessachmehl. [fol. $7 \mathrm{v}$ ]

22 In dir wird Israel gesegnet. In der Versammlung des gesamten hiesigen Vorstands, Gott schütze ihn, am Tag der Halbfeiertage von Pessach des Jahres $549^{48}$ wurde von allen einstimmig erklärt und ausgesprochen,

47 Die Gelder, die durch die Versteigerung der Ehrenämter in der Synagoge eingenommen werden.

$48 \quad 1789$ IV 12. 
dass von heute ab Recht und Gesetz sein soll, dass jeder von uns, der die Gemeindemitgliedschaft hier hat, aber nicht in unserer Gemeinde wohnt, seien es die, die heute in anderen Orten wohnen oder diejenigen, die noch immer abtrünnig sind und in anderen Orten leben, ${ }^{49} \mathrm{~d}$.h. ohne Ausnahme all diejenigen, die hier eingeschrieben sind, aber nicht hier in unserer Gemeinde wohnen, verpflichtet sind, jährlich den Mitgliedsbeitrag von insgesamt drei Gulden rheinisch zu entrichten. Die Bedingung, die oben in $\$ 10$ gegeben wurde, wonach einer, der in einen anderen Ort umzieht, um sich in seiner Mitgliedschaft ${ }^{50} \mathrm{zu}$ verbessern, soll weiter gültig sein. Danach ist er verpflichtet, für zwei aufeinander folgende Jahre die Gemeindeausgaben mit zu tragen, so wie oben erläutert.

\section{Punkt 23}

Am obigen Tag sprachen und erwiderten alle einstimmig, dass von heute an Recht und Gesetz für uns alle in unserer Gemeinde, Gott schütze sie, gelten soll, für jeden, der die Gemeindemitgliedschaft wie üblich an eins von seinen Kindern weitergeben will. Unabhängig davon, ob es der erste Sohn oder die erste Tochter, die zweiten oder dritten Kinder bis zu der erlaubten Mitgliedschaft laut $\$ 10$ sind, können solche, die die Mitgliedschaft vor ihrer Hochzeit erhalten sollen, diese nicht, wie beschrieben, formell bekommen, wenn nicht bis zum Tag der Hochzeit alle Schulden des Vaters des Bräutigams oder der Braut bei der Gemeinde, Gott schütze sie, beglichen wurden. Dies gilt für die Schulden bei der hiesigen Armenkasse, wie auch für die bei der hiesigen Beerdigungsbruderschaft und dem Lehrer der Gemeinde, Gott schütze sie. So soll es vom heutigen, oben genannten Tag an sein und eingehalten werden.

\section{Punkt 24}

In der Versammlung des gesamten Vorstands, Gott schütze ihn, haben alle in der Angelegenheit zugestimmt, nach der bis jetzt für jeden eine Bestimmung galt, dass jeder nach der Hochzeit sein Einzugsgeld von seiner Mitgift bezahlt hat, nämlich von den ersten Hundert wurden zwei Gulden gegeben und von den zweiten Hundert und weiter hinauf jeweils ein Gulden. Nun hat man nach dieser Bestimmung gesucht, sie aber nicht in schriftlicher Form finden können. Daher haben alle einstimmig beschlossen, dass diese Bestimmung weiter gültig und in dieser Form bleiben solle. Danach soll jeder, der der Gemeinde angehören möchte, sei es, dass er eine Jungfrau oder eine Witwe heiratet, wie erwähnt nach seiner Hochzeit Einzugsgeld zahlen, nämlich von

49 Gemeint sind offenbar solche Mitglieder, die sich ohne Billigung des Vorstands in anderen Orten niedergelassen hatten.

50 Andernorts. 
den ersten Hundert soll er zwei Gulden geben und von den zweiten Hundert und allen weiteren je einen Gulden. Ausdrücklich wurde festgelegt, dass bei Niederschrift des Verlobungsvertrags durch die ne'emanim der Gemeinde sie den Wert der Mitgift verkünden sollen. Wenn der Verlobungsvertrag durch andere geschrieben werden sollte, bleibt die Verantwortung zur Verkündung der Mitgift bei dem Paar, das hier die Mitgliedschaft bekommen möchte. Nach diesem angegebenen Wert soll das Einzugsgeld wie oben erwähnt entrichtet werden. So sei es und so soll es bleiben.

[fol. $8 \mathrm{r}$ ]

Punkt 25

Bei der Versammlung des gesamten Vorstands an den Halbfeiertagen von Pessach des Jahres $568^{51}$ haben alle einstimmig beschlossen, dass von jetzt an die Bestimmung für die Gemeinde Recht und Gesetz sein soll, wonach der Vorsänger an Neujahr, dem Versöhnungstag, den ersten und letzten Tagen von Pessach, dem Wochenfest, den ersten und letzten Tagen des Laubhüttenfestes und auch an Hosha'na Rabba ${ }^{52}$ keinen Jüngling, wer es auch sei, zur Toralesung aufrufen soll, solange er ledig ist. Auch wenn der Vorsänger die siebte Lesung und das Maftir ohne Namen aufruft, ist der Synagogendiener gewarnt, keinen ledigen Jüngling damit zu beehren. So sei es und so soll es bleiben.

\section{Punkt 26}

Am selben Tag wurde endgültig und einstimmig beschlossen, dass von heute an Recht und Gesetz sein soll, dass das Amt des segen nicht wie früher reihum vergeben werden soll, sondern dass es der Synagogendiener in der Synagoge ausrufen und verkaufen soll wie die übrigen Ehrenämter, allerdings nur unter den folgenden Bedingungen: Erstens sollen an jedem Schabbat, an dem der Monat gesegnet wird, der Ausheber ${ }^{53}$ und der Vorsteher zum Aufruf verpflichtet sein. Der Synagogendiener soll, so wie auch bei allen anderen Verpflichteten, in seinem Ausruf verkünden, dass für jedes Ehrenamt sieben Kreuzer zu geben sind. Zweitens sollen die Kohanim drei Kreuzer für einen Aufruf zur Lesung zahlen, wie auch die Israeliten und selbst der Vorsänger, wenn er ein Kohen ist, muss gezwungen werden, die drei Kreuzer für eine Lesung zu geben. Drittens soll die obige Bestimmung gültig bleiben, nach der der Vorsänger an Neujahr, dem Versöhnungstag, den drei Wallfahrtsfesten ${ }^{54}$ und an Hosha'na Rabba keinen Ledigen zur Tora aufrufen darf. Auch darf der

$51 \quad 1808$ IV 12-14.

52 Der siebte Tag des Laubhüttenfestes.

53 Der Torarolle.

54 Pessach, das Wochenfest und das Laubhüttenfest. 
Synagogendiener das Amt des segen an den genannten Tagen keinem Ledigen verkaufen, wenn er das Amt nicht an einen Verheirateten verkaufen möchte. Und viertens, die Bestimmung im Punkt 5 bleibt gültig, wonach das Amt des segen an den Mann einer Wöchnerin, den Vater eines zu beschneidenden Kindes oder an denjenigen, der eine Hochzeit in der Familie hat, zu geben ist. An einem Schabbat, an dem eine dieser Bestimmungen zutrifft, darf das Amt des segen nicht anderweitig verkauft werden. Auch die Bestimmung über zusätzliche Lesungen zu den sieben am Schabbat oder den fünf an einem Feiertag, nach der keine hinzugefügt werden sollen wie im Punkt 15 dargelegt, und der entsprechend nach der Reihenfolge des Alters gelesen werden soll bzw. zu Ehren eines anderen, bleibt unverändert gültig. Auch wurde beschlossen, dass der Armenpfleger jedes Mal einen ${ }^{55}$ bestimmen soll, der aufgerufen wird, und für diesen wird ${ }^{56}$ aus der Armenkasse gezahlt. Dafür soll das Amt des segen am Wochenfest teuer verkauft werden, [...] und die Armenkasse kann davon Gewinn haben. So sei es und so soll es bleiben.

In der Versammlung des gesamten Vorstands an den Halbfeiertagen von Pessach im Jahr $569^{57}$ wurde beschlossen, dass die oben in Punkt 5 dargestellte Bestimmung, wonach das Amt des segen nur für den Mann einer Wöchnerin ist, für den Vater eines zu beschneidenden Kindes oder für denjenigen, der eine Hochzeit in der Familie hat, vollständig aufgehoben ist und das Amt stattdessen an jenem Schabbat wie an den übrigen Schabbatot verkauft werden soll. Allerdings sind die Personen an den drei genannten Anlässen zum Aufruf verpflichtet. Auch wurde beschlossen, dass, weil die Ausgaben der Armenkasse hoch sind, jeder, dessen Anteil an den Gemeindesteuern einen Gulden beträgt, jetzt einen Gulden $30^{58}$ geben soll, und wer mit zwei und mehr veranlagt ist, zahlt jedes Jahr drei Gulden an die Armenkasse. Dafür ist er berechtigt, Ehrenämter zu kaufen. [fol. $8 \mathrm{v}$ ] Wenn er keine Ehrenämter kauft, muss er dennoch so viel an die Armenkasse zahlen.

Punkt 27

Bei der Versammlung des Vorstands, Gott schütze ihn, an den Halbfeiertagen von Pessach des Jahres 513 nach der kleinen Zeitrechnung ${ }^{59}$ wurde beschlossen, dass jeder Israelit, der zu einer Toralesung an einem Schabbat oder Feiertag gelangt, dafür zwei Kreuzer zahlen muss. An einem Wochentag soll er

55 Einen Armen.

56 Das Geld für die Lesung.

571809 IV 2-6.

58 Kreuzer.

591813 IV 18-20. 
für die Lesung einen Kreuzer zahlen. Wenn er jedoch ein Kohen oder Levit ist, ist die Regel dieselbe, wonach er sowohl an einem Schabbat oder Feiertag, wie auch an einem Wochentag für jede Lesung einen Kreuzer zahlen soll. Dieses Geld gehört ab jetzt der Kasse des Vorstands und darf nicht, wie bisher, für die Bezahlung der Gemeindeangestellten verwendet werden, außer in diesem Jahr 513 der kleinen Zeitrechnung bis zu den Halbfeiertagen von 514 der kleinen Zeitrechnung. Die erste Bestimmung bleibt gültig, wonach davon der Zuschuss von 30 Gulden bezahlt werden soll um unsere Gemeinde, Gott schütze sie, zu erhalten.

\section{Punkt 28}

Dies ist nichts Verlorenes, sondern etwas Vergessenes. Obwohl im obigen Punkt 25 festgelegt wurde, dass der Vorsänger an den Hohen Feiertagen, anderen Feiertagen und an Hosha'na Rabba keinen ledigen Jüngling zur Toralesung aufrufen soll, hat die Mehrheit des Vorstands in seiner Versammlung an den Halbfeiertagen von Pessach des Jahres 521 der kleinen Zeitrechnung ${ }^{60}$ zugestimmt, dass dies nur für unreife Jünglinge gelten soll. Wenn aber an den genannten Tagen ein Jüngling anwesend sein sollte, der nach den Regeln der Weisen zum Aufruf verpflichtet ist, oder der aus einer angesehenen Familie unserer Gemeinde ist, kann der gabbai nach seinem Ermessen den Vorsänger ermächtigen, diesen zur Tora aufzurufen.

\section{Punkt 29}

Unter Anwesenheit des Vorstands wurde an den Halbfeiertagen von Pessach des Jahres 600 nach der kleinen Zeitrechnung ${ }^{61}$ beschlossen, dass keine Genehmigung für das Aufstellen eines Grabsteins zur Erinnerung an einen Toten auf unserem Friedhof erteilt wird, bis nicht die Inschrift, die die Verwandten anbringen wollen, vorher vom more zedek, dem Vorsteher und dem gabbai unserer Gemeinde gesehen wurde. So, wie sie es vorschreiben, soll es geschrieben werden. Es soll nichts sein, was man zu Lebzeiten des Verstorbenen gesagt hätte, sondern nur Worte über den Toten. Daher soll nichts von den Gefühlen ${ }^{62}$ auf den Stein geschrieben werden, was nicht den Werten des Entschlafenen entsprach, und zum Spott gereichen kann.

Abänderung des Punktes 25

Mit Willen und bei Anwesenheit des gesamten Vorstands ist beschlossen worden, dass die Bestimmung: "Kein Lediger darf an den drei Wallfahrtsfesten

\footnotetext{
601821 IV 19-22.

$61 \quad 1840$ IV 20-23.

62 Der Hinterbliebenen.
} 
und den Hohen Feiertagen sowie an Hosha'na Rabba zur Toralesung aufgerufen werden «, gültig ist. D.h., dass er nicht unter den fünf zur Lesung verpflichteten Männern ist, oder an einem Feiertag, der auf einen Schabbat fällt, unter den sieben Männern. [fol. $9 \mathrm{r}$ ] Er ist jedoch berechtigt, die letzte Lesung und das Maftir zu kaufen und darf auch zur Lesung gelangen. Auch hat ein anderer das Recht, diese zu kaufen und den Ledigen damit zu beehren, jedoch keinesfalls an den drei Wallfahrtsfesten und den beiden ersten und letzten Tagen dieser Wallfahrtsfeste. Aber bezüglich Neujahr, Versöhnungstag und Hosha'na Rabba bleibt die alte Bestimmung gültig und kein Lediger darf an diesen Tagen eine Toralesung bekommen. Auch darf sonst jeder, wer es auch sei, eine Toralesung haben. Geschrieben auf Befehl der Vorsteher und der Obersten des Vorstands der Gemeinde, 8. Cheschwan 603 nach der kleinen Zeitrechnung, ${ }^{63}$ von mir bestätigt, dem geringen Gerschon [...] der Gemeinde Neuzedlisch.

\section{Punkt 30}

Am heutigen, unten angegebenen Tag, wurde beschlossen, dass jedes Mal für die letzte Toralesung 2.11. 11 Gulden und für die erste Lesung [im Zyklus] 1. 11.11 Gulden gezahlt werden müssen. Jedoch mit dem Zusatz, dass die genannten Summen jedes Mal schon an Hosha'na Rabba gezahlt werden müssen. Andernfalls werden beide in der Synagoge durch Versteigerung verkauft. Im folgenden Jahr geht es dann wieder der Reihenfolge nach.

1. Cheschwan 608 nach der kleinen Zeitrechnung. ${ }^{64}$

Der geringe Gerschon [...] der heiligen Gemeinde Neuzedlisch.

\section{Punkt 31}

Mit willen und bei Anwesenheit des gesamten Vorstands ist beschlossen worden, das von nun an weder für einen Trauernden, noch für einen, der eine Jahrzeit begeht, der Vorbeter vor das Lesepult treten darf, sondern für beide wird von ihm nur das Kedusha-Gebet gesagt. Diese Regel duldet keine andere Ausnahme, außer dass der, der den Vorsänger öfters an Wochentagen vertritt, in benannten Fällen die Aufgabe des Vorbeters übernehmen soll.

1. Cheschwan 610 nach der kleinen Zeitrechnung. ${ }^{65}$

Der geringe Gerschon [...] der heiligen Gemeinde Neuzedlisch.

[fol. $12 \mathrm{r}$ ]

Dies sind die Namen der Söhne Israels, die dies mit ihren Unterschriften, wie erläutert, unterzeichnen, und dies sind die Namen:

\footnotetext{
$631842 \times 12$.

$641847 \times 10$.

$651849 \times 29$.
} 
bestätigt von Jehuda Leib, Sohn des verstorbenen Herrn Sanwil, sein Angedenken zum Segen

bestätigt von Zwi Hirsch, Sohn des Herrn Abraham, sein Angedenken zum Segen

bestätigt von Isaak Eisak, Sohn des Herrn Mordechai, sein Angedenken zum Segen

bestätigt von Awiram Nathan, Sohn des Herrn [...], sein Angedenken zum Segen

bestätigt von Fischel, Sohn des verstorbenen Herrn Matitjahu Segal, sein Angedenken zum Segen

bestätigt von Moses, Sohn des [...] Moschel, sein Angedenken zum Segen

bestätigt von Gerschon, Sohn des verstorbenen, hohen Herrn Chajim [...], sein Angedenken zum Segen

bestätigt von Naftali, Sohn des hohen Herrn I., sein Angedenken zum Segen, gegenwärtig Einwohner der heiligen Gemeinde in Zedlisch $[\ldots]^{66}$

bestätigt von Moses, Sohn des Z., sein Angedenken zum Segen

bestätigt von Moses Leib, Sohn des Herrn [...] Katz

der geringe Moses, Sohn des hohen Herrn L., sein Angedenken zum Segen für das Leben in der kommenden Welt

bestätigt von Israel Ari, Sohn des ehrenwerten Herrn Zwi, sein Angedenken zum Segen

bestätigt von Moses, Sohn des ehrenwerten Herrn Eisak, sein Angedenken zum Segen

bestätigt von Jakob Leib, Sohn des Zwi, sein Angedenken zum Segen

bestätigt vom geringen Samuel, Sohn des hohen Herrn A. Bloch [?] aus Tachau, gegenwärtig in Neuzedlisch

bestätigt von Salman, Sohn des hohen Herrn Zwi Segal, sein Angedenken zum Segen

Jehuda Leib, Sohn des Herrn Zwi, sein Angedenken zum Segen

bestätigt von dem geringen Chajm

im, Sohn des Herrn Hirsch Segal, ich bin die Sühne für sein Siechtum, aus Neuzedlisch

Matitjahu, Sohn des hohen Herrn [...], sein Angedenken zum Segen, aus Neuzedlisch

bestätigt von $[\ldots]^{67}$

bestätigt von David, Sohn des ehrenwerten Herrn Moses, sein Angedenken zum Segen

66 Unterschrift nach Streichung unleserlich.

67 Name nach Streichung unleserlich. 
der geringe Leib, Sohn des hohen Herrn [...] aus Petscher, ${ }^{68}$ gegenwärtig in Neuzedlisch

der geringe Nachman, Sohn meines Herrn Vaters Moses aus Tachau, gegenwärtig in Neuzedlisch

Joel, Sohn des ehrenwerten Herrn Moses, sein Angedenken zum Segen, aus Neuzedlisch

bestätigt von Leib, Sohn des ehrenwerten Eisak, sein Angedenken zum Segen, aus Neuzedlisch

bestätigt von Moses Israel, Sohn des ehrenwerten und hohen Herrn Hirschel [...]

bestätigt von $[. .$.$] , Sohn des ehrenwerten und hohen Herrn N[..]$

68 Möglicherweise Petschau (Becov). 


\section{Anhang: \\ Aschkenasische Statutentexte in früheren Editionen}

\begin{tabular}{|c|c|c|c|c|}
\hline $\begin{array}{l}\text { Gemeinde/ } \\
\text { Landes- } \\
\text { judenschaft }\end{array}$ & Jahr & Umfang & Bemerkungen & Bibliografische Angaben \\
\hline $\begin{array}{l}\text { Altona/ } \\
\text { Hamburg/ } \\
\text { Wandsbek }\end{array}$ & $\begin{array}{l}1685- \\
1802\end{array}$ & $\begin{array}{l}224 \$ \$(\mathrm{Al}- \\
\text { tona } 1726) ; \\
138 \$ \$ \\
\text { (Hamburg } \\
1710) ; 90 \\
\$ \$ \text { (Wands- } \\
\text { bek } 1687) \text {; } \\
92 \$ \$ \\
\text { (Wandsbek } \\
1801 / 02 \text { ) }\end{array}$ & $\begin{array}{l}\text { Textausgabe aller } \\
\text { verfügbaren takkanot } \\
\text { der drei Gemeinden } \\
\text { im Original (teils } \\
\text { synoptisch) und mit } \\
\text { deutscher Über- } \\
\text { setzung, zahlreiche } \\
\text { Anmerkungen im } \\
\text { Text. }\end{array}$ & $\begin{array}{l}\text { Heinz Mosche Graupe } \\
\text { (Hg.), Die Statuten } \\
\text { der drei Gemeinden } \\
\text { Altona, Hamburg und } \\
\text { Wandsbek. Quellen zur } \\
\text { jüdischen Gemeindeor- } \\
\text { ganisation im 17. und } \\
\text { 18. Jahrhundert, } 2 \text { Bde., } \\
\text { Hamburg } 1973 .\end{array}$ \\
\hline $\begin{array}{l}\text { Altona/ } \\
\text { Hamburg }\end{array}$ & 1726 & $224 \$ \$$ & $\begin{array}{l}\text { Zeitgenössische deut- } \\
\text { sche Übersetzung der } \\
\text { Altonaer Statuten. }\end{array}$ & $\begin{array}{l}\text { Max Grunwald, Die } \\
\text { Statuten der »Hamburg- } \\
\text { Altonaer Gemeinde« } \\
\text { von 1726, in: Mitteilun- } \\
\text { gen der Gesellschaft für } \\
\text { jüdische Volkskunde } 11 \\
\text { (1903), 1-64. }\end{array}$ \\
\hline Amsterdam & 1711 & $112 \$ \$$ & Druck & $\begin{array}{l}\text { Elchanan Tal (Hg.), Ha- } \\
\text { kehilla ha-ashkenazit } \\
\text { be-Amsterdam ba-me'a } \\
\text { ha-y"h (Die aschke- } \\
\text { nasische Gemeinde in } \\
\text { Amsterdam im 18. Jahr- } \\
\text { hundert), Jerusalem } \\
2010 .\end{array}$ \\
\hline $\begin{array}{l}\text { Ansbach } \\
\text { (LJS) }\end{array}$ & 1711 & $\begin{array}{l}36 \$ \$+6 \\
\$ \$ \text { spätere } \\
\text { Ergänzun- } \\
\text { gen }\end{array}$ & $\begin{array}{l}\text { Stark auf die Kompe- } \\
\text { tenzen der parna- } \\
\text { sim ausgerichtete } \\
\text { takkanot. }\end{array}$ & $\begin{array}{l}\text { Daniel J. Cohen, The } \\
\text { Statute- and Minute } \\
\text { Book of the Jewry of } \\
\text { Brandenburg-Ansbach } \\
\text { (1710-1718, 1771), in: } \\
\text { Kovez al yad - Minora } \\
\text { Manuscripta Hebraica, } \\
\text { NS } 6 \text { (16) (1966), } \\
458-534 \text { (hebr.). }\end{array}$ \\
\hline
\end{tabular}




\begin{tabular}{|c|c|c|c|c|}
\hline $\begin{array}{l}\text { Gemeinde/ } \\
\text { Landes- } \\
\text { judenschaft }\end{array}$ & Jahr & Umfang & Bemerkungen & Bibliografische Angaben \\
\hline $\begin{array}{l}\text { Bamberg } \\
\text { (LJS) }\end{array}$ & 1682 & $\begin{array}{l}17 \$ \$ \text { und } \\
\text { einige } \\
\text { Nachträge }\end{array}$ & $\begin{array}{l}\text { Statuten der bamber- } \\
\text { gischen Landesjuden- } \\
\text { schaft, Übersetzung } \\
\text { bei Adolf Eckstein, } \\
\text { Geschichte der Juden } \\
\text { im ehemaligen Fürst- } \\
\text { bistum Bamberg, } \\
\text { Bamberg 1898, 66-74, } \\
\text { dort jedoch dem Jahr } \\
1678 \text { zugeschrieben. }\end{array}$ & $\begin{array}{l}\text { David Kaufmann, Pin- } \\
\text { kas K»K Bamberg [Pro- } \\
\text { tokollbuch der heiligen } \\
\text { Gemeinde Bamberg], } \\
\text { in: Kovez al yad 12/13 } \\
\text { (1896/97), 1-47 (hebr.). }\end{array}$ \\
\hline Den Haag & 1701 & $17 \$ \$$ & $\begin{array}{l}\text { Zeitgenössische nie- } \\
\text { derländische Überset- } \\
\text { zung der ersten } \\
\text { Statuten. }\end{array}$ & $\begin{array}{l}\text { Désiré S. van Zuiden, } \\
\text { De Hoogduitsche Joden } \\
\text { in 's Gravenhage van } \\
\text { af hunne komst tot op } \\
\text { heden, Den Haag 1913, } \\
\text { 13-17. }\end{array}$ \\
\hline $\begin{array}{l}\text { Deutsch- } \\
\text { kreutz }\end{array}$ & 1816 & $46 \$ \$$ & $\begin{array}{l}\text { Übersetzung des ur- } \\
\text { sprünglichen Textes. }\end{array}$ & $\begin{array}{l}\text { Shlomo Spitzer, Die } \\
\text { jüdische Gemeinde von } \\
\text { Deutschkreutz, Wien/ } \\
\text { Köln/Weimar, 1995, } \\
\text { 137-151. }\end{array}$ \\
\hline Dubno & 1717 & $\begin{array}{l}194 \$ \$ \text { und } \\
\text { Zusätze }\end{array}$ & $\begin{array}{l}\text { Jiddisch kommen- } \\
\text { tierte Wiedergabe des } \\
\text { Originaltextes. }\end{array}$ & $\begin{array}{l}\text { Yizchok A. Levitats, } \\
\text { Der pinkas fun Dubner } \\
\text { kahal, in: Elias Tsche- } \\
\text { rikower, Historishe } \\
\text { shriftn, Bd. 2, Wilna } \\
\text { 1937, 80-114. }\end{array}$ \\
\hline Dubno & 1717 & $37+18 \$ \$$ & $\begin{array}{l}\text { Widergabe im } \\
\text { ursprünglichen } \\
\text { Hebräisch und in } \\
\text { polnischer Überset- } \\
\text { zung. }\end{array}$ & $\begin{array}{l}\text { Anna Michałowska, } \\
\text { (Hg.), Gminy } \\
\text { Z.ydowskie w Daw- } \\
\text { nej Rzeczypospolitej, } \\
\text { Warschau 2003, 15-21, } \\
\text { 163-167. }\end{array}$ \\
\hline Friedberg & $\begin{array}{l}1664 / \\
1723\end{array}$ & $\begin{array}{l}228 \$ \$ \\
(\$ \$ 140- \\
165 \text { fehlen })\end{array}$ & $\begin{array}{l}\text { Originaltext und } \\
\text { deutsche Überset- } \\
\text { zung. }\end{array}$ & $\begin{array}{l}\text { Stefan Litt (Hg.), Proto- } \\
\text { kollbuch und Statuten } \\
\text { der Jüdischen Gemeinde } \\
\text { Friedberg (16.-18. Jahr- } \\
\text { hundert), Friedberg } \\
2003 \text {. }\end{array}$ \\
\hline
\end{tabular}




\begin{tabular}{|c|c|c|c|c|}
\hline $\begin{array}{l}\text { Gemeinde/ } \\
\text { Landes- } \\
\text { judenschaft }\end{array}$ & Jahr & Umfang & Bemerkungen & Bibliografische Angaben \\
\hline Fürth & 1728 & $70 \$ \$$ & $\begin{array}{l}\text { Übersetzung der } \\
\text { Luxusgesetze, teils } \\
\text { mit längeren Anmer- } \\
\text { kungen. }\end{array}$ & $\begin{array}{l}\text { Andreas Würfel, Histo- } \\
\text { rische Nachricht von } \\
\text { der Judengemeinde in } \\
\text { dem Hofmarkt Fürth, } \\
\text { Teil 2: Das Tekkunos } \\
\text { Büchlein der Fürther } \\
\text { Juden, Frankfurt/Prag } \\
\text { 1754. }\end{array}$ \\
\hline Glogau & 1715 & $80 \S \S$ & $\begin{array}{l}\text { Zur Zeit der Publika- } \\
\text { tion befand sich das } \\
\text { Original im Staatsar- } \\
\text { chiv Breslau. }\end{array}$ & $\begin{array}{l}\text { Marcus Brann, Ge- } \\
\text { schichte der Juden in } \\
\text { Schlesien. VI, in: Jahres- } \\
\text { Bericht des jüdisch- } \\
\text { theologischen Seminars } \\
\text { Fraenckel'scher Stiftung } \\
\text { für das Jahr 1916, } \\
\text { Anhang VII: Die alten } \\
\text { Statuten der Glogauer } \\
\text { Judenschaft, 241-249, } \\
\text { LXXXIII-XC. }\end{array}$ \\
\hline $\begin{array}{l}\text { Hessen-Kas- } \\
\text { sel (LJS) }\end{array}$ & 1690 & $44 \$ \$$ & $\begin{array}{l}\text { Wiedergabe einer } \\
\text { Abschrift und zeitge- } \\
\text { nössischen deutschen } \\
\text { Übersetzung von } \\
1740 .\end{array}$ & $\begin{array}{l}\text { Leo Munk, Die Consti- } \\
\text { tuten der sämmtlichen } \\
\text { hessischen Juden- } \\
\text { schaft im Jahre 1690, } \\
\text { in: Jubelschrift zum } \\
\text { siebzigsten Geburtstag } \\
\text { des Dr. Israel Hildeshei- } \\
\text { mer, Berlin 1890, 69-82, } \\
\text { 77-85 (Textedition im } \\
\text { hebräischen Teil). }\end{array}$ \\
\hline Iwieniec & 1759 & $39 \$ \$$ & $\begin{array}{l}\text { Widergabe des } \\
\text { ursprünglichen } \\
\text { Hebräisch und in } \\
\text { polnischer Überset- } \\
\text { zung. }\end{array}$ & $\begin{array}{l}\text { Anna Michałowska } \\
\text { (Hg.), Gminy } \\
\text { Zydowskie w Dawnej } \\
\text { Rzeczypospolitej } \\
\text { [Jüdische Gemeinden } \\
\text { in der Alten Repub- } \\
\text { lik], Warschau 2003, } \\
\text { 171-179. }\end{array}$ \\
\hline
\end{tabular}




\begin{tabular}{|c|c|c|c|c|}
\hline $\begin{array}{l}\text { Gemeinde/ } \\
\text { Landes- } \\
\text { judenschaft }\end{array}$ & Jahr & Umfang & Bemerkungen & Bibliografische Angaben \\
\hline Krakau & 1595 & $48 \$ \$$ & $\begin{array}{l}\text { Fragmentarische } \\
\text { Wiedergabe der } \\
\text { ältesten Krakauer } \\
\text { Statuten. }\end{array}$ & $\begin{array}{l}\text { Feivel H. Wettstein, } \\
\text { Kadmoniyot mi-pinka- } \\
\text { sot yeshanim le-korot } \\
\text { Yisra'el be-Polin bi- } \\
\text { khlal uwe-Kraka bifrat, } \\
\text { [Altertümer aus alten } \\
\text { Protokollbüchern zur } \\
\text { Geschichte Israels in } \\
\text { Polen allgemein und in } \\
\text { Krakau im Speziellen] } \\
\text { Krakau } 1892 .\end{array}$ \\
\hline Krakau & 1595 & $\begin{array}{l}93 \$ \$ \text { und } \\
\text { Nachträge }\end{array}$ & $\begin{array}{l}\text { Ältester bekannter } \\
\text { Statutentext größe- } \\
\text { ren Umfangs, von } \\
\text { Bałaban jedoch nur } \\
\text { nach einem Fragment } \\
\text { ediert, dabei hielt er } \\
\text { sich nicht immer an } \\
\text { die ursprüngliche } \\
\text { Aufteilung der Para- } \\
\text { graphen. }\end{array}$ & $\begin{array}{l}\text { Majer Bałaban, Die Kra- } \\
\text { kauer Judengemeinde- } \\
\text { Ordnung von } 1595 \text { und } \\
\text { ihre Nachträge, in: Jahr- } \\
\text { buch der Jüdisch-litera- } \\
\text { rischen Gesellschaft } 10 \\
(1912), 296-360 \text {; } \\
11 \text { (1916), 88-114. }\end{array}$ \\
\hline Kremsier & 1708 & $200 \$ \$$ & $\begin{array}{l}\text { Teilwiedergabe der } \\
\text { zeitgenössischen } \\
\text { deutschen Überset- } \\
\text { zung. }\end{array}$ & $\begin{array}{l}\text { Adolf Frankl-Grün, Die } \\
\text { Gemeindeverfassung von } \\
\text { Kremsier, in: Monats- } \\
\text { schrift für Geschichte } \\
\text { und Wissenschaft des } \\
\text { Judentums 40,4 (1896), } \\
\text { 180-184; 40,5 (1896), } \\
\text { 209-219; 40,6 (1896), } \\
\text { 255-261. }\end{array}$ \\
\hline $\begin{array}{l}\text { Kuttenplan } \\
\text { (Chodová } \\
\text { Planá) }\end{array}$ & $\begin{array}{l}1645- \\
1739\end{array}$ & $208 \$ \$$ & $\begin{array}{l}\text { Offenbar kumula- } \\
\text { tive Statuten, die } \\
\text { von Ochser nur in } \\
\text { deutscher Überset- } \\
\text { zung wiedergegeben } \\
\text { wurden, einzelne } \\
\text { Abschnitte und } \\
\text { Paragraphen auch in } \\
\text { Originalsprache. }\end{array}$ & $\begin{array}{l}\text { Schulim Ochser, Der } \\
\text { Pinkas der Gemeinde } \\
\text { Kuttenplan, in: Mittei- } \\
\text { lungen zur Jüdischen } \\
\text { Volkskunde 13,1 (1910), } \\
\text { 32-38; 13,2 (1910), } \\
\text { 57-89. }\end{array}$ \\
\hline
\end{tabular}




\begin{tabular}{|c|c|c|c|c|}
\hline $\begin{array}{l}\text { Gemeinde/ } \\
\text { Landes- } \\
\text { judenschaft }\end{array}$ & Jahr & Umfang & Bemerkungen & Bibliografische Angaben \\
\hline Kyov (Gaya) & $\begin{array}{l}1680 \\
\text { (nach- } \\
\text { trägl } \\
\text { iche Er- } \\
\text { gänzun- } \\
\text { gen bis } \\
1749)\end{array}$ & $52 \S \$$ & $\begin{array}{l}\text { Deutsche Überset- } \\
\text { zung des hauptsäch- } \\
\text { lich hebräischen Tex- } \\
\text { tes der mährischen } \\
\text { Gemeinde. }\end{array}$ & $\begin{array}{l}\text { Heinrich Flesch, Die } \\
\text { Tekkanoth (Statuten) } \\
\text { der Gemeinde Gaya, } \\
\text { in: Hugo Gold (Hg.), } \\
\text { Die Juden und Juden- } \\
\text { gemeinden Mährens } \\
\text { in Vergangenheit und } \\
\text { Gegenwart, Brünn 1929, } \\
\text { 31-44. }\end{array}$ \\
\hline $\begin{array}{l}\text { Mähren } \\
\text { (LJS) }\end{array}$ & $\begin{array}{l}1650 / \\
51\end{array}$ & $\begin{array}{l}31 \S \S \text { und } \\
\text { spätere } \\
\text { Zusätze }\end{array}$ & $\begin{array}{l}\text { Deutsche Überset- } \\
\text { zung der Landessta- } \\
\text { tuten. }\end{array}$ & $\begin{array}{l}\text { Gerson Wolf (Hg.), } \\
\text { Die alten Statuten der } \\
\text { jüdischen Gemeinden in } \\
\text { Mähren, Wien } 1880 .\end{array}$ \\
\hline $\begin{array}{l}\text { Mähren } \\
\text { (LJS) }\end{array}$ & $\begin{array}{l}1650- \\
1748\end{array}$ & $\begin{array}{l}316 \$ \$ \text { und } \\
\text { spätere } \\
\text { Zusätze }\end{array}$ & $\begin{array}{l}\text { Originalsprachliche } \\
\text { Wiedergabe. }\end{array}$ & $\begin{array}{l}\text { Israel Halpern (Hg.), } \\
\text { Takkanot medinat } \\
\text { Mehrin (5410-5508) } \\
\text { [Satzungen des Landes } \\
\text { Mähren (1649/50- } \\
\text { 1747/48)] Jerusalem } \\
\text { 1951. }\end{array}$ \\
\hline Mattersdorf & $\begin{array}{l}\text { 2. Hälfte } \\
\text { 18. Jahr- } \\
\text { hundert } \\
(?)\end{array}$ & $23 \$ \$$ & $\begin{array}{l}\text { Originaltext und } \\
\text { deutsche Über- } \\
\text { setzung, genaue } \\
\text { Herkunft und Ver- } \\
\text { bleib des Originals } \\
\text { unbekannt. }\end{array}$ & $\begin{array}{l}\text { Max Grunwald, Mat- } \\
\text { tersdorf, in: Jahrbuch } \\
\text { für Jüdische Volks- } \\
\text { kunde } 26 / 27 \text { (1924/25), } \\
\text { 402-563, hier: 505-524. }\end{array}$ \\
\hline Metz & 1769 & $24 \$ \$$ & $\begin{array}{l}\text { Bei der fragmentari- } \\
\text { schen Vorlage handelt } \\
\text { es sich vielleicht um } \\
\text { einen Zwischenschritt } \\
\text { hin zu den endgülti- } \\
\text { gen Statuten. }\end{array}$ & $\begin{array}{l}\text { Simon Schwarzfuchs, } \\
\text { Un règlement de la } \\
\text { communauté de Metz } \\
\text { 1769, in: Revue des Étu- } \\
\text { des Juives } 129 \text { (1970), } \\
23-41 .\end{array}$ \\
\hline Metz & 1769 & $125 \$ \$$ & $\begin{array}{l}\text { Französische Über- } \\
\text { setzung der hier } \\
\text { edierten takkanot. }\end{array}$ & $\begin{array}{l}\text { Samuel Kerner, Le } \\
\text { règlement des la com- } \\
\text { munauté juive de Metz } \\
\text { de } 1769 \text {, in: Annales } \\
\text { de l'Ést } 24 \text { (1972), } \\
\text { 201-253. }\end{array}$ \\
\hline
\end{tabular}




\begin{tabular}{|c|c|c|c|c|}
\hline $\begin{array}{l}\text { Gemeinde/ } \\
\text { Landes- } \\
\text { judenschaft }\end{array}$ & Jahr & Umfang & Bemerkungen & Bibliografische Angaben \\
\hline Metz & $\begin{array}{l}1689- \\
1691\end{array}$ & $\begin{array}{l}\text { Mehrere } \\
\text { Gruppen } \\
\text { von Be- } \\
\text { stimmun- } \\
\text { gen zu ver- } \\
\text { schiedenen } \\
\text { Themen }\end{array}$ & $\begin{array}{l}\text { Nicht alle Bestim- } \\
\text { mungen aus der } \\
\text { benutzten Vorlage } \\
\text { wurden von Schwarz- } \\
\text { fuchs ediert, manche } \\
\text { der edierten Paragra- } \\
\text { phen erscheinen in } \\
\text { ähnlicher Form noch } \\
1769 \text {. }\end{array}$ & $\begin{array}{l}\text { Simon Schwarzfuchs, } \\
\text { Über das Wesen } \\
\text { der Takkonaus, der } \\
\text { jüdischen Gemeinde- } \\
\text { ordnungen. Von der } \\
\text { Provence bis Metz } \\
\text { (13.-17. Jahrhundert), } \\
\text { in: Christoph Cluse/Al- } \\
\text { fred Haverkamp/Israel } \\
\text { Y. Yuval (Hg.), Jüdische } \\
\text { Gemeinden und ihr } \\
\text { christlicher Kontext in } \\
\text { kulturräumlich verglei- } \\
\text { chender Betrachtung. } \\
\text { Von der Spätantike bis } \\
\text { zum 18. Jahrhundert, } \\
\text { Hannover 2003, 465- } \\
\text { 503, Metzer Statuten } \\
\text { 476-501. }\end{array}$ \\
\hline Nikolsburg & $\begin{array}{l}1720- \\
1768\end{array}$ & $\begin{array}{l}286 \$ \S \text { und } \\
\text { spätere } \\
\text { Hinzufü- } \\
\text { gungen }\end{array}$ & $\begin{array}{l}\text { Das Original befand } \\
\text { sich in der Bearbei- } \\
\text { tungszeit im Rab- } \\
\text { binerseminar in } \\
\text { Budapest. }\end{array}$ & $\begin{array}{l}\text { Avraham N. Z. Rot } \\
\text { [Ernst Roth] (Hg.) } \\
\text { Takkanot Nikolsburg } \\
\text { [Statuten von Nikols- } \\
\text { burg], Jerusalem } 1961 .\end{array}$ \\
\hline Posen & $\begin{array}{l}1621- \\
1835\end{array}$ & $2269 \$ \$$ & $\begin{array}{l}\text { Konsekutive takkanot } \\
\text { aus der Feder der je- } \\
\text { weiligen Wahlmänner } \\
\text { aus dem Zeitraum } \\
\text { von } 1621-1835 \text {, das } \\
\text { Original befindet sich } \\
\text { heute in den CAHJP } \\
\text { in Jerusalem. }\end{array}$ & $\begin{array}{l}\text { Dov Avron (Hg.), } \\
\text { Pinkas ha-ksherim shel } \\
\text { kehillat Pozna (1621- } \\
\text { 1835) [Protokollbuch } \\
\text { der Wahlmänner der } \\
\text { Gemeinde Posen], Jeru- } \\
\text { salem } 1966 \text { (hebr.) }\end{array}$ \\
\hline Schnaittach & 1689 & $\begin{array}{l}29 \$ \$ \text { und } \\
\text { einige Er- } \\
\text { gänzungen }\end{array}$ & $\begin{array}{l}\text { Teil des Schnaittacher } \\
\text { Pinkas. }\end{array}$ & $\begin{array}{l}\text { Meir Hildesheimer } \\
\text { (Hg.), Pinkas kehillat } \\
\text { Shnaitakh [Protokoll- } \\
\text { buch der Gemeinde } \\
\text { Schnaittach], Jerusalem } \\
\text { 1992, 157-173. }\end{array}$ \\
\hline
\end{tabular}




\begin{tabular}{|c|c|c|c|c|}
\hline $\begin{array}{l}\text { Gemeinde/ } \\
\text { Landes- } \\
\text { judenschaft }\end{array}$ & Jahr & Umfang & Bemerkungen & Bibliografische Angaben \\
\hline Schnaittach & 1710 & $68+13 \S \S$ & $\begin{array}{l}\text { Bestätigungen und } \\
\text { teilweise Ergän- } \\
\text { zungen der älteren } \\
\text { Statuten. }\end{array}$ & $\begin{array}{l}\text { Meir Hildesheimer } \\
\text { (Hg.), Pinkas kehillat } \\
\text { Shnaitakh, Jerusalem } \\
\text { 1992, 230-263. }\end{array}$ \\
\hline $\begin{array}{l}\text { Schwersenz } \\
\text { (Swarzędz) }\end{array}$ & 1729 & $18 \$ \$$ & $\begin{array}{l}\text { Wiedergabe auf } \\
\text { Hebräisch und in } \\
\text { polnischer Überset- } \\
\text { zung. }\end{array}$ & $\begin{array}{l}\text { Anna Michałowska } \\
\text { (Hg.), Gminy } \\
\text { Zydowskie w Dawnej } \\
\text { Rzeczypospolitej [Jüdi- } \\
\text { sche Gemeinden in der } \\
\text { Alten Republik], War- } \\
\text { schau 2003, 156-159. }\end{array}$ \\
\hline Sugenheim & 1756 & $32 \$ \$$ & $\begin{array}{l}\text { Von den Ortsherren, } \\
\text { den Freiherren von } \\
\text { Seckendorff, erlassene } \\
\text { Ordnung für die } \\
\text { Juden im Dorf. }\end{array}$ & $\begin{array}{l}\text { Max Freudenthal, Die } \\
\text { Verfassungsurkunde } \\
\text { einer reichsritterlichen } \\
\text { Judenschaft. Das Kahls- } \\
\text { buch von Sugenheim, } \\
\text { in: Zeitschrift für die } \\
\text { Geschichte der Juden in } \\
\text { Deutschland 1,1 (1929), } \\
\text { 44-68. }\end{array}$ \\
\hline $\begin{array}{l}\text { Wied-Runkel } \\
\text { (LJS) }\end{array}$ & $\begin{array}{l}1733- \\
1760\end{array}$ & $\begin{array}{l}18 \$ \$ \text { und } \\
22 \text { spätere } \\
\text { Hinzufü- } \\
\text { gungen }\end{array}$ & $\begin{array}{l}\text { Übersetzung des heb- } \\
\text { räischen Originals. }\end{array}$ & $\begin{array}{l}\text { Bernhard Wachstein, } \\
\text { Das Statut der jüdi- } \\
\text { schen Bevölkerung } \\
\text { der Grafschaft Wied- } \\
\text { Runkel (Pinkas Runkel), } \\
\text { in: Zeitschrift für die } \\
\text { Geschichte der Juden } \\
\text { in Deutschland 4,2/3 } \\
(1932), 129-149 .\end{array}$ \\
\hline Worms & $\begin{array}{l}1651 \\
1728\end{array}$ & $\begin{array}{l}64 \$ \$ \\
(1651) \text { und } \\
\text { spätere } \\
\text { Umarbei- } \\
\text { tungen; } 46 \\
\$ \$(1728, \\
\text { fragmenta- } \\
\text { risch) }\end{array}$ & $\begin{array}{l}\text { Originalsprachliche } \\
\text { und teils fragmentari- } \\
\text { sche Wiedergabe der } \\
\text { Texte, die Fortsetzung } \\
\text { von } 1728 \text { kam nie } \\
\text { zustande. }\end{array}$ & $\begin{array}{l}\text { Leopold Löwenstein, } \\
\text { Gemeindeordnungen, } \\
\text { in: Blätter für Jüdische } \\
\text { Geschichte und Littera- } \\
\text { tur, } 10 \text { (1903), 145-150; } \\
11(1903), 161-165 ; 12 \\
(1903), 77-79,3(1904) \text {, } \\
33-36,5(1904) 65-68 ; \\
6(1904), 81-84 .\end{array}$ \\
\hline
\end{tabular}




\section{Abkürzungen}

\section{Deutsche und englische Abkürzungen}

aram. aramäisch

CAHJP Central Archives for the History of the Jewish People

F, $f \quad$ florin (Gulden)

frz. französisch

hebr. hebräisch

Hg. Herausgeber

JJLG Jahrbuch für jüdische Literaturgeschichte

lat. lateinisch

LJS Landesjudenschaft

MGWJ Monatsschrift für Geschichte und Wissenschaft des Judentums

ndl. Niederländisch

ZGJD Zeitschrift für die Geschichte der Juden in Deutschland

Hebräische Abkürzungen und Ligaturen

\begin{tabular}{|c|c|c|c|}
\hline אף על פי & אעפ"י & אחד & 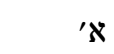 \\
\hline אף על פי כן & אעפ"כ & איש אחר & א"א - א \\
\hline אפילו הכי & אפ"ה & אלא אם כן & אא״כ - א \\
\hline אפילו & אפי & אין ברשותו & א"ב \\
\hline אין צורך & א"צ & אב בית דין & אב"ד \\
\hline \multirow[t]{2}{*}{ אין צורך לומר } & אצ"ל & אומות העולם & א"ה \\
\hline & & ארון הקודש & 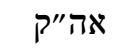 \\
\hline בין א׳ והב' & באוה"ב & אחד ואחד & 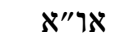 \\
\hline בעל בית & ב"ב & אומר זמירות & א"ז \\
\hline בעל ברית & & איסרו חג & א"ח \\
\hline במהרה בימינו & & אחר כך & 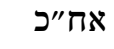 \\
\hline 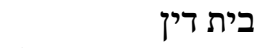 & ב"ד & ארץ ישראל & או"י \\
\hline בדיני אומות העולם & בדא"ה & אם ירצה השם & אי"ה \\
\hline בזמן הזה & ב"ה & אדוננו מלכנו ירום הודו & אמיר״ה \\
\hline בית הכנסת & & אינם נימולים & א״"נ \\
\hline & בן הרב & את עצמו & א"ע \\
\hline & בעזרת הו & אותו עניין & \\
\hline
\end{tabular}




\begin{tabular}{|c|c|c|c|}
\hline בית שטיבר (stuivers) & ב"ש & בעל הבית & \\
\hline \multirow[t]{2}{*}{ בשבועה דאורייתא } & בשד"א & בעלי השגחות & \\
\hline & & בית הכנסת חדש & בהכ"ח \\
\hline גאון אב בית דין & גאב"ד & בית הכנסת ישן & בהכ"י, \\
\hline ג' גולדן & ג"ג & בית המדרש & בהמ"ד \\
\hline גבאי דתלמוד תורה & גדת"ת & בן הרב & בהר״ב \\
\hline גבאי העיר & ג"ה & בן הרב רבי & \\
\hline גבאי חדש & ג"ח & בית הקברות & בה"ק \\
\hline גמילות חסדים & & בעל חוב & ב"ח \\
\hline גם כן & ג"כ & ביקור חולים & \\
\hline גדולים פוליש & ג"פ & בעל חתונה & \\
\hline גבאי צדקה & ג"צ & בעל חוב דינו קודם & ב"ח ד"ק \\
\hline גבאי קהלה & ג"ק & בני ישראל & ב"י, \\
\hline גבאי תלמוד תורה & גת"ת & בעל יולדת & \\
\hline & & באי כוחו & ב״כ \\
\hline 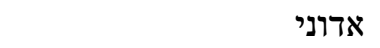 & 7 & בחירת לבו & ב"ל \\
\hline (Bezeichnung für Gott) & & בן לאדוני אבי & בלא"א \\
\hline דין אומות העולם & דא"ה & בר מנן & ב"מ \\
\hline דלית ארצות & ד"ד & בית משפט & \\
\hline דעפוטירטי & & בר מצוה & \\
\hline דברים טובים & ד"ט & במה שכתוב & במש״כ \\
\hline דין ישראל & ד"וי & בחירת נפשו & ב"נ \\
\hline דין קדימה & ד"ק & בנקיתת חפץ & בנק"ח \\
\hline דבר של חיוב & דש"ח & בעל סגן & ב"ס \\
\hline דין תורה & ד"ת & בעל הבית & בע"ה \\
\hline דין תוקף נאמנות & דת"ן & בעוונותינו הרבים & \\
\hline & & בעל(י) הבית & בעה"ב \\
\hline הבא עלינו & הבע"ל & בעזרת השם יתברך & בעזה"י \\
\hline הבא עלינו לטובה & הבעל"ט & בעזרת נשים & בעז"נ \\
\hline הרי הוא & ה"ה & בערב יום טוב & בעי"ט \\
\hline המפואר והחשוב & הו"ה & בערב יום כיפורים & בעי"כ \\
\hline היכל הספר & 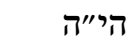 & בעתיד לבוא & בע"ל \\
\hline הנזכר לעיל & הנ"ל & בעל סכום & בע״ס \\
\hline הריני כפרת משכבו & הרכ"מ & בעל פה & בע"פ \\
\hline הרב רבי & הר״"ר & בעדי קיום & בע"ק \\
\hline & & בערב שבת & בע"ש \\
\hline ווילמרשדארפ & וו"ד & ב' פרוטא & ב"פ \\
\hline (Wilhermsdorf) & & בגדי פשטן & \\
\hline זה אחר זה & זא"ז & בעל פה & \\
\hline זה בוחר לאחד & זבל"א & בעל פליטה & \\
\hline זה בחר לבי״ת & זבל"ב & בקבלת סודר & בק״ס \\
\hline
\end{tabular}




\begin{tabular}{|c|c|}
\hline כבוד הרב רבי & כהר״ך \\
\hline כל המוסיף גורע & כה"ג \\
\hline כמו הנזכר & כה"נ \\
\hline כתב יד & כ"וי \\
\hline כמו כן & כ"כ \\
\hline כל פעם & כ"פ \\
\hline כל שכן & כ"ש \\
\hline
\end{tabular}

כתחז"ל

$$
\begin{aligned}
& \text { ל"איא } \\
& \text { לאי"ט } \\
& \text { לכ"ש }
\end{aligned}
$$

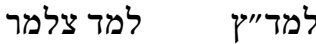

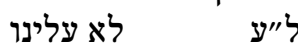

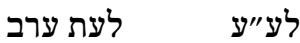

$$
\begin{aligned}
& \text { לפ"ע } \\
& \text { לפ"ק לפרט }
\end{aligned}
$$

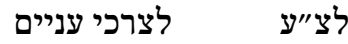

$$
\begin{aligned}
& \text { לש"ש } \\
& \text { מ' מחמת } \\
& \text { מו"ב } \\
& \text { מוהר"ר } \\
& \text { משא ומתן מורנו הקוב } \\
& \text { מכל מקום } \\
& \text { מעות מזומנים מקום } \\
& \text { מעות עליה מעות מזים } \\
& \text { מעבר לדף מעליה } \\
& \text { מעת לעת מערוף } \\
& \text { מורה צדק לעת } \\
& \text { מי שבירך } \\
& \text { מה שאין כן מביך } \\
& \text { מוצאי שבת קודש מהי כיש } \\
& \text { מכחישי תורה שבת קור } \\
& \text { מו"מוחריר } \\
& \text { מוממי מי } \\
& \text { מע"ע } \\
& \text { מע"ל מעלי } \\
& \text { מעל"עיל מע"ל } \\
& \text { מיץ } \\
& \text { מש"ש משי" } \\
& \text { משא"כ } \\
& \text { מש"ק משאיק } \\
& \text { מית משיק }
\end{aligned}
$$

\section{נאום}

נירנברג נאום

נאמן הקהלה נירניה נילה נמולת

נחיה ולא נמות נחיה נמה נמות

נחיה ולא נמות נמות ניתות

נשאר חייב וליב
נא' ניכ

נ"נא"ב

נ"ה נ"ל

נול"נינ" נר נינ

נו"נולנינ

נ"נר

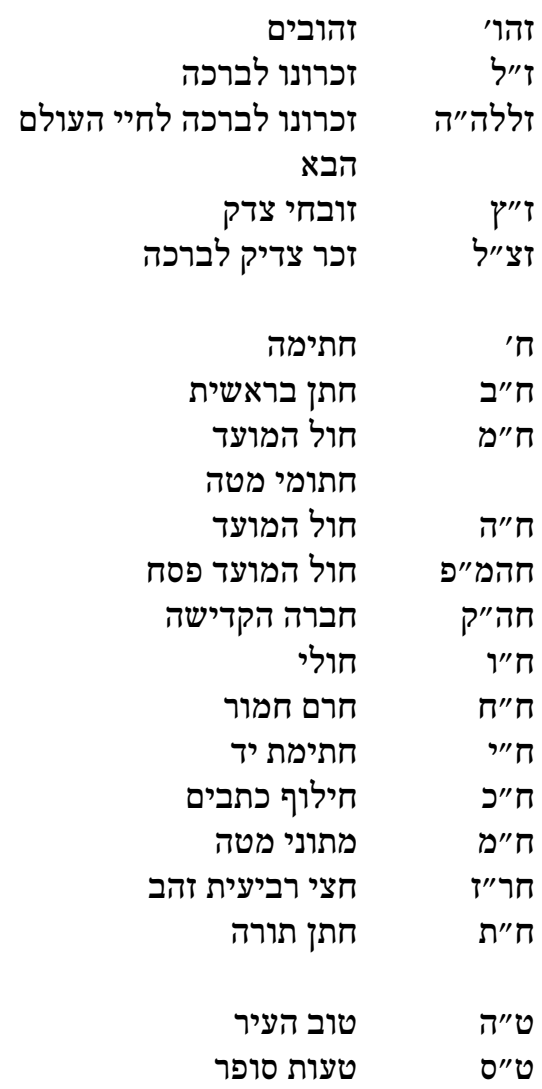

יא"ק

יהל"נ

יו"ט

יי"

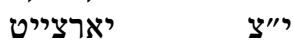

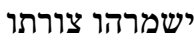

יע"א יגן עליה אלוהים

יצ"ו

יר״"ה ירום הודו/ה

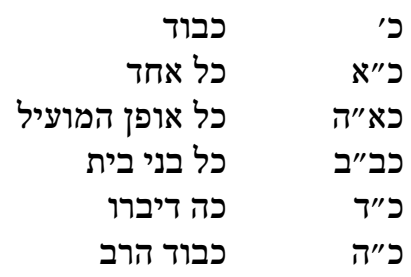




\begin{tabular}{|c|c|c|c|}
\hline פוליש & פ' & נקיתת חפץ & נק"ח \\
\hline פרנס - - פרנס & & נטרי רחמנא ופרקי & נר"ו \\
\hline \multicolumn{4}{|l|}{ פרשה - פר } \\
\hline פרותא אחרונה & פ" פ"א & ספר תורה & ס"ת \\
\hline \multicolumn{4}{|l|}{ פרוטא אחת } \\
\hline פערינבאך & פ"ב & על אחד כמה וכמה & עאכ"ו \\
\hline פתיחת ארון הקודש & פאה"ק & עזרת אנשים & ע"א \\
\hline פפניגה (Pfennige) & פגיי & על אף - ( על & \\
\hline פרנס מנהיג & פ"ו & עמוד א' & \\
\hline פרנס וגובה & פו"ג & עמוד ב' & ע"ב \\
\hline ופרנסים ומנהיגים & פו"מ & על דעת השם & עד"ה - - ער \\
\hline פרנס חודש & פ"ח - פ & עליו השלום & ע"ה \\
\hline פסק דין & פס"ד & על החתום & 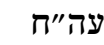 \\
\hline פחותי ערך & פ"ע & עוונותינו הרבים & 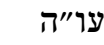 \\
\hline \multirow[t]{2}{*}{ פרוטה קטנה } & פ"ק & על זה & ע"ז \\
\hline & & עזרת אנשים & עז"א - (עא \\
\hline צעלמר & צ' & עזרת נשים & עז"נ \\
\hline צירנדארף & צ"ד & על חשבון & ע"ח \\
\hline צעלמר & צ"ול & על חשבון הקהל & 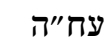 \\
\hline \multirow[t]{2}{*}{ צרכי עניים } & צ"ע & על ידי & ע״וי \\
\hline & & על ידי זה & עי"ז \\
\hline קינד בעט & ק"ב & ערב יום טוב & עי"ט - - עי \\
\hline קריאת התורה & ק"ה & על ידי כך & עי״״ - ע - ע \\
\hline קריאת התורה & 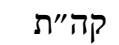 & על ידי סרסור & עי"ס \\
\hline קל וחומר & ק"ו & עד כאן & ע"כ \\
\hline קנין סודר & ק"ס & על כל זה & עכ"ז \\
\hline קהילה קדושה & ק"ק & על כל פנים & עכ"פ - עכ \\
\hline קבלת שבת & ק"ש & על ידי & על"י \\
\hline קוואטר שפט & & על מנת & ע"מ \\
\hline (Gevatterschaft) & & על מנת כן & עמ"כ - עמ \\
\hline \multirow[t]{2}{*}{ קופף שטיק (Kopfstück) } & & עזרת נשים & ע"נ \\
\hline & & עת עתה & ע"ע \\
\hline ראש בית & ר״ב & על פי & עפ"יו \\
\hline ראשית דבר & ר"ד & על פי כן & עפ"כ - ע \\
\hline ראש הקהל & ר"ה & על צד התר עסקא & עצה"ע \\
\hline ראש הבית & רה"ב & על צד הכתוב & עצה"ק \\
\hline ראש חודש & ר"ח & עדי קיום & ע"ק \\
\hline רבנים, חזנים, שמשים & רח"ש & ערב ראש חודש & ער״ח \\
\hline רייכשטאליר & ר"ט & ערב שבת קודש & עש"ק \\
\hline ראש ישיבה & ר"ו, & & \\
\hline רחמנא ליצלן & ר"ל & & \\
\hline
\end{tabular}




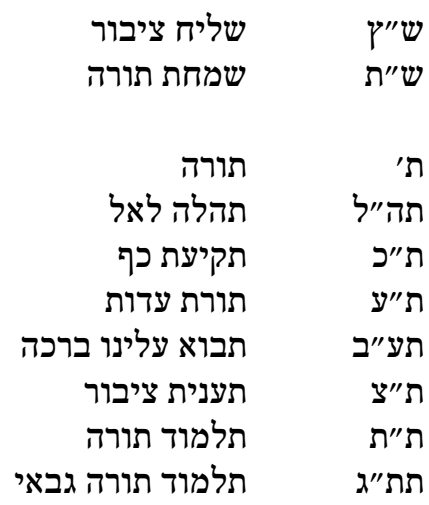

\begin{tabular}{|c|}
\hline ראש מדינה \\
\hline רביעית שעה \\
\hline
\end{tabular}

\begin{tabular}{|c|c|}
\hline שיחיה & שי \\
\hline שנה חדשה & ש"ש \\
\hline שבעה טובי העי & זט"ה \\
\hline שטר חוב & זט"ח \\
\hline שכיב מרע & "מן \\
\hline ששה סדרים & "ס \\
\hline שלחן ערוך & \\
\hline
\end{tabular}




\section{Gesamtbibliografie}

Arnsberg, Paul, Chronik der Rabbiner in Frankfurt am Main, Frankfurt a. M. 22002.

Avron, Dov (Hg.), Pinkas ha-ksherim shel kehillat Pozna (1621-1835) [Protokollbuch der Gemeinde Poznan], Jerusalem 1966.

Bader, Jan, Oorspronkelijk in Oisterwijk ... De oudste joodse gemeente in Noord-Brabant (1757-1857); Thans te Tilburg. De joodse gemeente Tilburg (1813-1873); Klein pogrom te Vught (1785) [Ursprünglich in Oisterwijk ... Die älteste jüdische Gemeinde in Nord-Brabant (1757-1857), jetzt in Tilburg. Die jüdische Gemeinde Tilburg (1813-1873); Kleine Pogrome in Vught (1785)], Breda 1995.

Barzen, Rainer, Jüdische Regionalorganisation am Mittelrhein. Die Kehillot SchUM um 1300, in: Christoph Cluse (Hg.), Europas Juden im Mittelalter. Beiträge des internationalen Symposiums in Speyer vom 20. bis 25. Oktober 2002, Trier 2004, 248-258.

Berkovitz, Jay R., Rites and Passages. The Beginnings of Modern Jewish Culture in France, 1650-1860, Philadelphia 2004.

Brann, Marcus, Geschichte der Juden in Schlesien. VI, in: Jahres-Bericht des jüdisch-theologischen Seminars Fraenckel'scher Stiftung für das Jahr 1916, Anhang VII: Die alten Statuten der GLogauer Judenschaft, 241-249, LXXXIII-XC.

Debler, Ulrich, Die jüdische Gemeinde von Niederwerrn, Sennfeld 1988.

Drossbach, Gisela (Hg.), Von der Ordnung zur Norm. Statuten in Mittelalter und Früher Neuzeit, Paderborn u.a. 2010.

Eidelberg, Shlomo (Hg.), R. Juspa, Shammash of Warmaisa (Worms). Jewish Life in 17th Century Worms, Jerusalem 1991 (teilw. hebr.).

Encyclopaedia Judaica, 22 Bde., Detroit 22007.

Finkelstein, Louis, Jewish Self-Government in the Middle Ages, New York ${ }^{2} 1964$.

Graupe, Heinz Mosche (Hg.), Die Statuten der drei Gemeinden Altona, Hamburg und Wandsbek. Quellen zur jüdischen Gemeindeorganisation im 17. und 18 Jahrhundert, 2 Bde., Hamburg 1973.

Grunwald, Max, Samuel Oppenheimer und sein Kreis. Ein Kapitel aus der Finanzgeschichte Österreichs, Wien/Leipzig 1913.

Grunwald, Max, Mattersdorf, in: Jahrbuch für Jüdische Volkskunde 26/27 (1924/25), 402-563.

Hamburger, Benjamin Salomon/Zimmer, Eric (Hg.), Wormser Minhagbuch des R. Jousep (Juspa) Schammes, 2 Bde., Jerusalem 1988-1992.

Härter, Karl, Statut und Policeyordnung. Entwicklung und Verhältnis des Statuarrechts zur Policeygesetzgebung zwischen spätem Mittelalter und Früher Neuzeit in mitteleuropäischen Reichs- und Landstädten, in: Gisela Drossbach (Hg.), Von der Ordnung zur Norm. Statuten in Mittelalter und Früher Neuzeit, Paderborn u.a. 2010, $127-152$. 
Hildesheimer, Meir (Hg.), Pinkas kehillat Shnaitakh [Protokollbuch der Gemeinde Schnaittach], Jerusalem 1992.

Hörz, Peter F. N., Jüdische Kultur im Burgenland. Historische Fragmente - volkskundliche Analysen, Wien 2005.

Horovitz, Markus, Frankfurter Rabbinen. Ein Beitrag zur Geschichte der Israelitischen Gemeinde in Frankfurt a. M.,Jerusalem 1969.

Kaufmann, David, R. Jaïr Chajjim Bacharach (1638-1702) und seine Ahnen, Trier 1894.

Kerner, Samuel, La vie quotidienne de la communauté juive de Metz au dix-huitième siècle (à partir du Pinkas [registre] inédit de cette commune, 1749-1789), Paris 1979.

Kerner, Samuel, Le règlement de la communauté juive de Metz de 1769, in: Annales de l'Est 24 (1972), 201-253.

Kerner, Samuel, Les démarches des envoyés de la communauté juive de Metz à Paris et à Versailles relatives à la »taxe Brancas«, in: Annales de l'Est 26 (1974), 217-264.

Kracauer, Isidor, Geschichte der Juden in Frankfurt a. M. (1150-1824), 2 Bde., Frankfurt a. M. 1925-1927.

Landau, Peter, Über die Wiederentdeckung der Gesetzgebung im 12. Jahrhundert, in: Gisela Drossbach (Hg.), Von der Ordnung zur Norm. Statuten in Mittelalter und Früher Neuzeit, Paderborn u.a. 2010, 13-15.

Levitats, Yizchok A., Der pinkas fun Dubner kahal [Das Protokollbuch der Dubnoer Gemeindeführung], in: Elias Tscherikower (Hg.), Historishe shriftn, Bd.2, Wilna 1937, 80-114.

Litt, Stefan (Hg.), Protokollbuch und Statuten der Jüdischen Gemeinde Friedberg (16.18. Jahrhundert), Friedberg 2003.

Litt, Stefan, Pinkas, Kahal, and the Mediene. The Records of Dutch Ashkenazi Communities in the Eighteenth Century as Histrical Sources, Leiden/Boston 2008.

Löwenstein, Leopold, Wormser Gemeindeordnungen, in: Blätter für Jüdische Geschichte und Litteratur, 10 (1903), 145-150; 11 (1903), 161-165; 12 (1903), 77-79, 3 (1904), 33-36, 5 (1904) 65-68; 6 (1904), 81-84.

Löwenstein, Leopold, Zur Geschichte der Juden in Fürth. 3 Teile in einem Bd., Hildesheim/New York 1974 (zuerst in: Jahrbuch der Jüdisch-Literarischen Gesellschaft 7-11 (1909-1913).

Margoliot, Hayyim Z., Dubno rabbati. Toldot ha-ir Dubno we-ha'atakot mi-pinkas hakahal shela mi-shnat 475 we-hal'a umi-mazevot she-al kivre gedole ha-ir ha-zot u-nikhbadeha [Groß-Dubno. Geschichte der Stadt Dubno und Abschriften ihres Protokollbuchs seit dem Jahr 1715 sowie von Grabsteinen für bedeutende und ehrenvolle Bürger der Stadt], Jerusalem 1968 (Erstausgabe: Warschau 1910).

Michałowska, Anna (Hg.), Gminy Zydowskie w Dawnej Rzeczypospolitej [Die jüdischen Gemeinden in der frühen Republik], Warschau 2003.

Nadav, Mordechai(Hg.), The Minutes Book of the Jewish Community Council of Tykocin. 1621-1806. Decisions and Regulations, 2 Bde, Jerusalem 1996-1999 (hebr.).

Nadav, Mordechai, Pinkas kahal Frankfurt de-Main [Protokollbuch der Gemeindeleitung Frankfurt am Main], in: Mordechai Nadav, Pinkas patuah. Meḥarim be-toldot yehude Polin we-Lita [Offenes Buch. Forschungen zur Geschichte der Juden in Polen und Litauen], Tel Aviv 2003, 257-266 (zuerst in: Kiryat Sefer 31 (1957), 507-516). 
Nachalon, Aharon, The Kahal and its Enactments in the Geonic Period, Jerusalem 2001 (hebr.).

Neubürger, Friedrich, Das Sonderrecht der gemeinen Judenschaft zu Fürth und in dessen Amt im achtzehnten Jahrhundert, Fürth/Nürnberg 1902.

Ochser, Schulim, Der Pinkas der Gemeinde Kuttenplan, in: Mitteilungen zur Jüdischen Volkskunde 13,1 (1910), 32-38; 13,2 (1910), 57-89.

Ophir, Baruch Zvi, Pinkas ha-kehillot. Germany - Bavaria [Protokollbuch der Gemeinden. Deutschland, Bayern], Jerusalem 1972.

Petersen, Heidemarie, Judengemeinde und Stadtgemeinde in Polen. Lemberg 1356-1581, Wiesbaden 2003.

Raspe, Lucia, Individueller Ruhm und kollektiver Nutzen. Berend Lehmann als Mäzen, in: Rotraud Ries/ J. Friedrich Battenberg (Hg.), Hofjuden - Ökonomie und Interkulturalität. Die jüdische Wirtschaftselite im 18. Jahrhundert, Hamburg 2002, 191-208.

Schön, Josef, Die Geschichte der Juden in Tachau, Brünn 1927.

Schwarzfuchs, Simon, Un règlement de la communauté de Metz 1769, in: Révue des Études Juives 129 (1970), 23-41.

Schwarzfuchs, Simon, Über das Wesen der Takkonaus, der jüdischen Gemeindeordnungen. Von der Provence bis Metz (13.-17. Jahrhundert), in: Christoph Cluse/Alfred Haverkamp/Israel J. Yuval (Hg.), Jüdische Gemeinden und ihr christlicher Kontext in kulturräumlich vergleichender Betrachtung. Von der Spätantike bis zum 18. Jahrhundert, Hannover 2003, 465-503.

Spitzer, Shlomo, Die jüdische Gemeinde von Deutschkreutz, Wien/Köln/Weimar 1995.

Tal, Elchanan, Ha-kehilla ha-ashkenazit be-Amsterdam ba-me’a ha-y“'̣ [Die aschkenasische Gemeinde in Amsterdam im 18. Jahrhundert], Jerusalem 2010.

Wilke, Carsten, »Den Talmud und den Kant.« Rabbinerausbildung an der Schwelle zur Moderne, Hildesheim/Zürich/New York 2003.

Würfel, Andreas, Historische Nachricht von der Judengemeinde in dem Hofmarkt Fürth, 2 Teile, Frankfurt/Prag 1754.

van Zuiden, Désiré S., De Hoogduitsche Joden in 's Gravenhage van af hunne komst tot op heden [Die Hochdeutschen Juden in s'Gravenhage von ihrer Ankunft bis heute], Den Haag 1913. 


\section{Deutscher Sach-, Namens- und Ortsindex}

Aaron Samuel Kaidanower 50

Aaron Teomim 87

Abraham Levi Oettingen Models 501

Altona 19, 21, 24, 267, 537

Amsterdam 13, 23 f., 318-320, 323, 509 f., 512,537

Amtseid 481

Ansbach 23, 210, 345, 537

Anschel Oppenheim 465

Antonis de Veer 322, 513

Armenkasse 26, 448, 452, 456, 461, 493, 497-499, 508-512, 518, 524, 526, 528, 530,532

Armenpfleger 135, 460, 493, 516, 519, $522,526,529,532$

Ärzte 485

Ascher Enslen 277 f., 282, 286, 502-507

Aschkenas 8, 18, 24, 132, 491 f., 519

Ausrufung (kleiner Bann) 353, 462, 469, $503 \mathrm{f} ., 525$

Awiram Nathan 535

ba'al segen $469,511,517,524,528$, $531 \mathrm{f}$.

Baiersdorf 224, 529

Bamberg 22, 224, 345, 538

Bann 86, 318, 324, 460, 467-500, 503, 505,512

Bar Mizwa 510, 512 f., 517

Bärmann Fränkel 210

Beauftragte (Marktaufseher) 472, 481, 484, 489, 492, 495, 499

Berend Lehmann 112

Beschneidung 268, 368, 421, 430, 505, 516 f., 524,529

Bibel 8, 11, 26, 51, 85, 133, 256, 298, $310,494,508,517$
Brancas (Familie) 367

Bücher 109

Chajim ben Abraham Boas 344, 519

Chajm 535

Chanukka 49, 454, 464, 477, 484, 519

Cheder 489

Chodová Planá (Kuttenplan) 297, 540

David Reis 500

David, Sohn des Moses 535

Dayyan (Richter) 135, 237

Den Haag 9, 15-17, 19-21, 23, 317 f., 323, $333 \mathrm{f} ., 335,339,509,512,538$

Deutschkreutz 9, 15, 20 f., 24, 429 f., 432, 538

Diebe $491 \mathrm{f}$.

Diener 320, 466, 491, 496, 503, 510

Doters Oppenheim 500

Druckerei 221

Dubno 9, 21, 23, 25, 399 f., 402, 538

Ehevertrag 483, 485, 521, 525

Eid 457, 459, 464, 474 f., 478, 481-484, 492, 494, 500, 504

Eindhoven 347

Elieser, Sohn des Jakob Katz Schiff 501

Elsass 9, 24, 390

Etrog 527

Fest der Torafreude 451, 518 f., 528

Fiol-Kasse 515

Fischel, Sohn des Matitjahu Segal 535

Fleischer 482

Forth 235, 277

Frankfurt a.M. 9, 14 f., 17-21, 35, 49-52, $85,370,486$ 
Frankreich 9, 24, 353 f., 359

Frauen 266, 478, 484, 499

Friedberg 15-17, 20 f., 25, 49, 538

Friedhof 297, 375, 512, 533

Fürth 9, 13, 16-18, 20-22, 132-135, $162,210,221,224,235,256,368$, 539

Gabriel ben Naftali Levi aus Fürth 210

Garköche 217, 492

Gast(durchreisender Armer) 448, 452 f., $460,492,505,516,520,526$

Gebetbuch 474 f., 482, 484

Gemeindemitgliedschaft 8,13 f., 134, 298, 355, 386, 463, 476, 478 f., 488 f., 492, 511, $520 \mathrm{f}$., $530 \mathrm{f}$.

Gemeindesteuern 511, 528, 532

Gemeindeverband 12, 235, 277

Gericht, rabbinisches $12,51,135,430$, 447, 468, 472, 477, 481-484, 493, 496, 504 f., 507, 515

Gerichtsurteil 496

Gerschon Dorheim 490

Gerschon, Sohn des Chajim 535

Gevatterschaft 306, 331, $523 \mathrm{f}$.

Gilden 7

Glogau 50, 107 f., 443, 539

Gottesdienst 85 f., 108, 132, 202 f., 278, 333,450 f., 467-469, 486, 512, 514, $523,526,528$

Grabfeld 225

Grabstein 533

Halacha $8,11,14,17$

Halberstadt 9, 13, 16, 18, 21, 107-109, 112

Hamburg 13, 24, 267, 537

haver (Titel) 448, 476, 501

Hekdesh 108, 451, 453, 459, 482, 494

Herberge 104, 485-487, 489

Hevra Kaddisha (Beerdigungsgesellschaft) $521 \mathrm{f}, 530$

Hilfslehrer 483

Hirsch Segal 535
Hochzeit 34, 97, 117, 267 f., 271, 355, $366,368,430,453,463$ f., 476, 478, $489,495,505,516$ f., 524, 526, 530, 532

Hoffaktor, auch Hofjude 34, 112, 465

Hurerei 478 f., 492

Hüttenbach 235, 277

Isaak bar Israel Jakob 318, 333

Isaak Eisak, Sohn des Mordechai 535

Israel Ari, Sohn des Zwi 535

Itzik Ballin 106, 465

Jair Chajim Bacharach 465

Jakob Leib, Sohn des Zwi 535

Jakob, Sohn des David Schwelim 501

Jechiel Katz 500

Jehuda Leib, Sohn des Sanwil 535

Jehuda Leib, Sohn des Zwi 535

Jehuda Selker aus Baiersdorf 529

Jehuda, Sohn des Ischai 501

Jekutiel Süßkind Rofe 345

Jerusalem 21, 27, 527

Jeschiwa $34,86,402,447 \mathrm{f}$.

Jiddisch $10,17,21,23,27,34,49-51,85$, $108,133,277,285,298,317,323,333$, $345,353,399,430,490,519,526,538$

Jidel Katz 354

Joel, Sohn des Moses 536

Josef Cohen 500

Judengasse 85, 485-487

Judenordnungen 19, 21

Kaiser 52, 493 f., 498

Kalman Cohen 490

Kinder 372, 430, 451, 479, 502, 510, 516 f., 519-521, 524, 529, 532

Kirchenordnungen 7

Klamen 453, 467

Klaus (Privatsynagoge und -lehrhaus) $112,210,402$

Kleiderhändler 51, 477 f., 485-490, 495 f.

Knechte 518, $521 \mathrm{f}$.

Königsberg 13 
Krakau 17, 20, 22, 50, 399, 518, 540

Krämer 51, 477 f., 488, 490, 495 f.

Kriechingen (Reichsgrafschaft) 390

Kultgegenstände 506

Laubhüttenfest 111, 203, 449, 450, 509, 527,531

Legbrett 309, 503, 529

Lehrer 261, 279, 448, 483, 488 f., 500, 502, 507 f., 516 f., 525 f., 528, 530

Lehrhaus 210, 448

Leib Essi 465

Leib, Sohn des [...] aus Petscher 536

Leib, Sohn des Eisak 536

Leipzig 109

Leviratsehe 525

Longuich 390

Luxemburg 390

Luxusgesetze 22, 133, 354, 539

Mägde 483

Mannführen 202, 271

Manuel Levy Duarte 317-319, 509, 512

Marktbreit 224

Marsal 390

Matitjahu, Sohn des [...] aus Neuzedlisch 535

Mattersdorf 13, 429, 541

Meereslied 284, 507

Meir Hacohen 127

Meir Levi Schnapper 501

Meir 465

Memorbuch 220, 333, 394

Mendel Rapp 477

Mergentheim 225

Messe 8, 109, 484 f., 488, 496

Metz 9, 18, 20 f., 23 f., 353-355, 358, 367, $541 \mathrm{f}$.

Michael Fürth (Michael ben Abraham Kohn) 251

Mischna 10, 26, 117, 161, 305-307, 357, 375, 462 f., 508
Mitgift 224, 449, 464, 485, 505, 511, 521, $530 \mathrm{f}$.

Mizwotgelder 529

Mörchingen 390

Mordechai Diesbeck 278, 507

Mordechai 465

Morenu (Titel) 452

Moses Cohen 500

Moses Gaikel 507

Moses Halevi aus Glogau 443

Moses Israel, Sohn des Hirschel 536

Moses Leib, Sohn des [...] Katz 535

Moses Pinto 317-319, 509, 512

Moses Simson Bacharach 465

Moses Sofer 51, 466, 494

Moses Ulif 500

Moses Waag Bacharach 501

Moses 535

Moses, Sohn des [...] Moschel 535

Moses, Sohn des Eisak 535

Nachman, Sohn des Moses aus Tachau 536

Nachum Och 501

Naftali 535

Naftali, Sohn des Moses Segal 501

Nancy 319

Nathan Cohen 500

Ne'eman (Notar) 26, 51, 108, 318, 333, $466,483,485,494,515,519,527,529$, 531

Neujahr 57, 100, 161, 449, 452, 523, 526, $528,531,534$

Neujahrsgeld 184

Neuzedlisch 9, 16, 18, 20 f., 26, 297 f.

Nichtjuden 377, 453 f., 477, 485-488, 491, 495, 499, 504, 506, 515

Nichtjüdin 453, 487 f., 495

Nürnberger Wechselordnungen 155 
Obrigkeit 19, 318, 419, 453, 456, 466, 468, 473, 478, 482, 493 f., 497-500, 504, 508 f., 512, 515, $519 \mathrm{f}$.

Oettingen in Bayern 224, 501

Ottensoos 235, 277

Pessach 111, 180, 203, 205, 365, 449, 514, 526, 528 f., 531-533

Pessachmehl 180, 526, 529,

Pfenniggeld 34, 453-455

Pferdehändler 490

Pijut 53, 202

Policey-Ordnungen 7, 14, 19, 285

Privatgottesdienst 514

Purim 453, 484, 526

Quorum 282, 448, 455, 463, 478, 502-504

Rabbenu Gerschom, Me'or ha-Gola 269

Rabbinatsapprobation 452

Rabbiner 10 f., 15, 22, 50, 87, 210, 224, 269, 277 f., 339, 345 f., 377, 443, 447-449, 452 f., 463, 465, 471, 479, $491 \mathrm{f} ., 507,526$

Saarwellingen 390

Säkularisierung 14, 18, 52, 298

Salman Loonstein 339

Salman Scheuer 501

Salman, Sohn des Zwi Segal 535

Samuel Ne'eman 51, 466, 494

Samuel Oppenheimer 34, 465

Samuel, Sohn des A. Bloch [?] aus

Tachau 535

Samuel, Sohn des Israel Jakob Bacharach 501

Sanwil Langibach 501

Schabbesdeckel 221, 365

Schach 371, 484

Schächter 477, 506

Schijndel 347

Schmuck 266
Schnaittach 24, 224, 235, 277 f., 507, $542 \mathrm{f}$.

Schreiber $34,51,85-87,108,127,134$, $277,286,298,318,323,333,345,354$, 399,485

Schulden 457 f., 511 f., 530

Schuldschein 181, $466 \mathrm{f}$.

Schulmantel 158

Schwabach 224

Schwangerschaft 457, $478 \mathrm{f}$.

's Hertogenbosch 9, 315, 345

Shulhan Arukh 518

Sierck 390

Simon Heschech 507

Simon Wolf Oppenheimer 34

Spiele 484

Spielverbot 86

Statutenkommission $34,51,84,107,455$, 464 f., 500

Steuererheber 108, 134, 472, $476 \mathrm{f}$., 480-482, 484, 489, 494, 496, 499

Steuern 14, 453, 480 f., 484, 494, 511, $521 \mathrm{f} ., 528,532$

Steuerschätzer $34,86,107,109,455-459$, $476,480,484$

Synagoge 16, 18, 26, 34, 107 f., 112, 121, $158,202,216,269,278,318,333,338$, $353,368,402,430,449-453,457,460$, 462, 467, 469-471, 478, 484, 486, 496, 502-504, 506-509, 511-514, 516-518, $523-526,529,531,534$

Synagogenbuch 317, 323

Synagogendiener (shammash) 26, 447, 449 f., 452, 456 f., 460, 463, 466 f., $472,477,480,482,496,511,523$, $531 \mathrm{f}$.

Tachau $314,535 \mathrm{f}$.

Talmud 11, 26, 51, 85, 133, 249, $448 \mathrm{f}$.

Talmud-Tora-Schule 108, 135, 483

Theater 371

Tobias Boas 332, 344, 519 
Toleranzedikte 18

Torarolle 450 f., 453, 517, 524, 526, 528, 531

Ühlfeld 9 f., 16 f., 20 f., 277-279, 502-508

(Unter-)Farrnbach 162, 172

Veghel 347

Verdun 391

Versöhnungstag 53, 100, 112, 449, 452, $528,531,534$

Vertreibung $13 \mathrm{f}$.

Vieh 293, 504

Vorsänger 203, 207, 449, 452 f., 463, $477,480,496,507$ f., 514, 516, 523 f., 525

Vorsänger 203, 207, 449, 452 f., 463, 477, 480, 496, 507 f., 514, 516, 523-526, 528 f., 531, 533

Vorsitzender des Gerichts 447, 450, 453, 460, 471, 479, 482 f., 493, 502 f., 506, 508
Waalwijk 347

Waffen 509

Wahlen 16, 49, 354, 400, 430, 455, $470 \mathrm{f}$., $476,479-481,496,498,510$

Wahlmänner 16, 23, 471, 480 f., 484, 496, 542

Waise 489,521

Wallfahrtsfeste $111,205,449,531,533 \mathrm{f}$.

Wandsbek 24, 267, 537

Wein $98,257,377,449,454,459,483$, 499,505 f.,

Wien 14

Wilhermsdorf 221, 545

Wirtshäuser 486

Witwe 375, 483, 490, 521 f., 525, 530

Wochenfest $111,348,523,531 \mathrm{f}$.

Wöchnerin 201, 368, 484, 524, 532

Worms 8 f., 11 f., 16-19, 21, 33-35, 49, $85,87,106,465,543$

Würzburg 224

Zirndorf 224

Zwi Hirsch, Sohn des Abraham 535 


\section{Hebräischer und Jiddischer Sachindex}

$$
\begin{aligned}
& \text { אב"ד (אב בית דין, ראה גם : רב) 38, 36, 36, 40, 40, }
\end{aligned}
$$

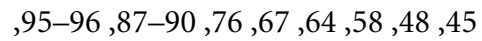

$$
\begin{aligned}
& \text { 99, 102, 106-105, 121, 114, 114, 111, } \\
& \text { 129 } \\
& \text {,177-178, 173, 162, 160 154-154 } \\
& \text { 180 } \\
& \text { 205 } \\
& \text {,248-250, 245, 242-243,240 } \\
& \text {,283-284, 280-281, 271, 254-258 } \\
& \text {,363-364, 356,347-349,339-340 } \\
& \text {,374-375, 371, 368 } 368 \\
& \text {,388-389, 385, 380-381,377-378 } \\
& \text { ופים 394-393, 408, 421, 437, 439, 441, } 41 \\
& \text { אופים } 423
\end{aligned}
$$

415 אלמער 112

אמט/ אמפט 62-159, 66, 76, 154, 137, 146-146, 146, 155-154 $442,434,258,249$
אפטרופס 118, 174, 185, 187, 191-195, 193, 195, 211, 241, 245-244, 247, 249, 249

ארחי ופרחי 213, 232 אשכנז/ אשכינז 75-74, 118, 208 אשכנזים 319, 322 אתרוג 262, 308, 377, 327, 381, 406

באקין טרעגר 261 בגדי קודש 209, 236, 302 בהעלף 67, 87, בגרי קורי בורגמיינשטירס 322 מבוררים 57, 59, 68, 101,68, בחורים 36, 40, 47, 68-67, 57, 71, 74, 74, 88-87, 90 , $160,140,128-131,123,117-118$ ,163 201 ,261-263, 249-254, 245-234 328, 308, 303-304, 282, 267-268 ,338 $439,411,401$ בייא זיצר 111, 120, 125, 143-141, 163, 165, 176, 190, 200-197, 222 224 $439,386-387$

371 ביליאר (Billiard) בימה 39, 204, 208, 421 ביקור חולים 184, 208, 251 בימה 204 בית אושפיז (ראה גם הערבערגין) 70-69, 72, 372,104

בית דין (ב"ד) 56, 62, 64, 68-66, 137, 159, 100, ,138 198 380, 389, 408, 437, 439 בית הכובס 261 בית המדרש / בהמ״ד 71, 71, 139, 158, 210, 212, $367,236,221$ 


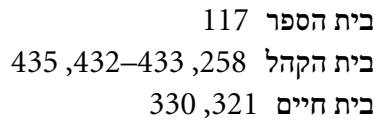

בית כנסת/ בה"כ / בית הכניסת (ראה גם : שול/ שוהל) 38-37, 40, 58-56, 79, 90-89-89, גריסת 101 141 ,205-206, 201-203, 194-199 ,229-230,218-226, 216, 214,208-212 ,234 ,260, 260 260 268-269, 266, ,356-359, 347, 311, 306-300-303 382, 380,376-377,369-370, 362-366 385 $441,421-423,416,414$ בית מטבחים 392

בית צום ורעליכן מאן 72 בית/ בתי הקהל 179, 258, 435

בלעטין/ פלעטין 104, 127-123, 130, 178, 235-233, 255, 280, 301, 309, 303,

$$
385,383
$$

בן נדה 372 בס 118, בוניה 207 בעל סגן 57, 111, 206-204, 302, 438

בעלי מלאכות 438, 424 בעלי מלחמו' בעלי מלית 370 בעלי מעריכים 44-41, 59, 62, 65, 68, 90-92 בראנקאס 367, 373, 379 ברייא הוי"ז 412 ברירת הקהל 140-138, 150, 155, 178, 191, 196, 211, 273 בתולה/ות 70, 74, 104-102, 1182, 123, 128, , 163 231 ,377, 373 , 368-370,361, 358-359 411,387 גבאי צדקה 59, 76, 114, 119, 127-126, 280, 284, 301, 325, 305, 308, 309, 309, 325, ,364-365, 362, 358, 334, 332 $436,406,394,381-382$

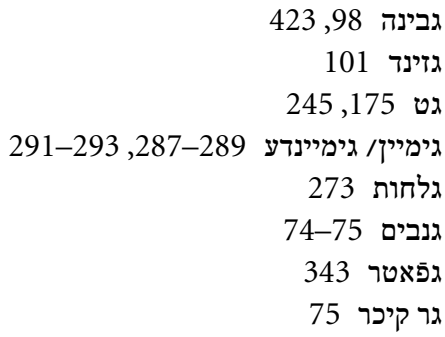

דיינים 56, 66, 80-79, 113, 141, 146-144, 151 242-243 407-408 דינא דמלכותא 246

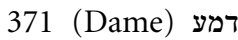
דרשה 38, דמע (11, 11, 161, 308

האנדל 293 הויבט בוך (ראה גם: פנקס קהל) 178 הויזירין 104 הויסיר צעטיל 260-259-104 הכרזה 46, 57, 101-100, 105, 131, 131, 179, 331, כיוז 342, 348, 381, 383, 433, 441 הכשר 114, 248, 259-255 הספקה 105, הכשר 250 הערבערגין 74 הערשאפט 287, 288, 293-291 הקדש 38, 44, 66, 89, 91, 96, 101-98, 106-105, 129-125, 149, 169, 189, 210, ,251-252, 235-236, 231-233, 262 הרה לזנונים 64, 370, 442-441-372 השגת גבול 72, 119, 378-377 השינונים השכמה 112, 213-212, 329, 332, 340, 342,

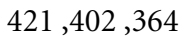
התמניות/ התמנות 65, 764, 81, 81,79, 90, 114 255 $437-438,433-434,421$

ווינר וועהרונג 431 ווערטש הייזר/ ווערצהייזר 69, 121 וירט שענק 292 


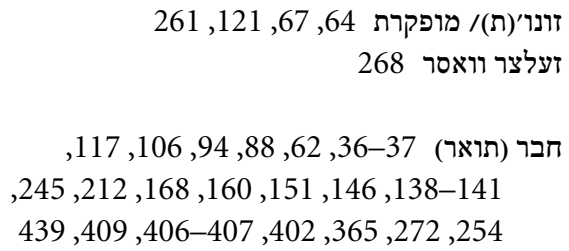

חברת שומרים 202 חדר חברת שרות

חדר הקהל/ קהלש שטוב 42, 44, 62, 79, 81,

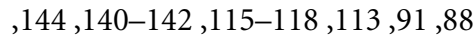

,191, 185, 176 146-150-153

$378,239,236$

חול קרייש 269, 368

חותם הקהל 178

חזן 37, 40-39, 47, 63-62, 65, 89-88, 94, , $140,128,118,110-112,105$ 149 208 ,335,323,328-330,311-313,306-309 ,370,364-365,357,343-344,340-341 389, 406, 417, 423-440-421, 436, 421,

חייטים 417 חילול שבת 215, חייטים 266 חילול השם 72, 103 חילוף 63, 74 חמאה 98, 121, 260, 423 חנווני 410, 420

חנוכה 40, 48, 63, 67, 79, 102, 121, 137,

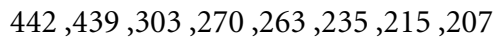
חרם 41, 45, 57-56, 68-67, 72, 76-74, 78, 81 339,332,329-330,322,281-282 ,371-372,362-363,343-344 ,416-417, 408, 403,383, 381 $426,419-421$ חתונה 39, 47, 94, 97-96, 99, 106-103, 103, 110,

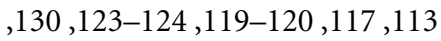
,160-166 149-149, 146, 141, ,160-170 202 201-204, 204, 207, 222, 225, 264, 268, ,307-308,301-302, 267-268 ,405-407,348,338-339,310-311 433,419-422, 416,414, 409-41

$$
\text { 439-441 }
$$

\section{טאנץ 262, 267, 370 טבילת נשים 281 358 טובאק טבילת נשים \\ טרויא שיין 117, 121}

יאר צייט 57, 75, 112,110, 328, 341, 419 יהודי 41, 71, 75-74, 80, 158, 281, 319, 322, 420

יודן 293-287

יודש/ יוטש קערץ 269-268, 369-368 יולדת 102, 120, 205, 207, 224, 232, 236, 469-269

438

יום הוועד 349-347 יום כיפור 39, 89, 110, 216, 365-364, 375, 422-423,401 יידש 310 יין 37, 59, 66, 67, 88, 92, 98, 120, 257-255, $442,412,271$

יין נסך 256, 283, 377 יין שרף 120, יוך 412 ימים נוראים 39, 112, 303-302,367, 312, 312, 341 438-439

יריד לייפסיג 113,113 ישיבה 37-36, 88, 101, 117, 123, 129, 131, $439,401,364,245,161$

כלה בריב 226-224, 228, 271-263 כלי זמר 263-262, כלה בריב 442 כלי קודש 39, כלי זמר 105, 381,115 כתובה 68-67, 98-97, 158, 307, 37, 375, 402, 440-441 כתבי חריות 79

לויה לולב לולב 262, לויה 377 ליג ברעט 281, 309 לצנים 105, 268, 370-369 ברעט

מאהן פיהרן 268, 368 270 מדפיסים מדריגות מעלה/ סדר מעלות 145, 150, 169, $249,213,181$ 
מוהל 110, 120, 205, 268-267, 369, 415, 442

מור(י)נו 39, 82, 89, 117, 160, 245, 272, 402, 402, 439, 426, 407-405, 409

מותרות 36, 43, 70, 92, 262, 309 מי שבירך 79, 101, 111, 204, 208,328, 207, 207, 306, 362, 377,362-363, 342, 331, 328-329 422

מילדת 236, 268 מלבושים 43, 70-69, 72, 81, 92, 123-172, 123, ,356-357, 265, 166, 170 $416,394,387,381,365,359-361$ מלך 367, 373, 381, 381, 381 מלמד 36, 67, 88, 104, 104, 112, 118, 127, 158, 198 284 417,406

ממונים 63, 68-67, 67, 72, 75, 78, 81, 88, 98, 100, 102, 106, 113, 113, 141, 144, 146, 146, 140 191 $423,404,392-393,271$ מנין 41, 63, 105, 122, 139, 210, 212, 358,2800 281 מעלץ הויז 412 מעשר 170, 417-415 מעליו 412, מצוי מצבות 185, 272, מעשר 343 מקוה 291

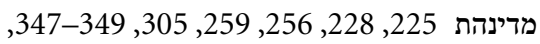
,377-379,375, 371-373, 367 $441,405,383-393$

משפט 45, 56, 62, 80, 90, 93, 151, 154, 160, 163 , 150 , 165 331, 310-311, 308, 305, 301 ,341 423 משרת 71-70, 74, 104-102, 102, 119-118, 129, 158, 280 $403,392,370-372,358,303-305$ משרתת 67, 104-102, 119-118, 121, 129, 158 370,361 משתה 37, 39, 89-88, 91, 99, 267, 377
נאטוויין 282 נאמן / נאמני הקהלה 42, 47, 43, 67, 67-67, 76, 98-97, 100, 115, 119-119-127-128, ,147, 145, 142-143,139-140 ,165, 163 160 160, 158, 159 222, 192, 190, 177-178, 169-172 230 ,310-311, 308,301-303, 282,273 ,342,335-338, 332,329-330,325-327 ,395,391-393,374-375, 344 419- ,414-417, 408-409, 402-404 420 נחלה 407, 411, 416,

נירנבורגר וועקסל רעכט/ אורדנונג 156-156, 158, 158,158 נכרי 39, 41, 47, 63, 68, 76-74, 74, 90, 90, 283 נעבן שוהל 137, 212-211, 221 נערים 39,36, 75, 80, 88, 99, 102, 105, 140, 140, 2715-213, 230-231, 2217, 228, 228, 280 394

נשים (אשה, אישה, נשות) 38, 44, 68-67, 74, , 81 ,174-175, 168, 158, 128, 126, 121-123 , 190 ,255, 245, 241, 230-232, 227-228 ,281-283, 271-272, 265-269-262 ,358-361, 356, 301 343 ,328, 308, 308, 363 $441,422,419,411,406$ סוחר 75, 372, 410, 425-424

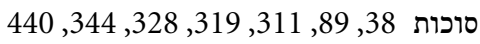
סוסים 69, 6וכות 376, 378, 391, 425 סוסים הענדליר/ מוכרי סוסים 74, 74, 391,391-391, סוסים

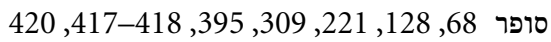
סחורה 40, 71-69, 74, 217, 281, 281, 376-375, 424-425, 320, 381 סנדק 111-110, 121-120, 207-205, 340, 331, 310, 307, 268, 262, 442,421 ספר תורה (ס״ת) 40-37, 57, 79, 90-89, 102, 102, 110, 118, 203, 208-206

,340,338,311-312,307-309, 364-366 
ספרדים 319 ספרים 92, 118, 186, 423 סרסור 138, 246, 425

עונש 42-41, 45, 56, 61-59, 64-63, 68, 72, , 105, 101-102, 91-92-81-82, 138 227

391, 383,380-381,377-378,373

,393

442

עניי ארץ ישראל/ א״יי 404, 407 ערונים 97, 106

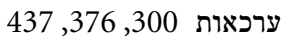
ערל 41-40, 71-69, 75-74, 79, 79, 90, 282-281, $423,420,413$ ערלת (!) 71-70, 90

פדיון שבוים 404 פורטגיזן 322 פורים 40, 67, 120, 207, 218, 233, 235, $442,341,261,263$ פושקא 407, 426 פלאנטש(י) 42, 92 פנקס (ה)קהל/ פנקס פראטיקאל (ראה גם : הויבט בוך/ קהלש בוך) 46 , 53, 60, 68-66, 82,

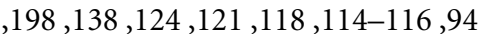
269, 280, 308, 416, 434, 439-440 פנקס הזכרת נשמות/ מעמר בוך 394,220 פנקס החלטות 102 פנקס התקנות 106 פנקס קטן 66, 178, 194 פסח 113, 180, 218, 231, 236, 300, 308, $412,408,401-402,341,310-312$ פסק 41, 53, 56, 63, 79, 102, 105, 147, 151, ,242-248, 237-240, 160,154-155 ,423, 418-420, 264-407-408, 389 436-437 פפעניג געלט 41-437

צאהל חתונה 267 צוואה 174, 190, 239, 249-248, 374, 379, 390
צורפים 417, 425

קאמעדיע 371 קאפיו קאפע 369-368, 442 קאפיהייזר 263, 371 קארטין 371 קאשט גענגר 71, 198, 213, 263-262 קבורה 189, 262, 305, 321 קדיש 38-37, 198, 202, 212-211, 300

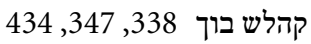
קהלס/ש שטוב 42, 44, 62, 88, 91,208 קופת ארץ ישראל 209-208 קופת מתן בסתר 211, 214 קינד 38, 47, 75, 89-88, 89 201, 101, 263-262, 280, $357,343,340,335,330,320,291$ קינד בעט 120, 201, 232, 261 קיסר 76, 78, 81, קירזנר 417, קיסר 424 קלאהמן/ קלאמין 40, 154, 237 קירונר 202

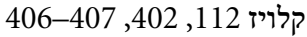
קליידר אורדנונג 265 קליידר הענדליר/ מלבושים הענדליריר/ מוכרי מלבושים 63, 69, 72-71, 80-78

קמחא דפסחא 310

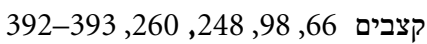
קראשער/ קראשר/ גראשין 70,69, 103, 103, 372-373

קרוזירר/ קרזירער 74, 80,8373

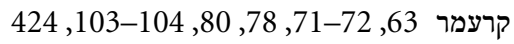

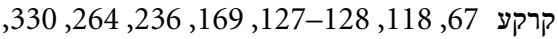
384-385,340

$$
\text { ראבינר 293-288 }
$$

רב/ רבי (ראה גם : אב"ד, ראבינר) 36, 39, 48, 47,

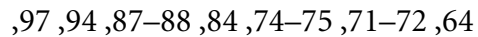

100

,406-408, 403-404,362,330

,436-439, 434, 422, 414-420, 441-442

רבני אשכנז 75-74

רבנית 185, 369-368, 371, 394 רנים רגלים 37, 88, 233, 251, 312-311,363,366, 36 רופית רופא/ רופאים 68, 68, 146, 149, 173, 212, 347, $394,376,372,364,349$ 
רחוב היהודיס 360-358, 371, 375-374 ריסטר 404, 410-409, 415-413, 413, 419, 419, $425-426,421$

שאכצאבעלו שאכצייעל 67, 371 שאקעלאדאן 369

שבועה 42, 44, 47, 56, 61, 66-65, 65, 75, 82, 88, 92-91, 97-96, 96, 106, 124, 138, 140, 146,

,170-173, 157, 156, 149 176 393-391-303, 403, 407, 409, 418-414, 44

שבועת הערך 42, 92 שבת הגדול 111, 161, 205, 308 שדכנים 68, 246, 424 שוחטים 62, 179, 248, 259, 283, 349, 391-393 שוטר 380-379-393

שול/ שוהל (ראה גם: בית כנסת, ב״כ, בה"כ)

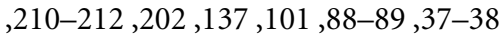
, 290-292, 221 ,332,329-330,321-322,319,313 335, 338, 340, 343, 343-342,348, 348 שומרי חולאים 122 שומרי יולדות 122 שוצגעלד 432, 441-440 שומרות שוק 260, 362, 373, 390, 411 שותפות 41, 98, 104, 198, 198, 220, 223, 410, 410, 422 שטר 53, 56, 63, 68, 78, 95, 98-97, 101 239 $420,407-408,376,374$
שטר הרבנות 438

שידוכים 47, 95, 163, 175, 246, 268, 308 שכר רבנות 349-347 שידוכים

שלויף/ שלאף שטעטר 218-217, 227-226, 373,233

שמחת לקפוץ על האש 99 שמחת תורה 38, 102, 112-111, 207, 224

שנוף טבאק 335 שענק וויין 267, 369-368 שילק שפילן 103-102, 121, 270, 371 שפני וויון שפינהולץ/ שפי"ו האל"יץ 97, 268

69 שפיצן הענדליר שפינוליר שפראך מיינשטר 261

שררה 40, 41, 53, 56, 60, 64, 66, 66, 76, 78, 76 , 65, , 197-82-199, 149, 165, 162, ,303-304, 301,241 284, 261 ,336,330-333,325-328,322,319 ,419,386, 384, 377, 363,342-343 434-435 שתדלן 66-64, 80, 417, 423 שתדלנות/ השתדלות 46, 78, 80, 82, 94, 116, 149, 161, 179, 198, 209, 304, 374, 384, $431,388-389,386$ תבואה 40, 43, 92, 423 תופרי בגדים 417 תינוק 38, תופרי בגדים 190, 301 תכשיטי' 92, 359, 361, 365, 381, 394, 409, 411, 413, 416-415, 424 תלמידים 127, 171, 200, 250, 254-253 